\title{
Water Resources of the
}

\section{UpperColoradoRiverBasin-}

Technical Report

GEOLOGICAL SURVEY PROFESSIONAL PAPER 441

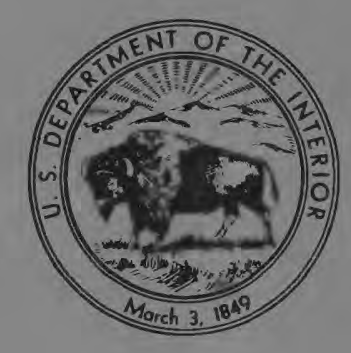


Water Resources of the

UpperColoradoRiverBasin-

Technical Report

By W. V. IORNS, C. H. HEMBREE, and G. L. OAKLAND

GEOLOGICAL SURVEY PROFESSIONAL PAPER 441

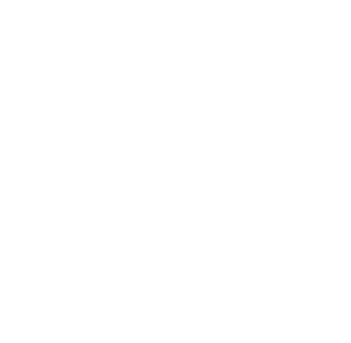

UNITED STATES GOVERNMENT PRINTING OFFICE, WASHINGTON : 1965 


\section{UNITED STATES DEPARTMENT OF THE INTERIOR \\ STEWART L. UDALL, Secretary \\ GEOLOGIGAL SURVEY}

Thomas B. Nolan, Director

For sale by the Superintendent of Documents, U.S. Government Printing Office Washington, D.C. 20402 


\section{CONTENTS}

[Letters in parentheses preceding titles designate the separate chapters]

(A) Introduction and summary- Page

(B) Hydrologic techniques and criteria used in appraising the surface-water

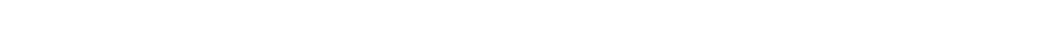

(C) Surface-water resources of the Grand division

(D) Surface-water resources of the Green division.

(E) Surface-water resources of the San Juan division

Index . . . . . 


\section{Introduction and Summary}

By W. V. IORNS, C. H. HEMBREE, and G. L. OAKLAND

WATER RESOURCES OF THE UPPER COLORADO RIVER BASIN-TECHNICAL REPORT

GEOLOGICAL SURVEY PROFESIONAL PAPER 441-A

Introduction and summary of an appraisal of the water resources of the Upper Colorado River Basin, with special emphasis on surface water and its quality

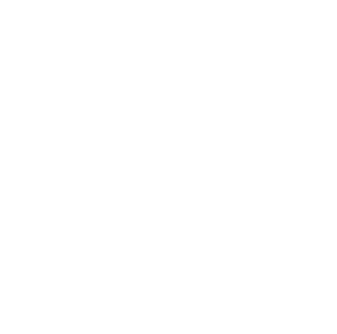





\section{CONTENTS}

Abstract

Introduction

Location

Stream system . . .

Geology

Hydrologic unit-

8. Igneous and metamorphic rocks........

7. Igneous rocks.

6. Predominantly marine rocks. ........

5. Continental and marine rocks..........

4. Predominantly continental rocks ........

3. Marine and continental rocks . . . . . . .

2. Continental rocks . . . . . . . . . . . .

1. Unconsolidated continental deposits ....

Physiographic and structural features . . . . . . . . . .

Climate. . . .

Population...

Organization of the report . . . . . . .

Previous investigations and reports

Acknowledgmen ts.

\begin{tabular}{|c|c|}
\hline & \\
\hline 1 & nary. \\
\hline 1 & tilization \\
\hline 2 & Water supply \\
\hline 2 & Water budget \\
\hline 2 & Chemical quality of water \\
\hline 4 & Dissolved-solids discharge and concentration \\
\hline & Variations in chemical quality \\
\hline 4 & Relation to streamflow \\
\hline 5 & Relation to geology \\
\hline 5 & Relation to ground water \\
\hline 5 & Effect of transmountain diversions \\
\hline 5 & Effect of the activities of man \\
\hline 5 & Flu vial sediment \\
\hline 5 & Suitability of water for various uses. \\
\hline 8 & Domestic \\
\hline 8 & Agricultural \\
\hline 8 & Industrial__._. \\
\hline 10 & Recreational \\
\hline 10 & nces \\
\hline 12 & 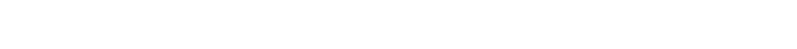 \\
\hline & \\
\hline
\end{tabular}

Page

12

12

14

19

19

19

20

23

24

29

31

32

34

36

36

37

39

39

40

365

\section{ILLUSTRATIONS}

[Plates are in separate volume]

Plates 1-3. Map of Upper Colorado River Basin showing the distribution of hydrologic units and-

1. Average annual precipitation.

2. Chemical quality of surface water.

3. Quality of water from representative wells and springs, principally in river alluvium.

Page

3

9

2. Divisions and subbasins in the Upper Colorado River Basin

3. Normal precipitation and temperature and frost-free seasons at representative stations in the Upper Colorado

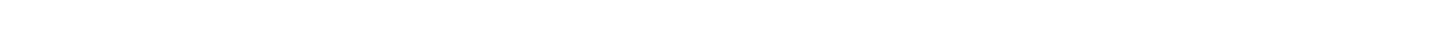

4. Annual transmountain diversions in Colorado and Utah from the Upper Colorado River Basin, water years 1914-57.

5. Seasonal pattern of streamflow for selected streams in the Upper Colorado River Basin, 1954 water year

6. Variability of annual discharges of selected streams in the Upper Colorado River Basin, water years 1914-57 adjusted to 1914 base.

7. Flow-duration curves for selected streams in the Upper Colorado River Basin

8. Approximate dissolved-solids discharge and streamflow, expressed as percentages of the combined dissolvedsolids discharge and combined streamflow of the Colorado and Paria Rivers at Lees Ferry, Ariz .......

9. Dissolved-solids concentration and discharge and water discharge, Green River near Ouray, Utah......

10. Relation of concentration of dissolved solids to water discharge, Green River near Ouray, Utah.........

11. Relation of the variability of dissolved-solids concentration to the variability of water discharge at daily chemical-quality stations, Upper Colorado River Basin . . . . .

12, 13. Relation of the chemical composition and concentration of dissolved solids to water discharge-

12. At stations on the three main streams in the Upper Colorado River Basin

13. For streams in the headwaters, Upper Colorado River Basin

14. Weighted-average concentration of dissolved solids at selected sites in the Upper Colorado River Basin

15. Analyses of water from selected streams in the Upper Colorado River Basin and from the alluvium nearby .-

16. Approximate water and suspended-sediment discharge expressed as percentages of the combined streamflow and combined suspended-sediment discharge of the Colorado and Paria Rivers at Lees Ferry, Ariz.

\section{1}

13

15

16

17

21

23

23

24

25

28

30

31

35 


\section{TABLES}

TABLe 1. Geologic formations in the Upper Colorado River Basin

2. Areal distribution of precipitation in the Upper Colorado River Basin, calendar years 1921-50

3. Average annual evaporation from water surfaces in the Upper Colorado River Basin.

4. Summary data on utilization of surface water in the Upper Colorado River Basin for the level of development in $1957 \ldots$

5. Flow-duration tables for selected gaging stations in the Upper Colorado River Basin

6. Water budget, Upper Colorado River Basin . . .

7. Water and dissolved-solids discharge at selected stations in the Upper Colorado River Basin.......................

8. Duration table of dissolved-solids concentration for eight stations in the Upper Colorado River Basin

9. Duration table of dissolved-solids discharge for eight stations in the Upper Colorado River Basin........

10. Relation between water discharge and chemical quality of water

11. Water and dissolved-solids contributed by ground water to selected headwater streams in the Upper Colorado River Basin...

12. Yield rates of dissolved solids from irrigated lands in 21 areas that comprise about 41 percent of the irrigated lands in the Upper Colorado River Basin . .

13. Average annual dissolved-solids discharge and probable amounts from natural sources and the activities of man in the Upper Colorado River Basin _.

14. Water and suspended-sediment discharge at gaging stations in the Upper Colorado River Basin................

15. Suitability of surface water for irrigation in the Upper Colorado River Basin.

Page

6

10

10

13

18

19

20

22

22

26 


\title{
WATER RESOURCES OF THE UPPER COLORẢDO RIVER BASIN-TECHNICAL REPORT
}

\section{INTRODUGTION AND SUMMARY}

\author{
By W. V. Iorns, C: H. Hembree, and G. L. OAKLand
}

\begin{abstract}
This chapter contains an introduction and a summary.

The introduction gives background information on the area: geography, geology, physiography, climate, and stream regimen. Included is a table of hydrologic units, prepared by D. A. Phoenix, which separates the complex assortment of rocks according to generalized hydrologic properties.

The rest of the chapter summarizes the quantity and chemical quality of the surface water of the basin. There is a great deal of water which enters the basin annually as precipitation $(92,739,000$ acre-ft). Only a small part of this $(2,257,500$ acreft) is consumed by humans or is diverted out of the basin. The rest leaves the basin through outflow $(12,733,100$ acre-ft) or is lost by evaporation and plant transpiration $(77,748,400$ acre$\mathrm{ft})$.

The amount and chemical quality of the streamflow vary with time and place owing to both natural and human causes. To give a common base for comparing streamflow, an average was used which would have occurred if the level of upstream development existing in 1957 had existed throughout water years 1914-57.
\end{abstract}

Natural factors affect the streamflow and chemical quality : the amount of precipitation, the underlying soils, and the ground water. The human factor, however, greatly influences streamflow and chemical quality. Water quantity and quality are changed as the water is diverted for domestic, industrial, and agricultural uses. Domestic and industrial uses add 33,600 tons of dissolved solids annually to the streamflow; irrigation adds $3,446,700$ tons. Water quality also depends on the proportion of individual constituents and the amount of suspended sediment.

\section{INTRODUCTION}

The first comprehensive study of the water resources of the Colorado River Basin was made by $\mathbf{E}$. C. LaRue (1916). The introduction to the report was written by Nathan C. Grover, Chief Hydraulic Engineer, Water Resources Division, U.S. Geological Survey. Much of what Grover said about the Colorado River Basin is as timely today (1957) as it was in 1916:

The region traversed by the Colorado and its tributaries is for many reasons of intense interest to the people of the United States. Here was the home of that forgotten people of which there is almost no record except the hieroglyphics on the rocks, the ruins of their irrigation systems, and the cliff dwellings by which they are most widely known; here were Spanish missions whose history extends back nearly to the days of Balboa and Cortez; here is the Grand Canyon, whose sublimity was first fully disclosed by Maj. Powell and his associates, who navigated it from end to end in 1869 and 1872; here are the greatest known natural bridges, so remote and inaccessible $* * *$ here is the mighty river and its tributaries ***. We are interested in its mysteries, its traditions, its history, and its possible future; in the fascination of its deserts, whose immensity awes us; in the grandeur of its mountains, from the highest peaks of the Rockies on the east to the beauties of the Uinta and Wasatch mountains on the west; in the wonders of its canyons, perhaps the most famous in the world; in the range of its climate, from its short and cold summer season in Wyoming, where frosts may occur in every month of the year, to the sub-tropical temperatures of the valleys of Arizona, where the growing season never ends.

Its high valleys contain valuable forests and its mountains extensive deposits of minerals. At many points within its borders prosperous agricultural communities have been established $* * *$

What is to be the future of this immense region? Doubtless its forests will be utilized, its mineral wealth will be exploited, its wonderful scenic beauties will be unfolded. Its greatest development must come, however, from its water resources, on which the development of its other resources must largely depend $* * *$

Water in the rivers, creeks, lakes, ponds, and surface-water and ground-water reservoirs of the Colorado River Basin constitutes the water resources of the region. This is a continuously renewing resource, and its visible occurrence in the streams and impoundments and its hidden movements underground are parts of the recurring succession of events known as the hydrologic cycle. The surface and ground waters in the Colorado River Basin have their origin in precipitation, derived mostly from water evaporated from the Pacific Ocean or the Gulf of Mexico. Some of the precipitation is returned to the atmosphere by evapotranspiration, some percolates downward to the ground-water reservoirs, and some flows directly into the surface-water bodies. Part if not most of the water 
that enters the ground-water reservoirs ultimately finds its way to the streams. Man takes water from the surface-water bodies and ground-water reservoirs and consumes part of it for his sustenance and livelihood. Eventually, water flowing in the streams, except the water that is consumed by natural process or man, flows out of the basin toward the ocean.

Water from the first moment of contact with the land surface as precipitation is subjected to various natural environmental factors that influence its physical behavior and chemical character. The most important of these factors are climate, topography, type of rocks and soils, and vegetation. In addition to natural factors, the activities of man have changed the natural physical behavior and chemical character of many of the streams in the basin.

\section{PURPOSE AND SCOPE}

Much of the water supply of the Colorado River Basin is already being used. Additional water developments are planned to meet the evergrowing demands of the region. As these developments may be limited by legal, physical, and economic factors, an appraisal of the water-supply situation is needed.

The U.S. Geological Survey has prepared this report on the surface-water resources of the Upper Colorado River Basin as part of an appraisal of the water resources of the entire Colorado River Basin. The surface-water resources of the region are described and the effects of environmental factors on these resources are explained on the basis of available data and water uses existing in 1957. The report does not contain forecasts of changes in water quantity and quality which may take place as a result of water-utilization projects constructed after 1957.

The area encompassed by the report is the drainage basin of the Colorado River above "Lee Ferry," Ariz. "Lee Ferry" is an arbitrary point dividing the Upper Colorado River Basin and the Lower Colorado River Basin and is defined by the Colorado River Compact as "a point in the main stem of the Colorado River one mile below the mouth of the Paria River." "Lee Ferry" should not be confused with Lees Ferry, a small community at an old ferry site on the Colorado River about 1 mile above the mouth of the Paria River, where a gaging station is located.

Studies for the report have included the following: The assembling of basic data on the water resources; identification of deficiencies in the data; collection of additional data to fill obvious gaps; and an analysis of the influence of natural environmental factors and the activities of man on the occurrence, quantity, and quality of the water resource. The influence of natural factors on water regimen is complex because the factors and their effects on water are interrelated. The effects of the activities of man are also complex and are not easily discriminated from the effects of natural factors. Nonetheless, so far as can be demonstrated or reasonably inferred from the basic water data, this report seeks to explain the current (1957) water situation of the basin and, in so doing, to discriminate between natural and human effects. Ultimately, additional hydrologic research and collection of essential basic data will be needed to identify, more precisely than has been possible in this study, the effects of the activities of man on the chemical quality of the streams.

\section{LOCATION}

The Upper Colorado River Basin (fig. 1) comprises about 109,500 square miles in western Colorado $(38,670 \mathrm{sq} \mathrm{mi})$, southwestern Wyoming $(17,430 \mathrm{sq} \mathrm{mi})$, eastern Utah $(37,310 \mathrm{sq} \mathrm{mi})$, northwestern New Mexico (9,580 sq mi), and northeastern Arizona (6,510 $\mathrm{sq} \mathrm{mi})$. The basin is within parts of two large physical divisions of the United States-the Rocky Mountain system and the Intermontane Plateau (Fenneman and Johnson, 1946). The basin extends from lat $35^{\circ} 34^{\prime} \mathrm{N}$. to $43^{\circ} 27^{\prime} \mathrm{N}$., a distance of about 550 miles, and from long $105^{\circ} 38^{\prime}$ W. to $112^{\circ} 19^{\prime}$ W., a distance of about 350 miles.

The boundary of the basin from "Lee Ferry," Ariz., northward follows the crests of the Paria, Aquarius, and Wasatch Plateaus and the Wasatch and Wyoming Ranges to the Continental Divide at the north end of the Wind River Range in Wyoming.

The basin boundary from "Lee Ferry" southward and eastward follows a divide that trends first southward and then eastward across the Kaibito Plateau, along the north and east rim of Black Mesa, and across the south end of the Chuska Mountains to the Continental Divide a few miles northeast of Gallup, $\mathrm{N}$. Mex. From here northward, the east boundary of the basin follows the Continental Divide almost 1,000 miles to the north end of the Wind River Range.

\section{STREAM SYSTEM}

The Colorado River (fig. 1) rises near the extreme eastern part of the basin on the east slope of Mount Richthofen, a peak having an altitude of 13,000 feet on the Continental Divide, and flows generally southwestward to "Lee Ferry." The Green River, the largest tributary, rises in the Wind River Range at the north end of the basin and flows southward to its junction with the Colorado River about 60 miles south of the town of Green River, Utah. The San Juan River, the second largest tributary, rises on the west slope of the 


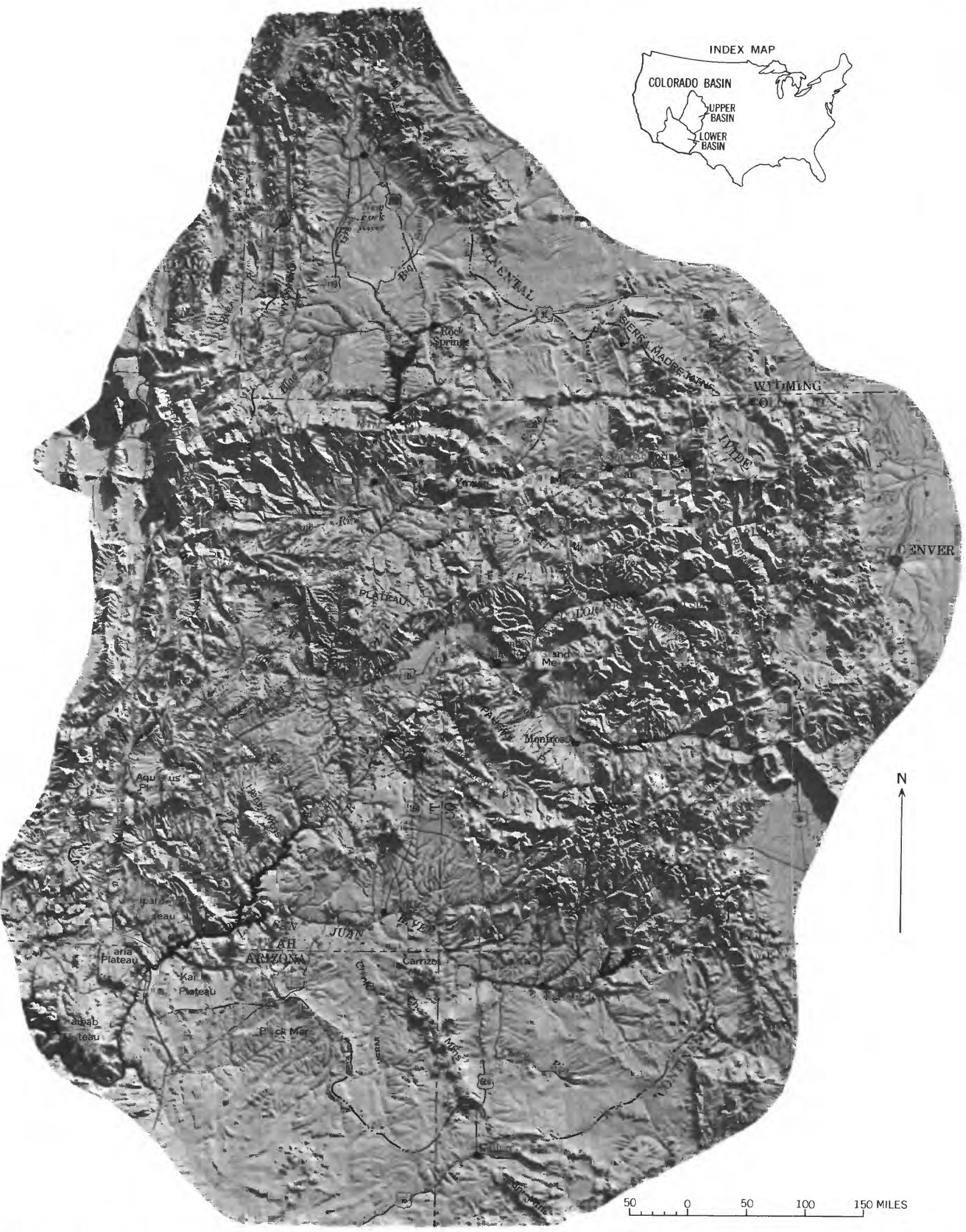

FIGURE 1.-Relief map of area including the Upper Colorado River Basin. Adapted from photograph by I. V. Goslin, Upper Colorado River Compact Commission. 
Continental Divide in the southeastern part of the basin and flows westward to its junction with the Colorado about 75 miles west of Bluff, Utah.

The principal tributaries of the Colorado River above the Green River (in earlier years the river above the mouth of the Green River was called Grand River, but in 1921 Grand was changed to Colorado) are the Eagle River, Roaring Fork, Gunnison River, and the Dolores River. The principal tributaries of the Green River are New Fork River, Big Sandy Creek, Blacks Fork, Henrys Fork, and Yampa, White, Duchesne, Price, and San Rafael Rivers. The principal tributaries of the San Juan River are the Navajo, Los Pinos, Animas, and La Plata Rivers. Other tributaries that enter the Colorado River below the Green River are the Dirty Devil, Escalante, and Paria Rivers.

\section{GEOLOG Y}

The geology in the Upper Colorado River Basin profoundly influences the occurrence, behavior, and chemical quality of the water resources. In the mountains, where most of the water supply originates, there is a close relation between ground water in the consolidated rocks and in the alluvium and water in the streams. In these mountain areas some of the rainfall and snowmelt enters ground-water reservoirs and ultimately reaches the streams through springs, seeps, or through the alluvium along the stream channels. As the streams rise and fall, water alternately moves from the streams into the alluvium along the stream channels and back to the streams. Thus, there is an almost continuous interchange between ground water and surface water. In the process the rocks react with the water and impart distinctive chemical characteristics to the water.

In the interior valleys and basins, ground water in the consolidated rocks has only a minor relation to the discharge and chemical quality of water in the streams, except locally where thermal springs from deep-seated sources discharge to the streams. For the most part, precipitation is insufficient to provide any appreciable ground-water recharge. Aquifers, whose recharge areas are in and along the mountains where precipitation is abundant, are buried beneath great thicknesses of impermeable strata in the interior valleys.

Although the consolidated rocks at or close to the surface in the interior of the basin do not contribute an appreciable amount of ground water to the streams, they do influence the chemical quality of streams. As in the mountains, the rocks react with the surface runoff from infrequent, but intense, rainfall and impart distinctive chemical characteristics to the water. Extensive deposits of river alluvium occur along some of the streams in the interior valleys, and interchange between the water in the streams and the alluvium results in a close relation between the chemical quality of water in the streams and that in the alluvium.

The rocks exposed in the basin range in age from Precambrian to Recent. Generally, the Precambrian rocks, which include the older plutonic and metamorphic rocks, form the basement upon which the sedimentary rocks rest, but in places, mostly in the mountains, the older rocks have been exposed through uplifting, folding, faulting, and erosion. More than 200 formational subdivisions of sedimentary rocks in the basin have been named. Some of these formations are thin and only crop out locally, but others are thousands of feet thick and crop out throughout large areas in the interior of the basin and along the flanks of the mountains. Volcanic rocks, mostly of Tertiary age, are widely distributed, but the area of these rocks, when compared to the total area of the basin, is rather small. The youngest deposits are the surficial debris from the weathering of older rocks. The surficial deposits, which have been transported from place to place by wind, glaciers, and streams, cover the consolidated rocks as a veneer in many places but may be a hundred or more feet thick in other places.

The rocks differ greatly in their lithologic and hydrologic properties. Some are composed of minerals that are resistant to rapid weathering, but others contain readily soluble minerals. Some are relatively permeable, whereas others are relatively impermeable. These properties vary widely, even in the same formation.

The complex assortment of rocks in the Upper Colorado River Basin has been classified into several subdivisions or units by D. A. Phoenix. (See table 1.) Each of the units conforms to the time-rock system of classification which separates the rocks according to generalized hydrologic properties. Some of the units include many formations, and others include only a few. The areal extent of the units is shown in plate 1.

The following summarizes the characteristics of the units and areas of occurrence, as described by Phoenix :

\section{HYDROLOGIC UNIT 8, IGNEOUS AND METAMORPHIC} ROCK8

The granitic and related metamorphic rocks of Precambrian age of unit 8 crop out in about 7 percent, or 7,900 square miles, of the basin, mostly in the mountains. The rocks are composed largely of several common rock-forming minerals, most of which are slow to react with water.

Most of the rocks of this group are granitic types associated with schist and gneiss. In some areas, chiefly in the Uinta Mountains, metamorphic rocks consist of 
shale, argillite, and quartzite. Highly foliated and metamorphosed rocks crop out in the Wind River Range, in the Uncompahgre Plateau, and in the Rocky Mountains.

\section{HYDROLOGIC UNIT 7, IGNEOUS ROCKS}

The rocks of unit 7 occur as lava flows, ash falls, laccoliths, volcanic necks, and diatremes and as dikes, sills, and larger discordant intrusive masses that transgress bedding in sedimentary or volcanic rocks. Rocks of this unit occur in small bodies in many localities and crop out in about 3 percent, or 3,500 square miles, of the basin.

The most notable of the intrusive bodies of igneous rocks are the laccoliths of the Henry, La Sal, Abajo, Carrizo, Ute, and La Plata Mountains. Irregular bodies of intrusive rock also occur in the Rocky Mountains. Many of the physical and chemical characteristics of these rocks are similar to those in unit 8 .

Lava flows and basaltic rocks crop out in the San Juan Mountains, West Elk Mountains, Grand and Black Mesas, and the Aquarius Plateau in southern Utah. Dark-colored basalt flows, the most conspicuous rocks of this group, are associated with thick deposits of pale-gray to reddish-brown andesite, latite, dacite, and rhyolite and with deposits of tuff, agglomerate, and flow breccia.

HYDROLOGIC UNIT 6, PREDOMINANTLY MARINE ROCKS

The rocks of unit 6 consist of limestone, dolomite, quartzose sandstone, shale, and saline minerals. These rocks range in age from Cambrian to Permian and have been mapped and classified into about 35 formations. They crop out in about 6 percent, or 6,900 square miles, of the basin and mostly are extensively exposed in the White River Plateau; along the flanks of the Rocky, Uinta, and San Juan Mountains; and in a large area in southern Utah and northern Arizona.

In the mountainous areas-particularly in the White River Plateau and surrounding areas in western Colorado, in parts of the Uinta Mountains, and in parts of the Wyoming Range-these rocks are covered with talus, with partly decomposed rock, and with soil.

HYDROLOGIC UNIT 5, CONTINENTAL AND MARINE ROCKS

Unit 5 is composed of six formations. The Moenkopi and Chinle formations, included in the unit, also underlie virtually all the other rocks. The rocks crop out in many places in the Canyon Lands of southwestern Colorado, southeastern Utah, and northeastern Arizona. About 5 percent, or 5,300 square miles, of the basin is underlain by this unit.

The formations of the unit are characterized by differences in lithology: in places they are composed of thick deposits of silty mudstone and shale and near the middle, of thin lenticular beds of coarse-grained sandstone and conglomerate. Common minerals are anhydrite and gypsum. These soluble minerals appear as beds, seams, and interstitial fillings in the finegrained sediments. Much of the exposed upper part is covered by a thin fluffy coating of bentonitic clay, which is susceptible to rapid erosion by surface runoff.

\section{hYdRoLOGIC UNIT 4, PREDOMINANTLY CONTINENTAL
ROCKS}

The rocks of unit 4 crop out in many places in the Canyon Lands and in southern Utah and southeastern Colorado. Many of the conspicuous hogbacks and ridges in the foothills of the San Juan and Rocky Mountains are formed by these rocks, which crop out in about 25 percent, or 27,000 square miles, of the basin.

Rocks of this group, from oldest to youngest, are divided into the Glen Canyon Group, San Rafael Group, and Burro Canyon, Dakota, and Morrison Formations. Other formations of related age and lithology are also included, but because of their restricted distribution are of less importance to the regional hydrology. Siltstone and mudstone interbedded with fine- to medium-grained quartzose sandstone, and locally with limestone, characterize the upper part. Massive quartzose sandstone composes most of the lower part.

\section{HYDROLOGIC UNIT 3, MARINE AND CONTINENTAI ROCKS}

The upper part of unit 3 contains a large number of intertonguing and overlapping formations of continental sandstone and marine shale. The lower part is mostly marine Mancos Shale and the Mesaverde Group and related formations.

These rocks crop out in about 23 percent, or more than 25,000 square miles, of the basin; their area of outcrop is almost equal to that of hydrologic unit 4 . They crop out in and along the Book Cliffs, the Wasatch, Aquarius, and Kaiparowits Plateaus, the cliffs around Black Mesa, and large areas near the San Juan and Rocky Mountains and in the Green River basin in Wyoming and in the Uinta Basin. Many broad valleys underlain by the lower part of the unit have attracted settlers. Valleys in the vicinity of Price, Vernal, and Green River, Utah; Rock Springs, Wyo.; Grand Junction, Delta, and Montrose, Colo.; Farmington, N. Mex.; and many smaller towns are underlain by the Mancos Shale and related formations.

HYDROYOGIC UNIT 2, CONTINENTAL ROCKS

The oldest and most extensive formations of unit 2 are the Wasatch, Green River, Uinta, Bridger, and related formations of Tertiary (Eocene) age. The youngest rocks include the Browns Park (Miocene?), 
TABLE 1.-Geologic formations in the Upper Colorado River Basin

\begin{tabular}{|c|c|c|c|c|}
\hline Colorado & Wyoming & Utah & New Mexico & Arizona \\
\hline \multicolumn{5}{|c|}{ HYDROLOGIC UNIT 1, UNCONSOLIDATED CONTINENTAL DEPOSITS } \\
\hline $\begin{array}{l}\text { All unconsolidated deposits in- } \\
\text { cluding alluvial deposits, tor- } \\
\text { rential wash, landslides, terrace } \\
\text { deposits, mudflows, Wisconsin } \\
\text { Till, glacial outwash, Durango } \\
\text { Till, glacial outwash, Florida } \\
\text { Gravel, Cerro Till, moraines. }\end{array}$ & $\begin{array}{l}\text { All unconsolidated deposits in- } \\
\text { cluding alluvial deposits, lake } \\
\text { sediments, landslide deposits, } \\
\text { windblown sand, glacial de- } \\
\text { posits. }\end{array}$ & $\begin{array}{l}\text { All unconsolidated deposits in- } \\
\text { cluding alluvial deposits, ter- } \\
\text { race and pediment gra vels, } \\
\text { landslides, mudflows, dunes, } \\
\text { glacial till, moraines, out- } \\
\text { wash. }\end{array}$ & $\begin{array}{l}\text { All unconsolidated deposits in- } \\
\text { cluding alluvial deposits, bol- } \\
\text { son, pediment, windblown } \\
\text { sand, high-level terrace de- } \\
\text { posits, landslides, spring, and } \\
\text { morainal deposits. }\end{array}$ & $\begin{array}{l}\text { All unconsolidated deposits in- } \\
\text { cluding alluvial deposits, } \\
\text { dunes, landslides, playas, and } \\
\text { terrace deposits. }\end{array}$ \\
\hline \multicolumn{5}{|c|}{$\begin{array}{l}\text { HYDROLOGIC UNIT 2, CONTINENTAL ROCKS } \\
\text { Chuska Sandstone and other formations of related lithology }\end{array}$} \\
\hline $\begin{array}{l}\text { Bridgetimber Gravel, North } \\
\text { Park Formation. } \\
\text { Browns Park Formation, Creede } \\
\text { Formation, Arikaree Sand- } \\
\text { stone. } \\
\text { Telluride Conglomerate, Blanco } \\
\text { Basin Formation. }\end{array}$ & $\begin{array}{l}\text { Bishop Conglomerate, Browns } \\
\text { Park Formation. }\end{array}$ & $\begin{array}{l}\text { Sevier River Formation } \\
\text { Bishop Conglomerate, Browns } \\
\text { Park Formation, Brian Head } \\
\text { Formation. }\end{array}$ & $\begin{array}{l}\text { Santa Fe Group. } \\
\text { Chuska Sandstone, alluvial and } \\
\text { lacustrine deposits, basalt } \\
\text { flows. }\end{array}$ & $\begin{array}{l}\text { Chuska Sandstone, Bidahochi } \\
\text { Formation. }\end{array}$ \\
\hline \multicolumn{5}{|c|}{ Uinta Formation and other formations of related lithology } \\
\hline $\begin{array}{l}\text { Bridger Formation } \\
\text { Green River Formation... } \\
\text { Wasatch Formation, Ohio Creek } \\
\text { Conglomerate, Blanco Basin } \\
\text { Formation, Fort Union For- } \\
\text { mation. } \\
\text { Animas Formation, Middle } \\
\text { Park Formation. }\end{array}$ & $\begin{array}{l}\text { Bridger Formation, Pass Peak } \\
\text { Conglomerate, Fowkes For- } \\
\text { mation. } \\
\text { Green River Formation........ } \\
\\
\text { Wasatch Formation, Almy For- } \\
\text { mation, Fort Union Forma- } \\
\text { tion, also conglomerate along } \\
\text { the southwest flank of the } \\
\text { Wind River Mountains. } \\
\text { Evanston Formation........... }\end{array}$ & $\begin{array}{l}\text { Duchesne River Formation.... } \\
\text { Bridger Formation.......... } \\
\text { Uinta Formation, Green River } \\
\text { Formation, Currant Creek } \\
\text { Formation. } \\
\text { Wasatch Formation, Flagstaff } \\
\text { Limestone. } \\
\\
\text { North Horn Formation.......... }\end{array}$ & $\begin{array}{l}\text { San Jose Formation, Torrejon } \\
\text { Formation, Puerco Forma- } \\
\text { tion, Nacimiento Formation. } \\
\text { Animas Formation. }\end{array}$ & \\
\hline \multicolumn{5}{|c|}{$\begin{array}{l}\text { HYDROLOGIC UNIT 3, MARINE AND CONTINENTAL ROCKS } \\
\text { Mesaverde Formation and other formations of related lithology }\end{array}$} \\
\hline $\begin{array}{l}\text { Lance Formation, McDermott } \\
\text { Formation, Kirtland Shale, } \\
\text { Fruitland Formation, Pictured } \\
\text { Cliffs Sandstone, Lewis Shale, } \\
\text { Williams Fork Formation, Iles } \\
\text { Formation, Cliff House Sand- } \\
\text { stone, Menefee Formation, } \\
\text { Point Lookout Sandstone, } \\
\text { Mesaverde Formation and } \\
\text { Group, Pierre Shale. }\end{array}$ & $\begin{array}{l}\text { Lance Formation, Lewis Shale, } \\
\text { Almond Formation, Mesa- } \\
\text { verde Formation, Adaville } \\
\text { Formation, Ericson Sand- } \\
\text { stone, Steele Shale, Rock } \\
\text { Springs Formation. }\end{array}$ & $\begin{array}{l}\text { Mesaverde Formation and } \\
\text { Group, Price River Forma- } \\
\text { tion, Blackhawk Formation, } \\
\text { Star Point Sandstone, Kai- } \\
\text { parowits Formation. }\end{array}$ & $\begin{array}{l}\text { Ojo Alamo Sandstone, McDer- } \\
\text { mott Formation, Kirtland } \\
\text { Shale, Fruitland Formation, } \\
\text { Pictured Cliffs Sandstone, } \\
\text { Lewis Shale. } \\
\text { Cliff House Sandstone, Menefee } \\
\text { Formation, Point Lookout } \\
\text { Sandstone, Crevasse Canyon } \\
\text { Formation, Gallup Sand- } \\
\text { stone. }\end{array}$ & $\begin{array}{l}\text { Yale Point Sandstone, Wepo } \\
\text { Formation and Toreva For- } \\
\text { mation in the Black Mesa } \\
\text { Basin, Crevasse Canyon For- } \\
\text { mation, Gallup Sandstone. }\end{array}$ \\
\hline \multicolumn{5}{|c|}{ Mancos Shale and other formations of related lithology } \\
\hline $\begin{array}{l}\text { Mancos Shale, Niobrara Forma- } \\
\text { tion. } \\
\text { Benton Shale............. }\end{array}$ & $\begin{array}{l}\text { Cody Shale, Hilliard Shale, } \\
\text { Blair Formation, Baxter } \\
\text { Shale. } \\
\text { Mowry Shale, Thermopolis } \\
\text { Shale, Bear River Formation, } \\
\text { Gannett Group. }\end{array}$ & $\begin{array}{l}\text { Frontier Formation, Wahweap } \\
\text { Sandstone, Tropic Shale, } \\
\text { Mancos Shale. } \\
\text { Aspen Shale, Straight Cliffs } \\
\text { Sandstone. }\end{array}$ & Mancos Shale... & Mancos Shale. \\
\hline \multicolumn{5}{|c|}{$\begin{array}{l}\text { HYDROLOGIC UNIT 4, PREDOMINANTLY CONTINENTAL ROCKS } \\
\text { Dakota and Morrison Formations and other formations of related lithology }\end{array}$} \\
\hline $\begin{array}{l}\text { Dakota Sandstone, Burro Can- } \\
\text { yon Formation. } \\
\text { Morrison Formation. }\end{array}$ & $\begin{array}{l}\text { Cloverly Formation...... } \\
\text { Beckwith Formation..... } \\
\text { Morrison Formation..... }\end{array}$ & $\begin{array}{l}\text { Dakota Sandstone, Burro Can- } \\
\text { yon Formation, Cedar Moun- } \\
\text { tain Formation. } \\
\text { Morrison Formation. }\end{array}$ & Morrison Formation..... & Morrison Formation. \\
\hline \multicolumn{5}{|c|}{ San Rafael Group in the Colorado Plateau province of Arizona, Utah, Colorado, and New Mexico } \\
\hline $\begin{array}{l}\text { Summerville Formation, Wane- } \\
\text { kah Formation, Curtis Forma- } \\
\text { tion, Entrada Sandstone. }\end{array}$ & Twin Creek Limestone..... & $\begin{array}{l}\text { Summerville Formation, Curtis } \\
\text { Formation, Entrada Sand- } \\
\text { stone, Carmel Formation, } \\
\text { Bluff Sandstone. }\end{array}$ & $\begin{array}{l}\text { Cow Springs Sandstone (not } \\
\text { part of the San Rafael } \\
\text { Group). Bluff Sandstone, } \\
\text { Summerville Formation, } \\
\text { Todilto Limestone, Entrada } \\
\text { Sandstone, Lukachukai } \\
\text { Member of the Wingate } \\
\text { Sandstone, Carmel Forma- } \\
\text { tion. }\end{array}$ & $\begin{array}{l}\text { Morrison Formation and Cow } \\
\text { Springs Sandstone (not part } \\
\text { of the San Rafael Group). } \\
\text { Summerville Formation, } \\
\text { Bluff Sandstone, Entrada } \\
\text { Sandstone, Carmel Formation. }\end{array}$ \\
\hline
\end{tabular}


TABLE 1.-Geologic formations in the Upper Colorado River Basin-Continued

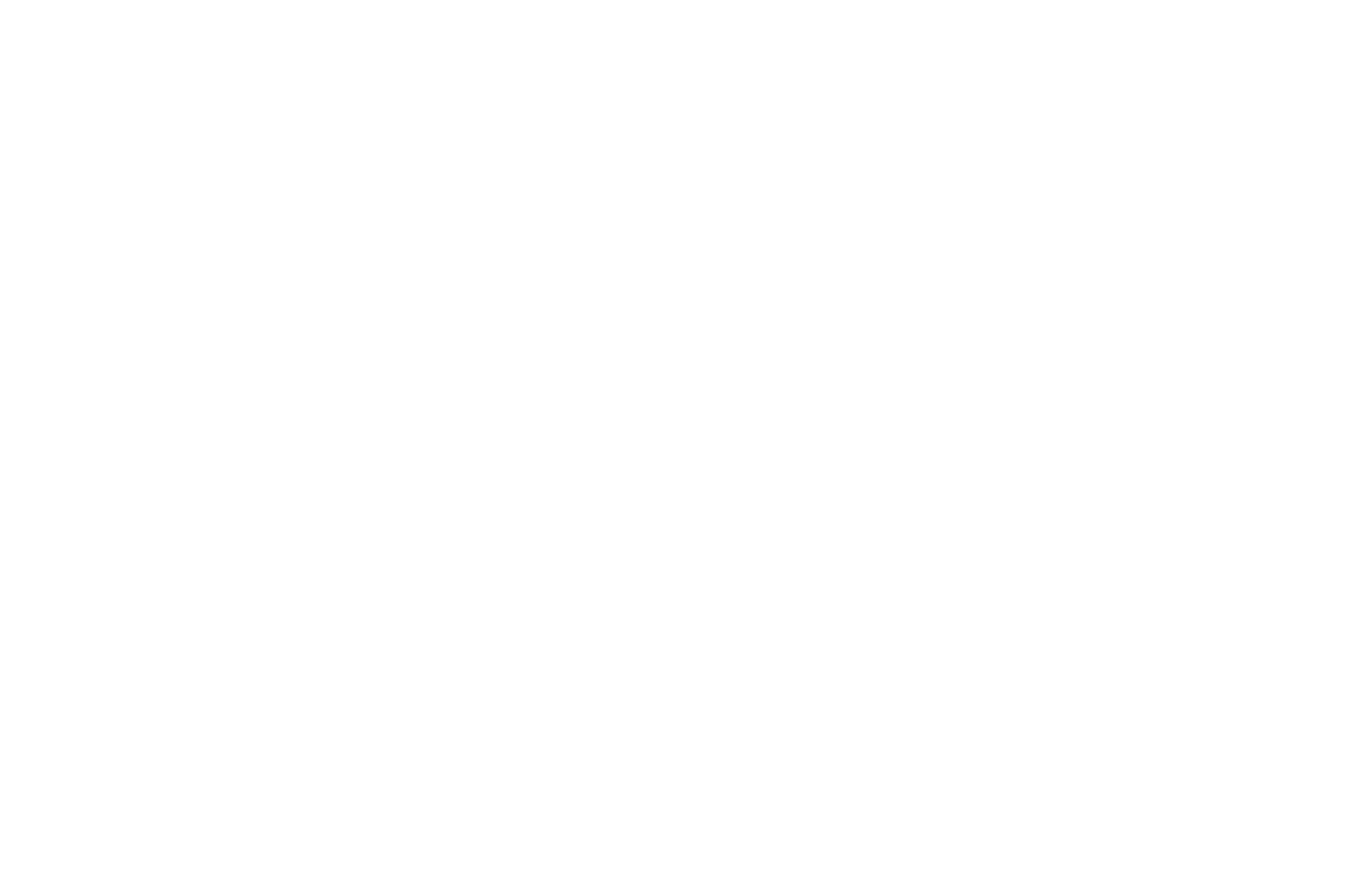

Formations of early Paleozoic, Devonian, and early Mississippian age

\begin{tabular}{|c|c|c|c|c|}
\hline $\begin{array}{l}\text { Leadville Limestone............ } \\
\text { Ouray Limestone, Elbert For- } \\
\text { mation, Chaffee Formation, } \\
\text { Manitou Formation, Dotsero } \\
\text { Formation, Ignacio Quartzite, } \\
\text { Sawatch Quartzite. }\end{array}$ & $\begin{array}{l}\text { Brazer Limestone, Madison } \\
\text { Limestone. } \\
\text { Three Forks Shale, Jefferson } \\
\text { Limestone, Darby Forma- } \\
\text { tion. }\end{array}$ & $\begin{array}{l}\text { Brazer Limestone, Madison } \\
\text { Limestone. } \\
\text { Devonian, Silurian, Ordovician, } \\
\text { and Cambrian rocks un- } \\
\text { divided. }\end{array}$ & & $\begin{array}{l}\text { Leadville Limestone (subsur- } \\
\text { face). } \\
\text { Ouray Limestone, Elbert For- } \\
\text { mation (subsurface). }\end{array}$ \\
\hline
\end{tabular}

HYDROLOGIC UNIT 7, IGNEOUS ROCKS

Extrusive igneous rocks

\begin{tabular}{|c|c|c|c|c|}
\hline $\begin{array}{l}\text { Basalt flows capping high } \\
\text { plateaus. }\end{array}$ & Basalt flows & $\begin{array}{l}\text { Basalt flows capping high } \\
\text { plateaus. }\end{array}$ & Basalt flows............... & Flow rocks locally. \\
\hline \multicolumn{5}{|c|}{ Intrusive igneous rocks } \\
\hline $\begin{array}{l}\text { Sills, laccoliths, plugs, and dikes } \\
\text { chiefly in La Plata, Ute, San } \\
\text { Juan Mountains. }\end{array}$ & & $\begin{array}{l}\text { Chiefly laccoliths in the Henry, } \\
\text { Abajo, and La Sal Mountains. }\end{array}$ & Scattered diatremes, dikes...-... & Scattered diatremes, dikes. \\
\hline
\end{tabular}

\section{HYDROLOGIC UNIT 8, IGNEOUS AND METAMORPHIC ROCKS}

Precambrian complex

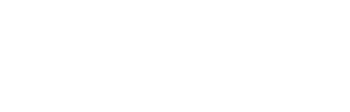

Chiefly granite with minor amounts of metamorphic Metamorphic and plutonic rocks.

Metamorphic and plutonic Group, Needle Mountains rocks.

\begin{tabular}{l|l}
\multicolumn{1}{l|}{ rocks. } & rocks. \\
Uinta Mountain Group & \\
\end{tabular}


Bishop (Oligocene or Miocene), Chuska (Pliocene?), and Bidahochi (Pliocene) Formations. The older rocks are predominantly lacustrine and fluviatile. They consist of marl, siltstone, and fine-grained sandstone interbedded with diatomite, limestone, evaporite, oil shale, and trona and related saline minerals. The younger rocks are principally lenticular deposits of coarse sand and conglomerate. In part, the younger rocks are lacustrine and fluviatile and, in part, glacial and fluvioglacial.

In Wyoming, Utah, and Colorado, the Green River and many of its tributaries flow for long distances over these rocks. In other parts of the Upper Colorado River Basin the rocks occur below altitudes of 7,000 feet in an arid to semiarid region, and direct runoff is not large. About 30 percent, or 34,000 square miles, of the basin is underlain by these rocks.

\section{HYDROLOGIC UNIT 1, UNCONSOLIDATED} CONTINENTAL DEPOSITS

Unit 1 consists of all unconsolidated material mantling the consolidated rocks. This material is classed as residuum and alluvium. Residuum consists of products of rock weathering that have accumulated faster than they can be removed by water and wind. Material of this type mantles hillsides and tops of mesas and plateaus. Alluvium consists of products of rock weathering and erosion that have been transported and deposited by water. Hunt $(1956$, p. 72$)$ estimated that unconsolidated deposits cover bedrock in about 75 percent of the Henry Mountains region of southeastern Utah. This estimate probably applies to the entire Upper Colorado River Basin. Much of these deposits are very thin, but in some areas, especially in the valleys, they may be thick.

River and glacial alluvium, which cover an estimated 1,200 square miles, or less than 1 percent, of the basin, are shown on the hydrologic map (pl. 1). The deposits of residuum are not shown on the map but are estimated to cover about three-fourths of the basin, or 82,000 square miles.

\section{PHYSIOGRAPHIC AND STRUCTURAL FEATURES}

The plateaus and mountains that form the boundaries of the Upper Colorado River Basin and the highlands in the interior are a series of uplifted earth masses deeply dissected by erosion, by glaciation, and by weathering. Between the intersecting mountain ranges in the interior of the basin are plateaus, mesas, and broad basins, some gently rolling and others deeply carved by erosion.

Long before the earth movements that created the present mountains started, the area was the scene of alternate encroachment and retreat of great inland seas. The sedimentary material that accumulated and was not subsequently removed by erosion during the periods when the land stood above the seas is represented by the sedimentary rocks that underlie much of the basin. These rocks are thousands of feet thick and range in attitude from sharply tilted around the mountains to nearly horizontal in the interior. These events took place during the Paleozoic and Mesozoic Eras.

Earth movement that formed the present mountains began in the Mesozoic and continued into the Cenozoic Era. These movements formed the ancestral Rocky Mountains and started regional downwarps, which culminated in at least six large structural basins. These basins received thick deposits of sediment eroded from the highlands. During middle Cenozoic time streams began to downcut into the Cenozoic and older Paleozoic and Mesozoic rocks. Continuous erosion since middle Cenozoic time has produced the present topography.

The topography and stream system divide the area into three major drainage systems, referred to in this report as "divisions." The divisions are designated the Grand, the Green, and the San Juan. The Grand division is the drainage basin of the Colorado River above the Green River. The Green division is the drainage basin of the Green River. The San Juan division is the drainage basin of the Colorado River below the Green River and above "Lee Ferry," Ariz. (fig. 2).

\section{CLIMate}

The climate of the Upper Colorado River Basin is due more to the influence of mountain ranges on the movement of air masses than to latitude. The high mountains are comparatively wet and cool, whereas the plateaus and lower mountains are dryer and are subject to wide ranges of temperature. The interior valleys at lower altitudes are hot and dry in the summer and cold in the winter.

Moist Pacific airmasses can move across the entire basin. Dry polar air from the north and moist tropical air from the south move into the basin at times, but rarely continue all the way across. Movement of both types of airmasses is obstructed and deflected by the encircling mountains so that their interactions and effects within the basin are weaker and more erratic than airmasses in most other parts of the United States.

The Pacific Ocean and the Gulf of Mexico, whose nearest coastlines are 600 and 1,000 miles, respectively, from the center of the basin, provide most of the moisture for precipitation. Airmasses moving in from these sources are pushed up to high altitudes and lose much of their moisture before they enter the basin. 


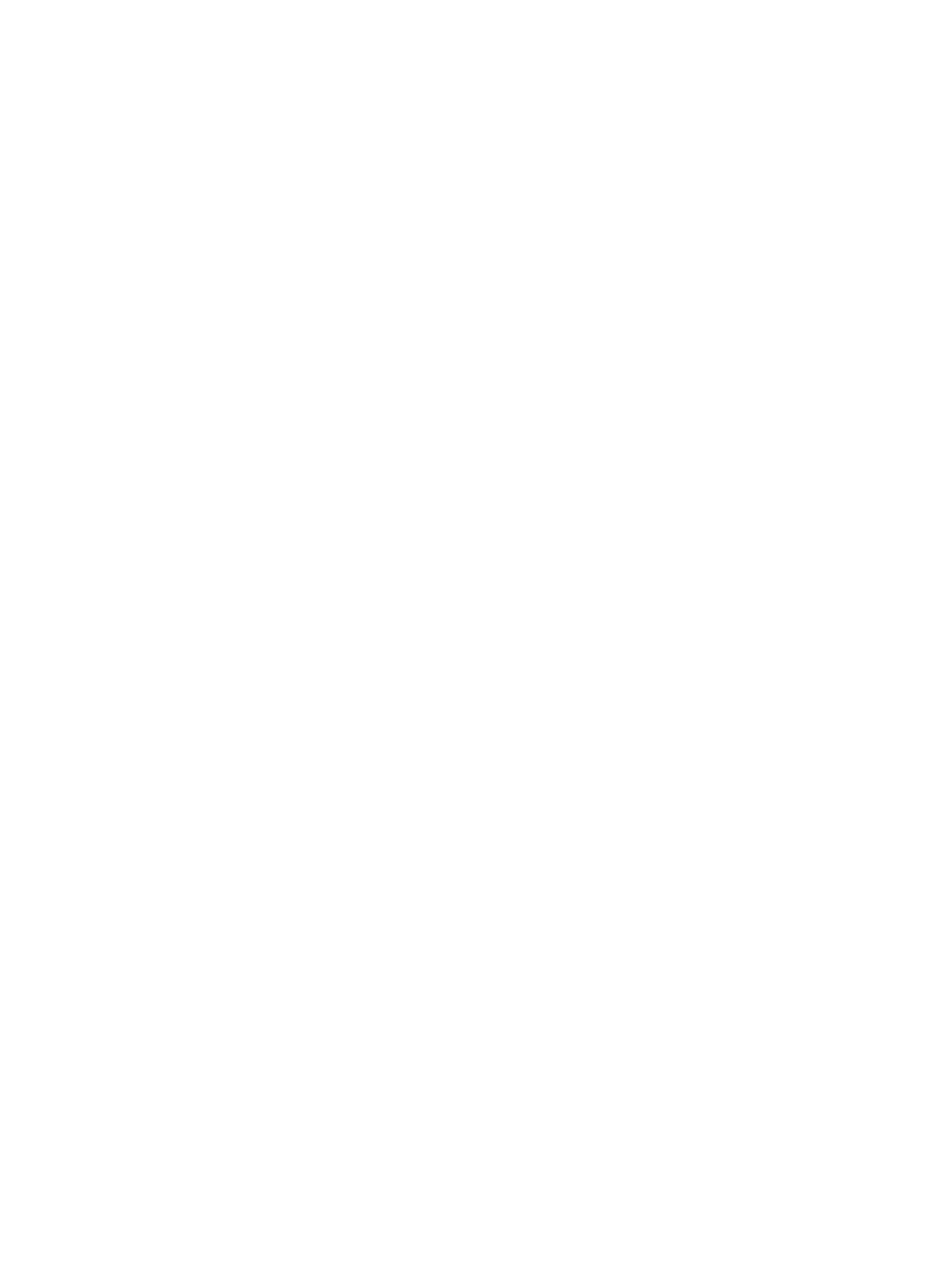

Figure 2.-Divisions and subbasins in the Upper Colorado River Basin. 
Generally, from about October through April, airmasses from the Pacific Ocean dominate. During the late spring and summer a large part of the basin receives precipitation from moisture that originates in the Gulf of Mexico.

Figure 3 shows monthly precipitation and average monthly temperature at 11 weather stations in the upper basin. Except in the southern part, the monthly precipitation is greater in the winter than during the remainder of the year. The effects of altitude and latitude on the average annual temperature are noticeable.

The average annual precipitation ranges from less than 6 inches in the arid parts of the basin to more than 60 inches in parts of the Wind River Range and San Juan Mountains (pl. 1).

Table 2 gives the areal distribution of average annual precipitation (calendar years 1921-50) in the Upper Colorado River Basin. The average annual precipitation was 15.88 inches on the basis of precipitation computed from this tabulation is 15.97 inches. For water years 1914-57 the average annual precipitation at 46 stations for calendar years 1921-50 and water years 1914-57. Precipitation of 15.88 inches on 109,500 square miles is equivalent to $92,739,000$ acre-feet of water.

Average annual lake evaporation generally ranges from 28 to 60 inches. The average annual evaporation from water surfaces in the basin is about 575,000 acrefeet (table 3).

\section{POPULATION}

The population of the Upper Colorado River Basin is about 335,600 (1960 census), which is only about $61 / 2$ people per square mile. Approximate distribution of the population is Colorado, 170,000; Wyoming, 33,100; Utah, 69,000; New Mexico, 59,000; and Arizona, 4,500.

TABLE 2.-Areal distribution of precipitation in the Upper Colorado River Basin, calendar years 1921-50

\begin{tabular}{|c|c|c|}
\hline \multirow{2}{*}{ Precipitation range (inches) } & \multicolumn{2}{|c|}{ Area } \\
\hline & Square miles & $\begin{array}{c}\text { Percent of } \\
\text { total }\end{array}$ \\
\hline $\begin{array}{l}60-70 \\
50-60 \\
40-50 \\
250 \\
200\end{array}$ & $\begin{array}{r}46 \\
374 \\
1,815 \\
7,271 \\
6,906 \\
9,071 \\
13,911 \\
23,634 \\
15,201 \\
15,417 \\
14,126 \\
1,728\end{array}$ & $\begin{array}{r}\text { 0. } 04 \\
\text { 1. } 34 \\
\text { 6. } 64 \\
\text { 6. } 31 \\
\text { 8. } 28 \\
\text { 12. } 70 \\
\text { 21. } 59 \\
\text { 13. } 88 \\
\text { 14. } 08 \\
\text { 12. } 90 \\
\text { 1. } 58\end{array}$ \\
\hline Total & 109,500 & 10000 \\
\hline
\end{tabular}

TABLE 3.-Average annual evaporation, in acre-feet, from water surfaces in the Upper Colorado River Basin

[After Meyers (1962)]

Principal reservoirs and regulated lakes........... 83,000 Other lakes more than 500 acres. . . . . . . . . . . 16, 000

Principal streams and canals _... . . _ _.

Small ponds and reservoirs................... 217, 000

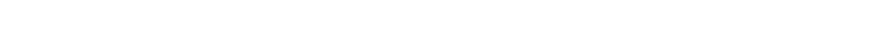

Total

575,000

The five largest communities and their populations are Farmington, N. Mex., 23,786; Grand Junction, Colo., 18,694; Durango, Colo., 10,530; Rock Springs, Wyo., 10,371; and Price, Utah, 6,802. Rock Springs, Wyo., the only large community not on a major tributary of the Colorado River, is one of the few that does not depend on farming and ranching to support most of its population. Railroad, mining, and oil industries employ many of the people of Rock Springs. However, a shutdown of the mines has resulted in some decrease in population. The population of other towns in which people depend heavily on mining has decreased. On the other hand, some communities such as Farmington, N. Mex., have had large increases in population. Farming and stock raising, however, occupy people throughout the basin and contribute to a fairly stable economy and a uniform population growth.

\section{ORGANIZATION OF THE REPORT}

To facilitate the presentation of data and appraisal of the surface water resources of the Upper Colorado River Basin, a technical report and a basic-data report have been prepared.

This, the technical report, is composed of five chapters. The first chapter contains the introduction and summary; the second explains the techniques and criteria used in appraising the surface-water resources; and the third, fourth, and fifth discuss the surfacewater resources of the Grand, Green, and San Juan divisions, respectively. In the last three chapters the divisions are further subdivided into subbasin units (fig. 2), so that the effects of climate, topography, geology, vegetation, and the activities of man on the surface-water resource may be identified locallly.

The basic-data report (Iorns and others, 1964) contains tables of duration of water discharge, monthly and annual summaries of chemical-quality and sediment data obtained at sites of continuous record, results of chemical-quality and sediment analyses at other sites, data on the chemical quality and other characteristics of ground water, a map showing location of surface- and ground-water sampling sites, and isohyetal maps of normal seasonal and annual precipitation. 

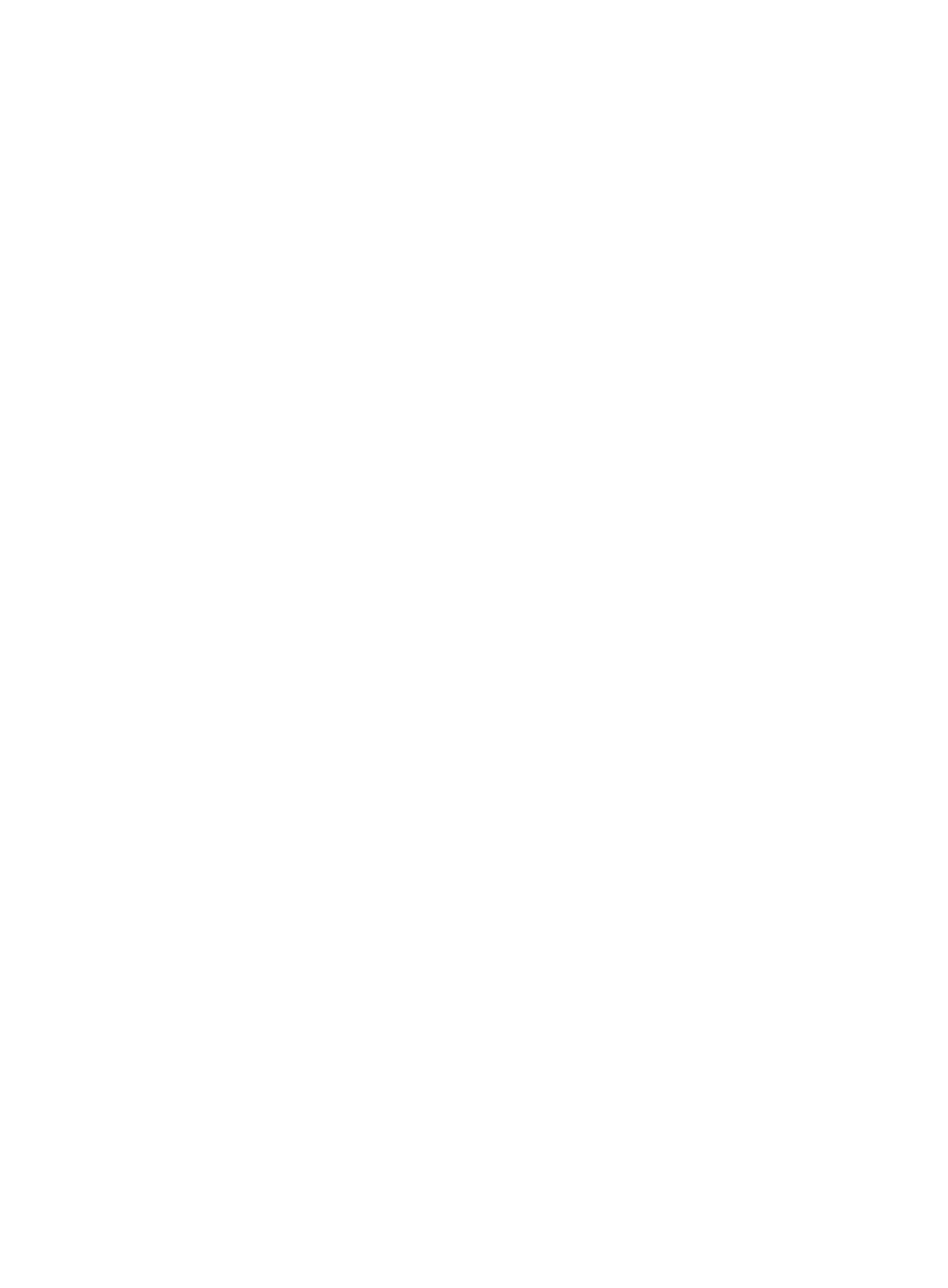

FigURE 3.-Normal precipitation and temperature and frost-free seasons at representative stations $\mathrm{n}$ the Upper Colorado River Basin. Data from U.S. Weather Bureau normals (average calendar years, 1921-50). 
PREVIOUS INVESTIGATIONS AND REPORTS

The water resources of the Upper Colorado River Basin, and plans for their development have been the subjects of several reports by the U.S. Geological Survey and the U.S. Bureau of Reclamation. Some of these reports discussed only parts of the Upper Colorado River Basin. Others dealt with much larger areas. All the reports, the first of which was published in 1916, were based on water-resources data available at the time of preparation. In addition, other Federal bureaus and State and other organizations have occasionally published reports relating to the water resources of the area. Notable among those pertaining to the Upper Colorado River Basin are the reports of the State Engineers of Colorado, Wyoming, Utah, New Mexico, and Arizona, and annual reports of the Upper Colorado River Commission.

The following reports relate principally to the surface waters of the basin and deserve special mention:

Colorado River and its Utilization, E. C. La Rue, 1916: U.S. Geol. Survey Water-Supply Paper 395.

Water Power and Flood Control of the Colorado River below Green River, Utah, E. C. La Rue, 1925 : U.S. Geol. Survey Water-Supply Paper 556.

Upper Colorado River and its Utilization, Robert Follansbee, 1929: U.S. Geol. Survey Water-Supply Paper 617.

The Green River and its Utilization, Ralf R. Wooley, 1930 : U.S. Geol. Survey Water-Supply Paper 618.

The Colorado River, U.S. Department of the Interior, 1946 : U.S. 80th Cong., 1st sess., H. Doc. 419.

Final Report of the Engineering Advisory Committee to Upper Colorado River Basin Compact Commission, 1948: Upper Colorado River Basin Compact Comm.

The Colorado River, Ten Rivers in America's Future: Rept. of the President's Water Resources Policy Comm., 1950, v. 2.

Colorado River Storage Project, U.S. Bureau of Reclamation, 1954, 83d Cong., 2d sess., H. Doc. 364.

Water Utilization in the San Juan River Basin, by E. C. La Rue. This is an unpublished report, available for public inspection in the offices of the Geological Survey in Washington, D.C., and Denver, Colo.

In addition, chapters of this report cite other references which contain information on the surface-water resources.

\section{ACKNOWLEDGMENTS}

The precipitation maps were prepared by E. L. Peck, Hydrologist in charge, Water Supply Forecast Unit, and M. J. Brown, State Climatologist, both of U.S. Weather Bureau, Salt Lake City, Utah.
J. S. Meyers prepared tables of precipitation for the 46 index stations. The vegetation maps were prepared by F. A. Branson.

D. A. Phoenix participated in the study and prepared a report on the geology, ground-water provinces, and occurrence and chemical quality of ground water. The hydrologic maps, ground-water data, and listing of formations in the eight hydrologic units given in this report were obtained from the report prepared by Phoenix.

The authors have benefited greatly from suggestions made by colleagues in the Geological Survey. An early draft of the report was reviewed by C. H. Hardison and B. R. Colby. A. M. Piper reviewed a later draft and L. B. Leopold, E. L. Hendricks, S. K. Jackson, T. G. McLaughlin, F. C. Ames, F. M. Bell, and W. D. E. Cardwell reviewed one or more chapters. The counsel and criticism of these colleagues have contributed greatly to the report.

For their work in compiling and computing data, the authors gratefully acknowledge the assistance of J. M. Knott, D. C. Hahl, Afton Wright, L. L. Stewart, M. E. Young, N. D. Thornton, P. A. Davies, Betty Owens, A. H. Beers, R. K. Glanzman, D. L. Haney, T. A. Pudlewski, I. B. Droz, T. A. Holt, G. M. Baxter, F. J. Sidlauskas, Jr., J. R. Brochu, L. B. Salazar, J. L. Bird, and E. K. Maurer.

\section{SUMMARY \\ WATER UTILIZATION}

The surface waters in the Upper Colorado River Basin are used for domestic, industrial, and municipal purposes, including the dilution of sewage and industrial wastes, irrigation, watering of livestock, production of hydroelectric power, preservation of fish and wildlife, and recreation. Water is also exported for use in adjoining basins. These uses of water by man have resulted in changes in the natural regimen of many of the streams in the basin.

The major use of water is for irrigation. In 1957 about 1,413,000 acres of land was irrigated (table 4). Most of the irrigated lands have been developed by private enterprise; however, Bureau of Reclamation projects furnish water for about 270,000 acres (including some previously irrigated lands on which supplemental water is supplied). In addition, the Bureau of Indian Affairs operates five projects totaling about 93,000 acres on Indian reservations (President's Water Resources Policy Comm., 1950, p. 365).

The average annual irrigation consumptive use of water has been estimated to be 1,769,100 acre-feet (Upper Colorado River Basin Compact Comm., 1948). Several times this amount is diverted from the streams, 
applied to the lands, and-except for the amount used consumptively - is returned to the streams.

Ninety-two storage reservoirs each having capacities greater than 1,000 acre-feet had been constructed in the basin by 1957. The combined capacity of these reservoirs, which were constructed to utilize more of the water supply, is about $1,635,000$ acre-feet. Of the total capacity, about 738,000 acre-feet is primarily used to provide water for irrigation, domestic, and industrial uses within the Upper Colorado River Basin. The rest of the stored water is primarily for export or is used to supplement the water supply in the basin at times when transmountain diversions reduce the flow of the streams to the point that prior rights are affected.

An average of about 468,400 acre-feet of water was being exported annually in 42 transmountain canals and tunnels as of 1957. Part of this water was used in Colorado, east of the Continental Divide, and part was used in the Great Basin of Utah. One canal in Wyoming also diverts water across the Continental Divide from the Green River basin. An average of about 2,600 acre-feet is annually imported through one diversion into the Upper Colorado River Basin from the Great Basin. Figure 4 shows the increase in

TABLE 4.-SUmmary data on utilization of surface water in the Upper Colorado River Basin, 1957

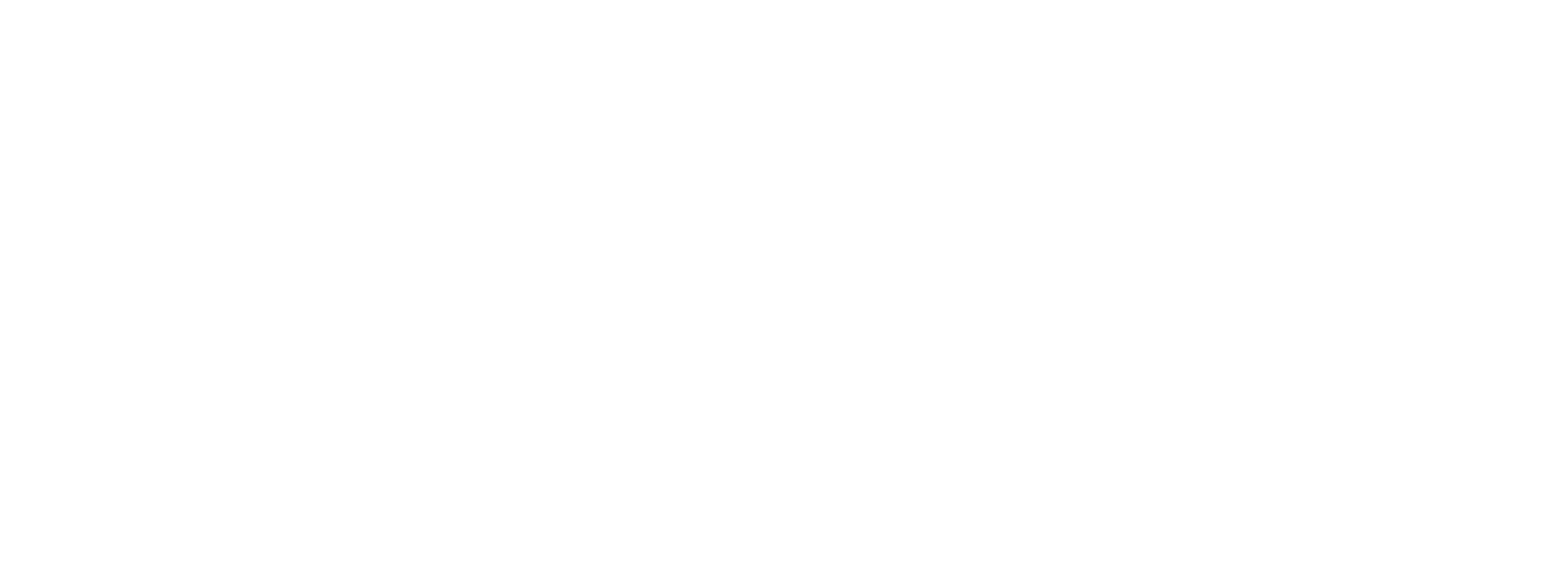

1 Of the 44 transmountain diversions, 42 exported water out of the basin, 1 imported water into the basin, and 1 transported water between divisions of the basin.

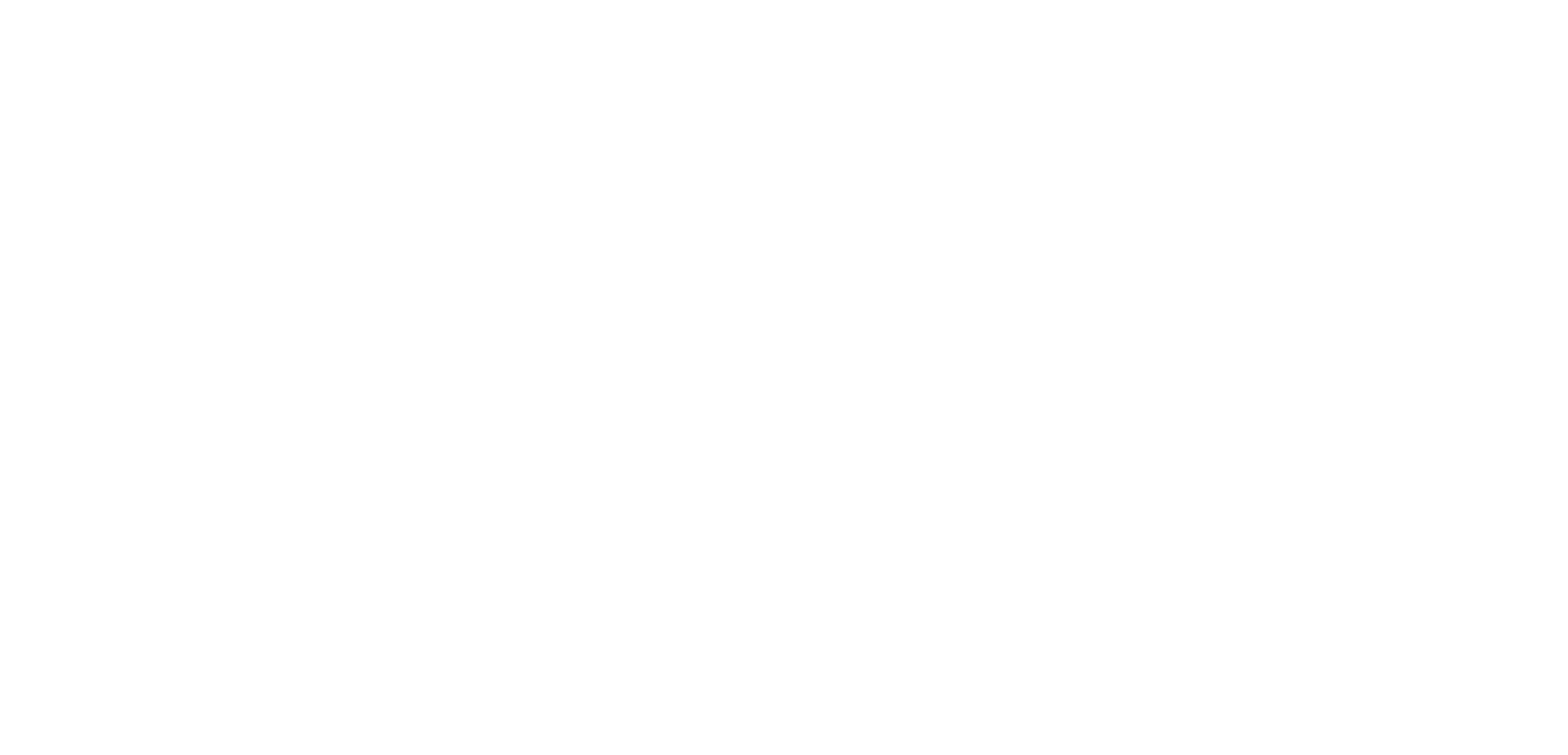

FiguRE 4.-Annual transmountain diversions in Colorado and Utah from the Upper Colorado River Basin, water years 1914-57. 
transmountain diversions in Colorado and Utah since 1914.

Consumption of water by domestic and industrial uses is estimated to average about 22,600 acre-feet annually (1957). The total amount of water withdrawn for this purpose is several times the amount consumed.

In the basin, 25 hydroelectric powerplants have a total installed capacity of about 55,410 kilowatts. No data are available on the amount of water passed through the turbines in the production of hydroelectric power.

\section{WATER SUPPLY}

Streamflow in the Upper Colorado River Basin varies from day to day, month to month, and year to year. The annual hydrographs in figure 5 illustrate daily and monthly variations in discharge at four gaging stations, and figure 6 illustrates the yearly variations at the same stations for water years 1914-57.

Most of the water supply comes from the mountains where precipitation is abundant. During the winter the precipitation in the mountains is mostly snow, which in places accumulates to great depths. As temperatures rise in the late spring and early summer, the snow melts rapidly causing the streams to rise and then subside as the stored supply of snow is exhausted. Usually by late July, the perennial streams that flow from the mountains have subsided to a base flow, which generally prevails until the snowmelt period begins the following spring; then the cycle is repeated.

Precipitation in the mountains during the summer does not contribute much water to the streams; native vegetation consumes most of it.

Large areas in the interior of the basin, where precipitation is low, contribute little water to the streams. About 77 percent of the basin receives an average annual precipitation of less than 20 inches, and 42 percent receives less than 12 inches. Many of the tributary streams that drain the interior areas are dry most of the time, and water flows in them only after infrequent storms.

If records of streamflow had been obtained before and after the activities of man began in the basin, the magnitude of the change in stream regimen caused by man's use of water could be determined accurately; however, man's use of water in the basin was far advanced before collection of records began. Although precise determinations cannot be made, many useful appraisals of man's effect and the effects of natural environmental factors on the streams can be determined from available data.

For the appraisal, the streamflow records for the period October 1, 1913, to September 30, 1957, were adopted as being indicative of the long-term water supply. During this period water-use development in- creased, which decreased the flow of some streams. To have a common base for comparisons of streams, the level of development in 1957 was adopted for the report. This common base is useful for comparing streams that have different environments and for appraising the magnitude of changes in streamflow and chemical quality of water caused by the activities of man. Where upstream water use changed during the base period (1914-57), the streamflow records were adjusted to be representative of what would have occurred had the water-use developments existing in 1957 been in operation throughout the 1914-57 period.

Flow-duration curves, which show the percentage of time that water discharges of various magnitude have been equaled or exceeded during the 44-year base period, were computed for many streams from the headwaters to "Lee Ferry." At sites where upstream water use had resulted in changes in stream discharge during the base period, the curves were adjusted to be representative of the level of upstream use in 1957. Flowduration curves for four streams are shown in figure 7. The data for these and other curves for selected gaging stations are given in table 5. Similar flow-duration curves and tables were computed for many other sites. By arithmetically integrating the area under the flowduration curves, the average water discharge for the period represented by the curve may be determined.

The shape and slope of the flow-duration curves for many streams were used to study and compare the effects of drainage environmental factors on stream behavior. The curves for snowmelt streams, when plotted on logarithmic-probability paper, tend to have a flat slope at the upper end and a fairly steep slope in the central part. The effects of dense vegetation tend to flatten, whereas the effects of sparse vegetation tend to steepen the top part of the curve. Flow-duration curves for streams draining areas underlain by permeable rocks tend to have a relatively flat slope because part of the precipitation infiltrates to ground-water reservoirs. These reservoirs maintain the flow during periods of low flow. If the drainage basin is underlain by relatively impermeable rocks, the lower part of the curve is steep.

In the mountains, ground water and surface water are closely related. Here, precipitation is abundant, and where the formations are permeable, there is ample opportunity for recharge of ground-water reservoirs. Because most streams in the mountains are deeply incised, most ground-water reservoirs are effluent to the streams at all times and sustain them during periods of low flow. Ground-water contribution to the streams, expressed as a percentage of the total water discharge, is an indication of the relative premeability of the rocks underlying the drainage basin. For example, 11 


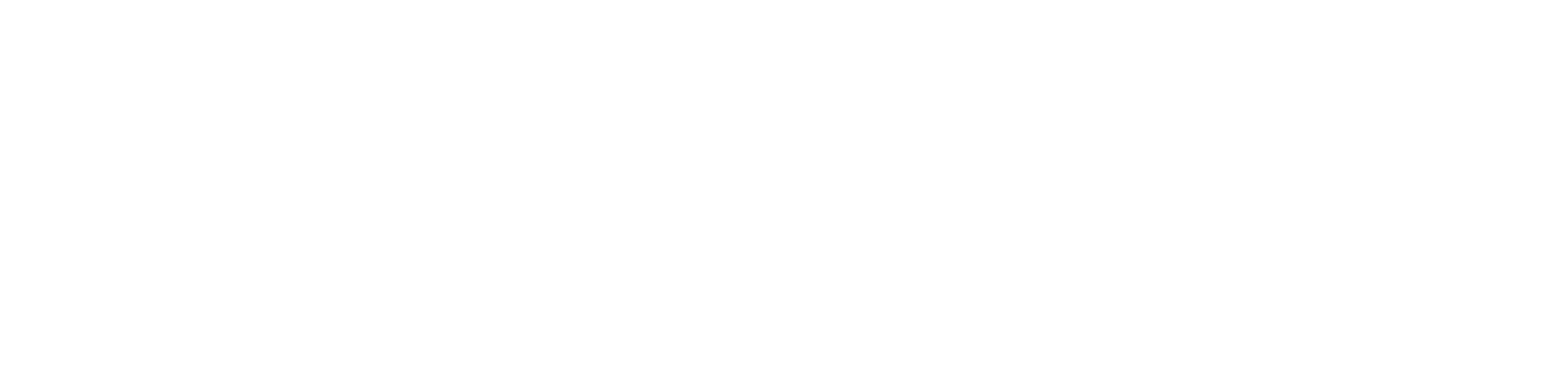

$A$. Colorado River at Glenwood Springs, Colo.
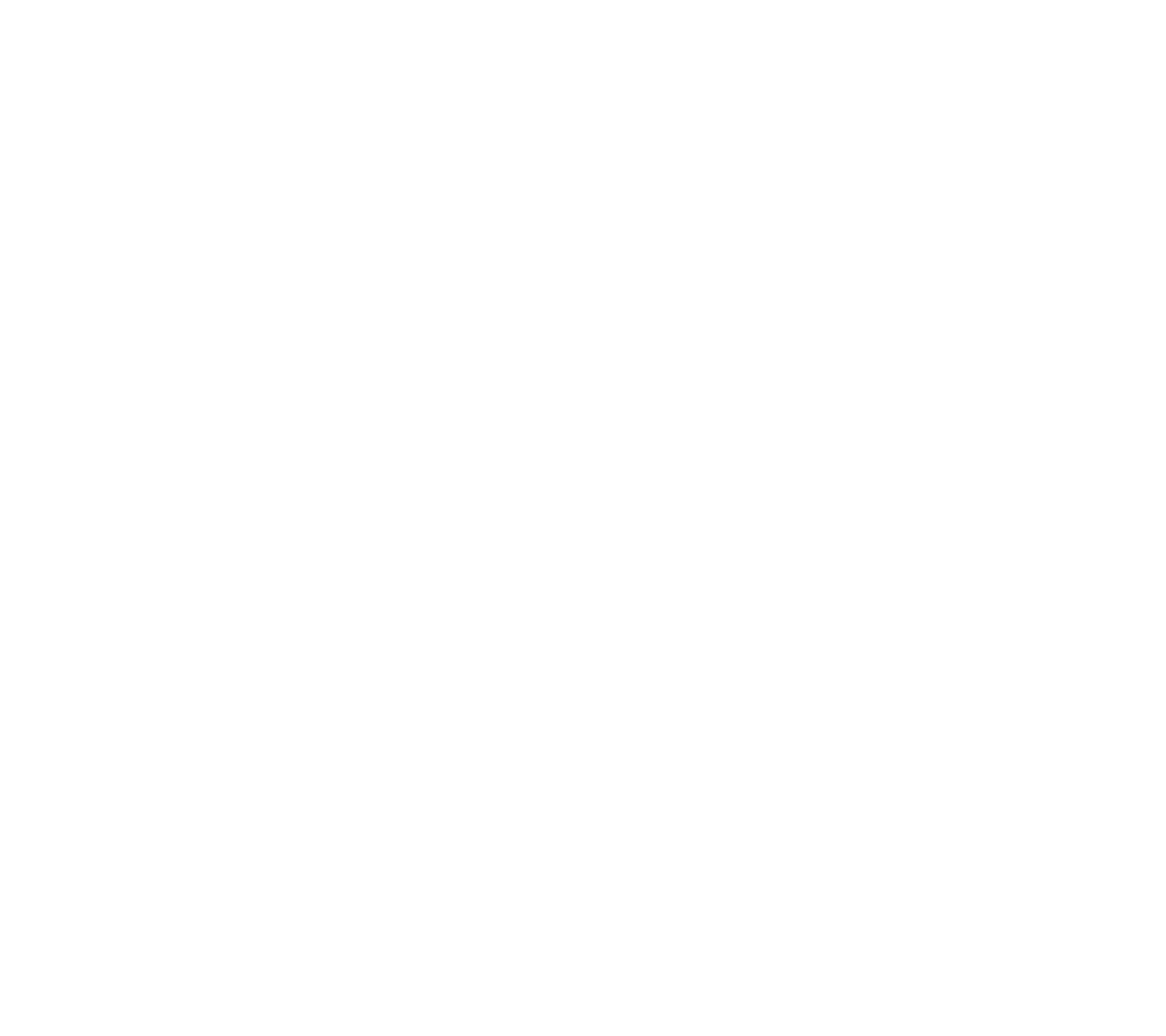

FigURE 5.-Seasonal pattern of streamflow for selected streams in the Upper Colorado River Basin, 1954 water years. 

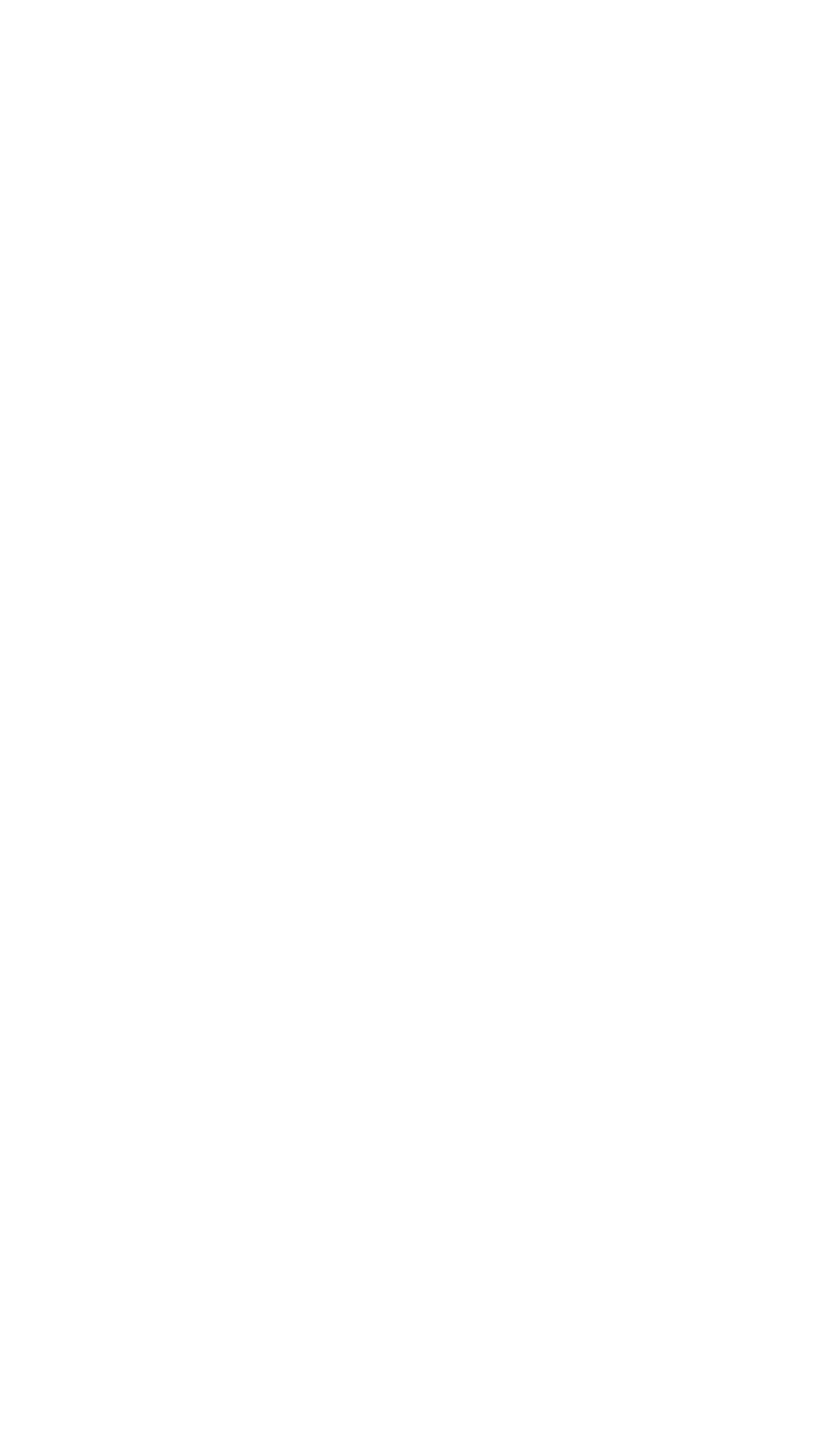

FIGURE 6.-Variability of annual discharges of selected streams in the Upper Colorado River Basin, water years 1914-57 adjusted to 1914 base. 
INTRODUCTION AND SUMMARY
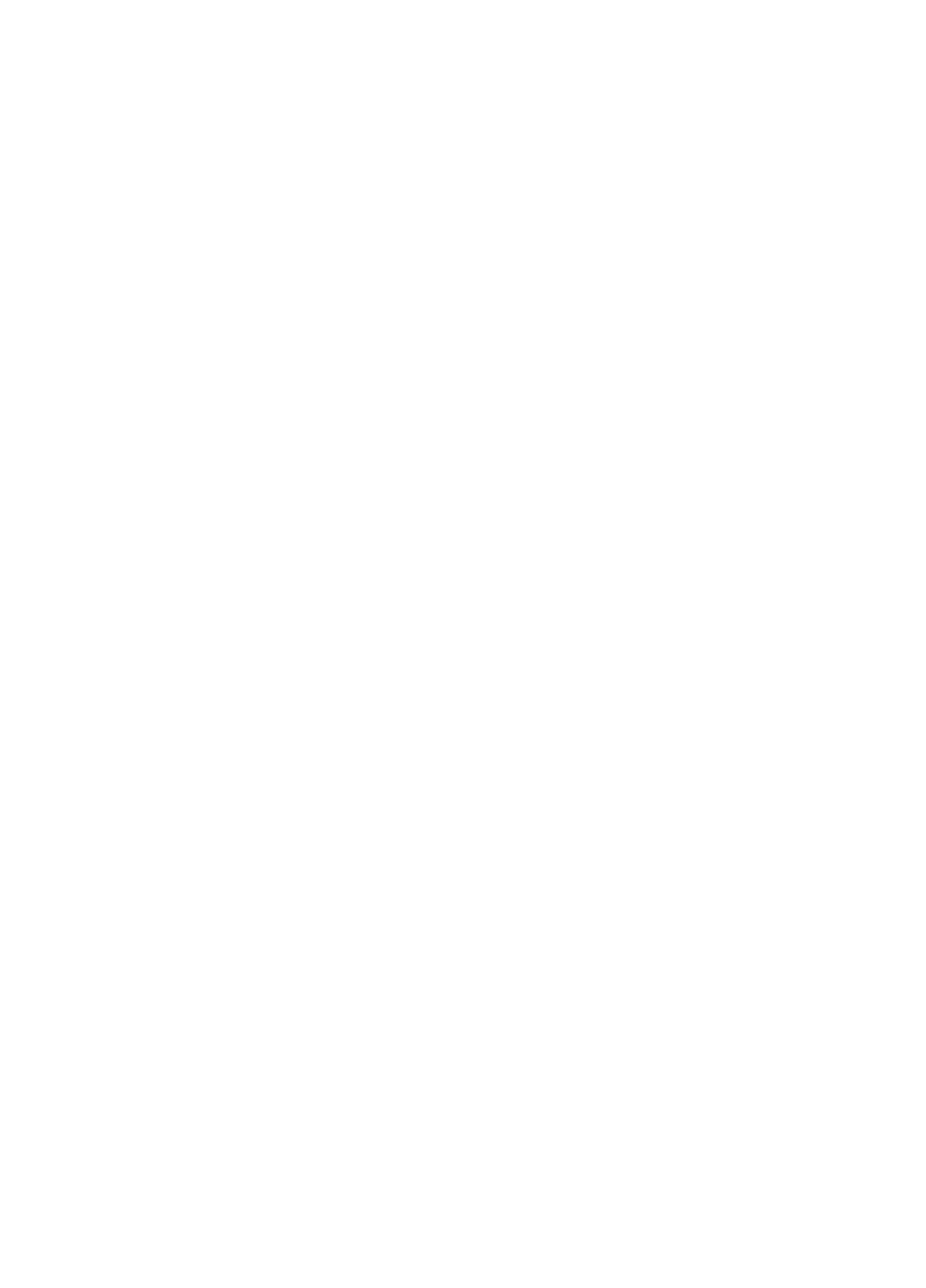

FIGURE 7.-Flow-duration curves for selected streams in the Upper Colorado River Basin, water years 1914-57 adjusted to 1957 conditions. 


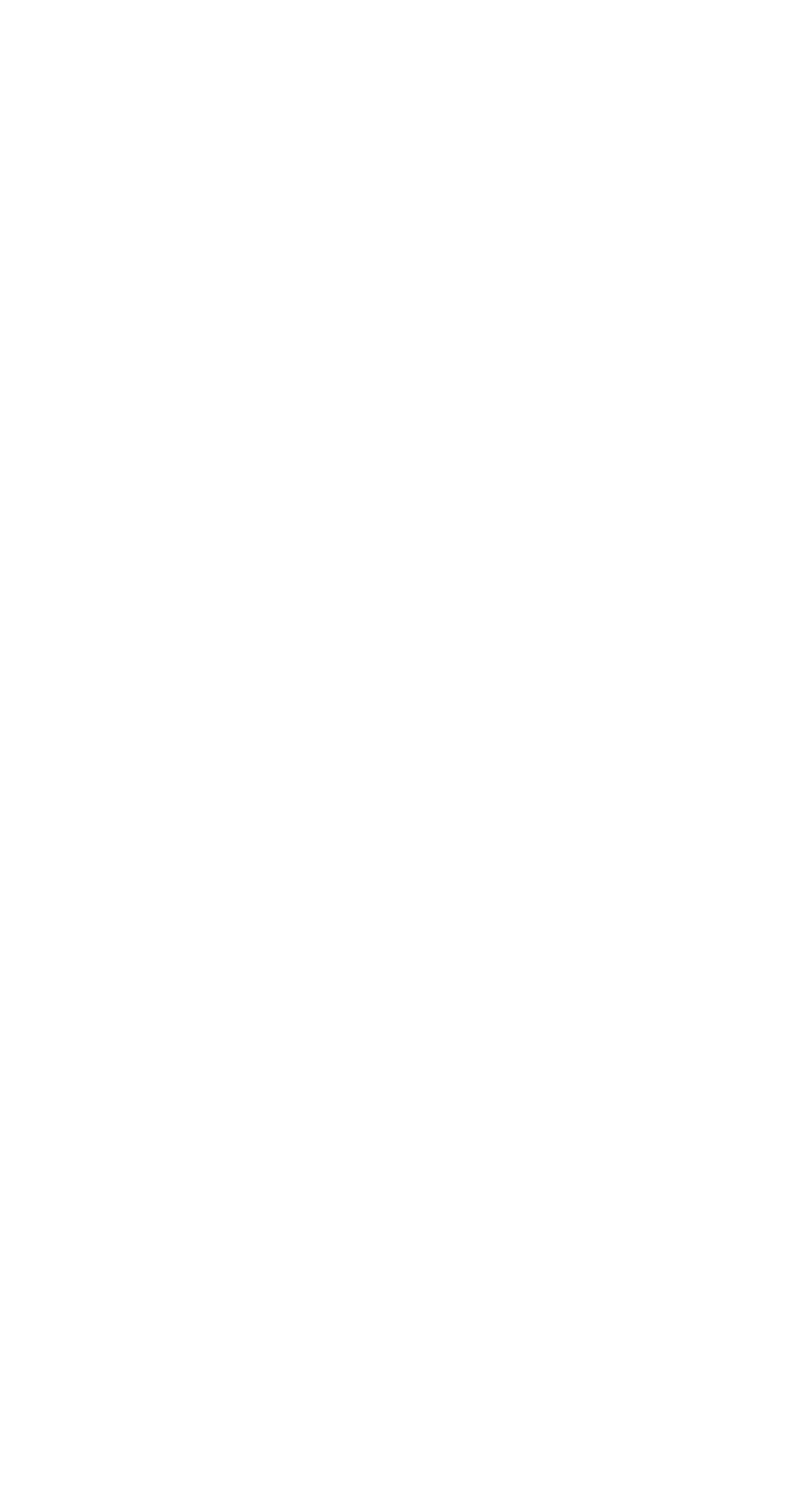


percent of the water discharge of Homestake Creek near Red Cliff, Colo., is base flow contributed largely by ground water. This drainage basin is underlain by Precambrian rocks that are relatively impermeable but are broken by joints and faults through which water may enter and circulate. However, the intake rate, capacity of the openings, and rate of release to the stream system are small. A contrasting example is Gypsum Creek near Gypsum, Colo. Of the total water discharge at this station, about 66 percent is base flow, largely from ground water. The drainage basin of Gypsum Creek is underlain by rocks and Pennsylvanian and Permian age. They consist of conglomerate, sandstone, some limestone, and shale beds interbedded and interspersed with gypsum. These rocks weather deeply and are relatively permeable.

Yearly variations in stream discharge, except where modified by the activities of man, are principally the result of differences in annual precipitation. However, the geologic environment considerably modifies the annual variations in the discharge of some streams, principally through carryover storage in ground-water reservoirs. Coefficient of variation (ratio of standard deviation of annual discharges to the average discharge) is a statistical measure of the annual variability of streamflow. Perennial headwater streams, whose source of supply is principally snowmelt, have a relatively narrow range in coefficients of variation, from about 0.25 to about 0.38 . However, in some drainage basins the coefficients greatly exceed this range because of low permeability and structure of the underlying rocks. Where the rocks are relatively permeable and extensive ground-water reservoirs are present, the coefficient is as low as 0.18 . Where the rocks are relatively impermeable, the coefficient is as high as 0.60 . Intermittent streams that flow only in response to infrequent thunderstorms have high coefficients, usually about 0.80 .

By considering geographic location, character of underlying rocks, and the coefficients of variation of streams having a similar environment, one can estimate the variability of annual discharge for many streams that have relatively short periods of record.

\section{WATER BUDGET}

Table 6 gives an approximate water budget for the Upper Colorado River Basin. The budget is based on the assumption that no water moves from the basin by ground-water underflow. The irrigation consumptive use was compiled by the Upper Colorado River Basin Compact Commission (1948). The total average annual precipitation supply is $92,739,000$ acre-feet, which is equivalent to an average annual precipitation over the basin of 15.88 inches. All the precipitation supply not accounted for by outflow from the basin, by transmountain diversions (less imported water), and by consumptive use due to the activities of man is considered to be evapotranspiration from the land surface and native vegetation.

\section{TaBle 6.-Water budget, Upper Colorado River Basin}

Average annual (acre-ft)

Outflow from the basin

$12,733,100$

Transmountain diversions exporting water

Transmountain diversion importing water........

468,400

Irrigation consumptive use _._.

Domestic and industrial consumptive use ........

Evapotranspiration

$1,769,100$

22,600

Total

$92,739,000$

1 Includes 575,000 acre-ft estimated evaporation from water surfaces.

\section{CHEMICaL QUALITY OF WaTER}

DISSOLVED-SOHIDS DISCHARGE AND CONCENTRATION

Water and dissolved-solids discharge and weightedaverage concentration of dissolved solids at selected sites in the Upper Colorado River Basin are given in table 7. These data represent the long-term average that would have occurred if the water-use developments in 1957 had been in operation throughout water years 1914-57. Similar data at many other sites were also computed.

The water and dissolved-solids discharge at the sites listed in table 7 expressed as a percentage of the combined water and dissolved-solids discharge of Colorado and Paria Rivers at Lees Ferry, Ariz. (outflow from the Upper Colorado River Basin) are given in figure 8 . The precision of the percentages varies, and the last figure of the values shown in figure 8 may not be trustworthy for some stations. Comparison of the percentages at the different sites shows that most of the water comes from the mountains and high plateaus, but most of the dissolved-solids content comes from the lower parts of the basin. Here, precipitation is low and relatively little water is contributed to the streams. The rocks exposed in the mountains are generally much more resistant to the solvent action of water than the rocks that underlie a large part of the lowlands.

The Grand division, though the smallest in drainage area of the three divisions, contributes more water and dissolved solids than either of the other two divisions. About 44 percent of the water and 48 percent of the dissolved solids at "Lee Ferry," Ariz. (combined water and dissolved solids of Colorado and Paria Rivers at Lees Ferry) come from the Grand division $(26,500$ sq $\mathrm{mi})$, about 37 percent of the water and 33 percent of the dissolved solids come from the Green division $(44,700 \mathrm{sq} \mathrm{mi})$, and about 19 percent of the water and 19 percent of the dissolved solids come from the San 
TABLE 7.-Water and dissolved-solids discharge at selected stations in the Upper Colorado River Basin

[Water and dissolved-solids diseharge for the water years 1914-57 adjusted to 1957 conditions except as indicated]

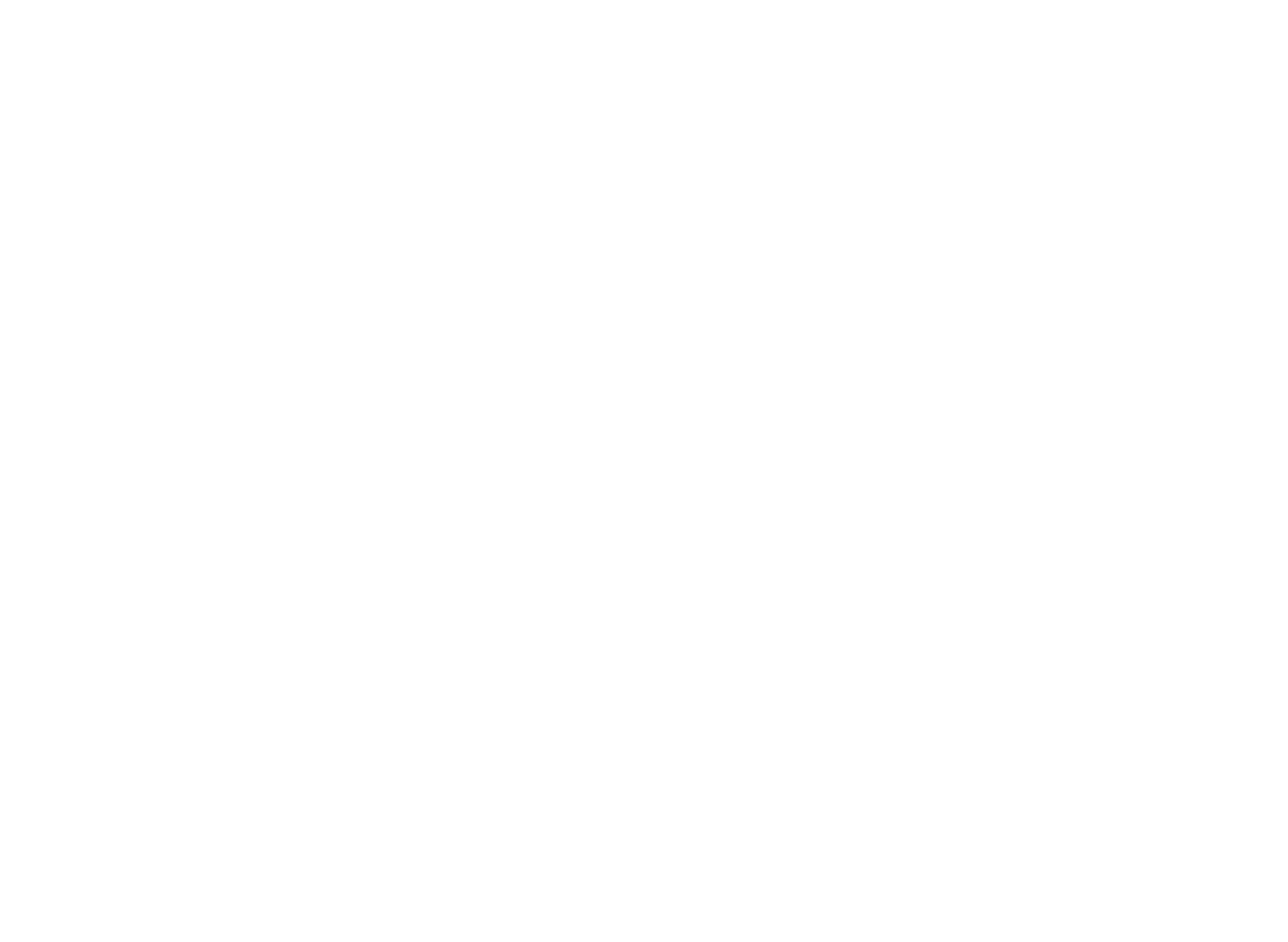

1 For water years $1939-57$.

2 For water years $1948-57$. $1947-57$.

4 For water years $1947-57$.
8 For water years $1951-55$.

Juan division $(38,300 \mathrm{sq} \mathrm{mi})$. In the San Juan division, the San Juan River contributes about 16 percent of the water and about 11 percent of the dissolved solids at "Lee Ferry," Ariz. The weighted-average concentration of dissolved solids in the Colorado River at "Lee Ferry," Ariz. (12,733,100 acre-ft) is 501 ppm (parts per million) for water years 1914-57 adjusted to 1957 conditions.

In computing the dissolved-solids concentrations and discharges given in table 7, duration tables of dissolved-solids concentrations and discharges, similar to tables 8 and 9 , were prepared. Four of the stations given in the tables are at or near the lower end of the divisions, and four are near the headwaters. In the computations for these tables the analyses of water samples, water discharge at the time of sampling, curves showing relation of dissolved-solids discharge to water discharge, and flow-duration curves of water discharge were used. The computed dissolved-solids concentrations and discharges are representative of conditions in 1957 , and will probably continue to be representative until conditions change.

\section{VARIATIONS IN CHEMICAI QUALTTY}

The chemical quality of water of the streams in the Upper Colorado River Basin varies from day to day and month to month. The concentration of dissolved solids varies nearly in inverse relation to streamflow; it is lowest during high flows and highest during low flows. The relation between water discharge and dissolved-solids concentration shown in figures 9 and 10 is representative of streams in the basin.

In the headwaters the range in concentration between high and low flows is relatively small, but in the downstream reaches of many streams the range is large. 


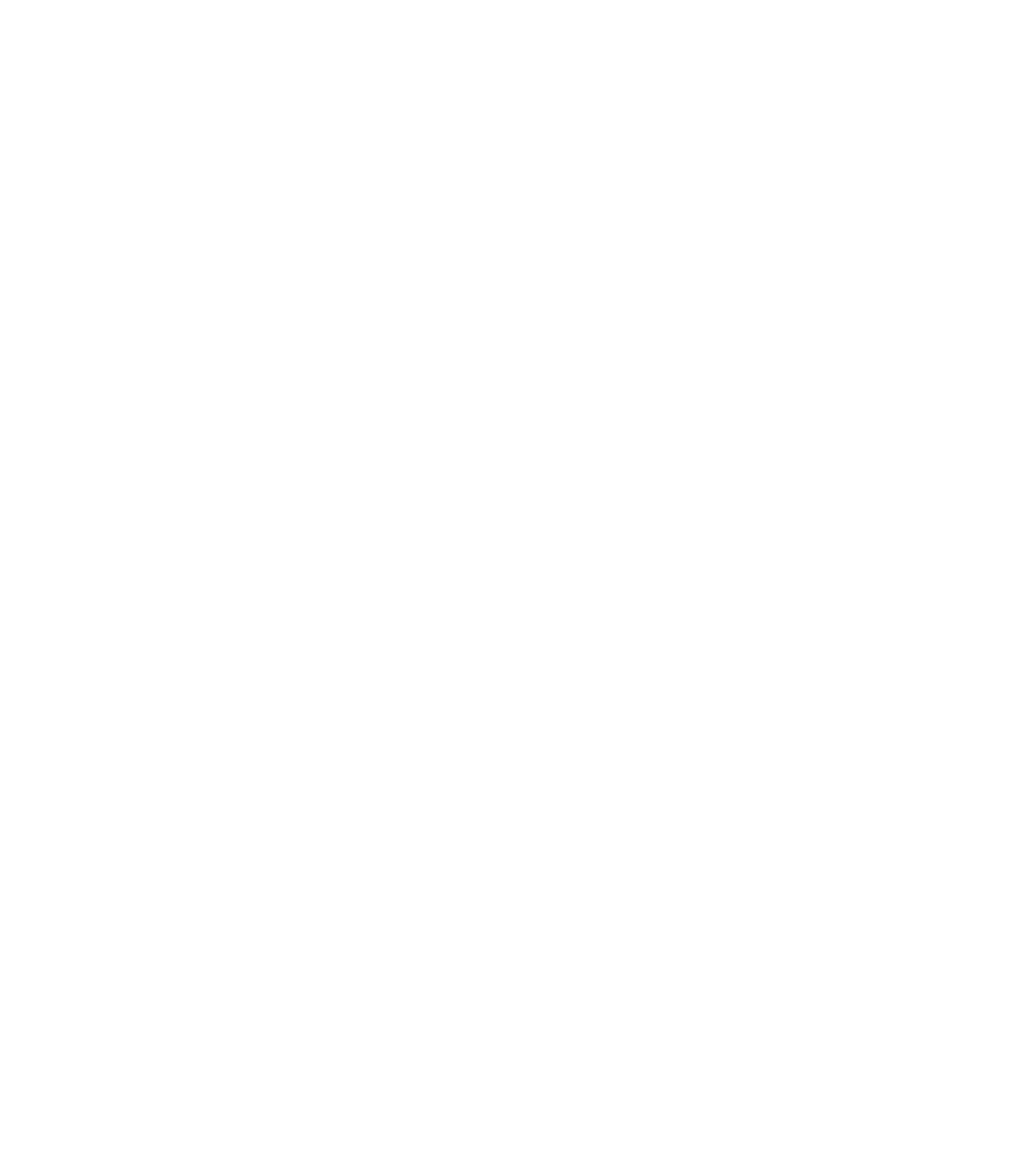



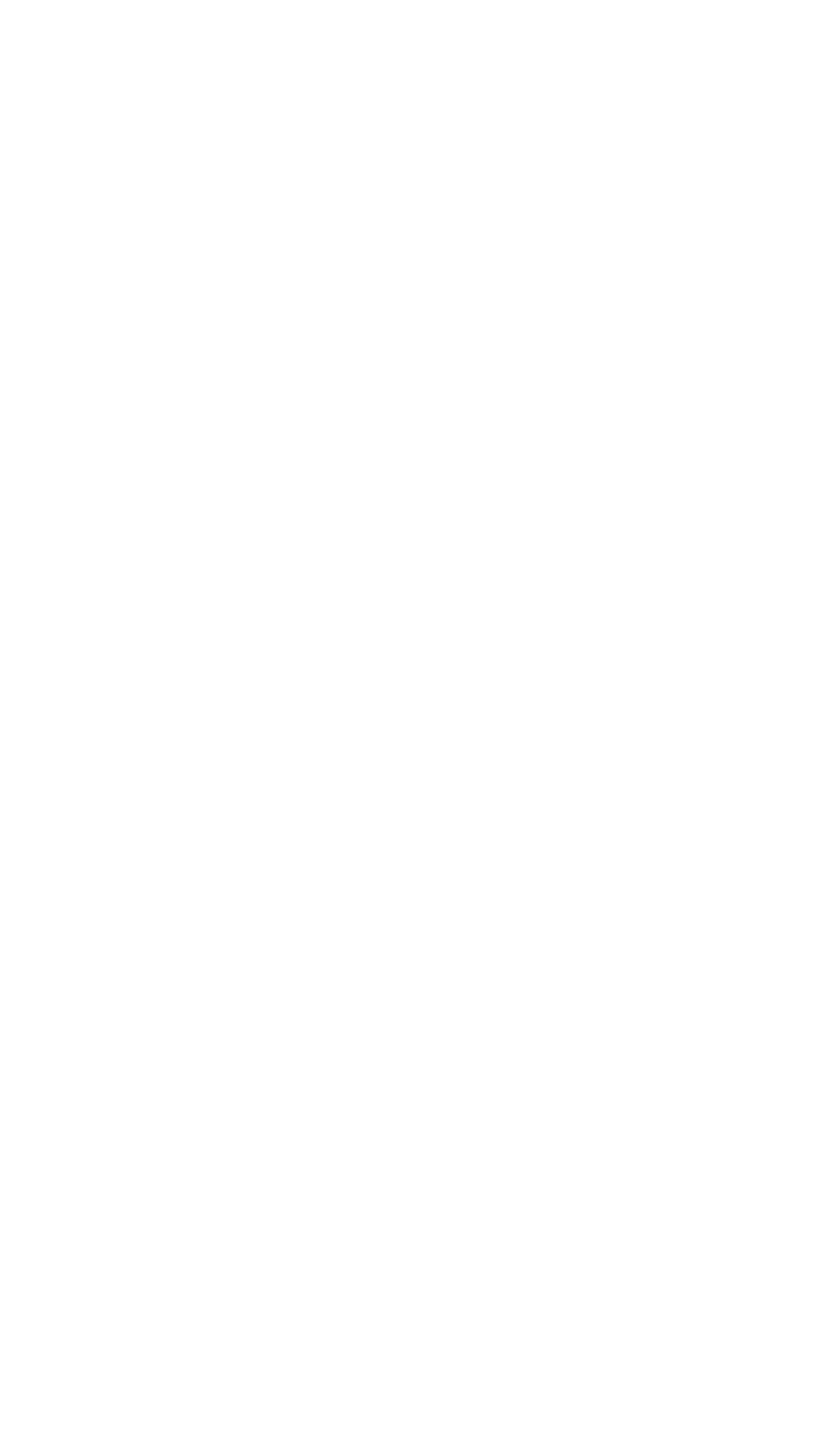


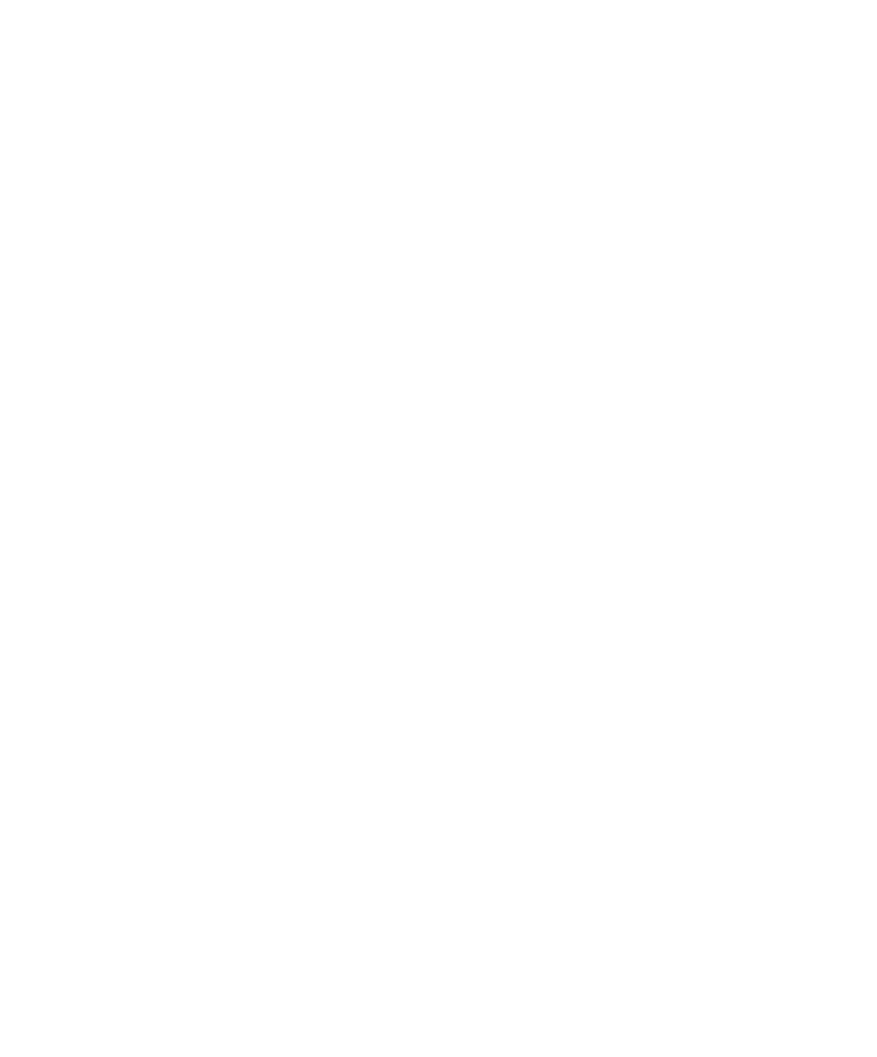

Figure 9.-Dissolved-solids concentration and discharge and water discharge, Green River near Ouray, Utah, 1951 water year.

Yampa River at Steamboat Springs, Colo., is representative of headwater streams, and Colorado River near Cisco, Utah, is representative of streams in downstream reaches.

A relation between coefficients of variation for weighted-average concentration of dissolved-solids and for water discharge is indicated by daily records at chemical-quality stations (fig. 11). In the Grand divi- sion a linear relation is indicated, whereas in the Green and San Juan divisions the relation, though probably linear, is not as clear. Linear equations (computed by the least-squares method) for each of the divisions are given in figure 11. Chapter B explains how these equations can be used to compute approximate long-term coefficients of variation of dissolvedsolids concentration at sites where continuous records of chemical quality are of short duration or where chemical-quality data have been obtained only infrequently.

\section{RELATION TO STREAMFLOW}

The relations between streamflow and chemical composition of water at four stations near the lower ends of the three divisions are given in table 10 and figure 12. At these locations during high flows, calcium and bicarbonate are the predominate cations and anions, except in Colorado River near Cisco, Utah, where sulfate is slightly greater than bicarbonate. At median and low flows, sodium and sulfate become the predominate cations and anions, except in San Juan River near Bluff, Utah, where calcium is greater than sodium. In this classification of high, median, and low flows, a high flow is the discharge equaled or exceeded 10 percent of the time, a median flow is the discharge equaled or exceeded 50 percent of the time, and a low flow is the discharge equaled or exceeded 90 percent of the time. These flow rates are also indicated by the diagrams in figure 12 . In table 10 the water discharges equaled and exceeded 12, 50, and 90 percent of the time are indicated.

In the headwaters the range in dissolved-solids concentrations is not as large as it is in the same streams at lower altitudes where the terrane is composed of sedimentary rocks and the climate is more arid. Fig-

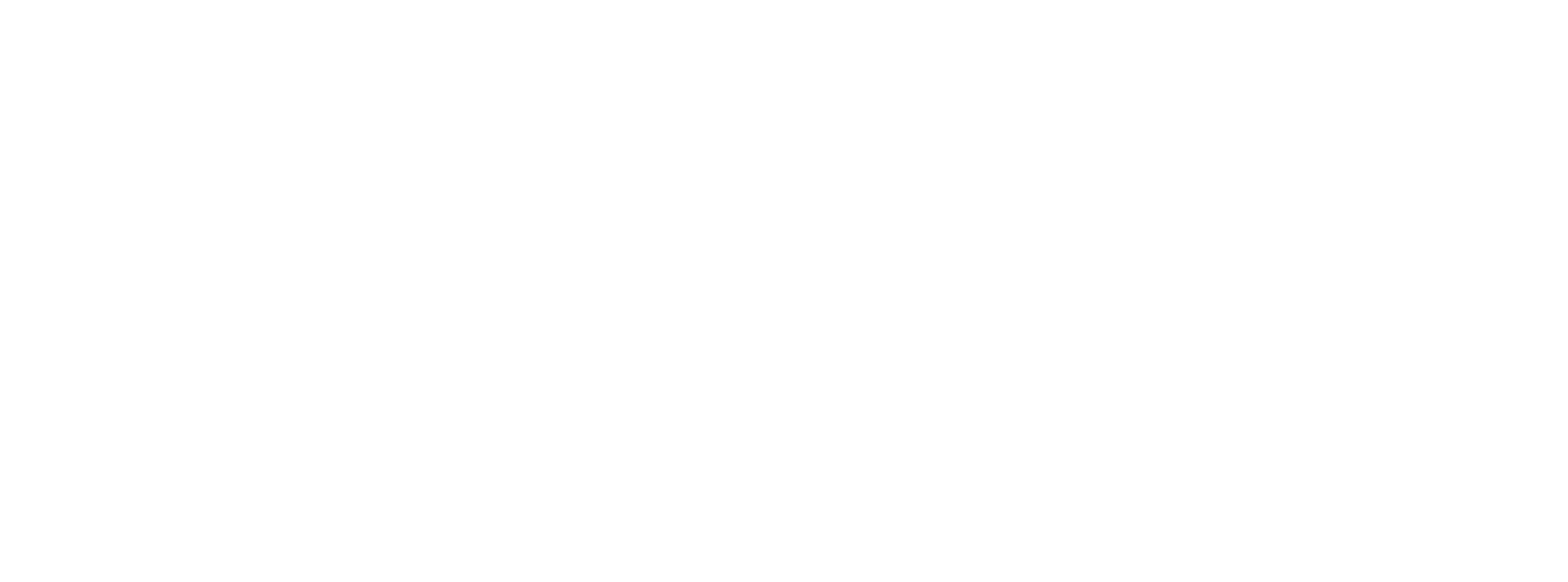

Figure 10.-Relation of concentration of dissolved solids to water discharge, Green River near Ouray, Utah. Curve is based on monthly a verage discharges and monthly weighted-a verage concentrations for periods of available data, water years 1951-52 and 1957 . 


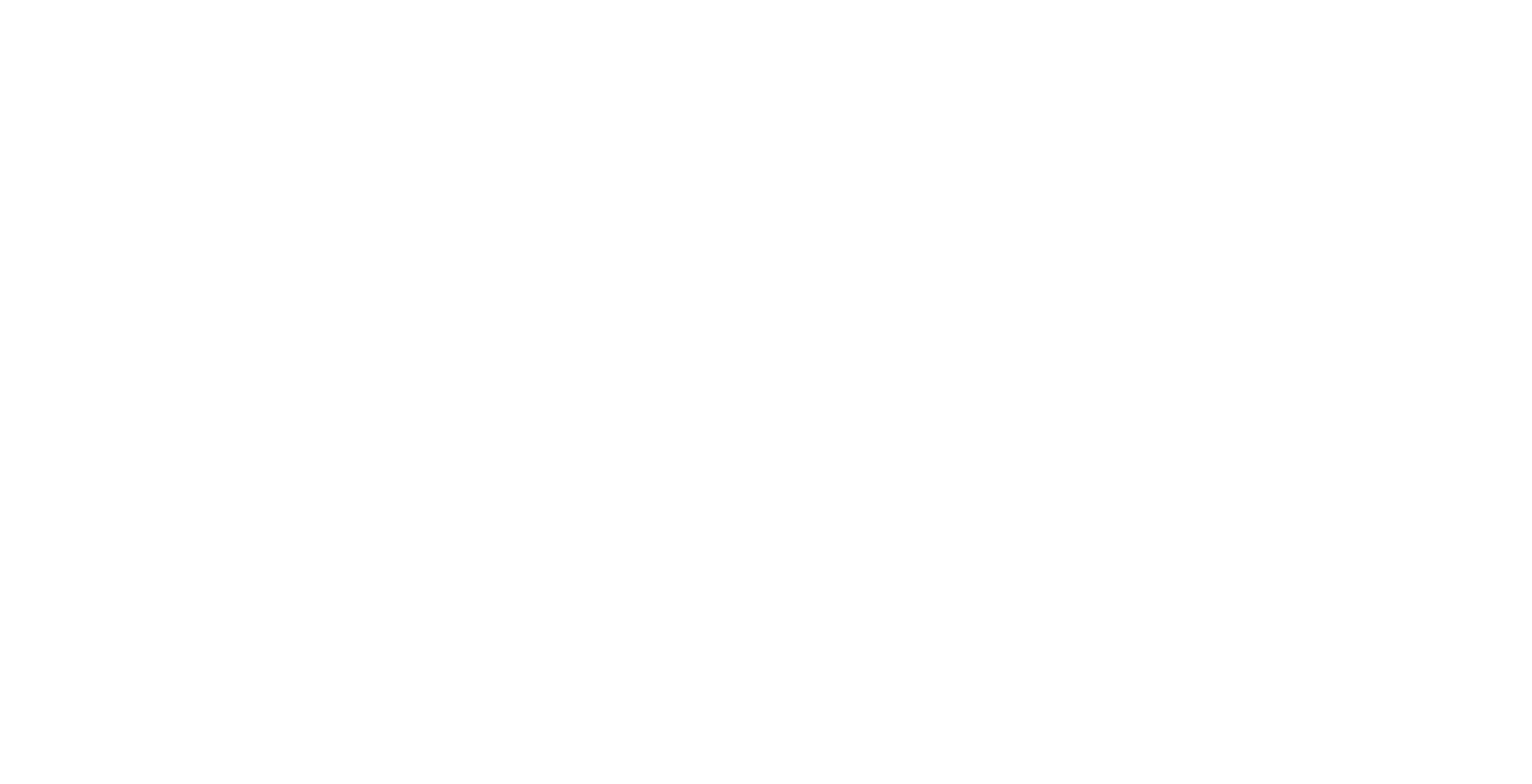

FrGuRe 11.-Relation of the varlability of dissolved-solids concentration to the variability of water discharge at daily chemical-quality stations, Upper Colorado River Basin.

ure 13 shows the relation of chemical composition and concentration of dissolved solids to water discharge for four typical headwater streams. Calcium is the predominate cation in all four streams for all flows, and bicarbonate is the predominate anion in all four streams during high flows but only in Yampa River at Steamboat Springs, Colo., and Duchesne River at Duchesne, Utah, for all flows. For median and low flows bicarbonate and sulfate are about equal in San Juan River near Blanco, N. Mex., whereas sulfate is predominate in Uncompahgre River at Colona, Colo. The difference in composition at median and low flows seems to be principally dependent on the type of soil and rocks that underlie the areas upstream from the stations.

\section{RELATION TO GEOLOGY}

The dissolved-solids concentrations of the water and the proportions of the individual constituents in streams of the Upper Colorado River Basin differ greatly from place to place. These differences are the result of hydrologic and other environmental factors that prevail in each drainage basin. One of the major factors that determine the chemical quality of each stream is the type of rocks that underlie each drainage basin.

The headwaters of the Colorado, Green, and San Juan Rivers and their principal tributaries are underlain by rocks that are relatively resistant to the solvent action of water; these rocks are chiefly granite and associated metamorphic, volcanic, and the more indurated sedimentary rocks.

Igneous and metamorphic rocks are composed of similar minerals and therefore the waters of the streams that drain areas underlain by these rocks are similar in chemical composition and dissolved-solids concentration. The principal difference between the waters draining the areas underlain by the volcanic, granitic, and associated metamorphic rocks is that waters from the volcanic terranes usually have a slightly higher concentration of dissolved solids and silica.

The most dilute surface waters in the upper basin come from the high mountain areas that are underlain by igneous and associated metamorphic rocks. The water of the streams close to the divides may contain less than $20 \mathrm{ppm}$ of dissolved solids. The weightedaverage concentration of the dissolved solids in streams at any point in the mountains along the Continental Divide, in the higher parts of the San Juan Mountains, in the Uinta Mountains, and in some of the high plateaus never exceeds $100 \mathrm{ppm}$ and seldom exceeds $50 \mathrm{ppin}$.

The waters of the mountain streams are a calcium bicarbonate type at all rates of streamflow, but the waters with concentrations of less than about $30 \mathrm{ppm}$ may contain relatively large percentages of sodium and sulfate ions. The concentration of silica in the mountain streams ranges from about 6 to $15 \mathrm{ppm}$, except 


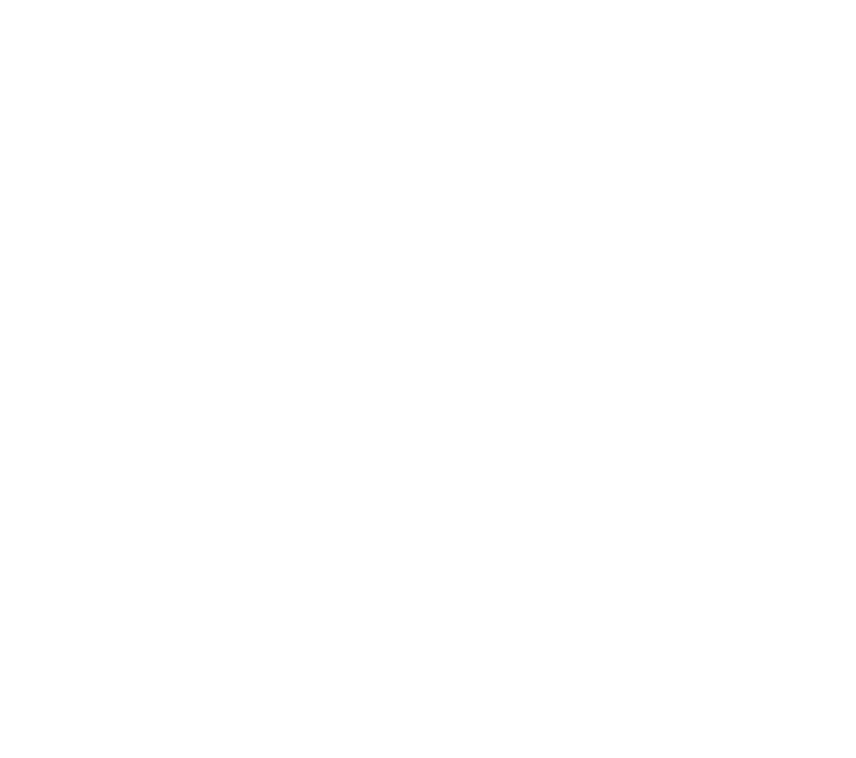

A. Colorado River near Cisco, Utah
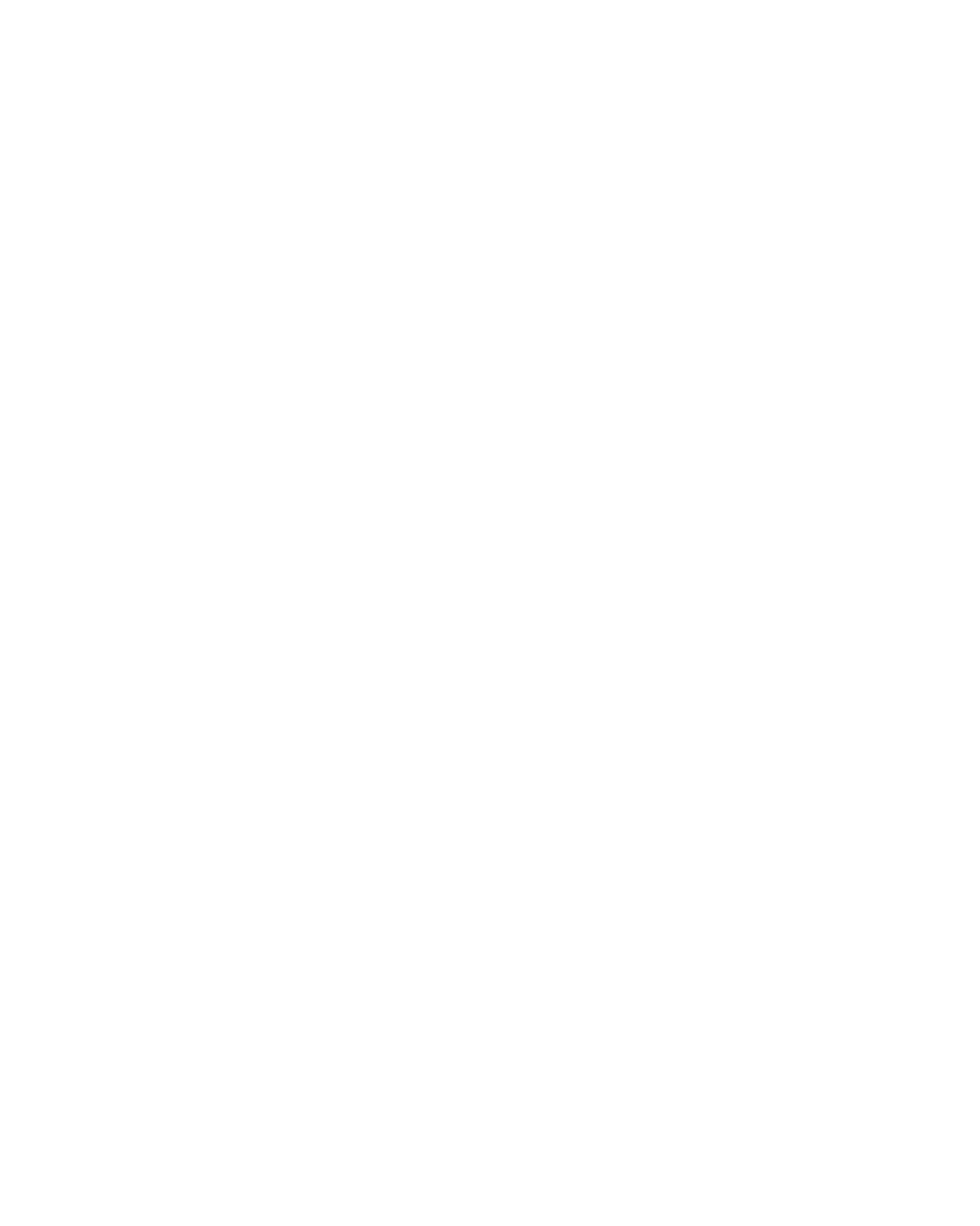

FIGURE 12.-Relation of the chemical composition and concentration of dissolved solids to water discharge at stations on the three main streams in the Upper Colorado River Basin. The concentration of specific ions, in equivalents per million (epm), is shown for the 10th, 50th, and 90th percentiles of the fiow-duration curve for each location. The flow-duration curves are for the water years 1914-57 adjusted to 1957 conditions. 
TABLE 10.-Relation between water discharge and chemical quality of water

[Chemical-quality data and weighted averages are in parts per million and equivalents per million (italic) except as indicated; data are for the water years 1914-57 adjusted

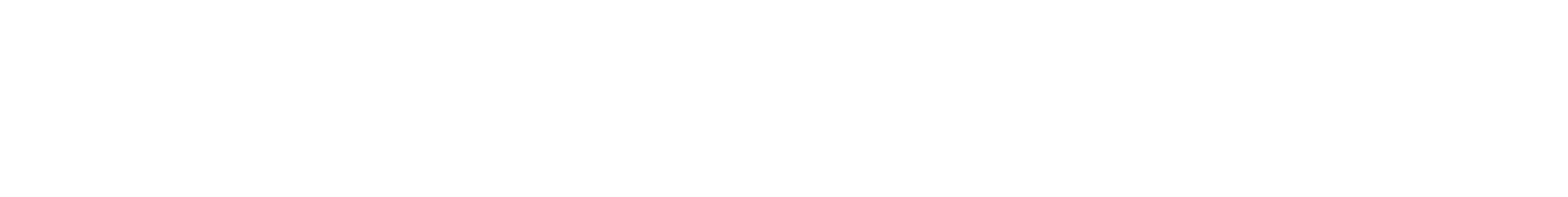

\begin{tabular}{|c|c|c|c|c|c|c|c|c|c|c|c|c|c|c|c|c|}
\hline \multicolumn{17}{|c|}{ Colorado River near Cisco, Utah } \\
\hline 62,270 & 39 & 6. 8 & 13 & 2.2 & 120 & 53 & 2.4 & 0.04 & 238 & 0.32 & 40,010 & 126 & 27 & 18 & 378 & 0.5 \\
\hline 59,540 & 39 & 6. .56 & $14^{.57}$ & 2.06 & 121.97 & 1.10 & $\begin{array}{l}.07 \\
2.5\end{array}$ & .04 & 239 & .33 & 38,420 & 126 & 27 & 10 & 380 & .5 \\
\hline 55,710 & $\begin{array}{l}1.95 \\
40\end{array}$ & 7.1 & $15^{.61}$ & 2.06 & $\begin{array}{r}1.98 \\
122\end{array}$ & 57 & $\begin{array}{l}.07 \\
2.5 \\
\end{array}$ & .04 & 240 & .33 & 36,100 & 129 & 29 & 20 & 380 & .6 \\
\hline 47,950 & 41 & 7.5 & $16^{\circ 00}$ & 2.20 & 125 & 63 & 2.67 & .04 & 241 & .33 & 31,200 & 134 & 31 & 20 & 380 &.$\overline{6}$ \\
\hline 38,090 & 2. 05 & $\begin{array}{c}.62 \\
8.5 \\
70\end{array}$ & $18^{.70}$ & 2.06 & $\begin{array}{r}2.05 \\
128\end{array}$ & 73 & 3. 07 & .05 & 248 & .34 & 25,510 & 142 & 38 & 21 & 390 & .7 \\
\hline 30,970 & 45 & 9.3 & $22^{.78}$ & 2.2 & 134.10 & 85 & 3. 28 & .05 & 258 & .35 & 21,570 & 150 & 40 & 24 & 403 &. .8 \\
\hline 25,250 & $\begin{array}{l}2.25 \\
47\end{array}$ & $11^{\circ}$ & $25^{.96}$ & 2.3 & $\begin{array}{r}8.20 \\
139\end{array}$ & ${ }^{1.77}$ & 3. 69 & .05 & 273 & .37 & 18,610 & 162 & 48 & 25 & 435 & .9 \\
\hline $18,760^{1}$ & 51 & $13^{\circ}$ & 31.09 & 2.56 & $\begin{array}{l}\text { 2. } 88 \\
146\end{array}$ & $121^{2.02}$ & $\begin{array}{l}.10 \\
4.5 \\
19\end{array}$ & .05 & 309 & .42 & 15,650 & 180 & 61 & 27 & 480 & 1.0 \\
\hline $11,020 \ldots$ & 60 & 17 & 47 & 2.7 & 160 & $\begin{array}{l}2.0 \% \\
176\end{array}$ & 6. 6 & .05 & 415 & .56 & 12,350 & 220 & 88 & 31 & 645 & 1.4 \\
\hline $6,060 \ldots$ & 70 & 25 & $\begin{array}{c}8.04 \\
79\end{array}$ & $\begin{array}{l}.07 \\
3.6\end{array}$ & $\begin{array}{c}2.62 \\
178\end{array}$ & 281.66 & $11^{19}$ & .08 & 660 & .90 & 10,800 & 278 & 132 & 38 & 1,010 & 2.1 \\
\hline $4,200 \ldots$ & 84.40 & 33 & 106.44 & 4.3 & 194 & 389 & $15^{.31}$ & .09 & 895 & 1.22 & 10,150 & 345 & $186^{-1}$ & 40 & 1,300 & 2.5 \\
\hline $3,540^{2}$. & 97 & 37 & 123 & 4.9 & 202 & 460 & $17^{.48}$ & .10 & 1,030 & 1.40 & 9,840 & 394 & 228 & 40 & $1,480^{\circ}$ & 2.7 \\
\hline 3,180 & $\begin{array}{r}4.84 \\
102 \\
5.09\end{array}$ & $\begin{array}{c}3.04 \\
40\end{array}$ & $\begin{array}{c}138.95 \\
6.00\end{array}$ & 5.19 & 211 & $\begin{array}{l}9.57 \\
506\end{array}$ & $19^{.48}$ & 11 & 1,130 & 1.54 & 9,700 & 419 & $246^{-}$ & 41 & 1,600 & 2.0 \\
\hline 2,820 . & 109 & $\begin{array}{c}\text { s. } 28 \\
46 \\
3.78\end{array}$ & $\begin{array}{c}160^{\circ} \\
6.96\end{array}$ & 5.6 & 219.40 & $\begin{array}{l}575 \\
11.98\end{array}$ & $21^{.54}$ & .12 & 1,240 & 1.69 & 9,440 & 461 & 282 & 43 & 1,740 & 3.2 \\
\hline $2,520$. & 125 & 50 & 172 & 5. 94 & 230 & 650 & $24^{.09}$ & $.14^{-}$ & 1,350 & 1.84 & 9,190 & 518 & 329 & 42 & 1,850 & $\overline{3} . \overline{3}$ \\
\hline $2,160^{\circ}$ & $\begin{array}{r}142^{0.84} \\
7.09\end{array}$ & $60^{4.11}$ & $\begin{array}{r}190.48 \\
8.26\end{array}$ & 6.7 & $\begin{array}{l}93.77 \\
230\end{array}$ & $\begin{array}{l}18.52 \\
770\end{array}$ & $29^{.68}$ & .17 & 1,470 & 2.00 & 8,570 & 601 & 412 & 40 & 2,000 & 3.4 \\
\hline $1,580 \ldots$ & $180^{\circ}, 98$ & 78 & 210 & 8.5 & 230 & $\begin{array}{l}16.08 \\
975 \\
90.8\end{array}$ & $35^{.82}$ & .22 & 1,680 & 2.28 & 7,170 & 770 & 581 & 37 & 2,280 & $\overline{3.3}$ \\
\hline 975. & $\begin{array}{l}220.90 \\
10.98\end{array}$ & $\begin{array}{c}8.41 \\
6.99\end{array}$ & 215 & $10^{.22}$ & 230 & 1,080 & $48^{.99}$ & .27 & 1,810 & 2.46 & 4,760 & 898 & 710 & 34 & 2,400 & 3.1 \\
\hline 746 & $\begin{array}{r}235.80 \\
11.79 \\
\end{array}$ & $\begin{array}{c}0.98 \\
7.40 \\
\end{array}$ & $\begin{array}{r}220.50 \\
9.57 \\
\end{array}$ & $\begin{array}{r}12.86 \\
.81 \\
\end{array}$ & $\begin{array}{r}230.77 \\
3.77 \\
\end{array}$ & $\begin{array}{c}1,150.46 \\
28.98\end{array}$ & $\begin{array}{c}1.35 \\
60 \\
1.69\end{array}$ & .28 & 1,850 & 2.52 & 3,780 & 956 & 768 & 63 & 2,450 & 3.1 \\
\hline 7,639 & $\begin{array}{l}66 \\
3.29\end{array}$ & 21 & $\begin{array}{l}62 \\
2.70\end{array}$ & $\begin{array}{c}3.2 \\
.08\end{array}$ & $\begin{array}{l}162 \\
2.66\end{array}$ & $\begin{array}{l}233 \\
4.85\end{array}$ & $\begin{array}{l}8.8 \\
.25\end{array}$ & .07 & 547 & .74 & 11,280 & 251 & 118 & 35 & 806 & 1.7 \\
\hline \multicolumn{17}{|c|}{ Green River at Green River, Utah } \\
\hline 63,430 & 44.20 & 10 & 19 & 1.9 & 160 & 52 & 8. 5 & 0.07 & 222 & 0.30 & 38,020 & 151 & 20 & 21 & 345 & 0.7 \\
\hline 56,430 & 44 & 10 & $10^{\circ}$ & 1.9 & 160 & 52.00 & 8. 64 & .07 & 222 & .30 & 33,820 & 151 & 20 & 21 & 350 & .7 \\
\hline 51,450 & $44^{200}$ & $10^{\circ}$ & $10^{\circ}$ & 2.05 & 160 & 52.08 & 8. 64 & .07 & 222 & .30 & 30,840 & 151 & 20 & 21 & 350 & .7 \\
\hline 41,720 . & 44.20 & $10^{\circ}$ & $20^{\circ}$ & 2.0 & $\begin{array}{l}2.62 \\
160\end{array}$ & 54.08 & 8.64 & .07 & 225 & .31 & 25,350 & 151 & 20 & 22 & 350 & .7 \\
\hline 32,100 & $45^{z \cdot z}$ & $10^{\circ}$ & $21^{\circ}$ & 2.2 & 160 & 59 & 8. 84 & .08 & 230 & .31 & 19,980 & 154 & 22 & 23 & 355 & .7 \\
\hline 25,850 & $4^{2.20}$ & $11^{\circ}$ & $23^{.91}$ & 2.06 & $\begin{array}{c}8.62 \\
160\end{array}$ & 64.28 & 9.25 & .08 & 240 & .33 & 16,750 & 158 & $\overline{26}$ & 24 & 375 & .8 \\
\hline 20,210 & 45 & $11^{\circ}$ & 25 & 2.4 & $\begin{array}{l}2.68 \\
160\end{array}$ & $69^{1.35}$ & $10^{.26}$ & .08 & 270 & .37 & 14,730 & 158 & 26 & 25 & 410 & .9 \\
\hline 14,80 & $\begin{array}{l}46 \\
2.30\end{array}$ & 12 & 29 & 2.6 & 162 & $80^{1.44}$ & $11^{.28}$ & .09 & 326 & .44 & 13,030 & 164 & 32 & 27 & $\mathbf{4 7 5}$ & 1.0 \\
\hline 9,267 . & 50 & $14^{\circ 0}$ & 37 & 2.8 & $169^{2.00}$ & 104 & $15^{.31}$ & .09 & 430 & .58 & 10,760 & 182 & 44 & 30 & 615 & 1.2 \\
\hline 5,614 & 57 & 20 & 56 & 3.1 & 193 & 153 & $23^{.4 z}$ & .10 & 570 & .78 & $8,640^{-}$ & 224 & $-\overline{66}$ & 35 & $780^{-}$ & 1.6 \\
\hline 3,881 . & 65 & 26 & 75 & 3.4 & 214 & 210 & $30^{.6 b}$ & .11 & 655 & .89 & 6,860 & 269 & 94 & 37 & $890^{-}$ & 2.0 \\
\hline $2,966^{\circ}$ & 71 & 31.55 & 86 & 3. 6 & 228 & 252 & 36.80 & .11 & 700 & .95 & 5,610 & 304 & 118 & $-\overline{38}$ & 945 & $2 . \overline{1}$ \\
\hline 2,439 & 74 & $\begin{array}{r}34 \\
2.79\end{array}$ & 05 & 3.8 & 230 & 280 & 30 & .11 & 735 & 1.00 & 4,840 & 324 & 136 & 39 & 1,000 & 2.3 \\
\hline 2,091 . & $\begin{array}{l}76 \\
3.79\end{array}$ & 36 & $100^{4.1}$ & $\begin{array}{l}\text { 3. } 9 \\
10\end{array}$ & 232 & 300 & 43 & .12 & 755 & 1.03 & 4,260 & 338 & 148 & 39 & 1,030 & 2.4 \\
\hline 1,793 & 78 & $\begin{array}{l}39 \\
\text { S. } 21\end{array}$ & 106 & 4. 0 & 234.80 & 322.84 & $\begin{array}{l}1.21 \\
46\end{array}$ & .12 & 775 & 1.05 & 3,750 & 355 & 163 & 39 & 1,050 & 2.4 \\
\hline 1,424 & 81 & 41 & 112 & $\begin{array}{l}4.2 \\
111\end{array}$ & 236 & 345 & 50 & .12 & 800 & 1.09 & $3,080^{\circ}$ & $\mathbf{3 7 0}$ & $177^{-}$ & 39 & 1,100 & 2.5 \\
\hline 1,006 & 83 & 42 & 119 & 4.5 & 238 & $360^{10}$ & 54 & .13 & 820 & 1.12 & 2,230 & 380 & $184^{-}$ & 40 & 1,130 & 2.7 \\
\hline 637 & 85 & $\begin{array}{r}43 \\
3.58\end{array}$ & 122 & 5. 0 & 240 & $370^{40}$ & 57 & .14 & 850 & 1.16 & 1,460 & 388 & 192 & 40 & 1,170 & 2.7 \\
\hline 462. & $\begin{array}{r}87.24 \\
4.34 \\
\end{array}$ & $\begin{array}{c}3.00 \\
44 \\
3.62\end{array}$ & $\begin{array}{r}0.31 \\
122 \\
6.31\end{array}$ & $\begin{array}{l}.18 \\
5.4 \\
.14\end{array}$ & $\begin{array}{r}3.94 \\
240 \\
3.94\end{array}$ & $\begin{array}{c}370 \\
7.70\end{array}$ & $\begin{array}{c}1.61 \\
1.64\end{array}$ & .14 & 860 & 1.17 & 1,070 & 398 & 201 & 40 & 1,170 & $2 . \overline{7}$ \\
\hline $6,292 \ldots$ & $\begin{array}{c}54 \\
2.69\end{array}$ & ${ }_{1.48}^{18}$ & $\stackrel{45}{1.96}$ & $\begin{array}{c}2.8 \\
.07\end{array}$ & $\begin{array}{l}181 \\
2.97\end{array}$ & $\begin{array}{l}130 \\
2.70\end{array}$ & ${ }^{19} .54$ & .09 & 427 & .58 & 7,260 & 208 & 80 & 32 & 608 & 1.4 \\
\hline
\end{tabular}

See footnotes at end of table. 
TABLE 10.-Relation between water discharge and chemical quality of water-Continued

[Chemical-quality data and weighted averages are in parts per million and equivalents per million (italic) except as indicated; data are for the water years 1914-57 adjusted

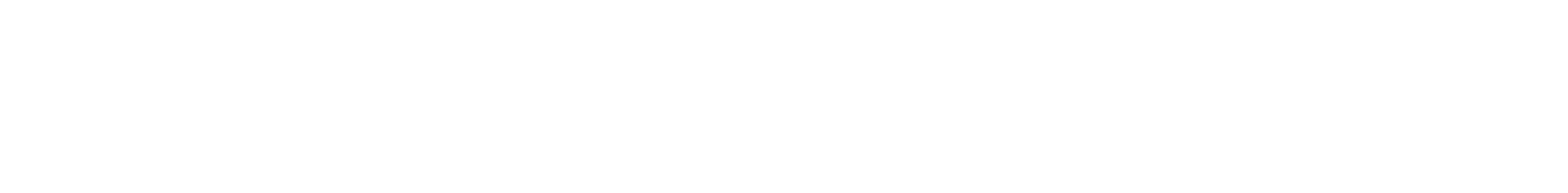

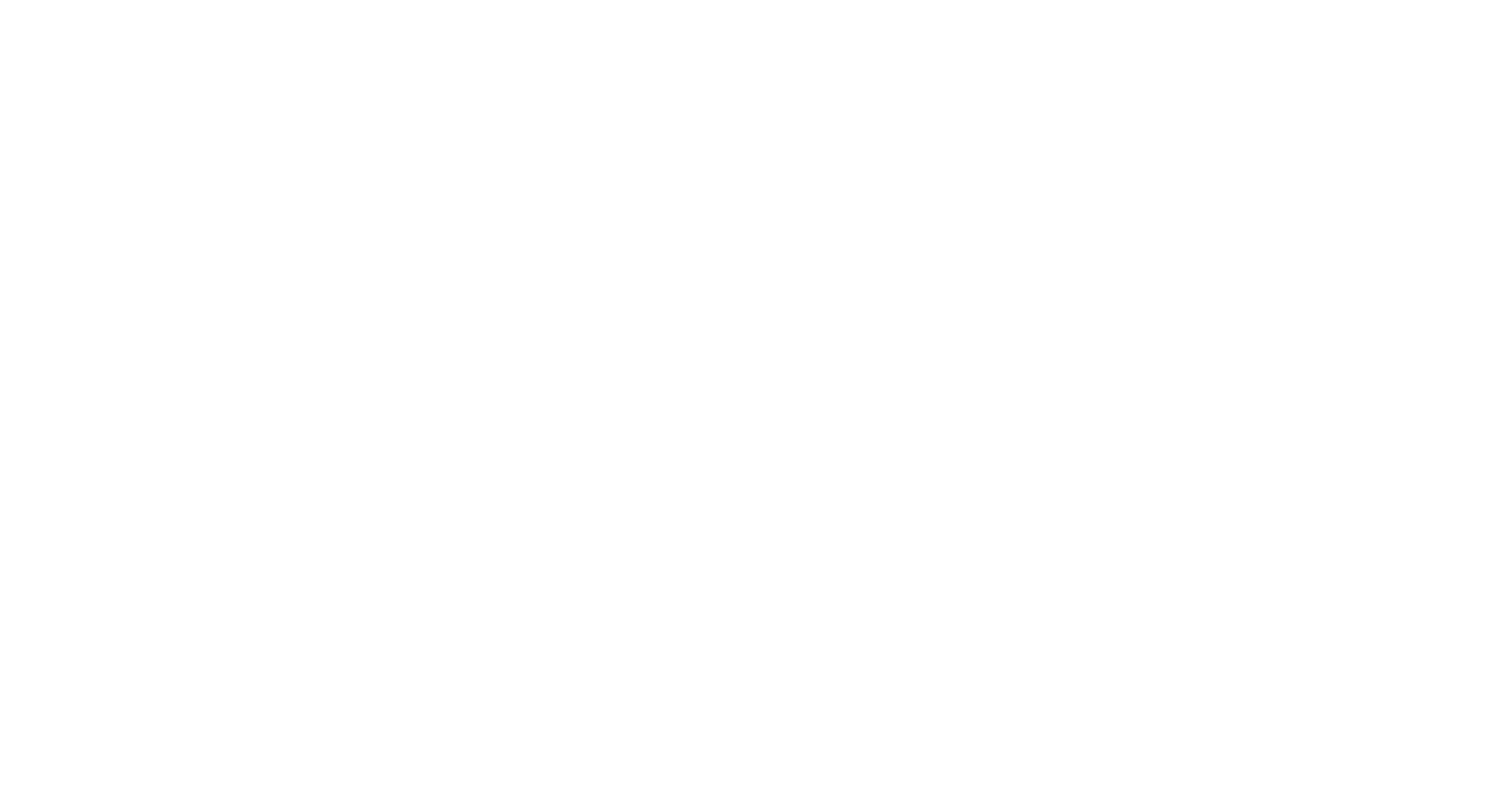

Colorado River at Lees Ferry, Arizona

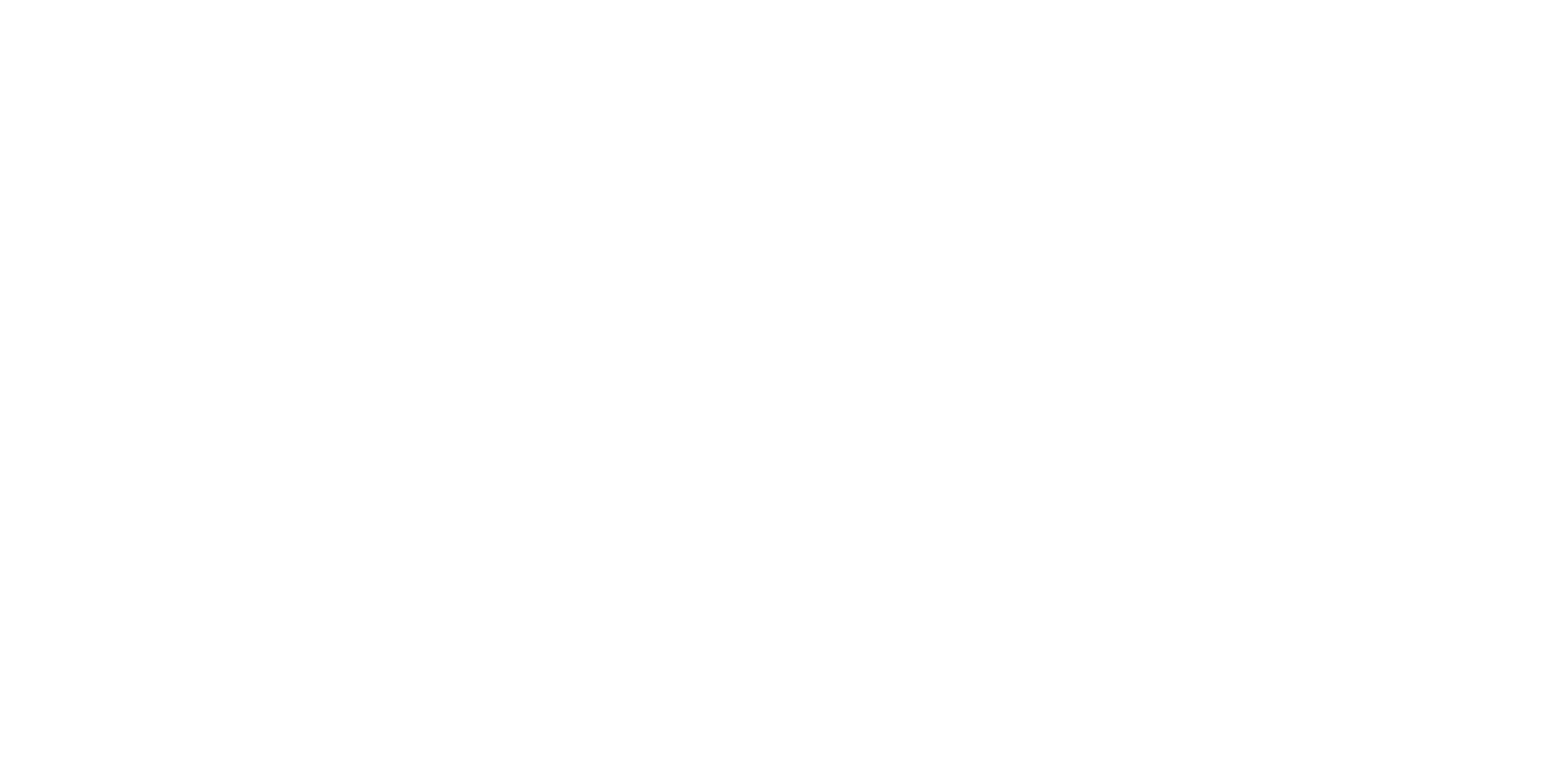

112 percentile. 250 percentile. 290 percentile. 


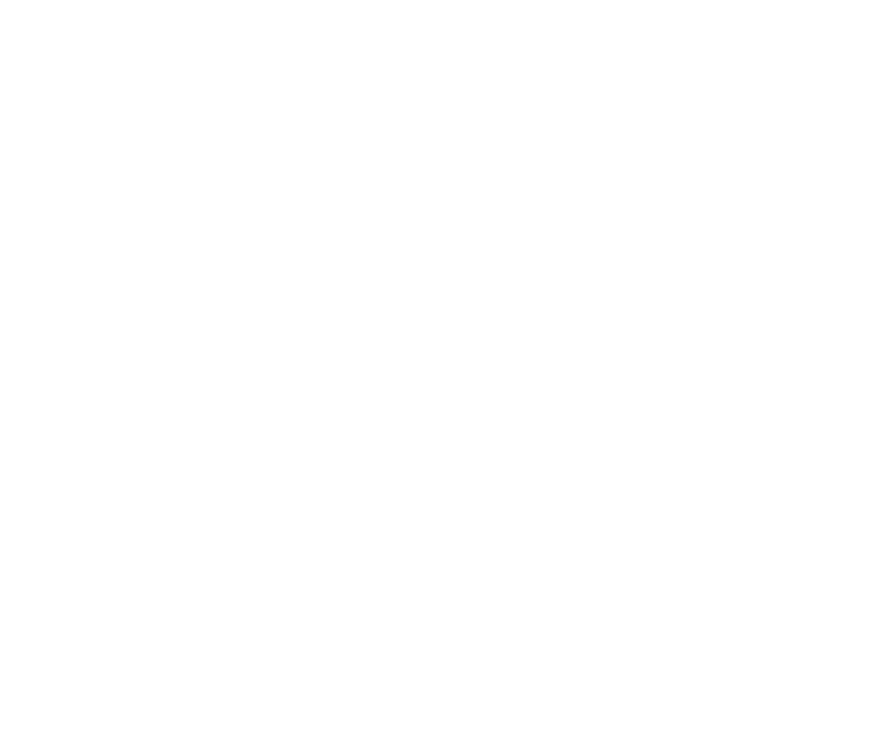

EXCEEDED DISCHARGE INDICATED

$A$. Uncompahgre River at Colona, Colo.

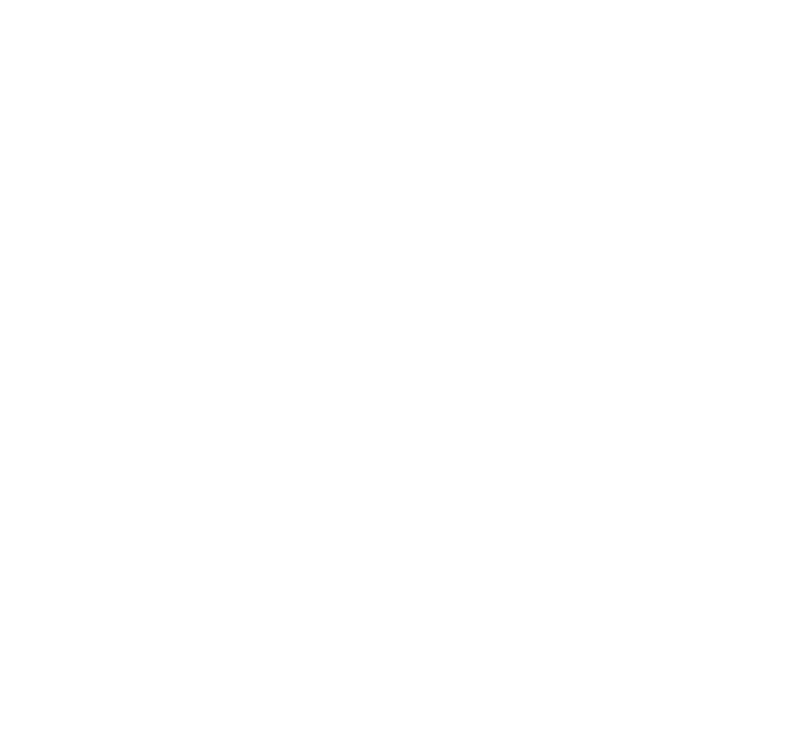

EXCEEDED DISCHARGE INDICATED

B. Yampa River at Steamboat Springs, Colo.

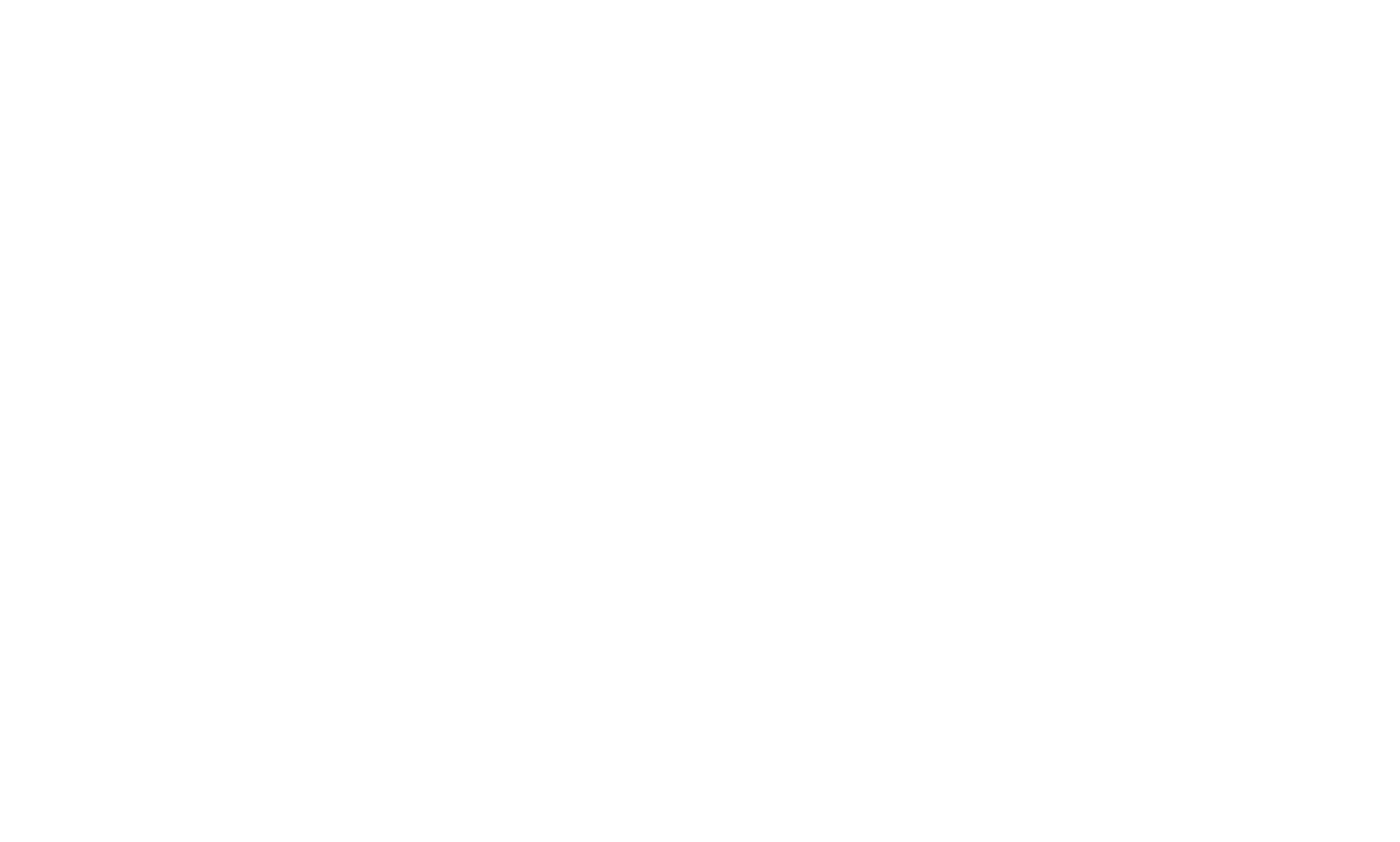

EXPLANATION

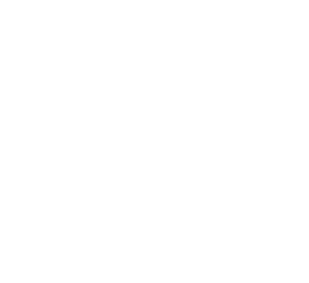

Figure 13.-Relation of the chemical composition and concentration of dissolved solids to water discharge for streams in the headwaters of the Upper Colorado River Basin. The concentration of specific ions, in equivalents per million (epm), is shown for the 10th, 50th, and 90th percentiles of the flow-duration curve for each location. The flow-duration curves are for the water years 1914-57 adjusted to 1957 conditions. 
for streams that drain areas underlain by volcanic rocks, such as in the San Juan Mountains and on some of the high mesas where concentration of silica may at times exceed $40 \mathrm{ppm}$ and usually averages more than $20 \mathrm{ppm}$.

The middle and lower reaches of the Colorado, Green, and San Juan Rivers and their principal tributaries are underlain chiefly by sedimentary rocks, which contain minerals that are more soluble than the minerals in rocks in the headwaters. For this reason and as a result of irrigation, the concentration of dissolved solids in the streams increases progressively downstream. Concurrently, the composition of the water changes from a calcium bicarbonate type to types that contain progressively greater percentages of magnesium, sodium, sulfate, and chloride. (See pl. 2). The diagrams in plate 2 show the chemical character of the streams during low flow, when the effect of geology on chemical quality is more pronounced than it is during high flow.

In general, the weighted-average concentration of dissolved-solids in streams near the mountains is less than $100 \mathrm{ppm}$; the weighted-average concentration in most main streams and their principal tributaries does not exceed about $500 \mathrm{ppm}$, except in their lower reaches; and the weighted-average concentration in only a few of the main streams and principal tributaries in their lower reaches exceeds $800 \mathrm{ppm}$. Figure 14 shows the approximate weighted-average concentration in streams at 50 sites for water years 1914-57 adjusted to 1957 conditions.

The principal natural factors affecting the dissolvedsolids concentration and chemical composition of the surface water in any area seem to be the underlying rocks and soils developed therefrom and the amount of precipitation. The effect of any factor is, of course, modified by other factors, such as water use.

\section{RELATION TO GROUND WATER}

Ground-water inflow to the streams comes from ground-water reservoirs recharged by precipitation, from alluvium bordering the streams that is recharged intermittently by the stream, from thermal springs, and from ground-water return flow from irrigated lands. The quality of the ground water entering the streams greatly influences the quality of the water in the streams. During periods of low flow most of the stream water is ground-water inflow and is a mixture of all ground water entering the stream system.

Extensive ground-water reservoirs occur in the mountains where precipitation is abundant. Estimates of the amount of dissolved-solids contributed to some headwater streams by ground water are given in table 11. The estimates are based on the amount of water contributed to the streams from ground-water reser- voirs and the dissolved-solids concentration of the streams during base flow. Comparison of the weighteda verage concentration of dissolved solids in the ground water with the weighted-average concentration of dissolved solids in the stream shows that the ground water almost invariably has the higher concentration.

The chemical composition of water in the streams and of water in the flood plain alluvium nearby is commonly similar. Both the stream water and the water in the alluvium are usually mixtures of surface and ground water because of the interchange of water between the stream and the alluvium. The interchange may be due to the rise and fall of the stream or to the irrigation of lands along the river.

Generally, water in the alluvium contains more dissolved solids than that in the streams (pls. 2 and 3 ). In the middle and lower reaches of the principal streams and their tributaries, the ground-water contribution is mostly surface water that has entered the alluvium during high flow, or is return flow of irrigation. This ground water contains dissolved solids leached from the soluble minerals in the alluvium through which it has passed. Because of the concentrating effect of evapotranspiration and the solution of minerals by the water in its journey through the alluvium, the water that enters the streams from the alluvium usually has a higher dissolved-solids concentration than the water in the stream (fig. 15). Thus, the dissolved-solids concentration of the stream water is increased.

High concentrations of certain mineral constituents occur in water in the alluvium in local areas. In some arid areas water in the alluvium contains large amounts of calcium, magnesium, sodium, and sulfate. In these areas high concentrations of chloride, carbonate, and bicarbonate also may occur in the streams. In some local areas concentrations of nitrate in the ground water exceed $45 \mathrm{ppm}$. Along some of the northward-flowing tributaries in the Duchesne River basin, boron in the ground water exceeds $10 \mathrm{ppm}$. High concentrations of boron also occur in the ground water along the lower reaches of Willow Creek near Ouray, Utah.

Many thermal springs discharge along the streams. The flow of most springs is small in comparison with the flow of the streams into which they discharge; and though their concentration of dissolved solids may be high, the net effect on the quality of the stream water is small. Some springs, however discharge substantial quantities of water containing high concentrations of dissolved solids into streams and the effect on the quality of the stream water is marked. For example, computations based on the flow and dissolved-solids concentration of hot springs in the reach of the Colorado River 


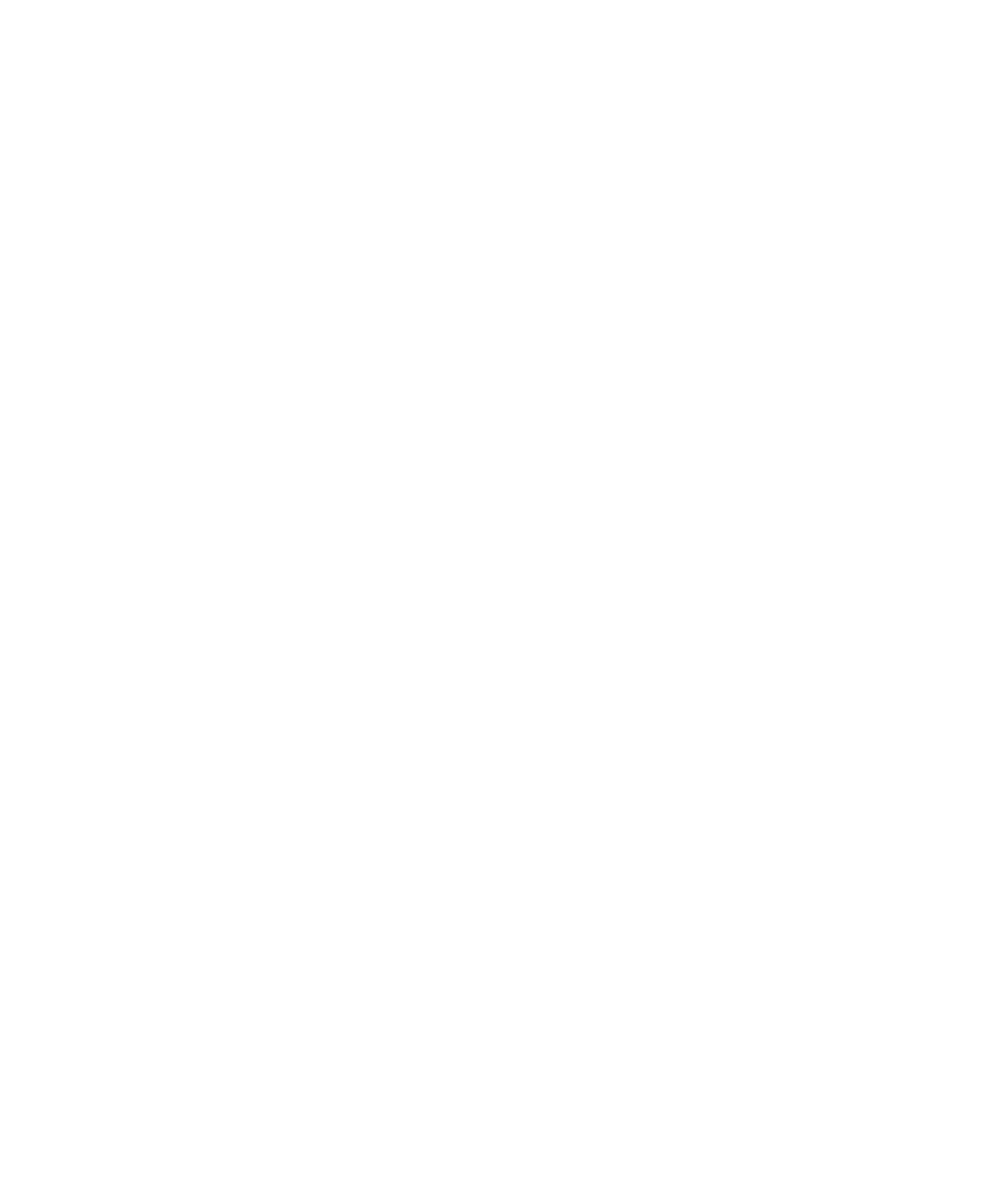

Figure 14.-Weighted-average concentration of dissolved solids at selected sites in the Upper Colorado River Basin, water years $1914-57$ adjusted to 1957 conditions.

between Eagle River and the Shoshone powerplant, about 17 miles downstream, indicate that springs in this reach contribute about 182,600 tons of dissolved solids to the river annually, of which about 160,700 tons is sodium chloride. The annual water and dissolved solids contributed by all known thermal springs in the Upper Colorado River Basin is about 59,100 acre-feet and 541,600 tons, respectively. The amounts of water and 
TABLE 11.-Water and dissolved solids contributed by ground water to selected headwater streams in the Upper Colorado River Basin [Water and dissolved solids for the water years 1914-57 adjusted to 1957 conditions]

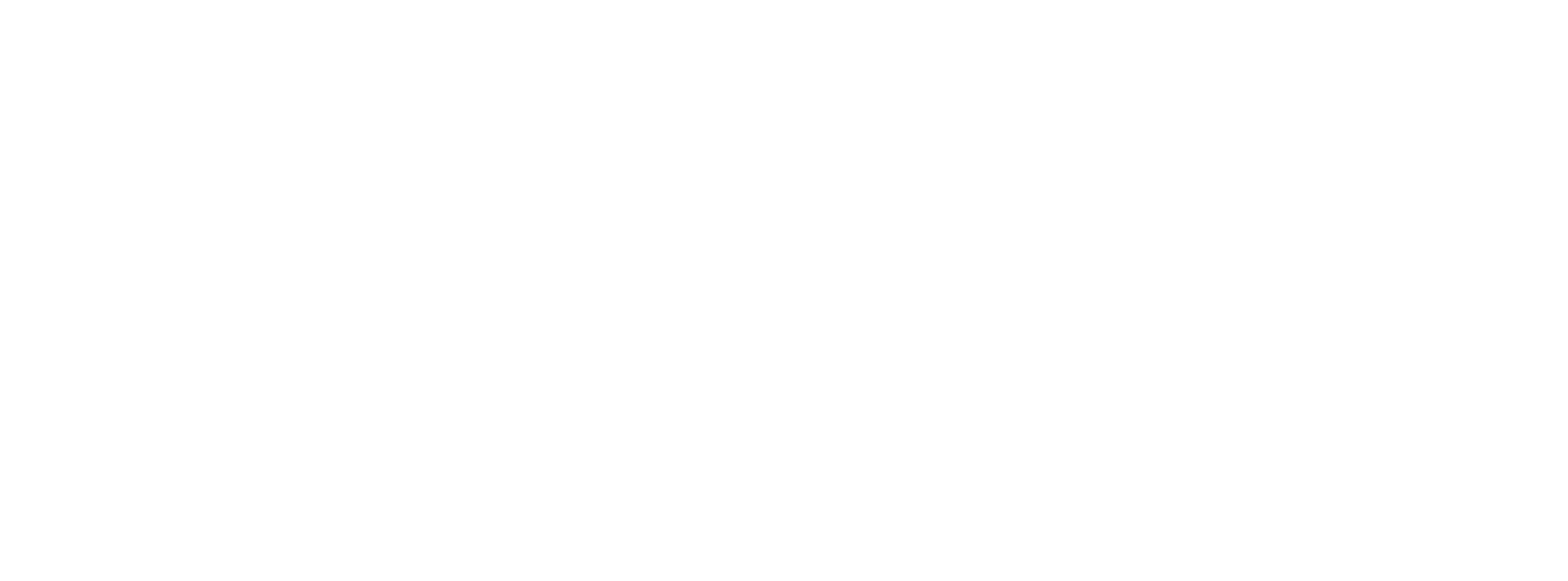

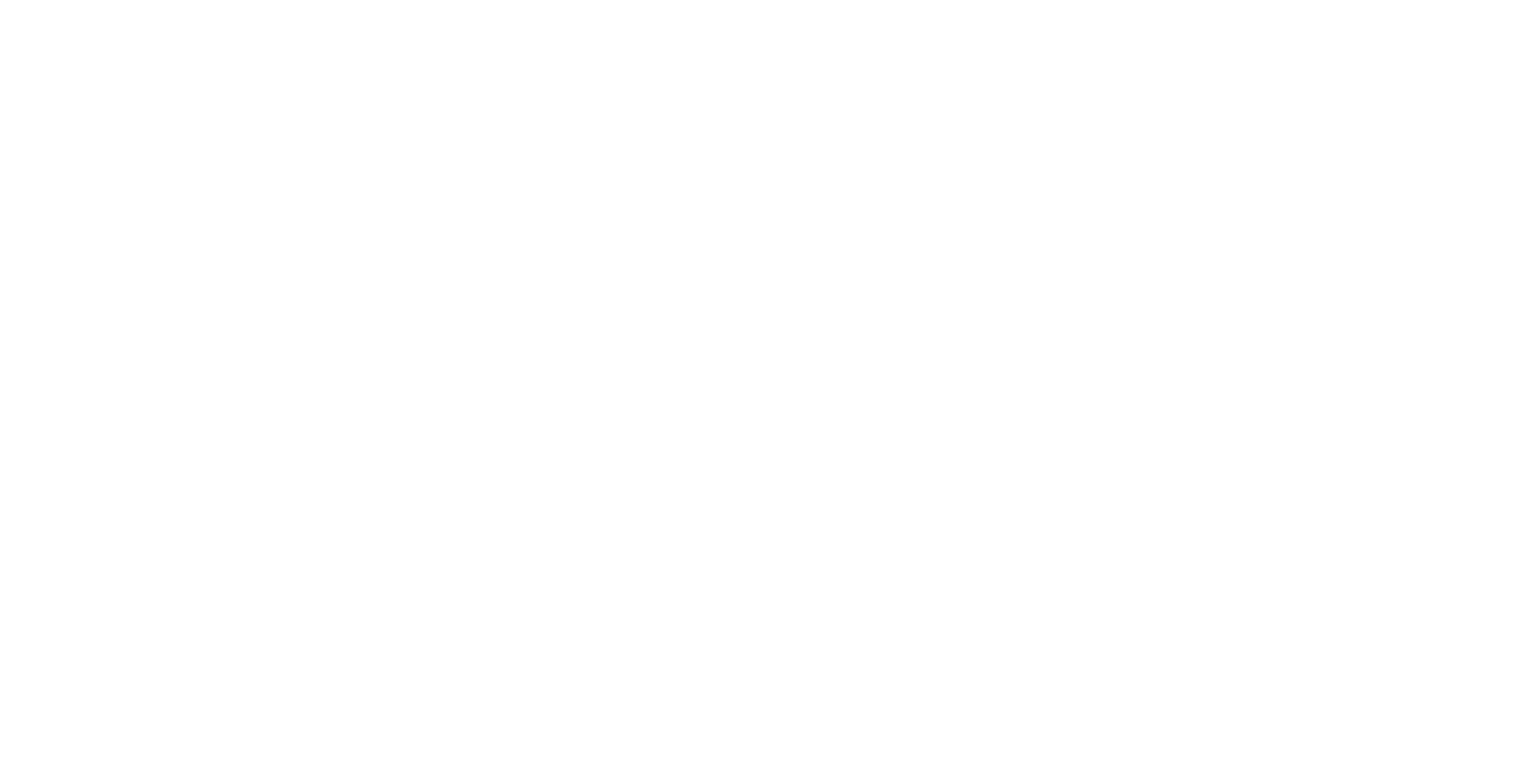

Fiadre 15.-Analyses of water from selected streams in the Upper Colorado River Basin and from the alluvium nearby.

dissolved solids contributed annually by thermal springs in the three divisions are as follows:

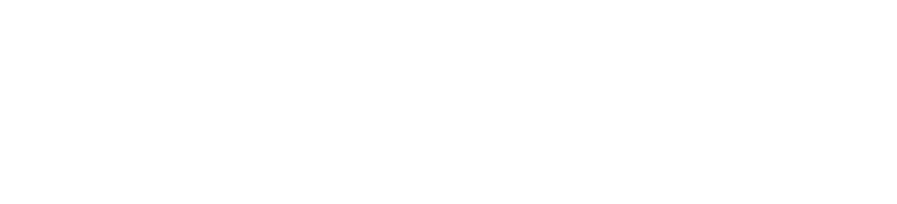

EFFECT OF TRANSMOUNTAIN DIVERSIONS

At the end of the 1957 water year, an average of about 468,400 acre-feet of water and 37,500 tons of dissolved solids were being diverted annually out of the
Upper Colorado River Basin in transmountain diversions. Of these, about 353,100 acre-feet of water and 17,800 tons of dissolved solids were being diverted from the Colorado River and its tributaries above the Gunnison River, and about 112,200 acre-feet of water and 19,300 tons of dissolved solids were being diverted from the Green division, mostly from the Strawberry and Duchesne River basins in Utah.

There may be relatively large changes in the weighted-average dissolved-solids concentration of streams whose flow is greatly depleted by transmoun- 
tain diversions. For example, the transmoutain diversions from the Colorado River above Hot Sulphur Springs, Colo., have decreased the average annual water discharge from about 417,300 acre-feet in 1914 to about 176,800 acre-feet in 1957 ; have decreased dissolved-solids discharge from about 34,900 tons to about 18,260 tons; and have increased the weighted-average concentration from about 61 to $76 \mathrm{ppm}$. Similarly, the diversion of 102,100 acre-feet annually through Strawberry River and Duchesne River tunnels has increased the weighted-average concentration of the Duchesne River below the mouth of the Uinta River from about 533 to $608 \mathrm{ppm}$.

The net effect of all transmountain diversions on the weighted-average concentration of the Colorado River at "Lee Ferry," Ariz., however, is relatively small. The weighted-average concentration of the Colorado River at this point is about $501 \mathrm{ppm}$ for the level of development in 1957. If there were no water exported out of the basin, the weighted-average concentration of the river would be $485 \mathrm{ppm}$, or $16 \mathrm{ppm}$ less than that for the 1957 level of upstream development. Without transmountain diversions, the water and dissolvedsolids discharge of the Colorado River at "Lee Ferry" would be about 13,201,500 acre-feet and 8,713,800 tons, respectively, if one assumes no change in stream losses. Transmountain diversion of water has increased the weighted-average concentration at "Lee Ferry" about $3.4 \mathrm{ppm}$ for each 100,000 acre-feet of water diverted.

\section{HFFECT OF THE ACTIVITIES OF MAN}

Part of the water used for domestic and industrial purposes is consumed and part returns to the stream system. The water returned to streams contains dissolved solids that were added to the water during its use for domestic or industrial purposes. The effect of these uses is to decrease the amount of water that would flow down the streams under natural conditions and to increase the dissolved-solids concentration of the streams. This report presents data which show that about 100 tons of dissolved solids are added to the stream system annually by domestic and industrial uses of water for each 1,000 people in the basin.

Part of the water diverted from the streams for irrigation never returns to the stream system, but is used consumptively by evaporation from the surfaces of canals, ponded areas, and wetted ground and by transpiration of water by the crops and vegetation. In evapotranspiration only a small amount of dissolved solids is taken up and retained in the plants; most of the dissolved solids remains in the soil or in the soil solution. The dissolved solids contained in the consumed water must not be allowed to accumulate in the soil but must be flushed away; otherwise, salinity of the soil will be increased to a level that will diminish the productivity of the lands.

To maintain a favorable salt balance, some of the water applied in irrigation is used to flush, beyond the root zone, the dissolved solids that were contained in the consumed water. Part of this water may move over the ground surface and pick up additional soluble solids on its way back to the stream system. Another part of this water, together with water that seeps from the canals and laterals, moves downward through the soil and subsoil to the water table. This water, in addition to transporting its part of the dissolved solids from the consumed water, also leaches soluble minerals from the soils and rocks as it moves to and through the ground-water reservoir on its route back to the stream system.

The leaching is not confined to carrying away in solution the soluble salts that have been deposited by evapotranspiration of irrigation water or that were present in the soil before irrigation began. The leaching also picks up soluble solids that are constantly being made available by chemical weathering. In the irrigated areas, chemical weathering is greatly accelerated by moisture and by carbon dioxide from decaying vegetation.

Irrigation water in its journey through the irrigated areas picks up dissolved solids in addition to those contained in the water at points of diversion; accordingly, the return flow adds to the dissolved-solids loads already being carried by the streams. Because of the added dissolved solids and consumption of part of the diverted water, the dissolved-solids concentration of the return flows is much greater than that of the stream water; thus, the dissolved-solids concentrations of the streams are increased below the points of return flow. As irrigated lands are on terraces, benches, and flood plains, the surface runoff from the irrigated lands and water from the ground-water reservoirs under these lands are usually tributary to the same stream system from which the irrigation water is diverted.

The quantities of dissolved solids that are leached from the land by irrigation and the effect of these additional salts on the concentration of the streams to which the drainage water returns, differ greatly from place to place. In many of the headwater areas, such as the Fraser and New Fork River basins, the soils and rocks that underlie the irrigated lands are composed of relatively insoluble materials, and the amount of dissolved solids picked up by the leaching of irrigation water is relatively small (table 12). However, most of the irrigated land is in the arid and semiarid parts of the basin, where the soils and underlying rocks contain 
minerals that are relatively soluble. Large amounts of dissolved solids, contained in the return flow from the irrigated land in these areas, are contributed to the stream system. The dissolved-solids yield from irrigated lands, over and above the amount that would come from these lands naturally, generally ranges from 0.1 ton per acre per year in the headwater areas to 5.6 tons per acre per year in some of the interior valleys. The irrigated lands in the areas listed in table 12 comprise 41 percent of the total irrigated acreage. The amount of dissolved solids contributed by irrigation in any area depends principally on the amount of land irrigated, on the amount of water applied to the irrigated land, and on the types of soils and underlying rocks.

The data in this report show that the activities of man in the basin add about 3,480,300 tons of dissolved solids to the stream system annually (table 13). Of this amount, domestic and industrial uses of water, which consume about 22,600 acre-feet of water annually, are estimated to add about 33,600 tons of dis- solved solids annually. Contribution by domestic and industrial uses is relatively small because of the sparse population and small amount of industrial development. Irrigation, which consumes about $1,769,100$ acrefeet of water annually, probably contributes about $3,446,700$ tons of dissolved solids to the stream system.

The average annual water and dissolved-solids discharges from the Upper Colorado River Basin for the water years 1914-57 adjusted to 1957 conditions, are about 12,733,100 acre-feet and 8,676,300 tons, respectively. If there were no activities of man, exclusive of transmountain diversions, the long-term weighted-average concentration of dissolved solids of the Colorado River at "Lee Ferry," Ariz., would be about $263 \mathrm{ppm}$. Thus, there is an increase of $238 \mathrm{ppm}$ in dissolvedsolids concentration (501 ppm minus $263 \mathrm{ppm}$ ) caused by domestic, industrial, and agricultural uses of water. This increase is equivalent to $13.3 \mathrm{ppm}$ for each 100,000 acre-feet of water consumed, and is about four times that caused by the diversion of an equivalent amount of water from the basin.

TABLE 12.-Yield rates of dissolved solids from irrigated lands in 21 areas that comprise about 41 percent of the irrigated lands in the Upper Colorado River Basin

[Data are for the water years 1914-57 adjusted to 1957 conditions]

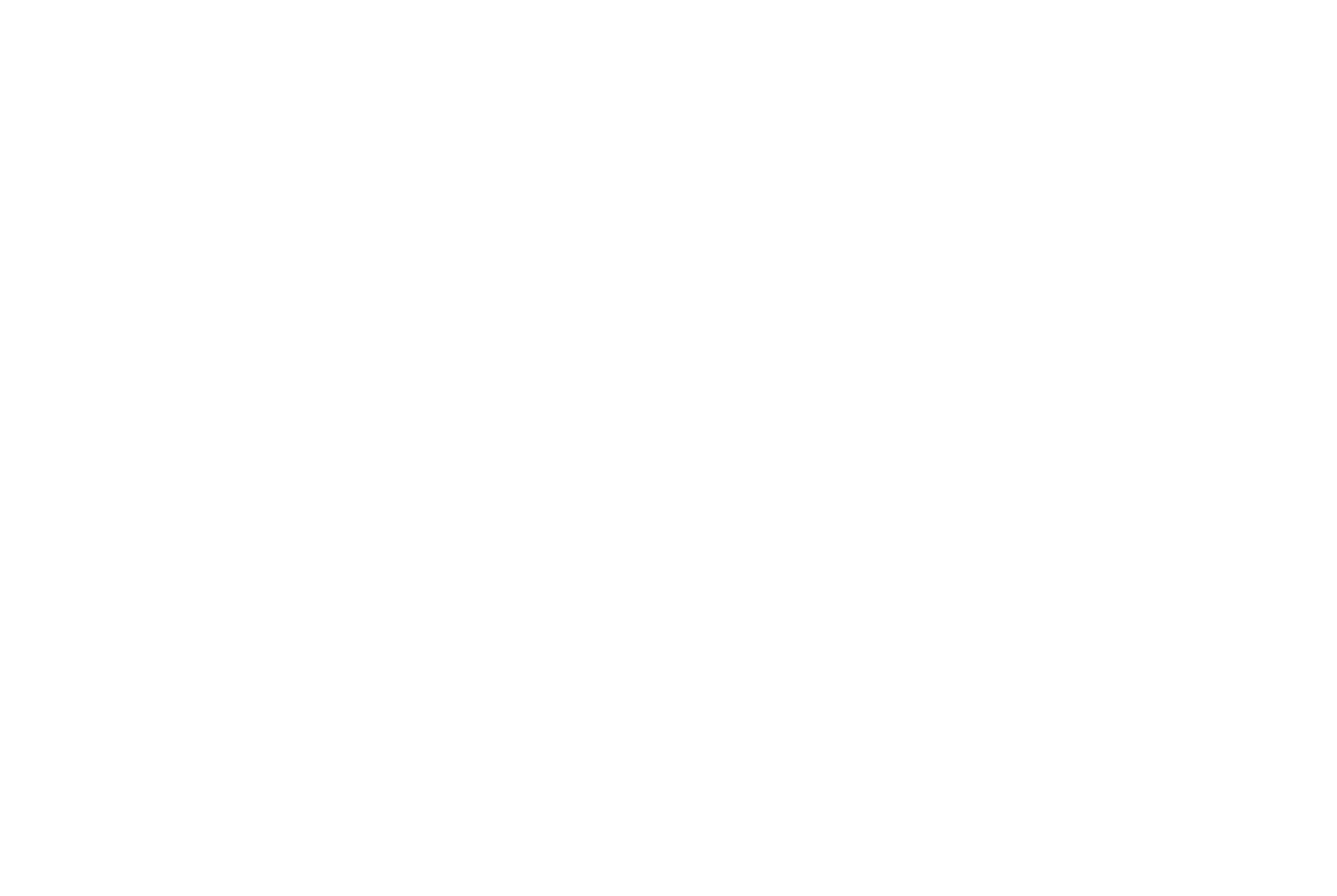


TABLE 13.-Average annual dissolved-solids discharge and probable amounts from natural sources and the activities of man in the Upper Colorado River Basin

[Data are for the water years 1914-57 adjusted to 1957 conditions]

\begin{tabular}{|c|c|c|c|c|c|c|c|c|}
\hline $\begin{array}{l}\text { Colorado River Basin above the Gunnison River } \\
\text { Gunnison River basin } \\
\text { Colorado River Basin between the Gunnison and Green Rivers. }\end{array}$ & $\begin{array}{l}8,670 \\
8,020 \\
9,810\end{array}$ & $\begin{array}{r}3,168,200 \\
1,884,000 \\
1481,800\end{array}$ & $\begin{array}{l}192,500 \\
269,400 \\
121,300\end{array}$ & $\begin{array}{l}1,644,100 \\
1,519,000 \\
1,041,500\end{array}$ & $\begin{array}{r}1,242,100 \\
542,000 \\
469,900\end{array}$ & $\begin{array}{r}143 \\
68 \\
48\end{array}$ & $\begin{array}{l}402,000 \\
977,000 \\
571,600\end{array}$ & $\begin{array}{l}2.1 \\
3.6 \\
4.7\end{array}$ \\
\hline Total for Grand division. & 26,500 & $15,534,000$ & 583,200 & $4,204,600$ & $2,254,000$ & 85 & $1,950,600$ & 3.4 \\
\hline $\begin{array}{l}\text { Green River basin above the Yampa River } \\
\text { Yampa River basin } \\
\text { Green River basin between the Yampa and White Rivers, including the }\end{array}$ & $\begin{array}{r}17,000 \\
8,000\end{array}$ & $\begin{array}{l}21,645,000 \\
31,602,600\end{array}$ & $\begin{array}{r}258,400 \\
73,700\end{array}$ & $\begin{array}{l}967,100 \\
405,800\end{array}$ & $\begin{array}{l}646,600 \\
343,400\end{array}$ & $\begin{array}{ll}38 \\
43\end{array}$ & $\begin{array}{r}320,500 \\
62,400\end{array}$ & 1.2 \\
\hline $\begin{array}{l}\text { White River basin } \\
\text { Green River basin below the white River. }\end{array}$ & $\begin{array}{r}10,800 \\
8,900 \\
\end{array}$ & $\begin{array}{r}1,260,400 \\
\quad 3152,100 \\
\end{array}$ & $\begin{array}{r}188,000 \\
60,000\end{array}$ & $\begin{array}{r}1,034,100 \\
521,100\end{array}$ & $\begin{array}{l}471,800 \\
288,400\end{array}$ & $\begin{array}{l}44 \\
32 \\
\end{array}$ & $\begin{array}{l}562,300 \\
232,700\end{array}$ & $\begin{array}{l}2.3 \\
3.9 \\
\end{array}$ \\
\hline Total for Green division.. & 44,700 & $64,660,100$ & 590,100 & $2,928,100$ & $1,750,200$ & 39 & $1,177,900$ & 2.0 \\
\hline
\end{tabular}

1 Does not include runoff from $2,400 \mathrm{sq} \mathrm{mi}$ between Colorado River near Cisco, Utah, gaging station and the Green River.

Does not include runoff from $1,900 \mathrm{sq} \mathrm{mi}$ in the subbasin between Green River near Greendale gaging station and the Yampa River.

Does not include runoff from $800 \mathrm{sq}$ mi in the subbasin between Yampa River near Maybell, Colo., and Little Snake River near Lily, Colo., gaging station and the Green River.

Doludes runofi from the two areas described in footnotes 2 and 3.

6 Does not include runoff from 2,400 sq mi between Green River at Green River.

\section{FLUVIAL SEDIMENT}

Water and suspended-sediment concentration and discharge at 42 sites in the Upper Colorado River Basin are given in table 14. Most of the data in the table represent the long-term average that would have occurred if the water-use developments as of $1957 \mathrm{had}$ been in operation throughout water years 1914-57. The data for shorter periods are probably representative of the long-term average and 1957 conditions.

Figure 16 shows the water and suspended-sediment discharge at the sites listed in table 14, expressed as percentages of the combined water and suspendedsediment discharge of Colorado and Paria Rivers at Lees Ferry, Ariz. (outflow from the Upper Colorado River Basin). The precision of the percentages varies, and the last significant figure shown in the values presented in figure 16 may not be trustworthy for some of the stations. Of the combined sediment discharge of the Colorado and Paria Rivers (103,955,000 tons), about 20,495,000 tons (20 percent) comes from the Colorado River Basin above Green River, about $27,875,000$ tons (27 percent) comes from the Green River basin, and about $55,585,000$ tons ( 53 percent) comes from the remainder of the Upper Colorado River Basin below the mouth of the Green River. Of the amount from the basin below the Green River,
Utah, and San Rafael River near Green River, Utah, gaging stations and the Colo-

rado River.
6 Includes runoff from the two areas described in footnotes 2 and 3 but not that described in 5 .

7 From San Juan River basin above gaging station near Bluff, Utah

8 Includes 17,000 tons of dissolved solids imported from the Dolores River.

- Includes contribution from San Juan River basin below the gaging station near Bluff, Utah, and from the areas described in footnotes 1 and 5 .

10 Includes 700 tons of dissolved solids imported in the Tropic and East Fork Canal.

about $39,840,000$ tons, or 38 percent of the combined suspended-sediment of the Colorado and Paria Rivers, comes from the San Juan River basin.

Of the streams listed in table 14, the drainage basin of the San Juan River above the gaging station near Blanco, N. Mex., has the highest annual yield of suspended sediment per square mile of drainage area (2,607 tons). However, a greater annual yield was computed for the 2,332 square miles intervening above this station and below the stations on San Juan River at Rosa, N. Mex.; Los Pinos River near Bayfield, Colo.; and Spring Creek at La Boca, Colo. This computed yield is about 3,900 tons. The area involved is mostly underlain by shale, siltstone, sandstone, and conglomerate of Tertiary age.

From another intervening area, that between the stations on the Colorado River and Roaring Fork at Glenwood Springs, Colo., and the station on Colorado River near Cameo, Colo. (2,040 sq mi), about 8,475,000 tons of suspended sediment is contributed to the Colorado River annually. This amount of sediment is equivalent to a yield of about 4,200 tons per square mile per year. Most of the drainage area south of the river is underlain by the Wasatch Formation of Tertiary age. This formation also crops out in part of the area north of the river, where a large area of the 
Green River Formation is also exposed. Other units exposed on the north side of the river are the Mesaverde Formation, Mancos Shale, Dakota Sandstone, Morrison Formation, and rocks of Permian and Mississippian ages. Most of the rocks are siltstone, sandstone, and shale and are relatively soft and erodible.
The high sediment yield is caused by the erodible rocks, which occur at all altitudes in this area of rugged relief where precipitation is as much as 30 inches annually.

Similar rocks underlie large areas in the interior of the basin. If these interior areas were less arid, the

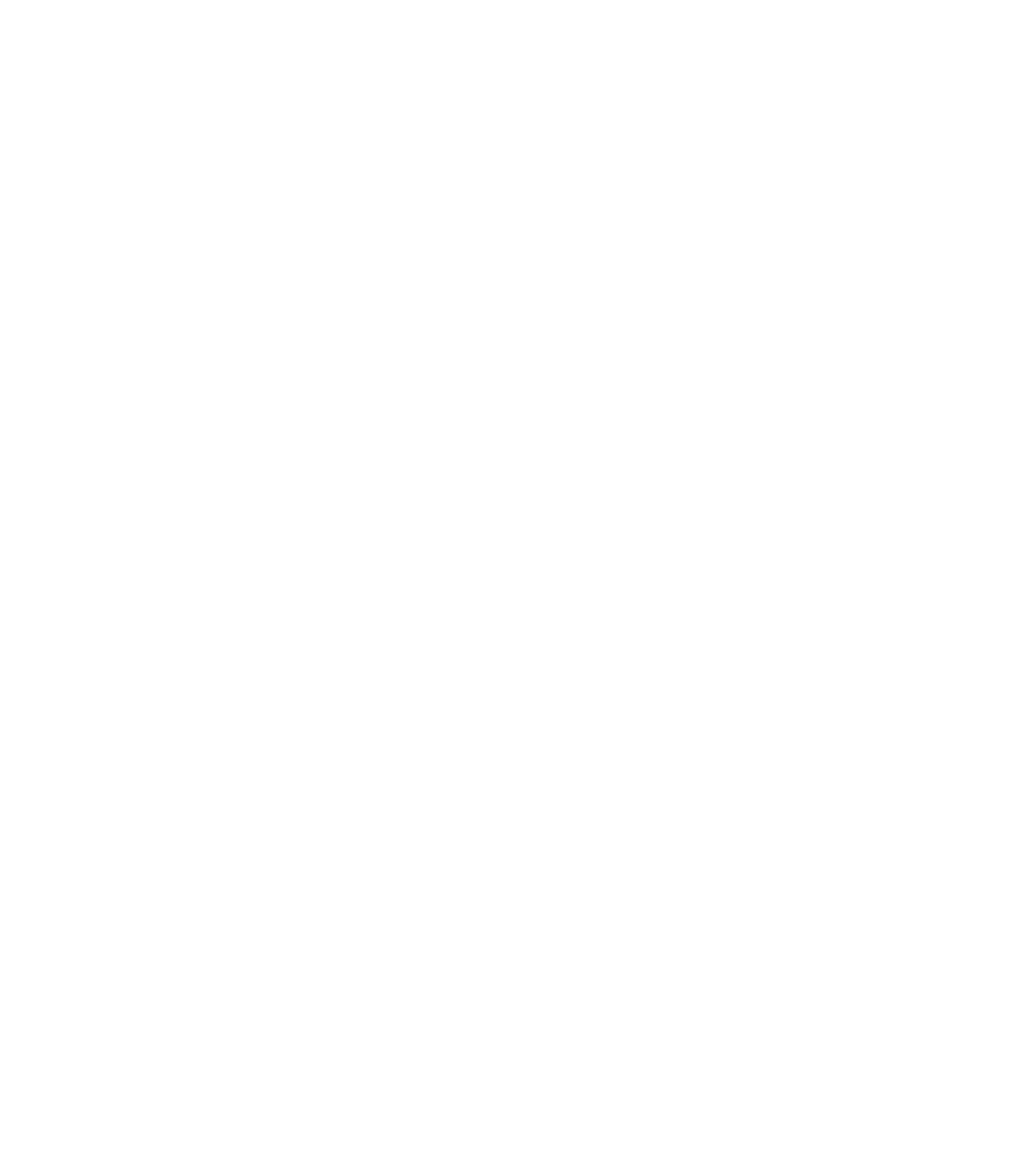

FIGURE 16.-A pproximate water and suspended-sediment discharge expressed as percentages of the combined streamflow and combined suspended-sediment discharge of the Colorado and Paria Rivers at Lees Ferry, Ariz. 
TABLE 14.-Water and suspended-sediment discharge at gaging stations in the Upper Colorado River Basin [Discharges for the water years 1914-57 adjusted to 1957 conditions, except as indicated]

\begin{tabular}{|c|c|c|c|c|c|}
\hline \multirow{3}{*}{$\begin{array}{l}\text { Station } \\
\text { No. }\end{array}$} & \multirow{3}{*}{ Station name } & \multirow{3}{*}{$\begin{array}{l}\text { A verage annual } \\
\text { water discharge } \\
\quad \text { (acre-ft) }\end{array}$} & \multicolumn{3}{|c|}{ Suspended sediment } \\
\hline & & & \multirow{2}{*}{$\begin{array}{c}\text { Weighted- } \\
\text { average } \\
\text { concentration } \\
\text { (ppm) }\end{array}$} & \multicolumn{2}{|c|}{ Discharge } \\
\hline & & & & Tons per year & $\begin{array}{l}\text { Tons per sq } \\
\text { mi per year }\end{array}$ \\
\hline 725 & Colorado River at Glenwood Springs, Colo & $1,738,000$ & 200 & 485,800 & 107 \\
\hline 850 & Roaring Fork at Glenwood Springs, Colo & 980,200 & 220 & 287,100 & 197 \\
\hline 920 & Rifle Creek near Rifle, Colo. ${ }^{1} \ldots \ldots \ldots$ & 17,800 & 1,800 & 43,500 & 311 \\
\hline 955 & Colorado River near Cameo, Colo & $2,998,000$ & 2,300 & $9,248,000$ & 1,150 \\
\hline 965 & Plateau Creek near Cameo, Colo & 170,200 & 180 & 19,000 & 216 \\
\hline $1275 \mathrm{~A}$ & Gunnison River above Gunnison tunnel, Colo & $1,281,000$ & 105 & 183,000 & 46 \\
\hline 1285 & Smith Fork near Crawford, Colo & 39,600 & 224 & 12,000 & 287 \\
\hline 1295 & Iron Creek near Crawford, Colo.2- & 12,200 & 986 & 16,400 & 245 \\
\hline 1435 & Surface Creek near Cedaredge, Colo. ${ }^{3}-$ & 19,600 & 112 & 3,000 & 70 \\
\hline 1525 & Gunnison River near Grand Junction, Colo & $1,884,000$ & 806 & $2,067,000$ & 258 \\
\hline 1665 & Dolores River at Dolores, Colo. & 356,400 & 245 & 119,100 & 214 \\
\hline 1800 & Dolores River near Cisco, Utah ${ }^{4}$ & 549,900 & $3, \overline{370}$ & $2,524,000$ & 545 \\
\hline 1805 & Colorado River near Cisco, Utah ${ }^{5}$ & $5,141,000$ & 2,050 & $14,351,000$ & 595 \\
\hline 1885 & Green River at Warren Bridge, near Daniel, Wyo............. & 391,200 & 36 & 19,000 & 41 \\
\hline 2095 & Green River near Fontenelle, Wyo & $1,166,000$ & 180 & 292,000 & 74 \\
\hline 2165 & Green River at Green River, Wyo & $1,305,000$ & 350 & 625,000 & 81 \\
\hline 2250 & Blacks Fork near Green River, Wyo. ${ }^{6}$ & 249,900 & 3,000 & $1,020,000$ & 278 \\
\hline 2295 & Henrys Fork at Linwood, Utah & 65,800 & 960 & 85,800 & 162 \\
\hline $2510 A$ & Yampa River at bridge on county road, near Maybell, Colo...... & $1,152,000$ & 196 & 308,000 & 90 \\
\hline 2550 & Slater Fork near Slater, Colo & 60,800 & 212 & 17,500 & 109 \\
\hline 2555 & Savery Creek at upper station, near Savery, Wyo & 36,800 & 146 & 7,300 & 39 \\
\hline $2595 \mathrm{C}$ & Little Snake River at bridge on State Highway 318 , near Lily, Colo_- & 450,600 & 1,790 & $1,099,000$ & 295 \\
\hline 2610 & Green River near Jensen, Utah & $3,333,000$ & 1,300 & $5,902,000$ & 226 \\
\hline 3030 & White River at Buford, Colo... & 239,800 & 102 & 33,200 & 131 \\
\hline 3070 & Green River near Ouray, Utah ${ }^{7}$ & $4,448,000$ & 2,120 & $12,824,000$ & 361 \\
\hline 3145 & Price River at Woodside, Utah & 84,000 & 33,900 & $3,879,000$ & 2,586 \\
\hline 3150 & Green River at Green River, Utah ${ }^{5}$ & $4,067,000$ & 3,760 & $20,800,000$ & 512 \\
\hline 3285 & San Rafael River near Green River, Utah. & 102,100 & 6,700 & 931,000 & 551 \\
\hline 3335 & Dirty Devil River near Hite, Utah 8 & 73,900 & 50,200 & $5,000,000$ & 1,147 \\
\hline 3350 & Colorado River at Hite, Utah...... & $10,260,000$ & 4,000 & $55,960,000$ & 731 \\
\hline 3395 & Escalante River at mouth, near Escalante, Utah ${ }^{0}$ & 61,700 & 20,900 & $1,757,000$ & 874 \\
\hline 3505 & San Juan at Rosa, N. Mex & 875,100 & 3,800 & $4,400,000$ & 2,211 \\
\hline 3535 & Los Pinos River near Bayfield, Col & 287,600 & & 1,800 & \\
\hline 3550 & Spring Creek at La Boca, Colo & 25,600 & 940 & 32,000 & 552 \\
\hline 3565 & San Juan River near Blanco, N. Mex... & $1,100,000$ & 6,400 & $9,280,000$ & 2,607 \\
\hline 3645 & Animas River at Farmington, N. Mex & 703,500 & 1,800 & $1,720,000$ & 1,263 \\
\hline 3665 & La Plata River at Colorado-New Mexico State line...... & 27,900 & 740 & 28,000 & 85 \\
\hline 3680 & San Juan River at Shiprock, N. Mex & $1,941,000$ & 11,600 & $30,600,000$ & 2,372 \\
\hline 3715 & McElmo Creek near Cortez, Colo.... & 38,800 & 2,600 & 141,000 & 605 \\
\hline 3795 & San Juan River near Bluff, Utah_ & $2,028,000$ & 13,500 & $37,100,000$ & 1,613 \\
\hline 3800 & Colorado River at Lees Ferry, Ariz & $12,710,000$ & 5,800 & $101,300,000$ & 939 \\
\hline 3820 & Paria River at Lees Ferry, Ariz & 23,100 & 84,400 & $2,655,000$ & 1,691 \\
\hline $\begin{array}{l}2 \\
3 \\
4\end{array}$ & $\begin{array}{l}8 \text { For water } \\
\text { For water }\end{array}$ & $\begin{array}{l}1914-57 . \\
1951-55 .\end{array}$ & & & \\
\hline
\end{tabular}

sediment yield to the Colorado River would be much higher.

\section{SUITABILITY OF WATER FOR VARIOUS USES DOMESTIC USE}

Concentration of dissolved minerals in water is a criteria used for judging the suitability of water for domestic use. The criteria sets specific maximum limits for concentration of total dissolved solids and concentration of specific constituents such as iron, manganese, chloride, fluoride, nitrate, and sulfate.

The waters of most perennial streams, near their headwaters, have less than the maximum specified concentrations of dissolved solids and are suitable for domestic use. After the streams leave the mountains, the waters of some streams become unsuitable for domestic use during periods of low flow, principally because of high concentrations of total dissolvedsolids or high concentrations of one or more of the chloride, nitrate, and sulfate ions. Some streams, however, are not suitable for domestic use even during times of high flow.

On the basis of maximum total dissolved-solids concentration (limit $500 \mathrm{ppm}$ ), streams listed in table 7 whose waters have weighted-average concentrations of $500 \mathrm{ppm}$ or more would be suitable for domestic use no more than 30 percent of the time. 
Table 10 indicates that the total dissolved-solids limit is exceeded in Colorado River near Cisco, Utah, when the water discharge is less than about $9,000 \mathrm{cfs}$ (cubic feet per second). Sulfate concentration also exceeds the limit $(250 \mathrm{ppm})$ at about the same discharge.

Table 10 indicates that the total dissolved-solids limit is exceeded in Green River at Green River, Utah, when the water discharge is less than about $7,000 \mathrm{cfs}$. The sulfate concentration exceeds the limit for discharges less than about 3,000 cfs.

Table 10 indicates that the total dissolved solids in San Juan River near Bluff, Utah, exceeds the limit when the discharge is less than about $1,800 \mathrm{cfs}$. The sulfate limit is exceeded when discharge is less than about $1,500 \mathrm{cfs}$.

Table 10 indicates that the total dissolved solids in Colorado River at Lees Ferry, Ariz., exceeds the limit when discharge is less than about $21,500 \mathrm{cfs}$. The sulfate limit is exceeded when the discharge drops below about 15,000 cfs.

The waters of the perennial streams in their headwaters are usually soft but become progressively harder with increasing distance from the mountains. Beyond the mountains, softening of the surface waters would be desirable for most uses and almost mandatory for some uses.

The monthly weighted-average concentration of nitrate has been as much as $40 \mathrm{ppm}$ in Colorado River near Cisco, Utah, and as much as $61 \mathrm{ppm}$ in Dolores River near Cisco, Utah. Though nitrate is present in all streams, it is usually not in sufficient concentrations to constitute a hazard for domestic use except locally during low flows.

Some of the surface water, whose source is principally springs, such as Steamboat Springs, Colo., contains flouride in amounts sufficient to cause mottling of children's teeth if used continuously for drinking and cooking.

\section{AGRICULTURAL USE}

Agricultural use of water in the Upper Colorado River Basin includes among other uses watering livestock and irrigation. A high concentration of dissolved solids and of certain ions in the water may cause the water to be unsuitable for these purposes.

Sheep and cattle are the main livestock in the basin. They apparently have the ability to tolerate relatively high concentrations of dissolved solids in their drinking water, although low concentrations of certain constituents, such as selenium, are toxic. Most of the surface water is suitable for watering livestock.

Data indicating the suitability of water for irrigation at the 50 sites listed in table 7 and shown in figure 8 are given in table 15 . Methods proposed by Wilcox, Blair, and Bower (1954, p. 259-266), U.S. Salinity Laboratory Staff (1954), and Eaton (1954) were used to compute the data. The classifications are based entirely on chemical analyses of water at high, medium, and low discharges. Not taken into account are minerals that may be present in the soils irrigated, irrigation practices, and other factors that may significantly change a water-usability classification based only on chemical analyses of applied water.

Terms in the box heads of table 15 are those proposed for the classification of water for irrigation in the cited references. In the classification of water discharges, high flows are those greater than the flow exceeded 20 percent of the time; low flows are those less than the flow exceeded 80 percent of the time; and medium flows are those greater than the flow exceeded 80 percent of the time but less than the flow exceeded 20 percent of the time.

Of the streams listed in table 15 , residual sodium carbonate exceeded 1.25 equivalents per million only in Strawberry River at Duchesne, Utah. This concentration is considered to be the lower limit for waters marginal for irrigation. Mixing of Strawberry River water with Duchesne River water a short distance downstream should result in a water much lower in residual sodium carbonate. A few other streams investigated also exceeded the limit for residual sodium carbonate, but these were in areas where the water is not used for irrigation.

As indicated in the table, most sources of water supply serving irrigated lands range from $\mathrm{C} 1-\mathrm{S} 1$ to $\mathrm{C} 3-$ S1. According to the U.S. Salinity Laboratory Staff (1954), waters in the C1 category can be used for irrigation of most crops on most soils with little likelihood that soil salinity will occur, and waters in the C3 category cannot be used on soils with restricted drainage. The S1 category implies that the water can be used for irrigation on almost all soils with little danger of the occurrence of harmful levels of exchangeable sodium. Water in the poorer quality categories, for the most part, occurs in the lower reaches of the streams below irrigated lands and in canyon areas where the water is not used for irrigation.

The degree of leaching required for good crop yields as computed for the sources of water supply that serve irrigated lands is generally low, and probably higher percentages of applied water actually pass through most irrigated soils than are indicated in table 15. Waters in downstream reaches of some streams have high required leaching percentages. These waters, for the most part, are in tributary streams below the points that water is diverted for irrigation. As the 
TABLE 15.-Suitability of surface water for irrigation in the Upper Colorado River Basin

[Calcium $a$, to adjust water to 70 percent sodium; calcium $b$, to offset bicarbonate precipitation; and calcium $c$, to supply calcium plus magnesium taken by plants in excess

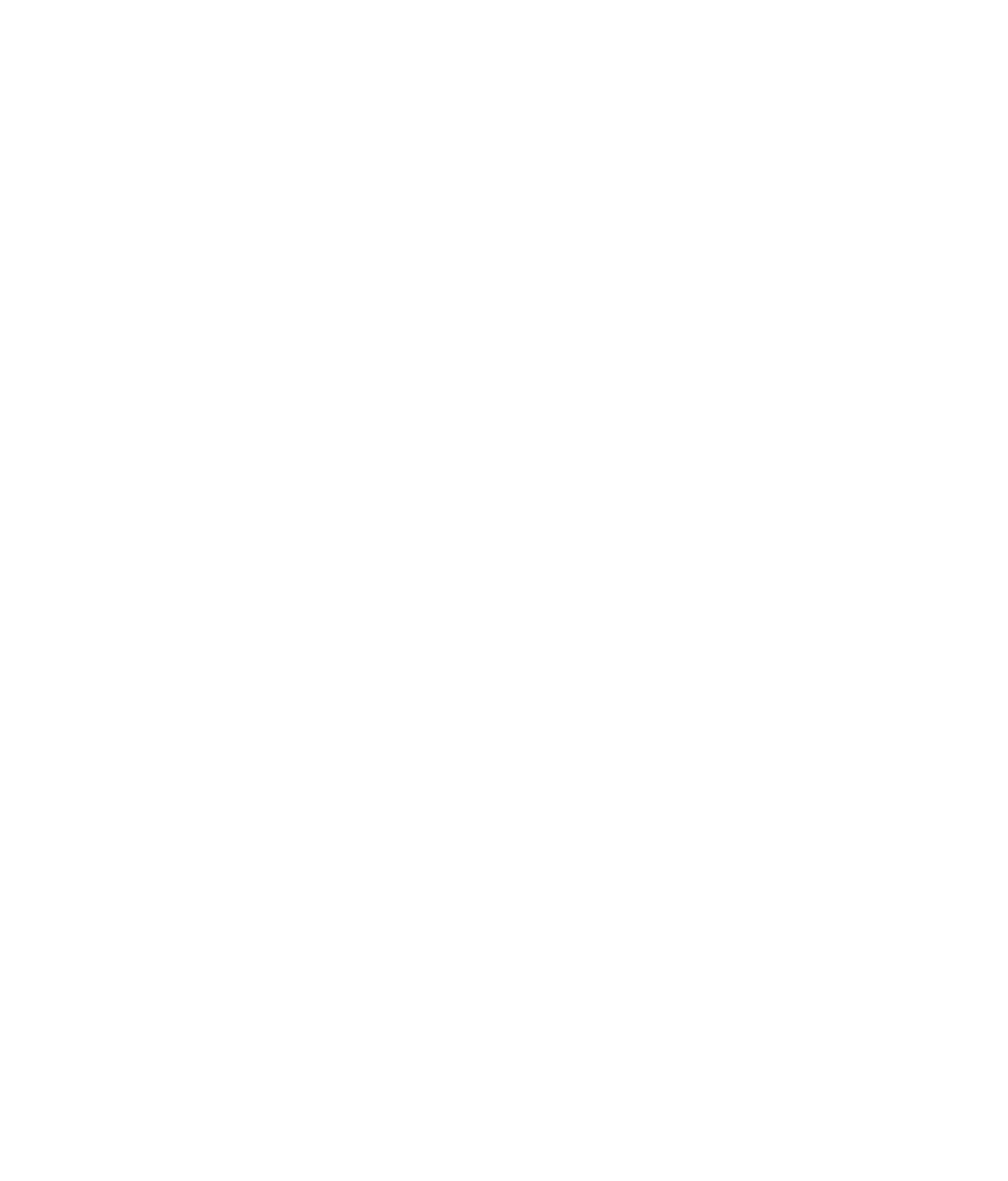


TABLE 15.-Suitability of surface water for irrigation in the Upper Colorado River Basin-Continued

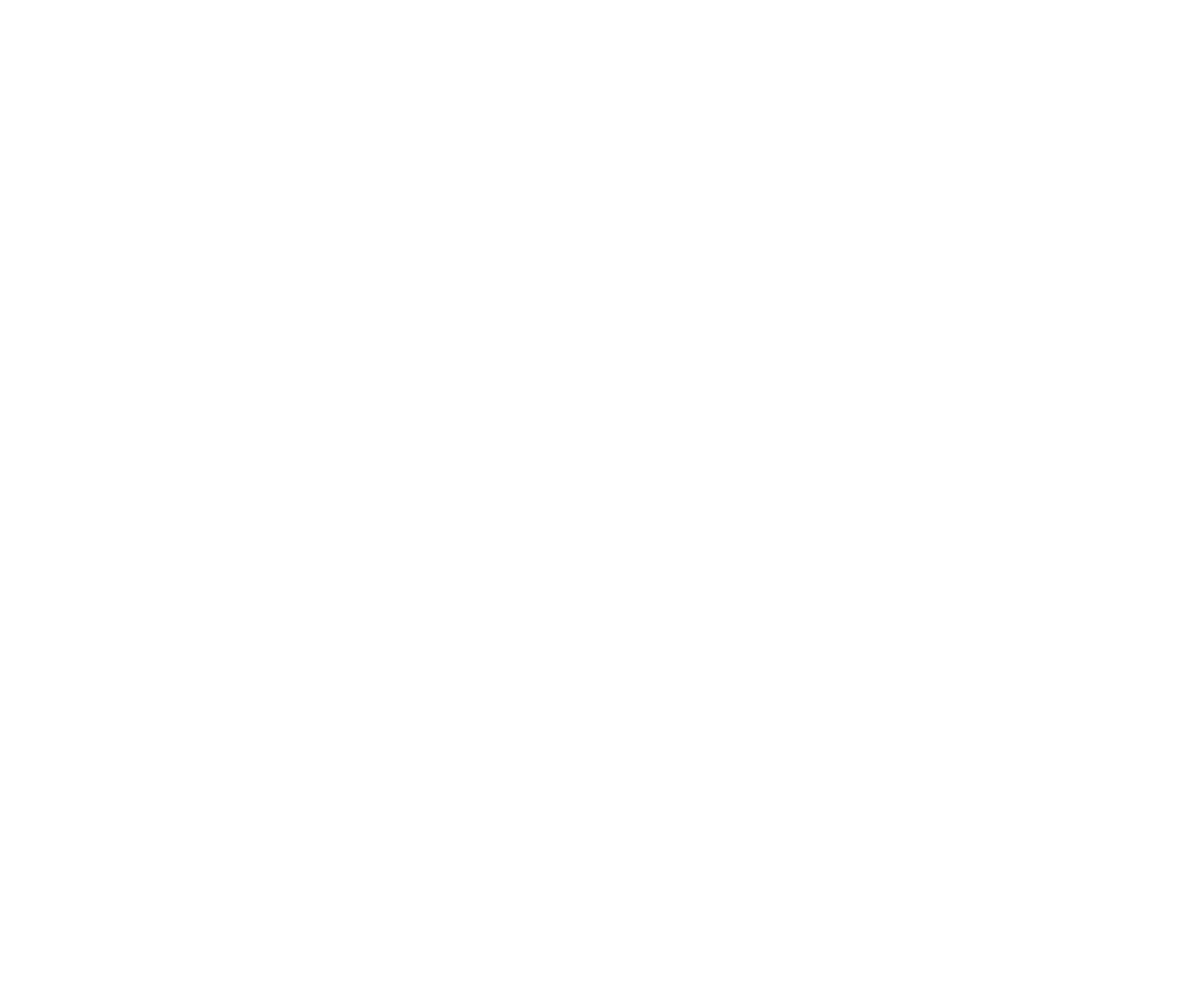

1 For good yield.

flow of the tributaries is small compared to that of the main stream, the required leaching percentage of mainstream water is not materially increased by inflow from the tributaries.

The amounts of gypsum required (table 15) for good crop yields are based on the assumption that all calcium required to adjust the sodium percentage to 70 , to offset bicarbonate precipitation, and to supply the calcium needs of the plants must come from the irrigation water. This may not be applicable to all irrigated lands in the Upper Colorado River Basin, as most soils are gypsiferous and the addition of gypsum is not necessary for good crop yields.

\section{INDUSTRIAL USE}

The water of headwater streams can be used in many industrial applications without treatment. Most of the water in the middle and lower reaches of the streams cannot be used for many industrial applications without treatment, and the water in the streams near most of the larger towns and cities would require extensive treatment. Most of the surface water could be used without treatment by mining industries and for certain phases of metal fabrication, where the tolerances of dissolved solids are high.

\section{RECREATIONAL USE}

Most streams are suitable for recreation. The few exceptions include tributary streams during periods of 
low flow or when suspended-sediment concentrations are exceedingly high. Specifically, the dissolved-solids concentrations in the lower reaches of Blacks Fork and the Duchesne, Price, San Rafael, and San Miguel Rivers and in several smaller streams are intermittently high enough to be objectionable for some recreational uses and to be detrimental to aquatic life.

\section{REFERENCES}

Colby, B. R., Hembree, C. H., and Rainwater, F. H., 1956, Sedimentation and chemical quality of surface water in the Wind River Basin, Wyoming; U.S. Geol. Survey WaterSupply Paper 1373, 336 p.

Eaton, F. M., 1954, Formulas for estimating the drainage and gypsum requirements of irrigation waters: Tex. Agr. Expt. Sta. Misc. Rept. 111, 18 p.

Fenneman, Nevin M., and Johnson, D. W., 1946, Physical divisions of the United States: U.S. Geol. Survey Misc. Maps and Charts.

Hunt, C. B., 1956, Cenozoic geology of the Colorado Plateau: U.S. Geol. Survey Prof. Paper 279, 99 p.
Iorns, W. V., Hembree, C. H., Phoenix, D. A., Oakland, G. L., 1964, Water resources of the Upper Colorado River Basin, Basic Data Report: U.S. Geol. Survey Prof. Paper 442, $1036 \mathrm{p}$.

La Rue, E. C., 1916, Colorado River and its utilization: U.S. Geol. Survey Water-Supply Paper 395, 231 p.

Meyers, J. S., 1962, Evaporation from the 17 Western States with a section on evaporation rates, by T. J. Norderson: U.S. Geol. Survey Prof. Paper 272-D, p. 71-100.

President's Water Resources Policy Commission, 1950, Ten rivers in America's future: U.S. Govt. Printing Office, Washington, D.C., 801 p.

Upper Colorado River Basin Compact Commission, 1948, Final Report of Engineering Advisory Committee to Upper Colorado River Basin Compact Commission: Upper Colorado Comm., 1948, 203 p.

U.S. Salinity Laboratory Staff, 1954, Diagnosis and improvement of saline and alkali soil: U.S. Dept. Agriculture Handb. 60, $160 \mathrm{p}$.

Wilcox, L. V., Blair, G. Y., and Bower, C. A., 1954, Effect of bicarbonate on suitability of water for irrigation: Soil Sci., v. 77 , no. 4 , p. $259-266$. 
Hydrologic Techniques and Criteria Used in Appraising

\section{the Surface-Water Resources}

By W. V. IORNS, C. H. HEMBREE, and G. L. OAKLAND

WATER RESOURCES OF THE UPPER COLORADO RIVER BASIN-TECHNICAL REPORT

GEOLOGICAL SURVEY PROFESIONAL PAPER 441-B

Summary of available data and explanation of techniques and criteria used in appraising the water resources of the Upper Colorado River Basin

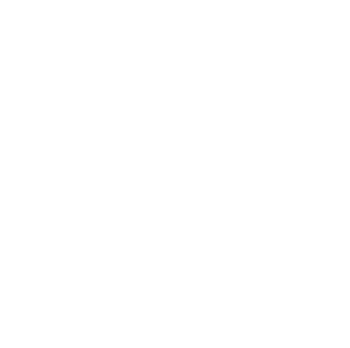

UNITED STATES GOVERNMENT PRINTING OFFICE, WASHINGTON : 1965 
. 


\section{CONTENTS}

Glossary

Abstract

Introduction _. . . . . . . .

Base for appraising the surface-water resources........

Available data.

Streamflow............

Chemical quality . . . .

Sediment_.........

Climate. . .

Base map...........

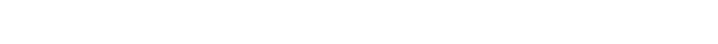

Map of native vegetation and irrigated lands.......

Computing and adjusting precipitation data

Computing and adjusting streamflow data

Flow-duration curves

General characteristics...........................

Adjusting flow-duration curves to base period.

Adjusting flow-duration curves to 1957 condi-

tions of upstream development.

Relation of geology and ground water to streamflow ....

Statistical analysis of annual flows.

Computing chemical-quality data

Duration tables of dissolved solids
Page

IV

41

41

41

42

42

43

43

44

44

44

44

44

45

45

45

46

46

48

53

58

58
Computing chemical-quality data-Continued Dissolved solids contributed to streams by ground

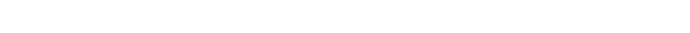

Variability of dissolved-solids concentration........

Effect of transmountain diversions on the chemical quality of water of streams...... Effects of the activities of man on dissolved-solids

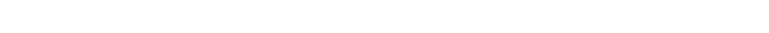

General...

Computation of dissolved solids added to the streams by the activities of man. Computing sediment data..... Water-quality criteria

Properties and characteristics of water........... Physical properties................................. Chemical properties and characteristics........

Water-quality criteria for major uses........... Domestic......... Industrial_...Agricultural_........... Important mineral constituents....... Suitability for irrigation. References... (-. Index.
Page

61

61

62

66

66

66

66

67

68

68

69

69

69

71

73

365

\section{ILLUSTRATIONS}

FIGURE 17. Number of streamflow-gaging stations operated annually in the Upper Colorado River Basin, water years 18941957.

18. Number of daily chemical-quality stations operated annually in the Upper Colorado River Basin, water years 1905-57.

19. Number of daily sediment stations operated annually in the Upper Colorado River Basin, water years 1928-57_.-

20. Flow-duration curves for Gypsum and Homestake Creeks .

21. Hydrographs of discharge and estimated ground water for Gypsum and Homestake Creeks. . . . . . .

22. Relation between the variability index of streamflow and percentage of average annual discharge estimated to be contributed by ground water for selected streams in the Upper Colorado River Basin.

23. Distribution of average flows for periods of various length, Roaring Fork at Glenwood Springs, Colo........

24. Relation of weighted-average concentration of dissolved solids to water discharge, Green River near Ouray, Utah.--

25. Relation of the variability of dissolved-solids concentration to the variability of water discharge in the Grand division. - . . - . . .

26. Relation of concentration of suspended sediment to water discharge, Savery Creek at upper station near Savery, Wyo . . . . .

27. Diagram by U.S. Salinity Laboratory Staff for classification of irrigation waters.

\section{TABLES}

TABLE 1. Average precipitation for groups of stations in the Upper Colorado River Basin for water years 1914-45 and 1914-47 in relation to the average precipitation for water years 1914-57

2. Summary of adjustments to correct historical flow-duration curves to conditions of upstream development existing in 1957 
TABLE 3. Computation of total discharge and ground-water discharge of Gypsum Creek near Gypsum and Homestake Creek near Red Cliff, Colo., by flow-duration tables . . . . .

4. Comparative data in computing ground-water contribution, Gypsum Creek near Gypsum and Homestake Creek near Red Cliff, Colo . . . . . .

5. Variability index of streamflow and percentage of average annual discharge estimated to be contributed by ground water to the stream system at selected sites in the Upper Colorado River Basin .

6. Adjustment of streamflow records for Roaring Fork at Glenwood Springs, Colo., to 1914 base . . . . . . . . .

7. Computations of ratios of the average discharge and plotting position in probability analysis, Roaring Fork at Glenwood Springs, Colo .............

8. Factors for computing probable range in deviation of the average discharge for various periods of years and confidence limits from the average discharge in a 44-year period.

9. Duration table of water discharge and dissolved-solids concentration and discharge of Green River near Ouray,

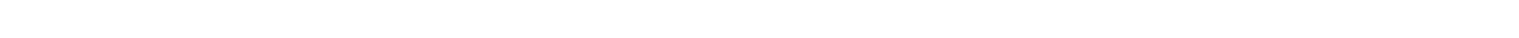

10. Computation of dissolved solids contributed to the stream system by ground water, Green River near Ouray, Utah

11. Variability of annual weighted-average concentration as related to variability of annual water discharge for stations in the Colorado River Basin above the Gunnison River.

12. Partial chemical analyses, in parts per million, of water supply and sewage for three communities in the Great Basin and two communities in the Upper Colorado River Basin .

13. Water and dissolved-solids budget, Frazer River basin and Grand Valley area

14. Yield rates of dissolved solids from irrigated lands in 21 areas that are about 41 percent of the irrigated lands in the Upper Colorado River Basin . . .

15. Duration table of water discharge and suspended-sediment discharge and concentration, Savery Creek at upper station near Savery, Wyo.

16. Water-quality tolerances for ind

\section{GLOSSARY}

Acre-foot is a unit for measuring volume and is equal to the quantity of water or other material required to cover 1 acre to a depth of 1 foot or a volume of 43,560 cubic feet.

Average annual precipitation is an average of the yearly precipitation usually expressed in inches of water that falls or is computed to fall at a point or on an area during a specified number of calendar or water years.

Base flow is sustained or fair-weather streamflow. In most streams, base flow is composed largely of groundwater effluent.

Chemical-quality station is a particular site on a stream, canal, lake, or reservoir where water samples are collected on a systematic basis for chemical study.

Chemical quality of water is a term that embodies all the chemical and physical properties or attributes of water which are imparted to the water by the amounts and kinds of chemical constituents in colloidal suspension or dissolved in the water.

Coefficient of variation is the ratio of the standard deviation to the average of an array of data.

Concentration is a term used to describe the amounts of a material or substance in relation to the total mixture. In this report concentration is expressed in parts per million and in equivalents per million.

Consumptive use is the quantity of water discharged to the atmosphere or incorporated in the products of the process in connection with domestic use, vegetative growth, food processing, or an industrial process.

Cubic feet per second (cfs) is a unit expressing rates of discharge, and is equal to the discharge through a rectangular cross section, 1 foot wide and 1 foot deep, flowing at an average velocity of 1 foot per second.

Direct runoff is the water from rainfall or melting snow that enters the stream system rapidly either as overland flow or as subsurface flow that does not reach the zone of saturation and whose time spent underground is so brief that its rate of movement into the stream is almost as rapid as overland flow.

Dissolved solids are solids that originate mostly from rocks and are in solution. Some colloidal material is treated as if it were in solution in determining dissolved solids.

Dissolved-solids discharge is (1) the rate at which dry weight of dissolved solids passes a section of a stream or other conveyance channel or (2) the quantity of dissolved solids, measured by dry weight or by volume, that is discharged in a given time.

Dissolved-solids yield. See Tons per square mile per year. 
Duration curve is a cumulative frequency curve that shows the percentage of time that specified water, dissolvedsolids, or sediment discharges, or dissolved-solids concentration are equaled or exceeded. A duration curve of water discharge is called a flow-duration curve.

Equivalents per million (epm) is a unit for expressing the concentration of chemical constituents in terms of the electrically charged particles, or ions, in solution. One equivalent per million of a positively charged ion (cation) will react with 1 equivalent per million of a negatively charged ion (anion). Parts per million are converted to equivalents per million by multiplying the reciprocal of the combining weight of the ion. The reciprocals for the more common constituents (ions) are given in the following table:

\begin{tabular}{|c|c|c|c|}
\hline Cations & Factor & Anions & Factor \\
\hline$\left(\mathrm{a}^{++}\right.$ & 0.0499 & $\mathrm{e}\left(\mathrm{CO}_{3}{ }^{--}\right)-$ & 0.0333 \\
\hline Magnesium $\left(\mathrm{Mg}^{++}\right)$ & .0823 & Bicarbonate $\left(\mathrm{HCO}_{3}\right)$ & .0164 \\
\hline Sodium $\left(\mathrm{Na}^{+}\right)$ & .0435 & $\left(\mathrm{SO}_{4}^{--}\right)_{-} \ldots$ & .0208 \\
\hline+ & .0256 & $\begin{array}{l}\text { Chloride }\left(\mathrm{Cl}^{-}\right) \\
\text {Nitrate }\left(\mathrm{NO}_{3}{ }^{-}\right)\end{array}$ & $\begin{array}{l}.0282 \\
.0161\end{array}$ \\
\hline
\end{tabular}

Evaporation is the process by which water is changed from the liquid or solid state into the vapor state.

Evapotranspiration is the process by which water is withdrawn from a land area by evaporation from water surfaces and moist soil and transpiration by plants.

Flow-duration curve See Duration curve.

Fluvial sediment is sediment that is transported by, suspended in, or deposited from water.

Gaging station is a particular site on a stream, canal, lake, or reservoir where systematic observations of gage height or water discharge are obtained. A streamflow gaging station is a gaging station on a stream.

Gallons per minute (gpm) is a unit expressing rates of discharge. One cubic foot per second is equal to 448.8 gpm or 646,272 gpd (gallons per day).

Hardness is a property of water which has generally been associated with the effects observed in the use of soap, or with the deposit left by some types of water when they are heated. Hardness, expressed in terms of an equivalent quantity of calcium carbonate $\left(\mathrm{CaCO}_{3}\right)$, is calculated from the equivalence of calcium and magnesium, or is determined by direct titration. Hardness caused by calcium and magnesium (and other ions if significant) equivalent to the carbonate and bicarbonate is called carbonate hardness; the hardness in excess of this quantity is called noncarbonate hardness.

Histogram is a graphical representation of yearly variability of annual water discharge by rectangles.

Hydrogen-ion concentration ( $\mathbf{p H}$ ) is the negative logarithm of the concentration of hydrogen ions. The $\mathrm{pH}$ is a measure of the activity of the hydrogen ions and thus is a numerical value or measure of the alkalinity or acidity of the water. Ordinarily, water having a $\mathrm{pH}$ of 7.0 is regarded as neutral; a $\mathrm{pH}$ lower than 7.0 indicates acidic properties; and a $\mathrm{pH}$ higher than 7.0 indicates alkalinity. However, a water that is acid, alkaline, or neutral according to the $\mathrm{pH}$ scale is not necessarily the same by another standard.

Hydrograph is a graph showing stage, flow, velocity, or other property of water with respect to time.

Index station is a precipitation or streamflow-gaging station, the data from which is used as an index in adjusting or computing the precipitation or streamflow at other stations.

Intermittent stream is one which flows part of the time, as after a rainstorm, or during part of the year.

Ion is an electrified particle formed when a neutral atom or group of atoms loses or gains one or more electrons. If electrons are lost, the particle is positively charged and is called a cation. If electrons are gained, the particle is negatively charged and is called an anion. When a molecule goes into solution, it breaks down into one or more cations and one or more anions. For example, a molecule of the mineral gypsum or calcium sulfate $\left(\mathrm{CaSO}_{4}\right)$ when dissolved in water dissociates into a calcium ion $\left(\mathrm{Ca}^{++}\right)$and a sulfate ion $\left(\mathrm{SO}_{4}^{--}\right)$.

Irrigation is the controlled application of water to arable lands to supply water requirements not satisfied by rainfall.

Leaching percent is the ratio, expressed in percentage, of the amount of water that passes downward through the root zone of crops to the amount of water that is applied to the land surface.

Low, medium, and high flows are arbitrary designations based on the percentage of time a water discharge was equaled or exceeded. High flows are those greater than a discharge that was equaled or exceeded 20 percent of the time; low flows are those less than a discharge that was equaled or exceeded 80 percent of the time; and medium flows are those greater than a discharge equaled or exceeded 80 percent of the time but less than a discharge equaled or exceeded 20 percent of the time. 
Parts per million (ppm) is a unit for expressing concentration of dissolved solids and sediment. A part per million of dissolved solids is a unit weight of dissolved solids in a million unit weights of a water-dissolved solids solution. A part per million of sediment is a unit weight of sediment in a million unit weights of watersediment mixture.

Percent sodium is the ratio, expressed in percentage, of equivalents per million of sodium ions to the sum of equivalents per million of calcium, magnesium, sodium, and potassium ions.

Perennial stream is one which flows continuously from source to mouth during most years.

Precipitation is the discharge of water, in liquid or solid state, out of the atmosphere, generally upon land or water surface. The term is also used to designate the quantity of water that is precipitated.

Probable deviation. An array of data that is normally distributed has a spread of values on each side of the mean within which 50 percent of the individual values fall. Such a spread is defined as one probable deviation above and one probable deviation below the mean. It is equal to 0.6745 times the standard deviation.

Rainfall is the quantity of water that falls as rain only. The term is not synonymous with precipitation.

Residual sodium carbonate (RSC) is the amount of carbonate plus bicarbonate, expressed in equivalents per million, that would remain in solution if all the calcium and magnesium were precipitated as carbonate.

$$
\mathrm{RSC}=\left(\mathrm{CO}_{3}+\mathrm{HCO}_{3}\right)-(\mathrm{Ca}+\mathrm{Mg})
$$

Return flow is the water returned to the stream system or source after being used. Return flow is generally equal to water use less consumptive use.

Runoff is that part of the precipitation that appears in surface streams. It is the same as streamflow unaffected by artificial diversions, storage, or other works of man in or on the stream channels or on the drainage area.

Sediment is fragmental material that originates mostly from rocks and is transported by, suspended in, or deposited from water or air, or is accumulated in beds by other natural agencies.

Sediment discharge is (1) the rate at which dry weight of sediment passes a section of a stream or (2) the quantity of sediment, as measured by dry weight or by volume, that is discharged in a given time.

Sediment station is a particular site on a stream, canal, or other waterway where a record of sediment discharge is obtained.

Sediment yield. See Tons per square mile per year.

Sodium-adsorption-ratio (SAR) is related to the adsorption of sodium by the soil and is an index of the sodium, or alkali, hazard of the water. In the computation of SAR, concentrations of constituents are in equivalents per million.

$$
\mathrm{SAR}=\frac{\mathrm{Na}^{+}}{\sqrt{\frac{\mathrm{Ca}^{++}+\mathrm{Mg}^{++}}{2}}}
$$

Specific conductance is a measure of the capacity of a solution to conduct an electrical current and is expressed in micromhos per centimeter at $25^{\circ} \mathrm{C}$. It is 1 million times the reciprocal of specific resistance at $25^{\circ} \mathrm{C}$. Specific resistance is the resistance in ohms of a column of water 1 centimeter long and 1 square centimeter in cross section. Because the specific conductance is related to the number and specific chemical types of ions in solution, it can be used for approximating the salinity of the water. The following general relations are applicable:

Specific conductance $\times(0.65 \pm 0.10)=\mathrm{ppm}$ dissolved solids

$$
\frac{\text { Specific conductance }}{100}=\frac{\text { total epm }}{2}
$$

Standard deviation of an array of data that is normally distributed is:

$$
S=\sqrt{\frac{\Sigma x^{2}}{n-1}}
$$

where $S$ is the standard deviation, $x$ is the difference between the value of an individual item and the average of all the items in a sample, and $n$ is the number of items in the sample.

Streamflow is the water discharge that occurs in a natural channel, whether or not the water discharge is affected by regulation or underflow.

Suspended sediment is sediment that is supported by the upward components of turbulent currents or by colloidal suspension if the sediment particles are very small. 
Tons per day is a unit for expressing discharge and is commonly used in expressing the discharge of dissolved solids and sediment.

Tons per square mile per year is a unit for expressing the discharge of dissolved solids or sediment from an area. Sediment yield and dissolved-solids yield is usually given in tons per square mile per year.

Use (water) is the total quantity of water pumped, diverted, applied, or utilized for any purpose.

Variability index is the standard deviation of the logarithms of stream discharge (Lane and Lei, 1950). The index may be determined approximately from a flow-duration curve plotted on logarithmic probability paper by scaling vertically the number of log cycles between the points defined by the intersection of the flowduration curve with the 16 and 84 percent lines and dividing this number by 2 .

Water and dissolved-solids budget is an accounting of the water and dissolved-solids inflow to and outflow from a drainage area, including additions and losses in the drainage area.

Water discharge is the flow of a stream or canal, outflow from a basin, or flow of water from a pipe. Water discharge includes the sediment mixed with and solids dissolved in the water.

Water type is a term used to denote the predominate cations and anions in water. Whether certain cations (calcium, magnesium, sodium, and potassium) and certain anions (bicarbonate, sulfate, and chloride) predominate depends on the concentrations in equivalents per million and the relation of the concentration of the individual ions to each other. For example, if the concentration of sodium makes up most of the total cations and the concentration of bicarbonate makes up most of the total anions, the water is classified as a sodium bicarbonate type. However, if the second most abundant cation or anion is more than half the most abundant cation or anion, and the third most abundant cation or anion is more than half the second, they are included in the water-type classification in order of magnitude. Examples of these more complex water types would be calcium magnesium bicarbonate, calcium magnesium bicarbonate sulfate, and sodium magnesium calcium chloride sulfate.

Water year is the 12-month period October 1 through September 30 of the following calendar year. The water year is designated by the calendar year in which it ends.

Water years 1914-57 adjusted to 1957 conditions means that the data given are representative of what would have occurred if the upstream water developments existing in 1957 had been in operation throughout the water years 1914-57.

Water yield is the runoff from a drainage basin.

Weighted-a verage concentration is a discharge-weighted average that approximated the dissolved-solids concentration of water that would be found in a reservoir containing all the water passing a given station during a specified period after thorough mixing in the reservoir. The effects of evaporation, precipitation, or the addition or removal of dissolved constituents by plants or animals is not considered in this definition. 


\title{
WATER RESOURCES OF THE UPPER COLORADO RIVER BASIN-TECHNICAL REPORT
}

\section{HYDROLOGIC TEGHNIQUES AND GRITERIA USED IN APPRAISING THE SURFACE-WATER RESOURGES}

\author{
By W. V. Iorns, C. H. Hembree, and G. L. Oakland
}

\begin{abstract}
This chapter of the report on the water resources of the Upper Colorado River Basin explains the techniques and criteria used in appraising the surface-water resources of the area.

The base used in evaluating streamflow, dissolved-solids discharge and concentration, and sediment yield is the average which would have occurred if the level of upstream development existing in 1957 had existed throughout water years 191457. The available basic data, which were adjusted to this base, are briefly discussed as are other data used in the appraisal such as climatic data, topographic and geologic maps, and maps of native vegetation and irrigated lands.

The methods used in computing and adjusting to the common base precipitation data, flow-duration curves, duration curves of dissolved-solids concentration and discharge, and sediment yield are described in some detail if the procedures have not been previously described in published hydrologic literature. Statistical methods for determining the variability of streamflow, dissolved-solids concentration, and sediment yield are explained. A method is given for computing the amount of water and dissolved solids contributed to stream systems by ground water. In addition, the method used to estimate the amount of dissolved solids added to the stream system by the activities of man is outlined. The criteria used in appraising the suitability of water for various users are also given.
\end{abstract}

\section{INTRODUCTION}

This chapter outlines the hydrologic techniques and criteria used in appraising the surface-water resources of the region. Brief discussions of precipitation maps, vegetation maps, and other data used in the appraisal are also included.

Many methodologies for solving hydrologic problems are given in the engineering and hydrologic literature. Published methodologies were applicable to some of the problems encountered in this study, but other problems could not be solved by the methods available. It was necessary, therefore, to develop methods of analysis, based on accepted hydrologic concepts, to answer some of the problems that were unique to this study. Some of the hydrologic techniques that have not been previously published are relatively new, having been developed prior to this study by one or more of the authors and others or by the authors during this study.

This chapter will not only assist the reader in understanding the methods used to determine the answers to specific problems discussed in other chapters of the report, but will also serve those who may wish to solve similar problems for streams and areas in the basin for which solutions are not included in this report.

\section{BASE FOR APPRAISING THE SURFACE-WATER RESOURCES}

The period beginning October 1, 1913, and ending September 30,1957 , was selected as a base period representative of long-term climatic conditions in the Upper Colorado River Basin. Previous studies by the Upper Colorado River Compact Commission (1948) and the U.S. Bureau of Reclamation (1954) used the periods 1914-45 and 1914-47, respectively. All three periods include years of high runoff and the extended drought period between 1930 and 1940. Consequently, the general water-supply picture portrayed by these two previous studies and the present one should be about the same. Precipitation is probably the best measure of climatic differences for the three study periods. Table 1 shows the average precipitation for groups of stations for the water years $1914-45$ and 1914-47 in relation to the average for the water years 1914-57.

The average precipitation values for the water years 1914-45 and 1914-47 are consistently slightly higher than those for the water years 1914-57 in the Upper Colorado River Basin and its subdivisions. The minor difference in mean precipitation in various periods chosen for study does not affect the conclusions of the present investigation. Rather, it is clearly desirable 
TABLE 1.-Average precipitation for groups of stations in the Upper Colorado River Basin for water years 1914-45 and 191447 in relation to the average precipitation for water years $1914-5$ i

\begin{tabular}{|c|c|c|c|}
\hline \multirow[t]{2}{*}{ Station } & \multirow{2}{*}{$\begin{array}{l}\text { Number } \\
\text { of precipi- } \\
\text { tation } \\
\text { stations }\end{array}$} & \multicolumn{2}{|c|}{$\begin{array}{l}\text { A verage annual pre- } \\
\text { cipitation expressed as } \\
\text { percentage of 1914-57 } \\
\text { precipitation }\end{array}$} \\
\hline & & $1914-45$ & $1914-47$ \\
\hline $\begin{array}{l}\text { Colorado River Basin above Green River } \\
\text { Green River basin } \\
\text { San Juan basin. }\end{array}$ & $\begin{array}{r}17 \\
16 \\
8\end{array}$ & $\begin{array}{l}101.64 \\
100.48 \\
105.07\end{array}$ & $\begin{array}{l}101.15 \\
100.06 \\
103.67\end{array}$ \\
\hline $\begin{array}{l}\text { Colorado River Basin below Green and San } \\
\text { Juan Rivers and above "Lee Ferry"- } \\
\text { Colorado River Basin above "Lee Ferry"-..- }\end{array}$ & $\begin{array}{r}5 \\
46\end{array}$ & $\begin{array}{l}102.13 \\
101.03\end{array}$ & $\begin{array}{l}102.86 \\
101.35\end{array}$ \\
\hline
\end{tabular}

to include years of record after 1947, during which much additional streamflow, chemical quality, and sediment data became available.

The native vegetative cover and water use existing in 1957 were selected as the environmental base for appraising the water resources of the basin. Changes in natural environmental factors and the activities of man during the water years 1914-57 have resulted in modifications in the streamflow, chemical quality of water, and sediment yield of some of the streams. Except in the irrigated areas, which constitute only a small percentage of the total area, little change has occurred during the water years 1914-57 in the hydrologic effect of the natural environmental factors such as topography, rocks, and soils. Although there may have been some changes in the native vegetative cover, the magnitude of the hydrologic effect of any such change on streamflow, chemical quality of water, and sediment yield was considered negligible.

The major expansion of irrigation took place before 1914. Between 1914 and 1957 irrigation increased, but the increase was small as compared with the amount of land being irrigated in 1914. For this study, it was assumed that the effect of irrigation on stream depletion remained about the same throughout the water years $1914-57$.

In 1914 there were only a few reservoirs and diversions out of the basin. Between 1914 and 1957 the number of reservoirs increased, and the diversions increased greatly. Data on these water-use facilities, constructed since 1914, are generally sufficient to evaluate their effect on stream regimen and to adjust historical records of streamflow to be representative of 1957 conditions of upstream development.

In this report the term "water years $1914-57$ adjusted to 1957 conditions," means that the data given are representative of what would have occurred if the upstream water-use developments existing in 1957 had been in operation thoroughout the water years 1914-57.

\section{AVAILABLE DATA} STREAMFLOW

Collection of streamflow data in the Upper Colorado River Basin began in 1891, when a short period of record of the discharge of Green River at Green River, Wyo., was obtained by the State Engineer of Wyoming. Systematic streamflow measurements, however, did not begin until 1894, when the U.S. Geological Survey established gaging stations on Colorado and Gunnison Rivers at Grand Junction, Colo., Green River at Green River, Utah, and Price River at Wellington, Utah.

Stream gaging expanded slowly, and by 1911 records were being obtained at only 116 sites (fig. 17). From 1911 until the early 1930's the number of gaging stations decreased more than 50 percent. The adoption by Congress in 1929 of dollar-for-dollar cooperation with the States for stream gaging by the Geological Survey, the serious droughts of the early 1930's, and the need of the Bureau of Reclamation for more streamflow data gave impetus to the stream-gaging program. When the Upper Coloriado River Compact was adopted by Congress in 1949 , additional stations were established at the request of the Upper Colorado River Commission.

During 1894 to 1957 continuous records were obtained at 753 sites. At 93 of these, less than 1 year of record was obtained, but for one site, 62 years of continuous record is available. The following tabulation shows the number of sites for which records of the stated lengths, or longer, are available:

\begin{tabular}{|c|c|c|c|}
\hline $\begin{array}{l}\text { Number } \\
\text { of siter }\end{array}$ & $\begin{array}{c}\text { Years of } \\
\text { record }\end{array}$ & $\begin{array}{l}\text { Number } \\
\text { of sites }\end{array}$ & $\begin{array}{l}\text { Years of } \\
\text { record }\end{array}$ \\
\hline 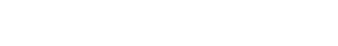 & 62 & 139 & \\
\hline $10 \ldots$ & 50 & 198. & 1 \\
\hline $38 \ldots .$. & 40 & 294_- & 1 \\
\hline $61 \ldots$ & 30 & 489 & \\
\hline 85 & 25 & 660 & \\
\hline
\end{tabular}

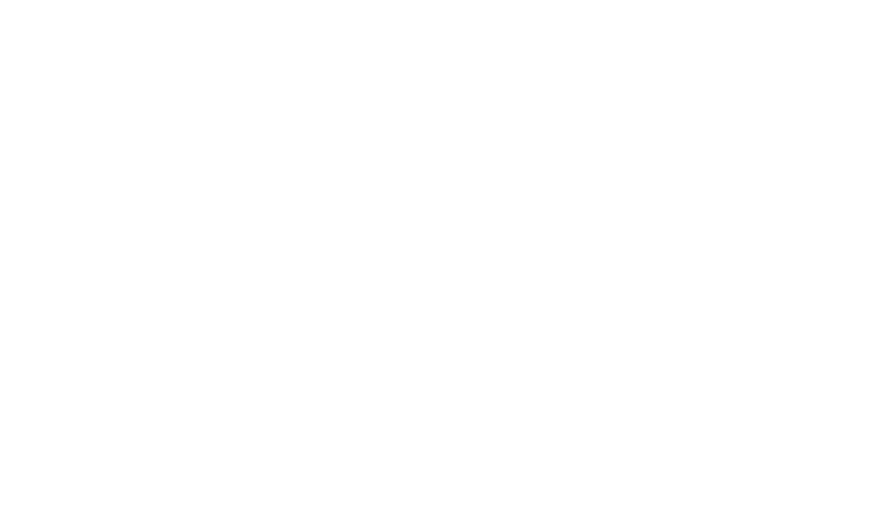

Figure 17.-Number of streamflow-gaging stations operated annually in the Upper Colorado River Basin, water years 1894-1957. 
An inventory of streamflow records is included in the basic data report (Iorns and others, 1964, table 292).

\section{CHEMICAL QUALITY}

The first chemical analyses of surface water in the Upper Colorado River Basin by the Geological Survey were made in 1905 and 1906 to determine the quality of waters likely to be used for reclamation projects. Chemical-quality data were obtained by the Geological Survey at six stream-gaging sites in these years. In 1916 and 1917 the Utah State Agricultural College obtained and analyzed samples of water used for irrigation at 16 sites (Greaves and Hirst, 1918).

Systematic collection of chemical-quality data began in 1928 when chemical-quality stations were established on Colorado River near Cisco, Utah, and on Green River at Green River, Utah. The following year, a station was established on San Juan River near Bluff, Utah. Figure 18 shows the number of stations that have been operated annually.

By the end of the 1957 water year, daily records of chemical quality had been obtained at 41 sites. The records range in length from 7 months to 29 years and total about 340 station years of record. The following tabulation shows the number of sites for which records of the stated lengths, or longer, are available:

\begin{tabular}{|c|c|c|c|}
\hline $\begin{array}{l}\text { Number } \\
\text { of sites }\end{array}$ & $\begin{array}{l}\text { Years of } \\
\text { record }\end{array}$ & $\begin{array}{c}\text { Number } \\
\text { of sites }\end{array}$ & $\begin{array}{l}\text { Years of } \\
\text { record }\end{array}$ \\
\hline $2 \ldots$ & 29 & 12. & 9 \\
\hline $3 \ldots$ & 28 & 13. & \\
\hline $4 \ldots \ldots \ldots$ & 26 & $22 \ldots \ldots \ldots$ & \\
\hline 5.1.2. & 24 & 23 & \\
\hline $6 \ldots$ & 17 & $26 \ldots \ldots$ & \\
\hline 7 & 16 & $30 \ldots$ & \\
\hline $11 \ldots$ & 10 & $38 \ldots \ldots$ & \\
\hline
\end{tabular}

In addition to the daily records of chemical quality, chemical analyses are available for more than 850 miscellaneous sites. Most of these sites are at, or near, streamflow-gaging stations. From 1 to 100 determinations of water quality were obtained at each of these sites.

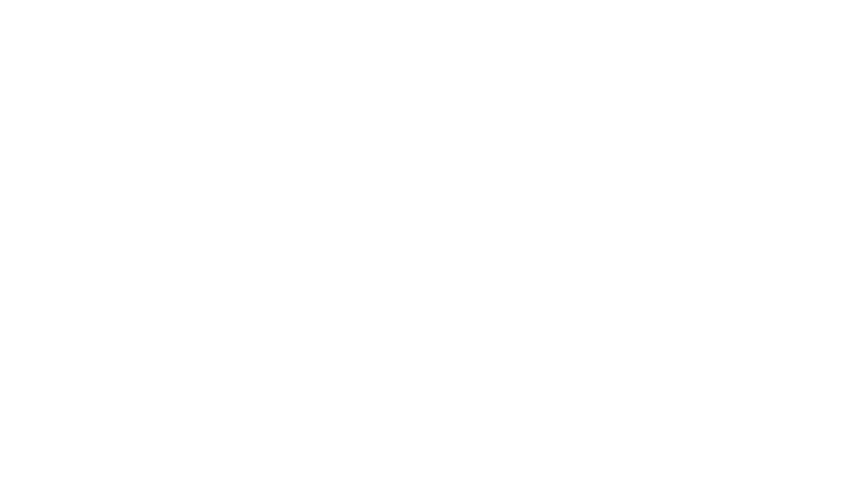

FiguRE 18.-Number of dally chemical-quality stations operated annually in the Upper Colorado River Basin, water years 1905-57.
An inventory of chemical-quality data is included in the basin data report (Iorns and others, 1964, table 292). The report also contains monthly and annual summaries of chemical-quality analyses for daily stations and analyses of water obtained at other sites.

\section{SEDIMENT}

Suspended-sediment data were obtained periodically at five sites in the Upper Colorado River Basin in 1905 and 1906. The periods during which data were obtained ranged from 6 to 14 months. No other suspended-sediment data were obtained unitl 1928 , when daily data were obtained for 2 months on San Juan River near Bluff, Utah. Daily sampling began at this station the following year and has continued. A daily suspended-sediment station was established on Colorado River near Lees Ferry, Ariz., in the 1929 water year, and except for two short breaks the record has been continuous. Daily sampling of suspended sediment was begun on Colorado River near Cisco, Utah, and Green River at Green River, Utah, in 1930 and has been continuous. Between 1948 and 1951 the number of daily suspended-sediment stations was greatly increased (fig. 19).

By the end of the 1957 water year daily suspendedsediment data had been obtained at 21 sites. The records range in length from 1 year to more than 28 years and total about 192 station years of record. The following tabulation shows the number of sites for which records of the stated lengths, or longer, are available.

\begin{tabular}{l|l|r|}
$\begin{array}{l}\text { Number } \\
\text { of sites }\end{array}$ & \multicolumn{1}{|c|}{$\begin{array}{c}\text { Years of } \\
\text { record }\end{array}$} & $\begin{array}{l}\text { Number } \\
\text { of sites }\end{array}$ \\
1 & 288 &
\end{tabular}

In addition to the daily suspended-sediment data collected at the 21 stations, suspended-sediment samples have been collected at about 200 other sites. Particle-

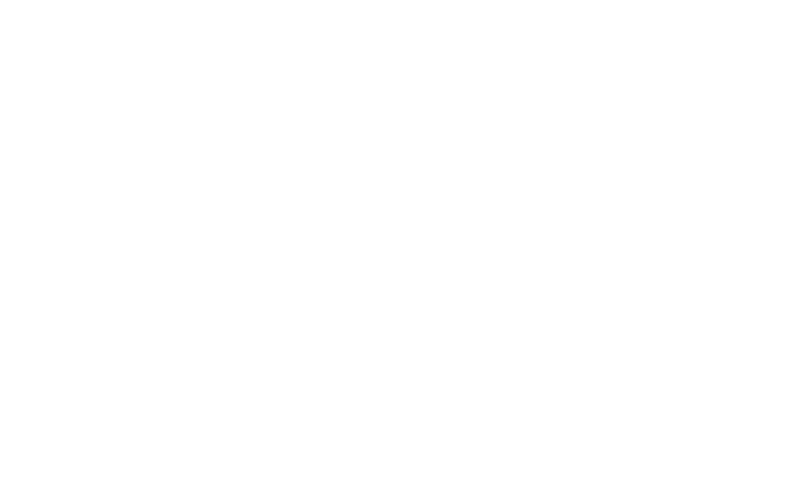

Figure 19.-Number of daily sediment stations operated annually in the Upper Colorado River Basin, water years 1928-57. 
size analyses of many of the suspended-sediment samples have been made. An inventory of the suspendedsediment data collected in the Upper Colorado River Basin is included in the basic data report (Iorns and others, 1964, table 292). The basic data report also contains monthly and annual summaries of suspended-sediment discharge at the daily stations, measurements of the suspended-sediment discharge at the 200 other sites, and particle-size analyses.

\section{CLIMATE}

The U.S. Weather Bureau, in cooperation with the Survey, developed average (calendar years 1921-50) seasonal precipitation maps, October to April and May to September, and an average annual precipitation map for the Upper Colorado River Basin. The seasonal and annual maps, at a scale of $1: 500,000$, are contained in the basic data report (Iorns and others, 1964, pls. 2, 3, and 4). The maps are adjusted for topography, exposure to airmass movements, and other parameters. The techniques used in developing the maps are discussed by Peck and Brown (1962), and the base maps used were the latest Sectional Aeronautical Charts published by the U.S. Coast and Goedetic Survey.

The average annual precipitation maps (calendar years 1921-50) at scales of $1: 750,000$ are shown on maps for chapters $\mathrm{C}, \mathrm{D}$, and $\mathrm{E}$ of the report. These maps also show average annual lake evaporation from maps prepared by Kohler, Nordenson, and Baker $(1959$, pl. 2). Other data on precipitation, temperature, and frost-free seasons given in the report were obtained from publications of the U.S. Weather Bureau.

\section{BASE MAP}

The base map for the report was adapted from the Sectional Aeronautical Charts of the U.S. Coast and Geodetic Survey. Other maps, such as quadrangle maps, State maps, county maps, and 2-degree Army Map Series were also used in this study.

\section{HYDROLOGIC MAP}

The consolidated and unconsolidated rocks in the Upper Colorado River Basin have been studied and mapped for deposits of minerals, for resources of coal, gas, and oil, and to a much less degree for the water resources they influence and contain. Regional and State geologic maps of various parts of the Upper Colorado River Basin have been published (Burbank and others, 1935; Andrews and Hunt, 1948; Love and others, 1955; Dane and Bachman, 1957). On these maps more than 200 formational units have been distinguished; some are thin and crop out only locally, whereas others are thick and exposed over large areas.
The rocks range in age from late Precambrian to Recent, and owing to folding, faulting, and weathering, the system of exposure is complex.

In an effort to simplify this complex assortment of rocks into a system for hydrologic study, the rock formations have been classified into eight units by D. A. Phoenix and are shown on hydrologic maps (pls. 1-3). Each of the groupings, besides conforming to the conventional time-rock system of classification, includes those formations having similar hydrologic properties, and each group is called a hydrologic unit. The formations in the eight hydrologic units are listed in a table and their general characteristics are described in chapter $\mathbf{A}$. The classifications into hydrologic units, however, pertain more to geochemical properties and sediment production than to the effect of the rocks on the physical behavior of streams.

The names of specific rock formations shown on regional and State geologic maps have been used in discussing the hydrologic effects of geologic factors on streams. The hydrologic units, into which the different rock formations have been classified, may be determined by reference to the hydrologic map (pl. 1) and to table 1 , in chapter $\mathrm{A}$.

\section{MAP OF NATIVE VEGETATION AND IRRIGATED LANDS}

Native vegetation zones shown on the maps of native vegetation and irrigated lands in chapters $\mathrm{C}$, $\mathrm{D}$, and $\mathrm{E}$ were adapted from a map compiled by $\mathrm{F}$. $\mathrm{A}$. Branson, U.S. Geological Survey. The irrigated lands shown on these maps were compiled from maps in a report entitled "The Colorado River" (U.S. Dept. of the Interior, 1947).

\section{COMPUTING AND ADJUSTING PRECIPITATION DATA}

The average annual preciptiation for calendar years 1921-50 was determined for the Upper Colorado River Basin and subareas by planimetering the areas between the isohyetal lines on the precipitation maps. Average annual precipitation at 46 index stations, scattered over and adjacent to the basin, was also computed for water years 1914-57. On the assumption that the precipitation at the index stations, which are in valleys, is proportional to that occurring over the adjacent areas, the precipitation map data were adjusted to the index-station data to obtain areal precipitation data for desired periods of time.

The following tabulation demonstrates the adjustment of 1921-50 average annual precipitation data to the water years 1914-57 in the Grand division.

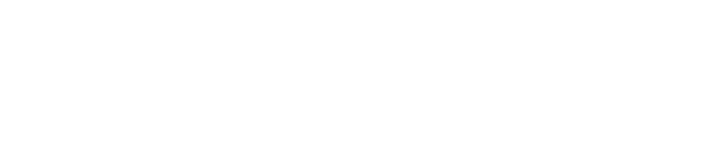


Index-station data are also used to compute average annual precipitation over drainage basins for comparison with annual runoff, as follows:

$$
\text { Factor }=\frac{20.27}{15.86}=1.278
$$

The factor is used with the average annual precipitation for the 17 index stations to obtain precipitation over the division for each water year. (See following tabulation.)

\begin{tabular}{|c|c|c|c|}
\hline Year & $\begin{array}{l}\text { Average, } \\
17 \text { index } \\
\text { stations } \\
\text { (inches) }\end{array}$ & Factor & $\begin{array}{c}\text { Average, } \\
\text { Grand } \\
\text { divizion } \\
\text { (inches) }\end{array}$ \\
\hline $14 \ldots$ & $\begin{array}{l}18.41 \\
14.27\end{array}$ & 1. 278 & $\begin{array}{l}23.53 \\
18.24\end{array}$ \\
\hline
\end{tabular}

Another use of index-station data is to compute average annual precipitation for periods of years for which runoff data are available. An example would be the computation of the average annual precipitation in the drainage basin above the streamflow-gaging station on Mill Creek near Moab, Utah, for water years 1951-57. The 1921-50 average annual precipitation as planimetered from the precipitation map is 16.70 inches. Of the 46 selected stations, the precipitation stations at Moah, Utah (Grand division), and Blanding, Utah (San Juan division), bracket the Mill Creek drainage basin. For these two stations the ratio of the 1951-57 average annual precipitation (8.90 in.) to the 1921-50 average (10.86 in.) is 0.82 . Thus the average annual precipitation in the drainage basin for water years $1951-57$ is computed as 16.70 times 0.82 , or 13.69 inches.

The precipitation quantities obtained by the above procedures are subject to deficiencies inherent in the precipitation maps and are affected by possible variation between annual valley precipitation and annual area precipitation. The computed precipitation for individual years may differ from reality by an unknown and possibly significant amount, but computed values for long periods of time are probably close to reality.

\section{COMPUTING AND ADJUSTING STREAMFLOW DATA FLOW-DURATION CURVES}

The flow-duration curve is a means of representing streamflow data and combines in one curve the flow characteristics of a stream throughout the range of discharge. As described by Searcy (1959), the flowduration curve is a cumulative-frequency curve that shows the percentage of time specified discharges were equaled or exceeded during a period of time. It can be used to study and to compare the effects of environmental factors on the behavior of streams. A flowduration curve that represents the long-term flow of a stream may be used to estimate long-term dissolved- solids and sediments yields and the distribution of future streamflow for waterpower, water supply, and pollution studies.

In the Upper Colorado River Basin about 8,400 station years of daily streamflow records had been obtained at more that 750 sites by the end of the 1957 water year. Historical flow-duration tables were prepared for stations at 174 of these sites by using an electronic computer to process about 4,000 station years of daily streamflow records. The historical flow-duration tables for the 174 stations are given in the basic data report (Iorns and others, 1964, tables 1-174). Flow-duration curves of the historical data and flowduration curves adjusted to the 44-year base period and to 1957 conditions were prepared for this report.

Many writers have discussed the development and statistics of flow-duration curves, and the reader is referred to the hydrologic literature on this subject. The basic techniques used in this study for adjusting flowduration curves or short periods to represent long-term conditions are described by Searcy (1959). The following discussion of flow-duration curves is limited to the special techniques developed for this study.

\section{GENERAL CHARACTERISTICS}

A large part of the annual runoff of most of the streams in the Upper Colorado River Basin is derived from snowmelt. During the winter snow accumulates in the high mountain ranges. As temperatures rise in the late spring and early summer, the accumulated snow melts. The streams rise to a peak, then subside to near a base or minimum flow, which generally prevails until the cycle is repeated the following spring.

This annual, cyclic hydrograph pattern results in a typical shape of flow-duration curve characteristic of snowmelt-type streams; that is, about 5 to 15 percent of the days will have sustained high flow during the melting period. This results in a flow-duration curve which has a flat slope at the upper end and a fairly steep slope in the central part. The lower end of the curve may be either relatively flat or steep, depending on ground-water conditions and natural regulation by lakes. Differences in topography, geology, and vegetative cover also cause some variations in individual curves, but in general, the curves tend to have the characteristics described.

The runoff in streams draining the areas of lower altitudes is intermittent and is mostly derived from infrequent thundershower-type storms. The shape of the flow-duration curves for these streams is entirely different from those for snowmelt-type streams. Generally, the curves for these streams are steep at the 
upper end and vertically intersect the bottom line of the logarthmic-plotting paper. The flow from this type of stream, which may be dry as much as 90 percent of the time, constitutes only a minor part of the runoff of the major streams in their downstream reaches.

ADJUSTING Flow-duration CURVES TO BASE PERIOD

Flow-duration curves for short periods of record were adjusted to the base period, water years 1914-57. The index-station method (Searcy, 1959, p. 12-17) was used for adjusting most of short period flow-duration curves to the base period. In addition, three others were developed to adjust records to this base. These methods, which have been named "record-completion method," "monthly means method," and "substitute method," were used where applicable to fill out the periods of missing record.

The record-completion method was used where streamflow records were missing for part of a year. If the missing record consisted of periods when little streamflow fluctuation normally would occur, an average discharge was estimated by interpolation or correlation with index stations, and the estimated average was used for each day of missing record. If the missing record consisted of periods when streamflow fluctuation was likely, an estimated hydrograph based on index stations was prepared and daily discharges filled in from the hydrograph. The completed years of record were combined with other years of daily flow-duration data to fill out the base period. Generally, this method was used for years in which the streamflow record was mostly complete.

The monthly means method was used where 1 or more years of record were missing and reliable monthly estimates could be obtained by correlation with index stations. A flow-duration curve was prepared for the missing years of record using the estimated monthly means. The high and low extremities of this curve were drawn parallel to the flow-duration curve prepared from the historical flow-duration data. The two curves were then combined into one curve for the base period.

The substitute method was used for stations where historical flow-duration data were missing for a few years and satisfactory daily or monthly estimates were impossible, but where acceptable annual averages had been or could be estimated. The method consisted of substituting for years of missing record the historical flow-duration data for other years which had approximately the same average discharges. Flow-duration data for nearby stations and stations on the same stream were used as guides in selecting the substitute years. The method was used only where few. years had to be substituted and not where the discharge for missing years was much more, or less, than any of those for which historical data were available.

\section{ADJUSTING FLOW-DURATION CURVES TO 1957 CONDITIONS} OF UPSTREAM DEVELOPMENT

A characteristic of the snowmelt streams in the Upper Colorado River Basin is that within any geographic area, over which the climate does not vary greatly, the runoff events occur at about the same time at all stations. The similarity in time of occurrence of runoff events is shown in the relation between annual hydrographs of daily discharge of the streams. It is also displayed in the relation of annual flow-duration curves for the streams: the percentage of time that flows of relative magnitude (high, medium, and low flows) occur is about the same.

As the source of water supply of the main-stem streams is principally the snow-fed tributaries, the time of occurrence of runoff events in the main-stem streams is also approximately the same as in the headwater streams. Annual hydrographs of the streams at successive downstream points are similar, although there is some time lag and flattening of peaks in a downstream direction. Annual flow-duration curves for these streams at successive downstream points, where not influenced by artificial factors, agree closely in the percentage of time that flows of relative magnitude occur.

Beginning at upstream gaging stations, the authors developed two flow-duration curves for the period of years corresponding to each level of upstream development. One curve was representative of streamflows which would have taken place had the water development project not been in existence and the other curve was representative of streamflows after development. These duration curves were computed by adjusting the historic records as described in the next four paragraphs.

An approximation of what the discharges at the gaging station for water years 1914-57 would have been had the upstream developments not been in existence was obtained by adjusting the historical record at the gaging station for the effect of the upstream changes. As upstream changes principally involved transmountain diversions and reservoir operations (effect of irrigation was assumed to be constant because total acres of irrigated land remained relatively constant), the historical record during each level of development was adjusted by adding to it the quantities diverted out of the basin or stored in the reservoirs (subtracted if water was released from the reservoir). Because data of diversions and reservoir changes were available only 
in monthly quantities, the reconstructed record could only be prepared in terms of monthly quantities.

From the reconstructed monthly record a flow-duration curve representative of conditions had the development not taken place was prepared for the period of each level of development and was compared with the historical flow-duration curve for the same period. The differences in discharge between the two curves at selected percentages were used as the adjustment due to the development. This adjustment was applied to the historical flow-duration curve for the station for the period before the upstream development became effective.

For some streams several levels of upstream development existed in the 44-year base period. For these streams the adjustments, beginning with the time the last development became effective, were cumulated and applied to the historical flow-duration curves for each earlier level of development. The adjusted curves were then combined with the latest curve, which required no adjustment, to obtain a final adjusted curve for the water years 1914-57. The curves were combined by giving weight to the number of years each curve was applicable and to the percentage of time shown by each curve for a given discharge.

Each tributary stream on which upstream developments took place was treated in a similar manner. The adjustments in cubic feet per second for each percent- age point were cumulated in a downstream direction and applied to the historical flow-duration curves at downstream stations. Although the adjustment basically requires that the downstream flow-duration data be divided into as many periods as there were different levels of upstream development, there was little difference in results if adjustments based on the difference between the final adjusted curve and the historical curve at main-stem control points for the 44-year period were applied to other downstream 44-year historical flow-duration curves.

A summary of the adjustments for upstream developments which have appreciable effects on flowduration curves at downstream points is given in table 2. The summary does not include adjustments for many small reservoirs and diversions whose effects, except locally, were negligible. It was not necessary to adjust for the diversion from the Dolores River to the San Juan basin or from the Strawberry Reservoir in Utah to the Great Basin because these were virtually in full operation throughout water years 1914-57.

Controls were maintained at all stages of computations by checking the average discharges computed from the flow-duration curves against average discharges computed from summarization of actual records. Within the limits of accuracy of plotting flowduration curves and picking data from them, close

TABLE 2.-Summary of adjustments, in cubic feet per second, to correct historical flow-duration curves to conditions of upstream development existing in 1957

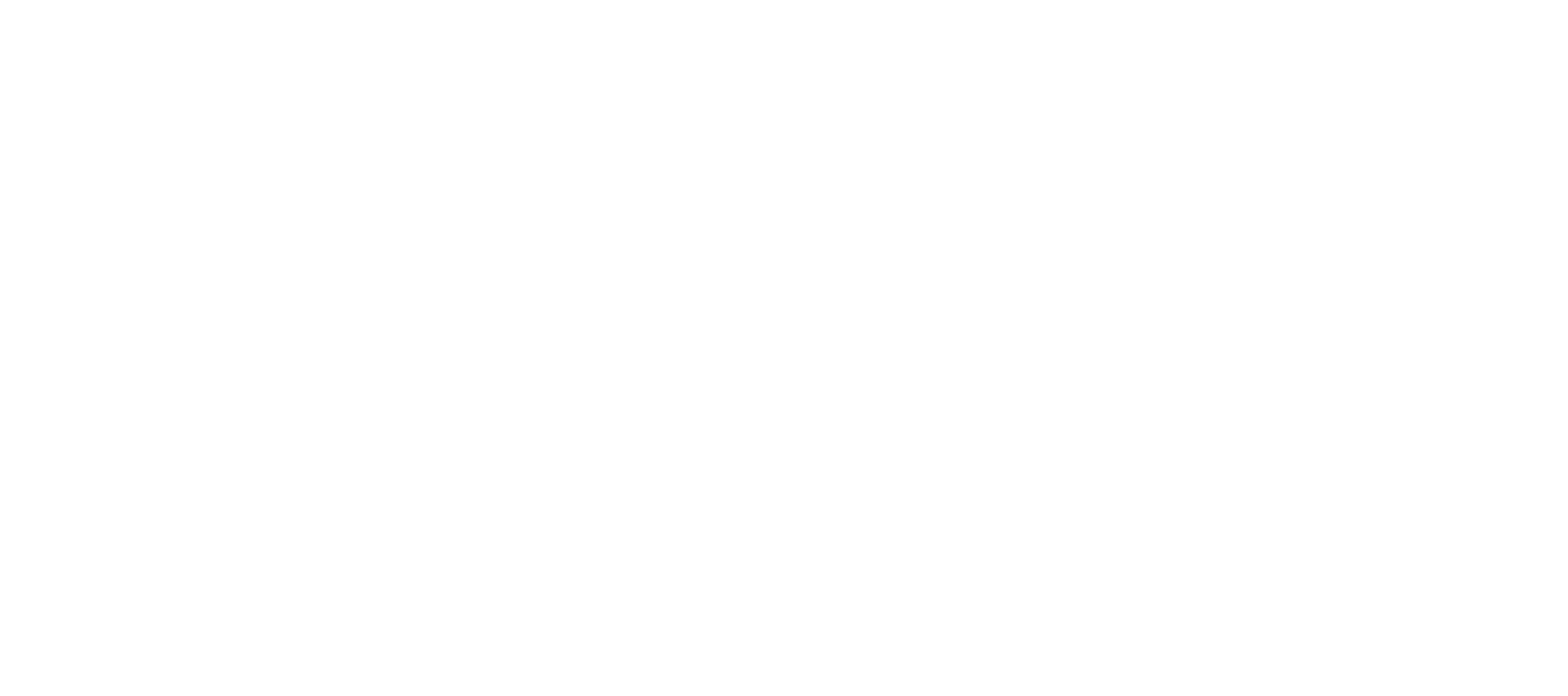

1 Includes adjustments for Berthoud Pass ditch, Moffat tunnel, Grand River ditch, Colorado Btg-Thompson project, and Willow Creek Reservolr. 2 Sum of adjustments in columns 2-7.

Includes adjustments for Twin Lakes and Busk-Ivanhoe tunnels.

- Includes adjustments for Taylor Park Reservoir and Gunnison tunnel.

s Sum of columns 8-10.

- Adjustment for Duchesne tunnel only.

7 Sum of columns 11 and 12 .

B Adjustment for Vallecitos Reservoir and increase in water use on reservoir project lands.

Sum of 13 and 14. 
agreement was maintained between the two sets of data.

Tables in chapters C, D, and E, indicate the methods used to adjust the flow-duration curves to the 44-year base period, list the upstream developments that necessitated the adjustment to 1957 conditions, and rate the accuracy of the results.

\section{RELATION OF GEOLOGY AND GROUND WATER TO STREAMFLOW}

Flow-duration curves were used to assess the relation between geology and streamflow and the amount of ground water contributed to the stream systems.

Searcy $(1959$, p. 22$)$ in his discussion of the shape of flow-duration curves said:

As the shape of the flow-duration curve is determined by the hydrologic and geologic characteristics of the drainage area, the curve may be used to study the characteristics of a drainage basin or to compare the characteristics of one basin with those of another. A curve with a steep slope throughout denotes a highly variable stream whose flow is largely from direct runoff, whereas a curve with a flat slope reveals the presence of surfaceor ground-water storage, which tends to equalize the flow. The slope of the lower end of the duration curve shows the characteristics of the perennial storage in the drainage basin; a flat slope at the lower end indicates a large amount of storage; and a steep slope indicates a negligible amount. Streams whose high flows come largely from snowmelt tend to have a flat slope at the upper end. The same is true for streams with large floodplain storage or those that drain swamp areas.

Later in his discussion of the effect of geology on low flows Searcy (1959, p. 24) stated:

The flow-duration curve is a valuable medium for studying and comparing drainage basin characteristics, particularly the effect of basin geology on low flows. Except in basins with a highly permeable surface, the distribution of high flows is governed largely by the climate, the physiography, and the plant cover of the basin. The distribution of low flows is controlled chiefly by the geology of the basin. Thus, the lower end of the flowduration curve is a valuable means for studying the effect of geology on the ground-water runoff to the stream. Where the stream drains a single formation, the position of the low-flow end of the curve is an index of the contribution to streamflow by the formation.

Lane and Lei (1950) introduced a method of measuring the slope of flow-duration curves that was used in this study. Their measure of slope is called the "variability index" and was defined as the standard deviation of the logarithms of stream discharge. On log probability paper, this index represents the fall (in terms of $\log$ cycles) of the duration curve in one standard deviation. It may be determined approximately by scaling vertically the number of log cycles between the 16-percent and 84-percent intersection points of the flow-duration curve and dividing this by 2 .
The variability indexes for many streams were determined. For headwater snowmelt streams, the index values were found related to the relative permeability of exposed rocks in the drainage basins. The index values are high for basins underlain by impermeable rocks. In these basins the impermeable rocks offer little opportunity for infiltration of water to the groundwater reservoirs and subsequent release to the stream system during periods of low flow. On the other hand, the index values are low for basins underlain by relatively permeable rocks. In these basins the opportunity for ground-water recharge and discharge is great. There is, however, no means of assigning permeability values to rock formations except in generalized terms such as the following: Intrusive igneous rocks are relatively impermeable, and coarse-grained sandstones are relatively permeable. Where several rock formations are exposed in a drainage basin, any relative permeability classification would be exceedingly complex to formulate.

A method of using flow-duration curves to determine the amount of ground water contributed to streams was developed by the authors. The method is principally applicable to headwater streams of the snowmelt-type that are affected little by the activities of man and which have minimal regulation by natural lakes. In the following paragraphs, the method is described and results are compared with the results obtained from hydrographs.

Two types of discharge occur in most streams in the mountainous areas of the Upper Colorado River Basin, direct runoff and base or sustained flow. Direct runoff is water from rainfall or melting snow that enters the stream system rapidly either as overland flow or as subsurface flow that does not reach the zone of saturation and whose time spent underground is so brief that its rate of movement into the stream system is almost as rapid as overland flow. The base or sustained flow of the streams is mostly water discharged from ground-water reservoirs. Natural lake and marsh storage may also contribute water to the base flow of some streams, but in this study, this contribution was considered negligible. Generally, the rate of contribution of ground water to the stream system in the mountains is a maximum immediately after the snowmelt period and gradually diminishes until the snow begins to melt the following spring. For most streams ground water continues to contribute to the stream system during the snowmelt period.

The average time that the flow in a snowmelt-type stream is controlled by ground water may be approximately determined from a flow-duration curve by 
drawing a line tangent to the steep part of the curve and noting the percentage point at which the lower part of the curve definitely departs from the straight line. (See fig. 20.) The flow represented by the part of the curve below this point consists principally of water discharged from ground-water storage. The streamflow that comes from ground-water storage can be computed by arithmetically integrating the area under the flow-duration curve between the departure point and 100 percent of time.

In the mountain areas the streams are deeply incised, and the slope of the ground-water table is toward the stream chaninels. Consequently, even during periods of high discharge (when flow is controlled by direct runoff) the ground-water reservoirs are effluent to the streams. In this study the average rate of ground-water discharge during the time that the streams are controlled by direct runoff was found to be approximately equal to the flow-duration-curve discharge that is equaled 70 percent of the time. By adding the ground-water increment of flow, for the percentage of time that the flow-duration-curve discharge is greater than the departure-point discharge, to that obtained by integrating the area under the flow-duration curve below the departure point, the amount of ground water contributed to the stream is obtained.

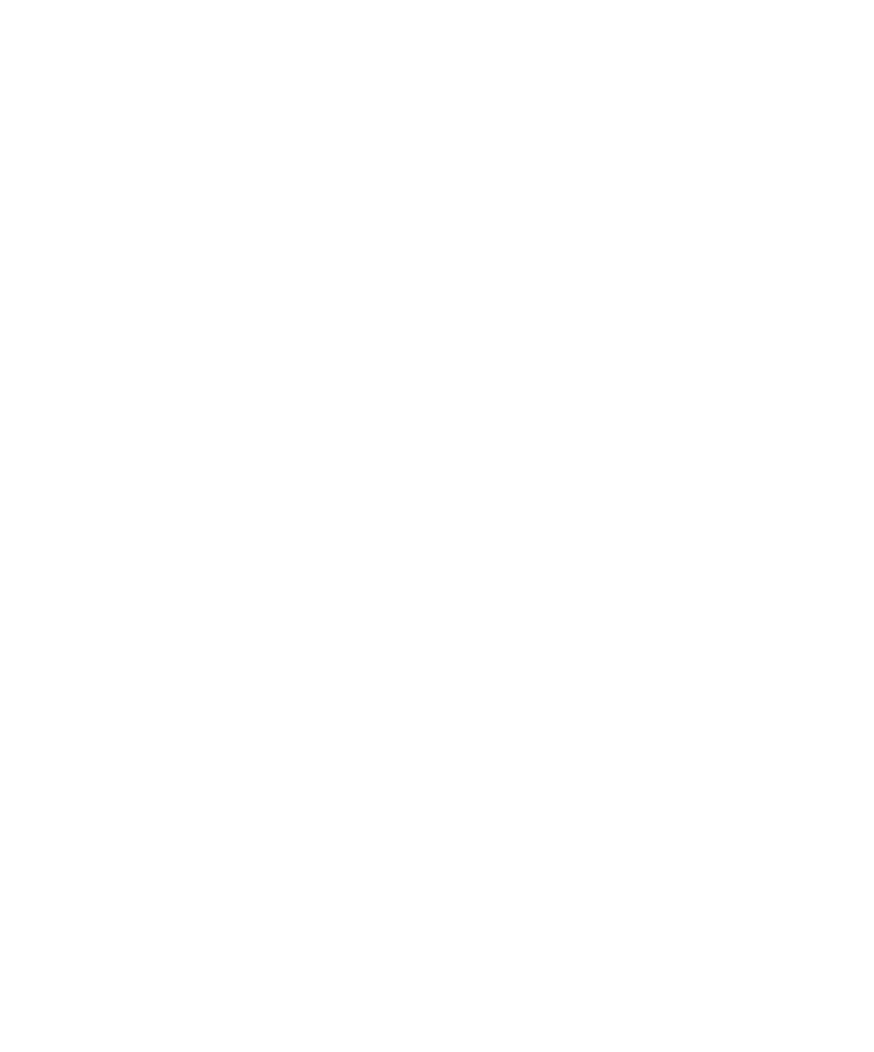

Flow-duration curves and tables for high and low water years and for a period of years for Gypsum Creek near Gypsum, Colo., and Homestake Creek near Red Cliff, Colo., are used as examples to illustrate the method. (See fig. 20 and table 3.) Figure 21 shows hydrographs for the respective annual flowduration curves given in figure 20. On these hydrographs the estimated flow contributed by ground water is shown. Table 4 gives the comparative data of the amounts of water computed using the duration curve and hydrograph methods. Data are also given in the table for other water years computed in the same manner. In the determinations, data from the plotted flow-duration curves and hydrographs were used. No attempt was made to balance average annual discharges computed from the flow-duration table and from the actual record.

Gypsum and Homestake Creeks were used to illustrate the method of determining the amount of ground water contributed to streams because of their widely different stream behavior and difference in geology. The drainage basin of Gypsum Creek is underlain by the Eagle Valley Evaporite. This formation is composed of sandstone and shale containing much gypsum. Rocks of this formation weather to thick deposits of permeable material. The soil mantle in Gypsum Creek basin supports thick stands of vegetative cover. Such

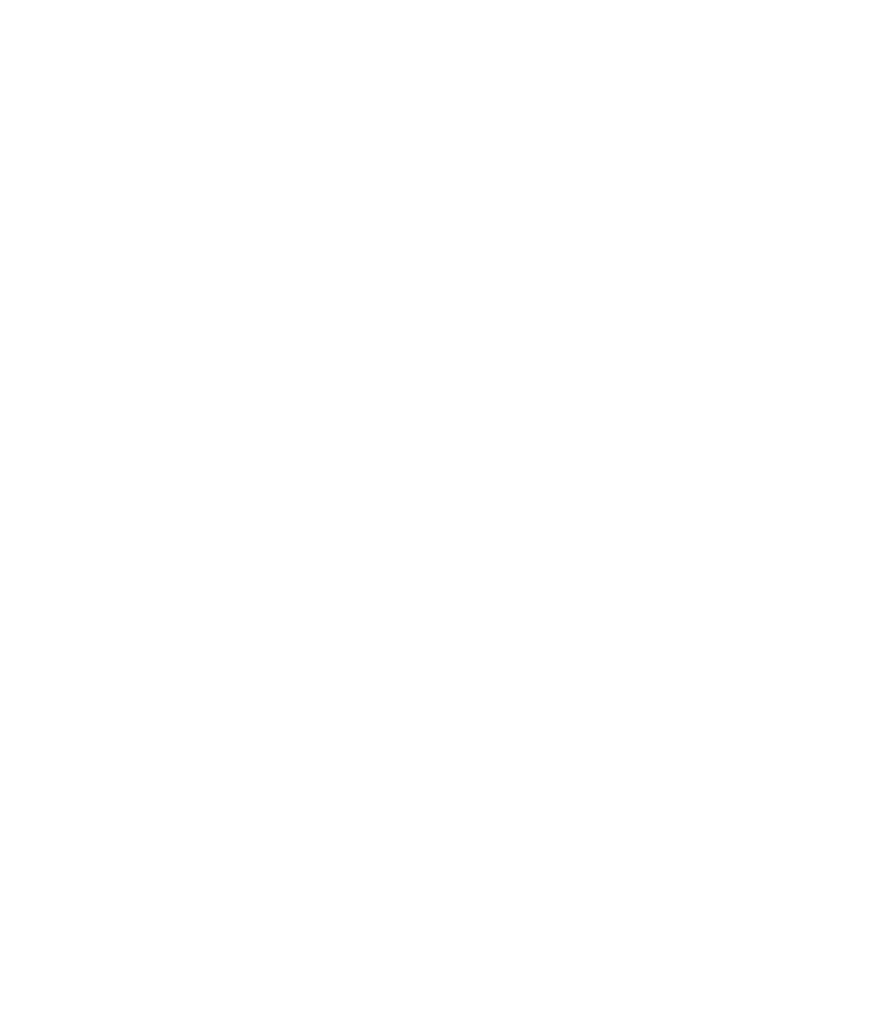

$B$. Homestake Creek near Red Cliff, Colo. 


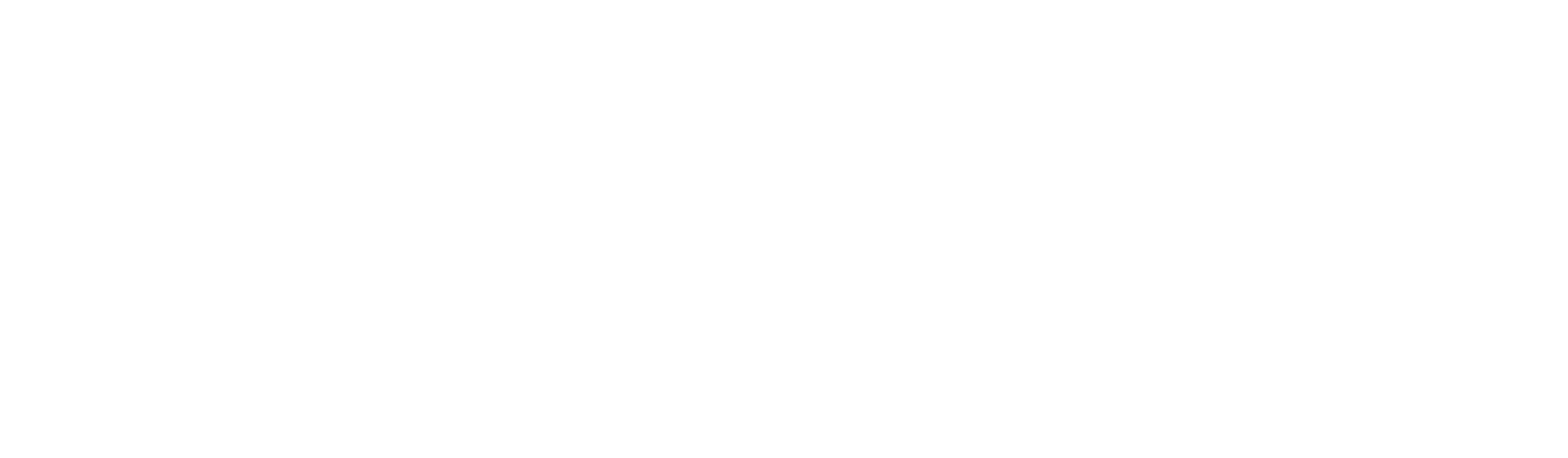

A. Gypsum Creek near Gypsum, Colo., 1952 water year
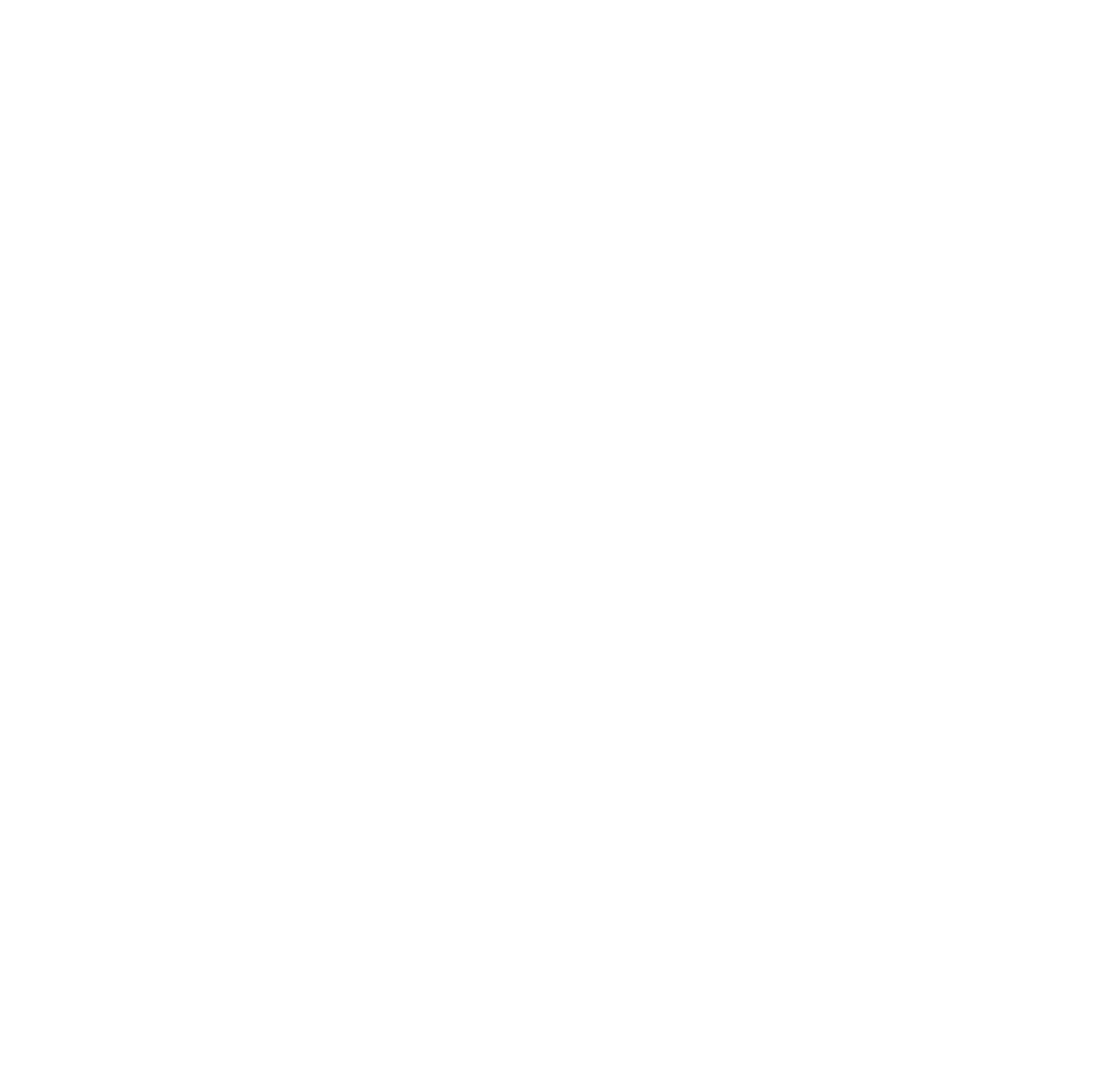

Figure 21.-Hydrographs of discharge and estimated ground water for Gypsum and Homestake Creeks. 
TABLE 3.-Computation of total discharge and ground-water discharge of Gypsum Creek near Gypsum and Homestake Creek near Red Cliff, Colo., by flow-duration tables

\begin{tabular}{c|c|c|c|c|c|c|c|c|c}
\hline \multicolumn{3}{c|}{ Total discharge } & \multicolumn{3}{c}{ Ground-water discharge } \\
\hline $\begin{array}{c}\text { Time limits } \\
\text { (percent) }\end{array}$ & $\begin{array}{c}\text { Time interval } \\
\text { (percent) }\end{array}$ & $\begin{array}{c}\text { Mean of } \\
\text { interval } \\
\text { (percent) }\end{array}$ & $\begin{array}{c}\text { Discharge } \\
\text { (cfs) }\end{array}$ & $\begin{array}{c}\text { Increment } \\
\text { of discharge } \\
\text { (cfs) }\end{array}$ & $\begin{array}{c}\text { Time limits } \\
\text { (percent) }\end{array}$ & $\begin{array}{c}\text { Time interval } \\
\text { (percent) }\end{array}$ & $\begin{array}{c}\text { Mean of } \\
\text { interval } \\
\text { (percent) }\end{array}$ & $\begin{array}{c}\text { Discharge } \\
\text { (cfs) }\end{array}$ & $\begin{array}{c}\text { Increment } \\
\text { of discharge } \\
\text { (efs) }\end{array}$ \\
\hline
\end{tabular}

GYPSUM CREEK NEAR GYPSUM, COLO.

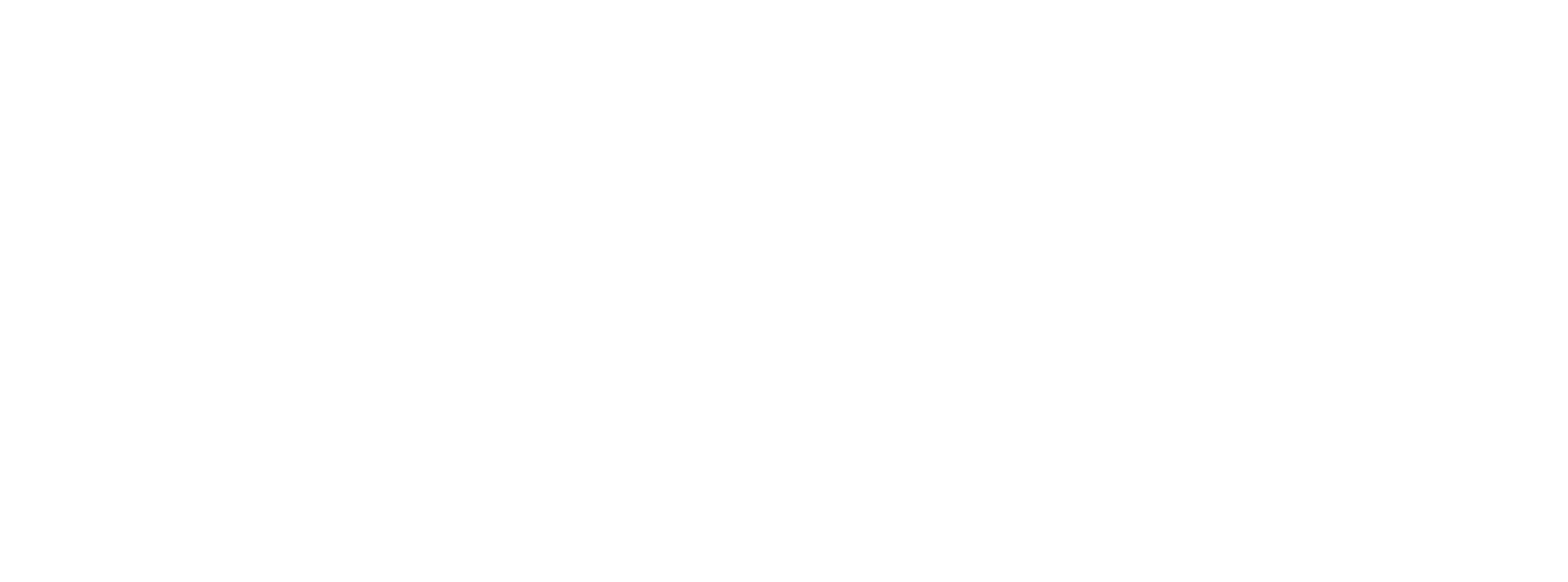

\begin{tabular}{|c|c|c|c|c|c|c|c|c|c|}
\hline \multicolumn{10}{|c|}{1954 water year } \\
\hline 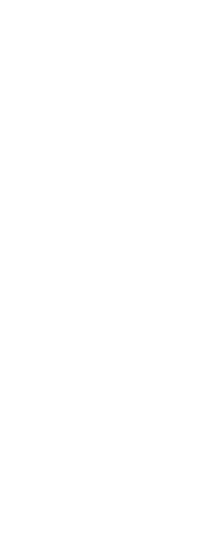 & $\begin{array}{r}0.02 \\
.08 \\
.10 \\
.80 \\
2.0 \\
2.0 \\
4 \\
6 \\
10 \\
10 \\
10 \\
10 \\
10 \\
10 \\
10 \\
10 \\
4 \\
.8 \\
.2\end{array}$ & $\begin{array}{l}0.01 \\
.06 \\
.15 \\
.6 \\
2.0 \\
4.0 \\
7.0 \\
12 \\
20 \\
30 \\
40 \\
50 \\
60 \\
70 \\
80 \\
90 \\
97 \\
99.4 \\
99.9\end{array}$ & $\begin{array}{l}54 \\
54 \\
54 \\
49 \\
41 \\
34 \\
30.5 \\
27.5 \\
25.0 \\
23.0 \\
21.8 \\
20.7 \\
19.9 \\
19.0 \\
18.2 \\
17.2 \\
16.2 \\
15.3 \\
14.5\end{array}$ & $\begin{array}{l}.01 \\
.04 \\
.05 \\
.39 \\
.82 \\
.68 \\
1.22 \\
1.65 \\
2.50 \\
2.30 \\
2.18 \\
2.07 \\
1.99 \\
1.90 \\
1.82 \\
1.72 \\
.65 \\
.12 \\
.03\end{array}$ & $\begin{array}{l}0.00-3.00 \\
3.00-5.00 \\
5.00-9.00 \\
9=\mathbf{1 5} \\
\mathbf{1 5}-\mathbf{2 5} \\
\mathbf{2 5}-\mathbf{3 5} \\
\mathbf{3 5}-\mathbf{4 5} \\
\mathbf{4 5}-\mathbf{5 5} \\
\mathbf{5 5}-\mathbf{6 5} \\
\mathbf{6 5}-\mathbf{7 5} \\
\mathbf{7 5}-\mathbf{8 5} \\
\mathbf{8 5}-\mathbf{9 5} \\
\mathbf{9 5}-\mathbf{9 9} \\
\mathbf{9 9}-\mathbf{9 9} .8 \\
\mathbf{9 9 . 8}-\mathbf{1 0 0}\end{array}$ & \begin{tabular}{c}
3 \\
\hdashline 2.0 \\
4.0 \\
6 \\
10 \\
10 \\
10 \\
10 \\
10 \\
10 \\
10 \\
10 \\
4 \\
.8 \\
.2
\end{tabular} & $\begin{array}{l}4.0 \\
7.0 \\
12 \\
20 \\
30 \\
40 \\
50 \\
60 \\
70 \\
80 \\
90 \\
97 \\
99.4 \\
99.9\end{array}$ & $\begin{array}{l}19 \\
34 \\
30.5 \\
27.5 \\
25.0 \\
23.0 \\
21.8 \\
20.7 \\
19.9 \\
19.0 \\
18.2 \\
17.2 \\
16.2 \\
15.3 \\
14.5\end{array}$ & $\begin{array}{r}0.57 \\
.68 \\
1.22 \\
1.65 \\
2.50 \\
2.30 \\
2.18 \\
2.07 \\
1.99 \\
1.90 \\
1.82 \\
1.72 \\
.65 \\
.12 \\
.03\end{array}$ \\
\hline
\end{tabular}

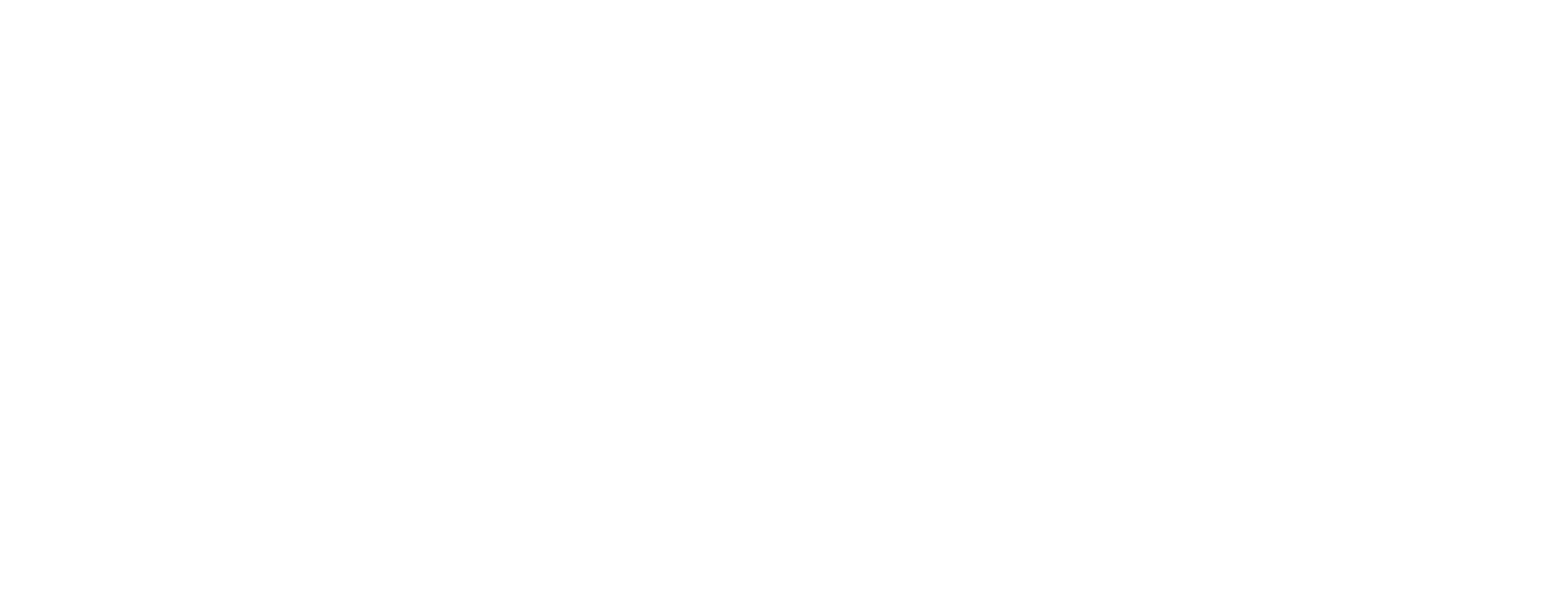


TABLE 3.-Computation of total discharge and ground-water discharge of Gypsum Creek near Gypsum and Homestake Creek near Red Cliff, Colo., by flow-duration tables-Continued

\begin{tabular}{|c|c|c|c|c|c|c|c|c|c|}
\hline \multicolumn{5}{|c|}{ Total discharge } & \multicolumn{5}{|c|}{ Ground-water discharge } \\
\hline \multicolumn{10}{|c|}{$\begin{array}{l}\text { HOMEST AKE CREEK NEAR RED CLIFF, COLO. } \\
1951 \text { water year } \\
\end{array}$} \\
\hline \multirow[t]{2}{*}{ 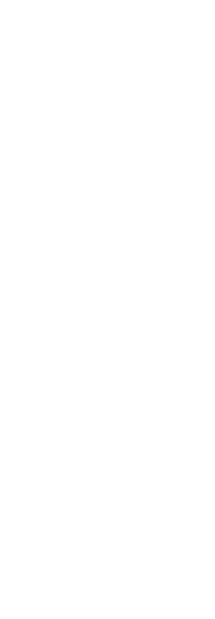 } & $\begin{array}{l}0.02 \\
.08 \\
.10 \\
.80 \\
2.0 \\
2.0 \\
4 \\
6 \\
10 \\
10 \\
10 \\
10 \\
10 \\
10 \\
10 \\
10 \\
4 \\
.8 \\
.2\end{array}$ & \multirow[t]{2}{*}{$\begin{array}{l}0.01 \\
.06 \\
.15 \\
.6 \\
2.0 \\
4.0 \\
7.0 \\
12 \\
20 \\
30 \\
40 \\
50 \\
60 \\
70 \\
80 \\
90 \\
97 \\
99.4 \\
99.9\end{array}$} & \multirow[t]{2}{*}{$\begin{array}{r}780 \\
760 \\
740 \\
715 \\
640 \\
550 \\
445 \\
325 \\
190 \\
70 \\
15 \\
9.3 \\
7.9 \\
7.0 \\
6.2 \\
5.5 \\
5.0 \\
4.7 \\
4.5\end{array}$} & $\begin{array}{r}0.16 \\
.61 \\
.74 \\
5.72 \\
12.80 \\
11.00 \\
17.80 \\
19.50 \\
19.00 \\
7.00 \\
1.50 \\
.93 \\
.79 \\
.70 \\
.62 \\
.55 \\
.20 \\
.04 \\
.01\end{array}$ & \multirow[t]{2}{*}{$\begin{array}{l}0.00-40 \\
40 \\
40\end{array}$} & \begin{tabular}{|r}
40 \\
\\
\\
5 \\
10 \\
10 \\
10 \\
10 \\
10 \\
4 \\
.8 \\
.2
\end{tabular} & \multirow[t]{2}{*}{$\begin{array}{l}42.5 \\
50 \\
60 \\
70 \\
80 \\
90 \\
97 \\
99.4 \\
99.9\end{array}$} & \multirow[t]{2}{*}{$\begin{array}{r}0.0 \\
\\
13.7 \\
9.3 \\
7.9 \\
7.0 \\
6.2 \\
5.5 \\
5.0 \\
4.7 \\
4.5\end{array}$} & \begin{tabular}{|r}
2.80 \\
\\
\end{tabular} \\
\hline & 100.00 & & & 99.67 & & 100.00 & & & 7.30 \\
\hline \multicolumn{10}{|c|}{1954 water year } \\
\hline \multirow[t]{2}{*}{ 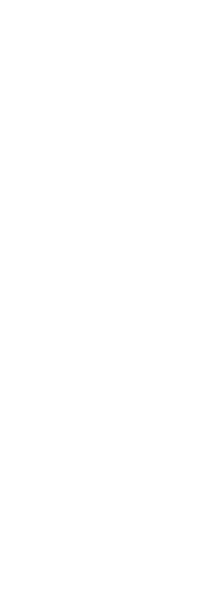 } & $\begin{array}{c}0.02 \\
.08 \\
.10 \\
.80 \\
2.0 \\
2.0 \\
4 \\
6 \\
10 \\
10 \\
10 \\
10 \\
10 \\
10 \\
10 \\
10 \\
4 \\
.8 \\
.2\end{array}$ & \multirow[t]{2}{*}{$\begin{array}{c}0.01 \\
.06 \\
.15 \\
.6 \\
2.0 \\
4.0 \\
7.0 \\
12 \\
20 \\
30 \\
40 \\
50 \\
60 \\
70 \\
80 \\
90 \\
97 \\
99.4 \\
99.9\end{array}$} & \multirow[t]{2}{*}{$\begin{array}{r}354 \\
350 \\
340 \\
310 \\
260 \\
215 \\
165 \\
118 \\
65 \\
26 \\
14 \\
9.0 \\
7.3 \\
6.5 \\
6.0 \\
5.5 \\
5.0 \\
4.8 \\
4.6\end{array}$} & $\begin{array}{r}0.07 \\
.28 \\
.34 \\
2.48 \\
5.20 \\
4.30 \\
6.60 \\
7.08 \\
6.50 \\
2.60 \\
1.40 \\
.90 \\
.73 \\
.65 \\
.60 \\
.55 \\
.20 \\
.04 \\
.01\end{array}$ & \multirow[t]{2}{*}{$\begin{array}{ll}35 & -45 \\
45 & -55 \\
55 & -65 \\
65 & -75 \\
75 & -85 \\
85 & -95 \\
95 & -99 \\
99 & -99.8 \\
99.8 & -100\end{array}$} & $\begin{array}{c}10 \\
10 \\
10 \\
10 \\
10 \\
10 \\
4 \\
.8 \\
.2\end{array}$ & \multirow[t]{2}{*}{$\begin{array}{l}40 \\
50 \\
60 \\
70 \\
80 \\
90 \\
97 \\
99.4 \\
99.9\end{array}$} & \multirow[t]{2}{*}{$\begin{array}{r}6.5 \\
\\
14 \\
9.0 \\
7.3 \\
6.5 \\
6.0 \\
5.5 \\
5.0 \\
4.8 \\
4.6\end{array}$} & $\begin{array}{r}2.28 \\
1.40 \\
.90 \\
.73 \\
.65 \\
.60 \\
.55 \\
.20 \\
.04 \\
.01\end{array}$ \\
\hline & 100.00 & & & 40.53 & & 100.00 & & & 7. 36 \\
\hline \multicolumn{10}{|c|}{ Water years 1951-55 } \\
\hline \multirow[t]{2}{*}{ 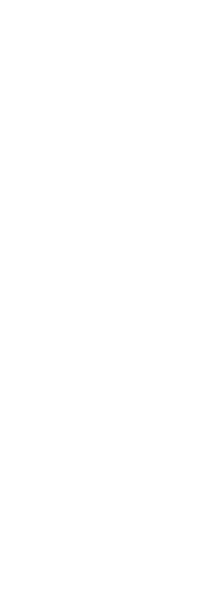 } & $\begin{array}{c}0.02 \\
.08 \\
.10 \\
.80 \\
2.0 \\
2.0 \\
4 \\
6 \\
10 \\
10 \\
10 \\
10 \\
10 \\
10 \\
10 . \\
10 \\
4 . \\
.8 \\
.2\end{array}$ & \multirow[t]{2}{*}{$\begin{array}{c}0.01 \\
.06 \\
.15 \\
.6 \\
2.0 \\
4.0 \\
7.0 \\
12 \\
20 \\
30 \\
40 \\
50 \\
60 \\
70 \\
80 \\
90 \\
97 \\
99.4 \\
99.9\end{array}$} & \multirow[t]{2}{*}{$\begin{array}{r}867 \\
840 \\
810 \\
720 \\
580 \\
460 \\
335 \\
220 \\
115 \\
50 \\
21 \\
11.5 \\
8.2 \\
7.2 \\
6.5 \\
5.8 \\
5.0 \\
4.4 \\
4.0\end{array}$} & $\begin{array}{r}0.17 \\
.67 \\
.81 \\
5.76 \\
11.60 \\
9.20 \\
13.40 \\
13.20 \\
11.50 \\
5.00 \\
2.10 \\
1.15 \\
.82 \\
.72 \\
.65 \\
.58 \\
.20 \\
.04 \\
.01\end{array}$ & $\begin{array}{ll}44 & -45 \\
45 & -55 \\
55 & -65 \\
65 & -75 \\
75 & -85 \\
85 & -95 \\
95 & -99 \\
99 & -99.8 \\
99.8 & -100\end{array}$ & $\begin{array}{r}1 \\
10 \\
10 \\
10 \\
10 \\
10 \\
4 \\
.8 \\
.2\end{array}$ & $\begin{array}{l} \\
\\
\end{array}$ & $\begin{array}{r}16.7 \\
11.5 \\
8.2 \\
7.2 \\
6.5 \\
5.8 \\
5.0 \\
4.4 \\
4.0\end{array}$ & $\begin{array}{r}3.17 \\
1.15 \\
.82 \\
.72 \\
.65 \\
.58 \\
.20 \\
.04 \\
.01\end{array}$ \\
\hline & 100.00 & & & 77.58 & & 100.00 & & & 7.51 \\
\hline
\end{tabular}


TABLE 4.-Comparative data in computing ground-water contribution, in cubic feet per second, Gypsum Creek near Gypsum and Homestake Creek near Red Cliff, Colo.

\begin{tabular}{|c|c|c|c|c|}
\hline \multirow{2}{*}{ Water year } & \multicolumn{2}{|c|}{$\begin{array}{l}\text { A verage annual } \\
\text { discharge }\end{array}$} & \multicolumn{2}{|c|}{$\begin{array}{l}\text { Average ground- } \\
\text { water discharge }\end{array}$} \\
\hline & $\begin{array}{l}\text { Actual } \\
\text { record }\end{array}$ & $\begin{array}{l}\text { Flow-dura- } \\
\text { tion curve }\end{array}$ & $\begin{array}{l}\text { Hydro- } \\
\text { graph }\end{array}$ & $\begin{array}{l}\text { Flow-dura- } \\
\text { tion curve }\end{array}$ \\
\hline \multicolumn{5}{|c|}{ Gypsum Creek near Gypsum, Colo. } \\
\hline $\begin{array}{l}1951 \\
1952 \\
1954 \\
1955\end{array}$ & $\begin{array}{l}32.5 \\
47.7 \\
34.6 \\
21.9 \\
25.0\end{array}$ & $\begin{array}{l}32.3 \\
47.2 \\
34.8 \\
22.1 \\
25.8\end{array}$ & $\begin{array}{l}23.1 \\
26.9 \\
26.4 \\
20.6 \\
19.0\end{array}$ & $\begin{array}{l}23.0 \\
26.6 \\
26.4 \\
21.4 \\
20.2\end{array}$ \\
\hline $\begin{array}{l}\text { Average } \\
\text { 1951-55 } 1\end{array}$ & 32.3 & $\begin{array}{l}32.4 \\
32.6\end{array}$ & 23.2 & $\begin{array}{l}23.5 \\
23.5\end{array}$ \\
\hline \multicolumn{5}{|c|}{ Homestake Creek near Red Clif, Colo. } \\
\hline 1951 (1952 & $\begin{array}{r}98.6 \\
102 \\
78.6 \\
41.8 \\
63.0\end{array}$ & $\begin{array}{c}99.7 \\
101 \\
80.0 \\
40.5 \\
64.5\end{array}$ & $\begin{array}{l}8.4 \\
8.7 \\
9.4 \\
8.6 \\
8.0\end{array}$ & $\begin{array}{l}7.3 \\
8.1 \\
7.4 \\
7.4 \\
8.8\end{array}$ \\
\hline $\begin{array}{l}\text { Average } \\
1951-551\end{array}$ & 76.8 & $\begin{array}{l}77.1 \\
77.6\end{array}$ & 8.6 & $\begin{array}{l}7.8 \\
7.5\end{array}$ \\
\hline
\end{tabular}

1 Computed from flow-duration curve for water years 1951-55.

an environment is favorable to infiltration of precipitation, part of which would build up the ground-water table which, in turn, would maintain the stream during the low-flow periods.

In contrast to Gypsum Creek basin, the drainage basin of Homestake Creek is underlain mostly by granite and much of the land surface is bare rock. This rock is relatively impermeable, but apparently absorbs some moisture along joints and faults and discharges it downgradient to the stream. Groundwater storage capacity in such formations is not large; the openings in the rock will accept only a small amount of recharge; and because of restricted passageways, ground water would discharge to the stream at a relatively constant rate.

Ground-water contribution to streams computed by the flow-duration curve method, when expressed as a percentage of the total stream discharge, shows good correlation with variability indices (table 5 and fig. 22) computed by the method proposed by Lane and Lei (1950). Stream sites above and below irrigated lands are included. Chapters $\mathrm{C}, \mathrm{D}$, and $\mathrm{E}$ give additional data on the variability indices and percentages of ground-water contribution to the streams and discuss the geologic characteristics of the drainage areas.

\section{STATISTICAL ANALYSIS OF ANNUAL FLOWS}

The probability techniques described by Leopold (1959) in an analysis of streamflows for Colorado River at Lees Ferry, Ariz., were used to determine the variability of the annual discharges of streams and to estimate the probable future flow of streams. The effect
TABLE 5.-Variability index of streamflow and percentage of average annual discharge estimated to be contributed by ground water to the stream system at selected sites in the Upper Colorado River Basin [Data are for the water years 1914-57 adjusted to 1957 conditions except as indicated]

\begin{tabular}{|c|c|c|c|}
\hline $\begin{array}{l}\text { Sta- } \\
\text { thon } \\
\text { No. }\end{array}$ & Station & $\begin{array}{l}\text { Varia- } \\
\text { bility } \\
\text { index of } \\
\text { stream- } \\
\text { flow }\end{array}$ & \begin{tabular}{|c} 
Percent \\
of average \\
annual \\
discharge \\
contrib- \\
uted by \\
ground \\
water
\end{tabular} \\
\hline 125 & orth Inlet at Grand Lake, Colo. & & \\
\hline $\begin{array}{l}200 \\
360\end{array}$ & $\begin{array}{l}\text { Willow Creek near Granby, Colo.. } \\
\text { Williams River near Leal, Colo... }\end{array}$ & .56 & \\
\hline 470 & Blue River at Dillon, Colo.......... & & \\
\hline & Rock Creek near Dillon, Colo. & & \\
\hline 595 & Pine Creek near State bridge, Colo & .54 & \\
\hline $\begin{array}{l}640 \\
695\end{array}$ & $\begin{array}{l}\text { Homestake Creek near Red Clin, Colo } \\
\text { Gypsum Creek near Gypsum, Colo... }\end{array}$ & .19 & \\
\hline 780 & Fryingpan Creek near Norrie, Colo. & .59 & \\
\hline 965 & $\begin{array}{l}\text { Crystal River near Redstone, Coll } \\
\text { Plateau Creek near Collbran, Colo }\end{array}$ & .52 & \\
\hline & Buzzard Creek near Colloran, Colo.... & & \\
\hline 1125 & East River at Almont, Colo - & .53 & \\
\hline 1155 & Tomichi Creek at Sargents, Colo & & \\
\hline & Lake Fort at Gat & .52 & \\
\hline 14 & Mud & .58 & \\
\hline 1665 & Dolor & & \\
\hline 1725 & Colo... & & \\
\hline 1855 & ear Daniel, Co & & \\
\hline & East Fork near Big S & .72 & \\
\hline & East Fo & & \\
\hline 20 & ear Mason, Wyo.....- & .48 & \\
\hline 2105 & $\begin{array}{l}\text { Labarge Creek near } \\
\text { Fontenelle Creek near Herschler Ranch, near Fonte- }\end{array}$ & & \\
\hline 2125 & $\begin{array}{l}\text { nelle, Wyo. } \\
\text { Big Sandy Creek at Leckie Ranch, near }\end{array}$ & .35 & \\
\hline & $\begin{array}{l}\text { Big sandy Creek at Lecke kanci, near big } \\
\text { Wyo }\end{array}$ & .56 & \\
\hline 2140 & Little Sandy Creek $n$ & & \\
\hline 2185 & Gres & .42 & \\
\hline 2230 & tion, wyo & .58 & \\
\hline 2260 & Henrys Fork near Lone Tree, Wyo & .52 & \\
\hline & Ir Oak Creek, Col & & \\
\hline & Elk & .58 & \\
\hline 2530 & Little & & \\
\hline & avery, $\mathrm{C}$ & .48 & \\
\hline 2665 & Ash & .40 & \\
\hline 2775 & $\begin{array}{l}\text { West Fork Duchesne River near Hanna, } \\
\text { Rock Creek near Mountain Home, Utah. }\end{array}$ & .42 & \\
\hline 2925 & Utah. & .34 & \\
\hline 2995 & Whit & .40 & \\
\hline & & .26 & \\
\hline 3180 & $\mathrm{Hu}$ & .38 & \\
\hline 3245 & Cot & .46 & \\
\hline 3265 & n, Utah... & .53 & \\
\hline $\mathbf{3 4 0 0}$ & ggs, Colo & .62 & \\
\hline 3460 & Colo ... & .50 & \\
\hline 3495 & & .61 & \\
\hline 350 & Sar & & \\
\hline 3575 & Ani & .58 & \\
\hline 3610 & & .58 & \\
\hline $\begin{array}{l}3615 \\
3655\end{array}$ & $\begin{array}{l}\text { Animas River at Durango, Colo- } \\
\text { Laplata River at Hesperus, Colo- }\end{array}$ & .46 & \\
\hline 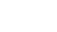 & I River near Bluff,' Uta & .51 & \\
\hline & at Lees Ferry, A & 40 & \\
\hline
\end{tabular}

1 Water years $1952-57$.

2 Water years $1940-57$.

of drainage-basin environmental factors were investigated by comparing the variability of annual discharges for streams. Variations in annual runoff are principally due to variations in precipitation, but other environmental factors also influence the magnitude of annual variations.

Not all the records of streamflow were long enough to make a reliable statistical analysis. However, a study of frequency data for the long-term records revealed two important characteristics. First, the distribution of the annual discharges of many streams for the water years 1914-57 was approximately normal. Second, the coefficients of variation (slope of the frequency curve 


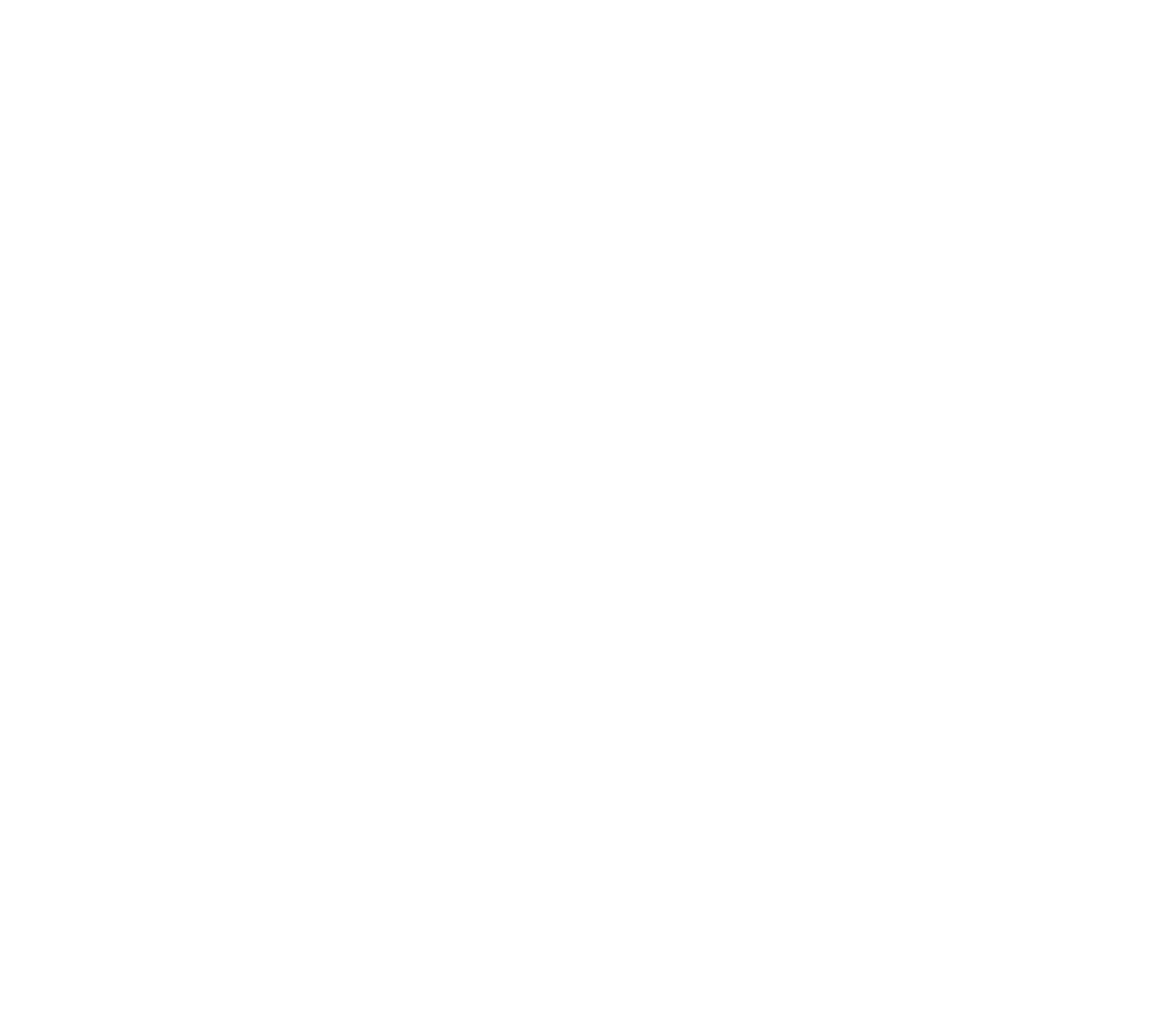

Fraure 22.-Relation between the variability index of streamflow and percentage of average annual discharge estimated to be contributed by ground water for selected streams in the Upper Colorado RIver Basin, water years 1914-57 adjusted to 1957 conditions.

expressed as the ratio of the standard deviation of the average discharge) had geographic significance. These two characteristics provide a basis for probability statements about streams which have short streamflow records.

The standard deviation of an array of data that is normally distributed is computed by the formula

$$
S=\sqrt{\frac{\Sigma x^{2}}{n-1}}
$$

where $S$ is the standard deviation, $x$ is the difference between the value of an individual item and the average of all the items in a sample, and $n$ is the number of items in the sample.
If the individual items are expressed as ratios of the average of all the items, $x$ becomes the difference between the individual ratios and 1.00 , and the computed standard deviation would also be in terms of a ratio to the average. Expressing annual-discharge data as a ratio to the average discharge eliminates most of the effect of size of drainage area and difference in annual runoff between basins. Normally distributed data expressed as ratios to the mean will plot on probability paper as a straight line passing through an abscissa value of 1.00 and an ordinate value of 50 percent. The line also passes through (1) an abscissa value of 1.00 plus the ratio of the standard deviation to the average discharge and an ordinate value of 84.1 percent, 
and (2) another abscissa value of 1.00 minus the ratio of the standard deviation to the average discharge and an ordinate value of 15.9 percent.

The probable deviation expressed as a ratio to the average discharge can be either determined from probability plotting at 25-percent or 75-percent abscissa values or computed by multiplying the ratio of the standard deviation to the average discharge (coefficient of variation) by the factor 0.6745 . Deviations from the mean ( 1.00 ordinate value) can be scaled from a probability plotting or computed by multiplying the standard deviation by a factor for other probabilities. For example, the factor for the deviation at 10 percent and 90 percent is 1.282 , at 5 percent and 95 percent is 1.645 and at 1 percent and 99 percent is 2.326 .

The computed effect of persistence of hydrologic data (tendency for grouping of years of high runoff and years of low runoff) for streams in this area generally agreed with the variability of mean values of streamflow for records of various lengths derived by Leopold (1959, p. 8). The following tabulation shows average values used in this report to correct for the effect of persistence of hydrologic data:
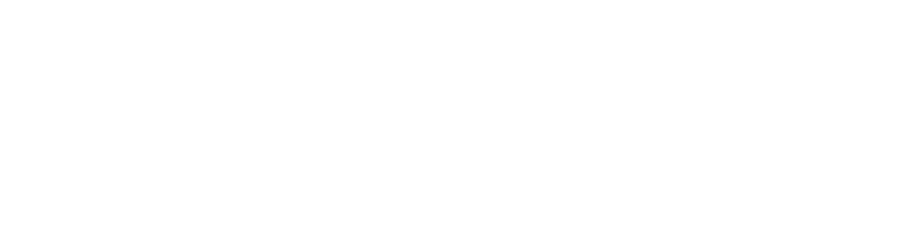

Most streams in the area are affected by changes in irrigation depletion, transmountain diversions, or reservoir regulation. In the statistical analysis of the variability of annual runoff of streams affected by these changes, the records of streamflow were adjusted to a fixed level of upstream development to eliminate the effect of changing conditions.

Annual irrigation depletions have been approximately constant as there has been little change in irrigated acreage. Irrigation depletion, therefore, has little effect on the variability values of annual runoff when expressed as the ratio of the standard deviation to the average discharge.

The annual discharges of streams, affected by transmountain diversions and reservoirs were adjusted to a 1914 base by adjusting for changes in diversions and reservoir storage after 1914. Coefficients of variation computed on this base can be used with the average discharge of streams for water years 1914-57 adjusted to 1957 conditions to determine the variability of runoff for the level of upstream development existing in 1957.

Streamflow data for Roaring Fork at Glenwood Springs, Colo., were used as an example to show adjustments to the 1914 base, the frequency distribution curve, the coefficient of variation, and frequency distribution for periods of different lengths. To adjust the streamflow record for the effect of changes in transmountain diversions, the annual quantities diverted by the Twin Lakes and Busk-Ivanhoe tunnels were added to the historical record of streamflow of Roaring Fork at Glenwood Springs (table 6). The discharges were then arranged in order of magnitude and converted to ratios of the average discharge for the 44-year period; the probability plotting position was computed from the formula

$$
\text { Plotting positon }=100-\frac{100 m}{n+1},
$$

in which $m$ is the order number and $n$ is the number of years of record (table 7). The ratios and probability values were then plotted on probability plotting paper, and a straight line was.drawn to conform to the points (fig. 23).

The standard deviation as a ratio to the average discharge is represented by $a$ and $a^{\prime}$ at abscissa values of 84.1 percent and 15.9 percent on figure 23 . The ratio value scaled from the graph is 0.27 .

TABLE 6.-Adjustment of streamflow records for Roaring Fork at Glenwood Springs, Colo., to 1914 base, in thousands of acre-feet

\begin{tabular}{|c|c|c|c|c|}
\hline \multirow{2}{*}{ Water year } & \multirow{2}{*}{$\begin{array}{l}\text { Historical } \\
\text { discharge }\end{array}$} & \multicolumn{2}{|c|}{ Adjustments } & \multirow{2}{*}{$\begin{array}{l}\text { Discharge } \\
1914 \text { base }\end{array}$} \\
\hline & & $\begin{array}{c}\text { Twin Lakes } \\
\text { tunnel }\end{array}$ & $\begin{array}{l}\text { Busk-Ivan- } \\
\text { hoe tunnel }\end{array}$ & \\
\hline $\begin{array}{l}1914 \\
1915 \\
1916 \\
1918 \\
1920 \\
1922\end{array}$ & $\begin{array}{c}1,845 \\
748.5 \\
1,231 \\
1,463 \\
1,362 \\
913.9 \\
1,356 \\
1,285 \\
1,072 \\
1,236 \\
990.4 \\
978.5 \\
987.6 \\
1,170 \\
1,100 \\
1,206 \\
944.1 \\
547.9 \\
1,141 \\
948.6 \\
499.1 \\
899.2 \\
1,048 \\
789.1 \\
1,194.1 \\
767.1 \\
589.9 \\
861.6 \\
1,008 \\
933.5 \\
884.4 \\
895.7 \\
798.3 \\
1,156 \\
1,087 \\
958.6 \\
798.0 \\
872.7 \\
1,239 \\
800.1 \\
477.9 \\
660.8 \\
717.4 \\
1,521\end{array}$ & $\begin{array}{l}0 \\
0 \\
0 \\
0 \\
0 \\
0 \\
0 \\
0 \\
0 \\
0 \\
0 \\
0 \\
0 \\
0 \\
0 \\
0 \\
0 \\
0 \\
0 \\
0 \\
0 \\
18.02 \\
23.24 \\
31.92 \\
45.46 \\
37.06 \\
27.04 \\
36.09 \\
13.40 \\
48.02 \\
37.73 \\
44.78 \\
39.32 \\
37.31 \\
25.03 \\
38.19 \\
34.88 \\
44.92 \\
51.36 \\
40.30 \\
27.47 \\
35.06 \\
36.44 \\
32.74\end{array}$ & $\begin{array}{l}0 \\
0 \\
0 \\
0 \\
0 \\
0 \\
0 \\
0 \\
0 \\
0 \\
0 \\
1.61 \\
4.19 \\
5.76 \\
4.65 \\
6.64 \\
5.28 \\
2.96 \\
6.37 \\
5.20 \\
3.47 \\
5.01 \\
7.07 \\
5.35 \\
5.54 \\
5.32 \\
4.02 \\
3.81 \\
.82 \\
4.85 \\
2.10 \\
4.90 \\
4.64 \\
1.44 \\
1.00 \\
4.30 \\
3.41 \\
5.13 \\
6.34 \\
5.08 \\
3.20 \\
5.27 \\
5.40 \\
5.51\end{array}$ & $\begin{array}{c}1,845 \\
748.5 \\
1,231 \\
1,463 \\
1,362 \\
913.9 \\
1,356 \\
1,285 \\
1,072 \\
1,236 \\
990.4 \\
980.1 \\
991.8 \\
1,176 \\
1,105 \\
1,213 \\
946.4 \\
550.9 \\
1,197 \\
953.8 \\
502.6 \\
922.2 \\
1,079 \\
826.4 \\
1,245 \\
809.5 \\
621.0 \\
901.5 \\
1,022 \\
986.4 \\
924.2 \\
945.4 \\
842.3 \\
1,195 \\
1,113 \\
1,001 \\
836.3 \\
922.7 \\
1,297 \\
845.5 \\
508.6 \\
701.1 \\
758.2 \\
1,559\end{array}$ \\
\hline Av & & & & 1,021 \\
\hline
\end{tabular}

Quantities rounded to four significant figures. 


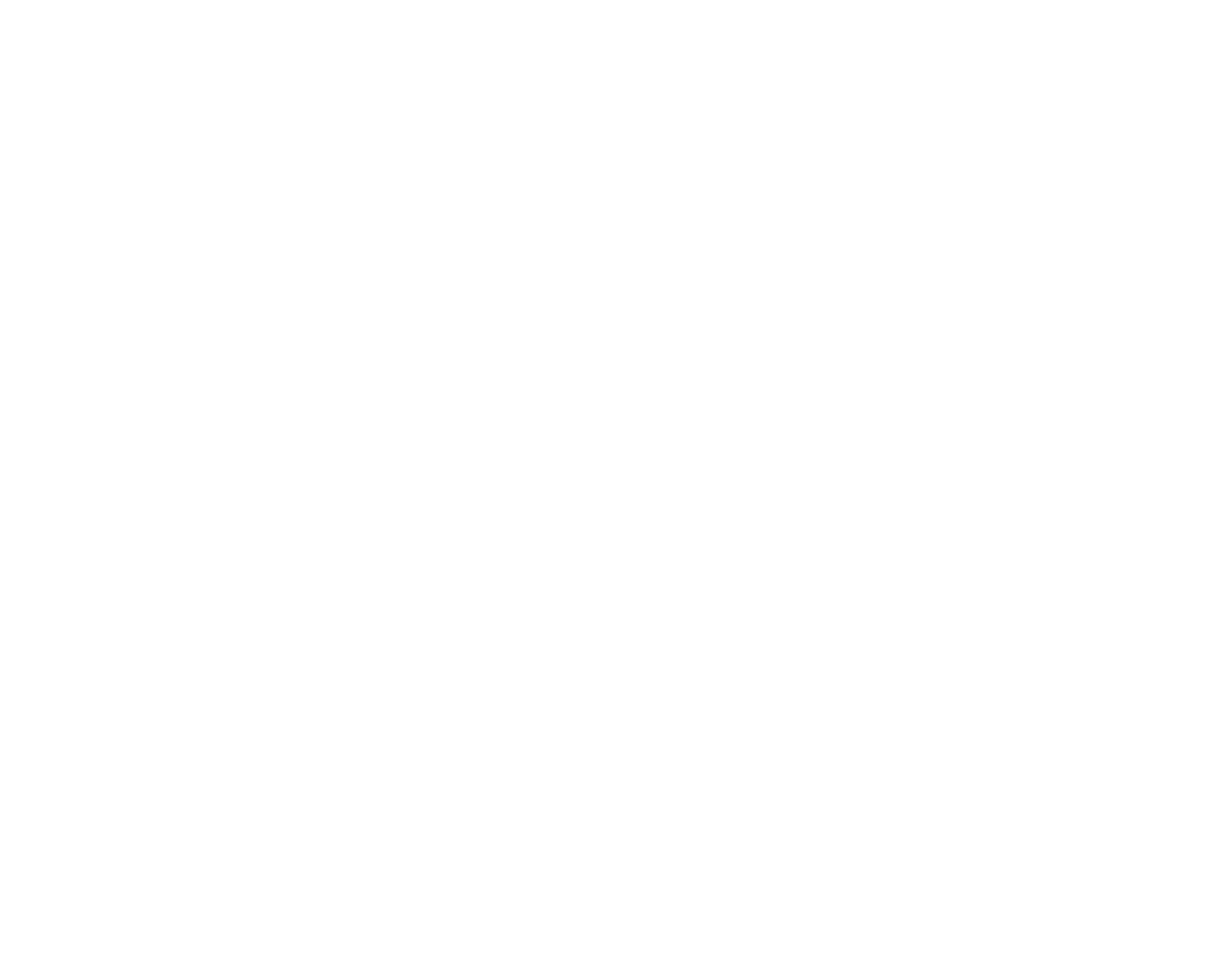

Figure 23.-Distribution of average flows for periods of various length, Roaring Fork at Glenwood Springs, Colo., water years $1914-57$ adjusted to 1914 base.

The standard deviation may also be computed from the adjusted annual discharges in table 6 by the formula given on page 54 . The average of all the discharges in the 44-year period is 1,021,000 acre-feet, and $n$ is 44. The computed standard deviation is 273,000 acrefeet, which when expressed as a ratio to the average discharge is $\frac{273,000}{1,021,000}$, or 0.27 .

In this report the coefficient of variation is defined as the ratio of the standard deviation to the average discharge, though in hydrologic literature it is sometimes expressed in percentage. This ratio, or coefficient of variation, is also a measure of the slope of the frequency curve when plotted on probability paper (ordinate $a$ in fig. 23). The frequency curve for a highly variable stream would have a steep slope and a high coefficient of variation. A less variable stream would have a flatter slope and lower coefficient of variation.

The lengths of the ordinates $b$ and $b^{\prime}$ in figure 23 at the 75 and 25 percentiles are equal to the ratio of one prob- able deviation to the average discharge: This length is plotted above and below the average (1.00). The ordinate distances $c$ and $c^{\prime}, d$ and $d^{\prime}$, and $e$ and $e^{\prime}$ are the ratios of deviations to the average flow at the 10 and 90 percentiles, 5 and 95 percentiles, and 1 and 99 percentiles, respectively.

The frequency distribution for the 2-, 4-, 10-, 20-, and 44-year average discharges are also plotted in figure 23 as dashed lines. The slopes of these lines were obtained by multiplying the slope of the 1-year period line by the ratios in the tabulation on page 55 . Ordinate values in terms of ratios to the average discharge at various percentiles may be scaled from the distribution graph or computed by multiplying the coefficient of variation by the appropriate factor.

The standard deviation and coefficient of variation were computed for many streams where streamflow records spanned the 44-year base period or where missing data could be estimated. Some records of shorter 
TABLE 7.-Computation of ratios of the average discharge and plotting position in probability analysis, Roaring Fork at Glenwood Springs, Colo.

[Data are for the water years 1914-57 adjusted to 1914 base]

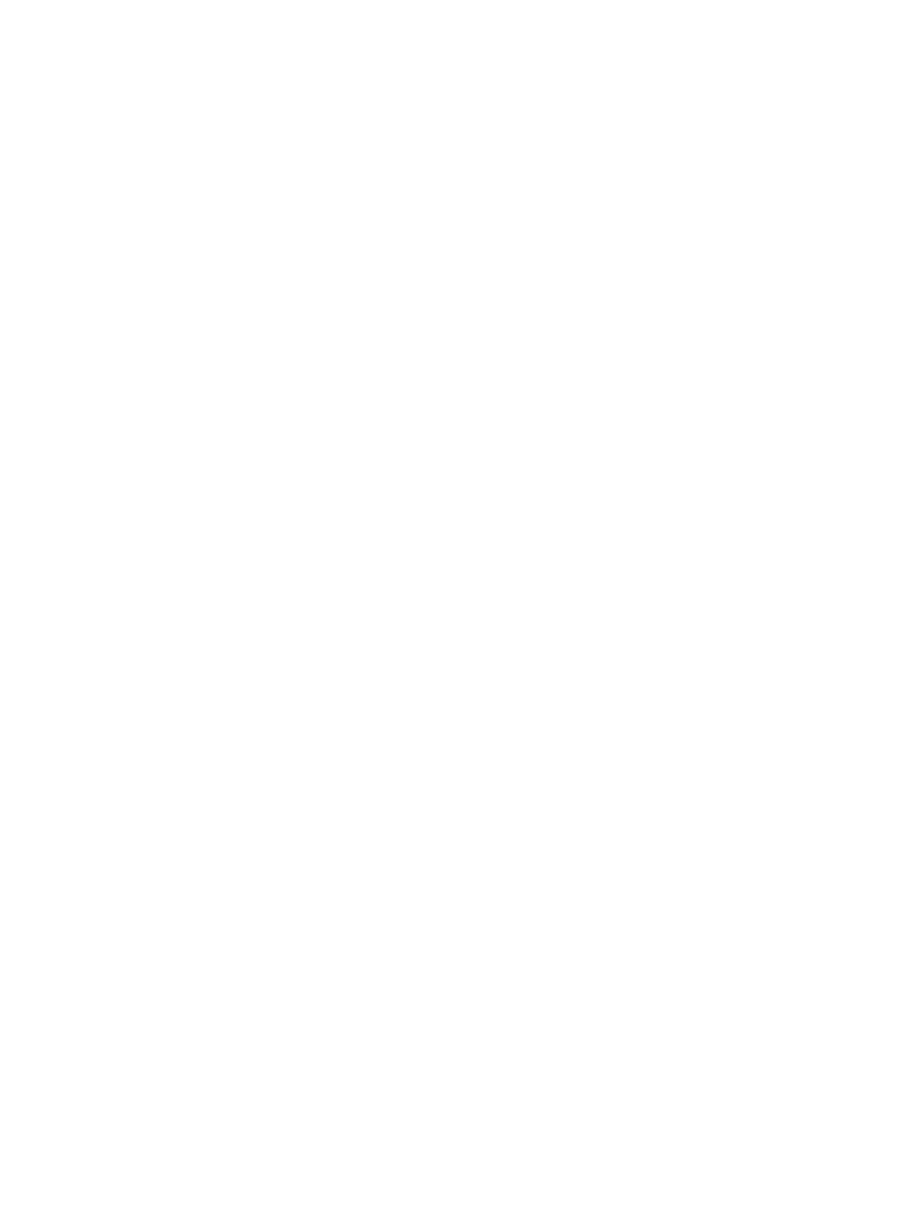

length were also used. The computed coefficients of variation were plotted on maps and the environmental factors examined to explain possible causes of differences in the coefficients for various drainage areas. By taking into consideration, climate, and other environmental factors, coefficients of variation can be estimated for many streams in the basin for which streamflow records are not long enough for a 44-year statistical analysis.

In addition to providing data on the variability of annual discharges in the 44-year period, the frequency data may be used to estimate how much future average streamflows for different periods of years are likely to deviate from the average observed in the 44-year period. For example, if the average discharge during water years 1914-57 and the coefficient of variation are known, or can be estimated, the probable difference between the average water discharge during the next 44-year period, or other selected periods of years, and the historical average can be computed for different selected confidence limits from the factors given in table 8 and the following equation:

$$
\text { Range in deviation }=V_{w} Q F \text {, }
$$

where $V_{w}$ is the coefficient of variation of annual discharge for the 44-year base period, $Q$ is the average annual discharge for the 44-year base period, and $F$ is the factor for means of periods of years for the selected confidence limits given in table 8 .

TABLE 8.-Factors for computing probable range in deviation of the average discharge for various periods of years and confidence limits from the average discharge in a 44-year period

\begin{tabular}{|c|c|c|c|c|c|c|}
\hline \multirow{2}{*}{$\underset{\text { (percent) }}{\text { Confidence limits }}$} & \multicolumn{6}{|c|}{ Factors $(F)$ for mean of periods of years indicated } \\
\hline & 1 & 2 & 4 & 10 & 20 & 44 \\
\hline $\begin{array}{l}50 \\
80\end{array}$ & $\begin{array}{l}0.67 \\
1.28 \\
1.64 \\
2.33\end{array}$ & $\begin{array}{l}0.58 \\
1.11 \\
1.42 \\
2.01\end{array}$ & $\begin{array}{l}0.48 \\
.91 \\
1.17 \\
1.66\end{array}$ & $\begin{array}{r}0.37 \\
.59 \\
.89 \\
1.26\end{array}$ & $\begin{array}{r}0.30 \\
.58 \\
.74 \\
1.05\end{array}$ & $\begin{array}{r}0.26 \\
.49 \\
.63 \\
.89\end{array}$ \\
\hline
\end{tabular}

Incorporated in the factors in table 8 is the variability of the mean of the 44-year sample and the variability of the means for various periods of years. For example, the factor in the table for a confidence limit of 50 percent and a 10 -year period is $0.6745 \sqrt{(0.27)^{2}+(0.47)^{2}}$, or 0.37 . The ratios 0.27 and 0.47 are from the tabulation for the 10-year and 44-year periods (p. 55).

Where the distribution of data is known to be approximately normal, the probable values of average flows for various periods in the future may be determined by computing the average discharge and standard deviation and by using the equation on page 54 with the factors given in table 8. For example, one may want to determine how much the average flow for Roaring Fork at Glenwood Springs for various periods of years might vary from the average observed during the water years $1914-57$, adjusted to the 1914 base.

The standard deviation computed from the equation on page 54 and the data in table 6 is 273,000 acre-feet. By use of the equation for range in deviation for selected confidence limits and periods of years

$$
\text { Range in deviation }=S_{w} F \text {, }
$$

where $S_{w}$ is the standard deviation for the 44-year period and $F$ is the factor for means of periods of years for the selected confidence limits from table 8, the following estimates of future average discharges (assuming a 50-percent confidence limit) can be made:

1. There is a 50-percent chance that the average discharge for any future year will lie between $1,204,000$ acre-feet $(1,021,000+183,000)$ and 838,000 acre-feet $(1,021,000-183,000)$, and there is a 25-percent chance, or one chance in four, that the average for any 1 year will be less than 
838,000 acre-feet and the same chance that it will be more than 1,204,000 acre-feet.

2. There is a 50-percent chance that the average discharge for any future 2-year period will lie between $1,179,000$ acre-feet $(1,021,000+158,000)$ and 863,000 acre-feet $(1,021,000-158,000)$, and there is a 25 -percent chance that the average will be less than 863,000 acre-feet and the same chance that it will be more than $1,179,000$ acre-feet.

3 . There is a 50-percent chance that the average discharge for any future 10-year period will lie between $1,122,000$ acre-feet $(1,021,000+101,000)$ and 920,000 acre-feet $(1,021,000-101,000)$, and there is a 25 -percent chance that the average will be less than 920,000 acre-feet and the same chance that it will be more than 1,122,000 acre-feet.

4. There is a 50-percent chance that the average discharge for any future 44-year period will lie between $1,092,000$ acre-feet $(1,021,000+71,000)$ and 950,000 acre-feet $(1,021,000-71,000)$, and there is a 25-percent chance that the average will be less than 950,000 acre-feet and the same chance that it will be more than $1,092,000$ acre-feet.

\section{COMPUTING CHEMICAL-QUALITY DATA} DURATION TABLES OF DISSOLVED SOLIDS

The concentration of dissolved solid's of most streams in the Upper Colorado River Basin varies nearly in inverse relation to the discharge of the stream. Figure 24 shows a typical curve of this relation. The concentration is maximum during low-flow periods when the flow of the stream is predominately effluent ground water. At times of high discharge, the higher concentration of the ground-water inflow is diluted by the lower concentration of the surface runoff. For high mountain streams draining areas of metamorphic and granitic rocks in the Upper Colorado River Basin, the shape of this curve is rather flat, and the range between maximum and minimum concentration is small. For streams draining areas where highly concentrated ground water enters the stream, the curve has a pronounced reverse S-shape on log-log paper, and the range between maximum and minimum concentration is large (fig. 24).

Curves showing relation between the concentration of dissolved solids and the discharge of the stream at the time of sampling were prepared for many streams. Data obtained from these curves were combined with the flow-duration tables of streamflow for water years 1914-57 adjusted to 1957 conditions to obtain values for duration tables of dissolved-solids concentration and dissolved-solids discharge. (See table 9.) Footnotes to table 9 explain the computations. The sum of the increments in column 5 is the average water discharge, and the sum of the increments in column 8 is the average dissolved-solids discharge. Weightedaverage concentration is computed by the following equation:

$$
C_{a}=\frac{t}{0.0027 q}
$$

where

$C_{a}=$ weighted-average concentration of dissolved solids,

$t=$ tons per day of dissolved solids,

$q=$ average water discharge in cubic feet per second, and

$0.0027=\mathrm{a}$ factor used for converting the product of concentration in parts per million and water discharge in cubic feet per second to tons per day. This factor is based on unit density of water and introduces no error of practical importance for water containing less than about $7,000 \mathrm{ppm}$ of dissolved solids.

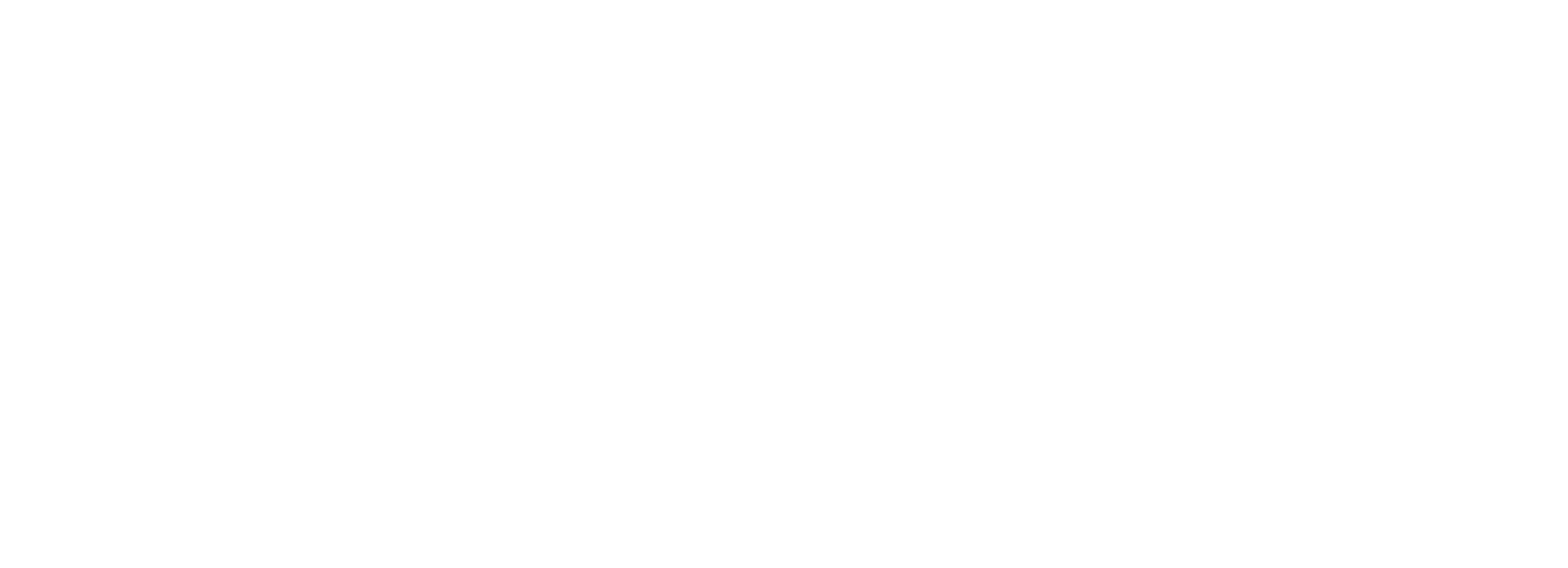

FiguRE 24,-Relation of weighted-average concentration of dissolved solids to water discharge, Green River near Ouray, Utah. Curve is based on monthly average discharges and monthly weighted-average concentrations for periods of available data, water years 1951-52 and 1957. 
TABLE 9.-Duration table of water discharge and dissolved-solids concentration and discharge of Green River near Ouray, Utah

[Data are for the water years 1914-57 adjusted to 1957 conditions]

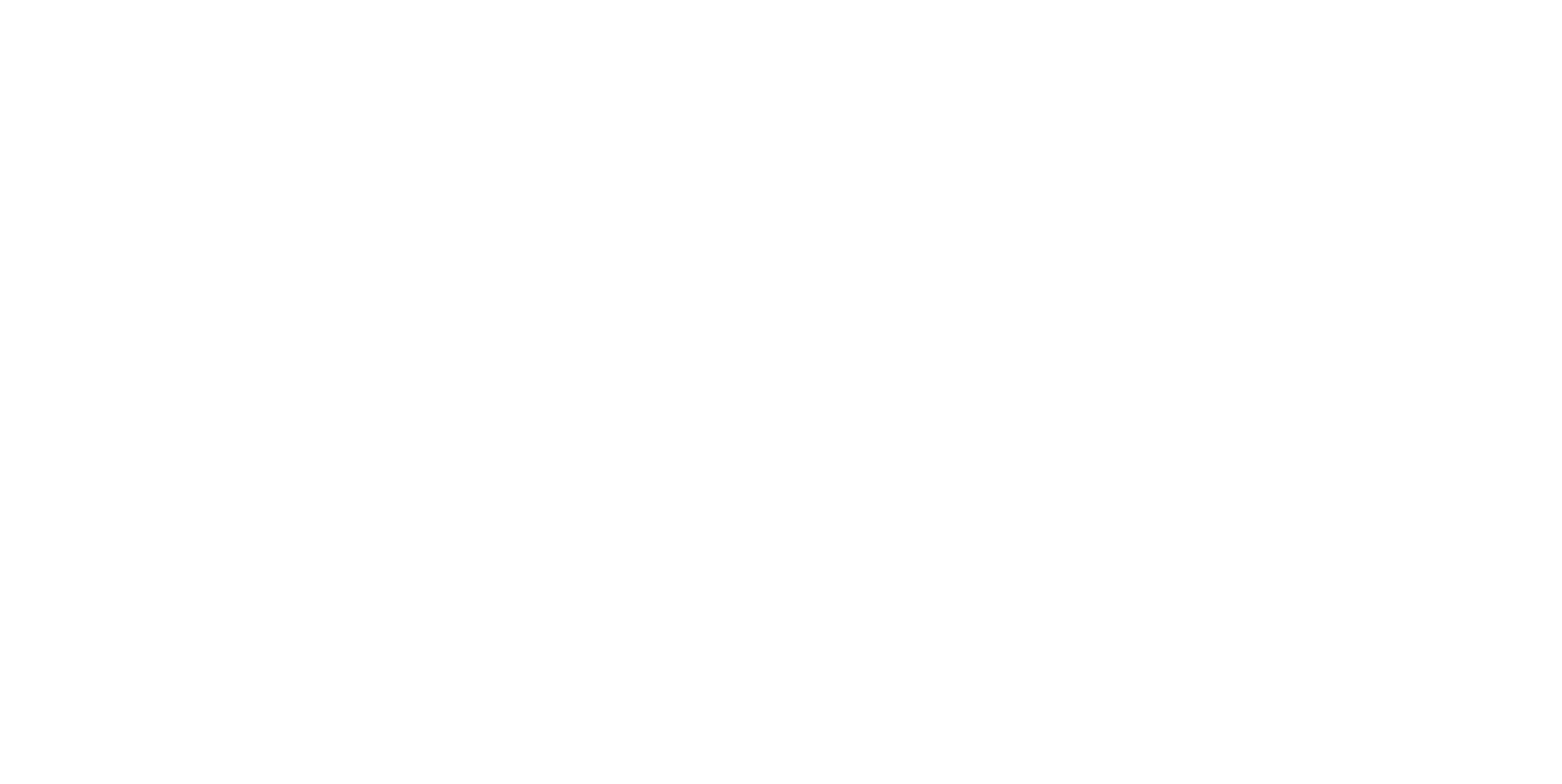

1. Limits of spread of time interval used in integrating area under duration curves by partial areas.

3. Selected percentages on duration curves used in duration tables for this study

4. Flow-duration table of water discharge for the water years 1914-57 adjusted to i957 conditions.

Computations similar to those illustrated in table 9 were used to develop duration tables of dissolved-solids concentration and tables of dissolved-solids discharge for many streams. (See chapters $C, D$, and E.) Curves showing relation between dissolved-solids concentration and water discharge were based on data obtained during the latter part of the 44-year period; consequently, the computed dissolved-solids concentration and loads are representative of conditions existing in 1957.

\section{DISSOLVED SOLIDS CONTRIBUTED TO STREAMS BY} GROUND WATER

The amount of dissolved solids carried into snowmelt-type streams in ground water was computed. The computations are based on the method described on pages 48-53 for computing the amount of groundwater contribution to streams from ground-water reservoirs, and the dissolved-solids concentration of the streams during the times that the flow is maintained principally by ground water. Duration tables of dissolved-solids discharge are used for the computation. Table 10 gives an example of the procedures applied to the records for Green River near Ouray, Utah. About 3,779 tons per day or $1,380,000$ tons per year is
5. Column 2 times column 4 divided by 100

6. From fig. 24 for water discharges in column 4. This is duration table of dissolved7. Column 4 times column 6 times 0.0027 . This is duration table of dissolved-solids 8. Column 2 times column 7 divided by 100 .

TABLE 10.-Computation of dissolved solids contributed to the stream system by ground water, Green River near Ouray, Utah

[Data are for the water years 1914-57 adjusted to 1957 conditions]

\begin{tabular}{|c|c|c|c|c|}
\hline \multicolumn{3}{|c|}{ Duration table percentage } & \multicolumn{2}{|c|}{$\begin{array}{l}\text { Ground-water dissolved- } \\
\text { solids discharge }\end{array}$} \\
\hline Time limits & Time interval & $\begin{array}{l}\text { Mean of } \\
\text { interval }\end{array}$ & $\begin{array}{l}\text { Discharge for } \\
\text { mean of in- } \\
\text { terval (tons } \\
\text { per day) }\end{array}$ & $\begin{array}{l}\text { Increment of } \\
\text { discharge in } \\
\text { time interval } \\
\text { (tons per day) }\end{array}$ \\
\hline 1 & 2 & 3 & 4 & 5 \\
\hline $\begin{array}{r}0.00-35 \\
35-45 \\
45-55 \\
55-65 \\
65-75 \\
75-85 \\
85-95 \\
95-99 \\
99-99.8 \\
99.8-100\end{array}$ & $\begin{array}{r}35 \\
10 \\
10 \\
10 \\
10 \\
10 \\
10 \\
4 \\
.8 \\
.2\end{array}$ & $\begin{array}{l}40 \\
50 \\
60 \\
70 \\
80 \\
90 \\
97 \\
99.4 \\
99.9\end{array}$ & $\begin{array}{r}3,670 \\
5,750 \\
4,730 \\
4,130 \\
3,670 \\
3,200 \\
2,610 \\
1,860 \\
1,100 \\
699\end{array}$ & $\begin{array}{r}1,284 \\
\mathbf{5 7 5} \\
\mathbf{4 7 3} \\
\mathbf{4 1 3} \\
\mathbf{3 6 7} \\
\mathbf{3 2 0} \\
\mathbf{2 6 1} \\
\mathbf{7 5} \\
\mathbf{9} \\
\mathbf{2}\end{array}$ \\
\hline Totals _ _- & 100 & & & 3,779 \\
\hline
\end{tabular}

1. Limits of spread of time interval used in integrating area under duration curve by partial areas. The time limit for the first line is the spread from 0.00 percent to the point of departure percentage on the flow-duration curve. (See page 48.) 2. Spread of time interval.

3. Selected percentages on duration curve used in the duration tables for this study. From duration table of dissolved-solids discharge for water years 1914-57 adjusted to 1957 conditions, except first line which is estimated to be the same as the dissolved-solids discharge equaled or exceeded 70 percent of the time. 
contributed to the stream system above the Ouray station by ground water. The Ouray record was used as an example because the same record was used to illustrate the computation of total water discharge and total dissolved-solids discharge. (See table 9.)

\section{VARIABILITY OF DISSOLVED-SOLIDS CONCENTRATION}

Continuous chemical-quality records were available at relatively few locations in the basin, and the length of these were for relatively short periods of time as compared with the 44-year base period. Annual variability is a parameter which may be ascertained even from relatively short records. Data on the annual variability of concentration of dissolved solids for the 44-year base period were developed.

For concurrent periods of daily chemical-quality and streamflow records in the different basin divisions, the coefficients of variation for annual weightedaverage concentrations of dissolved solids and annual historical discharges were computed. Table 11 and figure 25 show the relation between the concentration and discharge coefficients in the Grand division. The plot shows that empirically there is a linear relation for major streams in this division. The empirical relation computed by the least-squares method is defined by the following equation:

$$
V_{d}=0.573 V_{w}+0.036 \text {, }
$$

where $V_{d}$ is the coefficient of variation of annual weighted-average concentration of dissolved solids and $V_{w}$ is the coefficient of variation of annual discharge.

TABLE 11.-Variability of annual weighted-average concentration as related to variability of annual water discharge for stations in the Colorado River Basin above the Gunnison River

\begin{tabular}{|c|c|c|c|c|}
\hline \multirow[b]{2}{*}{$\begin{array}{l}\text { Station } \\
\text { No. }\end{array}$} & \multirow[b]{2}{*}{ Station } & \multirow[b]{2}{*}{$\begin{array}{l}\text { Water } \\
\text { years }\end{array}$} & \multicolumn{2}{|c|}{$\begin{array}{l}\text { Coefficient of } \\
\text { variation }\end{array}$} \\
\hline & & & $\mid \begin{array}{c}\text { Stream- } \\
\text { fow } \\
\left(V_{\bullet}\right)\end{array}$ & $\begin{array}{l}\text { Weighted- } \\
\text { average } \\
\text { concentra- } \\
\text { tion } \\
\left(V_{d}\right)\end{array}$ \\
\hline 690 & $\begin{array}{l}\text { Eagle River at Gypsum, Colo } \\
\text { Colorado River near Glenwood } \\
\text { Springs, Colo }\end{array}$ & & 0.28 & 0.19 \\
\hline $\begin{array}{l}955 \\
1525\end{array}$ & $\begin{array}{l}\text { Colorado River near Cameo, Colo } \\
\text { Gunnison River near Grand Junction, }\end{array}$ & $1934-57$ & .25 & .17 \\
\hline 1800 & $\begin{array}{l}\text { Dolores River near Cisco, Utah } \\
\text { Colorado River near Cisco, Utah.... }\end{array}$ & $\begin{array}{l}1932-57 \\
1948-57 \\
1929-57\end{array}$ & $\begin{array}{l}.39 \\
.67 \\
.34\end{array}$ & $\begin{array}{l}.26 \\
.42 \\
.23\end{array}$ \\
\hline
\end{tabular}

This relation was derived from actual records. The relation is a means for developing statistical expressions of the variability of dissolved-solids concentrations for the 44-year base period for stations where continuous records of chemical quality were not available, but where infrequent chemical-quality data had

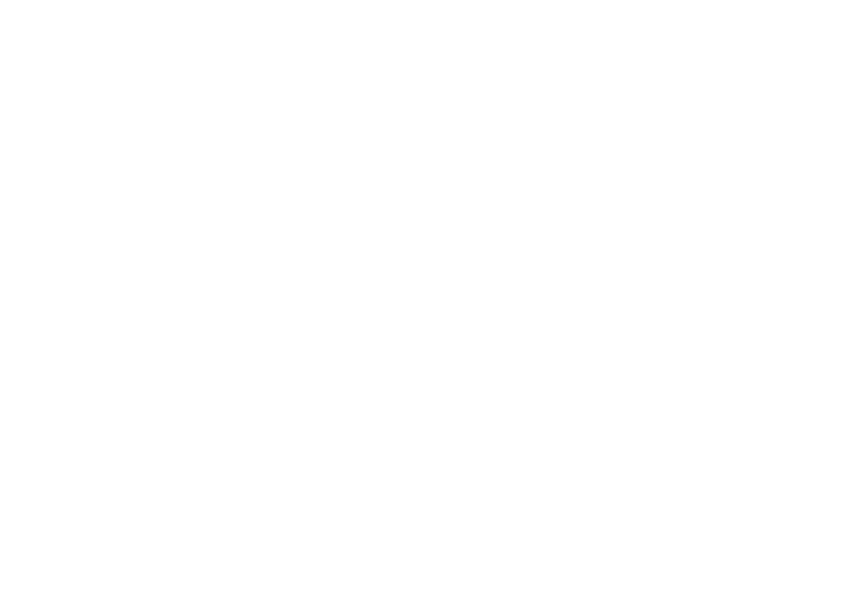

Figure 25,-Relation of the variability of dissolved-solids concentration to the variability of water discharge in the Grand divison. $A$, Dolores River near Cisco, Utah; $B$, Gunnison River near Grand Junction, Colo.; $C$, Colorado River near Cisco, Utah; $D$, Eagle River at Gypsum, Colo.; $E$, Colorado River near Glenwood Springs, Colo.; and F, Colorado River near Cameo, Colo.

been obtained. The coefficients of variation of annual water discharge were computed for a number of stations and are given in tables of the respective subbasin in which the stations are located. These coefficients were also plotted on maps. Coefficient values for other locations were interpolated from the maps. By use of computed or interpolated coefficients of variation of annual water discharge, and the empirical equation above, the coefficient of variation of weighted-average annual concentration of dissolved solids can be computed. As the coefficient of variation is the ratio of the standard deviation to the average concentration, the standard deviation in parts per million may be computed if the average concentration in parts per million is known or can be determined.

The foregoing may be illustrated by the example of an analysis of Roaring Fork at Glenwood Springs, Colo., where the coefficient of variation of water discharge is 0.27 , and the weighted-average concentration is $225 \mathrm{ppm}$ for water years $1914-57$ adjusted to 1957 conditions. Substituting the coefficient of variation of water discharge in the equation

$$
\begin{aligned}
V_{d} & =0.573 V_{w}+0.036 \\
& =(0.573)(0.27)+0.036 \\
& =0.19,
\end{aligned}
$$

and as

$$
\begin{aligned}
S_{d} & =V_{d}+C_{a} \\
& =0.19 \times 225 \\
& =43 \mathrm{ppm},
\end{aligned}
$$

wherein $V_{w}$ is the coefficient of variation of annual water discharges, $V_{d}$ is the coefficient of variation of annual weighted-average dissolved-solids concentrations, $C_{a}$ is the weighted-average concentration of dissolved solids, and $S_{d}$ is the standard deviation of 
annual weighted-average dissolved-solids concentrations.

If the weighted-average concentration of dissolved solids for periods of various length are assumed to have variances comparable to those of streamflow, the factors in table 8 can be used to compute probable values of concentration for various periods in the future. For example, if the level of development existing in 1957 were to exist during the next 44-year period, there is a 50-percent chance that the weighted-average concentration of dissolved solids of Roaring Fork at Glenwood Springs, Colo., will lie between $236 \mathrm{ppm}$ $(225+43 \times 0.26)$ and $214 \mathrm{ppm}(225-43 \times 0.26)$ and there is a 25-percent chance that the weightedaverage concentration of dissolved solids for the period will be less than $214 \mathrm{ppm}$.

\section{EFFECT OF TRANSMOUNTAIN DIVERSIONS ON THE CHEMICAL QUALITY OF WATER OF STREAMS}

Water diverted out of the Upper Colorado River Basin carries with it the minerals dissolved in the diverted water. The effect of a diversion on the master stream at a downstream point is to deplete the flow and to change the dissolved-solids discharge. Whether the diversion increases or decreases, the weightedaverage concentration of the master stream at a downstream point depends on the relation of the weightedaverage concentration of the diverted water to the original weighted-average concentration of the master stream at the downstream point. If the diverted water is the more dilute, the effect will be to increase the concentration of the master stream; and if less dilute, the effect will be to decrease the concentration of the master stream. If no changes in water loss are assumed to occur in the master stream channel, the relation between water discharges and weighted-average concentrations would be as follows:

or

$$
C_{c}\left(Q_{a}+Q_{b}\right)=Q_{a} C_{a}+Q_{b} C_{b}
$$

where

$$
C_{c}=\frac{Q_{a} C_{a}+Q_{b} C_{b}}{Q_{a}+Q_{b}}
$$

$Q_{a}=$ average discharge of master stream at downstream point when water is being diverted,

$C_{a}=$ weighted-average concentration of the water in the master stream when water is being diverted,

$Q_{b}=$ average discharge of diversion,

$C_{b}=$ weighted-average concentration of diverted water, and

$C_{c}=$ weighted-average concentration of master stream at downstream point when no water is being diverted.

\section{EFFECTS OF THE ACTIVITIES OF MAN ON DISSOLVED- SOLIDS DISCHARGE \\ GENERAL}

The program for collecting data on chemical-quality of water in the Upper Colorado River Basin is not designed to identify the dissolved-solids loads contributed to the stream system by irrigation, mining, industry, and other sources. The data program is directed toward evaluating the chemical character of water and streamflow at various points in the stream system. Where the drainage area above a sampling site has little or no water-use development, the data are representative of natural conditions. Where the sampling site is below areas containing irrigated tracts of land, communities, industries, and other activities of man, the dissolved-solids load at the site is the total contribution from natural sources and the activities of man.

In the studies conducted specifically for the report, chemical-quality data were collected to help determine the effects of man; so, collection sites were both above and below areas containing irrigated tracts of land and communities. From analysis and correlation of these data and other available chemical-quality data with the geology, location of irrigated lands and communities, soil characteristics, and other factors, the general effects of the activities of man on the dissolved-solids loads of the streams can be identified. The results of the study can be further refined by additional data collection specifically designed to identify the effects of man's activities.

Part of the water used by communities and industries is consumed, and part is used to transport waste products for disposal, usually to the nearest stream channel. Although some of the wastes from these activities are treated for removal of organic matter and purification, the treatment does not remove the dissolved solids which have been added.

Partial analyses of samples of water supply and sewage for three communities in the Great Basin in Utah and two communities in the Upper Colorado $I$ ver Basin are shown in table 12 . The analyses by the Utah State Department of Public Health were furnished by L. M. Thatcher and C. K. Sudweeks (written commun., 1961). Population figures are those collected for the 1960 census.

Little data are available on the average annual amount of water used by the communities or the average annual sewage discharge except for Salt Lake City. The average daily use of water by Salt Lake City has been estimated to be 45 million gallons daily (U.S. Dept. of Health, Education, and Welfare, 1962), and the sewage discharge has been estimated to average 32 million gallons daily (U.S. Dept. of Health, Education, and Welfare, 1959). The average daily supply of 
TABLE 12.-Partial chemical analyses, in parts per million, of water supply and sewage for three communities in the Great Basin and two communities in the Upper Colorado River Basin, Utah

\begin{tabular}{|c|c|c|c|c|c|c|c|c|c|c|}
\hline & \multicolumn{2}{|c|}{$\begin{array}{c}\text { Salt Lake City } \\
\text { (population 189,454 }\end{array}$} & \multicolumn{2}{|c|}{$\begin{array}{c}\text { Murray (population } \\
16,806 \text { ) }\end{array}$} & \multicolumn{2}{|c|}{$\begin{array}{l}\text { Spanish Fork (popu- } \\
\text { lation } 6,472)\end{array}$} & \multicolumn{2}{|c|}{$\begin{array}{c}\text { Vernal (population } \\
\mathbf{3}, \mathbf{6 5 5} \text { ) }\end{array}$} & \multicolumn{2}{|c|}{$\begin{array}{c}\text { Duchesne (population } \\
770)\end{array}$} \\
\hline & $\begin{array}{l}\text { Water } \\
\text { supply } 1\end{array}$ & Sewage 2 & $\begin{array}{l}\text { Water } \\
\text { supply } 3\end{array}$ & Sewage 4 & $\begin{array}{l}\text { Water } \\
\text { supply }\end{array}$ & Sewages & $\begin{array}{l}\text { Water } \\
\text { supply }{ }^{\circ}\end{array}$ & Sewage 7 & $\begin{array}{l}\text { Water } \\
\text { supply }{ }^{3}\end{array}$ & Sewage 3 \\
\hline $\begin{array}{l}\text { Calcium (Ca) } \\
\text { Magnesium }(\mathrm{Mg}) \\
\text { Sodium and potassium }(\mathrm{Na}+\mathrm{K}) \\
\text { Bicarbonate }\left(\mathrm{HCO}_{3}\right) \\
\left.\text { Sulfate ( } \mathrm{SO}_{4}\right) \\
\text { Chloride }(\mathrm{Cl}) \\
\text { Total dissolved solids }\end{array}$ & $\begin{array}{r}51 \\
14 \\
10 \\
184 \\
45 \\
12 \\
240\end{array}$ & $\begin{array}{r}138 \\
46 \\
445 \\
407 \\
292 \\
635 \\
1,780\end{array}$ & $\begin{array}{r}46 \\
18 \\
4 \\
165 \\
35 \\
13 \\
216\end{array}$ & $\begin{array}{r}75 \\
35 \\
162 \\
403 \\
109 \\
133 \\
731\end{array}$ & $\begin{array}{r}105 \\
18 \\
63 \\
248 \\
148 \\
89 \\
593\end{array}$ & $\begin{array}{r}93 \\
50 \\
230 \\
555 \\
192 \\
159 \\
1,006\end{array}$ & $\begin{array}{r}14 \\
4 \\
1 \\
56 \\
4 \\
0 \\
67\end{array}$ & $\begin{array}{r}50 \\
18 \\
34 \\
196 \\
52 \\
22 \\
322\end{array}$ & $\begin{array}{r}97 \\
23 \\
30 \\
381 \\
64 \\
11 \\
435\end{array}$ & $\begin{array}{r}66 \\
35 \\
114 \\
490 \\
86 \\
9 \\
599\end{array}$ \\
\hline
\end{tabular}

1 Weighted average of one sample each from five sources of supply, analyses U.S.

Geol. Survey (Lohr and Love, 1954, n. 427 and 428). 1959 (written commun., 1961). 3 One analysis by Utah State Dept. of Health (written commun., 1961).

water is about $240 \mathrm{gpd}$ (gallons per day) per capita, and the average daily sewage discharge is about 170 gpd per capita.

Most of the difference between Salt Lake City's water supply and sewage discharge ( $70 \mathrm{gpd}$ per capita) is probably water used in watering lawns and washing streets. The amount of water consumptively used in households and by industry is probably small. If the amount of water consumed in households and by industry is assumed to be negligible, and 170 gpd per capita is used for both the water supply and the sewage discharge, the increase attributable to domestic and industrial uses is about 400 tons per year per 1,000 people.

In Murray, Spanish Fork, and Vernal, Utah, industrial establishments are few or none. The sewage discharge for these small communities probably averages about $140 \mathrm{gpd}$ per capita. If the water consumed in households and by industry is assumed to be negligible and the supply is $140 \mathrm{gpd}$ per capita, the data in table 12 indicate the dissolved solids added per year by each 1,000 people are: Murray, 112 tons; Spanish Fork, 88 tons; and Vernal, 54 tons.

An important factor not taken into account in these determinations is the possibility that ground water infiltrates into the sewage disposal system. Ground-water infiltration may result in dilution or in increased dissolved-solids concentration. The latter alternative is probably partly the reason for the relatively high results obtained for Salt Lake City as compared with those obtained for the smaller communities. Also, Salt Lake City is highly industrialized, and its sewage probably includes wastes from at least one petroleum refinery.

Most communities in the Upper Colorado River Basin are comparable to Spanish Fork and Vernal, Utah, although some, which have a few industrial establishments, are comparable to Murray, Utah. A con-
: Average of five analyses by Utah State Dept. of Health (written commun., 1961). - A verage of six analyses by Utah State Dept. of Health (Written commun., 1961). 7 A verage of two analyses by Utah State Dept. of Health (writter commun.. 1961).

servative figure of 100 tons per year per 1,000 people has been adopted for this report as the amount of dissolved solids added to the stream system by domestic and industrial uses of water.

Part of the water that is diverted for irrigation never returns to the streams or to ground-water storage. This part is consumed by evaporation in the irrigation canals and fields and by evapotranspiration. A relatively minor amount of water is retained within the plants themselves. The dissolved solids in the irrigation water remain either in the soil, in groundwater recharge, or in the return flow to the stream system. Except in areas where the ground water is not tributary to the stream system, the ground-water reservoirs reach a state of equilibrium, and any recharge from irrigation is rejected as part of the return flow to the stream system.

In addition to the increase of dissolved-solids concentration caused by the consumption of water by irrigation, the total salt load is increased by leaching of the irrigated land. The amount of dissolved solids added to the return flow by leaching depends largely on the amount and solubility of the minerals in the irrigated soils and in the underlying rocks, though other factors-such as irrigation practices, addition of chemical amendments, and fertilizers-may also contribute to the amount of dissolved solids in the return flow. All soils and rocks are soluble to some extent, and thus there will always be additions of dissolved solids to the return flow over and above the amount contained in the diverted water. The only exception will be those few areas where salts are actively increasing in the soil-a situation which finally eliminates possibility of continued irrigation farming.

\section{COMPUTATION OF DISSOLVED SOLIDS ADDED TO THE STREAMS BY THE ACTIVITIES OF MAN}

For many areas in the Upper Colorado River Basin, sufficient data were available to compute approximate 
amounts of dissolved solids that are added to the streams by the activities of man. The results of these computations were used to estimate the amounts of dissolved solids added to the streams in other areas where data were insufficient to compute the effect of the activities of man and the environmental factors such as geology, extent of irrigated lands, and density of population and industry are similar.

Computations were made for drainage basins above gaging stations where determination of long-term dissolved-solids discharge had been computed or for reaches along the main streams where determinations of dissolved solids entering and leaving the reach had been computed. These areas include about 41 percent of the lands under irrigation in the Upper Colorado River Basin-a sample representing a considerable part of the total. The increase in dissolved solids over and above that which can be accounted for in the inflow and natural contributions in these areas is considered to be the amount added to the stream system by the activties of man. Long-term water and dissolved-solids discharges adjusted to 1957 conditions are used, and any transmountain diversions in the areas were assumed to have been in place and in operation throughout water years 1914-57 at their 1957 level of development.

Two examples, which follow, illustrate the method of computation for areas with widely different environments-first, for the basin of the Fraser River, typical headwater stream in Colorado; and second, for the Grand Valley area, which is at an intermediate altitude along the Colorado River between the gaging stations near Cameo, Colo., and near Cisco, Utah.

In the first example, the Fraser River basin, measured inflow is known for the gaging stations on Fraser River near Winter Park (27.6 sq mi ) and St. Louis Creek near Fraser (32.8 sq mi). Measured outflow is known for the station on Fraser River at Granby (285 $\mathrm{sq} \mathrm{mi}$ ). Intervening between the inflow stations and the outflow station are 194 square miles of mountainous watershed and 31 square miles (about 20,000 acres) of valley land. Of the valley land, 10,200 acres is irrigated from streams within the area; the remaining 9,800 acres is undeveloped. Table 13 is a summary budget of the water and dissolved solids contributed to and discharged from the intervening area.

The budget for the intervening area is estimated and involves the following considerations:

1. The one unmeasured item of the outflow budget, water consumed on irrigated land, is estimared on the basis of a consumptive use ranging from 0.7 to 1.0 foot. On 10,200 acres, therefore, aggregate consumption is from 7,000 to 10,200 acre-feet a year. This consumption represents net depletion of streamflow for conditions existing in 1957. Solids that were dissolved in the consumed water must, in the long run, be discharged from the area as part of the dissolvedsolids load passing the gaging station at Granby.

2. Unmeasured natural inflow to Fraser River may be considered in two parts, ground-water contribution and direct runoff (surface water). The geology of the area indicates that the ground-water contribution to the Fraser River would mostly come from the valley fill underlying the 20,000 acres of valley land. Precipitation, which over the valley land averages about 20 inches annually, would be the principal source of ground-water recharge under natural conditions. Evapotranspiration at this altitude consumes about 12 to 15 inches of the annual precipitation. Of the remainder it is estimated that under natural conditions 3 to 5 inches recharged the ground-water reservoir and 2 to 3 inches was direct runoff. Accordingly from the 20,000 acres of valley land, the unmeasured ground-water inflow to Fraser River under natural conditions would be from about 5,000 to 8,400 acre-feet a year. Presumably, its natural dissolved-solids content would have ranged from 35 to $50 \mathrm{ppm}$, in accord with chemical analyses of water from adjacent streams during low flow (Fraser River near Winter Park, 38 ppm; St. Louis Creek near Fraser, 58 ppm; and Ranch Creek near Tabernash, $37 \mathrm{ppm}$ ).

3. The surface-water inflow is calculated to balance the inflow-outflow budget. So calculated, the amount ranges from 91,200 to 97,700 acre-feet a year, or on the average from 405 to 435 acrefeet a year per square mile of intervening area. The calculation agrees in magnitude with virgin yields per square mile from adjacent gaged drainage areas that have a similar hydrologic environment: Williams Fork above Williams Fork Reservoir, 490 acre-feet per square mile; and Willow Creek above Willow Creek Reservoir, 480 acre-feet per square mile. Concentratration of dissolved solids in this unmeasured surface-water inflow under natural conditions should not differ greatly from the mean of weighted-average concentrations at the stations near Winter Park and near Fraser. A concentration of $36 \mathrm{ppm}$ is assigned in the budget.

Effluent ground water and net depletion by irrigation are complimentary in the sense that if the estimate of one tends to be too large, that of the other 
TABLE 13.-Water and dissolved-solids budget, Fraser River basin and Grand Valley area [Data are for water years 1914-57 adjusted to 1957 conditions]

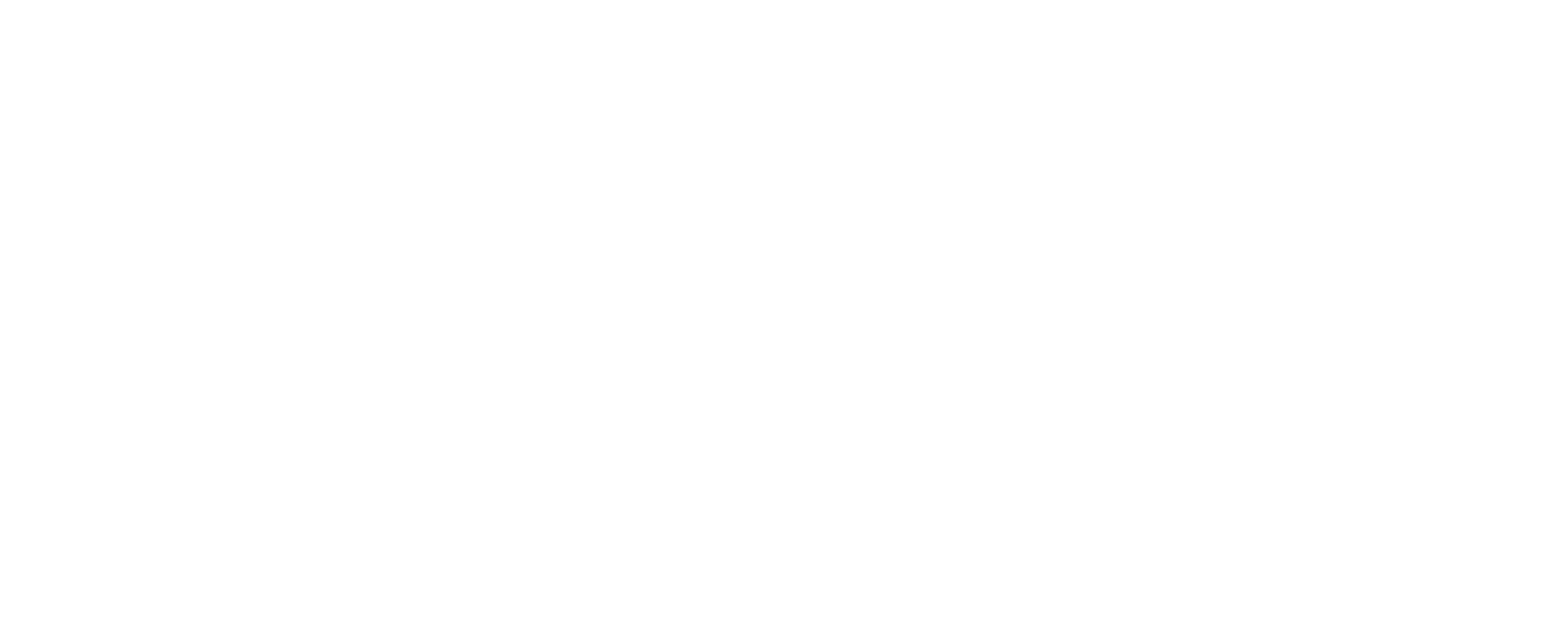

GRAND VALLEY AREA

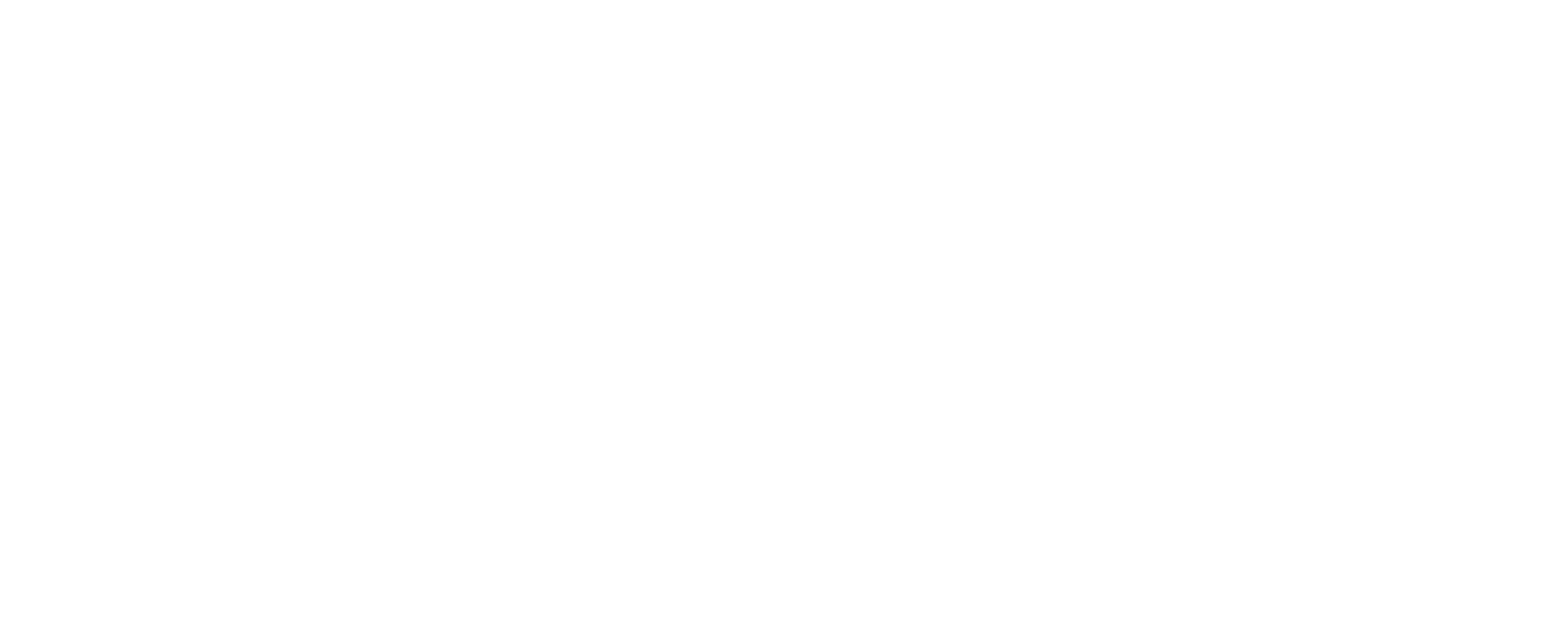

tends to be too small. In this particular subbasin budget, the volumes and dissolved-solids loads (tons per year) compensate one another algebraically.

The inflow items of the budget are so derived as to account for all the dissolved-solids load that should pass the measured-outflow station if there were no activities by man within the area. Yet the computed outflow load includes the effects of man's activities as of 1957. For the Fraser River basin, it exceeds the computed inflow load by 1,440 tons per year. This difference is due to man's activities, principally irrigation.

In the second example, that of the Grand Valley area, water and dissolved-solids inflow are recorded at the gaging stations on the Colorado River and Plateau Creek near Cameo, Colo., Gunnison River near Grand acre of irrigated land after deducting domestic and industrial contribution.

Junction, Colo., and Dolores River near Cisco, Utah (chap. C, table 14). Water and dissolved-solids outflow are recorded at the gaging station on Colorado River near Cisco, Utah (chap. C, table 14).

The area that intervenes between the inflow and outflow stations is 2,770 square miles-about 2,216 square miles north of the Colorado River and 554 square miles south of the river. Here, mean altitude and relief of the land surface are considerably less than in the Fraser River basin just described. Average yearly precipitation is from 8 to 10 inches on the lower part of the area. Of the intervening valley lands, about 78,700 acres (123 sq mi) is irrigated; 3,000 acres of this irrigated land is in the basin of the Little Dolores 
River. Table 13 summarizes inflow and outflow of water and of dissolved solids.

In this second example the unmeasured natural runoff from the intervening areas north and south of the Colorado River is known to be relatively small and is estimated to average 10 and 32 acre-feet per square mile per year, respectively. Some of these average values are derived from inflow data in a report by the Upper Colorado River Basin Compact Commission $(1948$, p. 48$)$, and others are determined from the characteristics of a few streams in other parts of the Colorado River Basin, under much the same hydrologic environment. In this runoff the dissolved-solids concentration is estimated to range from 900 to $1,470 \mathrm{ppm}$ in the north-side area. This range is based on partial chemical analyses of storm runoff in eight stock ponds in Badger Wash (K. R. Melin, oral commun.,) and the specific conductance of Westwater Creek in the summer of 1958. In contrast, the dissolved-solids concentration in the south-side area is estimated to range from 200 to $350 \mathrm{ppm}$. This range is based on chemical analyses of Little Dolores River near the ColoradoUtah State line and of West Creek at Gateway, Colo. (Iorns and others, 1964, table 220).

The conclusion that there would be no appreciable ground-water inflow from the intervening area under natural conditions is compatible with topographic, geologic, and climatic characteristics. In such an area substantially all the precipitation, about 8 to 10 inches, either runs off or is returned to the atmosphere by evapotranspiration.

Among the outflow items is one designated as "other depletions." Depletions in this category include water lost as evapotranspiration by irrigated crops and underflow that bypasses the outflow station or adds to ground-water storage beneath the irrigated area. In the Grand Valley area a depletion of 200,000 acre-feet a year is compatible with an irrigated acreage of 78,700 , a precipitation of 10 inches or less, and a consumptive use of 30 inches by irrigated crops. This value is somewhat larger than the value given by the Upper Colorado River Compact Commission; their estimate of consumptive use of water in the Grand Valley was 146,000 acre-feet a year. Available records indicate that virtually no underflow can bypass the outflow station at Cisco. Continuing accretion to ground-water storage is considered unlikely because irrigation in the Grand Valley has been practiced so long that groundwater storage and return flow to the river have probably reached a state of approximate equilibrium.

Of the increase from unbudgeted sources, less than 1 percent may conceivably be caused by domestic and industrial wastes. About 35,000 people live in the area
$-19,000$ in Grand Junction and 16,000 on farms and in other communities. If the dissolved-solids contribution from domestic and industrial wastes were assumed to be 100 tons per year per 1,000 people, the aggregate from all the area would amount to about 3,500 tons annually. This estimate is probably large (see p. 62); even so, it is only about 0.8 percent of the total dissolved-solids increase derived in the budget.

For the Grand Valley area the unbudgeted increase in dissolved-solids load-at least 440,000 tons per year, or 5.6 tons per year per irrigated acre-may be attributed to irrigation.

In the preceding two inflow-outflow budgets, used as examples, the indicated yields of dissolved solids per unit of area range widely. In this connection it is noteworthy that a large yield per unit area requires not only a substantial quantity of available soluble material in the rocks, in their weathering products, and in the soils-but also sufficient percolating and flowing water to dissolve the soluble and transport it to a stream. Conversely, a small dissolved-solids yield per unit of area implies any one of three environmental conditions: (1) little soluble material exists or ever existed in the soil and rocks of the area, (2) precipitation and runoff are so great and so widely dispersed that all the soil and rocks long since have been thoroughly leached to a substantial depth below the land surface, even though solubles may be plentiful at greater depth, or (3) precipitation is so very little that, even though solubles may be plentiful, leaching and transport of salts to the stream are minimal. All three of these environments exist in the Upper Colorado River Basin. It is implicit in this situation that, to characterize any particular area, water and dissolved solids contributions must be considered jointly.

Water and dissolved-solids budgets were made for 19 other areas in the Upper Colorado River Basin and are given in chapters $\mathrm{C}, \mathrm{D}$, and $\mathrm{E}$ of this report. All these budgets were derived by methods discussed in the preceding two examples. In these budgets the excess of dissolved-solids outflow over dissolved-solids inflow is commonly derived as a range also. This range may be construed as defining probable minimum and maximum values for the effect of man's activities in the particular subbasin, because each inflow budget seeks to conservatively account for all natural accretions to the dissolved-solids at the outflow station, so far as those accretions are measured or can reasonably be inferred from existing data. Only the minimum values are carried forward into summaries at gaging stations, for the subbasins, and for the divisions in the Upper Colorado River Basin. 
The results of the computations on the probable effect of irrigation in 21 areas are summarized in table 14, which includes data on average precipitation on the areas and information on the underlying forma-

tions. The effects of irrigation on the dissolved-solids load on the streams vary with major rock classes, as the rocks influence the relative quantities of soluble salts contained in the overlying soils.

TABLE 14.-Yield rates of dissolved solids from irrigated lands in 21 areas that are about 41 percent of the irrigated lands in the Upper Colorado River Basin

[Data are for the water years 1914-57 adjusted to 1957 conditions]

\begin{tabular}{|c|c|c|c|}
\hline Area & Underlying formation & $\begin{array}{c}\text { Average } \\
\text { annual } \\
\text { precipitation } \\
\text { (inches) }\end{array}$ & $\begin{array}{l}\text { Dissolved } \\
\text { solids (tons } \\
\text { per acre } \\
\text { per yr) }\end{array}$ \\
\hline $\begin{array}{l}\text { Fraser River basin, Colorado. } \\
\text { Colorado River Basin below Granby and Willow Creek } \\
\text { Reservoirs and above Hot Sulphur Springs, Colo., ex- } \\
\text { clusive of Fraser River basin, Colorado. } \\
\text { Troublesome Creek basin, Colorado. } \\
\text { Roaring Fork basin, Colorado. } \\
\text { Gunnison River basin below Gunnison tunnel and Un- } \\
\text { compahgre River Valley below Colona, Colo. } \\
\text { Colorado River Basin below Plateau Creek and Gunnison } \\
\text { River and above Dolores River. } \\
\text { San Miguel River basin between Placerville and Naturita, } \\
\text { Colo. } \\
\text { New Fork River basin above Boulder Creek, Wyo. } \\
\text { Fontenelle Creek basin, Wyoming } \\
\text { Big Sandy Creek basin, Wyoming-. } \\
\text { Blacks Fork basin above Muddy Creek, Wyo. } \\
\text { Hams Fork above Frontier, Wyo. } \\
\text { Yampa River basin between Morrison Creek and Steam- } \\
\text { boat Springs, Colo. } \\
\text { Elk River basin, Colorado } \\
\text { Little Snake River basin above Dixon, Colo }\end{array}$ & 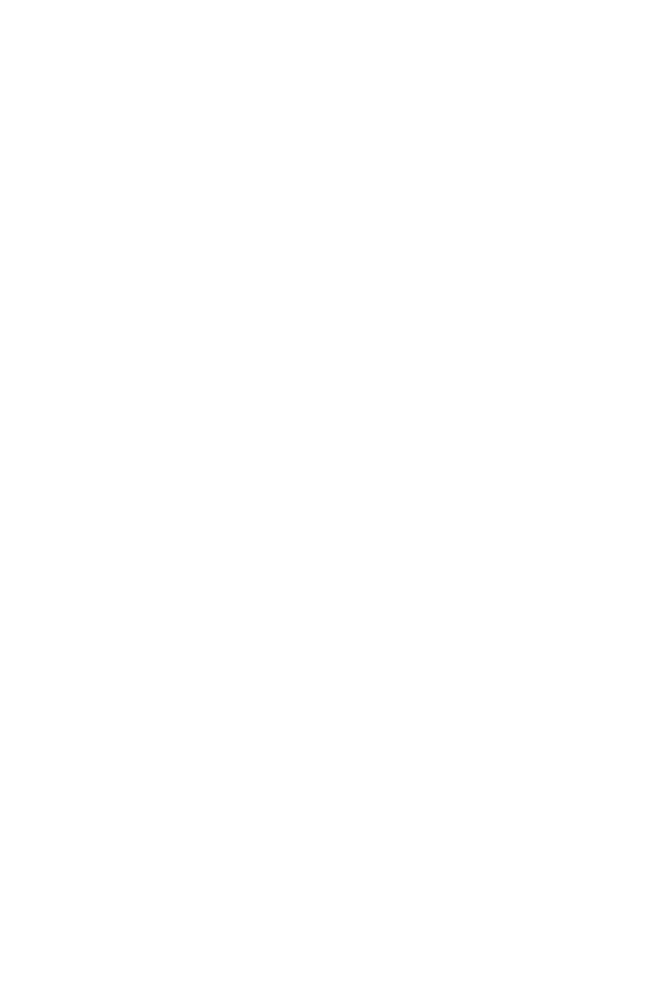 & 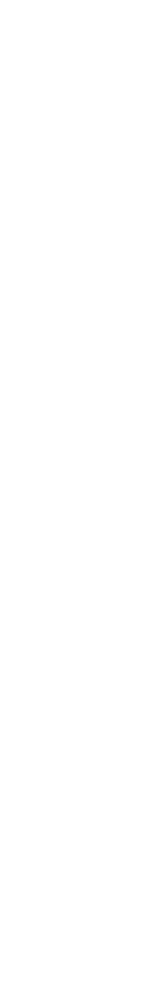 & $\begin{array}{r}2.1 \\
\text { 3. } 3 \\
\text { 4. } 8 \\
\text { 3. } 2 \\
\text {. } 5 \\
\text { 1. } 4\end{array}$ \\
\hline
\end{tabular}

\section{COMPUTING SEDIMENT DATA}

Curves showing relation between the concentration of suspended sediment and the discharge of the stream at the time of sampling were prepared for many streams where samples had been collected on less than a daily basis. Figure 26 is an example of this relation. On the basis of data obtained from these curves and the flow-duration tables of streamflow for water years 1914-57 adjusted to 1957 conditions, duration tables of suspended-sediment discharge were computed. (See table 15.) As the curves showing relation between suspended-sediment concentration and water discharge were based on data obtained during the latter part of the 44-year period, the computed suspended-sediment discharges are representative of conditions existing in 1957. A more detailed explanation of this method of computing suspended-sediment discharge, is given by Miller (1951).

\section{WATER-QUALITY CRITERIA}

Water is commonly described as good or bad; these relative terms are meaningless unless the use for the water is known. For example, a high-percent-sodium water may be bad if it is used for irrigation, but acceptable if it is used for domestic purposes.

\section{PROPERTIES AND CHARACTERISTICS OF WATER PHYSICAL PROPERTIES}

Water is used in each of its three physical states. Water as a gas is water vapor; as a liquid it is water, dew, or rain; and as a solid it is ice, snow, hail, or frost. Temperature determines the physical state of 
water and also its density. A unique characteristic of water is that it freezes at $32^{\circ} \mathrm{F}$ but has its greatest density at $39.2^{\circ} \mathrm{F}$.

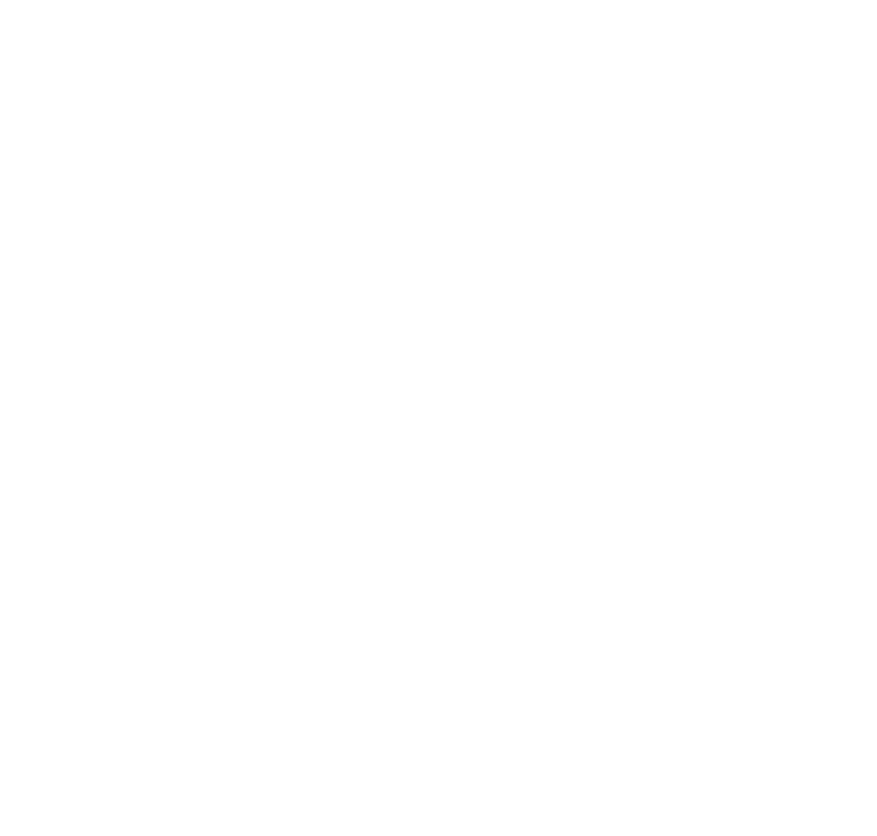

FIQURR 26.-Relation of concentration of suspended sediment to water discharge, Savery Creek at upper station near Savery, W yo.
The rate of evaporation from a water surface is controlled by such factors as temperature of the air and water, differences in vapor pressure, humidity, solar radiation, wind movement, altitude or barometric pressure, and the chemical quality of the water. Surface tension is one of the fundamental properties of liquid surfaces and produces capillarity, which is of great importance in the movement of ground water.

Water in movement has the ability to suspend and transport sediment. The amount of sediment that can be transported by water depends upon the size, specific gravity, and shape of the sediment particles, the forces acting upon the particles, and the amount of water flowing.

\section{CHEMICAL PROPERTIES AND CHARACTHRISTICS}

Water that falls to the earth as rain or snow is virtually devoid of dissolved constituents except for small amounts of dissolved gases, such as carbon dioxide. Natural waters in streams, lakes, oceans, and groundwater reservoirs contain dissolved mineral matter in variable amounts. These dissolved minerals are derived from the rocks and soils with which the water has been in contact. Differences in the dissolved-mineral composition and concentration of waters are due to differ-

TABLE 15.-Duration table of water discharge and suspended-sediment discharge and concentration, Savery Creek at upper station near Savery, Wyo.

[Data are for the water years 1914-57 adjusted to 1957 conditions]

\begin{tabular}{|c|c|c|c|c|c|c|c|}
\hline \multicolumn{3}{|c|}{ Duration table percentage } & \multicolumn{2}{|c|}{ Water discharge } & \multirow{2}{*}{$\begin{array}{c}\text { Suspended-sedi- } \\
\text { ment concentra- } \\
\text { tion for mean } \\
\text { of time interval } \\
(\mathrm{ppm})\end{array}$} & \multicolumn{2}{|c|}{ Suspended-sediment discharge } \\
\hline Time limits & Time interval & Mean of interval & $\begin{array}{l}\text { Discharge for mean } \\
\text { of interval (cfs) }\end{array}$ & $\begin{array}{l}\text { Increment of dis- } \\
\text { charge in time inter- } \\
\text { val (cfs) }\end{array}$ & & $\begin{array}{c}\text { Discharge for mean } \\
\text { of interval (tons } \\
\text { per day) }\end{array}$ & $\begin{array}{l}\text { Increment of dis- } \\
\text { charge in time in- } \\
\text { terval (tons per day) }\end{array}$ \\
\hline 1 & 2 & 3 & 4 & 5 & 6 & 7 & 8 \\
\hline $\begin{array}{r}0.00-0.02 \\
02-0.10 \\
10-0.20 \\
20-1.00 \\
\text { 1. } 00-3.00 \\
\text { 3. } 00-5.00 \\
\text { 5. } 00-9.00 \\
9-15 \\
15-25 \\
25-35 \\
35-45 \\
45-55 \\
55-65 \\
65-75 \\
75-85 \\
85-95 \\
95-99 \\
99-99.8 \ldots \\
99.8-100 \\
9\end{array}$ & $\begin{array}{l}0.01 \\
.06 \\
.15 \\
.6 \\
2.0 \\
4.0 \\
7.0 \\
12 \\
20 \\
30 \\
40 \\
50 \\
60 \\
70 \\
80 \\
90 \\
97 \\
99.4 \\
99.9\end{array}$ & $\begin{array}{c}0.02 \\
.08 \\
.10 \\
.80 \\
2.0 \\
2.0 \\
4 \\
6 \\
10 \\
10 \\
10 \\
10 \\
10 \\
10 \\
10 \\
10 \\
4 \\
.8 \\
.2\end{array}$ & $\begin{array}{r}515 \\
475 \\
440 \\
370 \\
288 \\
229 \\
178 \\
128 \\
74 \\
38 \\
27 \\
22 \\
18 \\
15 \\
12 \\
9.3 \\
4.2 \\
.9 \\
.5\end{array}$ & $\begin{array}{l}0.1 \\
.4 \\
.4 \\
\text { 3. } 0 \\
5.8 \\
4.6 \\
\text { 7. } 1 \\
\text { 7. } 7 \\
\text { 7. } 4 \\
\text { 3. } 8 \\
2.7 \\
2.2 \\
1.8 \\
1.5 \\
1.2 \\
.9 \\
.2 \\
0 \\
0\end{array}$ & $\begin{array}{r}900 \\
780 \\
680 \\
505 \\
327 \\
220 \\
143 \\
80 \\
47 \\
38 \\
36 \\
35 \\
35 \\
35 \\
34 \\
34 \\
34 \\
33 \\
33\end{array}$ & $\begin{array}{r}1,250 \\
1,000 \\
808 \\
504 \\
254 \\
136 \\
69 \\
28 \\
9.4 \\
3.9 \\
2.6 \\
2.1 \\
1.7 \\
1.4 \\
1.1 \\
.9 \\
.4 \\
.1 \\
.0\end{array}$ & $\begin{array}{r}0.2 \\
.8 \\
.8 \\
4.0 \\
5.1 \\
2.7 \\
2.8 \\
1.7 \\
.9 \\
.4 \\
.3 \\
.2 \\
.2 \\
.1 \\
.1 \\
.1 \\
0 \\
0 \\
0\end{array}$ \\
\hline Totals_...... & 100.00 & - & $-\cdots-\cdots$ & 50.8 & - n- n- & $\ldots-\ldots$ & 20. 4 \\
\hline
\end{tabular}

1. Limits of spread of time interval used in integrating area under duration curves by partial areas.

2. Spread of time interval.

3. Selected percentages on duration curves used in duration table for this study.

4. Flow-duration table of water discharge for water years 1914-57 adjusted to 1957 conditions.
5. Column 2 times column 4 divided by 100 .

6. From fig. 26 for water discharges in column 4. This is duration table of suspended-

7. Column 4 times column 6 times 0.0027 . This is duration table of suspended-sediment discharge.

8. Column 2 times column 7 divided by 100 . 
ences in the mineral composition of the rocks and in the solubility of these minerals. The different types of rocks and soils and the solubility of the minerals therein affect the rate of leaching.

The mineral constituents that affect the value of water for most uses are silica, iron, manganese, calcium, magnesium, sodium, potassium, carbonate, bicarbonate, sulfate, chloride, fluoride, nitrate, and boron. Detailed discussions of these constituents are found in Clarke (1924), California Institute of Technology (1957), and Hem (1959).

Other chemical properties and characteristics of water that are of importance are temperature, dissolved-oxygen content, color, turbidity, hydrogen-ion concentration, acidity, alkalinity, specific conductance, hardness, sodium-adsorption-ratio, and corrosiveness. These terms are explained by Lohr and Love (1954 p. 2-13, 427, 428) and Hem (1959).

Water is classified as to type on the basis of predominate mineral constituents. Whether certain cations (calcium, magnesium, sodium, and potassium) and certain anions (bicarbonate, sulfate, and chloride) predominate depends on the concentrations in equivalents per million and the relation of the concentration of the individual ions to each other. For example, if the concentration of sodium makes up most of the total cations and the concentration of bicarbonate makes up most of the total anions, the water is classified as a sodium bicarbonate type. However, if the second most abundant cation or anion is more than half the most abundant cation or anion, and the third most abundant cation or anion is more than half the second, they are included in the water-type classification in order of magnitude. Examples of these more complex water types would be calcium magnesium bicarbonate, calcium magnesium bicarbonate sulfate, and sodium magnesium calcium chloride sulfate.

\section{WATER-QUAITY CRITERIA FOR MAJOR USES}

The chemical and physical properties of a water are often the factors that control its use. An ample supply of water is of little moment if the quality of water is such that it cannot be used for the purpose desired. For example, the ocean is an unlimited source of water, but the high concentration of dissolved solids in sea water prevents its use at the present time except for very limited purposes. The following discussion of the criteria that are used to appraise the suitability of water for various uses is by no means complete, and the reader is referred to the literature for more complete discussions of water-quality criteria. Only the dissolved constituents that are normally determined by the Geological Survey were used in the appraisal.

\section{DOMESTIC USE}

A water that is turbid, or noticeably colored, or has an unpleasant or unusual odor or taste should obviously not be used for domestic purposes if clarification is practicable or if a more acceptable supply is available. (U.S. Public Health Service, 1962.) Moreover, the water should be reasonably cool and noncorrosive, should not form deposits, and should be free of disease-causing organisms.

The U.S. Public Health Service (1962) has devised standards for the drinking water furnished by interstate carriers. This agency was empowered to set the standards under the provisions of the Interstate Quarantine Regulations, which were enacted in 1914. The standards are mandatory only for waters used for drinking and cooking on railroad cars, aircraft, vessels, and any other carriers engaged in interstate traffic. However, the American Water Works Association has adopted and has recommended these standards for all public water supplies. The standards for the chemical constituents usually considered to be most important are listed in the following tables. Water containing dissolved material in excess of the listed concentrations should not be used where more suitable supplies are, or can be made, available.

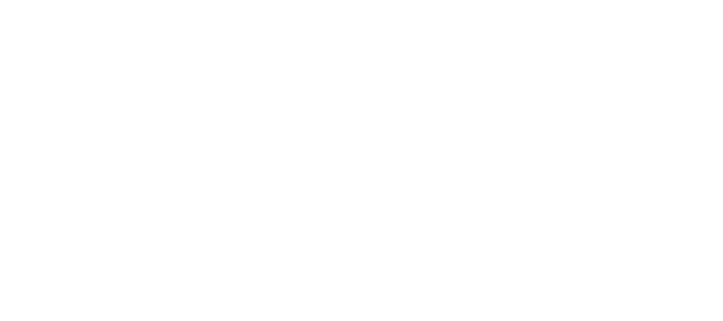

When fluoride is naturally present in drinking water, the concentration should not average more than indicated in the following table:

$\begin{gathered}\text { Annual average of maximum } \\ \text { daily air temperatures }\end{gathered}$
$50.0-53.7$
$53.8-58.3$

Concentrations of chemical constituents that exceed certain limits may be very undesirable. Surface waters seldom contain as much as $1 \mathrm{ppm}$ of dissolved iron; although in some regions, where the water is acid, large concentrations of iron may be in solution. Iron and manganese in solution may cause reddish-brown stains on porcelain or enameled ware and fixtures and on fabrics washed in the water. The effect of sulfates and 
especially magnesium sulfate on the digestive tract is well known, and concentrations of these salts high enough to produce cathartic effects should be avoided. The salty taste of water due to chloride can be detected by most people when the concentration of chloride exceeds $500 \mathrm{ppm}$.

Small quantities of fluoride in the water supply have been shown to lessen the incidence of dental caries. The American Dental Association recommends that water used for drinking by children should contain about $1.0 \mathrm{ppm}$ of fluoride. However, when the fluoride content of the water supply exceeds about $2.00 \mathrm{ppm}$, the enamel of children's teeth may become irregularly stained or mottled (Dean, 1936).

In a report by the National Research Council, Maxcy (1950, p. 271) stated that nitrates in excess of $44 \mathrm{ppm}$ may cause cyanosis in infants (blue babies). Nitrate in surface water is usually present in concentrations of less than $5 \mathrm{ppm}$, which is too low to adversely affect the value of the water for most purposes. In surface waters the aquatic vegetation is constantly utilizing nitrate by converting it to organic nitrogen in the plant cells by photosynthetic action. Thus, nitrates are seldom abundant in surface water. Nitrate may be present in ground water as a result of leaching of fertilizer or effluent from cesspools; and because photosynthetic action is not active beneath the ground, the nitrates in ground water will remain. Harmful amounts of nitrate are much more likely to be found in ground water than in surface water.

Hardness is the characteristic of water that is most often recognized by the difficulty of producing a lather or by the increased quantity of soap necessary to form a lather. Hard water is also objectionable because it causes the formation of scale in pipes, boilers, and other equipment. Hardness is caused principally by compounds of calcium and magnesium. Other constituents such as iron, aluminum, strontium, barium, zinc, and free acid also cause hardness, although these constituents are usually not in the water in sufficient quantity to be troublesome.

Hardness may be classified as follows:

\begin{tabular}{|c|c|c|}
\hline $\begin{array}{c}\text { Hardness } \\
(p p p m)\end{array}$ & Rating & Usability \\
\hline$<60_{-} \ldots$ & Soft $\ldots$ & $\begin{array}{l}\text { Suitable for many uses with- } \\
\text { out further softening. }\end{array}$ \\
\hline $61-120 \ldots$ & Moderately hard... & $\begin{array}{l}\text { Usable except in some indus- } \\
\text { trial applications. Soft- } \\
\text { ening profitable for } \\
\text { laundries. }\end{array}$ \\
\hline $121-180 \ldots$ & Hard . . . . & $\begin{array}{l}\text { Softening required by laun- } \\
\text { dries and some other in- } \\
\text { dustries. }\end{array}$ \\
\hline$>180 \ldots$ & Very hard . . . . . . & $\begin{array}{l}\text { Sof tening desirable for most } \\
\text { purposes. }\end{array}$ \\
\hline
\end{tabular}

INDUSTRIAL USE

The mineral constituents in water and the properties and characteristics of water determine whether the water can be used for specific industrial purposes. Water-quality tolerances for some industrial applications are given in table 16 . The chemical analyses of waters, when compared with the data in table 16 , indicate the suitability of the water for industrial purposes.

\section{AGRICULTURAL UGE}

The successful use of water for irrigation depends on many factors such as climate, texture and internal drainage of the soil and subsoil, management of the soil or farming practices, crops, and the chemical quality of the water used for irrigation. The importance of individual ions depends on their effect on the structure of the soil, their physiological effect on the plants, and on how they combine with other ions after the water is applied to the land.

\section{IMPORTANT MINERAL CONSTITUENTS}

The following constituents are important in determining the suitability of water for irrigation:

Calcium.- The element calcium is essential for plant growth and, in addition, has a beneficial effect on the soil. Therefore, in reasonable concentration, calcium is a desirable constituent in irrigation water. If sufficient calcium ions are adsorbed on the soil colloids, the soil will be friable and will readily absorb and transmit water. High concentrations of calcium, however, as of any other ion, can be harmful to plants.

Magnesium.-In many respects magnesium is similar to calcium and is essential for plant growth. Water in which the concentration of magnesium is high is undesirable for irrigation because of the adverse effect of high concentrations on plants.

Sodium.--One of the essential plant nutrients is sodium. In irrigation, however, its importance as a plant nutrient is often outweighed by its undesirable effects on the soil. If the concentration of sodium in equivalents per million exceeds that of calcium plus magnesium, the sodium will tend to replace the calcium ions on the soil coloids. Such a soil becomes almost impermeable to water and drains with difficulty.

Potassium.-An essential plant nutrient is potassium, whose chemical reactions are similar to those of sodium. Concentrations of potassium in waters are usually so low as to have no effect on the classification of the waters for irrigation.

Carbonate and bicarbonate.-If calcium and magnesium are precipitated in the soil as carbonates, the percent sodium would obviously increase and an alkali soil would result. Therefore, the ratio of the concentration of carbonate and bicarbonate to calcium, magnesium, and sodium is sometimes a critical factor in the classi- 


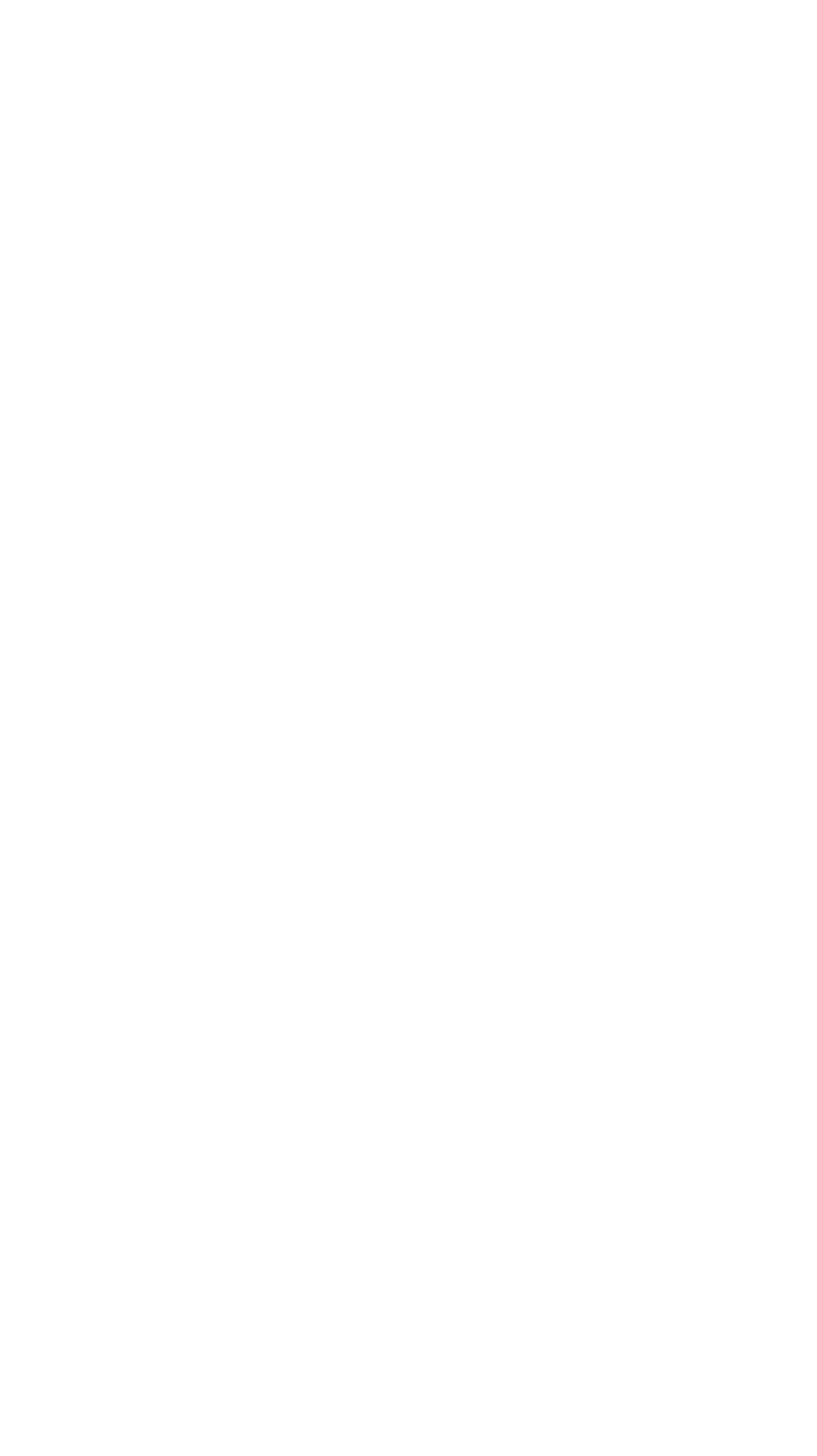


fication of an irrigation water. Residual sodium carbonate may be present if the carbonate is in excess of the combining weights of calcium and magnesium.

Sulfate and chloride.-Sulfate is an essential plant nutrient, whereas high concentrations of chloride are toxic to most land plants, especially fruit trees. Sulfate is about half as toxic as chloride.

Boron.-The presence of boron in irrigation water is critical because a very slight amount of boron is toxic to many plants. However, boron is one of the essential plant nutrients and some must be available to plants for proper growth. Limiting concentrations of boron for several classes of irrigation water for different crops (Scofield, 1936) are given in the following table.

Permissible limits of boron, in parts per million, for several classes of irrigation water

\begin{tabular}{|c|c|c|c|c|}
\hline \multicolumn{2}{|r|}{ Classes of water } & \multicolumn{3}{|c|}{ Crops } \\
\hline Rating & Grade & Sensitive & $\underset{\text { Solerant }}{\text { Semi- }}$ & Tolerant \\
\hline (1 & $\begin{array}{l}\text { Excellent } \\
\text { Good. } \\
\text { Permissible. } \\
\text { Doubtful } \\
\text { Unsuitable... }\end{array}$ & $\begin{array}{r}0.33 \\
0.33-0.67 \\
.67-1.00 \\
1.00-1.25 \\
1.25\end{array}$ & $\begin{array}{r}0.67 \\
0.67-1.33 \\
1.33-2.00 \\
2.00-2.50 \\
2.50\end{array}$ & $\begin{array}{r}1.00 \\
\text { 1. } 00-2.00 \\
2.00-3.00 \\
\text { 3. } 00-3.75 \\
3.75\end{array}$ \\
\hline
\end{tabular}

\section{SUITABIITTY FOR IRRIGATION}

Irrigation specialists have known for a long time that the chemical quality of the water is important in determining the economic feasibility of any irrigation project. Several methods of classifying water for irrigation have been developed, and all are based on the mineral content of the water. The different classifications are empirical in that they are based on field observation, experience, and research in plant tolerance and are predicated on the presumption that the soil to be irrigated is neither impermeable nor exceptionally porous, that the correct soil management practices are followed, and that, in general, average conditions prevail.

Wilcox developed a diagram that may be used to rate water for irrigation on the basis of specific conductance and percent sodium. Thorne and Thorne (1951, p. 10) modified the Wilcox diagram to include more classes of water and to define more clearly the probable effect of the water and the required irrigation practices, soils, and drainage.

The U.S. Salinity Laboratory Staff (1954) introduced the sodium-adsorption-ratio (SAR) as a method of predicting the sodium or alkali hazard in the use of irrigation water. SAR is calculated by dividing the sodium concentration by the square root of one-half the calcium and magnesium concentration (all concentrations are in equivalents per million). The interpretation of salinity and sodium hazards indicated by a diagram (fig. 27) devised by the U.S. Salinity Laboratory Staff is as follows:

Low-salinity water (C1) can be used for irrigation with most crops on most soils with little likelihood that soil salinity will develop. Some leaching is required, but this occurs under normal irrigation practices except in soils of extremely low permeability.

Medium-salinity water (C2) can be used if a moderate amount of leaching occurs. Plants with moderate salt tolerance can be grown in most cases without special practices for salinity control.

High-salinity water (C3) cannot be used on soils with restricted drainage. Even with adequate drainage, special management for salinity control may be required and plants with good salt tolerance should be selected.

Very high salinity water (C4) is not suitable for irrigation under ordinary conditions, but may be used occasionally under very special circumstances. The soils must be permeable, drainage must be adequate, irrigation water must be applied in excess to provide considerable leaching, and a very salt-tolerant crop should be selected.

The classification of irrigation waters with respect to SAR is based primarily on the effect of exchangeable sodium on the physical condition of the soil. Sodiumsensitive plants may, however, be injured as a result of

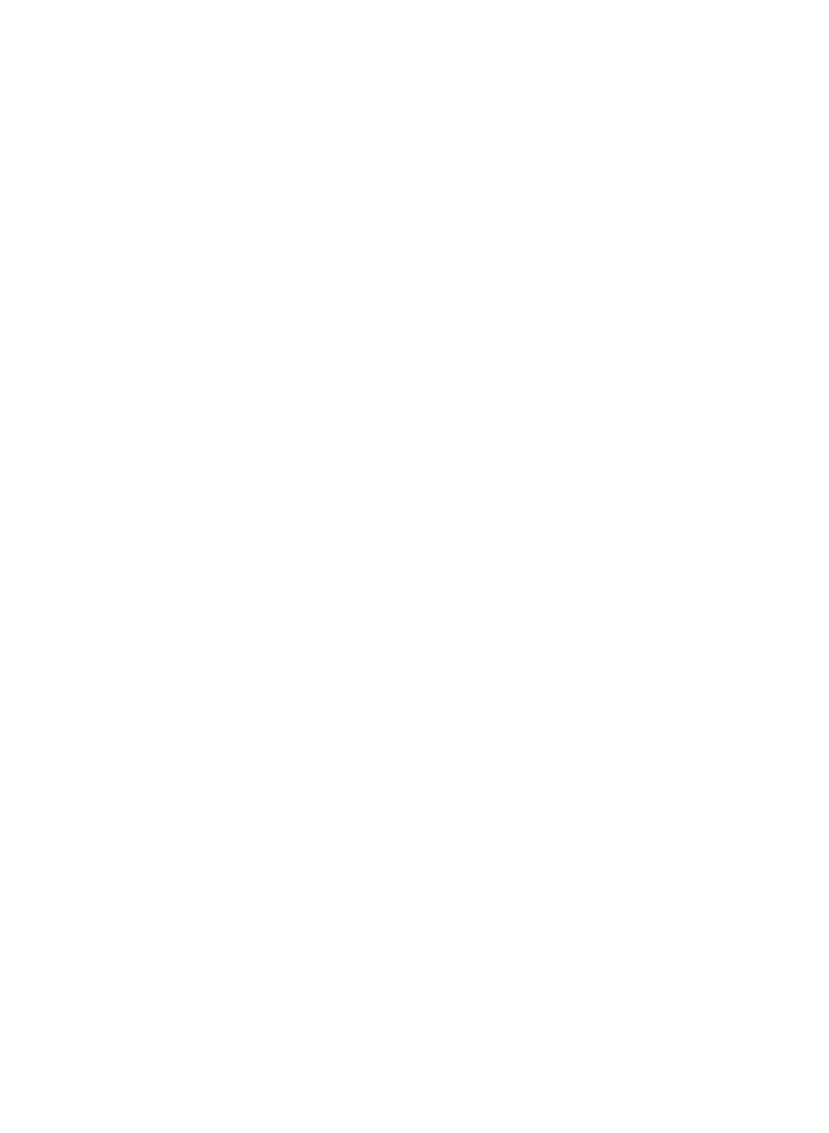

FiguRE 27.-Classification of irrigation waters by U.S. Salinity Laboratory Staff. 
sodium accumulation in plant tissues when exchangeable sodium values are lower than those effective in causing deterioration of the physical conditions of the soil.

Low-sodium water (S1) can be used for irrigation on almost all soils with little danger of the development of harmful levels of exchangeable sodium. However, sodium-sensitive crops such as stone-fruit trees and avocados may accumulate injurious concentrations of sodium.

Medium-sodium water (S2) will present an appreciable sodium hazard in fine-textured soils having high cation-exchangecapacity, especially under low-leaching conditions, unless gypsum is present in the soil. This water may be used on coarse-textured or organic soils with good permeability.

High-sodium water (S3) may produce harmful levels of exchangeable sodium in most soils and will require special soil management, good drainage, high leaching, and organic-matter additions. Gypsiferous soils may not develop harmful levels of exchangeable sodium from such waters. Chemical amendments may be required for replacement of exchangeable sodium, except that amendments may not be feasible with waters of very high salinity.

Very high sodium water (S4) is generally unsatisfactory for irrigation purposes except at low and perhaps medium salinity, where the solution of calcium from the soils or use of gypsum or other amendments may make the use of these waters feasible.

When the content of bicarbonate and carbonate of an irrigation water exceeds that of calcium plus magnesium, residual sodium carbonate may form if the calcium and magnesium are precipitated as carbonates. Thus, the formation of residual sodium carbonate will accompany the increase in percent sodium. The residual sodium carbonate will cause the water to be alkaline, and the organic material of the soil will dissolve. The color of the soil will become a grayish black, a condition referred to as "black alkali." Wilcox, Blair, and Bower (1954, p. 265-266) studied the effects of residual sodium carbonate. The following tabulation summarizes their tentative conclusions:

\begin{tabular}{ll} 
Residual sodium carbonate $(\mathrm{epm})$ & \multicolumn{1}{|}{$\begin{array}{l}\text { Suitability for irrigation } \\
\text { Not suitable. }\end{array}$} \\
$\mathbf{1 . 2 5} 2.5 .5$ & Marginal.
\end{tabular}

They point out that the amount of leaching will modify the permissible limit to some extent.

Leaching is required because the water applied to the land will be reduced in volume and the salts will become more concentrated by evaporation and plant uptake. Water, as it moves through the soil, will displace the antecedent water downward. Therefore, to keep salts from accumulating in the root zone of the soil, part of the applied irrigation water must be used to leach and transport the salts beyond the root zone. Obviously, the more saline the applied water, the more water necessary for required leaching.

The deleterious effects caused by using irrigation water of unsuitable quality can be partly offset by adding gypsum to (1) adjust the percent sodium below 70 (considered to be a maximum safe level), (2) off set carbonate precipitation with calcium and magnesium, and (3) supply calcium and magnesium taken by the plants in excess of sodium.

Eaton (1954) presented a method for estimating (1) the percentage of irrigation water that must move downward beyond the root zone and (2) the amount of gypsum required to reduce the percent sodium and residual sodium carbonate of an irrigation water to safe levels. The ratio of the amount of water that moves downward through the root zone to the amount of water that is applied to the land is the percentage of leaching. "Required leaching" is the percentage of leaching that is necessary to keep the root zone free of excessive accumulations of salts.

Eaton's formulas (1954) and explanation of symbols used in the formulas are as follows:

$S w$-Salinity of irrigation waters expressed as milliequivalents per liter of chloride plus one-half the sulfate.

$d$ and $D$-Tentative $(d)$ and final $(D)$ are percentages of applied irrigation water passed through the root zone as drainage.

Mss-Salinity of mean soil solution measured as chloride plus half the sulfate, milliequivalent per liter. The value 40 is taken as a $M s s$ concentration that is expected to produce reasonable yields; and the value 20 , to produce good yields of crops of intermediate salt tolerance grown in a semiarid climate, such as that at Riverside, Calif.

Required leaching for good yield-tentative

$$
d=\frac{S w \times 100}{(2 \times \overline{M s s})-S w}
$$

or

$$
d=\frac{S w \times 100}{(2 \times 20)-S w}
$$

Calcium requirements-calcium in milliequivalents per liter:

a. To adjust water to 70 percent sodium:

$$
\begin{array}{rl}
(\mathrm{Na} \times 0.429)-(\mathrm{Ca}+\underset{ }{\mathrm{Mg}})=\mathrm{Ca} & \mathrm{Ca} \text { (retain plus or minus sign) }
\end{array}
$$

b. To offset $\mathrm{HCO}_{3}$ precipitation:

$$
\frac{\mathrm{HCO}_{3} \times(100-d)}{100}=\mathrm{Ca}
$$

c. To supply calcium plus magnesium taken by plants in excess of sodium:

$$
\begin{aligned}
& \frac{0.30 \times(100-d)}{100}=\mathrm{Ca} \\
& \text { "Total Ca" }=a+b+c
\end{aligned}
$$


Multiply "total Ca" by 234 to get pounds of gypsum per acre-foot of irrigation water.

Required leaching for good yield-final

$$
\frac{(S w+1 / 2 \text { "total Ca" }) \times 100}{(2 \times M s s)-(S w+1 / 2 \text { "total Ca" })}=D
$$

Eaton (1954) defined a reasonable yield as the production level of crops; that is, between 70 and 80 percent of yields obtained in a semiarid climate on nonsaline soil; he defined a good yield as 85 to 90 percent.

By use of the previously described methods and chemical analyses of water for high, medium, and low discharges, the suitability of the water for irrigation at many sites in the Upper Colorado River Basin was investigated and the results tabulated in tables in the report. The data indicate the chemical suitability of water for irrigation where average conditions prevail with respect to soil, irrigation and drainage practices, climate, and type of crops. Deviations in these variables may permit the use of a water of poor quality or cause a water of good quality to be unsafe for irrigation. Successful irrigation with marginal waters is possible in many places having soil and water amendments and good management practices.

The amounts of required gypsum computed by Eaton's formulas are based on obtaining good yields and on the assumption that all calcium to adjust the percent sodium to 70, to offset bicarbonate precipitation, and to supply the calcium needs of the plants must come from the irrigation water. This may not be applicable to all irrigated lands in the Upper Colorado River Basin as generally the soils are gypsiferous, and the addition of gypsum would not be necessary until the natural gypsum was depleted.

\section{REFERENCES}

American Water Works Association, 1950, Water quality and treatment, 2d ed.: New York, Am. Water Works Assoc., $451 \mathrm{p}$.

Andrews, D. A., and Hunt, C. B., 1948, Geologic map of eastern and southern Utah: U.S. Geol. Survey Oil and Gas Inv. Prelim. Map 70, 1 sheet.

Burbank, W. S., Lovering, T. S., Goddard, E. N., and Eckel, E. B., 1935, Geologic map of Colorado: U.S. Geol. Survey map, 2 sheets; reprinted 1959.

California Institute of Technology, 1957, Water quality criteria: StateWater Pollution Control Board Pub. 3, 409 p.

Clarke, F. W., 1924, The data of geochemistry 5th ed.: U.S. Geol. Survey Bull. 770, 841 p.

Dane, C. H., and Bachman, G. O., 1957, Preliminary geologic map of northwestern New Mexico: U.S. Geol. Survey MP-5979, 1 sheet.

Dean, H. T., 1936, Chronic endemic dental fluorosis: Am. Med. Assoc. Jour., v. 107, p. 1269-1272.
Eaton, F. M., 1954, Formulas for estimating the drainage and gypsum requirements of irrigation waters: Tex. Agr. Expt. Sta. Misc. Rept. 111, 18 p.

Greaves, J. E., and Hirst, C. T., 1918, Composition of the irrigation waters of Utah: State Agr. Coll. Expt. Sta. Bull. 163, $43 \mathrm{p}$.

Hem, J. D., 1959, Study and interpretation of the chemical characteristics of natural water: U.S. Geol. Survey WaterSupply Paper 1473, 254 p.

Iorns, W. V., Hembree, C. H., Phoenix, D. A., and Oakland, G. L., 1964, Water Resources of the Upper Colorado River Basin-Basic Data: U.S. Geol. Survey Prof. Paper 442, $1036 \mathrm{p}$.

Kohler, M. A., Nordenson, T. J., and Baker, D. R., 1959, Evaporation maps of the United States: U.S. Weather Bur. Tech. Paper 37, 13 p.

Lane, E. W., and Lei, Kai, 1950, Streamflow variability: Am. Soc. Civil Engineers Trans., v. 115, p. 1084-1134.

Leopold, L. B., 1959, Probability analysis applied to a watersupply problem: U.S. Geol. Survey Circ. 410, 18 p.

Lohr, E. W., and Love, S. K., 1954, The industrial utility of public water supplies in the United States, 1952: U.S. Geol. Survey Water-Supply Paper 1300, 462 p.

Love, J. D., Weitz, J. L., and Hose, R. K., 1955, Geologic map of Wyoming: U.S. Geol. Survey Map, 1 sheet.

Maxcy, K. F., 1950, Report on the relation of nitrate concentrations in well waters to the occurrence of methemoglobinemia: Natl. Research Council Bull., Sanitary Engineer, app. D, p. 265-272.

Miller, Carl R., 1951, Analysis of flow-duration, sediment-rating curve method of computing sediment yield: U.S. Bur. of Reclamation Proj. Plan. Div., 55 p.

Peck, E. L., and Brown, J. J., 1962, An approach to the development of isohyetal maps for mountainous areas: Jour. Geophys, Research, v. 67, no. 2, p. 681-694.

Scofield, C. S., 1936, The salinity of irrigation water: Smithsonian Ann. Rept., 1935, p. 275-287.

Searcy, J. K., 1959, Flow-duration curves: U.S. Geol. Survey Water-Supply Paper 1542-A, 33 p.

Thorne, J. P., and Thorne, D. W., 1951, Irrigation waters of Utah, their quality and use: Utah Agr. Expt. Sta. Bull. $346,64 \mathrm{p}$.

Upper Colorado River Basin Compact Commission, 1948, Final report of Engineering Advisory Committee to Upper Colorado River Basin Compact Commission: Upper Colo. River Basin Compact Comm., 203 p.

U.S. Bureau of Reclamation, 1954, Colorado River storage project: U.S. 83d Cong., 2d sess. H. Doc. 364, p. 141-155.

U.S. Department of Health, Education, and Welfare, 1959, Inventory of municipal and industrial waste facilities, Public Health Service Pub. 622, v. 8, 109 p.

1962, Municipal Water Facilities, Communities of 25,000 population and over, Public Health Service Pub. 661, 108 p. 1962, Public Health Service drinking water standards: U.S. Public Health Service Pub. 956, 61 p.

U.S. Department of the Interior, 1947, The Colorado River: U.S. 80th Cong., 1st sess. H. Doc. 419, 295 p.

U.S. Salinity Laboratory Staff, 1954, Diagnosis and improvement of saline and alkali soil: U.S. Dept. Agriculture Handb. 60, $160 \mathrm{p}$.

Wilcox, L. V., Blair, G. Y., and Bower, C. A., 1954, Effect of bicarbonate on suitability of water for irrigation: Soil Sci., v. 77 , no. 4 , p. $259-266$. 



\section{Surface-Water Resources}

of the Grand Division

By W. V. IORNS, C. H. HEMBREE, and G. L. OAKLAND

WATER RESOURCES OF THE UPPER COLORADO RIVER BASIN-TECHNICAL REPORT

GEOLOGICAL SURVEY PROFESSIONAL PAPER 441-C

Analysis and appraisal of the water resources of the Grand division of the Upper Colorado River Basin, with special emphasis on surface water and its quality

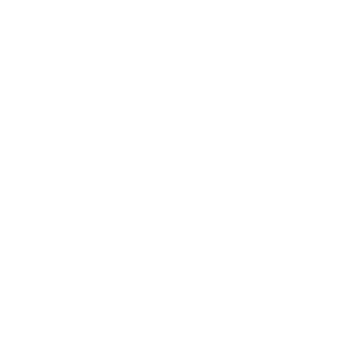




\section{CONTENTS}

Abstract

Introduction. . . .

Purpose and scope.

Location and subbasins....

Hydrologic environment. . . .

Physiography and stream net..

Soils. - -

Climate.........

Effect of topography and altitude........

Precipitation.

Temperature and evaporation.

Vegetation. . . .

Colorado River Basin above the Gunnison River.......

Present utilization of surface water

Storage reservoirs..........

Transmountain diversions....................

Irrigation............

Domestic and industrial. .....................

Streamflow

Variability of seasonal runoff.

Flow-duration curves........................

Variability of annual runoff

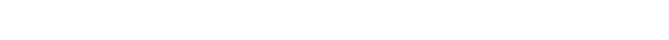

Chemical quality of water.

Dissolved-solids discharge and concentration... -

Variations in chemical quality . . . . . . . .

Relation to streamflow . . .

Relation to geology

Relation to ground water....................

Effect of transmountain diversions..........

Effects of the activities of man.........

Fluvial sediment.........

Suitability of water for various uses.....

Domestic........

Agricultural-1.

Industrial........

Recreational ...

Gunnison River basin .

Present utilization of surface water.

Storage reservoirs

Transmountain diversions...................

Irrigation ... . . - .

Domestic and industrial . . .

Streamflow

Variability of seasonal runoff

Flow-duration curves.

\begin{tabular}{r|}
\hline 75 \\
75 \\
75 \\
75 \\
76 \\
76 \\
77 \\
78 \\
78 \\
78 \\
78 \\
80 \\
81 \\
81 \\
81 \\
82 \\
82 \\
83 \\
84 \\
84 \\
84 \\
89 \\
91 \\
91 \\
91 \\
92 \\
95 \\
99 \\
99 \\
104 \\
104 \\
106 \\
106 \\
106 \\
107 \\
107 \\
108 \\
108 \\
108 \\
108 \\
108 \\
108 \\
109 \\
109 \\
109
\end{tabular}

Gunnison River basin-Continued

Variability of annual runoff ........... 110

Precipitation-runoff relation................ 111

Chemical quality of water.

Dissolved-solids discharge and concentration. . - 111

Variations in chemical quality ............... 113

Relation to streamflow . . . . .

Relation to geology . . . . . . . 114

Relation to ground water ................. 116

Effect of transmountain diversions........... 120

Effect of the activities of man .............. 120

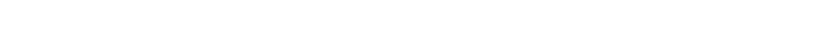

Suitability of water for various uses............ 121

Domestic ................. 121

Agricultural_.......... 122

Industrial _.................. 122

Recreational ............ 122

Colorado River Basin between the Gunnison and Green

Rivers_...

Present utilization of surface water........... 122

Storage reservoirs........................ 122

Transmoun tain diversions.................... 122

Irrigation. ... . . . . .

Domestic and industrial .................... 123

Streamflow_................ 123

Variability of seasonal runoff............. 123

Flow-duration curves...................... 123

Variability of annual runoff

Precipitation-runoff relation.............. 126

Chemical quality of water . . .

Dissolved-solids discharge and concentration ... $\quad 126$

Variations in chemical quality............. 126

Relation to streamflow . . . . . . . . . . . . 127

Relation to geology - ......... 127

Relation to ground water ................ 132

Effect of transmountain diversions........... 136

Effect of the activities of man . . . . . . 136

Fluvial sediment........ 138

Suitability of water for various uses.

Domestic ................ 139

Agricultural . . . 139

Industrial.

Summary ....... 139

Selected references.

Index

\section{ILLUSTRATIONS}

[Plates are in separate volume]

Plate 4. Map of Grand division showing average annual precipitation and evaporation, key streamflow-gaging stations, and coefficients of variation of annual runoff.

5. Map of native vegetation zones and irrigated lands in the Grand division. 
FiguRe 28. Relief map of the Grand division of the Upper Colorado River Basin

29. Normal precipitation and temperature and frost-free seasons at representative stations in the Grand division.

30. Photograph of alpine meadows and subalpine forest zones in the headwaters of the Blue River

31. Photograph of subalpine forest near Gore Pass, Colo

32. Photograph of big sagebrush 1 mile northwest of Kremmling, Colo

33. Transmountain diversions from the Colorado River Basin above the Gunnison River, water years 1914-57.

34. Seasonal pattern of runoff of headwater streams in the Colorado River Basin above the Gunnison River, 1954 water year

35. Seasonal pattern of runoff of the Colorado River above the Gunnison River, 1954 water year.......

36. Flow-duration curves of headwater streams in the Colorado River Basin above the Gunnison River......-

37. Flow-duration curves of the Colorado River main-stem stations above the Gunnison River...........

38. Relation between the variability index of streamflow and the percentage of average annual discharge estimated to be contributed by ground water for selected stations in the Grand division

39. Effect of environmental factors on flow-duration curves

40. Variability of annual discharges of selected streams in the Colorado River Basin above the Gunnison River, water years 1914-57 adjusted to 1914 base

41. Approximate dissolved-solids discharge and streamflow expressed as percentages of the combined dissolvedsolids discharge and combined streamflow of Colorado River and Plateau Creek near Cameo, Colo...-

42. Weighted-average concentration of dissolved solids at Eagle River at Gypsum, Colo., for the 1954 and 1957 water years.

43. Variability of the monthly and annual weighted-average concentration of dissolved solids at Eagle River at Gypsum, Colo

44. Dissolved-solids concentration at Colorado River at Hot Sulphur Springs, Colo., for the 1949 and 1954 water years

45. Relation of the variability of dissolved-solids concentration to the variability of water discharge in the Grand division.

46. Dissolved-solids concentration and discharge and water discharge at four daily stations in the Colorado River Basin above the Gunnison River, 1956 water year.

47. Relation of dissolved-solids concentration to water discharge, Colorado River at Hot Sulphur Springs, Colo_

48. Effect of the Colorado-Big Thompson project on the dissolved-solids concentration at Colorado River at Hot Sulphur Springs, Colo

49. Historical flow-duration curve for water years 1914-57 and flow-duration curve for water years 1914-57 adjusted to 1957 conditions for Colorado River at Hot Sulphur Springs, Colo _... . . .

50. Historical duration curve of dissolved-solids discharge for water years 1914-57 and duration curve of dissolved-solids discharge for water years 1914-57 adjusted to 1957 conditions for Colorado River at Hot Sulphur Springs, Colo.

51. Relation of chemical composition and concentration of dissolved solids to water discharge in the Colorado River Basin above the Gunnison River

52. Approximate weighted-average concentrations of dissolved solids in streams in the Colorado River Basin above the Gunnison River.

53. Analyses of water from Troublesome Creek near Troublesome, Colo., and from alluvium nearby ........

54. Seasonal pattern of runoff in the Gunnison River basin, 1954 water year.

55. Flow-duration curves of streams in the Gunnison River basin

56. Variability of annual discharges of selected streams in the Gunnison River basin, water years 1941-57 ...-

57. Approximate dissolved-solids discharge and streamflow expressed as percentages of the dissolved-solids discharge and streamflow of Gunnison River near Grand Junction, Colo -

58. Relation of chemical composition and concentration of dissolved solids to water discharge in the Gunnison River basin .

59. Relation of concentration of dissolved solids to water discharge, Gunnison River near Grand Junction Colo

60. Approximate weighted-average concentrations of dissolved solids in streams in the Gunnison River basin.61-65. Analyses of water-

61. From Gunnison River near Gunnison, Colo., and from alluvium nearby

62. From Tomichi Creek at Gunnison, Colo., and from alluvium nearby.

63. Associated with volcanic rocks of Tertiary age

64. From the Uncompahgre River and Cow Creek and from alluvium nearby

65. From a well, a drain, and Uncompahgre River at Delta, Colo

66. Seasonal pattern of runoff in the Colorado River Basin between the Gunnison and Green Rivers, 1954 water year.

67. Variability of annual discharges in the Colorado River Basin between the Gunnison and Green Rivers, water years 1914-57.

68. Mass diagram of contribution of dissolved solids to the Colorado River between the gaging stations on Colorado River near Cameo, Colo., and Colorado River near Cisco, Utah, water years 1934-57......

Page

77

79

82

82

82

83

85

86

87

88

89

89

90

93

94

94

95

95

96

97

98

98

98

100

101

102

110

111

112

113

115

116

117

118

118

118

118

119

124

125 
Fraure 69. Approximate dissolved-solids discharge and streamflow expressed as percentages of the dissolved-solids discharge and streamflow of Colorado River near Cisco, Utah

70. Cumulative dissolved-solids discharge and water discharge for Colorado River near Cisco, Utah, water years 1929-57 _ .

71. Dissolved-solids concentration and water discharge of Dolores River near Cisco, Utah, 1956 water year....

72. Dissolved-solids conecntration and water discharge of Colorado River near Cisco, Utah, 1956 water year

73. Relation of chemical composition and concentration of dissolved solids to water discharge in the Colorado River Basin between the Gunnison and Green Rivers.

74. Analyses of water from streams in the Grand Valley irrigation project.

75. Approximate weighted-average concentrations of dissolved solids in streams in the Colorado River Basin between the Gurnison and Green Rivers. 76-79. Analyses of water-

76. From irrigation laterals and from wells nearby in the Grand Valley irrigation project near Grand Junction, Colo . . .

77. From the Dolores River and from alluvium nearby

78. From the Dolores River above and below Paradox Valley

79. From the San Miguel River and West Creek and from alluvium nearby

\section{TABLES}

TABLE 1. Average monthly and annual precipitation at 17 index-precipitation stations in the Grand division......

2. Annual precipitation at 17 index-precipitation stations and weighted-average precipitation in the Grand division, water years $1914-57$

3. Irrigation and power reservoirs in the subbasins in the Grand division

4. Transmountain diversions from the Colorado River and tributaries above the Gunnison River, water years 1914-57 .

5. Irrigated acreage in the subbasins in the Grand division

6. Flow-duration table for stations in the subbasins in the Grand division.

7. Methods and accuracy of adjusting flow-duration data for stations in the subbasins in the Grand division to base period and 1957 conditions.

8. Variability index of streamflow and percentage of average annual discharge estimated to be contributed by ground water at selected stations in the subbasins in the Grand division.

9-10. Adjustment of streamflow records for water years 1914-57 for-

9. Fraser River near Winter Park, Colo., to 1914 base

10. Two stations in the Colorado River Basin to 1914 base

11. Average discharge, standard deviation, and coefficent of variation for selected stations in the subbasins in the Grand division.

12. Probable error in estimating (50-percent chance) future average discharges of some streams in the Colorado River Basin above the Gunnison River, Colo., for various periods of years.

13. Precipitation, runoff, and natural consumptive use in selected drainage areas in the subbasins in the Grand division . . .

14. Water and dissolved-solids discharges of streams in the subbasins in the Grand division

15-16. Duration table of dissolved-solids-

15. Concentration for selected stations in the subbasins in the Grand division.

16. Discharge for selected stations in the subbasins in the Grand division

17-18. Variability of annual weighted-average concentration of dissolved solids-

17. As related to variability of annual water discharge for selected daily stations in the Grand division. 18. For selected stations in the subbasins in the Grand division

19. Relation between water discharge and chemical quality of water for selected stations in the subbasins in the Grand division.

20. Water and dissolved solids contributed by ground water to selected streams in the subbasins in the Grand division . . .

21. Weighted-average concentration of dissolved solids of transmountain diversions in the Colorado River Basin above the Gunnison River.

22-23. Water and dissolved-solids budgets-

22. Grand division

23. Roaring Fork basin, Colorado

24. Average annual dissolved-solids discharge and probable amounts from natural sources and the activities of man in the Colorado River Basin above the Gunnison River, Colo

25. Suspended-sediment discharge at selected stations in the subbasins in the Grand division.....

Page

145

145

146

146

147

148

151

152

152

153

154

154

155

155

157

159

161

161

162

166

166

167

169

169

170 
TABLES 26-27. Suitability of surface waters for-

26. Domestic use in the Colorado River Basin above the Gunnison River.

28. Transmountain diversions from the Gunnison River basin, water years 1914-57 29. Summary of average annual dissolved-solids discharge between Colorado River near Cameo, Colo., and Colorado River near Cisco, Utah.

30. Annual contribution of dissolved-solids to the Colorado River near Cisco, Utah, water years 1934-57.

31. Summary of suspended-sediment discharge of Dolores and Colorado Rivers near Cisco, Utah. . . . . . .

32. Water budget, Grand division

33. Summary data on utilization of surface water in the Grand division for developments existing in 1957......

34. Summary of average annual water, dissolved-solids, and suspended-sediment discharges from the subbasins in the Grand division. 


\title{
WATER RESOURCES OF THE UPPER COLORADO RIVER BASIN--TECHNICAL REPORT
}

\section{SURFAGE-WATER RESOURGES OF THE GRAND DIVISION}

\author{
By W. V. Iorns, C. H. Hembree, and G. L. OAkLand
}

\begin{abstract}
This chapter presents the results of an appraisal of the surface-water resources of the Grand division, which includes the 26,500 square miles of the drainage area of the Colorado River above the Green River. Water uses existing in 1957 are reported, and interpretations are made of stream behavior, chemical quality of water, and sediment yield on the basis of the average that would have occurred if the $\mathbf{1 9 5 7}$ level of upstream development had existed throughout water years 1914-57. The appraisal will be useful in planning additional development of surface-water supplies and evaluating changes in streamfiow, chemical quality of water, and sediment yield that may result from water-development projects constructed after 1957.

An average of about $28,648,300$ acre-feet of water was annually precipitated in water years 1914-57. Had the developments in 1957 prevailed throughout the 44-year period, the average annual consumption of water for irrigation would have been about 739,100 acre-feet. An average of about 8,800 acrefeet would have been annually consumed for domestic and industrial uses, about 453,400 acre-feet would have been diverted annually out of the division, and an average of about $5,534,000$ acre-feet would have been annually discharged in the Colorado River. Evapotranspiration probably accounted for the remaining $21,913,000$ acre-feet on the assumption that there was no ground-water outflow.
\end{abstract}

About 34,800 tons of dissolved solids in 453,400 acre-feet of water was annually carried out of the division by the transmountain diversions existing in 1957. These transmountain diversions have caused an increase of about 39 parts per million in the weighted-average concentration of the Colorado River below the mouth of the Dolores River.

The dissolved-solids discharge from the Grand division in the Colorado River was computed to average about 4,204,600 tons annually for water years 1914-57 adjusted to 1957 conditions. About 2,254,000 tons of this amount comes from natural sources; about 482,000 tons of this total comes from thermal springs.

Activities of man, other than the diversion of water out of the area, consume water and result in the addition of dissolved solids-about $1,950,600$ tons annually-to the stream system. Exclusive of the effect of transmountain diversions, the weighted-average concentration of dissolved solids of the Colorado River below the mouth of the Dolores River is estimated to have been increased about 291 parts per million as a result of the activities of man. The major part of this increase is attributed to irrigation.
Domestic, industrial, and irrigation uses of water in the division have caused about five times as much increase in concentration of dissolved solids of the Colorado River below the Dolores River for each acre-foot of water consumed as the transmoutain diversions have caused for each acre-foot of water exported.

The average annual suspended-sediment discharge from the division totals about $20,495,000$ tons and from each subbasin is as follows : $9,269,000$ tons from the Colorado River Basin above the Gunnison River; 2,067,000 tons from the Gunnison River basin; and 9,159,000 tons from the Colorado River Basin between the Gunnison and Green Rivers.

Most of the surface water in the headwaters is suitable for domestic and industrial use. However, the waters of many streams in the central and western parts of the division are not suitable for domestic use because of high concentrations of sodium, magnesium, sulfate, chloride, and nitrate. The waters of practically all the streams are suitable for irrigation.

\section{INTRODUCTION PURPOSE AND SCOPE}

This chapter presents an appraisal of the surfacewater resources of the Grand division. The following items are considered: The present utilization of the surface-waters supplies, the flow characteristics of the streams and the effect of environmental factors on streamflow, the chemical-quality characteristics of the streams and the influence of environmental factors on the quality of water, and the sediment yield of the streams.

The basic data, hydrologic techniques, and criteria used in this appraisal are discussed and explained in. chapter B, which also contains a glossary of the technical terms used.

\section{LOCATION AND SUBBASINS}

The Grand division of the Upper Colorado River Basin is the area drained by the Colorado River above the mouth of the Green River (chap. A, fig. 2). The division includes parts of western Colorado and eastern Utah and has an area of 26,500 square miles.

To facilitate presentation of data and the analysis of the effects of natural environmental factors and the 
activities of man on the hydrology of the streams of the division, it was divided into three subbasins, as follows :

1. The subbasin of the Colorado River above the Gunnison River is the area $(8,670 \mathrm{sq} \mathrm{mi})$ drained by the Colorado River above a point just below the mouth of Plateau Creek. Gaging stations on Colorado River and on Plateau Creek near Cameo, Colo., measure the outflow from the subbasin. These gaging stations are 3.4 and 1.1 miles, respectively, upstream from the mouth of Plateau Creek.

2. The Gunnison River subbasin is the area $(8,020 \mathrm{sq}$ $\mathrm{mi})$ above the gaging station on Gunnison River near Grand Junction, Colo. This gaging station is 2 miles upstream from the mouth of the Gunnison River.

3. The subbasin of the Colorado River between the Gunnison and Green Rivers is the remaining area $(9,810 \mathrm{sq} \mathrm{mi})$ in the division. Computations of outflow from the subbasin are based on records for the gaging station on Colorado River near Cisco, Utah. The station is 97 miles above the Green River. There is some tributary inflow between the gaging station and the Green River.

\section{HYDROLOGIC ENVIRONMENT \\ PHYSIOGRAPHY AND STREAM NET}

The plateaus and mountains that form the boundaries of the Grand division (fig. 28), in a clockwise direction from the mouth of the Green River, are the East Tavaputs and White River Plateaus and the Park Range on the north; the Snowy and Sawatch Ranges on the east; and the San Juan, La Plata, and Abajo Mountains on the south. Other important topographic features include the Gore Range, Elk Mountains, Grand Mesa, Battlement Mesa, Book Cliffs, Uncompahgre Plateau, and La Sal Mountains. Some of these features form the natural boundaries between the subbasins in the division.

The western part of the area is essentially a dissected plateau, and the eastern part is a series of uplifted mountain masses, weathered and deeply dissected by agents of erosion, such as water and glaciers. The streams in the eastern part of the division flow in deep canyons or in $V$-shaped valleys between the mountain masses. Most of the flatland is restricted to relatively narrow flood plains and terraces along the main streams.

In much of the west half the relief is not so great as in the east half. In places, the streams flow through wide valleys bordered by extensive areas of relatively level land, such as the Grand Valley and the Uncompahgre River valley. However, in other places the streams flow in deep, narrow canyons cut below benches and table lands. All the division is at an altitude of more than 3,880 feet, and many of the mountain peaks exceed an altitude of 13,000 feet.

The drainage pattern is the result of the action of many forces during a long period of geologic history. Some streams follow ancient synclinal valleys, and other streams in parts of their courses follow strike valleys, where softer rocks are exposed along the fringes of uplifts. Some streams are antecedent in parts of their courses; that is they were able to maintain their courses across an uplift by downcutting while the uplift was taking place. Others have maintained a course superimposed from a drainage pattern that was established on rocks overlying those now exposed. In general, the main stem of the Colorado River follows a southwesterly route across the division near the north boundary. The major part of the area is drained by tributaries flowing generally northwestward to their junction with the main stem.

Long before the start of the earth movements that created the Rocky Mountains, the area was the scene of alternate encroachment and retreat of great inland or epicontinental seas. When the area was above sea level, erosion was active. When the area was covered by the great seas, erosion ceased but was still active on the surrounding emerged land. Streams drained the surrounding land and carried the products of erosion into the sea. Thus, during each submergence, great thicknesses of sediments of all sizes and types and beds of chemical precipitates, such as calcium carbonate, were built up. The sedimentary material that accumulated and that was not subsequently removed by erosion during the periods when the land was above sea level is represented by the sedimentary rocks that now underlie much of the area. These rocks, in total, are thousands of feet thick and range in attitude from the sharply tilted strata around the mountains to the flatter lying beds of some of the younger rocks in the intermontane basins.

The earth movements that culminated in formation of the Rocky Mountains and the erosion that accompanied and followed these movements were instrumental in determining the present topography and the structure of the rocks on which it is formed. In the latter part of the Tertiary period, which ended about a million years ago, the mountains were eroded, and part of the eroded material was deposited in basins between the mountains.

The exposed rocks in the Grand division range in age from late Precambrian to Recent. The pattern of exposures is complex because of the net effect of uplift, folding, faulting, weathering and erosion. The outcrop 


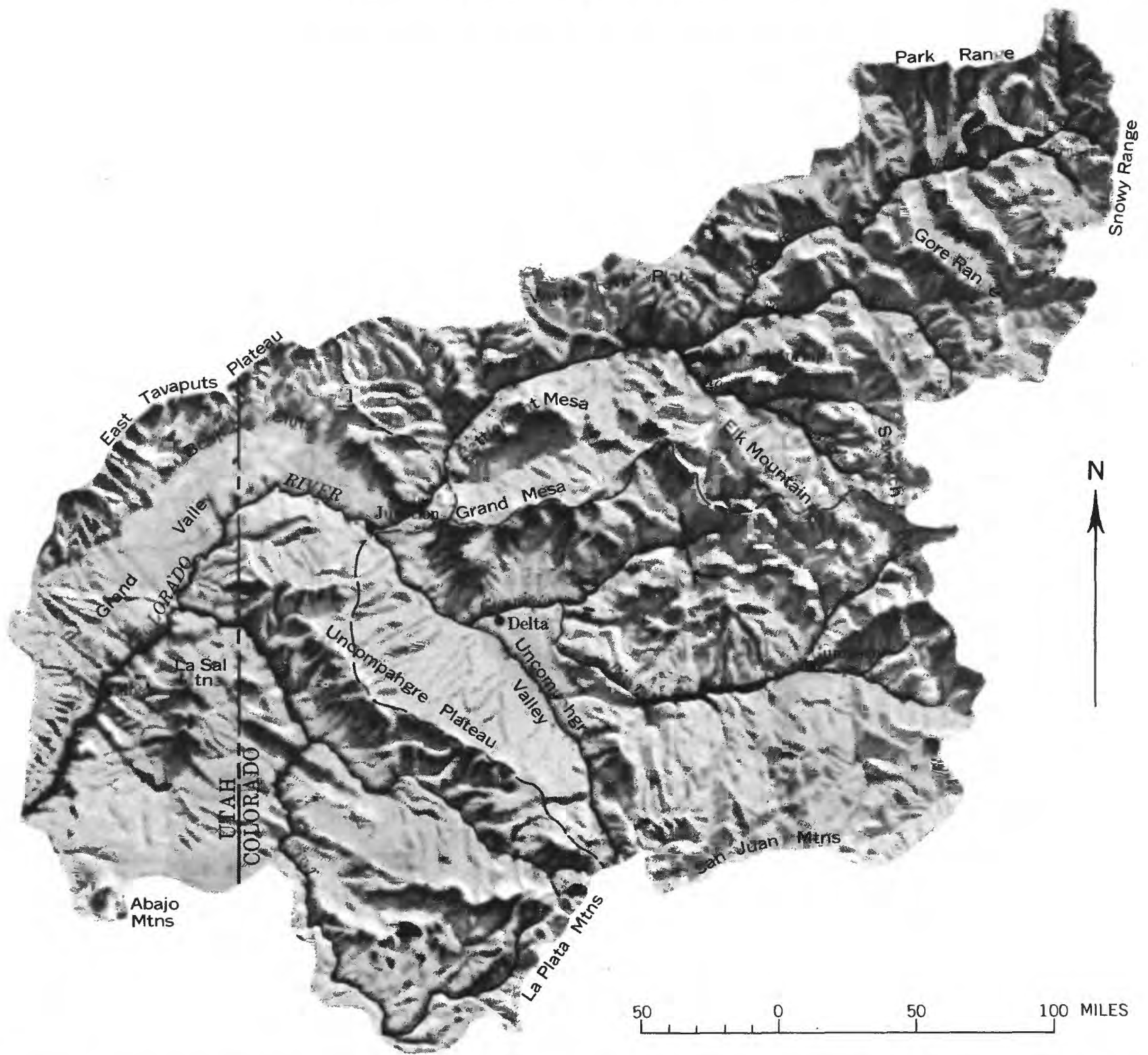

Figure 28.-Relief map of the Grand division of the Upper Colorado River Basin. Adapted from photograph by I. v. Goslin, Upper Colorado River Compact Commission.

areas of rock formations in the division, classified into eight units having similar hydrologic properties, are shown in plate 1. The formations and their characteristics are discussed in chapter $\mathbf{A}$.

\section{SOThs}

The unconsolidated material mantling the consolidated rocks is principally residuum and river alluvium. Residuum consists of products of rock weathering that have accumulated faster than they can be removed by water and wind. Material of this type mantles hillsides and the tops of mesas and plateaus. It ranges in thickness from a few inches to several tens of feet. As it is near its source, it retains many of the geochemical characteristics of the parent rock. Where the climate is favorable to the growth of vegetation, mature soils have developed on the residuum. In the drier parts of the division, where the climate is not favorable for the growth of vegetation, the mantle for the most part is relatively thin, and the soils are poorly developed. This condition is due in part to the slowness of weathering where precipitation and underground moisture are low and in part to the susceptibility of barren ground to erosion.

River alluvium consists of the products of erosion that have been transported and deposited by streams. It underlies the flood plains and the adjacent terraces 
along the streams. Generally, it consists of waterworked mixtures of silt, sand, and gravel. Its composition and texture differ from place to place in accordance with (1) the age of the material, (2) the distance and mode of transportation, and (3) the type of rocks from which it was derived. The soils developed on it vary widely in depth and maturity.

In the headwater areas, the river alluvium is derived principally from rocks that are resistant to the solvent action of water. In downstream areas, it is derived principally from shale and siltstone and contains the relatively soluble salts generally associated with these rocks. In the vicinity of Montrose and Grand Junction, the river alluvium consists principally of water-reworked Mancos Shale. It is generally underlain by the Mancos Shale, by the Dakota Sandstone, or by the Morrison Formation, but locally gravel intervenes between the bedrock and the fine sediment.

Most of irrigated lands are on river alluvium, but some are on residuum. Plate 1 shows the areas of river alluvium. As the residuum is closely associated with the parent rocks, its areas of occurrence and type of material are indicated by the outcrop areas in plate 1 .

\section{Crimate}

\section{EFFECT OF TOPOGRAPHY AND ALTITUDE}

The high mountain ranges that rim the Grand division on the north, east, and most of the south act as partial barriers to approaching moist airmasses. The west side is lower, and Pacific airmasses enter the area from that direction. The western part of the south side is also relatively low; thus airmasses from the Gulf of Mexico are permitted to enter the western part. The high mountain ranges and mesas trending north to south and east to west take their toll of moisture from the airmasses that move across the area. The effect of the topography on the distribution of precipitation can be seen by comparison of figure 28 and plate 4 .

Temperatures and rates of evaporation are also related to altitude. Valley temperatures and evaporation rates generally decrease from west to east as the altitude increases.

\section{PRECIPITATION}

Precipitation during the period October through April is more effective in producing runoff than precipitation in the summer months. Precipitation patterns for the two periods are different. During October to April, airmasses from the Pacific Ocean move across the Grand division. Most of the precipitation during this period, particularly in the high mountains, occurs as snow, which sometimes accumulates to a great depth along the high divides.
Precipitation during the summer usually occurs as thundershowers. In the western part, where the mountains along the south boundary are not high enough to block the movement of airmasses from the Gulf of Mexico, summer storms of high intensity occur occasionally and produce flash floods.

The monthly distribution of precipitation at representative precipitation stations is shown in figure 29 . The distribution of average annual precipitation is shown in plate 4. This map, which is adjusted for topography, exposure to airmass movements, and climatic factors, is based on precipitation data observed during calendar years 1921-50. The average annual precipitation for this period, as planimetered from the map, is 20.39 inches and ranges from less than 8 inches in the western part to more than 50 inches on the high mesas and in the mountains. The following tabulation shows the areal distribution of precipitation over the 26,500 square miles of drainage area:

\begin{tabular}{|c|c|c|c|}
\hline $\begin{array}{l}\text { Precipitation } \\
\text { range } \\
\text { (inches) }\end{array}$ & $\underset{(s q m i)}{\text { Area }}$ & $\begin{array}{c}\text { Precipitation } \\
\text { range } \\
\text { (inches) }\end{array}$ & $\underset{(s q m i)}{A r e a}$ \\
\hline $50-60 \ldots$ & 32 & $16-20 \ldots$ & 4,971 \\
\hline $40-50 \ldots$ & 606 & --------- & 5,414 \\
\hline $30-40 \ldots$ & 3,362 & $10-12_{--}$ & 1,983 \\
\hline $25-30 \ldots$ & 3,304 & $8-12$ & 1,592 \\
\hline $20-25 \ldots$ & 4,178 & $6-8 \ldots$ & 1,058 \\
\hline
\end{tabular}

In computing precipitation data applicable to the base period adopted for this study and for other periods, 17 index-precipitation stations in or adjacent to the division were selected (tables 1 and $2 ;$ pl. 4). As explained in chapter B (pp. 44-45), precipitation records at the index stations were used to compute average precipitation for various water years and periods of water years. The average annual precipitation for the 44-year base period thus computed was 20.27 inches. On the 26,500 square miles of drainage area, this precipitation would be equivalent to $28,648,300$ acre-feet of water per year.

The year of highest precipitation was 1927 , when the average precipitation computed by the index-station method was 26.98 inches; the year of lowest precipitation was 1931 , when the precipitation was 14.97 inches. The precipitation in these two years was, respectively, about 33 percent more than and 26 percent less than the 44-year annual average. As shown by the annual quantities in table 2, the precipitation was generally greater than average from 1914 to 1929 , less than average from 1930 to 1940, greater than average from 1942 to 1949 , and less than average from 1950 to 1956 .

\section{TEMPERATURE AND EVAPORATION}

Figure 29 shows the effect of altitude on average monthly temperatures and length of frost-free season. Between Moab, Utah, and Fraser, Colo., the altitude 

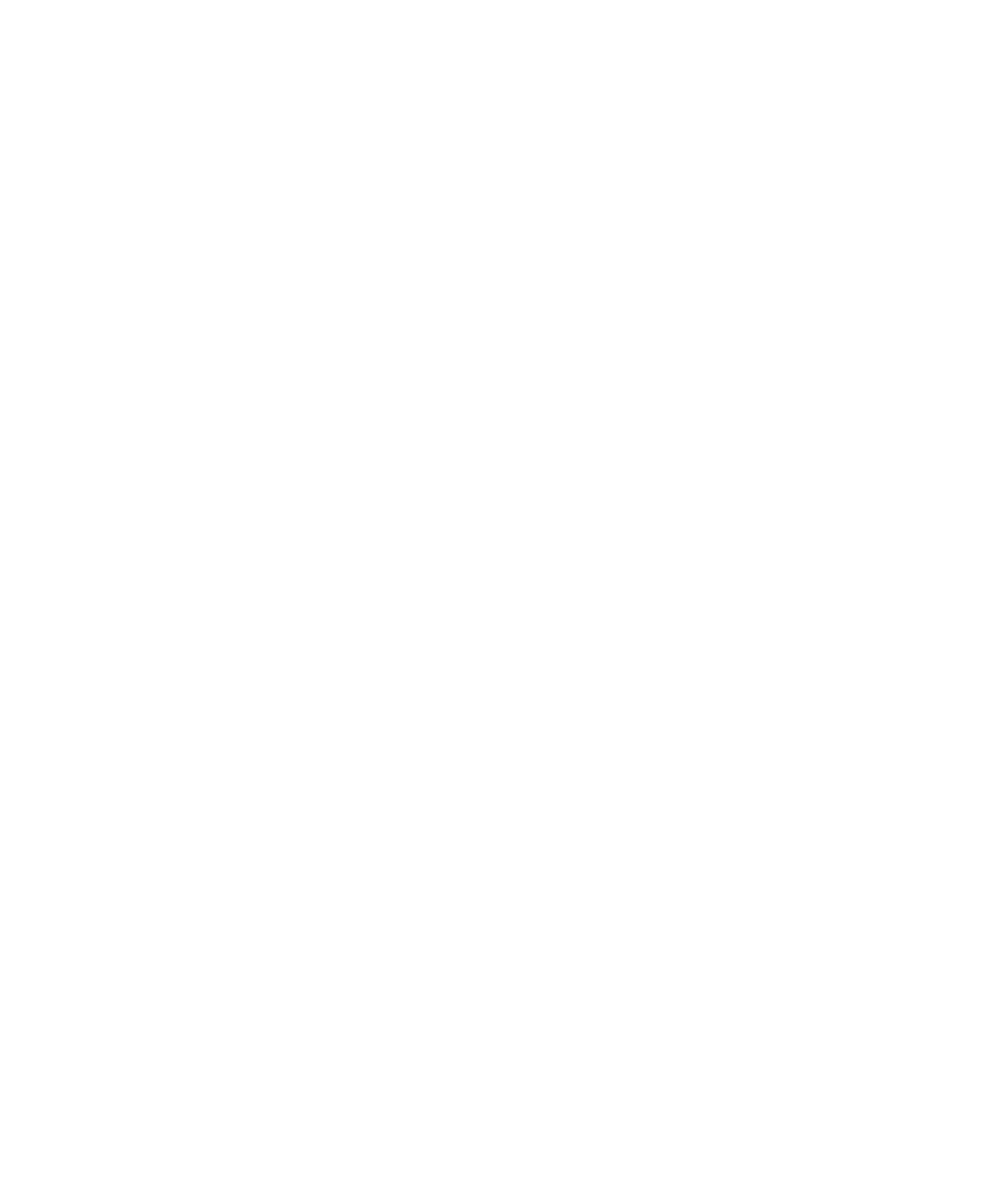

Figure 29.-Normal precipitation and temperature and frost-free seasons at representative stations in the Grand division. Data from U.S. Weather Bureau normals (average for 1921-50 calendar years). 
increases 4,600 feet and the average annual temperature decreases about $22^{\circ} \mathrm{F}$. while the frost-free season decreases from 182 days to 4 days.

Isopleths of average annual lake evaporation, from a map by Kohler and others $(1959$, pl. 2$)$, are shown on plate 4. The isopleths are generalized and do not take into account large variations in topography and exposure which may influence evaporation considerably at specific locations.

The annual amounts of evaporation from water surfaces in the 17 Western States have been estimated by Meyers (1962). The following tabulation gives his estimates of average annual evaporation from water surfaces in the Grand division:

Principal reservoirs and regulated lakes... _. _. . . . $\quad 35,000$

Principal streams and canals . . . . . . . . . . . . . 40, 000

Small ponds and reservoirs.

Small streams .........

Total

VEGETATION

Native species of vegetation, except in cultivated areas, are about the same as existed before settlement. Grazing and lumbering have partially removed the native grasses and trees in some areas, but other grasses, shrubs, or woody species have taken their place, partly as a result of reforestation and range-improvement programs. Only a small percentage of the total basin area is cultivated.

The native species, which developed through many thousands of years of evolution, are adapted to the conditions of cold, heat, wetness, dryness, and soil type of the areas in which they grow. Many grow only within narrow ranges of climate, topography, and type of soil. The most important plant communities in the Upper Colorado River Basin are the alpine meadows, subalpine forests, montane forests, mountain brush, pinyon-juniper, big sagebush, shadscale, blackbrush, greasewood, saltbrush, summer-cypress, and grasslands. F. A. Branson has described the species in the plant communities as follows:

Alpine meadows

The alpine meadows are at altitudes higher than the timberline, usually at more than 12,000 feet. The species usually found in the alpine meadows are sedges (Carex spp.), bluegrasses (Poa spp.), spike trisetum (Trisetum spicatum), alpine timothy (Phleum alpinum), willows (Salix spp.), bistort (Polygonum bistorta), bluebells (Mertensia alpina), gentian (Gentiana frigida), and clovers (Trifolium spp.).

subalpine rorests

The subalpine forests are at altitudes lower than the alpine meadows. At higher altitudes in the subalpine forest, which is sometimes called the spruce-fir forest, the dominant trees are Englemann spruce (Picea englemanni) and subalpine fir. At lower altitudes in the subalpine forest are three species that occupy large areas. These species are lodgepole pine (Pinus contorta latifolia), Douglas-fir (Pseudotsuga taxifolia), and quaking aspen (Populus tremuloides). Plants commonly found in the subalpine forest are pinegrass (Calamagrostis rubescens), elk sedge (Carex geyeri), arnica (Arnica cordifolia), and huckleberry (Vaccinium scoparium and $V$. membranaceum). Much of the subalpine forest has dense stands of trees and little undergrowth.

Streambank and meadow communities in the subalpine forest consist of woody plants such as willows, cottonwoods (chiefly Populus angustifolia), aspen, birches (Betula fontinalis and B. glandulosa), and dogwood (Cornus stolonifera). Some of the important herbaceous species are tufted hair-grass (Deschampsia cacspitosa), bluejoint (Calamagrostis canadensis), sedges, and rushes (Juncus spp.).

Montane rorests

The montane forests are characterized by the presence of ponderosa pine (Pinus ponderosa). Ponderosa pine forms open stands and usually has an abundance of understory plants. Some of the important plants are mountain muhly (Muhlenbergia montana), Arizona fescue (Festuca arizonica), Idaho fescue (Festuca idahoensis), slender wheatgrass (Agropyron trachycanlum), and oatgrasses (Danthonia intermedia and $D$. unispicata). Common shrubs are big sagebrush (Artemisia tridentata), serviceberry (Amelanchier alnifolia), snowberries, (Symphoricarpos spp.), mountain-mahogany (Cercocarpus montana), and bitterbrush (Purshia tridentata).

Streambank and meadow communities in the montane forest consist of a number of woody plants such as willows, cottonwoods (chiefly Populus angustifolia), aspen, birches (Beutla fontinalis and B. glandulosa), and dogwood (Cornus stolonifera). Some of the important herbaceous species are tufted hair-grass (Deschampsia caespitosa), bluejoint (Calamagrostis canadensis), sedges, and rushes.

In the mountain areas of Colorado the zonation between the subalpine and montane forests is well defined. In Utah the zonation between these two types is not well defined. Because of this poor definition, the two types have been grouped in Utah as subalpine forest.

\section{Mountain brush}

At lower altitudes mountain brush is sometimes termed chaparral and includes shrub types that commonly occur as a transition between coniferous forest and other vegetation types. Common shrubs of this 
type are oaks (chiefly Quercus gambelli), mountainmahogany, serviceberry, snowbrush (Ceanothus velutinus), bitterbrush, cliffrose (Cowania mexicana), chokecherry (Prunus virginiana), snowberry, and rose (Rosa spp.). Other plants commonly found in this zone are big sagebrush, bluebunch wheatgrass (Agropyron spicatum), needle-and-thread (Sipta comata), junegrass (Koeleria cristata), and annual bromes (Bromus spp.). Pinyon-juniper

Occurring in low mountain areas, pinyon-juniper types are not usually abundant at altitudes higher than 6,000 feet or lower than 4,000 feet. The most common junipers are Utah juniper (Juniperus osteospera), Rocky Mountain juniper (J. scopulorum), and one-seed juniper ( $J$. mono-sperma). Colorado pinyon (Pinus edulis) is the most common pine in this zone. Understory species include bitterbrush, big sagebrush, mountain-mahogany, and cliffrose (Cowania stansburiana). Some herbaceous species present are blue grama (Bouteloua gracilis), galleta (Hilaria jamesi), bluebunch wheatgrass, western wheatgrass (Agropyron smithi), Indian-ricegrass (Oryzopsis hymenoides), Russian-thistle (Salsola Kali), and cheatgrass (Bromus tectorum).

B1g sagebrush

Occurring in extensive zones, sagebrush is not as restricted by altitude as are the other communities and is found at altitudes of up to 10,000 feet. Sagebrush is found on well-drained, commonly sandy soils that are not usually saline. Many woody and herbaceous species are associated with sagebrush. Some of these shrubs are rabbitbrush (Chrysothamnus spp.), horsebrush (Tetradymia nuttalli and T. canescens), winterfat (Eurotia lanata), and snakeweed (Gutierrezia sarothrae). Understory grasses are galleta, blue grama, western wheatgrass, bluebunch wheatgrass, and squirreltail (Sitanion hystrix).

Shadscale

Limited to soils that are slightly saline and relatively impermeable, shadscale (Atriplex confertifolia) grows in some places in nearly pure stands but is commonly mixed with other shrubs such as sagebrush, horsebrush, and spiny hopsage (Grayia spinosa). Nuttall saltbrush (Atriplex nuttalli) commonly occurs locally as pure stands within this zone.

Blacklorush

Blackbrush grows in a zone characterized by sandy usually nonalkaline soils at lower altitudes. Plants associated with blackbrush (Coleogyne ramosissima) are fourwing saltbush (Atriplex canescens), Mormon tea (Ephedra spp.), yucca (Yucca spp.), snakeweed, and galleta.

\section{Greasewood}

Growing on terraces above permanent streams and along intermittent stream channels at lower altitudes greasewood is a phreatophyte which is very salt tolerant and deep rooted and which usually indicates the presence of ground water. It usually grows as nearly pure stands but is in some places associated with shadscale, sagebrush, and rabbitbrush. Herbaceous phreatophytes commonly associated with greasewood are saltgrass (Distichlis stricta) and alkali sacaton (Sporobolus airoides).

Saltbush (Nuttall)

Saltbush grows in nearly pure stands on soils that have very low infiltration rates and that are usually heavy textured and commonly saline. Greasewood and sagebrush are commonly associated with saltbush in small channel bottoms. Winterfat and black sage (Artemisia nova) are also mixed with nuttall saltbush in a few places or form alternate pure stands.

summer-cypress

Summer-cypress grows in scattered stands at lower altitudes in the northern part of the division on dry, heavy soils that are usually saline. Other plants commonly found growing with summer-cypress (Kochia americana) are bud sage (Artemisia spinescens), winterfat, and widely scattered plants of sandberg bluegrass (Poa secunda), Indian ricegrass, and scarlet globemallow (Sphaeralcea coccinea).

\section{Grassiands}

Grasslands and grasslands mixed with shrubs cover extensive areas. At the higher altitudes, grasses mixed with shrubs occur as small scattered "islands." The most common grasses are western wheatgrass, bluebunch, wheatgrass, squirreltail, and needlegrass (Stipa spp.). In the lower altitudes the most abundant grasses are blue grama and galleta.

All the plant communities occur in the Grand division except saltbush and summer-cypress (pl. 5). Vegetation that is typical of some of the zones in this division is shown in figures $30-32$.

\section{COLORADO RIVER BASIN ABOVE THE GUNNISON RIVER PRESENT UTILIZATION OF SURFACE WATER STORAGE RESERVOIRS}

Sixteen reservoirs that have storage capacities greater than 1,000 acre-feet have been constructed in the Colorado River Basin above the Gunnison River (table 3, pl. 4). The combined usable storage capacity of these reservoirs in 1957 was 659,430 acre-feet. Many small reservoirs and stock ponds are scattered over the subbasin. The Shadow Mountain, Lake Granby, and Willow Creek Reservoirs are a part of the ColoradoBig Thompson project and were constructed primarily for the exportation of water out of the Colorado River Basin. The Williams Fork and Ivanhoe Reservoirs were constructed to store water for use in the Colorado River Basin when transmountain diversions 


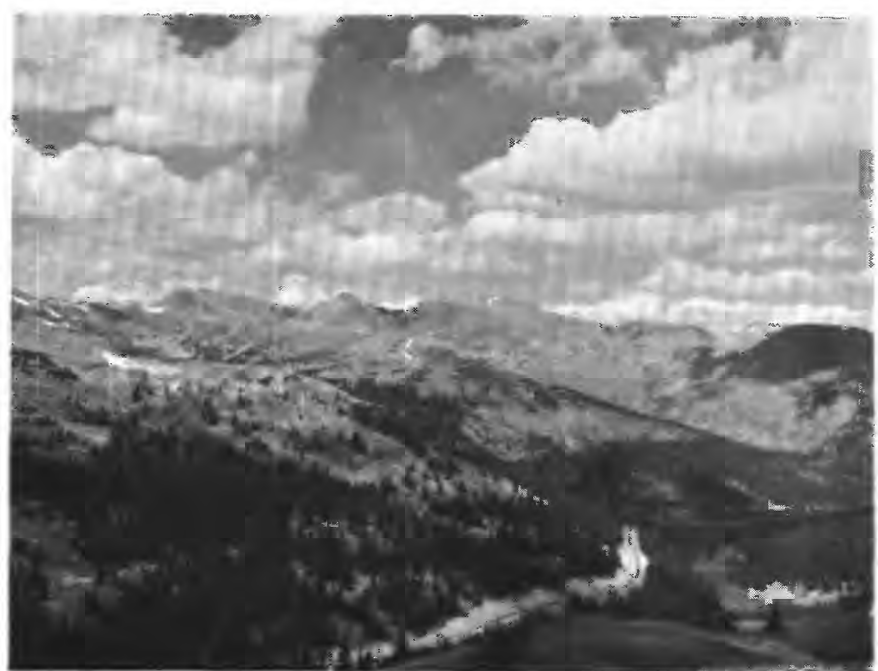

FiGURE 30.-Alpine meadows and subalpine forest zones in the headwaters of the Blue River. (Photograph by D. A. Phoenix.)

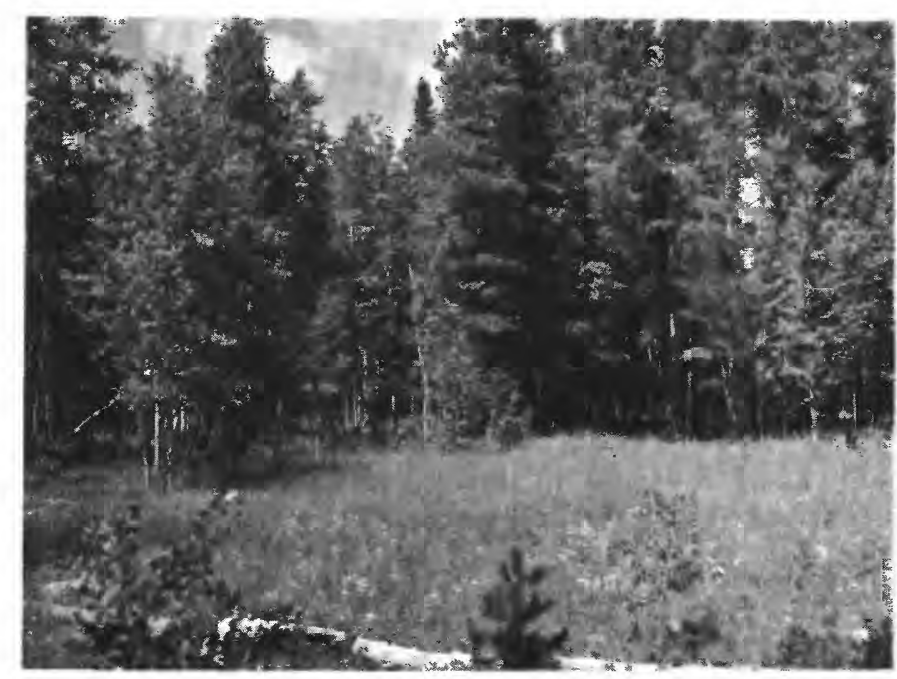

Figure 31. - Subalpine forest near Gore Pass, Colo. The vegetation is quaking aspen and mixed conifers, including lodgepole pine, and a small island of grassland in foreground. (Photograph by F. A. Branson.)

reduced downstream flows below irrigation requirements. The Green Mountain Reservoir also serves the same purpose and, in addition, provides storage for hydroelectric-power production. The remaining reservoirs provide storage for irrigation water. All reservoirs store water from the drainage basin in which they are located except Harvey Gap Reservoir, which stores water from East Fork Rifle Creek.

\section{TRANGMOUNTAIN DIVERSTONS}

The diversion of water out of the subbasin began in 1880, when the Ewing ditch was constructed to divert water from the headwaters of the Eagle River to the Arkansas River basin for placer mining. As the need for irrigation and municipal water east of the Conti-

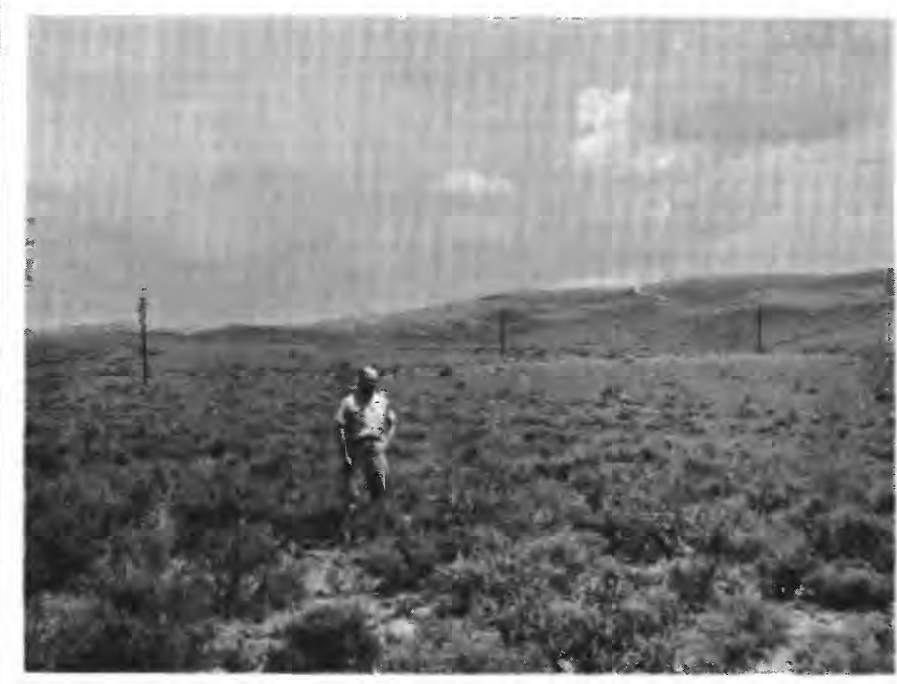

Figure 32.-Big sagebrush 1 mile northwest of Kremmling, Colo. The low-growing shrub in the background is winterfat. (Photograph by F. A. Branson.)

nental Divide grew, other transmountain diversion ditches and diversion tunnels were constructed. Thirteen transmountain ditches and tunnels were in operation by 1957 .

The average annual diversion for the four water years $1954-57$ was 353,000 acre-feet. The annual transmountain diversions from the subbasin during the 1914-57 period are listed in table 4. Water diverted through the East and West Hoosier ditches, which were operated in water years $1935-40$ and then abandoned, has been included in the data for Hoosier Pass tunnel. Diversion through the Fremont Pass ditch was discontinued after 1943.

Figure 33 shows the rate of increase of transmountain diversions and the annual variations through the years. In years of both high and low runoff some of the diversions are less than average, owing to lack of need and to a deficiency in supply, respectively.

\section{IRRIGATION}

The major use of water is for the irrigation of crops. In the Colorado River Basin above the Gunnison River in 1949 the U.S. Bureau of the Census (1953) reported 192,500 acres of irrigated land, which was about the same amount irrigated in 1957. The amount and distribution of irrigated land in the tributary basins along river reaches and above gaging stations are shown in table 5 and plate 5 .

Irrigated lands above Glenwood Springs are mostly on narrow valley bottoms along the streams at altitudes ranging from 6,500 feet near Dotsero to 8,500 feet near Fraser. Because of the short growing season and low temperature, the principal crop is native grasses for livestock feed. Water is generally plentiful during most of the irrigation season and is applied at rates 


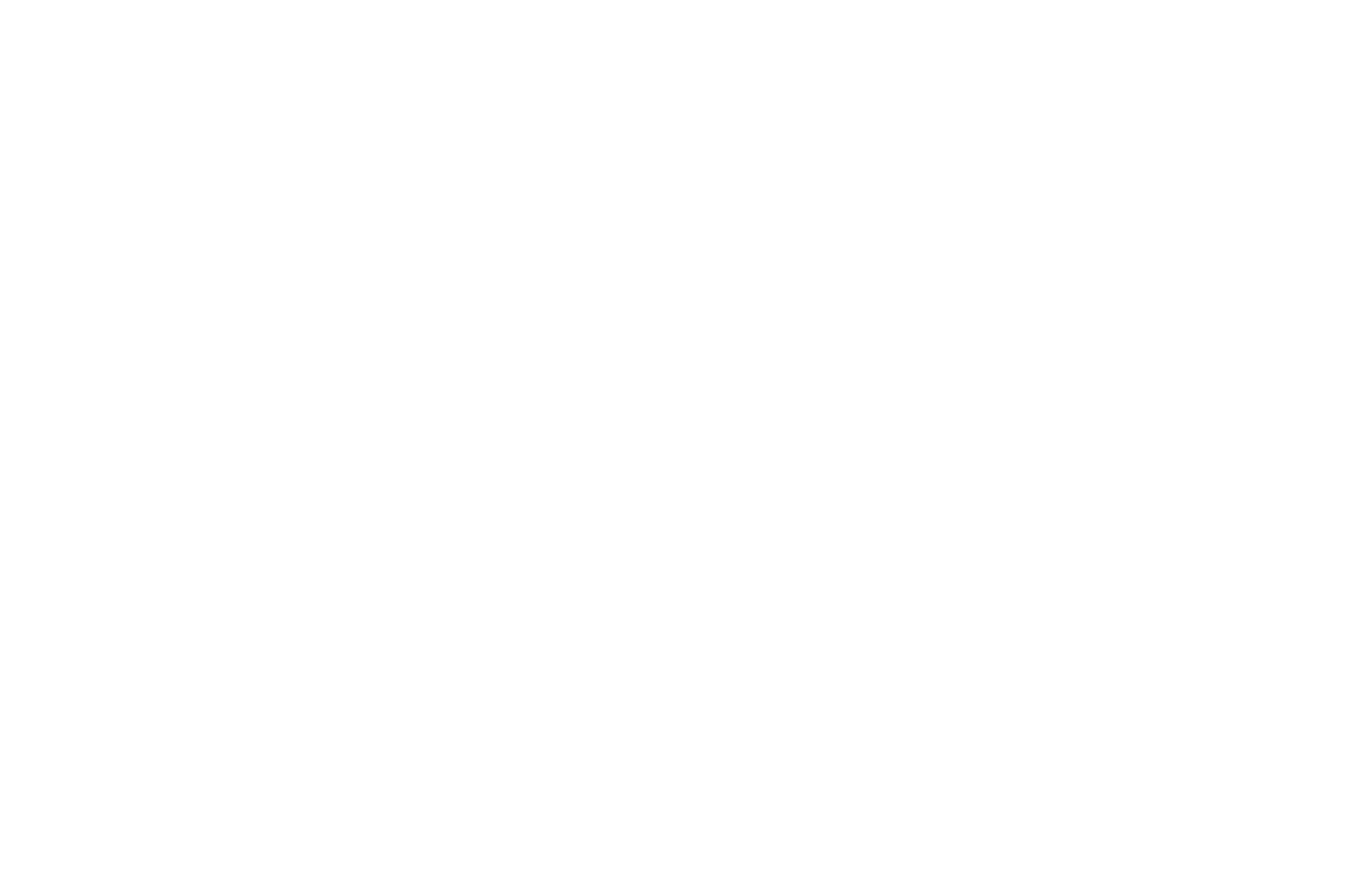

of as much as 5 to 8 acre-feet per acre annually. A large part of the applied water returns to the streams.

Between Glenwood Springs and Cameo the irrigated lands are mostly on benches at altitudes of about 5,000 feet. The climate in this area is favorable for growing fruit, vegetables, alfalfa, and sugar beets. Most of the irrigation water is obtained from tributary streams, and the supply in the latter part of the season is deficient for about half of the lands irrigated. Irrigation water is applied at rates of 3 to 5 acre-feet per acre annually. About half to two-thirds of the applied water returns to the streams. In the Plateau Creek basin the climate and irrigation practices are similar to those between Glenwood Springs and Cameo. The Upper Colorado River Compact Commission (1948) estimated that the 1914-45 average annual consumptive use of water in the subbasin due to irrigation was 190-300 acre-feet. In the Commission's study it was estimated that 179,800 acres of land was irrigated and that 20,300 acres of land received water incidental to irrigation practices.

\section{DOMESTIC AND INDUSTRIAI USES}

The 1960 population was about 26,200 , which is an average of about three persons per square mile. The five largest communities and their population are Glenwood Springs, 3,637; Rifle, 2,135; Climax, 1,609;
Aspen, 1,101; and Dillon, 814 (Bureau of the Census). Principal means of livelihood are farming, ranching, mining, and the tourist trade.

Most communities receive their water supplies from springs or mountain streams. Most of the larger communities have sewage-treatment plants or lagoons or individual family septic tanks. However, some sewage is discharged directly into the streams. Detailed data are not available on the domestic uses of water for supply or waste dilution, but the per capita use of water is estimated to be about $200 \mathrm{gpd}$ (gallons per day). This would be equivalent to about 6,000 acrefeet per year for domestic use. The consumptive use of water for domestic and industrial purposes is estimated to average about $60 \mathrm{gpd}$ per capita, or about 1,800 acre-feet annually.

Production of hydroelectric power is the major industrial use of water. Eight hydroelectric powerplants have an installed capacity of 37,400 kilowatts. The largest two are the Green Mountain plant on the Blue River (21,600 kilowatts) and the Shoshone plant on the Colorado River above Glenwood Springs (14,400 kilowatts). Other industries using water are mines and smelters, sugar factories, dairies, food-processing plants, and a few small industries. All the industries are relatively small and their use of water is negligible. 


\section{STREAMFLOW}

VARIABILITY OF SEASONAL RUNOFF

Melting of snow that accumulates in the mountains provides most of the water supply. Rising temperatures in the late spring and early summer rapidly melt the snow and cause the streams to peak and then subside as the stored supply of snow is exhausted. Usually by late July the streams have subsided to near a base flow, which generally prevails until the cycle is repeated the following spring. Relatively little runoff is produced by the local thundershowers, which occur during the summer months.

The seasonal pattern of the rise and fall of the headwater streams, being principally dependent on temperature, is practically the same throughout the area (fig. 34). The rise and fall of main-stem streams closely follows the pattern of the headwater streams (fig. 35). There is, however, a progressive lag in the downstream direction.

\section{FLOW-DURATION CURVES}

Historical flow-duration data were prepared for streams at 40 selected sites in the Colorado River Basin above the Gunnison River. For all but two of these sites, curves representative of the 44-year base period, adjusted to 1957 conditions, were developed. The historical and adjusted curves reduced to table form are given in table 6. In addition, flow-duration curves were synthesized for two sites for which historical flow-duration curves were not prepared. The usefulness of these curves in hydrologic studies, their characteristics, and the methods used to adjust flow-duration curves for short periods of record to the 44-year base period and for changes in upstream water developments are explained in chapter B (pp. 45-48).

Records of streamflow at only four of the selected sites in the subbasin were complete for the 44-year base period. At a few sites, more than 34 years of record was available, but at some sites as little as 5 years of record had been obtained. During the base period many changes in upstream water developments considerably affected some of the streamflow records. Methods used in adjusting the historical flow-duration curves are given in table 7 , and the upstream water developments-in which changes occurred-are outlined. The table also gives the author's accuracy ratings of the adjusted long-term curves. Computations and data necessary to show the details of the adjustments are too voluminous for inclusion in the report.

The flow-duration curves for the headwater streams have a typical shape and are similar to each other (fig. 36). The curves generally have a steep slope and are flat at the upper end. Differences in topography, rocks, soils, and vegetative cover in the drainage basins cause the curves to vary slightly.

The flow-duration curves for the Colorado River at three gaging stations are shown in figure $37 A-C$. These curves are generally similar in shape; however, those for the downstream stations are slightly modified by intervening water-use developments. In figure $37 D$ the curves for the Colorado River at the three stations are shown, the water discharge being expressed as a ratio to the average flow. Expressing the discharge as a ratio eliminates most of the effects of differences in size of drainage area and amount of runoff. The modifying effect of storage releases is apparent near the middle of the curves for the two downstream stations. The flatter slope of the lower end of the flow-duration curves for the downstream stations is caused by return flow from the irrigation of intervening lands.

The variability indices (Lane and Lei, 1950) and percentages of ground-water contribution to stream systems (see chap. B, pp. 48-53) were computed for selected streams (table 8 ). In general, the relation between the two parameters is inverse (fig. 38). The average curve in figure 38 is based on data for selected streams in this subbasin and other subbasins in the Upper Colorado River Basin.

North Inlet and Homestake Creek, two of the streams listed in table 8, flow in basins underlain entirely by Precambrian rocks and have the highest variability indices and lowest percentage of groundwater contribution. These rocks are impermeable but are broken by faults and joints through which water may enter and circulate. The ground-water storage capacity in rocks of this type is relatively small.

The drainage basins of Rock and Fryingpan Creeks and the Williams River also are principally underlain by Precambrian rocks, but the basins contain extensive deposits of glacial outwash. These deposits are permeable and provide considerable ground-water storage. These streams have a relatively low variability index and a relatively high percentage of ground-water contribution.

The Buzzard Creek basin is underlain by the Wasatch Formation, which consists of sandy clays and sandstones. The formation, as a whole, is relatively impermeable, and streams draining areas underlain by rocks of this type could be expected to have a high variability index and a low percentage of groundwater contribution. 

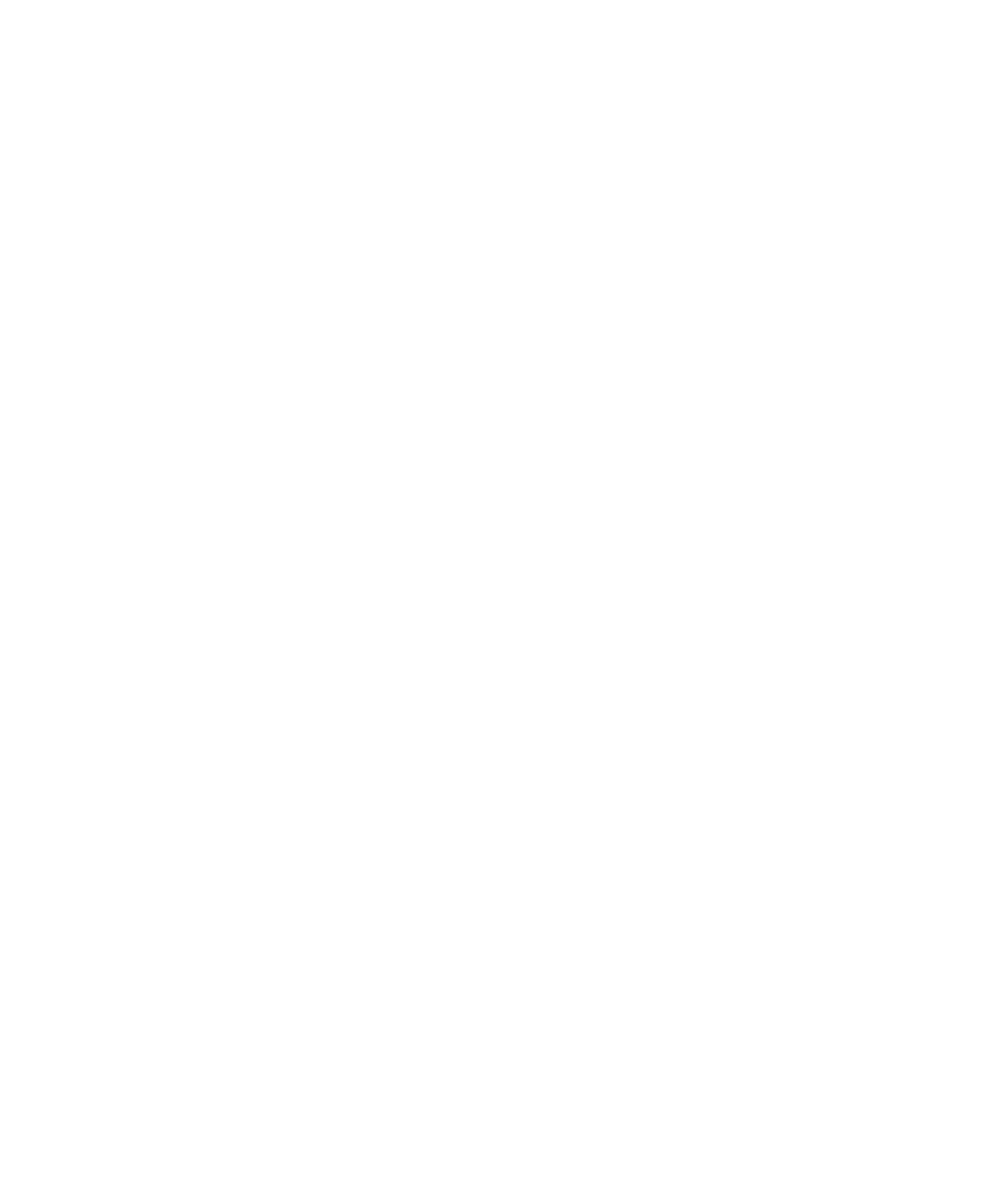

FIGURE 34.-Seasonal pattern of runoff of headwater streams in the Colorado River Basin above the Gunnison River, 1954 water year. 


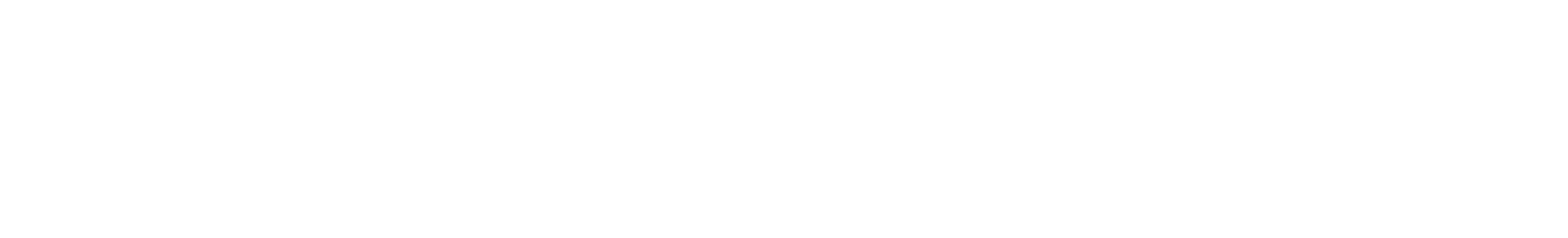

$A$. Colorado River at Hot Sulphur Springs, Colo.
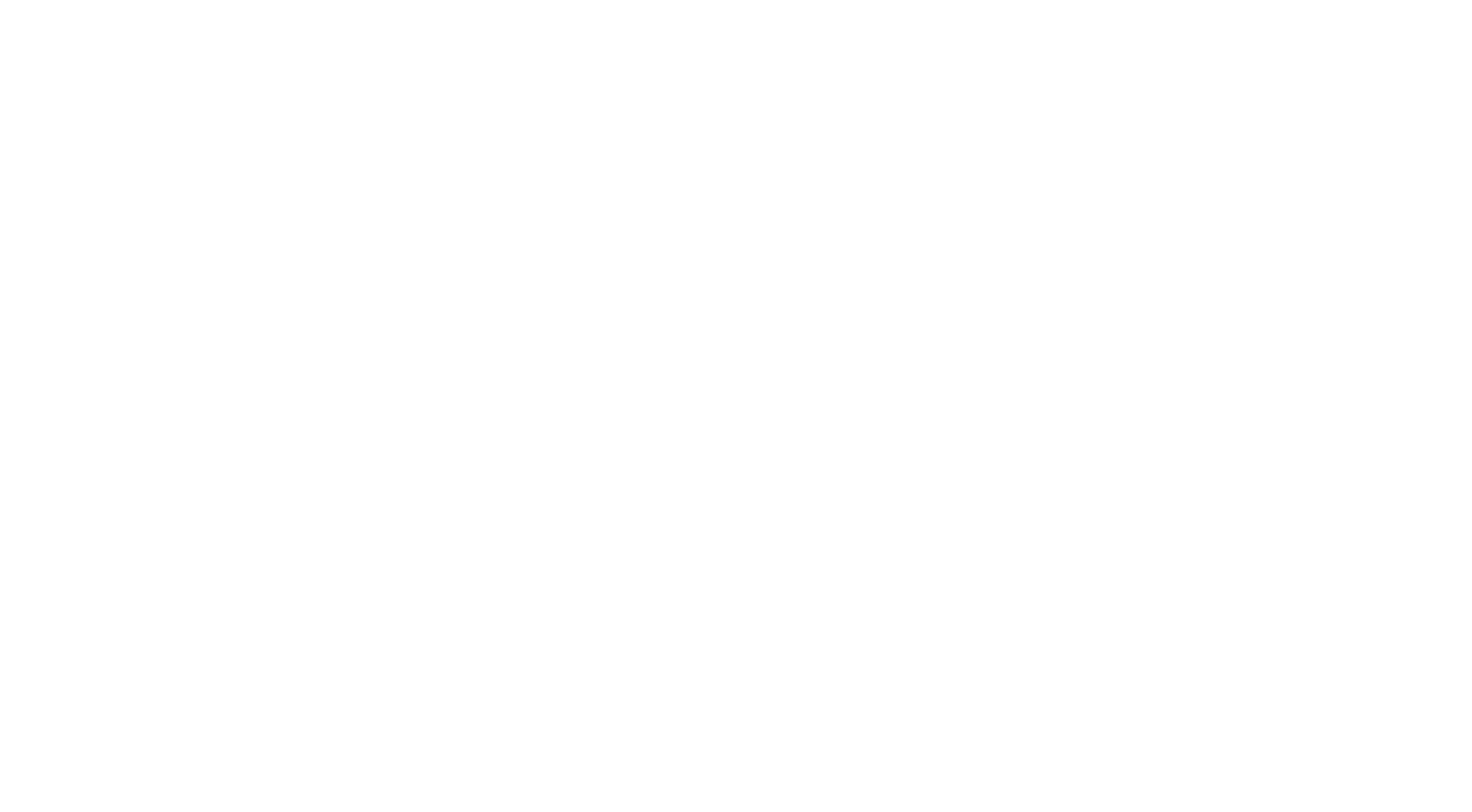

FiguRE 35.-Seasonal pattern of runoff of the Colorado River above the Gunnison River, 1954 water year.

The drainage basin of Gypsum Creek, which has the lowest variability index and highest percentage of ground-water contribution of the streams listed in table 8, is underlain by the Eagle Valley Evaporite. This formation consists of conglomerates and sandstones and some limestone and shale beds containing much gypsum. Rocks of this formation weather to thick deposits of permeable residuum. The rocks and weathered mantle provide opportunity for groundwater recharge and a relatively high storage capacity. Streams draining areas underlain by this type of formation could be expected to have a low variability index and a high percentage of ground-water contribution.

The drainage basins of the rest of the streams listed in table 8 contain more than one type of formation, some of which are steeply tilted and incised by streams.
As some of the rocks are permeable and some are impermeable, the combination would tend to cause streams draining such areas to have a variability index and percentage of ground-water contribution in the intermediate range.

The effect of environmental factors, particularly geology, on the shape of the flow-duration curves and the variability index can be further illustrated by comparing Homestake Creek near Red Cliff, Colo., with Gypsum Creek near Gypsum, Colo. These streams are both in the Eagle River basin. The drainage basins of these streams have about the same average annual precipitation and directional exposure and altitude. Figure 39 shows flow-duration curves for these two stations plotted as ratios of the a verage discharge of the streams.

As previously noted, the Gypsum Creek basin is underlain by relatively permeable rocks. With favora- 

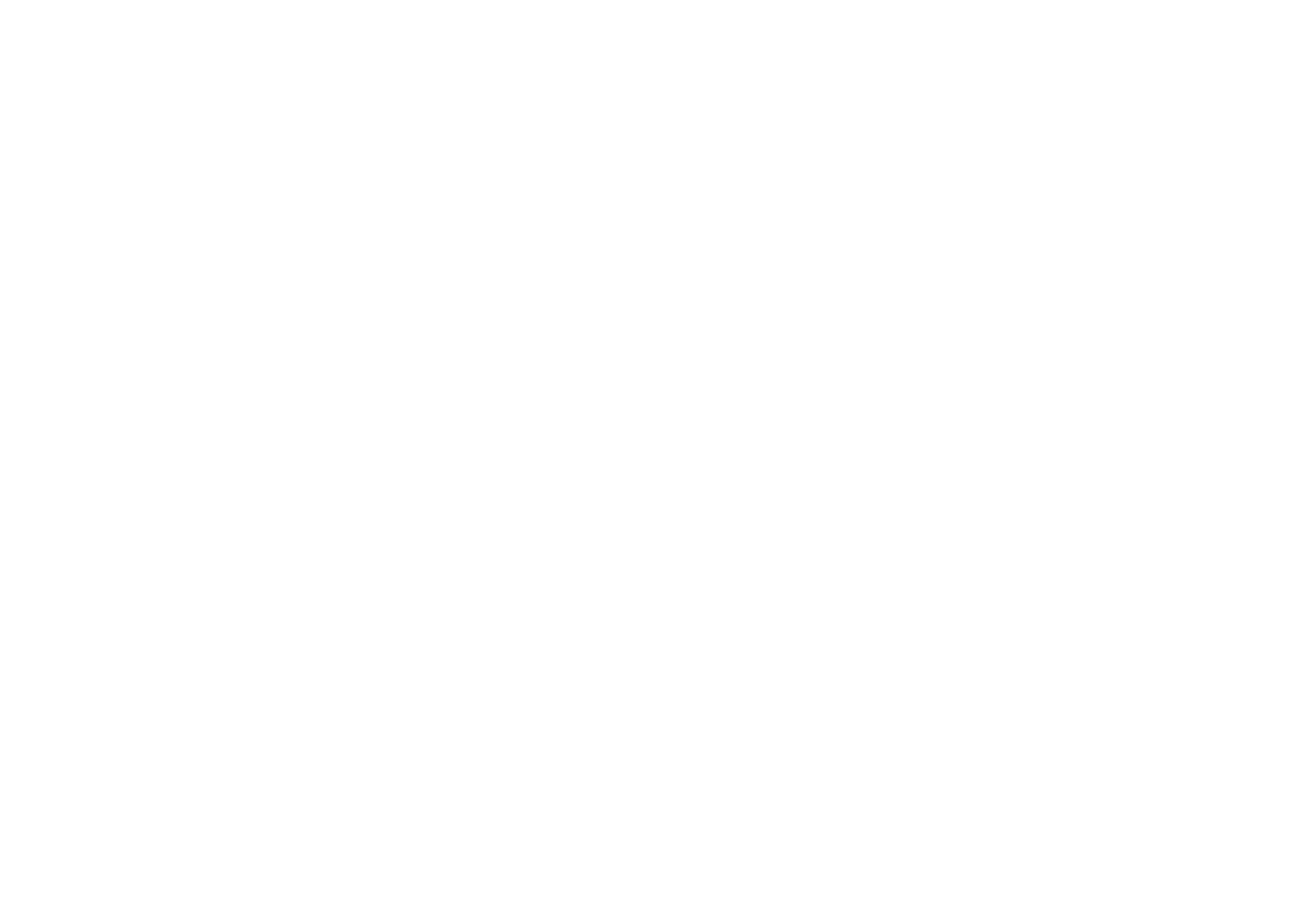

3
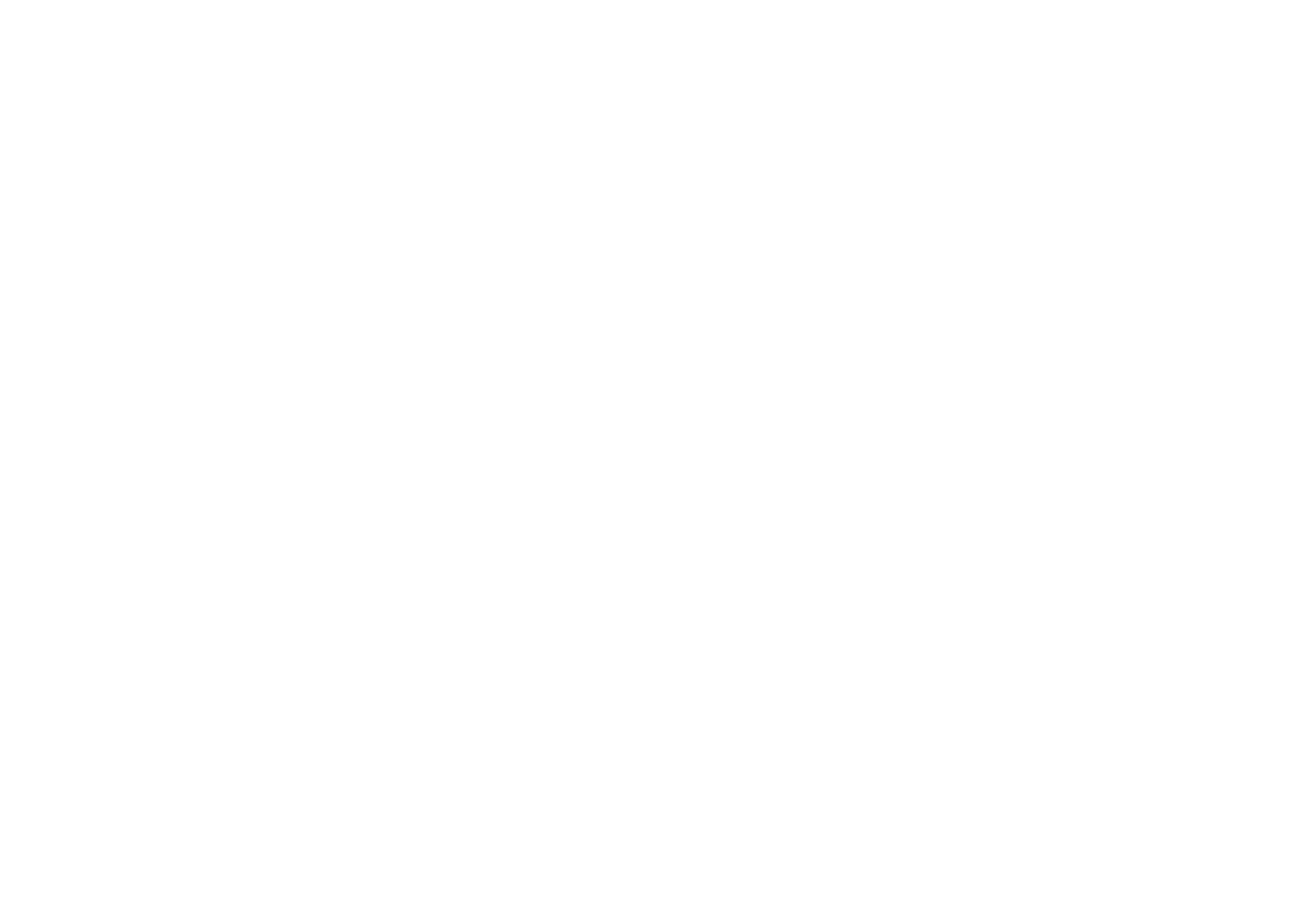

PERCENTAGE OF TIME INDICATED DISCHARGE WAS EQUALED OR EXCEEDED

C. Roaring Fork at Aspen, Colo.

D. Plateau Creek near Collbran, Colo.

Figure 36.-Flow-duration curves of headwater streams in the Colorado River Basin above the Gunnison River, water years 1914-57 adjusted to 1957 conditions. 

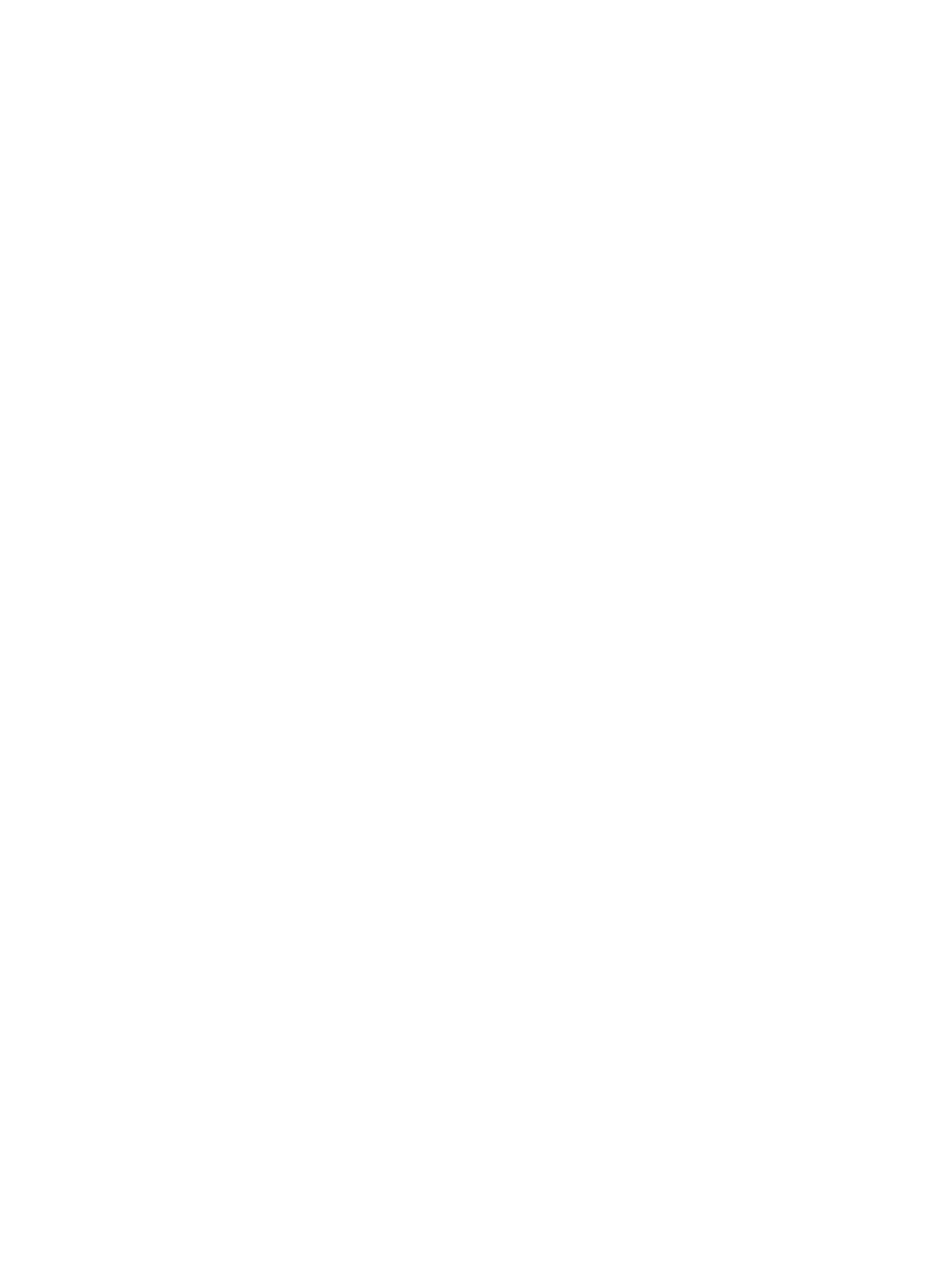

Figure 37.-Flow-duration curves of the Colorado River main-stem stations above the Gunnison River, water years 1914-57 adjusted to 1957 conditions. 


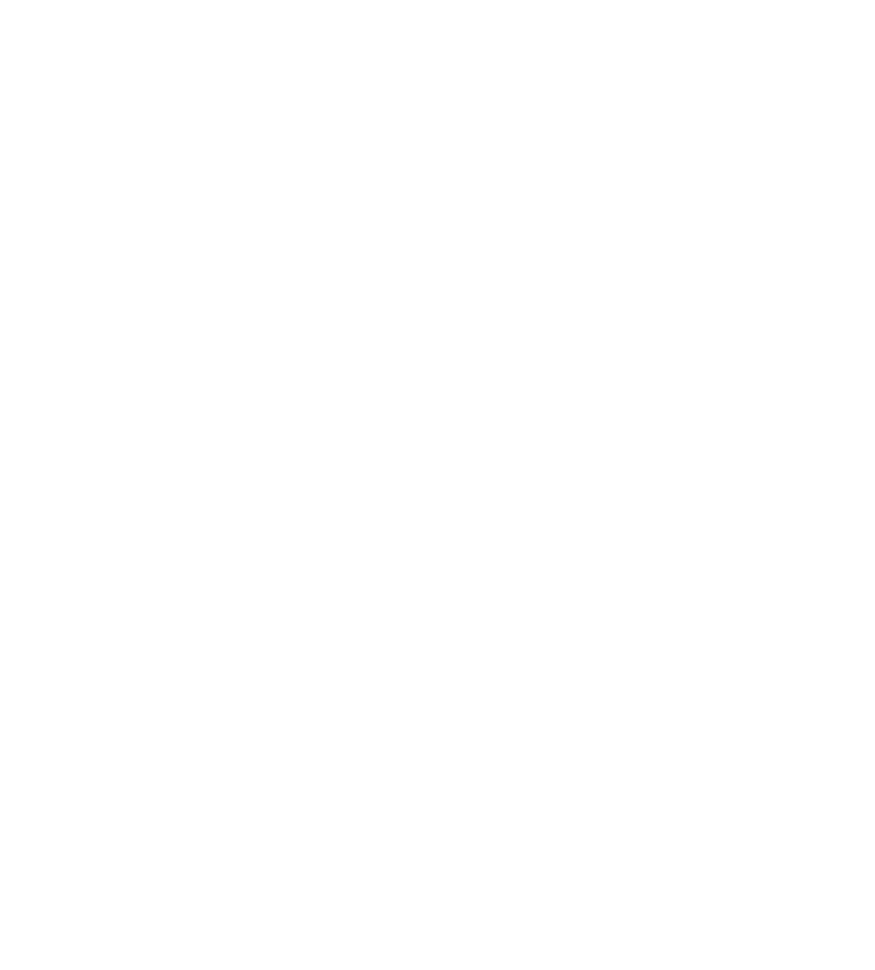

FIGURE 38.-Relation between the variability index of streamflow and the percentage of average annual discharge estimated to be contributed by ground water for selected stations in the Grand division, water years 1914-57 adjusted to 1957 conditions.

ble moisture, these rocks weather deeply and produce a relatively permeable soil mantle with good vegetative cover. The environment is favorable to infiltration of precipitation, part of which would build up the groundwater body, which in turn would maintain the stream during low-flow periods. The result is a relatively flat flow-duration curve, a low variability index, and high sustained flow.

The Homestake Creek drainage basin is underlain by relatively impermeable granite, much of which is exposed as bare rock. Glacial terrace deposits in the basin are relatively thin and overlie steeply sloping bedrock. This combination of environmental factors is reflected in a relatively high variability index.

\section{VARIABILITY OF ANNUAL RUNOFF}

The variations in annual discharge of streams in the subbasin are illustrated by the histograms for three selected stations (fig. 40). The quantities of water illustrated by the histograms were adjusted to the 1914 base. (See chap. B, pp. 53-60.) Changes in upstream use between 1914 and 1957 were considered in the adjustment. Tables 9 and 10 show the historical record and the adjustments applied for Fraser River

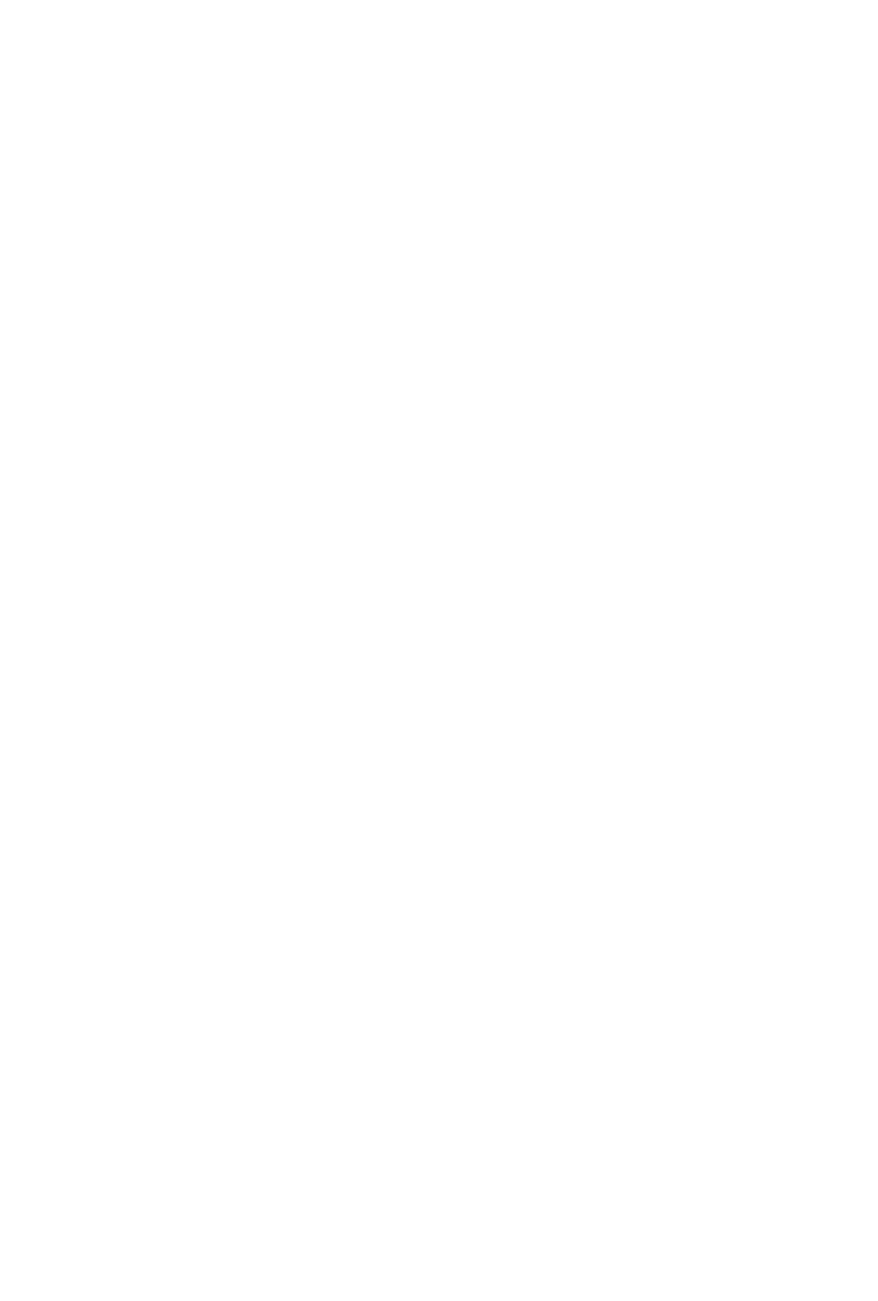

Frgdre 39.-Effect of environmental factors on flow-duration curves. Comparison of flow-duration curves for Homestake Creek near Red Cliff and Gypsum Creek near Gypsum, Colo., water years 1914-57 adjusted to 1957 conditions.

near Winter Park, Colo., and Colorado River at Glenwood Springs, Colo. Similar data for Roaring Fork near Glenwood Springs, Colo., are given in tables 6 and 7 , chapter B.

The standard deviation and coefficient of variation of annual discharges were computed for these three stations and other stations in the subbasin to investigate the effect of different environmental factors on the variability of annual discharges and to provide a basis for estimating probable future flows of streams in the area. (See chap. B, pp. 57-58.) The standard deviation and coefficient of variation for the streams are given in table 11. The coefficients are also plotted in plate 4. All the coefficients of variation in the table are considered to be applicable to natural conditions, but some are not applicable to present conditions be- 

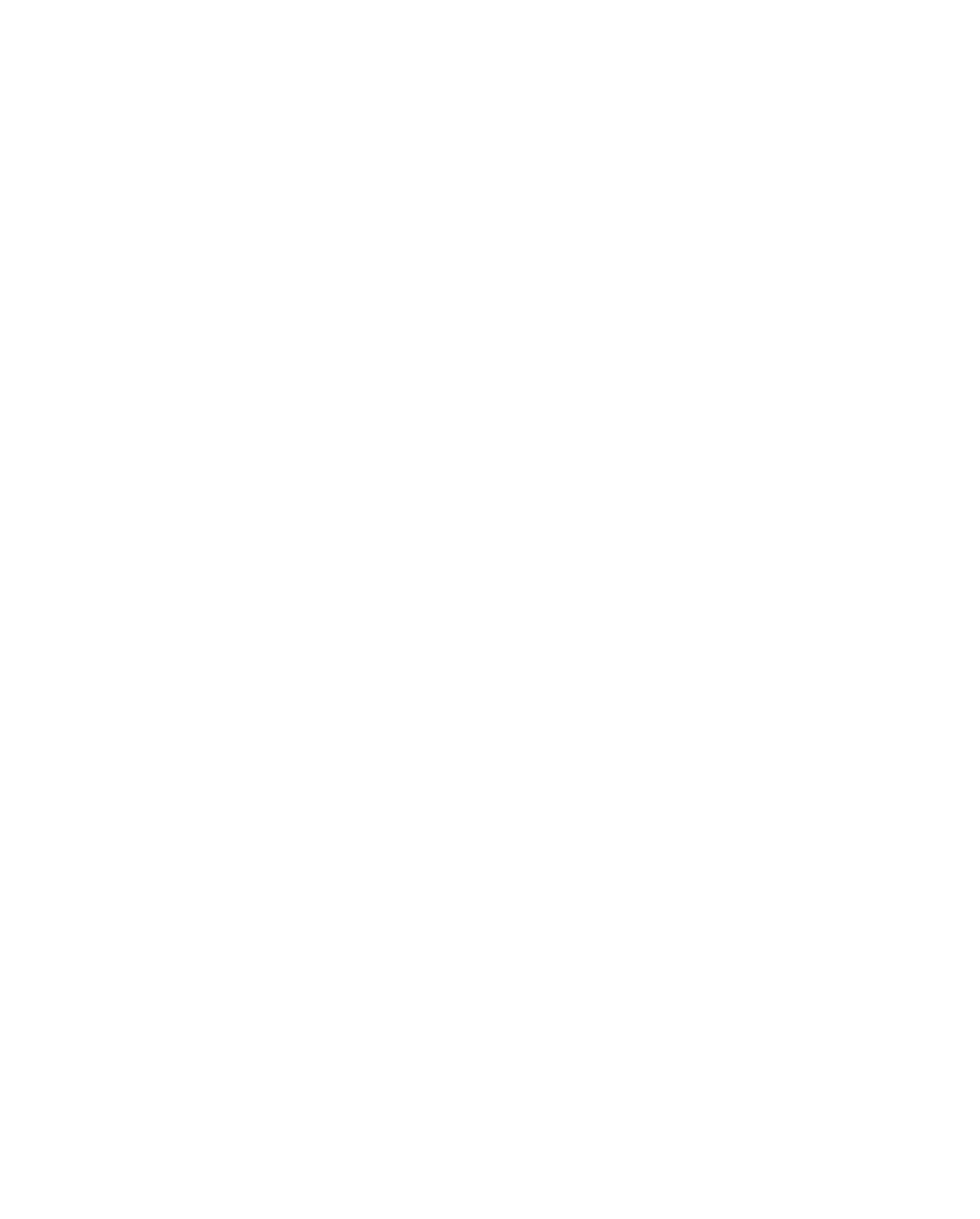

FIfURE 40.-Variability of annual discharges of selected streams in the Colorado River Basin above the Gunnison River, water years 1914-57 adjusted to 1914 base. 
cause the magnitude of changes in upstream developments during the period of record was large in relation to the total runoff. Coefficients that are not considered applicable to present conditions or for estimating probable future flows are indicated in the table.

The coefficients for south-side streams in the eastern part of the subbasin are approximately the same, probably owing to the similarity of climate in the different drainage areas and the relatively impermeable underlying rocks, which do not provide enough groundwater storage to sustain the streams in years of low precipitation. At downstream points along the main stream the coefficients are slightly reduced, possibly because of ground-water storage in the river alluvium.

The coefficient for Rifle Creek indicates a well-sustained flow even in years of low precipitation. The sustained flow comes mostly from East Rifle Creek. This stream crosses steeply tilted rocks bordering the White River Plateau. Though most of the headwater area is underlain by rocks of Pennsylvania age, older rocks of Mississippian age are exposed in the canyon upstream from the gaging station on East Rifle Creek. Springs discharging about 30 to 35 cfs issue from limestone beds in the Mississippian rocks about 2 miles above the gaging station (M. R. Collings, oral commun., 1962). The limestone strata are probably recharged at higher altitudes where precipitation is heavy, either where the limestone is exposed or through permeable beds in the Pennsylvania rocks.

Toward the western part of the basin, the coefficient of variation increases. The increase in variability reflects the effect of runoff from infrequent but intense summer storms, which are more common in this area.

The probable amounts (50-percent chance) by which average discharges for various periods in the future may differ from the long-term average discharge of some of the streams listed in table 11 are given in table 12. These determinations employ the probability techniques described by Leopold (1959) in an analysis of streamflows for Colorado River at Lees Ferry, Ariz. In chapter B (pp. 53-58) the statistical analysis of annual discharges is outlined, and an equation and table of factors are given for computing the most likely deviations in estimating average future streamflow for various periods of years and confidence limits. In table 12 the average discharges are those for water years 1914-57 adjusted to 1957 conditions (table 6), the coefficients of variation used are those given in table 11, and the factors used are those given for the 50-percent confidence band in table 8 , chapter $\mathrm{B}$. The quantities given in table 12 have been rounded to two significant figures. Similar determinations of probable errors in estimating the average annual flows for other periods of years and confidence bands may be made by using the other factors in table 8, chapter B.

\section{PRECIPITATION-RUNOFF RFLATION}

The overall effect of environmental factors on runoff may also be investigated by comparing total precipitation with water yield. The measured runoff from a drainage area is the residual water left from precipitation in excess of that required to satisfy natural and man-caused water consumption. Evaporation from water surfaces, soil, and vegetation and transpiration by native vegetation make up the major part of natural consumptive use. This is commonly referred to as "nature's take" and is sometimes called "water loss," even though much of it serves a beneficial purpose in promoting growth of trees and forage to protect the soil from erosion.

The precipitation, runoff, and natural consumptive use of water were computed for six small drainage basins (table 13). Among these six, only the basin of the Eagle River below Gypsum includes any appreciable irrigated land. The natural consumptive use for four of the areas shows that the combined effect of environmental factors on natural consumptive use is practically the same. This fact suggests that the natural consumptive use over much of the subbasin is about 15 inches annually. The Homestake and Gypsum Creek basins have lower and higher natural consumptive use, respectively, than the four others and are considerably different from each other, probably due to differences in vegetation and in permeability of the underlying formations and residual mantle. The impervious surface, steep slopes, thin soil, and sparse vegetation in the Homestake Creek basin permit rapid runoff and minimum water loss. In contrast, the relatively deep and permeable soil and heavier cover of vegetation in the Gypsum Creek basin permit greater infiltration of precipitation and greater evapotranspiration.

\section{CHEMICAL QUALITY OF WATER}

\section{DISSOLVED-SOIIS DISCHARGE AND CONCENTRATION}

Daily chemical-quality data have been obtained at five stations in the Colorado River Basin above the Gunnison River. Monthly and annual weighted-average chemical analyses for these stations are given in the basic data report (Iorns and others, 1964, tables 175-179). In addition to the daily data at the five stations, samples of stream water have been obtained for chemical analysis at many other sites in the sub- 
basin. The dissolved-solids discharge for the daily stations and that computed for some of the sites where fewer samples were collected have been computed (table 14).

Duration tables of dissolved-solids concentration and discharge for the stations listed in table 14 are given in tables 15 and 16 . The analyses of water samples, water discharge at the time of sampling, curves showing relation of dissolved-solids concentration to water discharge, and flow-duration curves of water discharge were used in the computations for these tables. The methods used to compute the data are described in chapter B (pp. 58-59).

By combining the average annual dissolved-solids and water discharges of Plateau Creek and Colorado River near Cameo, Colo., the average annual dissolved-solids discharge and water discharge from the subbasin were computed. Using these average annual quantities as a base, the percentage contribution of dissolved solids and water from other parts of the area were computed (fig. 41).

The data from figure 41 show that about 37 percent of the water but only about 15 percent of the dissolved solids come from the drainage basin above the Eagle River. Muddy Creek, a tributary above the Eagle River, contributes less than 2 percent of the water but at least 2 percent of the dissolved solids. The Eagle River contributes about 15 percent of the water and about 12 percent of the dissolved solids, whereas Roaring Fork, which contributes more than 30 percent of the water, contributes only about 18 percent of the dissolved solids.

Of the combined dissolved-solids discharges of Colorado River and Plateau Creek near Cameo, Colo., more than 10 percent is added to the Colorado River between the Eagle River and the chemical-quality station near Glenwood Springs (station 705C). The increase in flow in this reach is only about 0.2 percent of the combined flow of Colorado River and Plateau Creek near Cameo, Colo. The cause of the relatively large increase in dissolved solids in this reach is discussed on pages 102103.

\section{VARIATIONS IN CHEMICAL QUANTTY}

The seasonal variation in dissolved-solids concentrations of headwater streams in this subbasin is illustrated by the data for Eagle River at Gypsum, Colo. (fig. 42). The seasonal pattern of dissolved-solids concentration of this stream is typical of snowmelt streams. The concentrations are lowest in the months of maximum water discharge-May, June, and July-and highest in the months of low flow when the streams are maintained largely by ground water. Water year 1954 was a year of relatively low runoff, and 1957 was a year of relatively high runoff. The seasonal range from maximum to minimum concentration at this station is much greater than that in many streams in this subbasin. The greater seasonal range is largely due to environmental factors in which geology plays a predominant part. The drainage basin of the Eagle River is mostly underlain by limestones, shales, and siltstones of Pennsylvanian and Permian ages. Limestones, shales, and siltstones generally contain soluble minerals. Generally, streams draining areas underlain by rocks of this type have a greater range in concentration of dissolved solids than streams draining areas underlain by less soluble rocks, such as granitic and metamorphic rocks.

Figure 43 shows distribution curves of the variability of the monthly weighted-average concentration of dissolved solids. The procedures used in this anal$y$ sis are the same as those explained for the statistical analyses of streamflows in chapter B (pp. 53-58). As shown by the slopes of the monthly distribution curves, the months from November to March were the least variable, July and August were the most variable, and June, April, May, October, and September were less variable than July and August. The variability of annual weighted-average concentrations for Eagle River at Gypsum, Colo., for the period of record is also shown in figure 43.

The activities of man may considerably modify the natural seasonal variations in chemical quality of water in streams. A comparison of the seasonal variations in dissolved-solids concentration for Colorado River at Hot Sulphur Springs, Colo, for the 1949 and 1954 water years (fig. 44) reveals the effects of one modification by man. The change in pattern of seasonal variation at this station was caused principally by diversion of water containing relatively low dissolvedsolids content from the basin through Colorado-Big Thompson project, beginning in 1950. However, the effect of the project on the seasonal pattern of dissolved-solids concentration diminishes downstream because of additional water and dissolved-solids contributed by tributary areas. About 80 miles downstream at Dotsero, the times of occurrence of high and low concentrations also follow the pattern of snowmelt streams.

The variability of annual dissolved-solids concentration (chap. B, pp. 60-61) is less than the variability of streamflow, as indicated by the relation between the coefficients of variation of annual weighted-average concentration of dissolved solids and annual water discharge for concurrent periods at three sites where records of streamflow and chemical quality of water have been obtained (table 17). 


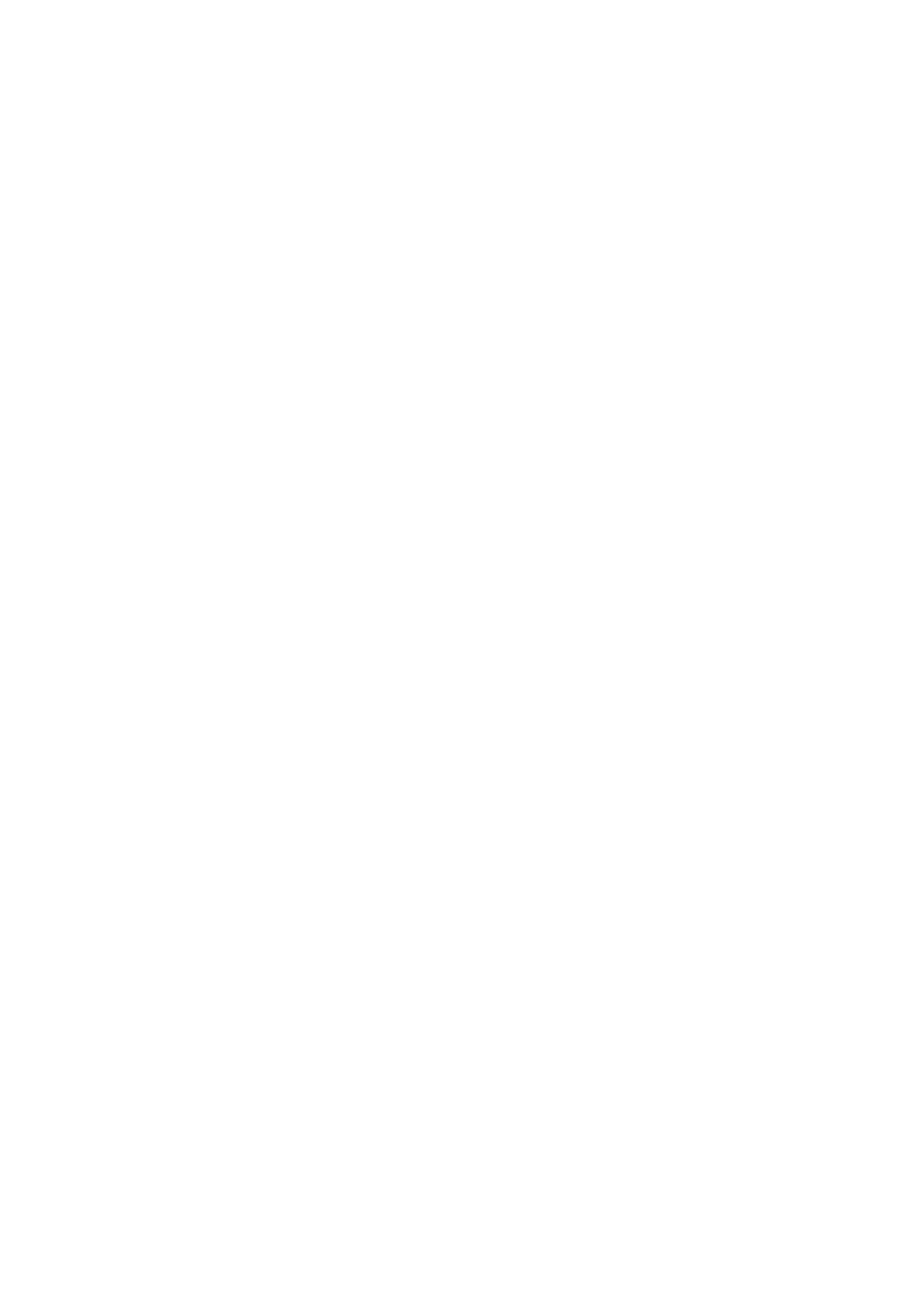




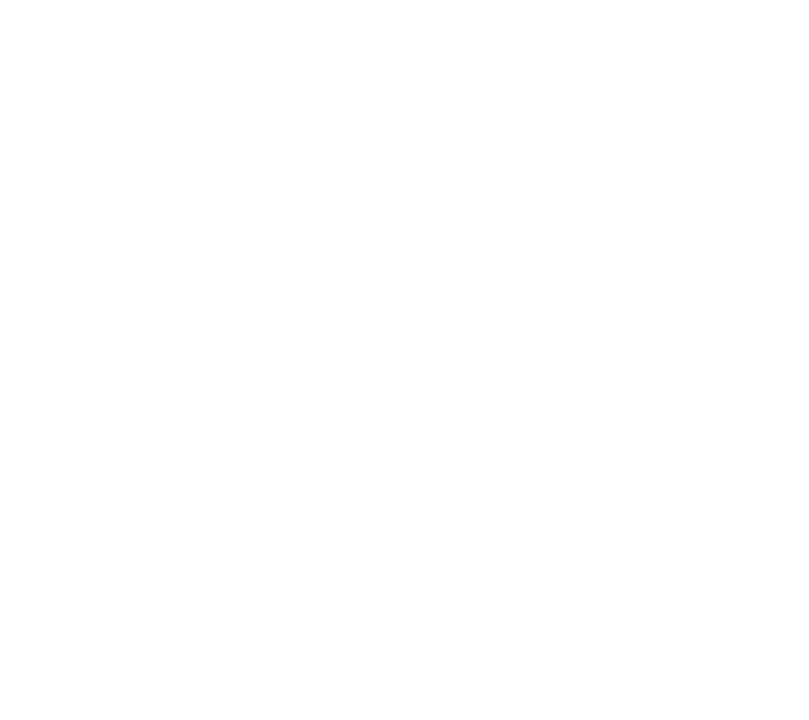

FiguRE 42.-Weighted-average concentration of dissolved solids at Eagle River at Gypsum, Colo., for the 1954 and 1957 water years.
In figure 45 the relation between the coefficients of variation for the three stations and others in the Grand division are shown. The equation of the line of relation (computed by the least-squares method) is

where

$$
V_{d}=0.573 V_{w}+0.036
$$

$V_{d}=$ coefficient of variation of annual weightedaverage concentration of dissolved solids, and

$V_{w}=$ coefficient of variation of annual discharge.

As described in chapter $B$, the relation between the variability of water discharge and that of concentration of dissolved solids can be used to compute values of weighted-average concentration at other sites within probability limits for various periods in the future. Table 18 gives computed values of coefficients of varia-

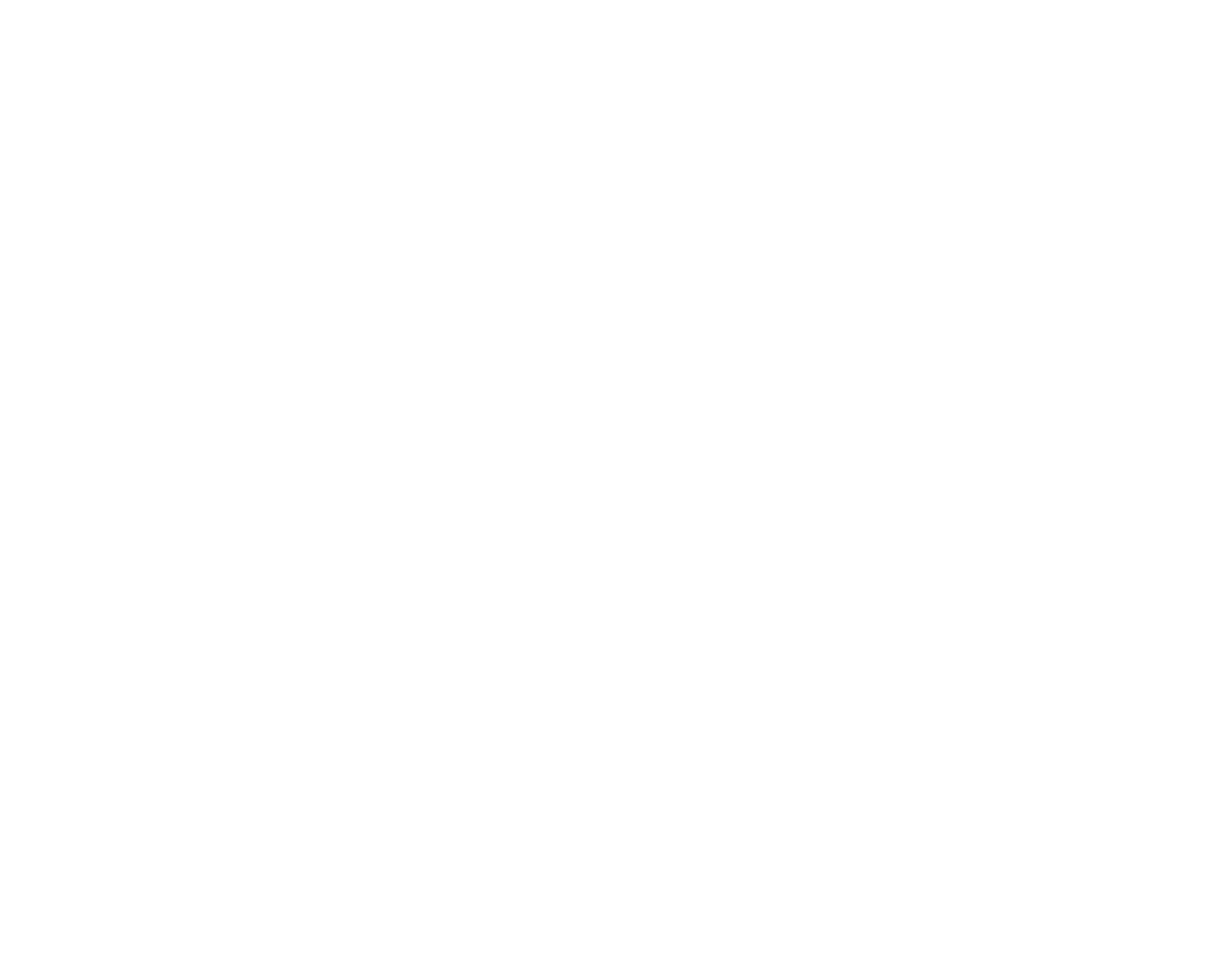

Figure 43.-Variability of the monthly and annual weighted-average concentration of dissolved solids at Eagle River at Gypsum, Colo., water years 1948-57. 


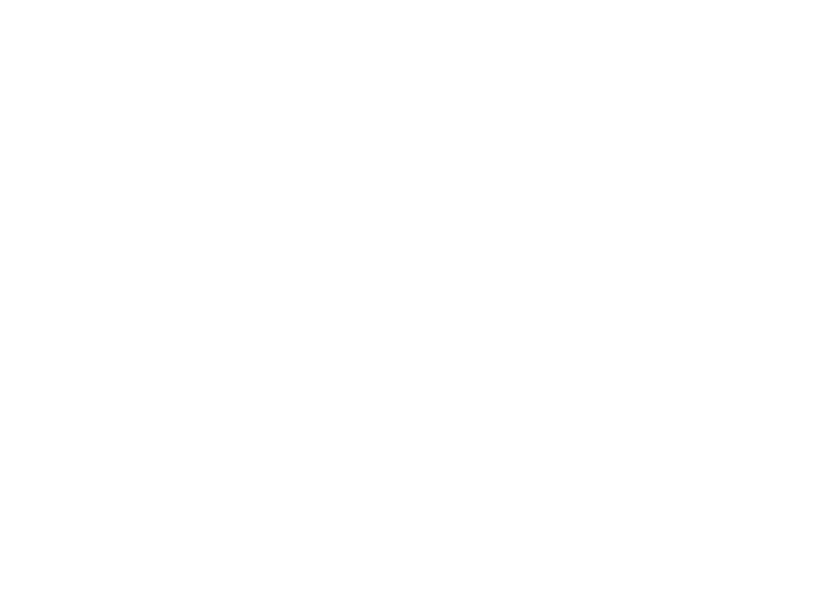

Figure 44.-Dissolved-solids concentration at Colorado River at Hot Sulphur Springs, Colo., for the 1949 and 1954 water years. Storage in Granby Reservoir began in September 1949.

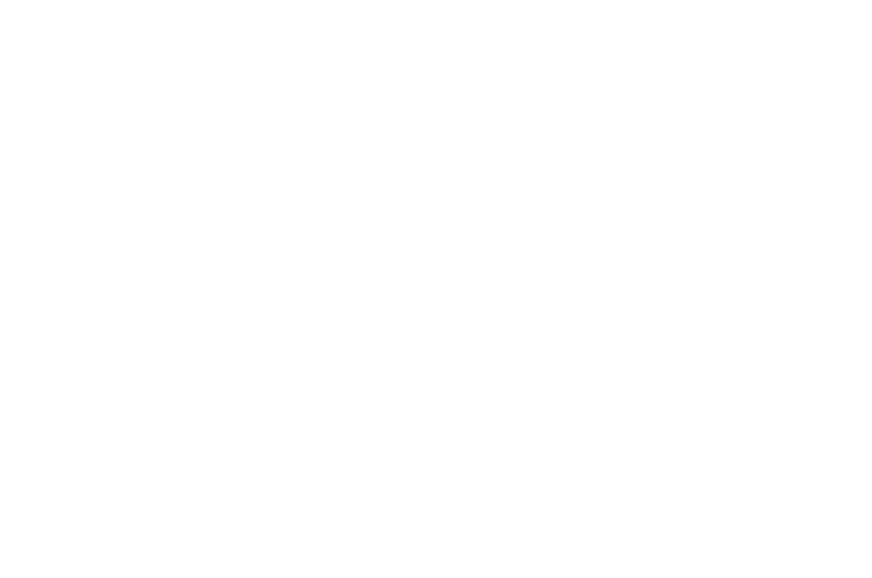

COEFFICIENT OF VARIATION OF ANNUAL WATER DISCHARGE

Figure 45.-Relation of the variability of dissolved-solids concentration to the variability of water discharge in the Grand division. $A$, Dolores River near Cisco, Utah; $B$, Gunnison River near Grand Junction, Colo.; $C$, Colorado River near Cisco, Utah; $D$, Eagle River at Gypsum, Colo.; $E$, Colorado River near Glenwood Springs, Colo.; $F$, Colorado River near Cameo, Colo.

tion and standard deviations of weighted-average concentrations of dissolved solids for selected stations. With these data and the factors in table 8, chapter B, probable deviations of dissolved-solids concentration for various periods in the future from the 1914-57 average, adjusted to 1957 conditions, can be computed.

\section{RELATION TO STREAMFLOW}

The patterns of relation between streamflow and dissolved solids for the level of upstream development existing in 1956 at four daily stations are shown in figure 46. The graphs for Colorado River at Hot Sulphur Springs, Colo., illustrate an abnormal relation caused by upstream developments. Although there are also developments above the other stations, the magnitude of their effect on the relation between streamflow and dissolved solids is not sufficient to alter the natural pattern generally exhibited by snowmelt streams.

Before the 1950 water year, the flow of Colorado River at Hot Sulphur Springs, Colo., showed an inverse relation between dissolved-solids concentration and water discharge for all ranges of discharge (fig. 47). Beginning with the 1950 water year, about 60 percent of the runoff upstream from Hot Sulphur Springs has been stored or diverted to the east side of the mountains through the Alva B. Adams Tunnel of the complex Colorado-Big Thompson project. This storage and regulation has changed the relation between concentration and water discharge at Hot Sulphur Springs, especially for water discharges of less than 500 cfs (cubic feet per second). For most water discharges, the concentration of dissolved solids has increased.

The effect of this substantial change in upstream water use on the chemical quality of water at Hot Sulphur Springs is further illustrated in figure 48 . The weighted-average concentration of dissolved solids in the river at this site from April 1947 to September 1949 was $53 \mathrm{ppm}$ (parts per million), or 0.07 ton per acre-foot of water. For the water years 1942-49 (water years 1942-46 estimated), the weighted-average concentration was computed to have been $60 \mathrm{ppm}$. For the water years $1950-57$, however, the weightedaverage concentration at Hot Sulphur Springs was $74 \mathrm{ppm}$, which is about one-fourth larger than for the water years $1942-49$.

Most of the irrigated lands upstream from Hot Sulphur Springs are below points of diversion or storage for the Colorado-Big Thompson project. Therefore, the total quantity of dissolved solids added to the river by return flow from irrigation probably was not affected by the project. However, the diversion of the more dilute water, as previously discussed, has apparently resulted in an increase in the weightedaverage concentration of dissolved solids in the river below the project.

Figure 49 shows two flow-duration curves for Colorado River at Hot Sulphur Springs, Colo., for water years 1914-57. The upper curve was developed from historical streamflow data. The lower curve represents what the long-term curve would have been if the level of upstream development existing in 1957 had existed throughout water years 1914-57. Figure 50 shows duration curves of dissolved-solids discharge for the same streamflow conditions. The upper curve was based partly on actual records of dissolved-solids discharge and partly on historical records of streamflow and the relation between dissolved-solids concentration and stream discharge prior to the Colorado- 

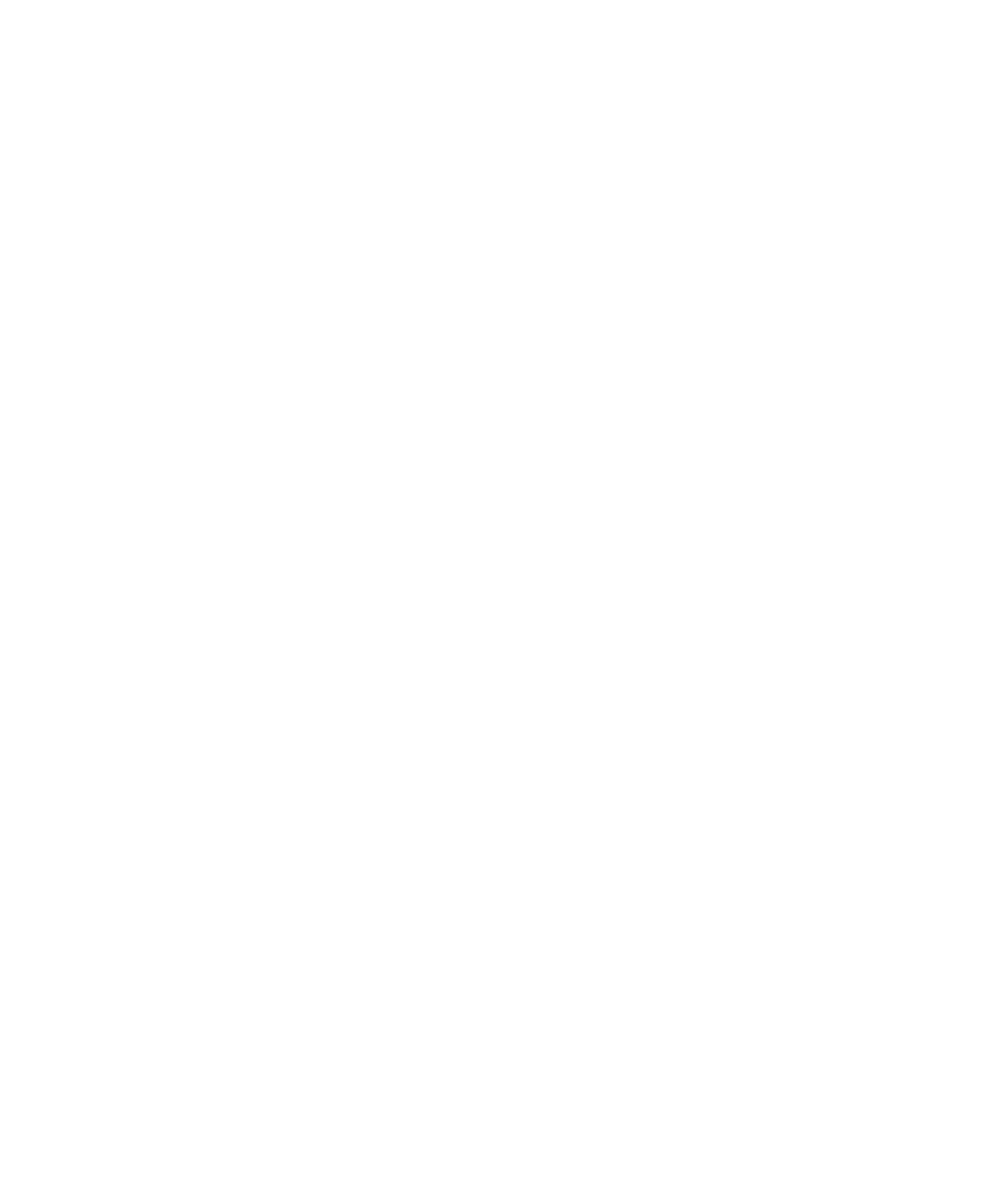

FIGURE 46.-Dissolved-solids concentration and discharge and water discharge at four daily stations in the Colorado River Basin above the Gunnison River, 1956 water year. 


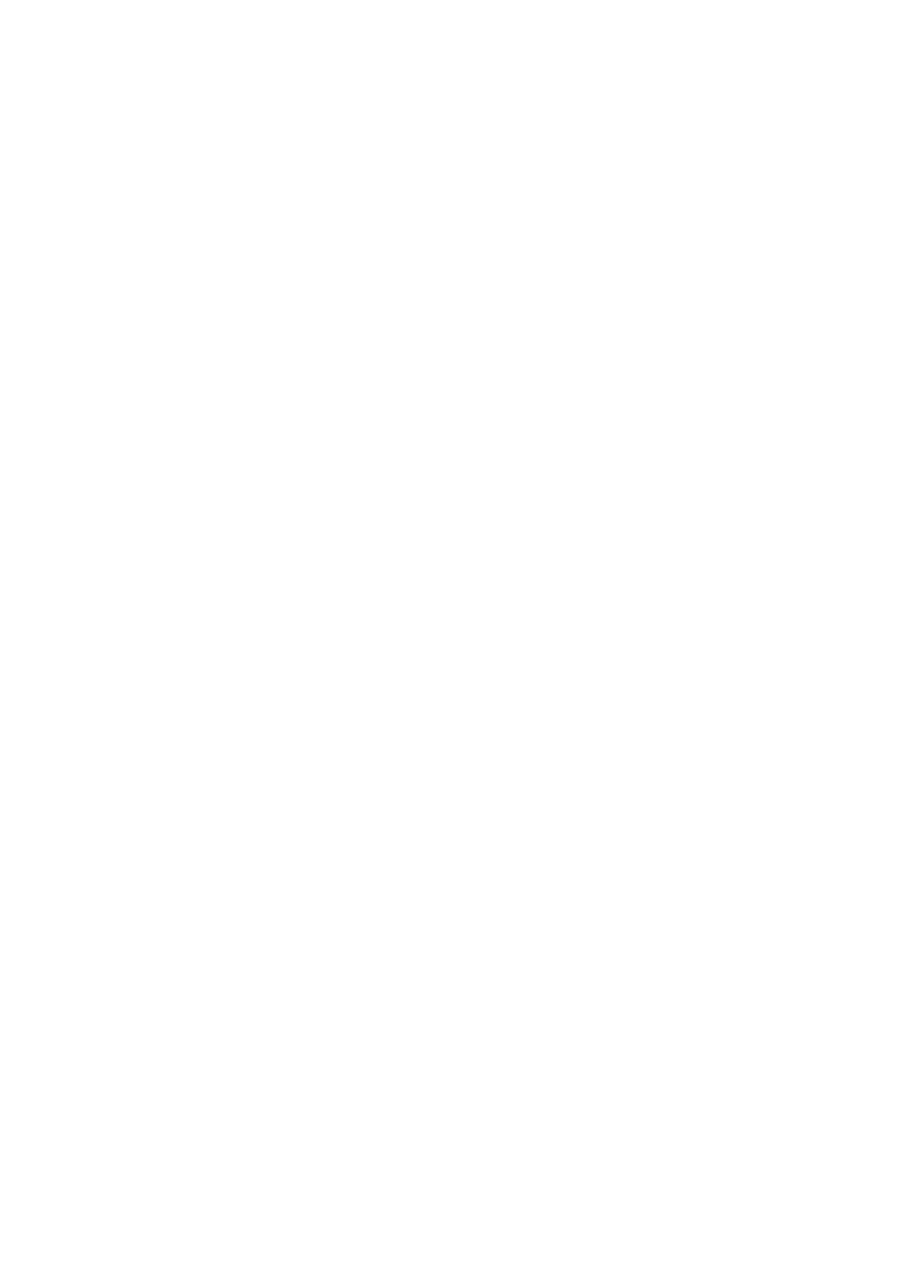

FIGURE 47.-Relation of dissolved-solids concentration to water discharge, Colorado River at Hot Sulphur Springs, Colo. 


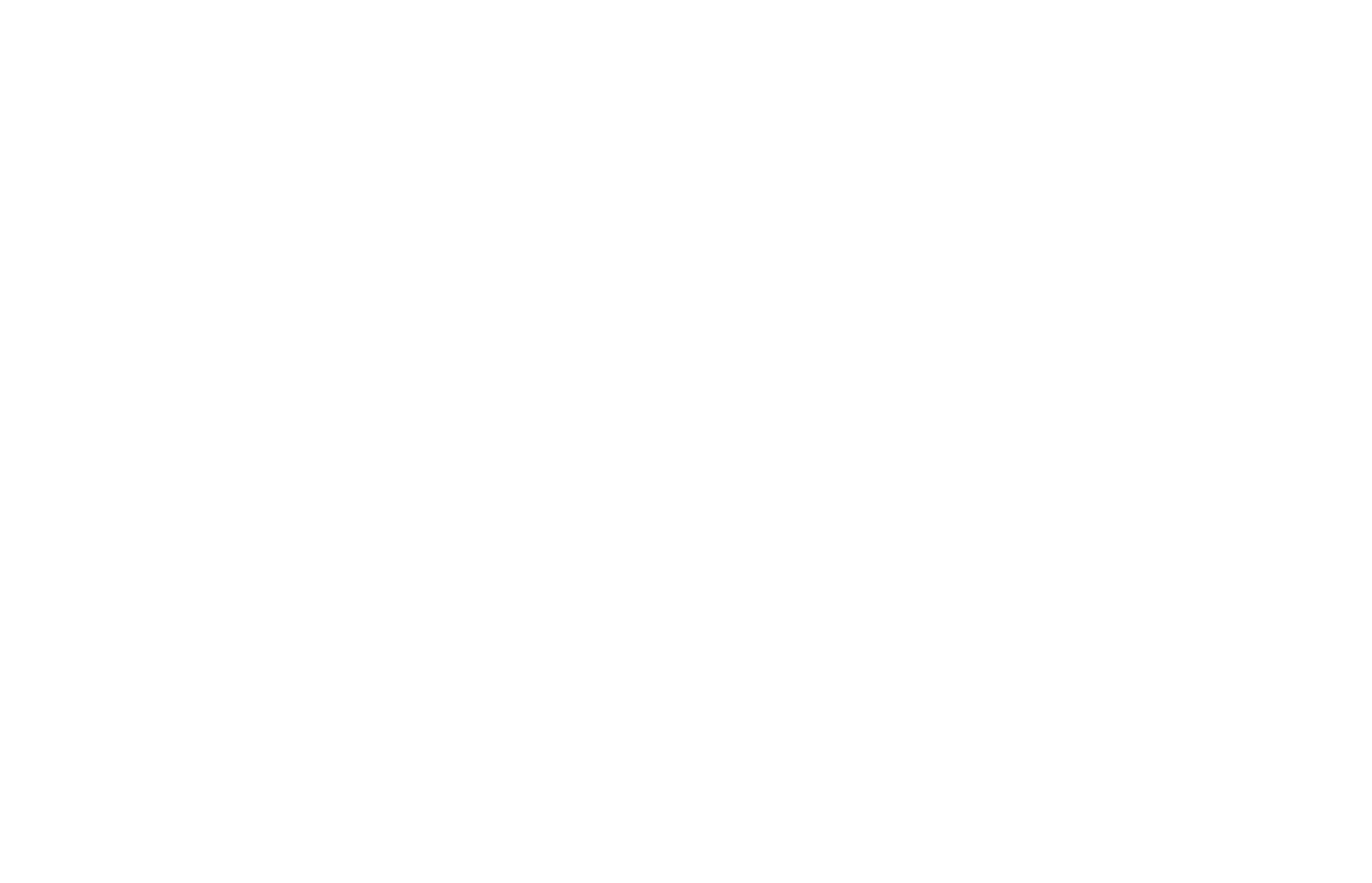

Figure 48.-Effect of the Colorado-Big Thompson project on the dissolved-solids concentration at Colorado River at Hot Sulphur Springs, Colo. Storage in Granby Reservoir began in September 1949.

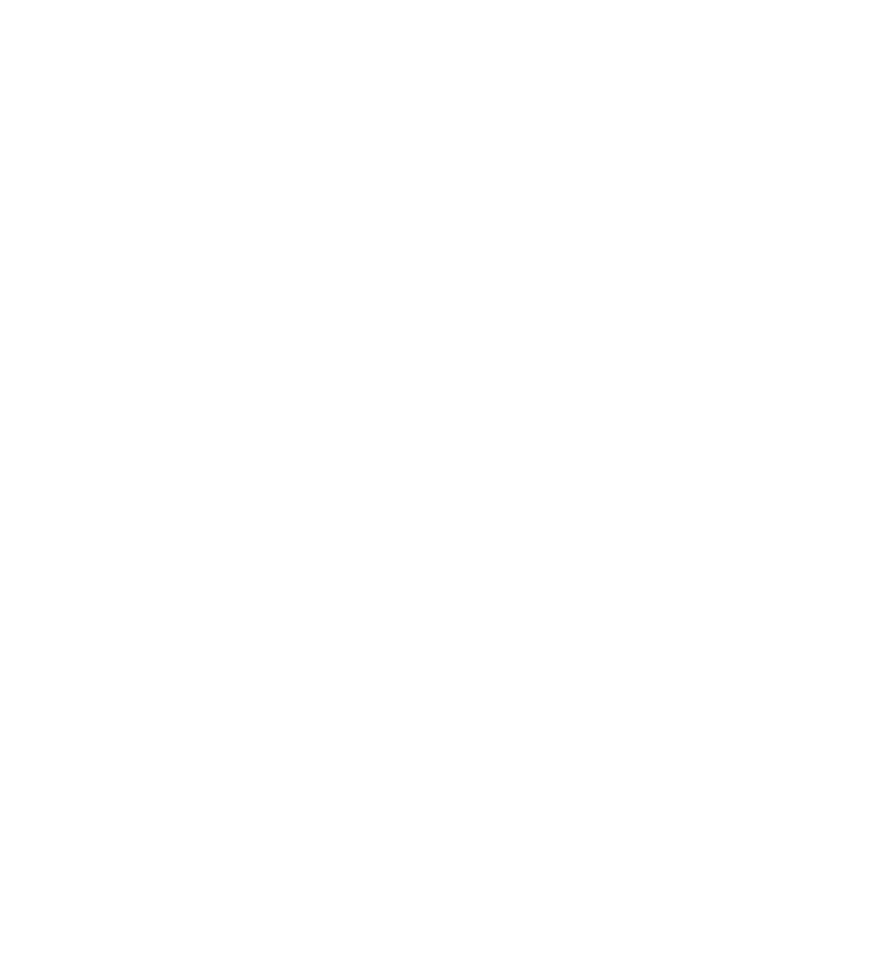

OR EXCEEDED INDICATED AMOUNT

FiguRe 49.-Historical flow-duration curve for water years 1914-57 (upper curve) and flow-duration curve for water years 1914-57 adjusted to 1957 conditions (lower curve) for Colorado River at Hot Sulphur Springs, Colo. Difference between the two curves is due to the effect of increasing upstream developments.

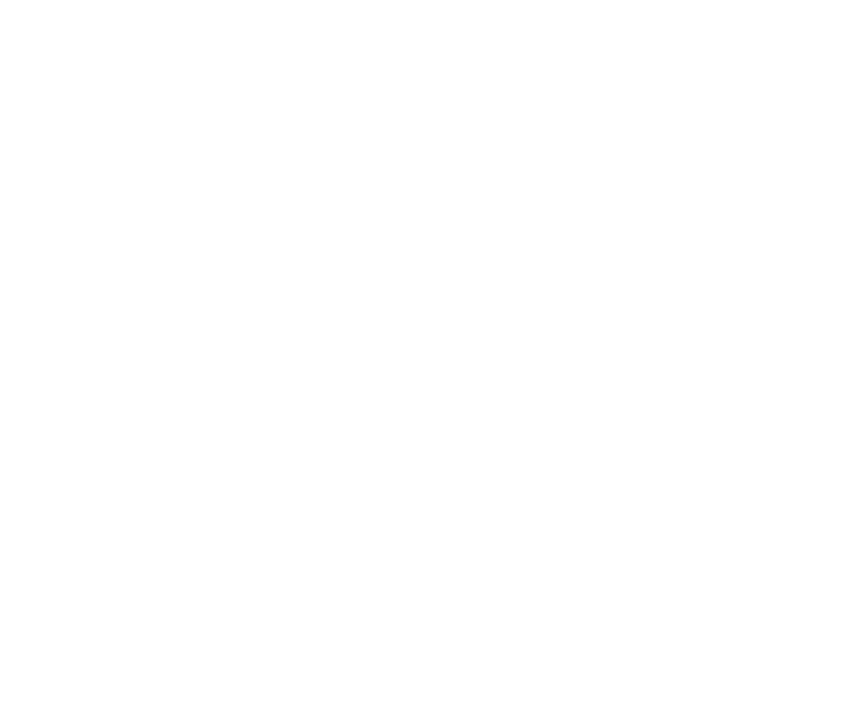

FIGURE 50.-Historical duration curve of dissolved-solids discharge for water years 1914-57 (upper curve) and duration curve of dissolved-solids discharge for water years 1914-57 adjusted to 1957 conditions (lower curve) for Colorado River at Hot Sulphur Springs, Colo. Difference between the two curves is due principally to increasing transportation of water out of the basin.

Big Thompson project. The lower curve was based on the flow-duration curve for water years 1914-57, adjusted to 1957 conditions, and the relation between dissolved-solids concentration and water discharge for water years 1950-57. The lower curve in tabular form is given in table 16 . 
The difference between the historical and the adjusted curves in figures 49 and 50, though an approximate measure of conditions before and after construction, illustrates an effect of transmountain diversions.

The relations between streamflow and chemical composition of water at four of the five daily chemicalquality stations in the subbasin are given in table 19 and illustrated in figure 51. The data in the table are based on tables of monthly and annual summaries of chemical analyses in the basic data report (Iorns and others, 1964, tables 175 and 177-179). The mean monthly discharges, in cubic feet per second, were plotted against the monthly weighted-average concentrations of the different constituents, in parts per million, and curves averaging the plotted points were drawn. Water discharges for which values were picked from the curves are the same as those shown in the flow-duration tables for the stations. Duration tables of dissolved-solids constituents may be prepared by using the values in tables $6,15,16$, and 19 . In table 19 the water discharges equaled and exceeded 12,50 , and 90 percent of the time are indicated.

\section{RELATION TO GEOLOGY}

The headwaters of the Colorado River and its principal tributaries above the Gunnison River are underlain by rocks that are relatively resistant to the solvent action of water. These rocks are predominantly granite and associated metamorphic rocks. Other rocks that underlie large areas in the headwaters are volcanic rocks of Tertiary and Quaternary ages and sedimentary rocks of Tertiary age, which were derived mostly from the older igneous and metamorphic rocks.

Because these metamorphic, granitic, and volcanic rocks are composed mostly of minerals of similar composition, surface waters from the areas that are underlain by them are similar in chemical composition and differ chiefly in the total amount of dissolved solids. The most dilute waters are from the high mountain areas that are underlain by granitic and metamorphic rocks. Water from these areas of high precipitation may contain less than $20 \mathrm{ppm}$ of dissolved solids. The weighted-average concentration at any point in the headwaters does not exceed $100 \mathrm{ppm}$ and seldom exceeds $50 \mathrm{ppm}$ (table 14).

The waters of the streams in the headwaters are of the calcium bicarbonate type (see glossary, chap. B, for method of classification of water type), but the more dilute waters may contain substantial percentages of sodium and sulfate ions. The concentration of silica ranges from about 6 to $15 \mathrm{ppm}$ and averages about 12 ppm, except for the streams that drain areas underlain by volcanic rocks, which contain siliceous minerals that are more soluble than those found in granitic rocks. The concentration of silica for streams that drain areas underlain by volcanic rocks may exceed 40 $\mathrm{ppm}$, at times, and averages about $25 \mathrm{ppm}$.

The middle and lower reaches of the principal tributaries are underlain mostly by sedimentary rocks such as limestone, sandstone, siltstone, and shale. These rocks contain minerals that are more readily soluble than those in the rocks that underlie the headwaters. Consequently, the dissolved-solids concentrations of the streams increase progressively downstream.

Downstream from the headwaters, in the upper parts of areas underlain by sedimentary rocks, the waters are mostly of the calcium bicarbonate type. However, at downstream points the water contains progressively larger proportions of magnesium, sodium, sulfate, and chloride.

Broad zones of weighted-average concentration of dissolved solids have been delineated. Within these zones, weighted-average concentrations in the surface waters are between certain limits (fig. 52). These zones indicate that most surface waters have a weightedaverage concentration of dissolved solids of less than $300 \mathrm{ppm}$, and almost none have a weighted-average concentration greater than $800 \mathrm{ppm}$.

The diagrams shown in plate 2 show the geochemical character and ionic concentration of surface waters at many sites. The diagrams are representative of the chemical character of the streams during low flow, when the effect of geology on chemical quality is more evident than during high flow. The significance of the size and shape of the diagrams is given in the explanation on plate 2 .

The principal environmental factor affecting the dissolved-solids concentration and chemical composition of the stream waters in any area seems to be the types of rocks that underlie each area. The effect of this factor is, of course, modified by the other factors. Comparisons of the zones shown in figure 52 with the different rock units and the precipitation map shown in plate 1 reveal the similarity between the distribution of the different zonal patterns of concentration and the areal distribution of the underlying rocks and of precipitation.

\section{RELATION TO GROUND WATER}

Chemical analyses of ground water are given in the basic data report (Iorns and others, 1964, table 227). These data are insufficient to permit a detailed appraisal of the effect of ground water on the surface water in the subbasin, but some of the relationships between the quality of water in the ground-water reservoirs and in the streams can be pointed out.

Ground-water flow to the streams comes from ground-water reservoirs recharged by precipitation, from alluvium bordering the streams that is recharged 


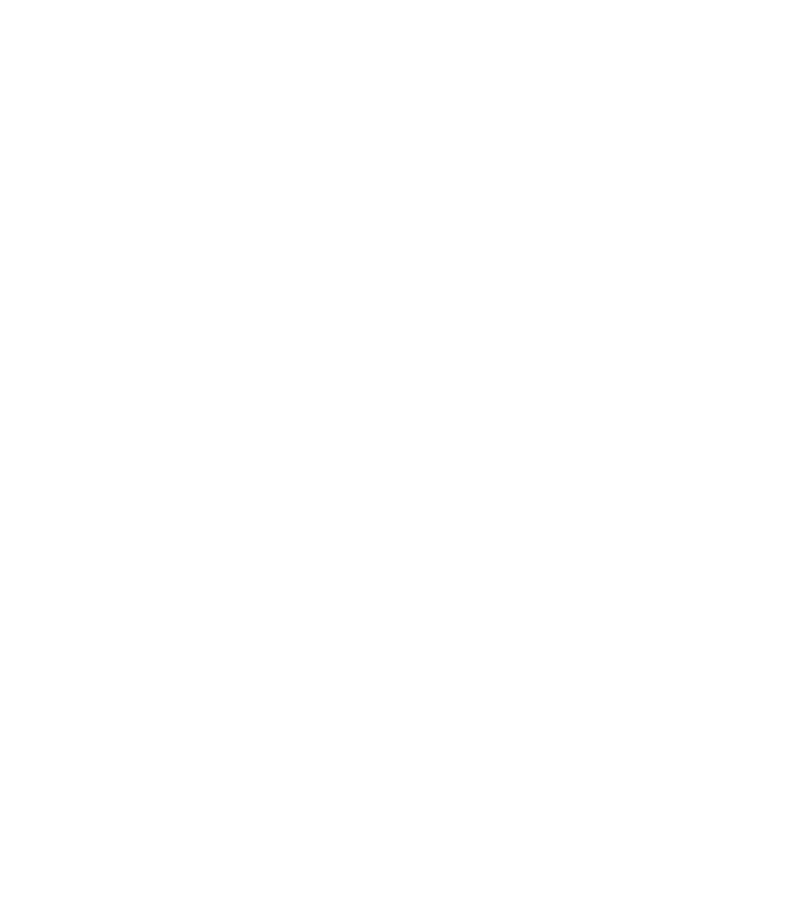

A. Colorado River near Cameo, Colo.
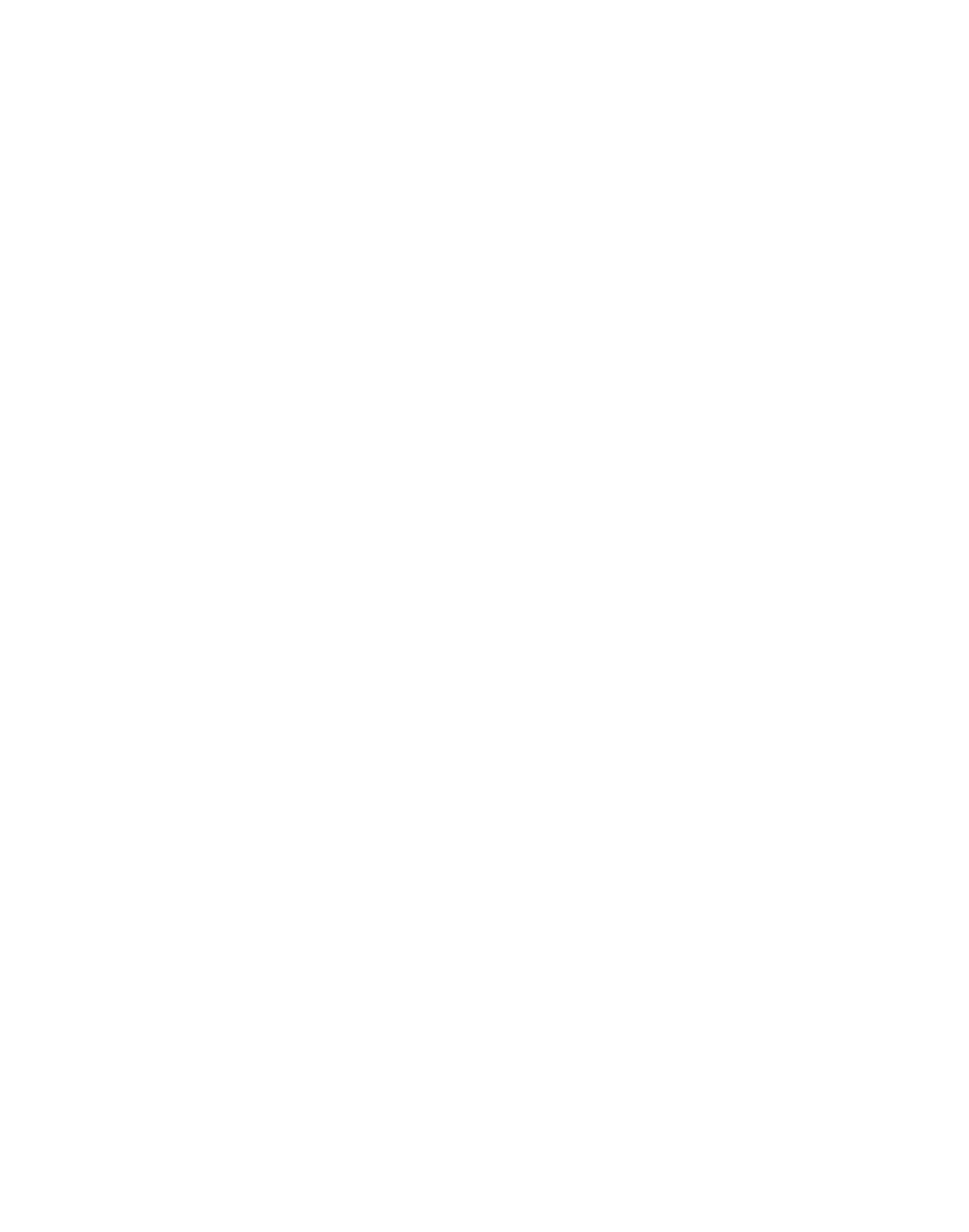

FiguRE 51.-Relation of the chemical composition and concentration of dissolved solids to water discharge in the Colorado River Basin above the Gunnison River. The concentration of specific ions, in equivalents per million (epm), is shown for the 10th, 50th, and 90th centiles of the flow-duration curve for each location. The flow-duration curves are for water years 1914-57 adjusted to 1957 conditions. 

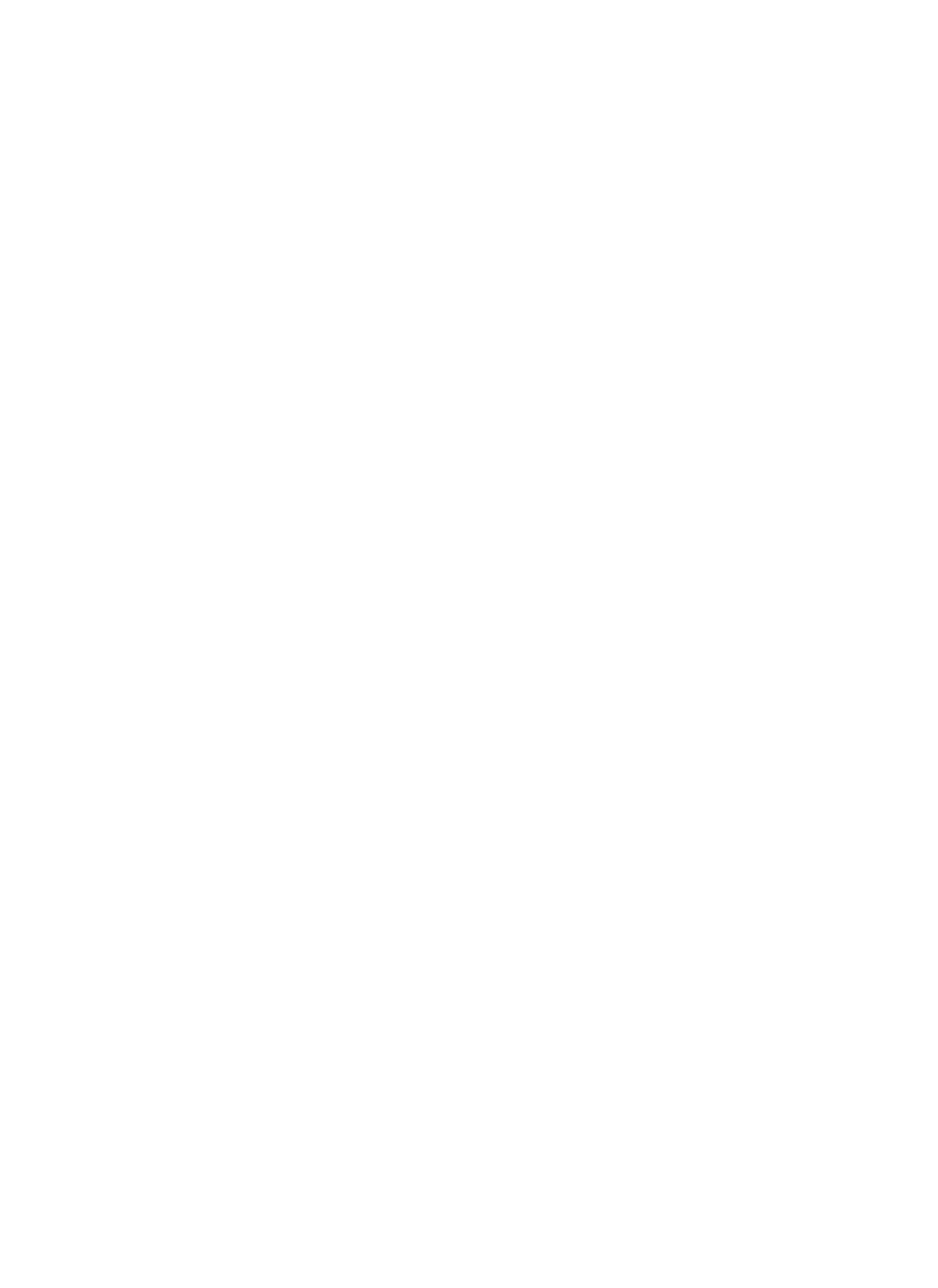
from the streams, from thermal springs, and from ground-water return flow from irrigated lands. The chemical quality of the ground water entering the streams from these sources greatly influences the chemical quality of the water in the streams. During periods of low flow, most of the stream water is effluent ground water and thus is a mixture of all ground water entering the stream system above the point of observation.

Extensive ground-water reservoirs are present in the mountainous areas where precipitation is abundant. Quantitative estimates of the amount of dissolved solids carried into selected headwater streams by water discharged from these reservoirs are given in table 20 . These figures are based on the amount of water estimated to be contributed to the streams from groundwater reservoirs and the dissolved-solids concentration of the water in the streams during the times that the flow is maintained principally by ground water. (See chap. B, p. 59.) Comparison of the weighted-average concentration of dissolved solids in the ground water with the weighted-average concentration of dissolved solids in the stream shows that the ground water almost invariably has a higher concentration than the surface water.

A close similarity commonly exists between the chemical composition of water in flood-plain alluvium and that of the water in the stream. Both the river water and the water in the alluvium are a mixture of surface and ground water because of the interchange of water between the stream and the alluvium. The interchange may be due to the rise and fall of the stream or to the application of water to irrigated lands along the river. The chemical quality for low flow shown in figure 51 is probably representative of a mixture of all the ground water that enters the streams above each station.

Water from a well dug 18 feet into alluvium along the Colorado River below the Fraser River had a dissolved-solids concentration of $253 \mathrm{ppm}$. Both the ground water and the surface water in the immediate vicinity are of the calcium bicarbonate type. The concentration of the water in the alluvium is greater than the concentration of the water of the Colorado and Fraser Rivers nearby. Also, the water from the well had a higher percent sodium and greater percentage of sulfate than the surface water. Any water that flows into the Colorado River from the alluvium near this well would cause an increase in the concentration of the river water at all times of the year.

Water from a shallow well in alluvium on the north side of the Colorado River east of Kremmling has a chemical composition similar to that of Troublesome Creek near its mouth (fig. 53). The concentration of

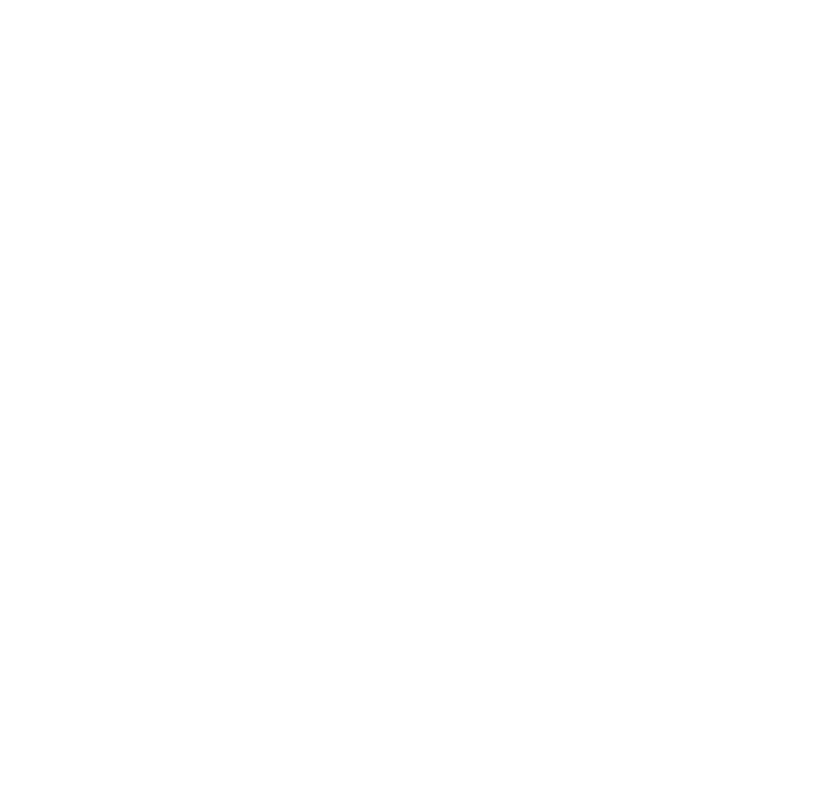

Figure 53.-Analyses of water from Troublesome Creek near Troublesome, Colo., and from alluvium nearby.

the ground water at the well is only slightly higher than that of Troublesome Creek during low flows.

Analyses of water from a spring and from a well at Gore Pass Ranch in the valley of Pass Creek, a tributary of Muddy Creek, illustrate the differences in the chemical character of ground water that may exist within one small area. The water from the spring, which rises out of alluvium that overlies shale of Cretaceous age, had a dissolved-solids concentration of $290 \mathrm{ppm}$ and is of the calcium bicarbonate type. The water from the well, which is reportedly drilled in alluvium overlying the shale, had a concentration of $848 \mathrm{ppm}$ and is of the calcium sulfate bicarbonate type. Apparently the chemical quality of the water in the well is affected by the shale, whereas the spring water is affected sparingly, if at all, by that rock. In chemical composition and concentration the spring water closely resembles water from a well that penetrates the granite complex to the south and along the east side of the Gore Range.

In the subbasin many thermal springs, some of which have substantial concentrations of saline minerals, add their waters to the streams. Six thermal springs at Hot Sulphur Springs, Colo., have dissolvedsolids concentrations of about 1,600 to $1,700 \mathrm{ppm}$ (George and others, 1920). The water of the springs is of the sodium bicarbonate type. One spring is reported to discharge $75 \mathrm{gpm}$ (gallons per minute) and another, $10 \mathrm{gpm}$. Though data are not available on the discharge of the other springs, the total discharge of all the springs probably does not exceed $100 \mathrm{gpm}$. 
At this rate, the springs would discharge less than 400 tons of dissolved solids to the Colorado River annually.

In the Blue River basin near Dillon, Colo., four thermal springs discharge about $8 \mathrm{gpm}$ of water having a dissolved-solids concentration of 1,300 to $1,800 \mathrm{ppm}$ (George and others, 1920). These springs add about 27 tons of dissolved solids annually to the Blue River.

Two thermal springs below Dotsero, which discharge a total of about $1 \mathrm{cfs}$, have an average concentration of dissolved solids of about $10,700 \mathrm{ppm}$ of which 88 percent is sodium chloride. At Glenwood Springs nine thermal springs discharge about $5 \mathrm{cfs}$. The average dissolved-solids concentration of these springs is about $20,200 \mathrm{ppm}$, of which about 87 percent is sodium chloride (Iorns and others, 1964, table 227). These 11 springs discharge about 91,300 tons per year of sodium chloride. In addition to these springs, there is evidence that other thermal springs rise in the bed of the river.

The dissolved-solids discharges of the Colorado River at the stream-gaging station near Dotsero, Colo., and at the chemical-quality station near Glenwood Springs (at Shoshone powerplant 6 miles upstream from Glenwood Springs) have been computed (table 14). As shown by the dissolved-solids discharge at the two sites, the increase in dissolved solids in the river reach is about 197,200 tons per year, most of which must be contributed by thermal springs rising in or near the bed of the stream. The amount of the contribution from the thermal springs may be approximately computed.

Between the gaging stations near Dotsero and at Glenwood Springs, Colo., the average increase in discharge is 152 cfs (table 14). On the basis of drainage area, about half the increase in surface flow would be tributary to the river above the quality station near Glenwood Springs. Chemical analyses of streams that enter the Colorado River in the reach indicate that the concentration of dissolved solids in the surface inflow would probably be less than $200 \mathrm{ppm}$. If we assume that the increase in streamflow between the gaging station near Dotsero and the quality station near Glenwood Springs is $76 \mathrm{cfs}$, that the concentration of the surface inflow is $200 \mathrm{ppm}$, and that the concentration of the ground-water inflow is $10,700 \mathrm{ppm}$ (average of the two springs below Dotsero), then the ground-water discharge would be about $17 \mathrm{cfs}$. On the other hand, if we assume that the concentration of the ground-water inflow is $20,200 \mathrm{ppm}$ (average of nine springs at Glenwood Springs), the ground-water discharge would be about 9 cfs. Either rate of ground-water discharge, with its respective dissolved-solids concentration, gives about 182,600 tons per year of dissolved solids as the amount contributed by ground water to the river be- tween the stations near Dotsero and near Glenwood Springs. On the basis of percentage of sodium chloride at the two groups of springs, 160,700 tons per year of the dissolved-solids contribution is sodium chloride.

The water discharge of Colorado River at Glenwood Springs, Colo. (drainage area $4,560 \mathrm{sq} \mathrm{mi}$ ), was used in computing the dissolved-solids discharge at the quality station near Glenwood Springs (drainage area $4,486 \mathrm{sq}$ mi, table 14 ). The small amount of inflow between the two stations would have little effect on the computation of dissolved-solids discharge in table 14 or the preceding determinations.

Thermal springs below the quality station near Glenwood Springs also discharge large quantities of dissolved solids, mostly sodium chloride, into the Colorado River. Between the daily quality stations near Glenwood Springs and near Cameo, exclusive of the Roaring Fork basin, an average of 639,200 tons per year of dissolved solids are added to the stream (table 14). About 252,000 tons per year of this increase is sodium chloride. This determination was based on the a verage tons of sodium chloride transported past the station on Colorado River near Cameo, Colo., less the sodium chloride contributed by Colorado River near Glenwood Springs, Colo., and Roaring Fork at Glenwood Springs, Colo. Chemical analyses of water from the tributary streams in the reach indicate that most of the sodium chloride must come from ground-water inflow, most of which is probably from thermal springs.

In the Roaring Fork basin, thermal springs occur on Conundrum Creek, Fryingpan Creek, and Crystal River (George and others, 1920; Stearns and others, 1937). The springs on Conundrum Creek (about 18 miles south of Aspen, Colo.) have a dissolved-solids concentration of about $2,300 \mathrm{ppm}$ and a discharge of less than $500 \mathrm{gpm}$. Those on Fryingpan Creek (below Norrie, Colo.) have a dissolved-solids concentration of about 2,200 ppm, and the discharge, though unknown, is reported to be large. The springs on the Crystal River, about 4 miles north of Redstone, Colo. (Avalanche Springs), have dissolved-solids concentrations ranging approximately from 2,000 to $3,100 \mathrm{ppm}$ and range in discharge from 1 to $100 \mathrm{gpm}$. The weightedaverage concentration of dissolved solids of the Avalanche Springs is about 2,700 ppm, and the total discharge is estimated to be less than $300 \mathrm{gpm}$. Assuming that the discharge of the springs on Fryingpan Creek is $500 \mathrm{gpm}$, the total dissolved-solids discharge of all the thermal springs in the Roaring Fork basin would be about 6,700 tons annually.

Four thermal springs in the Plateau Creek basin near Mesa, Colo., discharge from 1 to $50 \mathrm{gpm}$ (George and others, 1920). The weighted-average dissolvedsolids concentration of these springs is about 2,500 
$\mathrm{ppm}$, and the total discharge is $\mathbf{5 8} \mathbf{g p m}$. At these rates, the springs discharge about 320 tons of dissolved solids annually.

The combined discharge of all the known thermal springs in the subbasin (including those rising in the bed of the Colorado River) probably does not exceed $50 \mathrm{cfs}$, but the dissolved-solids discharge of the springs may be as much as 476,000 tons annually. This dissolved-solids discharge is about 30 percent of the combined dissolved-solids discharge of Colorado River and Plateau Creek near Cameo, Colo.

\section{EFFECT OF TRANSMOUNTANN DIVERSIONS}

The weighted-average concentration of dissolved solids in water diverted through the Alva B. Adams Tunnel near Grand Lake, Colo., was computed to be $35 \mathrm{ppm}$. An average of about 250,000 acre-feet of water annually was diverted or stored for diversion by this tunnel and appurtenant works in the water years 1954 57. This amount would normally be a part of the flow of Colorado River at Hot Sulphur Springs, Colo. Under conditions existing in the 1957 water year, the weighted-average concentration at Colorado River at Hot Sulphur Springs, Colo., was computed to be 76 ppm and the average annual discharge, 176,800 acrefeet (table 14). If the water now diverted through the tunnel still flowed past Hot Sulphur Springs, the weighted-average concentration in the water would be $62 \mathrm{ppm}$. (See chap. B, p. 61.) Records of the chemical quality of Colorado River at Hot Sulphur Springs, Colo., show that $62 \mathrm{ppm}$ is about the same as computed for the short period the station was in operation before storage and diversion began.

Table 21 gives the estimated average annual amounts of water diverted out of the basin for the level of development existing upstream in 1957 and the weightedaverage concentration of dissolved solids in the diverted water. With these data and those in table 14, the effect of the transmountain diversions on the quality of water for other streams and locations may be computed. For example, under conditions existing in 1957, about 353,100 acre-feet of water having a weighted-average concentration of $37 \mathrm{ppm}$ was being diverted from this subbasin annually. The dissolved solids in the diverted water would amount to about 17,800 tons annually. The average annual discharge of Colorado River near Cameo, Colo., is 2,998,000 acre-feet, and weighted-average concentration is $387 \mathrm{ppm}$ for water years $1914-57$ adjusted to 1957 conditions. If there were no transmountain diversions, the average annual discharge would be about $3,351,100$ acre-feet, and the weightedaverage concentration would be about $350 \mathrm{ppm}$, or 37 ppm less than under 1957 conditions.
The average annual discharge of Colorado River and Plateau Creek near Cameo, Colo., is 3,168,200 acrefeet, and the weighted-average concentration is 382 ppm for water years $1914-57$ adjusted to 1957 conditions. If there were no transmountain diversions, the combined average annual discharge of the two streams would be about 3,521,300 acre-feet, and the weightedaverage concentration would be about $347 \mathrm{ppm}$, or 35 ppm less than under 1957 conditions.

\section{EFFECT OF THE ACTIVITIES OF MAN}

Sufficient data are available for several areas in the subbasin to provide a fairly reliable basis for computing the amounts of dissolved solids contributed to the streams as a result of the activities of man. In chapter B (pp. 61-66) the general procedures for making the determinations are discussed. In that discussion the dissolved-solids contributions to the Fraser River were used as an example. The following paragraphs briefly outline the data and computations for three other areas. Table 22 gives a budget of the water and dissolved solids contributed to and discharged from the area below Lake Granby and Willow Creek Reservoirs and above Hot Sulphur Springs.

Consumptive use on 5,500 acres of irrigated land in the intervening area is taken as 1.0 acre-foot per acre, according to relative altitude and mean temperature. Of the intervening area $(50 \mathrm{sq} \mathrm{mi})$ about 12 square miles $(7,600$ acres $)$ is valley land, and about 38 square miles is mountainous. It is estimated that under natural conditions, the 7,600 acres of valley land would receive an average yearly ground-water recharge of about 4 inches, which would be effluent to the stream system. The estimated range of dissolved-solids concentration of this ground-water inflow is based on chemical analyses of water from a well on the north side of the Colorado River near the mouth of the Fraser River $(253 \mathrm{ppm})$, of Fraser River at Granby at times of low flow (100 ppm), and of Colorado River at Hot Sulphur Springs at times of low flow (108 ppm).

The unmeasured surface-water inflow from the 32 square miles of mountainous terrain is the amount required to balance the inflow-outflow budget $(16,000$ acre-feet). Part of this area is underlain by rocks similar to the drainage area above Granby Dam, and part is underlain by rocks similar to the drainage area above the Willow Creek Reservoir. The weightedaverage concentrations of dissolved solids in runoff from these two areas are 35 and $65 \mathrm{ppm}$, respectively. Accordingly, it is presumed that the weighted-average concentration of the intervening runoff would probably be in the same range.

Substantially all the indicated increase in dissolved solids within the intervening area-5,600 to 6,800 tons 
per year-is presumed to be the effect of irrigation. The smaller figure is equivalent to 1.0 ton per acre per year.

The second of the areas is the Troublesome Creek basin (table 22). In this budget, inflow is measured from 126 square miles and estimated for an intervening 52 square miles above the outflow station. Total unmeasured inflow of surface and ground water from the 52 square miles is the amount necessary to balance the outflow budget and estimated to be three-fourths surface water $(4,800$ acre-ft) and one-fourth effluent ground water (1,600 acre-ft). This proportion is based on the average annual precipitation in the area (about 14 in.), the nature of the underlying rocks and soils, and general topographic features. Because the rocks that underlie the intervening area are about the same as those above the two inflow stations, the dissolvedsolids concentration of the unmeasured surface water would range somewhere between the weighted-averages for the two inflow stations. The natural concentration of the effluent ground water would probably range from about 75 to $120 \mathrm{ppm}$, as indicated by analyses of water from streams in the area during low flow (Troublesome Creek near Pearmont, 77 ppm, and East Fork Troublesome Creek near Troublesome, $112 \mathrm{ppm}$ ).

Water consumed on the intervening irrigated land is presumed to average 0.7 foot over the 8,000 acres of valley land involved. This relatively small consumption is compatible with the climatic environment and altitude of the irrigated lands-about 9,000 feet above sea level.

Substantially all the indicated increase in dissolved solids-not less than about 3,700 tons per year-is inferred to be an effect of irrigation. This increase is equivalent to about 0.5 ton per year per acre of irrigated land.

The third area is the Roaring Fork basin (table 23). In this area, four stations determine inflow from 486 square miles (see table 14); the intervening ungaged area, above the outflow station at Glenwood Springs, is 974 square miles. Being so extensive, this intervening area will be first considered according to the nature of underlying rocks and second, according to distribution of valley lands.

Granitic and Precambrian rocks underlie the drainage basins above the two inflow stations-Roaring Fork near Aspen and Fryingpan Creek at Norrie - and an equally extensive area within the ungaged intervening area. Being similar in mean altitude and other environmental features, the gaged and ungaged areas underlain by granitic and Precambrian rocks are presumed to yield water and dissolved solids in equal yearly amounts $(171,700$ acre-ft of water and 6,100 tons of dissolved solids, each).
Of the remaining intervening area, which is underlain by diverse rocks of sedimentary and volcanic origin, about 144 square miles is valley land and 918 square miles is mountainous terrain of which 282 square miles is above the gaging stations on Castle Creek near Aspen and Crystal River near Redstone. Valley lands in the vicinity of Aspen (about $50 \mathrm{sq} \mathrm{mi}$ ) at altitudes generally more than 7,500 feet receive an annual precipitation of about 25 inches of which 7 inches is estimated to become ground-water recharge effluent to the stream system. In the lower part of the basin in the vicinity of Carbondale, at an altitude of about 6,000 feet, about 94 square miles of valley land receives an annual precipitation of about 18 inches of which about $4 \frac{1}{4}$, inches a year is estimated to become effluent ground water. Thus, natural ground-water inflow from valley lands underlain mostly by sedimentary rocks would total about 40,000 acre-feet annually. Chemical analyses of water from two wells in the area showed dissolvedsolids concentrations of 404 and $744 \mathrm{ppm}$. The dissolved-solids concentration of Roaring Fork at Glenwood Springs at low flow is about $500 \mathrm{ppm}$ and that for Sopris Creek at low flow is about $450 \mathrm{ppm}$. However, the water in the wells may be more dilute than under natural conditions because of the application of large amounts of irrigation water; and the waters in the streams at times of low flow may not be indicative of natural ground water effluent from the valley lands because of dilution by water from headwater streams. For these reasons, a probable range in weighted-average concentration of dissolved solids of natural ground water from 400 to $900 \mathrm{ppm}$ is used, though the higher limit is about $150 \mathrm{ppm}$ greater than the maximum indicated by available data.

Water consumed on irrigated land is estimated at 1.1 feet per year from 31,400 irrigated acres, or 34,540 acre-feet yearly.

Unmeasured surface-water inflow from the mountainous part of the intervening area that is underlain by sedimentary and volcanic rocks is the amount which, with all other inflow items, will balance the outflow budget. The amount is 285,110 acre-feet a year. The dissolved-solids concentration of this last inflow item is taken as $160 \mathrm{ppm}$-that is, equal to the concentration of Castle Creek and the Crystal River after adjustment for thermal-spring water received by these two streams.

Excluding a nominal amount probably due to pickup of domestic and industrial wastes, the indicated increase in dissolved solids within the intervening area is considered an effect of irrigation. Per irrigated acre, this increase would be at least 3.0 tons per year.

The activities of man in other parts of the subbasin not included in the tabulations are estimated to result in a contribution of 297,100 tons of dissolved solids 
annually. This estimate is based on the indicated rates of dissolved-solids yield per acre of irrigated land for the areas in the preceding tabulations and for other areas in the Upper Colorado River Basin, the geologic character of the formations underlying irrigated lands, and chemical analyses of water at miscellaneous sites in the subbasin. It was assumed in the estimate that the distribution of population and industry were approximately proportional to the distribution of irrigated lands. Table 24 summarizes, at gaging stations and for the subbasin, data on dissolved solids contributed by natural sources and as a result of the activities of man. About 402,000 tons of the 1,644,100 tons of dissolved solids discharged annually from the subbasin are contributed as a result of the activities of man. The natural dissolved-solids discharge from the subbasin averages about $1,242,100$ tons annually.

Had there been no activities of man, the weightedaverage concentration of dissolved solids in the water flowing out of the basin would have been about 272 ppm, as compared to a weighted average of $382 \mathrm{ppm}$ for water years 1914-57 adjusted to 1957 conditions. This figure is based on annual consumptive use of 1,800 acre-feet of the water withdrawn for domestic and industrial purposes and 190,300 acre-feet of the water used in irrigation.

The increase in dissolved solids due to irrigation may be approximately determined. If 100 tons per year per 1,000 people is assumed as the rate of contribution resulting from domestic and industrial water uses in the basin, the annual contribution would amount to about 2,620 tons of dissolved solids. This would leave a balance of about 399,600 tons per year as resulting from irrigation.

\section{FLUVIAL SEDIMENT}

Sediment records obtained by the U.S. Forest Service on two small tributaries of St. Louis Creek in the Fraser Experimental Forest in 1950-52 (Raymond Price, written commun., 1960) give some indication of the sediment contributed from forested lands. The concentration of suspended sediment in these streams indicated that the sediment transported by streams that drain similar areas would be about 36 tons per square mile per year. The drainage basin of St. Louis Creek is underlain by Precambrian rocks, such as schist and gneiss, and by glacial debris derived from these rocks.

Only one suspended-sediment station has been operated in the Colorado River Basin above the Gunnison River. This station, Colorado River near Kremmling, Colo., was operated for intermittent periods in 1905 and 1906. Because of the changes that have occurred upstream from this station since that time, this record is not as useful for indicating the probable sediment load under present conditions. However, if the Colorado River carried sediment in about the same concentration at the end of 1957 as it did in 1905-06, an average of about 186,000 tons per year would be transported past the station.

The sediment transported by the Colorado River at the Kremmling station, with the conditions of upstream development that existed in 1957 , is at least 40,000 to 50,000 tons a year less than in 1905-06. Lake Granby and the Willow Creek, Williams Fork, and Green Mountain Reservoirs now trap the sediment that is removed from about 1,330 square miles of drainage area above the Kremmling station.

Estimates of the suspended-sediment discharge for other streams where suspended-sediment samples have been collected are given in table 25. (See chap B. p. 66.) A relatively large part of the sediment transported past the station near Cameo, Colo., comes from the drainage area between that station and the Roaring Fork. This area contributes an average of about 4,710 tons per year per square mile of drainage area.

Most of the sediment transported in suspension in the streams above the Gunnison River is smaller than $0.062 \mathrm{~mm}$, or below sand size. Large amounts of sediment are probably transported by these streams on or close to the bed because the beds of the streams are composed of coarse material. No quantitative estimate can be made of the amount transported in this manner because of the lack of sediment data.

\section{SUITABILITY OF WATER FOR VARIOUS USES}

The following appraisals, based on chemical-quality criteria (see chap. B, pp. 66-73) indicate the general suitability of stream waters in the subbasin for domestic, agricultural, and industrial purposes. Pathological organisms which would require treatment of the water to make it bacteriologically safe for some uses, are not considered in the appraisal. The chemical analyses in the basic data report (Iorns and others, 1964) were used in appraising the suitability of water for various uses.

\section{DOMGSTIC USE}

Generally, all streams in the subbasin in their headwater areas, where most of the water supply is produced, are of good quality and satisfactory for domestic use. Downstream, the quality of water in the streams is not as good as in the headwaters. The water in the main stem of the river above Glenwood Springs, Colo., even during periods of low flow is satisfactory for domestic uses, but at the gaging station near Cameo the concentrations of sulfate, chloride, and total dis- 
solved solids at times exceed the maximum limits used in this appraisal.

Concentrations of dissolved solids in Muddy Creek in its lower reaches, the Eagle River as far upstream as Wolcott, and the Roaring Fork and Plateau Creek in their lower reaches also exceed the criteria for domestic use at times in periods of low flow. In addition, many of the smaller tributaries of these streams and of the main stem of the river between Glenwood Springs and Cameo are not satisfactory for domestic use in their lower reaches during periods of low flow. However, in any part of the subbasin, water satisfactory for domestic use is obtainable within a relatively short distance of the point of need. Table 26 shows the general suitability of water for domestic use in different parts of the subbasin.

Nitrate is present in most stream waters but usually in concentrations of less than $5 \mathrm{ppm}$. The waters in the streams range from soft to very hard.

\section{AGRICULTURAL USE}

Large quantities of water are used for irrigation in the subbasin. Water is also used for livestock, mostly sheep and cattle. Most livestock have the ability to tolerate relatively high concentrations of dissolved solids in their drinking water, although even small concentrations of certain constituents, such as selenium, are toxic. Most, if not all, of the surface water in the subbasin is suitable for livestock watering.

The suitability of surface water for irrigation varies from place to place. In table 27 the waters of the streams at many sites, for conditions of upstream development existing in 1957, are appraised as to their suitability for irrigation use. The criteria and methods used in the appraisal are given in chapter B (pp. 69-73). Chemical analyses for high, medium, and low flows in the basic data report (Iorns and others, 1964) were used for the appraisal. High flows are those greater than the flow exceeded 20 percent of the time; low flows are those less than the flow exceeded 80 percent of the time; and medium flows are those greater than the flow exceeded 20 percent of the time. The range of discharge for low, medium, and high flows for most of the sampling sites was determined from table 6 .

One to three determinations of residual sodium carbonate were made for almost 100 sampling sites on streams in this subbasin. These determinations show that most of the surface waters contain no residual sodium carbonate or extremely small amounts. The greatest amount determined was $0.69 \mathrm{epm}$ (equivalents per million) for Divide Creek at mouth, near Silt, Colo. This amount is considerably less than $1.25 \mathrm{epm}$, the upper limit for water considered generally safe for irrigation.
Surface waters in the subbasin range from C1-S1 to C4-S2 according to the criteria given in chapter B and to interpretation of plots of the relation of specific conductance to computed sodium-adsorption-ratio (SAR), as shown in figure 27, chapter B. Most of the water in this subbasin would be classified as $\mathrm{C} 2-\mathrm{S} 1$ or better. The U.S. Salinity Laboratory Staff (1954) states that C2-S1 waters can be used successfully for irrigation if a moderate amount of leaching occurs (usually less than 10 percent). Waters in this or a better category can be used on almost all soils with little danger of the accumulation of exchangeable sodium in harmful amounts.

Computations of the "required leaching" by Eaton's formulas (1954) show that for most of the surface water in the subbasin the required leaching for good yields would be less than 10 percent, except for the low flows of some streams. The greatest "required leaching" computed was 54 percent and was for a low flow of Roan Creek at De Beque. Even for low flows, a required leaching of more than 30 percent was com-puted for only a few sampling sites. These sites are at the mouths of Muddy, Rifle, and Roan Creeks.

Adverse effects of using irrigation water that has certain undesirable chemical properties can be partly offset by adding calcium sulfate (gypsum) to the fields or to the irrigation water. Computations show that most of the surface water above the Gunnison River needs less than 100 pounds of gypsum per acre-foot of applied water (table 27). Amounts of gypsum shown in table 27 are based on the assumption that all the calcium required to maintain a percent sodium of less than 70 to offset bicarbonate precipitation, or to supply calcium for plant assimilation, would have to come from the irrigation water. This assumption would, of course, not be applicable for most of the soils along the Colorado River and its tributaries above the Gunnison River. Most of the soils contain available calcium sufficient for plant uptake, and the addition of gypsum would not be necessary.

In summation, most of the surface waters of the Colorado River Basin above the Gunnison River can be used successfully for irrigation on most soils and for most crops if a moderate amount of leaching occurs. If the soils are such that the required leaching can take place, there is little danger of developing a saline soil or harmful levels of exchangeable sodium.

INDUSTRIAL USE

The surface water of the subbasin can be used in many industrial applications without further treatment. Comparisons of the chemical analyses of surface waters in the basic data report (Iorns and others, 1964) with the water-quality tolerances for many industrial 
uses given in chapter B (table 16) indicate that the waters will meet the requirements of most uses, especially if the water receives a minor amount of treatment.

Turbidity in water is due to suspended matter, such as clay, silt, sand, and organic material. The turbidity of many of the streams above the Gunnison River is usually low, but at times during the spring runoff and after storms the water from some of the streams would need to be clarified by filtering or by holding in settling basins before use. Some industries, such as those producing carbonated beverages or rayon, have very low tolerances for turbidity.

Industrial requirements for hardness in water vary greatly. The tolerance may be as low as $8 \mathrm{ppm}$, or even lower, for some boiler-feed water and as much as 200 $\mathrm{ppm}$ for water used in carbonated beverages, in brewing, and in distilling. Most industries, however, require a soft to moderately hard water. The water of many of the streams above the Gunnison River is soft to moderately hard and could be used for many industries without further softening.

Dissolved-solids concentration, $\mathrm{pH}$, and concentrations of iron, manganese, and silica are important factors in the suitability of a water for industrial use. The dissolved-solids concentrations of most of the streams above the Gunnison River do not exceed maximum tolerances for most industries. Those industries that have low tolerances for total dissolved solids could be located near, or obtain water from, the headwaters of most of the streams. The $\mathrm{pH}$ of surface water in the drainage basin above the Gunnison River ranges from about 6.7 to 8.3. However, most of the waters have a $\mathrm{pH}$ of 7.5 to 8 , which is within the tolerance range for $\mathrm{pH}$ of most industries. Water-quality tolerances of iron and manganese in water for industrial use are very low. The water from many of the streams in this subbasin would require treatment to remove these constituents before the water would be suitable for many industrial uses, such as most textile manufacturing.

Water-quality tolerances for many mining and metalfabrication industries are rather broad. Most of the surface waters in the subbasin would be satisfactory for these uses without further treatment.

\section{RECREATIONAL USE}

Use of water for recreation is expanding rapidly. The streams and lakes in the subbasin are mostly ideal for this purpose. The surface waters offer unlimited opportunities for trout fishing, and private and public lands that border the streams and lakes are rapidly becoming a national playground. Boating and swimming in the many natural and manmade lakes attest to the suitability of these surface waters for recreational uses.

\section{GUNNISON RIVER BASIN}

PRESENT UTILIZATION OF SURFACE WATER STORAGE RESERVOIRS

Ten reservoirs that have storage capacities greater than 1,000 acre-feet are in operation in the Gunnison River basin (table 3). The combined usable storage capacity of these reservoirs (1957) is 130,120 acre-feet, and all are used to store water for irrigation. Many small reservoirs, lakes, and stock ponds are scattered over the basin.

Most of the 10 reservoirs store water from the drainage basins in which they are located. However, Gould Reservoir receives part of its supply from Crystal Creek, and Fruitgrowers Reservoir receives its water supply from Surface and Currant Creeks.

\section{TRANSMOUNTAIN DIVERSIONS}

Three transmountain diversions export water out of the basin into the Arkansas and Rio Grande basins east of the Continental Divide. Table 28 lists the annual quantities exported by two of the diversions for the water years 1914-57. No records are available for the Tarbell ditch, which began diverting water in 1913. The average annual diversion by the Larkspur and Taber ditches for the 4 water years 1954-57 was 303 acre-feet.

Water is imported into the Surface Creek drainage basin from Leon Lake (Plateau Creek basin) and into the Uncompahgre River basin from Mineral Creek (San Juan basin). These diversions are small, and no records are available on the amount imported.

\section{IRRIGATION}

The major use of water in the Gunnison River basin is for irrigation. The U.S. Bureau of the Census (1953) reported 269,400 acres of irrigated land in 1949. Of this amount, 103,700 acres is in the Uncompahgre River and Roubideau Creek basins. Since 1949, the increase in irrigated acreage has been small; most of it has resulted from reclamation of land by drainage. The distribution of the irrigated lands is shown in plate 5 and summarized in table 5 .

Most of the irrigated lands above the North Fork are at high altitudes, and the growing season is short. Along the North Fork and in the Uncompahgre River basin, the climate is favorable for growing fruit, vegetables, alfalfa, and sugar beets. Much of the irrigated land, particularly that irrigated from tributary streams, does not have a full water supply. Taylor Park Reservoir, completed by the U.S. Bureau of Reclamation in 1937, supplements the available supply from natural flow for a large area in the Uncompahgre 
River valley. Water is diverted to this valley from the Gunnison River through the Gunnison tunnel which was completed in 1914. (See pl. 5.)

The Upper Colorado River Basin Compact Commission (1948) estimated that the 1914-45 average annual consumptive use of water in the subbasin due to irrigation practices was 348,200 acre-feet. The Commission estimated that 251,800 acres of land was irrigated and that 32,900 acres of land received water incidental to irrigation practices.

\section{DOMESTIC AND INDUSTRIAL USES}

The population (1960) of the Gunnison River basin was about 38,000 , a little less than five persons per square mile. The five largest communities and their populations are Montrose, 5,044; Delta, 3,832; Gunnison, 3,477; Cedaredge, 1,152; and Paonia, 1,083.

Montrose is the only community that has a sewagetreatment plant. Most sewage wastes go directly into adjacent streams, but, because streamflows are relatively large and amounts of waste are small, pollution problems are not acute.

There are no hydroelectric plants and no major industrial plants in the basin. There are, however, a few mines in the headwater areas and a sugar refinery at Montrose. Domestic and industrial consumptive uses of water in the subbasin are estimated to be about 2,600 acre-feet per year.

\section{STREAMFLOW}

VARIABIHTY OF SEASONAL RUNOFF

Flow behavior of headwater streams in the Gunnison River basin is similar to that of headwater streams in the Colorado River Basin above the Gunnison River because the environmental factors in the two subbasins are similar. Summer thunderstorms increase in frequency and intensity toward the western part of the subbasin and cause sudden increases in runoff of short duration in some streams.

Seasonal patterns of runoff are shown by the hydrographs for streams at three sites for the 1954 water year (fig. 54). The hydrograph for East River at Almont, Colo., shows the pattern of runoff characteristic of a stream whose water is derived principally from melting snow and is only slightly affected by the activities of man. The hydrograph for Uncompahgre River at Colona, Colo., shows the effect of depletion by diversions for irrigation. Summer thundershowers cause brief increases in flow at the Colona station. The hydrograph for Gunnison River near Grand Junction, Colo., shows the outflow from the basin. Increases in runoff from storms during the July-October period are very apparent.

\section{FLOW-DURATION CURVES}

Historical flow-duration curves were developed for streams at 19 selected sites. Using the methods described in chapter B (pp. 46-48), flow-duration curves for streams at 15 sites were developed and adjusted to the 44-year base period and conditions of upstream development existing in 1957. Adjustment to 1957 conditions of water use consisted principally of adjusting streamflow records at main-stem stations for the effect of Taylor Park Reservoir and the effect of increasing diversions through the Gunnison tunnel. The historical flow-duration curves and adjusted curves reduced to table form are given in table 6 . The pattern of flow in the Gunnison River below the Gunnison tunnel was affected after 1914 by diversions through the tunnel and after the 1937 water year by regulation of Taylor Park Reservoir. For this reason, three historical flowduration curves are given for Gunnison River below Gunnison tunnel in table 6 . In table 7 the methods used in adjusting the historical flow-duration curves and the upstream developments in which changes occurred are shown. The table also gives the authors' accuracy rating of the adjusted long-term curves.

Flow-duration curves for streams at three sites, with discharges as ratios of the average discharges, are shown in figure 55. The influence of the summer thunderstorms in the western part of the basin probably explains why the upper part of the curve for Uncompahgre River at Colona, Colo., is steeper than the upper part of the curve for East River, whose major source of water is snowmelt. Summer storms and irrigation return flow, both of which affect the flow patterns of Uncompahgre River at Colona, Colo., and Gunnison River near Grand Junction, Colo., cause the middle and lower parts of the curves for these two stations to be similar.

Variability indices of the flow-duration curves and percentages of average annual discharge estimated to be contributed to the stream system by ground water for selected streams in the subbasin are given in table 8. (See fig. 38 and chap. B, pp. 48-53.) The percentage value of ground-water contribution for Smith Fork could not be computed because of the effect of irrigation.

The headwaters of Tomichi Creek, which has the lowest variability index and highest percentage of ground-water contribution, are mostly underlain by extrusive igneous rocks. Fractures in these rocks allow precipitation to infiltrate into ground-water storage, which, in turn, maintains the stream during low-flow periods. The drainage basin of Uncompahgre River above Colona, Colo., which has the next lowest index value, also contains large areas of extrusive igneous rocks, such as tuff and breccia, in its headwaters. 

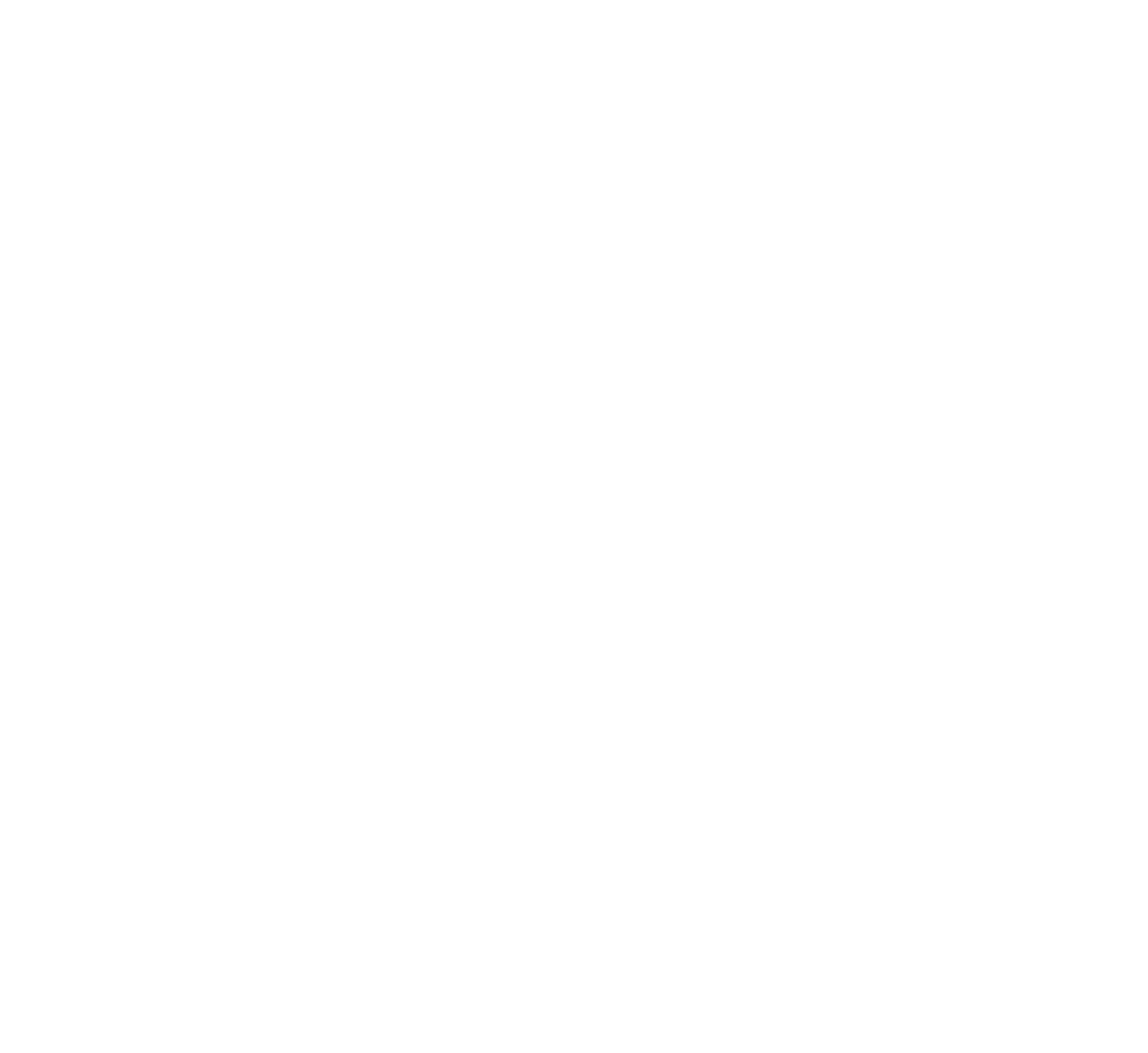

FIGURE 54.-Seasonal pattern of runoff in the Gunnison River basin, 1954 water year.

Because the permeability of these rocks is probably great, water can infiltrate to ground-water storage. Ground-water return flow from irrigation of lands upstream from the gaging station also contributes to the stream during low flow. The Lake Fork drainage basin also is underlain by extrusive igneous rocks that are highly altered, rich in clay, and consequently less permeable than those in the Tomichi Creek and Uncompahgre River basins.

The East River and Smith Fork drainage basins are mostly underlain by the Mancos Shale and the Mesaverde Formation, and the Muddy Creek drainage basin is mostly underlain by the Wasatch Formation. These sedimentary rocks are relatively impermeable, and runoff from these basins is rapid. Thus, flow-duration curves have steep slopes, and index values are high. These rocks afford relatively little opportunity for ground-water storage.

\section{VARIABILITY OF ANNUAL RUNOFF}

The variations in annual water discharges of three streams for the water years 1914- 57 , unadjusted, are shown in figure 56. The annual water discharges of East River at Almont, Colo., for the water years 1923-34 and of Gunnison River near Grand Junction, Colo., for the water years 1914-16 were estimated. 
The histogram for East River is approximately representative of natural flow. The histogram for the Uncompahgre River does not represent natural flow, but the consumptive use of water above the station was probably constant throughout the period. The flow of Gunnison River near Grand Junction, Colo., is affected by irrigation consumptive use, in which some increase occurred during the 1914-57 period.

The standard deviation and coefficient of variation of annual discharges at five streamflow stations in the Gunnison River basin are given in table 11 . The coefficients of variation are also shown in plate 4 . The coefficients of all the streams except Gunnison River near Grand Junction, Colo., are remarkably close to the same value. The coefficient of variation of Uncompahgre River at Colona, Colo., might be expected to be slightly higher because of more frequent summer storms in the western part of the basin, but this is not the case. Permeable volcanic rocks in the headwaters of this stream may be the principal reason why the

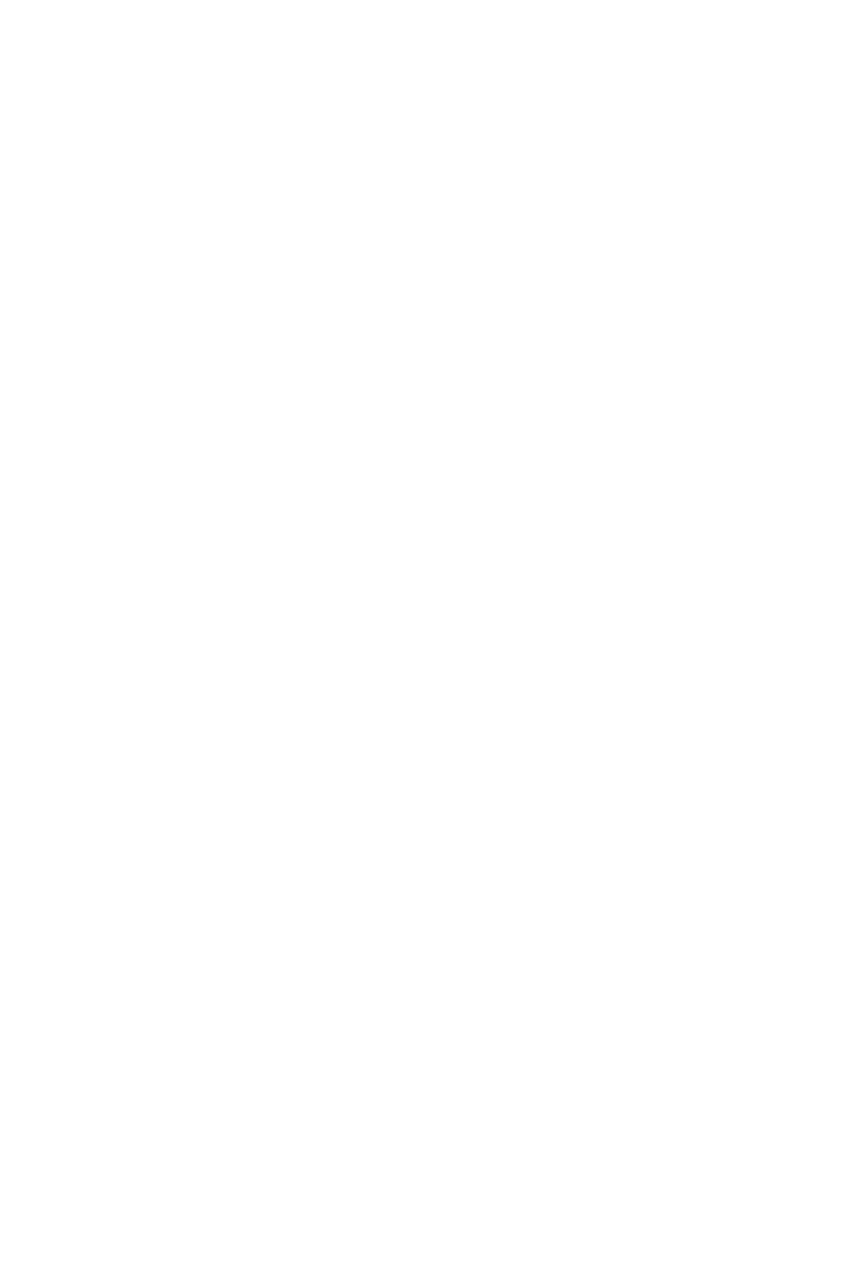

Figure 55.-Flow-duration curves of streams in the Gunnison River basin, water years 1914-57 adjusted to 1957 conditions. coefficient is lower thian might be expected.

The coefficient of variation of Gunnison River near Grand Junction, Colo., is higher than those of the headwater streams. The higher coefficient is probably due mainly to the cumulative effect of infrequent summer storms over a large area in the lower part of the basin, but it may be due in part to the effect of irrigation. If irrigation consumptive use were greater in years of low runoff and less in years of high runoff, the range in discharge between years of low and high runoff would be greater. On the other hand, the ground-water reservoir under the irrigated lands may serve to maintain a higher discharge in low-runoff years than would occur without irrigation.

\section{PRECIPITATION-RUNOFF RELATION}

Precipitation, water yield, and natural consumptive use for four drainage areas in the subbasin are given in table 13. The water yield from the East River and Smith Fork basins is high because the basins are underlain by relatively impermeable rocks. Much of the headwater area of the Taylor River is underlain by rocks of the Precambrian complex and is an area of high runoff and low consumptive use. However, Taylor Park and the valley downstream contain extensive deposits of Quaternary alluvium, which is highly permeable and supports a heavy growth of vegetation. Consumptive use by this vegetation is appreciable. The extrusive volcanic rocks and extensive talus slopes at the edges of Grand Mesa in the headwaters of Kahnah Creek readily absorb precipitation. The talus slopes support a heavy growth of vegetation which consumes much of the precipitation.

\section{CHEMICAL QUAIITY OF WATER}

DISSOLVED-SOLIDS DISCHARGE AND CONCENTRATION

Daily chemical-quality data have been obtained at only one station in the Gunnison River basin. Monthly and annual weighted-average chemical analyses for this site are given in the basic data report (Iorns and others, 1964, table 181). In addition to the daily data at this station, chemical analyses of streams at other sites have been obtained.

The chemical analyses of water at 16 sites, the daily record for Gunnison River near Grand Junction, Colo., and flow-duration tables were used to compute duration tables (tables 15 and 16) of dissolved-solids concentration and discharge. (See chap. B, pp. 58-59, for description of computation method.) Water and dissolved-solids discharge for the 17 stations is summarized in table 14. The computed dissolved-solids discharges for the 17 sites show that the average annual yield of dissolved solids from the Gunnison River basin ranges from about 21 tons per square mile in the areas that 


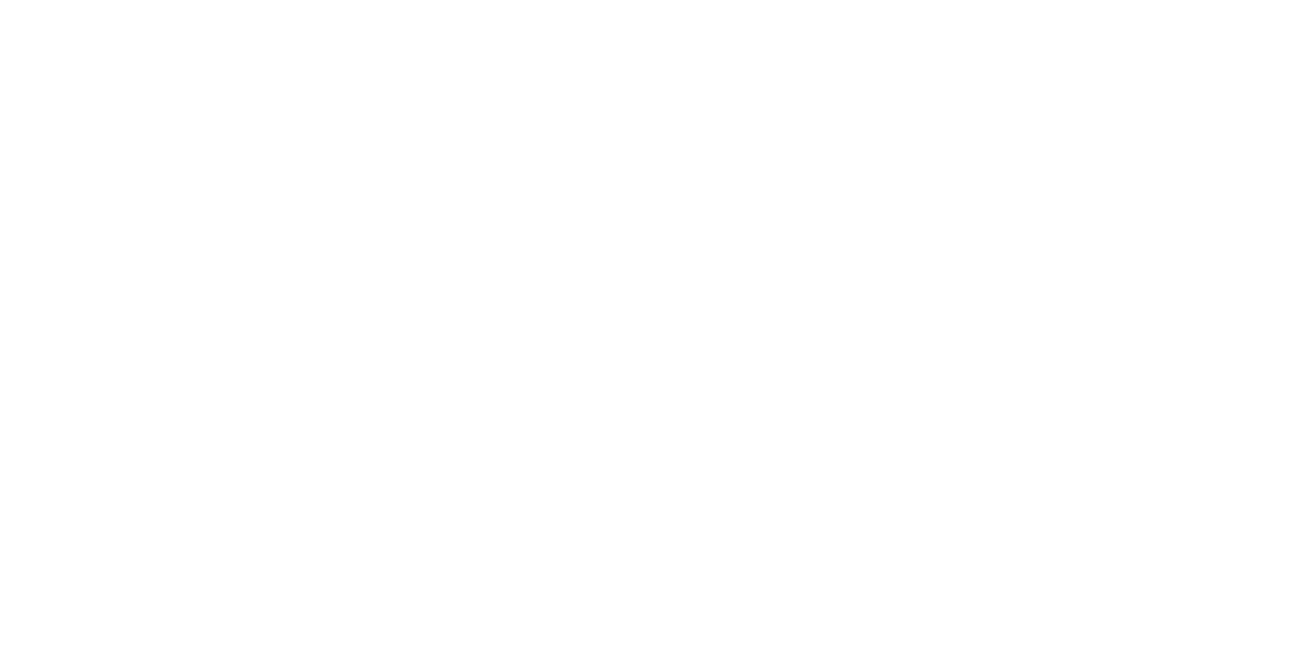

A. East River at Almont, Colo.
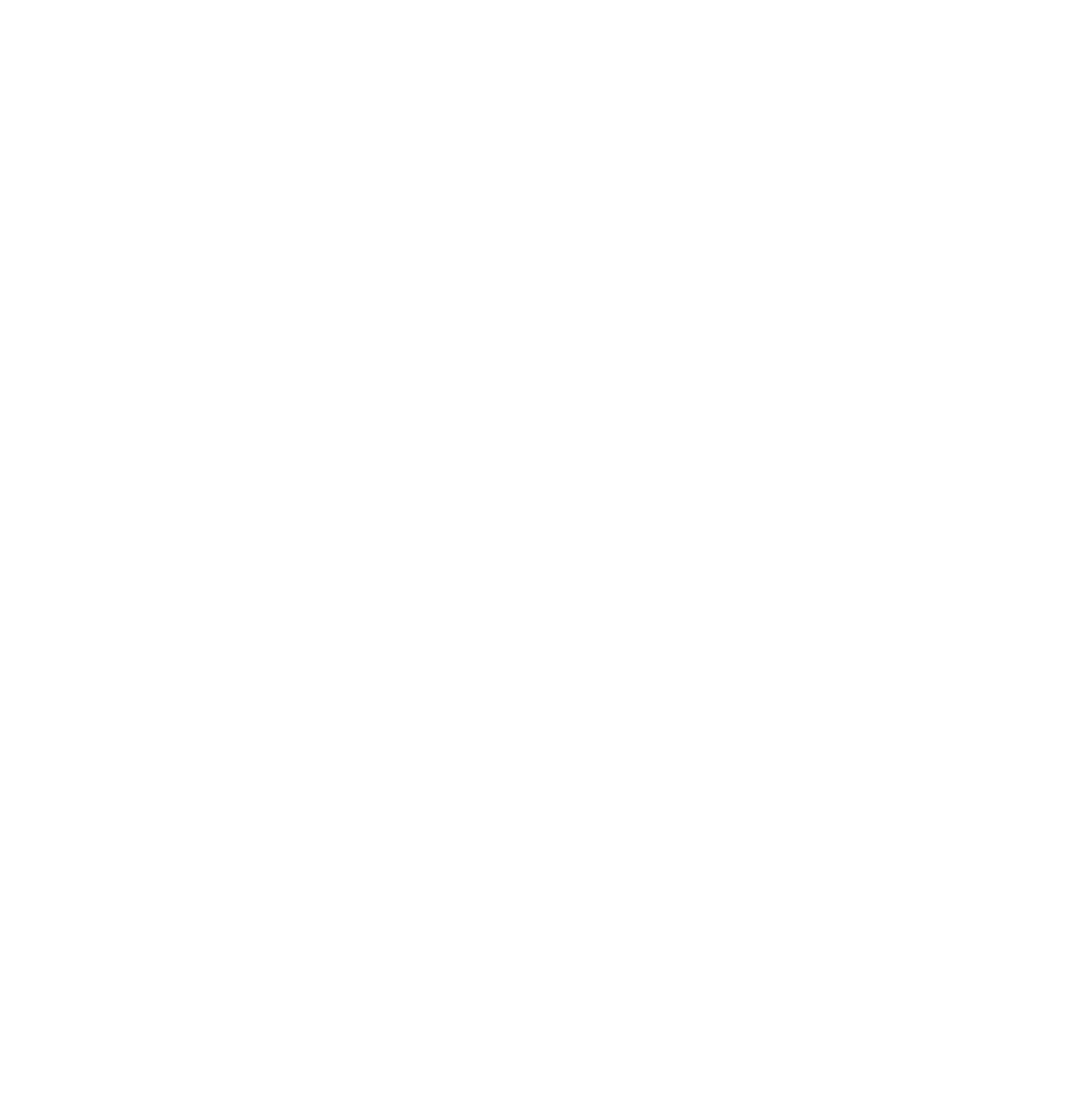

FIGURE 56.-Variability of annual discharges of selected streams in the Gunnison River basin, water years 1914-57. 
are underlain by volcanic rocks on the north side of the San Juan Mountains to more than 400 tons per square mile for the Uncompahgre River basin above Delta.

Percentages of contribution of dissolved solids and water discharges from different parts of the basin, based on the dissolved-solids and water discharges of Gunnison River near Grand Junction, Colo., were computed from the data in table 14 (fig. 57).

The average annual discharge of the Gunnison River above the Gunnison tunnel (Gunnison River below Gunnison tunnel, Colo., 944,000 acre-ft, and Gunnison tunnel diversion, 337,000 acre-ft) is equivalent to about 68 percent of the outflow from the basin. This water contains an average of about 193,600 tons of dissolved solids per year (weighted-average concentration of dissolved solids, $111 \mathrm{ppm}$ ), which is only about 13 percent of the average annual discharge of dissolved solids of
Gunnison River near Grand Junction, Colo. The drainage area above the Gunnison tunnel is about 50 percent of the total drainage area in the subbasin.

\section{VARIATIONS IN CHEMICAL QUALITY}

The seasonal variation in the concentration of dissolved solids in all streams investigated in the Gunnison River basin, except immediately below the Taylor Park Reservoir, follows the normal pattern of snowmelt streams; the concentrations are highest during periods of low flow and lowest during periods of high flow. Mixing of water in Taylor Park Reservoir causes the concentration in the released water, at all times, to approximate the weighted-average concentration in the inflow to the reservoir. Above the Gunnison tunnel the seasonal range between minimum and maximum concentration is not great. The maximum concentration in streams in this area is usually less than twice the minimum concentration. The chemical composition of the

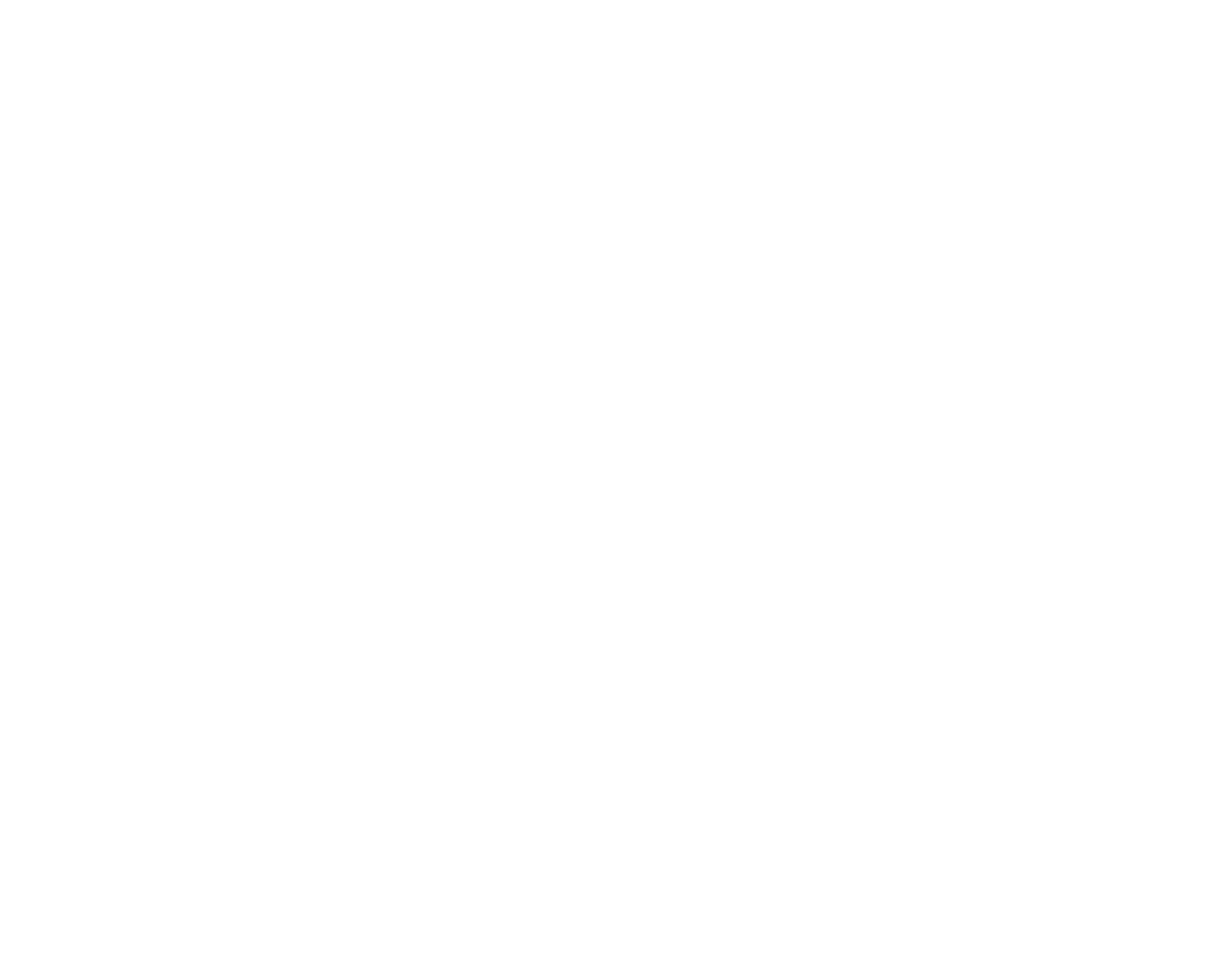

FIGURE 57.-Approximate dissolved-solids discharge and streamflow expressed as percentages of the dissolved-solids discharge and streamflow of Gunnison River near Grand Junction, Colo. 
water in these headwater streams also does not change much between high and low flow.

Below the Gunnison tunnel, many streams have a much higher range in concentration during the year, particularly in their downstream reaches. For example, the maximum concentration at Gunnison River near Grand Junction, Colo., is more than 11 times the minimum concentration. The chemical composition of the water passing this station also changes considerably between high and low flow.

The coefficient of variation of yearly weightedaverage concentration of dissolved solids for Gunnison River near Grand Junction, Colo., based on the period of historical chemical-quality record (water years (1932-57), is 0.26. For the same period, the coefficient of variation of annual water discharge is 0.39. Adjustment to water years 1914-57 increases both coefficients by 0.01 . The relation between the coefficients of variation at this station is shown with others in the Grand division in figure 45 . In table 18 , coefficients of variation and standard deviations of weighted-average concentrations for selected stations, computed by the equation of relation shown on page 94 , are given.

\section{RELATION TO STREAMFLOW}

The relation between water discharge and chemical composition of water of Gunnison River near Grand Junction, Colo., is given in table 19. The relation between chemical quality of water and streamflow at three other stations in the basin are also shown in figure 58. The chemical composition of Gunnison River below Gunnison tunnel, Colorado, is fairly representative of the streams above this station where the range in concentration is small between low and high discharges. Duration tables of dissolved-solids constituents may be prepared from the values in tables 6 , 15,16 , and 19 .

Chemical-quality records obtained for Gunnison River near Whitewater, Colo., in 1905 and the more recent records obtained a short distance downstream near Grand Junction indicate that a pronounced change in the relation between water discharge and dissolvedsolids concentration has occurred during the intervening years (fig. 59). The solid curve plotted on figure 59 is based principally on the average relation between concentration and water discharges for water years 1950-57 at the gaging station on Gunnison River near Grand Junction, Colo.

\section{RELATION TO GEOLOGY}

Except for two streams, the chemical type of water in the headwater streams does not vary greatly, regardless of the underlying rocks. The two exceptions are Tomichi Creek and the Uncompahgre River above Dallas Creek. The waters of Tomichi Creek are of the calcium bicarbonate type but contain large percentages of silica. The Tertiary volcanics underlying a large part of the Tomichi Creek basin are the most likely source of the silica. The waters of the Uncompahgre River above Dallas Creek are of the calcium sulfate type. Tertiary volcanic rocks underlying most of the drainage basin of the Uncompahgre above Dallas Creek have been faulted and highly altered. In such rocks, soluble sulfate and carbonate minerals are common.

In the rest of the subbasin, waters of the streams in their headwaters are of the calcium bicarbonate type with the concentration of dissolved solids differing measurably according to the type of underlying rock. For example, the concentration of dissolved solids in East River, whose basin is underlain largely by the Mancos Shale and the Mesaverde Formation of Late Cretaceous age, is about twice that of the Taylor River above the Taylor Park Reservoir, whose basin is underlain by igneous and metamorphic rocks of Precambrian age. At their junction during periods of low flow, the concentrations of dissolved solids in the East and Taylor River are about 150 and $77 \mathrm{ppm}$, respectively. The headwaters of Smith Fork and of Muddy Creek near Bardine, Colo., also are underlain by Cretaceous rocks and have concentrations during low flow of less than $300 \mathrm{ppm}$. It is most likely that in these areas of high precipitation much of the readily soluble minerals near the surface have been rather thoroughly leached from the Cretaceous rocks.

The interior of the subbasin below Cimarron Creek is mostly underlain by the Mancos Shale, the Mesaverde Formation, and the Dakota Sandstone of Cretaceous age. The waters of the streams as they pass through this area change from the calcium bicarbonate type to the calcium sodium magnesium sulfate type and increase greatly in dissolved-solids concentration. The average annual precipitation over this area is less than 12 inches, and consequently there is relatively little natural runoff. Most of the change in the quality of water in the streams is probably caused by irrigation. The irrigated lands are situated on alluvial material derived from the underlying parent rocks, which are mostly of marine origin. Because of the low precipitation, there has been little opportunity for leaching, and these deposits still retain much of the soluble mineral matter common in the parent rocks.

The quality of the water of the Gunnison River at its mouth is the result of all the upstream environmental factors that affect the water as it passes over and through the ground. Likewise, the quality of water of the streams in the drainage system at any point is the result of all the environmental factors above that point. This is illustrated by figure 60 , in which zones of 

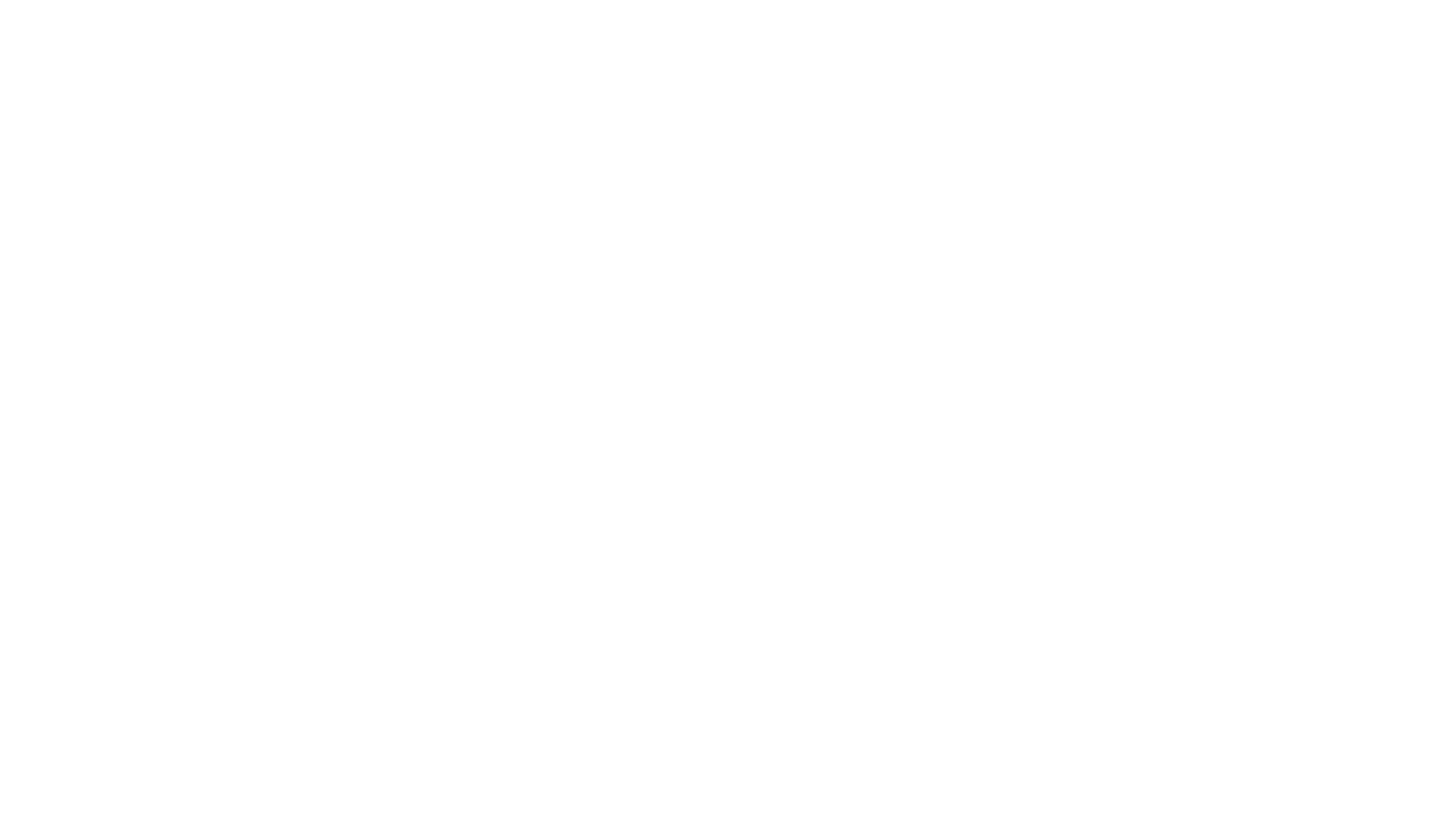

$A$. Gunnison River near Grand Junction, Colo.

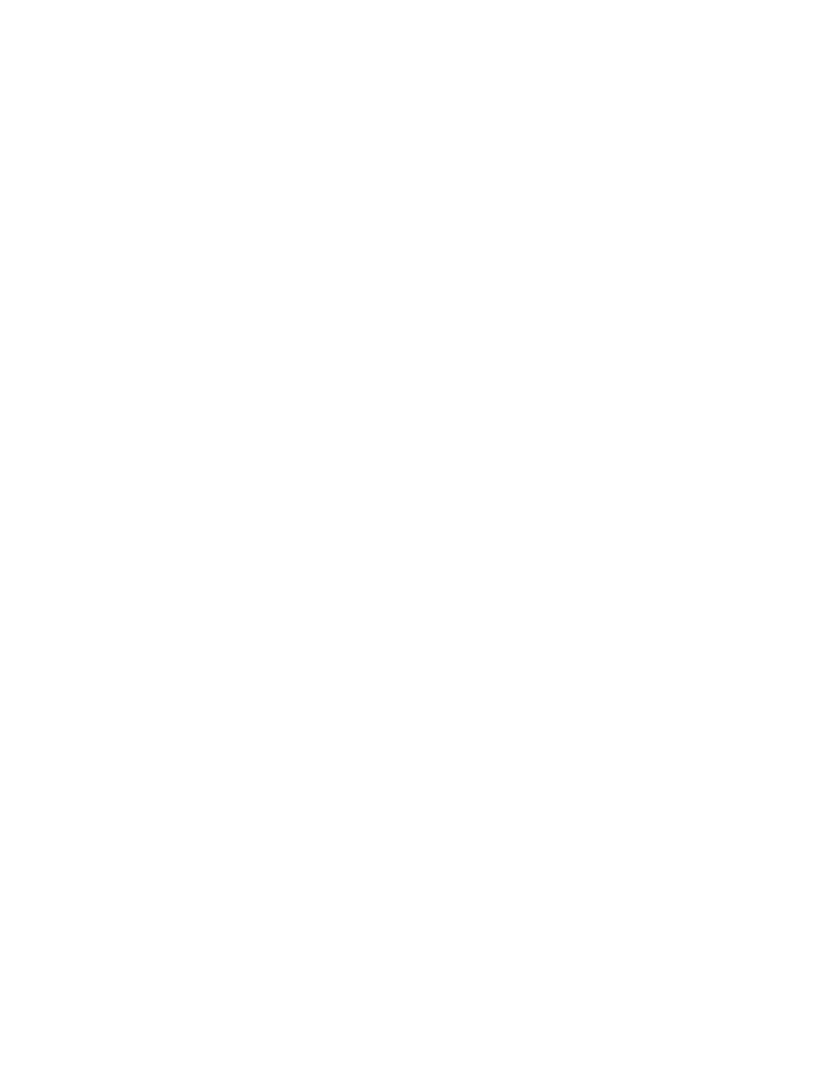

C. Uncompahgre River at Delta, Colo.
$B$. Gunnison River below Gunnisontunnel, Colo.

B. Gunnison River below Gunnisontunnel, Colo. 


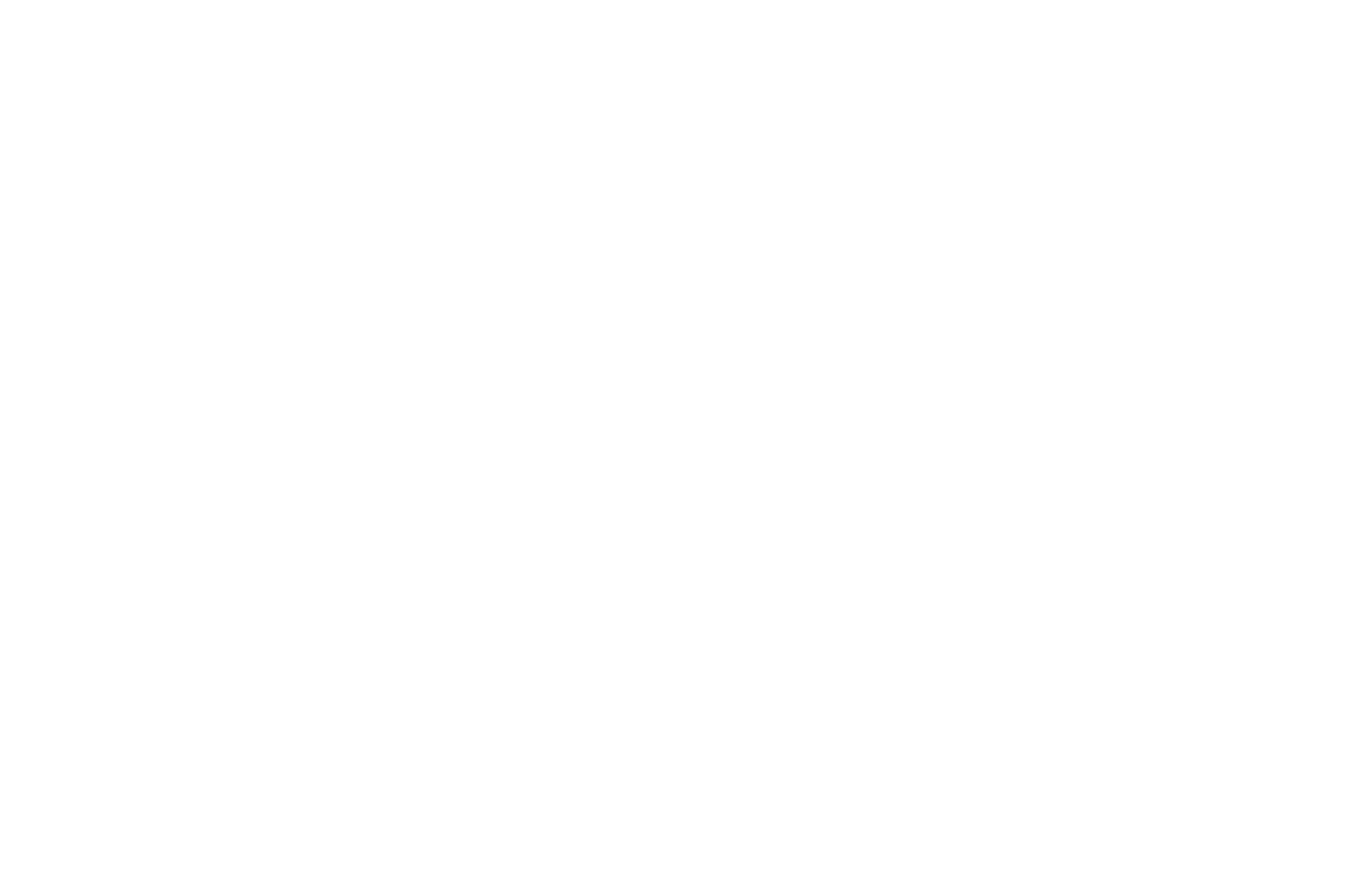

Frgure 59.-Relation of concentration of dissolved solids to water discharge, Gunnison River near Grand Junction, Colo. Plotted points are monthly average discharges and monthly weighted-average concentrations.

weighted-average concentration of dissolved solids in streamflows are delineated. The general effect of rock types and irrigation on the concentration of dissolved solids in the streams can be observed by comparison of the zones shown on figure 60 with the different rock types in plate 1 and the location of irrigated lands in plate 5.

The diagrams in plate 2 show the geochemical character and ionic concentrations of surface water at many sites $\mathrm{m}$ the subbasin. These diagrams show the chemical character of the streams during low flow when the effect of geology on chemical quality is the most pronounced. The significance of the size and shape of the diagrams is given in the explanation in plate 2.

\section{RELATION TO GROUND WATER}

Extensive ground-water reservoirs are present in the mountainous areas where precipitation is abundant. Table 20 shows the water and dissolved solids contributed to some selected streams from the groundwater reservoirs in headwater areas. The concentration of dissolved solids of the ground-water contribution is greater than the weighted-average concentration in the streams in the four examples for this subbasin given in table 20. The same relation probably exists for all headwater streams in the basin.

The chemical composition of water in the alluvium along the Gunnison River in the vicinity of Gunnison, Colo., is similar to that of water in the river during low flow (fig. 61). Water in the alluvium contains more dissolved solids and proportionately more bicarbonate than water in the river.

Ground water from the alluvium of Tomichi Creek at Gunnison, Colo., contains almost twice as much dissolved material as the water of the creek even during low flows (fig. 62). The ground water contains much more sulfate than the surface water, which is of the calcium bicarbonate type.

An analysis of water from a spring issuing from the volcanic rocks that blanket the area between Gunnison and Cimarron shows that the chemical character of the surface water and the ground water associated with these rocks is almost identical (fig. 63). The principal difference between the two is that ground water usually contains more silica.

Water from a well in the Mancos Shale at Ridgway had a dissolved-solids concentration of about 4,200 ppm and was of the sodium calcium sulfate type. 
During low flow, water from the river near this well contained less than one-eighth as much dissolved solids and was of the calcium sulfate type. Obviously, any ground water that reaches the river from the Mancos Shale in this area will cause an increase in the concentration of dissolved solids in the stream.

Water from two wells in terrace alluvium along the Uncompahgre River near the mouth of Cow Creek had concentrations of about 600 and $1,200 \mathrm{ppm}$. The water from these wells contains more dissolved solids than the water from either Cow Creek or the Uncompahgre River, during low flows (fig. 64). The water from the Uncompahgre River is of the calcium sulfate type, but that from Cow Creek is of the calcium bicarbonate type. The Cow Creek basin is underlain by volcanic rocks of Tertiary age and glacial outwash derived from them.

Two wells in the alluvium along the Gunnison River near Delta produce a calcium sodium magnesium sulfate water that has a concentration of 2,500 to $3,000 \mathrm{ppm}$. The water from these two wells is very similar to the water from irrigation drains near Delta and from Uncompahgre River at Delta, Colo., during the low flows of the irrigation season (fig. 65). Water from these two wells, dug 15 feet and 20 feet into alluvium, contained almost $70 \mathrm{ppm}$ of nitrate. The water from another well nearby, 96 feet deep and also in alluvium, contained $220 \mathrm{ppm}$ of nitrate.

The water of Gunnison River near Grand Junction, Colo., during the period from September to February,

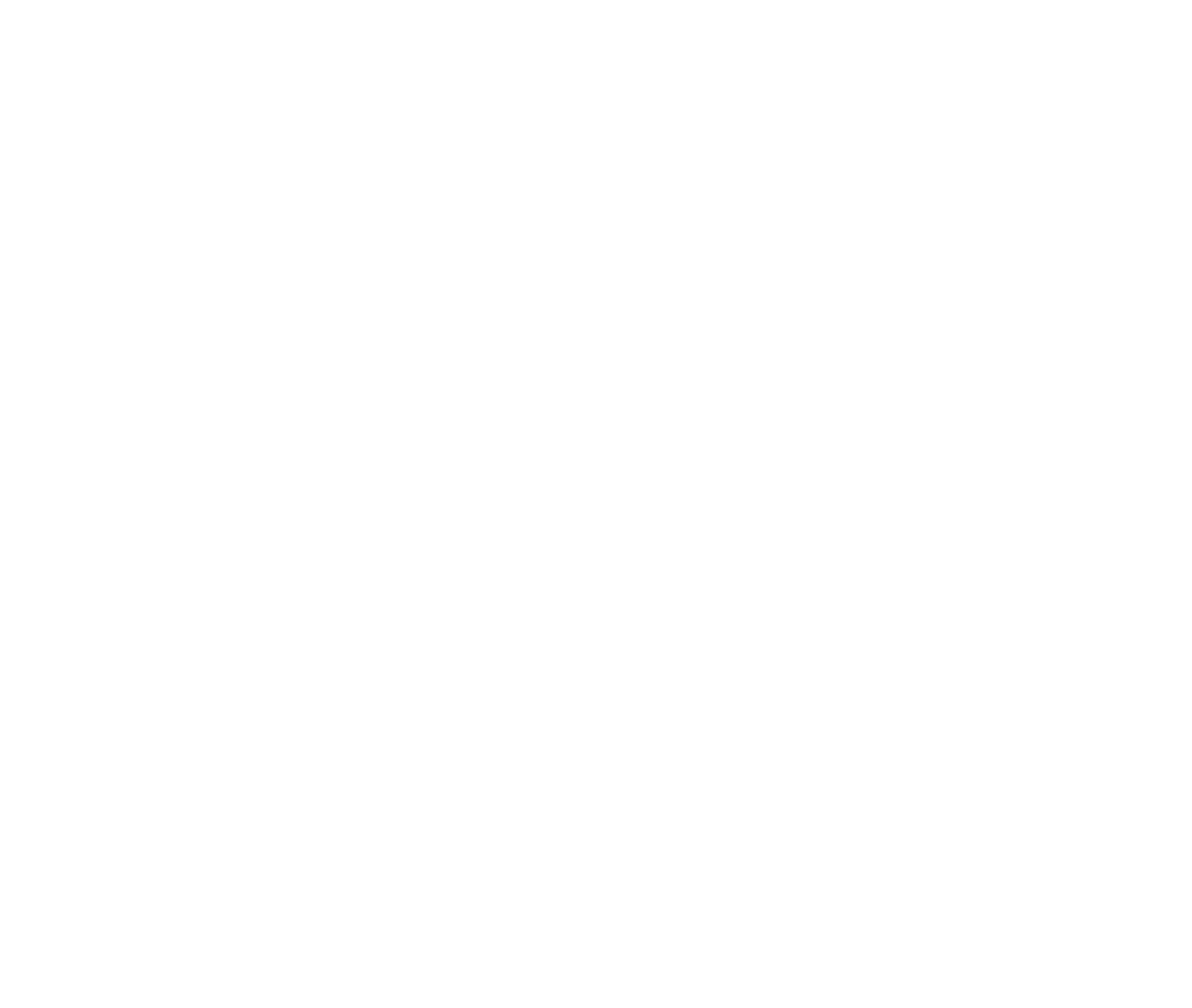

FIGURE 60.-Approximate weighted-average concentrations of dissolved solids in streams in the Gunnison River basin. 


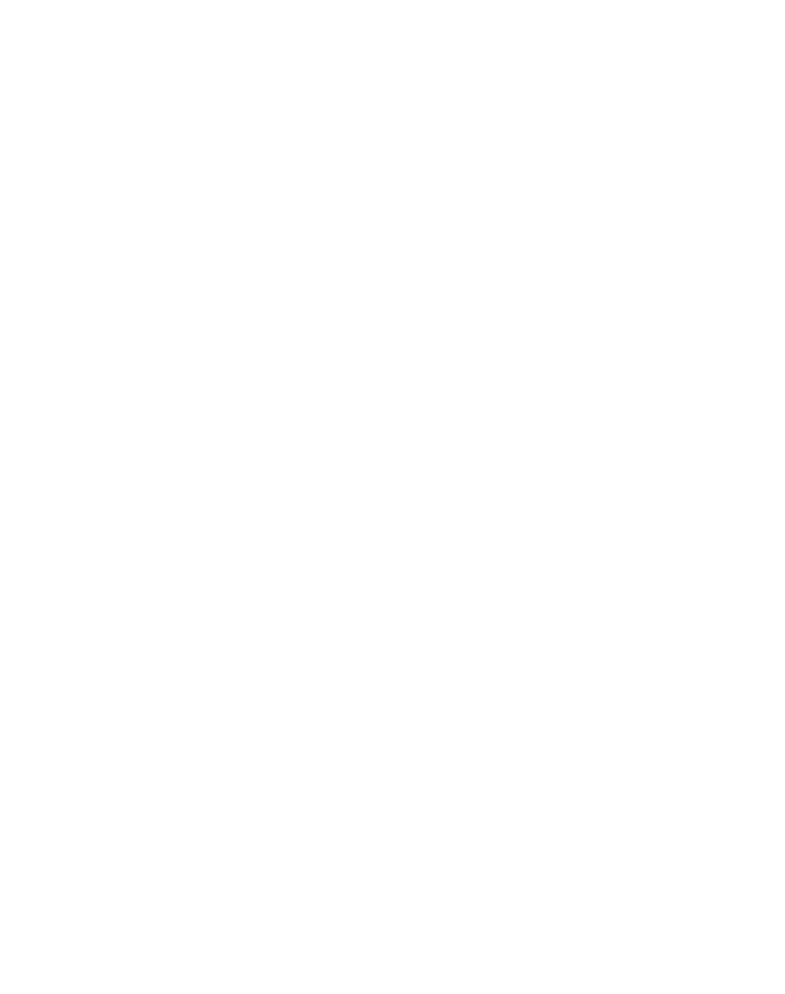

Figure 61.-Analyses of water from Gunnison River near Gunnison, Colo., and from alluvium nearby.

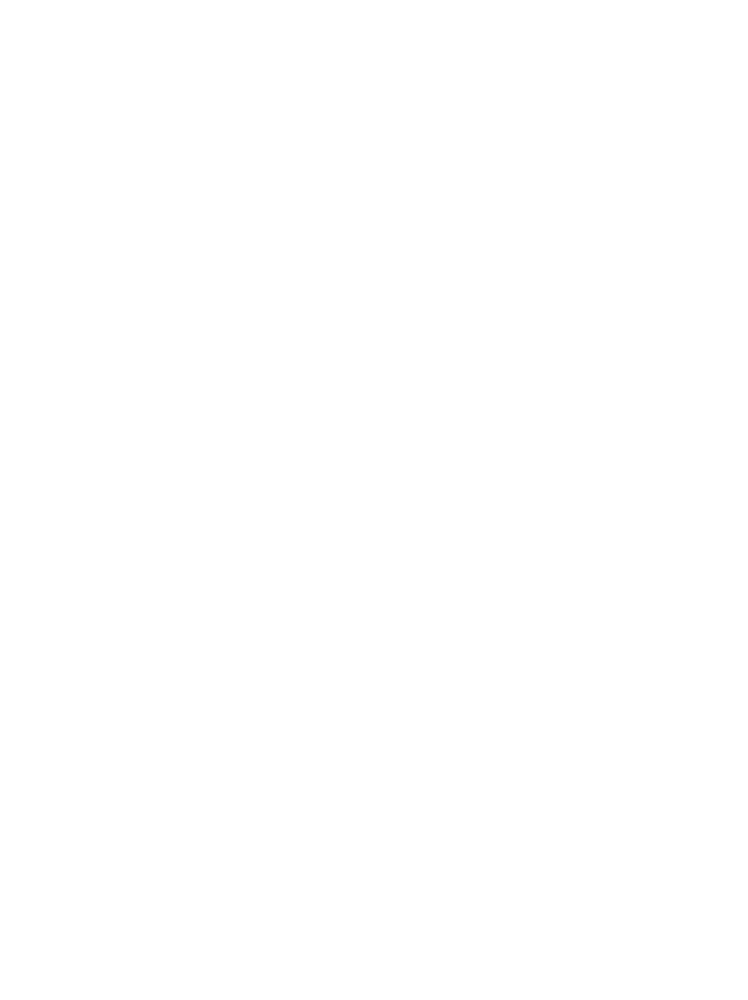

FifURe 62.-Analyses of water from Tomichi Creek at Gunnison Colo., and from alluvium nearby. has a concentration of more than $10 \mathrm{ppm}$ of nitrate. Part of the nitrate in the river water probably comes from ground water that seeps into the stream from the alluvium upstream.

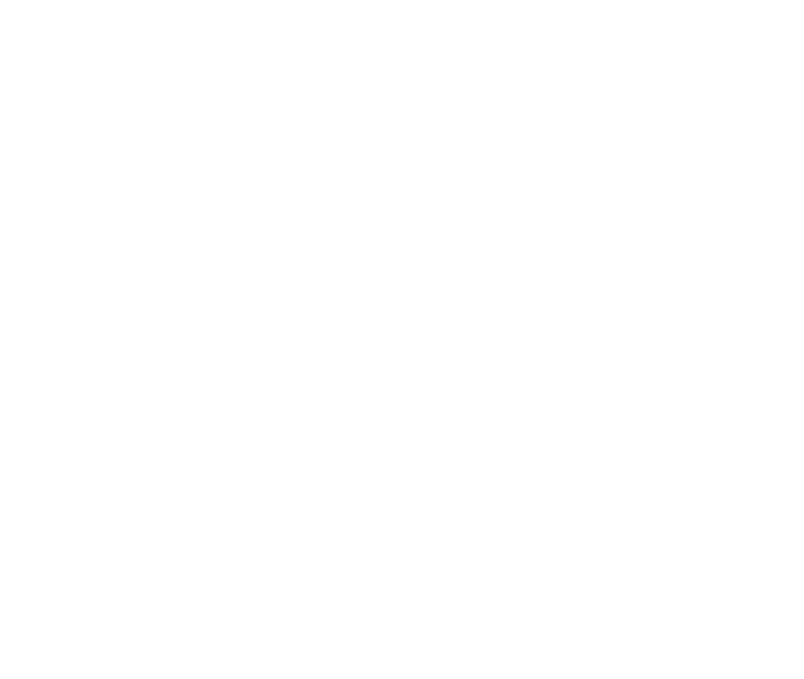

FIGURE 63.-Analyses of water associated with volcanic rocks of Tertiary age.

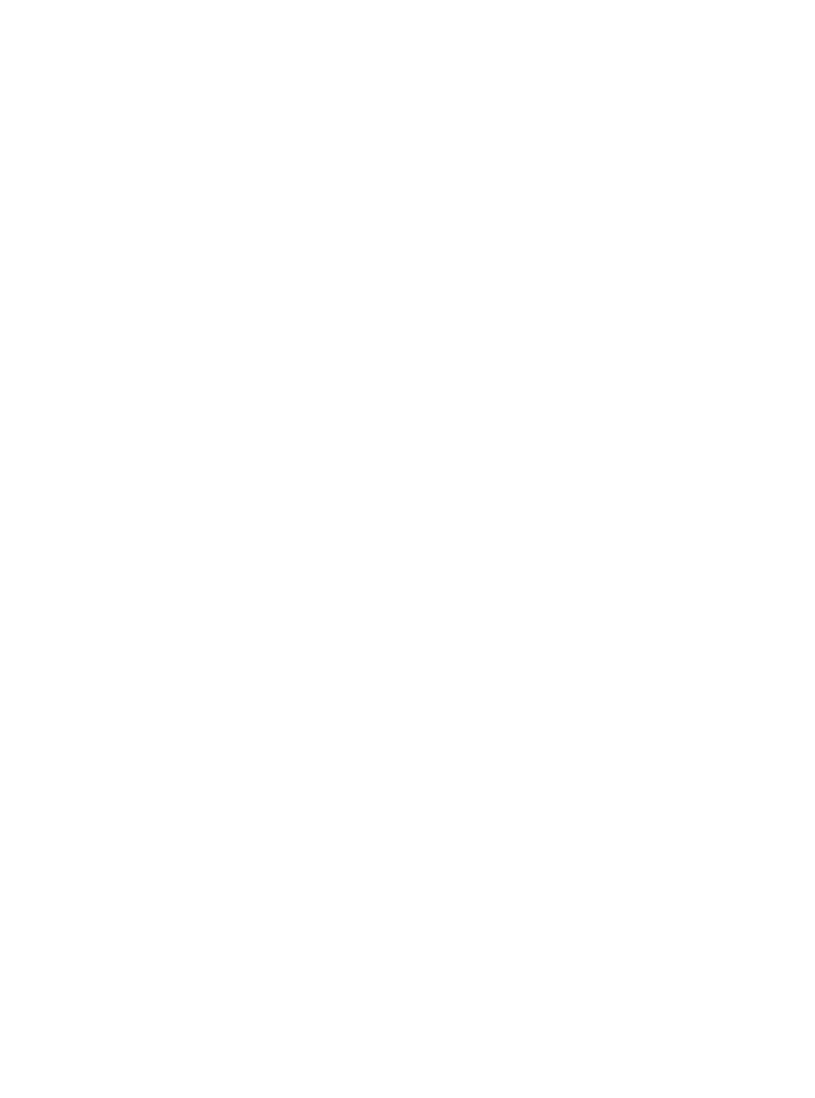

Fifure 64.-Analyses of water from the Uncompahgre River and Cow Creek and from alluvium nearby. 
Comparison of analyses of water from the streams and from the alluvium nearby indicates that ground water entering the streams will almost invariably cause an increase in the dissolved-solids concentration of the streams. The effect of the inflowing ground water during high flows is small because of the relatively small proportion of ground water entering the streams at these times. As the flow in the streams decreases, the proportion of inflowing ground water and its effect on the quality of the water in the streams increase. (See fig. 58.)

Several thermal springs issue along the East River and its tributaries in the vicinity of Crested Butte, Colo. (George and others, 1920). Jarvis Springs discharge about $25 \mathrm{gpm}$ of calcium magnesium bicarbonate sulfate water. One spring ( $20 \mathrm{gpm})$ has a dissolved-solids concentration of about $800 \mathrm{ppm}$ and the other spring ( $5 \mathrm{gpm})$, about $400 \mathrm{ppm}$. Two groups of

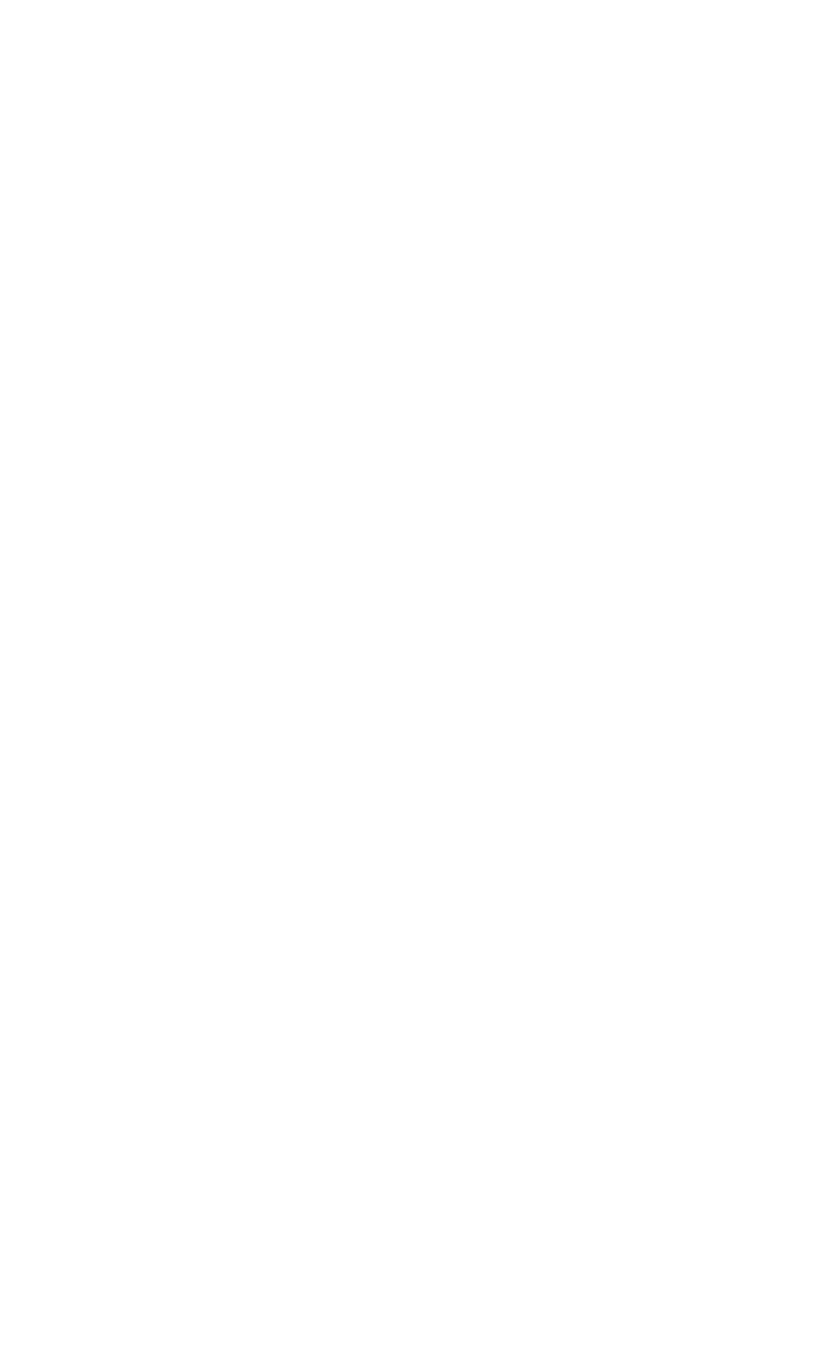

Figure 65.-Analyses of water from a well, a drain, and Uncompahgre River at Delta, Colo. springs on Cement Creek have dissolved-solids concentrations ranging from 500 to $700 \mathrm{ppm}$. The combined discharge of these springs is estimated to be about $1,840 \mathrm{gpm}$ (Stearns and others, 1937). These springs are of the calcium sodium magnesium bicarbonate type. Of the 15,700 tons of dissolved solids estimated to be contributed to the East River annually in ground water (table 20), about 2,500 tons is contributed by the springs discussed in this paragraph.

Waunita Hot Springs along Hot Springs Creek, a tributary of Tomichi Creek, is a sodium sulfate bicarbonate water having a dissolved-solids concentration of about $600 \mathrm{ppm}$ (George and others, 1920). The discharge of the springs in this group has been estimated to be about 1,000 gpm (Stearns and others, 1937).

A group of thermal springs discharging into Cebolla Creek near Powderhorn, Colo., yield water ranging in dissolved-solids concentration from about 1,600 to 2,600 ppm (George and others, 1920). Individual springs discharge 1 to $15 \mathrm{gpm}$. The weighted-average concentration of dissolved solids in the springs is estimated to be about $2,300 \mathrm{ppm}$, and the total contribution to the creek from the spring area is estimated to be about $100 \mathrm{gpm}$ (Stearns and others, 1937).

Near Lake City, Colo., two small thermal springs discharge into Lake Fork. One spring, discharging about $1 \mathrm{gpm}$, has a dissolved-solids concentration of $1,700 \mathrm{ppm}$; the other, which discharges about $5 \mathrm{gpm}$, has a dissolved-solids concentration of $200 \mathrm{ppm}$ (George and others, 1920).

A small thermal spring discharges about $0.5 \mathrm{gpm}$ near the mouth of Cimarron Creek. The dissolvedsolids concentration of this spring is about $2,600 \mathrm{ppm}$ (George and others, 1920).

Several thermal springs yielding sodium bicarbonate water rise along the North Fork. One spring about 19 miles east of Somerset, Colo., has a discharge of about $3 \mathrm{gpm}$. A group of springs near Hotchkiss have an average dissolved-solids concentration of about $4,300 \mathrm{ppm}$ (George and others, 1920) and are of the sodium bicarbonate chloride type. The total discharge of three of the springs is reported to be $17 \mathrm{gpm}$; that from all the springs in the group is probably about $25 \mathrm{gpm}$.

Cold Sulphur Spring near Austin, Colo., yields a sodium chloride bicarbonate water having a dissolvedsolids concentration of about $11,900 \mathrm{ppm}$. Alkali Spring, located nearby, yields the same type of water but has a concentration of about $16,000 \mathrm{ppm}$. The discharge of Cold Sulphur Spring is about $15 \mathrm{gpm}$, and the discharge of Alkali Spring is $3 \mathrm{gpm}$ (George and others, 1920). 
Park Springs, in the headwaters of the Uncompahgre River near Ironton, Colo., have a dissolvedsolids concentration of about $1,000 \mathrm{ppm}$ (George and others, 1920). Data are not available on the discharge of the springs, but the discharge probably does not exceed $50 \mathrm{gpm}$. Downstream at Ouray are numerous hot springs. These springs are of the calcium sulfate type. The dissolved-solids concentration of the group ranges from about 1,000 to about $1,700 \mathrm{ppm}$ (George and others, 1920), and the combined discharge is about $200 \mathrm{gpm}$ (Stearns and others, 1937). Farther downstream near Ridgway, two springs discharging 20 and $15 \mathrm{gpm}$ have dissolved-solids concentrations of 2,500 $\mathrm{ppm}$ and $700 \mathrm{ppm}$, respectively. The water of the larger spring is of the sodium calcium sulfate type.

There may be a few other small thermal springs in the Gunnison River basin in addition to those listed. The combined discharge of the reported thermal springs is only slightly more than 7 cfs, and the dissolved-solids discharge is about 6,000 tons annually.

EFFECT OF TRANSMOUNTAIN DIVERSIONS

Three small transmountain diversions from the Gunnison River basin were in existence at the end of the 1957 water year. The effect of these small diversions on the quality of the water leaving the Gunnison River basin is negligible. With an average diversion of about 300 acre-feet annually and a weighted-average concentration of $60 \mathrm{ppm}$, about 25 tons of dissolved solids is taken out of the basin annually in the transmountain diversions.

EFFECT OF THE ACTIVITIES OF MAN

In the Gunnison River basin, as in the Colorado River basin above the Gunnison River, the activities of man have caused an increase in the dissolved-solids discharge of the streams. That much of this increase is caused by irrigation is indicated by the high concentrations of dissolved solids in ground water in the alluvium and in the return flow in the drains in the irrigated areas of the lower part of the Uncompahgre River valley. The irrigation water in the Uncompahgre valley is a mixture of water from the Gunnison tunnel and the Uncompahgre River. On the basis of the average annual discharge of the Gunnison tunnel and of the river at the Colona gaging station, about 63 percent of the irrigation water comes from the Gunnison River through the tunnel (111 ppm) and about 37 percent comes from the Uncompahgre River (376 ppm). The weighted-average concentration of the irrigation water therefore would be about $209 \mathrm{ppm}$. The average dissolved-solids concentration of the drains in the Uncompahgre River valley is about $2,300 \mathrm{ppm}$ (Iorns and others, 1964, table 219). These concentrations are used in the following tabulation, which indicates amounts of dissolved solids leached per acre per year from the soil and underlying material with irrigation application rates of 4 and 5 acre-feet per acre and consumptive use rates of 1.5, 2.0, and 2.5 acre-feet per acre:

Applied in irrigation
(acre-ft per acre)
4
4
4
5
5
5

Consumptive use
(acre-ft per acre)
1.5
2.0
2.5
1.5
2.0
2.5

Return flow
(acre-ft per acre)
2.5
2.0
1.5
3.5
3.0
2.5
Leached from lands (lons per actor 6. 7 5. 2 3. 6 9. 5 8. 0 5. 4

This tabulation illustrates the wide range in dissolved-solids yield from irrigated lands - a range that may be expected with different rates of applied water and consumptive use. It does not, however, take into account other natural sources of dissolved solids that may be included in the return flow.

Because of the large amount of water that bypasses the Uncompahgre River at Delta gaging station, a water and dissolved-solids budget cannot be computed for the Uncompahgre River valley. However, an approximate budget can be prepared for that part of the Gunnison River basin below the Gunnison tunnel and the gaging stations on the Uncompahgre River at Colona and Roubideau Creek near Delta and above the gaging station on the Gunnison River near Grand Junction. Table 22 gives the budget of water and dissolved solids for the area.

Records for Roubideau Creek near Delta indicate the average annual base flow (mostly ground water) of this stream (drainage area, $165 \mathrm{sq} \mathrm{mi}$ ) to be about 5,000 acre-feet (30 acre-ft per sq mi). Applying this rate to the 673 square miles of drainage area between the gaging stations on the Uncompahgre River at Colona and at Delta indicates that about 20,000 acrefeet of ground water would be contributed to the Uncompahgre River under natural conditions. This unmeasured natural ground-water inflow is estimated to have a weighted-average concentration of dissolved solids between 1,300 and $2,300 \mathrm{ppm}$. The estimated concentration range is based on chemical analyses of water of wells and streams in the area during times of low flow (Iorns and others, 1964, tables 219 and 227).

The unmeasured natural surface-water contribution of 50,000 acre-feet in the Uncompahgre River valley is based principally on the direct runoff from Roubideau Creek near Delta (30,000 acre-ft less base flow) and on the relation of the ungaged drainage area west of the Uncompahgre River to that of Roubideau Creek. Because of the similarity between the Roubideau Creek basin and the ungaged area, the weighted-average concentration of dissolved solids in the unmeasured surface water (200 to $350 \mathrm{ppm}$ ) is based on chemical analyses of water of Roubideau Creek near Delta and other streams draining the Uncompahgre Plateau. 
Measured natural inflow, mostly above irrigated lands, of tributaries to the Gunnison River in the area below Gunnison tunnel, Uncompahgre River at Delta, and Roubideau Creek at mouth is about 483,000 acrefeet (Smith Fork, 34,000; Iron Creek, 12,000; North Fork Gunnison River, 317,000; Current Creek, 5,000; Surface Creek, 3,000; Tongue Creek, 50,000; and Kahnah Creek, 32,000). Chemical analyses for many streams in the area indicate that, under natural conditions, the weighted-average concentration would be between 130 and $150 \mathrm{ppm}$ (Iorns and others, 1964, table 219).

The unmeasured natural inflow from the area described in the preceding paragraph is the quantity of water needed to balance the inflow-outflow budget after allowing for 70 acre-feet estimated to be contributed annually by thermal springs. As this water comes from drainages similar to those listed in the preceding paragraph, the concentration of dissolved solids is estimated to be the same.

In the area above the Gunnison tunnel about 74,000 acres are irrigated. Data are not sufficient in this area to determine the amount of dissolved solids coming from natural sources. However, the rates of dissolvedsolids yield from irrigated lands would be similar to irrigated lands in the Colorado River Basin above Hot Sulphur Springs and the Troublesome Creek basinthat is would range from 0.1 ton per acre per year to 1.0 ton per acre per year. On the basis of similarity of environments, irrigated lands in the Gunnison River basin above Tomichi Creek would probably yield about 0.7 ton per acre per year of dissolved solids, those in the Tomichi Creek basin about 0.5 ton per acre per year, and those in the basin below Tomichi Creek and above the Gunnison tunnel about 0.25 ton per acre per year. Application of these rates indicates that at least 36,000 tons annually of dissolved solids are added to the Gunnison River above the Gunnison tunnel by the activities of man.

In the Uncompahgre River basin above the gaging station at Colona, Colo., about 18,500 acres is irrigated. These lands are mostly on alluvium derived from the more resistant rocks in the headwaters of the Uncompahgre River, but the alluvium is underlain by the Mancos Shale, the Dakota Sandstone, and the Morrison Formation. On the basis of dissolved-solids yields from irrigated lands in areas of similar rocks and precipitation in other parts of the Upper Colorado River Basin, it is estimated that about 45,000 tons of dissolved solids annually are contributed to the stream system above the Colona station as a result of the activities of man.
As indicated by the preceding discussion of three areas in the Gunnison River basin, about 977,000 tons of dissolved solids $(895,700+36,000+45,000)$ is added to the Gunnison River by the activities of man, and 542,000 tons $(1,519,000-977,000$ tons) comes from natural sources. In proportion to area, the amount resulting from man's activities is 3.6 tons per acre irrigated, and the amount from natural sources is 68 tons per square mile of drainage area. If there had been no activities of man in the basin, the weighted-average concentration of dissolved solids in the Gunnison River near Grand Junction, Colo., would have been about $178 \mathrm{ppm}$ as compared to a weighted-average concentration of $592 \mathrm{ppm}$ for water years 1914-57 adjusted to 1957 conditions. In the computation of the change in concentration, 2,600 acre-feet of water was considered to be consumptively used annually for domestic and industrial purposes, and 348,200 acre-feet was considered to be the annual amount of water consumptively used in irrigation.

Of the total amount of dissolved-solids discharge estimated to be caused by the activities of man in the subbasin, 3,800 tons is estimated to be due to domestic and industrial use of water and 973,200 tons, to irrigation. The estimate of 3,800 tons is based on 100 tons per year per 1,000 people as the rate of contribution resulting from domestic and industrial use of water.

\section{FLUVIAL SEDIMENT}

Suspended-sediment data were obtained at Gunnison River near Grand Junction, Colo (near Whitewater), in 1905. However, so many changes have occurred in the upstream environment since 1905 that these data are not representative of the stream under conditions that existed in the 1957 water year. Suspended-sediment data obtained in later years by the Bureau of Reclamation have been used to estimate the suspendedsediment discharge of the Gunnison River at this station.

Suspended-sediment samples have been collected at many other sites by the Bureau of Reclamation and at three sites by the Forest Service. The records collected by the Bureau of Reclamation have been used in conjunction with flow-duration curves to estimate the probable sediment discharge at several stations (table 25). Most of the sediment apparently comes from areas underlain by rocks of Cretaceous age.

\section{SUITABILITY OF WATER FOR VARIOUS USES DOMESTIC USE}

The basis for appraising the suitability of stream waters in this subbasin is the same as that for the subbasin of the Colorado River above the Gunnison River. (See chap. B, pp. 66-73.) 
In the headwater areas the waters of all tributaries to the Gunnison River are suitable for domestic use, so far as chemical quality is concerned, except for that in some of the headwater streams of the Uncompahgre River, where the concentrations of sulfate may exceed recommended limits. Most of the waters of the headwater streams are moderately hard to hard.

Above Smith Fork the water of the main stem of the Gunnison River also is chemically suitable for domestic use, but that in the lower reaches of many tributaries between Cimarron and Smith Fork is not satisfactory. The principal cause of unsuitability is high sulfate concentrations, but some streams have higher concentrations of iron, magnesium, chloride, and fluoride than are desirable for domestic use.

The waters of the Gunnison River below Smith Fork and most of the waters of the Uncompahgre River are not satisfactory for domestic use, except at times of high discharge. The same applies to the water of Smith Fork below its headquarters, the lower reaches of most tributaries of the Gunnison River below Smith Fork, and the lower reaches of most tributaries of the Uncompahgre River.

The fact that some of the stream waters do not meet the criteria adopted in this report for domestic uses does not mean that they cannot be used if necessary.

\section{AGRICULTURAL USE}

The principal use of surface water in the Gunnison River basin is for irrigation. Table 27 gives the classification of low, medium, and high flows of selected streams as to their suitability for irrigation. All the terms used in the table are self-explanatory or are explained on page 107 and in chapter B (pp. 69-73).

The determinations of residual sodium carbonate for the streams in table 27 indicate that residual sodium carbonate is either nonexistent or much less than 1.25 epm. This limit is considered the maximum permissible for irrigation waters, though some marginal waters are permissible.

The surface waters in the Gunnison River basin range from $\mathrm{C} 1-\mathrm{S} 1$ to $\mathrm{C} 4-\mathrm{S} 4$; most of the water that is used for irrigation is $\mathrm{C} 3-\mathrm{S} 1$ or better. The water in the poorer categories is mostly downstream from irrigated lands and is affected by return flow. According to the U.S. Salinity Laboratory Staff (1954), waters in the $\mathrm{C} 3$ category cannot be used on soils having restricted drainage. The S1 category implies that the water can be used on almost all soils with little danger of development of harmful levels of exchangeable sodium.

INDUSTRIAL USE

The water of most of the headwater streams in the Gunnison River basin can be used for many industries without treatment. Most of the water in streams near the centers of population would require extensive treatment. The water of Gunnison River near Grand Junction could be used for only a few industries without treatment.

Most of the surface water in the Gunnison River basin could be used without treatment by mining industries and for certain phases of metal fabrication where quality tolerances are liberal.

RECREATIONAL USE

Most of the streams and lakes in the headwaters of the Gunnison River basin are ideal for recreation. The use of the surface water for this purpose is expanding rapidly and will probably continue to do so as the population continues to increase.

\section{COLORADO RIVER BASIN BETWEEN THE GUNNISON AND GREEN RIVERS \\ PRESENT UTILIZATION OF SURFACE WATER STORAGE RESERVOIRS}

Seven reservoirs that have storage capacities greater than 1,000 acre-feet were in operation in the Colorado River Basin between the Gunnison and Green. Rivers in 1957 (table $3 ;$ pl. 4). These reservoirs have a total usable capacity of 42,050 acre-feet. In addition, there were a number of smaller reservoirs and stock ponds. Lake Hope and Trout Lake provide storage for hydroelectric-power production; the other reservoirs store irrigation water.

\section{TRANSMOUNTAIN DIVERSIONS}

About 100,000 acre-feet of water is diverted annually from Lost Canyon Creek and the Dolores River to irrigate approximately 37,000 acres in the San Juan basin (U.S. Dept of the Interior, 1947, p. 128). These diversions were in operation before 1914. A small amount of water is diverted from the headwaters of the San Miguel River to the Uncompahgre River drainage basin, but no records of the amount diverted are available.

\section{IRRIGATION}

About 121,300 acres is irrigated in the Colorado River Basin between the Gunnison and Green Rivers (table 5). Of this amount, about 75,700 acres is in the Grand Valley. About 3,000 acres of the cultivated land in the Grand Valley is irrigated with water diverted from the Gunnison River; all the rest, except for a few hundred acres, is irrigated with water diverted from the Colorado River. Of the 37,100 acres irrigated in the Dolores River basin, about 25,600 acres is in the San Miguel River basin.

The climate is favorable for growing a wide variety of crops, except in the headwater areas. Lands irri- 
gated in Grand Valley have an adequate water supply, but the water supply is deficient for much of the land in the rest of the subbasin.

The Upper Colorado River Basin Compact Commission (1948) estimated that the 1914-45 average annual consumptive use of water in the Grand Valley by irrigation practices was 146,000 acre-feet. The Commission estimated that in the valley 75,700 acres of land was irrigated and 12,600 acres received water incidental to irrigation practices. In the rest of the subbasin, the Commission estimated the consumptive use to be 54,600 acre-feet on 45,625 acres of irrigated land and 4,670 acres that received water incidental to irrigation practices.

\section{DOMESTIC AND INDUSTRIAL USES}

The 1960 population was about 66,000 , most of which is concentrated in and around Grand Junction, Colo. The five largest communities and their populations are Grand Junction, Colo., 18,694; Moab, Utah, 4,682; Fruita, Colo., 1,830; Uravan, Colo., 1,005; and Naturita, Colo., 979. Grand Junction, Fruita, and Naturita obtain their water supply from surface streams, and Uravan and Moab use well water. Ground water on the north side of the Colorado River in the vicinity of Grand Junction is generally not satisfactory for domestic use, and most small communities in this area obtain their domestic water from the Grand Junction or Fruita water-supply systems. Some small communities and most rural inhabitants in this area depend on hauled water for domestic use. Of the five largest communities, only Grand Junction and Moab have sewage-treatment plants.

The major industrial plants in the basin are uranium mills at Grand Junction, Uravan, and Vancorum, Colo., and Moab, Utah, and a gilsonite-processing plant at Grand Junction. At Grand Junction there is also a flour mill, a fruit-packing plant, and a cannery. Each of these installations uses water, but the consumptive use is negligible. The consumptive use of water for domestic and industrial uses is estimated to be about 4,400 acre-feet per year.

The following tabulation shows the hydroelectricpower installations in the subbasin:

Location of powerplant

Colorado River at Palisades, Colo . . . . . . . . . . .

Gunnison River at Grand Junction, Colo .........

Lake and Howard Forks near Ames, Colo............

San Miguel River near Ames, Colo...............

Bridal Veil Creek near Telluride, Colo...........

San Miguel River at Uravan, Colo..............

Mill Creek at Moab, Utah

Total Installed $c a p a c i t y$
$(k w)$

3,000

1,400

3,600

1,200 800 160 50

10,210

\section{STREAMFLOW}

VARIABIUTY, OF SEASONAL RUNOFF

Most of this subbasin is at a low altitude compared to the other two subbasins of the Grand division. Little or no snow accumulates during the winter months except in the mountainous headwaters of the Dolores and San Miguel Rivers and in the LaSal Mountains. Streams, except those draining mountainous areas, are intermittent and carry water only after infrequent summer storms. Most of these are thunderstorms, are of short duration, and cover only a small area. However, some are of high intensity and cause flash floods.

The pattern of seasonal runoff from the headwaters of the Dolores River, the principal tributary in the subbasin, is shown in figure 66. The hydrographs for Colorado River near Cameo, Colo. (fig. 35), and that for Gunnison River near Grand Junction, Colo. (fig. 54), show the pattern of inflow into the subbasin from these two major streams. The hydrograph for Colorado River near Cisco, Utah (fig. 66), shows the pattern of outflow from the subbasin and the Grand division.

\section{FLOW-DURATION CURVES}

Historical flow-duration data were developed for streams at nine sites in the subbasin. Flow-duration curves representative of the 44-year base period adjusted to 1957 conditions were developed for all but two of these sites. The historical and adjusted curves reduced to table form are given in table 6 . In the adjustment of historical data for Colorado River near Cisco, Utah, to 1957 conditions, adjustments were made for increasing amounts of transmountain diversions and reservoir regulation. Similar adjustments of historical data for stations in the Dolores basin were not necessary because practically no change in developments occurred after 1914. In table 7 are outlined the methods used in adjusting the historical flow-duration curves to 1957 conditions and the upstream water development in which changes occurred. The adjustment methods are explained in chapter B (pp. 46-48). The table also gives the authors' accuracy rating of the adjusted long-term curves.

The variability indices of the flow-duration curves and percent of average annual discharge estimated to be contributed to the stream system by ground water for two streams in the subbasin are given in table 8 . (See fig. 38 and chap. B, pp. 48-53.) An indeterminate but negligible amount of the water attributed to ground water may be from natural lakes or from upstream reservoirs.

The drainage basin above the gaging station on Dolores River at Dolores, Colo., from higher to lower altitudes, is underlain principally by the Rico Formation, the Dakota Sandstone, the Morrison Formation, 


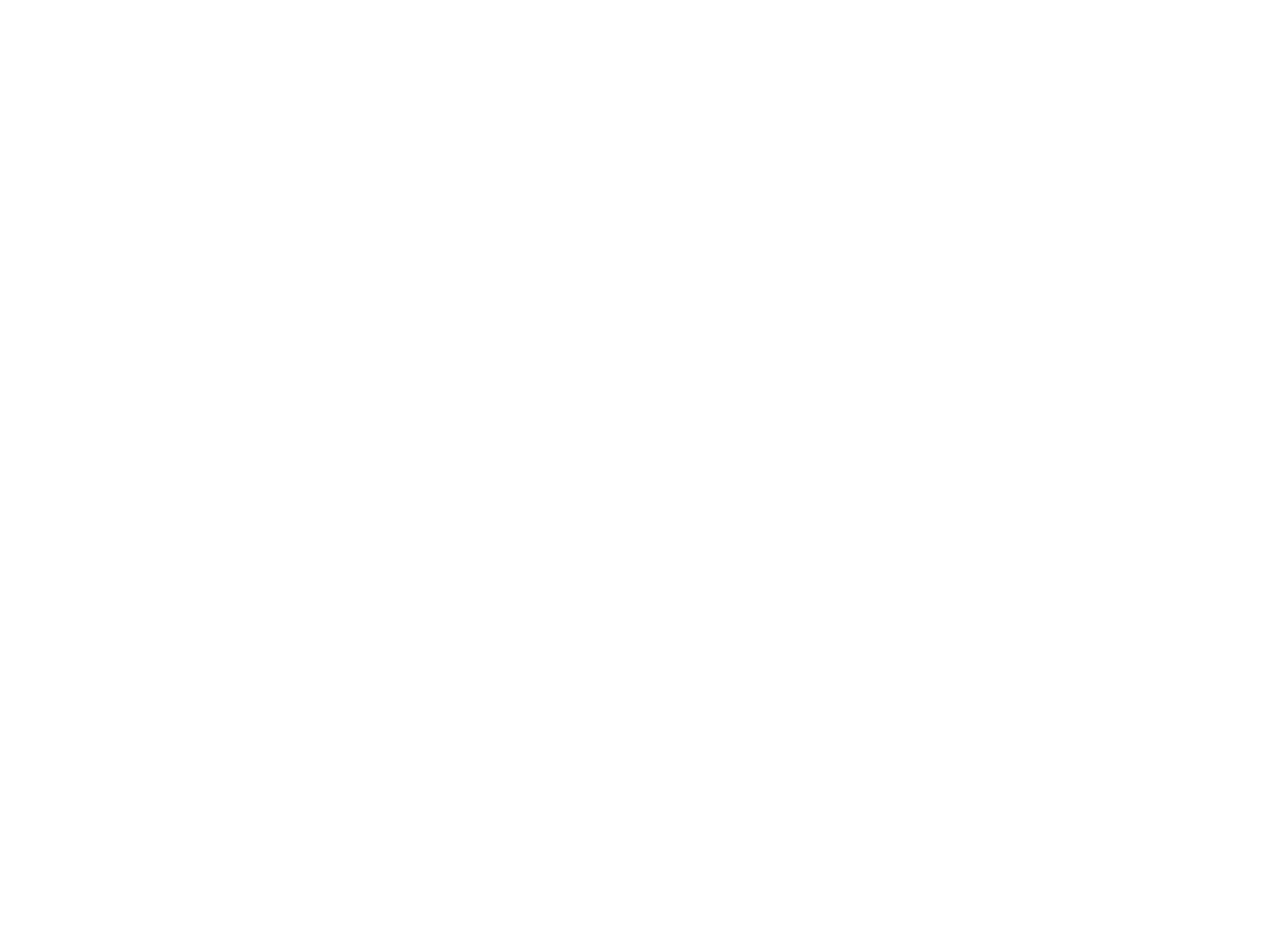

FIGURE 66.-Seasonal pattern of runoff in the Colorado River Basin between the Gunnison and Green Rivers, 1954 water year.

and the Mancos Shale. The drainage basin above the gaging station on San Miguel River at Placerville, Colo., from higher to lower altitudes is underlain principally by Tertiary volcanics, the Mancos Shale, the Dakota Sandstone, and the Morrison Formation. As indicated by the variability indices and percentage of groundwater contribution, the Tertiary volcanics underlying the major water-producing areas of the San Miguel River are apparently much more permeable than the Rico Formation, which underlies the major waterproducing area of the Dolores River.

\section{VARIABHLTYY OF ANNUAL RUNOFF}

The streamflow record for Dolores River at Dolores, Colo., is representative of runoff from the mountainous areas in the subbasin (fig. 67). The record for this station was extended to the base period by estimating the discharge for the water years 1914-21. Only about 3,500 acres is irrigated above the station, and probably little change occurred between 1914 and 1957 in the amount of land irrigated.
The outflow from the Grand division is represented by the record for Colorado River near Cisco, Utah. Additional inflow from the 2,400 square miles of drainage area between this gaging station and the Green River is approximately offset by channel losses. Discharge records were not collected for water years 1918-22 but have been estimated by the Upper Colorado River Compact Commission and are published in Water-Supply Paper 1313 (U.S. Geol. Survey, 1954, p. 248). The annual discharges for this station (fig. 67) were adjusted to the 1914 base. (See chap. B, p. 55.) The adjustments take into consideration changes in upstream use between 1914 and 1957. Table 10 gives the historical record and the adjustments.

The standard deviation and coefficient of variation of annual discharge for Dolores River at Dolores, Colo., Colorado River near Cisco, Utah, and three other streams were computed and are given in table 11. The coefficients are also plotted in plate 4 . The values given in the table for the shorter periods of record at some 
of the stations are believed to be near the average for the long-term base period.

Differences in topography and climate are the major factors causing the variability of annual runoff of tributary streams in this subbasin to be generally greater than the variability of annual runoff in the other two subbasins of the Grand division. Intense summer storms are common in this subbasin. The cumulative effect of infrequent summer storms over large areas is illustrated by the downstream increase in co-

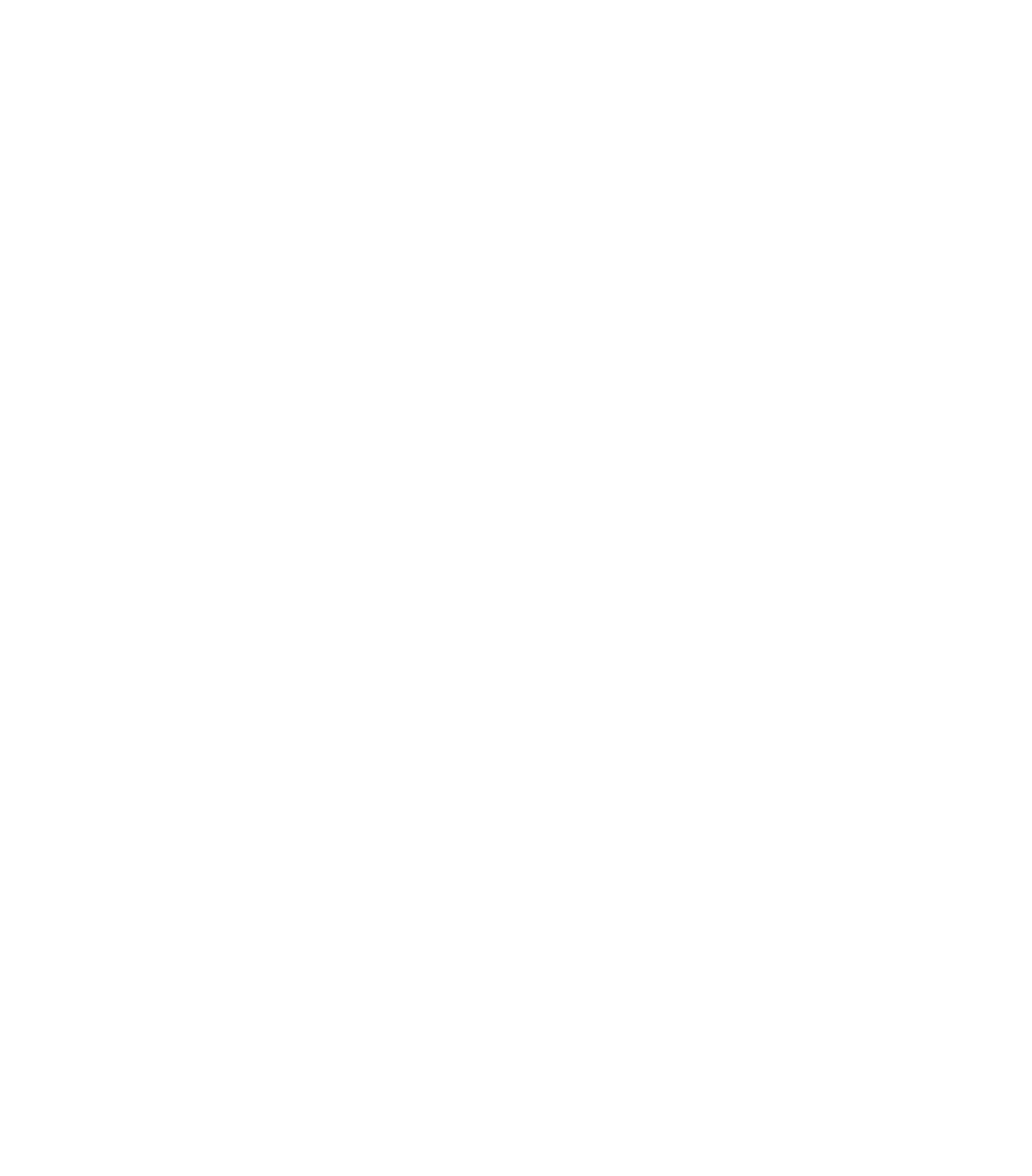

FJGURE 67.-Variability of annual discharges in the Colorado River Basin between the Gunnison and Green Rivers, water years 1914-57. 
efficients of variation for the Dolores River and its principal tributary, the San Miguel River.

Streamflow records for such streams as Courthouse Wash and Hatch Wash in Utah are too short to use for the computations of coefficients of variation for each stream alone. However, by use of the station-year method and the short records for Courthouse Wash near Moab, Hatch Wash near La Sal, Salaratus Wash at Green River, Browns Wash near Green River, White Canyon near Hite, and North Wash near Hite, all in Utah, the approximate variability of these and similar streams can be computed. A computed coefficient of variation of 0.76 is probably representative of the average variability of streams draining the lower areas in the western part of the subbasin.

\section{PRECIPITATION-RUNOFF RELATION}

Precipitation, water yield, and natural consumptive use for two drainage basins in the subbasin are shown in table 13.

The headwaters area of the drainage basin above the gaging station on Dolores River at Dolores, Colo., is underlain by the Rico Formation. Consumptive use by the trees and other vegetation which grow densely on the favorable soils derived from this formation is probably responsible for the low runoff from this wet part of the subbasin.

The average annual precipitation in the Mill Creek drainage basin is about equal to the natural consumptive use in most areas investigated in the Grand division. As "nature's take" must first be satisfied from the available moisture, the water yield from the Mill Creek basin and similar basins is small.

\section{CHEMICAL QUALITY OF WATER}

\section{DISSOLVED-SOLIDS DISCHARGE AND CONCENTRATION}

Daily chemical-quality data have been obtained at three sites in the Colorado River Basin between the Gunnison and Green Rivers. The records obtained at two of the sites-Dolores River at Gateway, Colo. (194852 ), and near Cisco, Utah (1952-57) - are almost equivalent. Monthly and annual weighted-average chemical analyses of water at these sites are given in the basic data report (Iorns and others, 1964, tables 184 to 186 ). In addition, chemical analyses of streams have been obtained at many other sites.

Daily chemical-quality data obtained at the three sites and chemical analyses of streams at six other sites were used with flow-duration tables to compute duration tables of dissolved-solids discharge and concentration (tables 15 and 16). (See chap. B, pp. 58-59, for description of computation method.) Water and dissolved-solids discharges for the nine sites are summarized in table 14. The range of average annual dis- solved-solids discharge per square mile of drainage area for the streams is large. For example, the average annual yield per square mile of drainage area ranged from 21 tons for Lost Canyon Creek to 171 tons for Colorado River near Cisco, Utah.

In the reach between the Cameo and Cisco gaging stations about 496,700 tons of dissolved solids are added annually to the Colorado River, exclusive of the amount contributed by Plateau Creek and the Gunnison and Dolores Rivers (table 29). This is the computed longterm average contribution for conditions existing in 1957. The yearly contribution of dissolved solids in this reach for water years 1934-57 is shown in table 30 .

A mass diagram of the dissolved-solids contribution in the reach is shown in figure 68 . The average rate of dissolved-solids contribution in the 24-year period is 745,000 tons per year (solid line). As indicated by the trends of the general slope (dashed lines) of the mass diagram, the average annual rate in the early years was about 860,000 tons, followed by an extended period having an average rate of about 745,000 tons. The trend in the most recent years was about 490,000 tons, which is about the same as the computed long-term average adjusted to 1957 conditions (table 29).

About 77 percent of the dissolved-solids discharge of Colorado River near Cisco, Utah, comes from the other two subbasins in the Grand division, 12 percent is added in the reach above the Dolores River, and 11 percent is contributed by the Dolores River (fig. 69).

The relation between water discharge and dissolvedsolids discharge of Colorado River near Cisco, Utah, changed little during the period that chemical-quality data have been obtained at the gaging station (fig. 70). In years of low runoff, 1931 and 1954, the dissolvedsolids discharge did not decrease as much as the water discharge. In years of intermediate and high runoff, the proportionality was fairly constant.

\section{VARIATIONS IN CHEMICAL QUALITY}

The seasonal variation in the chemical quality of the streams, particularly in their downstream reaches, is large. This variation is illustrated by the graphs in figures 71 and 72 for Dolores and Colorado Rivers near Cisco, Utah.

Coefficients of variation of the annual weightedaverage concentration of dissolved solids were computed for the periods of available record at two stations in this subbasin where daily chemical-quality records have been obtained. These coefficients and the coefficients of variation of the annual water discharge for the same periods are given in table 17 .

The relation between the coefficients of variation of water discharge and concentration at these stations is shown with others in the Grand division in figure 45 . 


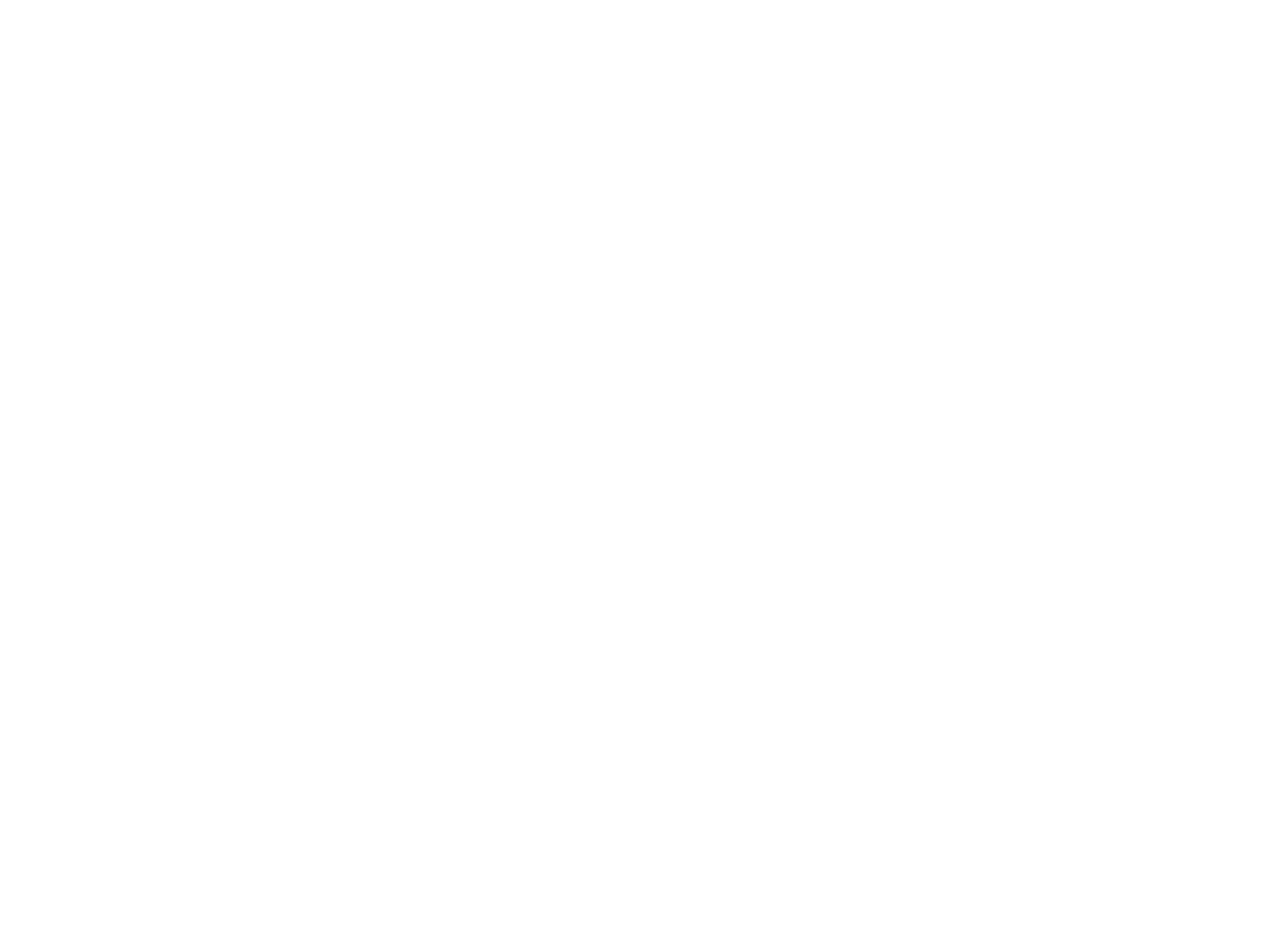

Figure 68.-Mass diagram of contribution of dissolved-solids to the Colorado River between the gaging stations on Colorado River near Cameo, Colo., and Colorado River near Cisco, Utah, water years 1934-57. Solid line indicates average rate for 24-year period; dashed lines indicate trends for periods of years.

In table 18 , coefficients of variation and standard deviations of weighted-average concentration for selected stations in the subbasin, computed by the equation of relation shown on page 94 , are given.

\section{RELATION TO STREAMFLOW}

The range in the dissolved-solids concentration of the Dolores River and its principal tributary, the San Miguel River, near their headwaters is not great between high and low flows (fig. 73). Downstream, the range in concentration between high and low flows increases in both streams, and the chemical type of water changes (fig. 73). The chemical quality of water of Colorado River near Cisco, Utah, also varies greatly between high and low discharges (fig. 73).

The relation between the chemical composition of water and streamflow at this station and the two daily stations operated on the Dolores River are shown in table 19. Duration tables of dissolved solids constituents may be prepared from the values in these tables and in tables 6, 15, and 16 and 19.
RELATION TO GEOLOGY

The type of rocks underlying this subbasin greatly influences the chemical quality of the streams. The chemical character and ionic concentration of surface waters at many sites in the subbasin at times of low flow are shown by the diagrams in plate 2 . The significance of the size and shape of the diagrams is given in the explanation in plate 2.

It has already been explained (p. 124) that large amounts of dissolved solids are added to the Colorado River in the Grand Valley. The residuum and Mancos Shale which underlie most of this valley are the primary source of the dissolved solids added to the river. Figure 74 shows an example of the chemical composition of water contributed to the river from the area underlain by these rocks.

Rocks of the Glen Canyon Group of Triassic and Jurassic age underlie most of the drainage basin of the Little Dolores River, which is the only stream of consequence draining the north end of the Uncompahgre 


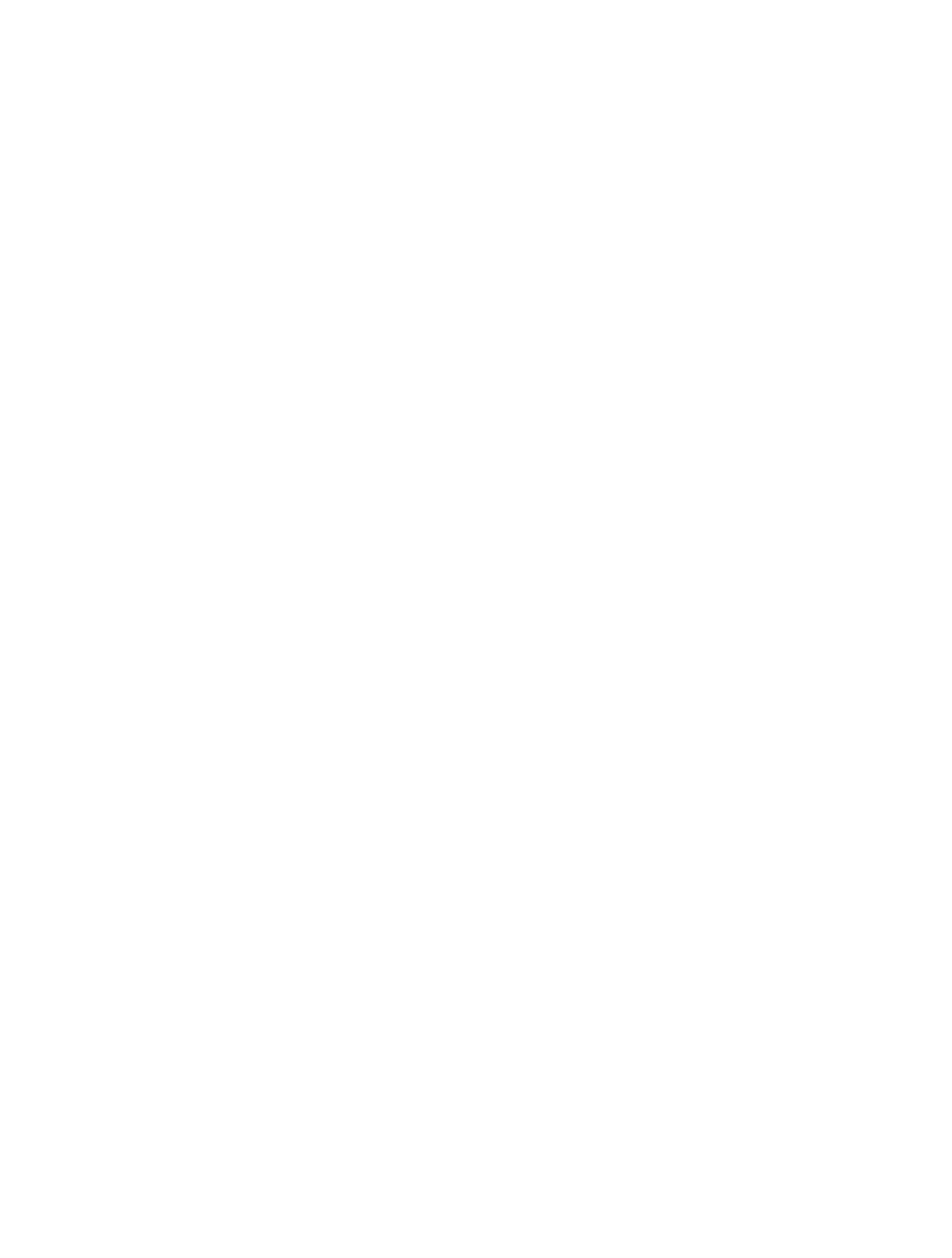

FigURE 69.-Approximate dissolved-solids discharge and streamflow expressed as percentages of the dissolved-solids discharge and streamflow of Colorado River near Cisco, Utah. 


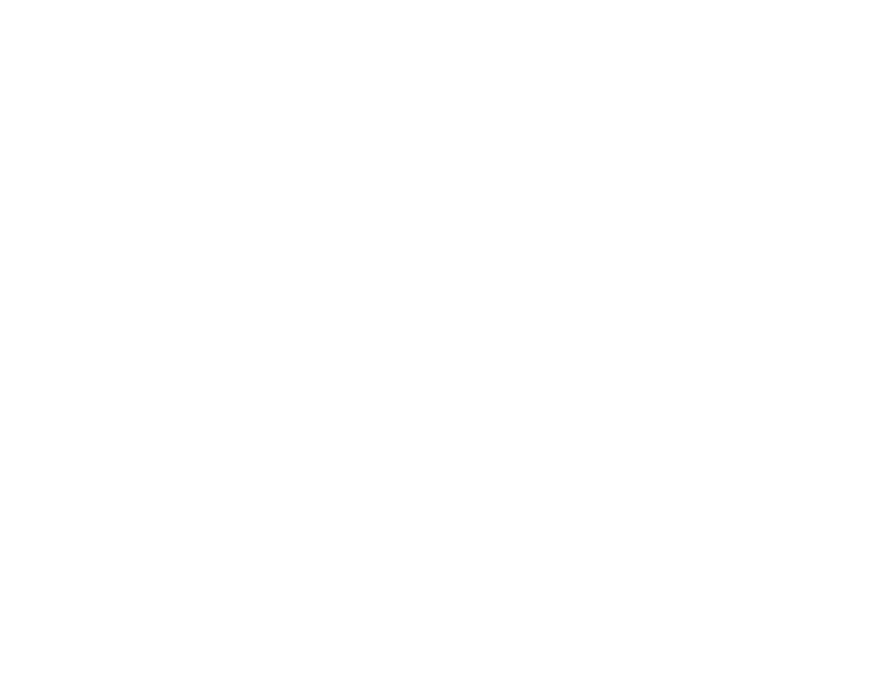

CUMULATIVE WATER DISCHARGE, IN MILLIONS OF ACRE-FEET

FIGore 70.-Cumulative dissolved-solids discharge and water discharge for Colorado River near Cisco, Utah, water years 1929-57.

Plateau. In its lower reaches the river has eroded through these rocks and into igneous rocks of Precambrian age. Springs and seeps in the rocks of Triassic age are the source of most of the flow in the Little Dolores River at times of low flow. At these times, the water is of the calcium magnesium sulfate bicarbonate chloride type. At times of higher flows (above about $2 \mathrm{cfs}$ ) the water is of the calcium bicarbonate type. The source of most of the higher flows is runoff from the areas underlain by rocks of the Glen Canyon Group, which are mostly sandstones containing relatively insoluble minerals.

The Dolores River basin, which is about 62 percent of the drainage area between the Gunnison River and Colorado River near Cisco, Utah, is underlain predominantly by sedimentary rocks of Cretaceous age. In the headwaters of the Dolores River above Dolores, on the south flank of the San Miguel Mountains, rocks of Cretaceous age underlie the divides, and rocks of Permian, Triassic, and Jurassic ages underlie the valleys and the valley sides.

The water of Dolores River below Rico, Colo., which is downstream from a canyon cut by the Dolores River through the Rico Mountains, is of the calcium bicarbonate type during high flows and of the calcium sulfate bicarbonate type during low flows. The quality of the water is apparently influenced mostly by the limestone and gypsiferous limestone of the Rico Formation. At the station below Rico, the dissolved-solids concentration of the river water usually does not exceed 300 ppm. The water of West Fork Dolores River near Stoner, Colo., is similar in concentration and type to that of Dolores River below Rico, Colo. At Dolores,
Colo., the water of the Dolores River is of the calcium bicarbonate type except when the streamflow is very low. At these times, the water may contain more equivalents per million of sulfate than of carbonate. The dissolved-solids concentration of Dolores River at Dolores, Colo., ranges from about 100 to $300 \mathrm{ppm}$ for 90 percent of the time (table 15).

The drainage basins of the tributaries entering the Dolores River from the east between Dolores and Bedrock are underlain by rocks that contain readily soluble minerals. The predominant rocks are the Mancos Shale, the Dakota Sandstone, and the Morrison

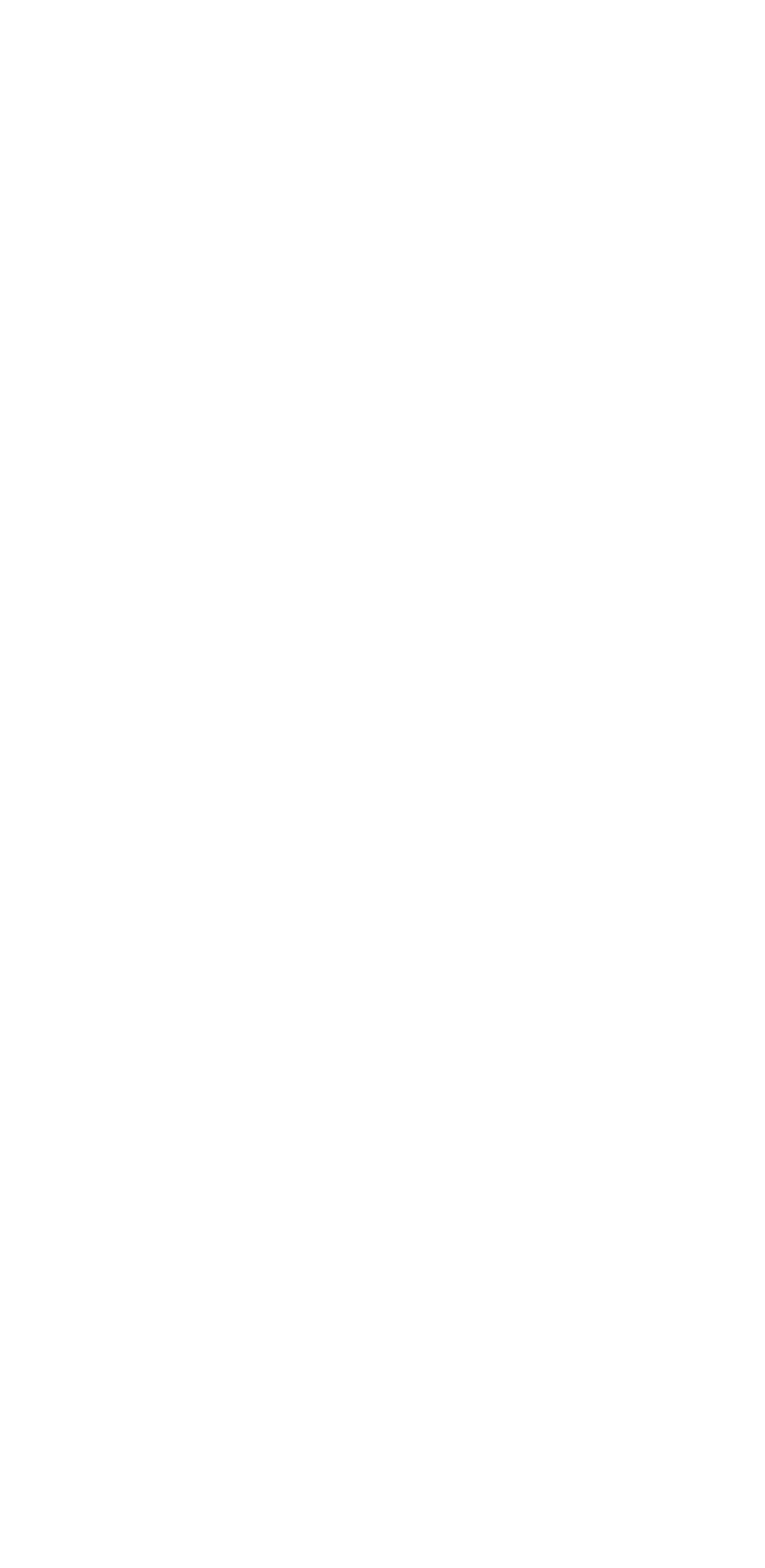

FIGURE 71.-Dissolved-solids concentration and water discharge of Dolores River near Cisco, Utah, 1956 water year. 


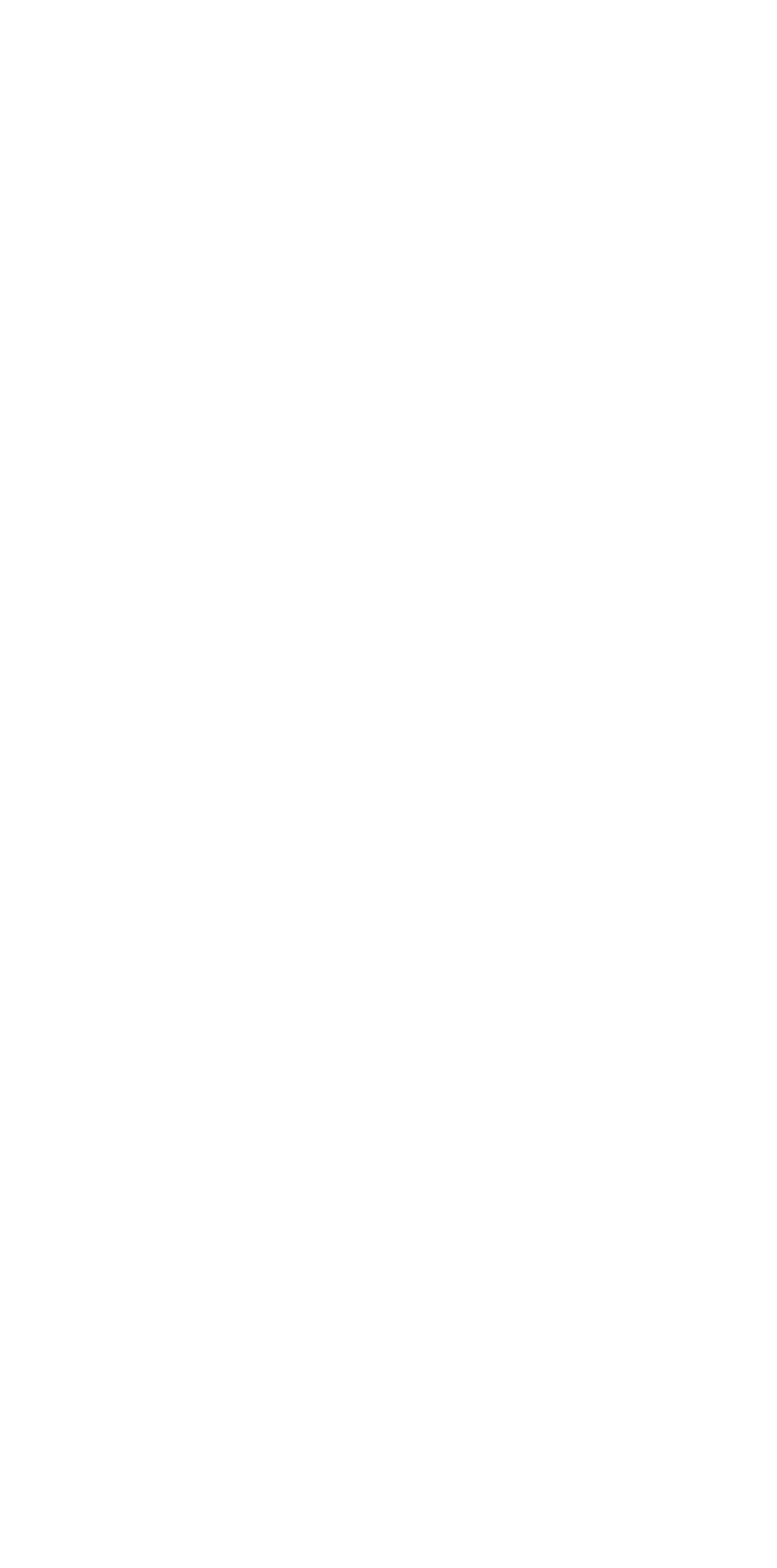

FIGURE 72.-Dissolved-solids concentration and water discharge of Colorado River pear Cisco, Utah, 1956 water year.

Formation. Disappointment Creek, one of the tributaries underlain almost entirely by the Mancos Shale, contributes water that is of the calcium sulfate type except at very low flows, when the water is of the sodium sulfate type. The dissolved-solids concentration of Dissappointment Creek ranges from about 600 ppm to more than 6,000 ppm.

At low flow, the concentration of the water of Dolores River at Bedrock, Colo., at times exceeds 1,200 ppm, and the water is of the sodium chloride type. The sodium chloride most likely comes from the reach where the Dolores River cuts across the west end of the
Gypsum Valley anticline or from Gypsum Creek, which drains the breached Gypsum Valley anticline. The Paradox Member of the Hermosa Formation is exposed in the Gypsum Valley. Great thicknesses of salt (sodium chloride) occur in the Paradox Member.

The Paradox Member is also exposed in, or underlies the alluvial fill in the Paradox Valley. Water from a well drilled 500 feet into the Paradox Member along the Dolores River contained 80,200 ppm of dissolved solids. Sodium and chloride were the predominant ions in this well water.

The San Miguel River rises in the west end of San Juan Mountains. In the extreme headwaters, the underlying rocks are mostly volcanic rocks of Tertiary age. The remainder of the drainage basin is predominantly underlain by the Dakota Sandstone, the Morrison Formation, and the Mancos Shale. These rocks, particularly the Mancos Shale and Morrison Formation, contain minerals that dissolve readily in water.

At times of high flows, when the runoff comes mostly from areas underlain by volcanic rocks, the water is of the calcium bicarbonate sulfate type. At times of low flow the water is of the calcium sulfate bicarbonate type. This change is probably caused by the greater influence of the Morrison Formation and Mancos Shale on the low flows as compared to their influence on high flows.

The waters of streams that rise on the Uncompahgre Plateau and enter the Dolores River between the San Miguel River and the mouth of the Dolores River are of the calcium bicarbonate type, and the concentration is usually less than $300 \mathrm{ppm}$. This area is underlain mostly by the Dakota Sandstone and rocks of the Glen Canyon Group, which are mostly sandstones.

Salt Creek, which flows into the Dolores River upstream from Gateway, drains the Sinbad Valley. This valley, which is a breached anticline, is underlain by the salt beds of the Paradox Member. The water of Salt Creek at the mouth had a specific conductance of 37,000 micromhos in March 1952 and a specific conductance of 44,400 micromhos in September 1951. In September 1951 the water contained 28,800 ppm of sodium chloride.

The dissolved-solids concentration of the water of Dolores River near Cisco, Utah, ranges from about 200 to $6,000 \mathrm{ppm}$. The concentration is more than $1,000 \mathrm{ppm}$ for 60 percent of the time (table 15). At low flow, the quality of the water at this station is strongly imfluenced by water from the Gypsum, Paradox, and Simbad Valleys and is of the sodium chloride type.

Many small tributaries flow into the Colorado River between the Dolores and Green Rivers. The dramage 

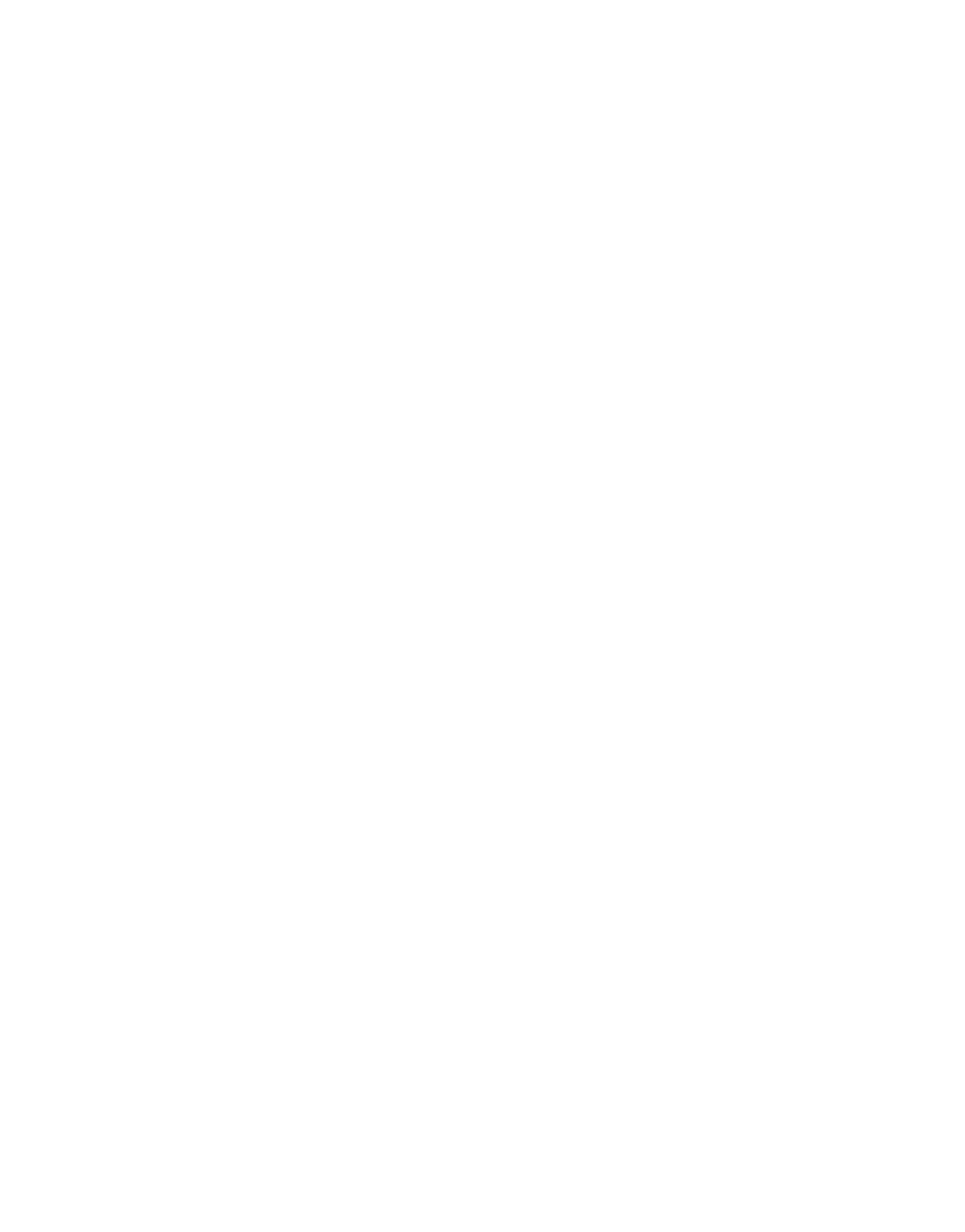

FIGURE 73.-Relation of the chemical composition and concentration of dissolved solids to water discharge in the Colorado River Basin between the Gunnison and Green Rivers. The concentration of specific ions, in equivalents per million (epm), is shown for the 10th, 50th, and 90th centiles of the flow-duration curve for each location. The flow-duration curves are for water years 1914-57 adjusted to 1957 conditions. 


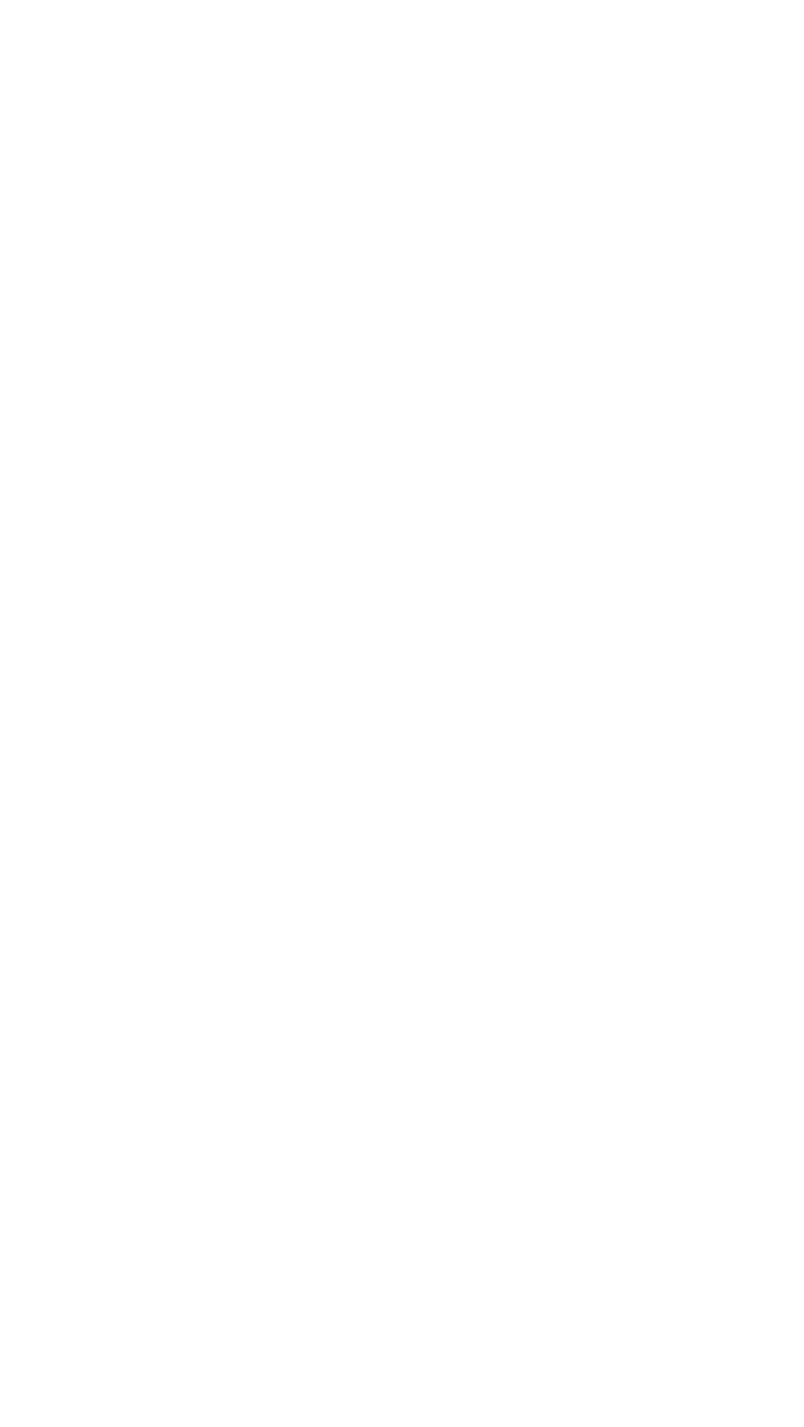

Figure 74.-Analyses of water from streams in the Grand Valley irrigation project. basins of these tributaries are underlain mostly by sedimentary rocks of the Mesozoic Era. All the tributaries are intermittent, except for a few streams that head in the La Sal and Abajo Mountains east of the Colorado River. The dissolved-solids concentration of some of these streams is relatively high, but their flow is so small in comparison to the flow of the Colorado River that the quality of the Colorado River is only slightly affected. Many of the streams have high concentrations of sodium chloride.

Zones of approximate weighted-average concentration are shown in figure 75. Comparison of these zones with the different rock types shown in plate 1 and the irrigated areas (pl. 5) gives an indication of the effect of the rock types and irrigation on the quality of water.
Analyses of a few samples of water from the Colorado River collected immediately above the Green River indicate that the weighted-average concentration of the river water at this point is about the same as at the Cisco station.

\section{RELATION TO GROUND WATER}

The headwaters of the Dolores and San Miguel Rivers are the only two areas in this subbasin in which the precipitation is sufficient for appreciable recharge to ground-water reservoirs. Quantities of dissolved solids estimated to be contributed by ground water to these two streams in their headwaters are given in table 20. Volcanic rocks underlying the headwaters of the San Miguel River apparently contain less soluble minerals than the Rico Formation underlying the headwaters of the Dolores River, as is indicated by the greater weighted-average concentration of ground water from the headwaters of the Dolores River. The large area of outcrop of the Mancos Shale in the higher areas of the San Miguel River basin is probably why the weighted-average concentration of San Miguel River near Placerville, Colo., is greater than that of Dolores River at Dolores, Colo.

Ground-water inflow to the Colorado River between the Gunnison and Dolores Rivers was probably negligible before irrigation began. The average annual precipitation is less than 10 inches over the valley area, and it exceeds 20 inches in only a small part of the highlands. The small tributaries that head in the highlands north of the river and flow across the valley are mostly dry washes and provide little water to maintain a ground-water reservoir in the residuum and alluvial mantle that covers the Mancos Shale underlying the valley. South of the river, the few tributaries that drain the Uncompahgre uplift are deeply incised in the rocks of the Glen Canyon Group. The fact that little ground water is contributed to these streams, even where they have eroded down to the Precambrian rocks, indicates that very little ground water is discharged to the Colorado River from the south.

As a result of irrigation, an extensive ground-water reservoir has been created beneath the irrigated lands in the Grand Valley. This reservoir is effluent to the Colorado River by seepage and drains. As this ground water has high concentrations of dissolved solids, it has a deteriorating effect on the quality of the water in the river. Analyses of samples of irrigation water, drainage water, and ground water have been made by the U.S. Salinity Laboratory at Riverside, Calif. These samples were collected during a soil survey of the Grand Junction area (Knobel and others, 1955). The analyses of these samples show the great differences 


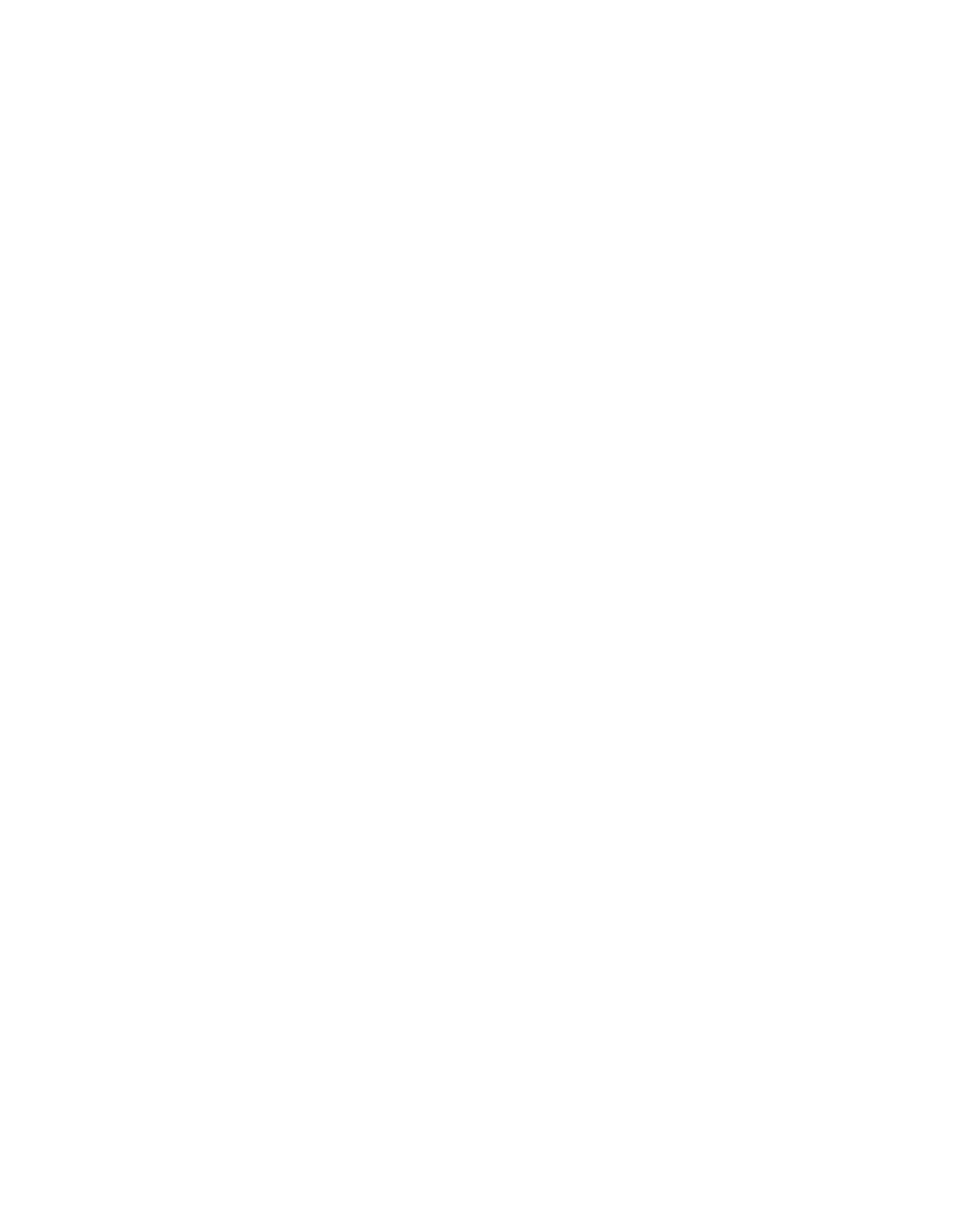


between the quality of the water before it is applied to the land and after it reaches the water table (fig. 76).

Water from two shallow wells in the alluvium along the Dolores River-one at Gladel, Colo., and one downstream at Bedrock-are similar in chemical type to the water in the river (fig. 77). Water from the well at Gladel contains more dissolved solids than water from the river at low flows. Water from the well at Bedrock contains slightly more dissolved solids than does the water from the well at Gladel. That the water in the well at Bedrock is more dilute than the water in the river is believed to be due to dilution from a nearby canal, which diverts water from upper West Paradox Creek.

Between Bedrock and Uravan, above and below the Paradox Valley, the concentration of the Dolores River on August 11, 1958, increased from 1,260 to $35,600 \mathrm{ppm}$, and most of the increase was in sodium chloride (fig. 78). The increase in dissolved solids in the river on this day was equivalent to about 160,000 tons per year. Apparently, most of the increased content of dissolved solids in the river was added by effluent ground water from the alluvium that fills the Paradox Valley, as there was no surface inflow to the river.
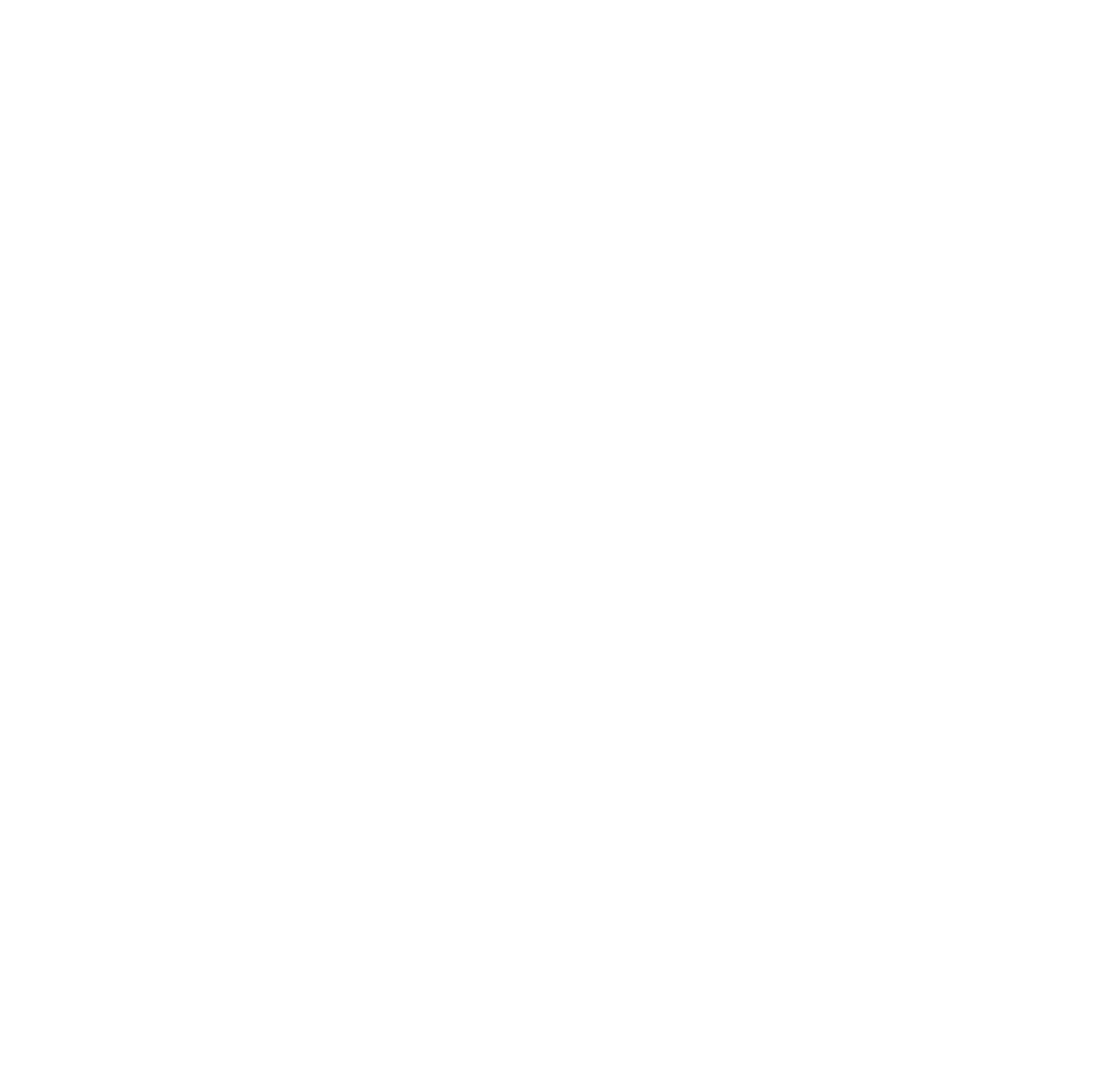

FIGURE 76.-Analyses of water from irrigation laterals and from wells nearby in the Grand Valley irrigation project near Grand Junction, Colo. 


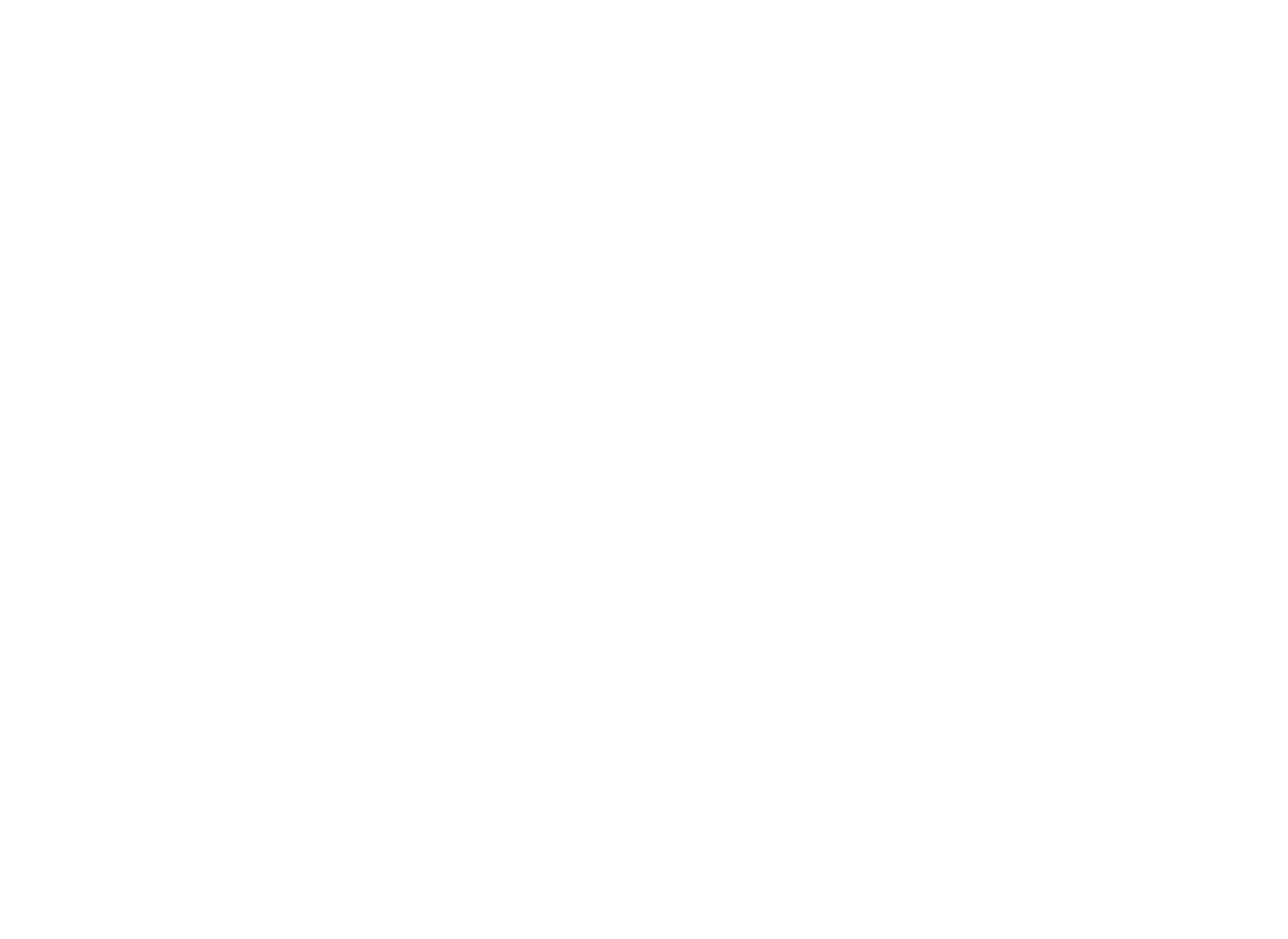

Firure 77.-Analyses of water from the Dolores River and from alluvium nearby.

Analyses of water in West Paradox Creek at times of discharge indicate very little sodium chloride in surface runoff from the Paradox Valley.

Ground water in the alluvium along the San Miguel River is generally of the calcium bicarbonate sulfate type in the upper reaches and of the calcium sulfate bicarbonate type in the lower reaches. At times of low flows, the water of the San Miguel River is of the same type as the ground water in the nearby alluvium. A similar relation exists between the water in West Creek at Gateway and the alluvium along West Creek (fig. 79). The water in the alluvium along the streams generally has a greater concentration of dissolved solids than the water in the streams.

Ground water that reaches the Colorado River by way of the streams that enter from the right bank between the Dolores and Green Rivers contains as little as $200 \mathrm{ppm}$ and as much as 2,500 ppm of dissolved solids. Ground water from the Entrada and Wingate Sandstones and from the alluvium that overlies these formations is consistently low in dissolved solids. Ground water associated with the Salt Wash Sandstone Member of the Morrison Formation usually contains about 1,500 ppm. Some ground water comes from the Paradox Member of the Hermosa Formation west of the river in this reach, and this water usually contains more than 2,000 ppm of dissolved solids, most of which is calcium sulfate. Water from the Salt Wash Sandstone member of the Morrison Formation and the Wingate and Entrada Sandstones may be of either the sodium sulfate or the sodium bicarbonate type.

Between the IDolores and Green Rivers, ground water in the area east of the Colorado River is similar in quality to that entering from the right bank, except ground water associated with the Paradox Member. Water from the Paradox Member east of the river is of the sodium chloride type and contains as much as $15,000 \mathrm{ppm}$ of dissolved solids at shallow depth. Water from a deep well in the Paradox Member along the Colorado River below the mouth of Cane Creek is of the sodium chloride type and contains more than $300,000 \mathrm{ppm}$ of dissolved solids, more than $4,500 \mathrm{ppm}$ of which is borate.

Two thermal springs in the headwater area of the San Miguel River basin have a combined discharge of less than $5 \mathrm{gpm}$ (Iorns and others, 1964, table 227) and 
an average concentration of about $3,300 \mathrm{ppm}$. The waters of the springs are of the sodium sulfate bicarbonate chloride type. Two thermal springs in the headwaters of the Dolores River have a reported combined discharge of about $50 \mathrm{gpm}$ (Stearns and others, 1937). On the assumption that the average concentration of all the springs is $3,300 \mathrm{ppm}$ they would add only about 400 tons of dissolved solids to the streams annually.

FFFECT OF TRANSMOUNTAIN DIVERSIONS

About 100,000 acre-feet of water having a weightedaverage concentration of dissolved solids of $125 \mathrm{ppm}$

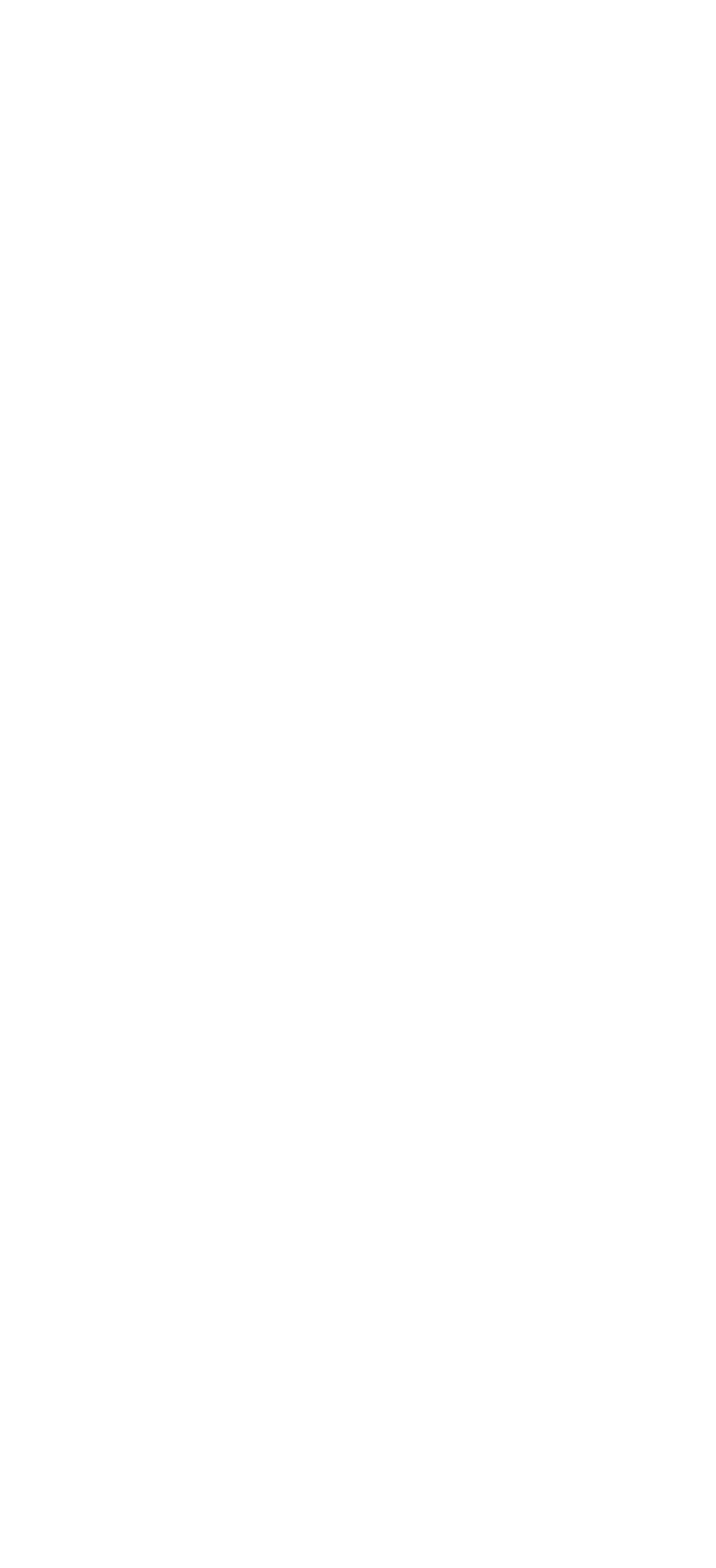

Figure 78.-Analyses of water from the Dolores River above and below Paradox Valley. is diverted annually from the Dolores River to irrigate land in the San Juan River basin (U.S. Dept. of the Interior, 1947 , p. 128). This diversion, which is made below the streamflow station at Dolores, Colo., adversely affects the quality of the water downstream in the Dolores and Colorado Rivers. The effect of the diversion on the quality of water of the two streams is to increase the weighted-average concentration and to decrease the dissolved-solids discharge by 17,000 tons.

If the 100,000 acre-feet per year of water had not been diverted, the weighted-average concentration in Dolores River near Cisco, Utah, for the water years 1914-57 would have been about 48 ppm less. Similarly, the weighted-average concentration in Colorado River near Cisco, Utah, would have been about 7 ppm less.

About 453,400 acre-feet of water is diverted annually from the Colorado River Basin above the gaging station on Colorado River near Cisco, Utah. If this water had not been diverted, the weighted-average concentration in Colorado River near Cisco, Utah, for the water years 1914-57 would have been decreased by about 37 ppm. Existing transmountain diversions out of the division have caused an average increase of about 8 ppm at the Cisco gaging station for each 100,000 acrefeet per year diverted.

\section{FFFECT OF THE ACTIVITIES OF MAN}

About 78,700 acres is irrigated in this subbasin between Plateau Creek and the Dolores River. Other factors that affect the quality of water of this area are several small industries and a population of about 35,000 .

Most of the irrigated lands are in the Grand Valley, which is underlain by the Mancos Shale and other rocks of Cretaceous age. These rocks are, in general, of the same type as those beneath most of the irrigated lands in the Uncompahgre River basin. According to the findings of a soil survey in the Grand Valley (Knobel and others, 1955, p. 30-31), the soils:

have a high content of lime carbonate, gypsum, and salts of sodium, potassium, magnesium, and calcium. In many places irrigation has brought about a concentration of salts toxic to plants *** Many of the soils having favorable physical characteristics have become more productive through the years of cultivation. This results from incorporation of organic matter by the growing of legumes and the application of moderate to large amounts of barnyard manure $* * *$ Some soils of the area have limited agricultural suitability, or are entirely unsuited to irrigation farming. Large areas of alluvial soils have limited agricultural use because restricted internal drainage causes water logging and accumulation of strong concentration of salts.

An average of about 496,700 tons of dissolved solids are added annually to the Colorado River between Plateau Creek and the Dolores River, exclusive of the Gunnison River. (See p. 126.) Of this amount, about 52,600 tons comes from natural sources and about 


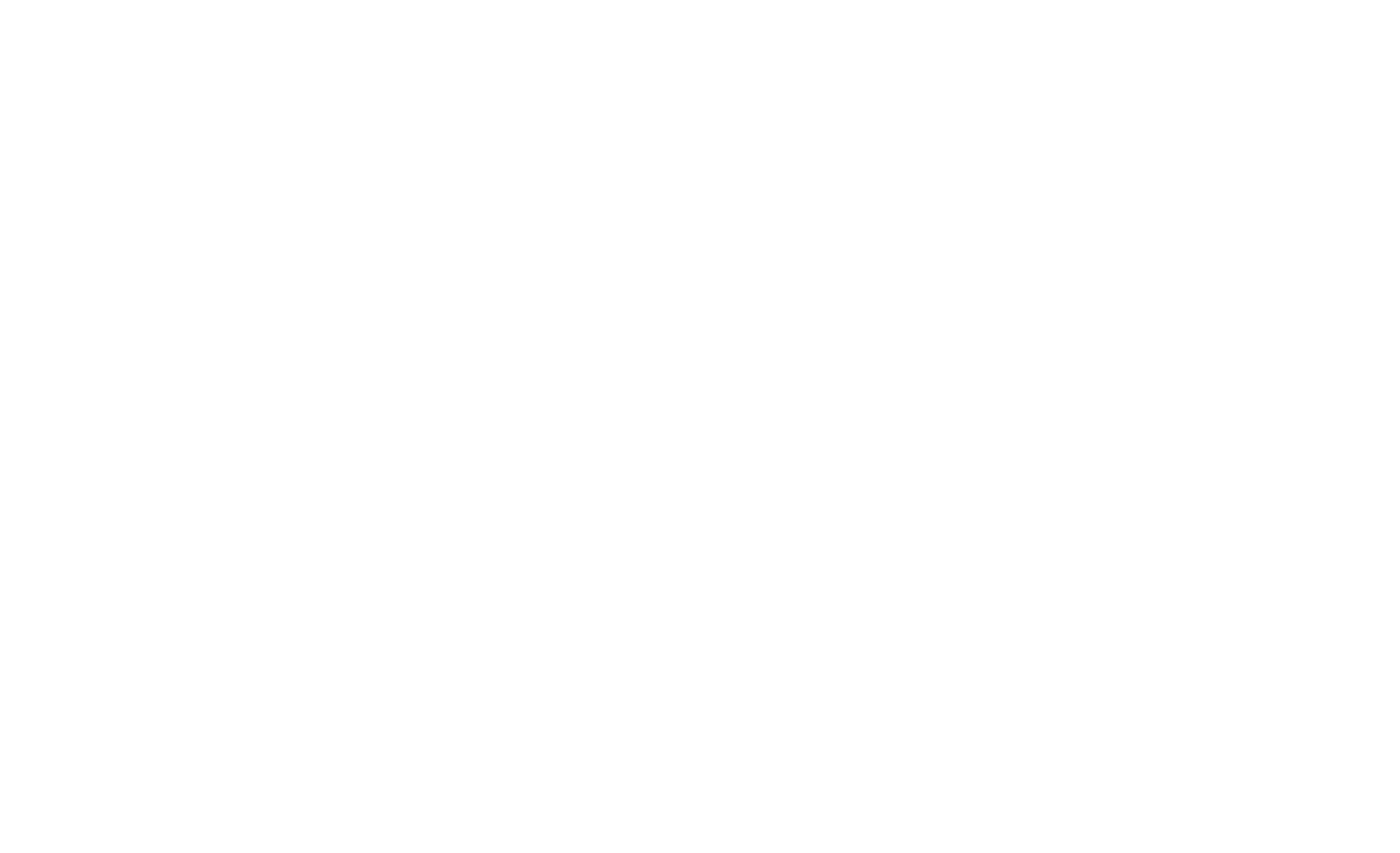

FIGURE 79.-Analyses of water from the San Miguel River and West Creek and from alluvium nearby.

444,100 tons is contributed as a result of the activities of man. (See chap. B, p. 61.) If 100 tons per year per 1,000 people is used as the rate of contribution of dissolved solids to the stream system as a result of domestic and industrial uses, the contribution from these sources would amount to 3,500 tons annually. The balance of 440,600 tons may be attributed principally to irrigation- 5.6 tons per year per acre of irrigated land.

In the Dolores River basin, from which an average of about 460,200 tons of dissolved solids are added annually to the Colorado River, most of the irrigated lands are underlain by rocks of Cretaceous age, predominantly the Dakota Sandstone. In the part of this basin drained by the San Miguel River between the gaging stations near Placerville, Colo., and at Naturita, Colo., about 15,000 acres of land underlain by the Dakota Sandstone is irrigated. Table 22 gives an approximate budget of water and dissolved solids for the area.

The unmeasured inflow is estimated to be 96,700 acre-feet-that is, the difference between the measured inflow (San Miguel River near Placerville) and the measured outflow (San Miguel River at Naturita) plus 30,000 acre-feet estimated to be used consumptively on 15,000 irrigated acres.

Part of the 96,700 acre-feet of unmeasured inflow is surface water and part is ground water recharged by precipitation on the valley lands. Under natural conditions, about 2 inches of the average annual precipitation of 12-16 inches is estimated to enter the groundwater reservoir under about 25,000 acres of valley lands and ultimately to reach the streams. The natural ground-water inflow (about 4,200 acre-ft) is estimated to have a weighted-average dissolved-solids concentration of $400-600 \mathrm{ppm}$. The estimated concentration in the unmeasured natural ground-water inflow is based on chemical analyses of water from streams in the area during low flow-San Miguel River at Naturita (525 ppm), Tabeguache Creek near Uravan (358 ppm), and Rock Creek near Uranium (662 ppm). (See table 14 and Iorns and others, 1964, table 220.)

The unmeasured surface-water inflow of 92,500 acrefeet is the total unmeasured inflow $(96,700$ acre- $\mathrm{ft}$ ) minus unmeasured natural ground-water inflow $(4,200$ acre-ft). Environmental factors, such as the type of rocks underlying the part of the basin from which the unmeasured surface water comes, are about the same as those above San Miguel River near Placerville. Therefore, the dissolved-solids concentration of the unmeasured surface water is estimated to be about 150 to $160 \mathrm{ppm}$.

The minimum computed increase in dissolved solids in table 22 , if attributed entirely to irrigation, is equivalent to about 2.8 tons per year per acre of irrigated land. 
For the rest of the Dolores River basin, about 71,300 tons of dissolved solids are estimated to be contributed annually to the streams as a result of the activities of man. This estimate is based on the indicated rate of dissolved-solids yield per acre determined for the 15,000 acres of irrigated land underlain by the Dakota Sandstone along the San Miguel River, data on other areas in the Upper Colorado River Basin where yield rates could be identified (see chap. B, table 14), the characteristics of rocks underlying irrigated lands, and chemical analyses of water at miscellaneous sites.

The disolved-solids contribution to the Colorado River from the 2,400 square miles of drainage area between the Dolores and Green Rivers is estimated to average 84,600 tons annually. This estimate was obtained by prorating, on the basis of drainage area, the dissolved-solids increase between the downstream chemical-quality stations in this subbasin and the Green division, and the upstream chemical-quality stations in the San Juan division. About 14,300 tons of the 84,600 tons is estimated to be contributed annually as a result of the activities of man.

Of the total dissolved solids contributed to the stream system $(1,041,500$ tons annually), about 469,900 tons comes from natural sources and about 571,600 tons is contributed as a result of the activities of man. Per unit of area, that from natural sources is 48 tons per square mile drained, and that caused by man is 4.7 tons per acre irrigated. On the basis of a population of $66,000,6,600$ tons of the contribution of dissolved solids due to the activities of man is estimated as caused by domestic and industrial uses of water and 565,000 tons as a result of irrigation.

In the other two subbasins of the Grand division and the part of this subbasin above the gaging station on Colorado River near Cisco, Utah, consumptive use of water by irrigation is about 732,500 acre-feet annually. Domestic and industrial uses of water are estimated to consume about 8,600 acre-feet annually. The activities of man are estimated to contribute an average of about 1,936,300 tons of dissolved solids to the river annually above the Cisco station. If there were no activities of man in the basin (exclusive of transmountain diversions), the weighted-average concentration of dissolved solids in Colorado River near Cisco, Utah, would be about $256 \mathrm{ppm}$ as compared to a weightedaverage concentration of about $547 \mathrm{ppm}$ for water years 1914-57 adjusted to 1957 conditions.

Existing consumptive uses of water for domestic, industrial, and irrigation purposes in the Grand division above the Cisco gaging station have caused an average increase of about $39 \mathrm{ppm}$ at the Cisco gaging station for each 100,000 acre-feet of water consumed. Domestic, industrial, and irrigation uses of water in the division have caused about five times as great an increase in dissolved-solids concentration at the Cisco station, for each acre-foot of water consumed, as the transmountain diversions have caused for each acre-foot of water transported out of the division.

\section{FLUVIAL SEDIMENT}

The collection of daily suspended-sediment data for Colorado and Dolores Rivers near Cisco, Utah, began in the 1930 and 1951 water years, respectively. Suspended-sediment discharges have been obtained at a few other sites, such as Dolores River at Dolores, Colo. The annual suspended-sediment discharges for the two daily stations are given in table 31 . Suspended-sediment data collected at other sites are contained in the basic data report (Iorns and others, 1964, tables 232, 233 , and 255).

The suspended-sediment discharge at the two stations near Cisco and the computed sediment discharge in Dolores River at Dolores, Colo., are given in table 25. Of the 14,351,000 tons of suspended sediment discharged annually by Colorado River near Cisco, Utah, about 3,015,000 tons originates in this subbasin. About 84 percent of the $3,015,000$ tons is contributed by the Dolores River.

The suspended-sediment contribution to the Colorado River from the 2,400 square miles of drainage area between the Dolores and the Green Rivers is estimated to average $6,144,000$ tons annually. This estimate was obtained by prorating, on the basis of drainage area, the suspended-sediment increase between the downstream suspended-sediment stations in this subbasin and in the Green division, and the upstream suspendedsediment stations in the San Juan division. The computed yield from the 5,850 square miles of intervening drainage area is 2,560 tons per square mile per year.

A statistical analysis of the annual suspended-sediment discharge shows that the variability of the suspended-sediment discharge for Colorado River near Cisco, Utah, is greater than the variability of either water discharge or dissolved-solids discharge at this station. The coefficient of variation of suspended-sediment discharge is 0.64 . The coefficients for streamflow and dissolved-solids concentration are 0.31 and 0.22 , respectively.

During the time in which the sediment station has been operated on Colorado River near Cisco, Utah, significant changes have taken place with time in the relation of sediment discharge to water discharge. After the 1942 water year, the annual suspended-sediment concentration of Colorado River near Cisco was generally less than in the the preceding years of record (table 31). The reasons for these changes are un- 
known, but they may be associated with variations in the intensity of summer storms or with periods of below-normal and above-normal precipitation.

\section{SUITABILITY OF WATER FOR VARIOUS USES DOMESTIC USE}

The classification of the surface waters in the Colorado River Basin between the Gunnison and Green Rivers is based on the water-quality criteria for major uses. (See chap. B, pp. 66-73.)

The waters of all the streams that enter the Colorado River between the Gunnison River and the Dolores River, except the Little Dolores River, contain at times more than 1,000 ppm of dissolved solids. The waters of these streams also contain more than $250 \mathrm{ppm}$ of sulfate, which is the maximum permitted by the accepted standards for domestic use. A few of the streams also contain more than the allowable $125 \mathrm{ppm}$ of magnesium. Only the water of the Little Dolores River, except during extremely low flows, is considered suitable for domestic purposes. All the stream waters are hard, and softening would be desirable for most purposes.

The waters of the Dolores River and tributaries above Disappointment Creek are suitable for domestic use. Between Disappointment Creek and the San Miguel River, the waters of the Dolores River and tributaries do not meet the criteria for domestic purposes used in this appraisal, except during the high flow in the spring. All these waters are moderately hard to hard.

The waters of the San Miguel River and its tributaries, except near their mouths during times of low flow, are suitable for domestic use. At low flows the waters of these streams contain more than the permissible amounts of sulfate. All the waters are hard to very hard.

Below the San Miguel River, the concentration of dissolved minerals in the water of the Dolores River and all tributaries from the west exceeds the maximum acceptable limits for domestic use. Tributaries that enter the Dolores River from the east between the San Miguel River and Gateway contain less than the maximum acceptable concentration of constituents adopted for this appraisal. The waters of the tributaries from the east and west sides are moderately hard to very hard.

Between the Dolores and Green Rivers, almost all the waters at the mouths of tributaries of the Colorado River contain more sulfate than is permissible according to the adopted domestic-use standards. The waters are hard to very hard. The dissolved solids in the Colorado River in this reach exceed the maximum of accepted standards except during high flow in the spring, and the water is not satisfactory for domestic purposes for about 9 months of the year.

The monthly weighted-average concentration of nitrate in Dolores and Colorado Rivers near Cisco, Utah, has been as much as $61 \mathrm{ppm}$ and $40 \mathrm{ppm}$, respectively. Samples of ground water and water in drains in the Grand Valley collected in November 1960 contained as much as $84 \mathrm{ppm}$ of nitrate. These high nitrate concentrations indicate that the use of some of these waters for domestic purposes, especially for preparing babies' formulas, might have serious consequences.

\section{AGRICULTURAL USE}

Table 27 gives the classification of selected streams as to their suitability for irrigation use at low, medium, and high flows. The chemical analysis on which the classification is based are in the basic data report (Iorns and others, 196t). The terms used in the table are self-explanatory or are explained on page 107 and in chapter B, pp. 69-73.

The waters of the streams at the sites listed in table 27 all contain less than $1.25 \mathrm{epm}$ of residual sodium carbonate and are thus permissible for use in irrigation insofar as this measure of usability is concerned.

The surface waters in this subbasin range from the $\mathrm{C} 1-\mathrm{S} 1$ to the $\mathrm{C} 4 \mathrm{~S} 4$ category, and most of the waters that are presently used for irrigation are classified as C3-S1 or better, acording to the method of classification of the U.S. Salinity Laboratory Staff (1954).

The waters of many of the streams at the sites listed in the table should not be used for irrigation, and some of the waters should be used only on soils that have exceptionally good drainage. Many of the waters of the streams have a high sodium-absorption-ratio and a high required leaching percentage.

\section{INDUSTRIAL USE}

Most of the waters in this subbasin would require treatment for most industrial applications. A few of the streams in the headwaters could be used for some industries without treamtent. (See chap. B, table 17, and the basic data report (Iorns and others, 1964).)

\section{SUMMARY}

The eastern part of the Grand division is a series of uplifted mountain masses deeply dissected as a result of erosional processes including weathering and glaciation. In the western part, essentially a dissected plateau, the streams flow in wide valleys or in deep narrow canyons cut below benches and tablelands. All the division is above an altitude of about 3,880 feet, and many of the mountain peaks rise above 13,000 feet. The Colorado River flows southwestward across the division near its north boundary. 
The exposed rocks range in age from late Precambrian to Recent. The pattern of exposures is complex, owing to uplift, folding, faulting, and weathering. Hard rocks, mainly igneous and metamorphic, form the ridges and mountain cores, and softer rocks, such as siltstones and shales, underlie the valleys and lowlands. The unconsolidated deposits mantling the consolidated rocks are principally residuum developed from the underlying parent rock. and river alluvium derived mostly from nearby sources.

The climate is governed largely by topography and altitude. The precipitation ranges from less than 8 inches in the western part to more than 50 inches on the high mesas and in the mountains. The precipitation on about three-fifths of the division is less than 20 inches. The annual average precipitation over the division is 20.27 inches (water years 1914-57).

Runoff varies with the seasons. Snow that accumulates in the mountains provides most of the water supply. As the snow melts in the late spring and early summer, the flow in the perennial streams rises to a peak and then subsides as the supply of snow is exhausted. Relatively little runoff occurs from local thunderstorms, which occur infrequently during the summer.

Flow-duration curves, which show the percentage of time during which specified rates of flow were equaled or exceeded, were adjusted to be representative of the streamflows that would have occurred if the level of development in 1957 had existed throughout water years 1914-57. The average discharges of the streams for the 44-year base period were computed from these curves.

Differences in the shape of flow-duration curves are the result of differences in drainage-basin characteristics. For snowmelt streams, which predominate, the relative permeability of the rocks underlying the drainage basins of the streams is apparently the major cause of variation in the slope of the flow-duration curves. The relative permeability of the rocks is reflected also in the percentage of average annual discharge contributed to the stream systems from groundwater reservoirs. For example, ground-water contribution to Gypsum and Homestake Creeks is computed to be 66 percent and 11 percent of the average annual discharge of the streams, respectively. The Gypsum Creek drainage basin is underlain by relatively permeable rocks and Homestake Creek drainage basin by relatively impermeable rocks. The average annual precipitation and the directional exposure and altitude are about the same for both drainage basins.
A statistical analysis for selected gaging stations indicates that the annual discharges of many streams for the base period (1914-57) are normally distributed and that the coefficients of variation (ratio of standard deviation to the average discharge) have geographic significance. These two characteristics provide a basis for estimating the probabilities of streamflow for a year or a group of years in streams for which the record is short. The coefficients of variation of the perennial streams investigated ranged from 0.18 to 0.59 and, on the average, increased from 0.27 in the eastern part to 0.39 in the western part. For intermittent streams in the western part, the coefficient was estimated to be about 0.76 .

Table 32 shows an approximate water budget for the division. The total supply from precipitation is $28,648,300$ acre-feet, which is equivalent to an annual average precipitation of 20.27 inches. All the precipitation not accounted for in outflow, transmountain diversions, and consumptive use due to the activities of man is considered to be evapotranspiration loss from land and water surfaces and native vegetation. This loss accounts for 76.5 percent of the precipitation, or 15.5 inches of water over the drainage basin.

Data on water utilization and storage reservoirs are summarized in table 33. The major use of water is for irrigation.

The differences in the chemical quality of the streams result from the differences in hydrologic and other environmental factors prevailing in the drainage basins. The major environmental factors that determine the chemical quality of each stream are precipitation, type of rock and soils that underlie each drainage basin, and the activities of man.

Most of the streams are of the snowmelt type and have the normal pattern of change in the dissolvedsolids concentration. The concentrations are lowest in the months of maximum water discharge and highest in the months of low flow when the streams are maintained largely by ground water.

A statistical analysis of the variations in the concentration of dissolved solids for six stations indicates a linear relation between the coefficients of variation of yearly weighted-average concentration and the coefficients of variation of yearly water discharge. The variability of weighted-average concentration is about 60 percent of that of streamflow. This relation provides a means of developing statistical expressions of the variability of dissolved-solids concentration for many locations where chemical-quality stations have not been operated.

The range in concentraton of dissolved solids between high and low discharges is generally small in 
headwater streams but increases downstream. The range in concentration is especially large downstream from areas that contribute relatively large amounts of dissolved solids.

Most headwater streams do not change in chemical type from high to low flows, the water generally being of the calcium bicarbonate type at all flows. In their downstream reaches, the waters of most of the streams are of the calcium bicarbonate type during high flow and of the sodium sulfate type during low flow.

The mountainous headwaters of the Colorado and Gunnison Rivers are mostly underlain by granitic and associated metamorphic rocks of Precambrian age and volcanic rocks of Tertiary age that are resistant to the solvent action of water. The weighted-average concentration of dissolved solids of the headwater streams draining areas underlain by the Precambrian rocks is as low as $20 \mathrm{ppm}$ and seldom exceeds $50 \mathrm{ppm}$. The concentration of silica in runoff from headwater areas underlain by the Tertiary volcanics may, however, average as much as $25 \mathrm{ppm}$.

The western part of the division is underlain principally by sedimentary rocks. Such rocks also underlie the central part at lower altitudes and in some places, the eastern part at lower altitudes. Many of these sedimentary rocks are of marine origin and contain substantial amounts of readily soluble minerals. Tributary streams draining areas underlain by marine sediments have relatively large concentrations of sodium, magnesium, sulfate, and chloride.

Sedimentary rocks, including those of marine origin, are also exposed in some of the headwater areas. Streams draining such areas have substantially higher concentrations of dissolved solids than streams draining nearby areas that are underlain by igneous and metamorphic rocks and that receive comparable precipitation.

The dissolved-solids concentration of most streams increases downstream. Most streams in the headwater areas, which are the source of most of the water supply, have weighted-average concentrations of less than $100 \mathrm{ppm}$. Downstream, the long-term weighted-average concentration of the Colorado River increases from $76 \mathrm{ppm}$ at Hot Sulphur Springs, Colo., to $270 \mathrm{ppm}$ at the station near Glenwood Springs, Colo., $387 \mathrm{ppm}$ at the station near Cameo, Colo., and $547 \mathrm{ppm}$ at the station near Cisco, Utah. The principal natural causes for the increase are the relatively high dissolved-solids concentration of the runoff from downstream areas underlain by sedimentary rocks, pickup by the streams as they flow over formations containing soluble minerals, and natural ground-water discharge, particularly from thermal springs. Among the principal ac- tivities of man that cause the concentration to increase are the consumptive use of water, the discharge of domestic and industrial wastes to the streams, and the leaching of soluble minerals from the soils and underlying rocks by irrigation water.

Ground-water contribution to the streams affects the chemical quality of the water in the streams, especially during periods of low flow when the streams are sustained largely. by ground water. During periods of high flow, the relatively concentrated ground-water contribution to the streams is diluted by surface runoff.

In some areas water is interchanged between the streams and the adjacent flood-plain alluvium as a result of the rise and fall of the streams. The concentration of dissolved solids in the streams is usually much less than that of the ground water in the alluvium. The movement of ground water from the alluvium to the stream increases the concentration of dissolved solids in the stream.

Thermal springs having high concentrations but small discharge as compared to the receiving streams add appreciable quantities of dissolved solids to some of the streams. About 482,000 tons of dissolved solids are added to the streams annually by thermal springs. The combined annual water discharge of the springs is only about 41,000 acre-feet.

Water diverted out of the Grand division carries with it the dissolved minerals in the diverted water. The effect of the exportation on the master stream at downstream points is to deplete the flow, to decrease the dissolved-solids load, and to increase the dissolvedsolids concentration. About 17,800 tons of dissolved solids is annually carried out of the Colorado River Basin above the Gunnison River in the 353,100 acrefeet of water diverted across the Continental Divide and about 25 tons is annually carried out of the Gunnison River basin in 300 acre-feet of water. The 100,000 acre-feet diverted annually from the Dolores River basin to the San Juan River basin carries with it about 17,000 tons of dissolved solids. The effect of the transmountain diversions on the Colorado River below the Dolores River has been an increase in the weighted-average concentration of about $37 \mathrm{ppm}$. This increase is equivalent to about $8 \mathrm{ppm}$ for each 100,000 acre-feet of water exported.

Domestic, industrial, and irrigation use of water results in the consumption of about 748,000 acre-feet of water annually (table 33) and in the addition of about $1,950,600$ tons of dissolved solids annually to the stream system (table 34 ). These activities of man (exclusive of transmountain diversions) have caused an increase of about $291 \mathrm{ppm}$ in the weighted-average concentration of the Colorado River below the Dolores 
River. This increase is equivalent to an average increase of about $39 \mathrm{ppm}$ for each 100,000 acre-feet of water consumed or about five times the effect caused by the exportation of an equivalent amount of water. The major part of the increase in dissolved-solids concentration is attributed to irrigation.

About 20,495,000 tons of suspended sediment is discharged from the Grand division annually (table 34). Of this amount, about 45 percent comes from the Colorado River Basin above the Gunnison River, about 10 percent comes from the Gunnison River basin, and about 45 percent comes from the rest of the division below the Gunnison River.

Determinations of suspended-sediment discharge of streams were made at 3 sites on the Colorado River and at 10 sites on tributaries. Of the 13 areas above the sites, the drainage basin of the Gunnison River above the Gunnison tunnel, with a yield of 46 tons per square mile per year, had the lowest rate of yield. Colorado River near Cameo, Colo., had the highest rate-1,150 tons per year per square mile. Most of the suspended sediment transported past this station comes from the drainage area between the Cameo station and Roaring Fork. This area contributes an average of about 4,150 tons per year per square mile of drainage area.

Chemical-quality data indicate that the concentrations of dissolved solids in many streams are below the maximum accepted limits for domestic use, particularly in headwater streams. The concentrations in the lower reaches of some of these streams exceed the limits for domestic use. In the central and western parts of the basin, the waters of many streams do not meet the standards for domestic use because of high concentrations of sodium, magnesium, sulfate, or chloride. Below some of the irrigated areas the concentrations of nitrate also are relatively high. The monthly weightedaverage concentration of nitrate in Dolores and Colorado Rivers near Cisco, Utah, has been as much as 61 $\mathrm{ppm}$ and $40 \mathrm{ppm}$, respectively. Samples of ground water and water in drains in Grand Valley collected in November 1960 contained a maximum of $84 \mathrm{ppm}$ of nitrate. These high nitrate concentrations may cause methemoglobinemia ("blue baby disease") in infants if the water is used in preparing their formulas. Most surface waters in the division range from moderately hard to hard.

The waters of practically all streams in the Grand division are suitable for agricultural use. Exceptions to this are the return flows from some irrigated lands and low flows in the lower reaches of the Dolores River and some of its tributaries.

\section{SELECTED REFERENCES}

Andrews, D. A., and Hunt, C. B., 1948, Geologic map of eastern and southern Utah: U.S. Geol. Survey Oil and Gas Inv. Prelim. Map 70, 1 sheet; reprinted 1956.

Burbank, W. S., Lovering, T. S., Goddard, E. N., and Eckel, E. B., 1935, Geologic map of Colorado: U.S. Geol. Survey map, 2 sheets; reprinted 1959.

Cannon, H. L., 1960, The development of botanical methods of prospecting for uranium on the Colorado Plateau: U.S. Geol. Survey Bull. 1085-A, 56 p.

Colby, B. R., Hembree, C. H., and Rainwater, F. H., 1956, Sedimentation and chemical quality of surface waters in the Wind River Basin, Wyoming: U.S. Geol. Survey WaterSupply Paper 1373, 336 p.

Dane, C. H., and Bachman, G. O., 1957, Preliminary geologic map of the northwestern part of New Mexico: U.S. Geol. Survey Misc. Geol. Inv. Map I-224, 1 sheet.

Eaton, F. M., 1954, Formulas for estimating the drainage and gypsum requirements of irrigation waters: Texas Agr. Expt. Sta. Misc. Rept. 111, 18 p.

George, R. D., and others, 1920, Mineral waters of Colorado: Colorado Geol. Survey Bull. 11, 475 p.

Iorns, W. V., Hembree, C. H., Phoenix, D. A., and Oakland, G. L., 1964, Water resources of the Upper Colorado River Basin-basic data: U.S. Geol. Survey Prof. Paper 442, $1036 \mathrm{p}$.

Knobel, E. W., Dansdill, R. R., and Richardson, M. L., 1955, Soil survey, Grand Junction area, Colorado: U.S. Dept. Agriculture, Soil Conserv. Service ser. 1940, no. 19, 118 p.

Kohler, M. E., Nordenson, T. J., and Baker, D. R., 1959, Evaporation maps of the United States: U.S. Weather Bur. Tech. Paper 37, 13 p.

Lane, E. W., and Lei, Kai, 1950, Streamflow variability: Am. Soc. Civil Engineers Trans., v. 115, p. 1084-1134.

LaRue, E. C., 1916, Colorado River and its utilization: U.S. Geol. Survey Water-Supply Paper 395, $231 \mathrm{p}$.

Leopold, L. B., 1959, Probability analysis applied to a watersupply problem: U.S. Geol. Survey Circ. 410, 18 p.

Love, J. D., Weitz, J. L., and Hose, R. K., 1955, Geologic map of Wyoming: U.S. Geol. Survey map, 1 sheet.

Meyers, J. S., 1962, Evaporation from the 17 Western States, with a section on Evaporation rates, by T. J. Nordenson: U.S. Geol. Survey Prof. Paper 272-D, p. 71-100.

Shantz, N. L., and Zon, Raphael, 1924, Natural vegetation: U.S. Dept. Agriculture Atlas Am. Agriculture, 22 p.

Stearns, Norah D., Stearns, Harold T., and Waring, Gerald A., 1937, Thermal springs in the United States: U.S. Geol. Survey Water-Supply Paper 679-B, $191 \mathrm{p}$.

Upper Colorado River Basin Compact Commission, 1948, Final report of Engineering Advisory Committee to Upper Colorado River Basin Compact Commission: 203 p.

U.S. Bureau of the Census, 1953, Colorado and Utah, Irrigated acreage by drainage basins, 1949: U.S. Bur. Census map, 2 sheets.

U.S. Department of the Interior, 1947, The Colorado River: U.S. 80th Cong., 1st sess., H. Doc. 419, 295 p.

U.S. Geological Survey, 1954, Compilation of records of surface waters of the United States through September 1950, pt. 9, Colorado River basin: U.S. Geol. Survey Water-Supply Paper 1313, 749 p.

U.S. Salinity Laboratory Staff, 1954, Diagnosis and improvement of saline and alkali soil: U.S. Dept. of Agriculture, Agriculture Handb. 60, $160 \mathrm{p}$. 


\section{TABLES 1-34}




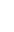


TABLE 1.-Average monthly and annual precipitation, in inches, at 17 index-precipitation stations in the Grand division

[Data are for water years 1914-57]

\begin{tabular}{|c|c|c|c|c|c|c|c|c|c|c|c|c|c|}
\hline Station name & October & November & December & January & February & March & April & May & June & July & August & September & Annual \\
\hline $\begin{array}{l}\text { Spicer, Colo } \\
\text { Estes Park, Colo } \\
\text { Fraser, Colo } \\
\text { Idaho Springs, Colo. } \\
\text { Dillon, Colo. } \\
\text { Leadville, Colo- } \\
\text { Shoshone, Colo- } \\
\text { Collbran, Colo... } \\
\text { Grand Junction, Colo } \\
\text { Cedaredge, Colo } \\
\text { Paonia, Colo, } \\
\text { Montrose, Colo } \\
\text { Gunnison, Colo } \\
\text { Pitkin, Colo } \\
\text { Ames, Colo } \\
\text { Rico, Colo } \\
\text { Moab, Utah }\end{array}$ & $\begin{array}{r}1.10 \\
1.23 \\
1.29 \\
1.00 \\
1.36 \\
1.22 \\
1.44 \\
1.38 \\
.83 \\
1.14 \\
1.49 \\
.90 \\
.66 \\
1.02 \\
2.17 \\
2.01 \\
1.04\end{array}$ & $\begin{array}{r}0.98 \\
.93 \\
1.17 \\
.67 \\
1.16 \\
1.08 \\
1.21 \\
1.04 \\
.59 \\
.73 \\
1.20 \\
.62 \\
.58 \\
.93 \\
1.40 \\
1.54 \\
.65\end{array}$ & $\begin{array}{r}1.04 \\
.78 \\
1.34 \\
.50 \\
1.32 \\
1.16 \\
1.48 \\
1.07 \\
.65 \\
.82 \\
1.34 \\
.64 \\
.73 \\
1.23 \\
1.77 \\
2.12 \\
.86\end{array}$ & $\begin{array}{r}0.89 \\
.57 \\
1.63 \\
.34 \\
1.33 \\
1.29 \\
1.64 \\
1.22 \\
.68 \\
.94 \\
1.42 \\
.61 \\
.92 \\
1.40 \\
1.93 \\
2.61 \\
.78\end{array}$ & $\begin{array}{r}0.90 \\
.87 \\
1.57 \\
.50 \\
1.39 \\
1.39 \\
1.54 \\
1.08 \\
.59 \\
.89 \\
1.27 \\
.48 \\
.81 \\
1.29 \\
2.04 \\
2.25 \\
.64\end{array}$ & $\begin{array}{r}1.13 \\
1.27 \\
1.72 \\
.89 \\
1.92 \\
1.62 \\
1.45 \\
1.44 \\
.80 \\
.91 \\
1.35 \\
.71 \\
.73 \\
1.41 \\
2.54 \\
2.54 \\
.76\end{array}$ & $\begin{array}{r}1.26 \\
2.27 \\
2.07 \\
2.01 \\
2.16 \\
1.81 \\
1.89 \\
1.64 \\
.78 \\
1.23 \\
1.70 \\
1.00 \\
.74 \\
1.38 \\
2.58 \\
2.12 \\
.88\end{array}$ & $\begin{array}{r}1.19 \\
2.15 \\
1.85 \\
1.92 \\
1.68 \\
1.48 \\
1.42 \\
1.42 \\
.72 \\
1.15 \\
1.36 \\
.98 \\
.90 \\
1.30 \\
2.05 \\
1.66 \\
.71\end{array}$ & $\begin{array}{r}0.90 \\
1.57 \\
1.33 \\
1.42 \\
1.06 \\
1.21 \\
1.20 \\
.80 \\
.42 \\
.75 \\
.76 \\
.51 \\
.72 \\
1.01 \\
1.26 \\
1.21 \\
.45\end{array}$ & $\begin{array}{r}1.21 \\
2.63 \\
1.97 \\
2.57 \\
1.85 \\
3.34 \\
1.32 \\
1.17 \\
.68 \\
.96 \\
.99 \\
.84 \\
1.69 \\
2.18 \\
2.64 \\
2.77 \\
.84\end{array}$ & $\begin{array}{l}1.37 \\
2.02 \\
1.71 \\
2.20 \\
1.80 \\
2.45 \\
1.80 \\
1.62 \\
1.21 \\
1.30 \\
1.35 \\
1.35 \\
1.43 \\
1.95 \\
2.99 \\
2.90 \\
.88\end{array}$ & $\begin{array}{r}1.05 \\
1.26 \\
1.17 \\
1.10 \\
1.26 \\
1.42 \\
1.39 \\
1.36 \\
.91 \\
1.12 \\
1.24 \\
.98 \\
.88 \\
1.30 \\
2.20 \\
2.62 \\
.83\end{array}$ & $\begin{array}{r}13.02 \\
17.55 \\
18.82 \\
15.12 \\
18.29 \\
19.47 \\
17.78 \\
15.24 \\
8.86 \\
11.94 \\
15.47 \\
9.62 \\
10.79 \\
16.40 \\
25.57 \\
26.35 \\
9.32\end{array}$ \\
\hline A verages. - & 1.25 & .97 & 1.11 & 1.19 & 1.15 & 1.36 & 1. 62 & 1.41 & .98 & 1.74 & 1.78 & 1.30 & 15.86 \\
\hline
\end{tabular}

TABLE 2.-Annual precipitation, in inches, at 17 index-precipitation stations and weighted-average precipitation in the Grand division, water years 1914-57

\begin{tabular}{|c|c|c|c|c|c|c|c|c|c|c|c|c|c|c|c|c|c|c|c|}
\hline \multirow{2}{*}{ Water year } & \multicolumn{18}{|c|}{ Index stations } & \multirow{2}{*}{$\begin{array}{l}\text { Grand } \\
\text { division } \\
\text { weighted } \\
\text { average }\end{array}$} \\
\hline & Spicer & $\begin{array}{l}\text { Estes } \\
\text { Park }\end{array}$ & Fraser & $\begin{array}{l}\text { Idaho } \\
\text { Springs }\end{array}$ & Dillon & $\begin{array}{l}\text { Lead- } \\
\text { ville }\end{array}$ & $\begin{array}{l}\text { Sho- } \\
\text { shone }\end{array}$ & Coll- & 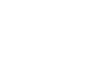 & $\begin{array}{l}\text { Cedar- } \\
\text { edge }\end{array}$ & Paonia & $\underset{\text { Monst- }}{\text { rose }}$ & $\underset{\text { nison- }}{\text { Gun- }}$ & Pitkin & Ames & Rico & Moab & $\begin{array}{c}\text { A ver- } \\
\text { age }\end{array}$ & \\
\hline & & & & & & & & & & & & & & & & & & & \\
\hline & $\mid \begin{array}{l}11.28 \\
11.46\end{array}$ & $\left|\begin{array}{|}24.40 \\
15.32\end{array}\right|$ & & $\begin{array}{l}13.85 \\
12.13\end{array}$ & & $\begin{array}{l}12.81 \\
16.64\end{array}$ & & & & & & & 058 & $\begin{array}{l}68 \\
63\end{array}$ & & $\begin{array}{l}33 \\
22\end{array}$ & $\begin{array}{l}71 \\
42 \\
2\end{array}$ & & \\
\hline & $\begin{array}{r}11.53 \\
980\end{array}$ & $\left|\begin{array}{l}23.63 \\
20.15\end{array}\right|$ & $\begin{array}{l}23.32 \\
23.88\end{array}$ & $\begin{array}{l}14.46 \\
18.23\end{array}$ & $\begin{array}{l}19.00 \\
16.23\end{array}$ & $\begin{array}{l}15.98 \\
16.79\end{array}$ & $\begin{array}{l}18.31 \\
15.78\end{array}$ & & & & & & 64 & 27 & 77 & \begin{tabular}{|l|}
19.13 \\
26.11
\end{tabular} & 66 & & \\
\hline & $\begin{array}{r}6.50 \\
6.59 \\
\end{array}$ & $\left|\begin{array}{|l}20.15 \\
15.36 \\
50\end{array}\right|$ & $\begin{array}{l}20.88 \\
16.14\end{array}$ & $\begin{array}{l}18.98 \\
12.98\end{array}$ & $\begin{array}{l}10.81 \\
11.81\end{array}$ & $\begin{array}{l}24.39 \\
249\end{array}$ & $\begin{array}{l}14.45 \\
11.48\end{array}$ & 14. & $\begin{array}{l}0.07 \\
7.22\end{array}$ & & & & $\begin{array}{r}72.08 \\
12.08\end{array}$ & $\begin{array}{l}20.80 \\
19.69\end{array}$ & & 17 & $\begin{array}{l}01 \\
41\end{array}$ & & \\
\hline & $\begin{array}{l}13.30 \\
10.35\end{array}$ & $\left|\begin{array}{l}21.76 \\
22.71\end{array}\right|$ & & $\begin{array}{l}14.66 \\
19.17\end{array}$ & & $\begin{array}{l}23.99 \\
25.94\end{array}$ & 15.03 & & & & & & $\begin{array}{l}\begin{array}{l}13.01 \\
10.53\end{array} \\
\text { lo }\end{array}$ & & & & & & \\
\hline & $\begin{array}{r}5.81 \\
71\end{array}$ & $\mid \begin{array}{l}14.16 \\
29\end{array}$ & & $\begin{array}{l}14.44 \\
19.37\end{array}$ & & & $\begin{array}{l}13.66 \\
1863\end{array}$ & & & & & & 36 & 63 & & 吾8 & 91 & & \\
\hline & 8.86 & \begin{tabular}{|l|}
19.50 \\
19
\end{tabular} & 16 & & & 15.49 & 12. 31 & & & & & 3 & $\begin{array}{l}10.07 \\
8.45\end{array}$ & 15 & & & $\begin{array}{l}02 \\
13\end{array}$ & & \\
\hline & $\begin{array}{l}15.07 \\
11.88\end{array}$ & $\begin{array}{l}15.47 \\
21.72\end{array}$ & $\begin{array}{l}{ }_{21.63}^{22.12} \\
21.63\end{array}$ & & 24 & $\begin{array}{l}22.93 \\
19.25\end{array}$ & $\begin{array}{l}15.50 \\
14.48\end{array}$ & 15 & $\begin{array}{l}9.73 \\
9.79\end{array}$ & & & & $\begin{array}{r}9.54 \\
10.97\end{array}$ & $\left|\begin{array}{l}15.20 \\
15.55\end{array}\right|$ & & $\left|\begin{array}{l}29.14 \\
30.91\end{array}\right|$ & $\begin{array}{l}94 \\
90\end{array}$ & & \\
\hline & $\begin{array}{l}13.64 \\
11.38\end{array}$ & 18.61 & $\begin{array}{l}25.64 \\
21.66\end{array}$ & & & & & & & & & & $\begin{array}{l}13.88 \\
11.33\end{array}$ & & $\begin{array}{ll}62 \\
17\end{array}$ & \begin{tabular}{|l|l|}
35.70 \\
1989
\end{tabular} & 64 & & \\
\hline & 14.11 & 17. & & & & & 14.76 & & & & & & & & & & 14 & & \\
\hline & 11. & & & & & & 14.24 & & & & & & & & & & & & \\
\hline & & & & & & & & & & & & & & & & & & & \\
\hline & $\begin{array}{l}14.25 \\
9.66\end{array}$ & 11. & 22. & ${ }_{17 .}^{16 .}$ & 21. & 17. 10 & $\begin{array}{l}15.09 \\
11\end{array}$ & & & & & & & & & & 87 & & \\
\hline & 12.15 & 16. & 15 & 13.43 & 20 & 20.77 & 26.31 & & 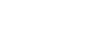 & & & & 13.73 & & & & 0 & & \\
\hline & $\begin{array}{l}13.14 \\
13.14\end{array}$ & 17. & 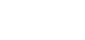 & & & $\begin{array}{l}24.04 \\
24.09\end{array}$ & & & & & & & & & & & . & & \\
\hline & $\begin{array}{l}16 . \\
11 .\end{array}$ & $\begin{array}{l}2 . \\
12 .\end{array}$ & $\begin{array}{l}19 . \\
13 .\end{array}$ & $\begin{array}{r}20.18 \\
7.01\end{array}$ & 10 & $\begin{array}{l}28.82 \\
16.69\end{array}$ & $\begin{array}{l}22.35 \\
15.66\end{array}$ & & & & & & 36 & & & & & & \\
\hline & $\begin{array}{l}14.16 \\
15.20\end{array}$ & $\mid$\begin{tabular}{l|}
16.48 \\
17.86
\end{tabular} & $\begin{array}{l}17 . \\
16 .\end{array}$ & & ${ }_{17}^{17}$ & $\begin{array}{l}17.71 \\
16.68\end{array}$ & & & $\begin{array}{r}8.54 \\
14.59\end{array}$ & & & $\begin{array}{r}6 \\
17\end{array}$ & $\begin{array}{r}9.85 \\
11.75\end{array}$ & $\left|\begin{array}{l}10.90 \\
15.69\end{array}\right|$ & & \begin{tabular}{|l|}
27.26 \\
39.61
\end{tabular} \mid & ${ }_{9}^{3}$ & & \\
\hline & $\begin{array}{l}11.72 \\
17.21\end{array}$ & $\begin{array}{ll}18 . \\
18\end{array}$ & 16 & & & 17.60 & & & & & & & 96 & & & & & & \\
\hline & 12.06 & 14. & 10 & & & & & & $\begin{array}{l}7.47 \\
6.47\end{array}$ & & & & 6 & & & & 3 & & \\
\hline & & 24. & $\begin{array}{l}19 . \\
13\end{array}$ & & & & & & & & & & & & & & & & \\
\hline & & & & & & & & & & & & & & & & & & & \\
\hline & & ${ }_{21}^{15}$ & 15 & & ${ }_{20}^{16}$ & 10 & 17. & & & & & & ${ }_{22}^{92}$ & & & & & & \\
\hline & & 10 & & & & 13 & & & & & & & 91 & & & & 5 & & \\
\hline & & & & & & & & & & & & & & & & & & & \\
\hline & & & & & & & & & & & & & & & & & & & \\
\hline & & & & & & & & & & & & & & & & & & & \\
\hline & & & & & & & & & & & & & & & & & & & \\
\hline & & & 29.62 & & 10.1 & $2.7 x$ & 00 & & .00 & & .00 & 13. 97 & 15.25 & 20.10 & 31.41 & 37.23 & 10.09 & 20.93 & \\
\hline $\begin{array}{l}\text {-year } \\
\text { avera }\end{array}$ & .02 & .55 & 18.82 & 15.12 & 18.29 & 19. 47 & 17.78 & 15.24 & 8.86 & 11.94 & 15.47 & 9.62 & 10.79 & 16.40 & 25.57 & 26.35 & 9.32 & 15.86 & 0.27 \\
\hline
\end{tabular}


TABLE 3.-Irrigation and power reservoirs in the subbasins in the Grand division [Source of data: U.S. Dept. of the Interior (1947)]

\begin{tabular}{|c|c|c|c|c|c|}
\hline Reservoir & Location & $\begin{array}{l}\text { Usable } \\
\text { capacity } \\
\text { (acre-ft) }\end{array}$ & Reservoir & Location & $\begin{array}{l}\text { Usable } \\
\text { capacity } \\
\text { (acre-ft) }\end{array}$ \\
\hline \multicolumn{6}{|c|}{ Colorado River Basin above the Gunnison River } \\
\hline $\begin{array}{l}\text { Shadow Mountain } \\
\text { Lake Granby } \\
\text { Willow Creek } \\
\text { Williams Fork } \\
\text { Troublesome } \\
\text { Barber } \\
\text { Green Mountain } \\
\text { Robinson Lake } \\
\text { Ivanhoe }\end{array}$ & $\begin{array}{l}\text { Colorado River } \\
\text { Willow Creek } \\
\text { Williams River- } \\
\text { Troublesome Creek } \\
\text { Red Dirt Creek (Muddy Creek) } \\
\text { Blue River } \\
\text { East Fork Eagle River } \\
\text { Ivanhoe Creek (Roaring Fork) }\end{array}$ & $\begin{array}{r}1,800 \\
465,600 \\
9,060 \\
7,180 \\
1,070 \\
4,500 \\
146,900 \\
2,520 \\
1,400\end{array}$ & $\begin{array}{l}\text { Missouri Heights. } \\
\text { Harvey Gap } \\
\text { Leon Lake } \\
\text { Big Creek No. 1. } \\
\text { Bonham } \\
\text { Atkinson. } \\
\text { Cottonwood Lake } \\
\quad \text { Total }\end{array}$ & $\begin{array}{l}\text { Cattle Creek (Roaring Fork) } \\
\text { Unnamed Creek } \\
\text { Leon Creek (Plateau Creek) } \\
\text { Big Creek (Plateau Creek) }\end{array}$ & $\begin{array}{r}2,800 \\
4,800 \\
3,000 \\
2,700 \\
1,800 \\
1,500 \\
2,800 \\
659,430\end{array}$ \\
\hline \multicolumn{6}{|c|}{ Gunnison River basin } \\
\hline $\begin{array}{l}\text { Taylor Park } \\
\text { Gould (Onion Valiey) } \\
\text { Overland } \\
\text { Island Lake- } \\
\text { Deep Ward Lake- } \\
\text { Baron Lake }\end{array}$ & $\begin{array}{l}\text { Taylor River } \\
\text { Iron Creek (Smith Fork) } \\
\text { Cow Creek (Muddy Creek) } \\
\text { Ward Creek (Tongue Creek) } \\
\text { K̇iser Creek (Tongue Creek) }\end{array}$ & $\begin{array}{r}106,200 \\
6,420 \\
2,600 \\
1,100 \\
1,400 \\
1,000\end{array}$ & $\begin{array}{l}\text { Eggleston Lake. } \\
\text { Trickel Park Lake } \\
\text { Cedar Mesa. } \\
\text { Fruitgrowers. } \\
\quad \text { Total }\end{array}$ & $\begin{array}{l}\text { Kiser Creek (Tongue Creek) } \\
\text { Surface Creek (Tongue Creek) } \\
\text { Tongue Creek }\end{array}$ & $\begin{array}{r}2,700 \\
3,200 \\
1,000 \\
4,500 \\
130,120\end{array}$ \\
\hline
\end{tabular}

Colorado River Basin between the Gunnison and Green Rivers

\begin{tabular}{|c|c|c|c|c|c|}
\hline Groundhog & Groundhog Creek (West Fork Dolores & 21,700 & Gurley & Beaver Creek (San Miguel River) & $\begin{array}{l}8,800 \\
1,800\end{array}$ \\
\hline Buckeye & West Paradox Creek (Dolores River) & 3,000 & Valley City & Thompson Wash (Salt Valley Wash) & 1,750 \\
\hline Trout Lake. & - do do vo & 2,700 & Total. & & 42,050 \\
\hline
\end{tabular}

TABLE 4.-Transmountain diversion, in acre-feet, from the Colorado River and tributaries above the Gunnison River, water years 1914-57

\begin{tabular}{|c|c|c|c|c|c|c|c|c|c|c|c|c|c|c|c|}
\hline \multirow{3}{*}{$\begin{array}{l}\text { Water } \\
\text { year }\end{array}$} & \multicolumn{15}{|c|}{ Stream and diversion } \\
\hline & \multicolumn{3}{|c|}{ Colorado River } & \multicolumn{2}{|c|}{ Fraser River } & \multirow{2}{*}{$\begin{array}{c}\begin{array}{c}\text { Williams } \\
\text { River }\end{array} \\
\begin{array}{c}\text { Jones } \\
\text { Pass } \\
\text { tunnel }\end{array}\end{array}$} & \multicolumn{3}{|c|}{ Blue River } & \multicolumn{3}{|c|}{ Eagle River } & \multicolumn{2}{|c|}{ Roaring Fork } & \multirow{2}{*}{ Total } \\
\hline & $\begin{array}{l}\text { Grand } \\
\text { River } \\
\text { ditch }\end{array}$ & $\begin{array}{c}\text { Eureka } \\
\text { ditch }\end{array}$ & $\begin{array}{l}\text { Alva B. } \\
\text { Adams } \\
\text { Tunnel }\end{array}$ & $\begin{array}{c}\text { Berthoud } \\
\text { Pass } \\
\text { ditch }\end{array}$ & $\begin{array}{l}\text { Moffat } \\
\text { tunnel }\end{array}$ & & $\begin{array}{c}\text { Hoosier } \\
\text { Pass } \\
\text { tunnel }\end{array}$ & $\begin{array}{c}\text { Boreas } \\
\text { Pass } \\
\text { ditch }\end{array}$ & $\begin{array}{c}\text { Fremont } \\
\text { Pass } \\
\text { ditch }\end{array}$ & $\begin{array}{l}\text { Colum- } \\
\text { bine } \\
\text { ditch }\end{array}$ & $\begin{array}{l}\text { Ewing } \\
\text { ditch }\end{array}$ & $\begin{array}{l}\text { Wurtz } \\
\text { ditch }\end{array}$ & $\begin{array}{l}\text { Twin } \\
\text { Lakes } \\
\text { tunnel }\end{array}$ & $\begin{array}{c}\text { Busk- } \\
\text { Ivanhoe } \\
\text { tunnel }\end{array}$ & \\
\hline $\begin{array}{l}1914 \\
1915 \\
1916 \\
1917 \\
1918 \\
1920 \\
1921 \\
1922 \\
1923 \\
1924 \\
1925 \\
1926 \\
1928 \\
1929 \\
1930 \\
1931 \\
1932 \\
1933 \\
1934 \\
1935 \\
1936 \\
1937 \\
1938 \\
1939 \\
1940 \\
1941 \\
1942 \\
1943 \\
1944 \\
1945 \\
1946 \\
1947 \\
1948 \\
1949 \\
1950 \\
1951 \\
1952 \\
1953 \\
1954 \\
1955 \\
1956 \\
1957\end{array}$ & 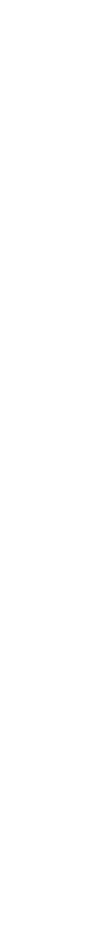 & $\begin{array}{r}36 \\
76 \\
0 \\
133 \\
85 \\
186 \\
152 \\
175 \\
102 \\
91 \\
77 \\
124 \\
103 \\
26 \\
27 \\
125 \\
52 \\
124\end{array}$ & $\begin{array}{r}\mid r \\
4,610 \\
9,240 \\
17,480 \\
26,270 \\
56,310 \\
56,020 \\
180,000 \\
302,100 \\
256,600 \\
210,700 \\
195,200\end{array}$ & $\begin{array}{r}\mathbf{4 7 6} \\
\mathbf{6 5 0} \\
832 \\
\mathbf{5 0 4} \\
\mathbf{8 6 8} \\
\mathbf{4 7 6} \\
\mathbf{0} \\
\mathbf{1 0 0} \\
576 \\
\mathbf{1 , 3 7 0} \\
\mathbf{1 , 1 6 0} \\
\mathbf{1 , 0 5 0} \\
\mathbf{4 5 2} \\
\mathbf{4 2 0} \\
\mathbf{4 2 2} \\
\mathbf{1 , 1 0} \\
\mathbf{1 , 0 3 0} \\
312 \\
\mathbf{7 6 8} \\
555 \\
\mathbf{6 4 9} \\
\mathbf{5 4 5} \\
\mathbf{7 2 0} \\
0 \\
777 \\
892 \\
572 \\
609 \\
261 \\
\mathbf{5 5 5} \\
\mathbf{4 3 0} \\
\mathbf{1 , 0 4 0} \\
397 \\
166 \\
\mathbf{5 6 1} \\
327 \\
\mathbf{4 9 0} \\
\mathbf{7 1 6} \\
\mathbf{7 3 0} \\
594 \\
217 \\
458 \\
396 \\
\mathbf{5 6 8}\end{array}$ & $\begin{array}{r}12,140 \\
21,630 \\
43,180 \\
30,860 \\
29,390 \\
36,290 \\
11,320 \\
32,490 \\
16,390 \\
36,600 \\
32,620 \\
23,600 \\
24,260 \\
24,660 \\
29,560 \\
33,800 \\
31,230 \\
35,070 \\
19,540 \\
37,020 \\
53,430 \\
48,180\end{array}$ & $\begin{array}{r}r, 560 \\
8,190 \\
1,600 \\
4,060 \\
3,860 \\
11,050 \\
11,000 \\
2,070 \\
2,050 \\
1,890 \\
9,090 \\
11,140 \\
6,810 \\
7,420 \\
5,480 \\
10,300 \\
8,880 \\
4,540\end{array}$ & $\begin{array}{r}309 \\
655 \\
295 \\
652 \\
481 \\
101 \\
0 \\
0 \\
0 \\
0 \\
0 \\
0 \\
0 \\
0 \\
0 \\
0 \\
0 \\
2,380 \\
4,840 \\
3,550 \\
6,450 \\
\mathbf{9}, 290 \\
7,110\end{array}$ & $\begin{array}{r}1200 \\
1200 \\
1200 \\
1200 \\
1200 \\
1200 \\
1200 \\
1200 \\
1200 \\
1200 \\
1200 \\
1200 \\
1200 \\
1200 \\
1200 \\
1200 \\
1200 \\
1200 \\
1200 \\
289 \\
73 \\
215 \\
430 \\
149 \\
275 \\
31 \\
171 \\
\vdots 0 \\
0 \\
0 \\
0 \\
0 \\
0 \\
0 \\
0 \\
0 \\
0 \\
69 \\
176 \\
13 \\
273 \\
136 \\
268 \\
260 \\
475\end{array}$ & $\begin{array}{r} \\
1,110 \\
1,220 \\
1,030 \\
2,490 \\
1,820 \\
1,800 \\
1,630 \\
1,900 \\
1,110 \\
1,650 \\
1,100 \\
635 \\
589 \\
0 \\
362 \\
0 \\
0 \\
0 \\
0 \\
0 \\
0 \\
0 \\
0 \\
0 \\
0 \\
0 \\
0 \\
0 \\
0\end{array}$ & \begin{tabular}{r} 
\\
\\
\hdashline \\
\hdashline \\
\hdashline \\
\hdashline \\
\hdashline 1, \\
1,290 \\
1,160 \\
1,240 \\
1,780 \\
1,280 \\
1,780 \\
1,270 \\
1,110 \\
1,320 \\
0 \\
1,160 \\
134 \\
1,090 \\
1,250 \\
0 \\
0 \\
0 \\
1,270 \\
1,740 \\
1,020 \\
1,040 \\
844 \\
1,160 \\
1,390 \\
1,110
\end{tabular} & $\begin{array}{r}2,360 \\
1,590 \\
2,410 \\
2,460 \\
2,210 \\
1,820 \\
1,740 \\
1,790 \\
1,660 \\
1,890 \\
2,330 \\
2,320 \\
1,610 \\
1,700 \\
1,810 \\
1,100 \\
612 \\
443 \\
809 \\
550 \\
303 \\
185 \\
540 \\
375 \\
1,400 \\
936 \\
173 \\
376 \\
0 \\
0 \\
0 \\
609 \\
1,030 \\
1,340 \\
146 \\
1,340 \\
783 \\
1,420 \\
1,820 \\
1,140 \\
498 \\
415 \\
1,100 \\
1,360\end{array}$ & $\begin{array}{r}716 \\
1,680 \\
1,370 \\
2,900 \\
3,740 \\
1,750 \\
2,580 \\
1,470 \\
992 \\
2,010 \\
2,090 \\
2,560 \\
1,800 \\
2,020 \\
2,210 \\
2,880 \\
2,330 \\
2,690 \\
1,990 \\
2,940 \\
2,950 \\
2,010 \\
905 \\
1,350 \\
2,590 \\
2,640\end{array}$ & $\begin{array}{l}-18,020 \\
24,240 \\
31,920 \\
45,460 \\
37,060 \\
27,040 \\
36,090 \\
13,400 \\
48,020 \\
37,730 \\
44,780 \\
39,320 \\
37,310 \\
25,030 \\
38,190 \\
34,880 \\
44,920 \\
51,360 \\
40,300 \\
27,470 \\
35,060 \\
36,440 \\
32,740\end{array}$ & $\begin{array}{r} \\
\end{array}$ & $\begin{array}{r}10,650 \\
14,650 \\
17,960 \\
10,750 \\
17,650 \\
12,630 \\
17,110 \\
11,300 \\
14,890 \\
16,010 \\
11,200 \\
21,900 \\
20,950 \\
24,570 \\
20,613 \\
30,165 \\
22,041 \\
15,781 \\
26,488 \\
22,513 \\
16,520 \\
41,333 \\
72,248 \\
77,502 \\
128,540 \\
98,054 \\
91,025 \\
108,550 \\
49,644 \\
111,720 \\
79,179 \\
125,575 \\
111,439 \\
98,411 \\
82,449 \\
108,158 \\
124,049 \\
183,386 \\
182,156 \\
297,543 \\
376,707 \\
370,626 \\
349,398 \\
315,617\end{array}$ \\
\hline
\end{tabular}


TABLE 5.-Irrigated acreage in the subbasins in the Grand division

[Source of data: U.S. Bur. of the Census (1953), U.S. Dept. of the Interior (1947), and Upper Colorado River Compact Comm. (1948)]

Location

Colorado River Basin above the Gunnison River

Source.

In tervening area..

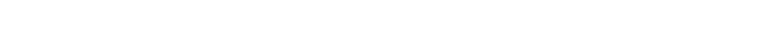

Intervening area.......

Total area, Colorado River at Hot Sulphur

Springs........

Intervening area.

Williams River tributary area

Intervening area......

Troublesome Creek tributary area........

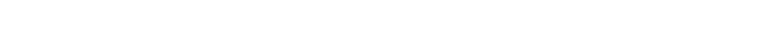

Muddy Creek tributary area

Total area, Colorado River near Kremmling.---

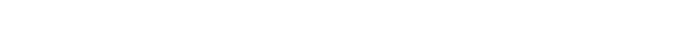

Eagle River tributary area.

Inter vening area......

Total area, Colorado River at Glenwood Springs -

Roaring Fork tributary area

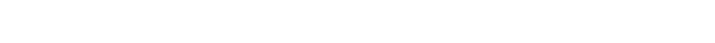

Total area, Colorado River near Cameo _..... 163, 400

Plateau Creek tributary area................. 29, 100

Total in subbasin

Gunnison River Basin

Taylor River at Almont.

East River at Almont tributary area

Intervening area.......

Total area, Gunnison River at Gunnison
192,500

\begin{tabular}{r|}
$\begin{array}{c}\text { Irrigated } \\
\text { acreage }\end{array}$ \\
0 \\
3,500 \\
10,200 \\
2,000 \\
\hline
\end{tabular}

15,700

1,500

3,500

500

8,000

10,900

10,200

50,300

17,500

15,400

500

83,700

31,400

48,300

0
5,700
17,300

23,000
Tomichi Creek tributary area _...

Intervening area....

Cebolla Creek tributary area.

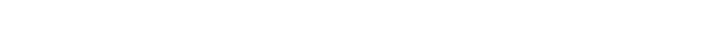

Lake Fork tributary area

Intervening area

Total area, Gunnison River at Gunnison tunnel.-

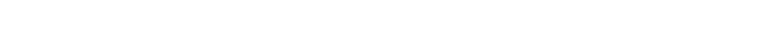

North Fork tributary area

In tervening area......

Uncompahgre River (including Roubideau Creek)

tributary area............ 103, 700

Intervening area.

Total area, Gunnison River near Grand Junction.

269,400

Colorado River Basin between the Gunnison and Green Rivers

Grand Valley:

North of Colorado River _................. 65, 700

South of Colorado River and above Gunnison

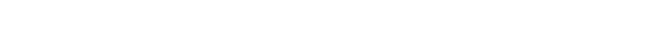

South of Colorado River and below Gunnison

River

Total tributary area above Colorado-Utah

State line............................... 75, 700

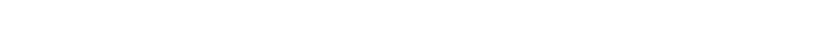

Dolores River tributary area _................ 37, 100

Intervening area.... 5, 500

Total in subbasin $\ldots \ldots 121,300$ 


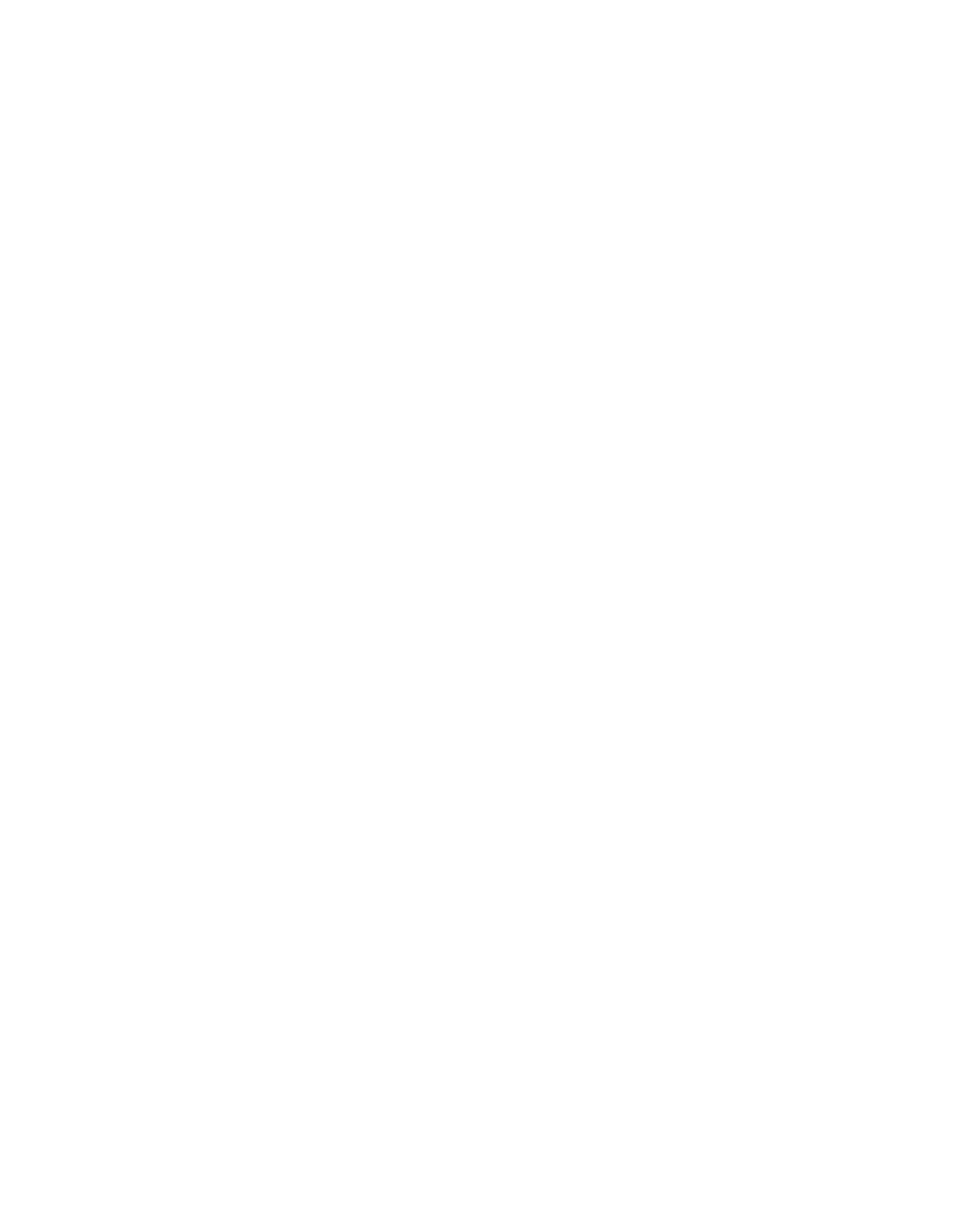




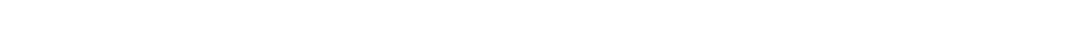

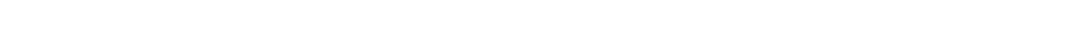
in $=$-ivi

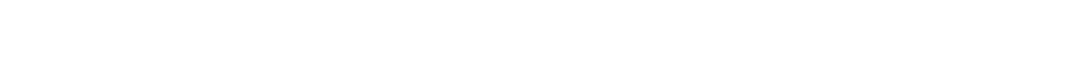

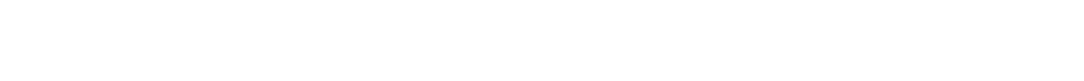

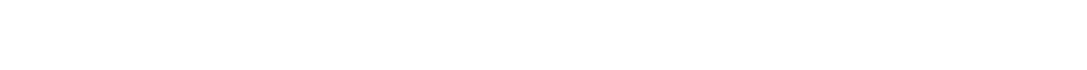

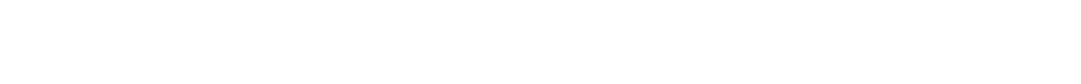

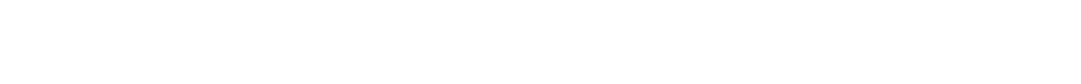

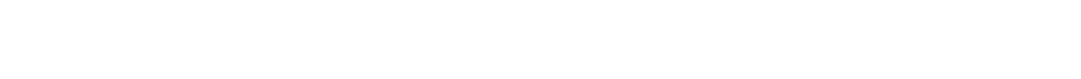

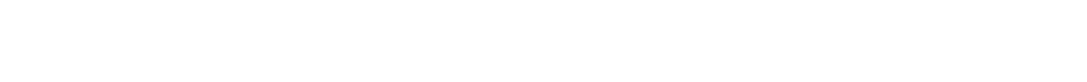
, 8요요

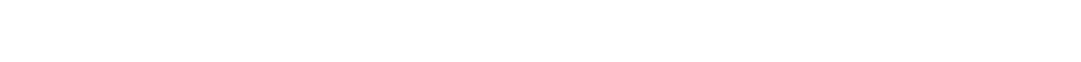

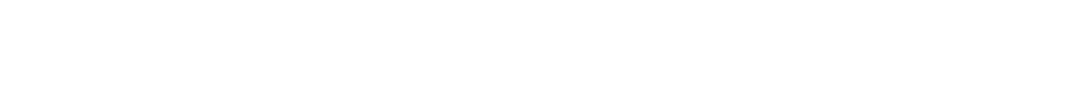

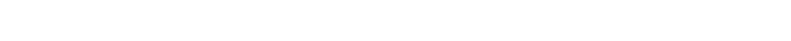

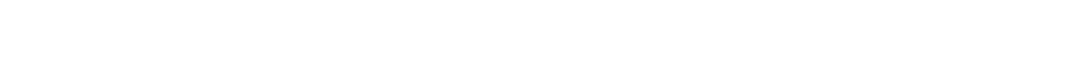
24:

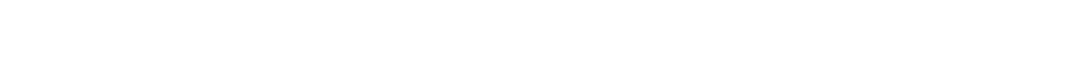

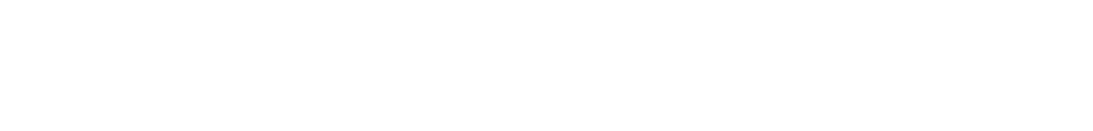

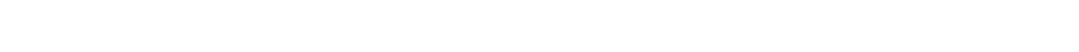

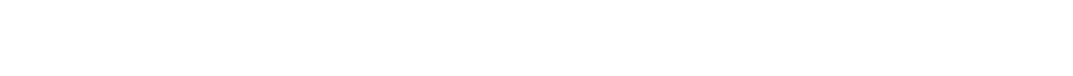

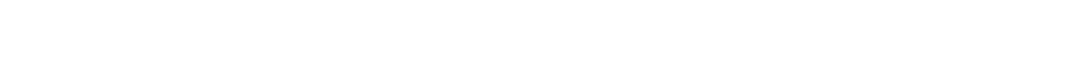

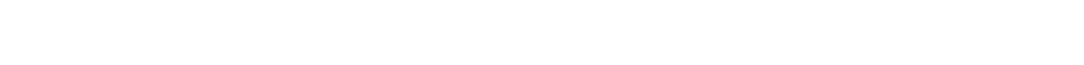

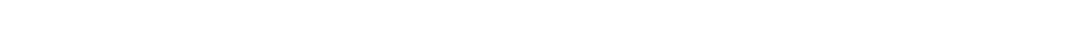

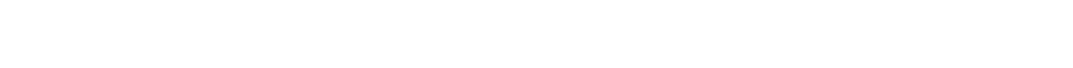

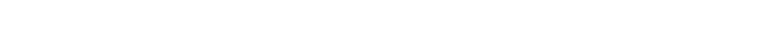

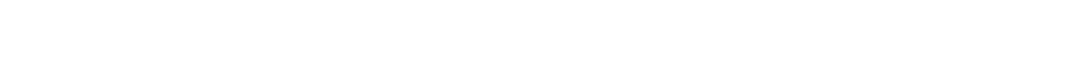

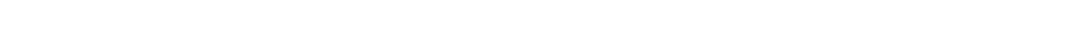

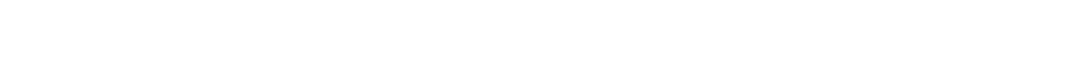

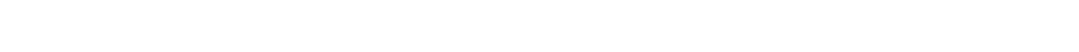

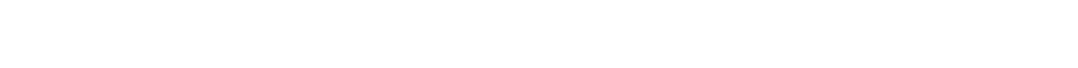

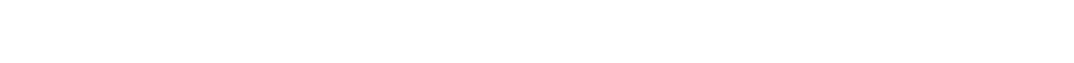

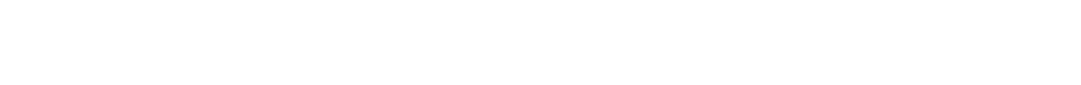

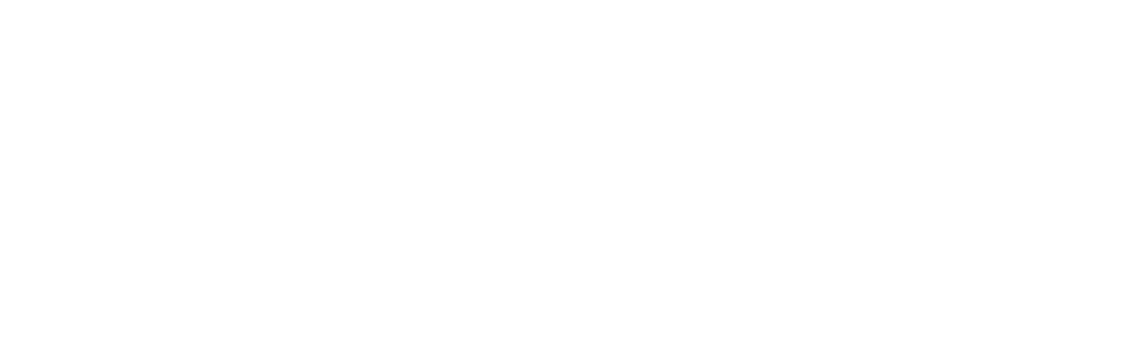

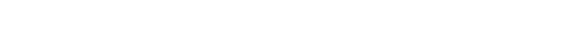

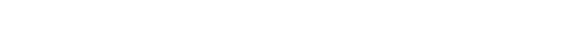

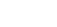

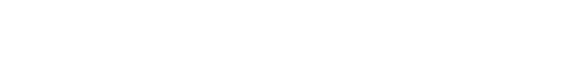

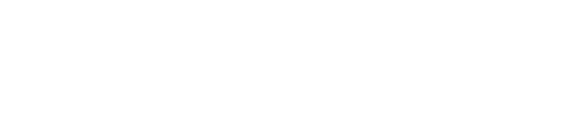

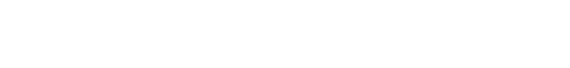

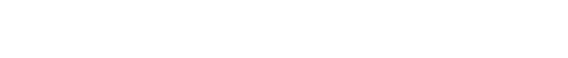

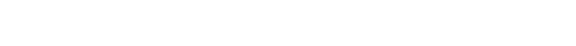

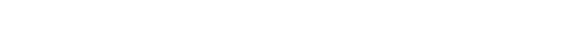

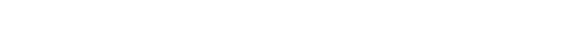

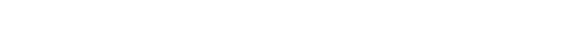

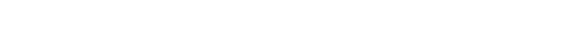

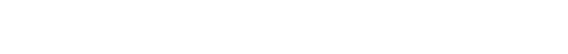

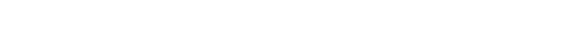

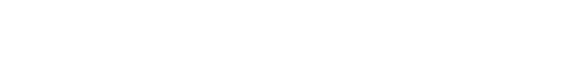

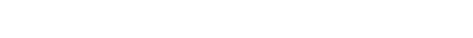

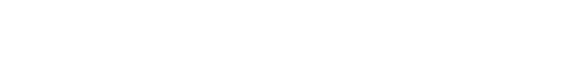

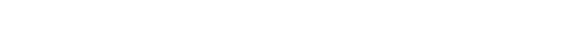

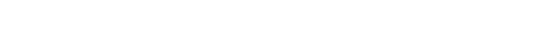

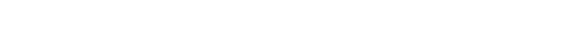

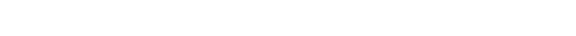

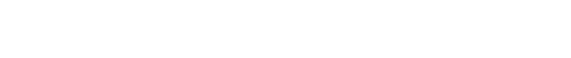

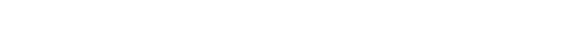

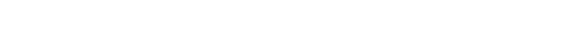

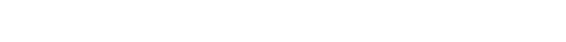

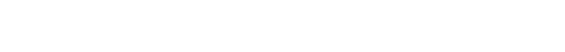

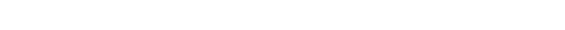

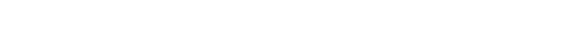
vivisios कo

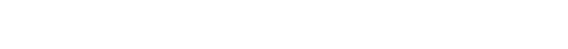

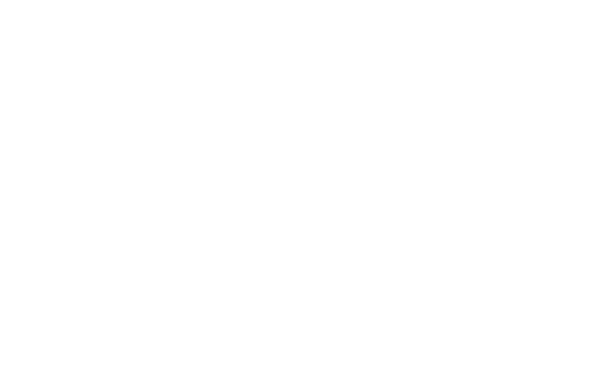




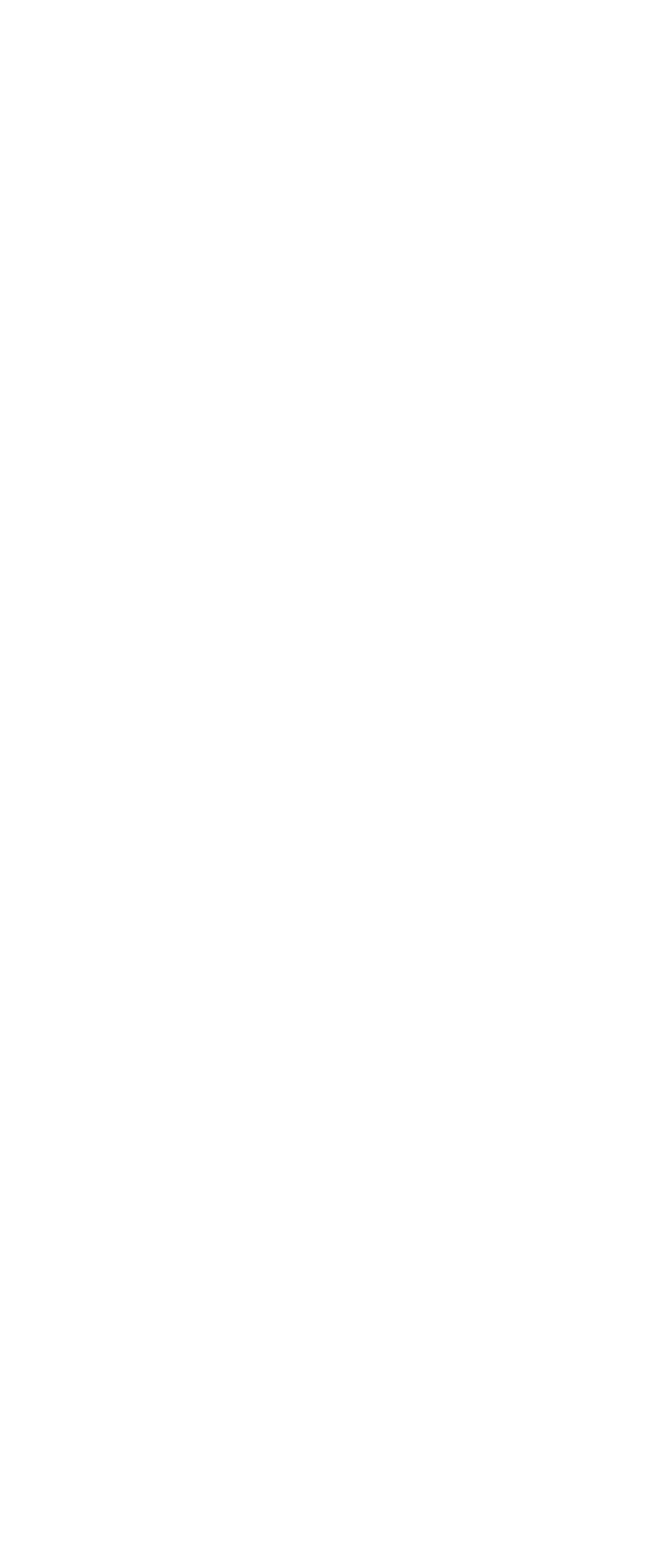

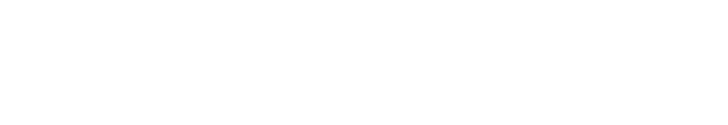

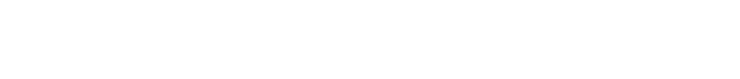

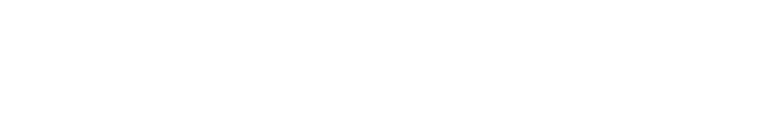

주

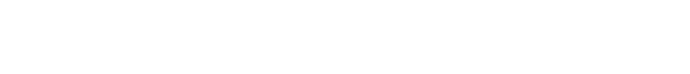

웅 00 8용

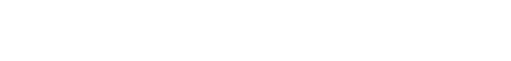

\&

内

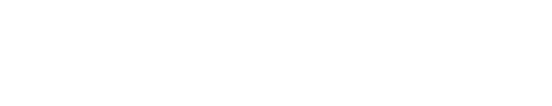

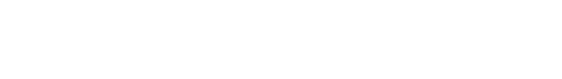

施

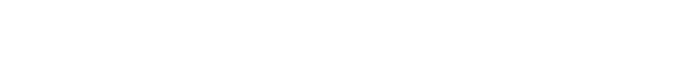

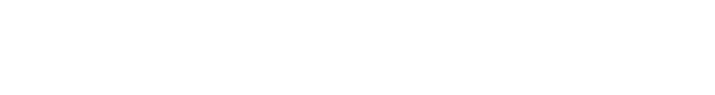

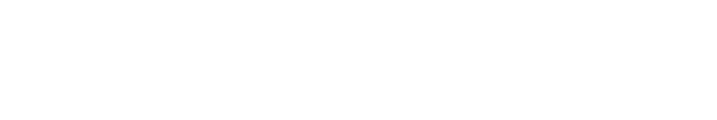

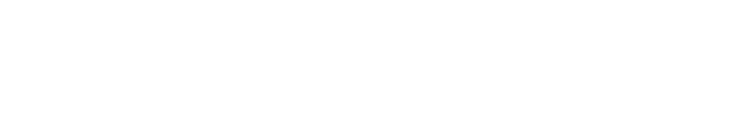

\begin{tabular}{|c|c|c|c|}
\hline 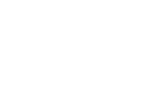 & 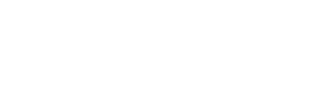 & $R$ & (q) \\
\hline 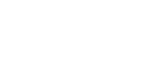 & 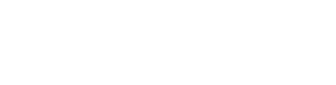 & 8 & i: \\
\hline 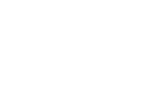 & 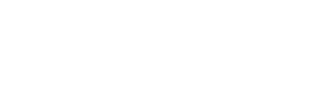 & : & $\infty$ \\
\hline
\end{tabular}

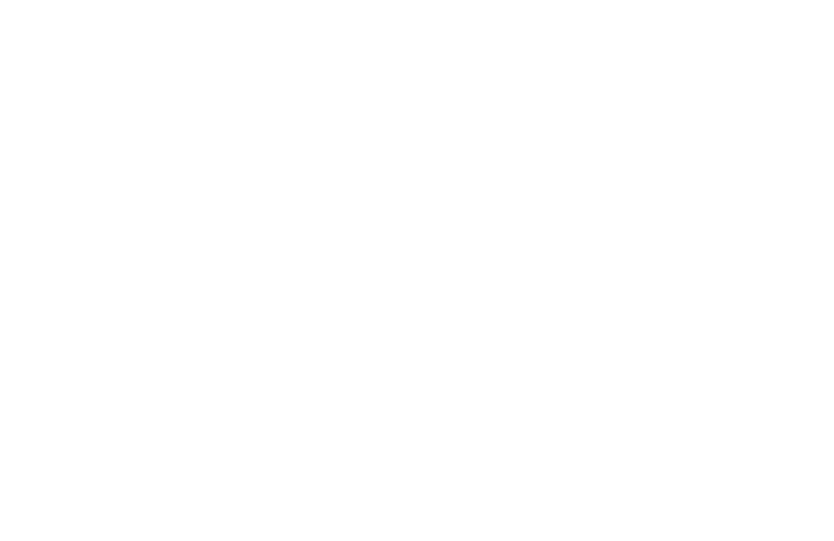


TABLE 7.-Methods and accuracy of adjusting flow-duration data for stations in the subbasins in the Grand division to base period and 1957 conditions

Years of record: Number of years of available historical flow-duration data during

water years 1914-57.
Base period adjustment method: Used in adjusting historical data to base period: I, index-station method; $C$, record-completion method; $M$, monthly means method: $\mathrm{S}$, substitute method

Index station number: Number of index station used in adjusting flow-duration curve to base period or correlation station used in estimating data for missing periods of record.

\begin{tabular}{|c|c|c|c|c|c|c|c|c|c|c|c|}
\hline $\begin{array}{l}\text { Station } \\
\text { No. }\end{array}$ & $\begin{array}{c}\text { Index station } \\
\text { No. }\end{array}$ & $\begin{array}{c}\text { Years } \\
\text { of } \\
\text { record }\end{array}$ & $\begin{array}{c}\text { Base } \\
\text { period } \\
\text { adjust- } \\
\text { ment } \\
\text { method }\end{array}$ & Upstream water developments & $\begin{array}{l}\text { Accuracy } \\
\text { rating in } \\
\text { percent }\end{array}$ & $\begin{array}{c}\text { Station } \\
\text { No. }\end{array}$ & $\begin{array}{c}\text { Index station } \\
\text { No. }\end{array}$ & $\begin{array}{l}\text { Years } \\
\text { of } \\
\text { record }\end{array}$ & $\begin{array}{c}\text { Base } \\
\text { period } \\
\text { adjust- } \\
\text { ment } \\
\text { method }\end{array}$ & Upstream water developments & $\begin{array}{l}\text { Accuracy } \\
\text { rating in } \\
\text { percent }\end{array}$ \\
\hline
\end{tabular}

Upstream water developments: Transmountain diversions and reservoirs in which changes occurred in base period requiring adjustment in historical data to 1957

Accuracy rating in percent: Authors' rating of accuracy of adjusted flow-duration curve for water years 1914-57 to 1957 conditions. The accuracy rating indicates that the final developed flow-duration curve throughout its range is believed to be correct within the percentage indicated.

Colorado River Basin above the Gunnison River

\begin{tabular}{|c|c|c|c|c|}
\hline \multirow{3}{*}{$\begin{array}{l}110 \\
125 \\
200 \\
240\end{array}$} & \multirow{3}{*}{$\begin{array}{r}345 \\
1110 \\
2395\end{array}$} & \multirow{3}{*}{$\begin{array}{r}29 \\
8 \\
19 \\
44\end{array}$} & \multirow{3}{*}{$\begin{array}{l}\text { I } \\
\text { I } \\
\text { I }\end{array}$} & \multirow{2}{*}{ Grand River ditch } \\
\hline & & & & \\
\hline & & & & \multirow{2}{*}{$\begin{array}{l}\text { Berthoud Pass ditch and } \\
\text { Moffat tunnel. } \\
\text { Diversion to Moffat tunnel. }\end{array}$} \\
\hline 265 & 2360 & 23 & I & \\
\hline 340 & 195 & 18 & $\mathrm{I}$ & $\begin{array}{l}\text { Includes adjustments for } 240 \\
\text { and } 265 \text {. }\end{array}$ \\
\hline 345 & 240,2395 & 42 & $\mathrm{C}$ & $\begin{array}{l}\text { Includes those for } 340 \text { and } \\
\text { Grand River ditch, Colo- } \\
\text { rado-Big Thompson project, } \\
\text { and Willow Creek Reser- } \\
\text { voir. }\end{array}$ \\
\hline \multirow{2}{*}{$\begin{array}{l}360 \\
375 \\
385\end{array}$} & \multirow{2}{*}{$\begin{array}{r}375,470 \\
470,360 \\
\mathbf{3 7 5}\end{array}$} & \multirow{2}{*}{$\begin{array}{r}24 \\
35 \\
6\end{array}$} & \multirow{2}{*}{$\begin{array}{l}\mathbf{M} \\
\mathbf{M} \\
\mathbf{M}\end{array}$} & Jones Pass tunnel \\
\hline & & & & $\begin{array}{l}\text { Williams Fork Reservoir and } \\
\text { Jones Pass tunnel. }\end{array}$ \\
\hline \multirow{4}{*}{$\begin{array}{l}405 \\
415 \\
470 \\
520 \\
535 \\
575\end{array}$} & \multirow{2}{*}{$\begin{array}{r}2395,375 \\
405\end{array}$} & 22 & \multirow[t]{2}{*}{$\begin{array}{l}\mathbf{S} \\
\mathbf{S}\end{array}$} & (n) \\
\hline & & 44 & & \multirow{2}{*}{ Hoosier Pass tunnel } \\
\hline & \multirow{2}{*}{$\begin{array}{r}2360 \\
470 \\
535,470\end{array}$} & 14 & \multirow{2}{*}{ I } & \\
\hline & & 22 & & $\begin{array}{l}\text { Hoosier Pass tunnel, Green } \\
\text { Mountain Reservoir. }\end{array}$ \\
\hline 580 & 345,725 & 5 & $I$ & $\begin{array}{l}\text { Includes those for } 345,385 \text {, } \\
\text { and } 575 \text {. }\end{array}$ \\
\hline
\end{tabular}

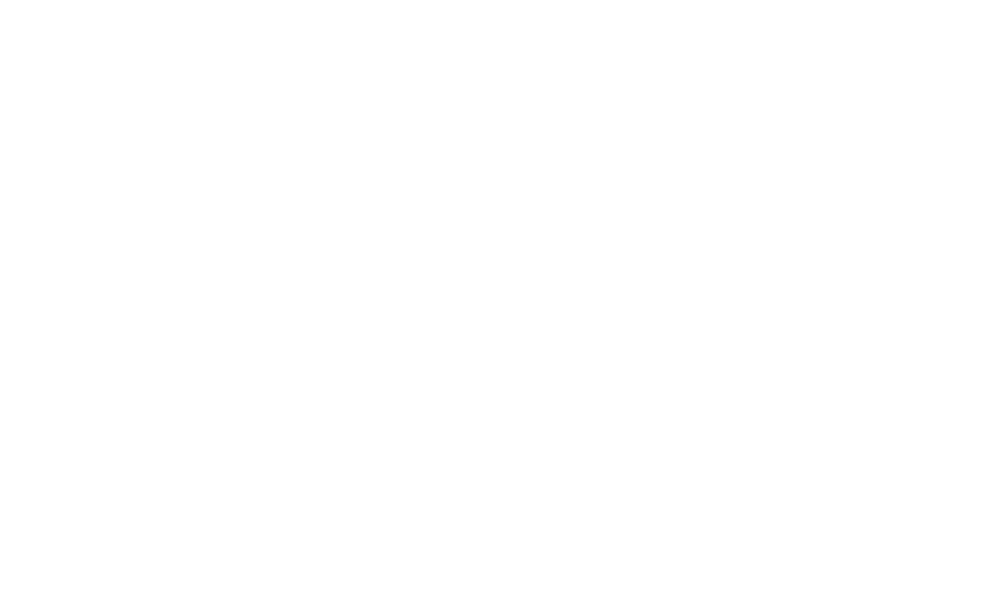

Gunnison River basin

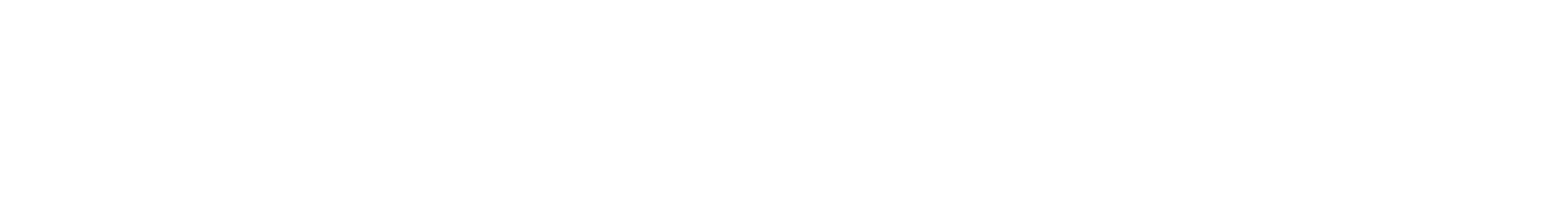

Colorado River Rasin between the Gunnison and Green Rivers

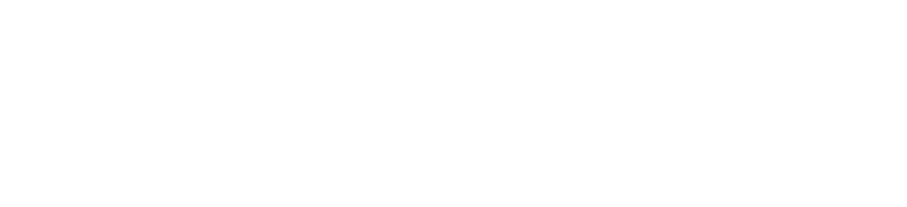

1 Flow-duration curve and data for index station that had been adjusted to base period and 1957 conditions were used.

${ }^{2}$ Flow-duration curve and data for index station that had been adjusted to base period were used.

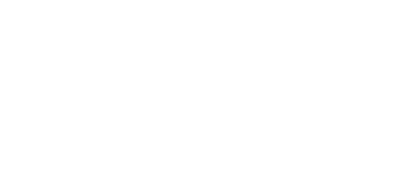

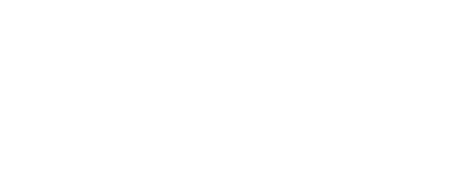

3 Annual estimates of discharge by Upper Colorado River Compact Commission (1948) were used

4 After 1937 adjusted for effect of Taylor Park Reservoir.

6 Monthly and annual estimates of discharge by Upper Colorado River Compact Commission were used. 
TABLE 8.-Variability index of streamflow and percentage of average annual discharge estimated to be contributed by ground water at selected stations in the subbasins in the Grand division, Colorado

[Data are for the water years 1914-57 adjusted to 1957 conditions]

\begin{tabular}{|c|c|c|c|}
\hline $\begin{array}{l}\text { Station } \\
\text { No. }\end{array}$ & Station name & $\underset{\text { index }}{\text { Variability }}$ & $\begin{array}{c}\text { Ground } \\
\text { water } \\
\text { (percent) }\end{array}$ \\
\hline \multicolumn{4}{|c|}{ Colorado River Basin above the Gunnison River } \\
\hline $\begin{array}{l}975 \\
125 \\
645 \\
520 \\
780 \\
200 \\
965 \\
595 \\
825 \\
360 \\
470 \\
695\end{array}$ & $\begin{array}{l}\text { Buzzard Creek near Collbran } \\
\text { North Inlet at Grand Lake. } \\
\text { Homestake Creek near Red Cliff } \\
\text { Rock Creek near Dillon } \\
\text { Fryingpan Creek at Norrie. } \\
\text { Willow Creek near Granby } \\
\text { Plateau Creek near Collbran } \\
\text { Piney River near State Bridge } \\
\text { Crystal River near Redstone } \\
\text { Williams River near Leal. } \\
\text { Blue River at Dillon } \\
\text { Gypsum Creek near Gypsum }\end{array}$ & $\begin{array}{r}0.81 \\
.75 \\
.74 \\
.59 \\
.59 \\
.56 \\
.55 \\
.54 \\
.52 \\
.48 \\
.47 \\
.19\end{array}$ & $\begin{array}{r}13 \\
9 \\
11 \\
22 \\
24 \\
18 \\
16 \\
21 \\
23 \\
30 \\
31 \\
66\end{array}$ \\
\hline
\end{tabular}

Gunnison River basin

\begin{tabular}{|c|c|c|c|}
\hline $\begin{array}{l}1155 \\
1475 \\
1245 \\
1125 \\
1285 \\
1315\end{array}$ & $\begin{array}{l}\text { Tomichi Creek at Sargents. } \\
\text { Uncompahgre River at Colona. } \\
\text { Lake Fork at Gateview } \\
\text { East River at Almont. } \\
\text { Smith Fork near Crawford. } \\
\text { Muddy Creek at Bardine. }\end{array}$ & $\begin{array}{l}0.34 \\
.43 \\
.52 \\
.53 \\
.56 \\
.58\end{array}$ & $\begin{array}{r}42 \\
31 \\
24 \\
23 \\
-16\end{array}$ \\
\hline
\end{tabular}

Colorado River Basin bet ween the Gunnison and Green Rivers

\begin{tabular}{l|l|r|r}
\hline 1665 & Dolores River at Dolores & & 0.67 \\
1725 & San Miguel River near Placerville_. & 13 \\
& &
\end{tabular}

TABLE 9.-Adjustment of streamflow records for water years 1914-57 for Fraser River near Winter Park, Colo., to 1914 base, in acre-feet

\begin{tabular}{|c|c|c|c|c|c|c|c|c|c|}
\hline Water year & $\begin{array}{l}\text { Historical } \\
\text { discharge }\end{array}$ & $\begin{array}{l}\text { Berthoud } \\
\text { Pass ditch }\end{array}$ & $\begin{array}{c}\text { Moffat tunnel } \\
\text { diversions }\end{array}$ & $\begin{array}{c}\text { Discharge } \\
\text { (1914 base) }\end{array}$ & Water year & $\begin{array}{l}\text { Historical } \\
\text { discharge }\end{array}$ & $\begin{array}{l}\text { Berthoud } \\
\text { Pass ditch }\end{array}$ & $\underset{\text { Moffat tunnel }}{\text { diversions }}$ & $\begin{array}{l}\text { Discharge } \\
\text { (1914 base) }\end{array}$ \\
\hline $\begin{array}{l}1914 \\
1915 \\
1916 \\
1917 \\
1918 \\
1920 \\
1921 \\
1922 \\
1923 \\
1925 \\
1927 \\
1928 \\
19290 \\
1931 \\
1932 \\
1933 \\
1935\end{array}$ & $\begin{array}{l}\mathbf{4 4 , 1 3 0} \\
\mathbf{4 0}, 170 \\
30,820 \\
31,400 \\
43,370 \\
23,780 \\
30,320 \\
39,370 \\
25,240 \\
32,700 \\
30,320 \\
28,440 \\
39,240 \\
31,490 \\
40,810 \\
35,140 \\
32,380 \\
21,140 \\
25,130 \\
33,120 \\
20,640 \\
26,430\end{array}$ & $\begin{array}{r}476 \\
650 \\
832 \\
504 \\
868 \\
\mathbf{4 7 6} \\
0 \\
100 \\
576 \\
1,370 \\
1,160 \\
1,050 \\
452 \\
420 \\
422 \\
1,210 \\
1,030 \\
312 \\
768 \\
555 \\
649 \\
545\end{array}$ & $\begin{array}{l}0 \\
0 \\
0 \\
0 \\
0 \\
0 \\
0 \\
0 \\
0 \\
0 \\
0 \\
0 \\
0 \\
0 \\
0 \\
0 \\
0 \\
0 \\
0 \\
0 \\
0 \\
0\end{array}$ & $\begin{array}{l}44,610 \\
40,820 \\
31,650 \\
31,900 \\
44,250 \\
24,260 \\
30,320 \\
39,470 \\
25,820 \\
34,070 \\
31,480 \\
29,490 \\
39,690 \\
31,910 \\
41,230 \\
36,350 \\
33,410 \\
21,450 \\
25,900 \\
33,680 \\
21,290 \\
26,980\end{array}$ & $\begin{array}{l}1936 \\
1937 \\
1938 \\
1940 \\
1941 \\
1942 \\
1943 \\
1944\end{array}$ & $\begin{array}{r}20,680 \\
12,880 \\
11,650 \\
9,660 \\
6,300 \\
7,570 \\
24,370 \\
7,140 \\
12,720 \\
6,610 \\
6,760 \\
21,870 \\
15,170 \\
21,840 \\
7,390 \\
11,530 \\
14,870 \\
6,360 \\
4,290 \\
5,010 \\
7,120 \\
31,640\end{array}$ & $\begin{array}{r}720 \\
0 \\
777 \\
892 \\
572 \\
609 \\
261 \\
555 \\
430 \\
1,040 \\
397 \\
166 \\
561 \\
327 \\
490 \\
716 \\
730 \\
594 \\
217 \\
458 \\
396 \\
568\end{array}$ & $\begin{array}{r}12,150 \\
11,280 \\
22,300 \\
14,970 \\
15,240 \\
20,150 \\
6,180 \\
18,500 \\
9,170 \\
17,470 \\
17,370 \\
12,020 \\
13,480 \\
9,950 \\
13,650 \\
15,100 \\
15,570 \\
15,330 \\
8,910 \\
15,620 \\
17,500 \\
5,680\end{array}$ & $\begin{array}{l}33,550 \\
24,160 \\
34,730 \\
25,520 \\
22,110 \\
28,330 \\
30,810 \\
26,200 \\
22,320 \\
25,120 \\
24,530 \\
34,060 \\
29,210 \\
32,120 \\
21,530 \\
27,350 \\
31,170 \\
22,280 \\
13,420 \\
21,090 \\
25,020 \\
37,890\end{array}$ \\
\hline
\end{tabular}


TABLE 10.-Adjustment of streamflow records for water years 1914-57 for two stations in the Colorado River Basin to 1914 base, in thousands of acre-feet

Transmountain diversions: Total adjustment for 12 diversions for Colorado River Storage reservoirs: Net adjustment for 5 reservoirs for Colorado River at Glenwood at Glenwood Springs, Colo., and for 16 diversions for Colorado River near Cisco, Springs, Colo., and for 6 reservoirs for Colorado River near Cisco, Utah.

\begin{tabular}{|c|c|c|c|c|c|c|c|c|c|}
\hline Water year & $\begin{array}{l}\text { Historical } \\
\text { discharge }\end{array}$ & $\begin{array}{l}\text { Trans- } \\
\text { mountain } \\
\text { diversions }\end{array}$ & $\begin{array}{c}\text { Storage } \\
\text { reservoirs }\end{array}$ & $\begin{array}{c}\text { Discharge } \\
\text { (1914 base) }\end{array}$ & Water year & $\begin{array}{l}\text { Historical } \\
\text { discharge }\end{array}$ & $\begin{array}{l}\text { Trans- } \\
\text { mountain } \\
\text { diversions }\end{array}$ & $\begin{array}{l}\text { Storage } \\
\text { reservoirs }\end{array}$ & $\begin{array}{l}\text { Discharge } \\
\text { (1914 base) }\end{array}$ \\
\hline \multicolumn{10}{|c|}{ 725. Colorado River at Glenwood Springs, Colo. } \\
\hline $\begin{array}{l}1914 \\
1915 \\
1916 \\
1918 \\
1919 \\
1920\end{array}$ & $\begin{array}{l}2,949 \\
1,735 \\
2,208 \\
2,948 \\
2,778 \\
1,596 \\
2,708 \\
2,887 \\
1,971 \\
2,494 \\
2,177 \\
1,771 \\
2,572 \\
2,387 \\
2,815 \\
2,735 \\
2,110 \\
1,244 \\
2,009 \\
1,920 \\
1,030 \\
1,621\end{array}$ & $\begin{array}{l}11 \\
15 \\
18 \\
11 \\
18 \\
13 \\
17 \\
11 \\
15 \\
16 \\
11 \\
20 \\
17 \\
19 \\
16 \\
24 \\
17 \\
13 \\
20 \\
18 \\
13 \\
18\end{array}$ & to & $\begin{array}{l}2,960 \\
1,750 \\
2,226 \\
2,959 \\
2,796 \\
1,609 \\
2,725 \\
2,898 \\
1,986 \\
2,510 \\
2,188 \\
1,791 \\
2,589 \\
2,406 \\
2,831 \\
2,759 \\
2,127 \\
1,257 \\
2,029 \\
1,938 \\
1,043 \\
1,639\end{array}$ & $\begin{array}{l}1936 \\
1937 \\
1938 \\
1939 \\
1941 \\
1942 \\
1943 \\
1945\end{array}$ & $\begin{array}{l}2,283 \\
1,463 \\
2,433 \\
1,728 \\
1,309 \\
1,690 \\
1,946 \\
1,777 \\
1,510 \\
1,717 \\
1,556 \\
2,261 \\
1,939 \\
2,048 \\
1,476 \\
1,848 \\
2,441 \\
1,589 \\
1,886 \\
1,469 \\
2,409\end{array}$ & $\begin{array}{r}41 \\
40 \\
78 \\
56 \\
60 \\
69 \\
35 \\
59 \\
39 \\
76 \\
67 \\
60 \\
56 \\
66 \\
86 \\
133 \\
124 \\
252 \\
346 \\
330 \\
309 \\
277\end{array}$ & $\begin{array}{r}0 \\
0 \\
0 \\
+2 \\
-2 \\
4 \\
60 \\
107 \\
-17 \\
25 \\
3 \\
19 \\
-28 \\
17 \\
102 \\
190 \\
223 \\
-38 \\
-254 \\
-12 \\
14 \\
258\end{array}$ & $\begin{array}{l}2,324 \\
1,503 \\
2,511 \\
1,786 \\
1,367 \\
1,763 \\
1,981 \\
1,943 \\
1,532 \\
1,818 \\
1,626 \\
2,340 \\
1,967 \\
2,131 \\
1,664 \\
2,171 \\
2,788 \\
1,803 \\
1,978 \\
1,794 \\
2,944\end{array}$ \\
\hline \multicolumn{10}{|c|}{ 1805. Colorado River near Cisco, Utah } \\
\hline $\begin{array}{l}1914 \\
1915 \\
1916 \\
1917 \\
1918 \\
1920 \\
1921\end{array}$ & $\begin{array}{l}8,527 \\
5,348 \\
7,504 \\
8,769 \\
6,396 \\
4,874 \\
8,900 \\
8,896 \\
6,880 \\
7,273 \\
5,932 \\
5,025 \\
6,601 \\
7,547 \\
7,492 \\
8,511 \\
6,097 \\
2,865 \\
6,687 \\
4,631 \\
2,220 \\
4,681\end{array}$ & $\begin{array}{l}11 \\
15 \\
18 \\
11 \\
18 \\
13 \\
17 \\
12 \\
15 \\
16 \\
11 \\
22 \\
21 \\
25 \\
21 \\
30 \\
22 \\
16 \\
27 \\
24 \\
17 \\
42\end{array}$ & 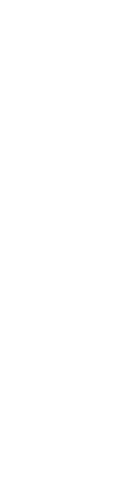 & $\begin{array}{l}8,538 \\
5,363 \\
7,522 \\
8,780 \\
6,414 \\
4,887 \\
8,917 \\
8,908 \\
6,895 \\
7,289 \\
5,943 \\
5,047 \\
6,622 \\
7,572 \\
7,513 \\
8,541 \\
6,119 \\
2,881 \\
6,714 \\
4,655 \\
2,237 \\
4,723\end{array}$ & $\begin{array}{l}1936 \\
1937 \\
1938 \\
1940 \\
1941 \\
1942 \\
1944 \\
1945 \\
1946 \\
1948 \\
1950 \\
1951 \\
1952 \\
1954 \\
1955 \\
1956 \\
1957\end{array}$ & $\begin{array}{l}5,766 \\
4,664 \\
7,422 \\
4,252 \\
3,463 \\
6,576 \\
7,706 \\
5,137 \\
5,903 \\
5,407 \\
4,062 \\
6,051 \\
6,554 \\
6,287 \\
4,236 \\
3,921 \\
7,707 \\
4,037 \\
2,329 \\
3,241 \\
3,604 \\
8,486\end{array}$ & $\begin{array}{r}73 \\
78 \\
129 \\
98 \\
91 \\
109 \\
50 \\
112 \\
79 \\
126 \\
112 \\
99 \\
83 \\
109 \\
124 \\
184 \\
183 \\
298 \\
377 \\
371 \\
350 \\
316\end{array}$ & $\begin{array}{r}0 \\
0 \\
45 \\
-5 \\
-30 \\
63 \\
-7 \\
135 \\
-28 \\
57 \\
-12 \\
58 \\
-77 \\
29 \\
72 \\
201 \\
255 \\
-67 \\
-266 \\
-15 \\
-2 \\
342\end{array}$ & $\begin{array}{l}5,839 \\
4,742 \\
7,596 \\
4,345 \\
3,525 \\
6,748 \\
7,749 \\
5,384 \\
5,954 \\
5,590 \\
4,162 \\
6,208 \\
6,560 \\
6,425 \\
4,432 \\
4,306 \\
8,145 \\
4,268 \\
2,440 \\
3,597 \\
3,952 \\
9,144\end{array}$ \\
\hline
\end{tabular}


TABLE 13.-Precipitation, runoff, and natural consumptive use, in inches, in selected drainage areas in the subbasins in the Grand division

\begin{tabular}{|c|c|c|c|c|c|c|}
\hline $\begin{array}{l}\text { Station } \\
\text { No. }\end{array}$ & Station name & $\begin{array}{c}\text { Drainage area } \\
\text { (sq mi) }\end{array}$ & $\begin{array}{c}\text { Average } \\
\text { altitude of } \\
\text { drainage } \\
\text { basin (feet) }\end{array}$ & Runoff & Precipitation & $\begin{array}{l}\text { Natural con- } \\
\text { sumptive use }\end{array}$ \\
\hline
\end{tabular}

Colorado River Basin above the Gunnison River, Colo.

[Runoff computed from average discharge for water years 1914-57, adjusted to 1957 conditions, plus transbasin diversions and plus estimated irrigation consumptive use. Precipitation planimetered from precipitation map (fig. 4) and adjusted to water years 1914-57 by multiplying by 0.994 ]

\begin{tabular}{|c|c|c|c|c|c|c|}
\hline 110 & Colorado River near Grand Lake & 103 & 10,200 & 15.8 & 30.8 & 15.0 \\
\hline 595 & Piney River near State Bridge.... & 82.6 & 9,600 & 10.4 & 25.3 & 14.9 \\
\hline 630 & Eagle River at Red Cliff. & 72.2 & 10,700 & 10.4 & 26.6 & 16. 2 \\
\hline 645 & Homestake Creek near Red Cliff. & 58.9 & 10,900 & 20.0 & 29. 7 & 9.7 \\
\hline 695 & Gypsum Creek near Gypsum. & 63 & 9,680 & 8. 7 & 26.9 & 18. 2 \\
\hline 700 & Eagle River below Gypsum & 957 & 9,400 & 9.6 & 24.6 & 15.0 \\
\hline
\end{tabular}

Gunnison River basin, Colorado

[Runoff computed from average discharge for water years 1914-57, adjusted to 195، conditions, plus estimated irrigation consumptive use. Precipitation planimetered from precipitation map (fig. 4) and adjusted to water years $1914-57$ by multiplying by 0.994$]$

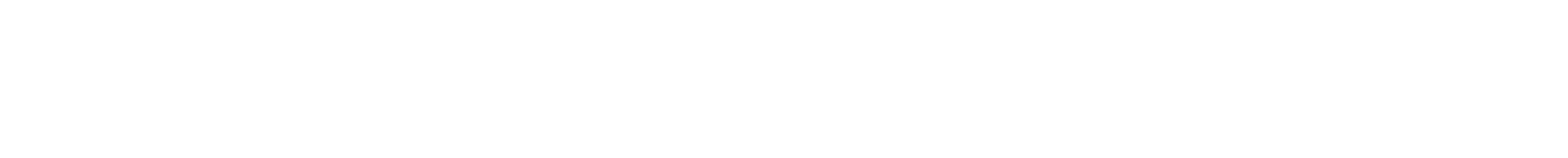

Colorado River Basin between the Gunnison and Green Rivers

\begin{tabular}{|c|c|c|c|c|c|c|}
\hline $\begin{array}{l}1665 \\
1840\end{array}$ & $\begin{array}{l}\text { Dolores River at Dolores, Colo } \\
\text { Mill Creek near Moab, Utah }\end{array}$ & $\begin{array}{r}556 \\
76\end{array}$ & $\begin{array}{l}9,680 \\
8,050\end{array}$ & $\begin{array}{r}12.2 \\
32.6\end{array}$ & $\begin{array}{l}232.3 \\
413.7\end{array}$ & $\begin{array}{l}20.1 \\
11.1\end{array}$ \\
\hline
\end{tabular}

1 Computed from average discharge for the water years 1914-57 adjusted to 1957 conditions, plus irrigation consumptive use.

3 Average discharge for water years 1951-57.

2 Plonimetered from precipitation map (fig 4$)$ and adjusted to water years $1914-57$

map (fig. 4) and adjusted to water years 1951-57

by multiplying by 0.994

TABLE 14.-Water and dissolved-solids discharges of streams in the subbasins in the Grand division

[Water and dissolved-solids discharges for the water years 1914-57 adjusted to 1957 conditions except as indicated]

\begin{tabular}{|c|c|c|c|c|c|c|c|c|}
\hline \multirow[b]{2}{*}{$\begin{array}{l}\text { Station } \\
\text { No. }\end{array}$} & \multirow[b]{2}{*}{ Station name } & \multirow[b]{2}{*}{$\begin{array}{l}\text { Drainage area } \\
\text { (sq mi) }\end{array}$} & \multicolumn{2}{|c|}{ Water discharge } & \multicolumn{4}{|c|}{ Dissolved solids } \\
\hline & & & Average (cfs) & $\begin{array}{c}\text { Average } \\
\text { annual } \\
\text { (acre-ft) }\end{array}$ & $\begin{array}{l}\text { Weighted- } \\
\text { average } \\
\text { concentra- } \\
\text { tion (ppm) }\end{array}$ & $\begin{array}{c}\text { Average } \\
\text { discharge } \\
\text { (tons per day) }\end{array}$ & $\begin{array}{c}\text { Average } \\
\text { annual } \\
\text { yield per } \\
\text { square } \\
\text { mile (tons) }\end{array}$ & $\begin{array}{l}\text { A verage } \\
\text { annual } \\
\text { discharge } \\
\text { (tons) }\end{array}$ \\
\hline
\end{tabular}

Colorado River Basin above the Gunnison River, Colo.

\begin{tabular}{|c|c|c|c|c|c|c|c|c|}
\hline 110 & Colorado River near Grand Lake. & 103 & 97. 8 & 70,850 & 38 & 10 & 35 & 3,650 \\
\hline 125 & North Inlet at Grand Lake & 46. 6 & 78. 4 & 56,800 & 16 & 3. 4 & 27 & 1,240 \\
\hline 190 & Colorado River below Lake Granby . . . . . & 311 & 35. 4 & 25,650 & 35 & 3. 3 & - & 1,210 \\
\hline 200 & Willow Creek near Granby & 105 & 69. 8 & 50,570 & 65 & 12 & 42 & 4,380 \\
\hline 240 & Fraser River near Winter Park & 27.6 & 20. 8 & 15,070 & 30 & 1. 7 & 22 & 621 \\
\hline 265 & St. Louis Creek near Fraser.... & 32. 8 & 23. 5 & 17,020 & 41 & 2. 6 & 29 & 950 \\
\hline 340 & Fraser River at Granby & 285 & 172 & 124,600 & 47 & 22 & 28 & 8,040 \\
\hline 345 & Colorado River at Hot Sulphur Springs & 782 & 244 & 176,800 & 76 & 50 & 23 & 18,260 \\
\hline 360 & Williams River near Leal & 89.5 & 103 & 74,620 & 30 & 8. 4 & 34 & 3,070 \\
\hline 375 & Williams River near Parshall & 186 & 137 & 99,250 & 35 & 13 & 26 & 4,750 \\
\hline 385 & Williams River below Williams Fork Reser- & & & & 40 & & & \\
\hline 405 & Troublesome Creek near Troublesome. & $\begin{array}{l}234 \\
178\end{array}$ & $\begin{array}{r}158 \\
57.1\end{array}$ & $\begin{array}{r}114,500 \\
41,370\end{array}$ & $\begin{array}{r}40 \\
156\end{array}$ & 24 & $\begin{array}{l}26 \\
49\end{array}$ & 8,770 \\
\hline 415 & Muddy Creek at Kremmling & 275 & 75. 1 & 54,410 & 444 & 90 & 119 & 32,870 \\
\hline 470 & Blue River at Dillon & 129 & 109 & 78,970 & 85 & 25 & 71 & 9,130 \\
\hline 520 & Rock Creek near Dillon & 15. 8 & 26. 5 & 19,200 & 22 & 1. 6 & 37 & 584 \\
\hline 575 & Blue River below Green Mountain Reser- & & & & & & & \\
\hline 595 & voir & $\begin{array}{r}623 \\
82.6\end{array}$ & $\begin{array}{r}523 \\
74.0\end{array}$ & $\begin{array}{r}378,900 \\
53,610\end{array}$ & $\begin{array}{l}101 \\
120\end{array}$ & $\begin{array}{r}142 \\
24\end{array}$ & $\begin{array}{r}83 \\
106\end{array}$ & $\begin{array}{r}51,870 \\
8,770\end{array}$ \\
\hline 605 & Rock Creek near Toponas.... & 48 & 30. 1 & 21,810 & 41 & 3. 3 & 25 & 1,210 \\
\hline 610 & Sunnyside Creek near Burns & 10 & 4. 5 & 3,260 & 100 & 1. 2 & 44 & 438 \\
\hline
\end{tabular}


SURFACE-WATER RESOURCES OF GRAND DIVISION

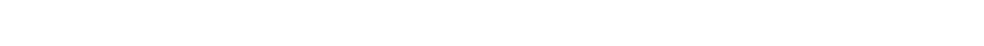

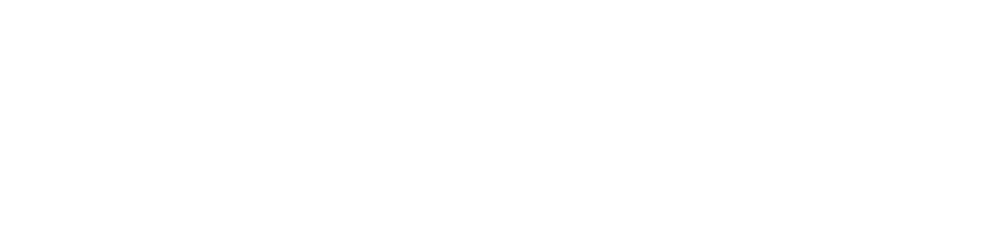

(

ㅅ:

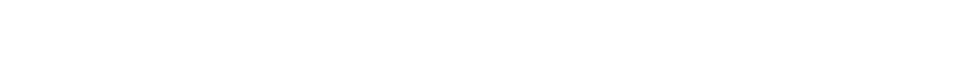

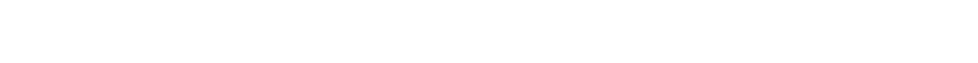

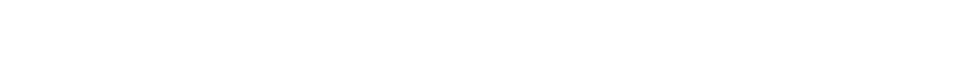

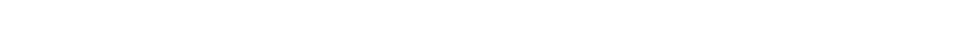

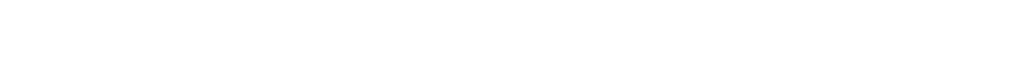

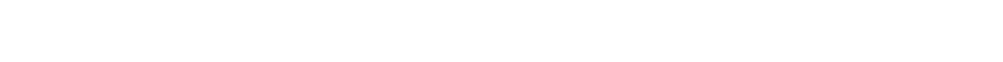

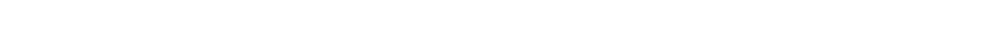

일

"1:

๓:

잉

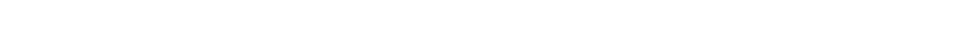

")

"

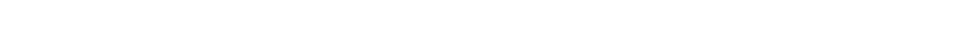

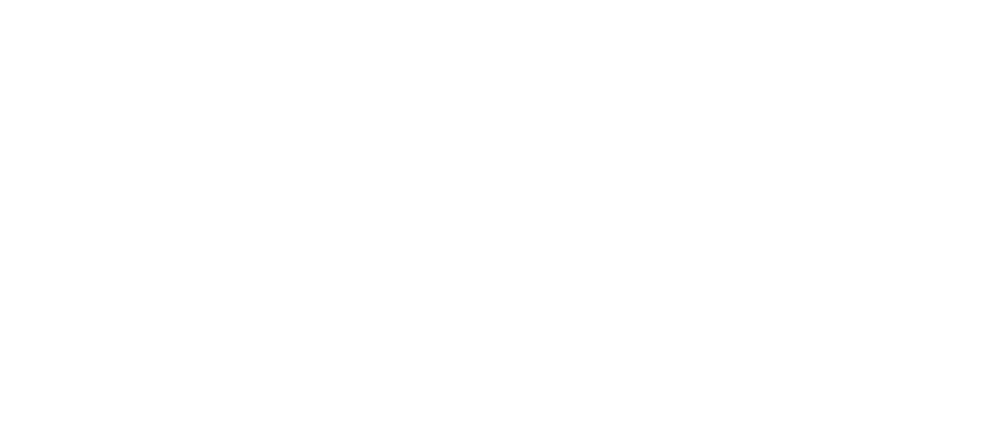

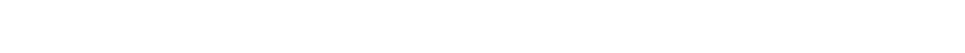



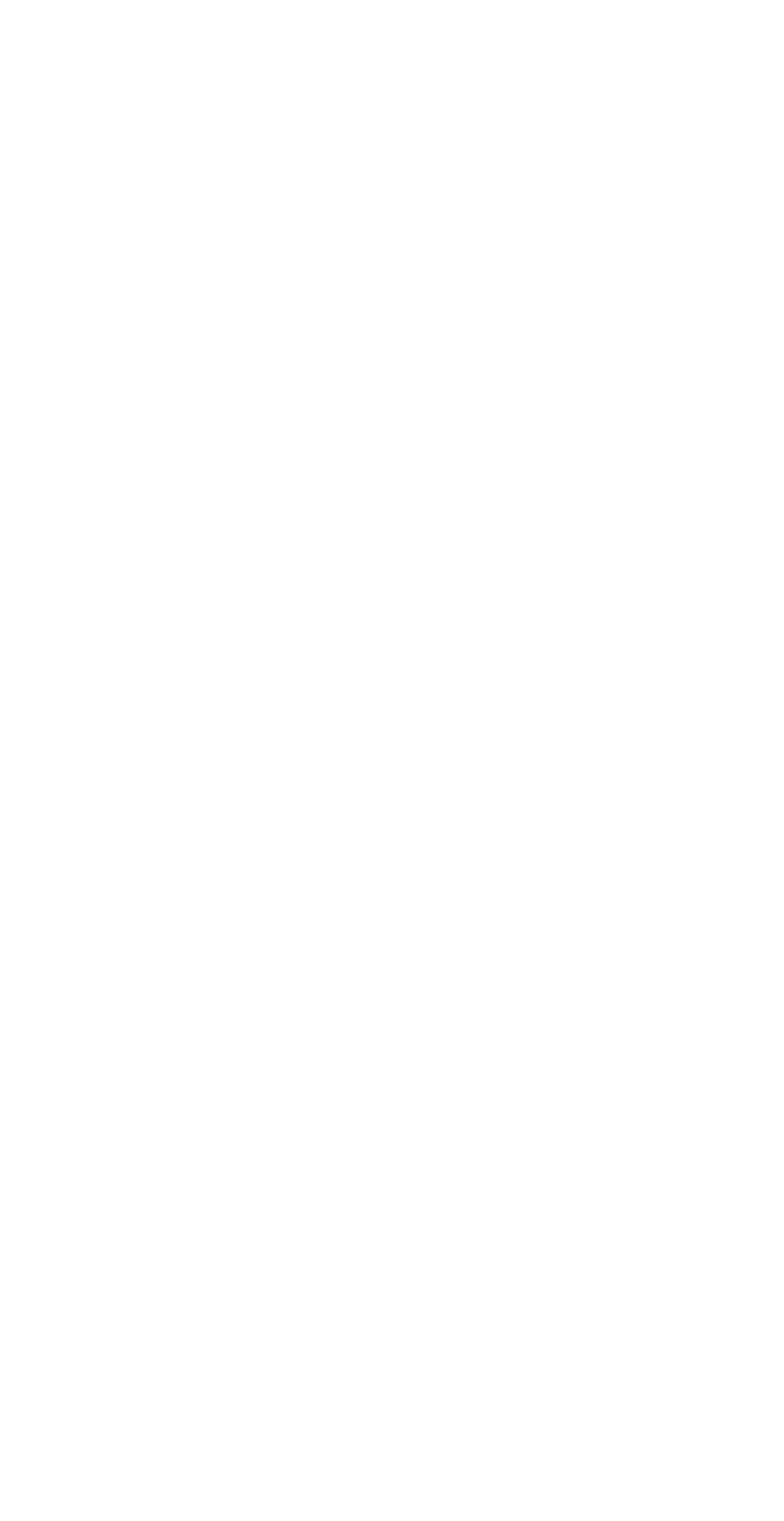


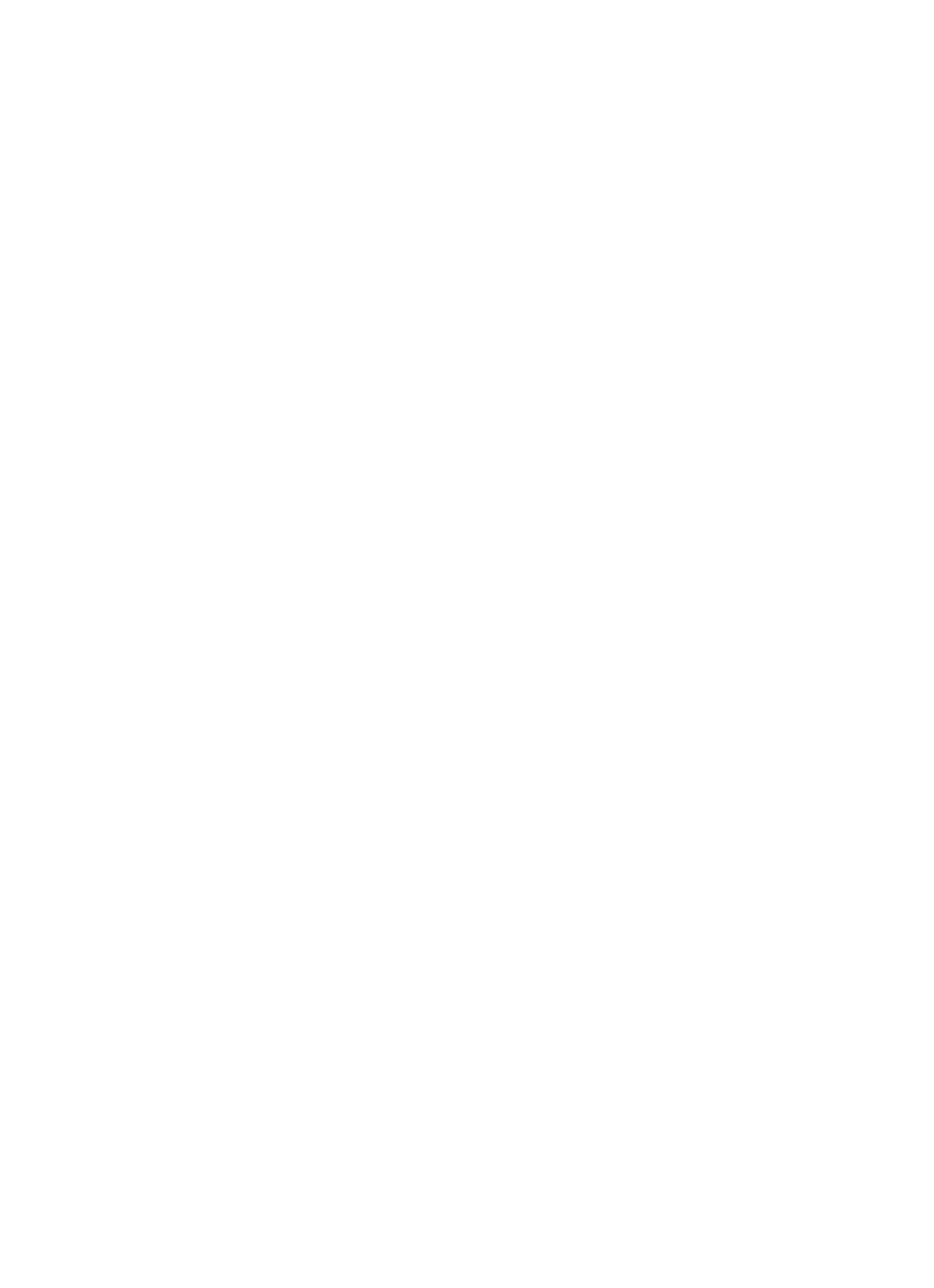


WATER RESOURCES OF UPPER COLORADO RIVER BASIN
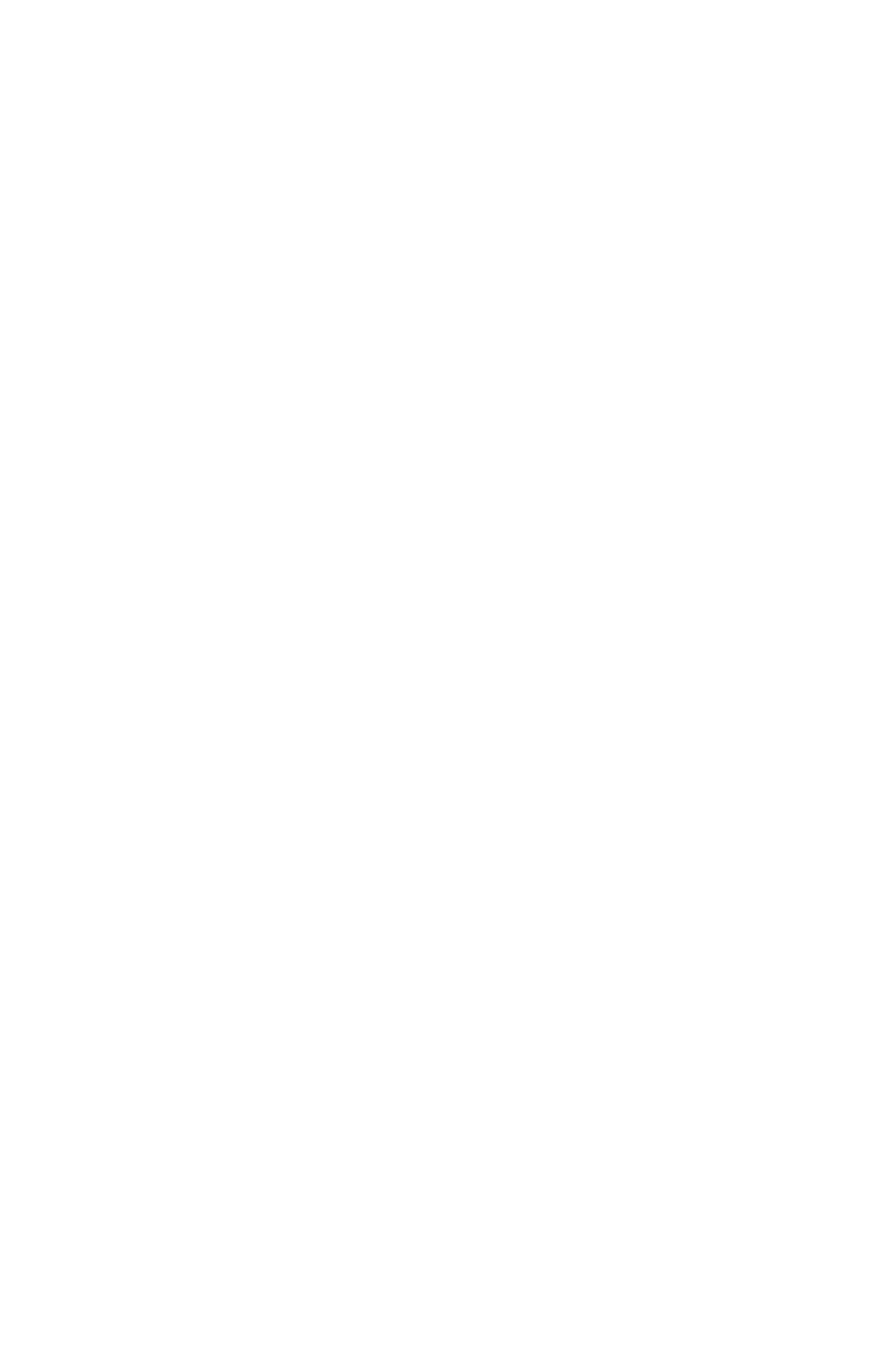
TABLE 17.-Variability of annual weighted-average concentration of dissolved solids as related to variability of annual water discharge for selected daily stations in the Grand division

\begin{tabular}{|c|c|c|c|c|}
\hline \multirow[b]{2}{*}{$\begin{array}{l}\text { Station } \\
\text { No. }\end{array}$} & \multirow[b]{2}{*}{ Station name } & \multirow[b]{2}{*}{ Water years } & \multicolumn{2}{|c|}{ Coefficient of variation } \\
\hline & & & $\begin{array}{c}\text { Water } \\
\text { discharge }\end{array}$ & $\begin{array}{l}\text { Weighted- } \\
\text { average } \\
\text { concen- } \\
\text { tration }\end{array}$ \\
\hline \multicolumn{5}{|c|}{ Colorado River Basin above the Gunnison River, Colo. } \\
\hline $\begin{array}{l}690 \\
705 \mathrm{C} \\
955\end{array}$ & $\begin{array}{l}\text { Eagle River at Gypsum } \\
\text { Colorado River near Glenwood Springs } \\
\text { Colorado River near Cameo. }\end{array}$ & $\begin{array}{l}1948-57 \\
1942-57 \\
1934-57\end{array}$ & $\begin{array}{r}0.28 \\
.26 \\
.25\end{array}$ & $\begin{array}{r}0 . \\
.20 \\
.17\end{array}$ \\
\hline \multicolumn{5}{|c|}{ Colorado River Basin below the Gunnison River, Utah } \\
\hline $\begin{array}{l}1800 \\
1805\end{array}$ & $\begin{array}{l}\text { Dolores River near Cisco, Utah 1 } \\
\text { Colorado River near Cisco, Utah }\end{array}$ & $\begin{array}{l}1948-57 \\
1929-57\end{array}$ & $\begin{array}{r}0.67 \\
.34\end{array}$ & $\begin{array}{r}0.47 \\
.23\end{array}$ \\
\hline
\end{tabular}

1 Combined record of stations at Gateway, Colo,, and near Cisco, Utah.

TABLE 18.-Variability of annual weighted-average concentration of dissolved solids for selected stations in the subbasins in the Grand division

[Data are for the water years 1914-57 adjusted to 1957 conditions; dissolved-solids weighted-average concentration from table 15]

\begin{tabular}{|c|c|c|c|c|c|}
\hline \multirow[b]{2}{*}{ Station No. } & \multirow[b]{2}{*}{ Station name } & \multirow[b]{2}{*}{$\begin{array}{l}\text { Streamflow } \\
\text { coefficient } \\
\text { of variation }\end{array}$} & \multicolumn{3}{|c|}{ Dissolved solids } \\
\hline & & & $\begin{array}{l}\text { Computed } \\
\text { coefficient } \\
\text { of variation }\end{array}$ & $\begin{array}{c}\text { Weighted- } \\
\text { average } \\
\text { concentration } \\
\text { (ppm) }\end{array}$ & $\begin{array}{c}\text { Computed } \\
\text { standard } \\
\text { deviation } \\
\text { (ppm) }\end{array}$ \\
\hline
\end{tabular}

Colorado River Basin above the Gunnison River, Colo.

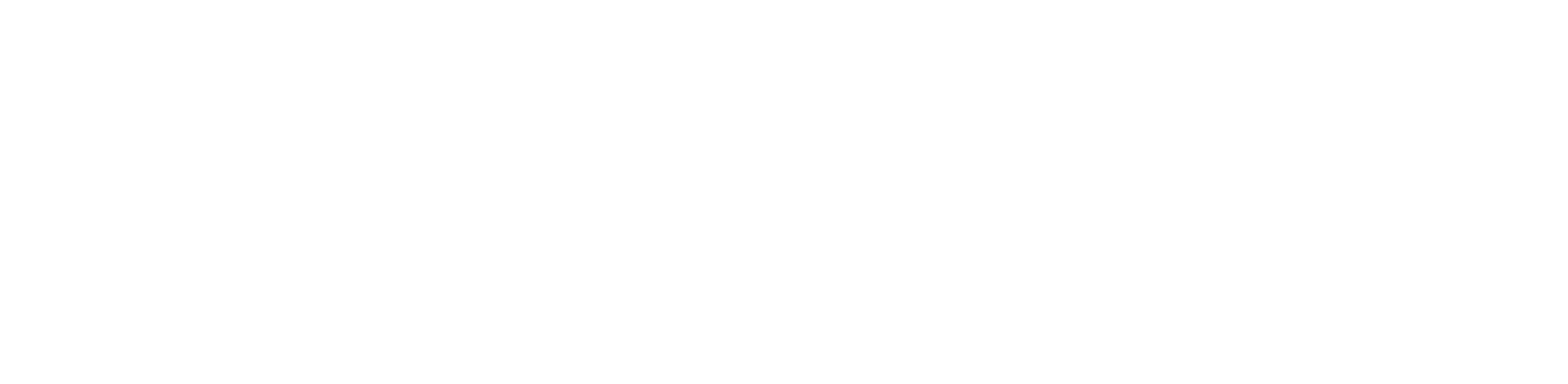

Gunnison River basin, Colorado

\begin{tabular}{|c|c|c|c|c|c|}
\hline $\begin{array}{l}1125 \\
1145 \\
1185 \\
1245 \\
1315 \\
1475 \\
1525\end{array}$ & $\begin{array}{l}\text { East River at Almont. } \\
\text { Gunnison River near Gunnison. } \\
\text { Cochetopa Creek near Parlin. } \\
\text { Lake Fork at Gateview } \\
\text { Muddy Creek at Bardine } \\
\text { Uncompahgre River at Colona } \\
\text { Gunnison River near Grand Junction }\end{array}$ & $\begin{array}{l}\text { 2. } 31 \\
\text { 1. } 31 \\
\text { 1. } 31 \\
\text { 1. } 31 \\
\text { 1. } 32 \\
\text { 2. } 31 \\
\text { 2. } 40\end{array}$ & $\begin{array}{l}0.21 \\
.21 \\
.21 \\
.21 \\
.22 \\
.21 \\
.23\end{array}$ & $\begin{array}{r}147 \\
126 \\
149 \\
85 \\
124 \\
376 \\
592\end{array}$ & $\begin{array}{r}31 \\
26 \\
31 \\
18 \\
27 \\
79 \\
136\end{array}$ \\
\hline
\end{tabular}

Colorado River Basin between the Gunnigon and Gre en River

[Streamflow coefficient of variation from table 12]

\begin{tabular}{|c|c|c|c|c|c|}
\hline $\begin{array}{l}1665 \\
1725 \\
1775 \\
1800 \\
1805\end{array}$ & $\begin{array}{l}\text { Dolores River at Dolores, Colo, } \\
\text { San Miguel River near Placerville, Colo } \\
\text { San Miguel River at Naturita, Colo } \\
\text { Dolores River near Cisco, Utah } \\
\text { Colorado River near Cisco, Utah. }\end{array}$ & $\begin{array}{r}0.38 \\
.33 \\
.42 \\
.59 \\
.31\end{array}$ & $\begin{array}{l}0.25 \\
.23 \\
.28 \\
.37 \\
.21\end{array}$ & $\begin{array}{l}125 \\
157 \\
316 \\
496 \\
547\end{array}$ & $\begin{array}{r}31 \\
36 \\
88 \\
183 \\
115\end{array}$ \\
\hline
\end{tabular}

1 Interpreted from figure 4.

2 From table 11.

3 Coefficient of variation assumed to be the same as that for Eagle River below

Gypsum, Colo. (station 700, table 11). 4 Coefficient of variation assumed to be the same as that for Colorado River at
Glenwood Springs, Colo. (station 725 , table 11). 
TABLE 19.-Relation between water discharge and chemical quality of water for selected stations in the subbasins in the Grand division [Chemical-quality data and weighted averages are in parts per million and equivalents per million (italicized) except as indicated; data are for the water years 1914-57 adjusted

\begin{tabular}{|c|c|c|c|c|c|c|c|c|c|c|c|c|c|c|c|c|}
\hline $\begin{array}{c}\text { Discharge } \\
\text { (cfs) }\end{array}$ & $\begin{array}{c}\text { Calcium } \\
(\mathrm{Ca})\end{array}$ & $\begin{array}{c}\text { Mag- } \\
\text { nesium } \\
(\mathrm{Mg})\end{array}$ & $\begin{array}{l}\text { Sodium } \\
\text { (Na) }\end{array}$ & $\begin{array}{l}\text { Potas- } \\
\text { sium } \\
\text { (K) }\end{array}$ & $\begin{array}{c}\text { Bicar- } \\
\text { bonate } \\
\left(\mathrm{HCO}_{3}\right)\end{array}$ & $\begin{array}{l}\text { Sulfate } \\
\left.\text { ( } \mathrm{SO}_{4}\right)\end{array}$ & $\begin{array}{c}\text { Chloride } \\
(\mathrm{Cl})\end{array}$ & $\begin{array}{l}\text { Boron } \\
\text { (B) }\end{array}$ & $\begin{array}{l}\text { Parts } \\
\text { per } \\
\text { mil- } \\
\text { lion }\end{array}$ & $\begin{array}{l}\text { Tons } \\
\text { per } \\
\text { acre- } \\
\text { foot }\end{array}$ & $\begin{array}{l}\text { Tons } \\
\text { per } \\
\text { day }\end{array}$ & $\begin{array}{c}\text { Calcium, } \\
\text { mag- } \\
\text { nesium }\end{array}$ & $\begin{array}{l}\text { Non- } \\
\text { carbon- } \\
\text { ate }\end{array}$ & $\begin{array}{c}\text { Per- } \\
\text { cent } \\
\text { so- } \\
\text { dium }\end{array}$ & $\begin{array}{c}\text { Specific } \\
\text { conduct- } \\
\text { ance } \\
\text { (micro- } \\
\text { mhos } \\
\text { per cm } \\
\text { at } 25^{\circ} \mathrm{C} \text { ) }\end{array}$ & $\begin{array}{c}\text { Sodium- } \\
\text { adsorp- } \\
\text { tion- } \\
\text { ratio }\end{array}$ \\
\hline
\end{tabular}

\section{COLORADO RIVER BASIN ABOVE THE GUNNISON RIVER}

345. Colorado River at Hot Sulphur Springs, Colo.

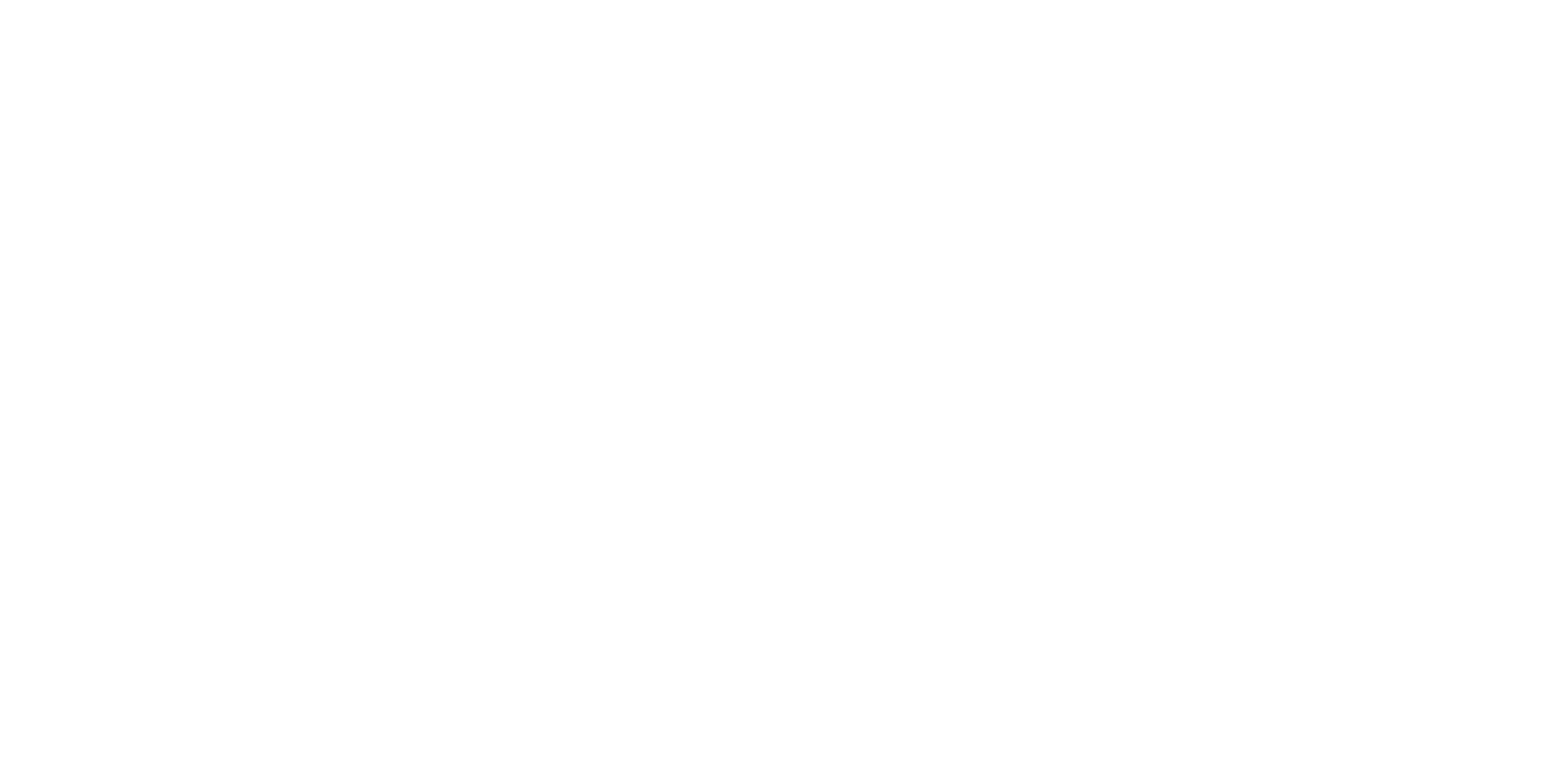

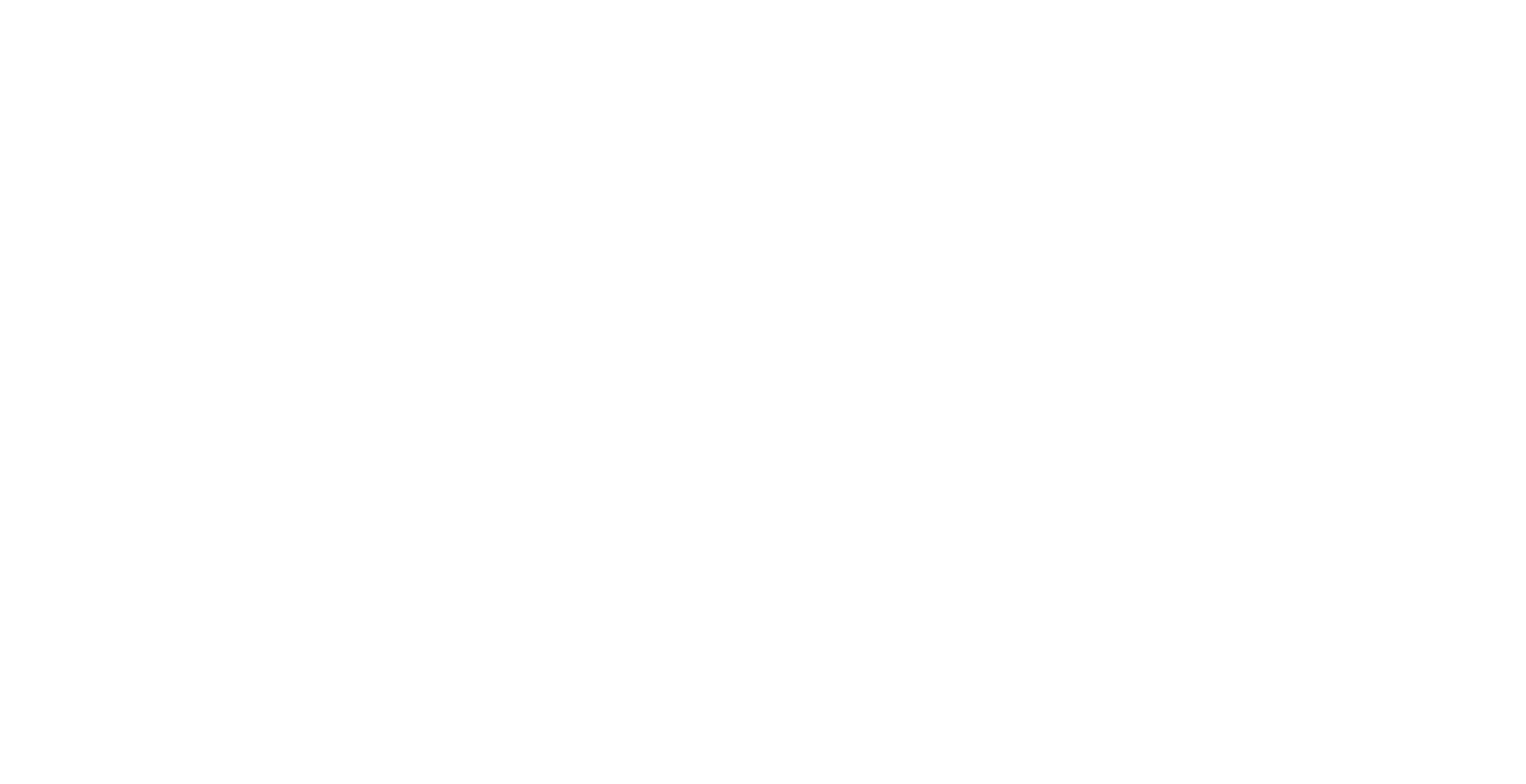

See footnotes at end of table. 
TABLE 19.-Relation between water discharge and chemical quality of water for selected stations in the subbasins in the Grand division-Con. [Chemical-quality data and weighted averages arei $n$ parts per million and equivalents per million (italicized) except as indicated; data are for the water years 1914-57 adj usted

\begin{tabular}{|c|c|c|c|c|c|c|c|c|c|c|c|c|c|c|c|c|}
\hline \multirow[b]{2}{*}{$\begin{array}{c}\text { Discharge } \\
\text { (cfs) }\end{array}$} & \multirow[b]{2}{*}{$\underset{(\mathrm{Ca})}{\text { Calcium }}$} & \multirow{2}{*}{$\underset{\text { nesium }}{\text { Mag- }}$} & \multirow[b]{2}{*}{$\underset{(\mathrm{Na})}{\text { Sodium }}$} & \multirow{2}{*}{$\begin{array}{l}\text { Potas- } \\
\text { sium } \\
(\mathbf{K})\end{array}$} & \multirow{2}{*}{$\begin{array}{c}\text { Bicar- } \\
\text { bonate } \\
\left(\mathrm{HCO}_{3}\right)\end{array}$} & \multirow[b]{2}{*}{$\begin{array}{l}\text { Sulfate } \\
\left(\mathrm{SO}_{4}\right)\end{array}$} & \multirow[b]{2}{*}{$\begin{array}{c}\text { Chloride } \\
\text { (CI) }\end{array}$} & \multirow[b]{2}{*}{$\begin{array}{c}\text { Boron } \\
\text { (B) }\end{array}$} & \multicolumn{3}{|c|}{$\begin{array}{l}\text { Dissolved solids } \\
\text { (residue at } 180^{\circ} \mathrm{C} \text { ) }\end{array}$} & \multicolumn{2}{|c|}{$\begin{array}{l}\text { Hardness } \\
\text { as } \mathrm{CaCO}_{3}\end{array}$} & \multirow{2}{*}{$\begin{array}{l}\text { Per- } \\
\text { cent } \\
\text { so- } \\
\text { dium }\end{array}$} & \multirow{2}{*}{$\begin{array}{l}\text { Specific } \\
\text { conduct- } \\
\text { ance } \\
\text { (micro- } \\
\text { mhos } \\
\text { per cm } \\
\text { at } 25^{\circ} \mathrm{C} \text { ) }\end{array}$} & \multirow{2}{*}{$\begin{array}{l}\text { Sodium- } \\
\text { adsorp- } \\
\text { tion- } \\
\text { ratio }\end{array}$} \\
\hline & & & & & & & & & $\begin{array}{c}\text { Parts } \\
\text { per } \\
\text { mil- } \\
\text { lion }\end{array}$ & $\begin{array}{l}\text { Tons } \\
\text { per } \\
\text { acre- } \\
\text { foot }\end{array}$ & $\begin{array}{l}\text { Tons } \\
\text { per } \\
\text { day }\end{array}$ & $\begin{array}{c}\text { Calcium, } \\
\text { mag- } \\
\text { nesium }\end{array}$ & $\begin{array}{l}\text { Non- } \\
\text { carboon- } \\
\text { ate }\end{array}$ & & & \\
\hline
\end{tabular}

COLORADO RIVER BASIN ABOVE THE GUNNISON RIVER-Continued

705 C. Colorado River near Glen wood Springs, Colo.

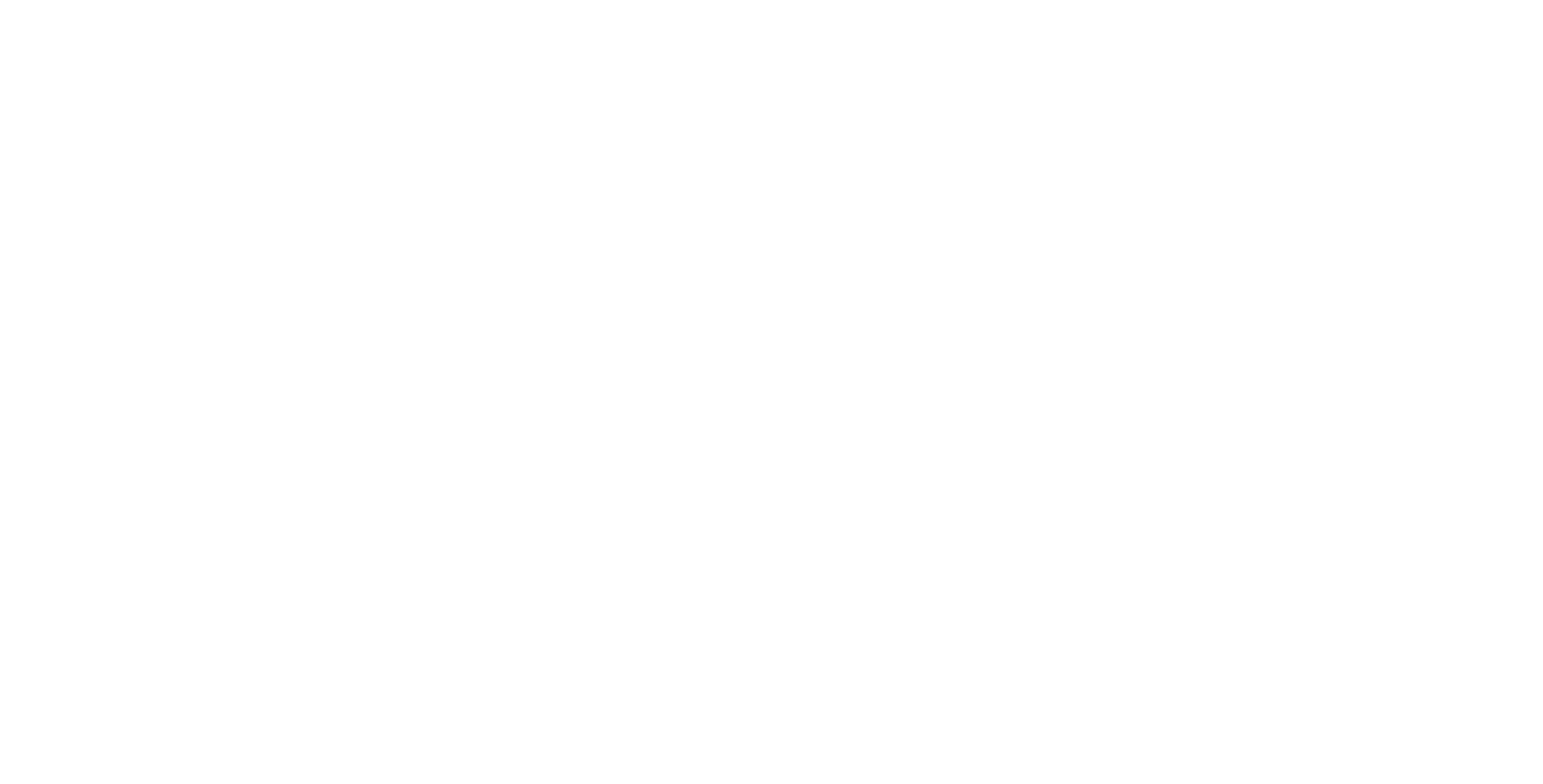

955. Colorado River near Cameo, Colo.

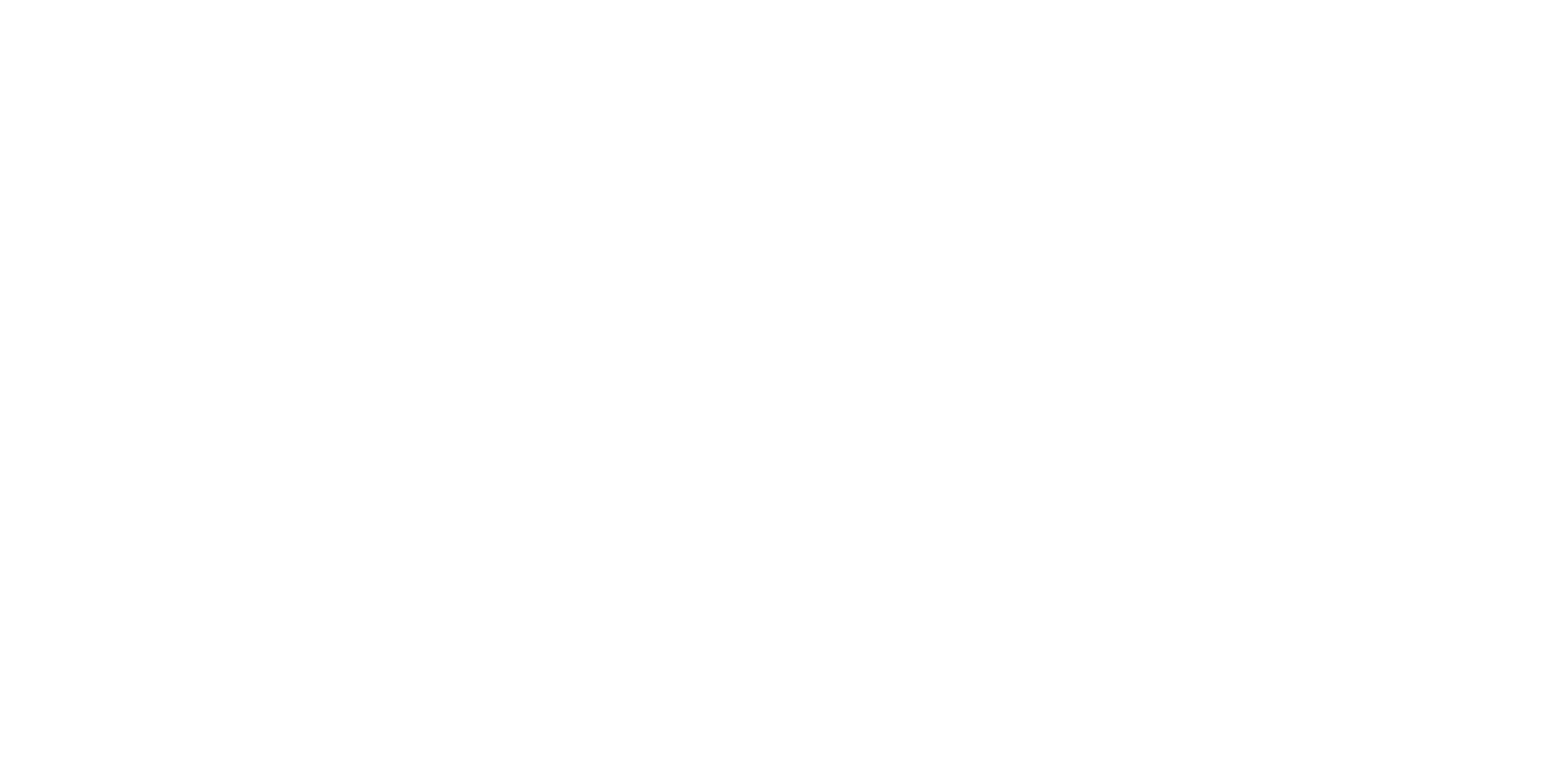


TABLE 19.-Relation between water discharge and chemical quality of water for selected stations in the subbasins in the Grand division-Con. [Chemical-quality data and weighted averages are in parts per million and equivalents per million (italicized) except as indicated; data are for the water years 1914-57 adjusted

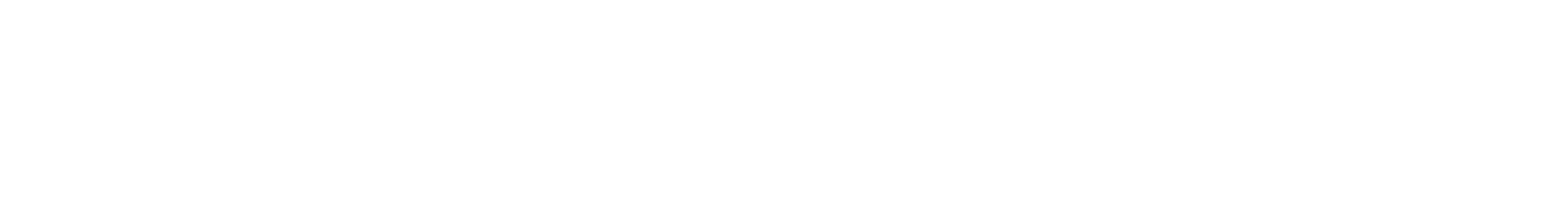

GUNNISON RIVER BASIN

1525. Gunnison River near Grand Junetion, Colo.

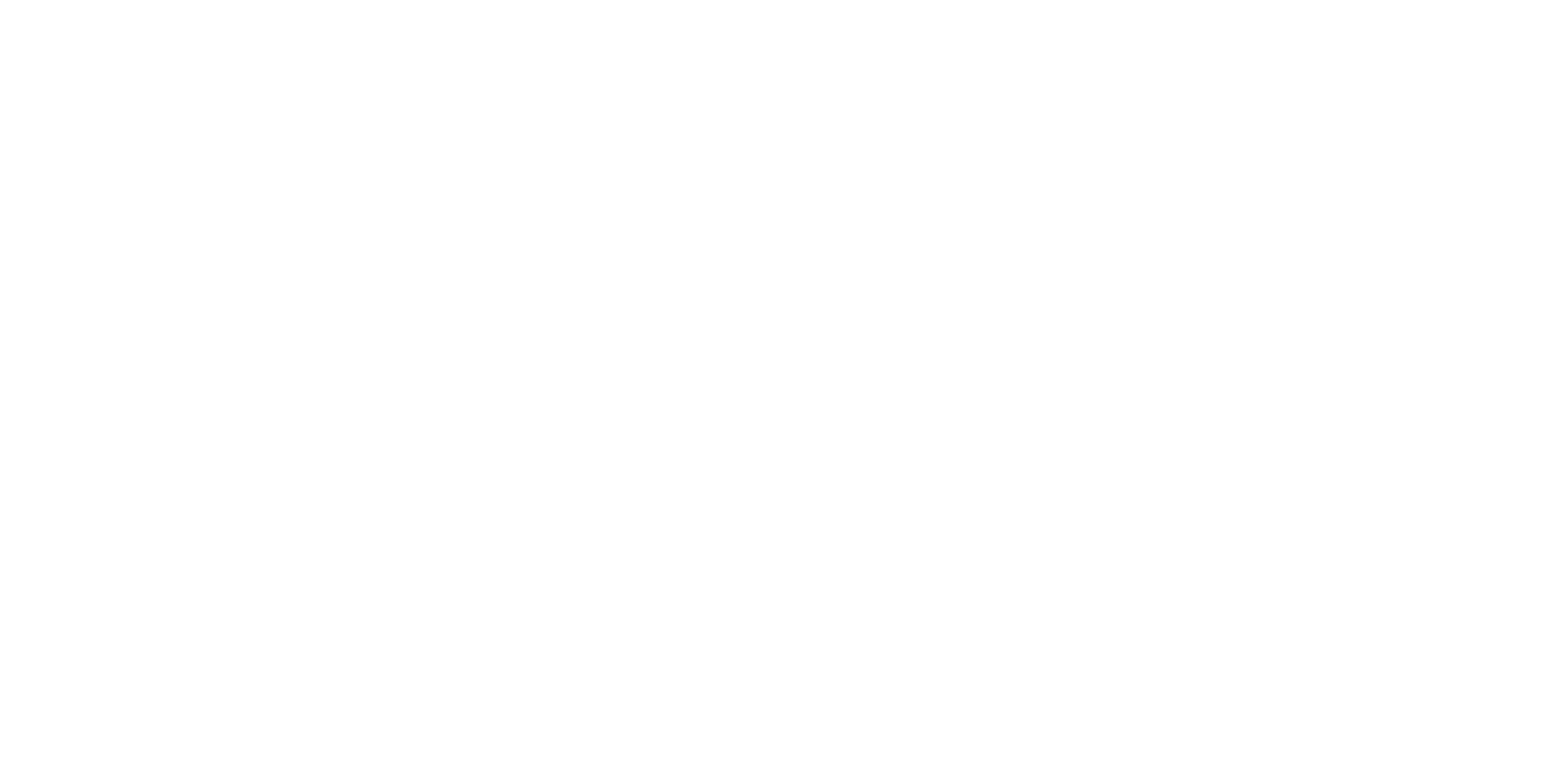

\section{COLORADO RIVER BASIN BETWEEN THE GUNNISON AND GREEN RIV ERS}

1795. Dolores River at Gateway, Colo.

\begin{tabular}{|c|c|c|c|c|c|c|c|c|c|c|c|c|c|c|c|c|}
\hline 15,000 & 9 & 8.4 & 13 & 3.7 & 124 & 50 & 16 & & 200 & 0.27 & 8,100 & 140 & 38 & 17 & 350 & 0.5 \\
\hline 12,800 & 42 & $\begin{array}{l}8.40 \\
80\end{array}$ & $13^{.07}$ & 3.7 & 124 & 50 & $16^{-40}$ & $-\cdots$ & 201 & .27 & 7,000 & 140 & 38 & 17 & $350^{-1}$ &.$\overline{5}$ \\
\hline 11,500 & $\begin{array}{l}2.10 \\
42\end{array}$ & $\begin{array}{l}8.48 \\
.09\end{array}$ & $13^{.07}$ & 3. 79 & 124 & 51.04 & $16^{.40}$ & 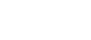 & 202 & .27 & 6,270 & $140^{-}$ & 38 & 17 & $35 i$ & $\overline{5}$ \\
\hline 8,900 . & $\begin{array}{c}2.10 \\
43\end{array}$ & $\begin{array}{l}8.49 \\
.69\end{array}$ & $13^{.07}$ & 3. .79 & 124 & 52.06 & $17^{.45}$ & $\cdots$ & 204 & .28 & 4,900 & 142 & 40 & 16 & 355 & $\overline{5}$ \\
\hline $6,600$. & 43 & 8.4 & $14^{.0 i}$ & 3.7 & 124 & 53 & $18^{-40}$ & - & 209 & .28 & $\overline{3}, 720$ & 142 & 40 & 17 & 360 &.$\overline{5}$ \\
\hline 5,100 & $\begin{array}{l}\text { z.10 } \\
43\end{array}$ & $\begin{array}{l}.68 \\
8.6\end{array}$ & $16^{.61}$ & $\begin{array}{l}.09 \\
3.7\end{array}$ & 125 & $\begin{array}{l}1.1 \\
56\end{array}$ & $20{ }^{.01}$ & - & 220 & $.30^{-1}$ & $3,030^{-}$ & 143 & $40^{\circ}$ & 19 & 372 & .6 \\
\hline 3,900 . & $\begin{array}{l}44 \\
4.20\end{array}$ & 9.0 & $21^{\circ}$ & $\begin{array}{l}3.89 \\
3.8\end{array}$ & $\begin{array}{r}z .00 \\
126\end{array}$ & 59 & $25{ }^{.00}$ & 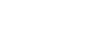 & 236 & .32 & 2,490 & 147 & 44 & 23 & 390 & .8 \\
\hline 2,580 & & $10^{-98}$ & 32 & $\begin{array}{l}4.0 \\
4.10\end{array}$ & 127 & 66 & 39.10 & - & 272 & .37 & 1,890 & 151 & 47 & 31 & 445 & 1.1 \\
\hline $1,250_{\text {_ }}$ & 49 & 14 & 70 & 5. 4 & 130 & 86 & 100 & 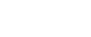 & 378 & .51 & 1,280 & 180 & 74 & 45 & 628 & 2.3 \\
\hline 550. & 62 & 23 & $\begin{array}{r}5.04 \\
185\end{array}$ & $\begin{array}{l}\cdot 14 \\
9.9\end{array}$ & $\begin{array}{r}7.25 \\
152\end{array}$ & 160 & $\begin{array}{r}265 \\
268\end{array}$ & - & 700 & .95 & 1,040 & 249 & 124 & 61 & 1,170 & 5.1 \\
\hline 360. & 78 & 32 & 310 & 15 & 171 & 234 & $450^{\circ}$ & 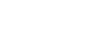 & 1,030 & 1.40 & 1,000 & 326 & 186 & 66 & 1,740 & 7.5 \\
\hline $260=$ & 94 & 40 & 430 & $19^{.00}$ & $180^{\circ}$ & $285^{\circ}$ & 638 & 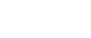 & 1,420 & 1.93 & 997 & 399 & 252 & 69 & 2,400 & 9.4 \\
\hline 200. & $\begin{array}{l}103 \\
103\end{array}$ & 47.20 & 530 & $23{ }^{.40}$ & 181 & 328 & 800 & - --- & 1,800 & 2.45 & 972 & $450^{\circ}$ & 302 & 71 & 3,040 & 11 \\
\hline 163. & 112 & 52 & 620 & $26^{\circ}$ & 183 & $\begin{array}{l}360 \\
0.0\end{array}$ & 940 & $-3-1$ & 2,110 & 2.87 & 929 & 493 & 343 & 72 & 3,550 & 12 \\
\hline 132. & 119 & 58 & 720 & 30 & $\begin{array}{l}184 \\
180 \\
3.09\end{array}$ & 391.4 & 1,100 & 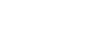 & 2,460 & 3.35 & 877 & 586 & 384 & 73 & 4,160 & 14 \\
\hline 968. & 127 & 64 & 860 & 35 & 185 & 440 & 1,320 & 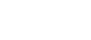 & 2,950 & 4.01 & 765 & 580 & 428 & 75 & 5,000 & 16 \\
\hline 58. & 133 & 70 & 1,050 & $41^{.05}$ & 186 & 498 & 1,620 & 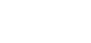 & 3,450 & 4.69 & $540^{\circ}$ & 620 & 467 & 77 & 5,890 & 18 \\
\hline 30. & $\begin{array}{c}133 \\
6.64\end{array}$ & 73 & 1,170 & 44 & 187.00 & 521 & 1,800 & 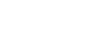 & 3,800 & 5.17 & 308 & 632 & 478 & 79 & 6,400 & 20 \\
\hline 19 & $\begin{array}{r}133 \\
6.64 \\
\end{array}$ & $\begin{array}{r}74 \\
6.08\end{array}$ & $\begin{array}{r}1,230 \\
53.50\end{array}$ & $\begin{array}{r}44 \\
1.18\end{array}$ & $\begin{array}{c}188 \\
3.08\end{array}$ & $\begin{array}{c}521 \\
10.84\end{array}$ & $\begin{array}{c}1,900 \\
68.68\end{array}$ & $\mid$ & 3,900 & 5. 30 & 200 & 636 & 482 & 79 & 6,650 & 21 \\
\hline 944 & $\begin{array}{l}53 \\
2.64\end{array}$ & ${ }_{1.28}^{15}$ & 101 & $\begin{array}{l}6.8 \\
.17\end{array}$ & $\stackrel{134}{2.20}$ & ${ }_{2.10}^{101}$ & $\begin{array}{l}147 \\
4.15\end{array}$ & $\ldots$ & 475 & .65 & 1,210 & 194 & 84 & 52 & 798 & 3.2 \\
\hline
\end{tabular}

See footnotes at end of table. 
TABLE 19.-Relation between water discharge and chemical quality of water for selected stations in the subbasins in the Grand division-Con. IChemical-quality data and weighted averages are in parts per million and equivalents per million (italicized) except as indicated; data are for the water years 1914-57 adjusted

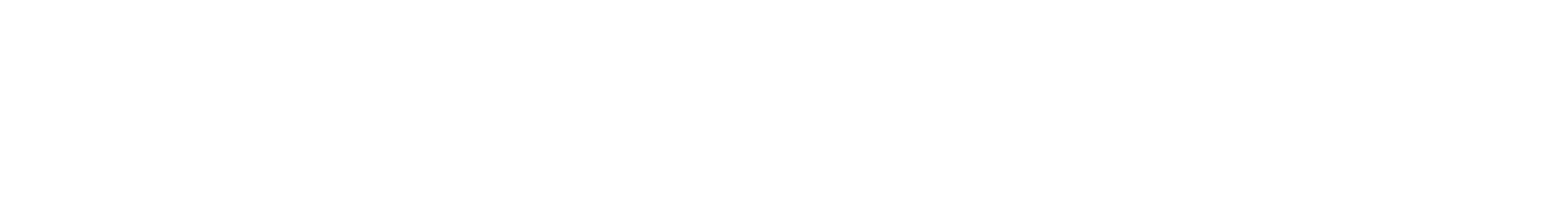
COLORADO RIVER BASIN BETWEEN THE GUNNISON AND GREEN RIVERS-Continued 1800. Dolores River near Cisco, Utah

\begin{tabular}{|c|c|c|c|c|c|c|c|c|c|c|c|c|c|c|c|c|}
\hline 14,000 & 46 & 3. 9 & & 1.6 & 110 & 30 & 25 & 0.03 & 197 & 0.27 & 7,450 & 131 & 41 & 14 & 338 & 0.4 \\
\hline 12,700 . & 46 & $\begin{array}{l}.38 \\
4.0\end{array}$ & $11^{.44}$ & $\begin{array}{l}.04 \\
1.6\end{array}$ & 112 & $31^{.62}$ & $27^{\circ}$ & .03 & 198 & .27 & 6,790 & 132 & 40 & 15 & 339 & .4 \\
\hline 11,500 & 47.00 & 4.2 & $11^{.40}$ & $\begin{array}{l}.04 \\
1.6 \\
04\end{array}$ & 113 & $33^{.04}$ & $28^{\circ}$ & .03 & 198 & .27 & 6,150 & 135 & 42 & 15 & 339 & 4 \\
\hline 9,100 & & 4.80 & $13^{.40}$ & i. 8 & 114 & 36 & $30_{85}^{\circ}$ & .04 & 199 & .27 & 4,890 & 137 & 44 & 17 & 340 & .5 \\
\hline 6,500 & $\begin{array}{c}8.30 \\
48\end{array}$ & $\begin{array}{l}.89 \\
5.6\end{array}$ & $16^{\circ}$ & 2.1 & 116 & $40^{.70}$ & & .04 & 200 & .27 & 3,510 & 143 & 48 & 19 & 345 & .6 \\
\hline 5,000 & 51.40 & 6.7 & $21^{\circ}$ & $\begin{array}{l}.04 \\
.06\end{array}$ & 116 & $48^{\circ} .00$ & $40^{\circ}$ & .04 & 208 & .28 & 2,810 & 154 & 60 & 22 & 357 & .7 \\
\hline 3,770 & 53 & 7.8 & $25^{\circ 81}$ & 2.7 & 117 & 56 & 47 & .04 & 220 & .30 & 2,240 & 164 & 68 & 25 & 380 & .9 \\
\hline 2,550 & $55^{2.04}$ & 9.54 & 34 & 3. 3 & 118 & 68 & 61 & .04 & 255 & .35 & 1,760 & 176 & 79 & 29 & 430 & $1 . \overline{1}$ \\
\hline 1,250 & 60 & $14^{.60}$ & 63 & 4.8 & 125 & 102 & 100 & .04 & 406 & .55 & 1,370 & 207 & 104 & 39 & $680^{-}$ & $1 . \overline{9}$ \\
\hline 565 & 70 & 23 & 128 & 7.8 & 138 & 176 & 183 & .05 & 740 & 1.01 & 1,130 & 269 & 156 & $\overrightarrow{50}$ & 1,200 & 3.4 \\
\hline 355 & $\begin{array}{l}79.49 \\
9.94\end{array}$ & 30 & 203 & $10^{.20}$ & $\begin{array}{c}7.20 \\
150\end{array}$ & 253 & 274 & .07 & 1,090 & 1.48 & 1,040 & 320 & 198 & 57 & 1,780 & 4.9 \\
\hline $265^{2}$ & 88 & 35 & ${ }_{11.70}^{269}$ & & 156 & $\begin{array}{l}313 \\
6.51\end{array}$ & $\begin{array}{l}363 \\
10.24\end{array}$ & .08 & 1,450 & 1.97 & 1,040 & 364 & 236 & 61 & 2,330 & 6.1 \\
\hline 210. & 99 & 41 & 334 & & 157 & 366 & 466 & .10 & 1,800 & 2.45 & 1,020 & 416 & 287 & 62 & 2,920 & 7.1 \\
\hline 177. & 111 & 4786 & 397 & $19^{\circ}$ & 155 & 401 & 576 & .11 & 2,110 & 2.87 & 1,010 & 470 & 343 & $64^{-}$ & 3,500 & 8.0 \\
\hline 142. & 128 & 54 & 492 & $23^{\circ}$ & $154^{2.4}$ & 462 & 732 & .14 & 2,580 & 3.51 & 989 & 542 & 415 & 65 & 4,320 & $\ddot{9.2}$ \\
\hline $96^{3}$ & 160 & $\begin{array}{c}4.44 \\
69\end{array}$ & 679 & $34_{87}^{.00}$ & 154 & 592 & 1,050 & .16 & 3,490 & 4.75 & 905 & 682 & 556 & 67 & 5,600 & 11 \\
\hline & $\begin{array}{l}218 \\
10.88\end{array}$ & 96 & 971 & 49 & $\begin{array}{l}153 \\
8.51\end{array}$ & 821.08 & 1,520 & .22 & 4,700 & 6.39 & 723 & 938 & 813 & 68 & 7,500 & 14 \\
\hline 32 & 292 & 128 & 1,300 & 67.78 & 157 & 1,210 & 2,040 & .28 & 5,900 & 8.02 & 510 & 1,250 & 1,130 & 68 & 9,100 & 16 \\
\hline 20. & $\begin{array}{c}375 \\
18.71\end{array}$ & $\begin{array}{c}164 \\
18.48\end{array}$ & $\begin{array}{c}1,560 \\
67.86\end{array}$ & $\begin{array}{c}80 \\
2.05\end{array}$ & $\begin{array}{r}157 \\
2.67\end{array}$ & $\begin{array}{c}1,660 \\
34.68\end{array}$ & 2,300 & .32 & 6,200 & 8.43 & 335 & 1,610 & 1,480 & 66 & 9,500 & 17 \\
\hline 940. & 61 3.04 & 14 & $\begin{array}{l}80 \\
3.48\end{array}$ & $\begin{array}{c}5.2 \\
.18\end{array}$ & $\begin{array}{r}124 \\
\quad 2.08\end{array}$ & $\begin{array}{l}109 \\
8.27\end{array}$ & $\begin{array}{l}124 \\
3.60\end{array}$ & .05 & 496 & .67 & 1,260 & 210 & 108 & 45 & 830 & 2.4 \\
\hline \multicolumn{17}{|c|}{ 1805. Colorado River near Cisco, Utah } \\
\hline & \multirow{19}{*}{$\begin{array}{c}39 \\
1.95 \\
39 \\
1.95 \\
40 \\
2.00 \\
41 \\
2.05 \\
43 \\
2.15 \\
45 \\
2.25 \\
47 \\
2.35 \\
51 \\
2.54 \\
60 \\
2.89 \\
70 \\
3.49 \\
84 \\
4.19 \\
97 \\
4.84 \\
102 \\
5.09 \\
109 \\
5.44 \\
125 \\
6.24 \\
142 \\
7.09 \\
180 \\
8.98 \\
220 \\
10.98 \\
235 \\
11.78 \\
\end{array}$} & \multirow{19}{*}{$\begin{array}{c}6.8 \\
.56 \\
6.9 \\
.57 \\
7.1 \\
.58 \\
7.5 \\
.68 \\
8.5 \\
.70 \\
9.3 \\
.76 \\
11.90 \\
13.90 \\
1.07 \\
17 \\
1.40 \\
25 \\
2.06 \\
33 \\
8.71 \\
37 \\
3.04 \\
40 \\
8.29 \\
46 \\
8.78 \\
50 \\
4.11 \\
60 \\
4.98 \\
78 \\
6.41 \\
85 \\
6.99 \\
90 \\
7.40 \\
\end{array}$} & \multirow{19}{*}{ 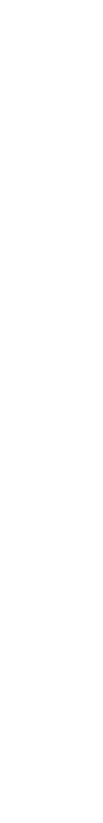 } & \multirow{19}{*}{$\begin{array}{l}2.2 \\
.06 \\
2.2 \\
.06 \\
2.2 \\
.06 \\
2.2 \\
.06 \\
2.2 \\
.06 \\
2.2 \\
.06 \\
2.3 \\
.06 \\
2.5 \\
.06 \\
2.7 \\
.07 \\
3.6 \\
.09 \\
4.3 \\
.11 \\
4.9 \\
.18 \\
5.1 \\
.13 \\
5.6 \\
.14 \\
5.9 \\
.15 \\
6.7 \\
.17 \\
8.5 \\
10.22 \\
10.26 \\
12.06 \\
.81\end{array}$} & \multirow{19}{*}{$\begin{array}{c}120 \\
1.97 \\
121 \\
1.98 \\
122 \\
2.00 \\
125 \\
2.05 \\
128 \\
2.10 \\
134 \\
2.20 \\
139 \\
2.28 \\
146 \\
2.39 \\
160 \\
2.69 \\
178 \\
2.98 \\
194 \\
8.18 \\
202 \\
8.81 \\
211 \\
3.46 \\
219 \\
3.59 \\
230 \\
8.77 \\
230 \\
8.77 \\
230 \\
3.77 \\
230 \\
3.77 \\
230 \\
8.77 \\
.79\end{array}$} & \multirow{19}{*}{$\begin{array}{c}53 \\
1.10 \\
55 \\
1.14 \\
57 \\
1.19 \\
63 \\
1.81 \\
73 \\
1.52 \\
85 \\
1.77 \\
97 \\
2.02 \\
121 \\
2.52 \\
176 \\
3.66 \\
281 \\
5.84 \\
389 \\
8.09 \\
460 \\
9.57 \\
506 \\
10.62 \\
575 \\
11.96 \\
650 \\
13.52 \\
770 \\
16.02 \\
975 \\
20.28 \\
1,080 \\
22.46 \\
1,150 \\
23.92\end{array}$} & \multirow{7}{*}{$\begin{array}{l}2.4 \\
.07 \\
2.5 \\
.07 \\
2.5 \\
.07 \\
2.6 \\
.07 \\
3.0 \\
.08 \\
3.2 \\
.09 \\
3.6\end{array}$} & 0.04 & 238 & & 40,010 & 126 & 27 & 18 & 378 & 0.5 \\
\hline 59,540 & & & & & & & & .04 & 239 & .33 & 38,420 & 126 & 27 & 19 & 380 &.$\overline{5}$ \\
\hline 55,7 & & & & & & & & .04 & $240^{-1}$ & .33 & 36,100 & 129 & 29 & 20 & 380 &.$\overline{6}$ \\
\hline 47,950 & & & & & & & & .04 & $24 \overline{1}$ & .33 & 31,200 & 134 & 31 & 20 & 380 & .6 \\
\hline 38,0 & & & & & & & & .05 & 248 & .34 & 25,510 & 142 & 38 & 21 & 390 & .7 \\
\hline 30,9 & & & & & & & & .05 & 258 & .35 & 21,570 & 150 & 40 & 24 & 403 &.$\overline{8}$ \\
\hline 25,25 & & & & & & & & .05 & 273 & .37 & 18,610 & 162 & 48 & 25 & 435 &.$\overline{9}$ \\
\hline 18 & & & & & & & 4.5 & .05 & 309 & .42 & 15,650 & 180 & $\tilde{\mathbf{6}} \tilde{\mathbf{1}}$ & 27 & $480^{\circ}$ & 1. 0 \\
\hline 11 & & & & & & & 6. 6 & .06 & 415 & .56 & 12,350 & 220 & 88 & 31 & 645 & 1.4 \\
\hline 6,060 . & & & & & & & $11^{.10}$ & .08 & 660 & .90 & 10,800 & 278 & 132 & 38 & 1,010 & 2.1 \\
\hline 4 , & & & & & & & $15^{.01}$ & .09 & 895 & 1.22 & 10,150 & 345 & 186 & $40^{-}$ & 1,300 & 2.5 \\
\hline 3,540 & & & & & & & $17^{.4 z}$ & .10 & 1,030 & 1.40 & 9,840 & 394 & 228 & 40 & 1,480 & 2.7 \\
\hline 3,180 & & & & & & & $19^{.48}$ & .11 & 1,130 & 1.54 & 9,700 & 419 & 246 & 41 & 1,600 & $2 . \overline{9}$ \\
\hline & & & & & & & $21^{.04}$ & .12 & 1,240 & 1.69 & 9,440 & 461 & 282 & 43 & 1,740 & 3.2 \\
\hline 2 & & & & & & & $24^{.09}$ & .14 & $1, \mathbf{3 5 0}$ & 1.84 & 9,190 & 518 & 329 & 42 & 1,850 & $\overline{3.3}$ \\
\hline 2,16 & & & & & & & $29^{.68}$ & .17 & 1,470 & 2.00 & 8,570 & 601 & 412 & $40^{\circ}$ & 2,000 & 3.4 \\
\hline 1, & & & & & & & $35^{.02}$ & .22 & 1,680 & 2.28 & 7,170 & 770 & 581 & 37 & 2,280 & $\overline{3.3}$ \\
\hline 97 & & & & & & & $48^{\circ}$ & .27 & 1,810 & 2.46 & 4,760 & 898 & $710^{-}$ & 34 & 2,400 & 3.1 \\
\hline 746 & & & & & & & $\begin{array}{l}60 \\
1.69\end{array}$ & .28 & 1,850 & 2.52 & 3,730 & 956 & 768 & 33 & 2,450 & $3 . \overline{1}$ \\
\hline 7,63 & $\stackrel{66}{8.29}$ & 21.78 & 62 70 & $\begin{array}{l}3.2 \\
.08\end{array}$ & $\begin{array}{l}162 \\
2.66\end{array}$ & $\stackrel{233}{4.85}$ & $\begin{array}{l}8.8 \\
.25\end{array}$ & .07 & 547 & .74 & 11,280 & 251 & 118 & 35 & 806 & 1.7 \\
\hline
\end{tabular}

112 percentile. ${ }^{2} 50$ percentile. ${ }^{3} 90$ percentile. 
TABLE 20.-Water and dissolved solids contributed by ground water to selected streams in the subbasins in the Grand division [Data are for the water years 1914-57 adjusted to 1957 conditions; weighted-average concentration of dissolved solids of streams from table 14]

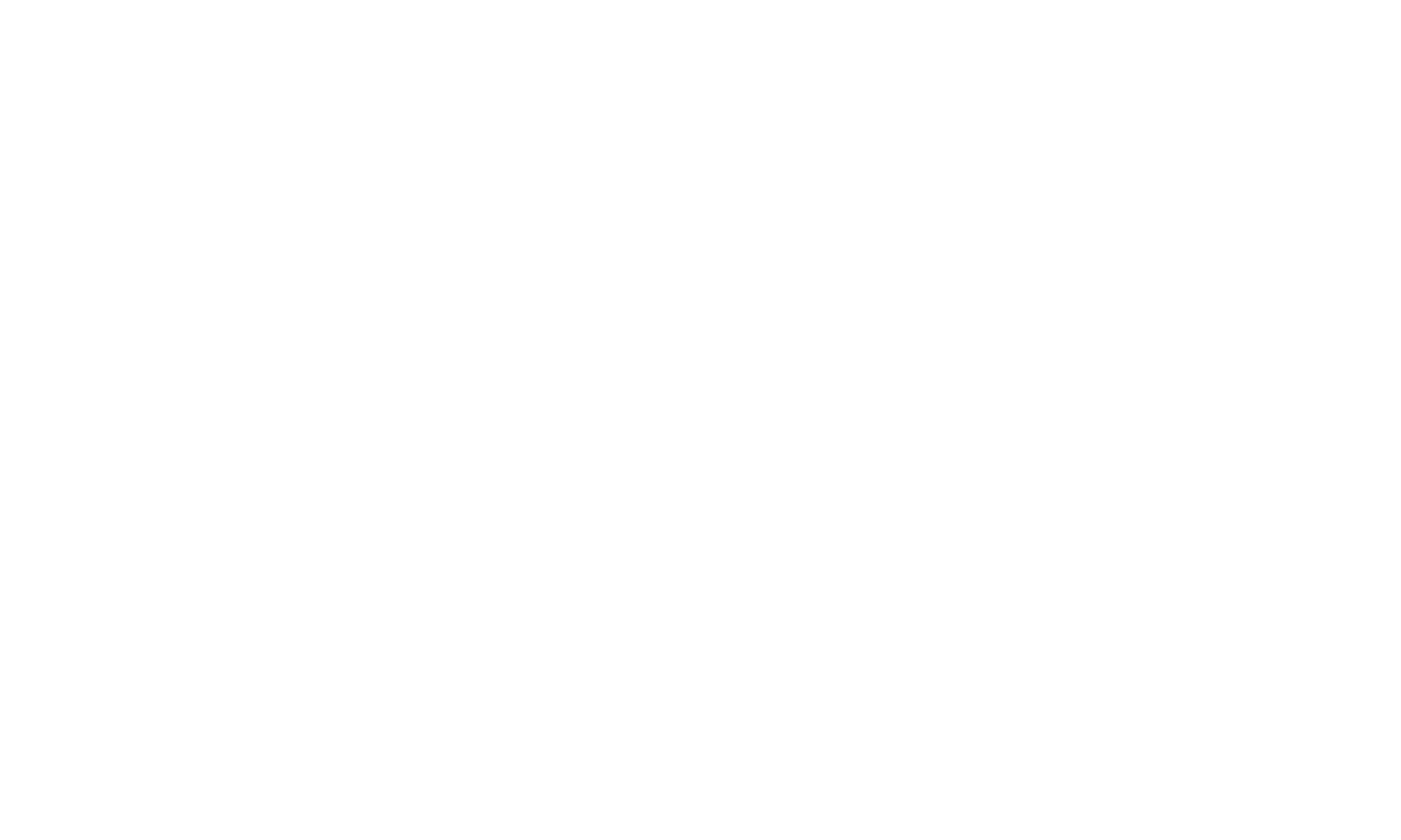

TABLE 21.-Weighted-average concentration of dissolved solids of transmountain diversions in the Colorado River Basin above the Gunnison River

[Data are for the water years 1914-57 adjusted to 1957 conditions; annual diversions based on average annual diversion for water years 1954-57]

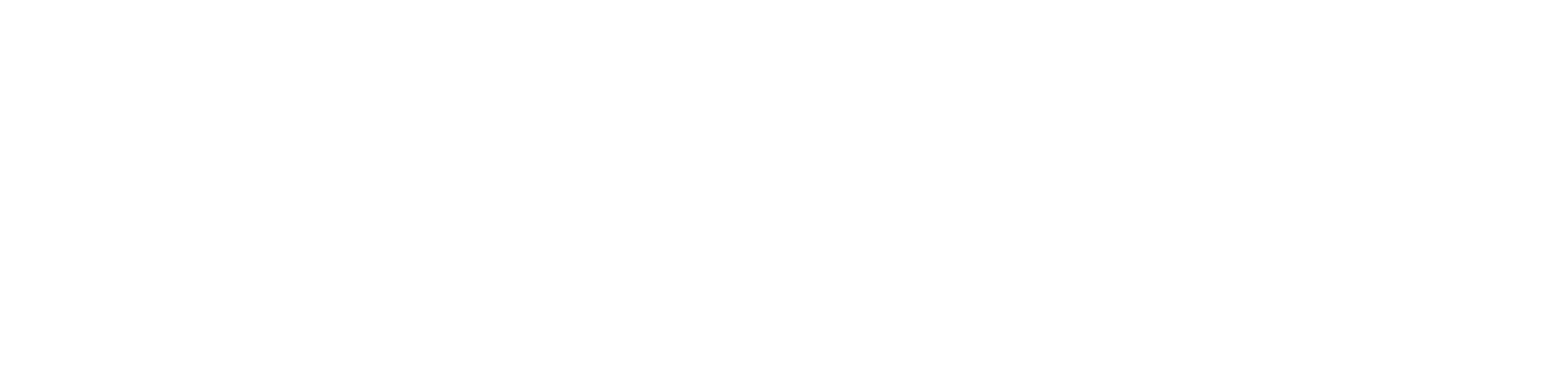


$\mathrm{T}_{\mathrm{ABLE}}$ 22.-Water and dissolved-solids budgets in the Grand division

[Data are for the water years 1914-57 adjusted to 1957 conditions]

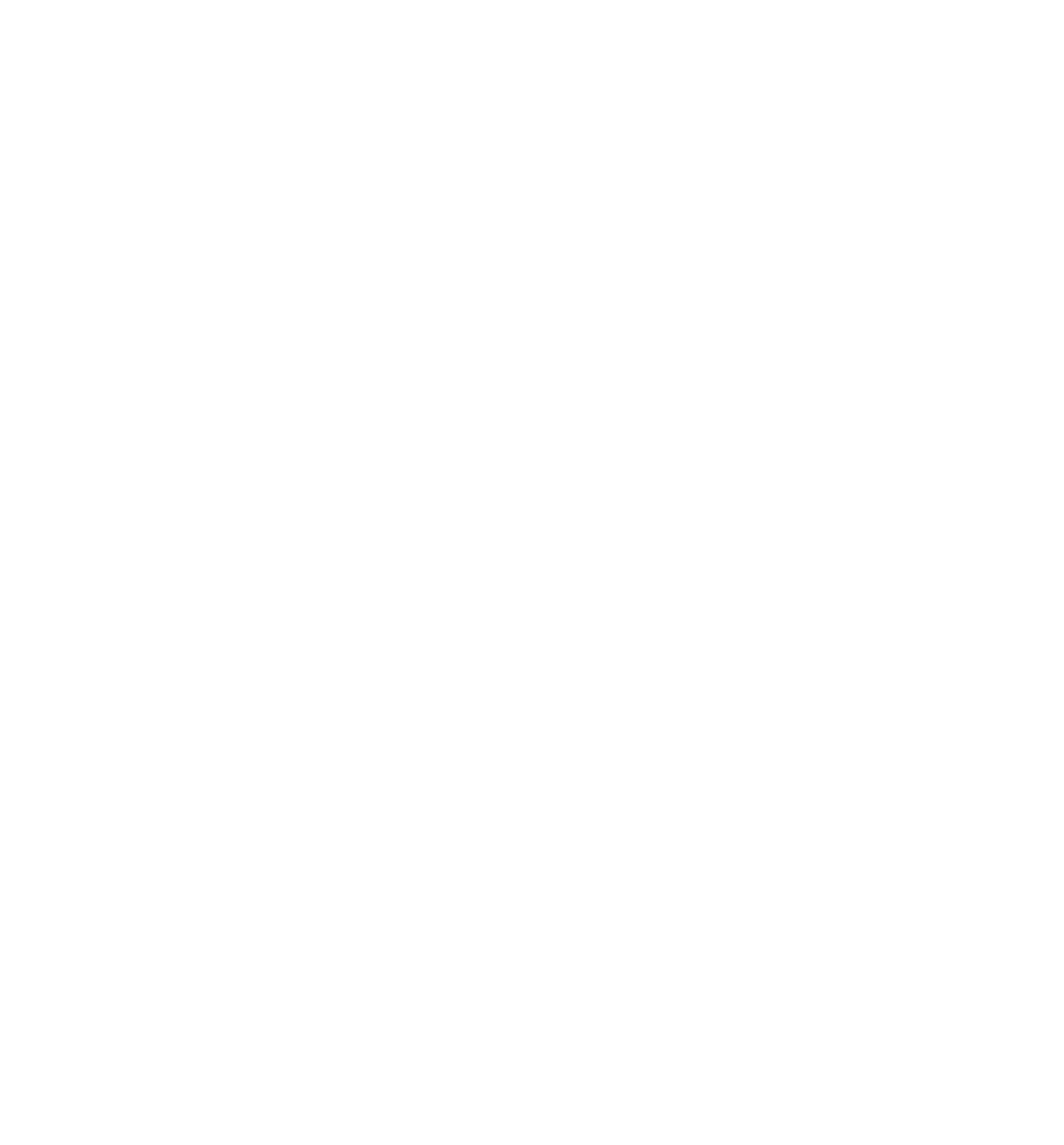


TABLE 22.-Water and dissolved-solids budgets in the Grand division-Continued [Data are for the water years 1914-57 adjusted to 1957 conditions]

\begin{tabular}{|c|c|c|c|}
\hline & \multirow{2}{*}{$\begin{array}{l}\text { A verage annual } \\
\text { discharge } \\
\text { (acre-ft) }\end{array}$} & \multicolumn{2}{|c|}{ Dissolved solids } \\
\hline & & $\begin{array}{l}\text { Weighted-aver- } \\
\text { age concentration } \\
(\mathrm{ppm})\end{array}$ & Tons per year \\
\hline \multicolumn{4}{|c|}{ Lower Gunnison River basin } \\
\hline \multicolumn{4}{|l|}{$\begin{array}{l}\text { Inflow: } \\
\quad \text { Gunnison River above Gunnison tun- }\end{array}$} \\
\hline $\begin{array}{l}\text { Gunnison River above Gunnison tun- } \\
\text { nel... }\end{array}$ & \multirow{3}{*}{$\begin{array}{r}1,281,000 \\
201,400 \\
30,000\end{array}$} & \multirow{2}{*}{$\begin{array}{l}111 \\
376 \\
350\end{array}$} & \multirow{3}{*}{$\begin{array}{r}277,100 \\
103,000 \\
14,300\end{array}$} \\
\hline $\begin{array}{l}\text { Uncompahgre River at Colona, Colo.-- } \\
\text { Roubideau Creek near Delta Colo }\end{array}$ & & & \\
\hline Unmeasured natural ground-water & & & \\
\hline inflow in Uncompahgre River valley & 20,000 & $1,300-2,300$ & $35,400-62,600$ \\
\hline inflow in Uncompahgre River valley. & 50,000 & $200-350$ & $13,600-23,800$ \\
\hline $\begin{array}{l}\text { Measured natural innow to the Gu } \\
\text { son River }\end{array}$ & 483,000 & \multirow{2}{*}{$\begin{array}{r}130-150 \\
130-150 \\
7,800\end{array}$} & $85,400-98,500$ \\
\hline $\begin{array}{l}\text { Unmeasured natural inflow to the } \\
\text { Gunnison River }\end{array}$ & $\begin{array}{r}211,930 \\
70\end{array}$ & & $37,500-43, \begin{array}{r}300 \\
700\end{array}$ \\
\hline Total. & $2,277,400$ & & $567,000-623,300$ \\
\hline \multirow{2}{*}{\multicolumn{4}{|c|}{ Outflow: }} \\
\hline & \multirow{2}{*}{$\begin{array}{r}1393,400 \\
1,884,000\end{array}$} & & \\
\hline $\begin{array}{l}\text { Gunnison River near Grand Junction, } \\
\text { Colo }\end{array}$ & & & $1,519,000$ \\
\hline Total & \multirow[t]{2}{*}{$2,277,400$} & \multirow{2}{*}{ - } & $1,519,000$ \\
\hline Increase from other sources.. & & & $2952,000-895,700$ \\
\hline \multicolumn{4}{|c|}{ San Miguel River basin between Placerville and Naturita, Colo. } \\
\hline \multirow{5}{*}{$\begin{array}{l}\text { Inflow: } \\
\text { San Miguel River near Placerville } \\
\text { Unmeasured surface water } \\
\text { Unmeasured natural ground water. } \\
\text { Total. }\end{array}$} & & \multirow{5}{*}{$\begin{array}{r}157 \\
150-160 \\
400-600\end{array}$} & \\
\hline & 187,600 & & 40,200 \\
\hline & 92,500 & & $16,900-23,700$ \\
\hline & 4,200 & & $2,300-3,400$ \\
\hline & 284,300 & & $59,400-67,300$ \\
\hline \multirow{2}{*}{$\begin{array}{l}\text { Outflow: } \\
\text { Consumed by irrigation } \\
\text { San Miguel River at Naturita. }\end{array}$} & & \multirow{3}{*}{316} & \\
\hline & $\begin{array}{r}30,000 \\
254,300\end{array}$ & & 109,200 \\
\hline Total & \multirow[t]{2}{*}{284,300} & & 109,200 \\
\hline Increase from other sources. & & & $49,800-41,900$ \\
\hline
\end{tabular}

1 Includes channel and other losses as well as irrigation consumptive use. 2 Equivalent to 5.1 tons per acre per year on 176,500 acres of irrigated land. 
TABLE 23.-Water and dissolved-solids budget, Roaring Fork basin, Colorado

[Data are for the water years 1914-57 adjusted to 1957 conditions]

\begin{tabular}{|c|c|c|c|c|}
\hline & \multirow[b]{2}{*}{$\begin{array}{c}\text { Drainage } \\
\text { area } \\
\text { (sq mi) }\end{array}$} & \multirow{2}{*}{$\begin{array}{c}\text { A verage } \\
\text { annual } \\
\text { discharge } \\
\text { (acre-ft) }\end{array}$} & \multicolumn{2}{|c|}{ Dissolved sohds } \\
\hline & & & $\begin{array}{l}\text { Weighted- } \\
\text { average } \\
\text { concentra- } \\
\text { tion (ppm) }\end{array}$ & Tons per year \\
\hline $\begin{array}{l}\text { Inflow: } \\
\text { Roaring Fork near Aspen } \\
\text { Fryingpan Creek at Norrie } \\
\text { Unmeasured surface and ground } \\
\text { water from area underlain by } \\
\text { granitic and Precambrian } \\
\text { rocks } \\
\text { Castle Creek near Aspen } \\
\text { Crystal River near Redstone. } \\
\text { Unmeasured surface water } \\
\text { Unmeasured natural ground water. } \\
\text { Thermal springs below Norrie. }\end{array}$ & $\begin{array}{r}199 \\
62 \\
220 \\
780 \\
---\end{array}$ & $\begin{array}{r}72,450 \\
99,250 \\
\\
171,700 \\
64,330 \\
281,100 \\
285,110 \\
40,000 \\
800\end{array}$ & $\begin{array}{r}26 \\
192 \\
165 \\
160 \\
400-900 \\
2,200\end{array}$ & $\begin{array}{r}6,100 \\
16,800 \\
63,200 \\
62,100 \\
21,800-49,000 \\
2,400\end{array}$ \\
\hline Total_- & 1,460 & $1,014,740$ & & $178,500-205,700$ \\
\hline $\begin{array}{l}\text { Outflow: } \\
\text { Consumed on irrigated land } \\
\text { Roaring Fork at Glenwood } \\
\text { Springs. }\end{array}$ & 1,460 & $\begin{array}{r}34,540 \\
980,200\end{array}$ & 225 & 299,900 \\
\hline Total _... & 1,460 & $1,014,740$ & & 299,900 \\
\hline Increase from other sources_. & 政 & . & & $121,400-94,200$ \\
\hline
\end{tabular}

$\mathrm{T}_{\mathrm{ABLE}} 24 .-$ Average annual dissolved-solids discharge and probable amounts from natural sources and the activities of man in the Colorado River Basin above the Gunnison River, Colo.

[Data are for the water years 1914-57 adjusted to 1957 conditions]

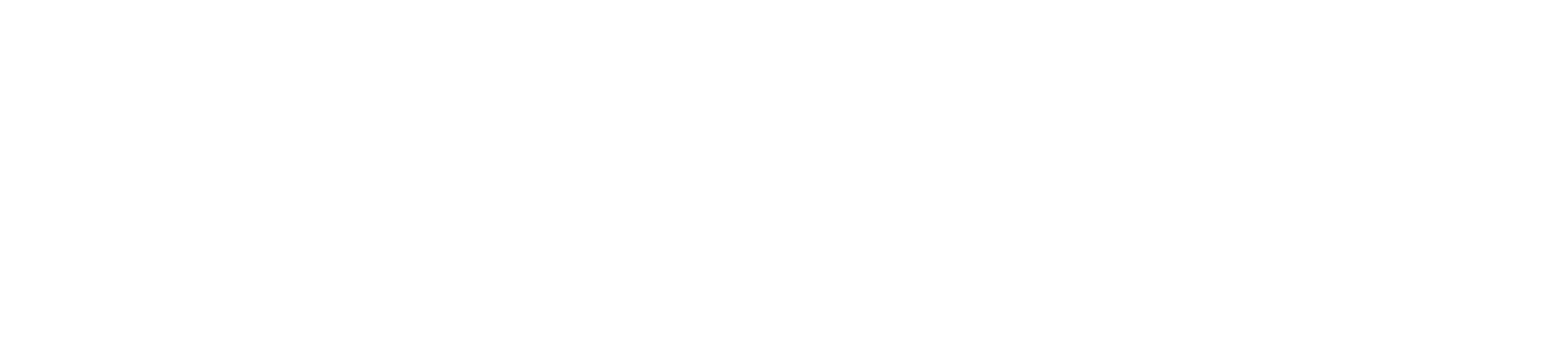

\footnotetext{
1 Exclusive of area above Granby and Willow Creek Reservoirs.
} 
TABLE 25.-Suspended-sediment discharge at selected stations in the subbasins in the Grand division [Data are for the water years 1914-57 adjusted to 1957 conditions, except as indicated. Asterisk indicates that data for subbasins are estimated]

\begin{tabular}{|c|c|c|c|c|c|}
\hline \multirow{2}{*}{$\begin{array}{l}\text { Station } \\
\text { No. }\end{array}$} & \multirow{2}{*}{ Station name } & \multirow{2}{*}{$\begin{array}{l}\text { A verage water } \\
\text { discharge } \\
\text { (cfs) }\end{array}$} & \multicolumn{3}{|c|}{ Suspended sediment } \\
\hline & & & $\begin{array}{l}\text { Weighted-av- } \\
\text { erage concen- } \\
\text { tration (ppm) }\end{array}$ & Tons per year & $\begin{array}{l}\text { Tons per sq } \\
\text { mi per } \mathrm{yr}\end{array}$ \\
\hline
\end{tabular}

Colorado River Basin above the Gunnison River, Colo.*

\begin{tabular}{|c|c|c|c|c|c|}
\hline $\begin{array}{l}725 \\
850 \\
920 \\
955 \\
965\end{array}$ & $\begin{array}{l}\text { Colorado River at Glenwood Springs. } \\
\text { Roaring Fork at Glenwood Springs } \\
\text { Rifle Creek near Rifle } 1 \\
\text { Colorado River near Cameo } \\
\text { Plateau Creek near Collbran }\end{array}$ & $\begin{array}{l}2,399 \\
1,353 \\
24.6 \\
4,138 \\
104\end{array}$ & $\begin{array}{r}200 \\
220 \\
1,800 \\
2,270 \\
180\end{array}$ & $\begin{array}{r}485,800 \\
287,100 \\
43,500 \\
9,248,000 \\
19,000\end{array}$ & $\begin{array}{r}107 \\
197 \\
311 \\
1,150 \\
216\end{array}$ \\
\hline \multicolumn{6}{|c|}{ Guṇñison River basin, Colorado* } \\
\hline
\end{tabular}

Colorado River Basin between the Gunnison and Green Rivers

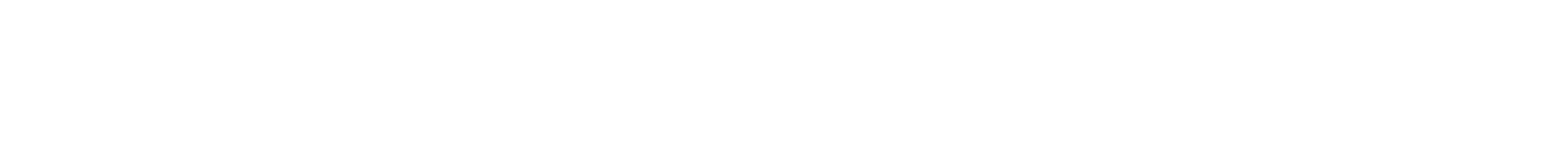

1 For water years 1940-46, 1953-57.

4 For water years $1952-57$.
3 For water years $1930-57$.

8 For water years 1918-57.

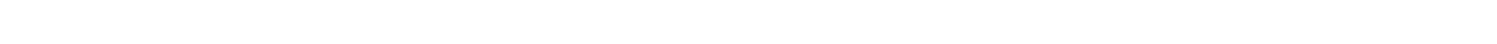

[-indicates that maximum concentration observed in streams is less than the maximum limit accepted for domestic use; + indicates that maximum concentration observed is greater than accepted limit for domestic use]

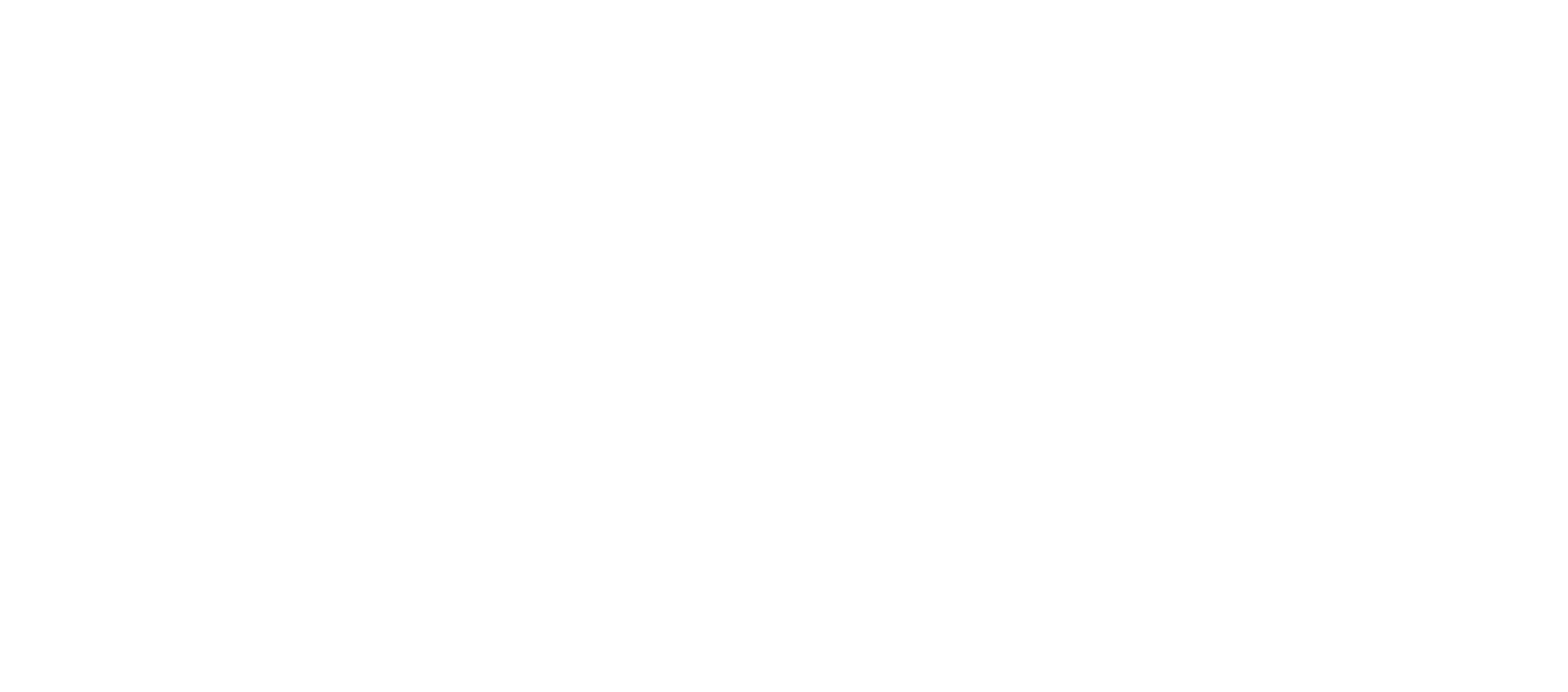


TABLE 27.-Suitability of surface waters for irrigation in the subbasins in the Grand division

[Calcium $a$, to adjust water to 70 percent sodium; calcium $b$, to offset bicarbonate precipitation; calcium $c$, to supply calcium plus magnesium taken by plants in excess of

\begin{tabular}{|c|c|c|c|c|c|c|c|c|c|c|c|c|c|c|}
\hline \multirow{4}{*}{$\begin{array}{l}\text { Station } \\
\text { No. }\end{array}$} & \multirow{4}{*}{ Source } & \multirow{4}{*}{ Date } & \multicolumn{2}{|c|}{ Water discharge } & \multirow{4}{*}{$\begin{array}{c}\text { Specific } \\
\text { conduct- } \\
\text { ance } \\
\text { (micro- } \\
\text { mhos } \\
\text { per cm } \\
\text { at } 25^{\circ} \mathrm{C} \text { ) }\end{array}$} & \multirow{4}{*}{$\begin{array}{l}\text { Per- } \\
\text { cent } \\
\text { so- } \\
\text { dium }\end{array}$} & \multirow{4}{*}{$\begin{array}{c}\text { Sodi- } \\
\text { um- } \\
\text { adsorp- } \\
\text { tion- } \\
\text { ratio }\end{array}$} & \multirow{4}{*}{$\begin{array}{l}\text { Resid- } \\
\text { ual so- } \\
\text { dium } \\
\text { car- } \\
\text { bonate }\end{array}$} & \multicolumn{6}{|c|}{ Classification } \\
\hline & & & \multirow{3}{*}{$\begin{array}{c}\text { Cubic feet } \\
\text { per } \\
\text { second }\end{array}$} & \multirow{3}{*}{$\underset{\text { tion }}{\text { Classifica- }}$} & & & & & & & After 1 & Eaton (1 & 54) 1 & \\
\hline & & & & & & & & & $\begin{array}{l}\text { After U.S. } \\
\text { Salinity } \\
\text { Laboratory }\end{array}$ & $\begin{array}{c}\text { Cal- } \\
\text { cium } a\end{array}$ & cium $b$ & $\begin{array}{c}\text { Cal- } \\
\text { cium } c\end{array}$ & \multirow{2}{*}{$\begin{array}{c}\text { Re- } \\
\text { quired } \\
\text { leach } \\
\text { ing } \\
\text { (per- } \\
\text { cent) }\end{array}$} & \multirow{2}{*}{$\begin{array}{c}\text { Re- } \\
\text { quired } \\
\text { gypsum } \\
\text { (1b per } \\
\text { acre- } \\
\text { ft) }\end{array}$} \\
\hline & & & & & & & & & (1954) & \multicolumn{3}{|c|}{$\begin{array}{c}\text { Milliequivalents per } \\
\text { liter }\end{array}$} & & \\
\hline
\end{tabular}

Colorado River Basin above the Gunnison River, Colo.

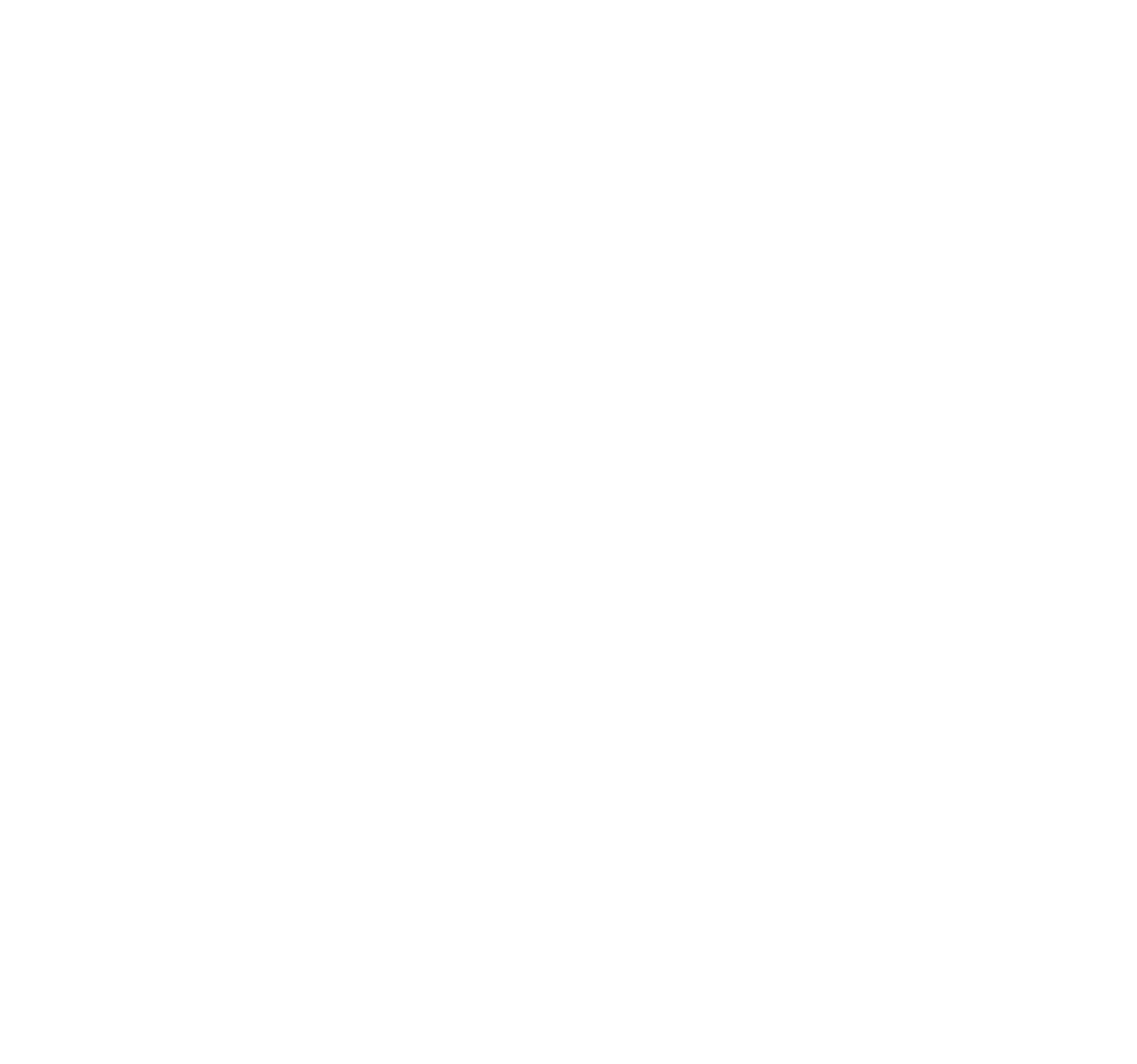


TABLE 27.-Suitability of surface waters for irrigation in the subbasins in the Grand division-Continued

\begin{tabular}{|c|c|c|c|c|c|c|c|c|c|c|c|c|c|c|}
\hline \multirow{4}{*}{$\begin{array}{l}\text { Station } \\
\text { No. }\end{array}$} & \multirow{4}{*}{ Source } & \multirow{4}{*}{ Date } & \multicolumn{2}{|c|}{ Water discharge } & \multirow{4}{*}{$\begin{array}{l}\text { Specific } \\
\text { conduct- } \\
\text { ance } \\
\text { (micro- } \\
\text { mhos } \\
\text { per cm } \\
\text { at } 25^{\circ} \mathrm{C} \text { ) }\end{array}$} & \multirow{4}{*}{$\begin{array}{l}\text { Per- } \\
\text { cent } \\
\text { so- } \\
\text { dium }\end{array}$} & \multirow{4}{*}{$\begin{array}{c}\text { Sodi- } \\
\text { um- } \\
\text { adsorp- } \\
\text { tion- } \\
\text { ratio }\end{array}$} & \multirow{4}{*}{$\begin{array}{c}\text { Resid- } \\
\text { ual so- } \\
\text { dium } \\
\text { car- } \\
\text { bonate }\end{array}$} & \multicolumn{6}{|c|}{ Classification } \\
\hline & & & \multirow{3}{*}{$\begin{array}{l}\text { Cubic feet } \\
\text { per } \\
\text { second }\end{array}$} & \multirow{3}{*}{$\begin{array}{c}\text { Classifica- } \\
\text { tion }\end{array}$} & & & & & \multirow{3}{*}{$\begin{array}{l}\text { After U.S. } \\
\text { Salinity } \\
\text { Laboratory } \\
\text { Staff } \\
\text { (1954) }\end{array}$} & \multicolumn{5}{|c|}{ After Eaton (1954) ${ }^{1}$} \\
\hline & & & & & & & & & & $\begin{array}{l}\text { Cal- } \\
\text { cium } a\end{array}$ & Cal- & $\begin{array}{l}\text { Cal- } \\
\text { cium } c\end{array}$ & \multirow{2}{*}{$\begin{array}{l}\text { Re- } \\
\text { quired } \\
\text { leach- } \\
\text { ing } \\
\text { (per- } \\
\text { cent) }\end{array}$} & \multirow{2}{*}{$\begin{array}{c}\text { Re- } \\
\text { quired } \\
\text { gypsum } \\
\text { (1b per } \\
\text { acre- } \\
\text { ft) }\end{array}$} \\
\hline & & & & & & & & & & \multicolumn{3}{|c|}{$\begin{array}{l}\text { Milliequivalents per } \\
\text { liter }\end{array}$} & & \\
\hline
\end{tabular}

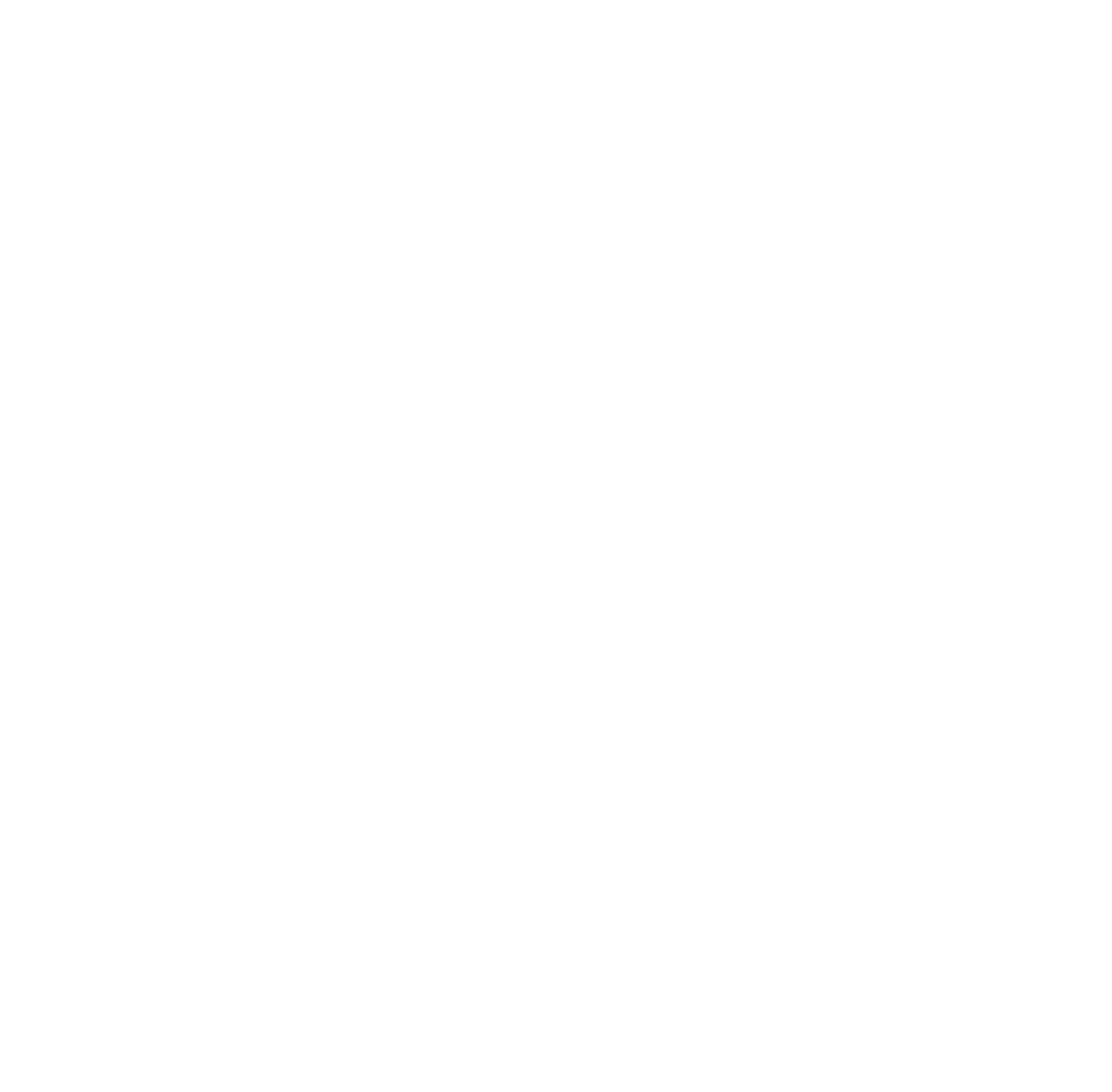

See footnotes at end of table. 
TABLE 27.-Suitability of surface waters for irrigation in the subbasins in the Grand division-Continued

\begin{tabular}{|c|c|c|c|c|c|c|c|c|c|c|c|c|c|c|}
\hline \multirow{3}{*}{$\begin{array}{l}\text { Station } \\
\text { No. }\end{array}$} & \multirow{3}{*}{ Source } & \multirow{3}{*}{ Date } & \multicolumn{2}{|c|}{ Water discharge } & \multirow{3}{*}{$\begin{array}{l}\text { Specific } \\
\text { conduct- } \\
\text { ance } \\
\text { (micro- } \\
\text { mhos } \\
\text { per cm } \\
\text { at } 25^{\circ} \mathrm{C} \text { ) }\end{array}$} & \multirow{3}{*}{$\begin{array}{l}\text { Per- } \\
\text { cent } \\
\text { so- } \\
\text { dium }\end{array}$} & \multirow{3}{*}{$\begin{array}{c}\text { Sodi- } \\
\text { um- } \\
\text { adsorp- } \\
\text { tion- } \\
\text { ratio }\end{array}$} & \multirow{3}{*}{$\begin{array}{c}\text { Resid- } \\
\text { ual so- } \\
\text { dium } \\
\text { car- } \\
\text { bonate }\end{array}$} & \multicolumn{6}{|c|}{ Classification } \\
\hline & & & \multirow[t]{2}{*}{$\begin{array}{c}\text { Cubic feet } \\
\text { per } \\
\text { second }\end{array}$} & \multirow[t]{2}{*}{$\begin{array}{l}\text { Classifica- } \\
\text { tion }\end{array}$} & & & & & $\begin{array}{l}\text { After U.S. } \\
\text { Salinity } \\
\text { Laboratory } \\
\text { Staff }\end{array}$ & $\begin{array}{c}\text { Cal- } \\
\text { cium } a\end{array}$ & cium $b$ & Cal- & \multirow{2}{*}{$\begin{array}{c}\text { Re- } \\
\text { quired } \\
\text { leach- } \\
\text { ing } \\
\text { (per- } \\
\text { cent) }\end{array}$} & \multirow{2}{*}{$\begin{array}{c}\text { Re- } \\
\text { quired } \\
\text { gypsum } \\
\text { (lb per } \\
\text { acre- } \\
\text { ft) }\end{array}$} \\
\hline & & & & & & & & & & \multicolumn{3}{|c|}{$\begin{array}{l}\text { Milliequivalents per } \\
\text { liter }\end{array}$} & & \\
\hline
\end{tabular}

Colorado River Basin above the Gunnison River, Colo.-Continued

\begin{tabular}{|c|c|c|c|c|c|c|c|c|c|c|c|c|c|c|}
\hline $915 B$ & West Rifle Creek near Rifle...... & $10-23-57$ & 21.2 & Low & 1,600 & 33 & 2.5 & 0.00 & C3-S1. & -10.44 & 4.72 & 0.25 & 18 & 0 \\
\hline \multirow{2}{*}{$915 \mathrm{C}$} & Middle Rifle Creek near Rifie _. & $\begin{array}{l}5-7-58 \\
4-25-41\end{array}$ & $\begin{array}{l}238 \\
23.3\end{array}$ & $\begin{array}{l}\text { High. } \\
\text { Low }\end{array}$ & $\begin{array}{l}598 \\
893\end{array}$ & $\begin{array}{r}15 \\
5\end{array}$ & .6 & .00 & C2-S1 & $\begin{array}{l}-5.13 \\
-8.42\end{array}$ & 3.04 & .29 & $\begin{array}{l}4.4 \\
7.8\end{array}$ & $\begin{array}{l}0 \\
0\end{array}$ \\
\hline & & $5-24-41$ & & High. & 505 & $\mathbf{3}$ & .1 & .00 & 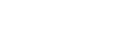 & -4.32 & 2.85 & .29 & 1.8 & 0 \\
\hline \multirow[t]{2}{*}{$915 \mathrm{D}$} & West Rifle Creek below Middle & $\begin{array}{l}6-27-41 \\
3-7-41\end{array}$ & $\begin{array}{c}11 \\
5.4\end{array}$ & Medium. - & $\begin{array}{r}642 \\
1,570\end{array}$ & $\begin{array}{r}4 \\
20\end{array}$ & .2 & $\begin{array}{l}.00 \\
.00\end{array}$ & iC2 & $\begin{array}{r}-6.27 \\
-13.25\end{array}$ & $\begin{array}{l}3.39 \\
3.87\end{array}$ & $\begin{array}{l}.29 \\
.24\end{array}$ & $2_{21}^{4.2}$ & $\begin{array}{l}0 \\
0\end{array}$ \\
\hline & Rifle Creek, near Rifie. ${ }^{3}$ & $5-24-41$ & 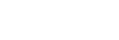 & High. & 847 & 10 & .4 & .00 & C3-S1. & -5.93 & 3.55 & .29 & 4.0 & 0 \\
\hline 920 & Riffe Creek near Rifle & $\begin{array}{r}12-19-40 \\
5-24-41\end{array}$ & $\begin{array}{r}52 \\
214.4\end{array}$ & $\begin{array}{l}\text { Medium - } \\
\text { Low } \\
\text { High }\end{array}$ & $\begin{array}{r}861 \\
1,460 \\
663\end{array}$ & $\begin{array}{r}15 \\
15 \\
8\end{array}$ & $\begin{array}{r}.7 \\
1.0 \\
.3\end{array}$ & $\begin{array}{l}.00 \\
.00 \\
.00\end{array}$ & C2- & $\begin{array}{r}-7.73 \\
-14.75 \\
-5.68\end{array}$ & $\begin{array}{l}3.47 \\
3.89 \\
3.51\end{array}$ & $\begin{array}{l}.27 \\
.23 \\
.29\end{array}$ & $\begin{array}{r}8.3 \\
22 \\
3.6\end{array}$ & $\begin{array}{l}0 \\
0 \\
0\end{array}$ \\
\hline $920 \mathrm{~A}$ & Rifle Creek at Rifle & $\begin{array}{l}9-20-41 \\
4-11-49\end{array}$ & $\begin{array}{l}222 \\
310\end{array}$ & Medium .. & $\begin{array}{r}979 \\
1,630\end{array}$ & $\begin{array}{l}11 \\
29\end{array}$ & 2.6 & .00 & C3-S1_. & $\begin{array}{r}-9.21 \\
-11.25\end{array}$ & $\begin{array}{l}3.78 \\
4.26\end{array}$ & .27 & 22.6 & $\begin{array}{l}0 \\
0\end{array}$ \\
\hline 926 & $\begin{array}{l}\text { Battlement Creek near Grand } \\
\text { Valley. }\end{array}$ & $\begin{array}{r}10-24-55 \\
5-7-58\end{array}$ & $\begin{aligned} 3 & \\
32 & \end{aligned}$ & High.. & $\begin{array}{r}2.230 \\
232\end{array}$ & 40 & 3.8 & $\begin{array}{l}.00 \\
.15\end{array}$ & C1-S1_ & $\begin{array}{r}-11.21 \\
-1.90\end{array}$ & $\begin{array}{l}3.72 \\
2.20\end{array}$ & .18 & $\begin{array}{l}39 \\
1.1\end{array}$ & $\begin{array}{r}0 \\
140\end{array}$ \\
\hline $926 \mathrm{~A}$ & $\begin{array}{l}\text { Battlement Creek at mouth, } \\
\text { near Grand Valley. }\end{array}$ & $10-22-57$ & .6 & Low_ & 818 & 42 & 2.3 & .47 & & -3.53 & 5.33 & .29 & 7.5 & 489 \\
\hline 935 & $\begin{array}{l}\text { Parachute Creek at Grand } \\
\text { Valley. }\end{array}$ & $\begin{array}{r}10-22-57 \\
5-5-58 \\
8-1-58\end{array}$ & $\begin{aligned} 22 \\
327 \\
2.9\end{aligned}$ & $\begin{array}{l}\text { Medium. } \\
\text { High....- } \\
\text { Low }\end{array}$ & $\begin{array}{r}1, \mathbf{1 8 0} \\
\mathbf{5 7 7} \\
1, \mathbf{7 3 0}\end{array}$ & $\begin{array}{l}39 \\
29 \\
44\end{array}$ & $\begin{array}{l}2.5 \\
1.3 \\
3.8\end{array}$ & $\begin{array}{l}.00 \\
.08 \\
.00\end{array}$ & $\mathrm{C}$ & $\begin{array}{l}-5.88 \\
-3.98 \\
-8.03\end{array}$ & $\begin{array}{l}5.79 \\
4.78 \\
6.50\end{array}$ & $\begin{array}{l}.27 \\
.29 \\
.24\end{array}$ & $\begin{array}{r}8.8 \\
3.9 \\
21\end{array}$ & $\begin{array}{r}42 \\
255 \\
0\end{array}$ \\
\hline 935A & Colorado River at De Beque .. & 4-11-49 & & & & 43 & 2.4 & .00 & & -3.39 & 2.32 & .26 & 14 & 0 \\
\hline $950 \mathrm{~A}$ & Roan Creek at De Beque........ & $\begin{array}{r}10-21-57 \\
5-5-58 \\
8-1-58\end{array}$ & $\begin{array}{c}50 \\
288 \\
5.8\end{array}$ & $\begin{array}{l}\text { Medium. } \\
\text { High. } \\
\text { Low }\end{array}$ & $\begin{array}{r}1,610 \\
767 \\
2,800\end{array}$ & $\begin{array}{l}48 \\
34 \\
51\end{array}$ & $\begin{array}{l}4.1 \\
1.7 \\
6.2\end{array}$ & $\begin{array}{l}.00 \\
.00 \\
.00\end{array}$ & C3-s1 & $\begin{array}{l}-6.02 \\
-4.46 \\
-9.68\end{array}$ & $\begin{array}{l}4.86 \\
4.87 \\
3.84\end{array}$ & $\begin{array}{l}.26 \\
.29 \\
.14\end{array}$ & 5.6 & $\begin{array}{r}0 \\
164 \\
0\end{array}$ \\
\hline 955 & Colorado River near Cameo ... & $\begin{array}{rr}10- & -55 \\
6- & -56 \\
7 & -56\end{array}$ & $\begin{array}{r}21,476 \\
210,700 \\
22,810\end{array}$ & Low - - & $\begin{array}{r}1,260 \\
377\end{array}$ & 51 & $\begin{array}{l}3.7 \\
1.1\end{array}$ & $\begin{array}{l}.00 \\
.00\end{array}$ & C3-S1-. & $\begin{array}{l}-3.28 \\
-1.98\end{array}$ & $\begin{array}{l}2.24 \\
1.54\end{array}$ & .23 & $\stackrel{23}{4.1}$ & $\begin{array}{l}0 \\
0 \\
0\end{array}$ \\
\hline 965 & Plateau Creek near Collbran & $5-27-58$ & 845 & Medium . . & $\begin{array}{r}865 \\
87 \\
100\end{array}$ & 44 & 2.4 & .00 & $\left\{\begin{array}{l}\text { C3-S1. } \\
\text { C1-S1. }\end{array}\right.$ & $\begin{array}{r}-3.12 \\
-.79\end{array}$ & $\begin{array}{r}2.11 \\
.79\end{array}$ & $\begin{array}{r}.26 \\
.30 \\
30\end{array}$ & $\begin{array}{r}13.4 \\
.4\end{array}$ & $\begin{array}{r}0 \\
70 \\
17\end{array}$ \\
\hline \multirow[t]{2}{*}{975} & Buzzard Creek near Collbran..- & $\begin{array}{r}0-8-58 \\
10-23-57 \\
5-27-58\end{array}$ & $\begin{array}{c}12.4 \\
350\end{array}$ & $\begin{array}{l}\text { Medium. } \\
\text { High. }\end{array}$ & $\begin{array}{l}188 \\
442 \\
214\end{array}$ & 20 & .7 & $\begin{array}{l}.09 \\
.34 \\
.00\end{array}$ & $\begin{array}{l}\text { C2-S1.- } \\
\text { C1-S1.. }\end{array}$ & $\begin{array}{l}-1.13 \\
-3.53 \\
-2.16\end{array}$ & $\begin{array}{l}1.33 \\
4.11 \\
2.09\end{array}$ & $\begin{array}{l}.30 \\
.29 \\
.30\end{array}$ & $\begin{array}{r}.8 \\
5.2\end{array}$ & $\begin{array}{r}117 \\
54\end{array}$ \\
\hline & Mesa & $\begin{array}{l}8-6-58 \\
5-27-58\end{array}$ & 1.4 & Low - & $\begin{array}{r}715 \\
84\end{array}$ & 36 & 1.9 & .00 & C2-S1-. & $\begin{array}{r}-4.13 \\
-43\end{array}$ & 6. 14 & .29 & 6.4 & 538 \\
\hline \multirow[t]{2}{*}{$\begin{array}{l}1045 \\
1050\end{array}$} & Plateau Creek near Cameo & $9-17-47$ & 88 & Mediur & 833 & 37 & 2.0 & .38 & Cl-SI.. & $\begin{array}{l}-.45 \\
-4.52\end{array}$ & 6.11 & .30 & $\begin{array}{l}1.1 \\
7.0\end{array}$ & $\begin{array}{l}154 \\
440\end{array}$ \\
\hline & & $\begin{array}{r}11-11-50 \\
5-7-58\end{array}$ & $\begin{array}{r}235 \\
1490\end{array}$ & Low - & 936 & 38 & 2.3 & .35 & C3-S1 & $\begin{array}{l}-4.94 \\
-262\end{array}$ & 6.70 & .28 & 8.2 & $\begin{array}{l}477 \\
133\end{array}$ \\
\hline \multirow{4}{*}{$\begin{array}{l}1050 \mathrm{~A} \\
1060 \\
1065\end{array}$} & Colorado River at Car & $10-24-55$ & $\begin{array}{l}1,480 \\
1,350\end{array}$ & & 1,000 & 50 & 3.2 & .00 & & -3.04 & 4. 27 & $\begin{array}{l}.50 \\
.27\end{array}$ & 14 & 351 \\
\hline & Colorado River near Palisade... & $11-1-42$ & 22,620 & - & $\mathbf{1}, \mathbf{3 7 0}$ & 49 & $3 . \overline{7}$ & .00 & C3-S1 & -4.01 & 2.57 & .23 & 25 & 0 \\
\hline & $\begin{array}{l}\text { Colorado River at Grand Junc- } \\
\text { tion }\end{array}$ & $\begin{array}{r}10-24-57 \\
5-27-58\end{array}$ & 22,700 & High. & $\begin{aligned} 1,090 \\
316\end{aligned}$ & 41 & 2.6 & .00 & & $\begin{array}{l}-4.65 \\
-2.26\end{array}$ & $\begin{array}{l}2.81 \\
1.98\end{array}$ & .25 & $\begin{array}{l}16 \\
2.0\end{array}$ & $\begin{array}{l}0 \\
2\end{array}$ \\
\hline & & $8-18$ & 273 & Low. & 2,080 & 41 & 3.8 & .00 & C3-S1 & -10. & 1.95 & .15 & 49 & 0 \\
\hline
\end{tabular}

Gunnison River basin, Colorado

\begin{tabular}{|c|c|c|c|c|c|c|c|c|c|c|c|c|c|c|}
\hline 1090 & $\begin{array}{l}\text { Taylor River below Taylor } \\
\text { Park Reservoir. }\end{array}$ & $6-18-58$ & 345 & & 77 & 17 & 0.2 & 0.00 & C1-S1_.... & -0.64 & 0.66 & 0.30 & 0.6 & 75 \\
\hline 1125 & East River at Almont & $10-23-57$ & 130 & Medium & 289 & 6 & .2 & .00 & C2-S1 & -2.84 & 2.42 & .30 & .7 & 0 \\
\hline $1125 \mathrm{~A}$ & Gunnison River at Almont. & $\begin{array}{r}5-20-58 \\
10-19-45\end{array}$ & $\begin{array}{l}1,950 \\
3200\end{array}$ & $\begin{array}{l}\text { High } \\
\text { Medium.-.-. }\end{array}$ & $\begin{array}{l}166 \\
263\end{array}$ & 7 & .2 & .00 & $\begin{array}{l}\text { C1-S1- } \\
\text { C2-S1. }\end{array}$ & $\begin{array}{l}-1.56 \\
-2.58\end{array}$ & $\begin{array}{l}1.33 \\
2.29\end{array}$ & $\begin{array}{l}.30 \\
.30\end{array}$ & $\begin{array}{l}.6 \\
1.0\end{array}$ & $\begin{array}{r}16 \\
2\end{array}$ \\
\hline 1145 & Gunnison River near Gunnison & $\begin{array}{r}5-2-46 \\
10-8-45\end{array}$ & $\begin{array}{l}3860 \\
2342\end{array}$ & High & 185 & 5 & .1 & .00 & C1-S1- & -1.78 & 1. 52 & .30 & .8 & $\begin{array}{r}9 \\
26\end{array}$ \\
\hline 1150 & Larkspur ditch at Marshall & $\begin{array}{r}10-8-45 \\
5-7-58 \\
7-1-58\end{array}$ & 2,100 & $\begin{array}{l}\text { Medrum.-- } \\
\text { High...-- }\end{array}$ & $\begin{array}{r}211 \\
166 \\
56\end{array}$ & & & $\begin{array}{l}.00 \\
.08\end{array}$ & $02-101$. & $\begin{array}{r}-1.44 \\
-.44\end{array}$ & $\begin{array}{r}1.33 \\
.56\end{array}$ & $\begin{array}{l}.30 \\
.30 \\
.30\end{array}$ & $\begin{array}{l}.8 \\
.6\end{array}$ & 44 \\
\hline 1155 & Tomichi Creek at Sargents & $5-8-58$ & 266 & High ...... & 105 & & & .00 & C1- & -.81 & .82 & .30 & .7 & $\begin{array}{l}73 \\
68\end{array}$ \\
\hline 1165 & Razor Creek near Doyleville.... & $\begin{array}{r}8-6-58 \\
10-23-57 \\
5-8-58\end{array}$ & $\begin{array}{l}\mathbf{3 6} \\
\mathbf{3 1}\end{array}$ & $\begin{array}{l}\text { Medium - } \\
\text { Medium.. } \\
\text { High }\end{array}$ & $\begin{array}{l}107 \\
364 \\
238\end{array}$ & 13 & .4 & $\begin{array}{l}.00 \\
.00 \\
.00\end{array}$ & $\begin{array}{l}\text { C2-S1.- } \\
\text { C1-S1.. }\end{array}$ & $\begin{array}{l}-1.62 \\
-3.11 \\
-1.98\end{array}$ & $\begin{array}{l}1.61 \\
2.47 \\
1.78\end{array}$ & $\begin{array}{l}.30 \\
.29 \\
.30\end{array}$ & $\begin{array}{l}.7 \\
1.8 \\
1.1\end{array}$ & $\begin{array}{r}08 \\
0 \\
23\end{array}$ \\
\hline $1180 \mathrm{~B}$ & $\begin{array}{l}\text { Cochetopa Creek below West } \\
\text { Pass Creek, near Parlin. }\end{array}$ & $\begin{array}{r}10-23-57 \\
5-8-58\end{array}$ & $\begin{array}{r}18 \\
262\end{array}$ & Medium & 251 & 20 & .5 & $\begin{array}{l}00 \\
.06\end{array}$ & C2-S1-- & $\begin{array}{r}-1.90 \\
-.81\end{array}$ & $\begin{array}{l}2.29 \\
1.02\end{array}$ & .30 & $\begin{array}{l}1.3 \\
1.0\end{array}$ & $\begin{array}{l}161 \\
119\end{array}$ \\
\hline 1190 & Tomichi Creek at Gunnison.. & $\begin{array}{l}9-11-54 \\
5-8-58 \\
8-5-58\end{array}$ & $\begin{array}{r}202 \\
224 \\
799 \\
92\end{array}$ & $\begin{array}{l}\text { Low } \\
\text { High... }\end{array}$ & $\begin{array}{l}121 \\
404 \\
177 \\
341\end{array}$ & & & $\begin{array}{l}.00 \\
.00 \\
00\end{array}$ & $\begin{array}{l}\text { C2-S1 } \\
\text { C1-S1 } \\
\text { C2-S1 }\end{array}$ & $\begin{array}{l}-3.01 \\
-3.77 \\
-1.37 \\
-3.07\end{array}$ & $\begin{array}{l}\text { 1. } 02 \\
1.94 \\
1.40 \\
3.18\end{array}$ & $\begin{array}{l}.00 \\
.30 \\
.30 \\
.30\end{array}$ & $\begin{array}{l}1.6 \\
1.1 \\
1.3\end{array}$ & $\begin{array}{r}110 \\
77 \\
96\end{array}$ \\
\hline 1205 & Gunnison River at Iola... & $9-11-54$ & 3409 & Medium & 234 & & & .00 & & -1.98 & 2.14 & .30 & 1.4 & 108 \\
\hline $\begin{array}{l}1220 \mathrm{~A} \\
1230\end{array}$ & $\begin{array}{l}\text { Cebolla Creek near Iola } \\
\text { Soap (Sapinero) Creek at }\end{array}$ & $\begin{array}{l}3-8-46 \\
3-8-46\end{array}$ & $\begin{array}{l}350 \\
222\end{array}$ & Medium - & $\begin{array}{l}132 \\
261\end{array}$ & $\begin{array}{l}23 \\
31\end{array}$ & .5 & .00 & & $\begin{array}{l}-1.14 \\
-1.52\end{array}$ & $\begin{array}{l}1.25 \\
1.74\end{array}$ & $\begin{array}{l}.30 \\
.29\end{array}$ & $\begin{array}{l}1.3 \\
2.4\end{array}$ & $\begin{array}{r}96 \\
119\end{array}$ \\
\hline 1230 & $\begin{array}{l}\text { Soap (Sapinero) Creek at } \\
\text { Sapinero. }\end{array}$ & $\begin{array}{l}3-8-46 \\
9-11-54 \\
5-14-58\end{array}$ & $\begin{array}{r}222 \\
35 \\
493\end{array}$ & $\begin{array}{l}\text { Medium } \\
\text { Low } \\
\text { High }\end{array}$ & $\begin{array}{r}261 \\
\mathbf{4 7 5} \\
96\end{array}$ & $\begin{array}{l}31 \\
36\end{array}$ & $\begin{array}{r}.9 \\
1.4\end{array}$ & $\begin{array}{l}.00 \\
.05 \\
.00\end{array}$ & 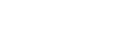 & $\begin{array}{l}-1.52 \\
-2.58 \\
-.82\end{array}$ & $\begin{array}{r}1.74 \\
3.33 \\
.79\end{array}$ & $\begin{array}{l}.29 \\
.29 \\
.30\end{array}$ & $\begin{array}{r}2.4 \\
4.4 \\
.6\end{array}$ & $\begin{array}{r}119 \\
243 \\
63\end{array}$ \\
\hline $1230 \mathrm{~A}$ & Gunnison River at Sapinero... & $5-9-45$ & 32,400 & High & 158 & 4 & 1 & .00 & Cl- & -1.46 & 1.27 & .30 & .5 & 26 \\
\hline 1245 & Lake Fork at Gateview... & $\begin{array}{r}10-17-45 \\
5-21-58\end{array}$ & $\begin{array}{r}3480 \\
1,430\end{array}$ & $\begin{array}{l}\text { Medium. } \\
\text { High...... }\end{array}$ & $\begin{array}{l}260 \\
119\end{array}$ & 11 & .3 & .00 & C2- & $\begin{array}{r}-2.40 \\
-.91\end{array}$ & $\begin{array}{r}2.29 \\
.61\end{array}$ & $\begin{array}{l}30 \\
.30\end{array}$ & $\begin{array}{r}1.2 \\
.8\end{array}$ & $\begin{array}{r}44 \\
0\end{array}$ \\
\hline $\begin{array}{l}1245 \mathrm{~A} \\
1260\end{array}$ & $\begin{array}{l}\text { Lake Fork near Sapinero } \\
\text { Cimarron Creek near Cimarron }\end{array}$ & $\begin{array}{l}8-6-58 \\
3-8-46 \\
5-21-58\end{array}$ & $\begin{array}{r}186 \\
360 \\
585\end{array}$ & Medium & $\begin{array}{r}140 \\
191 \\
80\end{array}$ & 15 & 3 & $\begin{array}{l}.00 \\
.00 \\
\end{array}$ & C1-S & $\begin{array}{l}-1.13 \\
-1.52 \\
-.60\end{array}$ & $\begin{array}{r}.79 \\
1.28\end{array}$ & $\begin{array}{l}.30 \\
.30 \\
30\end{array}$ & $\begin{array}{r}.7 \\
1.1\end{array}$ & $\begin{array}{r}0 \\
14 \\
87\end{array}$ \\
\hline $1260 \mathrm{~B}$ & $\begin{array}{l}\text { Cimarron Creek below Little } \\
\text { Cimarron Creek, near Cimar- }\end{array}$ & $2-19-52$ & $\begin{array}{l}000 \\
323\end{array}$ & Low & 529 & 25 & 1.0 & .00 & $\mathrm{C} 2-\mathrm{S} 1 \ldots$ & $\begin{array}{r}-.60 \\
-3.62\end{array}$ & $\begin{array}{l}.07 \\
1.68\end{array}$ & .28 & 5.1 & 0 \\
\hline 1270 & $\begin{array}{l}\text { Cimarron Creek below Squaw } \\
\text { Creek, at Cimarron. }\end{array}$ & $\begin{array}{r}10-21-57 \\
5-21-58 \\
8-10-58\end{array}$ & $\begin{array}{r}38 \\
1,040 \\
28\end{array}$ & $\begin{array}{l}\text { Medium } \\
\text { High } \\
\text { Low }\end{array}$ & $\begin{array}{r}898 \\
146 \\
1,050\end{array}$ & 25 & 1.3 & $\begin{array}{l}.00 \\
.00 \\
.00\end{array}$ & $\begin{array}{l}\text { C3-S1 } \\
\text { C1-S1-..- } \\
\text { C3-S1 }\end{array}$ & $\begin{array}{l}-6.56 \\
-1.07 \\
-7.90\end{array}$ & $\begin{array}{l}\text { 3. } 03 \\
\text { 1.04 } \\
\text { 3. } 60\end{array}$ & $\begin{array}{l}.27 \\
.30 \\
.26\end{array}$ & $\begin{array}{r}9.8 \\
12.9\end{array}$ & $\begin{array}{r}0 \\
63 \\
0\end{array}$ \\
\hline
\end{tabular}

See footnotes at end of table. 
TABLE 27.-Suitability of surface waters for irrigation in the subbasins in the Grand division-Continued

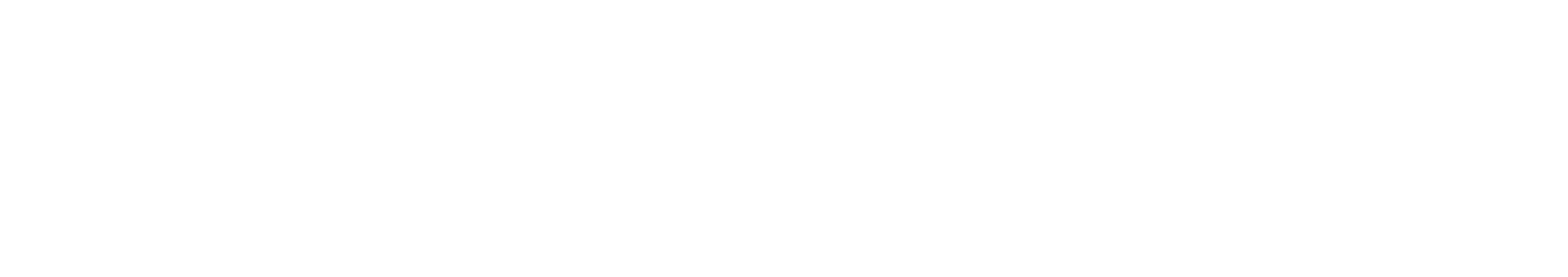

Gunnison River basin, Colorado-Continued

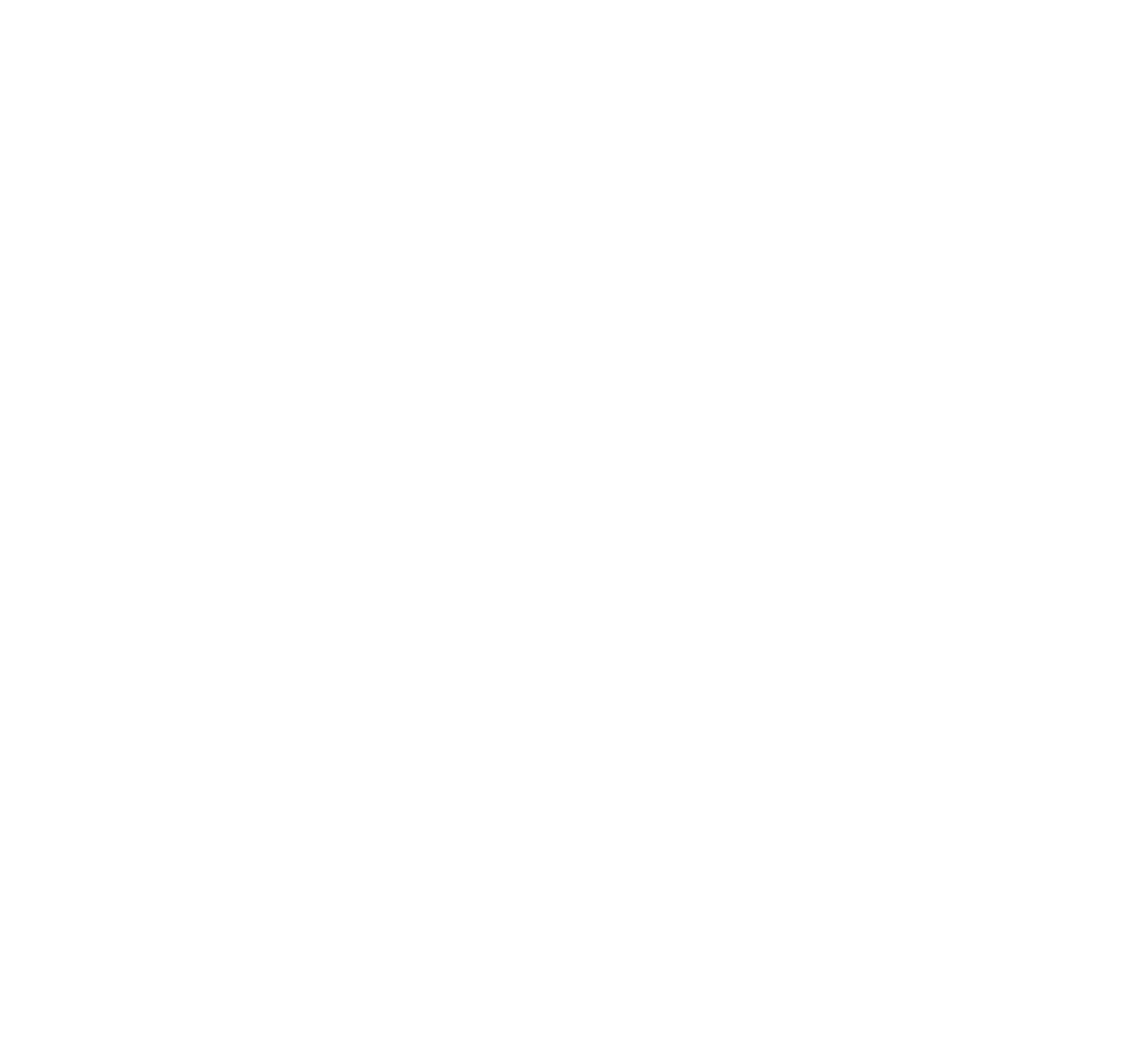

See footnotes at end of table. 
TABLE 27.-Suitability of surface waters for irrigation in the subbasins in the Grand division-Continued

\begin{tabular}{|c|c|c|c|c|c|c|c|c|c|c|c|c|c|c|}
\hline \multirow{3}{*}{$\begin{array}{l}\text { Station } \\
\text { No. }\end{array}$} & \multirow{3}{*}{ Source } & \multirow{3}{*}{ Date } & \multicolumn{2}{|c|}{ Water discharge } & \multirow{3}{*}{$\begin{array}{c}\text { Specific } \\
\text { conduct- } \\
\text { ance } \\
\text { (micro- } \\
\text { mhos } \\
\text { per cm } \\
\text { at } 25^{\circ} \mathrm{C} \text { ) }\end{array}$} & \multirow{3}{*}{$\begin{array}{l}\text { Per- } \\
\text { cent } \\
\text { so- } \\
\text { dium }\end{array}$} & \multirow{3}{*}{$\begin{array}{l}\text { Sodi- } \\
\text { um- } \\
\text { adsorp- } \\
\text { tion- } \\
\text { ratio }\end{array}$} & \multirow{3}{*}{$\begin{array}{l}\text { Resid- } \\
\text { ual so- } \\
\text { dium } \\
\text { car- } \\
\text { bonate }\end{array}$} & \multicolumn{6}{|c|}{ Classification } \\
\hline & & & \multirow[t]{2}{*}{$\begin{array}{c}\text { Cubic feet } \\
\text { per } \\
\text { second }\end{array}$} & \multirow[t]{2}{*}{$\begin{array}{c}\text { Classifica- } \\
\text { tion }\end{array}$} & & & & & $\begin{array}{l}\text { After U.S. } \\
\text { Salinity } \\
\text { Laboratory } \\
\text { Staff }\end{array}$ & $\begin{array}{c}\text { Cal- } \\
\text { cium } a\end{array}$ & Caum $b$ & $\begin{array}{c}\text { Cal- } \\
\text { cium } c\end{array}$ & \multirow{2}{*}{$\begin{array}{c}\text { Re- } \\
\text { quired } \\
\text { leach- } \\
\text { ing } \\
\text { (per- } \\
\text { cent) }\end{array}$} & \multirow{2}{*}{$\begin{array}{c}\text { Re- } \\
\text { quired } \\
\text { gypsum } \\
\text { (1b per } \\
\text { acre- } \\
\text { ft) }\end{array}$} \\
\hline & & & & & & & & & & \multicolumn{3}{|c|}{$\underset{\text { liter }}{\text { Milliequivalents per }}$} & & \\
\hline
\end{tabular}

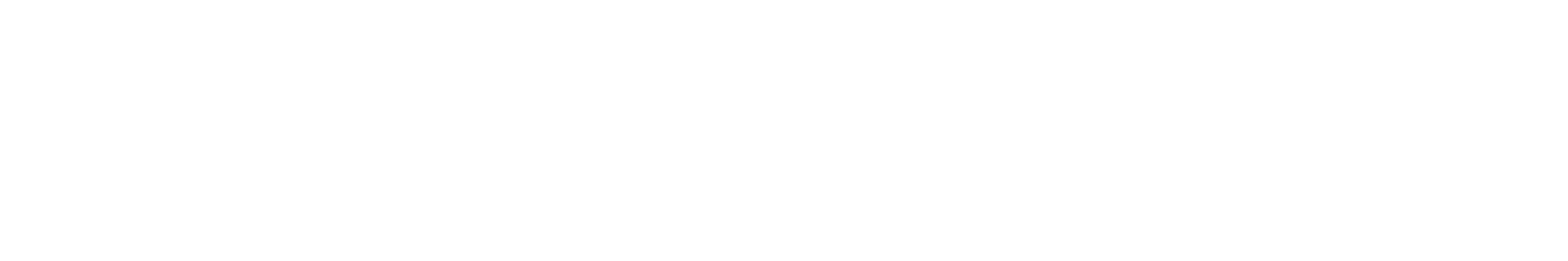

Colorado River Basin between the Gunnison and Green Rivers

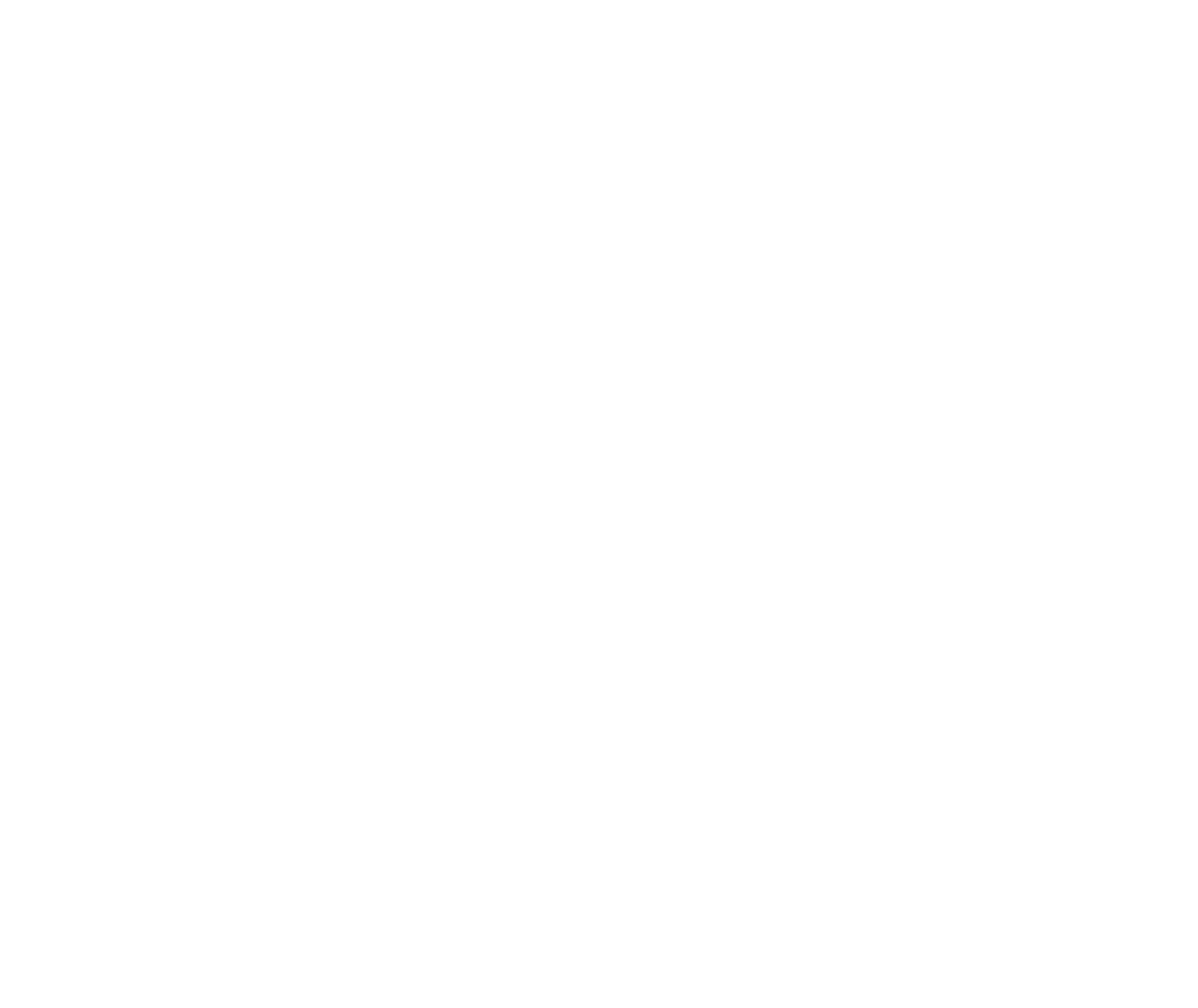

See footnotes at end of table. 
TABLE 27.-Suitability of surface waters for irrigation in the subbasins in the Grand aivision-Continued

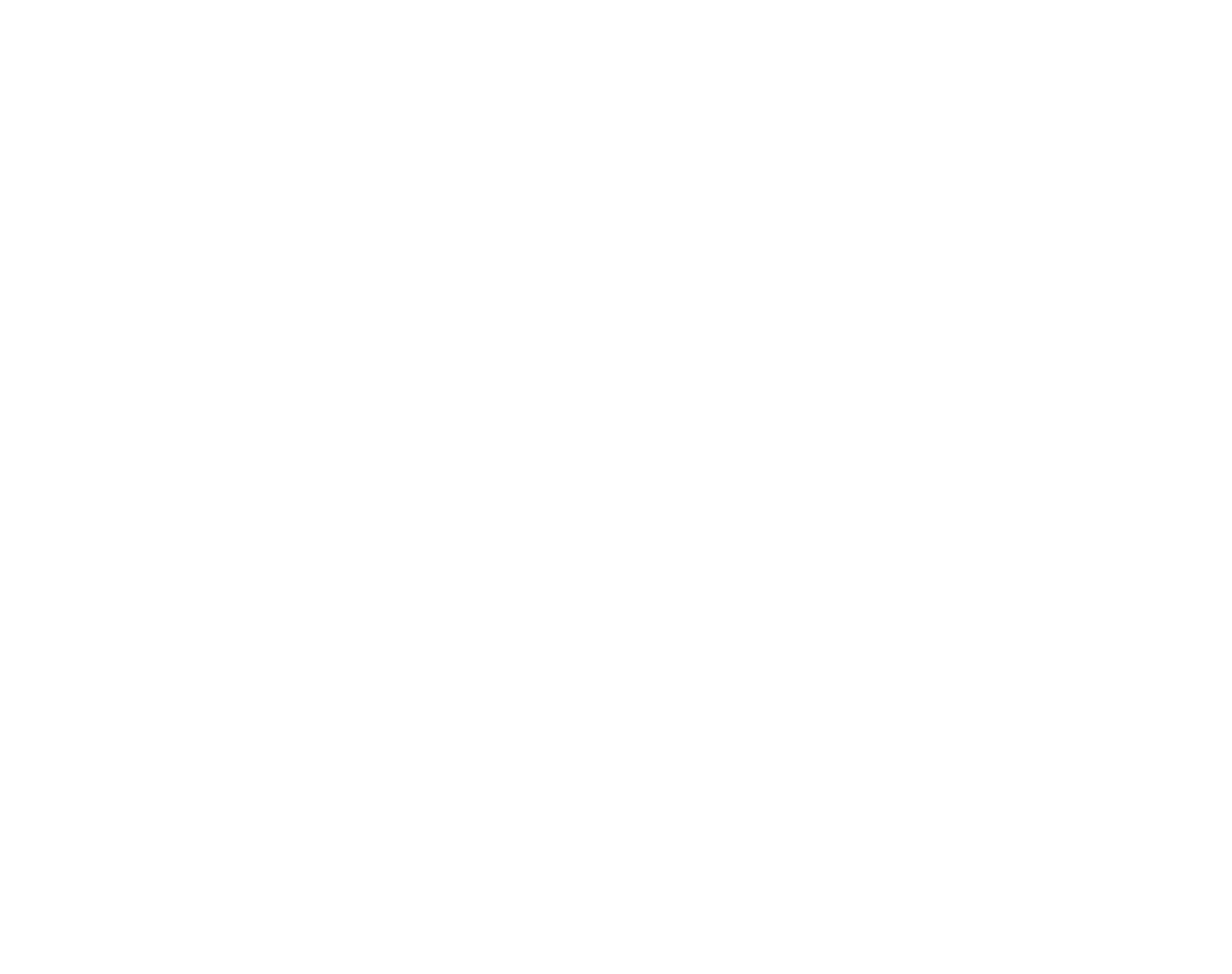


TABLE 28.-Transmountain diversions, in acre-feet, from the Gunnison River basin, water years 1914-57 1

\begin{tabular}{|c|c|c|c|c|c|c|c|}
\hline \multirow[b]{2}{*}{ Water year } & \multicolumn{2}{|c|}{ Diversion } & \multirow[b]{2}{*}{ Total } & \multirow[b]{2}{*}{ Water year } & \multicolumn{2}{|c|}{ Diversion } & \multirow[b]{2}{*}{ Total } \\
\hline & $\begin{array}{l}\text { Larkspur ditch } \\
\text { (Tomichi Creek) }\end{array}$ & $\begin{array}{c}\text { Taber ditch } \\
\text { (Cebolla Creek) }\end{array}$ & & & $\begin{array}{l}\text { Larkspur ditch } \\
\text { (Tomichi Creek) }\end{array}$ & $\begin{array}{c}\text { Taber ditch } \\
\text { (Cebolla Creek) }\end{array}$ & \\
\hline $1914 \ldots \ldots \ldots \ldots$ & $\ldots \ldots \ldots$ & 2220 & 220 & 1936 & 536 & 254 & 790 \\
\hline 1915 & - & 2220 & 220 & 1937 & 115 & 4 & 119 \\
\hline $1916 \ldots$ & $-\ldots \ldots \ldots$ & 2220 & 220 & $1938 \ldots$ & 255 & 35 & 290 \\
\hline 1917 & $\ldots \ldots \ldots$ & 2220 & 220 & 1939 & 167 & 258 & 425 \\
\hline $1918 \ldots$ & - & 2220 & 220 & 1940 & 12 & 278 & 290 \\
\hline 1919 & - $\ldots \ldots \ldots \ldots$ & 2220 & 220 & 1941 & 480 & 72 & 552 \\
\hline $1920 \ldots$ & $\ldots \ldots \ldots \ldots \ldots$ & 2220 & 220 & $1942 \ldots$ & 0 & 28 & 28 \\
\hline $1921 \ldots$ & 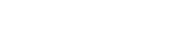 & 2220 & 220 & 1943 & 0 & 238 & 238 \\
\hline 1922 & - $-1-1-1-1-1$ & 2220 & 220 & 1944 & 0 & 77 & 77 \\
\hline 1923 & 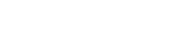 & 2220 & 220 & 1945 & 0 & 243 & 243 \\
\hline 1924 & - $-1-1-1-1-1$ & 2220 & 220 & 1946 & 76 & 549 & 625 \\
\hline 1925 & - $\ldots \ldots \ldots \ldots$ & 2220 & 220 & 1947 & 448 & 559 & 1,007 \\
\hline $1926 \ldots \ldots \ldots$ & 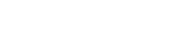 & 2220 & 220 & 1948 & 0 & 163 & 163 \\
\hline $1927 \ldots$ & - $-\ldots-\ldots$ & 2220 & 220 & 1949 & 394 & $\mathbf{0}$ & 394 \\
\hline 1928 & - & 227 & 227 & $1950 \ldots$ & 24 & 255 & 279 \\
\hline 1929 & - $\ldots \ldots-\ldots$ & 217 & 217 & $1951 \ldots \ldots$ & 121 & 396 & 517 \\
\hline 1930 & $\ldots \ldots-\ldots \ldots$ & 275 & 275 & $1952 \ldots$ & 422 & 308 & 730 \\
\hline 1931 & - & 235 & 235 & 1953 & 217 & 182 & 399 \\
\hline $1932 \ldots$ & $\ldots \ldots$ & 104 & 104 & 1954 & 0 & 174 & 174 \\
\hline 1933. & - $\ldots \ldots \ldots$ & 44 & 44 & 1955 & 16 & 31 & 47 \\
\hline - & $1-1-1-1-1$ & 192 & 192 & 1956 & 35 & 167 & 202 \\
\hline 1935 & 45 & 133 & 178 & $1957 \ldots$ & 0 & 788 & 788 \\
\hline
\end{tabular}

1 Does not include Tarbell ditch.

TABLE 29.-Summary of average annual dissolved-solids discharge between Colorado River near Cameo, Colo., and Colorado River near Cisco, Utah

[Data are for the water years 1914-57 adjusted to 1957 conditions]

\begin{tabular}{|c|c|}
\hline Station & $\begin{array}{l}\text { Dissolved-solids } \\
\text { discharge (tons) }\end{array}$ \\
\hline $\begin{array}{l}\text { Colorado River near Cameo, Colo } \\
\text { Plateau Creek near Cameo, Colo } \\
\text { Gunnison River near Grand Junction, Colo } \\
\text { Dolores River near Cisco, Utah }\end{array}$ & $\begin{array}{r}1,578,000 \\
66,110 \\
1,519,000 \\
460,200\end{array}$ \\
\hline Total Colorado River near Cisco, Utah & $\begin{array}{l}3,623,310 \\
4,120,000\end{array}$ \\
\hline Dissolved-solids increase in reach & 496,690 \\
\hline
\end{tabular}


TABLE 30.-Annual contribution of dissolved-solids to the Colorado River between Colorado River near Cameo, Colo., and Colorado River near Cisco, Utah, water years 1934-57

Plateau Creek near Cameo, Colo.: Water years 1937-57 computed on basis of annual flow-duration curves and a curve of relation of concentration of dissolved solids to water discharged based on 14 chemical analyses. Water years 1934-36 estimated on basis of comparable years of runnoff.

Dolores River near Cisco, Utah: Records for Dolores River at Gateway, Colo., used for water years 1948-51. Water years 1937-47 computed on basis of annual flow-duration curves and an average curve of relation of concentration of dissolved solids to water discharge. Water years $1934-36$ estimated on basis of comparable years of runoff.

\begin{tabular}{|c|c|c|c|c|c|c|c|c|c|}
\hline \multirow{2}{*}{ Water year } & \multicolumn{7}{|c|}{ Annual dissolved-solids load, in tons per day } & \multicolumn{2}{|c|}{$\begin{array}{l}\text { Increase in reach, in thou- } \\
\text { sands of tons }\end{array}$} \\
\hline & $\begin{array}{c}\text { Colorado } \\
\text { River near } \\
\text { Cameo, Colo. }\end{array}$ & $\begin{array}{c}\text { Plateau } \\
\text { Creek near } \\
\text { Cameo, Colo. }\end{array}$ & $\begin{array}{c}\text { Gunnison } \\
\text { River near } \\
\text { Grand Junc- } \\
\text { tion, Colo. }\end{array}$ & $\begin{array}{c}\text { Dolores } \\
\text { River near } \\
\text { Cisco, Utah }\end{array}$ & $\begin{array}{l}\text { Total inflow } \\
\text { at four } \\
\text { stations }\end{array}$ & $\begin{array}{l}\text { Colorado } \\
\text { River near } \\
\text { Cisco, Utah }\end{array}$ & $\begin{array}{l}\text { Increase in } \\
\text { reach }\end{array}$ & Per year & Cumulative \\
\hline 1934 & 3560 & 110 & 2650 & 945 & 7265 & 8280 & 1015 & 370 & \\
\hline 1935 & 3,660 & 230 & 3,330 & 1,180 & 8,400 & 10,470 & 2,070 & 756 & 1,126 \\
\hline $1936 \ldots$ & 4,370 & 210 & 4,080 & 1,170 & 9,830 & 12,120 & 2,290 & 838 & 1,964 \\
\hline 1937 & 4,180 & 147 & 3,950 & 1,290 & 9,567 & 11,980 & 2,413 & 881 & 2,845 \\
\hline $1938 \ldots \ldots$ & 5,380 & 207 & 5,470 & 1,390 & 12,447 & 15,110 & 2,663 & 972 & 3,817 \\
\hline 1939 & 4,140 & 148 & 4,120 & 1,040 & 9,448 & 11,640 & 2,192 & 800 & 4,617 \\
\hline $1940 \ldots$ & 3,470 & 116 & 3,950 & 1,040 & 8,576 & 10,780 & 2,204 & 807 & 5,424 \\
\hline $1941 \ldots$ & 4,390 & 205 & 5,280 & 1,600 & 11,476 & 14,960 & 3,484 & 1,272 & 6,696 \\
\hline $1942 \ldots \ldots \ldots$ & 5,260 & 262 & 6,090 & 1,770 & 13,382 & 15,800 & 2,418 & 883 & 7,579 \\
\hline $1943 \ldots$ & 4,220 & 169 & 4,420 & 1,160 & 9,969 & 12,620 & 2,651 & 968 & 8,547 \\
\hline $1944 \ldots$ & 3,840 & 189 & 4,110 & 1,430 & 9,569 & 12,000 & 2,431 & 890 & 9,437 \\
\hline 1945 & 4,160 & 184 & 4,140 & 1,210 & 9,694 & 11,760 & 2,066 & 754 & 10,191 \\
\hline 1946 & 3,790 & 155 & 3,730 & 1,000 & 8,675 & 9,920 & 1,245 & 454 & 10,645 \\
\hline $1947 \ldots$ & 4,440 & 179 & 4,200 & 1,130 & 9,949 & 12,190 & 2,241 & 818 & 11,463 \\
\hline 1948 & 4,450 & 191 & 4,650 & 1,600 & 10,891 & 13,070 & 2,179 & 798 & 12,261 \\
\hline 1949 & 4,460 & 187 & 4,410 & $\cdot 1,660$ & 10,717 & 12,900 & 2,183 & 797 & 13,058 \\
\hline 1950 & 4,070 & 159 & 3,750 & 1,150 & 9,129 & 10,800 & 1,671 & 610 & 13,668 \\
\hline 1951 & 4,220 & 112 & 3,200 & 781 & 8,313 & 10,250 & 1,937 & 707 & 14,375 \\
\hline 1952 & 5,530 & 176 & 4,699 & 1,470 & 11,876 & 13,730 & 1,854 & 679 & 15,054 \\
\hline 1953 & 4,160 & 137 & 3,700 & 1,080 & 9,077 & 10,690 & 1,613 & 589 & 15,643 \\
\hline & 3,580 & 113 & 3,040 & 941 & 7,674 & 9,290 & 1,616 & 590 & 16,233 \\
\hline & 3,830 & 132 & 3,190 & 1,030 & 8,182 & 9,230 & 1,048 & 383 & 16,616 \\
\hline & 3,880 & 106 & 2,970 & 908 & 7,864 & 9,460 & 1,596 & 584 & 17,200 \\
\hline & 5,220 & 192 & 5,180 & 1,620 & 12,212 & 13,920 & 1,708 & 623 & 17,823 \\
\hline
\end{tabular}


TABLE 31.-Summary of suspended-sediment discharge of Dolores and Colorado Rivers near Cisco, Utah

\begin{tabular}{|c|c|c|c|c|c|c|c|c|}
\hline \multirow{2}{*}{ Water year } & \multicolumn{2}{|c|}{ Water discharge } & \multicolumn{6}{|c|}{ Suspended sediment } \\
\hline & Cfs-days & Acre-ft & Load 1 (tons) & Average & Maximum & Minimum & $\begin{array}{c}\text { Weighted } \\
\text { mean }\end{array}$ & $\underset{\text { daily }}{\text { Maximum }}$ \\
\hline \multicolumn{9}{|c|}{ 1800. Dolores River near Cisco, Utah } \\
\hline \multicolumn{9}{|c|}{ 1805. Colorado River near Cisco. Utah } \\
\hline
\end{tabular}


TABLE 32.-Water budget, Grand division

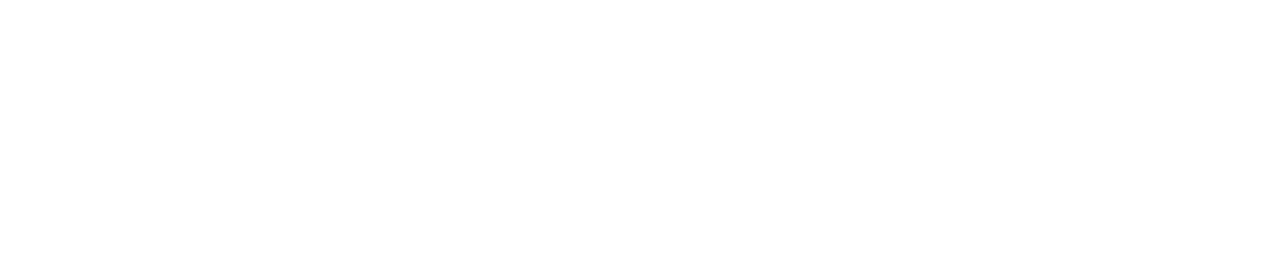

1 Includes 216,000 acre-feet estimated evaporation from water surfaces.

TABLE 33.-Summary data on utilization of surface water in the Grand division for developments existing in 1957

\begin{tabular}{|c|c|c|c|c|}
\hline Water use & \multicolumn{3}{|c|}{ Subbasin } & $\begin{array}{l}\text { Total in } \\
\text { division }\end{array}$ \\
\hline $\begin{array}{l}\text { Storage reservoirs having usable capacities greater than } 1,000 \text { acre-feet: } \\
\text { Number } \\
\text { Total usable capacity }\end{array}$ & 659,400 & 130,100 & 42,100 & 831,600 \\
\hline Acre-feet exported (average annual) & ${ }^{1} 353,100$ & ${ }^{1} 300$ & ${ }^{2} 100,000$ & 453,400 \\
\hline Irrigation: & & & & \\
\hline $\begin{array}{l}\text { Acres irrigated } \\
\text { Estimated consumptive use (average annual) }\end{array}$ & $\begin{array}{l}192,500 \\
190,300\end{array}$ & $\begin{array}{l}269,400 \\
348,200\end{array}$ & $\begin{array}{l}121,300 \\
200,600\end{array}$ & $\begin{array}{l}583,200 \\
739,100\end{array}$ \\
\hline Domestic and industrial use: & & & & \\
\hline Population (1960) & 26,200 & 38,000 & 66,000 & 130,200 \\
\hline $\begin{array}{l}\text { Estimated consumptive use (average annual) } \\
\text { Hydroelectric powerplants: }\end{array}$ & 1,800 & 2,600 & 4,400 & 8,800 \\
\hline
\end{tabular}

1 Diverted across the Continental Divide.

2 Diverted to San Juan River basin.

TABLE 34.-Summary of average annual water, dissolved-solids, and suspended-sediment discharges from the subbasins in the Grand Division

[Data are for the water years 1914-57 adjusted to 1957 conditions]

\begin{tabular}{|c|c|c|c|c|}
\hline \multirow[b]{2}{*}{ Data } & \multicolumn{3}{|c|}{ Subbasin } & \multirow[b]{2}{*}{ Grand division } \\
\hline & $\begin{array}{l}\text { Colorado River } \\
\text { Basin above the } \\
\text { Gunnison River }\end{array}$ & Gunnison River & $\begin{array}{c}\text { Colorado River } \\
\text { Basin between } \\
\text { the Gunnison } \\
\text { and Green Rivers }\end{array}$ & \\
\hline $\begin{array}{l}\text { Drainage area } \\
\text { Water discharge. } \\
\text { Dissolved-solids discharge: } \\
\text { Total } \\
\text { Probable from natural sources } \\
\text { Do } \\
\text { Probable from activities of man } \\
\text { Do. }\end{array}$ & $\begin{array}{r}8,670 \\
3,168,200 \\
1,644,100 \\
1,242,100 \\
143 \\
402,000 \\
2.1 \\
9,269,000\end{array}$ & $\begin{array}{r}8,020 \\
1,884,000 \\
1,519,000 \\
542,000 \\
68 \\
977,000 \\
3.6 \\
2,067,000\end{array}$ & $\begin{array}{r}9,810 \\
1481,800 \\
\\
1,041,500 \\
469,900 \\
48 \\
571,600 \\
4.7 \\
9,159,000\end{array}$ & $\begin{array}{r}26,500 \\
15,534,000 \\
4,204,600 \\
2,254,000 \\
85 \\
1,950,600 \\
3.4 \\
20,495,000\end{array}$ \\
\hline
\end{tabular}

1 Does not include runoff from 2,400 square miles between the gaging station on Colorado River near Cisco, Utah, and the Green River. 


\section{Surface-Water Resources}

of the Green Division

By W. V. IORNS, C. H. HEMBREE, and G. L. OAKLAND

WATER RESOURCES OF THE UPPER COLORADO RIVER BASIN-TECHNICAL REPORT

GEOLOGICAL SURVEY PROFESSIONAL PAPER 441-D

Analysis and appraisal of the water resources of the Green division of the Upper Colorado River Basin, with special emphasis on surface water and its quality

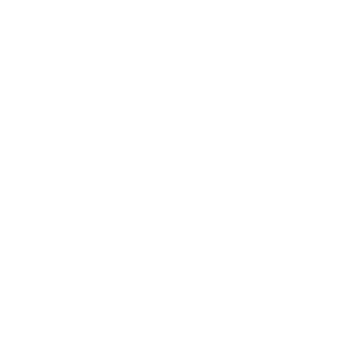

UNITED STATES GOVERNMENT PRINTING OFFICE, WASHINGTON : 1965 



\section{CONTENTS}

Abstract......

Introduction

Purpose and scope

Location and subbasins.....

Hydrologic environment. . . . . . . . . . . . . . . . . . .

Physiography and stream net.

Soils _ -

Climate

Effect of topography and altitude......... Precipitation ........ Temperature and evaporation . . . . . . . . .

Vegetation. . . . . . .

Green River basin above the Yampa River

Present utilization of surface water........ Storage reservoirs............ Transmountain diversions.................. Irrigation. . . . . . 2 . . . Domestic and industrial uses.

Streamflow...... Variability of seasonal runoff Flow-duration curves....................... Variability of annual runoff .

Chemical quality of water Dissolved-solids discharge and concentration ... Variations in chemical quality............ Relation to streamflow ..... Relation to geology ....... Relation to ground water Effect of transmountain diversions ........... Effect of the activities of man ...............

Fhuvial sediment.

Suitability of water for various uses. . . . . . . . .

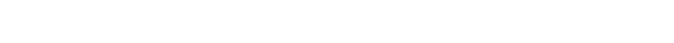
Agricultural Industrial and recreational .......

Yampa River basin

Present utilization of surface water............ Storage reservoirs Transmountain diversions . . . . . . . . . . . . . . . Irrigation. Domestic and industrial uses.

Streamflow Variability of seasonal runoff. Flow-duration curves........... Variability of annual runoff

Chemical quality of water..................... Dissolved-solids discharge and concen tration . .Variations in chemical quality........ Relation to streamflow

Relation to geology -

Relation to ground water.

Effect of the activities of man

Fluvial sediment

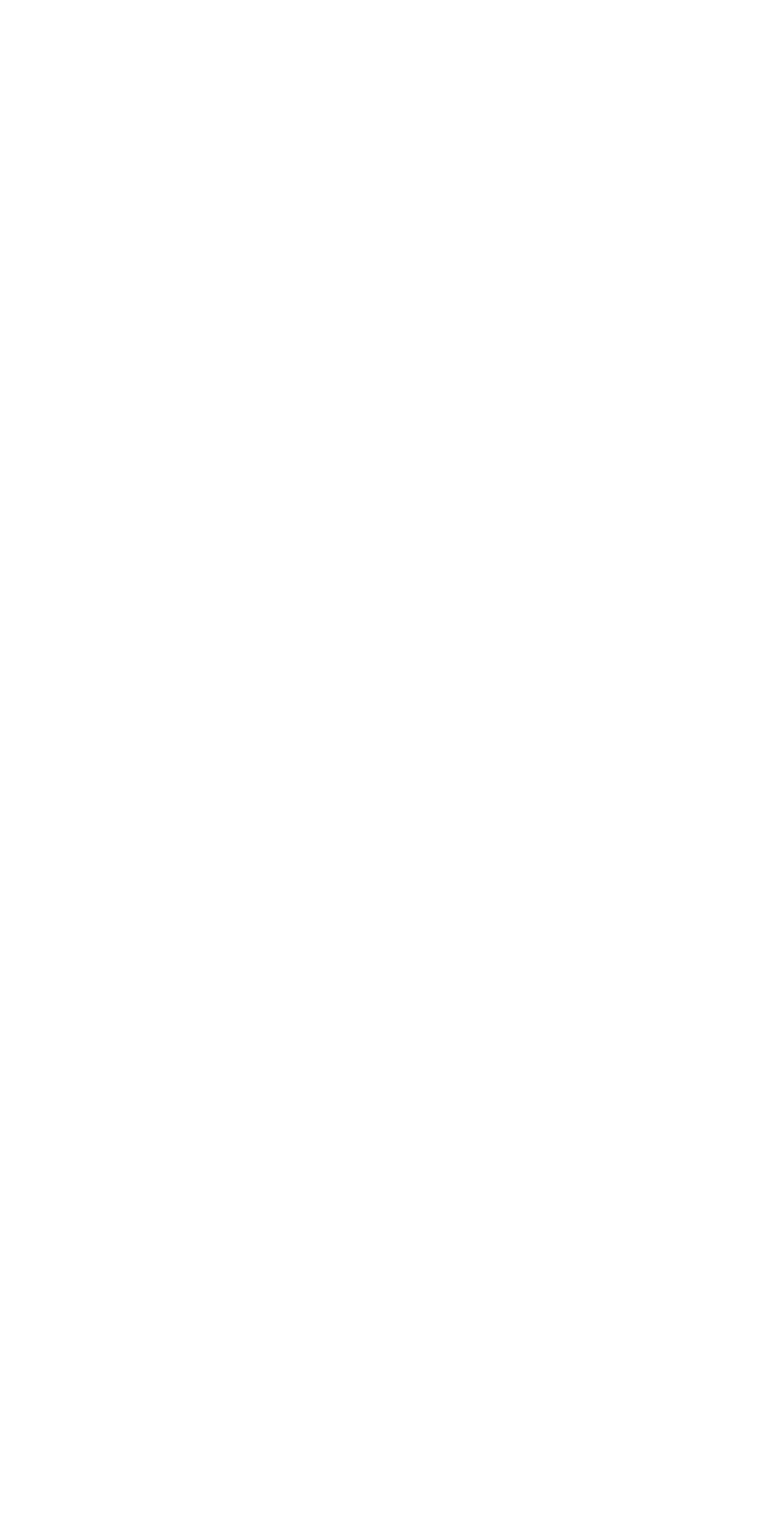




\title{
ILLUSTRATIONS
}

\author{
[Plates are in separate volume]
}

Plate 6. Map of Green division showing average annual precipitation and evaporation, key streamflow-gaging stations, and coefficien ts of variations of annual runoff.

7. Map of native vegetation zones and irrigated lands in the Green division.

Figure 80. Relief map of the Green division of the Upper Colorado River Basin.

81. Normal precipitation and temperature and frost-free seasons at representative stations in the Green division

82. Photograph of shadscale, 22 miles south of La Barge, Wyo

83. Photograph of greasewood along the Little Snake River 15 miles northwest of Maybell, Colo ..............

84. Photograph of pinyon-juniper about 10 miles north of Vernal, Utah.

85. Seasonal pattern of runoff of streams in the Green River basin above the Yampa River, 1954 water year ...-

86. Flow-duration curves for streams in the Green River basin above the Yampa River.

87. Relation between the variability index of streamflow and percentage of average annual discharge estimated to be contributed by ground water for selected stations in the Green division.

88. Variability of annual discharges of streams in the Green River basin above the Yampa River, water years 1914-57.

89. Approximate dissolved-solids discharge and streamflow expressed as percentages of the dissolved-solids discharge and streamflow of Green River near Greendale, Utah

90. Dissolved-solids concentration of Green River at Green River, Wyo., for the 1954 and 1957 water years

31. Relation of the variability of dissolved-solids concentration to the variability of water discharge in the Green division

92. Dissolved-solids concentration and discharge and water discharge at four daily stations in the Green River basin above the Yampa River.

93. Relation of the chemical composition and concentration of dissolved solids to water discharge in the Green River basin above the Yampa River

94. Approximate weighted-average concentration of dissolved solids of streams in the Green River basin above the Yampa River

95. Analyses of water from selected streams near the mountains in the Green River basin above the Yampa River and from alluvium nearby

96. Analyses of water from selected streams in the interior of the Green River basin above the Yampa River and from allu vium nearby ...

97. Seasonal pattern of runoff in the Yampa River basin, 1954 water year.

98. Flow-duration curves of two streams in the Yampa River basin

99. Variability of annual discharges in the Yampa River basin, water years 1914-57.

100. Approximate dissolved-solids discharge and streamflow expressed as percentages of the combined dissolved-solids discharge and combined streamflow of Yampa and Little Snake Rivers near Maybell and Lily, Colo .......-

101. Dissolved-solids concentration of Yampa River at bridge on county road, near Maybell, Colo., for the 1954 and 1957 water years

102. Dissolved-solids concentration and discharge and water discharge of streams at two daily stations in the Yampa River basin.

103. Relation of the chemical composition and concentration of dissolved solids to water discharge in the Yampa River basin

104. Approximate weighted-average concentration of dissolved solids of streams in the Yampa River basin

105. Analyses of water from selected streams near the moun tains in the Yampa River basin and from alluvium nearby -

106. Analyses of water from selected streams in interior of the Yampa River basin and from alluvium nearby ....--

107. Seasonal pattern of runoff in the Green River basin between the Yampa and White Rivers including the White River basin, 1954 water year.

108. Flow-duration curves of streams in the Green River basin between the Yampa and White Rivers including the White River basin

109. Variability of annual discharges of selected streams in the Green River basin between the Yampa and White Rivers including the White River basin, water years 1914-57.

110. Approximate dissolved-solids discharge and streamflow in the Green River basin between the Yampa and White Rivers including the White River basin expressed as percentages of the dissolved-solids discharge and streamflow of Green River near Ouray, Utah

111. Dissolved-solids concentration of White River near Watson, Utah, for the 1951 and 1954 water years

112. Dissolved-solids concentration and discharge and water discharge at four daily stations in the Green River basin between the Yampa and White Rivers including the White River basin

113. Relation of the chemical composition and concentration of dissolved solids to water discharge in the Green River basin between the Yampa and White Rivers including the White River basin .

114. Approximate weighted-average concentration of dissolved solids of streams in the Green River basin between the Yampa and White Rivers including the White River basin 
FiguRE 115. Analyses of water from selected streams in the Green River basin between the Yampa and White Rivers, including the White River basin and from alluvium nearby

116. Seasonal pattern of runoff in the Green River basin below the White River, 1954 water year....

117. Flow-duration curves for two tributary streams in the Green River basin below the White River..........

118. Variability of annual discharges in the Green River basin below the White River, water years 1914-57 ......

119. Approximate dissolved-solids discharge and streamflow expressed as percentages of the combined dissolvedsolids discharge and combined streamflow of Green River at Green River, Utah, and San Rafael River near Green River, Utah.

120. Dissolved-solids concentration at four stations in the Green River basin below the White River for two water years for each station

121. Dissolved-solids concentration and discharge and water discharge at four stations in the Green River basin below the White River -

122. Relation of the chemical composition and concentration of dissolved solids to water discharge in the Green River basin below the White River River basin below the White River $\ldots \ldots$

123. Approximate weighted-average concentration of dissolved solids of streams in the Green River basin below the White River

124. Analyses of water from selected streams in the Green River basin below the White River and from alluvium nearby .

\section{TABLES}

TABLE 1. Average monthly and annual precipitation at 16 index-precipitation stations in the Green division

2. Annual precipitation at 16 index-precipitation stations and weighted-average precipitation for the Green division, water years 1914-57 . .

3. Reservoirs in the subbasins in the Green division .

4. Irrigated acreage in the subbasin $\mathrm{s}$ in the Green division

5. Flow duration table for gaging stations in the subbasins in the Green division

6. Methods and accuracy of adjusting flow-duration data for selected stations in two subbasins in the Green division to base period and 1957 conditions

7. Variability index of streamflow and percentage of average annual discharge estimated to be contributed by ground water for selected streams in the subbasins in the Green division

8. Average discharge, standard deviation, and coefficient of variation for selected stations in the Green division.-.-

9. Water and dissolved-solids discharge of streams in the subbasins in the Green division

10. Duration table of dissolved-solids concentration for selected stations in the subbasins in the Green division....

11. Duration table of dissolved-solids discharge for selected stations in the subbasins in the Green division ........

12. Variability of annual weighted-average concentration of dissolved solids related to variability of annual water discharge for daily stations in the subbasins in the Green division

13. Relation between water discharge and chemical quality of water at selected stations in the Green division ......-

14. Water and dissolved solids contributed by ground water to selected streams in the subbasins in the Green division.

15. Water and dissolved-solids budgets in the subbasins in the Green division

16. Average annual dissolved-solids discharge and probable amounts of dissolved solids from natural sources and. from the activities of man in the subbasins in the Green division

17. Summary of the suspended-sediment discharge at daily stations in the subbasins of the Green division........

18. Estimated suspended-sediment discharge at selected stations in the subbasins in the Green division ..........

19. Suitability of surface water for irrigation in the subbasins in the Green division

20. Transmountain diversions from the Green River Basin between the Yampa and White Rivers including the White River Basin, water years 1914-57.

21. Upstream water developments and methods and accuracy of adjusting flow-duration data for selected stations in two subbasins in the Green division to base period and 1957 conditions.

22. Total dissolved-solids concentration and concentration of boron in water in the upper part of the Duchesne River basin in 1960 .

23. Recorded transmountain diversions from the Green River basin below the White River, water years 1950-57 . -

24. Total transmountain diversions from the Green River basin below the White River, water years 1914-57......-

25. Summary data on utilization of surface water in the Green division for developments existing in 1957 . . . . .

26. Water budget, Green division

27. Average annual streamflow and dissolved-solids data at stations on the Green River

28. Summary of average annual water, dissolved-solids, and suspended-sediment discharge from the subbasins in the Green division. 



\title{
WATER RESOURCES OF THE UPPER COLORADO RIVER BASIN-TECHNICAL REPORT
}

\section{SURFACE-WATER RESOURGES OF THE GREEN DIVISION}

\author{
By W. V. Iorns, C. H. Hembren, and G. L. OAKland
}

\begin{abstract}
This chapter presents the results of an appraisal of the surface-water resources of the Green division, which includes the 44,700 square miles of the Green River drainage basin. Water uses existing in 1957 are reported; and interpretations are made of stream behavior, chemical quality of water, and sediment yield on the basis of the average that would have occurred if the 1957 developments had existed throughout water years 1914-57. The appraisal will be useful in planning future development of surface-water supplies and in evaluating changes in streamflow, chemical quality of water, and sediment yield that may result from water-development projects constructed after 1957.

Annual precipitation in the division averaged about $39,645,900^{1}$ acre-feet in the water years 1914-57. Had the developments in 1957 existed throughout the 44 -year period, the average annual consumption of water would have been about 728,900 acre-feet for irrigation and about 6,700 acre-feet for domestic and industrial uses. Annually, about 112,200 acre-feet would have been diverted out of the division, and 4,660,100 acre-feet would have been discharged in the Green River. Evapotranspiration probably accounted for the remaining $34,138,000$ acre-feet, on the assumption that there was no ground-water outflow.

An average of about 19,300 tons of dissolved solids in 112,200 acre-feet of water was annually carried out of the division by the transmountain diversions existing in 1957. These diversions have caused an increase of about 7 parts per million in the weighted-average concentration of dissolved solids of the Green River at its mouth. The annual discharge of dissolved solids from the division in the Green River was computed to average about 2,928,100 tons for water years 1914-57 adjusted to 1957 conditions. About 1,750,200 tons of the total dissolved-solids discharge comes from natural sources; about 48,600 tons of this total comes from thermal springs. The activities of man in the division, other than the diversion of water out of the basin, consume water and result in the addition of dissolved solids to the stream system-about $1,177,900$ tons annually. The major part of the increase is attributed to irrigation. Domestic, industrial, and irrigation use of water has caused about five times as much increase in the dissolved-solids concentration of the Green River at its mouth for each acre-foot of water consumed as the transmountain diversions have caused for each acre-foot of water carried out.

The average annual suspended-sediment discharge of the Green River is about $27,875,000$ tons. Of this amount, about
\end{abstract}

\footnotetext{
1 To facilitate checking of the figures, they are given as computed rather than rounded off to reflect the probable of accuracy.
}

$3,677,000$ tons comes from the Green River basin above the Yampa River; about $1,807,000$ tons, from the Yampa River basin; about 7,339,000 tons, from the Green River basin between the Yampa and White Rivers including the White River basin; and about 15,051,000 tons, from the Green River basin below the White River.

Most of the surface water in the streams, where they emerge from the mountains, is suitable for domestic and industrial uses. Downstream, the water of most streams increases in concentration of dissolved solids. Many streams, especially in their lower reaches, have higher concentrations of some chemical constituents than the maximums accepted for domestic use. Some of the tributary streams in their lower reaches are not suitable for agricultural use during periods of low flow.

\section{INTRODUCTION PURPOSE AND SCOPE}

This chapter presents in detail an appraisal of the surface water resources of the Green division. In the appraisal the following items were considered: The present utilization of the surface-water supplies, the flow characteristics of the streams and the effects of environmental factors on streamflow, the chemicalquality characteristics of the streams and the influence of environmental factors on the quality of water, and the sediment yield of the streams.

The basic data, hydrologic techniques, and criteria used in this appraisal are discussed and explained in chapter B, which also contains a glossary of technical terms used.

\section{IOCATION AND SUBBASINS}

The Green division of the Upper Colorado River Basin has a drainage area of 44,700 square miles and is that part of Colorado, Wyoming, and Utah drained by the Green River. In this report the division is divided into four subbasins (fig. 2).

1. The Green River basin above the Yampa River is the drainage area $(17,000 \mathrm{sq} \mathrm{mi})$ above the mouth of the Yampa River. Green River near Greendale, Utah, gaging station measures the outflow from all but abont 1,900 square miles of this subbasin. 
2. The Yampa River basin is the drainage area of the Yampa River (8,000 sq mi). Yampa River near Maybell, Colo., and Little Snake River near Lily, Colo., gaging stations measure the outflow from all but about 800 square miles of this subbasin.

3. The Green River basin between the Yampa and the White Rivers, including the White River basin, is the drainage area of the Green River between the mouth of the Yampa River and a point just below the mouth of the White River (10,500 sq mi). Green River near Ouray, Utah, gaging station measures the outflow from this subbasin and the two upstream subbasins. This station is $31 / 4$ miles below the mouth of the White River, but the intervening drainage area is only about 33 square miles.

4. The Green River basin below the White River is the fourth subbasin. It includes 9,200 square miles of drainage area between the White River and the mouth of the Green River. Green River at Green River, Utah, and San Rafael River near Green River, Utah, gaging stations measure the outflow from all but about 2,400 square miles of the Green division.

\section{HYDROLOGIC ENVIRONMENT}

\section{PHYSIOGRAPHY AND STREAM NET}

The Green division extends from the sources of the Green River in the northern end of the Wind River Range, where altitudes are almost 14,000 feet, to the confluence of the Green River with the Colorado River at an altitude of about 3,880 feet. The east and west boundaries of the division are formed by a series of mountain ranges and plateaus of the Rocky Mountain system. In a clockwise direction from the mouth of the Green River, the principal mountain ranges and plateaus are the Wasatch Plateau, Wasatch Range, Wyoming Range, Wind River Range, Park Range, and White River Plateau. The Uinta Mountains cut transversely across the division from west to east and merge into hills which merge into the foothills of the Park Range on the east (fig. 80).

Powell (1875, p. 149), one of the first to describe the topographic features of the division, said:

Mountains, hills, plateaus, plains, and valleys are here found, as elsewhere throughout the earth, but in addition to these topographic elements in the scenic features of the region we find buttes, outlying masses of stratified rocks, often of great altitude, not as dome-shaped or conical mounds but usually having angular outlines. Their sides are vertical walls, terraced or buttressed, and broken by deep, reentering angles, and often naked of soil and vegetation. Then we find lines of cliffs, abrupt escarpments of rock of great length and great height, revealing the cut edges of strata swept away from the lower side. Thirdly, we find canyons, narrow gorges, scores or hundreds of miles in length and hundreds or thousands of feet in depth, with walls of preciptous rocks.

The central part of the Wind River Range is a rugged wilderness of granitic spires and massive buttresses, formed by prolonged erosion of the anticlinal range. The higher, central part, is a large plateau that bears the imprint of past glaciation. Here, countless sparkling lakes of glacial origin form a band astride the sometimes indistinct divide. On the western side, where glaciers spilled off the high plateau into the valleys below, great glacier-gouged lakes protrude like tongues from the monutain canyons. Along the highest ridge, which reaches an altitude of 13,785 feet at the top of Gannett Peak, glaciers are still actively eroding their cirques.

Lakes are also numerous in the Uinta Mountains, the Wasatch and Park Ranges, and the White Plateau. Many are of glacial origin and are the beginning of the principal streams in the division. The rough topography and cool moist climate of the mountains are in great contrast to the broad and, in some places, deeplygorged, valleys of the arid interior.

The Green River basin and Uinta Basin are the two principal structural basins of the Green River drainage basin. The Green River basin encompasses almost all the area north of the Uinta Mountains. The Uinta Basin is the area south of the Uinta Mountains and north of the Tavaputs Plateau, and includes the drainage basins of the Duchesne and White Rivers.

The rocks that compose the area range from Precambrian to Recent in age. In them are recorded the earth movements and the erosional and depositional history of the division. Rocks of Precambrian age are exposed in the Uinta Mountains and the Wind River and Park Ranges. Along the flanks of these mountains, rock formations of later age are exposed, in some places as narrow bands steeply dipping beneath even younger rocks. Along the westem slope of the Wind River Range, rocks of pre-Quaternary age are completely blanketed by glacial deposits of Quaternary age. In the Wyoming Range, rocks of Pennsylvania to Cretaceous age have been so highly folded and contorted that they now stand almost vertically and are eroded into ridges and strike valleys. In the interior of the Green River basin and Uinta Basin, rocks of Tertiary age are at the surface or beneath a shallow soil mantle. An interesting hypothesis of the history of the Colorado Plateau during the Tertiary and Quaternary ages and the episodes of mountain building, erosion, and deposition which formed the topography of most of the division as it is today is contained in Professional Paper 279 (Hunt, 1956, p. 73-87).

The outcrop areas of rock formations are classified into eight units having similar hydrologic properties 


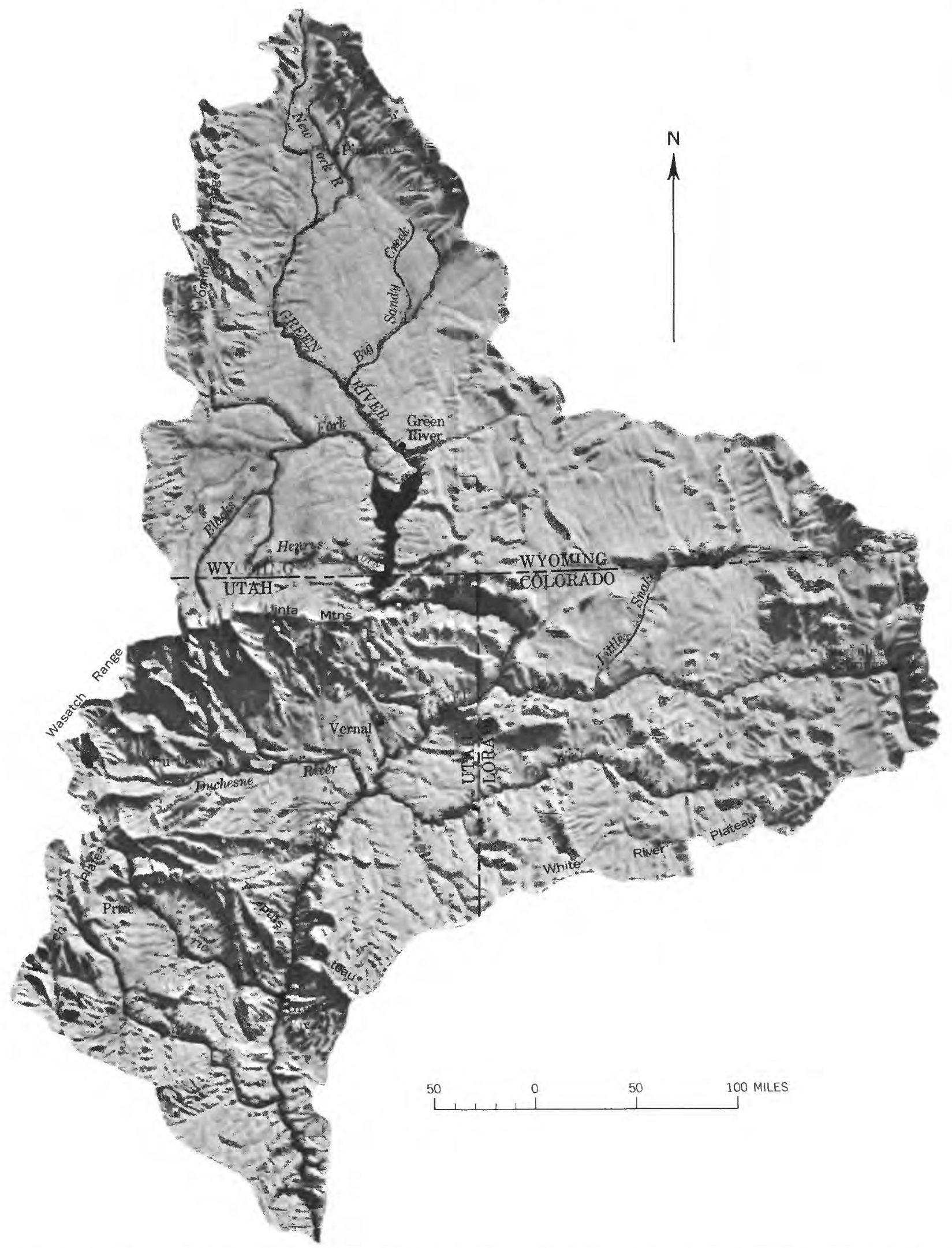

FIGURE 80.-Relief map of the Green division of the Upper Colorado River Basin. Adapted from photograph by I. V. Goslin, Upper Colorado River Commission. 
(chap. A, table 1, pl. 2). The hydrologic units and their characteristics are discussed in chapter $\mathbf{A}$.

The stream patterns and the influence of the rocks and structural features on these patterns have been the subject of discussion and speculation by many writers. Some of the earliest work on this problem was done by Powell and Davis (Hunt, 1956, p. 65). More recently, Bradley (1936, p. 168-189) and Hunt (1956, p. 65-71) have discussed the work of Powell and Davis and have given additional explanations for some of the anomalies of the drainage system.

The seeming disregard by the rivers of uplifted areas, Powell thought, was due either to antecedence or to the rivers being able to maintain their course across an uplift by downcutting during the period of uplift. Davis thought the streams were superimposed from a drainage pattern established on an overlying strata. Hunt $(1956$, p. 65$)$ did not believe that these explanations were completely adequate and postulated that the present stream courses are the result of a combination of the two concepts and coined the word "anteposition" to apply to the sometimes concurrent processes of antecedence and superimposition. The routes of the Green and Yampa Rivers across the uplifted Uinta Mountains and associated structural features are classic examples of anteposition. (See fig. 80.)

The headwaters of the Green River are a network of streams originating in the Wind River and Wyoming Ranges (see fig. 80, pl. 6). The river flows southward in Wyoming across a desert plateau to near the eastern end of the Uinta Mountains. Here it is deflected eastward by the Uinta Mountains, from where it flows southwestward and then generally southward to its junction with the Colorado River. Big Sandy Creek and Blacks and Henrys Forks are the principal streams that enter the Green River in the desert plateau area of Wyoming. The Yampa and White Rivers, whose headwaters are on the western slope of the Rocky Mountains in Colorado, are the principal tributaries from the east. The Duchesne River, which drains most of the south slope of the Uinta Mountains, and the Price and San Rafael Rivers, which head on the eastern slope of the Wasatch Plateau, enter the river from the west in Utah.

\section{sorrs}

The unconsolidated material mantling the consolidated rocks, except in small areas of glacial deposits and alluvium along the streams, is principally residuum developed from the underlying or nearby parent rocks. In the mountains where moisture and temperature are favorable, moderately mature soils have developed in the upper part of the residuum. Where the parent rocks are mainly crystalline rocks of igneous, metamorphic, or volcanic origin, the residuum is relatively permeable and contains minerals that are relatively insoluble. In some of the mountainous areas, such as the Wasatch Plateau and Wyoming Range, sedimentary rocks predominate and the residuum contains large quantities of the soluble minerals that are present in the parent rock.

The broad valleys of the interior basin are predominately underlain by rocks of marine and continental origin of Cretaceous and Tertiary ages. Residuum developed from these rocks is generally high in soluble minerals. The interior has an arid climate, and the soils which have developed are shallow and immature.

The river alluvium in the headwater areas is principally derived from resistant rocks, is generally permeable, and for the most part contains minerals that are relatively: insoluble. Downstream from the headwater areas, the river alluvium is a complex mixture derived from weathering of rocks from nearby and upstream sources. Where the underlying and nearby rocks are Mancos Shale and the Green River and Uinta Formations, the river alluvium generally contains an abundance of soluble minerals.

Plate 7 shows the irrigated lands, and by comparing this plate with plate 1 , the type of rocks underlying the irrigated lands can be determined.

\section{CLIMATF}

EFFECT OF TOPOGRAPHY AND ALTITUDE

Climate in the Green division is markedly affected by altitude. The climate ranges from extremes of high precipitation and cold temperature in the mountains to scant precipitation and high summer temperature in the interior basins. The 5-degree change in latitude from the southern to the northern part also has an effect on temperature.

The mountains along the western side act as partial barriers to the movement of Pacific airmasses that cross the division and the Uinta Mountains act as a barrier to north-south movement of airmasses. Cold, polar airmasses at times cover the area north of the Uinta Mountains. The area south of these mountains is at times affected by warm, moist airmasses from the Gulf of Mexico and by Pacific airmasses originating off the coasts of Southern California and Baja California.

\section{PRECIPITATION}

The precipitation during the period October to April is more effective in producing runoff than precipitation in the summer months. Most of the precipitation from October to April, particularly in the high mountains, occurs as snow. North of the Uinta Mountains, the average seasonal precipitation patterns for the summer and winter periods are generally similar, as Pacific airmasses predominate. The area south of the Uinta Mountains is more exposed to the moist airmasses from 
the south and has different summer and winter precipitation patterns. Summer storms of high intensity are more common in the southern part.

Average annual precipitation in the division ranges from less than 6 inches in the southern part of the division to more than 60 inches in the Wind River Range (pl. 6). Areas of low precipitation are near the mouth of the San Rafael River, in the lower Duchesne River valley, and in the central part of the Green River basin north of the Uinta Mountains. Monthly distribution of precipitation at representative stations is shown in figure 81 .

The distribution of averege annual precipitation is shown on plate 6. This map, which is adjusted for topography, exposure to airmass movement, and climatic factors, is based on precipitation data observed during calendar years 1921-50. The average annual precipitation for this period, as planimetered from the map, is 16.13 inches. The following tabulation shows the areal distribution of precipitation over the 44,700 square miles of drainage area:

\begin{tabular}{|c|c|c|c|}
\hline $\begin{array}{l}\text { Precipitation range } \\
\text { (inches) }\end{array}$ & $\begin{array}{c}\text { Area } \\
(8 q m i)\end{array}$ & $\begin{array}{c}\text { Precipitation range } \\
\text { (inches) }\end{array}$ & $\begin{array}{c}\text { Area } \\
(s q m i)\end{array}$ \\
\hline $60-70_{-}$ & 15 & 16-20. & \\
\hline $50-60$ & 129 & $12-16$ & 11 , \\
\hline $40-50$ & 582 & $10-12$ & \\
\hline $30-40$ & 3,006 & $8-10_{-}$ & \\
\hline $25-30 \ldots$ & 2,857 & $6-8 \ldots \ldots$ & $\mathbf{5}$ \\
\hline $20-25$ & 3,761 & $4-6 \ldots$ & \\
\hline
\end{tabular}

In computing precipitation data applicable to the base period adopted for this study and for other periods, 16 index-precipitation stations located in or adjacent to the division were used (tables 1,$2 ;$ pl. 6). As explained in chapter B (pp. 44-45), precipitation records at the index stations were used to compute the average annual precipitation. The average annual precipitation for the 44-year base period thus computed was 16.63 inches. On the 44,700 square miles of drainage area, this would be equivalent to $39,645,900$ acrefeet of water.

The year of highest precipitation was 1947, when the average precipitation in the basin was 21.10 inches; and the year of lowest precipitation was 1934, when the average was 10.78 inches. The precipitation in these years was about 27 percent and 35 percent above and below the 44-year annual average, respectively. As indicated by the annual quantities, the precipitation was generally above average from 1914 to 1930 , below average from 1931 to 1940 , about average from 1941 to 1952, and below average for 1953 to 1956 .

\section{TEMPERATURE AND EVAPORATION}

The average monthly temperature and length of frost-free season at five locations in the Green division are shown in figure 81 . Temperature and length of growing season are influenced by latitude and altitude.

Isopleths of average annual lake evaporation, from a map by Kohler and others $(1959$, pl. 2), are shown on plate 6. The isopleths are generalized and do not take into account large variations in topography and exposure which may influence evaporation considerably at specific locations.

The average annual evaporation from water surfaces in the division as estimated by Meyers (1962) is given in the following tabulation:

\begin{tabular}{|c|c|}
\hline & $\begin{array}{c}\text { Annual } \\
\text { evaporation } \\
\text { (acre-ft) }\end{array}$ \\
\hline Principal reservoirs and regulated lakes.. & 45,000 \\
\hline Other lakes over 500 acres & 5,000 \\
\hline Principal streams and canals & 48,000 \\
\hline Small ponds and reservoirs & 80,000 \\
\hline Small streams. & 56,000 \\
\hline
\end{tabular}

\section{VEGETATION}

Native species of vegetation in the Green division, except in the cultivated areas, are about the same ones that existed before settlement. In areas having a favorable climatic environment, the net hydrologic effect of native vegetative cover has probably changed little in the last hundred years; however, in the arid areas where native vegetation is always in a precarious state of existence, overgrazing may have locally resulted in some changes in the hydrologic effect of native vegetation. Data of runoff from the arid part of the basin are not sufficient to determine if any hydrologic change has taken place in the water years 1914-57.

The more important native plant communities are alpine meadow, subalpine forest, montane forest, mountain brush, pinyon-juniper, big sagebrush, shadscale, blackbrush, greasewood, grassland, saltbush, and summer-cypress. The species in these communities are described in chapter C, pp. 80-81. Plate 7 shows the native vegetation zones in the Green division and figures 8284 shows the typical vegetation in the area.

\section{GREEN RIVER BASIN ABOVE THE YAMPA RIVER}

\section{PRESENT UTILIZATION OF SURFACE WATER}

\section{STORAGE RESERVOIRS}

Eighteen reservoirs that have usable-storage capacities greater than 1,000 acre-feet have been constructed (1957) in the Green River basin above the Yampa River (table 3, and pl. 6). The combined usable-storage capacity of these reservoirs in 1957 was 141,140 acre-feet, and all these reservoirs are used for irrigation. The first five reservoirs listed in table 3 are natural mountain lakes that have fairly small dams built across the outlets. 

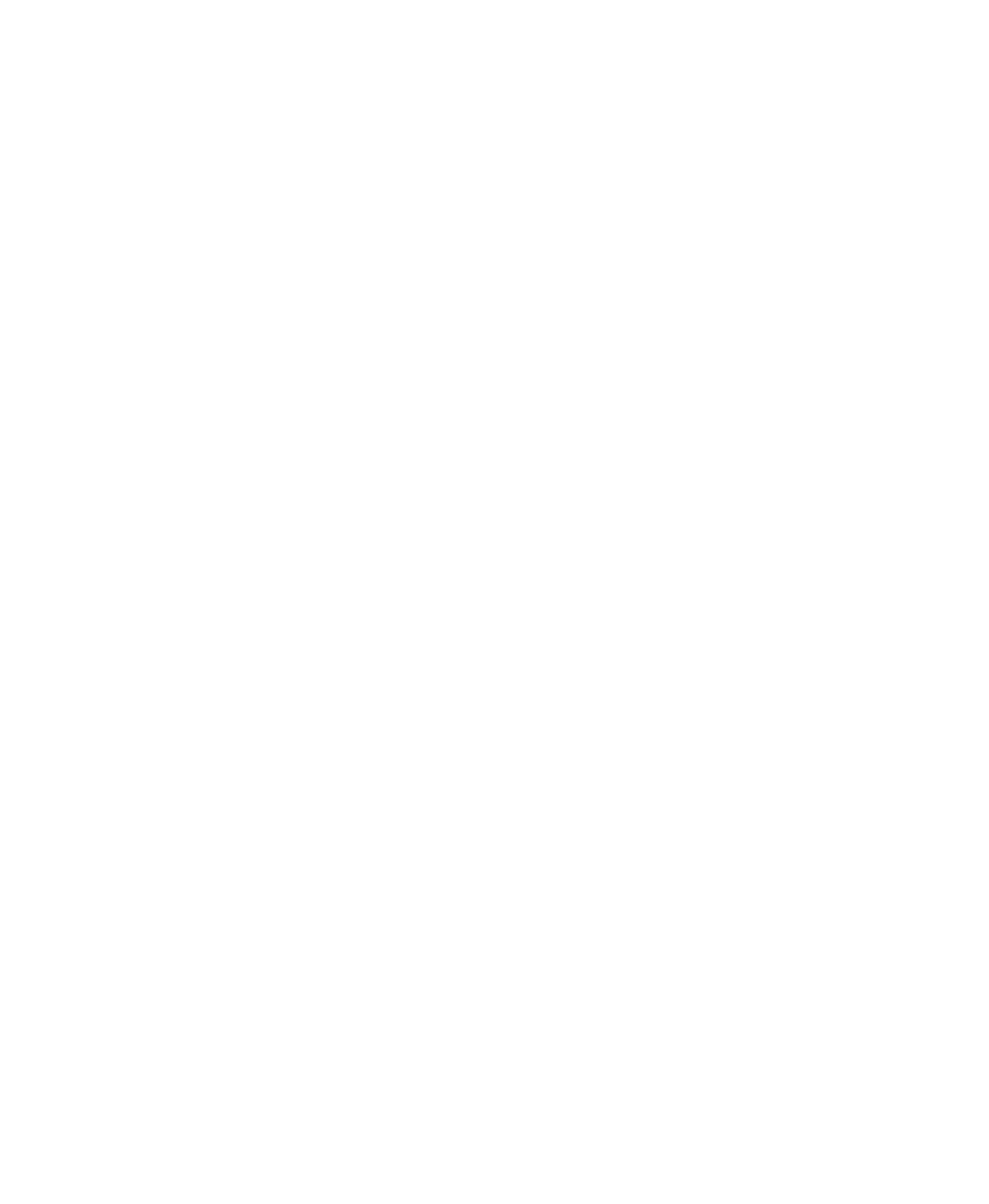


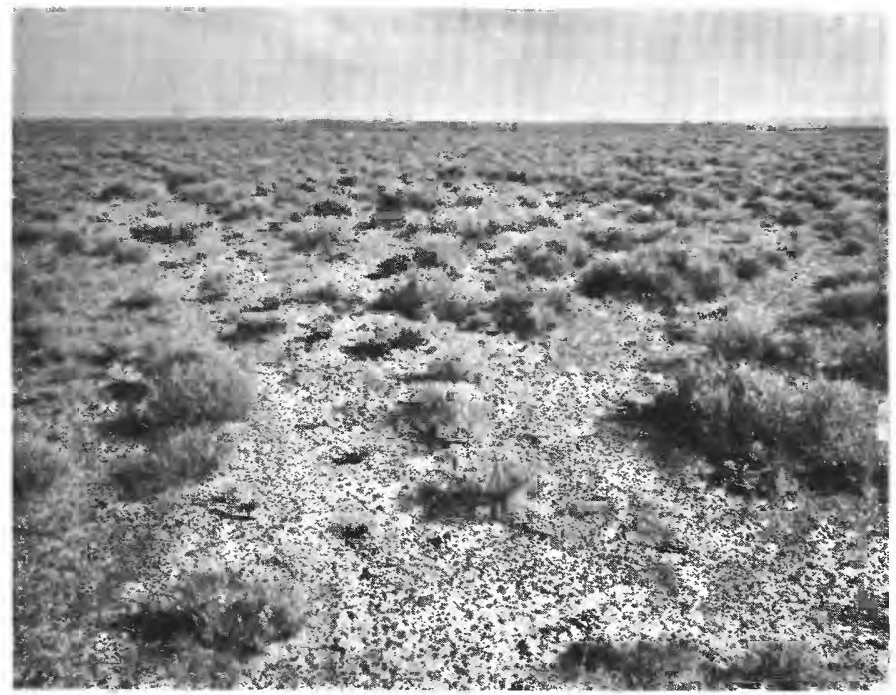

Figure 82.-Shadscale 22 miles south of La Barge, Wyo. Other shrubs present are nuttall horsebrush, big sagebrush, and rabbitbrush. Photograph by F. A. Branson.

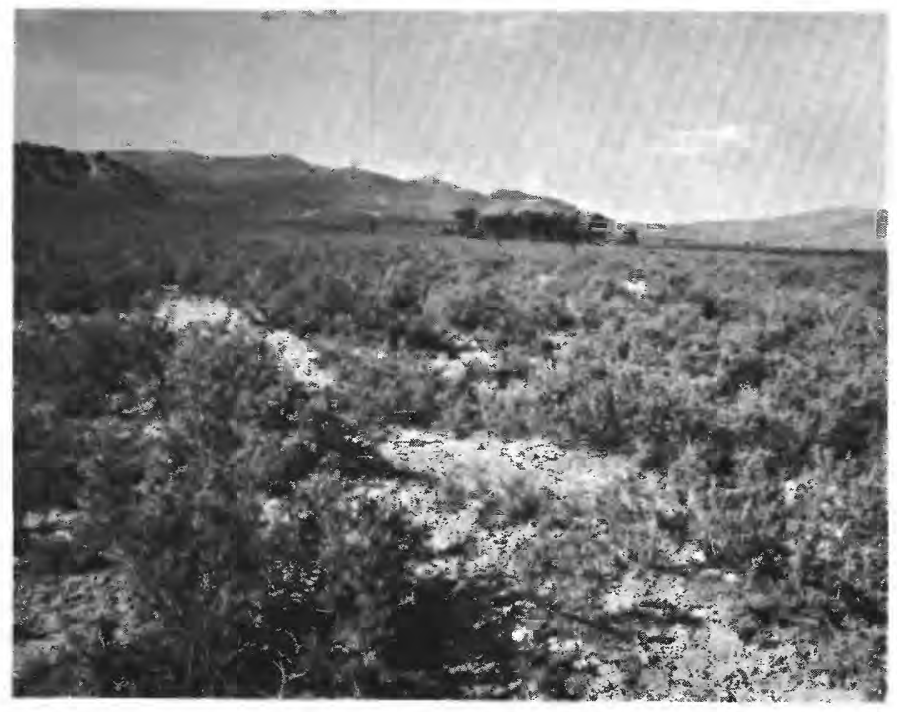

FIGURE 83.-Greasewood along the Little Snake River 15 miles northwest of Maybell, Colo. This extensive pure stand is similar to that found on many square miles of the Upper Colorado River Basin. Photograph by F. A. Branson.

In addition to the reservoirs listed in table 3 , numerous small lakes occur in the mountain areas and stock ponds are scattered throughout the subbasin. Most of the subbasin is at altitudes of more than 6,000 feet; and most lakes and reservoirs are at altitudes of more than 7,000 feet, where evaporation rates are relatively low.

\section{TRANSMOUNTAIN DIVERSIONS}

There are no known imports, and only one small export, of water from this subbasin. The Continental Divide ditch diverts water from the headwaters of Little Sandy Creek to Lander Creek in the North

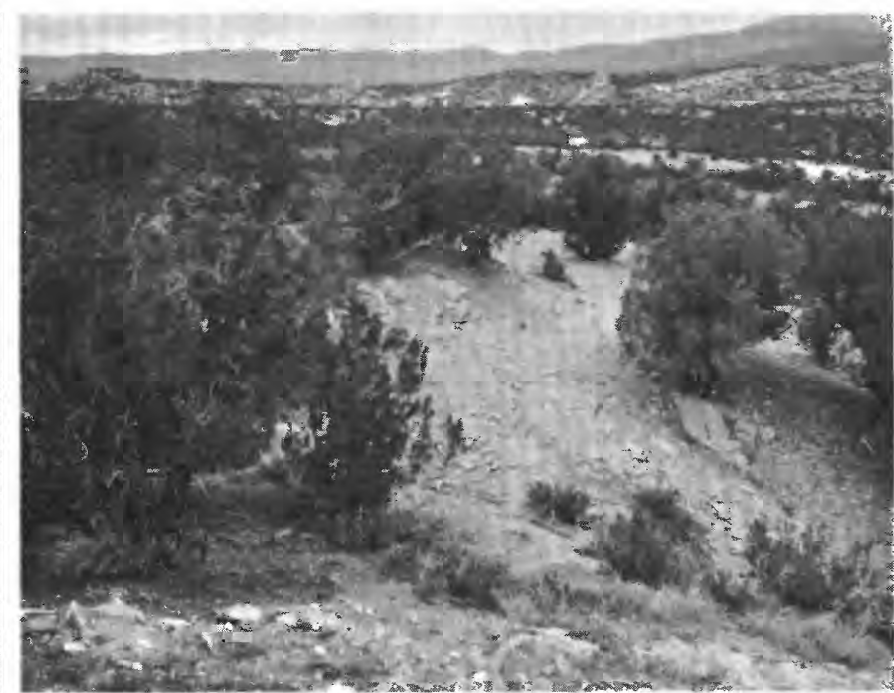

Frgure 84.-Pinyon-juniper about 10 miles north of Vernal, Utah. The trees are nearly all Utah juniper and have a very sparse understory of sand dropseed and Russian-thistle. Photograph by F. A. Branson.

Platte River basin. The appropriation permit is for $13.8 \mathrm{cfs}$ (cubic feet per second) to irrigate 964 acres, but no record of annual diversions is available.

\section{IRRIGATION}

The major use of water in the subbasin is for irrigation. The U.S. Bureau of the Census (1953) reported 255,500 acres of irrigated land in 1949. Between 1949 and 1957 , the acreage was increased to about 258,400 acres through irrigation of new lands in the Eden project (table 4 , and pl. 7). Of the irrigated lands, about 9,800 acres is in Utah, 500 acres in Colorado, and 248,100 acres in Wyoming. Except for a small increase in the later years, there was little change in the total irrigated acreage during the $1914-57$ period. La Rue (1916, p. 133) estimated, on the basis of adjudicated water rights, that 248,000 acres were irrigated in the Wyoming part of this subbasin in 1913 .

As most irrigated lands are at altitudes of more than 6,000 feet, the growing season is short and only the hardier forage crops are grown. Alfalfa, where grown, usually does not produce two full crops a year. Except on the Eden project near Farson, Wyo., irrigation consists chiefly of diverting snowmelt runoff onto the valley grasslands for several weeks while streamflow rates are high. This diversion is usually sufficient for the production of one cutting of wild hay.

The Upper Colorado River Basin Compact Commission (1948) estimated that the $1914-57$ average annual consumptive use of water in the subbasin by irrigation was about 218,000 acre-feet. The Commission estimated that about 226,300 acres was irrigated and that about 
25,700 acres of land received water incidental to irrigation practices.

\section{DOMESTIC AND INDUSTRIAL USES}

The 1960 population of the subbasin was only about 33,800 , which averages about two persons per square mile. The largest communities and their population are: Rock Springs, 10,371; Green River, 3,497; Kemmerer, 2,028; Mountainview, 1,721; and Pinedale, 965. Principal means of livelihood are farming and ranching, mining, oil recovery, supplying these activities, and the tourist trade.

Rock Springs and Green River receive their water supply from the Green River. All other communities receive their supply from springs, wells, or mountain streams. Rock Springs treats its sewage waste before discharging the effluent into Bitter Creek, an intermittent stream. Inhabitants of a few small communities that are not along stream channels have septic tanks, but for the most part domestic wastes are discharged to the nearest stream channel.

Bituminous coal is mined in the vicinity of Kemmerer and Rock Springs, Wyo. Oil and gas fields have been partially developed, and large reserves have been explored in the vicinity of Big Piney. Extensive deposits of trona (sodium bicarbonate) are in the early stage of development. Only small amounts of water are used in the development of these deposits, and the waste products from the trona mines are ponded in isolated areas away from the streams.

One hydroelectric powerplant with an installed capacity of 180 kilowatts is on Pine Creek near Pinedale, Wyo.

\section{STREAMFLOW}

\section{VARIABILITY OF SEASONAL RUNOFF}

Melting of snow that accumulates in the mountains provides most of the water supply. As temperatures rise in the late spring and early summer, the snow melts and causes the streams to rise. The streams then subside as the stored supply of snow is exhausted. Usually by late July, streams have subsided to near a base flow, which prevails until the cycle is repeated again the following spring. Relatively little runoff comes from much of the interior of the subbasin.

The seasonal patterns of the rise and fall of the streams are dependent on temperature and are similar, but the timing of peak flows and subsidence to base flows are somewhat staggered (fig. 85). Generally, the order of snowmelt runoff by streams is as follows: West-side streams, east-side streams, and streams draining the north slopes of the Uinta Mountains.

\section{FLOW-DURATION CURVES}

Historical flow-duration curves were developed for streams at 30 stations. For 22 of these stations, curves representative of the 44-year base period adjusted to 1957 conditions were prepared. The historical and adjusted curves reduced to tabular form are given in table 5 .

The usefulness of these curves in hydrologic studies, their characteristics, and the methods used to adjust flow-duration curves for short periods of record to the 44-year base period are explained in chapter B ( $\mathrm{pp}$. $45-48)$.

No streamflow record in the subbasin is complete for the 44-year period 1914-57, although records for some stations are complete except for a few years. Because little change in water developments occurred during the 44-year period, no adjustments for upstream developments were required to make the flow-duration curves representative of 1957 conditions; however, some minor changes occurred in irrigation and in storage on Big Sandy Creek and Blacks Fork. No adjustments for any effect that these changes had on the flow-duration curves for downstream stations were made because of lack of data; however, any error introduced in the flowduration curves for downstream stations by this omission is negligible. For extending the record of Green River at Green River, Wyo., the records for the two stations operated "at" and "near" Green River were combined. For all practical purposes the discharge at the two sites is equivalent.

Table 6 outlines the methods used in adjusting the historical flow-duration curves to the 44-year base period and gives the author's rating of accuracy of the resultant long-term curves. Computations and data necessary to show the details of the adjustments are too voluminous for inclusion in this report.

Typical flow-duration curves at four streamflow gaging stations are shown in figure 86 . These curves show duration of water discharge for the Green River near its headwaters and downstream, and for tributary streams from the east and west sides of the basin.

The variability indices (Lane and Lei, 1950) and percentages of ground-water contribution to the stream systems (see chap. B, pp. 48-53) for the streams whose flow-duration curves are shown in figure 86 and for other selected streams are given in table 7. Figure 87 shows the relation between the two parameters.

East Fork near Big Sandy, Wyo., has the highest variability index (0.72), and La Barge Creek near Viola, Wyo., has the lowest (0.28). The difference in slope of the flow-duration curves for the two stations is apparently caused by geologic and topographic factors. The East Fork drainage basin is underlain by relatively impermeable granitic rock, much of which is exposed. The drainage basin also has steep slopes. These factors would contribute to high variability-index 

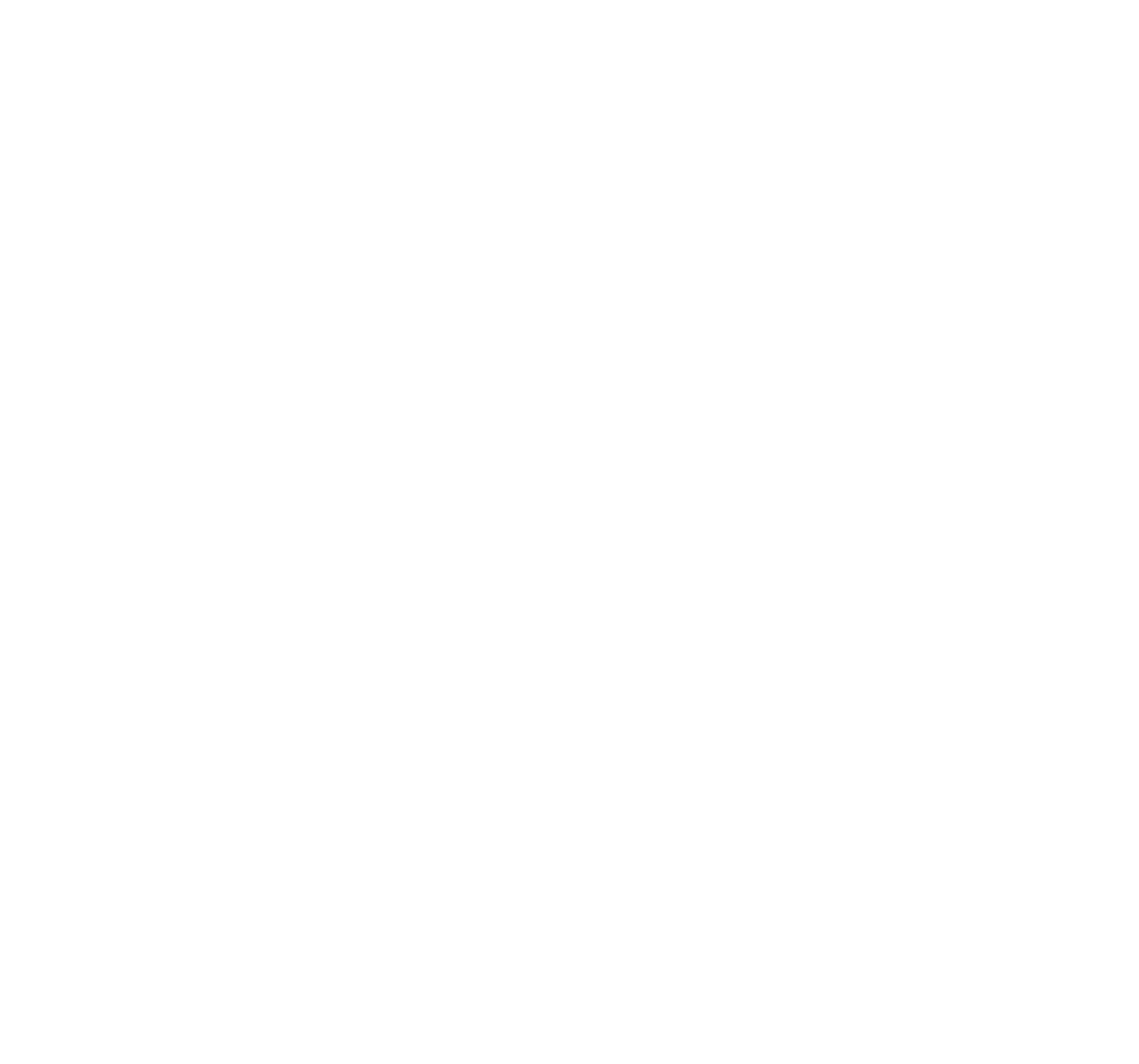

Figure 85.-Seasonal pattern of runoff of streams in the Green River basin above the Yampa River, 1954 water year.

values and little ground-water storage. The underlying rock in the La Barge Creek drainage basin is fractured limestone and other permeable rocks, covered mostly with residuum and alluvium. The valleys of the streams are filled with permeable alluvium, and the drainage basin has relatively flat slopes. These factors would be conducive to ground-water storage and hence to a low variability index for the basin. The drainage basin of Fontenelle Creek, which has the next lowest variability index and next highest percentage of ground-water contribution, has about the same environmental factors as La Barge Creek basin.

The drainage basin above the gaging station on Hams Fork near Elk Creek ranger station, Wyoming, which lies just west of the Fontenelle Creek drainage basin, is underlain principally by relatively impermeable shales. Though other environmental factors are similar to the Fontenelle Creek drainage, the impermeable shales would be conducive to a high index value and little ground-water storage. The variability indices and percentages of ground-water contribution for East Fork at Newfork, Wyo., and Green River at Green River, Wyo., are modified by upstream irrigation.

Explanations of the order of magnitude of the variability indices and ground-water contributions of the other stations in table 7 are not made as it is impossible to evaluate the cumulative effect of the various hydrologic factors where the values are grouped in a small 

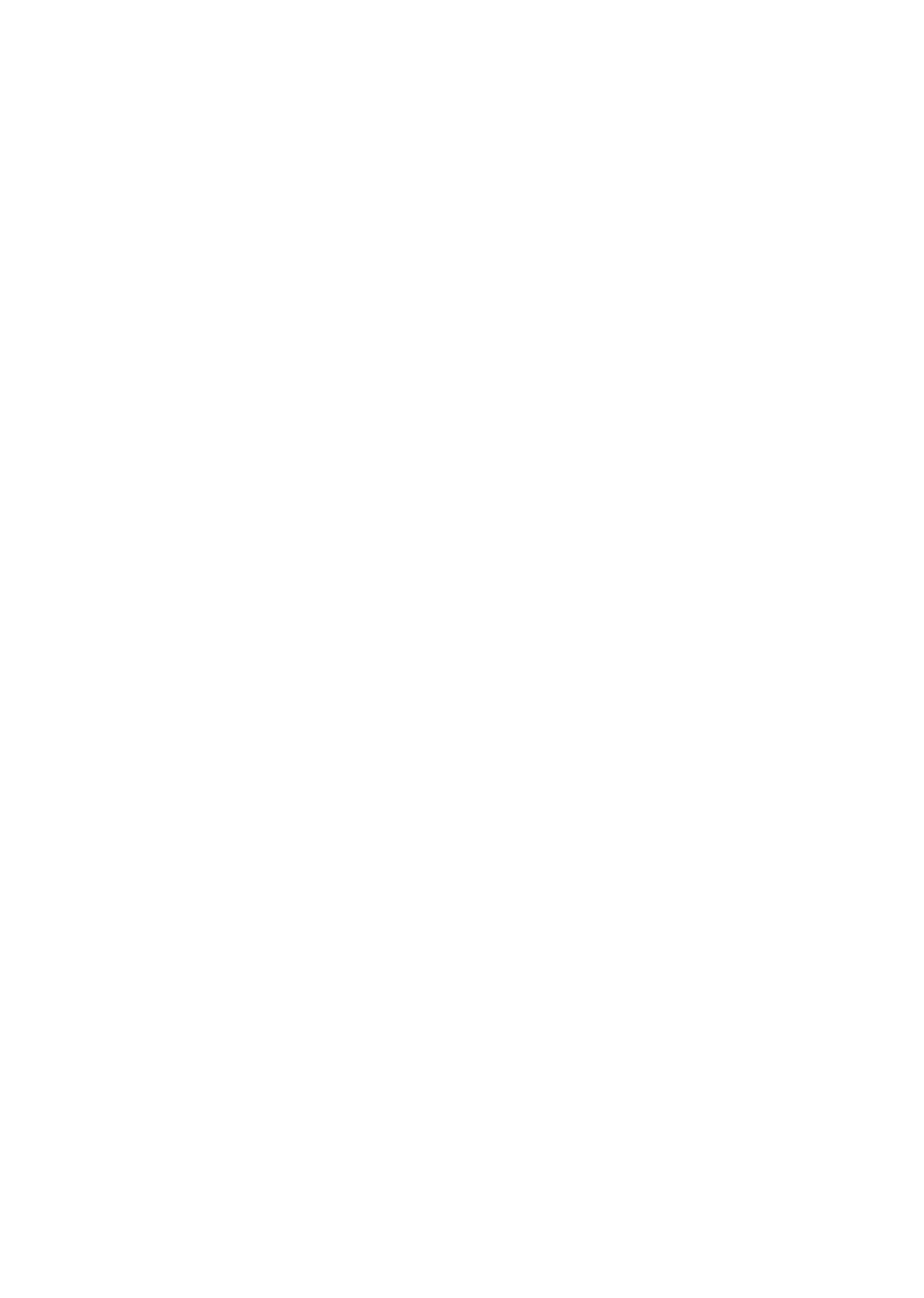

Figure 86.-Flow-duration curves for streams in the Green River basin above the Yampa River, water years 1914-57 adjusted to 1957 conditions. 
range. Logical explanations can be made only where the differences are large.

\section{VARIABIITYY OF ANNUAL RUNOFF}

Annual water discharges at three gaging stations for the base period are shown in figure 88 . None of the station records were complete for the base period, and the records for missing years were estimated. The record for Green River at Warren Bridge, near Daniel, Wyo., was estimated for water years 1914-31; that for Green River at Green River, Wyo., was estimated for water years 1914 and 1940-51; and that for Hams Fork near Frontier, Wyo., was estimated for water years 1914-17 and 1933-45. The histogram for Green River at Warren Bridge, Wyo., exhibits considerably less variability of annual discharges than the histograms for the other two stations.

The coefficients of variation of annual discharges (chap. B, pp. 53-57) for 12 selected streams are given in table 8. These coefficients are also shown on plate 6 . Except for New Fork near Boulder, Wyo., and Green River at Green River, Wyo., the period from about 1940 to 1957 was used in computing the coefficients.

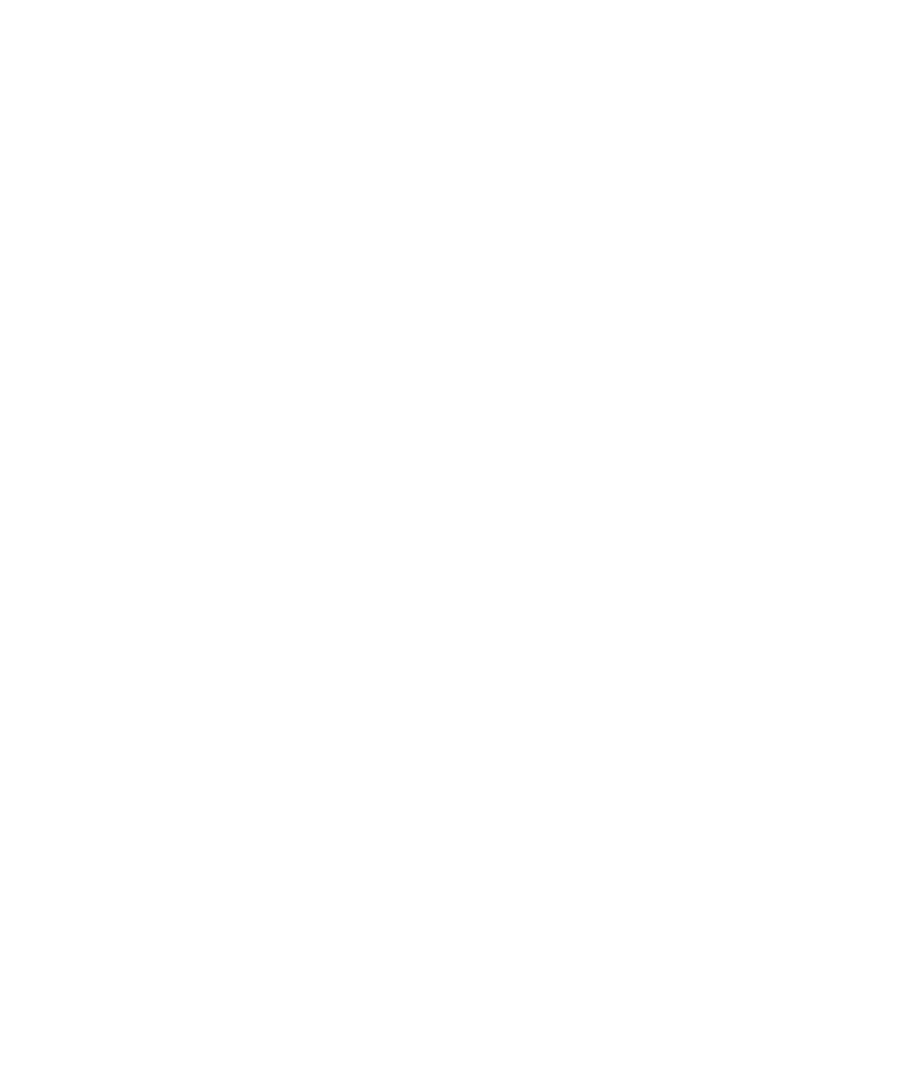

Figure 87.-Relation between the variability index of streamflow and percentage of average annual discharge estimated to be contributed by ground water for selected stations in the Green division, water years 1914-57 adjusted to 1957 conditions.
All streams draining the Wind River Range, except Green River at Warren Bridge near Daniel, Wyo., have an a verage coefficient of about 0.25 . The coefficients of variation of the streams draining the Wyoming Range probably range from about 0.32 at the northern end to about 0.46 at the southern end of the mountains. The coefficients of streams draining the north slope of the Uinta Mountains, except Blacks Fork near Millburne, Wyo., probably average between 0.25 and 0.29 .

If the ground-water storage in the drainage basins above the gaging stations on Green River at Warren Bridge, near Daniel, Wyo., and Blacks Fork near Millburne, Wyo., is sufficient to maintain the streams in drought years and cause the relatively low coefficients of variation, the variability indices for these two stations should also be relatively low, but they are not (table 7). The cause for the lack of consistency is unknown.

If the average annual discharge and coefficient of variation of the stations listed in table 8 are assumed to be representative of the 44-year base period, the data may be used for estimating probable future streamflow for periods of various length and confidence limits, as explained in chapter B (pp. 57-58). The data for Green River at Warren Bridge, near Daniel, Wyo., may be used as an example. The average annual discharge at Warren Bridge for the water years 1914-57 is 532 cfs and the coefficient of variation is 0.18 . The probable deviations for a 50 percent chance for periods of various length in the future from the 44-year average annual discharge are given in the following tabulation:

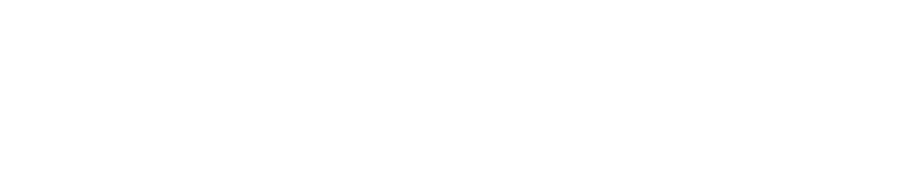

CHEMICAL QUALITY OF WATER

\section{DISSOLVED-SOLIDS DISCHARGE AND CONCENTRATION}

Daily chemical-quality data have been obtained at five stations in the Green River basin above the Yampa River. Monthly and annual weighted-average chemical analyses of water at these stations are given in the basic data report (Iorns and others, 1964, tables 187-192).

In addition to the daily data obtained at the five stations, chemical-quality analyses of streams at other sites in the subbasin have been obtained. The dissolvedsolids discharge for the daily stations and for some of the other sites have been computed (table 9).

Duration tables of dissolved-solids concentration and discharge for the stations listed in table 9 are given in tables 10 and 11. In the computation for these tables, the analyses of water samples, water discharge at the 


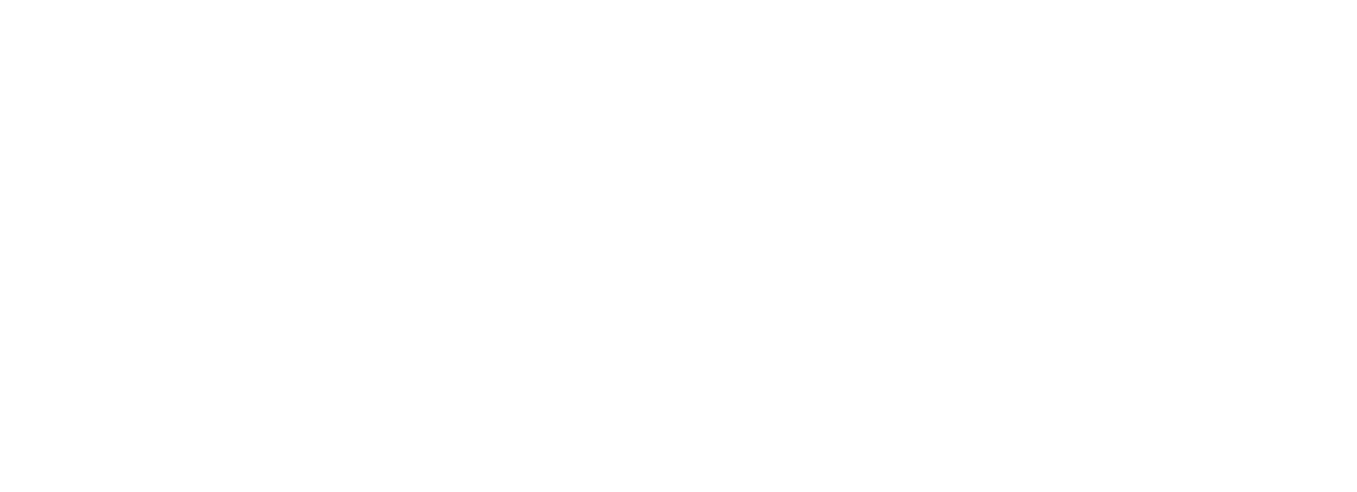

$A$. Green River at Warren Bridge, near Daniel, Wyo.

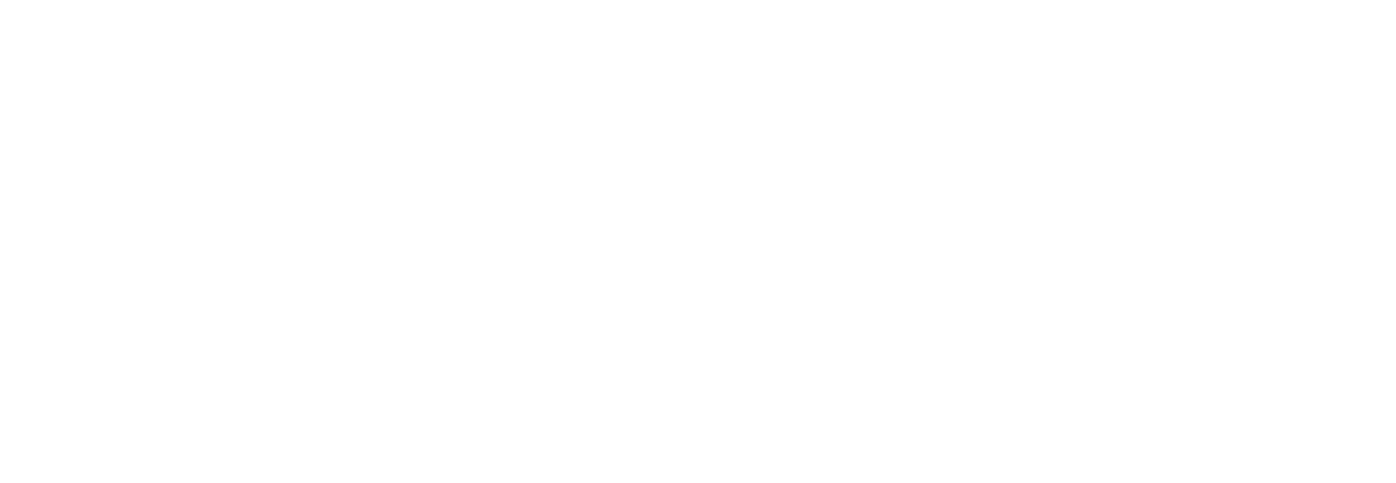

B. Hams Fork near Frontier, Wyo.

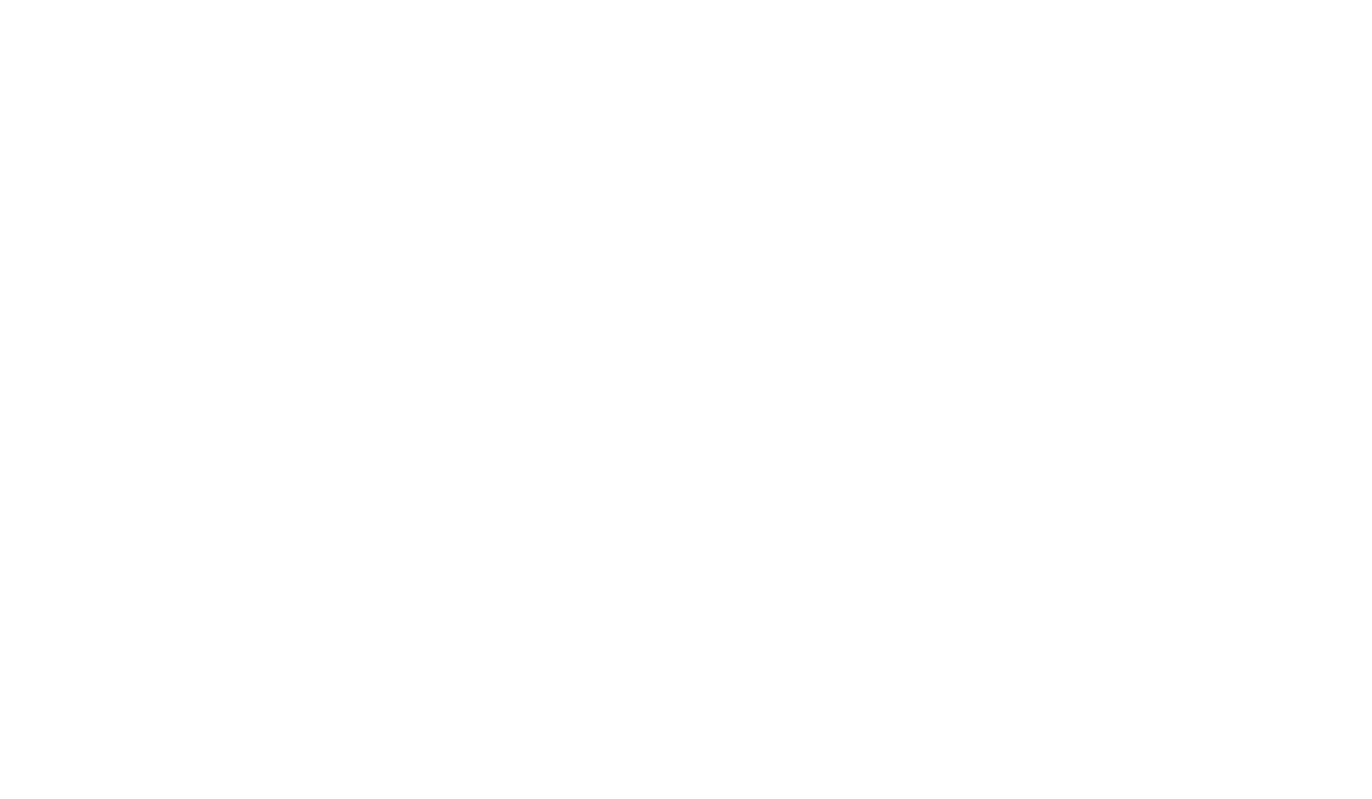

WATER YEAR

C. Green River near Green River, Wyo.

FIGURE 88.-Variability of annual discharges of streams in the Green River basin, above the Yampa River, water years 1914-57.

time of sampling, curves of relation of dissolved-solids concentration and water discharge, and flow-duration curves of water discharge were used. In Chapter B (pp. 58-59) the method used to compute the data is described.
The average annual dissolved-solids discharge for streams in and along the flanks of the Wind River Range ranges from 4 to 75 tons per day and the dissolved-solids yield ranges from 28 to 63 tons per square mile (table 9). Dissolved-solids discharges and yields 
for streams in the Uinta Mountains are similar in magnitude to those in the Wind River Range.

Most of the water passing the gaging station on Green River. near Greendale, Utah, comes from the mountain area, which is relatively small compared with the area of the drainage basin; but a large part of the dissolved solids passing the station comes from the interior, which produces little runoff (table 9 and fig. 89). For example, of the water and dissolved solids passing the Greendale station, about 42 percent of the water and about 11 percent of the dissolved solids come from the mountainous area above Green River at Warren Bridge, New Fork River below New Fork Lake, Pine Creek above Fremont Lake, and East Fork at New Fork gaging stations. The area above these stations is only about 6 percent of that above Greendale station. In contrast, about 3 percent of the water and about 24 percent of the dissolved solids come from the interior area above Green River at Green River gaging station and below Green River near Fontenelle, Big Sandy Creek at Leckie Ranch, and Little Sandy Creek near Elkhorn gaging stations. This area is about 24 percent of that above Greendale station.

\section{VARIATIONS IN CHEMICAL QUALITY}

The seasonal variation in dissolved-solids concentration of most streams is typical of snowmelt-type streams and similar to that illustrated in figure 90 . The concentrations are lowest in the months of maximum discharge-May, June, and July-and concentrations are highest in the months of low flow when the streams are maintained largely by ground water. The seasonal pattern does not change much in years of low and high runoff, as indicated by figure $90 ; 1954$ was a year of relatively low runoff, and 1957 was a year of relatively high runoff.

The coefficients of variation of annual weightedaverage concentrations of dissolved solids and annual historical water discharges were computed for three streams in this subbasin and nine other streams in the Green division (table 12). Explanation of the procedure for determining these values is contained in chapter B (pp. 60-61). The relations of the coefficients for the streams in the Green division are shown in figure 91. The plot does not indicate as good a correlation between the coefficients for the streams in the Green division as was found for streams in the Grand division. If the data for Henrys Fork at Linwood, Utah, were eliminated from the group, the equation of a straight line (least-squares method) averaging the balance of the plotted points in figure 91 would be

$$
V_{d}=0.37 V_{w}-0.05
$$

where $V_{d}$ is the coefficient of variation of weightedaverage annual concentration of dissolved solids and $V_{v}$ is the coefficient of variation of annual stream discharges.

The poorer correlation between the coefficients of variation for the Green division compared with the correlation between those for the Grand division may result from the shortness of available records, which are too short for a reliable statistical analysis. Another contributing factor may be that the dissolved-solids concentrations and the water discharges at some of the sites are greatly affected by the activities of man.

\section{RELATION TO STREAMFLOW}

The relation between streamflow and dissolvedsolids concentration at four stations is shown in figure 92. Similar data are not available for headwater streams. However, from scanty data obtained in the Wind River Range and Uinta Mountains, the dissolved-solids concentration of the headwater streams is known to vary little between low and high discharges. This is principally due to the nearly insoluble rocks in the mountain areas.

The relation between the chemical composition of water and streamflow at five stations is given in table 13 and is illustrated in figure 93 for four of the stations. Contributions of dissolved solids to the streams after they leave the mountains cause an increase in dissolved solids at all rates of flow and increase the range in concentration between low and high rates of water discharge. Relations between water discharge and total dissolved-solids concentration at common percentage points for other sites may be obtained from the flowduration table (table 5) and the duration table of dissolved-solids concentration (table 10).

\section{RELATION TO GEOLOGY}

Precipitation in the Wind River Range and the Uinta Mountains produce most of the runoff. The core of the Wind River Range is composed of granite and associated metamorphic rocks, and the rocks in the higher part of the Uinta Mountains are mostly quartzite. The rocks along the flank of the Uinta Mountains and in the Wyoming Range are sedimentary rocks of a type which is more resistant to chemical and mechanical weathering than the sedimentary rocks of Cretaceous and Tertiary ages that fill the interior of the basin (pl. 2). In these mountains and for different distances from them, the waters are dilute and have similar chemical composition. The weighted-average concentration of the streams in these reaches (see table 9) is usually less than $100 \mathrm{ppm}$ (parts per million). Most of the waters are of the calcium bicarbonate type.

The dissolved-solids concentration of the streams that rise in the mountains increase progressively down- 


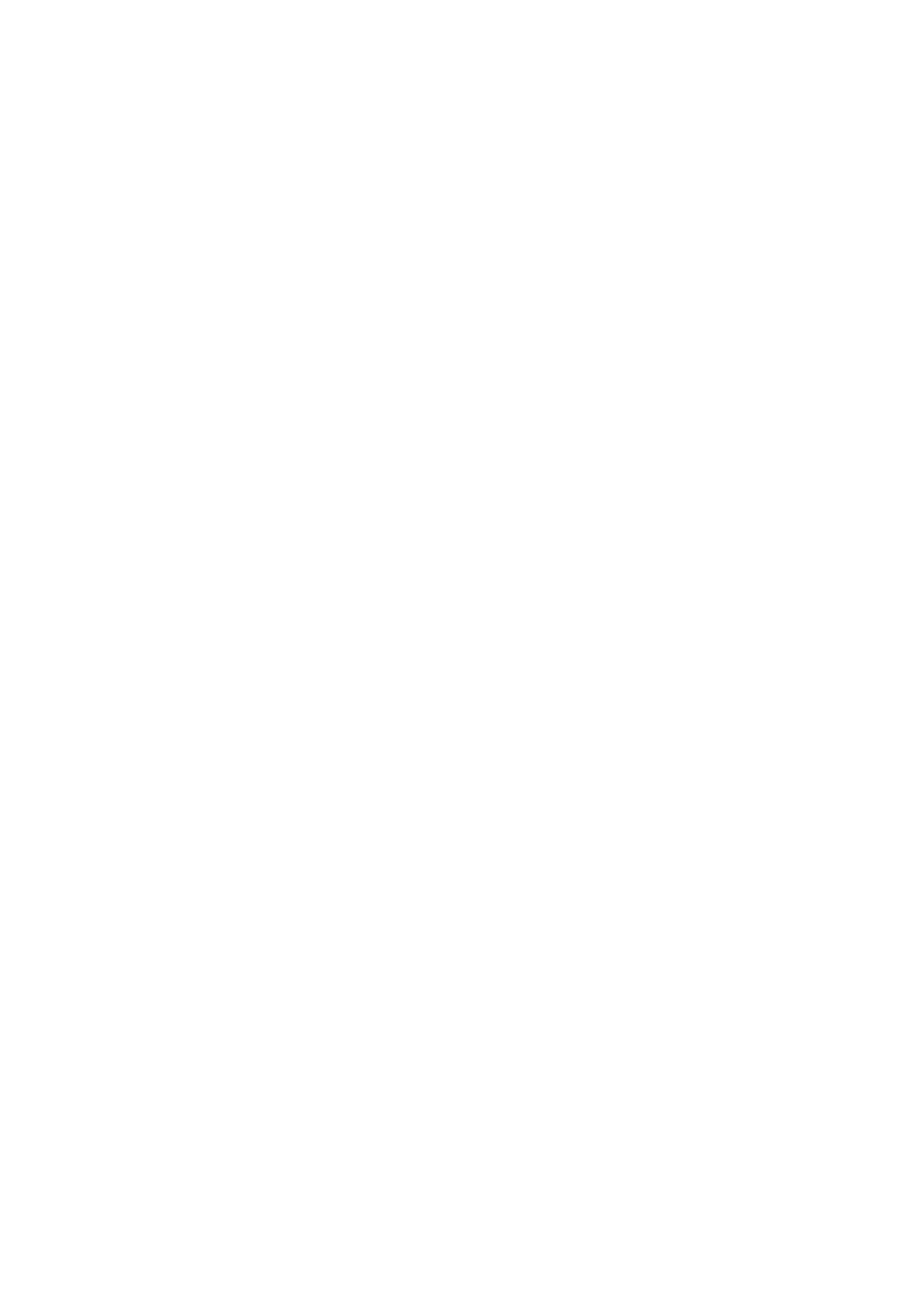

FIGURE 89.-Approximate dissolved-solids discharge and streamflow in the Green River basin above the Yampa River expressed as percentages of dissolved-solids discharge and streamflow of Green River near Greendale, Utah. 


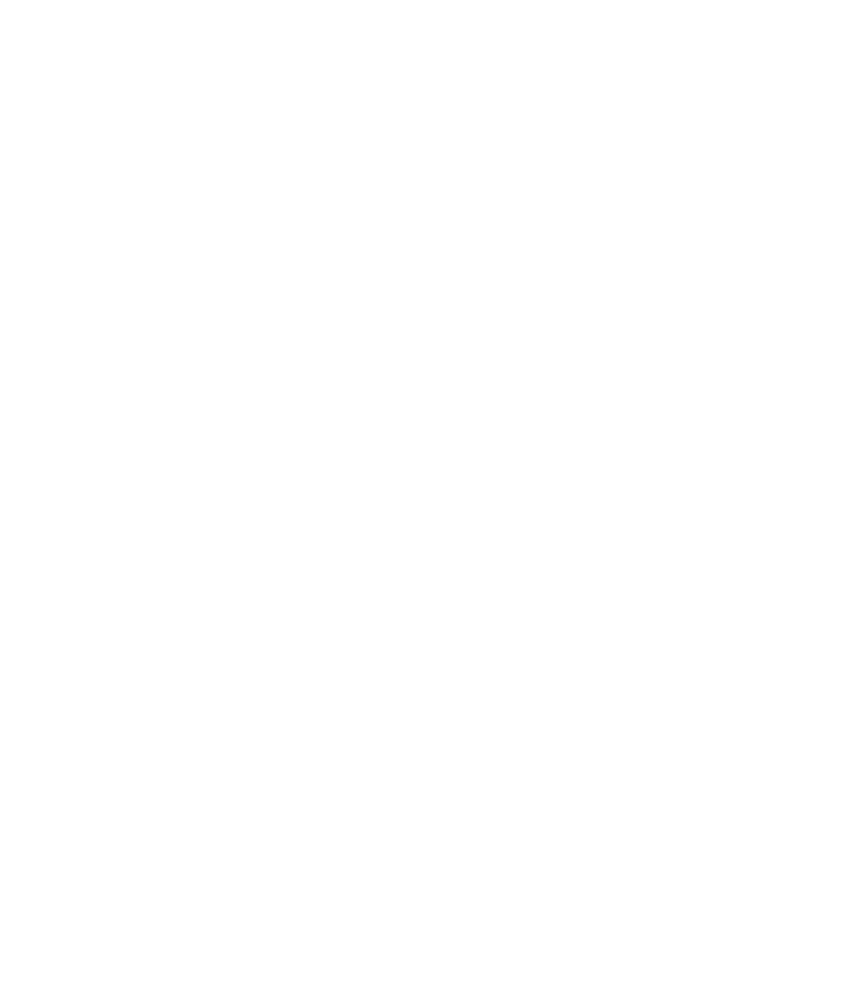

Frgure 90.--Dissolved-solids concentration of Green River at Green River, Wyo., for the 1954 and 1957 water years.

stream. The chemical composition of the waters of the streams also progressively change from principally calcium bicarbonate to greater and greater percentages of magnesium, sodium, sulfate, and chloride. This is because the sedimentary rocks which underlie the interior of the subbasin are mostly siltstones, sandstones, shales, and mudstones with thin but extensive beds of marl and limestone. As these rocks contain soluble minerals in abundance, the streams that drain or pass through areas underlain by them pick up large quantities of soluble minerals.

Zones of weighted-average concentration of surface waters are delineated in figure 94 . These zones indicate that most surface waters in the Green River basin above the Yampa River have a weighted-average concentration of less than $800 \mathrm{ppm}$ and that only a few streams have a weighted-average concentration greater than $1200 \mathrm{ppm}$.

The diagrams in plate 2 show the geochemical character and ionic concentrations of surface waters at 63 sites in the subbasin. The diagrams are representative of the chemical character of the streams during low flow, when the effect of geology on chemical quality is more evident than during high flows. The significance of the size and shape of the diagrams is given in the explanation on plate 2 .

\section{RELATION TO GROUND WATER}

Chemical analyses of ground water are given in the basic data report (Iorns and others, 1964, tables 227229). Though these data are insufficient to permit a detailed appraisal of the effect of ground water on surface water, some of the relations between the quality of water in the ground-water reservoirs and in the streams can be pointed out.

Ground-water inflow to the streams comes from ground-water reservoirs recharged by precipitation,

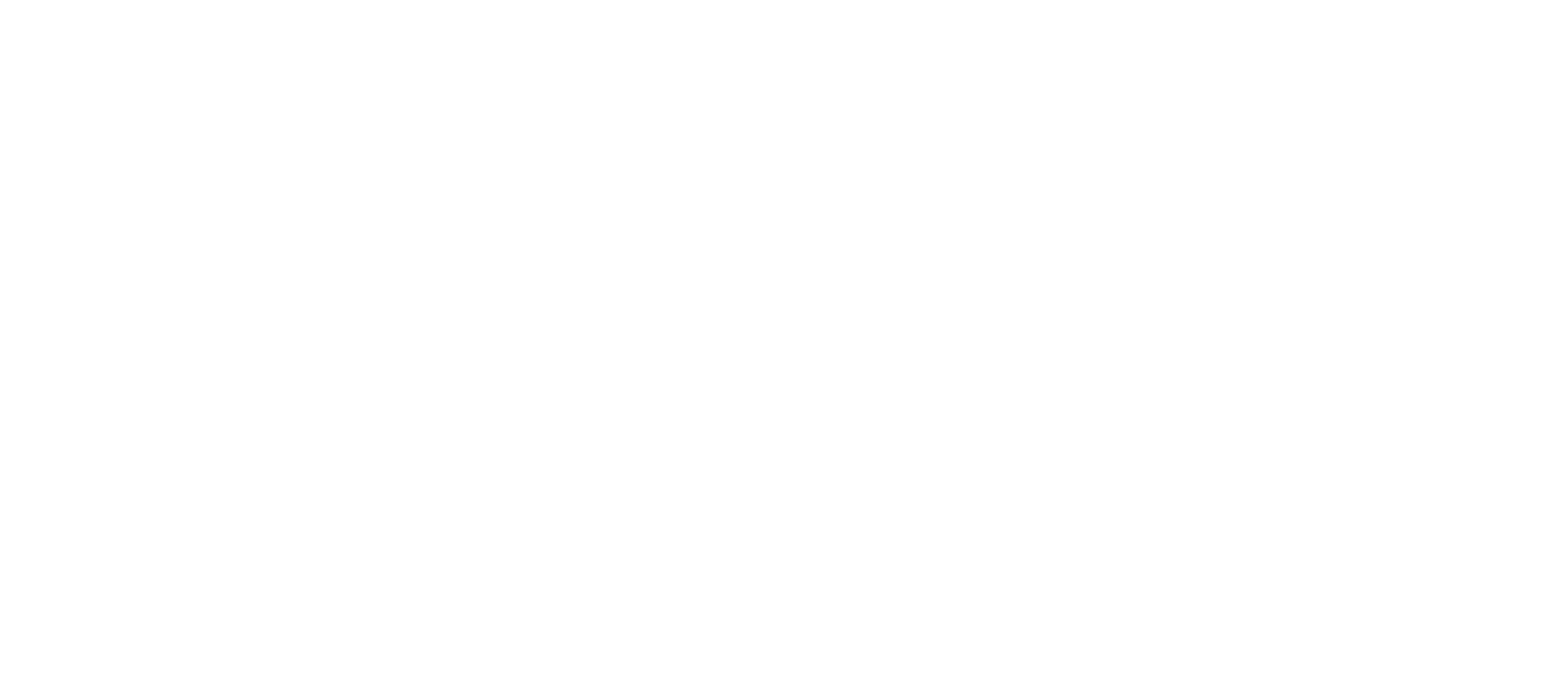

FIGURE 91.-Relation of the variability of dissolved-solids concentration to the variability of water discharge in the Green division. $A$, Green River at Green River, Wyo.; B, Blacks Fork near Marston, Wyo.; $C$, Henrys Fork at Linwood, Utah; $D$. Yampa River at bridge on county road, near Maybell, Colo.; $E$, Little Snake River at bridge on State Highway 318, near Lily, Colo.; $F$, White River near Watson, Utah; $G$, Price River at Woodside, Utah; $H$, Green River at Green River, Utah; I, San Rafael River near Green River, Utah. 

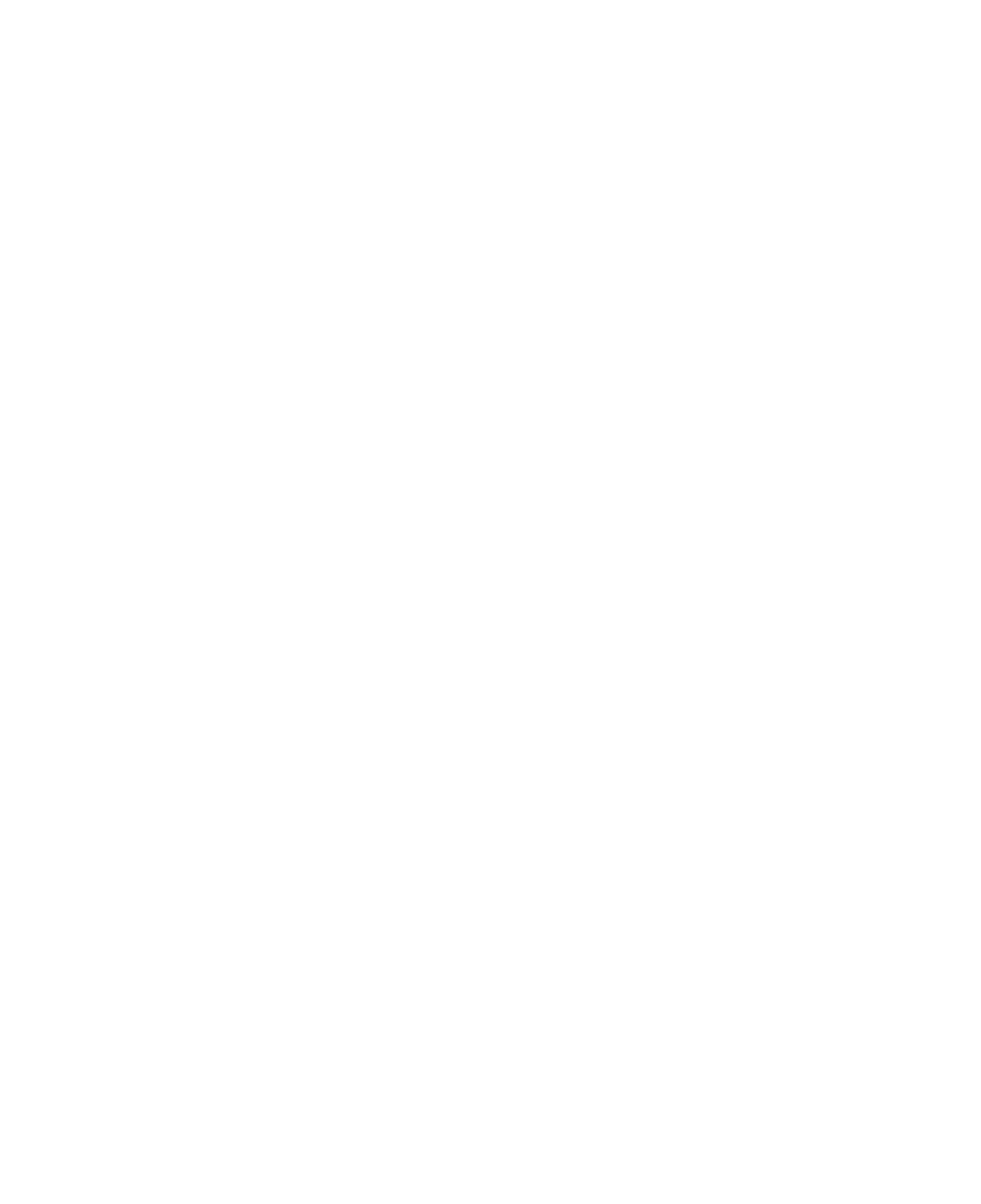

Figure 92,-Dissolved-solids concentration and discharge and water discharge at four dally stations in the Green River basin above the Yampa River. 

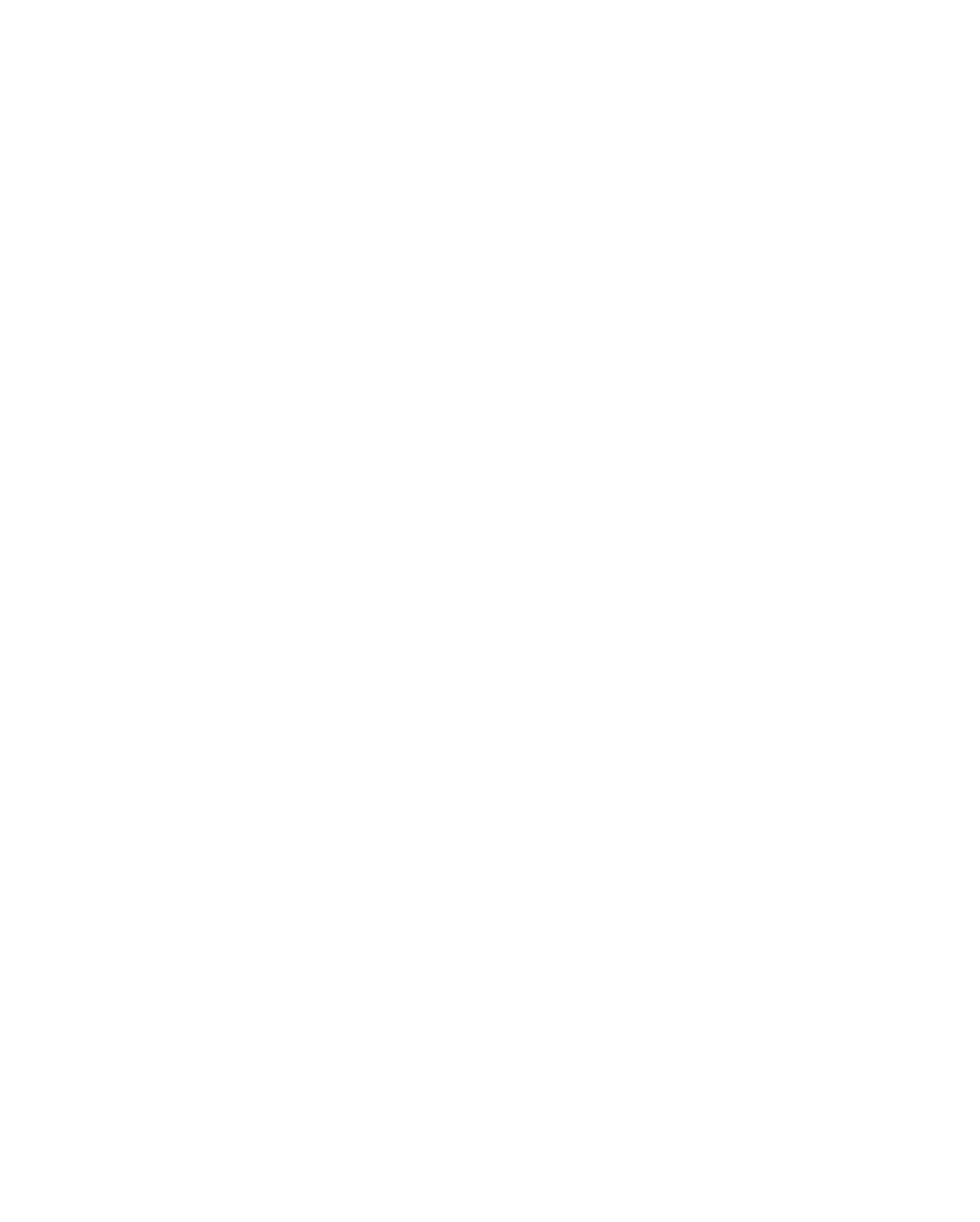

Figure 93.-Relation of the chemical composition and concentration of dissolved solids to water discharge in the Green River basin above the Yampa River. The concentration of specific ions, in equivalents per million (epm), is shown for the 10th, 50th, and 90th percentiles of the flow-duration curve for each location. The flow-duration curves are for the water years 1914-57 adjusted to 1957 conditions, except that for Blacks Fork near Green River, Wyo., which is for water years 1948-57. 


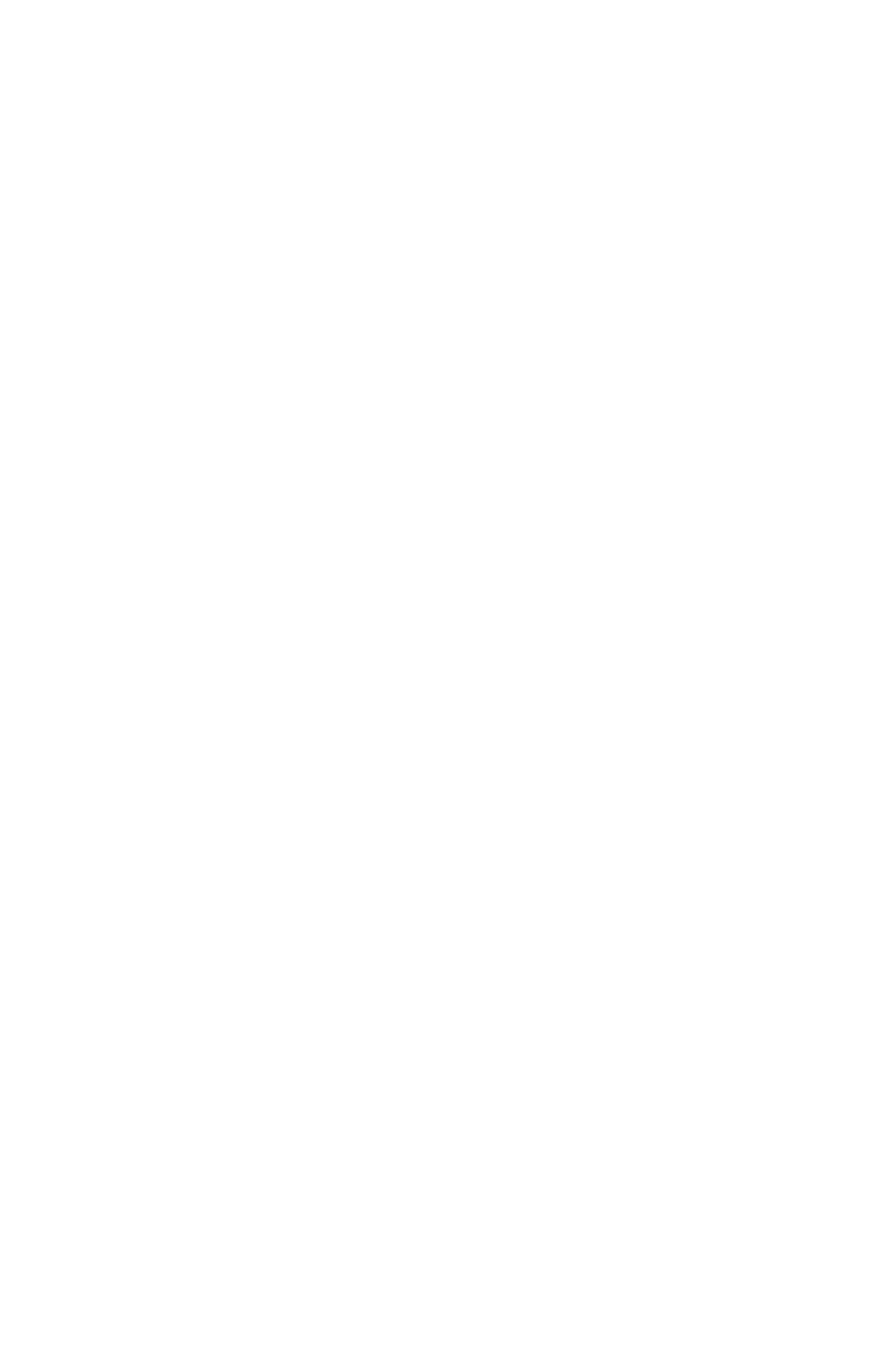

FIGURE 94.-Approximate weighted-average concentration of dissolved solids of streams in the Green River basin above the Yampa River. 
from alluvium bordering the streams which is recharged from the streams, from thermal springs, and from ground-water return flow from irrigated lands. The chemical quality of the ground water entering the streams from these sources greatly influences the chemical quality of the water in the streams. During periods of low flow, most of the stream water is groundwater effluent and is a mixture of all ground water entering the stream system.

Ground-water reservoirs occur in the mountains, where precipitation is abundant. Quantitative estimates of the amount of dissolved solids carried into selected headwater streams by water discharged from these reservoirs have been made (table 14). They are based on the estimated amount of water contributed to the streams from ground-water reservoirs and the dissolved-solids concentration of the water in the streams during the times that the flow is maintained principally by effluent ground water. (See chap. B, pp. 57-60.) Comparison of the weighted-average concentration of dissolved solids in the ground water with the weightedaverage concentration of dissolved solids in the stream shows that the ground water has a higher concentration than the surface water, even after mixing.

Ground water occurs in deeply buried permeable rocks underlying the interior of the subbasin. Recharge to these underlying beds probably comes from areas of fairly high precipitation, where the permeable rocks are exposed along the flanks of the mountains bordering the subbasin. This ground water, however, prob- ably has little relation to the water in the streams of the subbasin as it is confined beneath beds of shale and mudstone.

In the interior, shallow ground water occurs in significant quantities in deposits of glacial outwash in the valleys of New Fork River and its tributaries, in deposits of river alluvium that border and underlie the other streams in the subbasin, and in unconsolidated terrace deposits, residuum, and alluvium that underlie irrigated lands. Ground water in the river alluvium is closely associated with the water in the streams. During high flows in the spring, the surface water from the streams enters the alluvium, circulates through it, and later returns to the stream. In journeying through the alluvium, the water picks up additional amounts of dissolved solids, which are added to the streams by the returning ground water. Much of the water diverted from the streams for irrigation returns to the streams as ground-water inflow.

Figures 95 and 96 show comparisons of the chemical composition of surface water during low flow and of ground water from the alluvium nearby. The analyses illustrated on figure 95 are of samples collected near the mountains, and those on figure 96 are of samples collected at downstream sites. At some of the sites, ground-water inflow would improve the quality of the water in the streams during low flow; but at others, it would have a deteriorating effect. Also, at some of the sites, the chemical composition of the ground water in the alluvium is much different from that of the surface water.

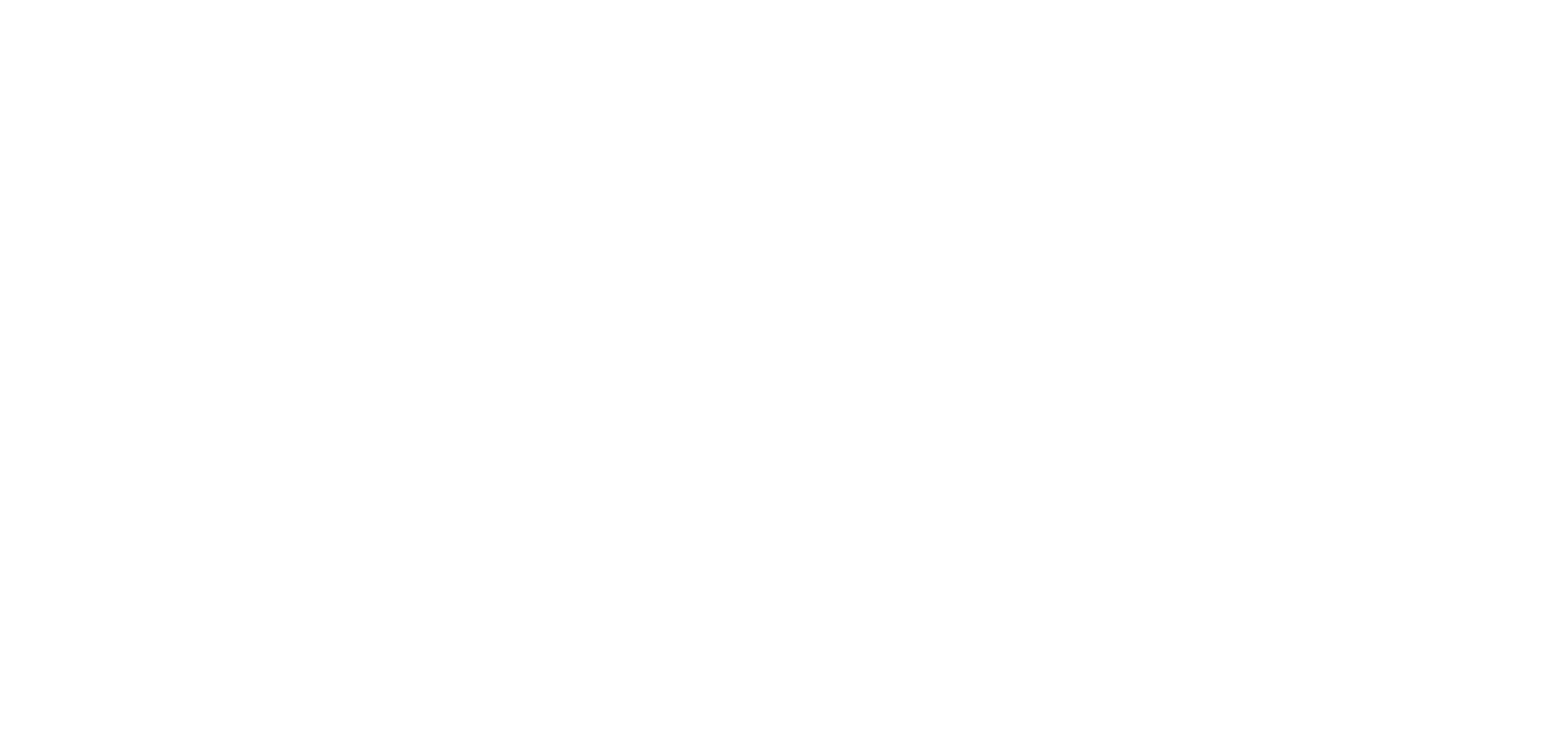

Froure 95.-Analyses of water from selected streams near the mountains in the Green River basin above the Yampa River and from alluvium nearby. 


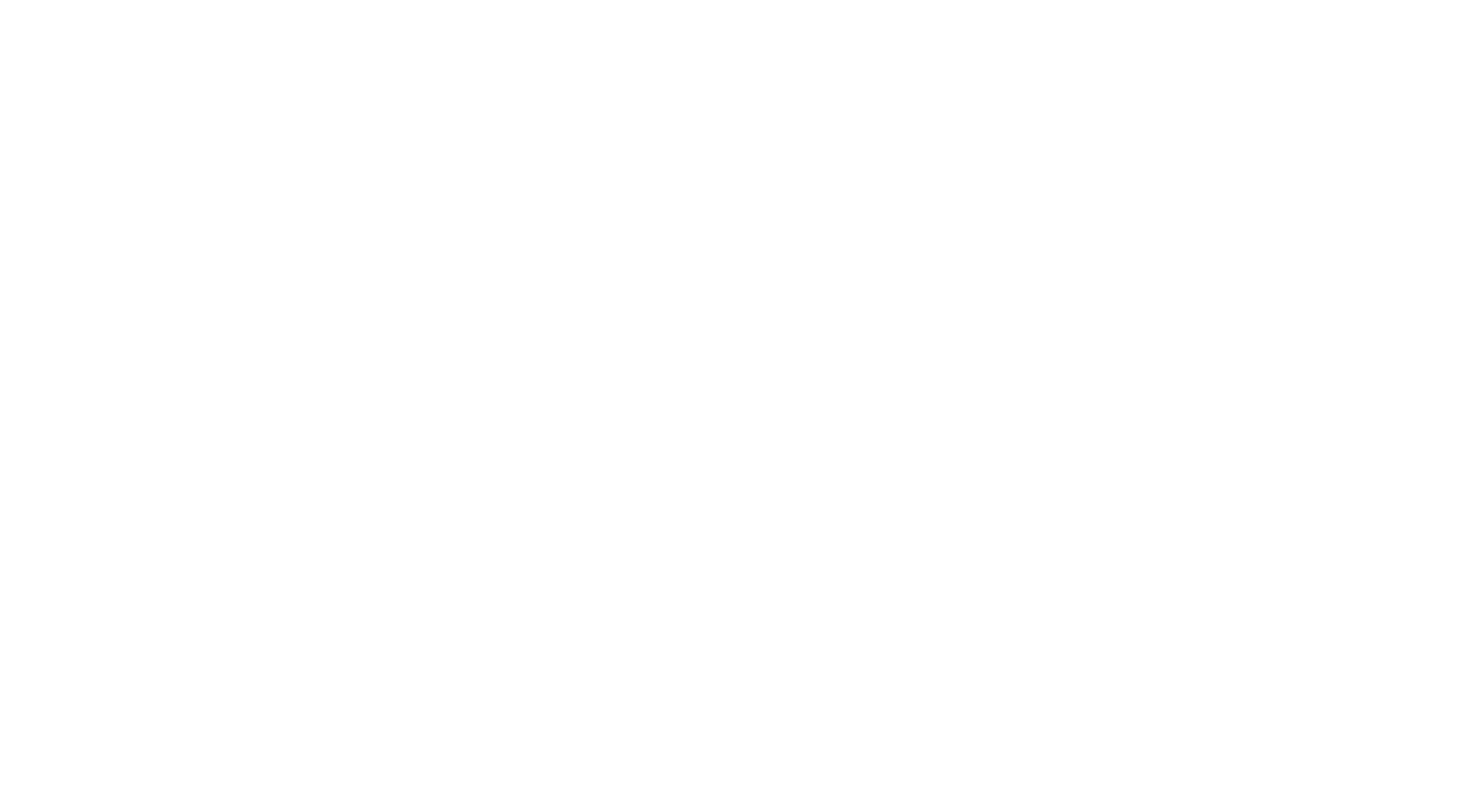

FIGURE 96.-Analyses of water from selected streams in the interior of the Green River basin above the Yampa River and from alluvium nearby.

The amount of ground-water discharge to the streams due to the seasonal rise and fall of the streams is probably not large, but the ground-water return flow from irrigation is probably considerable.

One thermal spring, Steele Hot Spring on the East Fork above New Fork, Wyo., has a flow of about 0.2 cfs and a dissolved-solids concentration of about 300 ppm. The water is of the sodium chloride bicarbonate type. Another spring, on the Green River above Warren Bridge, rises out of the Phosphoria Formation and flows $3 \mathrm{cfs}$ of calcium sulfate type water $(1,000$ ppm). These two springs discharge about 3,000 tons of dissolved solids annually.

\section{EFFECT OF TRANSMOUNTAIN DIVERSIONS}

The Continental Divide ditch which diverts water from Little Sandy Creek is the only transmountain diversion in this subbasin. No records are available on the amount of water diverted annually, but the average concentration of the water diverted probably does not greatly exceed $30 \mathrm{ppm}$. At this concentration, each acre-foot of water diverted would carry with it only 0.04 ton of dissolved solids.

\section{EFFECT OF THE ACTIVITIES OF MAN}

In chapter B (pp. 61-66) the effect of the activities of man, such as domestic and industrial uses of water and irrigation, on the dissolved-solids discharge of streams is discussed. Methods for computing the amount of dissolved solids added to the stream system by these uses are also described in that chapter. For this subbasin, determinations were made for five areas, where data were sufficient to provide a fairly reliable basis for identifying the amount of dissolved solids contributed to the streams by natural sources and the activities of man. In the determinations, water and dissolved-solids data not given in table 9 were estimated on the basis of streamflow records in the annual WaterSupply Papers of the Geological Survey and chemical analyses of water in the basic data report (Iorns and others, 1964, table 221). Dissolved-solids concentration of streams for which chemical analyses were not obtained are based on nearby streams with similar hydrologic and geologic characteristics.

In the drainage basin above the gaging station on New Fork River near Boulder, Wyo., about 29,000 acres is irrigated. The soils of the irrigated land overlie alluvium that is mostly of glacial origin. Table 15 gives an approximate budget of water and dissolvedsolids discharge for the area.

The average annual water and dissolved-solids discharges of New Fork Ri ver below New Fork Lake and near Boulder are given in table 9. The average annual water discharges of Willow, Lake, Pine, Pole, and Fall Creeks are based on the relation of the discharge during periods of available record to the discharge of New Fork River near Boulder for corresponding periods and the 44-year period. The weighted-average concentrations of these creeks are based on chemical analyses of water obtained from them, from East Fork near Big 
Sandy, Wyo., and from Little Sandy Creek near Elkhorn, Wyo. All these streams drain areas in the Wind River Range, consisting mostly of granitic rocks.

The average annual discharge of Duck Creek above the irrigated lands (drainage area, about $25 \mathrm{sq} \mathrm{mi}$ ) is based on the yield of Willow Creek near Cora (153 acre-ft per sq mi per year). The altitude of the two drainage basins is about the same and the drainage basin of Duck Creek is underlain by Tertiary rocks. The concentration of dissolved solids in runoff from this area is estimated to range from 100 to $150 \mathrm{ppm}$.

There is about 215 square miles in the drainage basin below the listed gaging stations and Duck Creek above irrigation and above the gaging station on New Fork River near Boulder. Of the 215 square miles, about 55 square miles is mountainous terrain and has an environment similar to that above the gaging station on Willow Creek near Cora. Water yield and concentration of dissolved solids from the mountainous terrain are based on those for Willow Creek.

About 65 square miles of the 215 square miles consists of low hills and mesa underlain mostly by Tertiary rocks that receive about 12 to 16 inches of precipitation annually. The water yield from this area is estimated to average about 75 acre-feet per square mile annually, and the concentration of dissolved solids in the runoff is probably about the same as that for Duck Creek.

About 95 square miles in the ungaged area is underlain by alluvium of glacial origin. This land is mostly river bottom lands and broad flat alluvial fans. Much of this land is natural meadow, about half of which is irrigated. This area receives about 12 to 16 inches of precipitation annually. It is estimated that under natural conditions about 4,800 acre-feet (50 acre-ft per sq mi) annually was not consumed by the native vegetation but infiltrated to ground water and was effluent to the stream system. Chemical analyses of water from two wells in the area indicate that the concentration of dissolved solids of this ground water would probably range from 140 to $220 \mathrm{ppm}$.

Most of the increase in dissolved-solids discharge from the area is probably the result of irrigation, as there are no industries and the population is small. This increase is equivalent to about 0.5 tons per year per acre of irrigated land.

Between the gaging stations on Fontenelle Creek near Hershler Ranch, near Fontenelle, Wyo., and Fontenelle Creek at Fontanelle, Wyo., about 4,000 acres is irrigated. The irrigated areas are mostly on alluvium underlain by rocks of Tertiary age. An approximate budget of water and dissolved solids entering and leaving the stream reach between the two stations is given in table 15.
The water and dissolved-solids discharges of Fontenelle Creek at the two gaging stations are from table 9. Irrigation consumptive use in the area is estimated to be about 0.8 acre-foot per acre on 4,000 acres of irrigated land. The unmeasured inflow is the amount required to balance the inflow-outflow budget, and the weighted-average concentration of this inflow is estimated to be $211 \mathrm{ppm}$. This concentration is based on the similarity of environmental factors in the intervening reach to those above Fontenelle Creek near Hershler Ranch. Some water may bypass the gaging station on Fontenelle Creek near Fontenelle as underflow or in irrigation canals. However, if one assumes that the increase in dissolved solids in the reach is the result of irrigation and none bypasses the lower station, the increase is equivalent to about 1.3 tons per year per acre of irrigated land.

In the Big Sandy Creek basin about 13,000 acres is irrigated, mostly on lands underlain by the Bridger and Green River Formations of Tertiary age. In the area below the gaging stations on Big Sandy Creek near Farson, Wyo., Little Sandy Creek above Eden, Wyo., and Pacific Creek near Farson, Wyo., and above the gaging station on Big Sandy Creek below Eden, Wyo., about 11,000 acres is irrigated. An approximate budget of water and dissolved solids entering and leaving the area is given in table 15 .

The water and dissolved-solids discharge of Big Sand Creek near Farson (drainage area, $320 \mathrm{sq} \mathrm{mi}$ ) and below Eden (drainage area, 1,610 sq mi) are from table 9. The water discharge of Little Sandy Creek above Eden (drainage area, $170 \mathrm{sq} \mathrm{mi}$ ) for the 1914-57 period is based on correlation with Little Sandy Creek near Elkhorn, Wyo., and the dissolved-solids concentration is based on water analyses obtained between November 1954 and July 1958. The water discharge of Pacific Creek near Farson (drainage area, about $500 \mathrm{sq} \mathrm{mi}$ ) is based on water years $1950-60$, which are probably representative of the long-term period. The dissolved-solids concentration of Pacific Creek is based on water analyses obtained between November 1954 and October 1958. The unmeasured inflow from the 620 square miles of intervening drainage area is estimated from the discharge of Pacific Creek (6 acre-ft per sq $\mathrm{mi}$ ) because of similarity of environment. The concentration of dissolved solids in the runoff from the ungaged area is estimated to be the same as Pacific Creek because of similarity of underlying rocks. The depletion in the reach is the amount necessary to balance the inflow-outflow budget.

The depletion indicates a consumptive use of about 4 acre-feet per acre of irrigated land. The Upper Colorado River Basin Compact Commission (1948) esti- 
mated that irrigated lands in this area consumed about 1.3 acre-feet per acre. It may be that the water table under the irrigated lands has not reached a state of equilibrium and some of the applied water is going into ground-water storage, or that considerable underflow is passing Big Sandy Creek below Eden, Wyo. The relatively high runoff per square mile (29 acrefeet per year) from the Green River basin between Green River near Fontenelle Wyo., and Green River at Green River, Wyo., exclusive of Fontenelle and Big Sandy Creeks, indicates that underflow may occur. This area has low precipitation, about 8 to 10 inches (pl. 6). The increase of dissolved solids in the intervening area $(49,000$ tons $)$, if all assigned to irrigation (11,000 acres), is equivalent to about 4.4 tons per year per acre of irrigated land. However, if water and dissolved solids are going into ground-water storage or underflow is occurring, the rate of dissolved solids leaching from the soil and rocks underlying the irrigated lands would be considerably higher.

In Blacks Fork basin about 74,500 acres of land is irrigated. Most of the irrigated lands are on river alluvium underlain by the Green River and Bridger Formations, except the irrigated lands along Hams Fork above Kenmerer, Wyo., which are partly underlain by the Wasatch Formation. Table 15 gives an approximate budget of water and dissolved-solids discharge for an area on Blacks Fork in which 59,500 acres is irrigated. The $1939-57$ period of record is closely equivalent to the 1914-57 period.

The water and dissolved-solids discharges of Blacks Fork near Millburne (drainage area, $156 \mathrm{sq} \mathrm{mi}$ ) and near Lyman (drainage area, $821 \mathrm{sq} \mathrm{mi}$ ) are from table 9. The weighted-average concentrations of East (drainage area, $53 \mathrm{sq} \mathrm{mi}$ ) and West (drainage area, $37 \mathrm{sq} \mathrm{mi}$ ) Forks of Smith Fork are estimated to be the same as Blacks Fork near Millburne because their environments are similar. Below the three inflow gaging stations there is about 30 square miles of mountainous terrain that receives about 16 to 20 inches of precipitation annually. Runoff from this terrain is estimated to average about 200 acre-feet per year per square mile and to have the same dissolved-solids concentration as the headwater streams. The foothill area between the mountains and the lowlands receives an average annual precipitation of 12 to 16 inches. Annual runoff from the foothill area (drainage area, about $30 \mathrm{sq} \mathrm{mi}$ ) is estimated to average about 50 acrefeet per square mile. This area is underlain by the Bridger and Browns Park Formations. The concentration of dissolved solids in the runoff from this area is $500 \mathrm{ppm}$, which is based on chemical analyses of Cottonwood Creek below Sage Creek, near Mountainview, Wyo. (See basic data report, Iorns and others, 1964, table 221.) The drainage basin of Cottonwood Creek is mostly underlain by the Bridger and Browns Park Formations.

River valley and lowlands occupy about 515 square miles of the intervening area between the Blacks Fork inflow and outflow stations. Average annual precipitation over this area is only about 7 to 10 inches, and annual runoff is estimated to average about 10 acre-feet per square mile and to have a dissolved-solids concentration of $500 \mathrm{ppm}$.

The depletion in the area is the amount necessary to balance the inflow-outflow budget. Most of the depletion of 77,500 acre-feet is probably due to irrigation consumptive use. The increase of dissolved solids in the reach, $52^{\prime}, 800$ tons, is equivalent to 0.9 ton per year per acre of irrigated land.

The water and dissolved-solids discharges for Hams Fork near Elk Creek ranger station and near Frontier are given in table 9. The irrigation consumptive use is estimated to be about 1.2 acre-feet per acre on the 4,000 acres of irrigated land. The unmeasured inflow is the amount required to balance the inflow-outflow budget. As the environmental factors in the intervening reach are similar to those above Hams Fork at Elk Creek ranger station, the concentration of dissolvedsolids in the unmeasured inflow is probably the same. The increase in dissolved solids in the area is equivalent to 0.25 ton per year per acre of irrigated land. Table 15 gives a water and dissolved-solids budget for the area on Hams Fork, where about 4,000 acres are irrigated.

Estimates were made of the dissolved solids contributed by natural sources and the activites of man for other areas in the subbasin. The estimates were based on the indicated rates of yield per acre of irrigated land for the selected areas and other selected areas in the Upper Colorado River Basin, the geologic character of the formations underlying irrigated lands, and chemical analyses of water at miscellaneous sites in this subbasin. In the estimates it was assumed that the distribution of population and industry were approximately proportional to the distribution of irrigated. lands. In table 16 the dissolved solids estimated to be contributed from natural sources and the activities of man are summarized at main-stem gaging stations and for the subbasin.

If there were no activities of man in the subbasin, the weighted-average concentration of dissolved solids of Green River near Greendale, Utah, would have been about 209 ppm as compared with a weightedaverage of $378 \mathrm{ppm}$ for water years 1914-57 adjusted to 1957 conditions. In this determination 2,300 acrefeet annually was estimated to be consumed by domes- 
tic and industrial uses and 218,000 acre-feet by irrigation.

The increase in dissolved solids due to irrigation is estimated to be about 317,100 tons per year. This estimate is based on assigning 100 tons per year per 1,000 people as the contribution of dissolved solids from domestic and industrial uses of water and attributing the balance of the dissolved solids to irrigation.

\section{FLUVIAL SEDIMENT}

Daily suspended-sediment records have been obtained at Green River at Green River, Wyo. The annual suspended-sediment discharges at this station are given in table 17. Estimates of the suspended-sediment discharge at several stations in the subbasin are given in table 18.

Apparently most of the sediment comes from the interior of the subbasin, which is underlain by rocks of Cretaceous and Tertiary ages. The suspendedsediment contribution to the Green River from the 5,130 square miles of drainage area between Green River at Green River, Wyo., Blacks Fork near Green River, Wyo., and Henrys Fork at Linwood, Utah, and the Yampa River is estimated to be about $1,946,400$ tons annually. This estimate is computed by prorating, on the basis of drainage area, the difference in suspended-sediment discharge between Green River near Jensen, Utah, and the sum of suspended-sediment discharges at Green River at Green River, Wyo., Blacks Fork near Green River, Wyo., Henrys Fork at Linwood, Utah, Yampa River at bridge on county road near Maybell, Colo., and Little Snake River at bridge on State Highway 318, near Lily, Colo. The computed yield from the 7,280 square miles of intervening drainage area is 380 tons per square mile per year.

\section{SUITABILITY OF WATER FOR VARIOUS USES}

\section{DOMESTIC USE}

The classification of the surface waters in the Green River basin above the Yampa River is based on water quality criteria for major uses. (See chap. B, pp. 66-73.)

Chemical analyses of the waters of the Green River and its perennial tributaries above the Yampa River indicate that the water of the main stem and of its tributaries in their headwaters are suitable for domestic purposes. In the lower reaches of some of the perennial tributaries and in the ephemeral streams that rise in the interior of the basin, concentrations of magnesium, chloride, and sulfate sometimes exceed the permissible maximum concentrations for domestic use. Hardness of the vaters ranges from soft in the headwater areas to very hard in the middle and lower reaches of the tributaries. Nitrate is present in all the streams but usually in concentrations of less than 5 ppm.

\section{AGRICULTURAL USE}

Table 19 classifies most of the surface waters of the Green River basin above the Yampa River according to their suitability for use in irrigation under conditions of development existing in 1957. Chemical analyses of surface water that are representative of low, medium, and high flows for many sampling sites were used to prepare the table.

All the terms in the boxheads of table 19 are selfexplanatory or are explained on pages 69-73 in chapter B, except the classification of water discharge as low, medium, or high. High flows are those greater than the flow exceeded 20 percent of the time, low flows are those less than the flow exceeded 80 percent of the time, and medium flows are those greater than the flow exceeded 80 percent of the time but less than the flow exceeded 20 percent of the time. The ranges of low, medium, and high discharges for most of the sampling sites were determined from table 5 .

Only a few of the streams, even during low flows, contain residual sodium carbonate in excess of 1.25 epm (equivalents per million), which is the maximum considered to be safe for irrigation use.

The surface waters range from $\mathrm{C} 1-\mathrm{S} 1$ to $\mathrm{C} 4-\mathrm{S} 4$, but most of the water used for irrigation would be classified as C2-S1 water or better. According to the U.S. Salinity Laboratory Staff (1954), waters of C2 class "can be used if a moderate amount of leaching occurs. Plants with moderate salt tolerance can be grown in most cases without special practices for salinity control." $\mathrm{S} 1$ signifies that the water "can be used for irrigation on almost all soils with little danger of the development of harmful levels of exchangeable sodium."

The required leaching computed by Eaton's formulas is generally low and can easily be satisfied on most of the irrigated lands. Though many of the waters indicate that addition of gypsum is required, this would not be necessary as most of the soils probably contain sufficient available calcium.

\section{INDUSTRLAI AND RECREATIONAI USES}

The surface water in most of the headwaters can be used by many industries without treatment. However, most stream water near the centers of population would require treatment before it could be used for most industries.

Most of the lakes and perennial streams in the headwaters of the subbasin are ideal for recreational use. The economy of several towns, for example, Pinedale, Wyo., is partly based on hunting and fishing. The use of surface waters for recreational use is ex- 
panding rapidly and will probably continue to do so as the population continues to increase.

\section{YAMPA RIVER BASIN}

\section{PRESENT UTILIZATION OF SURFACE WATER}

\section{STORAGE RESERVOIRS}

Stillwater Reservoir No. 1, on the headwaters of Yampa River, capacity about 6,200 acre-feet (U.S. Geol. Survey, 1959, p. 194), is the only reservoir in the Yampa River Subbasin with storage capacity greater than 1,000 acre-feet. There are, however, many small lakes, small reservoirs, and stock ponds.

\section{TRANSMOUNTAIN DIVERSIONG}

There are no diversions out of this subbasin to the east slope of the Continental Divide. Two small diversions, on which no data are available, transport water from the subbasin to Rock Creek, a tributary of the Colorado River in the Grand division.

\section{IRRIGATION}

The U.S. Bureau of the Census (1953) reported a total of 73,700 acres of irrigated land in 1949 (table 4). Of this total, 22,000 acres is above Steamboat Springs, Colo., 20,400 acres is in the Little Snake River basin, and the remaining acreage is distributed along the Yampa River and tributary valleys. Of the total irrigated acreage, about 15,700 acres is in Wyoming and about 58,000 acres is in Colorado.

The Upper Colorado River Basin Compact Commission (1948) estimated that the 1914-45 average annual consumptive use of water in the subbasin due to irrigation practices was about $82^{\prime}, 000$ acre-feet. The Commission estimated that 75,579 acres of land was irrigated; 11,551 acres was irrigated by natural overflow, and 24,344 acres of land received water incidental to irrigation practices.

\section{DOMESTIC AND INDUSTRIAL USFG}

The 1960 population was about 14,000 , less than two persons per square mile. The five largest communities and their populations are Craig, 3,984; Steamboat Springs, 1,843; Hayden, 864; Mount Harris, 730; and Oak Creek, 666; all in Colorado. The principal means of livelihood are farming, ranching, and tourist trade.

The five largest communities receive their water supplies from surface-water sources. Craig has a per capita use of water of about 175 gpd (gallons per day) and Hayden has a per capita use of water of about $90 \mathrm{gpd}$ (Gregg and others, 1961). No data are available for the other communities. For the report, the average consumptive use of water in the subbasin for domestic and industrial purposes is estimated to be about 60 gpd per capita, or about 900 acre-feet annu- ally. The five largest communities have septic tanks for treatment of sewage.

Oil and gas deposits have been developed in an area south of Craig, in the Williams Fork basin. Other than a small meat-processing plant at Craig and milk and locker plants at Steamboat Springs, there are no industries in the subbasin and no hydroelectric plants.

\section{STREAMFLOW}

VARIABILITY OF GEASONAL RUNOFF

The Yampa River rises in the Park Range along the Continental Divide and flows westward to its junction with the Green River. Snowmelt is the principal source of water supply in the subbasin, and the pattern of seasonal runoff of the river and its tributaries is like that of other streams in the Upper Colorado River Basin that have similar environment (fig. 97). Generally, summer precipitation has small effect on the discharge of the principal streams. The base flow of the streams draining the high mountain areas is usually very uniform for about 9 months of each year. The streams draining the areas of lower altitude in the central and western part of the basin are intermittent.

\section{FLOW-DURATION CURVES}

Historical flow-duration curves were developed for streams at 13 stations. The record at one of the stations was complete for water years 1914-57, and three other records were complete for more than 34 years. Using the methods described in chapter B (pp. 46-48), flow-duration curves for 12 streams were adjusted to the 44-year base period. As there was apparently little change in irrigated acreage during the 1914-57 period, no adjustment of the historical data to conditions existing in 1957 was made. The data on the historical and adjusted curves are given in table 5. Two examples of flow-duration curves are shown in figure 98. Both curves are typical of snowmelt-type streams.

In table 6 the methods used in adjusting the historical flow-duration curves to the 44-year base period are outlined, and the authors' rating of accuracy of the resultant long-term curves are given.

Table 7 gives the variability indices of streamflow and percentage of average annual discharge estimated to be contributed to the streams by ground water at four streamflow stations. Only headwater streams not affected appreciably by irrigation are included in the listing, which is arranged in order of magnitude of the variability indices.

The water-producing area of the stream having the lowest index value and highest ground-water contribution (station 2375) is underlain by Tertiary volcanic rocks which are relatively permeable. A reser- 


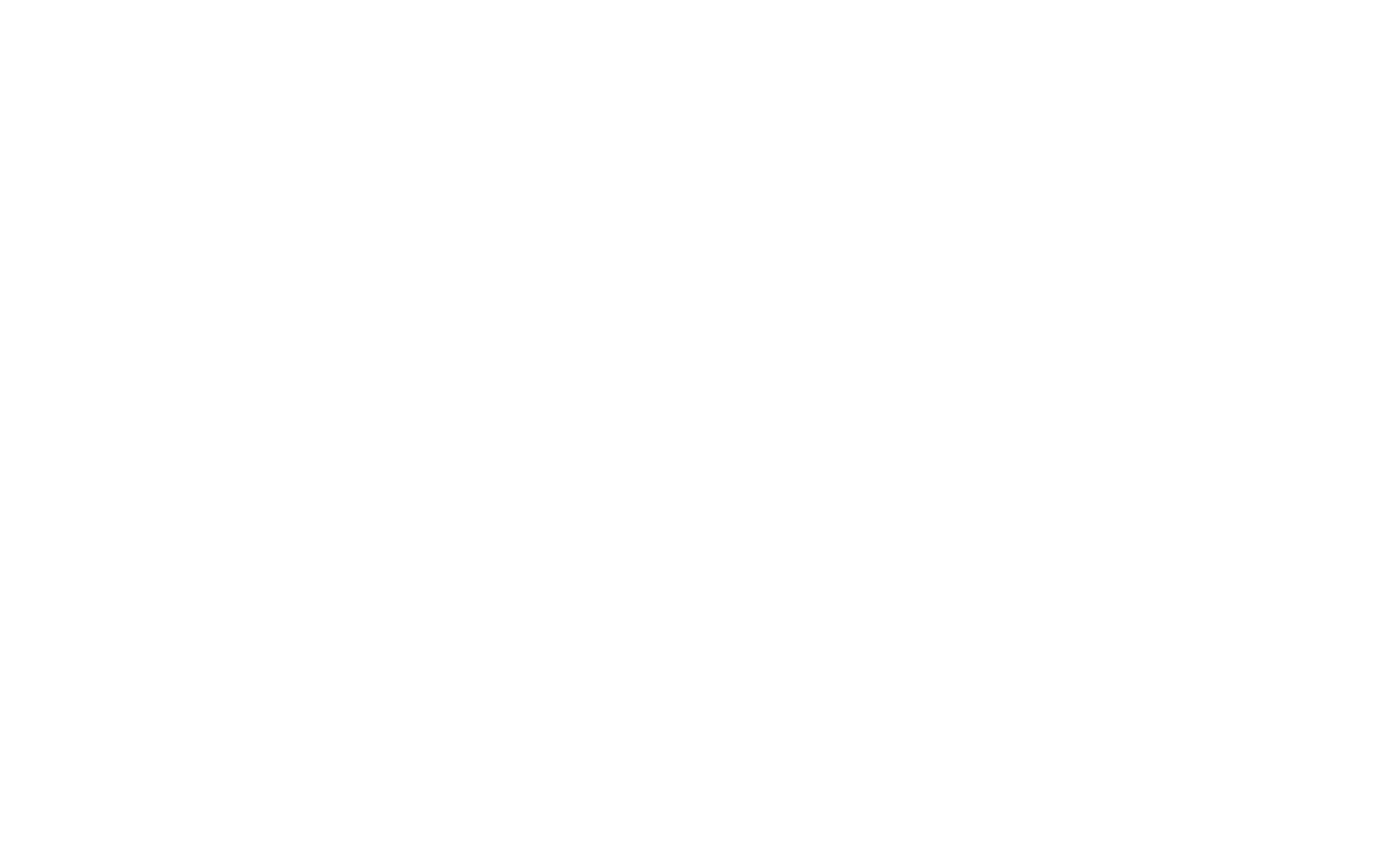

Figure 97.-Seasonal pattern of runoff in the Yampa River basin, 1954 water year.

voir of 6,200 acre-feet capacity is in the headwaters of this stream.

The water-producing areas of the two streams having the highest variability-index values and lowest percentage of ground-water contribution are underlain by Precambrian rocks. These rocks are relatively impermeable, which would tend to cause high index values and low ground-water contribution. The drainage basin of Savery Creek at upper station, near Savery, Wyo., is underlain in part by Precambrian rocks and in part by the Dakota Sandstone and Morrison Formation of Cretaceous age. The combination of relatively impermeable rocks of Precambrian age and the more permeable sandstones of Cretaceous age in the drainage basin causes the variability index and percentage of ground-water contribution to fall in the intermediate range.

The relation between the variability indices and percentage of ground-water contribution is shown in figure 87 .

\section{VARIABILITY OF ANNUAL RUNOFF}

The histograms in figure 99 show that annual variations in discharge of the Yampa River are less than that of the Little Snake River. Less variation in annual precipitation in the Yampa River drainage basin above
Steamboat Springs, Colo., than in the Little Snake River drainage basin is probably the principal cause for the greater variations in the Little Snake River. The streamflow record for the Yampa River at Steamboat Springs is complete for the 44-year period. The record for the Little Snake River near Dixon was estimated for water years 1924-38.

The coefficients of variation (chap. B, pp. 53-57) of annual discharges at four streamflow stations are given in table 8 and are plotted on plate 6 . The greater variability of the discharge of the Little Snake River as compared with that of the Yampa River is shown by the higher coefficient. These data may be used in determining probable future water discharge for periods of various length. (See p. 191 and chap. B, pp. 57-58.)

\section{CHEMICAL QUALTTY OF WATER}

\section{DISSOLVED-SOLIDS DISCHARGE AND CONCENTRATION}

Daily chemical-quality data have been obtained at two stations in the Yampa River basin. Monthly and annual weighted-average chemical analyses of water at these stations are given in the basic data report (Iorns and others, 1964, tables 193, 194). In addition to these data, chemical-quality analyses of streams at other sites in the subbasin have been obtained. The 

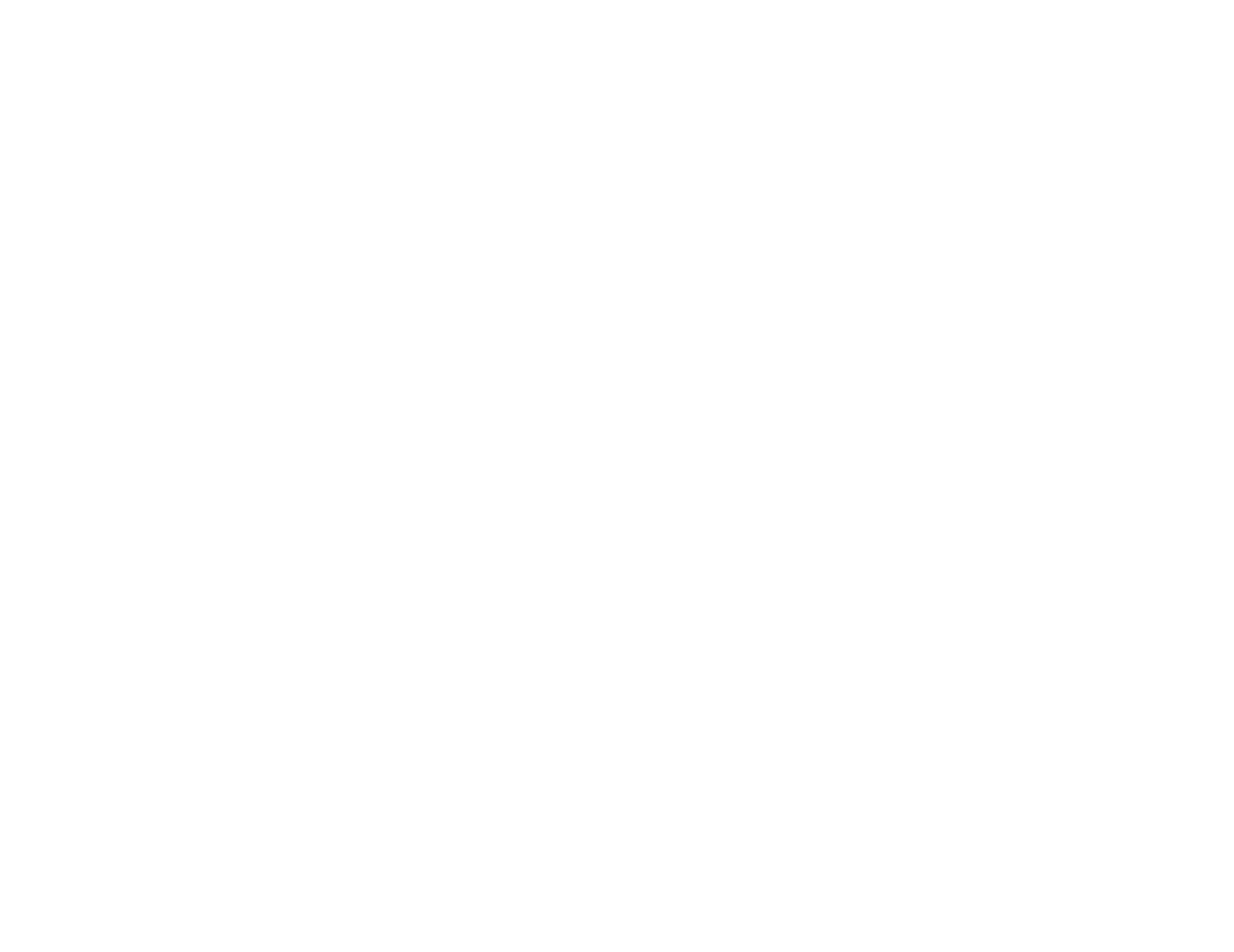

Frgure 98.-Flow-duration curves of two streams in the Yampa River basin, water years 1914-57 adjusted to 1957 conditions.

dissolved-solids discharge at the two daily stations and at other sites have been computed (table 9). The quantities given in the table are averages which would have occurred if the developments in 1957 had existed throughout water years 1914-57.

The a verage dissolved-solids discharge of the streams ranged from about 3 to 600 tons per day, and the average annual yield ranged from about 42 to 298 tons per square mile. The greatest yield per unit of runoff apparently comes from the more arid part of the basin, which is mostly underlain by sedimentary rocks of Tertiary age.

Duration tables of dissolved-solids concentration and discharge for the streams at sites listed in table 9 are given in tables 10 and 11 . (See chap. B, pp. 58-59, for description of computation method.)

Most of the water comes from the mountain area of the basin, but most of the dissolved solids come from the area of relatively low altitude, which compose about two-thirds of the basin (table 9, fig. 100). Although the drainage area of the Little Snake River above the station near Lily is only about 240 square miles smaller than that of the Yampa River above the station near Maybell, it produces less than half as much water, but more than half as much dissolved solids.

\section{VARIATIONS IN CHEMICAL QUALITYY}

The seasonal variation in the dissolved-solids concentration of Yampa River near Maybell is illustrated in figure 101. The lowest concentrations occur during the months of high water, in the spring and early summer, and the highest concentrations occur in the months when the stream is maintained largely by ground water. The pattern of seasonal variation does not change greatly in years of low and high runoff. Water year 1954 was a year of relatively low 


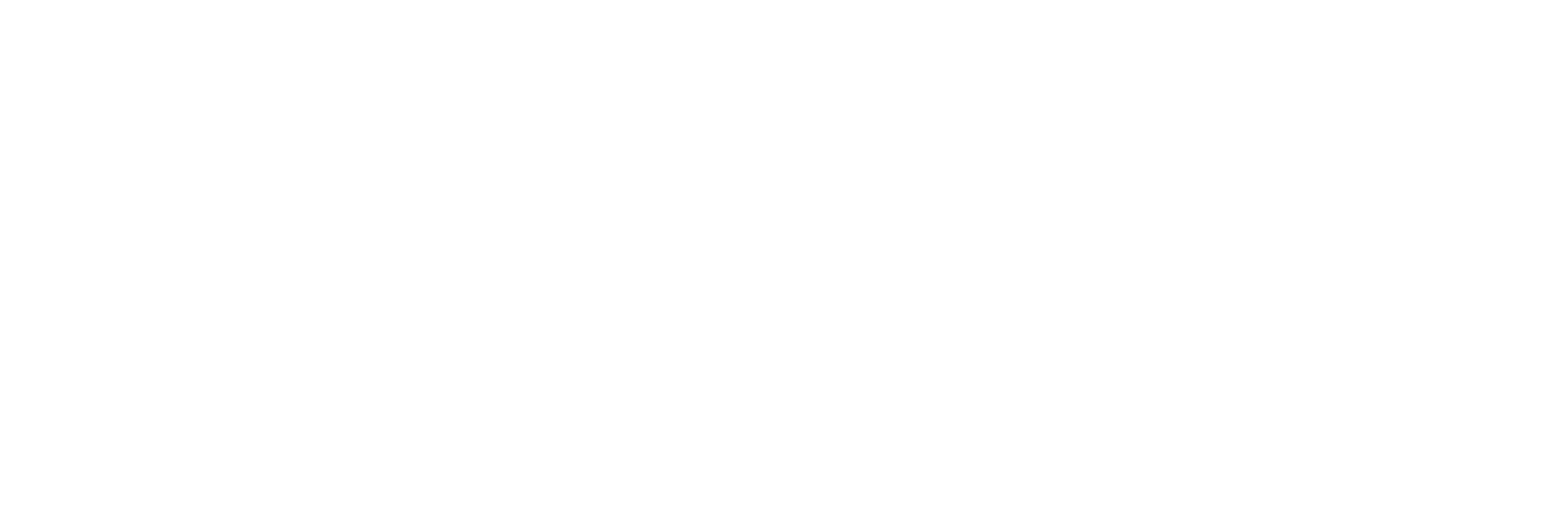

A. Yampa River at Steamboat Springs, Colo.

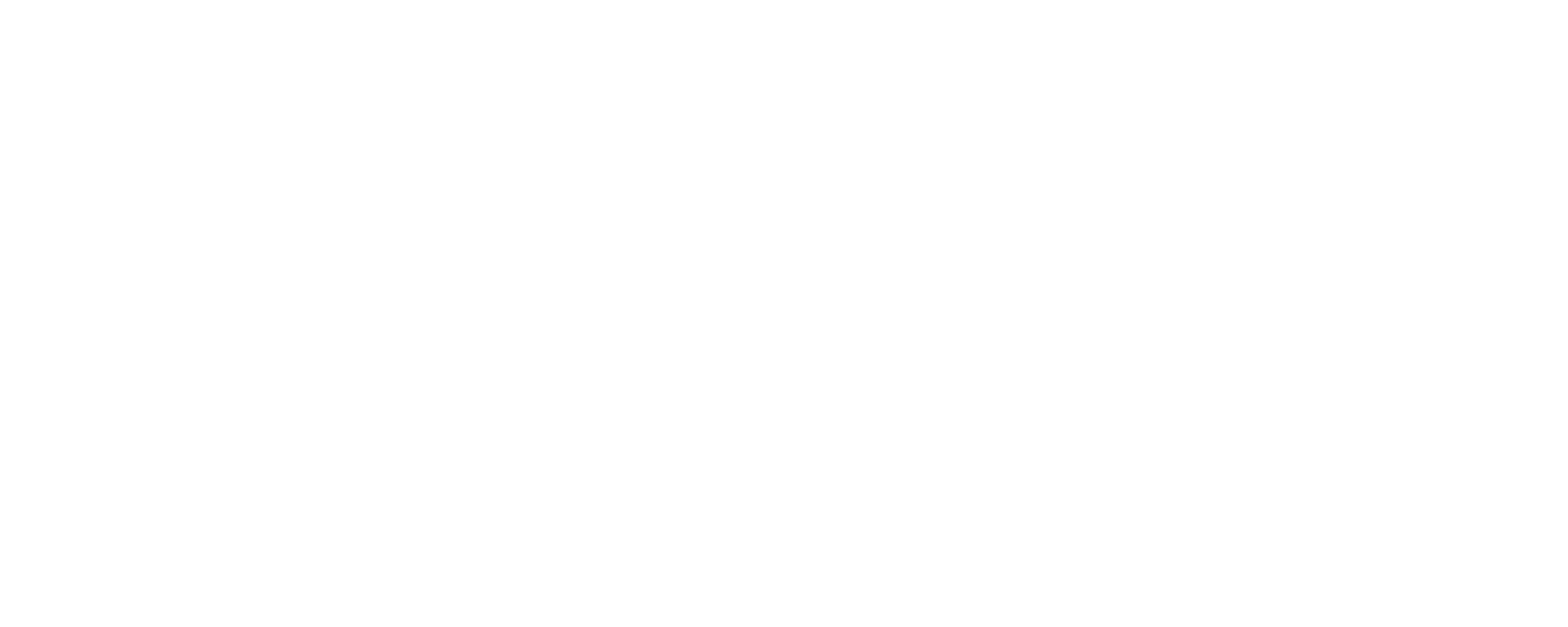

WATER YEAR

B. Little Snake River at Dixon, Wyo.

FrGURE 99.-Variabllity of annual discharges in the Yampa River basin, water years 1914-57.

runoff, and 1957 was a year of relatively high runoff.

The coefficients of variation of annual weightedaverage concentration of dissolved solids and annual historical water discharge for two streams are given in table 12. The computed coefficients are for concurrent periods of record, which may be too short for a reliable statistical analysis.

\section{RELATION TO STREAMFLOW}

The concentration of dissolved solids in the streams that flow from the granite terrane of the Park Range is low; and, as in the streams that flow from similar terranes along the Continental Divide, the range in dissolved-solids concentration with changing discharge is small. After the streams leave the mountains, contributions of dissolved solids cause an increase in dissolved-solids concentration at all rates of flow, and the range in concentration increases between low and high flows. Figure 102 shows the relation between streamflow and dissolved solids at two sites in the lower part of the Yampa River basin. The relation between the chemical composition of water and streamflow at these two sites is given in table 13 . Figure 103 also illustrates the relation between the chemical composition of water in the streams at these two sites and at two sites in the headwaters.

\section{RELATION TO GEOLOGY}

Precambrian granites and associated metamorphic rocks underlie the drainage areas of tributaries entering the Yampa River from the east above Elk River. These rocks also underlie the headwaters of Elk River and Little Snake River. The extreme headwaters of Williams Fork and some of the tributaries of the Yampa River above Elk River drain areas that are capped by Tertiary volcanics on the White River 


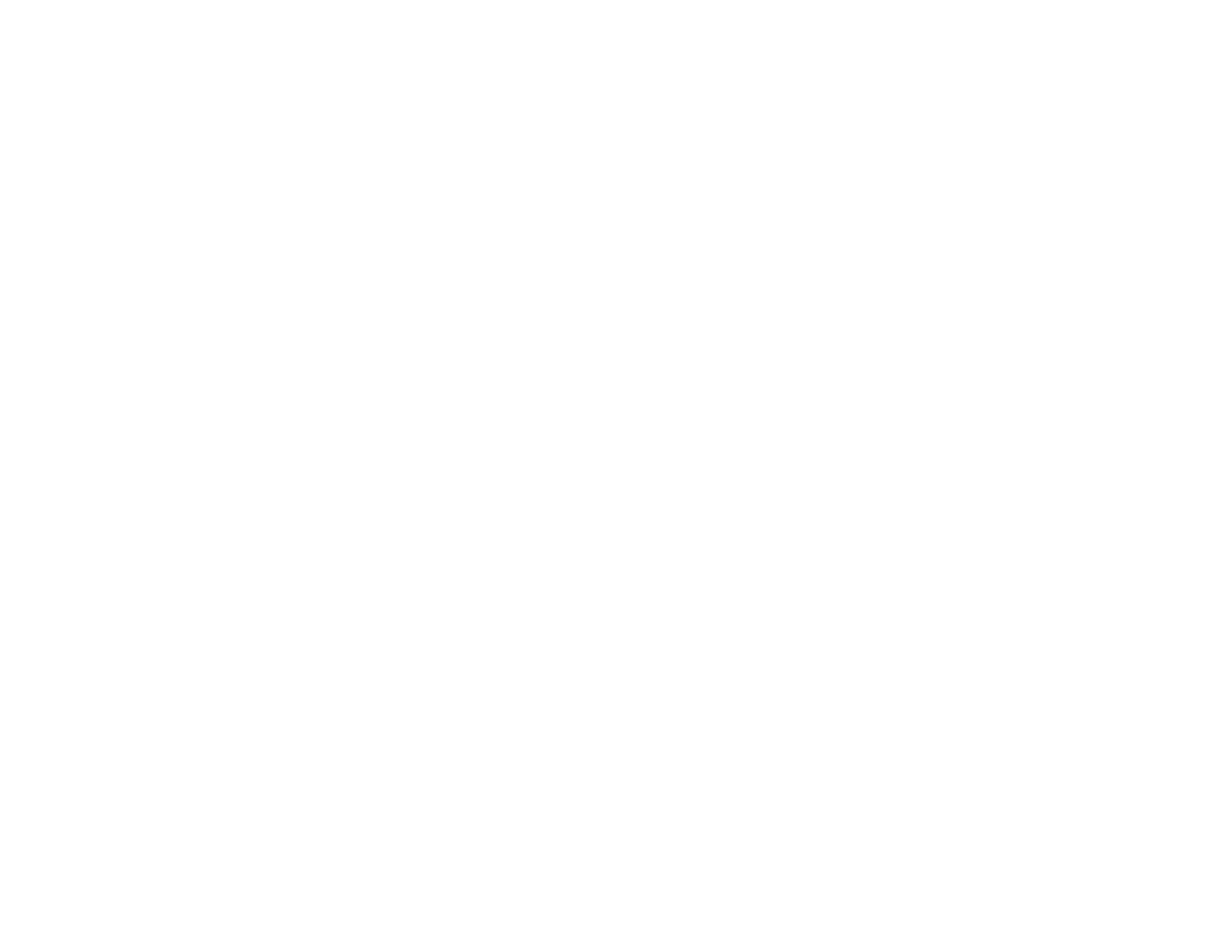

FiguRE 100.-Approximate dissolved-solids discharge and streamflow in the Yampa River basin expressed as percentages of combined dissolved-solids discharge and combined streamflow of Yampa and Little Snake Rivers near Maybell and Lily, Colo.

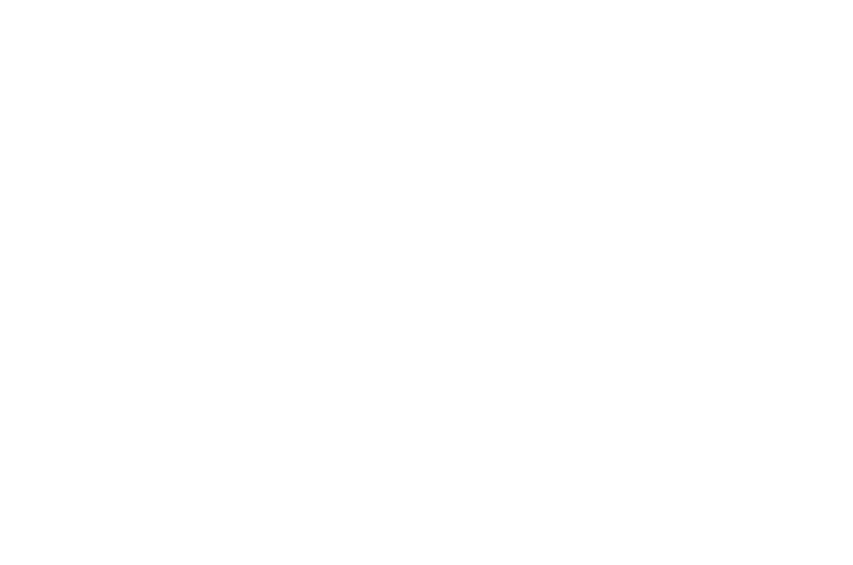

FIGURE 101,-Dissolved-solids concentration of Yampa River at bridge on county road, near Maybell, Colo., for the 1954 and 1957 water years.
Plateau. The remainder of the Yampa River basin is underlain by sedimentary rocks, which are mostly of Cretaceous and Tertiary age.

The Precambrian and associated metamorphis rocks are resistant to the solvent action of water; consequently, the streams draining them have low concentrations of dissolved solids. The water of Elk River at Clark, Colo., which has a weighted-average concentration of $40 \mathrm{ppm}$ (table 9) and is of the calcium bicarbonate type, is representative of streams draining these rocks. Areas underlain by these rocks occur at high altitudes and receive precipitation averaging from 30 to more than 40 inches annually; the streams draining these areas provide most of the water supply in the subbasin.

The Cretaceous and Tertiary rocks contain an abundance of soluble minerals. Streams draining areas 

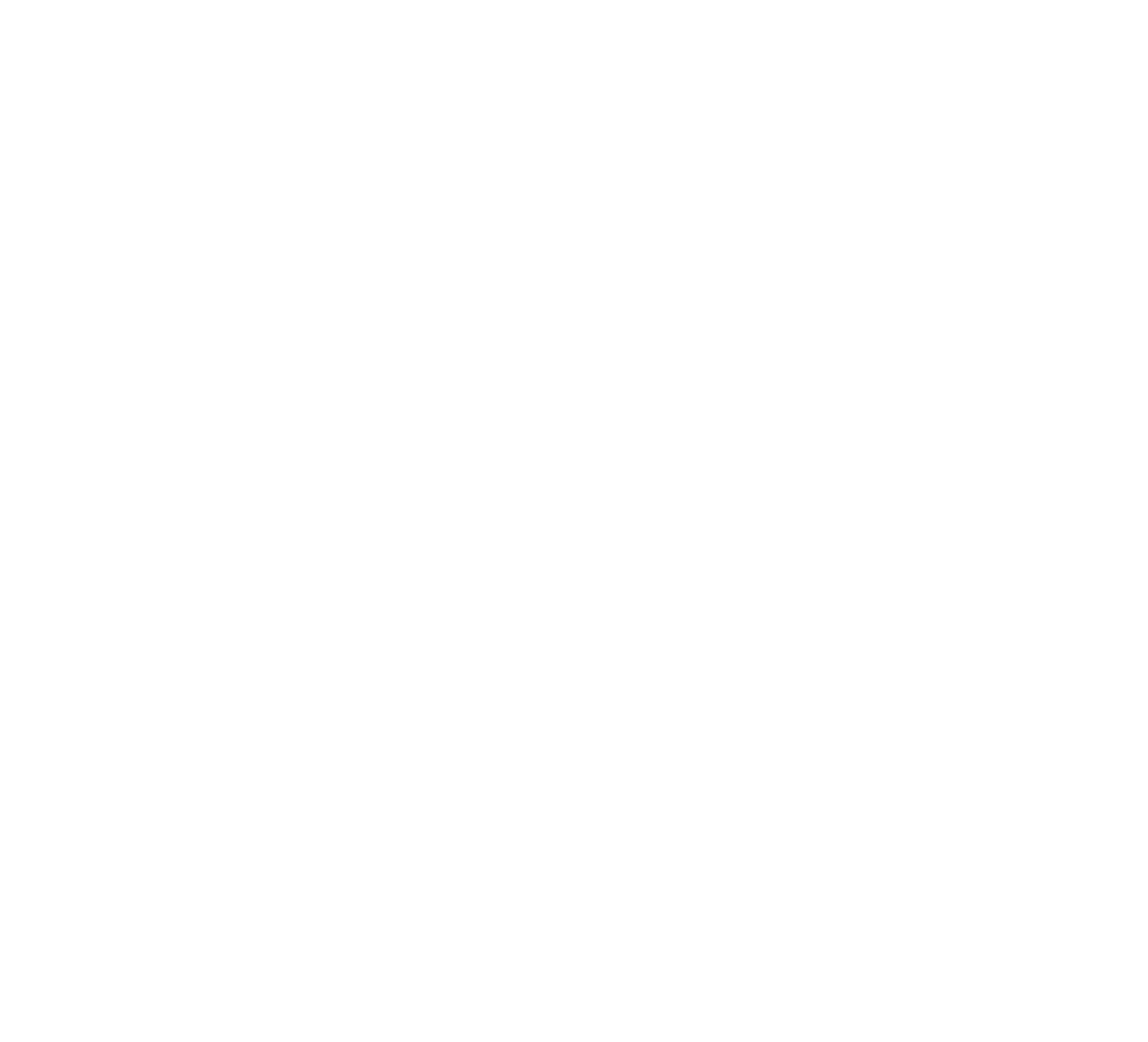

FIGURE 102.-Dissolved-solids concentration and discharge and water discharge of streams at two daily stations in the Yampa River basin.

underlain by these rocks usually contain higher proportions of magnesium, sodium, and sulfate than streams draining areas underlain by Precambrian rocks. Most of the area underlain by these sedimentary rocks is semi-arid and produces little runoff in comparison with the headwater area; this results in only a moderate increase of dissolved-solids concentration downstream in the Yampa and Little Snake Rivers. For example, the weighted-average concentration in the Yampa River between Steamboat Springs and Maybell, Colo., only increases from 74 to $140 \mathrm{ppm}$, and part of this increase is caused by irrigation in the intervening reach. The concentration of dissolved solids of the Little Snake River between Dixon, Wyo., and the mouth only increases from about 90 to $200 \mathrm{ppm}$. However, unlike the water of the Yampa River, which is of the calcium bicarbonate type both in the headwaters and downstream near Maybell, the water of the Little Snake River changes from a calcium bicarbonate type in the headwaters to a sodium sulfate type near the mouth, except at high flows in the spring.

Figure 104 is a map of the Yampa River basin showing zones within which the weighted-average concentrations of dissolved solids of the surface water are between indicated limits. The weighted-average concentrations in the principal streams are less than 300 ppm. Some of the intermittent streams that drain areas underlain by sedimentary rocks in the arid parts of the 


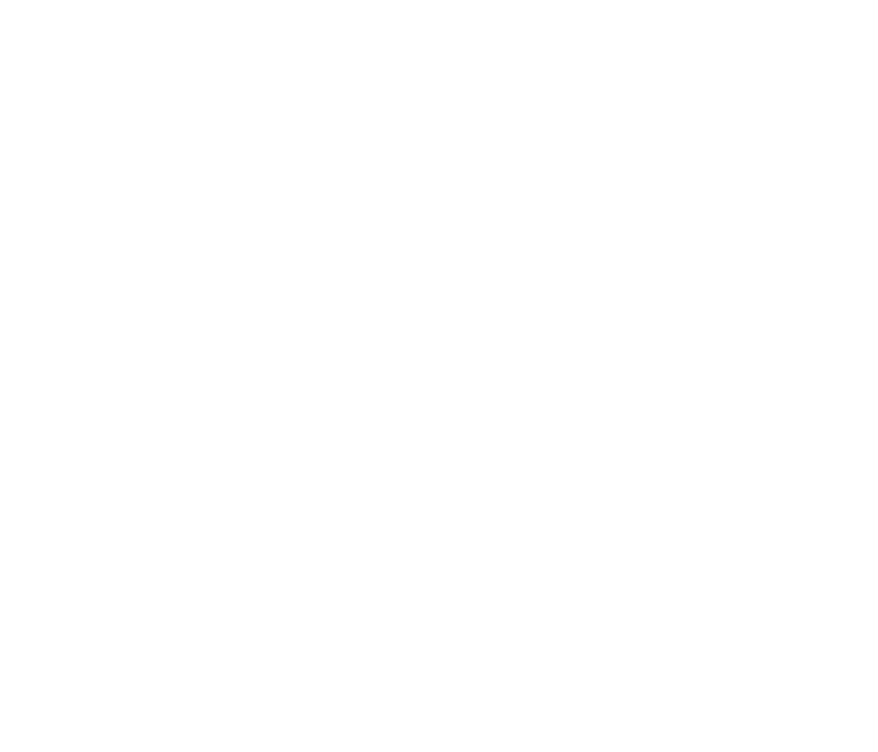

A. Yampa River at Steamboat Springs, Colo.

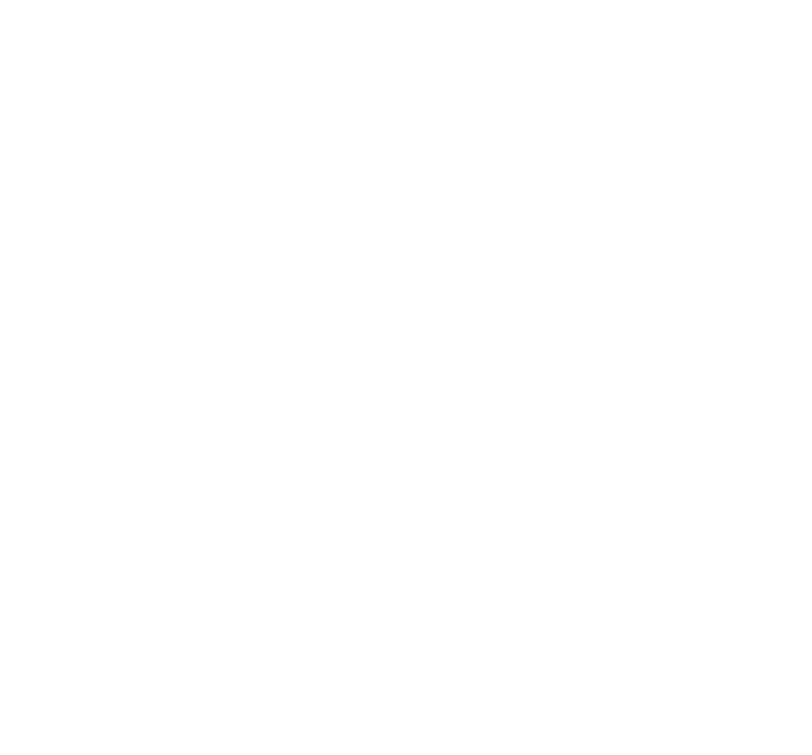

$B$. Elk River near Trull, Colo.

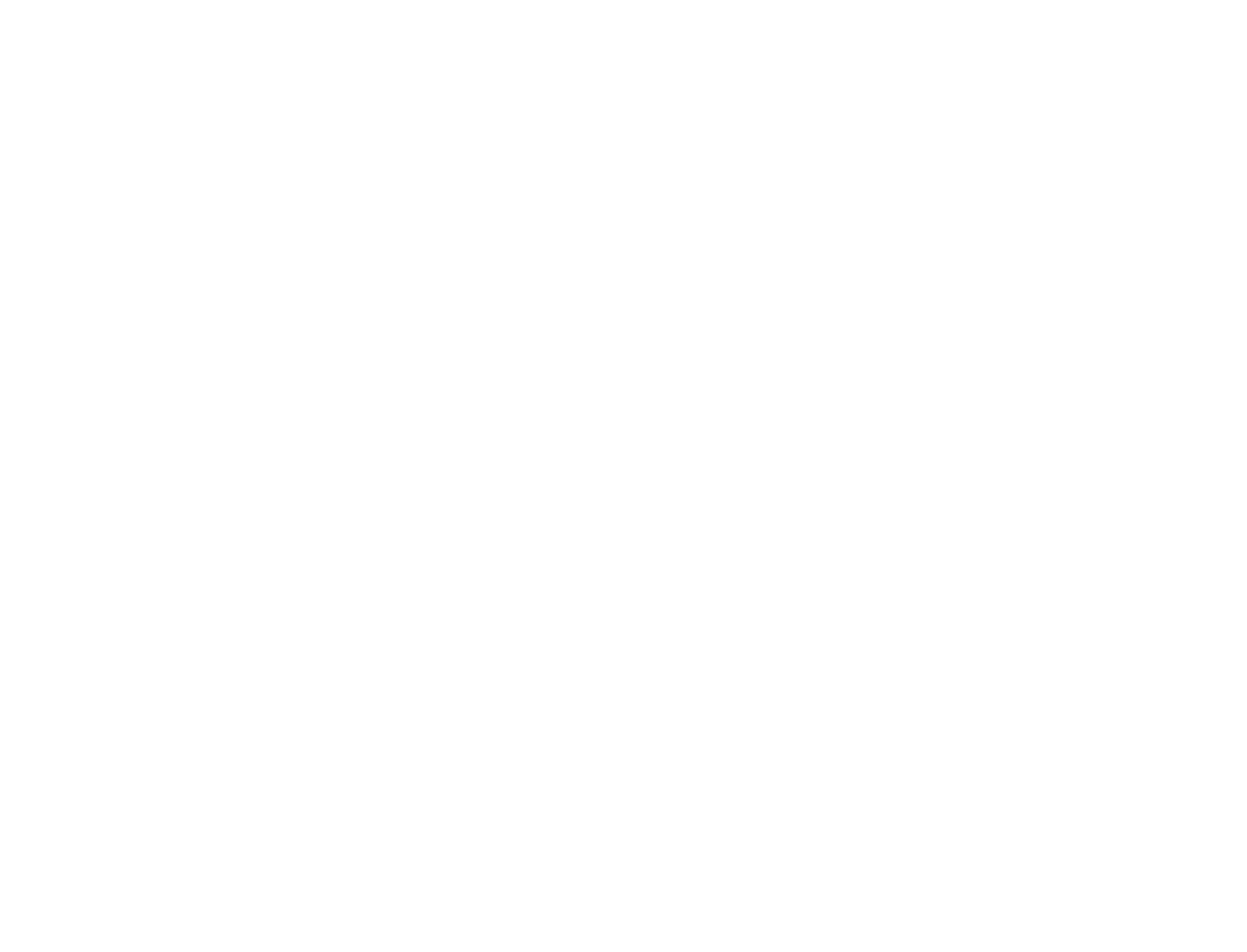

FIGURE 103.-Relation of the chemical composition and concentration of dissolved solids to water discharge in the Yampa River basin. The concentration of specific ions, in equivalents per million (epm), is shown for the 10th, 50th, and 90th percentiles of the flow-duration curve for each location. The flow-duration curves are for the water years 1914-57 adjusted to 1957 conditions. 


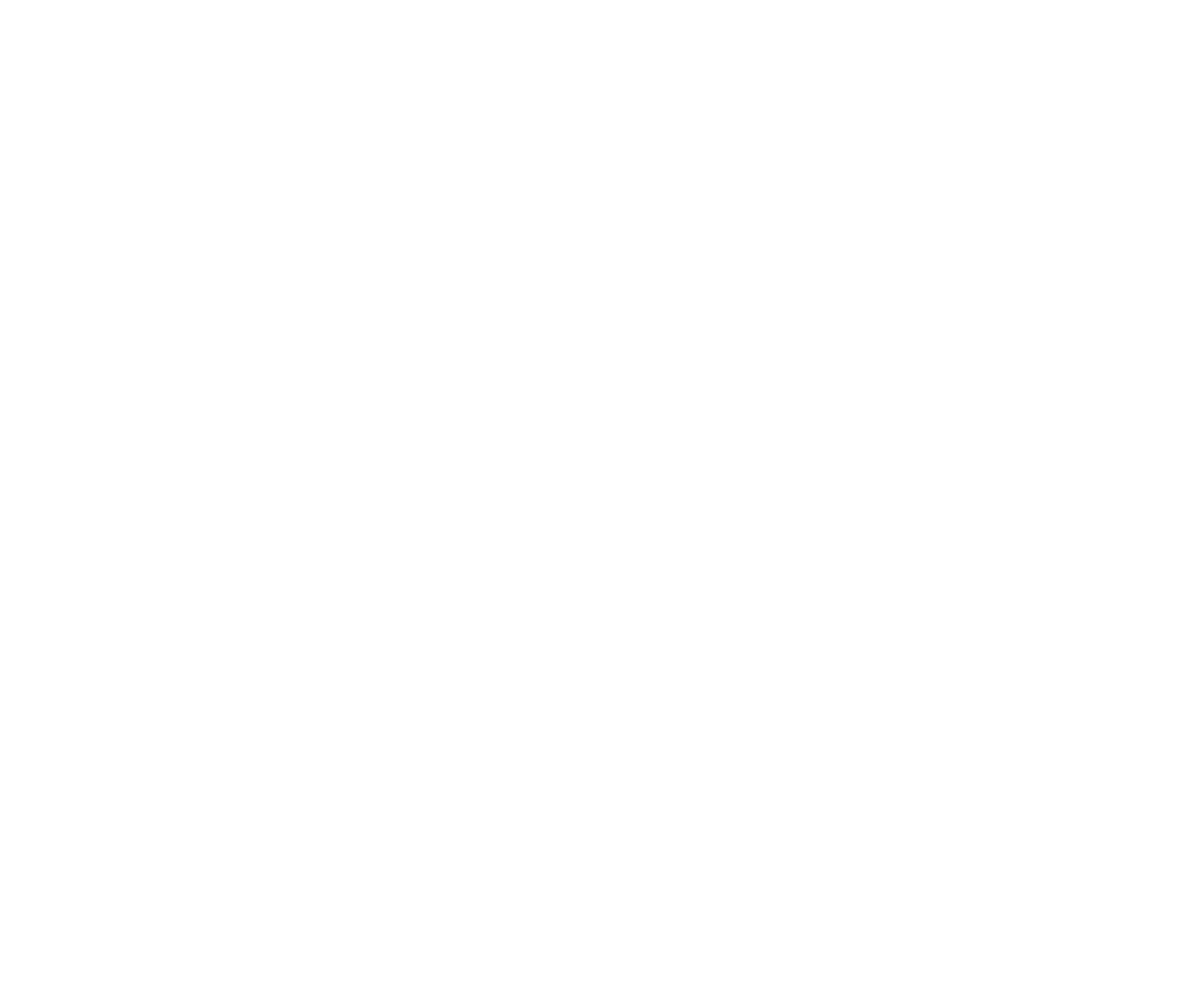

FigURE 104.-Approximate weighted-average concentration of dissolved solids of streams in the Yampa River basin.

basin have weighted-average dissolved-solids concentrations of more than $800 \mathrm{ppm}$.

The diagrams on plate 2 show the geochemical character and ionic concentrations of surface waters at 28 sites in the subbasin. The diagrams are representative of the chemical character of the streams during low flow, when the effect of geology on chemical quality is more evident than during high flows. The significance of the size and shape of the diagrams is given in the explanation on plate 2 .

\section{RELATION TO GROUND WATER}

Except in the headwater areas, ground water in the consolidated rocks has little effect on the streams. In the headwaters, the magnitude of the effect is closely related to the geologic environment. Table 14 gives the water and dissolved solids estimated to be contributed to some headwater streams by ground water. The weighted-average concentration of dissolved solids of the ground-water contribution is higher than the weighted-average concentration in the water in the streams, even after mixing.

Headwaters of the Yampa River above the gaging station near Oak Creek, Colo., are underlain by Tertiary volcanics, which are relatively permeable. These volcanic rocks overlie rocks of the Mesaverde Group and Mancos Shale, which contain an abundance of readily soluble minerals. The permeable volcanic rocks provide opportunity for recharge to ground-water reservoirs in contact with the underlying formations. Ground-water return flow from the irrigation of soils 
derived from Mancos Shale probably also contributes to the large percentage of dissolved solids contributed to the stream system by ground water in this headwater drainage basin.

The drainage basins above Elk River at Clark, Colo., and Little Snake River near Slater, Colo., are mostly underlain by rocks of Precambrian age. These rocks provide little opportunity for ground-water storage, and, in addition, the rocks are relatively insoluble. The headwater area of Savery Creek is underlain partly by Precambrian rocks and partly by the Dakota Sandstone and the Morrison Formation of Cretaceous age. The rocks of Cretaceous age are more permeable than the Precambrian rocks and contain more soluble minerals.

The low precipitation over the interior of the Yampa River basin provides little opportunity for groundwater recharge. In addition, the Cretaceous and Tertiary rocks, which are exposed over much of the interior of the basin, are poor aquifers. However, ground water does occur in the alluvial deposits in the stream valleys. In downstream areas, the river alluvium receives very little recharge except from the streams during high flows and from irrigation. The quantity of water involved in the recharge and discharge of ground water by the natural rise and fall of the streams would likely be small compared with the flow in the main streams. However, where irrigated lands are on alluvial deposits, the amount of ground water effluent to the streams would be substantially increased. For the most part, the river alluvium is composed of material derived from nearby sedimentary rocks and contains substantial quantities of soluble minerals.

In most places the ground water in the river alluvium has a higher concentration of dissolved solids than the water in the nearby stream, even during periods of low flow when the streams are at their maximum concentration (figs. 105, 106). The analyses of surface water shown in figures 105 and 106 are of samples collected in the late summer, when the streams were low. The water in the streams at this time of the year is mostly a mixture of all the ground water that has entered the stream above the sampling point.

The analysis of water in the alluvium at Steamboat Springs (253G, fig. 105) is probably representative of ground water in alluvium derived from Precambrian and associated rocks; which receives recharge from streams draining areas underlain by the same type of rocks and from local precipitation. This ground water would have a diluting effect on the Yampa River at low stages. However, other analyses of water from alluvium along the river upstream from Steamboat Springs show that concentrations of dissolved solids are about the same or greater than those of the water in the river at Steamboat Springs during low flow. Part of the valley fill upsteam was derived from the area of Cretaceous rocks above Morrison Creek.

At Steamboat Springs, the flow from several thermal springs enter the Yampa River. The spring water contains between 5,000 and $6,000 \mathrm{ppm}$ dissolved solids,

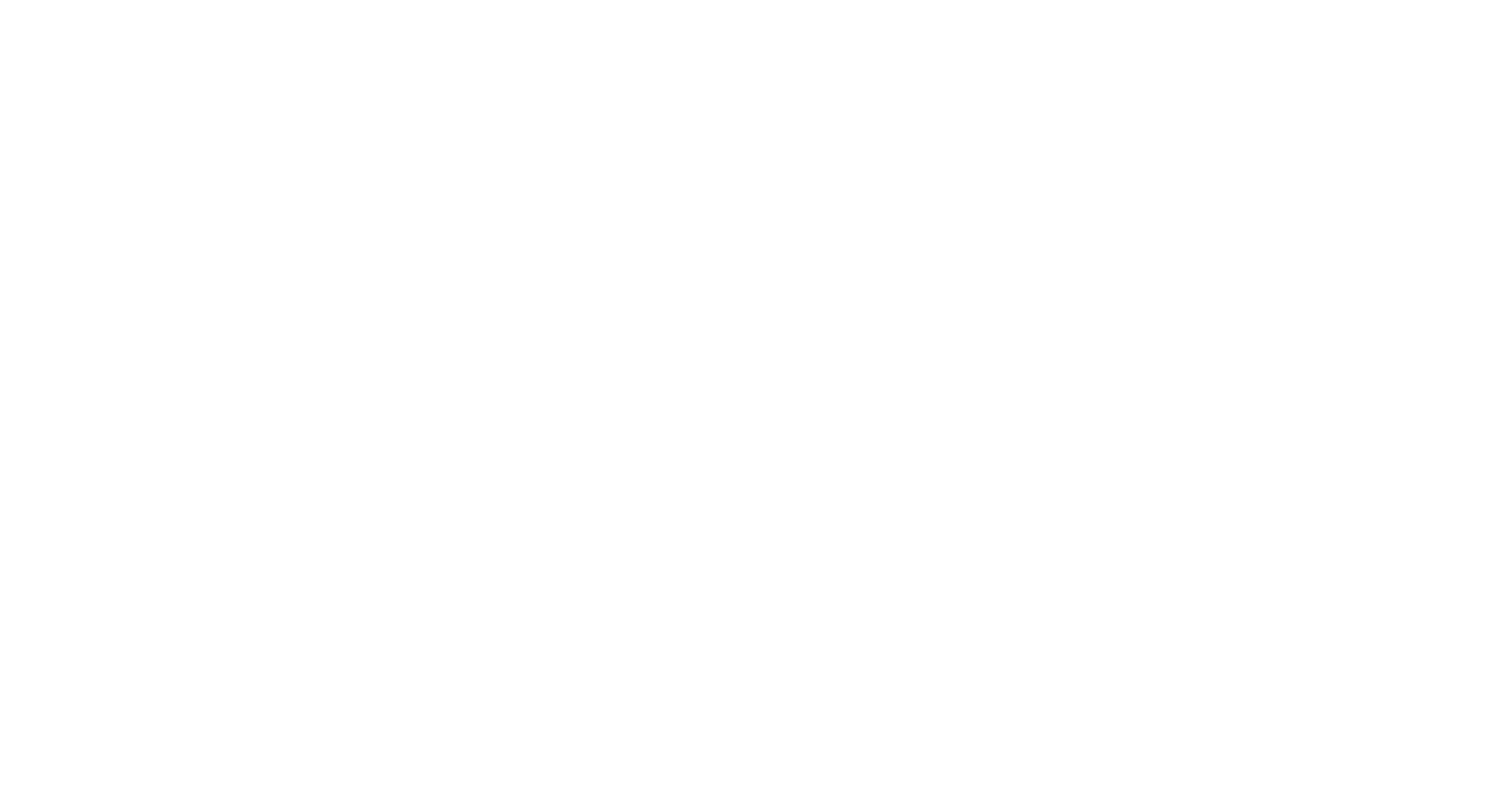

FIGURE 105.-Analyses of water from selected streams near the mountains in the Yampa River basin and from alluvium nearby. 


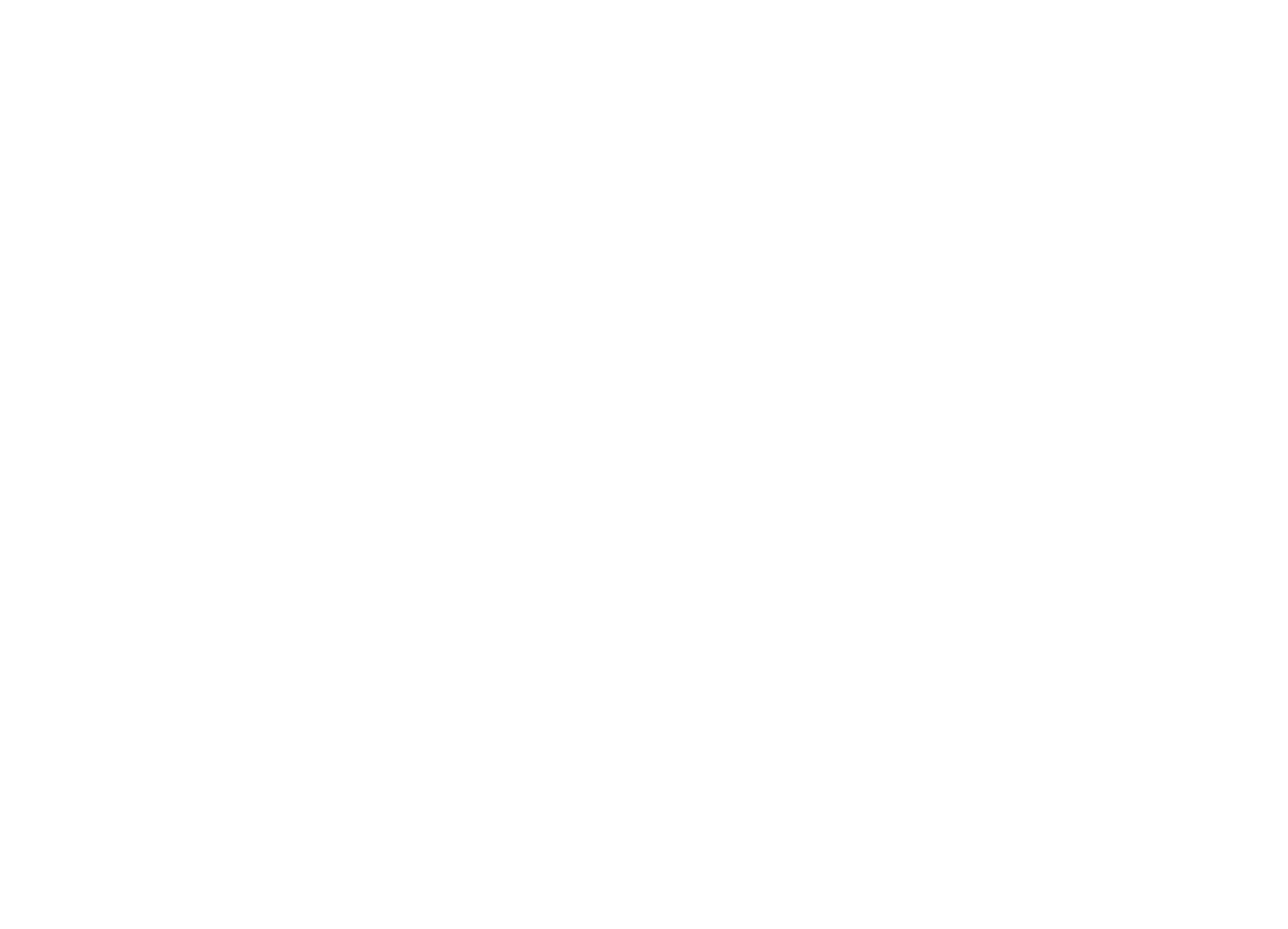

Figure 106.-Analyses of water from selected streams in the interior of the Yampa River basin and from alluvium nearby.

most of which are sodium, bicarbonate, and chloride. The spring water also contains as much as $15 \mathrm{ppm}$ of fluoride and about $5 \mathrm{ppm}$ of boron. About 22 thermal springs with an estimated total discharge of $7 \mathrm{cfs}$ and a dissolved-solids concentration of about $5,000 \mathrm{ppm}$ are known to occur in the Yampa River basin (George and other, 1920; Stearns and others, 1937). These springs discharge about 34,500 tons of dissolved solids annually.

\section{EFFECT OF THE ACTIVITIES OF MAN}

The amounts of dissolved solids contributed to stream systems by the activities of man were computed for three areas. In the determinations, which were made in a manner similar to that used in the Green River basin above the Yampa River, water and dissolved-solids data not given in table 9 were estimated on the basis of streamflow records in the annual WaterSupply Papers of the U.S. Geological Survey and chemical analyses of water in the basic data report (Iorns and others, 1964, table 222).
Between the gaging stations Yampa River near Oak Creek, Colo., and Yampa River at Steamboat Springs, Colo., about 12,000 acres is irrigated. The irrigated lands are mostly on alluvium of glacial origin. An approximate water and dissolved-solids budget for the area is given in table 15 .

The water and dissolved-solids discharges for Yampa River near Oak Creek and at Steamboat Springs are from table 9. The long-term average annual water discharges of Oak, Fish, and Walton Creeks are based on the relation of discharge during the periods of available record to the discharge of Yampa River at Steamboat Springs for corresponding periods and the 44-year period. The weighted-a verage concentration of dissolved solids of Oak Creek is based on chemical analyses of Trout Creek near Phippsburg, Colo., an adjacent stream having similar environment. The concentrations for Walton and Fish Creeks are based on chemical analyses of the waters of these streams. (See basic data report, Iorns and others, 1964, table 222). 
Of the ungaged area, about 48 square miles is in bottom lands and about 251 square miles is mountainous terrain. The bottom lands received about 20 inches of precipitation annually, of which an estimated 5 inches $(12,800$ acre-feet) infiltrated to the groundwater table and was effluent to the stream system. About half of the bottom lands are underlain by Cretaceous rocks. Chemical analyses of ground water from a well near the mouth of Oak Creek is probably representative of ground water under these lands. This well indicated a dissolved-solids concentration of 169 ppm (basic data report, Iorns and others, 1964, table 227 , well $257 \mathrm{G}$ ). Two other wells on the east side of the Yampa River had dissolved-solids concentrations of 46 and $71 \mathrm{ppm}$ (basic data report, Iorns and others, 1964, table 227 , wells $256 \mathrm{G}$ and $253 \mathrm{G}$ ). An average of dissolved solids in the waters of these two wells is probably representative of ground-water quality in the alluvium of glacial origin underlain by Precambrian rocks that occupies the eastern half of the bottom lands.

The unmeasured inflow from the mountainous terrain $(251 \mathrm{sq} \mathrm{mi})$ is the amount required to balance the inflow-outflow budget, if 0.8 acre-foot per acre is allowed for consumptive use by the 12,000 acres of irrigated land. This unmeasured inflow is runoff from an area having the same environment as Walton and Fish Creeks; consequently, the concentration of dissolved solids would most likely be the same.

The minimum increase in dissolved solids in the reach between Morrison Creek and Steamboat Springs is equivalent to 0.15 ton per year per acre of irrigated lands.

The irrigated lands on Elk River are mostly residuum underlain by Mancos Shale but some are on river alluvium underlain by Mancos Shale. As this is an area of fairly high precipitation (20 to 30 inches annually), the shale and overlying residuum and alluvium have been subjected to much natural leaching and consequently would yield much less dissolved solids because of irrigation than similar material in areas of low precipitation. Table 15 gives a water and dissolvedsolids budget for the part of the basin between the gaging stations on Elk River at Clark and near Trull, Colo., in which about 8,000 acres is irrigated.

The water and dissolved-solids discharges of Elk River at Clark and near Trull given in table 15 are from table 9. The water discharges of Big and Mad Creeks were computed on the basis of correlation with Elk River near Trull for periods of common record and the 44-year average discharge of that stream. The weighted-average concentration of these two creeks would be about the same as Walton and Fish Creeks because of similarity and environment. A thermal spring at Forest Camp with a dissolved-solids concentration of $458 \mathrm{ppm}$ discharges about $250 \mathrm{gpm}$ (gallons per minute) to the river.

About 42 square miles of the intervening ungaged drainage area is bottom lands and lands having little relief, and about 86 square miles consists of mountainous terrain. Only about 12 square miles of the bottom lands is underlain by alluvium predominantly of glacial origin; the balance is underlain by Mancos Shale. It is estimated that under natural conditions about 5 inches of the average annual precipitation (25 inches) would infiltrate into the alluvium and be effluent to the stream system. Chemical analyses of water from two wells in the area indicate this ground water would have an average dissolved-solids concentration of about 242 ppm (Iorns and others, 1964, table 227, wells 254G and $255 \mathrm{G}$ ). The unmeasured surface water inflow from the 116 square miles of ungaged area (includes 30 sq mi of bottom land underlain by Mancos Shale) is the amount required to balance the inflow-outflow budget if 6,400 acre-feet is allowed for consumptive use by irrigation on 8,000 acres. This area is underlain by Mancos Shale and other rocks of Cretaceous age. The concentration of dissolved solids in the runoff would probably be about the same as that of Elkhead Creek near Elkhead, Colo. (Iorns and others, 1964, table 222 ), whose drainage is underlain by similar rocks; however, the concentration may be as low as that of Elk River at Clark $(40 \mathrm{ppm})$. The computed minimum increase in dissolved solids in the area, if all attributed to irrigation, is equivalent to about 0.4 ton per year per acre of irrigated land.

In the Little Snake River basin between the gaging stations Little Snake River near Slater, Colo., and Little Snake River near Dixon, Wyo., about 4,000 acres is irrigated. Most of these lands are on river alluvium underlain by the Fort Union, Lance, and Bridger Formations of Tertiary age and Mancos Shale of Cretaceous age. Table 15 gives an approximate water and dissolved-solids budget for the area.

The data given in table 15 for Little Snake River near Slater, Slater Fork near Slater, Savery Creek at upper station near Savery, and Little Snake River near Dixon are from table 9. The water discharge of Battle Creek near Slater is based on the relation of the discharge for common periods of records of this station and Slater Fork near Slater and the 44-year average discharge of Slater Fork near Slater. The runoff of the east-side tributaries of Savery Creek is estimated to be about four-fifths of the difference between the discharge of Savery Creek at upper station and Savery Creek near Savery, Wyo., plus 1,500 acrefeet estimated to be consumptively used by irrigation 
in the reach. The drainage basins of Battle Creek and the east-side tributaries of Savery Creek are mostly underlain by Precambrian rocks. Walton and Fish Creeks near Steamboat Springs, whose drainage basins are underlain by similar rocks, have weighted-average concentrations of dissolved solids of 25 to $30 \mathrm{ppm}$. The concentration of dissolved solids of Battle Creek and the east-side tributaries of Savery Creek would probably be in the same range.

Irrigation in the reach $(4,000$ acres $)$ is estimated to consume about three-fourths acre-foot per acre. Water to irrigate about 3,000 acres is carried in a canal that bypasses the gaging station on Little Snake River near Dixon. It is estimated that the bypassed water is equivalent to about 5 acre-feet per acre and that the water has the same dissolved-solids concentration as Little Snake River near Dixon.

The unmeasured inflow is the amount required to balance the inflow-outflow budget. Most of the ungaged drainage area is underlain by rocks similar to those underlying the drainage basin above the upper station on Savery Creek. Consequently, it could be expected that the dissolved-solids concentration of the unmeasured inflow would be about the same as Savery Creek at upper station. The minimum computed increase in dissolved solids in the reach, if all caused by irrigation, is equivalent to 1.2 tons per year per acre of irrigated land.

Estimates were made of the dissolved solids contributed by natural sources and as a result of the activities of man for other areas in the Yampa River basin by use of the same method used for the Green River basin above the Yampa River. In table 16 the dissolved solids contributed from the different sources are summarized for the basin and at two gaging stations. Of the dissolved solids attributed to the activities of man, it is estimated that about 1,400 tons annually is caused by domestic and industrial uses of water and about 61,000 tons annually is caused by irrigation.

\section{FLUVIAL SEDIMENT}

Daily suspended-sediment data have been obtained on Yampa River at bridge on county road, near Maybell, Colo. (table 17). In addition, some suspendedsediment data have been collected at other sites. These records and records of streamflow have been used to estimate the sediment discharge at four sites for the water years $1914-57$ adjusted to 1957 conditions (table 18). The data indicate that about $31 / 2$ times more suspended sediment comes from the Little Snake River basin than from the Yampa River basin above Maybell. Also, most of the suspended sediment transported by the Little Snake River comes from the more arid parts of the drainage basin.
The suspended sediment contributed to the Yampa River from the 1,055 square miles of drainage area between the gaging stations Yampa River at bridge on county road, near Maybell, Colo., and Little Snake River at bridge on State Highway 318, near Lily, Colo., and the mouth of the Yampa River is estimated to be 400,400 tons annually. This estimate is based on a computed yield of 380 tons per square mile per year (see page 203). The total annual suspended-sediment discharge from the Yampa River basin is about $1,807,400$ tons.

\section{SUITABILITY OF WATER FOR VARIOUS USFS}

\section{DOMESTIC USE}

The water in the principal streams of the Yampa River basin is suitable for most domestic and agricultural uses. The classification of the surface waters in the basin is based on water criteria for major uses. (See chap. B, pp. 66-73.)

Most of the surface water comes from melting snow in the mountains and plateaus along the east and south boundaries of the basin. This water has a low concentration of dissolved solids and is of the calcium bicarbonate type. Very few of the perennial streams at any given time contain water whose concentrations of constituents exceed the maximum accepted limits for domestic use; however, during low flows, the waters of a few of the perennial tributaries in the south part. of the basin contain concentrations of dissolved solids that do exceed the accepted limits.

Most intermittent tributaries of the Little Snake and Yampa Rivers in the arid parts of the basin contain total concentrations of dissolved solids that make them unsuitable for domestic use. The waters of these intermittent tributaries usually contain more than the allowable maximum of magnesium, chloride, and sulfate ions.

The waters of the streams range from soft to very hard. In general, the streams in the mountains are the only ones that have soft water. Nitrate is present in most of the streams but not in concentrations sufficiently great to be a danger. The water from some of the springs at Steamboat Springs, Colo., has concentrations of fluoride high enough to cause mottling of the teeth, if used continuously.

\section{AGRICULTURAL USE}

As in the Green River basin above the Yampa River, the principal use of water in this subbasin is for irrigation. Table 19 gives the suitability classification of stream waters for irrigation for low, medium, and high flows. The chemical analyses used for the classification are in the basic data report (Iorns and others, 1964). Most of the terms used in table 19 are self- 
explanatory, and those that are not are explained on page 203 and in chapter $B$ (pp. 69-73).

The water in some of the intermittent streams, such as Sand Creek near Baggs, Wyo., should not be used for irrigation. However, streams of this type are not dependable sources of water and would rarely be used for irrigation. Most of the water that is used for irrigation would be classified as $\mathrm{C} 2-\mathrm{S} 1$ water or better. The required leaching is generally low, and the soils probably contain sufficient available calcium so that addition of gypsum would not be necessary.

\section{INDUSTRIAL AND RECREATIONAL USES}

In and near the mountains the surface waters can be used by many industries without treatment. The waters of the principal streams could be used after minor treatment, if treatment were required at all.

The water in the headwater areas is ideal for recreational use, particularly for fishing and hunting.

\section{GREEN RIVER BASIN BETWEEN THE YAMPA AND WHITE RIVERS INCLUDING THE WHITE RIVER BASIN}

\section{PRESENT UTILIZATION OF SURFACE WATER}

\section{STORAGE RESERVOIRS}

Thirteen reservoirs with usable capacities greater than 1,000 acre-feet have been constructed (1957) in this subbasin (table 3 ). The combined usable capacity is 334,610 acre-feet, and all reservoirs are used for irrigation. All are in the Duchesne River basin, except one in the Pot Creek basin and two in the Brush Creek basin. Strawberry Reservoir stores water for diversion through Strawberry tunnel into the Great Basin. Except for a small amount of spillage in the early 1920's and again in 1952, all runoff from the 170 square miles of drainage area above Strawberry River dam has been diverted out of the subbasin during water years $1914-57$.

There are, in addition, many small lakes and stock ponds scattered throughout the subbasin.

\section{TRANSMOUNTAIN DIVERSIONS}

Several transmountain diversions export water from the upper Duchesne River basin to the Great Basin. Diversion began through the Duchesne tunnel in the 1954 water year and through the Strawberry tunnel (from Strawberry Reservoir) in 1915. Strawberry River and Willow Creek ditches and the Hobble Creek ditch (all in the headwaters of the Strawberry River) began diverting water before 1914 .

The records of annual diversions through the $\mathrm{Du}$ chesne and Strawberry tunnels are complete, but records for the Strawberry River and Willow Creek ditches and the Hobble Creek ditch are available only for water years 1950-57. Available records of diver- sions and estimated total diversion from the subbasin are given in table 20 .

The average annual diversion from the headwaters of Strawberry River for water years 1950-5i was 71,590 acre-feet, and the average annual diversion through the Duchesne tunnel for water years 1954-57 was 30,500 acre-feet. For the report. it is assumed that these are representative of long-term averages for development existing in 1957.

\section{IRRIGATTON}

The U.S. Bureau of the Census (1953) reported about 198,000 acres irrigated in 1949 , which was about the same amount irrigated in 1957. (See table 4, pl. 7.) From 1914 to 1952 there was probably some increase in irrigated lands, but the increase was probably minor.

The altitude of the irrigated lands is generally high; only a small part of the lower Duchesne River valley is at altitudes of less than 5,000 feet. The benchlands north of the Duchesne River are at altitudes that average 6,000 feet or more, and some of the irrigated lands in these areas and in the White River basin are more than 7,000 feet in altitude. At these high altitudes, the climate limits crops to hardy species such as alfalfa, wild hay, sugar beets, grains, and a few other crops. Where flat slopes and fine-grained soil prevail, inadequate drainage also limits crop production.

The Upper Colorado River Basin Compact Commission (1948) estimated that the $1914-45$ average annual consumptive use of water by irrigation was about 326,300 acre-feet. The Commission estimated that about 200,100 acres was irrigated and that about 38,300 acres received water incidental to irrigation practices. Of the 326,300 acre-feet used consumptively by irrigation, about 238,600 acre-feet was consumed in the Duchesne River basin, about 33,600 acre-feet in the White River basin, and about 54,100 acre-feet in the remainder of the subbasin.

\section{DOMFSTIC AND INDUSTRIAL UAES}

The 1960 population of the subbasin was only about 24,600 , of which about 19,000 lived in Utah. The population averages a little more than two persons per square mile. The five largest communities and their population are: Vernal, Utah, 3,665; Roosevelt, Utah, 1,802; Meeker, Colo., 1,655; Rangely, Colo., 1,464; and Duchesne, Utah, 770.

Vernal obtains its water supply from Ashley Springs, and Meeker and Rangely obtain their water supply from the White River. The per capita water use in Meeker is about $160 \mathrm{gpd}$. Similar data are not available for other communities in the subbasin, but most communities probably obtain their water supply from 
wells. The domestic and industrial consumptive use of water is estimated to be about $60 \mathrm{gpd}$ per capita. Of the five largest communities, Rangely is the only community that does not have a sewage treatment plant.

Four hydroelectric powerplants in operation are: Ashley Creek $(250 \mathrm{kw})$, Lake Fork $(900 \mathrm{kw})$, Uinta River $(1,200 \mathrm{kw})$, and White River $(200 \mathrm{kw})$.

Oil and gas are produced at several fields in the subbasin; the Rangely field in the White River basin is the largest producer. Gilsonite is mined in the lower White River basin and is piped as a slurry to Grand Junction, where it is processed into gasoline and asphaltic products. Some of the water produced from oil wells in the Ashley Creek basin during the irrigation season is used for irrigation. In the past, some of the brines produced in oil production in the Red Wash oil field ran into natural drainage channels that lead to Green River, and some was evaporated in ponds. At present, however, the brines are injected back into the oil-producing horizons. In the Roosevelt oil field, the brines from oil wells are disposed of in evaporation ponds (Goode and Feltis, 1962, p. 9).

\section{STREAMFLOW}

\section{VARIABILITY OF SEABONAL RUNOFF}

Except for the water entering this subbasin in the Green River, most of the water supply comes from the melting of snow that accumulates on the south slopes of the Uinta Mountains and the north slopes of the White River Plateau. As temperatures rise in the late spring and early summer, the snow melts rapidly and causes the streams to rise. The streams then subside as the stored supply of snow is exhausted. Usually by late July, streams have subsided to near a base flow, which prevails until the cycle is repeated again the following spring.

Hydrographs for three streams are shown in figure 107. Although 1954 was a year of relatively low runoff, the hydrographs show the general seasonal pattern. In years of high runoff, the peak flow is generally in June and the snowmelt period lasts much longer than it did in the 1954 water year.

Three different conditions of streamflow are represented by the hydrographs in figure 107. Ashley Creek receives some water from the Oak Park Reservoir, and the inflow of this water is evinced by the increase in discharge on the hydrograph in late June. The hydrograph for Whiterocks River represents natural flow; only a small amount of irrigated land is above the station and regulation by small mountain lakes is negligible. The fairly high sustained flow in White River is probably the result of ground-water storage in the formations underlying the White River Plateau.

\section{FLOW-DURATION CURVES}

Historical flow-duration curves were developed for streams at 26 sites. For all of the sites, curves representative of the 44-year base period adjusted to 1957 conditions of upstream development were prepared. The data for historical and adjusted curves are given in table 5 .

Table 21 outlines the methods used in adjusting the historical flow-duration curves to 1957 conditions and lists the upstream water developments in which changes occurred. The authors' accuracy ratings of the adjusted long-term curves are also given. No adjustments were made for the Strawberry Reservoir and diversions through the Strawberry tunnel. Storage began in the reservoir in 1912, and from that time through the 1957 water year spillage was practically nil.

Flow-duration curves for four streams are shown in figure 108.

Table 7 gives the variability indices of streamflow and percentage of average annual discharge estimated to be contributed to the streams by ground water at six stations. Only headwater streams on which there is little irrigation are included in the listing, which has been arranged in order of magnitude of the variability indices.

The Whiterocks River and Rock, Ashley, and Yellowstone Creeks all head in areas underlain by Precambrian rocks in the Uinta Mountains and cross southward-dipping formations of limestone, sandstone, and shale ranging in age from Paleozoic to Jurassic (pl. 1). The gradient of the streams is steep, and deep canyons have been cut into the sedimentary rocks. Parts of the drainage basins are overlain by glacial debris and outwash gravel. Numerous small morainal and cirque lakes are in the headwaters, and most of the drainage basins between altitudes of about 9,000 and 11,000 feet are covered with dense growth of subalpine forest.

The environmental factors in the drainage basins of the Whiterocks River and Rock, Ashley, and Yellowstone Creeks cause the shape of their flow-duration curves to be very similar. However, the curve for the Whiterocks River is steeper at high and low discharges than the others, a fact indicating less groundwater storage in its drainage basin. The lower variability index and higher percentage of ground water for Yellowstone Creek compared with those for the other streams are probably caused by more extensive ground-water storage or natural-lake regulation in the Yellowstone Creek drainage basin than in the other basins. 

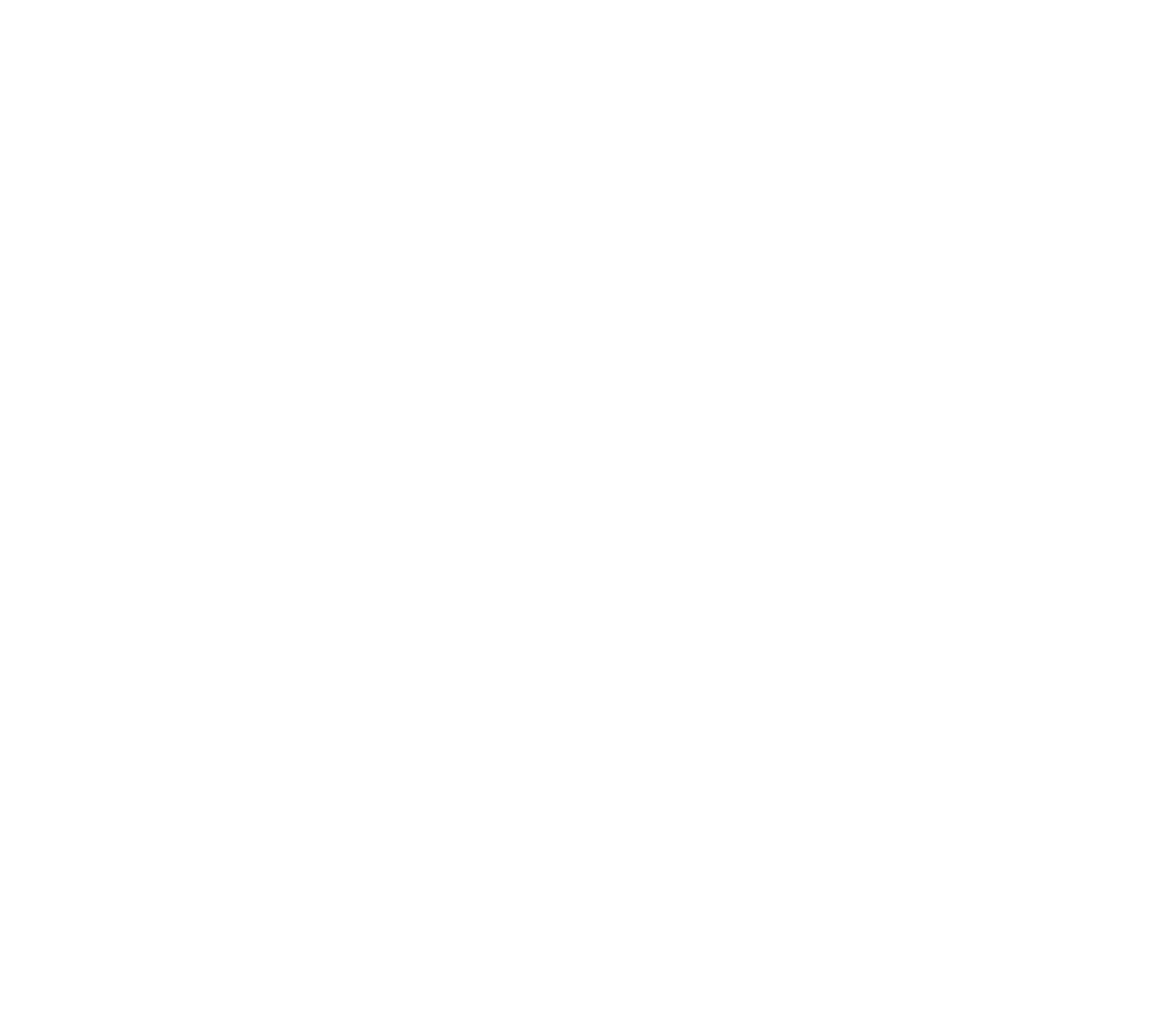

FIGURE 107.-Seasonal pattern of runoff in the Green River basin between the Yampa and White Rivers including the White River basin, 1954 water year.

The drainage basin of the West Fork Duchesne River is on the eastern slope of the Wasatch Range. This basin is underlain principally by sandstones of the San Rafael and Glen Canyon Groups. Tertiary volcanics underlie the extreme headwater area.

The White River has a relatively high sustained flow, the lowest variability index, and the highest percentage of ground-water contribution of the six streams listed in table 7. This stream drains the north slope of the White River Plateau, which is underlain by Pennsylvanian and Permian Rocks and partly capped with Tertiary volcanic rocks. These rocks, particularly the volcanic rocks, are permeable; and extensive ground-water reservoirs, which sustain the flow of the river, are apparently present.

\section{VARIABILITY OF ANNUAL RUNOFF}

Annual water discharges for three streams in the subbasin for the water years 1914-57 are shown in figure 109. The pattern of annual discharges for Ashley. Creek and the Whiterocks River is very similar, but different from the pattern of White River. The coefficients of variation for these three streams and the Duchesne River at Duchesne, Utah, are given in table 8. These coefficients are also shown on plate 6. Other streams with shorter periods of record that drain the south slope of the Uinta Mountains were also studied; their coefficients ranged from about 0.30 to 0.37 . The climate is almost the same along the length of the Uinta Mountains, but some streams apparently have groundwater reservoirs and lakes in their drainage basins that 

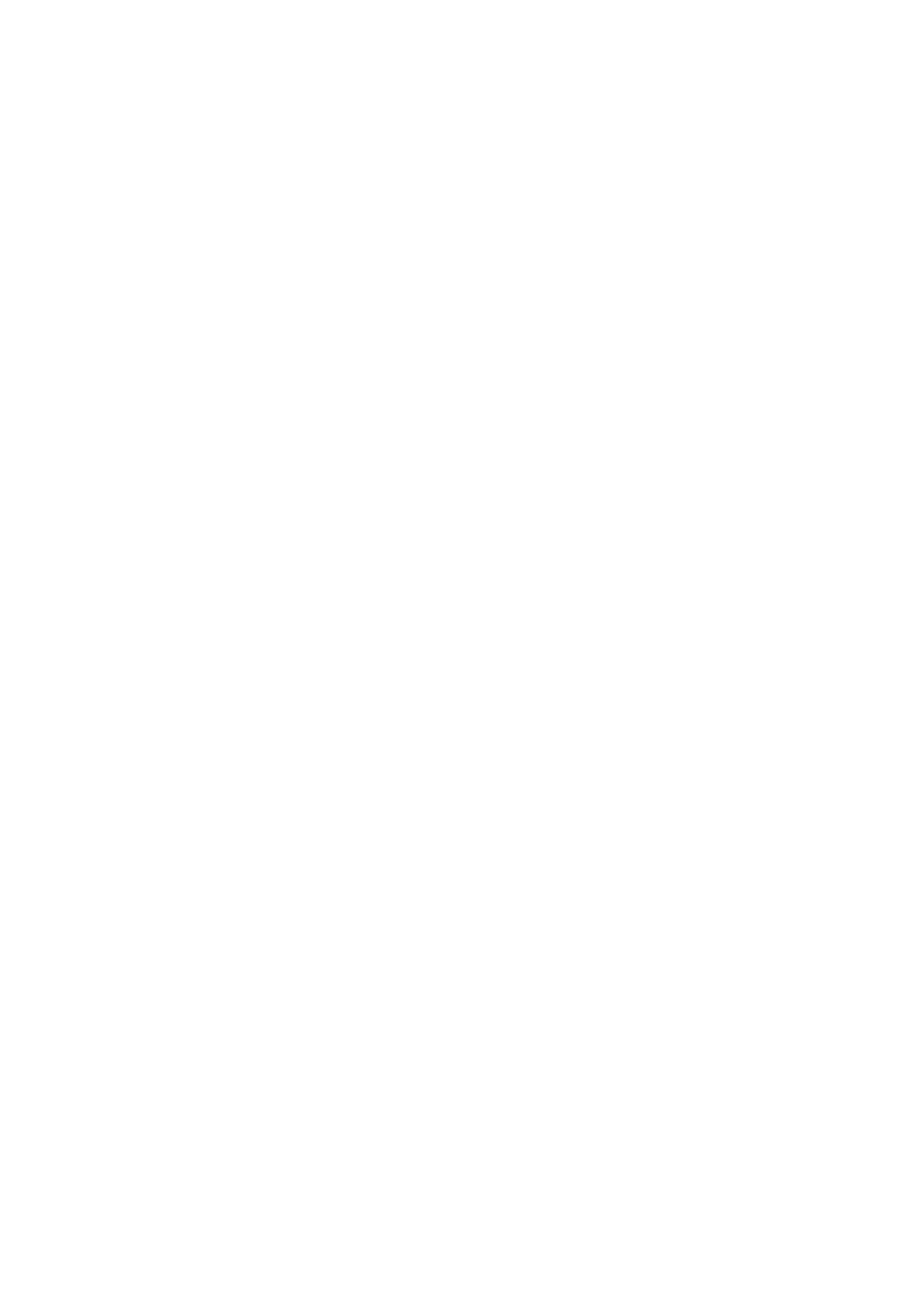

C. Whiterocks River near Whiterocks, Utah

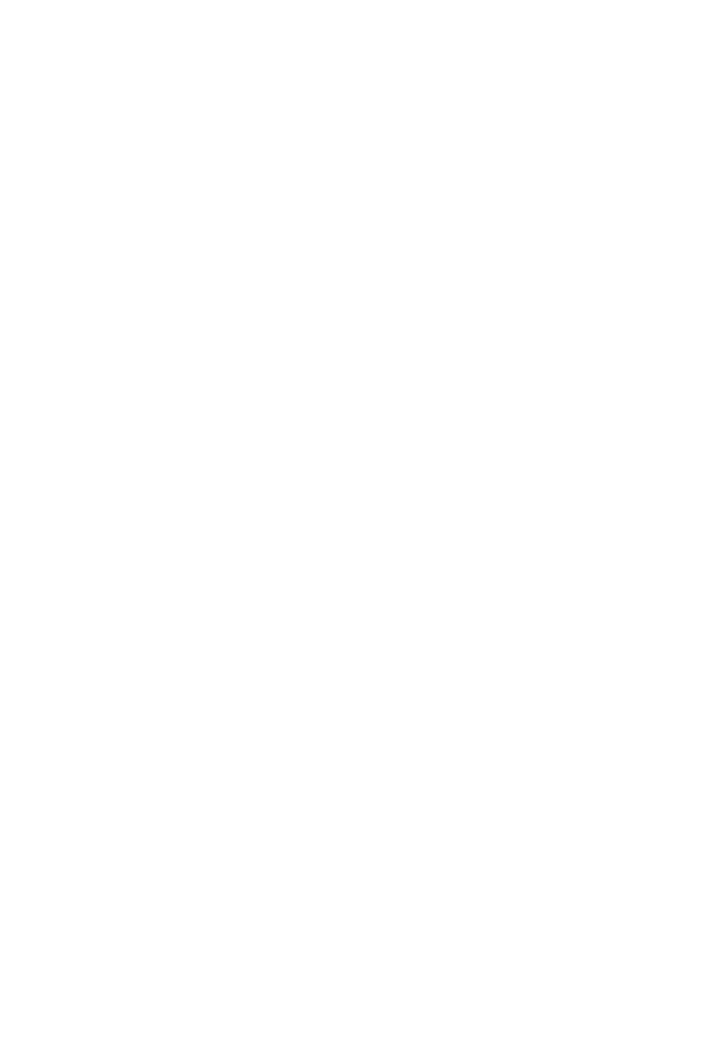

$D$. White River near Meeker, Colo.

Figure 108,-Flow-duration curves of streams in the Green River basin between the Yampa and White Rivers mcluding the White River basin, water years 1914-57 adjusted to 1957 conditions. 


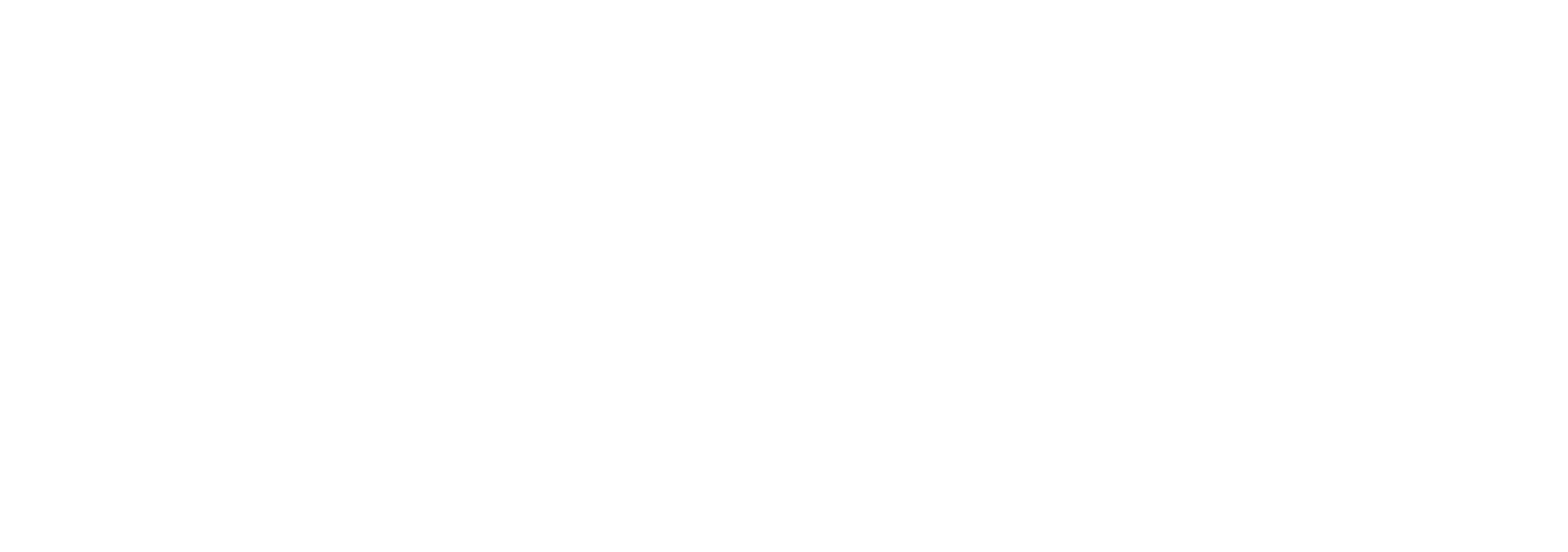

A. Ashley Creek near Vernal, Utah

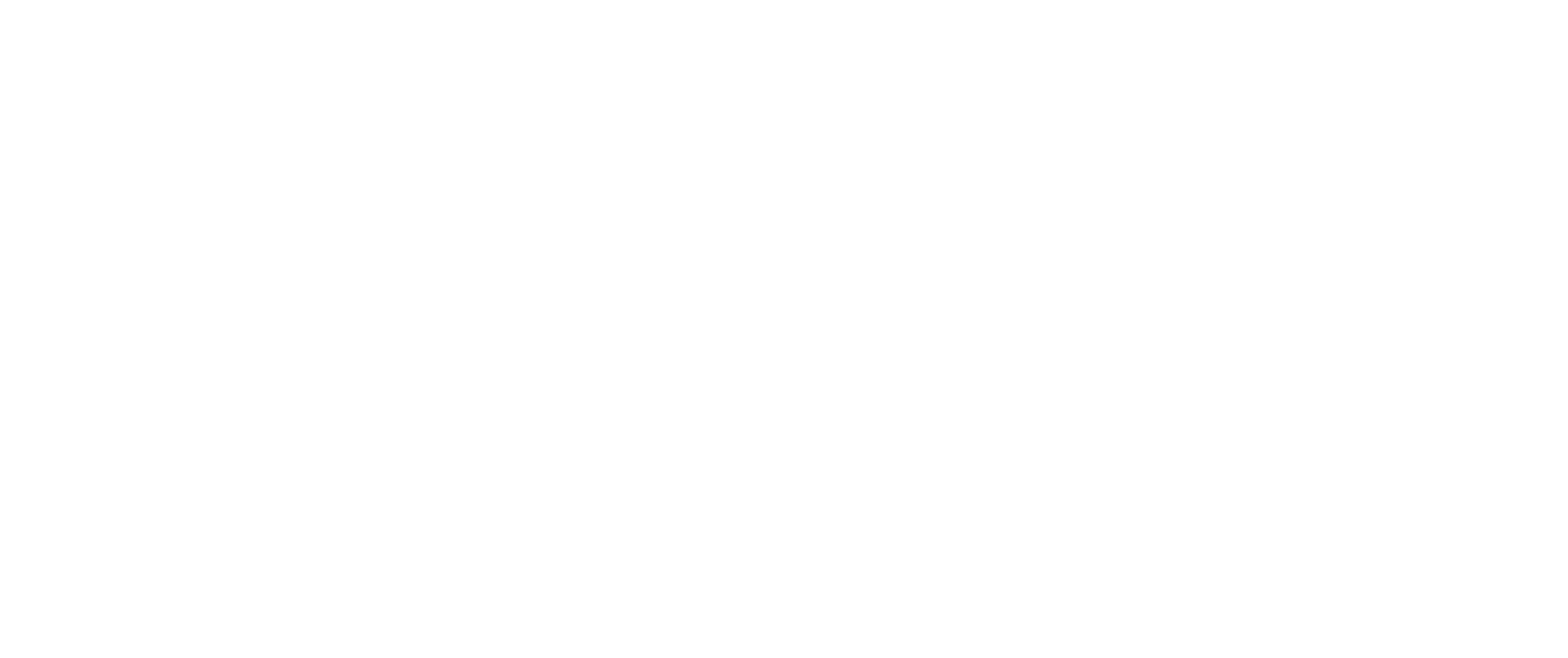

$B$. Whiterocks River near Whiterocks, Utah

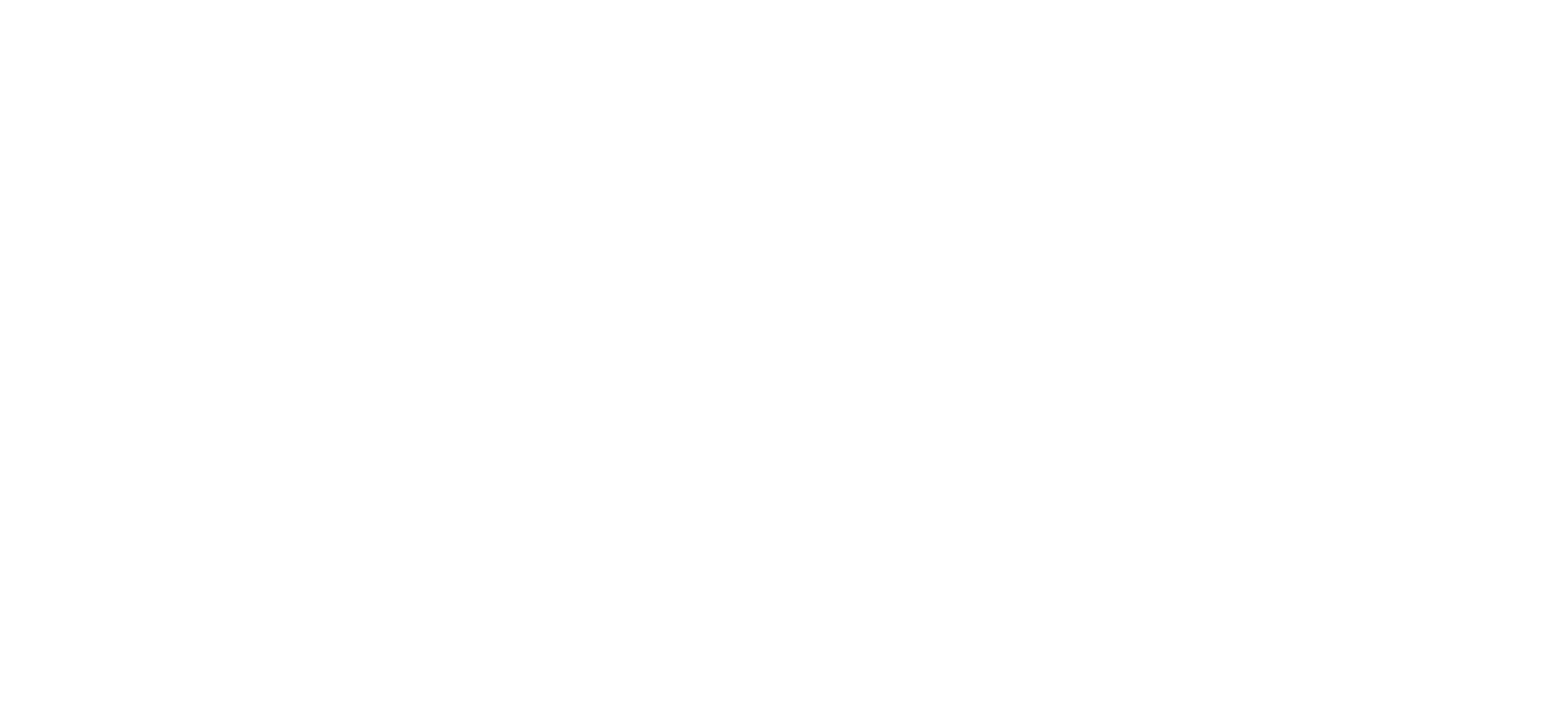

FIGURE 109.-Variability of annual discharges of selected streams in the Green River basin between the Yampa and White Rivers including the White River basin, water years 1914-57. 
sustain the flow during years of low precipitation. This results in coefficients of variation in the lower part of the range. Ground-water reservoirs in the permeable formations of the White River plateau are extensive enough to maintain good flows in the White River during periods of low precipitation. The data in table 8 may be used in determining probable future runoff for periods of various length. (See p. 191 and chap. B., pp. 57-58.)

\section{CHEMICAL QUALITY OF WATER}

\section{DISGOLVED-SOLIDS DISCHARGE AND CONCENTRATION}

Daily chemical-quality data have been obtained on water at six stations in the subbasin. Monthly and annual weighted-average chemical analyses of water at these stations are given in the basic data report (Iorns and others, 1964, tables 195-201). In addition to the daily data at the six stations, chemical analyses of streams have been obtained at other sites. The dissolved-solids discharge for the daily stations and for some of the other sites have been computed (table 9 ). The quantities given in table 9 are averages which would have occurred if 1957 developments had been in operation throughout water years 1914-57.

Duration tables of dissolved-solids concentration and discharge for the stations listed in table 9 are given in tables 10 and 11 . (See chap. B, pp. 58-59, for description of computation methods.)

In figure 110 the dissolved solids and water entering this subbasin via the Green River and the dissolvedsolids and water discharges at selected sites (table 12), expressed as percentages of the dissolved-solids and water discharges of Green River near Ouray, Utah, are shown. About 28 percent of the water and about 43 percent of the dissolved solids passing the station near Ouray come from this subbasin. In terms of percentage of water and dissolved-solids discharge of Green River near Ouray, the White River contributes about the same amount of water to the Green River as the Duchesne River but contributes about 5 percent less dissolved solids.

\section{VARIATIONS IN CHEMICAL QUALITY}

The streams of this subbasin have a relatively small seasonal range in dissolved-solids concentration near their headwaters. Downstream, the seasonal range in dissolved-solids concentration increases. Table 10 shows the maximum seasonal range which may be expected if developments that existed in 1957 do not increase or decrease.

The monthly weighted-average concentration of some streams is considerably different in years of low and high runoff, as is shown by figure 111 for White River near Watson, Utah. Water year 1954 was a year of relatively low runoff, and 1951 was a year of relatively high runoff. The concentration is less variable during the winter than it is during the summer.

The coefficient of variation of annual weighteda verage concentration of dissolved solids and of annual historical discharge for one stream in the subbasin is given in table 12. The computed coefficients are for the same period, but that period is probably too short for a reliable statistical analysis. (See p. 193 for discussion of relation between coefficients of variation in the Green division.)

\section{RELATION TO GTREAMFLOW}

The dissolved-solids concentration of the streams varies nearly inversely with the streamflow, and the dissolved-solids discharge varies directly with the streamflow (fig. 112). An exception to this may be Lake Fork below the Lake Fork Reservoir, Utah, where the variation in dissolved-solids concentration is small because of mixing in the reservoir.

The waters of the streams near their headwaters are principally of the calcium bicarbonate type, but the chemical composition of most streams changes in their downstream reaches, particularly during low flow. Table 13 gives the chemical composition of water for different rates of discharge at seven sites on streams in the subbasin. The data at four of these sites are illustrated in figure 113.

\section{RELATION TO GEOLOGY}

The rocks in the higher parts of the Uinta Mountains are mostly quartzites of Precambrian age and are relatively resistant to the solvent action of water. Along the south flank of the mountains, sedimentary rocks of Paleozoic to Jurassic ages are exposed as narrow bands. These rocks are more resistant to the solvent action of water than are the rocks of Cretaceous and Tertiary ages that underlie the greater part of the subbasin west of the Green River.

Rocks of Cretaceous and Tertiary ages also underlie much of the subbasin east of Green River. In the headwaters of the White River, Pennsylvanian and Permian rocks, partly capped with Tertiary volcanics, are exposed.

Streams in the subbasin draining the areas underlain by rocks of Precambrian to Jurassic ages and Tertiary volcanics contain fairly low concentrations of dissolved solids, and the water is of the calcium bicarbonate type. The weighted-average concentration of dissolved solids in the waters of these streams usually does not exceed $300 \mathrm{ppm}$ (table 9).

The sedimentary rocks of Cretaceous and Tertiary ages that underlie the greater part of the subbasin contain an abundant supply of soluble material, and they are in an area of low precipitation. From the headwaters of the main streams to their mouths, the waters 

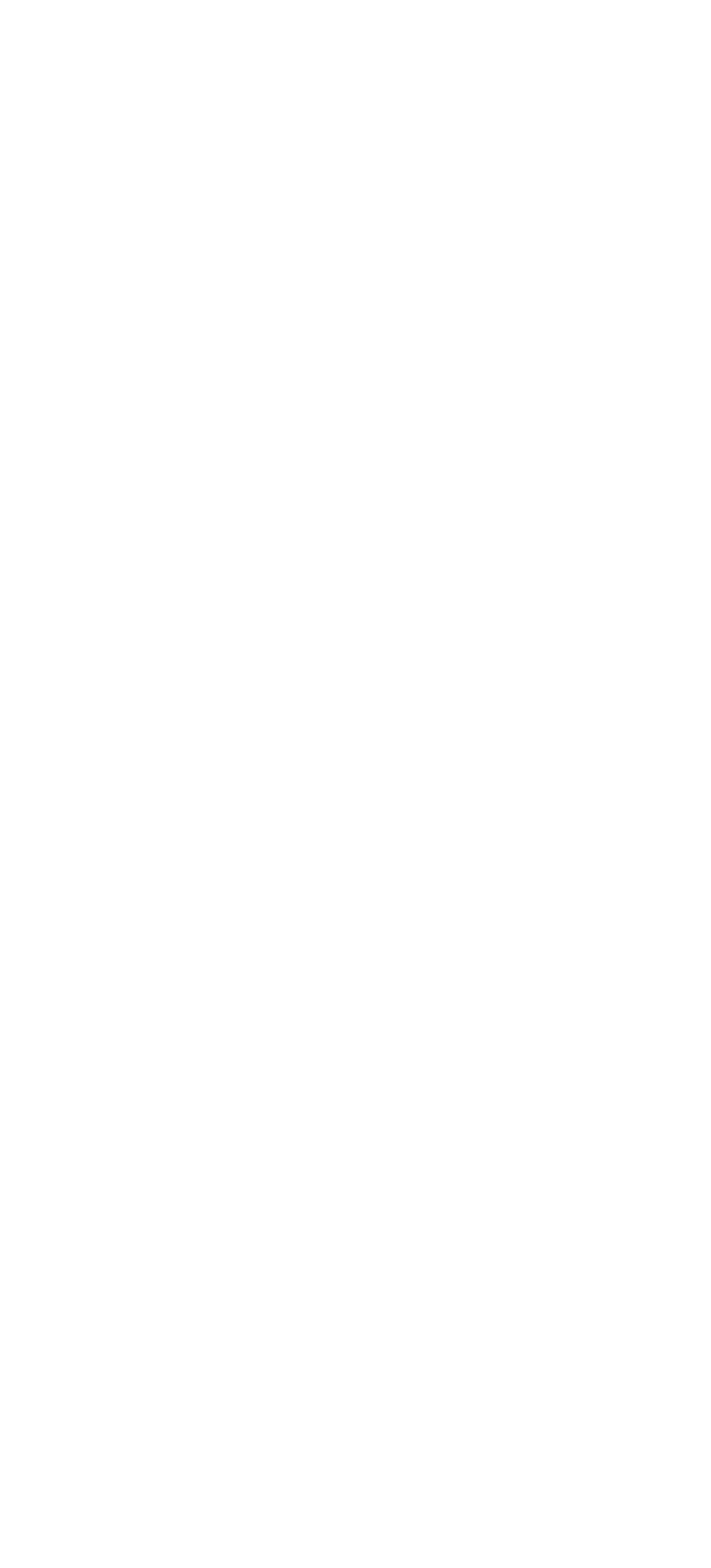


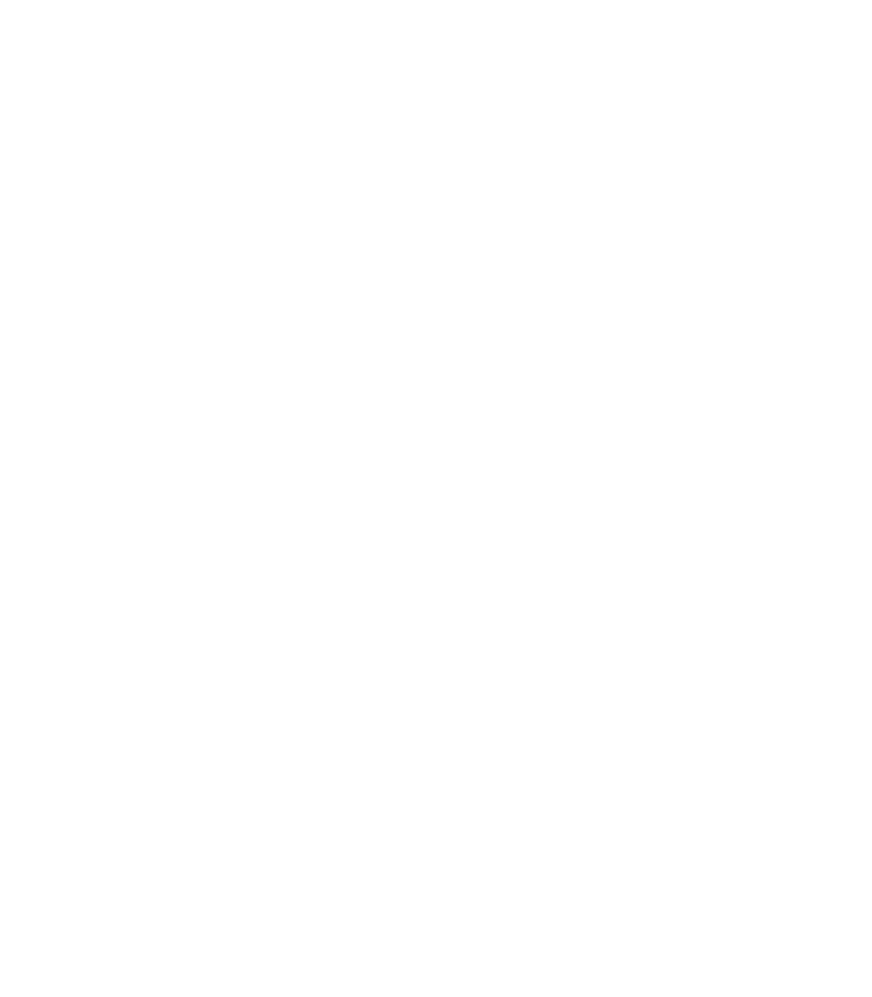

Figure 111.--Dissolved-solids concentration of White River near Watson, Utah, for the 1951 and 1954 water years.

of the streams become progressively more mineralized, and the chemical composition changes from a calcium bicarbonate type to a magnesium sodium sulfate or chloride type.

Most irrigated lands are in lower mountain valleys or in the interior of the subbasin (pl. 7). Here, the soils are derived from residuum and are closely associated with the underlying Cretaceous and Tertiary rocks. Return flow from the irrigated lands contains large quantities of dissolved material, leached from the soils and the underlying rocks. The addition of the return flow to the streams increases the concentration of dissolved solids in the streams and often causes a change in their chemical composition.

Figure 114 shows broad zones within which the weighted-average dissolved-solids concentrations of the streams are between certain limits. These zones correlate closely with the different rock types and the precipitation and indicate that the surface water in a large part of the subbasin contains high concentrations of dissolved minerals. Fortunately, the runoff from the areas that are capable of yielding high concentrations of dissolved-solids is so low that the total quantity of dissolved minerals is not sufficient to increase seriously the concentration of the water of the Green River insofar as local use is concerned.
The diagrams on plate 2 show the geochemical character and ionic concentrations of surface waters at 63 sites in the subbasin. The diagrams are representative of the chemical character of the streams during low flow, when the effect of geology on chemical quality is more evident than during high flows. The significance of the size and shape of the diagrams is given in the explanation on plate 2 .

\section{RELATION TO GROUND WATER}

Ground water in the subbasin occurs in deposits of glacial origin in the mountains, in permeable beds of consolidated rocks, and in unconsolidated deposits in the valleys. The recharge areas of the permeable consolidated rocks are along the flanks of the Uinta Mountains and in the Wasatch and White River Plateaus. Except for places where the streams are deeply incised into permeable beds of the consolidated rocks along the flanks of the mountains, ground water in these beds has little relation to the chemical quality of the water in the streams. The permeable beds dip steeply beneath the floor of the subbasin and are deeply buried by relatively impermeable beds of Cretaceous and Tertiary rocks.

The glacial deposits in the mountains are derived principally from relatively insoluble rocks, and the ground water in these deposits is low in dissolved solids and is of the calcium bicarbonate type. Ground water which enters the streams from the incised permeable beds at the edge of the mountains is mostly of the calcium bicarbonate or calcium sulfate type. As this area is fairly close to the area of recharge, the ground water has low to moderate concentrations of dissolved solids.

Table 14 gives the water and dissolved solids estimated to be contributed to selected headwater streams by ground water. The amount of dissolved solids contributed is dependent on the amount of ground water entering the streams and on the solubility of rock material in the ground-water reservoirs. As indicated by the data in table 14 the solubility of the rock complex underlying the drainage basins above the stations on Ashley Creek, West Fork Duchesne River, Rock Creek, Yellowstone Creek, and Whiterocks River is low, but the rocks of Pennsylvanian and Permian ages underlying much of the headwaters of White River apparently contain a relative abundance of soluble minerals.

Ground water in alluvium in the interior valleys originates principally by infiltration from streams and from irrigated lands. This alluvium is derived principally from rocks of Cretaceous and Tertiary ages and contains an abundance of soluble minerals. Figure 115 shows comparisons of analyses of water in the alluvium 

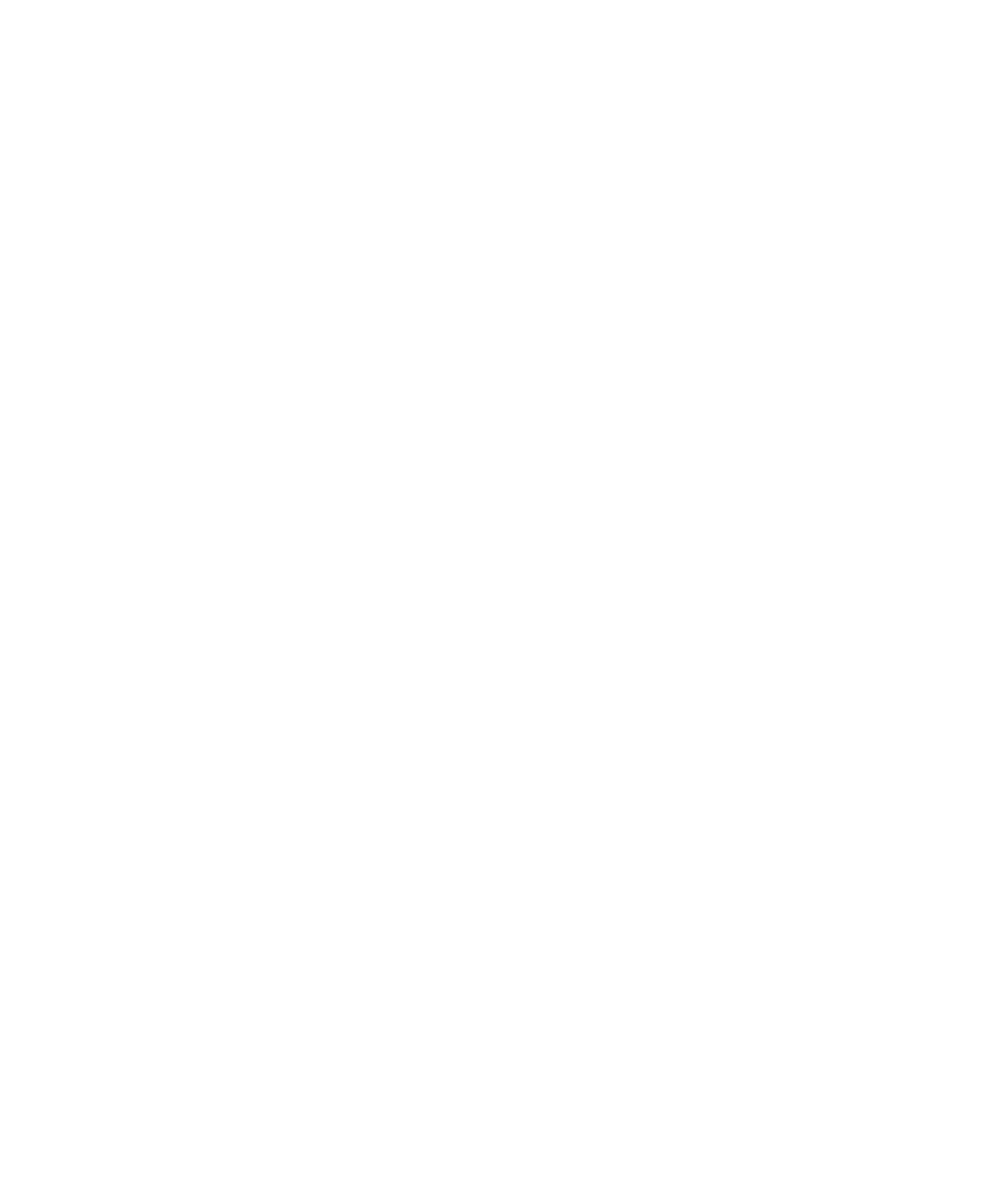

FIgURE 112.-Dissolved-solids concentration and discharge and water discharge at four daily stations in the Green River basin between the Yampa and White Rivers, including the White River basin. 

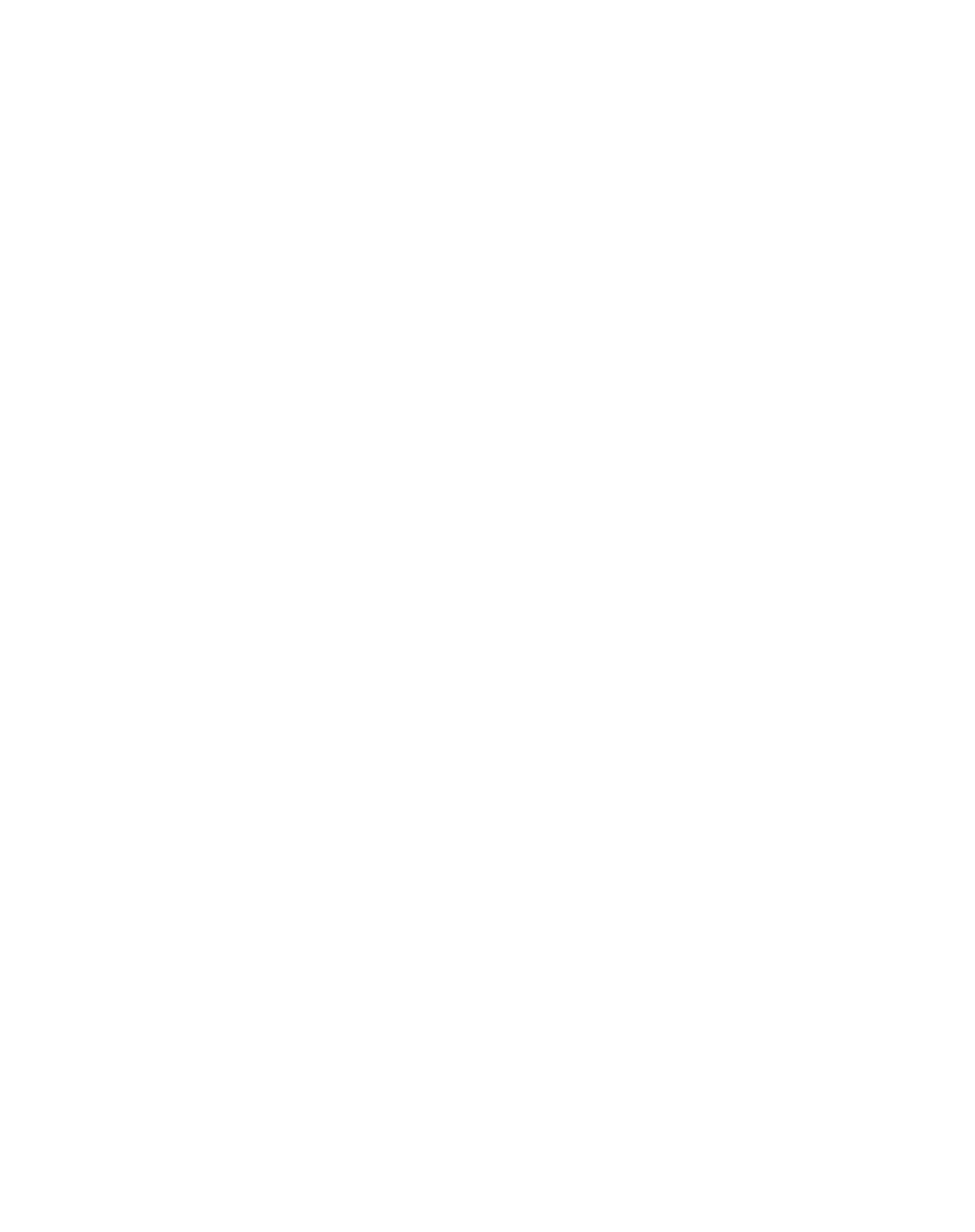

FIGURE 113.-Relation of the chemical composition and concentration of dissolved solids to water discharge in the Green River basin between the Yampa and White Rivers including the White River basin. The concentration of specific ions, in equivalents per million (epm), is shown for the 10th, 50th, and 90th percentiles of the flow-duration curve for each location. The flow-duration curves are for the water years 1914-57 adjusted to 1957 conditions. 


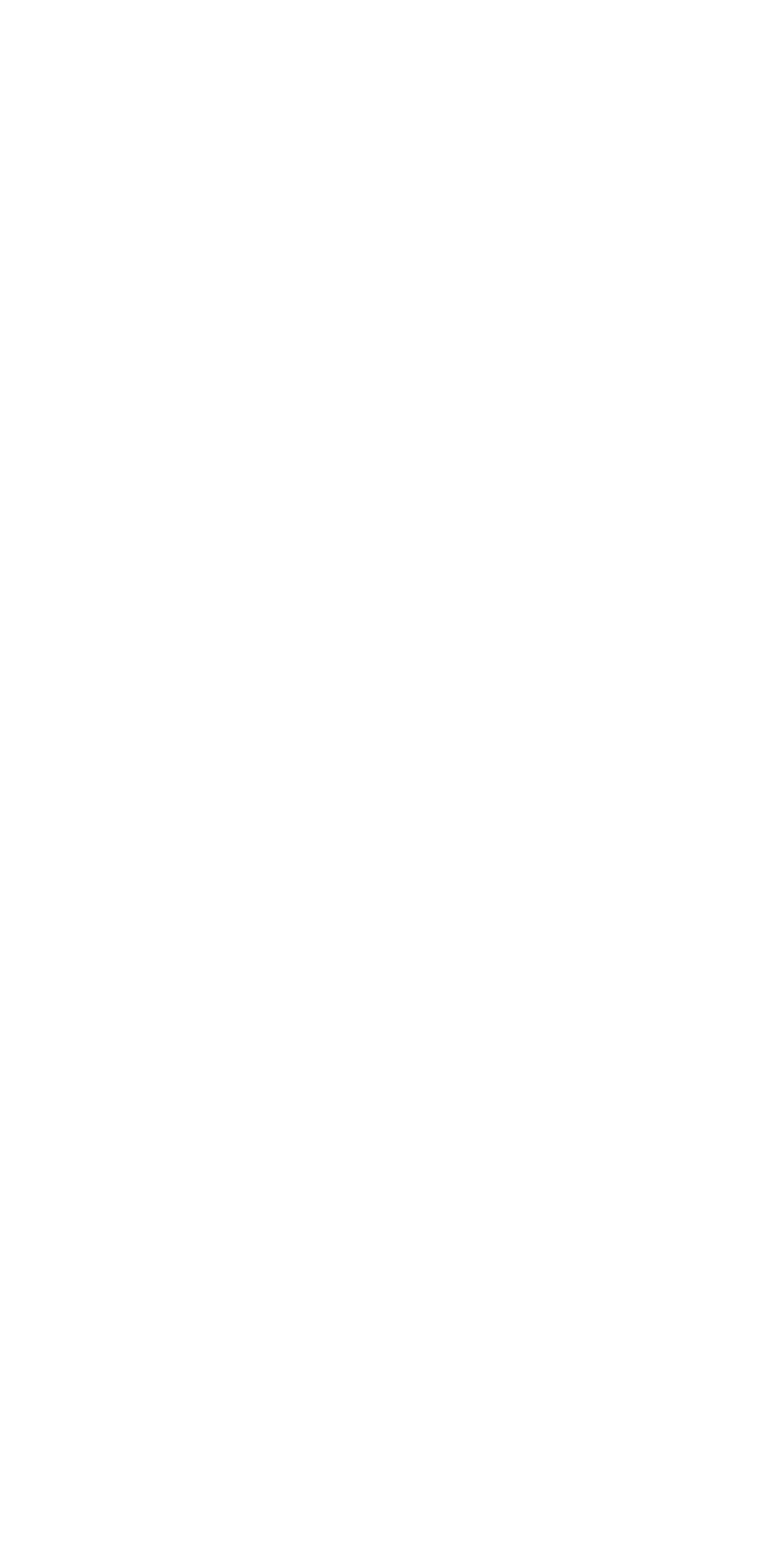


and in the nearby streams. The analyses of the water from alluvium and from Green River at Ouray, Utah, and White River near Watson, Utah, are examples of the chemical quality of ground water in alluvium that is recharged when the stream is high. In the other comparisons in figure 115, the ground water in the alluvium is recharged principally by irrigation.

The ground water in the alluvium, particularly in areas where recharge is from irrigation, contains fairly large quantities of calcium, magnesium, sodium, and sulfate ions. In some local areas of the subbasin, nitrate is present in concentrations approaching the maximum considered to be safe for domestic use.

In the western part of the subbasin, ground water contributes boron to some of the northward-flowing streams. Boron in these streams at times exceeds 10 ppm.

Warm Springs, a group of thermal springs which flow into the Green River from both sides of the channel about 12 miles north of Jensen, Utah, has an estimated flow of 12 cfs (Thomas, 1952, p. 12). The water from the springs has a dissolved-solids concentration of about $940 \mathrm{ppm}$, and the annual dissolved-solids discharge is about 11,100 tons.

\section{EFFECT OF TRANSMOUNTAIN DIVERSIONS}

Several canals and tunnels divert water from the headwaters of the Strawberry and Duchesne Rivers to the Great Basin (see p. 216). The effect of these diversions has been to reduce the water and dissolvedsolids discharges and increase the weighted-average concentration of dissolved solids in the Strawberry and Duchesne Rivers at downstream points. The weighted-average concentration of the diverted water is less than that of the streams from the points of diversion to the mouth of the Duchesne River.

The weighted-a verage concentration of dissolved solids in the 71,600 acre-feet of water diverted annually from the Strawberry River is about $170 \mathrm{ppm}$ (Iorns and others, 1964, table 223). The effect of the diversion on Strawberry River at Duchesne, Utah, has been to decrease the dissolved-solids discharge about 16,600 tons annually and increase the weighted-average concentration about $87 \mathrm{ppm}$ (see chap. B, p. 61 for method of computation). If the water were not diverted, the weighted-average concentration of Strawberry River at Duchesne, Utah, would be about $309 \mathrm{ppm}$ instead of $396 \mathrm{ppm}$.

The weighted-average concentration of dissolved solids in the 30,500 acre-feet annually diverted through Duchesne tunnel is about $25 \mathrm{ppm}$ (Iorns and others, 1964, table 223). The effect of this diversion on Duchesne River at Duchesne, Utah, has been to decrease the dissolved-solids discharge about 1,040 tons and increase the weighted-average concentration about 22 ppm. If the water were not diverted, the weightedaverage concentration of Duchesne River at Duchesne, Utah, would be about $196 \mathrm{ppm}$ instead of $218 \mathrm{ppm}$.

The diversions from the headwaters of the Strawberry and Duchesne Rivers have caused the long-term weighted-average concentration of Duchesne River

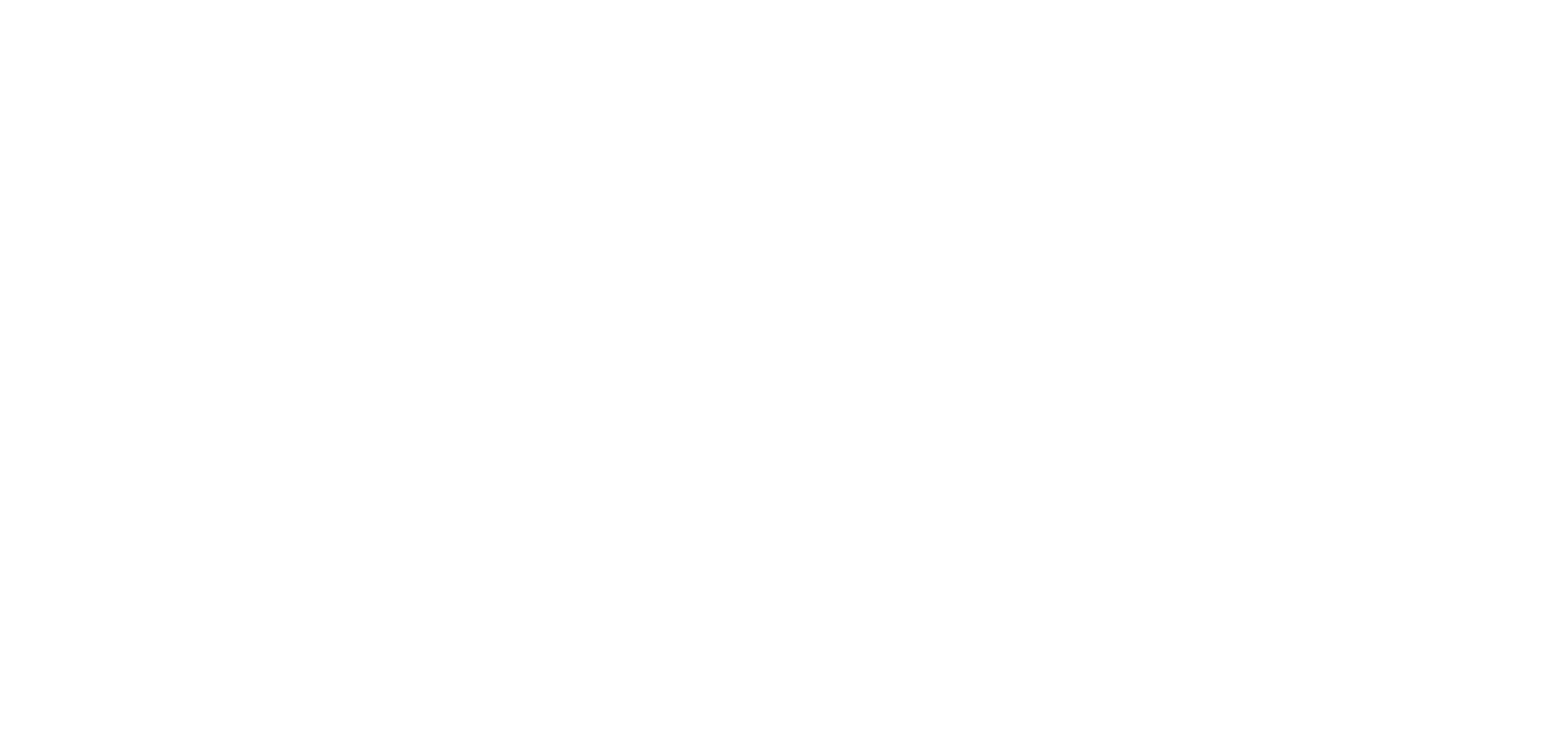

Frgure 115.-Analyses of water from selected streams in the Green River basin between the Yampa and White Rivers including the White River basin and from alluvium nearby. 
near Randlett, Utah, to increase from about $533 \mathrm{ppm}$ to $608 \mathrm{ppm}$.

\section{EFFECT OF THE ACTIVITIES OF MAN}

In this subbasin, the dissolved solids contributed to the stream systems in three areas were determined. General descriptions of the three areas and computations of the dissolved-solids contributions are given in the following paragraphs.

In Ashley Creek basin below Ashley Creek near Vernal, Utah, and Dry Fork at the mouth, near Dry Fork, Utah, and above Ashley Creek near Jensen, Utah, about 23,800 acres of land underlain by alluvium and by Mancos Shale is irrigated. Several oil wells in the area produce water which is discharged to irrigation canals. In 1960 these wells discharged about 2,400 acre-feet of water with dissolved-solids concentrations ranging from 416 to $1,960 \mathrm{ppm}$ (Goode and Feltis, 1962, table 2). The 2,400 acre-feet of oil-well water contained an estimated 4,000 tons of dissolved solids. An average of about 3,500, acre-feet of water is diverted annually out of the basin, and about 600 acre-feet of underflow bypasses the Jensen gaging station (Thomas and Wilson, 1952). Table 15 gives an approximate water and dissolved-solids budget for the area.

The water discharge of Dry Fork at mouth, near Dry Fork, Utah, (19,000 acre-feet) is the difference between the discharge of Ashley Creek at Sign of the Maine, near Vernal $(95,800$ acre-feet $)$, and the discharge of Ashley Creek near Vernal (76,800 acre-feet). The weighted-average dissolved-solids concentration of Dry Fork at mouth was computed from the water discharge and chemical analyses for Ashley Creek at Sign of the Maine (weighted-average concentration about $71 \mathrm{ppm}$, Iorns and others, 1964, table 223), the water discharge and weighted-average concentration for Ashley Creek near Vernal, and the water discharge for Dry Fork at mouth.

The weighted-average concentration of dissolved solids of the water diverted out of the area is assumed to be the same as that of Ashley Creek at Sign of the Maine. The concentration of dissolved solids of the ground-water outflow is based on analyses of Ashley Creek near Jensen at times of low flow (table 10 and Iorns and others, 1964, table 223).

In the budget the 42,500 acre-feet consumed in the area is the amount required to balance the inflow-outflow budget. This amount is equivalent to a consumptive-use rate of 1.8 acre-feet per acre of irrigated land. This rate is of the right order of magnitude for the environment and type of crops grown and indicates that any other inflow into the area is probably negli- gible. Average annual precipitation over the intervening area is only about 9 to 15 inches.

The increase in dissolved solids from other sources, 49,400 tons annually, is equivalent to 2.1 tons per year per acre of irrigated land.

Along the Duchesne River between the gaging stations near Tabiona and at Duchesne, Utah, about 6,500 acres is irrigated. The irrigated lands are underlain by the Uinta Formation of Tertiary (Eocene) age. Duchesne River near Tabiona, Utah, and Rock Creek near Mountain Home, Utah, record most of the inflow to the area (table 9). In addition to the water flowing out of the area in the Duchesne River at the Duchesne gaging station (table 9), some water is carried past the station in a canal, and some underflow probably occurs in the valley fill. Average annual precipitation over the intervening drainage area between the inflow and outflow stations is only about 9 to 12 inches. It is estimated that the runoff from this area would be about half an inch annually, or about 4,000 acre-feet from the 159 square miles of intervening area. This runoff is estimated to have the same weighted-average concentration of dissolved solids as Duchesne River near Tabiona. An approximate budget of water and dissolved solids for the area is given in table $\mathbf{1 5}$.

Irrigation in the intervening reach $(6,500$ acres $)$ is estimated to have the same consumptive-use rate as Ashley Creek basin (1.8 acre-ft per acre). The canal bypassing the Duchesne River near the Duchesne gaging station for the irrigation of 1,000 acres on the north side of the Duchesne River below the station is estimated to bypass about 5,000 acre-feet annually ( 5 acre$\mathrm{ft}$ per acre). About one-half of the irrigated lands in the area is above the point of diversion of this canal. The weighted-average concentration of dissolved solids of the bypassed water is estimated to be $180 \mathrm{ppm}$. This concentration was computed by averaging the concentration of dissolved solids for Duchesne River at Duchesne $(218 \mathrm{ppm})$ and the weighted-average concentration for Duchesne River near Tabiona and Rock Creek near Mountain Home (144 ppm).

The estimated ground-water underflow of 5,100 acrefeet is the amount required to balance the inflowoutflow budget. This amount is equivalent to about $7 \mathrm{cfs}$. The concentration of dissolved solids of the ground water is estimated to be the same as the concentration of water from Duchesne River at Duchesne during low flow.

The computed increase of dissolved solids in the reach $(22,700$ tons) is equivalent to about 3.3 tons per year per acre of irrigated land.

In the White River drainage basin below White River at Buford, Colo., and South Fork White River near Buford, Colo., and above White River near 
Meeker, Colo., about 11,000 acres is irrigated. In the upper part of the area, Permian rocks underlie the irrigated lands; but the lower part of the area, where most of the irrigated lands are located, is underlain by Mancos Shale. A canal supplying water for about 300 acres bypasses White River at Buford, Colo., gaging station and about 3,000 acres are irrigated by water that bypasses White River near Meeker, Colo., gaging station. Table 15 gives an approximate water and dissolved-solids budget for the area.

Water and dissolved-solids discharges for the gaging stations named in table 15 are from table 9 . The canals that bypass the gaging stations are estimated to carry about 5 acre-feet per year for each acre irrigated. The dissolved-solids concentration of water in the canal bypassing White River at Buford is estimated to be the same as that at this gaging station. The dissolved-solids concentration of the canals bypassing the station near Meeker is taken to be equal to the weighted-average of White River at Buford and South Fork White River near Buford.

The amount of water consumed by irrigation is based on a consumptive use of 1 acre-foot per acre, and the unmeasured inflow in the reach is the amount required to balance the inflow-outflow budget. Most of the unmeasured inflow is runoff from the White River Plateau, and as indicated by the stations at and near Buford would have a weighted-average concentration of dissolved solids between 144 and $164 \mathrm{ppm}$. However, some of the unmeasured inflow comes from Coal Creek, a north-side tributary above Meeker. The drainage basin of this creek is underlain by Mancos Shale, and the weighted-average concentration of its water would probably be above $200 \mathrm{ppm}$. As the amount of inflow from such streams as Coal Creek is small compared with the inflow from streams draining the White River Plateau, the weighted-average concentration of all the unmeasured inflow could be expected to range from 150 to $180 \mathrm{ppm}$.

If the minimum increase from other sources in table 15 were all caused by irrigation, it would be equivalent to 4.8 tons per year per acre of irrigated land.

Estimates were made of the dissolved solids contributed by natural sources and the activities of man for other areas in the subbasin. In table 16, the total computed and estimated quantities contributed by natural sources and activities of man are summarized for two principal gaging stations and for the subbasin.

If there had been no activities of man in the $\mathrm{Du}$ chesne River basin (exclusive of transmountain diversions), the weighted-average concentration of dissolved solids of Duchesne River near Randlett, Utah, would have been about $125 \mathrm{ppm}$ as compared with a weightedaverage concentration of $608 \mathrm{ppm}$ for water years 1914-57 adjusted to 1957 conditions. In this determination, the amount of water consumptively used by irrigation was estimated to be 234,000 acre-feet annually, and the water consumed by domestic and industrial uses of water was considered to be negligible.

If there had been no activities of man in the White River Basin, the weighted-average concentration of dissolved solids of White River at Watson, Utah, would have been about $209 \mathrm{ppm}$ instead of $439 \mathrm{ppm}$ for water years 1914-57, adjusted to 1957 conditions. In this determination, 33,600 acre-feet of water was considered to be the amount consumptively used by irrigation, and the domestic and industrial consumptive use was considered to be negligible.

The increase in dissolved solids due to irrigation in the subbasin is estimated to be about 555,800 tons per year. This estimate is based on assigning 100 tons per year per 1,000 people as the contribution of dissolved solids from domestic and industrial uses of water, 4,000 tons per year from oil wells, and the remainder from irrigation.

\section{FLUVIAL SEDIMENT}

Daily suspended-sediment data have been obtained only at Green River near Jensen, Utah (table 17). In addition, suspended-sediment discharges have been measured at a few other sites. Estimated long-term suspended-sediment data for the station near Jensen and for White River at Buford, Colo., are given in table 18.

The total suspended-sediment discharge from the subbasin is estimated to be about 7,339,400 tons annually. This estimate is based on the difference between the suspended-sediment discharges of Green River near Jensen, Utah, (table 18) and Green River near Ouray, Utah, (table 18), plus an estimated pickup of 417,400 tons annually between the Yampa River and the station near Jensen. The estimated pickup between the Yampa River and the station near Jensen is based on a computed yield of 380 tons per square mile per year from 1,100 square miles of drainage area (see p. 203).

\section{SUITABILITY OF WATER FOR VARIOUS USES}

\section{DOMESTIC USE}

The classifications of the surface water in this subbasin is based on water-quality criteria for major uses. (See chap. B, pp. 66-73.)

In and close to the Uinta Mountains and the White River Plateau, the waters of the streams are suitable for domestic purposes. Concentrations of iron, chloride, and fluoride in all the streams are generally low and do not exceed the maximums considered to be 
harmful. The limitation on concentration of magnesium $(125 \mathrm{ppm})$ is exceeded in some of the streams, but only for short periods of time.

In the more arid part of the area, close to the mouths of all tributaries of the Green River except the White River, concentrations of sulfate in the streams exceed the maximum limit accepted for this report for 50 percent or more of the time. In many of these tributary streams, the concentration of dissolved solids in the water exceeds $1,000 \mathrm{ppm}$ as much as half the time and exceeds $500 \mathrm{ppm}$ at least 80 percent of the time.

The waters of all the streams, except in the mountains, range from moderately hard to very hard and are mostly very hard.

\section{AGRICULTURAL USE}

As in other parts of the Green division, the principal use of water in this subbasin is for irrigation. Table 19 classifies low, medium, and high flows of streams at selected sites according to their suitability for use in irrigation. Most of the terms used in the table are selfexplanatory. Terms that are not self-explanatory are explained on page 203 and in chapter B (pp. 69-73).

The values for residual sodium carbonate given in table 19 indicate that the water of most of the streams is free of residual sodium carbonate or contains much less than $1.25 \mathrm{epm}$. Warm springs on the Strawberry River (2880B and 2880C) have high residual sodium bicarbonate values. The source of the sodium bicarbonate is probably the shales of the Green River Formation which underlie the Uinta Formation in this area. Discharge from these and other springs along the Strawberry River are apparently sufficient to cause the residual sodium carbonate to be fairly high in the Strawberry River at Duchesne, Utah, at times of medium and low flow. As indicated by the residual sodium carbonate in Indian Creek near Duchesne, Utah, and Piceance Creek near White River, Colo., similar springs probably occur along these streams.

Most of the water used for irrigation in the subbasin is $\mathrm{C} 2-\mathrm{S} 1$ category or better. This water is suitable for irrigation if a moderate amount of leaching occurs, and there is little danger of development of harmful levels of exchangeable sodium. In their lower reaches during times of low flow, many of the streams in the subbasin below irrigated land are classified as $\mathrm{C} 3-\mathrm{S} 1$ or poorer. Lands on which such water is used must have adequate drainage.

Percent sodium of the irrigation water is not a hazard, and the required leaching of most of the water used is usually less than 20 percent.

Fairly high concentrations of boron occur in groundwater contributions to the Strawberry River, Lake Canyon Creek, and Indian Creek above Duchesne,
Utah. This is indicated by analyses of water from springs and from Indian Creek when the discharge of that stream consisted mostly of ground water (table 22 ). The ground water also contains high concentrations of sodium, bicarbonate, and sulfate (see Iorns and others, 1964, table 229). The area in which the ground water occurs is underlain by the Wasatch and Green River Formations. The total ground-water discharge is apparently too small to cause a boron hazard in the main streams, except possibly at times of exceptionally low flow.

\section{INDUSTRIAL AND RECREATIONAL USES}

The water of most of the perennial streams in their headwaters can be used for many industries without treatment. The concentration of dissolved solids progressively increases downstream; and in the middle and lower reaches of most of the streams in this subbasin, the surface waters could not be used for many industries without treatment.

Most of the streams and lakes in the Uinta Mountains and White River Plateau are ideal for recreation. The use of surface waters for this purpose will, no doubt, continue to expand rapidly.

\section{GREEN RIVER BASIN BELOW THE WHITE RIVER}

\section{PRESENT UTHIIATION OF SURFACE WATER}

\section{STORAGE RESERVOIRS}

Nine irrigation reservoirs that have capacities greater than 1,000 acre-feet have been constructed (1957) in the Green River basin below the White River (table 3, and fig. 4). There are, in addition, several small natural lakes on the Wasatch Plateau and many stock ponds scattered throughout the subbasin.

\section{TRANSMOUNTANN DIVERSIONS}

In all, 13 ditches and tunnels divert water from this subbasin to the Sevier River basin. Records on the diversions are only available for water years 1950-57 (table 23). Fairview ditch diverts water from the headwaters of both the Price and San Rafael Rivers, and the others divert water from the headwaters of the San Rafael River.

On the basis of information on water rights, canal capacities, time of enlargements of canal capacities, and other data, estimates of annual diversions were made for the water years 1914-49. These estimates and total diversion for water years 1950-57 are given in table 24. The average annual diversions during water years $1950-57$ was 10,100 acre-feet. For this report, 10,100 acre-feet is assumed to be representative of the diversions for water years 1914-57 and developments existing in 1957. 


\section{IRRIGATION}

Irrigation is confined chiefly to the middle and upper reaches of the San Rafael and Price Rivers. A total of about 60,000 acres is irrigated (table 4), of which about 20,500 acres is above Green River at Green River, Utah. Crops are chiefly alfalfa, wild hay, and grains.

The Upper Colorado River Compact Commission (1948) estimated that the 1914-45 average annual consumptive use of water by irrigation was about 102,600 acre-feet. The Commission estimated that 61,740 acres was irrigated and that 9,330 acres of land received water incidental to irrigation practices.

\section{DOMESTIC AND INDUSTRIAL USES}

The 1960 population was about 27,000 , which averages about 3 persons per square mile. The five largest communities, all in Utah, and their population are: Price, 6,802; Dragerton, 2,959; Helper, 2,459 ; Sunnyside, 1,740; and Green River, 1,075. The principal means of livelihood in the four largest communities are coal mining and related activities; however, farming and ranching are the principal means of livelihood of over half the people in the subbasin. No data are available on the amount of water used by the communities; however, it is estimated that domestic and industrial uses consumed about 60 gpd per person or about 1,800 acre-feet annually. There are no known hydroelectric powerplants in the subbasin.

\section{STREAMFLOW}

\section{VARIABILITY OF SEASONAL RUNOFF}

Streams flowing from the west into the Green River receive most of their water supply from melting snow along the east slope of the Wasatch Mountains. The tributaries that enter the Green River from the east rise on the East Tavaputs Plateau. Snowfall on this plateau is light, and the average annual precipitation in the water-producing areas is only about 18 inches. Willow Creek, the principal tributary of Green River from the east, is dry at times in its lower reaches. Many of the smaller streams and washes that drain the areas at lower altitudes are intermittent and flow only in the early spring months or following thunderstorms.

Figure 116 shows hydrographs of two west-side streams and the Green River. Green River at Green River, Utah, and San Rafael River near Green River contribute practically all the outflow from the Green River basin.

\section{FLOW-DURATION CURVES}

Historical flow-duration curves were developed for streams at 14 sites. The historical and adjusted curves in table form are given in table 5. Table 21 outlines the methods used in adjusting the historical flow-duration curves and lists the upstream water developments in which changes took place. This table also gives the authors' accuracy rating of the adjusted long-term curves.

Flow-duration curves for two west-side streams are shown in figure 117. That for Price River above Scofield Reservoir, Utah, is representative of most westside streams near their headwaters. The curve for Huntington Creek is materially different and reflects the effect of both geology and storage. The hydrographs (fig. 116) also reflect the different runoff characteristics.

Table 7 gives the variability indices of streamflow and percentage of total discharge estimated to be contributed by ground water for three streams in the subbasin. The drainage basin of Huntington Creek is underlain by the Blackhawk Formation and Star Point Sandstone of Late Cretaceous age; that of Cottonwood Creek is underlain mostly by the North Horn Formation of Tertiary (Paleocene) and Late Cretaceous age, and that of Ferron Creek is underlain by the Flagstaff Limestone (late Paleocene and early Eocene(?) age) and the North Horn Formation. Of the three drainage basins, the rocks underlying Huntington Creek basin are apparently the most permeable, and the Flagstaff Limestone underlying part of the Ferron Creek Basin is the least permeable.

\section{VARIABILITY OF ANNUAL RUNOFF}

Figure 118 shows the historical annual discharges of Price River near Heiner, Utah, Huntington Creek near Huntington, Utah, and Green River at Green River, Utah. The histogram for Price River near Heiner, Utah, is the combined record for a station operated near Helper for water years 1914-34 and the station near Heiner for water years 1935-57. For all practical purposes, the discharge at these two sites is the same.

The coefficients of variation of three headwater streams and Green River at Green River, Utah, are given in table 8. The close agreement of the coefficients of the headwater streams is probably due to the uniformity of the climate and other hydrologic factors. The data in the table may be used in determining the probable future runoff for periods of various length. (See p. 191 and chap. B, pp. 57-58.)

\section{CHEMICAL QUALITY OF WATER}

\section{DISSOLVED-SOLIDS DISCHARGE AND CONCENTRATION}

Daily chemical-quality data have been obtained at five stations in the Green River basin below the White River. Monthly and annual weighted-ayerage chemical analyses of water at these stations are given in the basic data report (Iorns and others, 1964, tables 202206). In addition, chemical analyses of streams at 

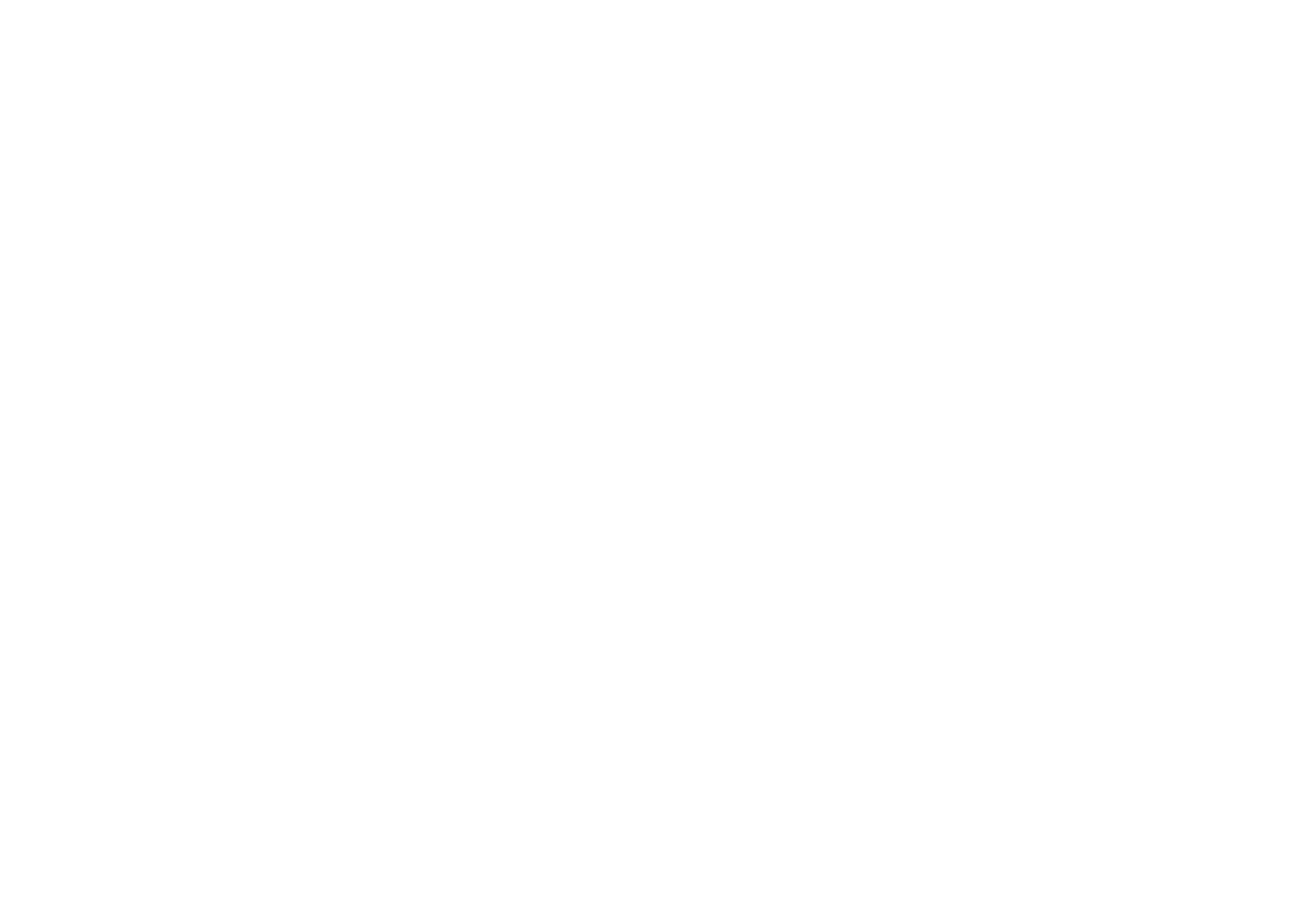

FIGURE 116.-Seasonal pattern of runoff in the Green River basin below the White River, 1954 water year.

other sites have been obtained. The dissolved-solids discharges at the five stations and at other sites have been computed (table 9). The quantities given in the table are averages which would have occurred if developments in 1957 had existed throughout water years 1914-57.

Duration tables of dissolved-solids concentration and discharge for the stations given in table 9 are given in tables 10 and 11. (See chap. B, pp. 58-59, for description of computation method.)

A daily chemical-quality station was operated on Green River near Ouray, Utah, in water years 1951, 1952 , and 1957. The weighted-average concentration for the period of record is $383 \mathrm{ppm}$ compared with the computed weighted-average concentration of 393 ppm for the water years 1914-57 adjusted to 1957 conditions. The long-term weighted-average concentration is almost identical with the weighted-average concentration of $387 \mathrm{ppm}$ for Colorado River near Cameo, Colo. However, the yield from the 35,500 square miles above the station near Ouray, Utah, is only 68 tons per square mile compared with 196 tons per square mile for the 8,060 square miles above the station on Colorado River near Cameo, Colo. An average of about $2,407,000$ tons of dissolved solids passes the Ouray station each year.

The weighted-average concentration of dissolved solids of Willow Creek near Ouray, Utah, for the water years 1951-52 was $994 \mathrm{ppm}$, and the computed weighted-average concentration for the water years $1914-57$ adjusted to 1957 conditions is $869 \mathrm{ppm}$. Although the concentration is relatively high, the low runoff from the 967 square miles of drainage area $(24,700$ acre- $\mathrm{ft}$ per $\mathrm{yr})$ results in a low average annual yield of dissolved solids ( 30 tons per sq $\mathrm{mi}$ ).

The daily records of dissolved-solids discharge of Price River at Woodside, Utah, for the water years 1952-57 show that the weighted-average concentration of the river water for this period is $2,350 \mathrm{ppm}$. For this station the computed dissolved-solids concentration for the water years $1914-57(2,110 \mathrm{ppm})$ is less than that for the period of record. The principal reason the weighted-average concentration for the period of record is higher than for the computed long-term 

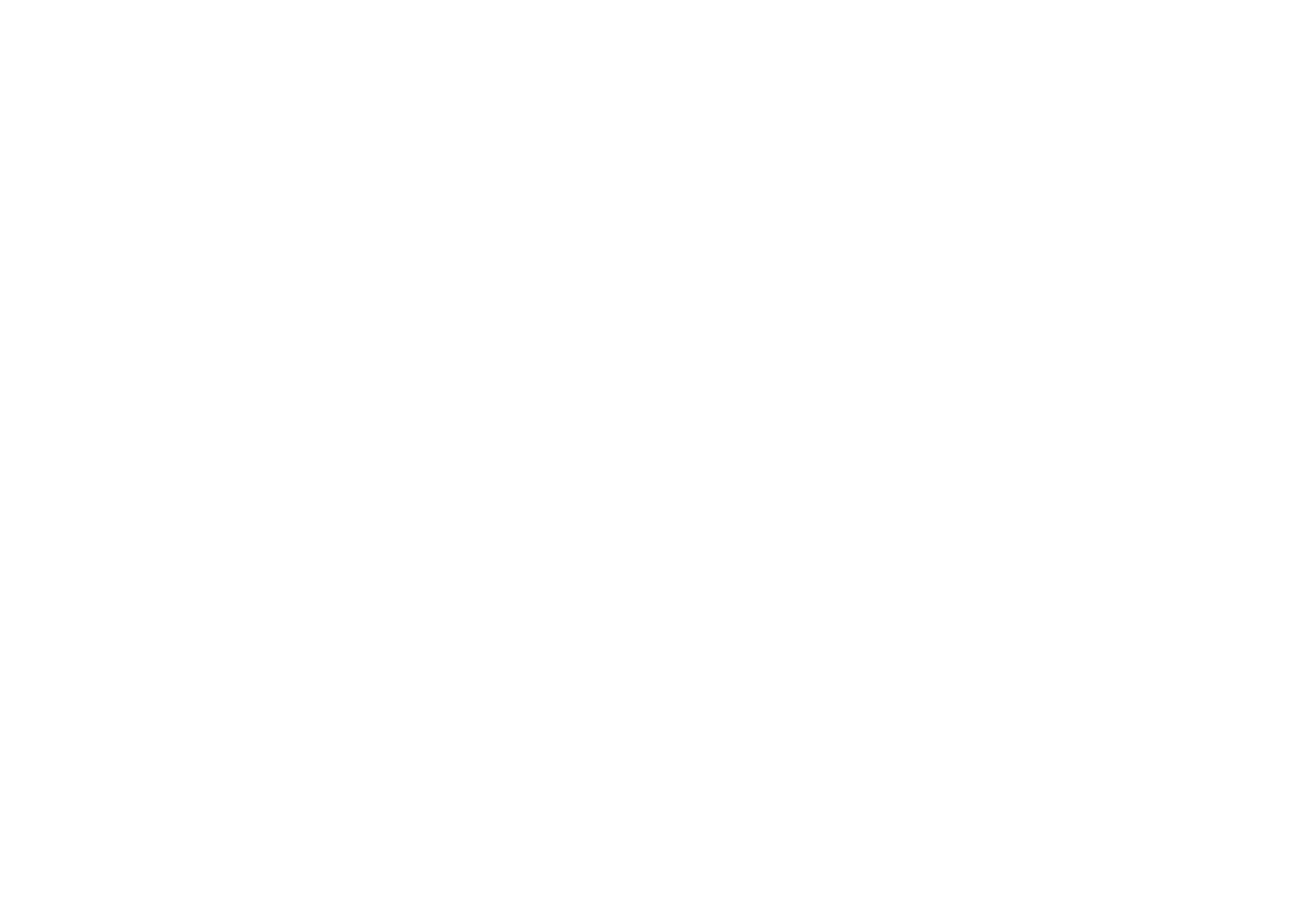

A. Price River above Scofield Reservoir, near Scofield, Utah

B. Huntington Creek near Huntington, Utah

Figure 117.-Flow-duration curves for two tributary streams in the Green River Basin below the White River, water years 1914-57 adjusted to 1957 conditions.

weighted-average concentration is probably because the record includes a period of drought.

The daily records of chemical quality of water for Green River at Green River, Utah, are for the water years 1929-57. The weighted-average concentration for this period is $443 \mathrm{ppm}$ compared with the computed weighted-average concentration of $427 \mathrm{ppm}$ for the water years 1914-57. The yield from the 40,600 square miles above the station at Green River is 65 tons per square mile, which is slightly less than that for the area above the station near Ouray. On the average, about 2,652,000 tons of dissolved solids a year passes the station on Green River at Green River, Utah.

San Rafael River near Green River, Utah, had a weighted-average concentration of $1,540 \mathrm{ppm}$ for the water years 1948-57 compared with the computed weighted-average concentration of $1,370 \mathrm{ppm}$ for water years 1914-57. The average annual dissolved-solids yield from the 1,690 square miles above this station for the water years 1914-57 was computed to be 113 tons per square mile. About 190,300 tons of dissolvedsolids passes the station each year.

The dissolved-solids and water entering this subbasin in the Green River are recorded at Green River near Ouray, Utah. Most of the dissolved solids and water leaving the subbasin are recorded at Green River at Green River, Utah, and San Rafael near Green River, Utah. Figure 119 shows the dissolved solids and water entering the subbasin in Green River and the dissolved-solids and water discharges at selected sites in the subbasin (table 9) expressed as percentages of the combined dissolved-solids discharges and combined water discharges of Green River at Green River, Utah, and San Rafael River near Green River, Utah.

This subbasin produces about 18 percent of the dissolved-solids discharge of the Green River below the San Rafael River but only about 3 percent of the water discharge. Most of the increase in dissolved solids comes from the Price and San Rafael Rivers. 


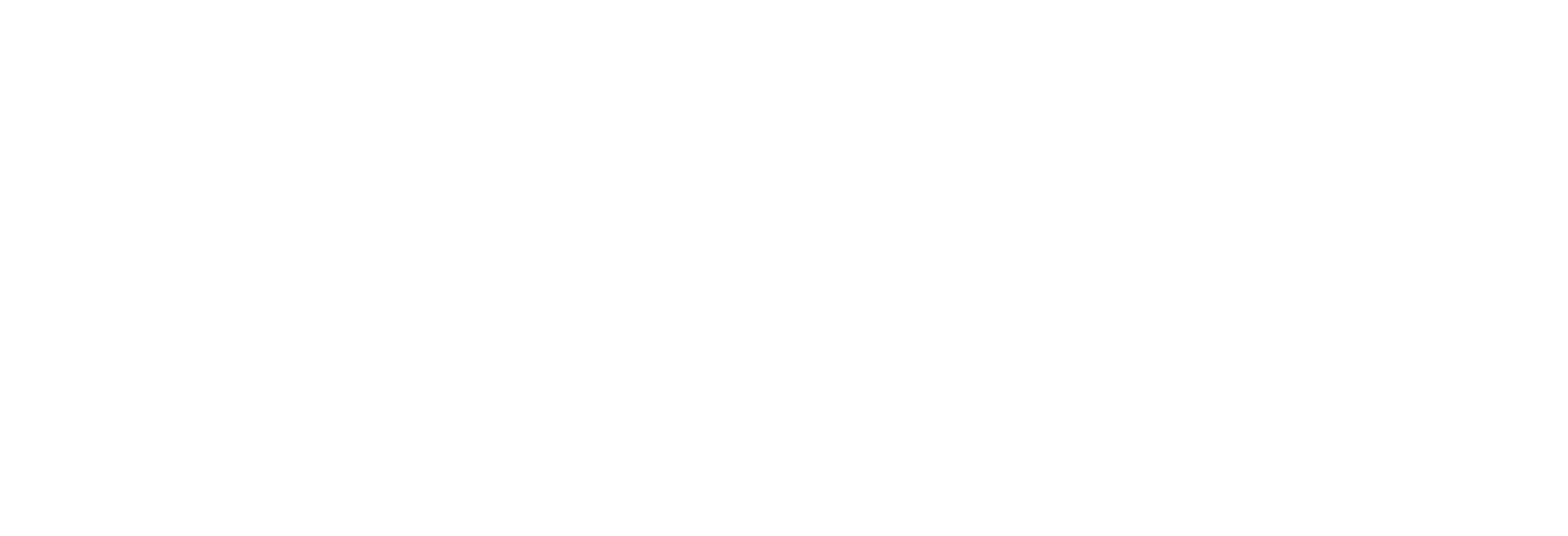

A. Price River near Heiner, Utah

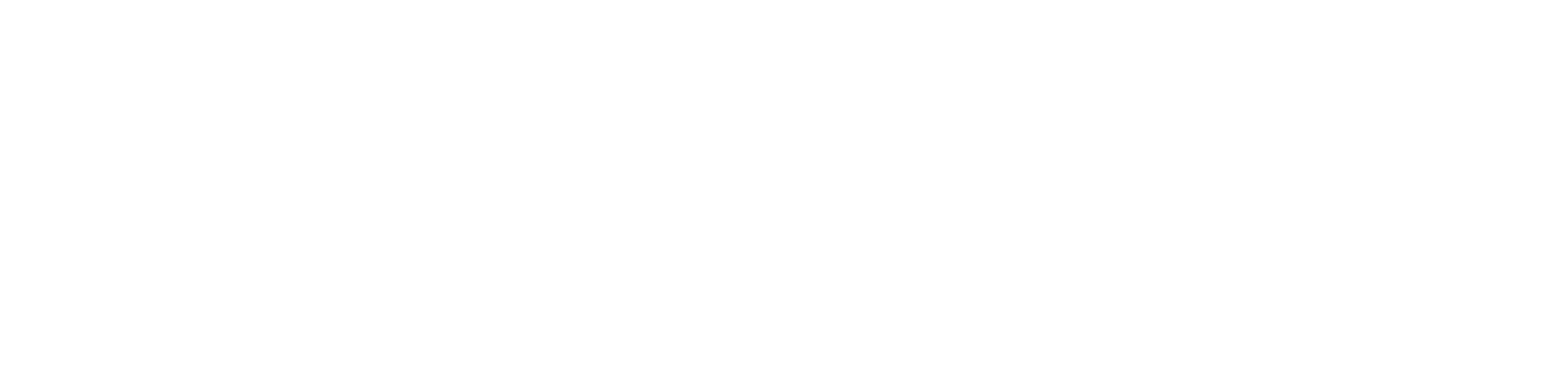

B. Huntington Creek near Huntington, Utah

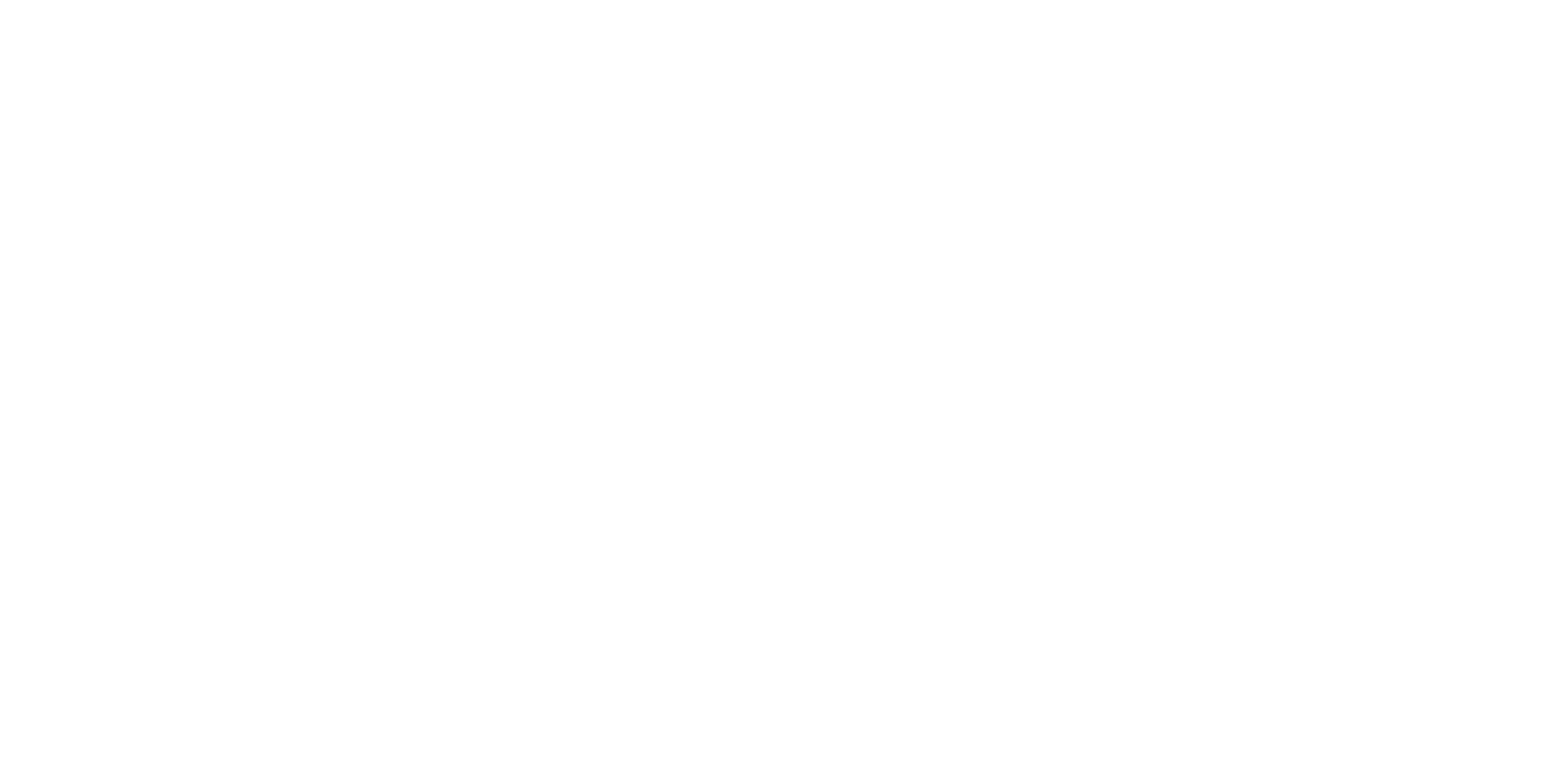

C. Green River at Green River, Utah

FIGURE 118,--Variability of annual discharges in the Green River Basin below the White River, water years 1914-57. 


\section{VARIATIONS IN CHEMICAL QUAITTY}

The range of dissolved-solids concentration in headwater streams of the San Rafael River is less than $100 \mathrm{ppm}$, but in the lower reaches of the river the range is about $3,500 \mathrm{ppm}$ (table 10). This is probably typical of other streams in the subbasin that rise in the Wasatch Plateau.

Figure 120 shows the variations of chemical quality by months for a daily station on the Green River and for stations on three tributaries during years of relatively high and low runoff. The differences in monthly weighted-average concentration of dissolved solids for a year of high streamflow and a year of low streamflow for a particular month is not great for Green
River at Green River, Utah. In contrast to the small variations in chemical quality for the same months in different years for the Green River, the variations in the monthly weighted-average concentration for individual months for the three tributaries may be large.

The coefficients of variation of annual weightedaverage concentration of dissolved solids and annual water discharge for three streams are given in table 12. The period is probably too short for a reliable statistical analysis. See page 193 for discussion of the relation between coefficients of variation for water discharge and coefficients of variation of dissolved-solids concentration in the division.

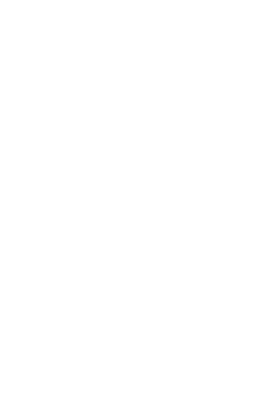

INDEX MAP

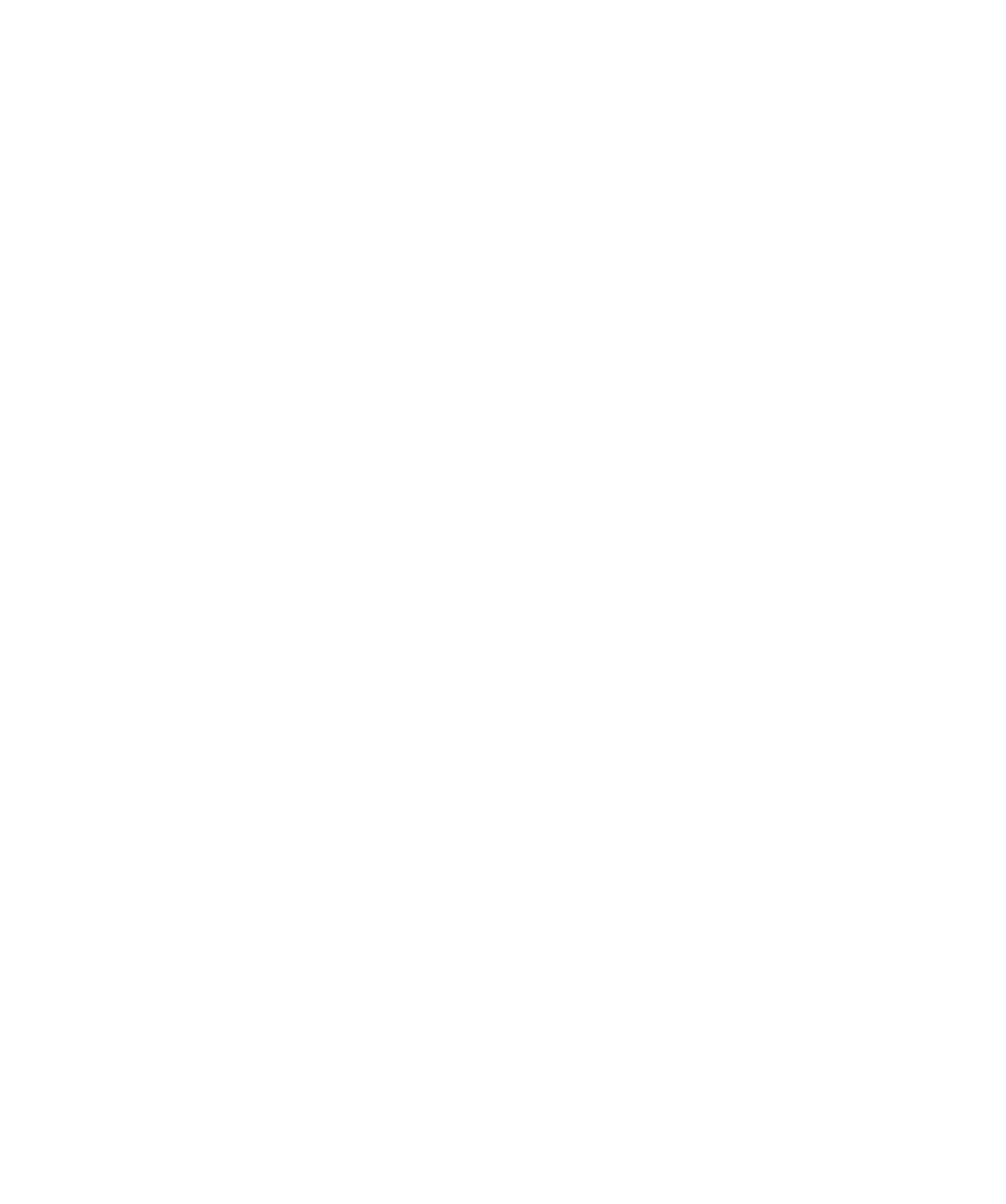

FIGURE 119-Approximate dissolved-solids discharge and streamflow in the Green River basin below the White River expressed as percentages of the combined dissolved-solids discharge and combined streamflow of Green River at Green River, Utah, and San Rafael River near Green River, Utah. 

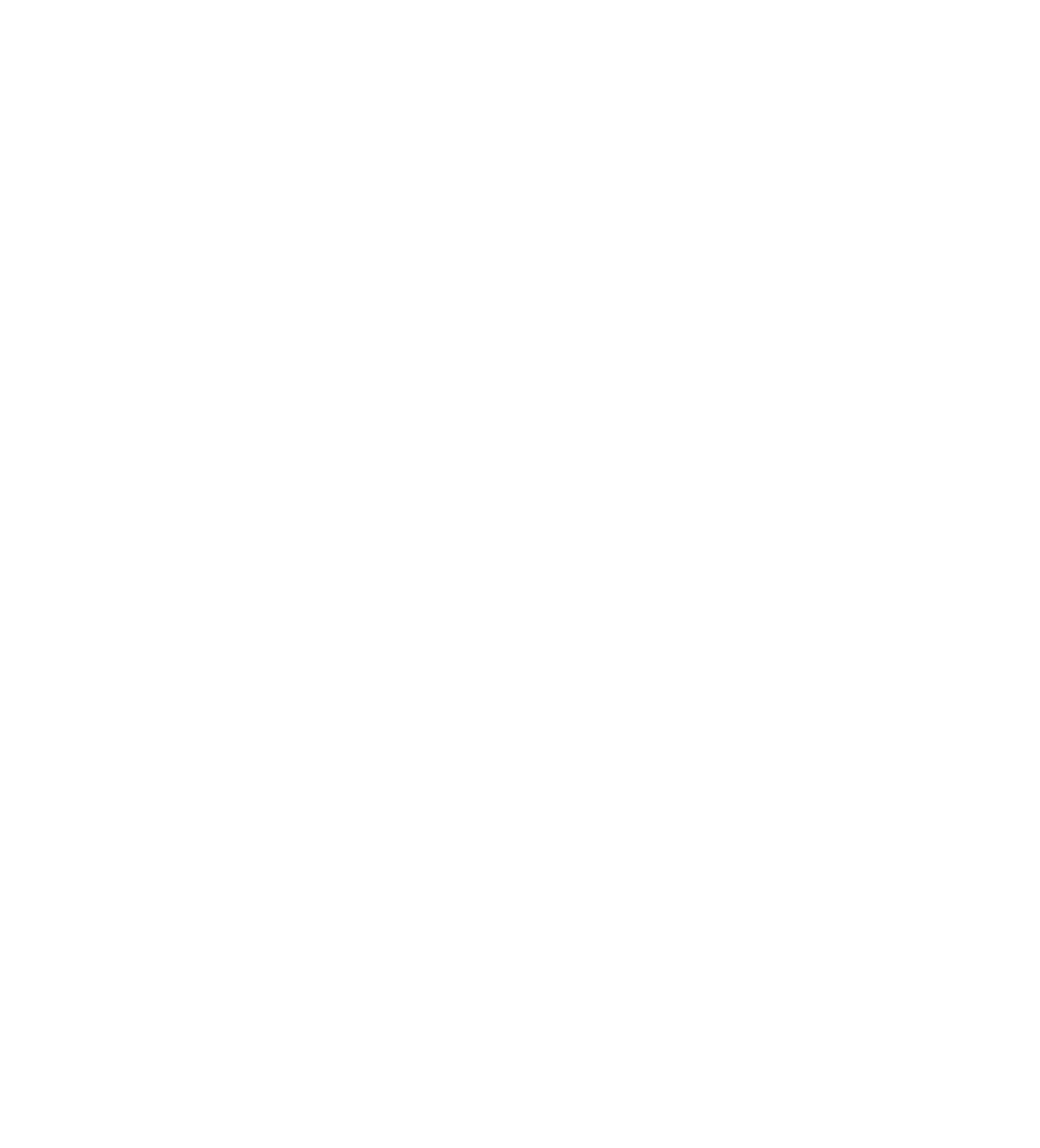

FIGURE 120.-Dissolved-solids concentration at four stations in the Green River basin below the White River for two water years for each station.

RELATION TO STREAMFLOW

The dissolved-solids concentration of the water in the streams of this subbasin, as in most of the streams in the Upper Colorado River Basin, decreases as the water discharge increases (fig. 121). In the headwaters of the San Rafael and Price Rivers, the variation in concentration with change in water discharge is not as large as it is in the same streams at lower altitudes where the climate is more arid. For example, the estimated dissolved-solids concentration of the water in Cottonwood Creek near Orangeville, Utah, a tributary of the San Rafael River, ranged from about 210 ppm for the highest flows to about $290 \mathrm{ppm}$ for the lowest flows (table 10), whereas, the concentration of San Rafael River near Castle Dale, Utah, which is downstream from Orangeville, ranged from about $390 \mathrm{ppm}$ to $3,700 \mathrm{ppm}$.

The chemical composition of water for different rates 

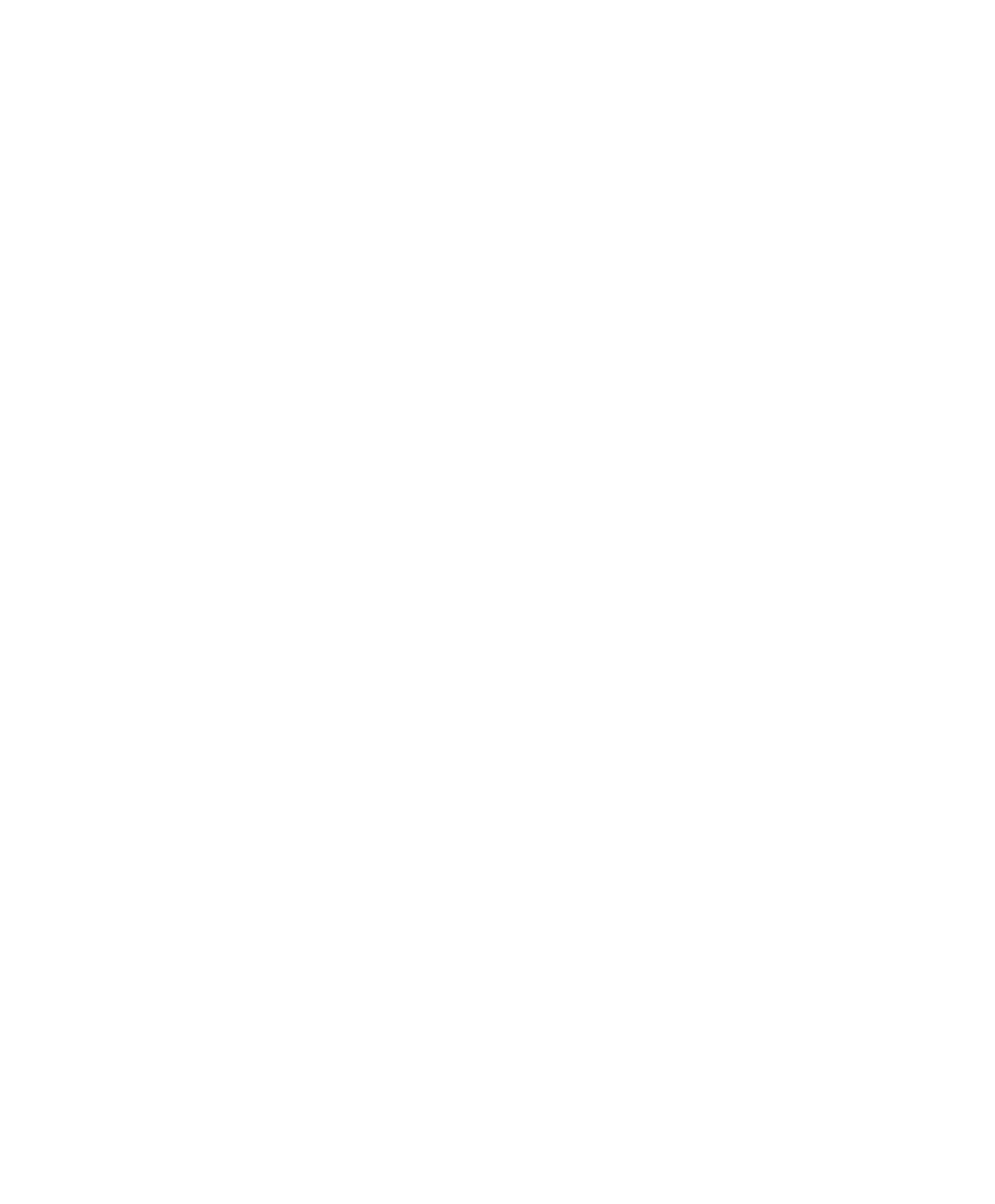

FIGURE 121.-Dissolved-solids concentration and discharge and water discharge at four stations in the Green River basin below the White River. 
of discharge at five stations where daily chemicalquality data have been obtained is given in table 13 . Data for four of these sites are illustrated in figure 122.

The variation in concentration and composition with change in water discharge for the two stations on the Green River is much less than that in the lower reaches of the Price and San Rafael Rivers. Also, the inflow from tributaries between the stations on Green River near Ouray and at Green River does not greatly increase the dissolved-solids concentration of the water of the Green River. This is because the total inflow from tributaries is small compared with the flow of the Green River.

\section{RELATION TO GEOLOGX}

The Green River basin below the White River is underlain by sedimentary rocks that range in age from Permian to Recent. However, most of the exposed rocks are of Cretaceous and Tertiary ages.

The drainage basin of Willow Creek, which flows into the Green River several miles below the chemicalquality station on Green River near Ouray, Utah, is
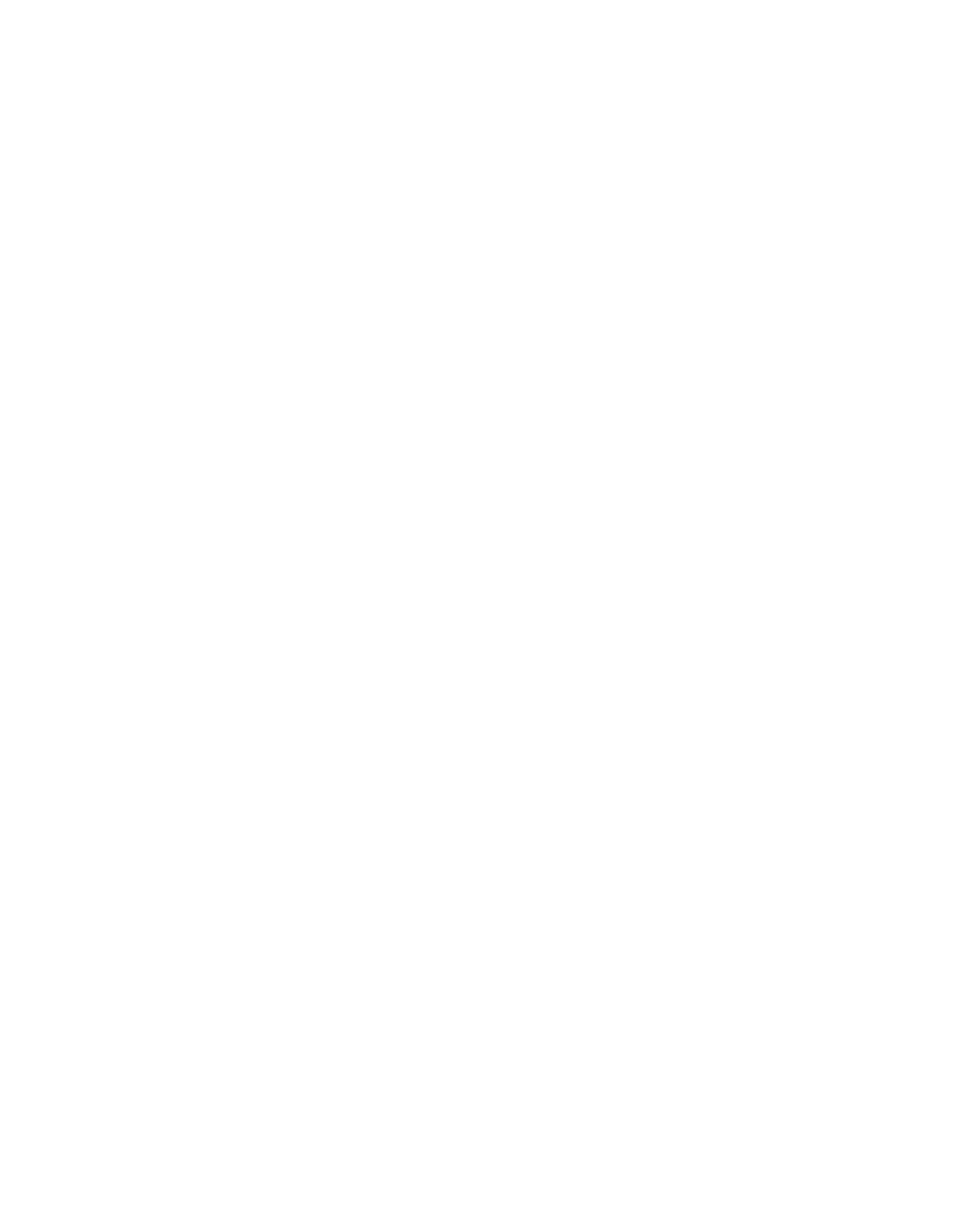

FIGURE 122.-Relation of the chemical composition and concentration of dissolved solids to water discharge in the Green River basin below the White River. The concentration of specific ions, in equivalents per million (epm), is shown for the 10 th, 50th, and 90 th percentiles of the flow-duration curve for each location. The flow-duration curves are for the water years 1914-57 adjusted to 1957 conditions. 
underlain mostly by the Green River Formation of Tertiary (Eocene) age. The lowest part of this basin is underlain by the Uinta Formation of Tertiary (Eocene) age. The water of the creek is of the sodium calcium magnesium bicarbonate sulfate type, and the weighted-average concentration for the water years 1914-57 adjusted to 1957 conditions is about $870 \mathrm{ppm}$ (table 47). Monthly weighted-average concentrations for the period of record ranged from about $540 \mathrm{ppm}$ to $5,200 \mathrm{ppm}$.

The Green River Formation underlies about 75 percent of the drainage basin of Minnie Maud Creek, which flows into the Green River below Willow Creek; however, in the headwaters of Minnie Maud Creek, other rocks such as the North Horn Formation of Cretaceous and Tertiary ages and the Wasatch Formation of Tertiary age are present. The water of the creek is of the magnesium bicarbonate type and at low flows contains large amounts of sodium and sulfate. The weighted-average concentration of the water of Minnie Maud Creek at Nutter Ranch, Utah, which is below most of the irrigated land in the basin, is about 490 ppm.

The Price River is the next stream of appreciable size which enters the Green River below Minnie Maud Creek. Most of the Price River basin is underlain by rocks of Cretaceous age; however, rocks of Jurassic and Tertiary ages are also present. Along the Roan and Book Cliffs, which form the southern edge of the West Tavaputs Plateau, and the Wasatch Plateau to the west, the Price River and Blackhawk Formations and the Star Point Sandstone of the Mesaverde Group and the North Horn Formation crop out. The remainder of the basin, except for some areas where rocks of the Morrison Formation and San Rafael Group are exposed along the south side of the Price River in its lower reaches, is underlain by Mancos Shale.

In the headwaters of the Price River and its tributaries in the Wasatch Plateau, the waters of the streams are a calcium bicarbonate type. Downstream from the headwaters, Price River and its tributaries contain progressively more magnesium, sodium, and sulfate. For example, the waters of Willow Creek at Castlegate, Utah, are of the magnesium bicarbonate type. The waters of Gordon Creek near Price, Utah, are of the magnesium sulfate type. At Woodside, below most of the irrigation, the water of the Price River is of the sodium sulfate type.

The weighted-average dissolved-solids concentration of Price River above Scofield Reservoir, Utah, is about $180 \mathrm{ppm}$. The concentration increases downstream from $226 \mathrm{ppm}$ near Heiner, Utah, to $1,190 \mathrm{ppm}$ near Wellington, Utah, and to $2,110 \mathrm{ppm}$ at Woodside, Utah (table 9). Most of the irrigated land in the
Price River basin is above the station at Woodside.

Huntington, Cottonwood, and Ferron Creeks are the three principal tributaries of the San Rafael River. The headwaters of Huntington Creek are mostly underlain by the Blackhawk Formation and the Star Point Sandstone of the Mesaverde Group of Late Cretaceous age. The headwaters of Cottonwood Creek are mostly underlain by the North Horn Formation of Tertiary and Late Cretaceous age. Ferron Creek drainage basin is underlain by the Flagstaff Limestone and the North Horn Formation. For 12 to 20 miles eastward from the base of the Wasatch Plateau, the drainage basin of the San Rafael River is underlain by Mancos Shale. Most of the irrigated lands are in this area. The lower two-thirds of the basin is underlain by rocks of the San Rafael Group of Middle and Late Jurassic age and by rocks of Permian and Triassic ages.

Above irrigated areas, the water of headwater tributaries of the San Rafael River is of the magnesium or calcium bicarbonate type. Below the irrigated areas, the water of the San Rafael River and its tributaries is of the sodium sulfate type and contains large percentages of magnesium and calcium. Sodium sulfate type water containing large percentages of magnesium and calcium seems to be typical of streams that are influenced by runoff and irrigation return flow from areas underlain by Mancos Shale.

The weighted-average concentration of dissolved solids in the water of the Green River between the station near Ouray, Utah, and the station at Green River, Utah, increases from $392 \mathrm{ppm}$ to $427 \mathrm{ppm}$; however, the composition of the water does not change greatly. Most of the change is an increase of sodium and sulfate ions but the water continues to be of the calcium sulfate type. Although the chemical quality of the water of the Green River is affected by inflow from tributaries, the volume of inflow is insufficient to cause a large change in the quality of the water.

Figure 123 is a map of this subbasin showing zones within which the weighted-average dissolved-solids concentrations of the surface water are between indicated limits. The zones indicate that the waters of the Green River and some of the tributaries in their headwaters have weighted-average concentrations of less than 500 ppm. In contrast, most of the tributaries of the Green River at their mouths have weighted-average concentrations of more than $1,200 \mathrm{ppm}$.

The diagrams on plate 2 show the geochemical character and ionic concentrations of surface waters at many sites in the subbasin. The diagrams are representative of the chemical character of the streams during low flow, when the effect of geology on chemical quality is more evident than during high flows. The 


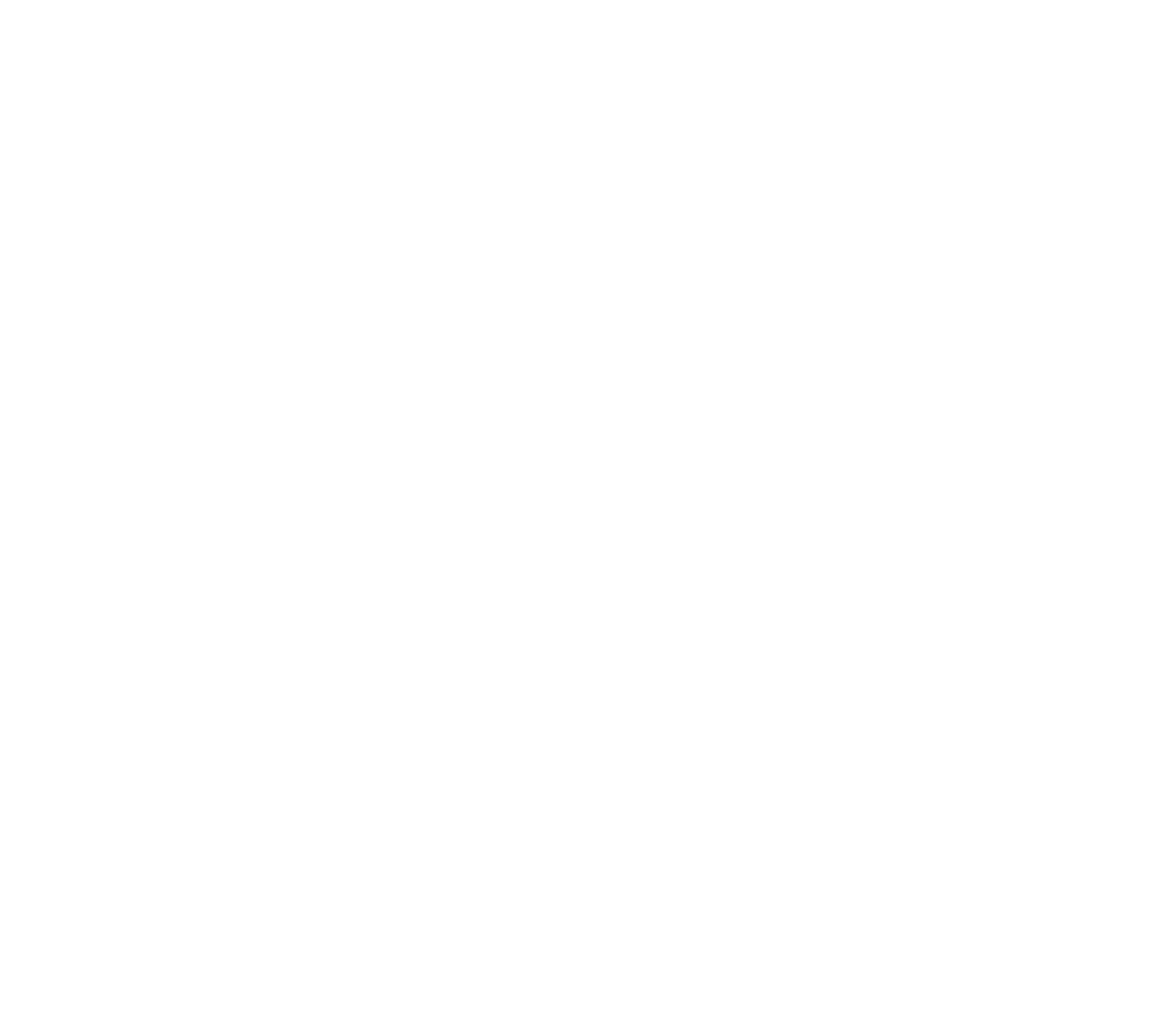

FIGURE 123.-Approximate weighted-a verage concentration of dissolved solids of streams in the Green River basin below the White River.

significance of the size and shape of the diagrams is given in the explanation on plate 2 .

\section{RELATION TO GROUND WATER}

Table 14 gives the water and dissolved-solids discharges estimated to be contributed to selected headwater streams by ground water. The amount of dissolved solids contributed by ground water is dependent on the amount of ground water contributed to the stream system and the solubility of rock material in the ground-water reservoirs. Apparently the Flagstaff Limestone in the Ferron Creek drainage basin is relatively soluble but also relatively impermeable. The solubility of the rock material in the North Horn
Formation is apparently less than in the Flagstaff Limestone but more than in the Blackhawk Formation and Star Point Sandstone of the Huntington Creek drainage basin.

The ground water in the alluvium along streams in the interior of the subbasin is similar in composition to the water in the streams during low flow, but the ground water usually contains a greater amount of dissolved solids (fig. 124).

In the lower reaches of the Price and San Rafael Rivers and along the Green River, the precipitation is low and most of the ground water in the alluvium comes from the streams. In the irrigated areas, part of the water that enters the alluvium is water that was 
diverted and spread on the irrigated fields. Almost all the ground water that enters the streams from the alluvium, whether it comes from the irrigated fields or is water that has circulated from the stream to the alluvium and back, is usually of poorer quality than the water of the river at the point of inflow. This inflow of ground water usually has an adverse effect on the water in the stream.

The flow and dissolved-solids concentration of a group of thermal springs along the Green River in Labyrinth Canyon, below the mouth of the San Rafael River, are unknown but the flow was stated to be small by Stearns and others (1937).

\section{FFFECT OF TRANSMOUNTAIN DIVERSIONS}

The long-term average annual transmountain diversion from the headwaters of the Price and San Rafael Rivers to the Sevier River basin was estimated to be about 10,100 acre-feet for developments existing in 1957 (p. 230). Chemical analyses of the diverted water and of streams from which diversions are made indicate that the weighted-average concentration of dissolved solids in the diverted water is about 125 ppm; and from this the dissolved solids carried out of the subbasin in the diverted water was computed to be about 1,700 tons annually. So little of the diverted water comes from the Price River basin that the effect of the diversions on the chemical quality of water in the Price River is negligible.

If all water diverted to the Sevier River basin is assumed to have come from the headwaters of the San Rafael River, the effect of the diversion on San Rafael River near Green River, Utah, has been to in-

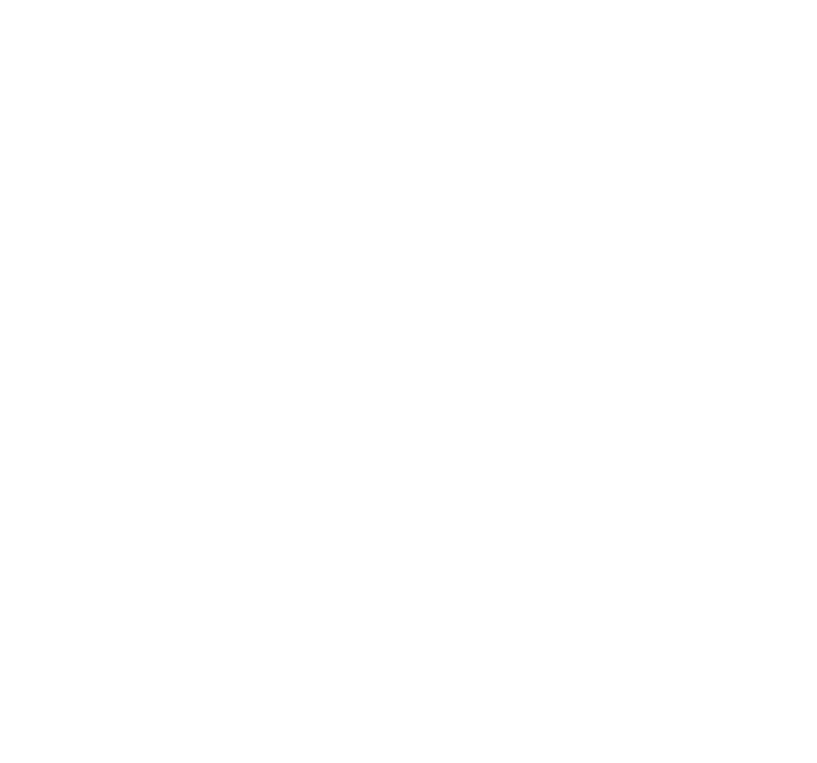

Figure 124.-Analyses of water from selected streams in the Green River basin below the White River and from alluvium nearby. crease the dissolved-solids concentration by about 112 ppm.

The effect of all transmountain diversions from the Green division has been to increase by about $7 \mathrm{ppm}$ the weighted-average concentration of the Green River at the mouth. This increase is equivalent to about 6 ppm for each 100,000 acre-feet of water exported out of the division.

\section{EFFECT OF THE ACTIVITIES OF MAN}

The population (1960) in the subbasin is about 27,000 , and about 60,000 acres is irrigated. The soils of the irrigated lands were mostly developed from residuum derived from Mancos Shale and contain an abundance of soluble minerals. The return flow from the irrigated lands contributes large quantities of dissolved solids to the streams.

Crystal Geyser well, which is on the left bank of Green River below the town of Green River, has an annual flow and dissolved-solids discharge of about 362 acre-feet and 7,000 tons, respectively (Thomas, 1952 , p. 31). This well is an abandoned oil prospect.

Sufficient data are available in the San Rafael River basin for an approximate determination of the amount of dissolved solids added to the stream system by other than natural sources. In the area above San Rafael River near Castle Dale, Utah, and below the gaging stations on Huntington, Cottonwood, and Ferron Creeks, about 36,000 acres is irrigated. The gaging stations on the creeks are above irrigation diversions and record practically the entire inflow to the area which is underlain mostly by shales of Cretaceous age. Runoff from the intervening area between the inflow and outflow stations is considered negligible, as the average annual precipitation is only about 8 to 10 inches. Table 15 gives an approximate budget of water and dissolved solids based on water and dissolvedsolids discharges given in table 9 . The increase in dissolved solids from other sources is equivalent to 3.2 tons per year per acre of irrigated land.

Estimates were made of the amount of dissolved solids contributed by natural sources and the activities of man in other areas of the subbasin. These estimates are summarized at gaging stations and for the subbasin in table 16 . The estimated amounts attributed to the activities of man are the increase over and above that which would normally come from inflow in each area. Of the estimated 232,700 tons of dissolved solids added to the streams by the activities of man, about 9,400 tons is added by domestic and industrial uses of water and the Crystal Geyser well near Green River, Utah, and about 223,300 tons is added by irrigation. In these estimates, 100 tons per year per 1,000 people 
was assigned as the contribution of dissolved solids by domestic and industrial uses of water.

\section{FLUVIAL SEDIMENT}

Daily suspended-sediment data have been obtained at three stations (table 17). In addition, suspendedsediment data have been obtained at other sites. These data and streamflow data have been used to estimate the suspended-sediment discharges for Price River at Woodside, Utah, and San Rafael River near Green River, Utah (table 18). The San Rafael River contributes less than one-quarter as much suspended sediment as the Price River, although the water discharge of the San Rafael River is greater than that of the Price River. The difference in the sediment discharge from the two river basins apparently is mostly caused by the different types of rocks that underlie the two basins.

The suspended-sediment contribution to the Green River between Green River near Ouray, Utah, and Green River at Green River, Utah, is 7,967,000 tons annually. The contribution to the river from the 2,410 square miles below Green River at Green River, Utah, and San Rafael River near Green River, Utah, and above the Colorado River is estimated to average $6,144,000$ tons annually. This estimate is obtained by prorating, on the basis of drainage area, the suspendedsediment increase between the downstream suspendedsediment stations in this division and in the Grand division and the upstream suspended-sediment stations in the San Juan division. The computed yield from the 5,850 square miles of intervening drainage area is 2,560 tons per square mile per year.

A statistical analysis of the annual loads for the period of record shows that the variability of the suspended-sediment load for Green River at Green River, Utah, is greater than either the variability of the water discharge or the chemical quality of the water at this station. The standard deviation for the annual suspended-sediment discharge of Green River at Green River, Utah, was 11.7 million tons, or 56 percent of the average annual load for the period of record.

During the period of record for Green River at Green River, Utah, changes have taken place in the relation of suspended-sediment concentration to water discharges. During the water years $1930-42$, the average annual suspended-sediment concentration of Green River at Green River, Utah, was greater than that for the water years 1943-56 (table 17). The reasons for these changes are unknown, but may be associated with periods of below normal and above normal precipitation or possibly with changes in the intensity of summer storms. The changes seem to be regional, as the pattern of the changes for Green River at Green River, Utah, is almost identical with that for Colorado River near Cisco, Utah.

An examination of the precipitation records of the IT.S. Weather Bureau indicates that during the water years 1930-41 most of the years had below-normal precipitation, and during the water years 1942-52 most of the years had above normal precipitation. A more significant fact may be that the amount of summer precipitation did not vary greatly between the periods. The below normal precipitation for the water years 1930-41 seems to have resulted largely from below normal recipitation during the winter months. The vegetation on the more arid areas, from which most of the sediment comes, may have deteriorated during the period of subnormal winter precipitation. Consequently, the land surface would have been more susceptible to erosion. Another possible reason for higher suspended-sediment concentrations during 193041 , and perhaps the major factor, is that the lower runoff from the mountains during this period coupled with what might have been a constant yield of sediment from the arid areas would have resulted in increased concentration during years when the flow was low.

\section{SUITABILITY OF WATER FOR VARIOUS USES}

\section{DOMESTIC USE}

The classification of the surface water in the Green River basin below the White River is based on waterquality criteria for major uses. (See chap. B, pp. 66-73.)

About 70 percent of the time, the concentration of the dissolved solids in Green River near Ouray, Utah, exceeds the maximum concentration permitted by the standards for domestic use accepted for this report. The concentrations of iron, manganese, magnesium, chloride, and fluoride are, at all times, less than the accepted maximum concentrations; but the concentration of sulfate at times exceeds the accepted maximum. The water of the Green River at this station is very hard and softening would be desirable for most purposes. Nitrate is usually less than $5 \mathrm{ppm}$.

The water of Willow Creek, which enters the Green River from the east, at all times contains more than $250 \mathrm{ppm}$ of sulfate and much of the time contains more than $500 \mathrm{ppm}$ of this constituent. At times, the concentration of sulfate in the water of Willow Creek near Ouray, Utah, exceeds 2,000 ppm. Magnesium often exceeds the maximum of $125 \mathrm{ppm}$ permitted by the standards for domestic use and may exceed $200 \mathrm{ppm}$. The maximum of $125 \mathrm{ppm}$ permitted for chloride is apparently never exceeded. The total dissolved-solids concentration is usually more than $1,000 \mathrm{ppm}$ and at times exceeds $3,000 \mathrm{ppm}$. The concentration of fluoride is always low and the concentration of nitrate is usually 
less than $8 \mathrm{ppm}$. The water of Willow Creek is very hard at all times.

The dissolved-solids constituents in the water of Minnie Maud Creek, which enters the Green River from the west downstream from Willow Creek, do not exceed the maximums permitted by the standards for domestic use, except for sulfate. The concentration of sulfate in the water of Minnie Maud Creek is usually slightly greater than $250 \mathrm{ppm}$. The total dissolved solids in the water of this creek sometimes exceeds 500 ppm but is seldom greater than $1,000 \mathrm{ppm}$. The concentration of nitrate in the water is usually less than 4 ppm.

In the headwaters of the Price River above Helper, Utah, the concentrations of all the constituents considered to be important for use as a domestic supply are less than the maximum permitted by the standards accepted for this report. The water is hard to very hard and softening would be required for laundries and most industries and would be profitable for most purposes.

Concentrations of magnesium, sulfate, and total dissolved solids of Price River at Woodside, Utah, always exceed the maximum permitted by the standards for domestic use. The concentrations of dissolved solids of most of the tributaries of Price River below Price, Utah, are similar to those of the Price River. At Woodside, Utah, the concentration of magnesium in the water of the Price River always exceeds $125 \mathrm{ppm}$, is usually more than $200 \mathrm{ppm}$, and sometimes exceeds $300 \mathrm{ppm}$. At Woodside, sulfate usually exceeds a concentration of $2,000 \mathrm{ppm}$, and the total dissolved solids is more than $3,000 \mathrm{ppm}$ most of the time. The concentrations of fluoride and iron are usually less than $0.6 \mathrm{ppm}$ and $0.3 \mathrm{ppm}$, respectively. The water of the Price River at Woodside, Utah, is very hard at all times.

The suitability for domestic use of the water of Green River at Green River, Utah, is about the same as that of Green River near Ouray, Utah. The maximum concentration of sulfate permitted by the standards accepted for this report is slightly exceeded at all times except during the spring runoff.

The waters of the tributaries of the San Rafael River in the Wasatch Plateau and above irrigated lands are suitable for domestic use; however, the waters of the streams are very hard, and softening would be profitable for most uses.

At the chemical-quality station on San Rafael River near Green River, Utah, the concentration of magnesium is more than $125 \mathrm{ppm}$, except during the spring runoff, and often exceeds $200 \mathrm{ppm}$. The concentration of iron is usually less than $0.1 \mathrm{ppm}$, and the concentration of chloride seldom exceeds $100 \mathrm{ppm}$. The total dissolved solids of the stream is usually more than 2,000 ppm and sometimes is more than 4,000 ppm. The concentration of sulfate is always more than 500 and frequently is more than $2,000 \mathrm{ppm}$. Nitrate is usually present in concentrations of less than $4 \mathrm{ppm}$. The water of the stream is very hard.

\section{AGRICULTURAL USE}

Table 19 gives the classification of the waters of many streams in this subbasin as to their suitability for irrigation. The classifications are based on chemical analyses in the basic data report (Iorns and others, 1964). Most of the terms used in the table are self-explanatory. The terms that are not self-explanatory are explained on page 203 and in Chapter B (pp. 69-73).

None of the waters of the streams listed in table 19 contains as much as $1.25 \mathrm{epm}$ of residual sodium carbonate, and the waters are thus suitable for use as irrigation water insofar as this measure of the suitability is concerned. Only a very few streams contain any residual sodium carbonate.

Most of the water used for irrigation in the subbasin is classified as $\mathrm{C} 2-\mathrm{S} 1$ or better. The water of the Green River, except at times of high flow, is in the category C3-S1. Development of harmful levels of sodium in the soils by use of this water is not probable, but moderate leaching is required to control salinity. The waters of the Price and San Rafael Rivers in their lower reaches are not suitable for irrigation.

\section{INDUSTRIAL USE}

According to the water-quality tolerances for industrial applications given in chapter B (table 16), the waters in this subbasin would require treatment for most industrial applications. A few of the streams in the extreme headwaters could be used by some industries without treatment.

\section{SUMMARY}

The Green division (drainage area 44,700 $\mathrm{sq} \mathrm{mi}$ ) is bounded on the east by the Wind River and Park Ranges and the White River Plateau, and on the west by the Wyoming and Wasatch Ranges and the Wasatch Plateau. The east-trending Uinta Mountains divide the division into two major topographic areas. The Green River flows generally southward near the north-south axis of the division from its source in the northern end of the Wind River Range to its junction with the Colorado River.

The area is a region of great contrasts. Towering mountains and uplifted plateaus, some of which approach altitudes of 14,000 feet, form the boundaries. North of the Uinta Mountains, the interior of the basin is a broad desert plateau. South of the Uinta Mountains, the streams which join the Green River from the east and west have carved broad, rugged valleys and 
deep, tortuous canyons. All the division is at altitudes of more than 3,880 feet.

The exposed rocks range in age from late Precambrian to Recent, and the system of exposure of much of the rocks is complex owing to uplift, folding, faulting, and weathering. In the interior, vast areas are underlain by rocks of Tertiary age. These rocks and rocks of Cretaceous age also are exposed on some of the uplifted plateaus, which partly form the boundaries of the division and the divides between the valleys in the interior. The unconsolidated mantle, except for areas of glacial deposits and alluvium along the streams, is principally residuum developed from the underlying or nearby parent rocks.

The climate is largely governed by topography and altitude. The average annual precipitation ranges from less than 6 inches in the southern part to more than 60 inches in the Wind River Range in the northern part. The precipitation on nearly four-fifths of the division is less than 20 inches. The average annual precipitation is 16.63 inches (water years 1914-57). Temperatures are closely related to altitude. The 5-degree change in latitude from the southern to the northern part of the division also has an effect on the temperature. At Price, Utah, where the altitude is 5,580 feet, the average annual temperature is $49.4^{\circ} \mathrm{F}$. At Green River, Wyo., where the altitude is 6,090 feet, the average annual temperature is $44^{\circ} \mathrm{F}$, and at Pinedale, Wyo., where the altitude is 7,280 feet, the average annual temperature is $36.1^{\circ} \mathrm{F}$.

The runoff varies with the seasons. Snow that accumulates in the mountains during the winter months provides most of the water supply. As the snow melts in the late spring and early summer, the flow in the perennial streams rises to a peak and then subsides as the supply of snow is exhausted. Usually by late July, the flow in the streams has subsided to a base flow, which generally prevails until the following spring. Many of the small streams and washes that drain areas of low altitude are intermittent and flow only in the early spring months or after thunderstorms.

The major use of water is for irrigation. Table 25 summarizes data on storage reservoirs and water utilization.

Table 26 shows an approximate water budget for the division. The budget is based on the assumptions that the contribution to the Green River between the San Rafael River and the Colorado River is equal to the natural loss in the reach and that no water is lost from the basin by underflow. The average annual precipitation supply is $39,645,900$ acre-feet, which is equivalent to an average annual precipitation of 16.63 inches. All the precipitation supply not accounted for in outflow from the basin, transmountain diversions, and consumptive use due to the activities of man is considered to be evapotranspiration loss from the land and water surfaces and native vegetation. This loss is 86.1 percent of the precipitation supply and is equivalent to a depth of 14.32 inches of water over the drainage basin.

Flow-duration curves, which show the percentage of time during which specified rates of flow were equaled or exceeded, were developed and adjusted to be representative of the streamflows that would have occurred if the water-use developments in 1957 had existed throughout water years 1914-57. The average discharges of the streams for the 44-year base period were computed from these curves.

The effect of environmental factors on the flow of the streams was analyzed by comparing the slopes of the flow-duration curves of different streams and by comparing the variability of annual discharges of these streams. The variability indices (slopes of flow-duration curves) ranged from 0.25 to 0.72 . The relative permeability of underlying rocks seems to be the major cause of difference in the variability indices of the snowmelt-type streams which predominate in the division. Climate is the major factor influencing the variability of annual discharges, but geologic formations exert a pronounced influence on some streams. The coefficient of variation (ratio of standard deviation to average discharge) of the streams for which statistical analyses of annual flows were made ranged from 0.18 to 0.46 .

Daily records of chemical quality have been obtained at 18 stations. In addition to the daily records of chemical quality, samples of water from many other sites have been collected and analyzed. The records from the daily stations and analyses of samples collected at other sites were used in conjunction with the flow-duration tables to develop duration tables of dissolved-solids concentration and discharge and other chemical-quality-of-water data for the water years 1914-57 adjusted to 1957 conditions. The weighted-average concentration at these sites ranged from 23 to $2,110 \mathrm{ppm}$, and the average annual yield of dissolved solids ranged from 13 to 298 tons per square mile of drainage area.

The differences in the chemical quality of the streams are the result of hydrologic and other environmental factors prevailing in the drainage basins. The major environmental factors that determine the chemical quality of each stream are apparently precipitation, type of rocks and soils that underlie each drainage basin, and the activities of man.

Most of the streams are of the snowmelt type, which have the normal pattern of dissolved-solids concentration-the lowest concentrations occur in the months of maximum water discharge and the highest concentra- 
tions occur in the months of low discharge, when the streams are largely maintained by ground water.

A statistical analysis of the variations in the annual weighted-average concentration of dissolved solids and annual water discharges was made for nine stations where daily chemical-quality data have been obtained. A plot of the data showed a relatively poorer correlation between the coefficients of variation of weightedaverage concentration of dissolved solids and water discharge for the Green division as compared with those for the Grand division. The poorer correlation is probably due to the available records being too short for a reliable statistical analysis.

Streams draining mountainous areas underlain by granitic and associated metamorphic rocks of Precambrian age, such as in the Wind River and Park Ranges and the Uinta Mountains, have low concentrations of dissolved solids and are of the calcium bicarbonate type. The weighted-average concentration of dissolved solids of headwater streams in these areas rarely exceeds $50 \mathrm{ppm}$, and the range in concentration between high and low flows is small. Where the mountains are principally underlain by sedimentary rocks-such as in the Wyoming Range, the Wasatch Plateau, and part of the White River Plateau-the streams have higher concentrations of dissolved solids; and though the water contains greater percentages of other ions than does the water from the areas underlain by the Precambrian rocks, it is still mostly of the calcium bicarbonate type. The weighted-average concentration of dissolved solids of headwater streams in these areas often exceeds 200 $\mathrm{ppm}$ and the range in concentration between high and low flows is relatively small. The chemical composition of water from most headwater streams does not change from high to low flows, as the water is generally of the calcium bicarbonate type for all flows.

The interior areas are mostly underlain by sedimentary rocks of Cretaceous and Tertiary ages. As the streams flow across the interior areas, they increase in dissolved-solids concentration. The increase is due to natural causes and the activities of man. The principal natural causes for the increase are the relatively higher dissolved-solids concentration of the runoff from downstream areas underlain by sedimentary rocks, pickup by the streams as they flow over formations containing soluble minerals, and natural ground-water discharge. Among the principal activities of man that cause the concentration to increase are the consumptive use of water, the discharge of domestic and industrial wastes to the streams, and the leaching of soluble minerals from the soils and underlying rocks by irrigation.

The concentration of dissolved solids in the water of most streams increases below their headwater areas, and the range in concentration between high and low flow becomes greater. The chemical composition of most streams also changes in a downstream direction, from principally calcium bicarbonate to greater percentages of magnesium, sodium, sulfate, and chloride. The increase is enough in many streams to result in a different type of water than is present in the headwaters. These changes are partly caused by natural factors and partly by the activities of man.

The chemical quality of ground water affects the chemical quality of the water in the streams. This effect is greatest during periods of low flow when streamflow is largely maintained by ground water. At these times the water in the streams at any point is a mixture of all ground water entering the stream above that point. During periods of high flow, the relatively higher dissolved-solids concentration of the ground-water contribution to the streams is diluted by surface runoff. As a general rule, within any one area the concentration of dissolved solids in the ground water is higher than that in the adjacent stream.

In some areas there is an interchange of water between the streams and flood-plain alluvium owing to the rise and fall of the streams. The concentration of dissolved solids in the streams is usually much less than that of the ground water in the alluvium. During periods of low flow, the movement of water from the alluvium to the stream increases the concentration of dissolved solids in the stream.

The concentration of ground-water return flow from irrigation is many times higher than that of the applied water. Movement of this water back to the stream system increases the dissolved-solids concentration of the streams.

Thermal springs add appreciable quantities of dissolved solids to some of the streams. About 48,600 tons of dissolved solids in 15,900 acre-feet of water is added to the streams annually by thermal springs. About 70 percent of the 48,600 tons of dissolved solids comes from thermal springs in the Yampa River basin.

Table 27 summarizes streamflow and dissolved-solids data at stations on the Green River from near the headwaters to Green River, Utah. At all stations from Green River, Wyo., downst ream, the yield per square mile is similar. For example, the average annual yield from 7,670 square miles above Green River, Wyo., was computed to be 66 tons per square mile. The average annual yield from 40,600 square miles above Green River, Utah, was computed to be 65 tons per square mile. The weighted-average concentration of dissolved solids increased progressively downstream except between the Greendale and Jensen stations. The decrease in the concentration between these stations is probably the result of the inflow of the water of the Yampa River, which contains less dissolved solids. 
Water diverted out of the division carries with it the dissolved minerals in the diverted water. The effect of the exportation on the master stream at downstream points is to deplete the flow and to decrease the dissolved-solids discharge. The effect of the transmountain diversion of water has been to decrease the average annual discharge of the Green River by about 112,200 acre-feet of water and 19,300 tons of dissolved solids. The effect of transmountain diversion has increased the weighted-average concentration of dissolved solids in the Green River at its mouth by about $7 \mathrm{ppm}$. This is equivalent to about $6 \mathrm{ppm}$ for each 100,000 acre-feet of water exported.

Domestic, industrial, and irrigation uses of water result in the consumption of about 735,600 acre-feet annually (table 25). These activities of man add about $1,177,900$ tons of dissolved solids to the stream system (table 28) of which about 11,000 tons comes from oil wells and abandoned oil prospects. The activities of man (exclusive of transmountain diversions) have caused an increase of about $223 \mathrm{ppm}$ in the weightedaverage concentration of the Green River at its mouth. This increase is equivalent to an average increase of about $30 \mathrm{ppm}$ for each 100,000 acre-feet of water consumed, or about five times the increase caused by the exportation of an equivalent amount of water. The major part of the increase in dissolved-solids concentration is attributed to irrigation.

The average annual suspended-sediment discharge from the Green division is estimated to be about $27,875,400$ tons (table 28). Of this amount, about 13 percent comes from the Green River basin above the Yampa River; about 7 percent, from the Yampa River basin; about 26 percent, from the Green River basin between the Yampa and White Rivers including the White River basin; and about 54 percent, from the Green River basin below the White River.

Determinations of suspended-sediment discharge were made at 6 stations on the Green River and at 9 stations on tributaries. Of the 15 areas, the drainage basin of Savery Creek above the upper station near Savery, Wyo., had the smallest rate of yield-39 tons per square mile per year. The drainage basin of Price River above the station at Woodside, Utah, had the highest rate2,586 tons per square mile. However, the average annual yield from the Green River basin below the San Rafael River was estimated to be 2,560 tons per square mile per year.

Concentrations of dissolved solids in many streams, especially in their headwaters, are below the maximum accepted limits for domestic use. The concentrations of dissolved solids in the lower reaches of some of these streams, however, exceed the accepted maximum limits. In the lower reaches of some of the tributaries of Green
River, concentrations of many constituents, as well as total dissolved solids, exceed the maximum accepted limits for domestic use. Some of the springs at Steamboat Springs, Colo., have concentrations of fluoride so high that sustained use of the water might cause mottling of teeth. Nitrate in surface water is apparently not a hazard in the Green division.

Except during periods of low flow when the waters of some tributary streams in their lower reaches should not be used for irrigation, the waters of the streams are suitable for agricultural use.

\section{REFERENCES}

Andrews, D. A., and Hunt, C. B., 1948, Geologic map of eastern and southern Utah: U.S. Geol. Survey Oil and Gas Inv. Prelim. Map 70, 1 sheet, reprinted 1956.

Bradley, W. H., 1936, Geomorphology of the north flank of the Uinta Mountains: U.S. Goel. Survey Prof. Paper 185-E, $203 \mathrm{p}$.

Burbank, W. S., Lovering, T. S., Goddard, E. H., and Eckel, E. B., 1935, Geologic map of Colorado: U.S. Geol. Survey map, 2 sheets, reprinted 1959 .

Cannon, H. L., 1960, The development of botanical methods of prospecting for uranium on the Colorado Plateau: U.S. Geol. Survey Bull. 1085-A, 56 p.

Colby, B. R., Hembree, C. H., and Rainwater, F. H., 1956, Sedimentation and chemical quality of surface water in the Wind River Basin, Wyoming: U.S. Geol. Survey WaterSupply Paper 1373, 336 p.

Dane, C. H., and Bachman, G. O., 1957, Preliminary geologic map of the northwestern part of New Mexico: U.S. Geol. Survey Misc. Geol. Inv. Map I-224, 1 sheet.

Eaton, F. M., 1954, Formulas for estimating the drainage and gypsum requirements of irrigation waters: Texas Agr. Expt. Sta. Misc. Rept. 111, 18 p.

George, R. D., and others, 1920, Mineral waters of Colorado: Colorado Geol. Survey Bull. 11, 475 p.

Goode, Harry D., and Feltis, Richard D., 1962, Water production from oil wells of the Uinta Basin, Utah: Utah Geol. and Mineralog. Survey, Water-Resources Bull. 1, 28 p.

Gregg, D. O., and others, 1961, Public water supplies of Colorado, 1959-60: Colorado State Univ. Agr. Expt. Sta. Rept. Gen. Ser. 757, 128 p.

Hunt, C. B., 1956, Cenozoic geology of the Colorado Plateau: U.S. Geol. Survey Prof. Paper 279, 99 p.

Iorns, W. V., Hembree, C. H., Phoenix, D. A., and Oakland, G. L., 1964, Water Resources of the Upper Colorado River Basin, Basic Data Report: U..S. Geol. Survey Prof. Paper 442, $1036 \mathrm{p}$.

Kohler, M. E., Nordenson, T. J., and Baker, D. R., 1959, Evaporation maps of the United States: U.S. Weather Bur. Tech. Paper 37, 13 p.

Lane, E. W., and Lei, Kai, 1950, Streamflow variability: Am. Soc. Civil Engineers Trans., v. 115, p. 1084-1134.

La Rue, E. C., 1916, Colorado River and its utilization: U.S. Geol. Survey Water-Supply Paper 395, 231 p.

Love, J. D., Weitz, J. L., and Hose, R. K., 1955, Geologic map of Wyoming: U.S. Geol. Survey map, 1 sheet.

Meyers, J. S., 1962, Evaporation from the 17 Western States with a section on evaporation rates, by $T$. J. Nordenson: U.S. Geol. Survey Prof. Paper 272-D, p. 71-100. 
Powell, J. W., 1875, Exploration of the Colorado River of the West and its tributaries: Smithsonian Inst. Ann. Rept., 291 p.

Shantz, N. L., and Zon, Raphael, 1924, Natural vegetation: U.S. Dept. Agriculture Atlas Am. Agriculture, 22 p.

Stearns, Norah D., Stearns, Harold T., and Waring, Gerald A., 1937, Thermal springs in the United States: U.S. Geol. Survey Water-Supply Paper 679-B, I9I p.

Thomas, H. E., 1952, Hydrologic reconnaissance of the Green River in Utah and Colorado: U.S. Geol. Survey Circ. 129, $32 \mathrm{p}$.

Thomas, H. E., and Wilson, M. T., 1952, Determination of total evaporation in Ashley Valley, Utah: U.S. Geol. Survey open-file rept., $21 \mathrm{p}$.
Upper Colorado River Basin Compact Commission, 1948, Final report of Engineering Advisory Committee to Upper Colorado River Basin Compact Commission, 203 p.

U.S. Bureau of the Census, 1953, Colorado, Utah, and Wyoming, irrigated acreage by drainage basins, 1949: U.S. Bur. Census map, 3 sheets.

U.S. Department of the Interior, 1947, The Colorado River: U.S. 80th Cong., 1st sess., H. Doc. 419, 295 p.

U.S. Geological Survey, 1959, Surface water supply of the United States, 1957: U.S. Geol. Survey Water Supply Paper 1513, pt. 9, 506 p.

U.S. Salinity Laboratory Staff, 1954, Diagnosis and improvement of saline and alkali soil: U.S. Dept. of Agriculture, Agriculture Handb. 60, 160 p. 

TABLES 1-28 

TABLE 1.-Average monthly and annual precipitation, in inches, at 16 index-precipitation stations in the Green division [Data are for the water years 1914-57]

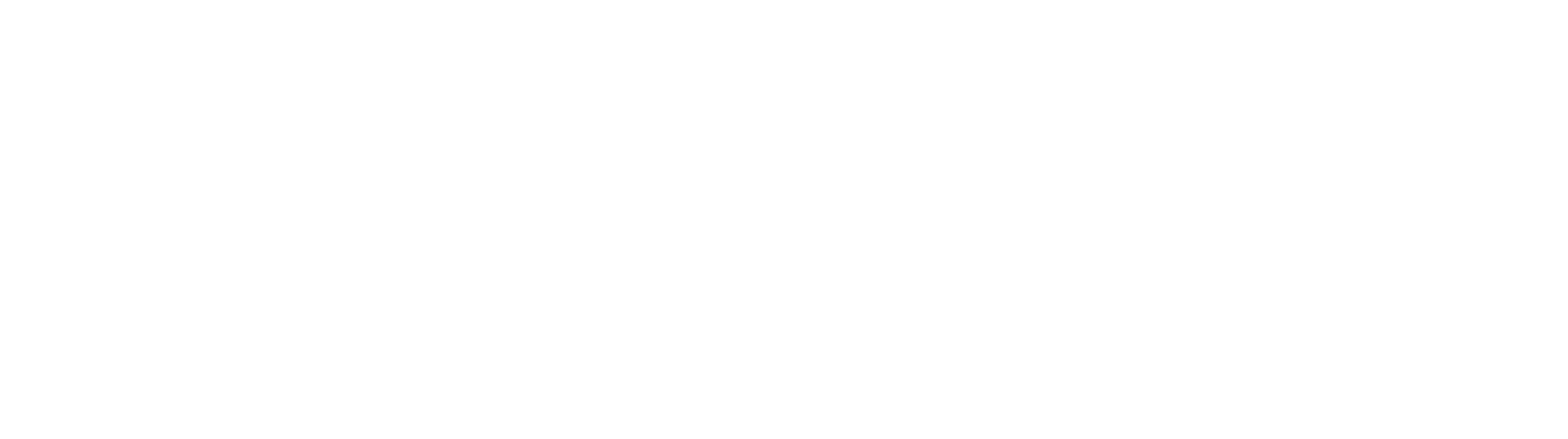

TABLE 2.-Annual precipitation at 16 index-precipitation stations and weighted-average precipitation, in inches, for the Green division for water years $1914-57$

\begin{tabular}{|c|c|c|c|c|c|c|c|c|c|c|c|c|c|c|c|c|c|c|}
\hline & \multicolumn{17}{|c|}{ ex station } & \\
\hline & nder & & rde & & & ed- & yden & & Meeker & Vernal & & chesse & & $\mathrm{rk}$ & | Moroni & een & $\begin{array}{l}\text { ver-r- } \\
\text { gge }\end{array}$ & \\
\hline & \multirow{28}{*}{ 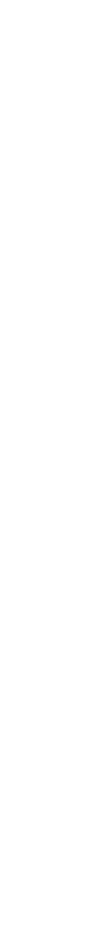 } & \multirow{28}{*}{ 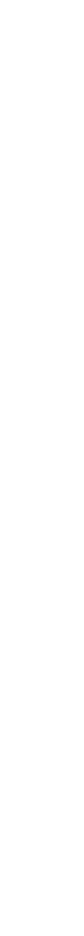 } & \multirow{28}{*}{$\begin{array}{c}15.78 \\
11.80 \\
7.52 \\
13.66 \\
11.94 \\
8.04 \\
15.00 \\
12.92 \\
15.41 \\
19.56 \\
10.84 \\
16.26 \\
12.21 \\
11.26 \\
11.30 \\
14.75 \\
11.04 \\
9.48 \\
13.33 \\
96.67 \\
6.95 \\
11.84 \\
15.84 \\
13.94 \\
15.88 \\
12.28 \\
10.90 \\
15.66 \\
12.13 \\
15.20 \\
12.60 \\
13.45 \\
14.53 \\
18.17 \\
12.00 \\
13.26 \\
17.86 \\
13.55 \\
12.55 \\
11.05 \\
10.32 \\
12.72 \\
12.72 \\
13.99\end{array}$} & \multirow{28}{*}{$\begin{array}{r}16.44 \\
12.03 \\
16.69 \\
11.82 \\
8.74 \\
14.54 \\
13.01 \\
14.68 \\
18.69 \\
14.81 \\
17.09 \\
13.11 \\
15.39 \\
10.98 \\
15.41 \\
13.02 \\
12.59 \\
12.19 \\
99.00 \\
99.87 \\
12.48 \\
12.83 \\
10.14 \\
7.53 \\
8.39 \\
12.15 \\
90.67 \\
10.14 \\
12.75 \\
13.56 \\
11.75 \\
17.61 \\
13.91 \\
8.55 \\
10.64 \\
9.70 \\
11.78 \\
7.24 \\
8.21 \\
8.77 \\
8.45 \\
11.74\end{array}$} & \multirow{28}{*}{$\begin{array}{r}5.84 \\
7.63 \\
4.40 \\
8.01 \\
8.01 \\
5.25 \\
3.60 \\
66.68 \\
9.96 \\
5.94 \\
10.34 \\
10.09 \\
13.24 \\
17.24 \\
7.49 \\
9.83 \\
4.84 \\
10.28 \\
9.76 \\
55.77 \\
8.51 \\
7.04 \\
3.51 \\
8.53 \\
7.54 \\
11.51 \\
10.75 \\
6.89 \\
8.80 \\
11.99 \\
7.84 \\
7.58 \\
10.42 \\
9.89 \\
7.30 \\
16.67 \\
8.67 \\
9.00 \\
11.55 \\
9.23 \\
10.73 \\
5.56 \\
7.31 \\
8.26 \\
6.20 \\
12.50\end{array}$} & \multirow{28}{*}{$\begin{array}{l}22.28 \\
20.65 \\
11.62 \\
15.45 \\
17.08 \\
13.95 \\
19.06 \\
19.89 \\
19.57 \\
18.95 \\
12.98 \\
25.02 \\
16.80 \\
22.90 \\
17.62 \\
22.19 \\
14.07 \\
1.35 \\
18.35\end{array}$} & \multirow{28}{*}{ 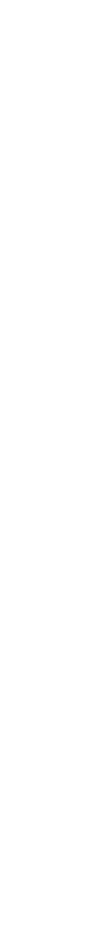 } & \multirow{28}{*}{$\begin{array}{l}33.43 .4 \\
18.99\end{array}$} & \multirow{28}{*}{$\begin{array}{l}18.35 \\
11.81 \\
18.19 \\
18.45 \\
15.15 \\
12.00 \\
15.77 \\
17.99 \\
12.86 \\
15.46 \\
11.28 \\
14.85 \\
14.42 \\
12.49 \\
19.46 \\
14.74 \\
16.05 \\
17.30 \\
14.68 \\
13.45 \\
15.30 \\
13.40 \\
17.27 \\
20.78 \\
16.77 \\
15.98 \\
18.89 \\
17.42 \\
20.93 \\
17.29 \\
21.10 \\
9.62 \\
18.74 \\
16.14 \\
16.42 \\
14.67 \\
14.19 \\
21.53 \\
17.94 \\
18.69 \\
15.19 \\
14.09 \\
23.51\end{array}$} & \multirow{28}{*}{ 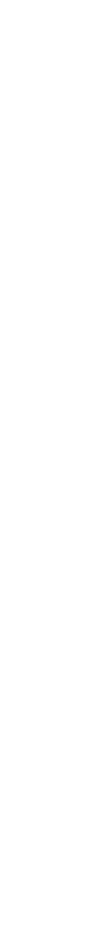 } & \multirow{28}{*}{ 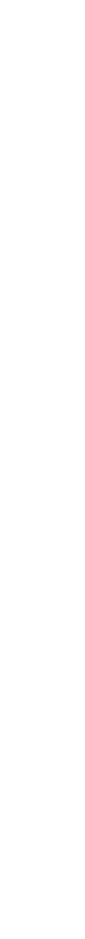 } & \multirow{28}{*}{$\begin{array}{r}11.02 \\
9.11 \\
8.42 \\
13.26 \\
8.09 \\
8.49 \\
9.27 \\
9.62 \\
10.45 \\
10.27 \\
7.52 \\
10.76 \\
9.24 \\
15.20 \\
6.72 \\
11.78 \\
8.77 \\
7.59 \\
10.44 \\
6.12 \\
5.99 \\
7.85 \\
10.62 \\
16.30 \\
11.34 \\
9.87 \\
9.94 \\
13.00 \\
7.22 \\
8.07 \\
8.80 \\
8.07 \\
7.18 \\
11.24 \\
6.69 \\
12.24 \\
7.66 \\
7.92 \\
15.92 \\
4.70 \\
8.39 \\
8.83 \\
5.83 \\
10.81\end{array}$} & \multirow{28}{*}{$\begin{array}{l}3.97 \\
1.86 \\
7.55 \\
7.32 \\
.13 \\
.10 \\
1.23 \\
0.59 \\
.35 \\
6.74 \\
.44 \\
1.01 \\
3.87 \\
.18 \\
.183 \\
5.19 \\
7.22 \\
.35 \\
.77\end{array}$} & \multirow{28}{*}{$\begin{array}{l}21.15 \\
18.42 \\
14.26 \\
20.61 \\
12.99 \\
12.58 \\
24.03 \\
24.27 \\
21.62 \\
24.14 \\
12.85 \\
19.16 \\
15.93 \\
18.64 \\
17.57 \\
21.89 \\
17.13 \\
13.67 \\
16.56 \\
14.03 \\
17.37 \\
17.64 \\
17.23 \\
17.11 \\
14.93 \\
15.97 \\
19.26 \\
17.68 \\
14.00 \\
20.09 \\
22.73 \\
15.39 \\
19.92 \\
16.49 \\
17.33 \\
15.25 \\
15.85 \\
26.79 \\
14.98 \\
14.39 \\
16.88 \\
13.11 \\
21.26 \\
\end{array}$} & \multirow{28}{*}{$\begin{array}{c}21.94 \\
14.41 \\
16.73 \\
14.93 \\
10.45 \\
9.55 \\
12.18 \\
12.12 \\
8.57 \\
10.20 \\
8.10 \\
10.45 \\
8.34 \\
11.91 \\
8.89 \\
12.09 \\
12.88 \\
6.12 \\
10.93 \\
7.85 \\
4.89 \\
9.38 \\
12.51 \\
10.64 \\
9.86 \\
10.91 \\
10.81 \\
11.69 \\
8.34 \\
11.01 \\
12.97 \\
11.73 \\
7.64 \\
12.85 \\
6.99 \\
8.79 \\
8.35 \\
7.64 \\
12.27 \\
8.17 \\
10.60 \\
10.50 \\
8.28 \\
9.93 \\
\end{array}$} & \multirow{27}{*}{$\begin{array}{r}7.85 \\
6.68 \\
6.91 \\
7.26 \\
3.58 \\
35.11 \\
55.84 \\
9.78 \\
6.10 \\
5.36 \\
5.68 \\
7.13 \\
5.78 \\
10.94 \\
6.94 \\
9.73 \\
7.69 \\
3.09 \\
66.70 \\
5.41 \\
3.34 \\
5.78 \\
4.52 \\
55.23 \\
6.74 \\
6.73 \\
6.51 \\
10.67 \\
6.31 \\
5.57 \\
6.53 \\
4.86 \\
5.20 \\
5.70 \\
7.60 \\
60.29 \\
3.91 \\
5.79 \\
7.45 \\
4.62 \\
6.03 \\
4.69 \\
2.23 \\
8.10\end{array}$} & \multirow{27}{*}{$\begin{array}{l}16.72 \\
13.55\end{array}$} & \multirow{27}{*}{ 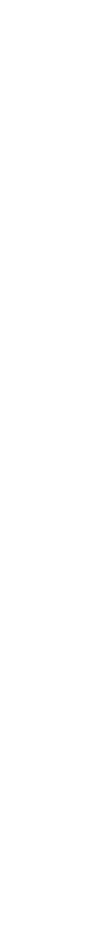 } \\
\hline & & & & & & & & & & & & & & & & & & \\
\hline & & & & & & & & & & & & & & & & & & \\
\hline & & & & & & & & & & & & & & & & & & \\
\hline & & & & & & & & & & & & & & & & & & \\
\hline & & & & & & & & & & & & & & & & & & \\
\hline & & & & & & & & & & & & & & & & & & \\
\hline & & & & & & & & & & & & & & & & & & \\
\hline & & & & & & & & & & & & & & & & & & \\
\hline & & & & & & & & & & & & & & & & & & \\
\hline & & & & & & & & & & & & & & & & & & \\
\hline & & & & & & & & & & & & & & & & & & \\
\hline & & & & & & & & & & & & & & & & & & \\
\hline & & & & & & & & & & & & & & & & & & \\
\hline & & & & & & & & & & & & & & & & & & \\
\hline & & & & & & & & & & & & & & & & & & \\
\hline & & & & & & & & & & & & & & & & & & \\
\hline & & & & & & & & & & & & & & & & & & \\
\hline & & & & & & & & & & & & & & & & & & \\
\hline & & & & & & & & & & & & & & & & & & \\
\hline & & & & & & & & & & & & & & & & & & \\
\hline & & & & & & & & & & & & & & & & & & \\
\hline & & & & & & & & & & & & & & & & & & \\
\hline & & & & & & & & & & & & & & & & & & \\
\hline & & & & & & & & & & & & & & & & & & \\
\hline & & & & & & & & & & & & & & & & & & \\
\hline & & & & & & & & & & & & & & & & & & \\
\hline & & & & & & & & & & & & & & & & & & \\
\hline & & & & & & & & & & & & & & & & & & \\
\hline & & & & & & & & & & & & & & & & & & \\
\hline
\end{tabular}


TABLE 3.-Reservoirs in the subbasins in the Green division [Sources of data, U.S. Dept. of the Interior (1947) and fles of the State Engineer of Utab]

\begin{tabular}{|c|c|c|c|c|c|}
\hline Reservoir & Location & $\begin{array}{l}\text { Usable } \\
\text { capacity } \\
\text { (acre-f t) }\end{array}$ & Reservoir & Location & $\begin{array}{l}\text { Usable } \\
\text { capacity } \\
\text { (acre-ft) }\end{array}$ \\
\hline \multicolumn{6}{|c|}{ Green River basin above the Yampa River } \\
\hline $\begin{array}{l}\text { New Fork Lake } \\
\text { Willow Lake } \\
\text { Fremont Lake- } \\
\text { Boulder Lake- } \\
\text { Silver Lake- } \\
\text { Sixty Seven } \\
\text { Middle Piney. } \\
\text { Black Joe Lake } \\
\text { Big Sandy } \\
\text { Elkhorn }\end{array}$ & $\begin{array}{l}\text { New Fork River } \\
\text { Lake Creek } \\
\text { Pine Creek } \\
\text { Boulder Creek } \\
\text { Silver Creek } \\
\text { North Piney (off channel) } \\
\text { Middle Piney Creek } \\
\text { Big Sandy Creek }\end{array}$ & $\begin{array}{r}22,700 \\
15,120 \\
10,760 \\
12,820 \\
1,220 \\
4,330 \\
4,200 \\
1,100 \\
38,300 \\
1,450\end{array}$ & $\begin{array}{l}\text { Eden No. 1. } \\
\text { Pacific No. 2 } \\
\text { Patterson Lake- } \\
\text { Uinta No. } 3 . \\
\text { Piedmont } \\
\text { Kemmerer } \\
\text { Hoop Lake. } \\
\text { Beaver Meadows. } \\
\quad \text { Total }\end{array}$ & $\begin{array}{l}\text { Little Sandy Creek (off channel) } \\
\text { Pacific Creek } \\
\text { Blacks Fork } \\
\text { Big Muddy Creek } \\
\text { Hams Fork } \\
\text { Beaver Creek (Henrys Fork) } \\
\text { Last Chance (Burnt Fork) }\end{array}$ & $\begin{array}{r}16,000 \\
1,400 \\
1,870 \\
2,000 \\
1,090 \\
1,060 \\
3,930 \\
1,790 \\
141,140\end{array}$ \\
\hline \multicolumn{6}{|c|}{ Green River basin between the Yampa and White Rivers including the White River basin } \\
\hline $\begin{array}{l}\text { Warner } \\
\text { Oaks Park } \\
\text { East Park } \\
\text { Strawberry } \\
\text { Midview } \\
\text { Kidney Lake..... } \\
\text { Moon Lake } \\
\text { Twin Pots... }\end{array}$ & $\begin{array}{l}\text { Pot Creek } \\
\text { Brush Creek } \\
\text { Little Brush Creek } \\
\text { Strawberry River } \\
\text { Duchesne River (off channel) } \\
\text { Duck Creek (Lake Fork) } \\
\text { Lake Fork. }\end{array}$ & $\begin{array}{r}1,520 \\
6,250 \\
1,300 \\
1265,400 \\
5,800 \\
\mathbf{3 , 9 2 0} \\
\mathbf{3 5 , 8 0 0} \\
\mathbf{3 , 9 5 0}\end{array}$ & $\begin{array}{l}\text { Fox Lake } \\
\text { Lake Atwoodd } \\
\text { Paradise Park } \\
\text { John Starr } \\
\text { Montez Creek } \\
\quad \text { Total }\end{array}$ & $\begin{array}{l}\text { Shale Creek (Uinta River) } \\
\text { Lake Atwood Creek (Unita River) } \\
\text { Whiterocks River } \\
\text { Cottonwood Creek (Üinta River) } \\
\text { Montez Creek (Unita River) }\end{array}$ & $\begin{array}{r}1,200 \\
2,700 \\
3,140 \\
2,370 \\
1,260 \\
334,610\end{array}$ \\
\hline \multicolumn{6}{|c|}{ Green River basin below the White River } \\
\hline $\begin{array}{l}\text { Fairview } \\
\text { Scofield } \\
\text { Desert Lake } \\
\text { Olson } \\
\text { Huntington } \\
\text { Cleveland }\end{array}$ & $\begin{array}{l}\text { Gooseberry Creek (Price River) } \\
\text { Price River } \\
\text { Huntington Creek (San Rafael) } \\
\text { do }\end{array}$ & $\begin{array}{r}1,900 \\
65,780 \\
7,300 \\
3,500 \\
4,410 \\
2,320\end{array}$ & $\begin{array}{l}\text { Millers Flat..... } \\
\text { Ferron } \\
\text { Buckhorn } \\
\text { Total }\end{array}$ & $\begin{array}{l}\text { Huntington Creek (San Rafael) } \\
\text { Indian Creek (San Rafael) } \\
\text { Buckhorn Draw (San Rafael) }\end{array}$ & $\begin{array}{r}5,560 \\
1,200 \\
1,520 \\
93,490\end{array}$ \\
\hline
\end{tabular}

1 Maximum usable capacity with stop logs. 
TABLE 4.-Irrigated acreage in the subbasins in the Green division

[Source of data, U.S. Bur. of the Census (1953), except as indicated]

Location

Green River basin above the Yampa River

Source of the Green River.

Intervening area

Irrigated acreage

Total area, Green River at Warren Bridge, near

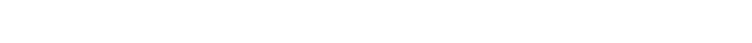
Daniel, Wyo.

Intervening area.

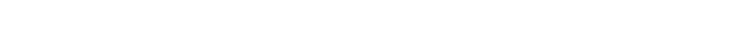

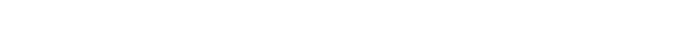

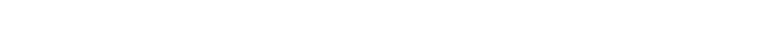

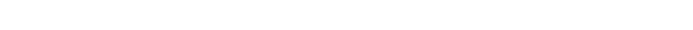

Intervening area...................

New Fork tributary area . . . . . . .

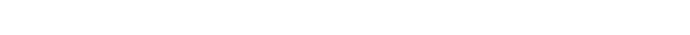

Piney Creeks tributary area....... Intervening area

La Barge Creek tributary area . . . . . . . . . . . . Intervening area

2,000

1,000

2,000

3,000

4,500

10,000

15,400

2,500

48,500

2,500

31,600

2,500

6,100

Total area, Green River near Fontenelle, Wyo-

Total area, Green River near Fontenelle, Wyo..

Fontenelle Creek tributary area

Intervening area...................................

Big Sandy Creek tributary area

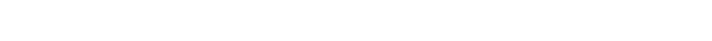

Total area, Green River at Green River, Wyo._ 151, 600

Intervening area......................................

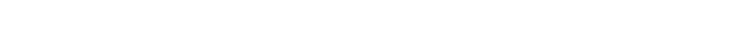

Intervening area.............

Total area, Green River near Linwood, Utah. _ 227, 100

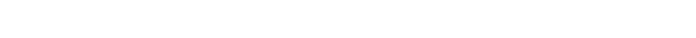

Henrys Fork tributary area

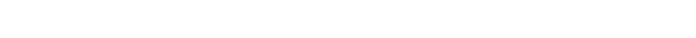

Sheep Creek tributary area

Intervening area.

Total area, Green River above Yampa River.- 258, 400

Yampa River basin

Source of the Yampa River

Intervening area

Total area, Yampa River at Oak Creek, Colo... Intervening area

Total area, Yampa River at Steamboat Springs,

Colo. . . . . . .

Intervening area

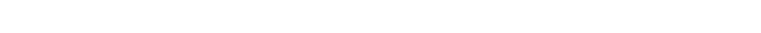

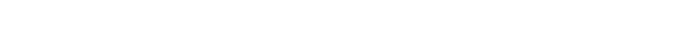

Fortification Creek tributary area..............

Intervening area

12,000

10,000

22,000

2,000

8,100

8,000

1,500

500
0

2,000

Location

Irrigated acreage

Williams Fork tributary area............. 3,000

Intervening area........... 6,200

Total area, Yampa River near Maybell, Colo_.._ $\quad 51,300$

Intervening area........................ 1, 500

Little Snake River tributary area. ... . . . . . . . . 20,400

Intervening area............ 500

Total area, mouth of the Yampa River..... 73, 700

Green River basin between the Yampa and White Rivers including the White River basin

Mouth of the Yampa River.

Intervening area................ 500

Brush Creek tributary area.

Intervening area....................... 1, 000

Ashley Creek tributary area................... 24, 300

Intervening area.................. 2,500

Total area, above Duchesne River

29,900

Intervening area......................... 0

Duchesne River above Duchesne, Utah, tributary

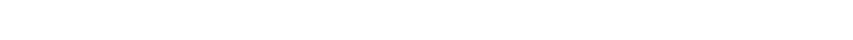

Intervening area..................

Strawberry River above Duchesne, Utah, tributary

area

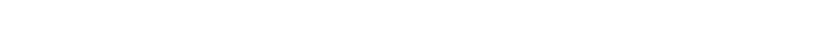

Duchesne River above Randlett, Utah, tributary area. 135,700

Intervening area....................... 2, 000

Total Duchesne River tributary area............. 137, 700

Intervening area........ 0

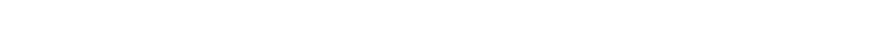

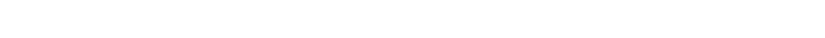

Total area, Green River basin between the White River basin.................... 198, 000

Green River basin below the White River

Total area, Green River below White River........

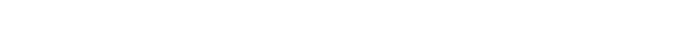

Willow Creek tributary area.

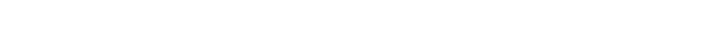

Minnie Maud Creek tributary area

Intervening area........

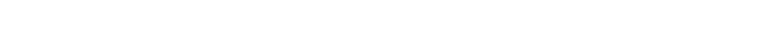

Intervening area

36,000

Intervening area....................... 0

Total, Green River basin below the White River $\quad 60,000$

1 Furnished by U.S. Bureau of Reclamation. Yampa and White Rivers including the 
WATER RESOURCES OF UPPER COLORADO RIVER BASIN

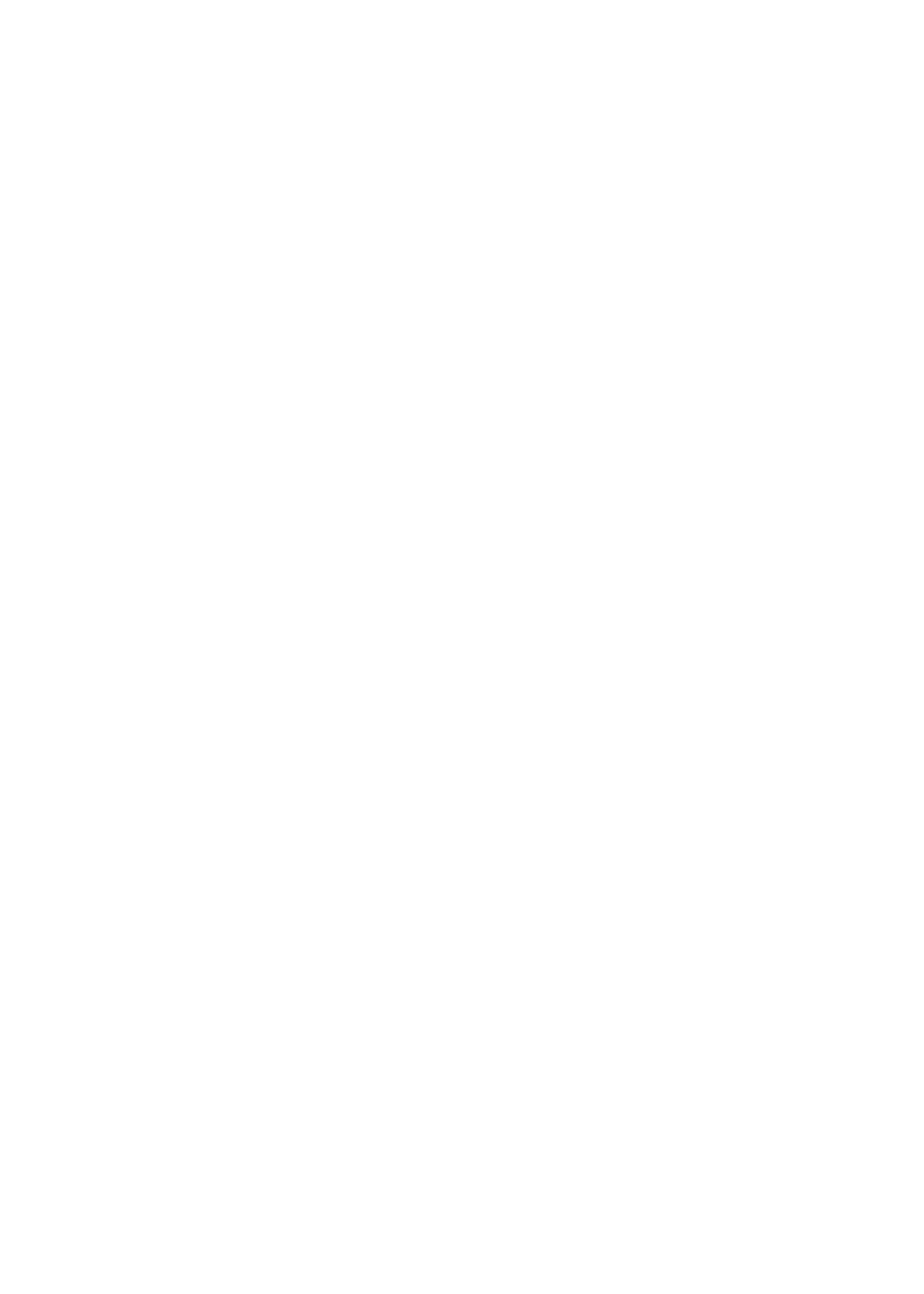




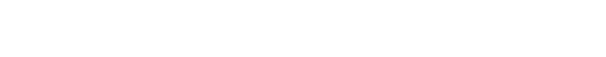

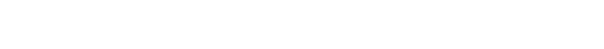

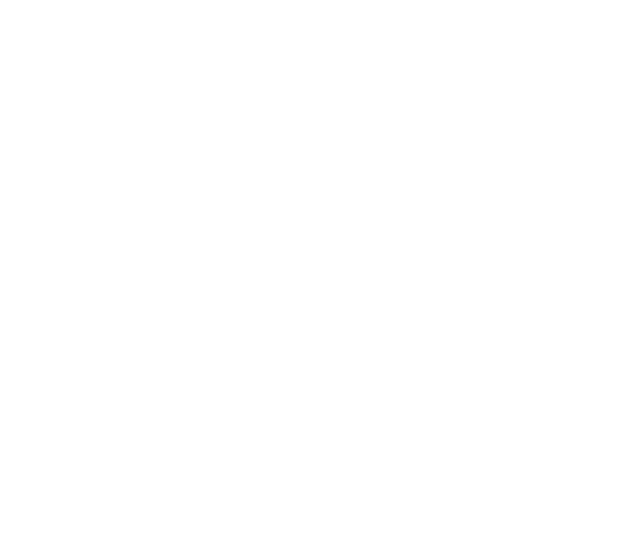

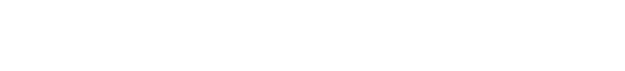

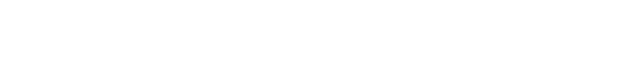

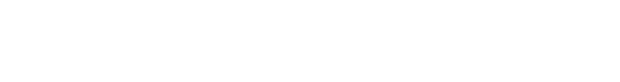

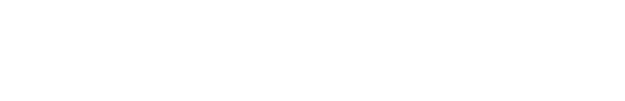

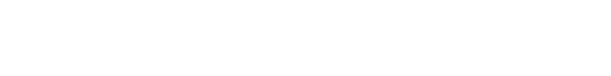

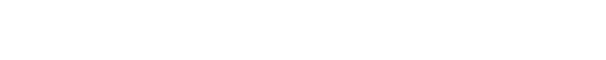

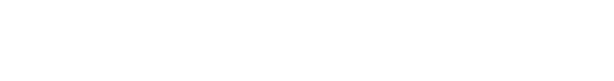

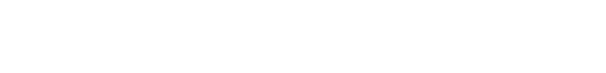

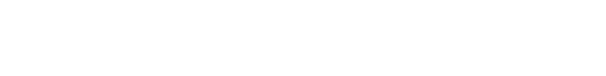

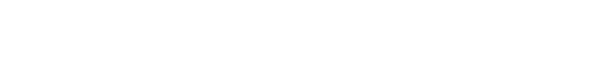

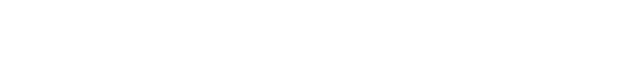

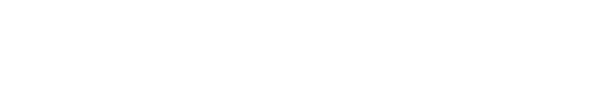

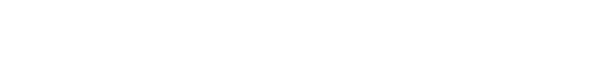

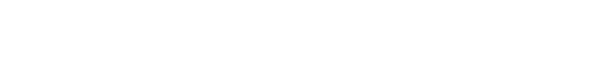

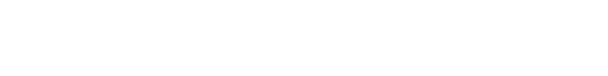

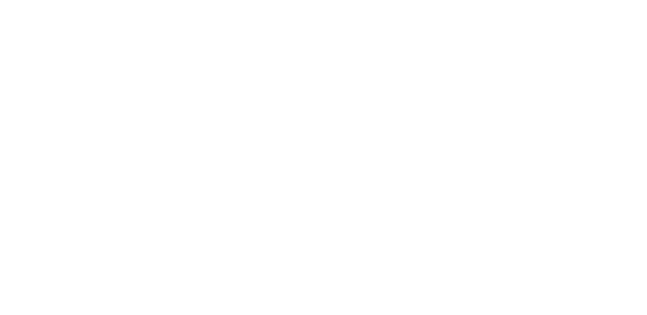

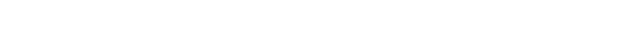

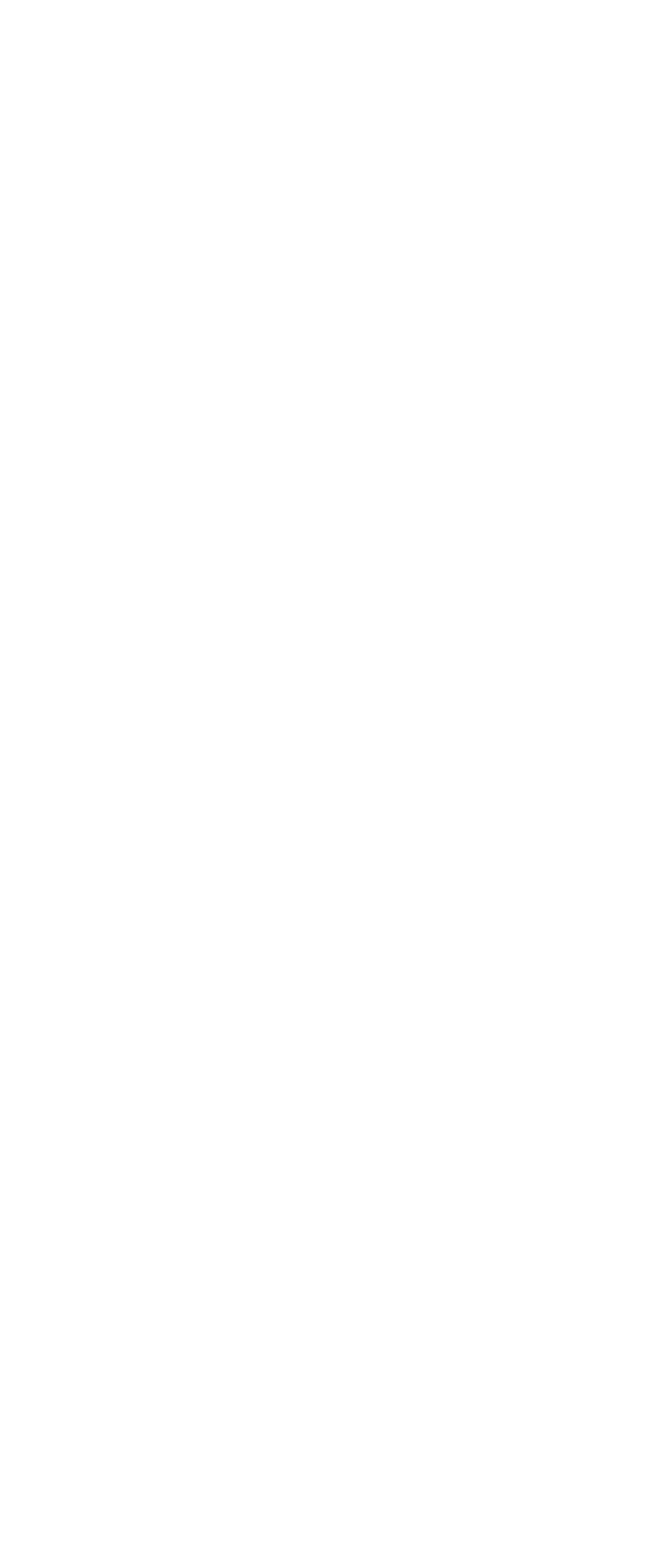




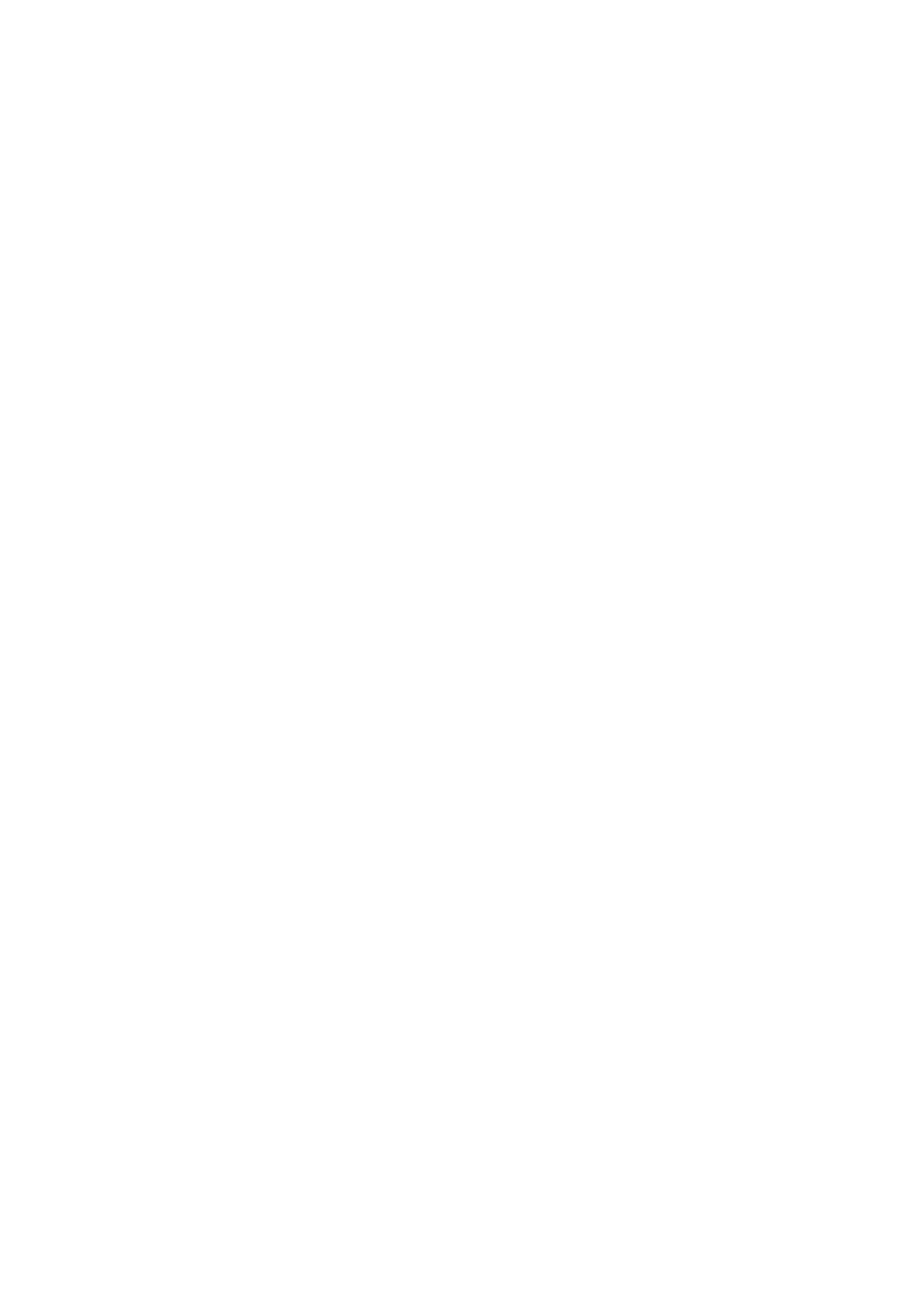




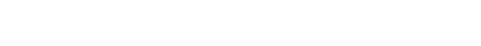

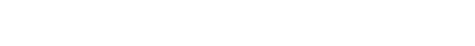

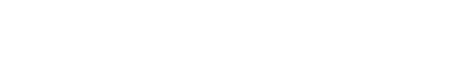

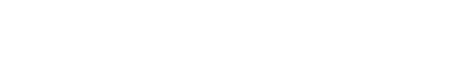

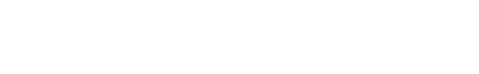

จัล

2ล

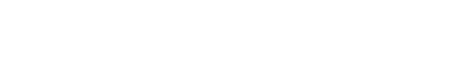

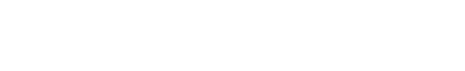

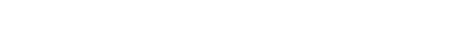

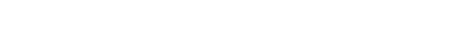

주용

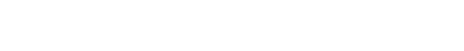

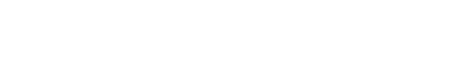

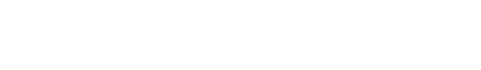

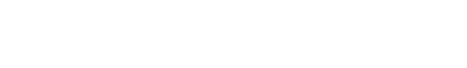

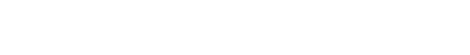

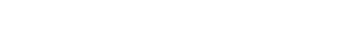

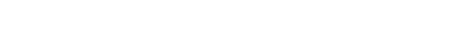

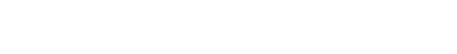

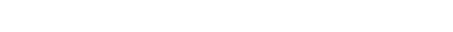

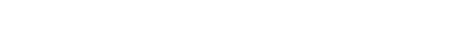
ini कiन

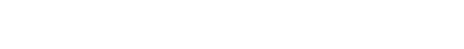

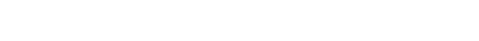

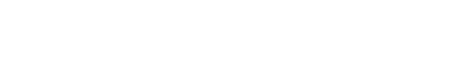

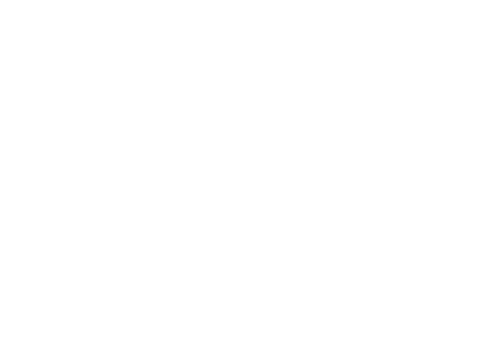

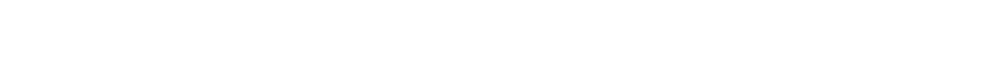

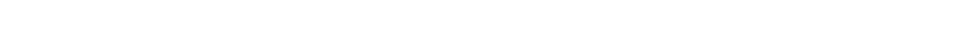
พ*i

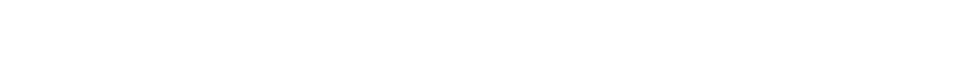

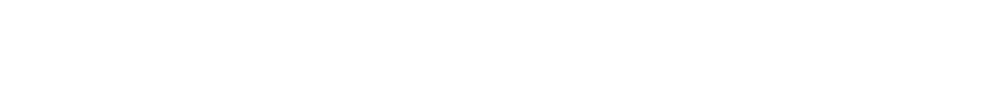

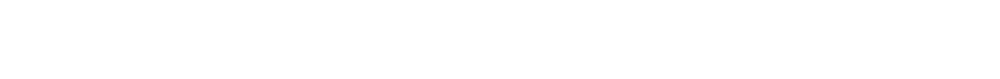

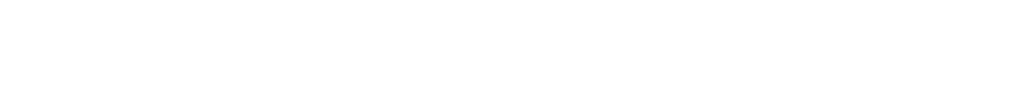

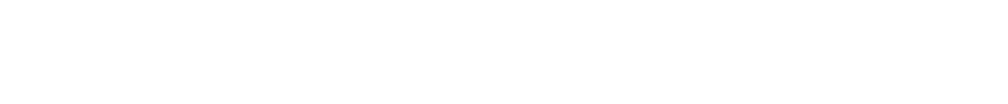
in

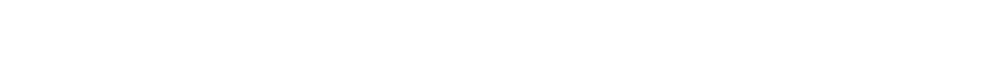
i-i

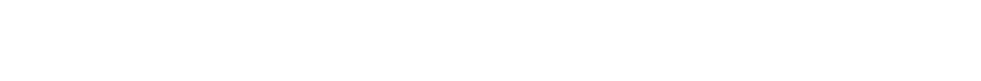

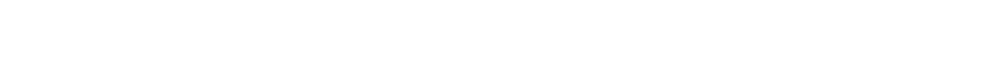

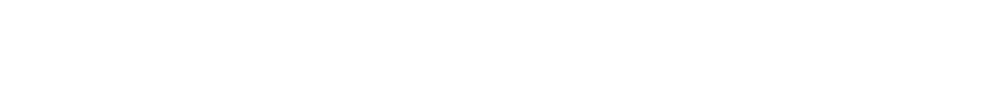

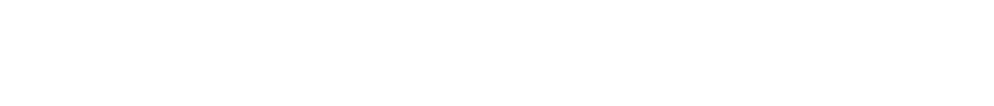
द⿳⺈冂大

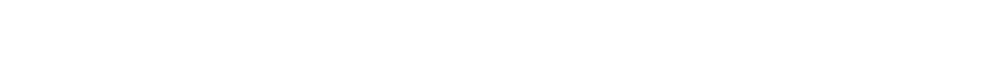
is

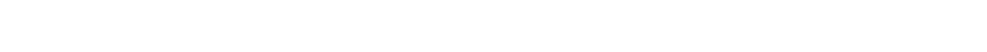
sis

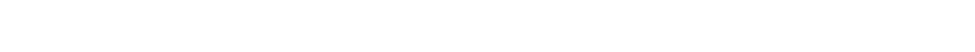
इंके इसे से की

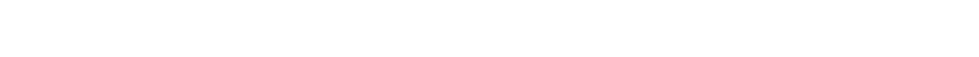

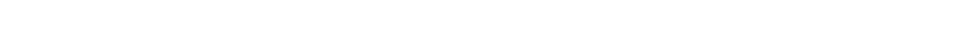

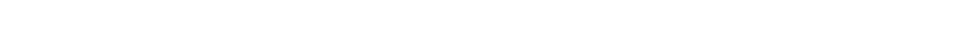

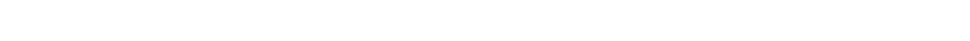

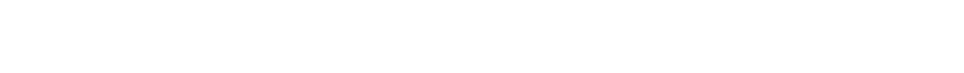

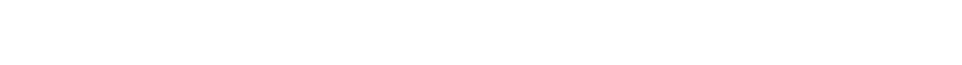

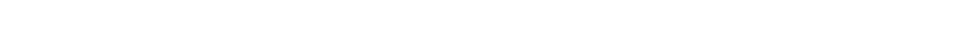

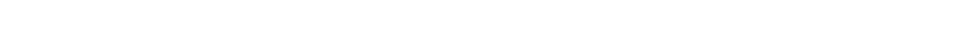

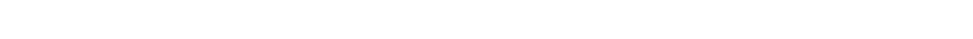

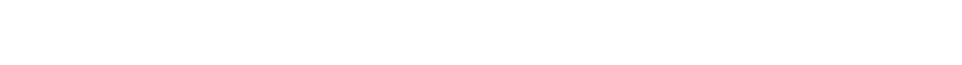
85

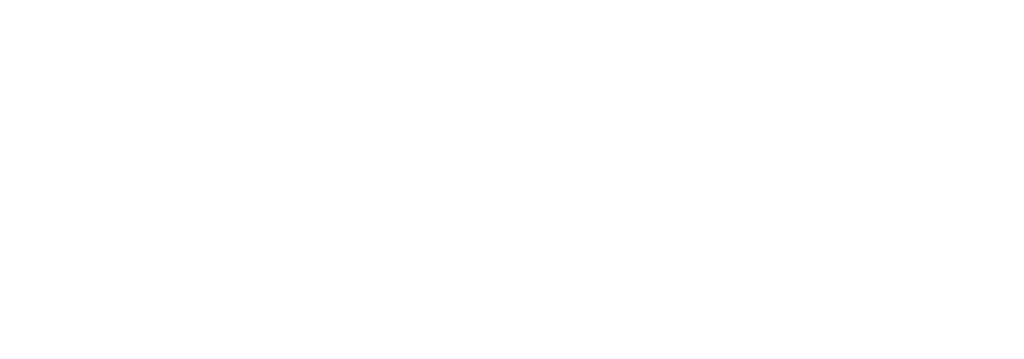


TABLE 6.-Methods and accuracy of adjusting flow-duration data for selected stations in two subbasins in the Green division to base period and $195 \%$ conditions

Years of record: Number of years of available historical flow-duration data during water years $1914-57$.

Base period adjustment method: Method used in adjusting historical data to base period; I, index-station method; S, substitute method.

ndex-station No.: Index station used in adjusting flow-duration curve tobaseperiod or correlation station used in estimating data for missing periods of record.

\begin{tabular}{|c|c|c|c|c|c|c|c|c|c|}
\hline Station No. & $\begin{array}{l}\text { Years of } \\
\text { record }\end{array}$ & $\begin{array}{l}\text { Base period } \\
\text { adjustment } \\
\text { method }\end{array}$ & Index-station No. & $\begin{array}{l}\text { Accuracy } \\
\text { rating } \\
\text { (percent) }\end{array}$ & Station No. & $\begin{array}{l}\text { Years of } \\
\text { record }\end{array}$ & $\begin{array}{l}\text { Base period } \\
\text { adjustment } \\
\text { method }\end{array}$ & Index-station No. & $\begin{array}{c}\text { Accuracy } \\
\text { rating } \\
\text { (percent) }\end{array}$ \\
\hline
\end{tabular}

Green River basin above the Yampa River

1885

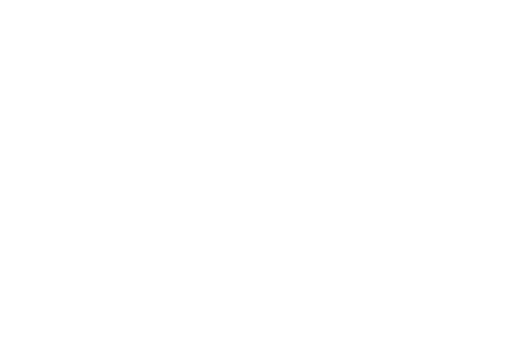

\begin{tabular}{c||}
10 \\
15 \\
15 \\
15 \\
5 \\
$15+$ \\
10 \\
$15+$ \\
$15+$ \\
10 \\
15
\end{tabular}

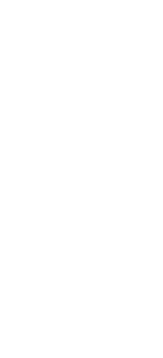

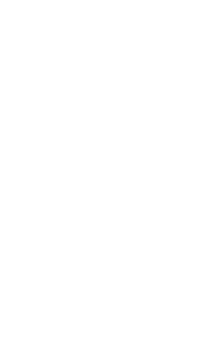

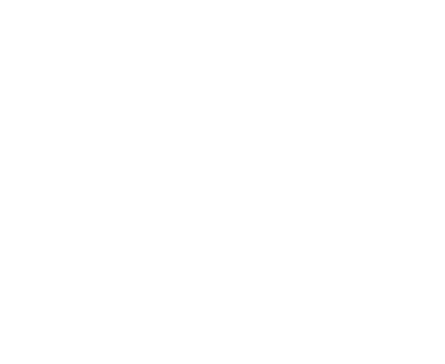

Yampa River basin

\begin{tabular}{|c|c|c|}
\hline 2375 & 5 & I.. \\
\hline $2395 \ldots$ & 44 & \\
\hline $2410 \ldots \ldots$ & 36 & \\
\hline $2425 \ldots \ldots$ & 14 & \\
\hline $2470 \ldots \ldots \ldots$ & 9 & \\
\hline $2510 \ldots \ldots$ & 41 & $\mathrm{~S}$ \\
\hline
\end{tabular}

$2395 \ldots \ldots$

\begin{tabular}{c||}
15 \\
5 \\
10 \\
$15+$ \\
15 \\
5
\end{tabular}

\begin{tabular}{r|l|}
12 & $\mathrm{I}-\ldots \ldots \ldots \ldots$ \\
26 & $\mathrm{I}-\ldots \ldots \ldots \ldots$ \\
6 & $\mathrm{I} \ldots \ldots \ldots \ldots \ldots$ \\
29 & $\mathrm{I}-\ldots \ldots \ldots \ldots$ \\
4 & $\mathrm{I}-\ldots \ldots \ldots \ldots$ \\
36 & $\mathrm{~S}$
\end{tabular}
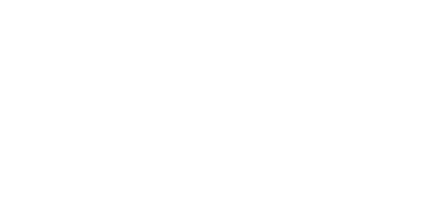
water years 1914-57 to 1957 conditions. The accuracy rating indicates that the anal developed flow-duration curve throughout its range is believed to be correct within the percentage indicated.

1 Flow-duration curve and data for index station that had been adjusted to base period were used.

2 Annual estimates of discharge by Upper Colorado River Compact Comm. (1948) were used. 
$\mathrm{T}_{\mathrm{ABLE}}$ 7.- Variability index of streamflow and percentage of average annual discharge estimated to be contributed by ground water for selected streams in the subbasins in the Green division

[Data are for the water years 1914-57 adjusted to 1957 conditions, except as indicated]

\begin{tabular}{|c|c|c|c|}
\hline $\begin{array}{l}\text { Station } \\
\text { No. }\end{array}$ & Station name & $\begin{array}{c}\text { Variability } \\
\text { index }\end{array}$ & $\begin{array}{l}\text { Ground water } \\
\text { (percent) }\end{array}$ \\
\hline \multicolumn{4}{|c|}{ Green River basin above the Yampa River } \\
\hline $\begin{array}{l}2030 \\
2230 \\
2140 \\
2125 \\
2185 \\
2260 \\
1855 \\
2055 \\
2165 \\
2045 \\
2105 \\
2085\end{array}$ & $\begin{array}{l}\text { East Fork near Big Sandy, Wyo. } \\
\text { Hams Fork near Elk Creek ranger station, Wyo } \\
\text { Little Sandy Creek near Elkhorn, Wyy } \\
\text { Big Sandy Creek at Leckie Ranch, Wyo } \\
\text { Blacks Fork near Millburne, Wyo.' } \\
\text { Henrys Fork near Lonetree, Wyo } \\
\text { Green River at Warren Bridge, near Daniel, Wyo } \\
\text { North Piney Creek near Mason, Wyo } \\
\text { Green River at Green River, Wyo. } \\
\text { East Fork at Newfork, Wyo } \\
\text { Fontenelle Creek near Herschler Ranch, near Fontenelle, } \\
\text { Wyo.2 } \\
\text { La Barge Creek near Viola, Wyo. }\end{array}$ & $\begin{array}{r}0.72 \\
.58 \\
.56 \\
.56 \\
.53 \\
.52 \\
.51 \\
.48 \\
.42 \\
.40 \\
.35 \\
.28\end{array}$ & $\begin{array}{l}11 \\
17 \\
21 \\
19 \\
22 \\
24 \\
27 \\
29 \\
30 \\
31 \\
\\
43 \\
52\end{array}$ \\
\hline \multicolumn{4}{|c|}{ Yampa River basin } \\
\hline $\begin{array}{l}2530 \\
2410 \\
2555 \\
2375\end{array}$ & $\begin{array}{l}\text { Little Snake River near Slater, Colo } \\
\text { Elk River at Clark, Colo } \\
\text { Savery Creek at upper station, near Savery, Wyo. } \\
\text { Yampa River near Oak Creek, Colo. }\end{array}$ & $\begin{array}{r}0.67 \\
.58 \\
.48 \\
.25\end{array}$ & $\begin{array}{l}12 \\
19 \\
33 \\
60\end{array}$ \\
\hline
\end{tabular}

Green River basin between the Yampa and White Rivers including the White River basin

\begin{tabular}{|c|c|c|c|}
\hline $\begin{array}{l}2790 \\
2665 \\
2995 \\
2755 \\
2925 \\
3045\end{array}$ & $\begin{array}{l}\text { Rock Creek near Mountain Home, Utah } \\
\text { Ashley Creek near Vernal, Utah. } \\
\text { Whiterocks River near Whiterocks, Utah } \\
\text { West Fork Duchesne River near Hanna, Utah. } \\
\text { Yellowstone Creek near Altonah, Utah. } \\
\text { White River near Meeker, Colo. }\end{array}$ & $\begin{array}{r}0.42 \\
.40 \\
.40 \\
.36 \\
.34 \\
.26\end{array}$ & $\begin{array}{l}36 \\
30 \\
30 \\
32 \\
44 \\
57\end{array}$ \\
\hline
\end{tabular}

Green River basin below the White River

\begin{tabular}{l|l|r|r}
\hline 3180 & Huntington Creek near Huntington, Utah. & 0.38 & 32 \\
3245 & Cottonwood Creek near Orangeville, Utah- Uta & .46 & 26 \\
3265 & Ferron Creek (upper station) near Ferron, Utah- & .53 & 19 \\
\hline
\end{tabular}

1 Water years 1940-57. 2 Water years 1952-57. 
TABLE 8.-Average discharge, standard deviation, and coefficient of variation for selected stations in the Green division

\begin{tabular}{|c|c|c|c|c|c|}
\hline $\begin{array}{l}\text { Station } \\
\text { No. }\end{array}$ & Station name & $\begin{array}{l}\text { Period of } \\
\text { record }\end{array}$ & $\begin{array}{c}\text { A verage } \\
\text { discharge } \\
\text { (cfs) }\end{array}$ & $\begin{array}{c}\text { Standard } \\
\text { deviation } \\
\text { (efs) }\end{array}$ & $\begin{array}{c}\text { Coefficient } \\
\text { of } \\
\text { variation }\end{array}$ \\
\hline \multicolumn{6}{|c|}{ Green River basin above the Yampa River } \\
\hline $\begin{array}{l}1885 \\
1980 \\
2010 \\
2030 \\
2055 \\
2125 \\
2170 \\
2185 \\
2200 \\
2235 \\
2260 \\
2285\end{array}$ & 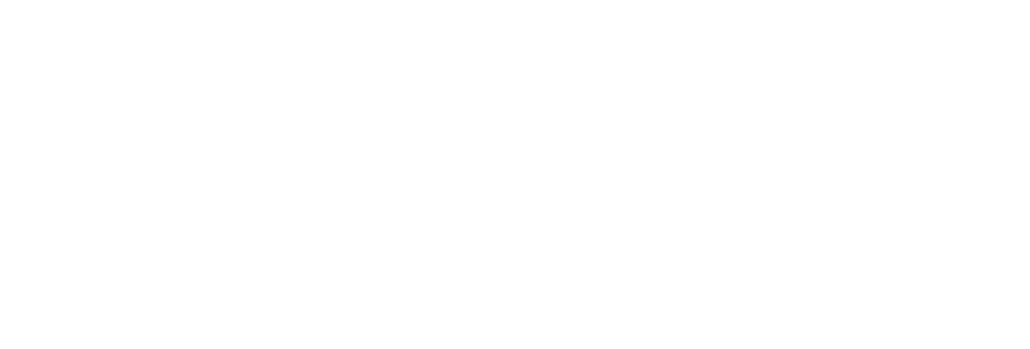 & $\begin{array}{l}1940-57 \\
1940-54 \\
1915-57 \\
1939-57 \\
1940-57 \\
1940-57 \\
1914-57 \\
1940-57 \\
1940-57 \\
1940-57 \\
1943-57 \\
1944-57\end{array}$ & $\begin{array}{c}532 \\
128 \\
401 \\
104 \\
60.3 \\
86.6 \\
1,802 \\
156 \\
45.0 \\
143 \\
39.4 \\
30.2\end{array}$ & $\begin{array}{c}98.1 \\
34.0 \\
113 \\
25.5 \\
19.7 \\
20.0 \\
577 \\
27.5 \\
11.2 \\
65.9 \\
11.3 \\
8.76\end{array}$ & $\begin{array}{r}0.18 \\
.27 \\
.28 \\
.25 \\
.32 \\
.23 \\
.32 \\
.18 \\
.25 \\
.46 \\
.29 \\
.29\end{array}$ \\
\hline
\end{tabular}

Green River basin between the Yampa and White Rivers including the White River basin

\begin{tabular}{|c|c|c|c|c|c|}
\hline $\begin{array}{l}2665 \\
2795 \\
2995 \\
3045\end{array}$ & $\begin{array}{l}\text { Ashley Creek near Vernal, Utah, } \\
\text { Duchesne River at Duchesne, Utah } \\
\text { Whiterocks River near Whiterocks, Utah } \\
\text { White River near Meeker, Colo }\end{array}$ & $\begin{array}{r}1914-57 \\
1914-57 \\
1914-57 \\
1914-57\end{array}$ & $\begin{array}{l}104 \\
385 \\
124 \\
638\end{array}$ & $\begin{array}{l}31.9 \\
121 \\
45.4 \\
142\end{array}$ & $\begin{array}{r}0.31 \\
.31 \\
.37 \\
.22\end{array}$ \\
\hline \multicolumn{6}{|c|}{ Green River basin below the White River } \\
\hline $\begin{array}{l}3105 \\
3150 \\
3180 \\
3265\end{array}$ & $\begin{array}{l}\text { Price River above Scofield Reservoir, near Scofield, Utah. } \\
\text { Green River at Green River, Utah. } \\
\text { Huntington Creek near Huntington, Utah } \\
\text { Ferron Creek (upper station) near Ferron, Utah. }\end{array}$ & $\begin{array}{l}1939-57 \\
1914-57 \\
1914-57 \\
1914-23 \\
1948-57\end{array}$ & $\begin{array}{c}47.5 \\
6,358 \\
100 \\
72.8\end{array}$ & $\begin{array}{r}17.3 \\
2,006 \\
34.1 \\
26.0\end{array}$ & $\begin{array}{r}0.36 \\
.32 \\
.34 \\
.36\end{array}$ \\
\hline
\end{tabular}

\footnotetext{
1 Water years 1914-17 estimated.
} 
TABLE 9.-Water and dissolved-solids discharges of streams in the subbasins in the Green division [Water and dissolved-solids discharge for the 1914-57 water years adjusted to 1957 conditions, except as indicated]

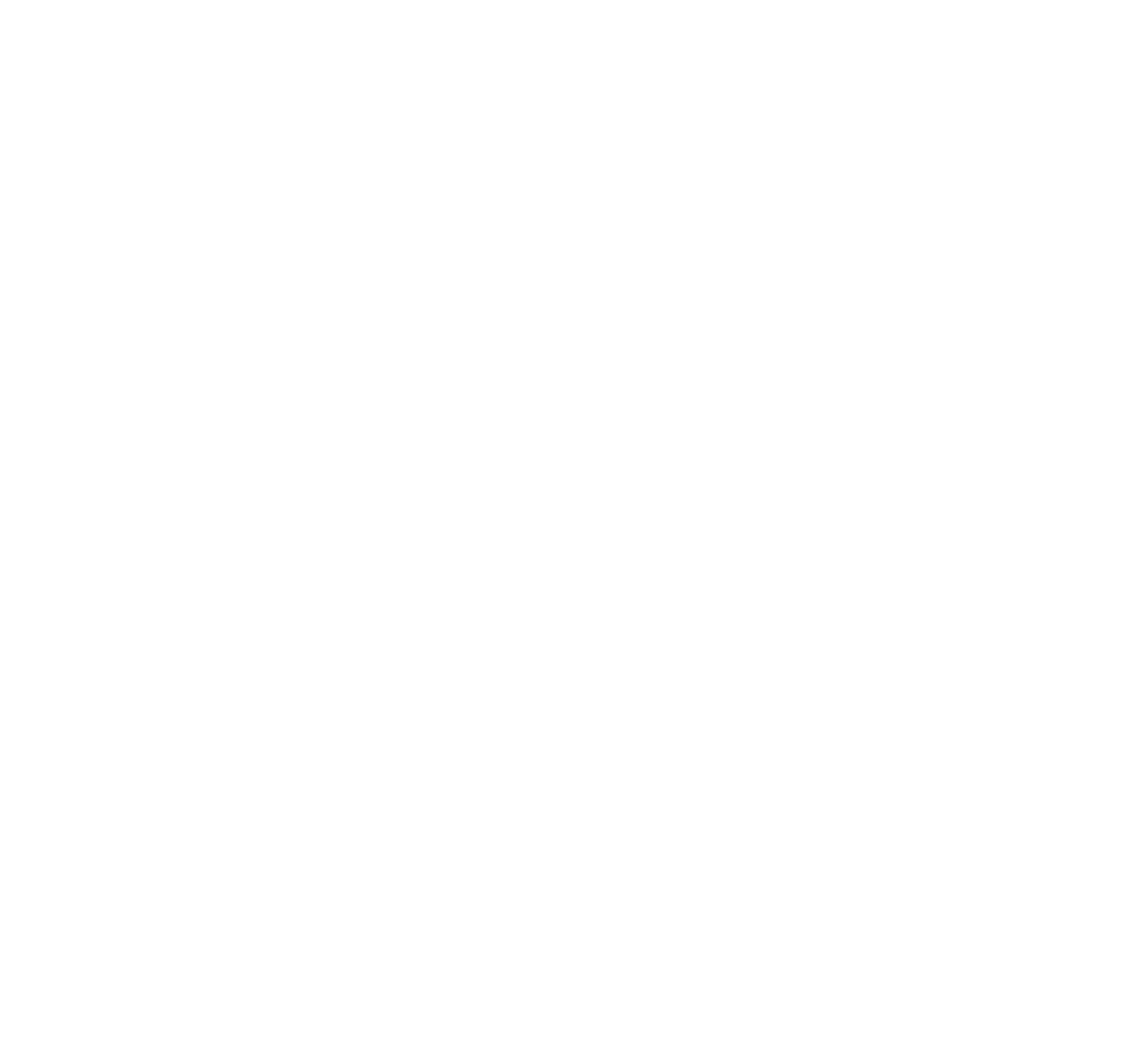

See footnotes at end of table. 
TABLE 9.-Water and dissolved-solids discharges of streams in the subbasins in the Green division-Continued [Water and dissolved-solids discharge for the 1914-57 water years adjusted to 1957 conditions, except as indicated]

\begin{tabular}{|c|c|c|c|c|c|c|c|c|}
\hline \multirow[b]{2}{*}{$\begin{array}{l}\text { Station } \\
\text { No. }\end{array}$} & \multirow[b]{2}{*}{ Chemical-quality station } & \multirow[b]{2}{*}{$\begin{array}{c}\text { Drainage } \\
\text { area } \\
\text { (sq mi) }\end{array}$} & \multicolumn{2}{|c|}{ Water discharge } & \multicolumn{4}{|c|}{ Dissolved solids } \\
\hline & & & $\begin{array}{l}\text { Average } \\
\text { (cfs) }\end{array}$ & $\begin{array}{l}\text { A verage annual } \\
\text { (acre-ft) }\end{array}$ & $\begin{array}{c}\text { Weighted- } \\
\text { average } \\
\text { concentration } \\
\text { (ppm) }\end{array}$ & $\begin{array}{c}\text { Average } \\
\text { discharge } \\
\text { (tons per } \\
\text { day) }\end{array}$ & $\begin{array}{l}\text { Average } \\
\text { annual yield } \\
\text { per sq mi } \\
\text { (tons) }\end{array}$ & $\begin{array}{l}\text { A verage } \\
\text { annual } \\
\text { discharge } \\
\text { (tons) }\end{array}$ \\
\hline \multicolumn{9}{|c|}{ Yampa River basin } \\
\hline $\begin{array}{l}2375 \\
2395 \\
2410 \\
2425 \\
2469 \\
2495 \\
2510 \mathrm{~A} \\
\\
2530 \\
2550 \\
2555 \\
2570 \\
2580 \\
2595 \mathrm{C}\end{array}$ & 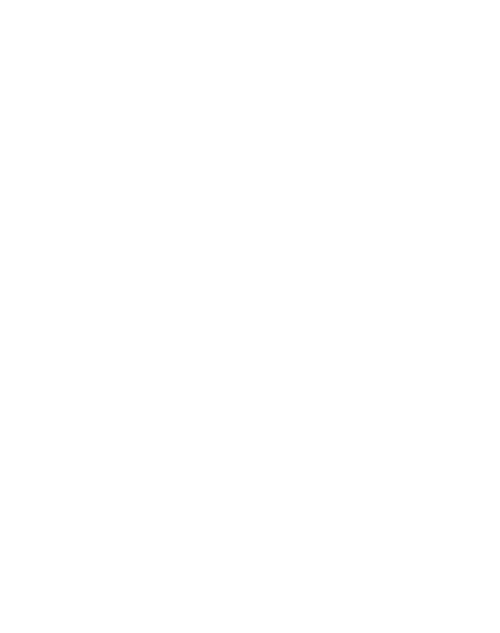 & $\begin{array}{c}227 \\
604 \\
206 \\
415 \\
34.3 \\
341 \\
3,590 \\
285 \\
161 \\
189 \\
988 \\
24 \\
3,355\end{array}$ & $\begin{array}{c}87.3 \\
472 \\
356 \\
544 \\
13.4 \\
218 \\
1,590 \\
260 \\
84.0 \\
50.8 \\
547 \\
11.8 \\
622\end{array}$ & $\begin{array}{r}63,250 \\
341,900 \\
257,900 \\
394,100 \\
9,710 \\
157,900 \\
1,152,000 \\
188,400 \\
60,850 \\
36,800 \\
396,300 \\
8,550 \\
450,600\end{array}$ & $\begin{array}{r}221 \\
74 \\
40 \\
44 \\
\\
774 \\
234 \\
140 \\
\\
78 \\
101 \\
\\
160 \\
91 \\
88\end{array}$ & $\begin{array}{r}52 \\
94 \\
38 \\
64 \\
28 \\
138 \\
599 \\
55 \\
23 \\
22 \\
135 \\
2.8 \\
330\end{array}$ & $\begin{array}{r}84 \\
57 \\
67 \\
56 \\
\\
298 \\
148 \\
\\
61 \\
70 \\
52 \\
43 \\
50 \\
42\end{array}$ & $\begin{array}{r}18,990 \\
34,330 \\
13,880 \\
23,380 \\
10,230 \\
50,400 \\
218,800 \\
20,090 \\
8,400 \\
8,040 \\
49,310 \\
1,020 \\
120,500\end{array}$ \\
\hline
\end{tabular}

Green River basin between the Yampa and White Rivers including the White River basin

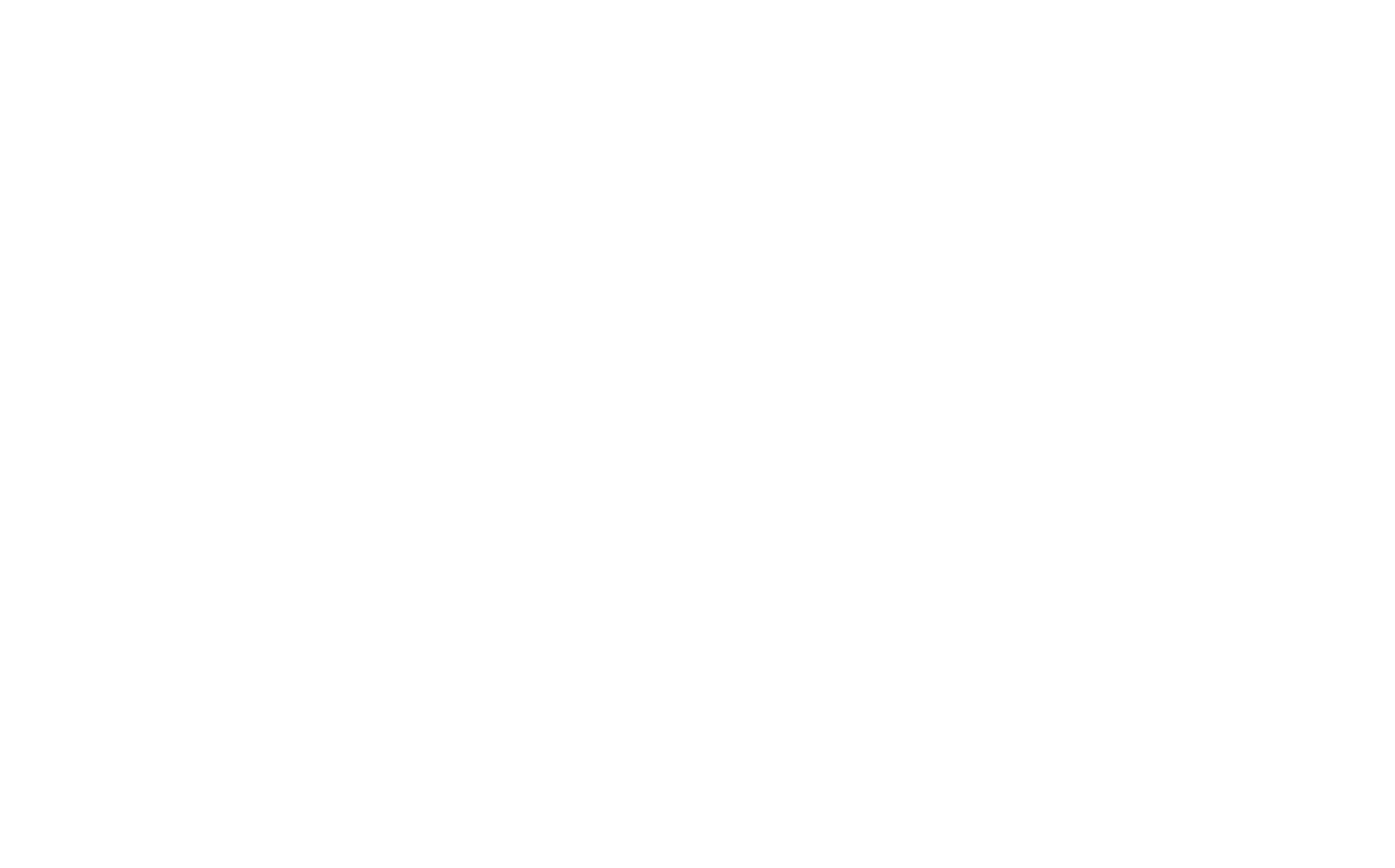

See footnotes at end of table. 
TABLE 9.-Water and dissolved-solids discharges of streams in the subbasins in the Green division-Continued

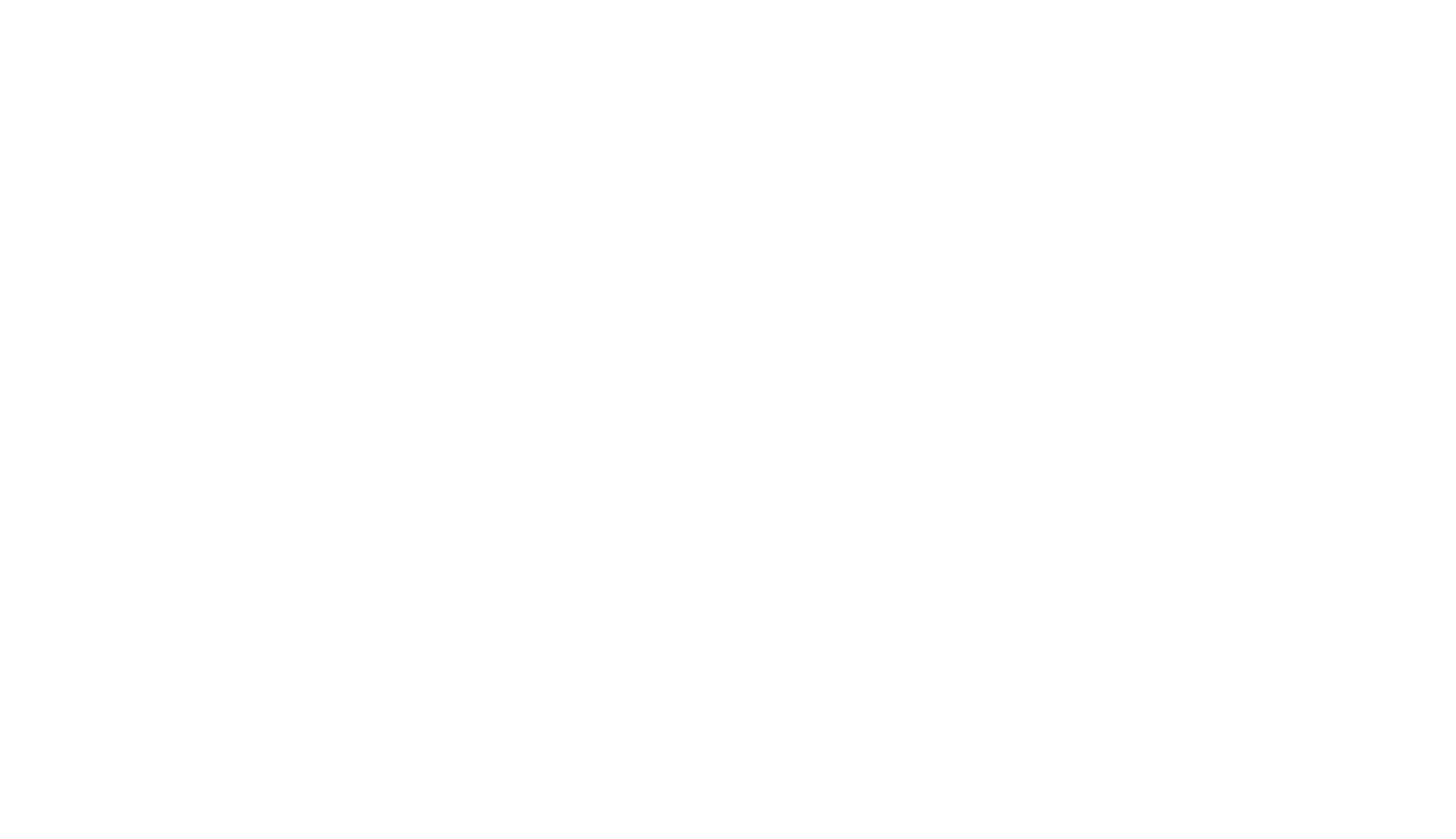


WATER RESOURCES OF UPPER COLORADO RIVER BASIN

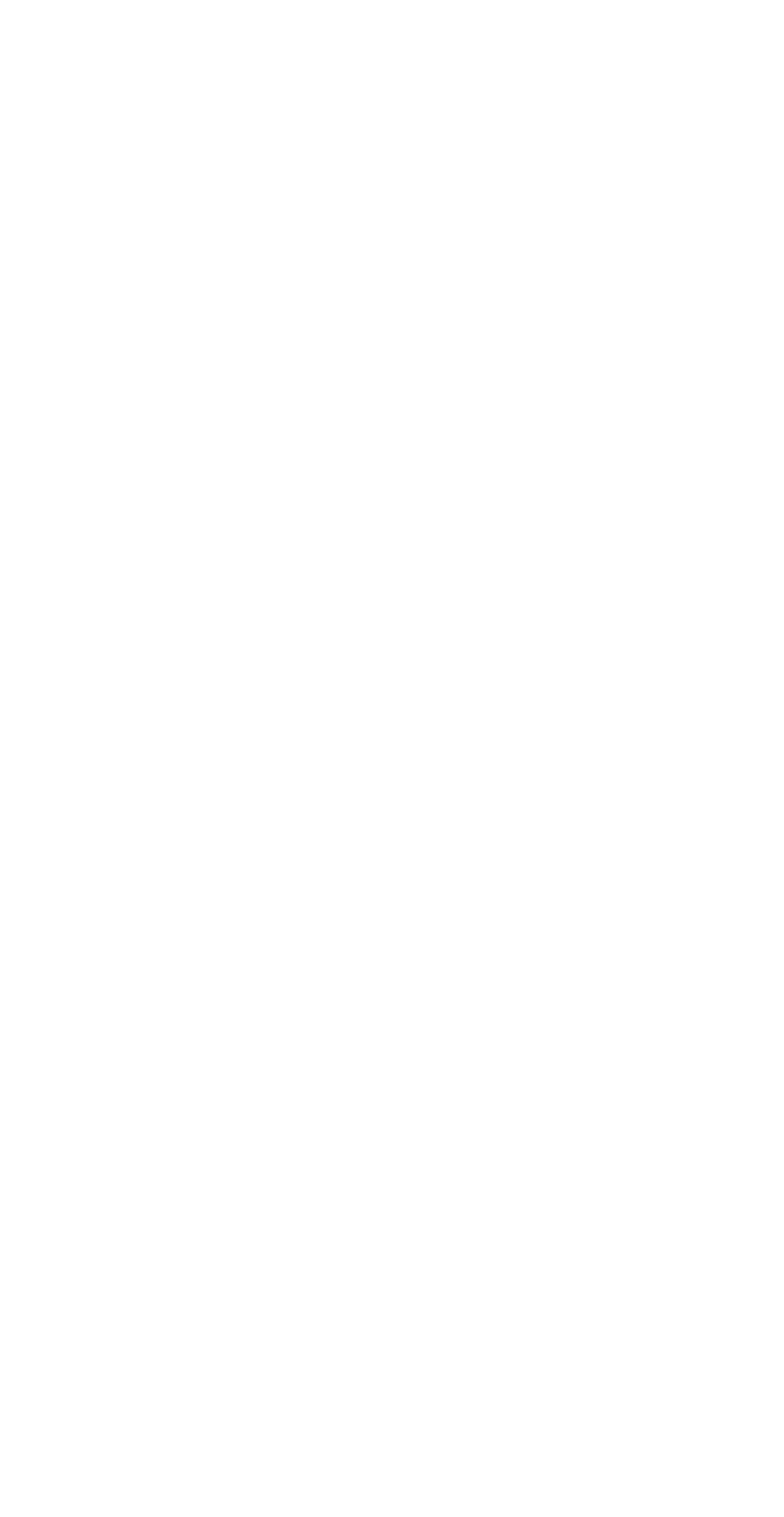

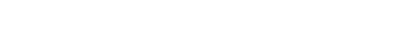

있 옹ำ:

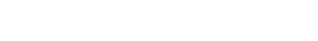

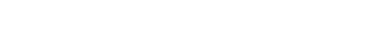

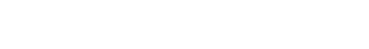

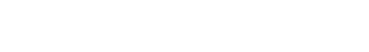

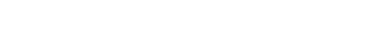

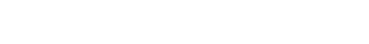

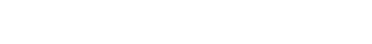

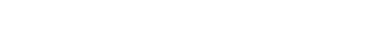

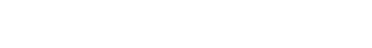

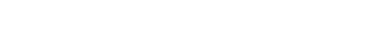

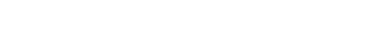

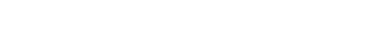

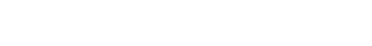

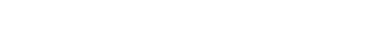

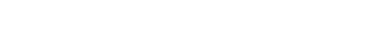

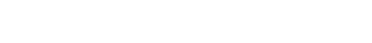

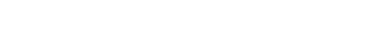

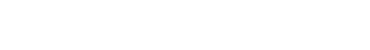

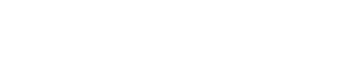

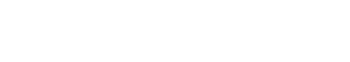

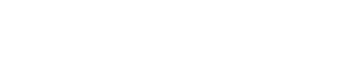

若

政

至论

순

m

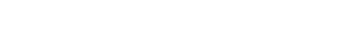

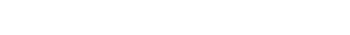

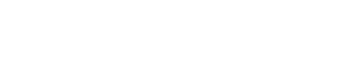




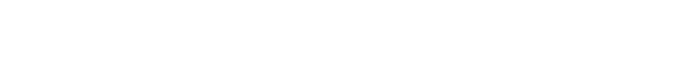

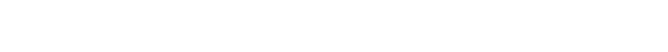

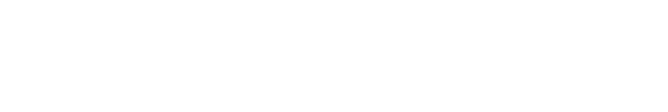

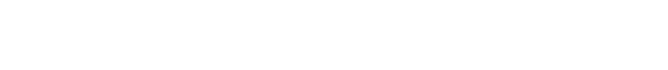

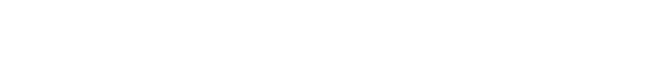

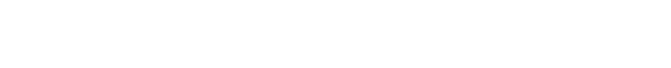

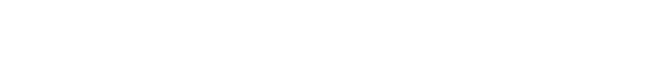

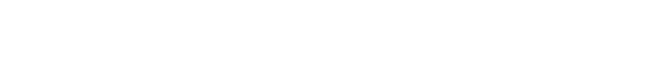

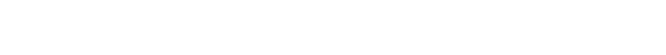

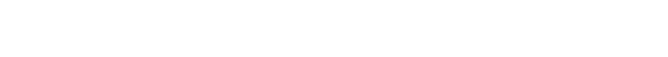

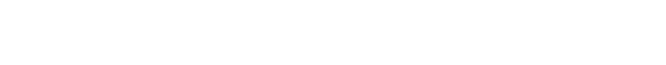

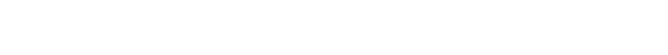

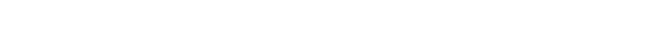

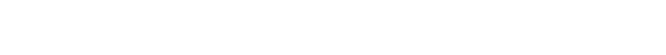

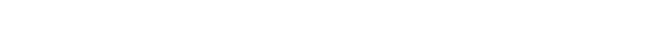

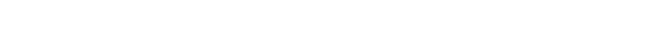

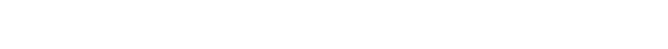

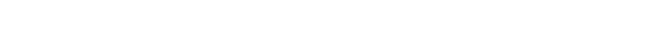

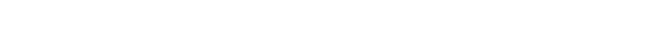

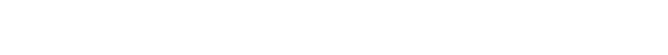

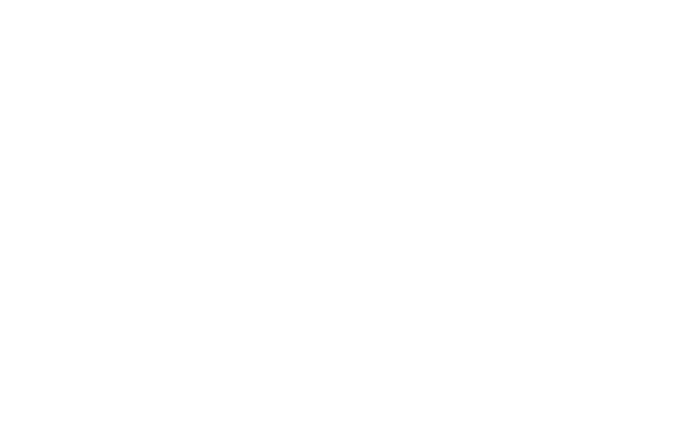

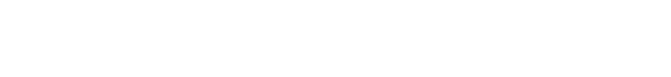

|

8 $\quad$ :

₹ి80

\%응 \&

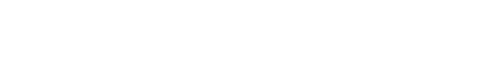

紫居 居

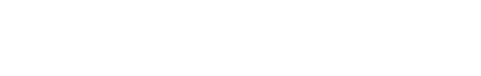

엉역 \&

뭉유

象总

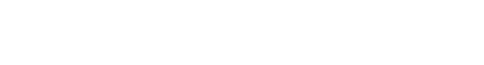
点兽

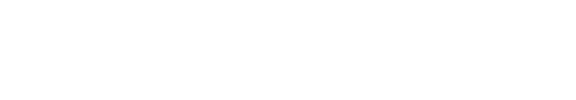

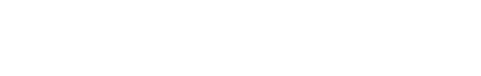

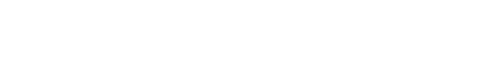

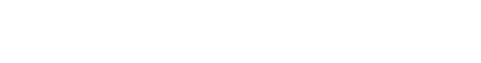

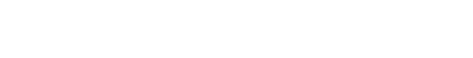

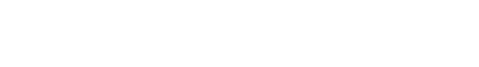

悤学嵒

带名㽞

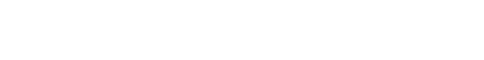

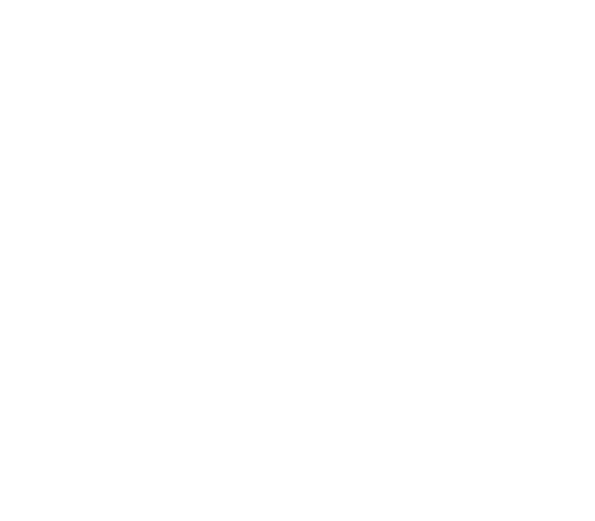


WATER RESOURCES OF UPPER COLORADO RIVER BASIN

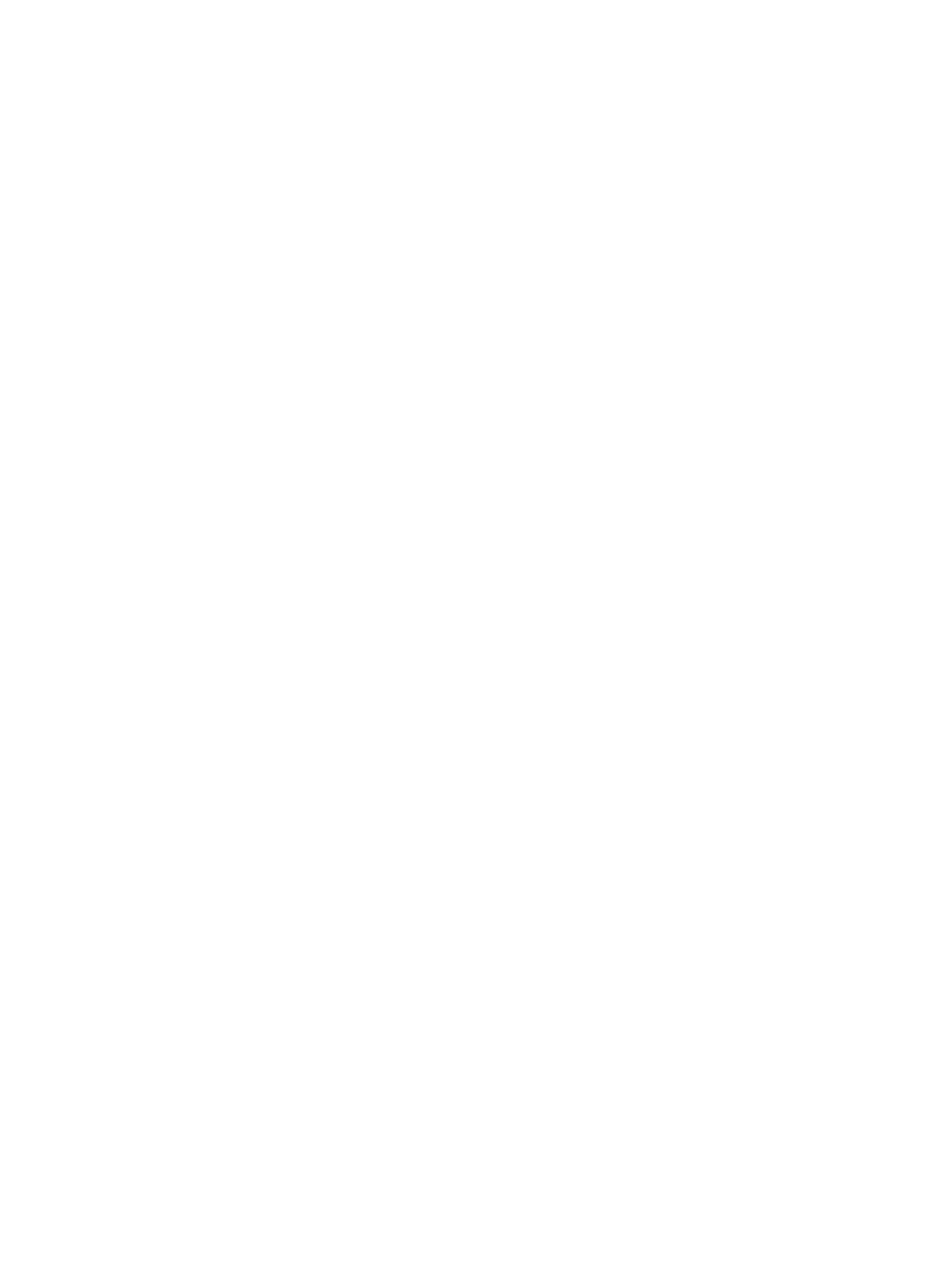




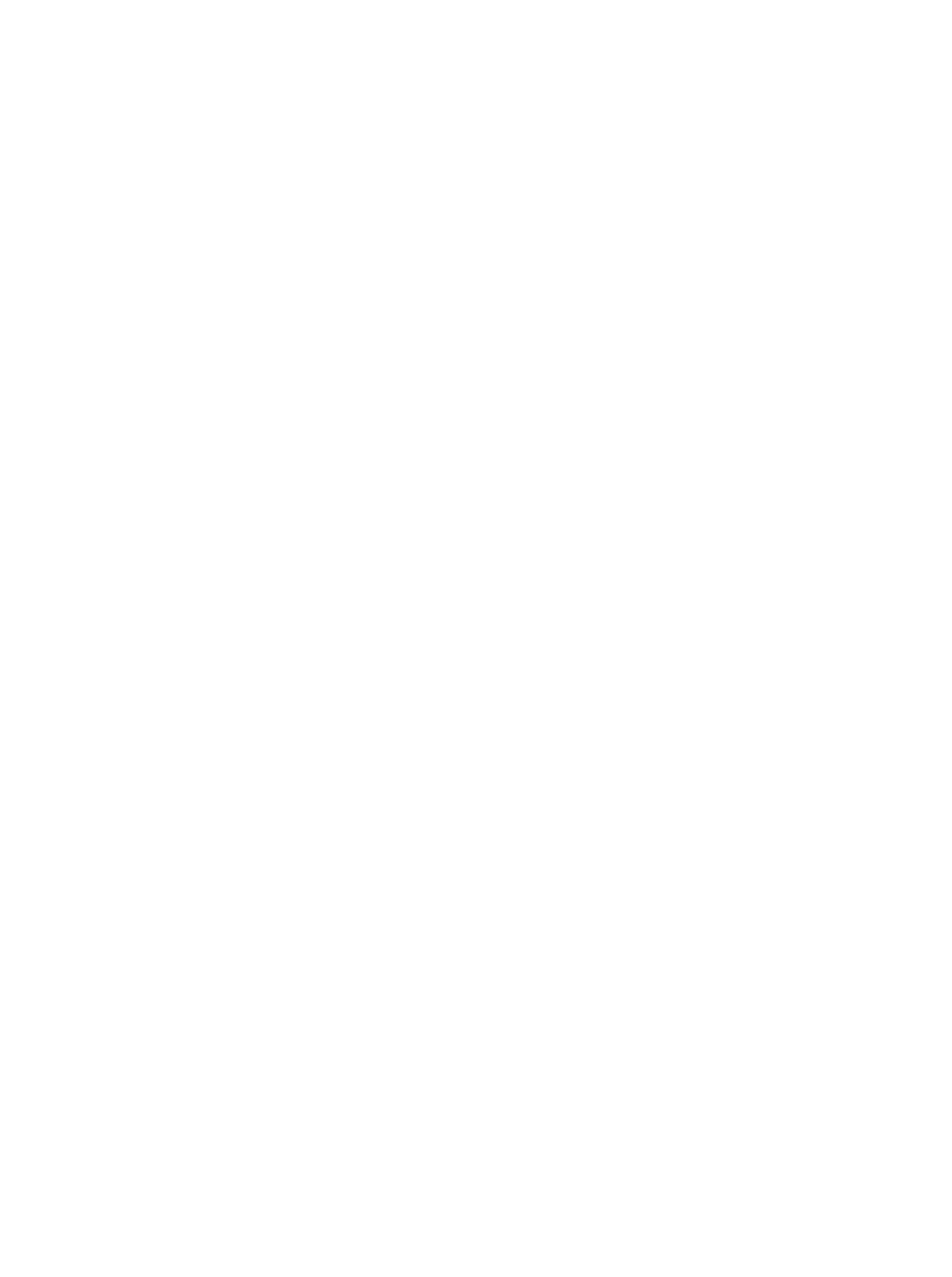




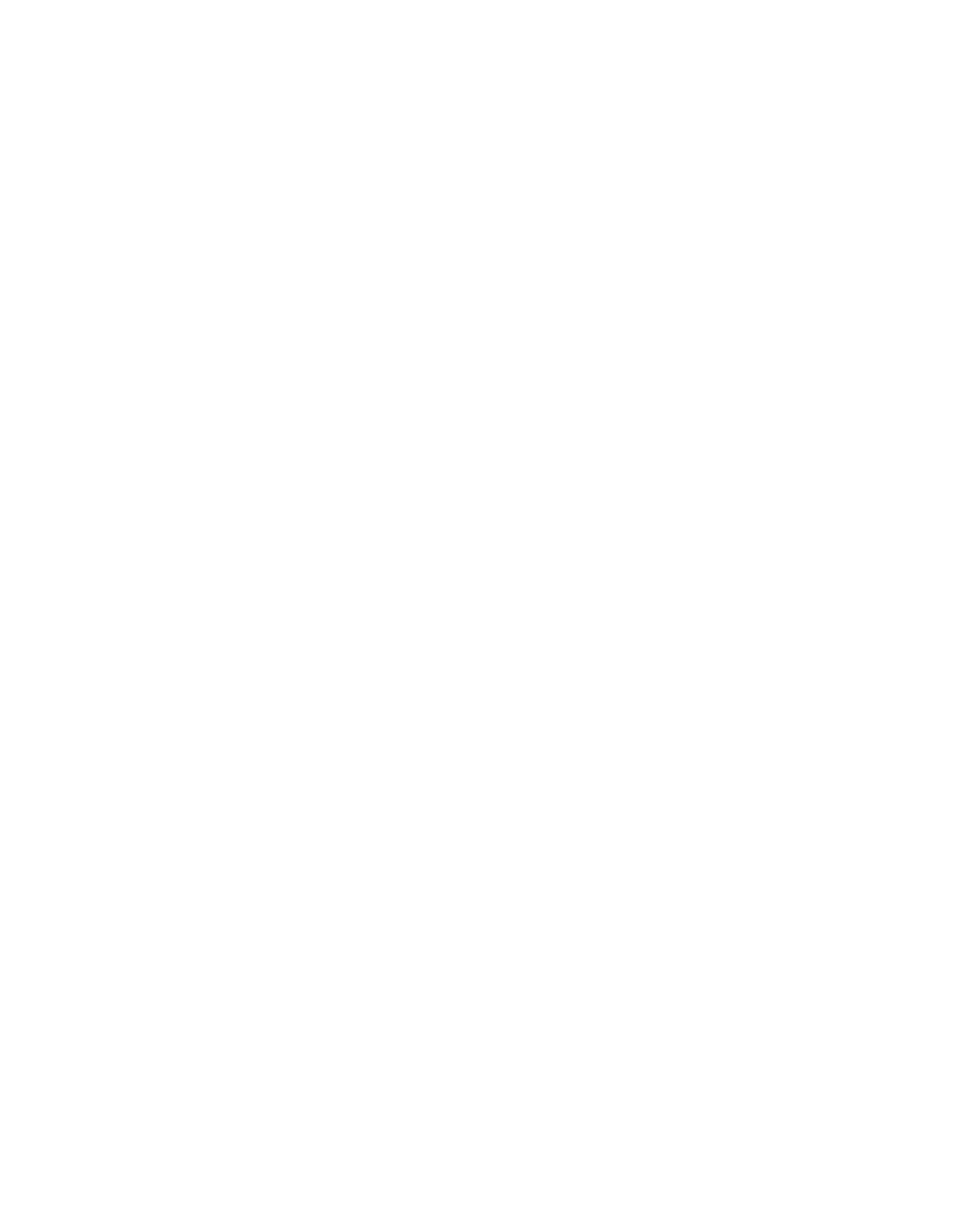


$\mathrm{T}_{\mathrm{ABLE}}$ 12.- Variability of annual weighted-average concentration of dissolved solids as related to the variability of annual water discharge for daily stations in the subbasins in the Green division

\begin{tabular}{|c|c|c|c|c|}
\hline \multirow[b]{2}{*}{$\begin{array}{c}\text { Station } \\
\text { No. }\end{array}$} & \multirow[b]{2}{*}{ Station name } & \multirow[b]{2}{*}{ Water years } & \multicolumn{2}{|c|}{ Coefficients of variation } \\
\hline & & & $\begin{array}{c}\text { Water } \\
\text { discharge }\end{array}$ & $\begin{array}{l}\text { Weighted- } \\
\text { average con- } \\
\text { centration }\end{array}$ \\
\hline \multicolumn{5}{|c|}{ Green River basin above the Yampa River } \\
\hline $\begin{array}{l}2165 \\
2245 B \\
2295\end{array}$ & $\begin{array}{l}\text { Green River at Green River, Wyo. } \\
\text { Blacks Fork near Marston, Wyo } \\
\text { Henrys Fork at Linwood, Utah. }\end{array}$ & $\begin{array}{r}1952-57 \\
1952-57 \\
1952-57\end{array}$ & $\begin{array}{r}0.24 \\
.67 \\
.69\end{array}$ & $\begin{array}{r}0.07 \\
.17 \\
.38\end{array}$ \\
\hline
\end{tabular}

Yampa River basin

\begin{tabular}{l|c|r|r|r}
\hline 2510A & $\begin{array}{c}\text { Yampa River at bridge on county road, near } \\
\text { Maybell, Colo }\end{array}$ & $1951-57$ & 0.40 & 0.07 \\
2600 & $\begin{array}{c}\text { Little Snake River at bridge on State Highway } \\
318, \text { near Lily, Colo }\end{array}$ & $1951-57$ & .51 & .10 \\
\hline
\end{tabular}

Green River basin between the Yampa and White Rivers including the White River basin

\begin{tabular}{|c|c|c|c|c|}
\hline 3020 & White River near Watson, Utah........... & $1951-57$ & 0.35 & 0.11 \\
\hline \multicolumn{5}{|c|}{ Green River basin below the White River } \\
\hline $\begin{array}{l}3145 \\
3150 \\
3285\end{array}$ & $\begin{array}{l}\text { Price River at Woodside, Utah } \\
\text { Green River at Green River, Utah. } \\
\text { San Rafael River near Green River, Utah. }\end{array}$ & $\begin{array}{l}1952-57 \\
1929-57 \\
1948-57\end{array}$ & $\begin{array}{r}0.98 \\
.30 \\
.86\end{array}$ & $\begin{array}{r}0.31 \\
.11 \\
.30\end{array}$ \\
\hline
\end{tabular}

1 Includes equivalent data for water years 1952 and 1953 for Blacks Fork near Green River, Wyo. 
TABLE 13.-Relation between water discharge and chemical quality of water at selected stations in the Green division

[Data are for the water years 1914-57 adjusted to 1957 conditions. Chemical quality data and weighted averages are in parts per million and equivalents per million (italicized),

\begin{tabular}{|c|c|c|c|c|c|c|c|c|c|c|c|c|c|c|c|c|}
\hline \multirow{2}{*}{$\underset{\text { (cfs) }}{\text { Mean }}$} & \multirow{2}{*}{$\underset{\text { (Calcium }}{\text { Calum }}$} & \multirow{2}{*}{$\begin{array}{c}\text { Mag- } \\
\text { nesium } \\
\text { (Mg) }\end{array}$} & \multirow{2}{*}{$\begin{array}{l}\text { Sodium } \\
\text { (Na) }\end{array}$} & \multirow{2}{*}{$\begin{array}{l}\text { Potas- } \\
\text { sium } \\
(\mathrm{K})\end{array}$} & \multirow{2}{*}{$\begin{array}{l}\text { Bicar- } \\
\text { bonate } \\
\left(\mathrm{HCO}_{3}\right)\end{array}$} & \multirow{2}{*}{$\begin{array}{l}\text { Sulfate } \\
\left(\mathrm{SO}_{4}\right)\end{array}$} & \multirow{2}{*}{$\begin{array}{l}\text { Chloride } \\
\text { (Cl) }\end{array}$} & \multirow{2}{*}{$\begin{array}{c}\text { Boron } \\
\text { (B) }\end{array}$} & \multicolumn{3}{|c|}{$\begin{array}{l}\text { Dissolved solids } \\
\text { (residue at } 180^{\circ} \mathrm{C} \text { ) }\end{array}$} & \multicolumn{2}{|c|}{$\begin{array}{c}\text { Hardness } \\
\text { as } \mathrm{CaCO}_{3}\end{array}$} & \multirow{2}{*}{$\begin{array}{l}\text { Per- } \\
\text { cent } \\
\text { so- } \\
\text { dium }\end{array}$} & \multirow{2}{*}{$\begin{array}{l}\text { Specific } \\
\text { conduct- } \\
\text { ance } \\
\text { (micro- } \\
\text { mhos at } \\
25^{\circ} \mathrm{C} \text { ) }\end{array}$} & \multirow{2}{*}{$\begin{array}{c}\text { Sodium } \\
\text { adsorp- } \\
\text { tion- } \\
\text { ratio }\end{array}$} \\
\hline & & & & & & & & & $\begin{array}{c}\text { Parts } \\
\text { per } \\
\text { million }\end{array}$ & $\begin{array}{l}\text { Tons } \\
\text { per } \\
\text { acre-ft }\end{array}$ & $\begin{array}{l}\text { Tons } \\
\text { per } \\
\text { day }\end{array}$ & $\begin{array}{c}\text { Caleium, } \\
\text { mag- } \\
\text { nesium }\end{array}$ & $\begin{array}{c}\text { Non- } \\
\text { carbon- } \\
\text { ate }\end{array}$ & & & \\
\hline
\end{tabular}

GREEN RIVER BASIN ABOVE THE YAMPA RIVER

Green River at Green River, Wyo.

\begin{tabular}{|c|c|c|c|c|c|c|c|c|c|c|c|c|c|c|c|c|}
\hline 21,800 . & 34 & 7.4 & 13 & 1.2 & 148 & 21 & 1.6 & 0.05 & 190 & 0.26 & 11,180 & 116 & 0 & 20 & 308 & 0.5 \\
\hline 20,700 . & 34 & 7.5 & $13^{.07}$ & 1.2 & 148 & $21^{.44}$ & 1.6 & .05 & 190 & .26 & 10,620 & 116 & 0 & 20 & 308 & .5 \\
\hline 19,000 . & 34.70 & $\begin{array}{l}7.62 \\
.62\end{array}$ & $13^{.07}$ & 1.2 & 148 & $23^{.44}$ & 1.7 & .05 & 190 & .26 & 9,750 & 116 & 0 & 20 & 308 &. $\overrightarrow{5}$ \\
\hline 14,500 . & 34 & 8.2 & $13^{* 07}$ & 1.2 & 148 & $27^{.40}$ & 1.90 & .05 & 190 & .26 & 7,440 & 118 & 0 & 19 & 308 & .5 \\
\hline 10,100 & 35 & 9.4 & $14^{\circ}$ & 1.3 & 148 & 37 & 2.2 & .05 & 191 & .26 & 5,210 & 126 & 4 & $19^{-}$ & 309 & .5 \\
\hline 7,500 & $\begin{array}{l}36 \\
1.80\end{array}$ & $10^{.17}$ & $15^{.01}$ & $\begin{array}{c}.00 \\
1.04\end{array}$ & $\begin{array}{r}149 \\
2.44\end{array}$ & $41_{.85}^{\circ}$ & $\begin{array}{c}.06 \\
2.6\end{array}$ & $.06^{-}$ & 197 & .27 & 3,990 & 131 & 9 & 20 & 320 & .6 \\
\hline 5,550 & 38 & $11_{90}^{.00}$ & $16^{\circ 00}$ & $\begin{array}{l}1.4 \\
04\end{array}$ & 15044 & $50^{\circ}$ & 3. 0 & .06 & 202 & .27 & 3,030 & $140^{\circ}$ & 17 & 20 & 325 & .6 \\
\hline $3,900^{1}$ & 41 & 13 & $19^{\circ}$ & 1.5 & 151 & $63^{1.04}$ & 3. 6 & .07 & 219 & .30 & 2,310 & 156 & 32 & 21 & 350 & .7 \\
\hline 2.550 & 44 & 15 & $25^{.00}$ & 1.6 & 162 & $86^{1.01}$ & 4. 5 & .07 & 255 & 35 & 1,760 & 172 & 38 & 24 & 410 & .8 \\
\hline 1,640 & 49 & 17 & 33 & 1.7 & 167 & 117 & 5. 9 & .08 & 313 & .43 & 1,390 & 192 & $\mathbf{5 6}$ & 27 & 500 & 1.0 \\
\hline 1,130 & 54 & 20 & $41_{178}^{1.44}$ & 1.84 & 171 & 148 & 7.2 & .09 & 378 & .51 & 1,150 & 216 & 76 & 29 & 590 & 1.2 \\
\hline $845^{2}$ - & 59 & 23.89 & 48 & $\begin{array}{l}1.9 \\
05\end{array}$ & $\begin{array}{c}182 \\
2,98\end{array}$ & 179 & 8. 0 & .10 & 435 & .59 & 992 & 242 & 92 & 30 & 655 & 1.3 \\
\hline 675 & 64 & 25 & 54 & 2.0 & 192 & 203 & 8. 6 & 11 & 485 & .66 & 884 & 262 & 105 & 31 & 720 & $1 . \overline{5}$ \\
\hline 550 . & 69 & 27 & 59 & 2.1 & 200 & 226 & 9.0 & .12 & 535 & .73 & 794 & 283 & 119 & 31 & 790 & $\overline{1.5}$ \\
\hline 465. & 72 & 29 & 63 & 2. 1 & 209 & 243 & $\begin{array}{l}9.4 \\
27\end{array}$ & .13 & 570 & .78 & 716 & 298 & 127 & 31 & 830 & 1.6 \\
\hline $380^{3}$ & 76 & 31 & 68 & 2.2 & 218 & 261 & 9.6 & .13 & 608 & .83 & 624 & 317 & 138 & 32 & 880 & 1.7 \\
\hline 310. & 79 & 33 & 71 & 2.3 & 227 & 278 & 9.8 & .14 & 635 & .86 & 531 & 332 & 146 & 32 & 900 & 1. 7 \\
\hline 250 & 80 & 34 & 74 & 2.4 & 235 & 289 & 9.8 & .14 & 655 & .89 & 442 & 339 & 146 & 32 & 920 & $1 . \overline{7}$ \\
\hline $210_{\ldots}$ & $\begin{array}{r}82 \\
4.09\end{array}$ & $\begin{array}{c}34 \\
2.79\end{array}$ & $\begin{array}{c}76 \\
\text { 3. } 31\end{array}$ & $\begin{array}{c}2.40 \\
.06\end{array}$ & $\begin{array}{r}241 \\
\quad 3.95\end{array}$ & $\begin{array}{r}293 \\
6.09\end{array}$ & $\begin{array}{c}9.8 \\
.28\end{array}$ & .14 & 660 & $.90^{-}$ & 374 & 344 & 146 & 32 & 935 & 1.8 \\
\hline $1,802 \ldots$ & $\stackrel{45}{2.25}$ & $\begin{array}{l}15 \\
1.28\end{array}$ & ${ }^{27} 1.17$ & $\begin{array}{l}1.6 \\
.04\end{array}$ & $\begin{array}{l}162 \\
2.66\end{array}$ & $\stackrel{93}{1.98}$ & $\begin{array}{l}4.6 \\
.18\end{array}$ & .07 & 284 & .39 & 1,380 & 174 & 41 & 25 & 443 & .9 \\
\hline
\end{tabular}

Blacks Fork near Marston, Wyo.

\begin{tabular}{|c|c|c|c|c|c|c|c|c|c|c|c|c|c|c|c|c|}
\hline 5,200 . & 64 & 11 & 24 & 2.9 & 220 & 52 & 18 & 0.12 & 370 & 0.50 & 5,190 & 204 & 24 & 20 & 580 & 0.7 \\
\hline 1,900 & & $11^{\circ}$ & 250 & 2.9 & 220 & 53 & $19^{.01}$ & .12 & 370 & .50 & 4,900 & 204 & 24 & 21 & 580 & .8 \\
\hline 4,550 & 64 & 11 & 25 & 2.07 & 220 & 54.10 & $19^{.5}$ & .12 & 370 & .50 & 4,550 & 204 & 24 & 21 & 580 & .8 \\
\hline 3,70 & 64 & $12^{.80}$ & $27^{1.09}$ & 2.97 & $220^{3}$ & $60^{1.12}$ & $20^{\circ}$ & .12 & 370 & .50 & 3,700 & 209 & 28 & 22 & 580 & .8 \\
\hline 650 & 65 & 13 & 29 & 3.0 & 220 & $70^{200}$ & $21^{.00}$ & .12 & 371 & .60 & 2,650 & 216 & 35 & 22 & 580 & .9 \\
\hline 1,920 & 65 & 14 & 33 & 3.1 & 220 & $81^{1.40}$ & $22^{\circ}$ & .12 & 376 & .51 & 1,950 & 220 & 39 & 24 & 590 & 1.0 \\
\hline 1.380 & 66 & 15 & 38.44 & 3.2 & 220 & 96 & $24^{\circ}$ & .12 & 388 & .53 & 1,450 & 226 & 46 & 26 & 619 & 1.1 \\
\hline 920 & 67 & 18 & $\begin{array}{c}46 \\
2.00\end{array}$ & $\begin{array}{l}3.30 \\
.08\end{array}$ & 220 & 118 & $27_{76}^{.00}$ & .13 & 415 & .56 & 1,030 & 241 & 60 & 29 & 650 & $1 . \overline{3}$ \\
\hline 490 & 70 & 22 & $\begin{array}{c}62 \\
2.70\end{array}$ & $\begin{array}{l}3.5 \\
.09\end{array}$ & 220 & 165 & $37_{1.04}$ & .14 & 500 & .68 & 662 & 265 & 84 & $\mathbf{3 3}$ & 780 & 1.7 \\
\hline 225 & 77.84 & $\begin{array}{c}29 \\
2.38\end{array}$ & 89 & $\begin{array}{l}3.8 \\
.10\end{array}$ & $\begin{array}{c}222.01 \\
3.64\end{array}$ & $\begin{array}{r}250.40 \\
5.20\end{array}$ & $\begin{array}{c}54.04 \\
1.52\end{array}$ & .17 & 650 & .88 & 395 & 311 & 129 & 38 & 990 & 2.2 \\
\hline 129 & 90 & $\begin{array}{l}35 \\
2.88\end{array}$ & $\begin{array}{r}114.96 \\
4.96\end{array}$ & 4. 0 & $\begin{array}{r}224 \\
3.67\end{array}$ & $\begin{array}{l}345 \\
7,18\end{array}$ & $6 \mathbf{1}_{1,72}$ & .20 & 820 & 1.12 & 286 & 368 & 185 & 40 & 1,220 & 2.6 \\
\hline $89^{2}$ & $\begin{array}{r}102 \\
5.09\end{array}$ & 38 & $\begin{array}{r}134 \\
6.83\end{array}$ & $\begin{array}{l}4.2 \\
.11\end{array}$ & $\begin{array}{l}224 \\
3.67\end{array}$ & 420 & 68 & .22 & 960 & 1.31 & 231 & 410 & 227 & $41^{-}$ & 1,400 & $2 . \overline{9}$ \\
\hline 58. & $\begin{array}{c}120 \\
5.99\end{array}$ & $\begin{array}{l}46 \\
3.78\end{array}$ & 161.00 & $\begin{array}{l}4.3 \\
.11\end{array}$ & $\begin{array}{r}225 \\
3.69\end{array}$ & $\begin{array}{c}530 \\
11.02\end{array}$ & $\begin{array}{l}74.82 \\
2.09\end{array}$ & .24 & 1,140 & 1.55 & 179 & 488 & 304 & $41^{-}$ & 1,630 & 3.2 \\
\hline $34 \ldots$ & $\begin{array}{c}146 \\
7.29\end{array}$ & $\begin{array}{c}54 \\
4.44\end{array}$ & $\begin{array}{r}198 \\
8.61\end{array}$ & $\begin{array}{l}4.6 \\
12\end{array}$ & $\begin{array}{r}225 \\
3.69\end{array}$ & 700 & 82 & .27 & $1, \mathbf{3 8 0}$ & 1.88 & 127 & 586 & 402 & 42 & 1,920 & 3.6 \\
\hline 16. & $\begin{array}{c}170 \\
8.48\end{array}$ & $\begin{array}{r}60 \\
4.99\end{array}$ & $\begin{array}{l}253 \\
11.01\end{array}$ & $\begin{array}{l}4.9 \\
.19\end{array}$ & $\begin{array}{l}225 \\
3.69\end{array}$ & $\begin{array}{l}880 \\
18.90\end{array}$ & $\begin{array}{l}94 \\
2.65\end{array}$ & .29 & 1,670 & 2.27 & 72 & 670 & 486 & 45 & 2,250 & $4 . \overline{3}$ \\
\hline $1.0^{3}$ & 200 & $\begin{array}{l}70 \\
5.75\end{array}$ & $\begin{array}{l}300 \\
18.05\end{array}$ & 6.5 & 230 & 1,010 & $160^{\circ}$ & .31 & 2,220 & 3.02 & 6. & 786 & 598 & 45 & 2,900 & 4.7 \\
\hline & 0.80 & & 10.00 & & 3.77 & 21.01 & & & & $\ldots$ & & & ....- & $\ldots$ & & 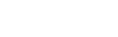 \\
\hline & $\cdots$ & - & $|-\cdots-|$ & & |----- & $\ldots$ & & & & & & & .... & $\cdots$ & 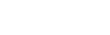 & \\
\hline 345 & $\begin{array}{l}71 \\
3.54\end{array}$ & $\begin{array}{l}19 \\
1.56\end{array}$ & $\begin{array}{l}53 \\
2.31\end{array}$ & $\begin{array}{l}3.3 \\
.08\end{array}$ & 221 & $\begin{array}{r}144 \\
3.00\end{array}$ & ${ }^{31} .87$ & .14 & 481 & .65 & 448 & 255 & 74 & 31 & 738 & 1.4 \\
\hline
\end{tabular}

See footnotes at end of table. 
TABLE 13.-Relation between water discharge and chemical quality of water at selected stations in the Green division-Continued [Data are for the water years 1914-57 adjusted to 1957 conditions. Chemical quality data and weighted averages are in parts per million and equivalents per million (italicized),

\begin{tabular}{|c|c|c|c|c|c|c|c|c|c|c|c|c|c|c|c|c|}
\hline \multirow{2}{*}{$\begin{array}{c}\text { Mean } \\
\text { discharge } \\
\text { (cfs) }\end{array}$} & \multirow{2}{*}{$\underset{(\mathrm{Ca})}{\text { Calcium }}$} & \multirow{2}{*}{$\begin{array}{c}\text { Mag- } \\
\text { nesium } \\
\text { (Mg) }\end{array}$} & \multirow{2}{*}{$\underset{(\mathrm{Na})}{\text { Sodium }}$} & \multirow{2}{*}{$\begin{array}{l}\text { Potas- } \\
\text { sium) } \\
\text { (K) }\end{array}$} & \multirow{2}{*}{$\begin{array}{c}\text { Bicar- } \\
\text { bonate } \\
\left(\mathrm{HCO}_{3}\right)\end{array}$} & \multirow{2}{*}{$\begin{array}{l}\text { Sulfate } \\
\left(\mathrm{SO}_{4}\right)\end{array}$} & \multirow{2}{*}{$\begin{array}{c}\text { Chloride } \\
\text { (Cl) }\end{array}$} & \multirow{2}{*}{$\begin{array}{l}\text { Boron } \\
\text { (B) }\end{array}$} & \multicolumn{3}{|c|}{$\begin{array}{c}\text { Dissolved solids } \\
\text { (residue at } 180^{\circ} \mathrm{C} \text { ) }\end{array}$} & \multicolumn{2}{|c|}{$\begin{array}{l}\text { Hardness } \\
\text { as } \mathrm{CaCO} 3\end{array}$} & \multirow{2}{*}{$\begin{array}{l}\text { Per- } \\
\text { cent } \\
\text { so- } \\
\text { dium }\end{array}$} & \multirow{2}{*}{\begin{tabular}{|} 
Specific \\
conduct- \\
ance \\
(micro- \\
mhos at \\
$25^{\circ} \mathrm{C}$ )
\end{tabular}} & \multirow{2}{*}{$\begin{array}{c}\text { Sodium- } \\
\text { adsorp- } \\
\text { tion- } \\
\text { ratio }\end{array}$} \\
\hline & & & & & & & & & $\begin{array}{c}\text { Parts } \\
\text { per } \\
\text { million }\end{array}$ & $\begin{array}{c}\text { Tons } \\
\text { per } \\
\text { acre-ft }\end{array}$ & $\begin{array}{c}\text { Tons } \\
\text { per } \\
\text { day }\end{array}$ & $\begin{array}{c}\text { Calcium, } \\
\text { mag- } \\
\text { nesium }\end{array}$ & $\begin{array}{c}\text { Non- } \\
\text { carbon- } \\
\text { ate }\end{array}$ & & & \\
\hline
\end{tabular}

GREEN RIVER BASIN ABOVE THE YAMPA RIVER-Continued

Blacks Fork near Green River, Wyo.

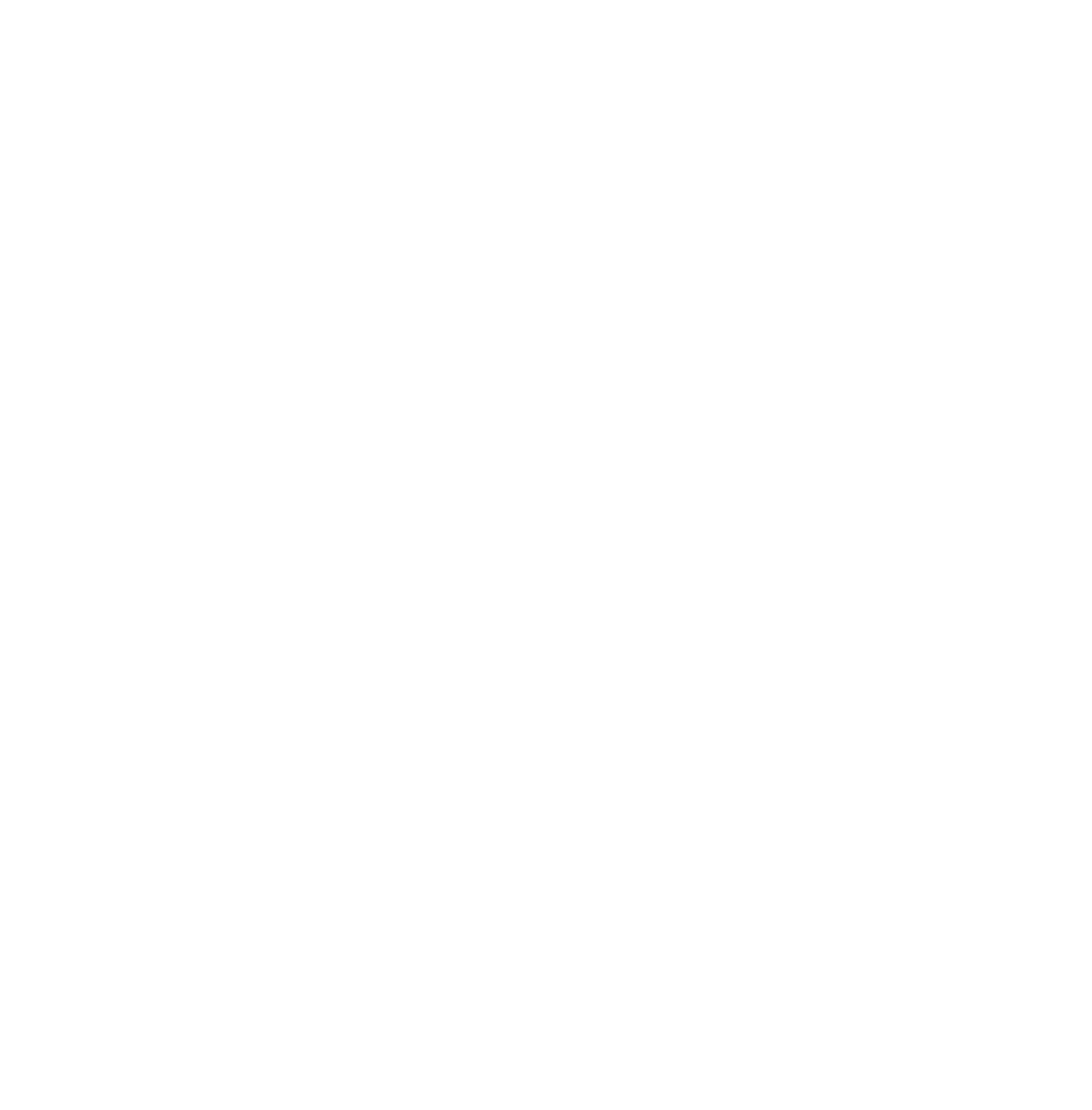

See footnotes at end of table. 
TABLE 13.-Relation between water discharge and chemical quality of water at selected stations in the Green division-Continued [Data are for the water years 1914-57 adjusted to 1957 conditions. Chemical quality data and weighted averages are in parts per million and equivalents per million (italicized), except as indicated )

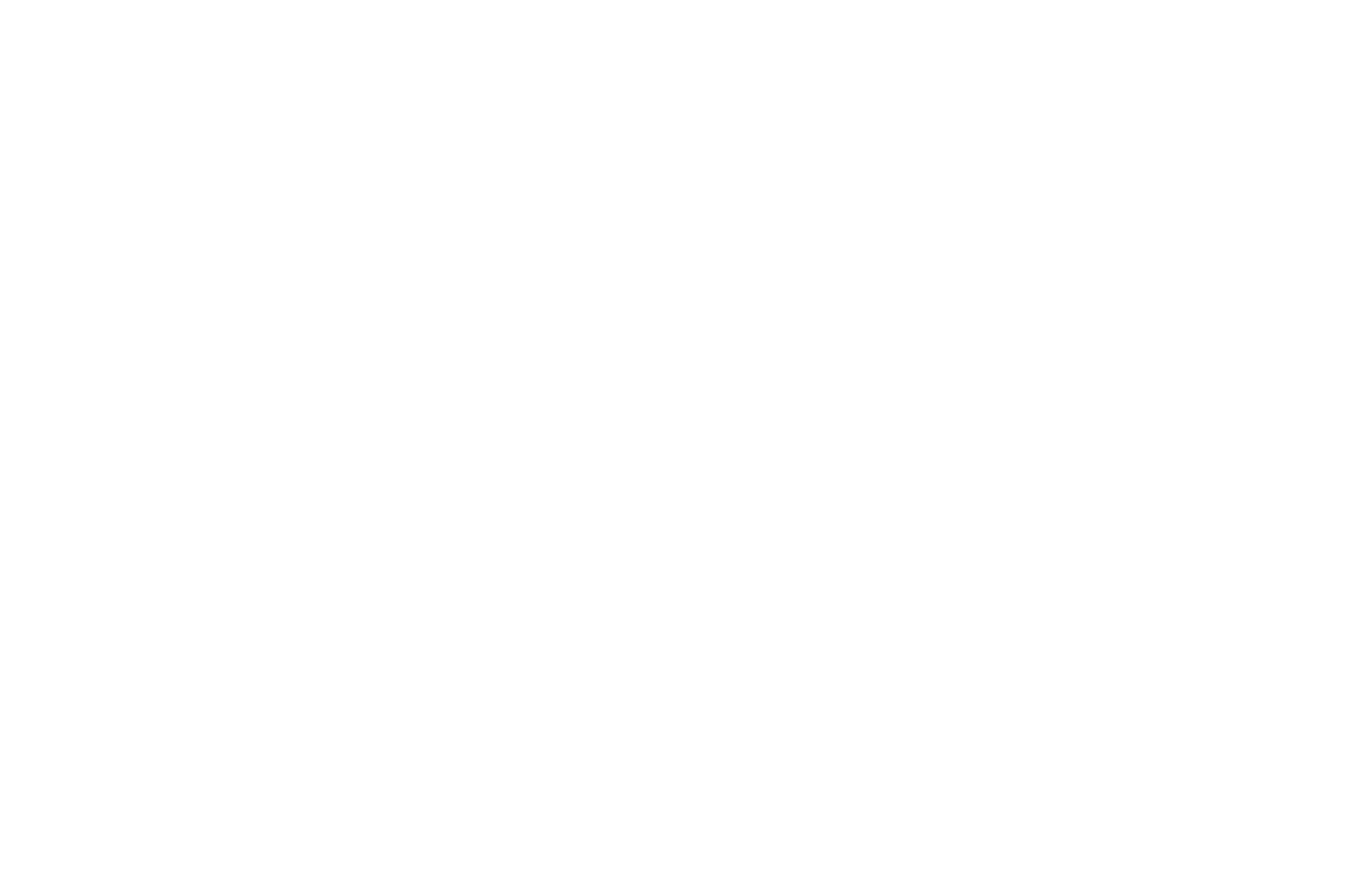

Yampa River at bridge on county road, near Maybell, Colo.

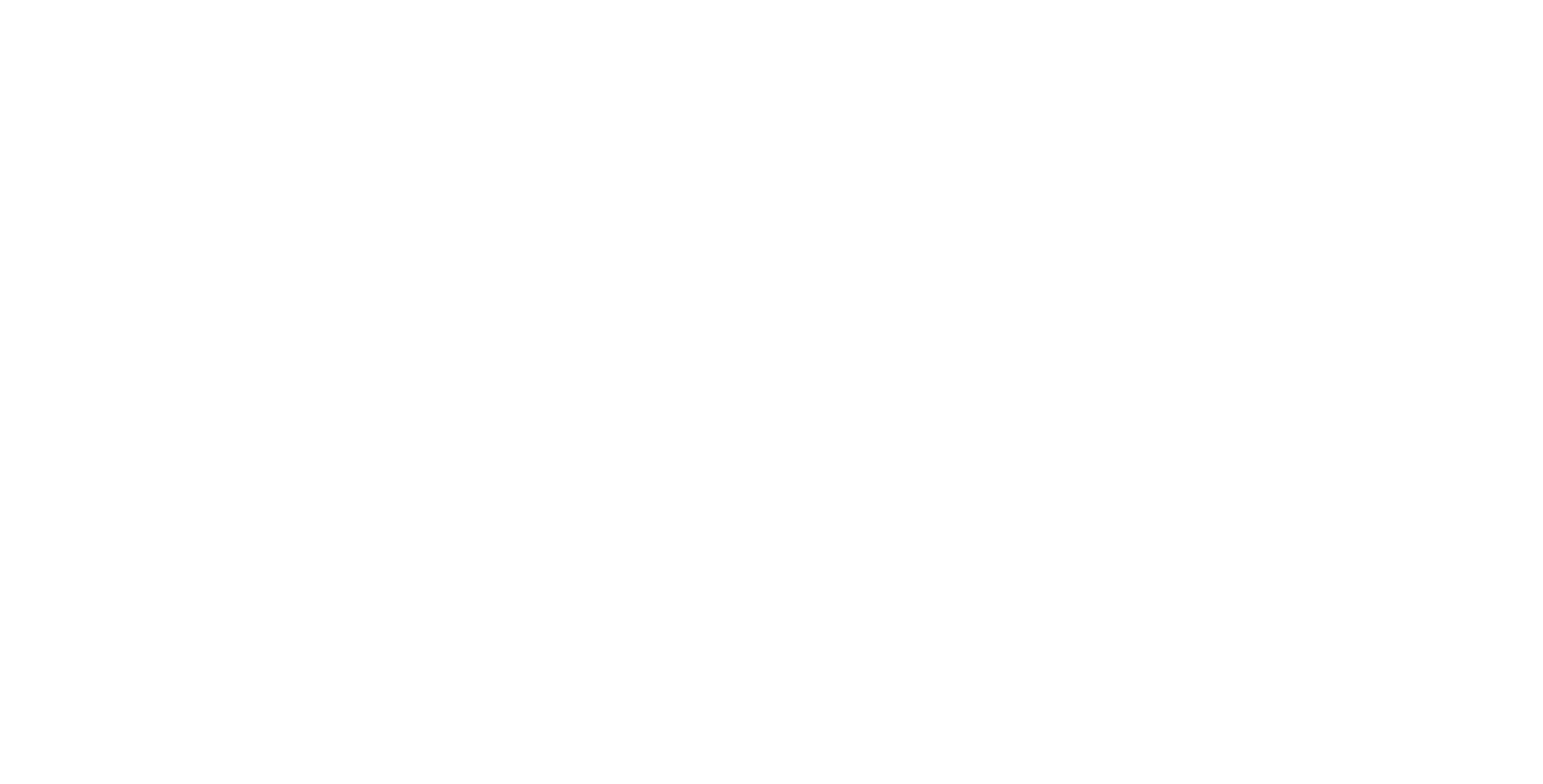

See footnotes at end of table. 
TABLE 13.-Relation between water discharge and chemical quality of water at selected stations in the Green division-Continued [Data are for the water years 1914-57 adjusted to 1957 conditions. Chemical quality data and weighted averages are in parts per million and equivalents per million (italicized), except as indicated

\begin{tabular}{|c|c|c|c|c|c|c|c|c|c|c|c|c|c|c|c|c|}
\hline \multirow{2}{*}{$\begin{array}{l}\text { Mean } \\
\text { discharge } \\
\text { (cfs) }\end{array}$} & \multirow{2}{*}{$\underset{(\mathrm{Ca})}{\text { Calcium }}$} & \multirow{2}{*}{$\begin{array}{c}\text { Mag- } \\
\text { nesium } \\
(\mathrm{Mg})\end{array}$} & \multirow[b]{2}{*}{$\begin{array}{l}\text { Sodium } \\
(\mathrm{Na})\end{array}$} & \multirow{2}{*}{$\begin{array}{l}\text { Potas- } \\
\text { sium } \\
(\mathbf{K})\end{array}$} & \multirow{2}{*}{$\begin{array}{c}\text { Bicar- } \\
\text { bonate } \\
\left(\mathrm{HCO}_{3}\right)\end{array}$} & \multirow[b]{2}{*}{$\begin{array}{c}\text { Sulfate } \\
\left(\mathrm{SO}_{4}\right)\end{array}$} & \multirow[b]{2}{*}{$\begin{array}{c}\text { Chloride } \\
\text { (Cl) }\end{array}$} & \multirow[b]{2}{*}{$\begin{array}{c}\text { Boron } \\
\text { (B) }\end{array}$} & \multicolumn{3}{|c|}{$\begin{array}{l}\text { Dissolved solids } \\
\text { (Residue at } 180^{\circ} \mathrm{C} \text { ) }\end{array}$} & \multicolumn{2}{|c|}{$\begin{array}{l}\text { Hardness } \\
\text { as } \mathrm{CaCO}_{3}\end{array}$} & \multirow{2}{*}{$\begin{array}{l}\text { Per- } \\
\text { cent } \\
\text { so- } \\
\text { dium }\end{array}$} & \multirow{2}{*}{$\begin{array}{l}\text { Specific } \\
\text { conduct- } \\
\text { ance } \\
\text { (micro- } \\
\text { mhos at } \\
25^{\circ} \mathrm{C} \text { ) }\end{array}$} & \multirow{2}{*}{$\begin{array}{c}\text { Sodium- } \\
\text { adsorp- } \\
\text { tion- } \\
\text { ratio }\end{array}$} \\
\hline & & & & & & & & & $\begin{array}{c}\text { Parts } \\
\text { per } \\
\text { mil- } \\
\text { lion }\end{array}$ & $\begin{array}{l}\text { Tons } \\
\text { per } \\
\text { acre- } \\
\text { ft }\end{array}$ & $\begin{array}{c}\text { Tons } \\
\text { per day }\end{array}$ & $\begin{array}{c}\text { Cal- } \\
\text { cium, } \\
\text { mag- } \\
\text { nesium }\end{array}$ & $\begin{array}{l}\text { Non- } \\
\text { car- } \\
\text { bon- } \\
\text { ate }\end{array}$ & & & \\
\hline
\end{tabular}

\section{YAMPA RIVER BASIN-Continued}

Little Snake River at bridge on State Highway 318, near Lily, Colo.

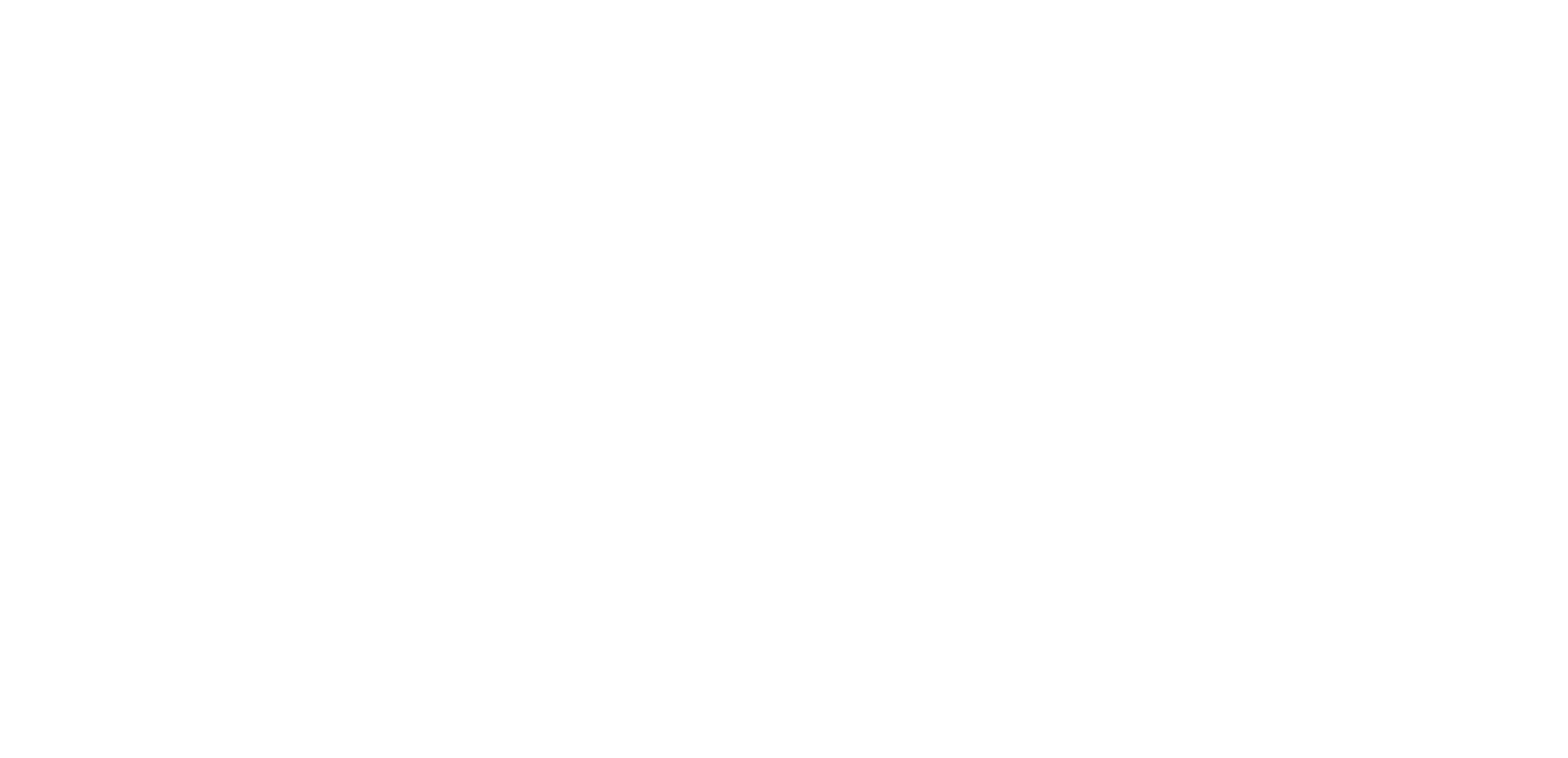

\section{GREEN RIVER BASIN BETWEEN THE YAMPA AND WHITE RIVER INCLUDING THE WHITE RIVER BASIN}

Green River at Jensen, Utah

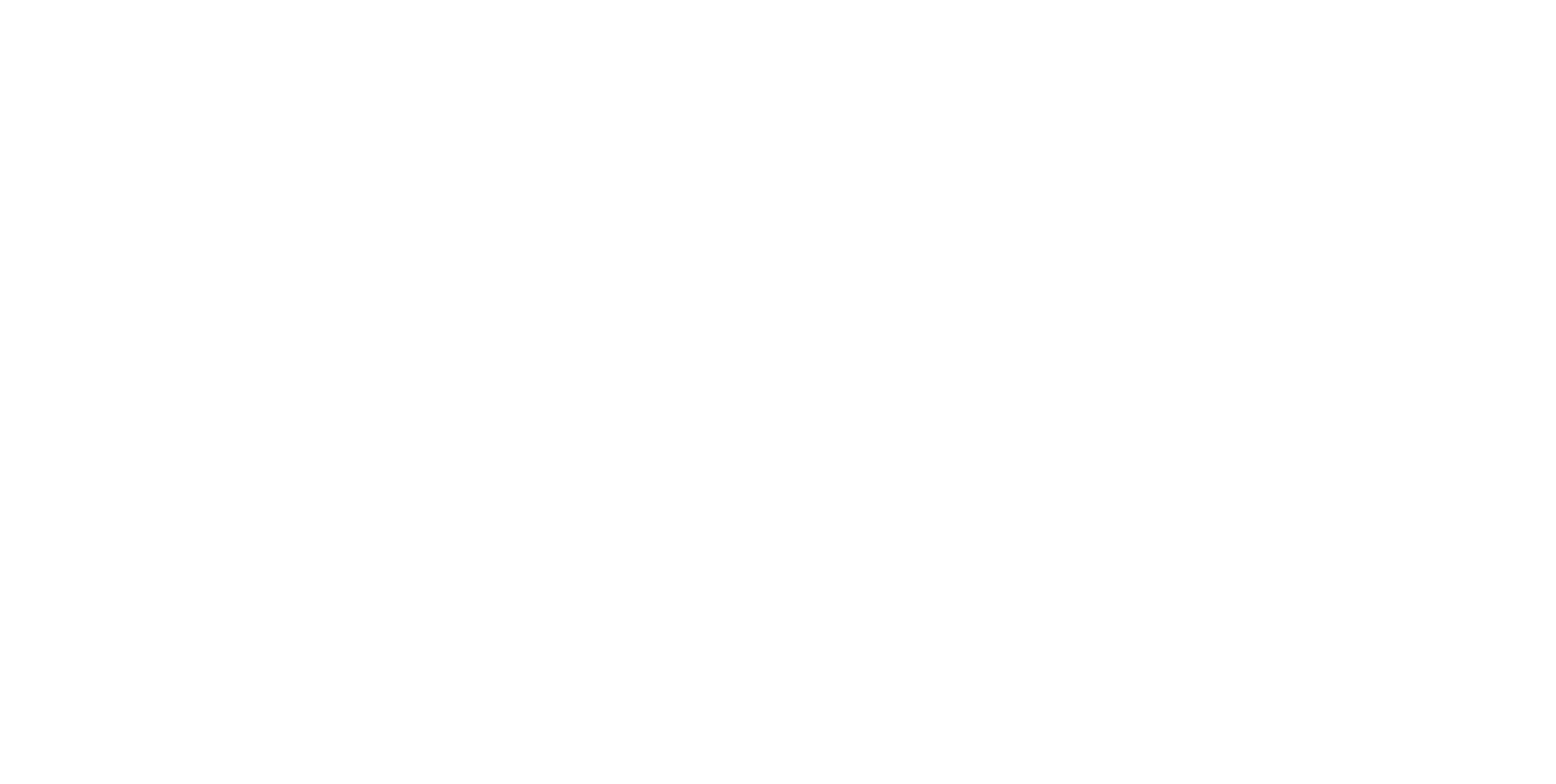

See footnotes at end of table. 
TABLE 13.-Relation between water discharge and chemical quality of water at selected stations in the Green division-Continued

[Data are for the water years 1914-57 adjusted to 1957 conditions. Chemical quality data and weighted averages are in parts per million and

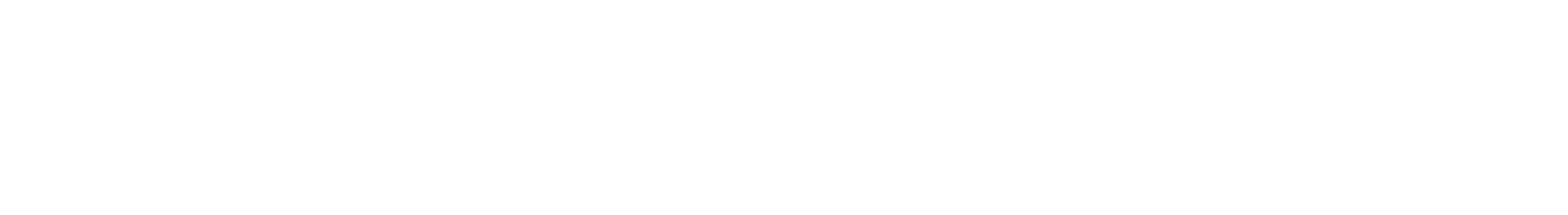

GREEN RIVER BASIN BETWEEN THE YAMPA AND WHITE RIVER INCLUDING THE WHITE RIVER BASIN-Continued

Duchesne River at Duchesne, Utah

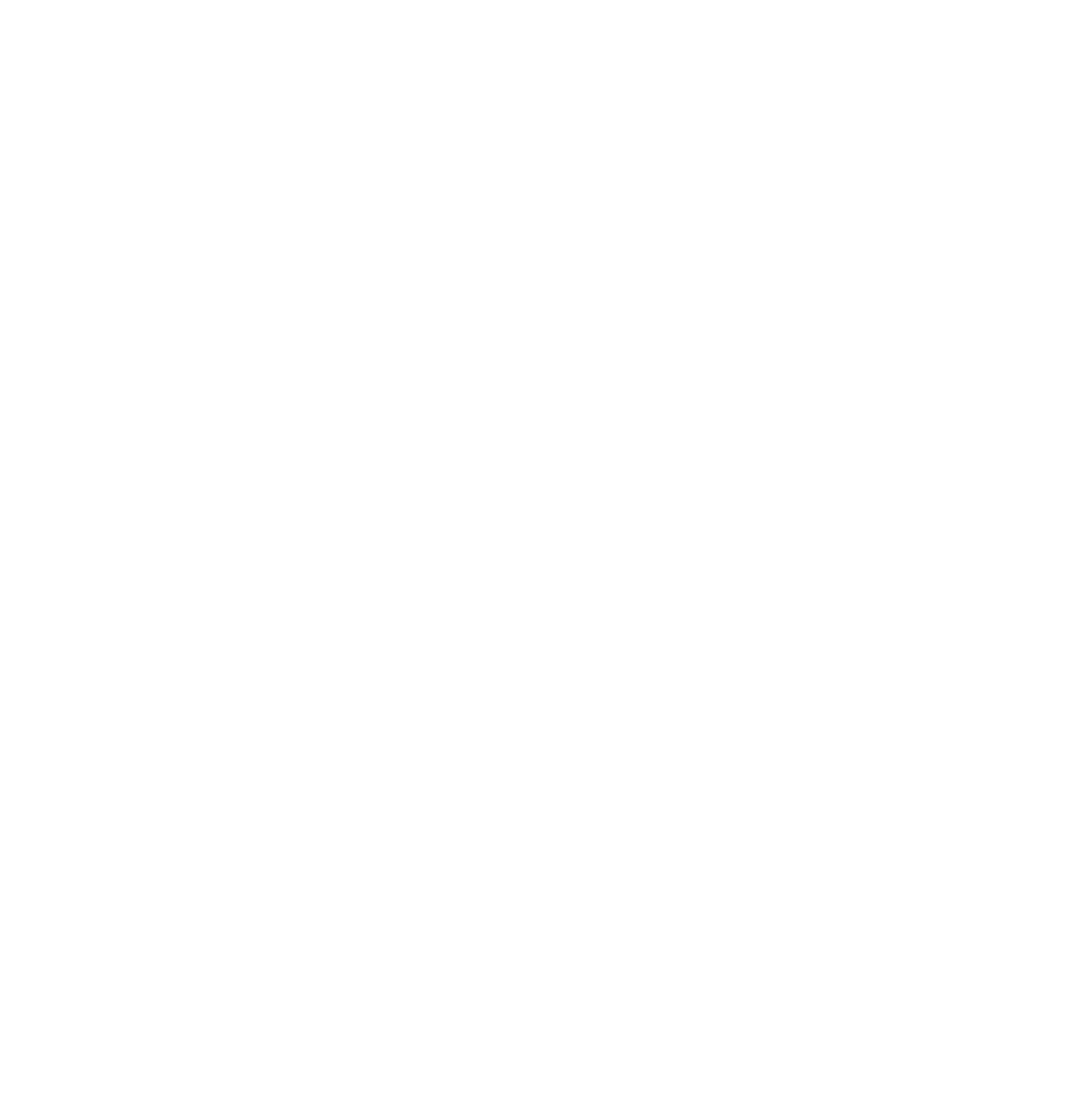

See footnotes at end of table. 
TABLE 13.-Relation between water discharge and chemical quality of water at selected stations in the Green division-Continued [Data are for the water years 1914-57 adjusted to 1957 conditions. Chemical quality data and weighted averages are in parts per million and

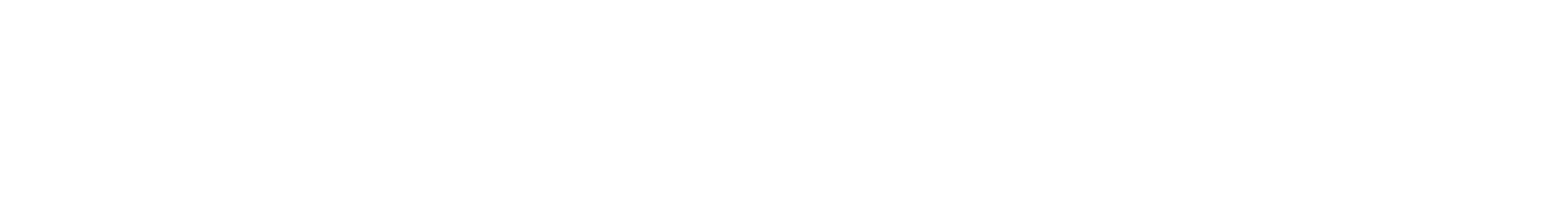

GREEN RIVER BASIN BETWEEN THE YAMPA AND WHITE RIVER INCLUDING THE WHITE RIVER BASIN-Continued Duchesne River at Myton, Utah

\begin{tabular}{|c|c|c|c|c|c|c|c|c|c|c|c|c|c|c|c|c|c|}
\hline 12,80 & & 11 & & 1.0 & 119 & 9 & 25 & 4.9 & 0.06 & 194 & 0.26 & 6,700 & 102 & 0 & 26 & 330 & 0.7 \\
\hline 8,300 & 23 & $11^{.50}$ & & $\begin{array}{l}.03 \\
1.0\end{array}$ & 119 & 8. 0 & $26^{.08}$ & 5. $0^{1 / 4}$ & .06 & 198 & .27 & 4,440 & 102 & 0 & 27 & 335 & .8 \\
\hline 6,900 & $\begin{array}{l}1.10 \\
1.20\end{array}$ & $11_{90}^{.90}$ & $18^{.7}$ & $\begin{array}{l}.08 \\
1.0 \\
.08\end{array}$ & $\begin{array}{c}1.95 \\
120\end{array}$ & 8. .27 & 28 & 5. 114 & .07 & 200 & .27 & 3,730 & 105 & 0 & 27 & 340 & .8 \\
\hline 4,800 & 25 & $12{ }^{\circ}$ & 20 & 1.1 & 124 & 8.2 & $32^{.00}$ & $\begin{array}{l}5.44 \\
15\end{array}$ & .08 & 203 & .28 & 2,630 & 112 & 0 & 28 & 345 & .8 \\
\hline 3,100 & 27 & $13^{.89}$ & & 1.2 & 129 & 8. 7 & $41_{85}^{.07}$ & $\begin{array}{c}.10 \\
6.2 \\
17\end{array}$ & $.10^{\circ}$ & 222 & 30 & 1,860 & 121 & 1 & 28 & 370 & .9 \\
\hline 2,100 & 31 & 14 & & $\begin{array}{l}.00 \\
1.3 \\
.09\end{array}$ & $\begin{array}{c}2.12 \\
139 \\
2.28\end{array}$ & $\begin{array}{l}.29 \\
9.2 \\
31\end{array}$ & $53^{.80}$ & $\begin{array}{l}7.5 \\
7.5\end{array}$ & .12 & 250 & .34 & 420 & 135 & 6 & 29 & 415 & 1.0 \\
\hline 1,420 & ${ }_{1.80}^{36}$ & 17.40 & 32 & $\begin{array}{l}1.5 \\
.04\end{array}$ & 154 & $\begin{array}{c}.01 \\
9.8 \\
.93\end{array}$ & 74 & $\begin{array}{l}.71 \\
9.4\end{array}$ & .17 & 290 & .39 & $1,110^{\circ}$ & 160 & 17 & 30 & 475 & 1.1 \\
\hline 960 & 44 & 22,81 & & $\begin{array}{l}1.8 \\
.05\end{array}$ & $\begin{array}{l}177 \\
2.90\end{array}$ & 11.87 & $\begin{array}{r}108 \\
2.25\end{array}$ & $13^{37}$ & .28 & 345 & .47 & 838 & 200 & 37 & 30 & 560 & 1.3 \\
\hline 54 & 54 & 29 & 60 & $\begin{array}{l}2.10 \\
.05\end{array}$ & 205 & $12^{\circ 01}$ & 160 & $20{ }^{0.07}$ & .39 & $410^{\circ}$ & .56 & 598 & 254 & 66 & 34 & 650 & 1.6 \\
\hline 410. & 60 & ${ }^{3}$ & 71 & 2.3 & 222 & $12^{.40}$ & 197 & & 48 & 455 & .62 & 504 & 285 & 83 & $\mathbf{3 5}$ & 710 & 1.8 \\
\hline 355. & 64 & $\begin{array}{l}35 \\
2.88\end{array}$ & $\begin{array}{l}79 \\
3.4\end{array}$ & $\begin{array}{l}2.5 \\
.06\end{array}$ & $\begin{array}{r}230 \\
3.77\end{array}$ & & $\begin{array}{r}218 \\
4.58\end{array}$ & 27.76 & .53 & 480 & .65 & 460 & 304 & 95 & 36 & 750 & 2.0 \\
\hline 0 & 67 & 37.04 & $\begin{array}{l}84 . \\
3.6\end{array}$ & $\begin{array}{l}2.6 \\
.07\end{array}$ & $\begin{array}{r}238 \\
3.90\end{array}$ & 12.40 & 235 & 29 & .57 & 490 & .67 & 423 & 319 & 104 & 36 & 770 & 2.0 \\
\hline 282 . & $\begin{array}{c}70.04 \\
3.49\end{array}$ & $\begin{array}{l}39 \\
3.21\end{array}$ & & 2.7 & 245 & & $\begin{array}{r}255 \\
6.30\end{array}$ & 31.87 & .62 & 515 & .70 & 392 & 335 & 112 & 37 & $800^{-1}$ & 2.2 \\
\hline 24 & $\begin{array}{l}73.40 \\
3.64\end{array}$ & $\begin{array}{l}42 \\
3.45\end{array}$ & 102 & $\begin{array}{l}2.8 \\
.07\end{array}$ & $\begin{array}{l}252 \\
4.19\end{array}$ & 13.49 & $\begin{array}{r}285 \\
5.99\end{array}$ & 34.96 & 69 & 543 & .74 & 352 & 354 & 126 & 38 & $840^{-1}$ & 2.4 \\
\hline $173 \ldots$ & 81 & 48 & $\begin{array}{r}125 \\
6.4\end{array}$ & $\begin{array}{l}3.1 \\
.08\end{array}$ & 270 & $14^{-40}$ & $\begin{array}{r}355 \\
7.38\end{array}$ & $\begin{array}{c}41^{\circ 0} \\
1.16\end{array}$ & .82 & 600 & .82 & 280 & 400 & 154 & 40 & 930 & 2.7 \\
\hline $64^{3}$. & $\begin{array}{r}95 \\
4.74\end{array}$ & 58 & $\begin{array}{c}175 \\
7.6\end{array}$ & $\begin{array}{l}4.0 \\
.10\end{array}$ & 280 & $15^{-40}$ & $\begin{array}{c}500 \\
10.40\end{array}$ & 62 & 1.2 & 830 & 1.13 & 143 & 476 & 221 & 44 & 1,250 & 3.5 \\
\hline . & $\begin{array}{r}107 \\
6.34\end{array}$ & $\begin{array}{l}66 \\
5.43\end{array}$ & $\begin{array}{c}234 \\
10.1\end{array}$ & $\begin{array}{l}4.8 \\
.12\end{array}$ & $298 \cdot 89$ & $16^{.00}$ & $\begin{array}{c}10.40 \\
640 \\
18.31\end{array}$ & $\begin{array}{c}80 \\
2.26\end{array}$ & $1 . \overline{3}$ & 1,260 & $1.71^{-}$ & 37 & 538 & 268 & 48 & 1,850 & 4.4 \\
\hline 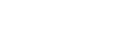 & $\begin{array}{r}109 \\
5.44\end{array}$ & $\begin{array}{r}67 \\
5.61\end{array}$ & $\begin{array}{c}238 \\
10.8\end{array}$ & $\begin{array}{l}4.9 \\
.13\end{array}$ & $\begin{array}{r}299 \\
4.90\end{array}$ & $17{ }^{1.57}$ & $\begin{array}{c}655 \\
18.62\end{array}$ & 82 & 1.4 & 1,300 & 1.77 & 7.7 & 548 & 274 & 48 & 1,900 & 4.4 \\
\hline 2 & $\begin{array}{r}110 \\
6.49 \\
\end{array}$ & $\begin{array}{c}68 \\
6.69 \\
\end{array}$ & $\begin{array}{r}240 \\
10.4 \\
\end{array}$ & $\begin{array}{l}5.0 \\
.18 \\
\end{array}$ & $\begin{array}{r}300 \\
4.92 \\
\end{array}$ & $\begin{array}{r}17.57 \\
\end{array}$ & $\begin{array}{c}660 \\
18.78 \\
\end{array}$ & $\begin{array}{c}83 \\
2.34 \\
\end{array}$ & 1.5 & 1,300 & 1.77 & 4.2 & 554 & 280 & 48 & 1,900 & $\begin{array}{l}4.4 \\
\end{array}$ \\
\hline & $\stackrel{48}{2.40}$ & $\stackrel{25}{\text { \&. } 06}$ & $\begin{array}{l}54 \\
2.8\end{array}$ & $\begin{array}{c}1.9 \\
.05\end{array}$ & $\stackrel{186}{3.05}$ & 11.37 & $\begin{array}{r}142 \\
2.95\end{array}$ & ${ }^{18} .51$ & .34 & 370 & .50 & 507 & 223 & 52 & 34 & 589 & 1.6 \\
\hline \multicolumn{18}{|c|}{ Duchegne River above the mouth of the Uinta River (at Ouray School canal headgate), Utah \& s } \\
\hline & \multirow{19}{*}{$\begin{array}{c}34 \\
1.70 \\
35 \\
1.75 \\
35 \\
1.75 \\
35 \\
1.75 \\
36 \\
1.80 \\
38 \\
1.90 \\
41 \\
2.05 \\
47 \\
2.35 \\
55 \\
2.74 \\
60 \\
2.99 \\
62 \\
3.09 \\
64 \\
3.19 \\
66 \\
3.29 \\
70 \\
8.49 \\
76 \\
8.79 \\
99 \\
4.94 \\
134 \\
6.69 \\
138 \\
6.89 \\
139 \\
6.94 \\
\end{array}$} & \multirow{19}{*}{\multicolumn{2}{|c|}{$\begin{array}{c}12 \\
12.99 \\
12.99 \\
12.99 \\
12.99 \\
13.99 \\
1.07 \\
15.98 \\
1.28 \\
18 \\
1.48 \\
24 \\
1.97 \\
32 \\
2.63 \\
36 \\
2.96 \\
39 \\
3.21 \\
40 \\
8.29 \\
43 \\
3.53 \\
46 \\
3.78 \\
52 \\
4.27 \\
75 \\
6.16 \\
113 \\
9.29 \\
119 \\
9.78 \\
119 \\
9.78 \\
\end{array}$}} & \multirow{19}{*}{ 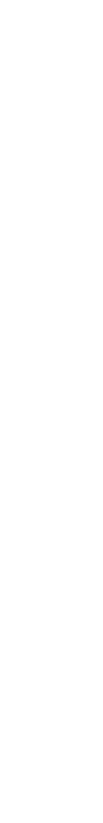 } & \multirow{19}{*}{$\begin{array}{l}1.2 \\
.08 \\
1.2 \\
1.09 \\
.08 \\
1.2 \\
.08 \\
1.2 \\
.03 \\
1.2 \\
.03 \\
1.3 \\
.03 \\
1.6 \\
.04 \\
1.9 \\
.05 \\
2.1 \\
.05 \\
2.2 \\
.06 \\
2.3 \\
.06 \\
2.4 \\
.06 \\
2.6 \\
.07 \\
2.9 \\
.07 \\
4.0 \\
.10 \\
6.1 \\
.16 \\
6.4 \\
.16 \\
6.4 \\
.16 \\
\end{array}$} & \multirow{19}{*}{$\begin{array}{c}140 \\
2.30 \\
142 \\
2.39 \\
143 \\
2.34 \\
143 \\
2.34 \\
148 \\
2.49 \\
150 \\
2.46 \\
166 \\
2.72 \\
203 \\
8.32 \\
231 \\
3.79 \\
235 \\
3.85 \\
242 \\
3.97 \\
245 \\
4.02 \\
250 \\
4.10 \\
263 \\
4.31 \\
273 \\
4.48 \\
308 \\
5.05 \\
350 \\
5.74 \\
397 \\
6.61 \\
399 \\
6.64 \\
\end{array}$} & \multirow{19}{*}{$\begin{array}{c}48 \\
1.00 \\
49 \\
1.02 \\
49 \\
1.02 \\
49 \\
1.02 \\
56 \\
1.16 \\
78 \\
1.62 \\
100 \\
2.08 \\
137 \\
2.85 \\
194 \\
4.04 \\
245 \\
5.10 \\
278 \\
5.78 \\
295 \\
6.14 \\
325 \\
6.76 \\
363 \\
7.65 \\
447 \\
9.30 \\
745 \\
15.60 \\
1,290 \\
26.83 \\
1,330 \\
27.66 \\
1,340 \\
27.87 \\
\end{array}$} & \multirow{6}{*}{$\begin{array}{c}4.1 \\
.12 \\
4.2 \\
.12 \\
4.2 \\
.12 \\
4.2 \\
.12 \\
5.0 \\
.14 \\
6.2 \\
1 \gamma\end{array}$} & 0.12 & 197 & 0.27 & 6,810 & 134 & 20 & 20 & 334 & 0.6 \\
\hline & & & & & & & & & 13 & 199 & .27 & 4,460 & $137^{-1}$ & 20 & 20 & 337 & $\overline{6}$ \\
\hline 6,900 & & & & & & & & & 13 & 200 & .27 & 3,730 & 137 & 20 & 20 & 339 & 6 \\
\hline & & & & & & & & & 13 & 202 & .27 & 2,620 & 137 & 20 & 20 & 340 & $\overline{6}$ \\
\hline & & & & & & & & & .13 & 214 & .29 & 1,790 & $144^{-}$ & 22 & 22 & 359 &.$\overline{7}$ \\
\hline 2,100 & & & & & & & & & .13 & 245 & .33 & 1,390 & $156^{\circ}$ & 34 & 26 & 401 &.$\overline{9}$ \\
\hline & & & & & & & & ${ }^{10} .28$ & .15 & 291 & .40 & 1,120 & 176 & 40 & 30 & $470^{\circ}$ & 1.1 \\
\hline 9001 & & & & & & & & 16 & .18 & 391 & .53 & 950 & 216 & 50 & 34 & 605 & 1.5 \\
\hline & & & & & & & & $24_{68}$ & .24 & 538 & .73 & 784 & 268 & 79 & 36 & 800 & $1 . \overline{9}$ \\
\hline & & & & & & & & $28^{\circ 00}$ & .29 & 630 & .86 & 697 & 298 & 105 & 38 & 920 & 2.2 \\
\hline & & & & & & & & $31^{.87}$ & .33 & 685 & .93 & 657 & 315 & 116 & 40 & 996 & 2.4 \\
\hline $320^{2}$ & & & & & & & & 32.90 & .34 & 725 & .99 & 626 & 324 & 123 & 41 & 1,030 & 2.5 \\
\hline & & & & & & & & $\begin{array}{l}35 . \\
.99\end{array}$ & .38 & 775 & 1.05 & 590 & $34 \mathrm{i}^{-1}$ & $136^{-}$ & 42 & 1,100 & 2.7 \\
\hline & & & & & & & & $\begin{array}{c}38 \\
1.07\end{array}$ & .44 & 842 & 1.15 & 546 & 364 & 148 & 43 & 1,190 & $2 . \overline{9}$ \\
\hline & & & & & & & & $\begin{array}{r}45 \\
1.27\end{array}$ & 54 & 995 & 1.35 & 465 & 403 & 179 & 46 & $\mathbf{1}, \mathbf{3 7 0}$ & 3.4 \\
\hline & & & & & & & & $\begin{array}{c}66 \\
1.86\end{array}$ & 1.09 & 1,500 & 2.04 & 259 & 555 & 302 & 50 & 1,980 & 4.8 \\
\hline & & & & & & & & $\begin{array}{r}100 \\
2.82\end{array}$ & 2.59 & 2,420 & 3.29 & 72 & 799 & 512 & 54 & 3,000 & 6.8 \\
\hline & & & & & & & & $\begin{array}{r}102 \\
2.88\end{array}$ & 2.72 & 2,490 & 3.39 & 13 & 834 & 508 & 54 & 3,090 & 7.0 \\
\hline & & & & & & & & $\begin{array}{r}102 \\
2.88 \\
\end{array}$ & 2.73 & 2,500 & 3.40 & 6.8 & $836^{-}$ & 509 & 55 & 3,100 & 7.0 \\
\hline 508 & $\stackrel{51}{2.64}$ & & & $\stackrel{65}{2.89}$ & $\begin{array}{l}1.8 \\
.05\end{array}$ & 202 & $\begin{array}{c}184 \\
3.88\end{array}$ & ${ }^{20}{ }_{.56}$ & .25 & 418 & .65 & 660 & 242 & 76 & 37 & 716 & 1.8 \\
\hline
\end{tabular}


TABLE 13.-Relation between water discharge and chemical quality of water at selected stations in the Green division-Continued [Data are for the water years 1914-57 adjusted to 1957 conditions. Chemical quality data and weighted averages are in parts per million and requivalents per million (italicized), except as indicated]

\begin{tabular}{|c|c|c|c|c|c|c|c|c|c|c|c|c|c|c|c|c|}
\hline \multirow{2}{*}{$\begin{array}{c}\text { Mean } \\
\text { discharge } \\
\text { (cfs) }\end{array}$} & \multirow[b]{2}{*}{$\begin{array}{c}\text { Calcium } \\
\text { (Ca) }\end{array}$} & \multirow{2}{*}{$\begin{array}{c}\text { Mag- } \\
\text { nesium } \\
(\mathrm{Mg})\end{array}$} & \multirow[b]{2}{*}{$\underset{(\mathrm{Na})}{\text { Sodium }}$} & \multirow{2}{*}{$\begin{array}{l}\text { Potas- } \\
\text { sium } \\
(\mathrm{K})\end{array}$} & \multirow{2}{*}{$\begin{array}{c}\text { Bicar- } \\
\text { bonate } \\
\left(\mathrm{HCO}_{3}\right)\end{array}$} & \multirow[b]{2}{*}{$\begin{array}{l}\text { Sulfate } \\
\left(\mathrm{SO}_{4}\right)\end{array}$} & \multirow[b]{2}{*}{$\underset{\text { (C) }}{\text { Chloride }}$} & \multirow[b]{2}{*}{$\begin{array}{c}\text { Boron } \\
\text { (B) }\end{array}$} & \multicolumn{3}{|c|}{$\begin{array}{c}\text { Dissolved solids } \\
\text { (Residue at } 180^{\circ} \mathrm{C} \text { ) }\end{array}$} & \multicolumn{2}{|c|}{$\begin{array}{l}\text { Hardness } \\
\text { as } \mathrm{CaCO}_{3}\end{array}$} & \multirow{2}{*}{$\begin{array}{l}\text { Per- } \\
\text { cent } \\
\text { so- } \\
\text { dium }\end{array}$} & \multirow{2}{*}{\begin{tabular}{|c} 
Speciffic \\
conduct- \\
ance \\
(micro- \\
mhos at \\
$25^{\circ} \mathrm{C}$ )
\end{tabular}} & \multirow{2}{*}{$\begin{array}{l}\text { Sodium- } \\
\text { adsorp- } \\
\text { tion- } \\
\text { ratio }\end{array}$} \\
\hline & & & & & & & & & $\begin{array}{c}\text { Parts } \\
\text { per } \\
\text { mil- } \\
\text { lion }\end{array}$ & $\begin{array}{c}\text { Tons } \\
\text { per } \\
\text { acre- } \\
\text { ft }\end{array}$ & $\begin{array}{l}\text { Tons } \\
\text { per day }\end{array}$ & $\begin{array}{c}\text { Cal- } \\
\text { cium, } \\
\text { mag- } \\
\text { nesium }\end{array}$ & $\begin{array}{l}\text { Non- } \\
\text { car- } \\
\text { bon- } \\
\text { ate }\end{array}$ & & & \\
\hline
\end{tabular}

GREEN RIVER BASIN BETWEEN THE YAMPA AND WHITE RIVER INCLUDING THE WHITE RIVER BASIN-Continued

Duchesne River near Randlett, Utah

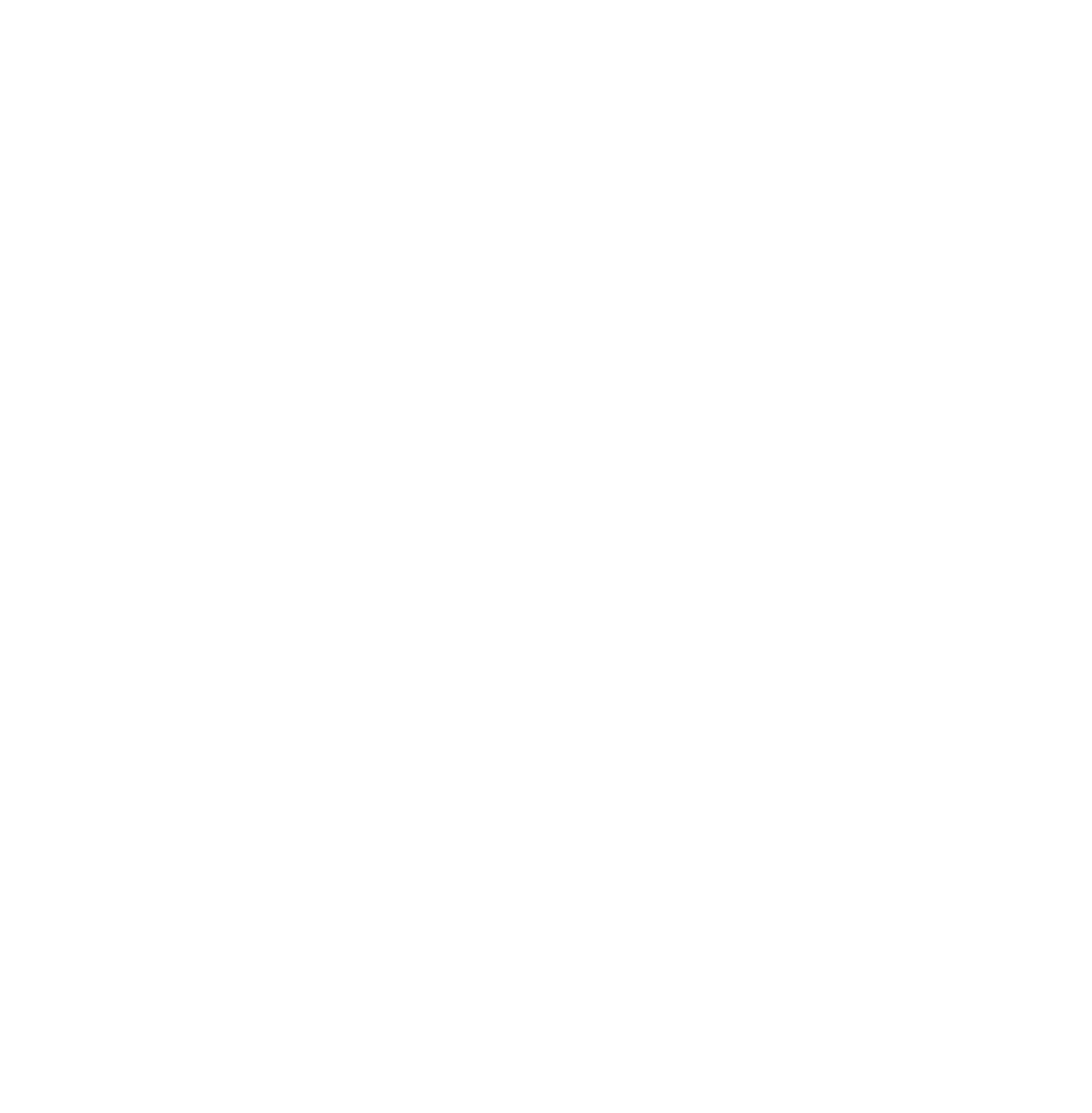

See footnotes at end of table. 
TABLE 13.-Relation between water discharge and chemical quality of water at selected stations in the Green division-Continued [Data are for the water years 1914-57 adjusted to 1957 conditions. Chemical quality data and weighted averages are in parts per million and

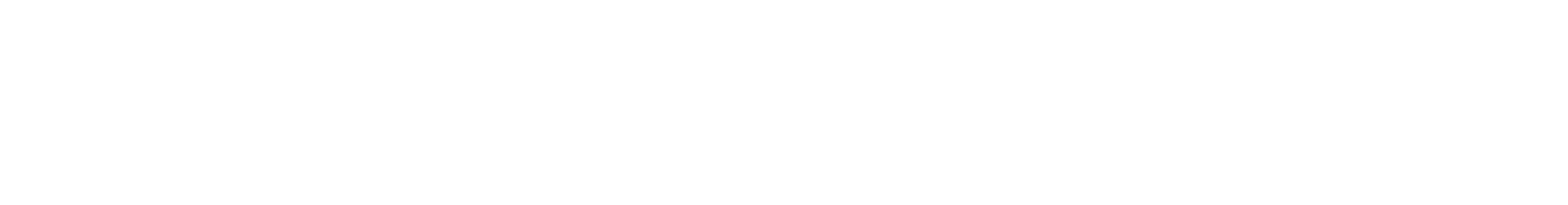

GREEN RIVER BASIN BELOW THE WHITE RIVER

Green River near Ouray, Utah

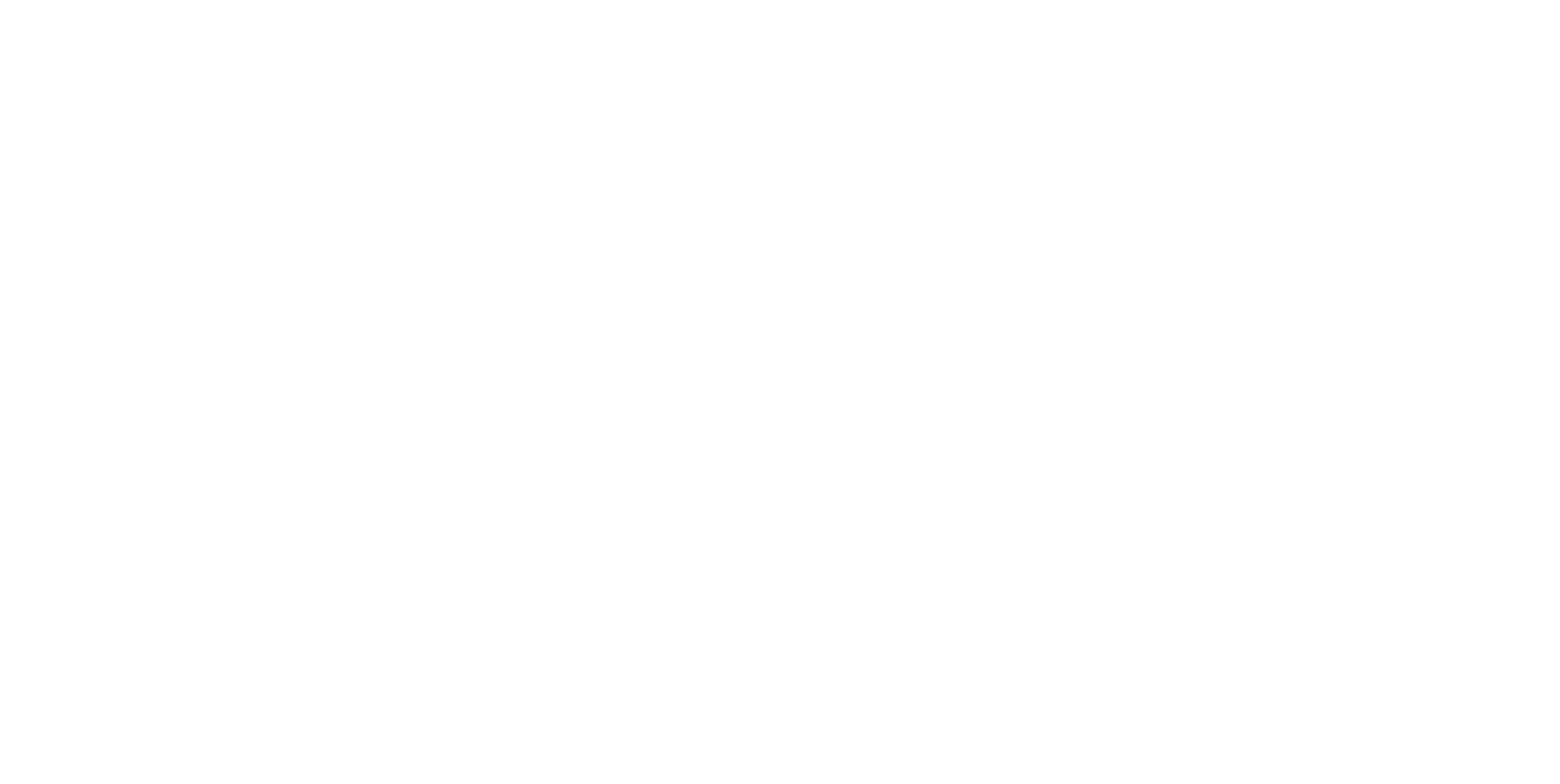

Willow Creek near Ouray, Utah

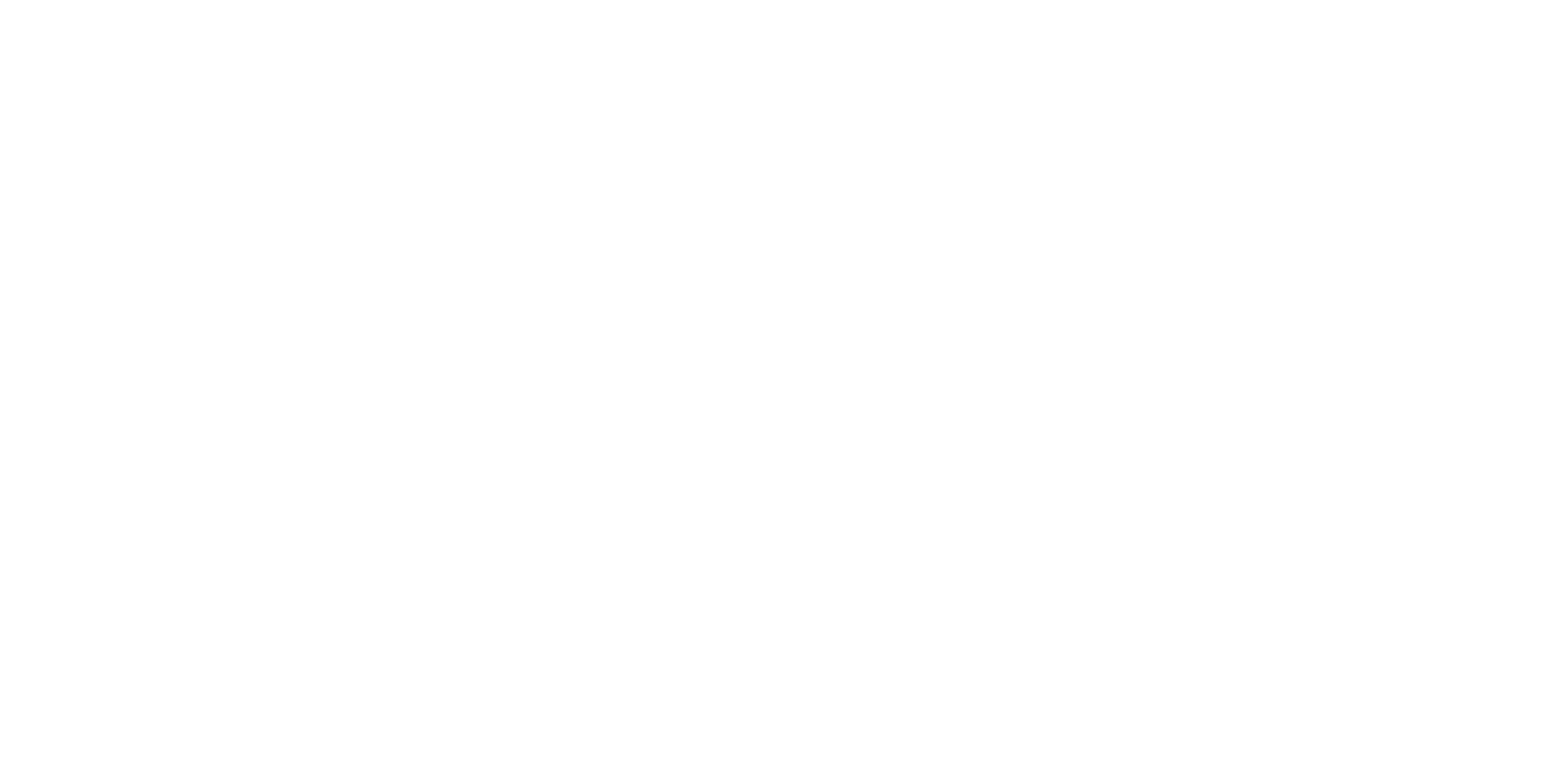


TABLE 13.-Relation between water discharge and chemical quality of uater at selected stations in the Green division-Continued [Data are for the water years 1914-57 adjusted to 1957 conditions. Chemical quality data and weighted averages are in parts per million and

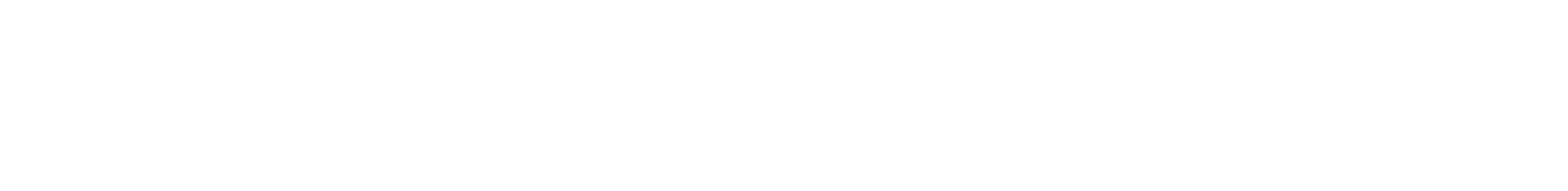

GREEN RIVER BASIN BELOW THE WHITE RIVER-Continued

Price River at Woodside, Utah

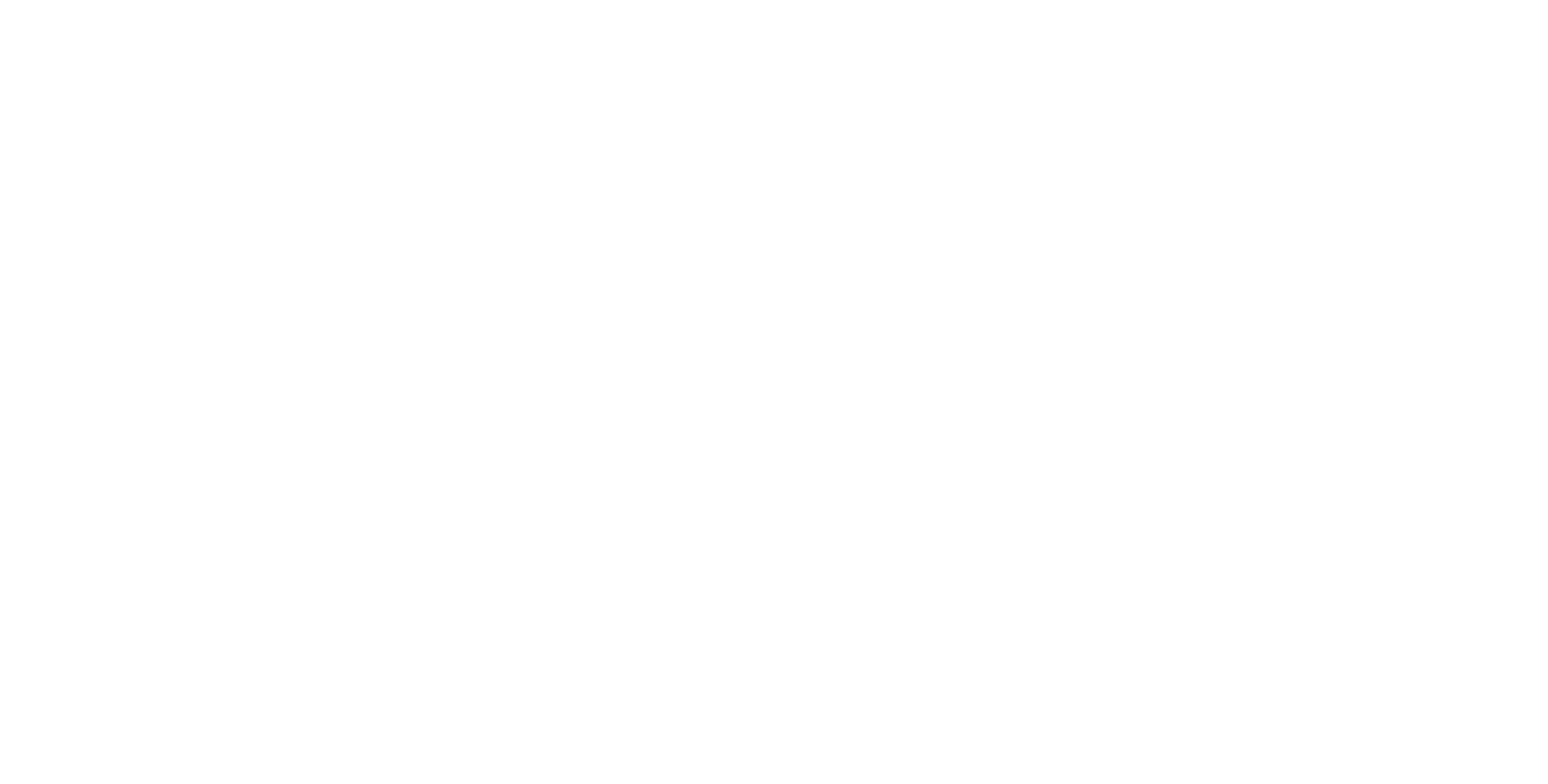

Green River at Green River, Utah

\begin{tabular}{|c|c|c|c|c|c|c|c|c|c|c|c|c|c|c|c|c|}
\hline $63,430 \ldots$ & & & 19 & 1.9 & 160 & 52 & 8.5 & 0.07 & 222 & 0.30 & 38,020 & 151 & 20 & 21 & 345 & 0.7 \\
\hline $56,430 \ldots$ & $\begin{array}{r}2.20 \\
44\end{array}$ & $10^{.82}$ & $19^{.85}$ & $\begin{array}{l}.05 \\
1.9\end{array}$ & $\begin{array}{r}2.62 \\
160\end{array}$ & 52 & 8.64 & .07 & 222 & .30 & 33,820 & 151 & 20 & 21 & 350 & .7 \\
\hline $51,450 \ldots$ & $\begin{array}{r}2.20 \\
44\end{array}$ & $10^{.82}$ & $19{ }^{.83}$ & $\begin{array}{l}.05 \\
2.0\end{array}$ & $\begin{array}{c}2.62 \\
160\end{array}$ & 52 & 8.24 & .07 & 222 & $.30^{-}$ & 30,840 & 151 & 20 & 21 & 350 & .7 \\
\hline $41,720 \ldots$ & $\begin{array}{r}z .20 \\
44 \\
0\end{array}$ & $10^{.82}$ & $20^{.85}$ & $\begin{array}{l}.00 \\
2.0\end{array}$ & 160 & 54 & $\begin{array}{l}.24 \\
8.6\end{array}$ & .07 & 225 & .31 & 25,350 & 151 & 20 & 22 & 350 & .7 \\
\hline $32,100 \ldots$ & $\begin{array}{r}8.20 \\
45\end{array}$ & $10^{.82}$ & $211^{.87}$ & $\begin{array}{l}.05 \\
2.2\end{array}$ & $160^{2.62}$ & $\begin{array}{c}1.12 \\
59\end{array}$ & 8. 84 & .08 & 230 & .31 & 19,930 & 154 & 22 & 23 & 355 & .7 \\
\hline $25,850 \ldots$ & 45 & $11^{0 .}$ & $23^{.91}$ & 2.3 & $\begin{array}{r}2.6 \\
160^{\circ}\end{array}$ & $64^{1.24}$ & $\begin{array}{l}. .20 \\
9.2\end{array}$ & .08 & 240 & .33 & 16,750 & 158 & 26 & 24 & 375 & .8 \\
\hline $20,210 \ldots$ & 4 & 11.00 & 25 & 2.40 & $160^{z-0 z}$ & 69 & $10^{.20}$ & .08 & 270 & .37 & 14,730 & 158 & 26 & 25 & 410 & .9 \\
\hline $14,800^{1}$ & 46 & 12.90 & 29 & 2.6 & 162 & 80.44 & $11^{-2}$ & $.0 \theta^{-}$ & 326 & $.44^{-}$ & 13,030 & 164 & 32 & 27 & 475 & 1.0 \\
\hline $9,276 \ldots$ & 50 & $14^{\circ}$ & $37^{1.20}$ & 2.87 & $\begin{array}{r}z .00 \\
169\end{array}$ & 104 & $15^{.3}$ & $.09^{-}$ & 430 & .58 & 10,760 & 182 & $44^{-1}$ & 30 & 615 & 1.2 \\
\hline $5,614 \ldots$ & 57 & 20 & 56 & 3.1 & 193 & 153 & $23^{.42}$ & .10 & 570 & .78 & 8,640 & 224 & 66 & 35 & $780^{-}$ & 1.6 \\
\hline $3,881 \ldots$ & $\begin{array}{c}2.04 \\
65\end{array}$ & 26 & $\begin{array}{ll}75 & 44 \\
75 & 96\end{array}$ & $\begin{array}{l}.08 \\
3.40\end{array}$ & 214 & 210 & $30^{.65}$ & .11 & 655 & .89 & 6,860 & 269 & 94 & 37 & 890 & 2.0 \\
\hline $2,966^{2}$ & 71 & 31.14 & $\begin{array}{l}3.20 \\
86\end{array}$ & $\begin{array}{l}.09 \\
3.6\end{array}$ & $\begin{array}{r}5.01 \\
228\end{array}$ & $\begin{array}{r}4.57 \\
252\end{array}$ & $36{ }^{.0 b}$ & .11 & 700 & .95 & $5,610^{-}$ & 304 & 118 & 38 & 945 & 2.1 \\
\hline 2,439_.. & 74 & 34 & 95.74 & $\begin{array}{l}.09 \\
3.8\end{array}$ & 23074 & $280^{6.04}$ & 39 & .11 & 735 & 1.00 & 4,840 & 324 & 136 & 39 & 1,000 & 2.3 \\
\hline $2,001 \ldots$ & 76 & 36 & 100 & $\begin{array}{l}.10 \\
3.9\end{array}$ & 232 & 300 & 43 & .12 & 755 & 1.03 & 4,260 & 338 & 148 & 30 & 1,030 & 2.4 \\
\hline 1,793_... & 78 & 39 & 106 & 4.0 & 234 & 322 & 46 & .12 & 775 & 1.05 & 3,750 & 355 & 163 & 39 & 1,060 & $2 . \overline{4}$ \\
\hline $1,424^{3}$ & 81.0 & $\begin{array}{l}3.21 \\
41\end{array}$ & $11^{4.61}$ & $\begin{array}{l}.10 \\
4.2\end{array}$ & $\begin{array}{r}336 \\
236\end{array}$ & $\begin{array}{c}6.70 \\
345\end{array}$ & $\begin{array}{l}1 . .80 \\
50\end{array}$ & .12 & 800 & 1.09 & $3,080^{-1}$ & $370^{-}$ & 177 & 39 & 1,100 & 2.5 \\
\hline 1,006 & 8304 & 42 & $119^{48}$ & $\begin{array}{l}.11 \\
4.5 \\
.12\end{array}$ & 238 & 360 & $\begin{array}{l}1.44 \\
54\end{array}$ & .13 & 820 & 1.12 & 2,230 & $380^{-}$ & 184 & 40 & 1,130 & 2.7 \\
\hline 637. & 85 & 4340 & 122 & $\begin{array}{l}5.0 \\
.8\end{array}$ & 2400 & $370^{40}$ & 57 & .14 & 850 & 1.16 & 1,460 & 388 & 192 & 40 & 1,170 & 2.7 \\
\hline 462 & $\begin{array}{r}87^{4.24} \\
4.34 \\
\end{array}$ & $\begin{array}{r}4.00 \\
3.62 \\
3.62 \\
\end{array}$ & $\begin{array}{r}\text { b2 } \\
121 \\
5.31 \\
\end{array}$ & $\begin{array}{c}.13 \\
5.4 \\
.14\end{array}$ & $\begin{array}{r}240.94 \\
3.94\end{array}$ & $\begin{array}{r}370 \\
7.70\end{array}$ & $\begin{array}{c}1.61 \\
58 \\
1.64\end{array}$ & .14 & 860 & 1.17 & 1,070 & 398 & 201 & 40 & 1,170 & 2.7 \\
\hline 6,292_. & $\stackrel{54}{2.69}$ & ${ }_{1.48}^{18}$ & $\begin{array}{l}45 \\
1.96\end{array}$ & $\begin{array}{c}2.8 \\
.07\end{array}$ & $\begin{array}{r}181 \\
2.97\end{array}$ & $\begin{array}{r}130 \\
2.70\end{array}$ & ${ }^{19} .54$ & .09 & 427 & .58 & 7,260 & 208 & 60 & 32 & 608 & 1.4 \\
\hline
\end{tabular}


TABLE 13.-Relation between water discharge and chemical quality of water at selected stations in the Green division-Continued [Data are for the water years 1914-57 adjusted to 1957 conditions. Chemical quality data and weighted averages are in parts per million and equivalents per million (italicized), except as indicated]

\begin{tabular}{|c|c|c|c|c|c|c|c|c|c|c|c|c|c|c|c|c|}
\hline \multirow{2}{*}{$\begin{array}{c}\text { Mean } \\
\text { discharge } \\
\text { (cfs) }\end{array}$} & \multirow{2}{*}{$\underset{\text { (Ca) }}{\text { Calcium }}$} & \multirow{2}{*}{$\underset{(\mathrm{Mg})}{\text { Mag- }}$} & \multirow{2}{*}{$\underset{(\mathrm{Na})}{\text { Sodium }}$} & \multirow{2}{*}{$\begin{array}{l}\text { Potas- } \\
\text { sium } \\
(\mathbf{K})\end{array}$} & \multirow{2}{*}{$\begin{array}{c}\text { Bicar- } \\
\text { bonate } \\
\left(\mathrm{HCO}_{3}\right)\end{array}$} & \multirow{2}{*}{$\begin{array}{c}\text { Sulfate } \\
\text { (SO4) }\end{array}$} & \multirow{2}{*}{$\begin{array}{c}\text { Chloride } \\
\text { (Cl) }\end{array}$} & \multirow{2}{*}{$\begin{array}{l}\text { Boron } \\
\text { (B) }\end{array}$} & \multicolumn{3}{|c|}{$\begin{array}{l}\text { Dissolved solids } \\
\left.\text { (residue at } 180^{\circ} \mathrm{C}\right)\end{array}$} & \multicolumn{2}{|c|}{$\begin{array}{l}\text { Hardness } \\
\text { as } \mathrm{CaCO}_{3}\end{array}$} & \multirow{2}{*}{$\begin{array}{c}\text { Per- } \\
\text { cent } \\
\text { so- } \\
\text { dium }\end{array}$} & \multirow{2}{*}{$\begin{array}{l}\text { Specific } \\
\text { conduct- } \\
\text { ance } \\
\text { (micro- } \\
\text { mhos at } \\
25^{\circ} \mathrm{C} \text { ) }\end{array}$} & \multirow{2}{*}{$\begin{array}{l}\text { Sodium } \\
\text { adsorp- } \\
\text { tion- } \\
\text { ratio }\end{array}$} \\
\hline & & & & & & & & & $\begin{array}{c}\text { Parts } \\
\text { per } \\
\text { million }\end{array}$ & $\begin{array}{c}\text { Tons } \\
\text { per } \\
\text { acre-ft }\end{array}$ & $\begin{array}{l}\text { Tons } \\
\text { per } \\
\text { day }\end{array}$ & $\begin{array}{c}\text { Calcium, } \\
\text { mag- } \\
\text { nesium }\end{array}$ & $\begin{array}{c}\text { Non- } \\
\text { carbon- } \\
\text { ate }\end{array}$ & & & \\
\hline
\end{tabular}

GREEN RIVER BASIN BELOW THE WHITE RIVER-Continued

San Rafael River near Green River, Utah

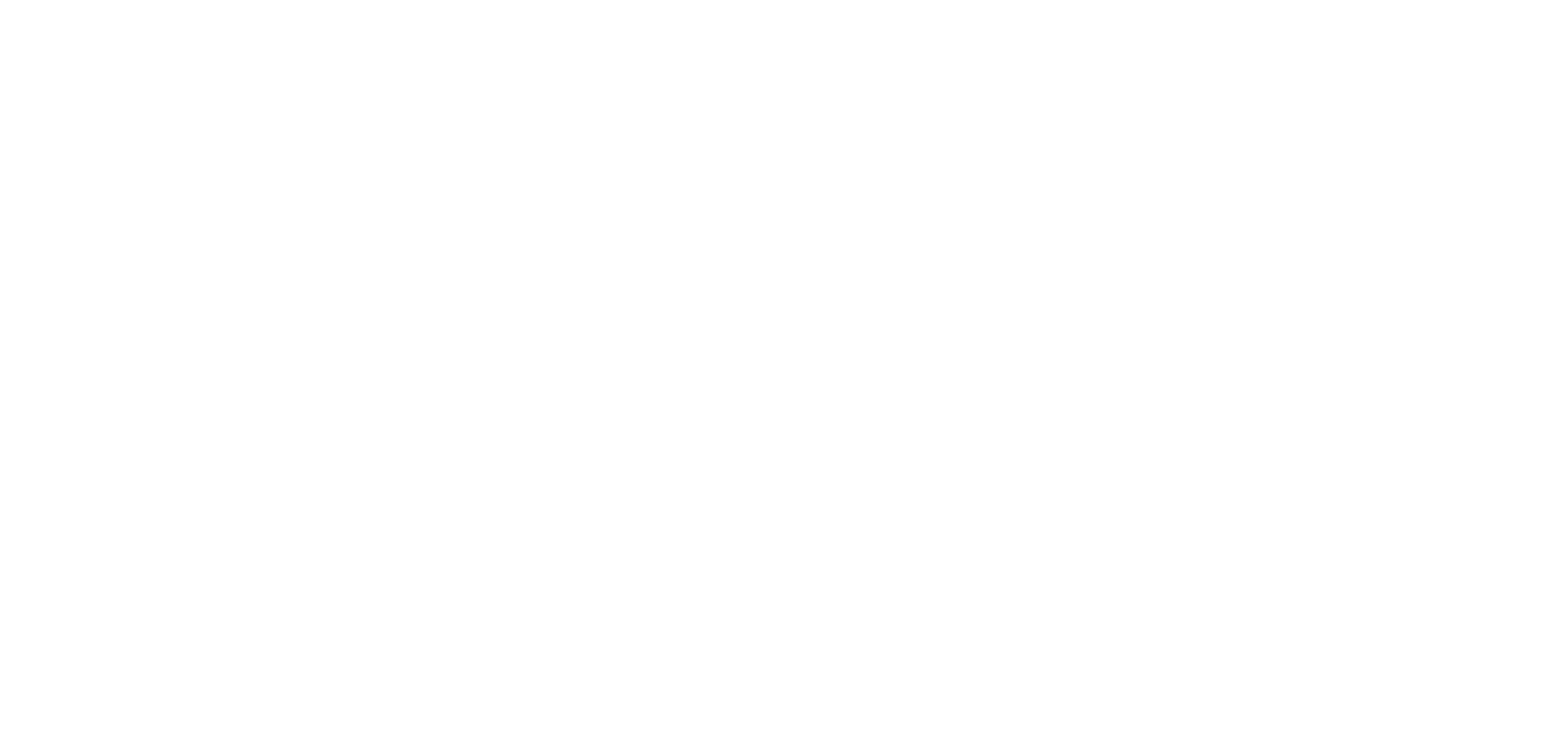

112 percentile of water discharge.

390 percentile of water discharge.

4 Water discharge is assumed to be the same as Duchesne River at Myton, Utah. s Values for bicarbonate include an average of about $10 \mathrm{ppm}$ carbonate $\left(\mathrm{CO}_{3}\right)$. 
TABLE 14.-Water and dissolved solids contributed by ground water to selected streams in the subbasins in the Green division [Data are for the water years 1914-57 adjusted to 1957 conditions, except as indicated. Weighted-average concentration of dissolved solids of streams from table 9]

\begin{tabular}{|c|c|c|c|c|c|}
\hline \multirow{2}{*}{$\begin{array}{l}\text { Station } \\
\text { No. }\end{array}$} & \multirow{2}{*}{ Station name } & \multirow{2}{*}{$\begin{array}{l}\text { Woighted- } \\
\text { average con- } \\
\text { centration of } \\
\text { dissolved } \\
\text { solids (ppm) }\end{array}$} & \multicolumn{3}{|c|}{ Ground water } \\
\hline & & & $\begin{array}{c}\text { Discharge } \\
\text { (acre-ft per } \\
\text { yr) }\end{array}$ & \multicolumn{2}{|c|}{ Dissolved solids } \\
\hline \multicolumn{6}{|c|}{ Green River basin above the Yampa River } \\
\hline \multicolumn{6}{|c|}{ Green River basin between the Yampa and White Rivers including the White River basin } \\
\hline $\begin{array}{l}2665 \\
2755 \\
2790 \\
2925 \\
2995 \\
3045\end{array}$ & $\begin{array}{l}\text { Ashley Creek near Vernal, Utah } \\
\text { West Fork Duchesne River near Hanna, Utah } \\
\text { Rock Creek near Mountain Home, Utah } \\
\text { Yellowstone Creek near Altonah, Utah } \\
\text { Whiterocks River near Whiterocks, Utah } \\
\text { White River near Meeker, Colo }\end{array}$ & $\begin{array}{r}56 \\
23 \\
49 \\
39 \\
27 \\
244\end{array}$ & $\begin{array}{r}23,300 \\
11,000 \\
49,200 \\
48,100 \\
26,900 \\
265,400\end{array}$ & $\begin{array}{r}2,600 \\
430 \\
4,800 \\
3,080 \\
1,390 \\
102,400\end{array}$ & $\begin{array}{r}82 \\
29 \\
72 \\
47 \\
38 \\
284\end{array}$ \\
\hline \multicolumn{6}{|c|}{ Green River basin below the White River } \\
\hline
\end{tabular}

\footnotetext{
1 Water years 1952-57. $\quad 2$ Water years $1940-57$.
} 
TABLE 15.-Water and dissolved-solids budgets in the subbasins in the Green division [Data are for the water years 1914-57 adjusted to 1957 conditions]

\begin{tabular}{l|r|r|r}
\hline & $\begin{array}{r}\text { Average } \\
\text { annual } \\
\text { discharge } \\
\text { (acre-ft) }\end{array}$ & $\begin{array}{r}\text { Welghted- } \\
\text { average } \\
\text { concentration } \\
\text { (ppm) }\end{array}$ & Tons per year \\
\hline \multicolumn{3}{c}{ GREEN RIV ER BASIN ABOVE THE YAMPA RIVER } \\
New Fork River basin, Wyoming
\end{tabular}

Fontenelle Creek basin, Wyoming

\begin{tabular}{|c|c|c|c|}
\hline $\begin{array}{l}\text { Inflow: } \\
\text { Fontenelle Creek near Hershler Ranch, near } \\
\text { Fontenelle, Wyo. } \\
\text { Unmeasured inflow }\end{array}$ & $\begin{array}{r}50,800 \\
1,900\end{array}$ & $\begin{array}{l}211 \\
211\end{array}$ & 14, $\begin{array}{r}600 \\
500\end{array}$ \\
\hline Total & 52,700 & $-1-1-1-1$ & 15,100 \\
\hline $\begin{array}{l}\text { Outflow: } \\
\text { Consumed by irrigation } \\
\text { Fontenelle Creek at Fontenelle, Wyo. }\end{array}$ & $\begin{array}{r}3,200 \\
49,500\end{array}$ & 304 & 20,400 \\
\hline Total $\ldots \ldots$ & 52,700 & $\ldots \ldots$ & 20,400 \\
\hline Increase from other sources. & $-\ldots$ & $\ldots \ldots \ldots$ & 5,300 \\
\hline
\end{tabular}

Big Sandy Creek basin, Wyoming

\begin{tabular}{|c|c|c|c|}
\hline $\begin{array}{l}\text { Inflow: } \\
\text { Big Sandy Creek near Farson, Wyo } \\
\text { Little Sandy Creek above Eden, Wyo. } \\
\text { Pacific Creek near Farson, Wyo } \\
\text { Unmeasured inflow }\end{array}$ & $\begin{array}{r}62,700 \\
12,200 \\
3,000 \\
3,700\end{array}$ & $\begin{array}{r}47 \\
188 \\
900 \\
900\end{array}$ & $\begin{array}{l}4,000 \\
3,100 \\
3,700 \\
4,500\end{array}$ \\
\hline Total $\ldots \ldots$ & 81,600 & $\mid-\ldots-n-1--1$ & 15,300 \\
\hline $\begin{array}{l}\text { Outflow: } \\
\text { Depletion in reach } \\
\text { Big Sandy Creek below Eden, Wyo. }\end{array}$ & $\begin{array}{l}46,200 \\
35,400\end{array}$ & 1,340 & $64,30 \overline{0}$ \\
\hline Total & 81,600 & 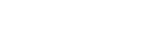 & 64,300 \\
\hline Increase from other sources. & & -- & 49,000 \\
\hline
\end{tabular}


$\mathrm{T}_{\mathrm{ABLE}}$ 15.-Water and dissolved-solids budgets in the subbasins in the Green division-Con.

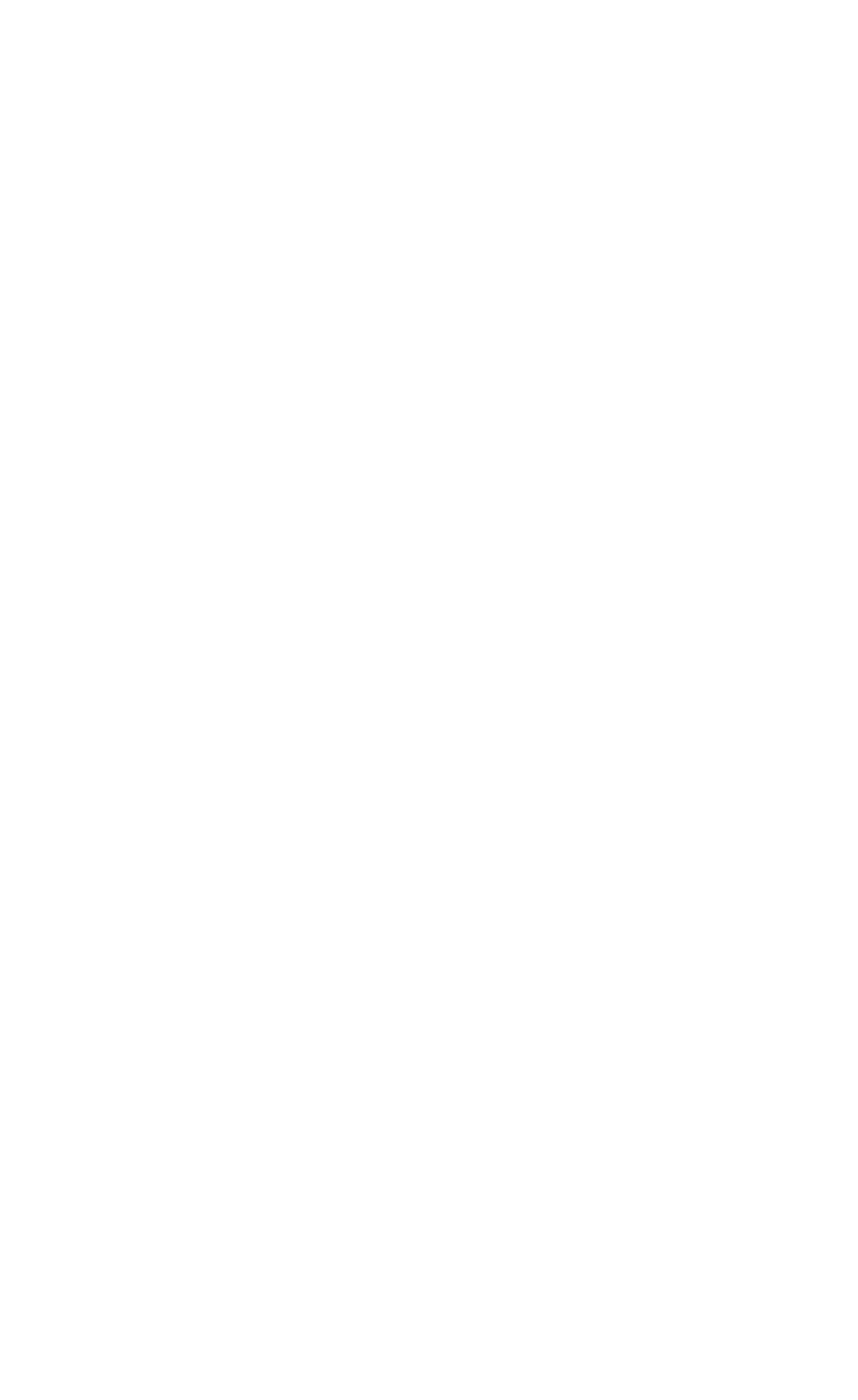


TABLE 15.-Water and dissolved-solids budgets in the subbasins in the Green division-Con.

\begin{tabular}{l|r|r|r}
\hline & $\begin{array}{r}\text { Average } \\
\text { annual } \\
\text { discharge } \\
\text { (acre-ft) }\end{array}$ & $\begin{array}{r}\text { Weighted- } \\
\text { average } \\
\text { concentration } \\
\text { (ppm) }\end{array}$ & Tons per year \\
YAMPA RIVER BASIN-Continued \\
Elk River basin, Colorado
\end{tabular}

Little Snake River basin above Dixon, Colorado

Inflow:

Little Snake River near Slater, Colo........

Battle Creek near Slater, Colo.

Slater Fork near Slater, Colo

Savery Creek at upper station near Savery, Wyo.

Savery Creek east-side tributaries below upper station

Total

Outflow:

Consumed by irrigation

Bypassed in canal . . . . . .

Little Snake River near Dixon, Colo

Total.

Increase from other sources.....
Unmeasured inflow

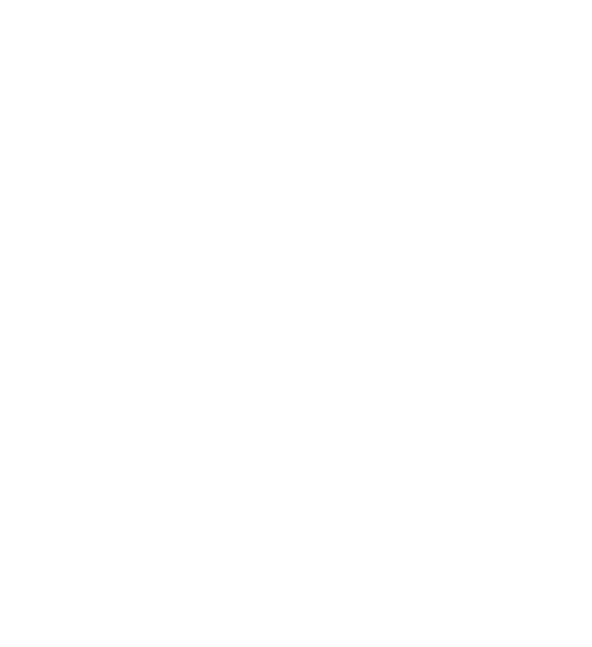
BASIN

Ashley Creek basin, Utah

\begin{tabular}{|c|c|c|c|}
\hline $\begin{array}{l}\text { Inflow: } \\
\text { Ashley Creek near Vernal, Utah. } \\
\text { Dry Fork at mouth near Dry Fork, Utah. } \\
\text { Water production from oil wells... }\end{array}$ & $\begin{array}{r}76,800 \\
19,000 \\
2,400\end{array}$ & $\begin{array}{r}56 \\
132 \\
1,200\end{array}$ & $\begin{array}{l}5,800 \\
3,400 \\
4,000\end{array}$ \\
\hline Total _ - & 98,200 & & 13,200 \\
\hline $\begin{array}{l}\text { Outflow: } \\
\text { Consumed in area } \\
\text { Diverted out of intervening area } \\
\text { Ground-water outflow. } \\
\text { Ashley Creek near Jensen, Utah. }\end{array}$ & $\begin{array}{r}42,500 \\
3,500 \\
600 \\
51,600\end{array}$ & $\begin{array}{r}71 \\
3,000 \\
583\end{array}$ & $\begin{array}{r}300 \\
2,400 \\
59,900\end{array}$ \\
\hline Total & 98,200 & & 62,200 \\
\hline Increase from other sou & & & 49,400 \\
\hline
\end{tabular}


TABLE 15.-Water and dissolved-solids budgets in the subbasins in the Green division-Con.

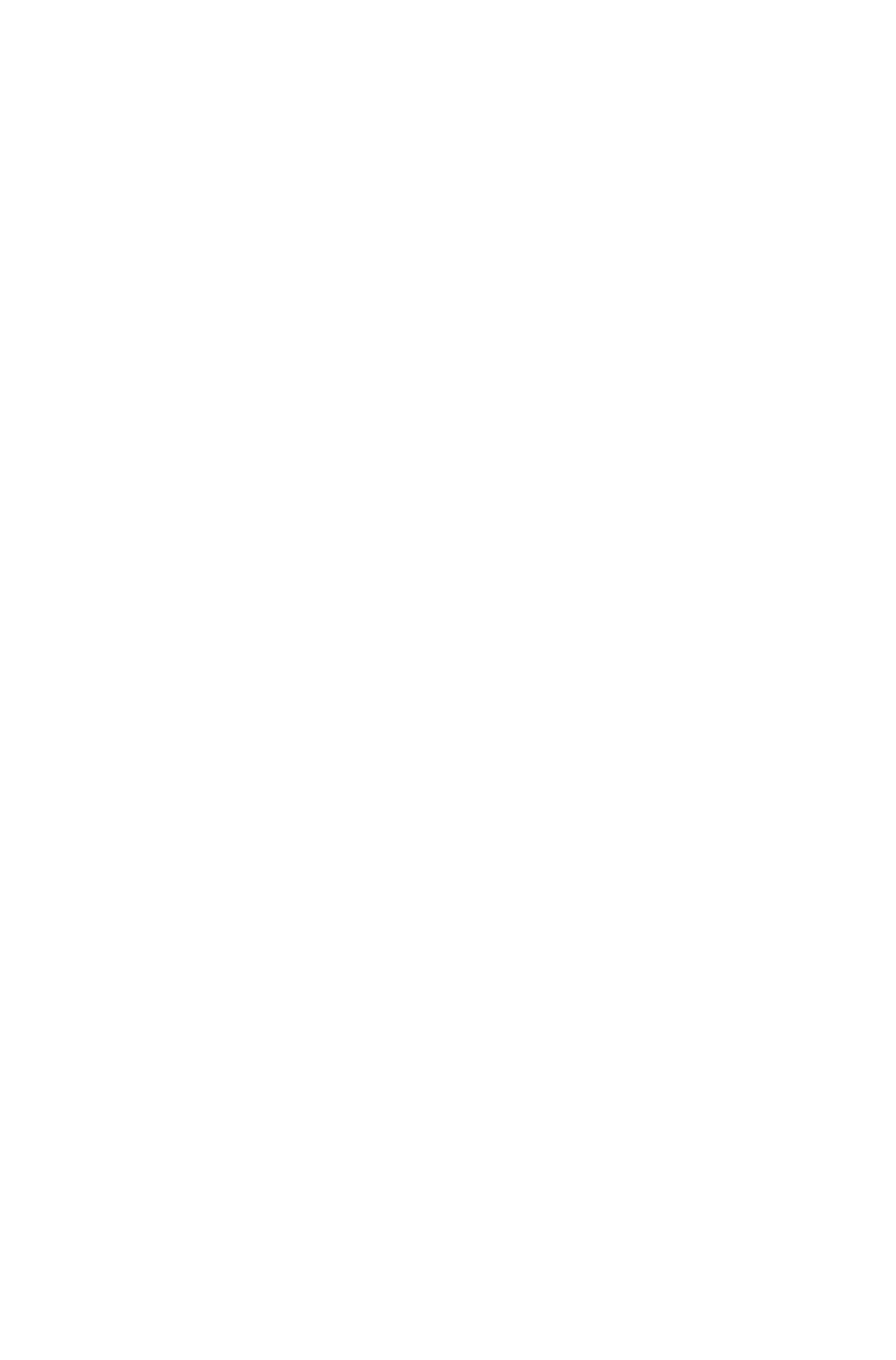


TABLE 16.-Average annual dissolved-solids discharge and probable amounts of dissolved solids from natural sources and from the activities of man in the subbasins in the Green division

[Data are for the water years 1914-57, adjusted to 1957 conditions]

\begin{tabular}{|c|c|c|c|c|c|c|c|}
\hline \multirow{3}{*}{ Gaging station or subbasin } & \multirow{3}{*}{$\begin{array}{l}\text { Drainage } \\
\text { area } \\
\text { (sq mi) }\end{array}$} & \multirow{3}{*}{$\begin{array}{c}\text { Acres } \\
\text { irrigated }\end{array}$} & \multicolumn{5}{|c|}{ Dissolved-solids discharge } \\
\hline & & & \multirow{2}{*}{$\begin{array}{l}\text { Total } \\
\text { (tons) }\end{array}$} & \multicolumn{2}{|c|}{ Natural } & \multicolumn{2}{|c|}{ Man caused } \\
\hline & & & & Tons & $\begin{array}{l}\text { Tons per } \\
\text { square mile }\end{array}$ & Tons & $\begin{array}{c}\text { Tons per acre } \\
\text { irrigated }\end{array}$ \\
\hline
\end{tabular}

Green River basin above the Yampa River

\begin{tabular}{|c|c|c|c|c|c|c|c|}
\hline $\begin{array}{l}\text { Green River near Fontenelle, Wyo. } \\
\text { Green River at Green River, Wyo } \\
\text { Green River near Linwood, Utah } \\
\text { Green River near Greendale, Utah. } \\
\text { Green River basin above the Yampa River }\end{array}$ & $\begin{array}{r}3,970 \\
7,670 \\
14,300 \\
15,100 \\
17,000\end{array}$ & $\begin{array}{l}131,600 \\
151,600 \\
227,100 \\
255,400 \\
258,400\end{array}$ & $\begin{array}{l}294,000 \\
504,000 \\
774,300 \\
847,400 \\
967,100\end{array}$ & $\begin{array}{l}182,200 \\
319,300 \\
513,800 \\
531,300 \\
646,600\end{array}$ & $\begin{array}{l}46 \\
42 \\
36 \\
35 \\
38\end{array}$ & $\begin{array}{l}111,800 \\
184,700 \\
260,500 \\
316,100 \\
320,500\end{array}$ & $\begin{array}{l}0.8 \\
1.2 \\
1.1 \\
1.2 \\
1.2\end{array}$ \\
\hline
\end{tabular}

Yampa River basin

\begin{tabular}{|c|c|c|c|c|c|c|c|}
\hline $\begin{array}{l}\text { Yampa River at bridge on county road near Maybell, Colo } \\
\text { Little Snake River at bridge on State Highway } 318 \text {, near Lily, Colo } \\
\text { Yampa River basin }\end{array}$ & $\begin{array}{r}3,590 \\
988 \\
8,000\end{array}$ & $\begin{array}{l}51,300 \\
20,400 \\
73,700\end{array}$ & $\begin{array}{l}218,800 \\
120,500 \\
405,800\end{array}$ & $\begin{array}{r}189,000 \\
90,100 \\
343,400\end{array}$ & $\begin{array}{l}53 \\
91 \\
43\end{array}$ & $\begin{array}{l}29,800 \\
30,400 \\
62,400\end{array}$ & $\begin{array}{r}0.6 \\
1.5 \\
.8\end{array}$ \\
\hline
\end{tabular}

Green River basin between the Yampa and White Rivers including the White River basin

\begin{tabular}{|c|c|c|c|c|c|c|c|}
\hline $\begin{array}{l}\text { Duchesne River near Randlett, Utah } \\
\text { White River near Watson, Utah. }\end{array}$ & $\begin{array}{l}3,920 \\
4,020\end{array}$ & $\begin{array}{r}135,700 \\
29,900\end{array}$ & $\begin{array}{l}460,200 \\
330,600\end{array}$ & $\begin{array}{l}134,700 \\
166,600\end{array}$ & $\begin{array}{l}34 \\
41\end{array}$ & $\begin{array}{l}325,500 \\
164,000\end{array}$ & $\begin{array}{l}2.4 \\
5.5\end{array}$ \\
\hline $\begin{array}{l}\text { Green River basin between the Yampa and White Rivers including } \\
\text { the White River basin }\end{array}$ & & 198,000 & $1,034,100$ & 471,800 & 44 & 562,300 & 2.8 \\
\hline
\end{tabular}

Green River basin below the White River

\begin{tabular}{|c|c|c|c|c|c|c|c|}
\hline $\begin{array}{l}\text { Green River at Ouray, Utah. } \\
\text { Green River at Green River, Utah } \\
\text { San Rafael River near Castle Dale, Utah } \\
\text { Green River basin below White River }\end{array}$ & $\begin{array}{r}35,500 \\
40,600 \\
927 \\
8,900\end{array}$ & $\begin{array}{r}530,100 \\
550,600 \\
36,000 \\
60,000\end{array}$ & $\begin{array}{r}2,407,000 \\
2,652,000 \\
171,300 \\
521,100\end{array}$ & $\begin{array}{r}1,461,800 \\
1,608,000 \\
55,900 \\
288,400\end{array}$ & $\begin{array}{l}41 \\
40 \\
60 \\
32\end{array}$ & $\begin{array}{r}945,200 \\
1,044,000 \\
115,400 \\
232,700\end{array}$ & $\begin{array}{l}1.8 \\
1.9 \\
3.2 \\
3.9\end{array}$ \\
\hline
\end{tabular}


TABLE 17.-Summary of the suspended-sediment discharge at daity stations in the subbasins of the Green division-Continued

\begin{tabular}{|c|c|c|c|c|c|c|c|c|}
\hline \multirow{2}{*}{ Water year } & \multicolumn{2}{|c|}{ Water discharge } & \multicolumn{6}{|c|}{ Suspended sediment } \\
\hline & Cfs-days & Acre-ft & Load' (tons) & Mean & Maximum & Minimum & $\begin{array}{c}\text { Weighted } \\
\text { mean }\end{array}$ & $\underset{\text { daily }}{\text { Maximum }}$ \\
\hline \multicolumn{9}{|c|}{ 3150. Green River at Green River, Utah } \\
\hline $\begin{array}{l}1935 \ldots \\
1936 \\
1937 \\
1938 \\
1939\end{array}$ & $\begin{array}{l}1,436,756 \\
2,090,772 \\
2,083,966 \\
2,393,274 \\
1,724,329\end{array}$ & $\begin{array}{l}2,850,000 \\
4,147,000 \\
4,134,000 \\
4,747,000 \\
3,420,000\end{array}$ & $\begin{array}{l}14,350,000 \\
33,800,000 \\
43,400,000 \\
38,200,000 \\
22,800,000\end{array}$ & $\begin{array}{r}39,320 \\
92,350 \\
118,900 \\
104,700 \\
62,470\end{array}$ & $\begin{array}{r}399,000 \\
2,230,000 \\
1,630,000 \\
1,400,000 \\
862,000\end{array}$ & $\begin{array}{l}216 \\
135 \\
562 \\
672 \\
392\end{array}$ & $\begin{array}{l}3,700 \\
5,990 \\
7,710 \\
5,910 \\
4,900\end{array}$ & 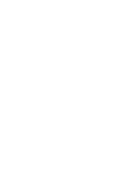 \\
\hline $\begin{array}{l}1945 \\
1946 \\
1947 \\
1948\end{array}$ & $\begin{array}{l}2,096,850 \\
1,748,700 \\
2,764,370 \\
2,091,130 \\
2,468,740\end{array}$ & $\begin{array}{l}4,159,000 \\
3,469,000 \\
5,484,000 \\
4,148,000 \\
4,897,000\end{array}$ & $\begin{array}{r}13,530,000 \\
9,400,000 \\
28,460,000 \\
16,730,000 \\
22,570,000\end{array}$ & $\begin{array}{l}37,070 \\
25,760 \\
77,970 \\
45,710 \\
61,840\end{array}$ & $\begin{array}{r}293,000 \\
213,000 \\
821,000 \\
505,000 \\
3629,000\end{array}$ & $\begin{array}{r}286 \\
297 \\
583 \\
0 \\
270\end{array}$ & $\begin{array}{l}2,390 \\
1,990 \\
3,810 \\
2,960 \\
3,390\end{array}$ & $\begin{array}{l}13,800 \\
24,300 \\
30,300 \\
14,600 \\
10,400\end{array}$ \\
\hline $\begin{array}{l}1950 \ldots \\
1951 \\
1952 \\
1953 \ldots \\
1954 \ldots\end{array}$ & $\begin{array}{l}2,778,247 \\
2,380,580 \\
3,447,270 \\
1,711,600 \\
1,320,060\end{array}$ & $\begin{array}{l}5,511,000 \\
4 ; 722,000 \\
6,838,000 \\
3,395,000 \\
2,618,000\end{array}$ & $\begin{array}{r}19,330,000 \\
14,590,000 \\
32,370,000 \\
7,854,000 \\
7,381,000\end{array}$ & $\begin{array}{l}52,960 \\
39,990 \\
88,440 \\
21,520 \\
20,220\end{array}$ & 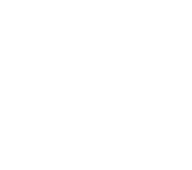 & $\begin{array}{r}251 \\
151 \\
151,000 \\
129 \\
120\end{array}$ & $\begin{array}{l}2,580 \\
2,270 \\
3,480 \\
1,700 \\
2,070\end{array}$ & $\begin{array}{l}10,000 \\
38,800 \\
15,300 \\
19,800 \\
62,100\end{array}$ \\
\hline $\begin{array}{l}1955 \\
1956 \\
1957\end{array}$ & $\begin{array}{l}1,431,336 \\
2,045,186 \\
2,773,028\end{array}$ & $\begin{array}{l}2,839,000 \\
4,056,000 \\
5,501,000\end{array}$ & $\begin{array}{l}11,600,000 \\
15,820,000 \\
23,610,000\end{array}$ & $\begin{array}{l}31,780 \\
43,220 \\
64,680\end{array}$ & $\begin{array}{r}482,000 \\
445,000 \\
3646,000\end{array}$ & $\begin{array}{r}213 \\
54 \\
94\end{array}$ & $\begin{array}{l}3,000 \\
2,860 \\
3,150\end{array}$ & $\begin{array}{l}41,800 \\
13,400 \\
27,000\end{array}$ \\
\hline
\end{tabular}

3285. San Rafael River near Green River, Utah

\begin{tabular}{|c|c|c|c|c|c|c|c|c|}
\hline $\begin{array}{l}\text { Mar. } 1 \text { to Sept. } 30,1948 \\
1949 \\
1951 \\
1952 \\
1953\end{array}$ & $\begin{array}{r}24,237.9 \\
65,947.3 \\
34,420.2 \\
158,681 \\
40,796.4\end{array}$ & $\begin{array}{r}48,080 \\
130,800 \\
68,280 \\
314,800 \\
80,930\end{array}$ & $\begin{array}{r}606,100 \\
1,767,000 \\
1,633,000 \\
4,760,000 \\
483,300\end{array}$ & $\begin{array}{r}2,830 \\
4,840 \\
4,470 \\
13,010 \\
1,320\end{array}$ & $\begin{array}{r}35786,000 \\
34236,000 \\
3474,000\end{array}$ & ${ }^{16} .5$ & $\begin{array}{r}9,260 \\
9,920 \\
17,570 \\
11,110 \\
4,390\end{array}$ & $\begin{array}{r}67,300 \\
49,400\end{array}$ \\
\hline $\begin{array}{l}1954 \\
19556 \\
1956 \\
1957\end{array}$ & $\begin{array}{l}20,581.6 \\
16,015.5 \\
17,254.3 \\
78,160\end{array}$ & $\begin{array}{r}40,830 \\
31,770 \\
34,230 \\
155,000\end{array}$ & $\begin{array}{r}413,800 \\
306,700 \\
359,400 \\
2,124,000\end{array}$ & $\begin{array}{r}1,130 \\
840 \\
982 \\
5,820\end{array}$ & $\begin{array}{r}4104,000 \\
450,200 \\
490,400 \\
4292,000\end{array}$ & $\begin{array}{l}0 \\
0\end{array}$ & $\begin{array}{r}7,450 \\
7,090 \\
7,710 \\
10,060\end{array}$ & $\begin{array}{r}62,600 \\
60,500 \\
103,000 \\
85,600\end{array}$ \\
\hline
\end{tabular}

1 Includes estimated loads for missing days.

2 Computed from concentration graph based on one size sample and a composite

3 Computed from partly estimated concentration graph. concentration.

\$ Computed by subdividing day. 
TABLE 18.-Estimated suspended-sediment discharge at selected stations in the subbasins in the Green division [Data are for the water years 1914-57 adjusted to 1957 conditions, except as indicated]

\begin{tabular}{|c|c|c|c|c|c|}
\hline \multirow[b]{2}{*}{ Station No. } & \multirow[b]{2}{*}{ Station name } & \multirow{2}{*}{$\begin{array}{c}\text { A verage } \\
\text { water dis- } \\
\text { charge (cfs) }\end{array}$} & \multicolumn{3}{|c|}{ Suspended sediment } \\
\hline & & & $\begin{array}{c}\text { Weighted- } \\
\text { average } \\
\text { concentration } \\
\text { (ppm) }\end{array}$ & \multicolumn{2}{|c|}{ Load } \\
\hline \multicolumn{6}{|c|}{ Green River basin above the Yampa River } \\
\hline \multicolumn{6}{|c|}{ Yampa River basin } \\
\hline $\begin{array}{l}2510 \mathrm{~A} \\
2550 \\
2555 \\
2595 \mathrm{C}\end{array}$ & $\begin{array}{l}\text { Yampa River at bridge on county road, near Maybell, Colo. } \\
\text { Slater Fork near Slater, Colo. } \\
\text { Savery Creek at upper station, near Savery, Wyo } \\
\text { Little Snake River at bridge on State Highway 318, near Lily, Colo. }\end{array}$ & $\begin{array}{c}1,590 \\
84 \\
50.8 \\
622\end{array}$ & $\begin{array}{r}196 \\
212 \\
146 \\
1,790\end{array}$ & $\begin{array}{r}308,000 \\
17,500 \\
7,300 \\
1,099,000\end{array}$ & $\begin{array}{r}90 \\
109 \\
39 \\
295\end{array}$ \\
\hline \multicolumn{6}{|c|}{ Green River basin between the Yampa and White Rivers including the White River basin } \\
\hline $\begin{array}{l}2610 \\
3030\end{array}$ & $\begin{array}{l}\text { Green River near Jensen, Utah } \\
\text { White River at Buford, Colo }\end{array}$ & $\begin{array}{r}4,607 \\
331\end{array}$ & $\begin{array}{r}1,300 \\
102\end{array}$ & $\begin{array}{r}5,902,000 \\
33,240\end{array}$ & $\begin{array}{l}226 \\
131\end{array}$ \\
\hline \multicolumn{6}{|c|}{ Green River basin below the White River } \\
\hline $\begin{array}{l}3070 \\
3145 \\
3150 \\
3285\end{array}$ & $\begin{array}{l}\text { Green River near Ouray, Utah }{ }^{2} \\
\text { Price River at Woodside, Utah } \\
\text { Green River at Green River, Utah }{ }^{3} \\
\text { San Rafael River near Green River, Utah }\end{array}$ & $\begin{array}{r}6,140 \\
116 \\
5,614 \\
141\end{array}$ & $\begin{array}{r}2,120 \\
33,900 \\
3,760 \\
6,700\end{array}$ & $\begin{array}{r}12,824,000 \\
3,879,000 \\
20,800,000 \\
931,400\end{array}$ & $\begin{array}{r}361 \\
2,586 \\
512 \\
551\end{array}$ \\
\hline
\end{tabular}

1 Water years 1948-57.

2 December 1,1950 to September 30, 1955, November 1, 1956, to September 30, 1957. 
TABLE 19.-Suitability of surface water for irrigation in the subbasins in the Green division

[Calcium $a$, to adjust water to 70 percent sodium, calcium $b$, to offset bicarbonate precipitation; and calcium $c$, to supply calcium plus magnesium taken by plants in excess of sodium]

\begin{tabular}{|c|c|c|c|c|c|c|c|c|c|c|c|c|c|c|}
\hline \multirow{4}{*}{$\begin{array}{c}\text { Station } \\
\text { No. }\end{array}$} & \multirow{4}{*}{ Source } & \multirow{4}{*}{ Date } & \multicolumn{2}{|c|}{ Water discharge } & \multirow{4}{*}{$\begin{array}{l}\text { Specific } \\
\text { conduct- } \\
\text { ance } \\
\text { (micro- } \\
\text { mhos at } \\
25^{\circ} \mathrm{C} \text { ) }\end{array}$} & \multirow{4}{*}{$\begin{array}{l}\text { Per- } \\
\text { cent } \\
\text { so- } \\
\text { dium }\end{array}$} & \multirow{4}{*}{$\begin{array}{l}\text { Sodium- } \\
\text { adsorp- } \\
\text { tion- } \\
\text { ratio }\end{array}$} & \multirow{4}{*}{$\begin{array}{c}\text { Resid- } \\
\text { ual } \\
\text { sodium } \\
\text { carbon- } \\
\text { ate }\end{array}$} & \multicolumn{6}{|c|}{ Classification } \\
\hline & & & \multirow{3}{*}{$\begin{array}{c}\text { Cubic } \\
\text { feet } \\
\text { per } \\
\text { second }\end{array}$} & \multirow{3}{*}{$\begin{array}{l}\text { Classi- } \\
\text { fication }\end{array}$} & & & & & \multirow{3}{*}{$\begin{array}{c}\text { After U.S. } \\
\text { Salinity } \\
\text { Laboratory } \\
\text { staff, } \\
\mathbf{1 9 5 4}\end{array}$} & \multicolumn{5}{|c|}{ After Eaton (1954)1 } \\
\hline & & & & & & & & & & $\begin{array}{l}\text { Cal- } \\
\text { cium } a\end{array}$ & $\begin{array}{c}\text { Cal- } \\
\text { cium } b\end{array}$ & $\begin{array}{c}\text { Cal- } \\
\text { cium } c\end{array}$ & \multirow{2}{*}{$\begin{array}{c}\text { Re- } \\
\text { quired } \\
\text { leach- } \\
\text { ing } \\
\text { (per- } \\
\text { cent) }\end{array}$} & \multirow{2}{*}{$\begin{array}{c}\text { Re- } \\
\text { quired } \\
\text { gypsum } \\
\text { (lb per } \\
\text { acre-ft) }\end{array}$} \\
\hline & & & & & & & & & & \multicolumn{3}{|c|}{$\begin{array}{l}\text { Milliequivalents per } \\
\text { liter }\end{array}$} & & \\
\hline
\end{tabular}

Green River basin above the Yampa River

\begin{tabular}{|c|c|c|c|c|c|c|c|c|c|c|c|c|c|c|}
\hline 1885 & $\begin{array}{l}\text { Green River at Warren Bridge, } \\
\text { near Daniel, W yo. }\end{array}$ & $\begin{array}{r}10-3-39 \\
5-15-58\end{array}$ & $\begin{array}{r}246 \\
21,040\end{array}$ & $\begin{array}{l}\text { Mediu } \\
\text { High. }\end{array}$ & 294 & 4 & 0.1 & $\begin{array}{r}0.00 \\
.00\end{array}$ & & $\begin{array}{l}-3.54 \\
-2.90\end{array}$ & $\begin{array}{l}1.45 \\
2.00\end{array}$ & $\begin{array}{r}0.29 \\
.30\end{array}$ & $\begin{array}{l}2.7 \\
1.4\end{array}$ & $\begin{array}{l}0 \\
0\end{array}$ \\
\hline 1890 & Beaver Creek near Daniel, Wyo.- & $8-2-58$ & 2.5 & & 448 & & & .00 & & -4.78 & 4.77 & .30 & .9 & 68 \\
\hline & Horse Creek near Daniel, Wyo.- & $\begin{array}{l}5-15-58 \\
8-3-58\end{array}$ & $\begin{array}{r}2209 \\
210\end{array}$ & $\begin{array}{l}\text { High } \\
\text { Medium..... }\end{array}$ & $\begin{array}{l}326 \\
375\end{array}$ & & & $\begin{array}{l}.00 \\
.12\end{array}$ & C2-S1.. & $\begin{array}{l}-3.19 \\
-3.57\end{array}$ & $\begin{array}{l}3.23 \\
3.88\end{array}$ & $\begin{array}{l}.30 \\
.30\end{array}$ & $\begin{array}{r}.8 \\
1.3\end{array}$ & $\begin{array}{r}80 \\
143\end{array}$ \\
\hline 1915 & $\begin{array}{l}\text { Cottonwood Creek near Daniel, } \\
\text { Wyo. }\end{array}$ & $8-3-58$ & 230 & Medium. & 439 & $\cdots$ & $\cdots$ & .00 & & -4.25 & 4.45 & .30 & 1.5 & 117 \\
\hline 1970 & $\begin{array}{l}\text { Pine Creek at Fremont Lake } \\
\text { outlet, Wyo. }\end{array}$ & $4-21-49$ & -... & & 26 & 25 & .2 & .00 & C1-S1. & -.15 & .09 & .30 & .6 & 56 \\
\hline 80 & $\begin{array}{l}\text { Pine Creek at Pinedale, Wyo... } \\
\text { New Fork River near Boulder. }\end{array}$ & $\begin{array}{l}8-31-39 \\
8-26-39\end{array}$ & $\begin{array}{r}48 \\
130\end{array}$ & Mediu & 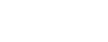 & $\begin{array}{r}3 \\
14\end{array}$ & .0 & .00 & & -.24 & $\begin{array}{r}.22 \\
186\end{array}$ & .30 & .5 & $\begin{array}{l}66 \\
84\end{array}$ \\
\hline & $\begin{array}{l}\text { New fork River near Boulder, } \\
\text { Wyo. }\end{array}$ & $5-15-58$ & 2525 & High... & 103 & 14 & .3 & .09 & & $\begin{array}{r}-1.80 \\
-.80\end{array}$ & $\begin{array}{r}1.86 \\
.97\end{array}$ & .30 & .8 & $\begin{array}{r}84 \\
110\end{array}$ \\
\hline 2030 & $\begin{array}{l}\text { East Fork near Big Sandy, } \\
\text { Wyo. }\end{array}$ & $\begin{array}{l}5-17-58 \\
8-2-58\end{array}$ & $\begin{array}{rl}2 & 295 \\
321\end{array}$ & $\begin{array}{l}\text { High } \\
\text { Medium..... }\end{array}$ & $\begin{array}{l}34 \\
27\end{array}$ & & $-\ldots$ & $\begin{array}{l}.04 \\
.02\end{array}$ & C1-S1_.. & $\begin{array}{l}-.27 \\
-.19\end{array}$ & $\begin{array}{l}.34 \\
.26\end{array}$ & $\begin{array}{l}.30 \\
.30\end{array}$ & .5 & $\begin{array}{r}87 \\
87\end{array}$ \\
\hline 2045 & $\begin{array}{l}\text { East Fork at New Fork, Wyo... } \\
\text { North Piney Creek near } \\
\text { Mason, Wyo. }\end{array}$ & $\begin{array}{l}5-15-58 \\
8-3-58\end{array}$ & $\begin{array}{r}2458 \\
235\end{array}$ & $\begin{array}{l}\text { High } \\
\text { Medium.-. }\end{array}$ & $\begin{array}{r}63 \\
329\end{array}$ & -... & & .11 & C2-S1_- & -3.39 & $\begin{array}{r}.59 \\
2.74\end{array}$ & $\begin{array}{l}.30 \\
.30\end{array}$ & $\begin{array}{r}.8 \\
1.2\end{array}$ & $\begin{array}{r}117 \\
0\end{array}$ \\
\hline $2055 \mathrm{~A}$ & $\begin{array}{l}\text { North Piney Creek at Big } \\
\text { Piney, Wyo. }\end{array}$ & $\begin{array}{r}10-10-39 \\
5-15-58\end{array}$ & $\begin{array}{l}320 \\
294\end{array}$ & $\begin{array}{l}\text { Mediu } \\
\text { High.. }\end{array}$ & 1,060 & $\begin{array}{l}29 \\
40\end{array}$ & $\begin{array}{l}1.5 \\
2.6\end{array}$ & .00 & $\mathrm{C} 3-\mathrm{S} 1$ & $\begin{array}{l}-4.96 \\
-5.33\end{array}$ & $\begin{array}{l}\text { 5. } 02 \\
\text { 5. } 92\end{array}$ & .28 & $\begin{aligned} 6.0 \\
10\end{aligned}$ & $\begin{array}{r}80 \\
201\end{array}$ \\
\hline 2085 & $\begin{array}{l}\text { La Barge Creek near Viola, } \\
\text { Wyo. }\end{array}$ & $\begin{array}{r}10-8-47 \\
5-14-58\end{array}$ & $\begin{array}{r}72 \\
2364\end{array}$ & $\begin{array}{l}\text { Medium. } \\
\text { High }\end{array}$ & $\begin{array}{r}463 \\
315\end{array}$ & 4 & .1 & .00 & & $\begin{array}{l}-4.90 \\
-2.98\end{array}$ & $\begin{array}{l}3.70 \\
2.49\end{array}$ & .29 & $\begin{array}{l}2.2 \\
1.0\end{array}$ & 0 \\
\hline $2090 \mathrm{~A}$ & $\begin{array}{l}\text { Green River below La Barge, } \\
\text { Wyo. }\end{array}$ & $\begin{array}{r}6-2-47 \\
10-8-47\end{array}$ & $\begin{array}{r}3520 \\
31,020\end{array}$ & $\begin{array}{l}\text { High } \\
\text { Medium...... }\end{array}$ & $\begin{array}{l}296 \\
319\end{array}$ & 13 & .4 & .00 & & $\begin{array}{l}-2.56 \\
-2.71\end{array}$ & $\begin{array}{l}2.42 \\
2.46\end{array}$ & .30 & $\begin{array}{l}1.1 \\
1.4\end{array}$ & $\begin{array}{l}37 \\
12\end{array}$ \\
\hline 2095 & $\begin{array}{l}\text { Green River near Fontenelle, } \\
\text { Wyo. }\end{array}$ & $\begin{array}{r}5-14-58 \\
8-4-58\end{array}$ & $\begin{array}{l}2 \\
2\end{array}, 970$ & $\begin{array}{l}\text { High } \\
\text { Medium... }\end{array}$ & $\begin{array}{l}317 \\
326\end{array}$ & & & .00 & $\mathrm{C} 2-\mathrm{S} 1$ & $\begin{array}{l}-2.68 \\
-2.59\end{array}$ & 2.48 & .30 & 1.3 & $\begin{array}{l}23 \\
61\end{array}$ \\
\hline 2105 & $\begin{array}{l}\text { Fontenelle Creek near Herschler } \\
\text { Ranch, near Fontenelle, w yo. }\end{array}$ & $\begin{array}{l}5-14-58 \\
8-4-58\end{array}$ & $\begin{array}{r}1,500 \\
238\end{array}$ & High & $\begin{array}{l}309 \\
401\end{array}$ & & & $\begin{array}{l}.00 \\
.00\end{array}$ & & $\begin{array}{l}-2.69 \\
-3.92\end{array}$ & $\begin{array}{l}2.65 \\
3.63\end{array}$ & $\begin{array}{l}.30 \\
.30\end{array}$ & $\begin{array}{l}1.2 \\
1.2\end{array}$ & 61 \\
\hline $2110 A$ & Fontenelle Creek at Fontenelle, & $10-10-39$ & & - & & 10 & .4 & .00 & & -4.60 & 3. 78 & .29 & 2.1 & 0 \\
\hline & wy & $\begin{array}{l}5-14-58 \\
8-4-58\end{array}$ & $\begin{array}{r}259 \\
26.0\end{array}$ & $\begin{array}{l}\text { High. } \\
\text { Low.. }\end{array}$ & $\begin{array}{l}446 \\
547\end{array}$ & 26 & 1.1 & $\begin{array}{l}.00 \\
.00\end{array}$ & \}C2-S1. & $\begin{array}{l}-4.03 \\
-3.79\end{array}$ & $\begin{array}{l}3.56 \\
3.30\end{array}$ & .29 & $\begin{array}{l}1.9 \\
4.0\end{array}$ & $\begin{array}{l}0 \\
0\end{array}$ \\
\hline $2110 \mathrm{~B}$ & $\begin{array}{l}\text { Slate Creek near Fontenelle, } \\
\text { Wyo. }\end{array}$ & $\begin{array}{r}10-24-57 \\
5-14-58 \\
8-5-58\end{array}$ & $\begin{array}{r}2 \\
2 \\
2.2 \\
3.5\end{array}$ & (n) & $\begin{array}{r}1,490 \\
720 \\
1,300\end{array}$ & $\begin{array}{l}43 \\
41 \\
53\end{array}$ & $\begin{array}{l}3.3 \\
2.1 \\
4.1\end{array}$ & $\begin{array}{l}.00 \\
.00 \\
.00\end{array}$ & C2-S1 & $\begin{array}{l}-6.54 \\
-3.19 \\
-3.37\end{array}$ & $\begin{array}{l}3.36 \\
2.46 \\
1.84\end{array}$ & $\begin{array}{l}.22 \\
.28 \\
.24\end{array}$ & $\begin{array}{l}28 \\
7.8\end{array}$ & $\stackrel{0}{0}$ \\
\hline $2110 \mathrm{C}$ & $\begin{array}{l}\text { Unnamed tributary of Green } \\
\text { River, near Fontenelle, Wyo. }\end{array}$ & $5-14-58$ & 2.1 & Low $\ldots$ & 1,100 & 47 & 3. 0 & .00 & C3 & -3.41 & .00 & .25 & 16 & 0 \\
\hline $2110 \mathrm{D}$ & Buckhorn Canyon Creek near & $5-14-58$ & & & 4,660 & 76 & 16 & .00 & C4-S & & & & 100 & \\
\hline 2125 & $\begin{array}{l}\text { Farson, W yo. } \\
\text { Big Sandy Creek at Leckie } \\
\text { Ranch, near Big Sandy, } \\
\text { Wyo. }\end{array}$ & $\begin{array}{r}5-17-58 \\
8-2-58\end{array}$ & $\begin{array}{l}2188 \\
227\end{array}$ & Migh & $\begin{array}{l}51 \\
47\end{array}$ & & & $\begin{array}{l}.02 \\
.05\end{array}$ & \} $\mathrm{C} 1$ & $\begin{array}{l}-.30 \\
-.33\end{array}$ & .39 & $\begin{array}{l}.30 \\
.30\end{array}$ & .7 & $\begin{array}{l}91 \\
89\end{array}$ \\
\hline $2125 \mathrm{~A}$ & $\begin{array}{l}\text { Big Sandy Creek at Buckskin } \\
\text { Crossing, near Big Sandy, } \\
\text { Wyo. }\end{array}$ & $5-(?)-39$ & & & & 33 & .3 & .10 & & -.16 & .30 & .30 & .7 & 103 \\
\hline 2130 & $\begin{array}{l}\text { Big Sandy Creek near Eden, } \\
\text { Wyo. }\end{array}$ & $5-(?)-39$ & & & & 17 & .2 & .00 & 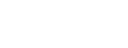 & -.46 & .40 & .30 & .4 & 56 \\
\hline 2135 & $\begin{array}{l}\text { Big Šandy Creek near Farson, } \\
\text { Wyo. }\end{array}$ & $\begin{array}{l}1-7-57 \\
4-1-57 \\
7-1-57\end{array}$ & $\begin{array}{r}5.0 \\
40 \\
835\end{array}$ & Low & $\begin{array}{r}156 \\
158 \\
65\end{array}$ & $\begin{array}{l}29 \\
35 \\
29\end{array}$ & $\begin{array}{l}.6 \\
.8 \\
.4\end{array}$ & $\begin{array}{l}.03 \\
.00 \\
.00\end{array}$ & & $\begin{array}{l}-.80 \\
=.72 \\
-.35\end{array}$ & $\begin{array}{r}1.00 \\
.85 \\
.42\end{array}$ & $\begin{array}{l}.30 \\
.30 \\
.30\end{array}$ & $\begin{array}{l}1.2 \\
1.4 \\
.8\end{array}$ & $\begin{array}{r}117 \\
101 \\
87\end{array}$ \\
\hline $2135 B$ & $\begin{array}{l}\text { Continental Divide ditch near } \\
\text { Little Prospect Mountain, } \\
\text { Wyo. }\end{array}$ & $5-17-58$ & 3.5 & - & 37 & & & .04 & & -.10 & .30 & .30 & .7 & 96 \\
\hline 2140 & $\begin{array}{l}\text { Little Sandy Creek near } \\
\text { Elkhorn, W yo. }\end{array}$ & $\begin{array}{r}5-17-58 \\
8-2-58\end{array}$ & $\begin{array}{l}238 \\
27.6\end{array}$ & $\begin{array}{l}\text { High } \\
\text { Medium..... }\end{array}$ & $\begin{array}{l}38 \\
44\end{array}$ & & & $\begin{array}{l}.00 \\
.05\end{array}$ & & $\begin{array}{l}-.26 \\
-.35\end{array}$ & $\begin{array}{l}.31 \\
.43\end{array}$ & $\begin{array}{l}.30 \\
.30\end{array}$ & .6 & $\begin{array}{l}82 \\
89\end{array}$ \\
\hline 2145 & $\begin{array}{l}\text { Little Sandy Creek above } \\
\text { Eden, Wyo. }\end{array}$ & $\begin{array}{r}1-7-57 \\
4-29-57 \\
7-1-57\end{array}$ & $23^{.5}$ & Low & $\begin{array}{r}1,250 \\
540\end{array}$ & 38 & 2.0 & .00 & C3-S1. & $\begin{array}{l}-6.28 \\
-1.80 \\
-70\end{array}$ & $\begin{array}{l}3.41 \\
1.54\end{array}$ & .26 & $\begin{aligned} 15 \\
5.3\end{aligned}$ & \\
\hline 2150 & $\begin{array}{l}\text { Pacific Creek near Farson, } \\
\text { Wyo. }\end{array}$ & $\begin{array}{r}7-1-57 \\
1-3-56 \\
3-26-56 \\
11-19-56\end{array}$ & $\begin{array}{l}147 \\
10 \\
70 \\
.2\end{array}$ & $\begin{array}{l}\text { High } \\
\text { Medium. } \\
\text { High..... } \\
\text { Low }\end{array}$ & $\begin{array}{r}140 \\
2,800 \\
990 \\
4,130\end{array}$ & $\begin{array}{l}32 \\
77 \\
59 \\
83\end{array}$ & $\begin{array}{c}13 \\
4.3 \\
20^{.6}\end{array}$ & $\begin{array}{r}.00 \\
.22 \\
.00 \\
3.04\end{array}$ & $\begin{array}{l}\text { C1-S1-- } \\
\text { C4-S3-- } \\
\text { C3-S1-: } \\
\text { C4-S4-- }\end{array}$ & $\begin{array}{r}-.70 \\
3: 21 \\
-1.56\end{array}$ & $\begin{array}{l}.68 \\
3.87 \\
3.40\end{array}$ & $\begin{array}{l}.30 \\
.16 \\
.27\end{array}$ & $\begin{array}{l}1.2 \\
70 \\
13 \\
100\end{array}$ & $\begin{array}{r}66 \\
1,690 \\
494\end{array}$ \\
\hline 2160 & $\begin{array}{l}\text { Big Sandy Creek below Eden, } \\
\text { Wyo. }\end{array}$ & $\begin{array}{r}11-18-57 \\
1-27-58\end{array}$ & $35^{.2}$ & Medium. & $\begin{array}{l}3,130 \\
3,560\end{array}$ & $\begin{array}{l}00 \\
50 \\
42\end{array}$ & $\begin{array}{r}6.1 \\
5.3\end{array}$ & $\begin{array}{l}0.00 \\
.00 \\
.00\end{array}$ & \}C4-S2 & $=10.69$ & .49 & .05 & $\begin{array}{r}84 \\
100\end{array}$ & 0 \\
\hline 2165 & $\begin{array}{l}\text { Green River at Green River, } \\
\text { Wyo. }\end{array}$ & $\begin{array}{r}6-2-58 \\
12-54 \\
3-57\end{array}$ & $\begin{array}{r}296 \\
288 \\
928\end{array}$ & How & $\begin{array}{r}533 \\
927 \\
731\end{array}$ & $\begin{array}{l}46 \\
46 \\
32 \\
34\end{array}$ & $\begin{array}{l}2.0 \\
2.0 \\
1.7 \\
1.7\end{array}$ & $\begin{array}{l}.00 \\
.00 \\
.00\end{array}$ & $\begin{array}{l}\text { C2-S1 } \\
\text { C3-S1-. } \\
\text { C2-S1 }\end{array}$ & $\begin{array}{l}-1.75 \\
-5.58 \\
-4.07\end{array}$ & $\begin{array}{l}1.32 \\
3.75 \\
2.91\end{array}$ & $\begin{array}{r}.28 \\
.27 \\
.28\end{array}$ & $\begin{array}{l}5.4 \\
8.9 \\
6.8\end{array}$ & $\begin{array}{r}0 \\
0\end{array}$ \\
\hline 2165A & $\begin{array}{l}\text { Bitter Creek at Bitter Creek, } \\
\text { Wyo. }\end{array}$ & $\begin{array}{r}6-57 \\
5-17-58\end{array}$ & ${ }_{2.6}^{8,007}$ & High..... & $\begin{array}{r}326 \\
1,510\end{array}$ & $\begin{array}{l}18 \\
84\end{array}$ & $12^{.5}$ & $\begin{array}{r}.00 \\
2.87\end{array}$ & C3-S3 & $\begin{array}{r}-2.46 \\
3.27\end{array}$ & $\begin{array}{l}2.39 \\
4.44\end{array}$ & $\begin{array}{l}.30 \\
.25\end{array}$ & 32.8 & $\begin{array}{r}54 \\
1,860\end{array}$ \\
\hline $2165 \mathrm{C}$ & $\begin{array}{l}\text { Bitter Creek at Thayer Junc- } \\
\text { tion, Wyo. }\end{array}$ & $\begin{array}{l}4-17-41 \\
5-17-58\end{array}$ & 23.3 & & $\begin{array}{r}970 \\
1,530\end{array}$ & $\begin{array}{l}68 \\
72\end{array}$ & $\begin{array}{l}6.1 \\
7.5\end{array}$ & .00 & $\mathrm{C} 3-\mathrm{S} 2$ & $\begin{array}{r}-.23 \\
.38\end{array}$ & $\begin{array}{l}3.12 \\
2.97\end{array}$ & .27 & $\begin{array}{l}16 \\
32\end{array}$ & $\begin{array}{l}739 \\
838\end{array}$ \\
\hline 2165D & $\begin{array}{l}\text { Salt Wells Creek near Thayer } \\
\text { Junction, Wyo. }\end{array}$ & $5-17-68$ & 217 & & 940 & 34 & 2.9 & .00 & C3-\$1. & -11.82 & 2.58 & .19 & 36 & 0 \\
\hline $2166 \mathrm{~A}$ & $\begin{array}{l}\text { Killpecker Creek near Rock } \\
\text { Springs, Wyo. }\end{array}$ & $\begin{array}{l}5-17-58 \\
8-1-58\end{array}$ & ${ }^{3}, 01$ & Low & $\begin{array}{r}1,450 \\
22,400\end{array}$ & $\begin{array}{l}80 \\
67\end{array}$ & 9.7 & $\begin{array}{r}.67 \\
00\end{array}$ & & 2.13 & 2.82 & .24 & $\begin{array}{r}32 \\
100\end{array}$ & 210 \\
\hline 2166B & $\begin{array}{l}\text { Bitter Creek } 2 \text { miles west of } \\
\text { Rock Springs, Wyo. }\end{array}$ & $5-18-58$ & ${ }^{3} 15$ & - & 1,940 & 43 & 3.8 & .00 & C3-S1 & -8.60 & 2.35 & 19 & 37 & \\
\hline
\end{tabular}

See footnotes at end of table. 
TABLE 19.-Suitability of surface water for irrigation in the subbasins in the Green division-Continued

[Calcium $a$, to adjust water to 70 percent sodium, calcium $b$, to offset bicarbonate precipitation; and calcium $c$, to supply calcium plus magnesium taken by plants in exces of sodium]

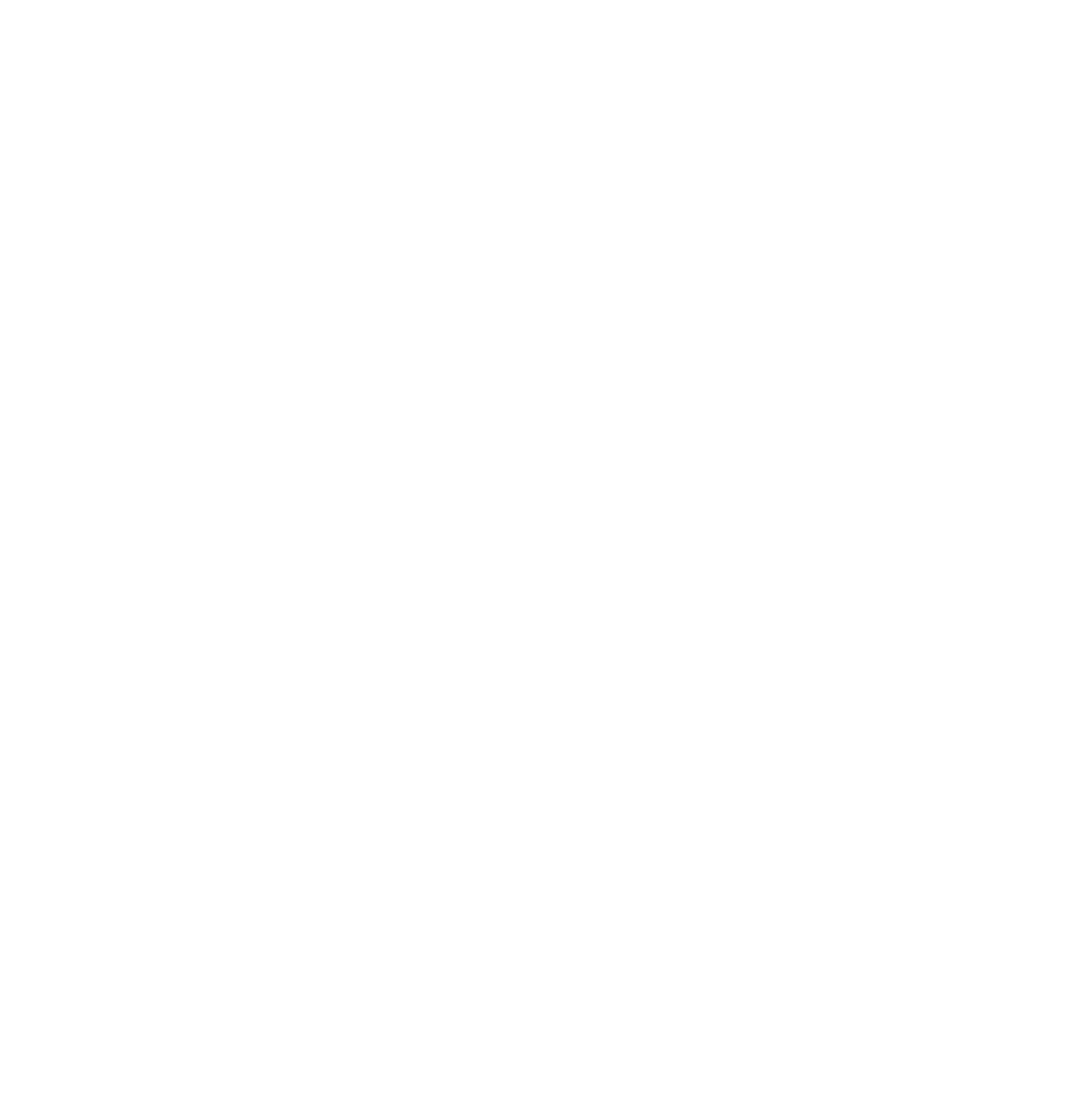

See footnotes at end of table. 
TABLE 19.-Suitability of surface water for irrigation in the subbasins in the Green division-Continued

[Calcium $a$, to adjust water to 70 percent sodium, calcium $b$, to offset bicarbonate precipitation; and calcium $c$, to supply calcium plus magnesium taken by plants in excess of sodium]

\begin{tabular}{|c|c|c|c|c|c|c|c|c|c|c|c|c|c|c|}
\hline \multirow{3}{*}{$\begin{array}{l}\text { Station } \\
\text { No. }\end{array}$} & \multirow{3}{*}{ Source } & \multirow{3}{*}{ Date } & \multicolumn{2}{|c|}{ Water discharge } & \multirow{3}{*}{$\begin{array}{l}\text { Specific } \\
\text { conduct- } \\
\text { ance } \\
\text { (micro- } \\
\text { mhos at } \\
25^{\circ} \mathrm{C} \text { ) }\end{array}$} & \multirow{3}{*}{$\begin{array}{l}\text { Per- } \\
\text { cent } \\
\text { so- } \\
\text { dium }\end{array}$} & \multirow{3}{*}{$\begin{array}{l}\text { Sodium- } \\
\text { adsorp- } \\
\text { tion- } \\
\text { ratio }\end{array}$} & \multirow{3}{*}{$\begin{array}{c}\text { Resid- } \\
\text { ual } \\
\text { sodium } \\
\text { carbon- } \\
\text { ate }\end{array}$} & \multicolumn{6}{|c|}{ Classification } \\
\hline & & & \multirow[t]{2}{*}{$\begin{array}{l}\text { Cubic } \\
\text { feet } \\
\text { per } \\
\text { second }\end{array}$} & \multirow[t]{2}{*}{$\begin{array}{l}\text { Classi- } \\
\text { fication }\end{array}$} & & & & & $\begin{array}{l}\text { After U.S. } \\
\text { Salinity } \\
\text { Laboratory } \\
\text { staff. }\end{array}$ & $\begin{array}{l}\text { Cal- } \\
\text { cium } a\end{array}$ & Caum $b$ & Cal- $c$ & \multirow{2}{*}{$\begin{array}{c}\text { Re- } \\
\text { quired } \\
\text { leach- } \\
\text { ing } \\
\text { (per- } \\
\text { cent) }\end{array}$} & \multirow{2}{*}{$\begin{array}{l}\text { Re- } \\
\text { quired } \\
\text { gypsum } \\
\text { (Ibser } \\
\text { acre-ft) }\end{array}$} \\
\hline & & & & & & & & & & \multicolumn{3}{|c|}{$\begin{array}{l}\text { Milliequivalents per } \\
\text { liter }\end{array}$} & & \\
\hline
\end{tabular}

Green River basin above the Yampa River-Continued

\begin{tabular}{|c|c|c|c|c|c|c|c|c|c|c|c|c|c|c|}
\hline 2345 & $\begin{array}{l}\text { Green River near Greendale, } \\
\text { Utah. }\end{array}$ & $\begin{array}{r}12-56 \\
3-57 \\
6-57\end{array}$ & $\begin{array}{r}416 \\
1,069\end{array}$ & Low & $\begin{array}{l}945 \\
795\end{array}$ & $\begin{array}{l}32 \\
33\end{array}$ & $\begin{array}{l}1.8 \\
1.7\end{array}$ & $\begin{array}{r}0.00 \\
.00\end{array}$ & $\int \mathrm{C} 3-\mathrm{S} 1$. & $\begin{array}{l}-5.62 \\
-4.54\end{array}$ & $\begin{array}{l}3.54 \\
3.49\end{array}$ & $\begin{array}{r}0.27 \\
.28 \\
.29\end{array}$ & $\begin{array}{l}9.8 \\
7.4\end{array}$ & $\begin{array}{r}0 \\
0 \\
12\end{array}$ \\
\hline $2350 \mathrm{~A}$ & $\begin{array}{l}\text { Beaver Creek near Ladore, } \\
\text { Colo. }\end{array}$ & $9-16-48$ & 3.2 & Low & 783 & 18 & .8 & .00 & C3-S1 & -6.75 & 5.56 & .29 & 4.6 & 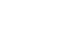 \\
\hline
\end{tabular}

Yampa River basin

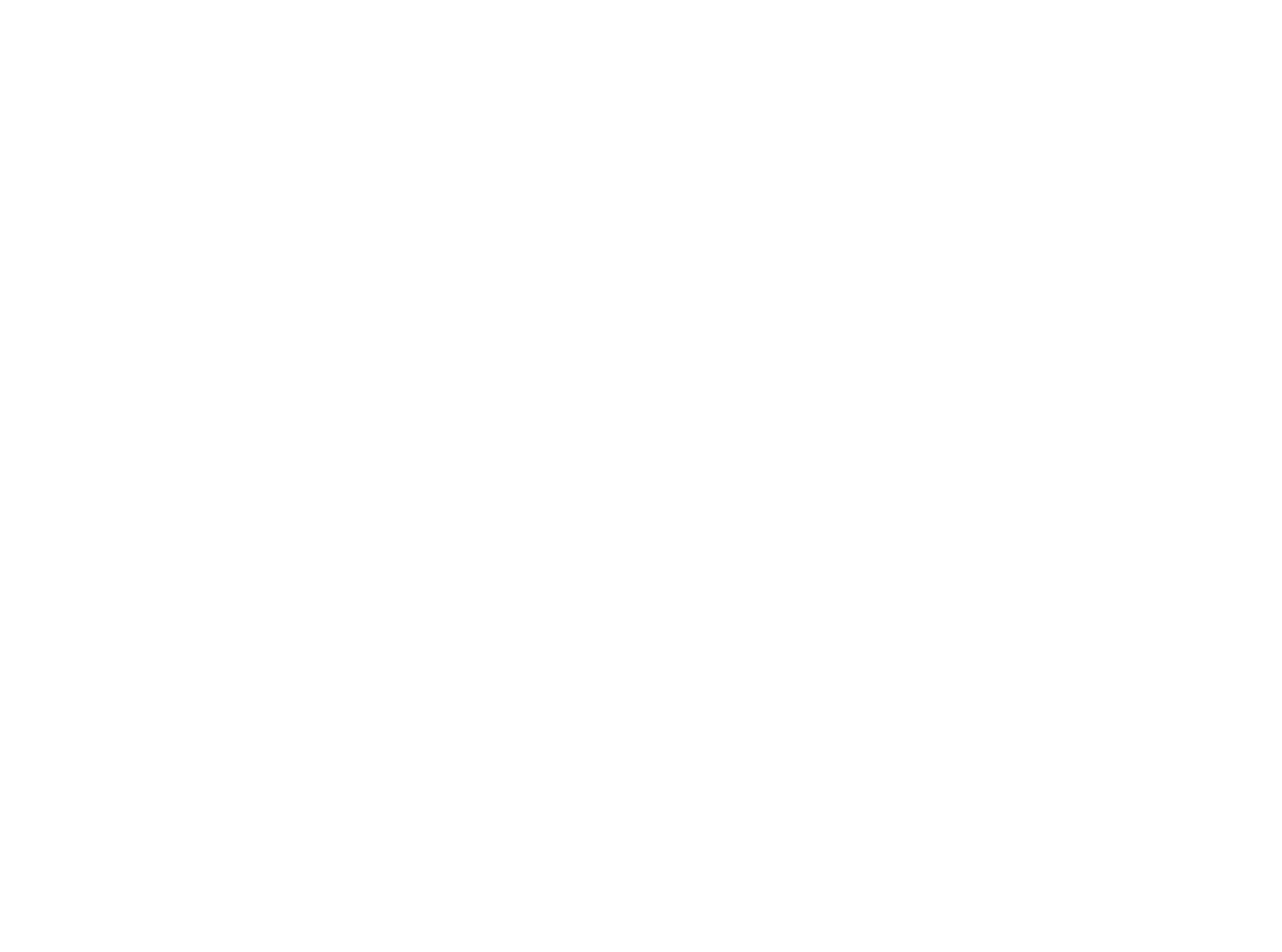

See footnotes at end of table. 
$\mathrm{T}_{\mathrm{ABLE}}$ 19.-Suitability of surface water for irrigation in the subbasins in the Green division-Continued

[Calcium $a$, to adjust water to 70 percent sodium, calcium $b$, to offset bicarbonate precipitation; and calcium $c$, to supply calcium plus magnesium taken by plants in excess

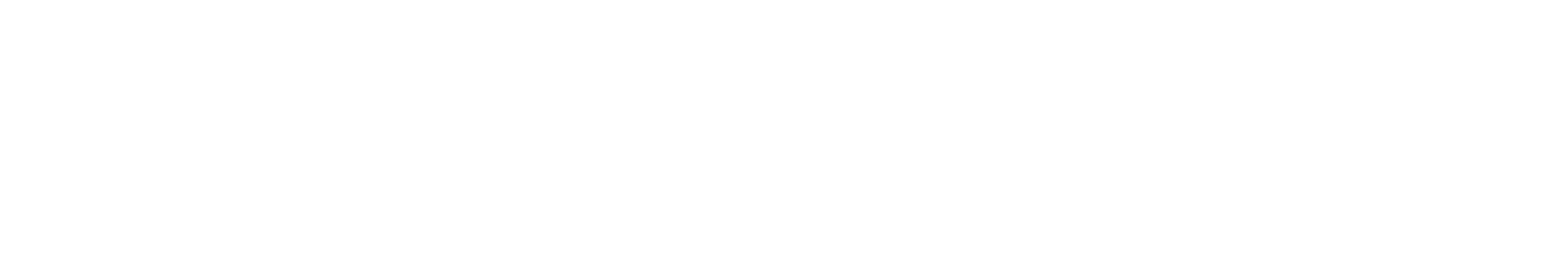

Green River basin between the Yampa and White Rivers including the White River basin

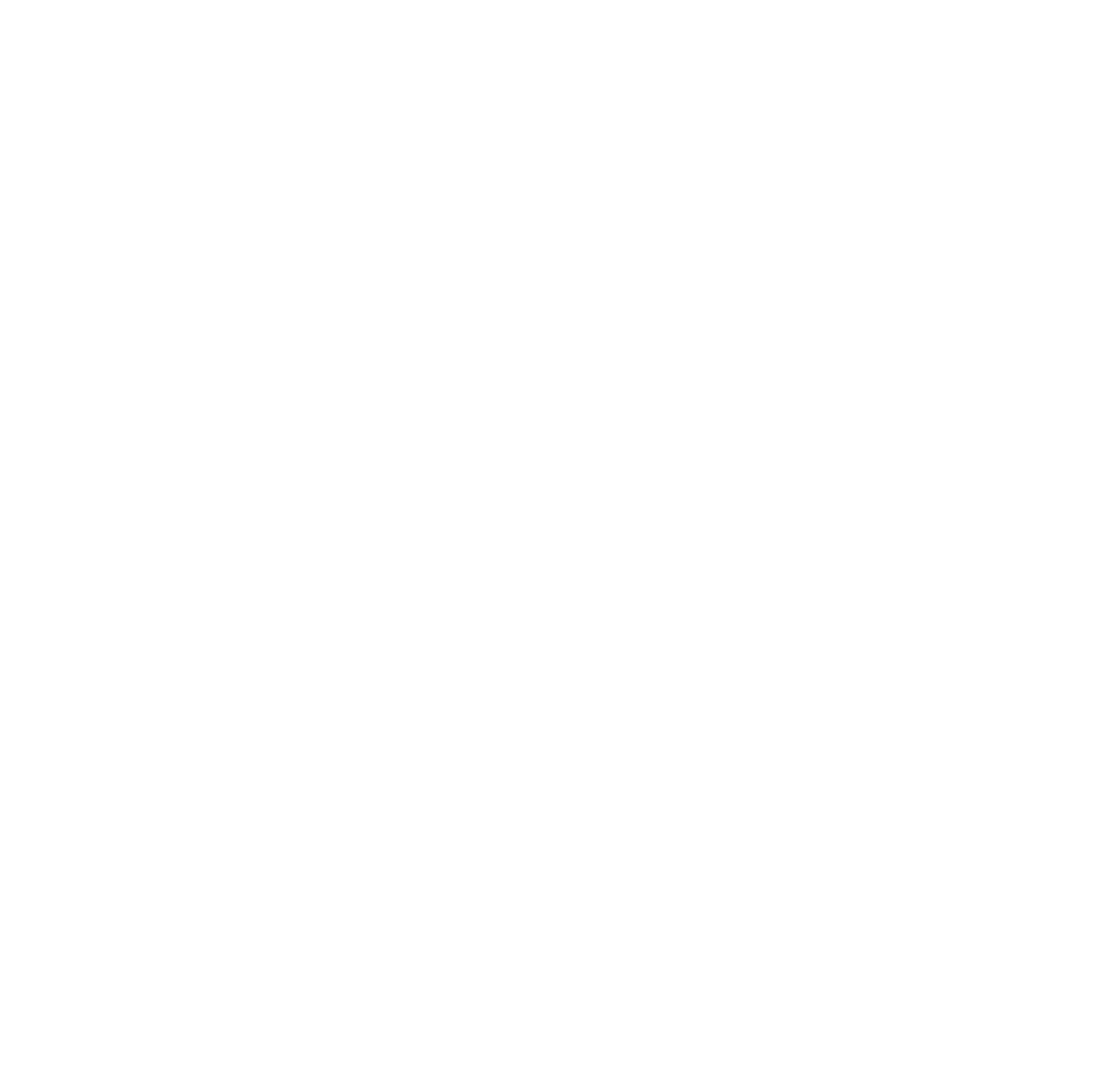

See footnotes at end of table. 
TABLE 19.-Suitability of surface water for irrigation in the subbasins in the Green division-Continued

[Calcium $a$, to adjust water to 70 percent sodium, calcium $b$, to offset bicarbonate precipitation; and calcium $c$, to supply calcium plus magnesium taken by plants in excess

\begin{tabular}{|c|c|c|c|c|c|c|c|c|c|c|c|c|c|c|}
\hline \multirow{3}{*}{$\begin{array}{l}\text { Station } \\
\text { No. }\end{array}$} & \multirow{3}{*}{ Source } & \multirow{3}{*}{ Date } & \multicolumn{2}{|c|}{ Water discharge } & \multirow{3}{*}{$\begin{array}{l}\text { Specific } \\
\text { conduct- } \\
\text { ance } \\
\text { (micro- } \\
\text { mhos at } \\
25^{\circ} \mathrm{C} \text { ) }\end{array}$} & \multirow{3}{*}{$\begin{array}{l}\text { Per- } \\
\text { cent } \\
\text { so- } \\
\text { dium }\end{array}$} & \multirow{3}{*}{$\begin{array}{l}\text { Sodium- } \\
\text { adsorp- } \\
\text { tion- } \\
\text { ratio }\end{array}$} & \multirow{3}{*}{$\begin{array}{c}\text { Resid- } \\
\text { ual } \\
\text { sodium } \\
\text { carbon- } \\
\text { ate }\end{array}$} & \multicolumn{6}{|c|}{ Classiffcation } \\
\hline & & & \multirow[t]{2}{*}{$\begin{array}{l}\text { Cuble } \\
\text { feet } \\
\text { per } \\
\text { second }\end{array}$} & \multirow[t]{2}{*}{$\begin{array}{l}\text { Classi- } \\
\text { flcation }\end{array}$} & & & & & \multirow{2}{*}{$\begin{array}{l}\text { After U.S. } \\
\text { Salinity } \\
\text { Laboratory } \\
\text { staff, } \\
1954\end{array}$} & $\begin{array}{l}\text { Cal- } \\
\text { cium } a\end{array}$ & $\begin{array}{l}\text { Cal- } \\
\text { cium } b\end{array}$ & $\begin{array}{c}\text { Cal- } \\
\text { cium } c\end{array}$ & \multirow{2}{*}{$\begin{array}{c}\text { Re- } \\
\text { quired } \\
\text { leach- } \\
\text { ing } \\
\text { (per- } \\
\text { cent) }\end{array}$} & \multirow{2}{*}{$\begin{array}{l}\text { Re- } \\
\text { quired } \\
\text { gypsum } \\
\text { (16 per } \\
\text { acre-ft) }\end{array}$} \\
\hline & & & & & & & & & & & $\begin{array}{l}\text { uivale } \\
\text { liter }\end{array}$ & & & \\
\hline
\end{tabular}

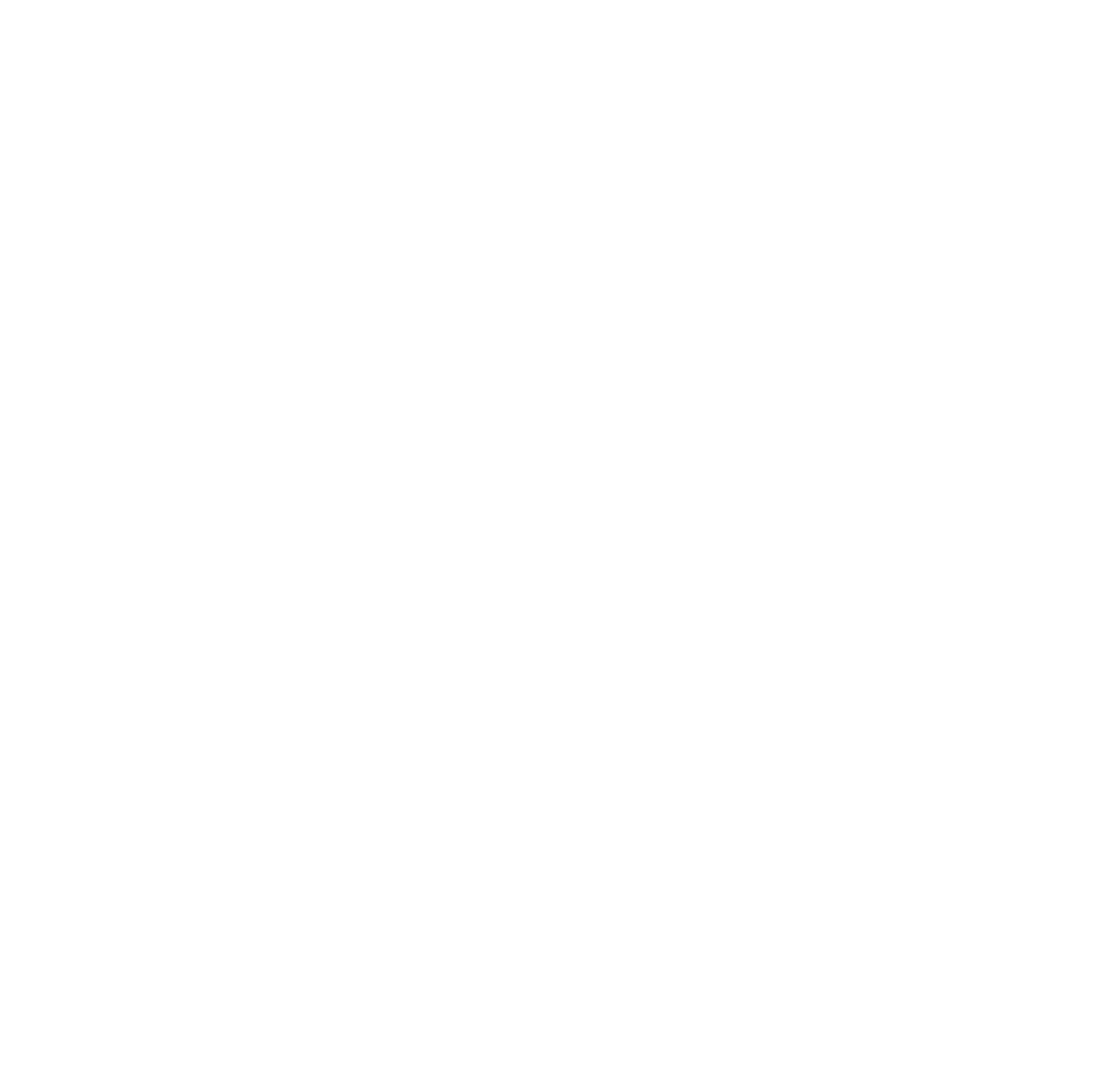

See footnotes at end of table. 
TABLE 19.-Suitability of surface water for irrigation in the subbasins in the Green division-Continued

[Calcium $a$, to adjust water to 70 percent sodium, calcium $b$, to offset bicarbonate precipitation; and calcium $c$, to supply calcium plus magnesium taken by plants in excess

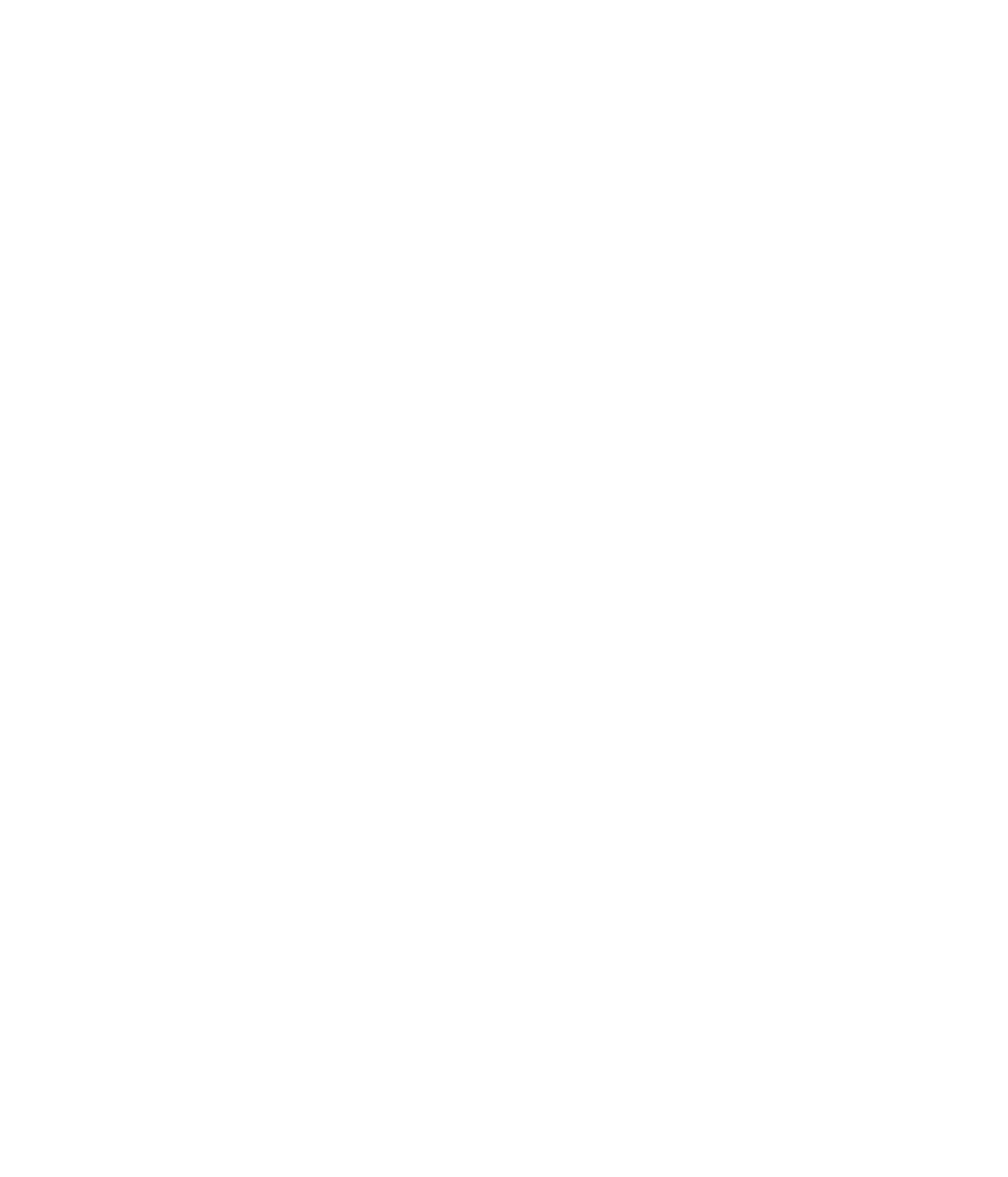

1 For good yield

3 Estimated.

2 From gage height or measurement at time of sampling. 
TABLE 20.- Transmountain diversions, in acre-feet, from the Green River basin between the Yampa and White Rivers including the White River basin, water years 1914-57

[Total includes estimates of diversions by the Strawberry River and Willow Creek ditches and the Hobble Creek ditch for water years 1914-49]

\begin{tabular}{|c|c|c|c|c|c|c|c|c|c|c|c|}
\hline Water year & $\begin{array}{c}\text { Duchesne } \\
\text { tunnel }\end{array}$ & $\begin{array}{l}\text { Strawberry } \\
\text { tunnel }\end{array}$ & $\begin{array}{c}\text { Strawberry } \\
\text { River and } \\
\text { Willow Creek } \\
\text { ditches }\end{array}$ & $\begin{array}{c}\text { Hobble } \\
\text { Creek } \\
\text { ditches }\end{array}$ & Total & Water year & $\begin{array}{c}\text { Duchesne } \\
\text { tunnel }\end{array}$ & $\begin{array}{c}\text { Strawberry } \\
\text { tunnel }\end{array}$ & $\begin{array}{c}\text { Strawberry } \\
\text { River and } \\
\text { Willow Creek } \\
\text { ditches }\end{array}$ & $\begin{array}{l}\text { Hobble } \\
\text { Creek } \\
\text { ditches }\end{array}$ & Total \\
\hline $\begin{array}{l}1914 \\
1915 \\
1916 \\
1917 \\
1918 \\
1919 \\
1920 \\
1921 \\
1922 \\
1923 \\
1924 \\
1926 \\
1927 \\
1928 \\
1929 \\
1930 \\
1931 \\
1932 \\
1933 \\
1934 \\
1935\end{array}$ & $\begin{array}{l}0 \\
0 \\
0 \\
0 \\
0 \\
0 \\
0 \\
0 \\
0 \\
0 \\
0 \\
0 \\
0 \\
0 \\
0 \\
0 \\
0 \\
0 \\
0 \\
0 \\
0 \\
0\end{array}$ & $\begin{array}{r}0 \\
10,410 \\
33, \mathbf{4 4 0} \\
60,710 \\
70,700 \\
72,870 \\
62,420 \\
65,880 \\
69,570 \\
79,500 \\
112,600 \\
82,580 \\
74,580 \\
64,740 \\
73,210 \\
57,800 \\
73,100 \\
73,840 \\
58,700 \\
51,520 \\
27,970 \\
\mathbf{4 3}, \mathbf{4 9 0}\end{array}$ & \begin{tabular}{|l} 
\\
\end{tabular} & $\cdots$ & $\begin{array}{r}3.300 \\
13,700 \\
36,700 \\
64,000 \\
74,000 \\
76,200 \\
65,700 \\
69,200 \\
72,900 \\
82,800 \\
115,900 \\
85,900 \\
77,900 \\
68,000 \\
76,500 \\
61,100 \\
76,400 \\
77,100 \\
58,700 \\
54,800 \\
31,300 \\
\mathbf{4 6 , 8 0 0}\end{array}$ & $\begin{array}{l}1936 \\
1937 \\
1938 \\
1939 \\
1940 \\
1941 \\
1943 \\
1944 \\
1945 \\
1946 \\
1947 \\
1948 \\
1949 \\
1950 \\
1951 \\
1952 \\
1954 \\
1955 \\
1956 \\
1957\end{array}$ & $\begin{array}{r}0 \\
0 \\
0 \\
0 \\
0 \\
0 \\
0 \\
0 \\
0 \\
0 \\
0 \\
0 \\
0 \\
0 \\
0 \\
0 \\
0 \\
0 \\
28,270 \\
32,060 \\
31,890 \\
29,790\end{array}$ & $\begin{array}{l}\mathbf{4 2 ,}, 960 \\
50,230 \\
55,840 \\
70,760 \\
53,770 \\
44,910 \\
53,180 \\
58,140 \\
57,020 \\
49,180 \\
69,340 \\
59,780 \\
72,350 \\
63,270 \\
69,140 \\
68,170 \\
\mathbf{4 5}, 780 \\
80,970 \\
78,910 \\
71,450 \\
74,060 \\
57,960\end{array}$ & $\begin{array}{r} \\
\end{array}$ & $\begin{array}{r} \\
\end{array}$ & $\begin{array}{r}\mathbf{4 6}, 300 \\
53,500 \\
59,100 \\
74,100 \\
57,100 \\
48,200 \\
56,500 \\
61,400 \\
60,300 \\
52,500 \\
72,600 \\
63,100 \\
75,600 \\
66,600 \\
72,521 \\
72,000 \\
48,300 \\
84,220 \\
109,465 \\
107,280 \\
109,560 \\
90,847\end{array}$ \\
\hline
\end{tabular}

TABLE 21.-Upstream water developments and methods and accuracy of adjusting flow-duration data for selected stations in two subbasins in the Green division to base period and 1957 conditions

Years of record: Number of years of available historical flow-duration data during water years 1914-57.

Base period adjustment method: Method used in adjusting historical data to base period; I, index-station method, $M$, monthly means method, S, substitute method. Index-station No.: Index station used in adjusting flow-duration curve to base period or correlation station used in estimating data for missing periods of record.
Upstream water developments: Upstream transmountain diversions and reservcirs

\begin{tabular}{c|c|c|c|c|c||c|c|c|c|c|c|c|c}
\hline $\begin{array}{c}\text { Station } \\
\text { No. }\end{array}$ & $\begin{array}{c}\text { Years } \\
\text { of } \\
\text { record }\end{array}$ & $\begin{array}{c}\text { Base } \\
\text { period } \\
\text { ment- } \\
\text { method }\end{array}$ & $\begin{array}{c}\text { Index- } \\
\text { station } \\
\text { No. }\end{array}$ & $\begin{array}{c}\text { Upstream water } \\
\text { developments }\end{array}$ & $\begin{array}{c}\text { Accu- } \\
\text { racy } \\
\text { rating } \\
\text { (percent) }\end{array}$ & $\begin{array}{c}\text { Station } \\
\text { No. }\end{array}$ & $\begin{array}{c}\text { Years } \\
\text { of } \\
\text { record }\end{array}$ & $\begin{array}{c}\text { Base } \\
\text { adjust- } \\
\text { ment } \\
\text { method }\end{array}$ & $\begin{array}{c}\text { Index- } \\
\text { station } \\
\text { No. } \\
\text { rating } \\
\text { (percent) }\end{array}$ \\
\hline
\end{tabular}

Green River basin between the Yampa and White Rivers including the White River basin

\begin{tabular}{|c|c|c|c|c|}
\hline 2610 & 11 & I & \multirow{3}{*}{$\begin{array}{rl}12255, & 12510 \\
1 & 2600 \\
2 & 2665 \\
2 & 2665 \\
\text { (3) } & \end{array}$} & \\
\hline $\begin{array}{l}2620 \\
2635\end{array}$ & \multirow{2}{*}{$\begin{array}{l}18 \\
18 \\
36\end{array}$} & \multirow{2}{*}{$\begin{array}{l}\mathbf{I} \\
\mathbf{I} \\
\mathbf{M}\end{array}$} & & Oak Creek Reservoir \\
\hline 2665 & & & & $\begin{array}{l}\text { Diversion from Oak Creek } \\
\text { Reservoir and Vernal city }\end{array}$ \\
\hline \multirow{2}{*}{$\begin{array}{l}2715 \\
2740 \\
2755 \\
2775 \\
2790\end{array}$} & \multirow{2}{*}{$\begin{array}{l}11 \\
13 \\
13 \\
39 \\
20\end{array}$} & \multirow{2}{*}{$\begin{array}{l}\mathbf{I} \\
\mathbf{I} \\
\mathbf{I} \\
\mathbf{M} \\
\mathbf{M}\end{array}$} & \multirow{4}{*}{$\begin{array}{r}12665 \\
22775 \\
22775 \\
32665 \\
32665,2775 \text {, } \\
2795 \\
2885,2950 \\
2885 \\
2885\end{array}$} & $\begin{array}{l}\text { water supply } \\
\text { Same as } 2665 \\
\text { Duchesne tunnel-a }\end{array}$ \\
\hline & & & & Duchesne tunnel. \\
\hline \multirow{2}{*}{$\begin{array}{l}2795 \ldots \\
2850 \\
2880\end{array}$} & \multirow{2}{*}{$\begin{array}{l}40 \\
14 \\
22\end{array}$} & \multirow{2}{*}{$\begin{array}{l}\text { M } \\
\text { I }\end{array}$} & & Duchesne tunnel. \\
\hline & & & & Currant Cr \\
\hline
\end{tabular}

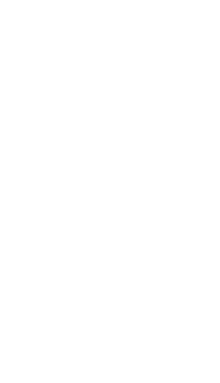
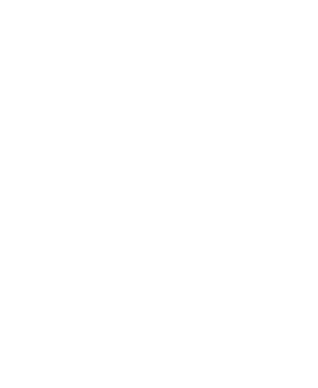

\begin{tabular}{|c|c}
\hline Currant Creek feeder canal. & 5 \\
\hline Moon Lake...... Currant & 15 \\
Duchesne tunnel, & 15 \\
Creek feeder canal, and & \\
Moon Lake. & 5 \\
\hline Same as 2950 & 15 \\
\hline & 10 \\
\hline & 15 \\
\hline
\end{tabular}

Green River basin below the White River

\begin{tabular}{|c|c|c|c|c|c|c|c|c|c|c|c|}
\hline \multirow{4}{*}{$\begin{array}{l}3070 \ldots \\
3080 \ldots \\
3090 \ldots \\
3105 \ldots \\
3125 \ldots \\
3130 \ldots \\
3140 \ldots \\
3145\end{array}$} & \multirow{4}{*}{$\begin{array}{r}9 \\
8 \\
8 \\
19 \\
18 \\
18 \\
23 \\
8 \\
11\end{array}$} & \multirow{4}{*}{$\begin{array}{ll}\text { I } & \\
\text { I } & \\
\text { I } & \\
\text { I } & \\
\text { I } & \\
& (4)\end{array}$} & \multirow{4}{*}{$\begin{array}{r}3150 \\
2 \mathbf{3 0 2 0} \\
2950 \\
223180 \\
23105,23180 \\
3140 \\
23140\end{array}$} & Duchesne tunnel.- & \multirow{4}{*}{$\begin{array}{l}10 \\
15+ \\
15+ \\
10 \\
15 \\
10 \\
15 \\
15+\end{array}$} & \multirow{4}{*}{$\begin{array}{l}3150 \ldots \ldots \\
3180 \ldots \ldots \\
3245 \ldots \ldots \\
\\
3265 \\
3280 \ldots \\
3285 \ldots\end{array}$} & \multirow{4}{*}{$\begin{array}{l}44 \\
39 \\
38 \\
\\
\\
22 \\
10 \\
17\end{array}$} & \multirow{4}{*}{$\begin{array}{l}\mathrm{S} \\
\mathbf{S} \\
\mathrm{I} \\
\mathrm{I} \\
\mathrm{I}\end{array}$} & \multirow{4}{*}{$\begin{array}{r}3180 \\
\\
223180 \\
23180,23245 \\
23180,23245\end{array}$} & Duchesne tunnel & \multirow{4}{*}{$\begin{array}{l}5 \\
10 \\
\\
10 \\
15 \\
15+ \\
15+\end{array}$} \\
\hline & & & & & & & & & & $\begin{array}{l}\text { Ephraim, Larsen, and } \\
\text { Spring City tunnels and }\end{array}$ & \\
\hline & & & & Schofield Reservoir & & & & & & Reeder ditch & \\
\hline & & & & - do & & & & & & Same as 3245 & \\
\hline
\end{tabular}

1 Flow-duration curve and data for index station that had been adjusted to base

2 Flow-duration curve and data for index station that had been adjusted to base
period and 1957 conditions were used. period were used. (1948) were used. in which changes occurred in base period requiring adjustment in historical data ccuracy rating: Authors' rating of accuracy of adjusted flow-duration curve for water years 1914-57 to 1957 conditions. The accuracy rating indicates that the final developed flow-duration curve throughout its range is believed to be correct within the percentage indicated. 
TABLE 22.-Total dissolved-solids concentration and concentration of boron in water in the upper part of the Duchesne River basin in 1960 [Map and analysis number from Iorns and others (1964, pl. 1)]

\begin{tabular}{|c|c|c|c|c|c|}
\hline Map No. & Location & Date & $\begin{array}{c}\text { Estimated } \\
\text { discharge } \\
\text { (cfs) }\end{array}$ & $\begin{array}{c}\text { Dissolved } \\
\text { solids } \\
\text { (ppm) }\end{array}$ & $\begin{array}{l}\text { Boron } \\
\text { (ppm) }\end{array}$ \\
\hline $\begin{array}{l}1010 \mathrm{G} \\
1006 \mathrm{G} \\
1007 \mathrm{G} \\
1009 \mathrm{G} \\
1008 \mathrm{G} \\
1019 \mathrm{G} \\
1020 \mathrm{G} \\
1014 \mathrm{G} \\
1016 \mathrm{G} \\
1017 \mathrm{G} \\
1015 \mathrm{G}\end{array}$ & $\begin{array}{l}\text { Indian Creek, } 0.1 \text { mile above mouth } \\
\text { Indian Creek, 1.6 miles above mouth } \\
\text { Indian Creek, 3.1 miles above mouth } \\
\text { Indian Creek, 3.8 miles above mouth } \\
\text { Indian Creek, 5.0 miles above mouth } \\
\text { Spring on Indian Creek, } 7 \text { miles above mouth } \\
\text { Spring on Indian Creek, } 7 \text { miles above mouth } \\
\text { Spring on North Fork Strawberry River, } 1 \text { mile above mouth } \\
\text { Spring on Lake Canyon Creek, 0.8 miles above mouth } \\
\text { Spring on Lake Canyon Creek, } 7 \text { miles above mouth } \\
\text { Stinking Spring on Strawberry River, about } 12 \text { miles west of Duchesne, } \\
\text { Utah. }\end{array}$ & 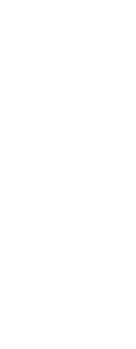 & $\begin{array}{l}1.5 \\
1.5 \\
1.5 \\
1.5 \\
1.5 \\
.5 \\
.2 \\
.01 \\
.05 \\
.5 \\
.05\end{array}$ & $\begin{array}{l}1,930 \\
1,870 \\
1,750 \\
1,720 \\
1,610 \\
1,840 \\
1,860 \\
1,500 \\
2,910 \\
2,710 \\
7,320\end{array}$ & $\begin{array}{r}7.6 \\
7.6 \\
6.2 \\
6.8 \\
6.6 \\
6.3 \\
6.5 \\
1.1 \\
7.7 \\
6.6 \\
20.0\end{array}$ \\
\hline
\end{tabular}

TABLE 23.-Recorded transmountain diversions, in acre-feet, from the Green River basin below the White River, water years 1950-57

\begin{tabular}{|c|c|c|c|c|c|c|c|c|c|c|c|c|c|c|}
\hline $\begin{array}{l}\text { Water } \\
\text { year }\end{array}$ & $\begin{array}{l}\text { Fair- } \\
\text { view } \\
\text { ditch }\end{array}$ & $\begin{array}{c}\text { Candland } \\
\text { diteh }\end{array}$ & $\begin{array}{c}\text { Ephraim } \\
\text { tunnel }\end{array}$ & $\begin{array}{l}\text { Larsen } \\
\text { tunnel }\end{array}$ & $\begin{array}{c}\text { Horse- } \\
\text { shoe } \\
\text { tunnel }\end{array}$ & $\begin{array}{l}\text { Coal } \\
\text { Fork } \\
\text { ditch }\end{array}$ & $\begin{array}{c}\text { Twin } \\
\text { Creek } \\
\text { tunnel }\end{array}$ & $\begin{array}{l}\text { Cedar } \\
\text { Creek } \\
\text { tunnel }\end{array}$ & $\begin{array}{c}\text { Black } \\
\text { Canyon } \\
\text { ditch }\end{array}$ & $\begin{array}{l}\text { Spring } \\
\text { City } \\
\text { tunnel }\end{array}$ & $\begin{array}{l}\text { Reeder } \\
\text { ditch }\end{array}$ & $\begin{array}{c}\text { Madsen } \\
\text { ditch }\end{array}$ & $\begin{array}{l}\text { John } \\
\text { August } \\
\text { ditch }\end{array}$ & Totals \\
\hline $\begin{array}{l}1950 \\
1951 \\
1952 \\
1953 \\
1954 \\
1955 \\
1956 \\
1957\end{array}$ & $\begin{array}{l}1,490 \\
1,820 \\
2,060 \\
1,700 \\
1,000 \\
1,280 \\
1,540 \\
2,410\end{array}$ & $\begin{array}{r}132 \\
224 \\
583 \\
134 \\
164 \\
81 \\
155 \\
151\end{array}$ & $\begin{array}{l}3,070 \\
3,180 \\
3,920 \\
3,720 \\
2,480 \\
2,950 \\
3,520 \\
2,460\end{array}$ & $\begin{array}{r}750 \\
910 \\
2,280 \\
923 \\
705 \\
786 \\
913 \\
993\end{array}$ & $\begin{array}{r}698 \\
703 \\
1,000 \\
539 \\
362 \\
409 \\
492 \\
600\end{array}$ & $\begin{array}{l}158 \\
209 \\
630 \\
205 \\
167 \\
210 \\
206 \\
426\end{array}$ & $\begin{array}{l}163 \\
205 \\
462 \\
103 \\
144 \\
221 \\
121 \\
377\end{array}$ & $\begin{array}{l}314 \\
338 \\
718 \\
223 \\
191 \\
329 \\
237 \\
496\end{array}$ & $\begin{array}{l}206 \\
260 \\
500 \\
180 \\
217 \\
231 \\
254 \\
428\end{array}$ & $\begin{array}{l}1,370 \\
1,630 \\
1,660 \\
1,960 \\
1,430 \\
1,880 \\
1,890 \\
2,330\end{array}$ & $\begin{array}{r}266 \\
116 \\
138 \\
44 \\
75 \\
272 \\
474 \\
493\end{array}$ & $\begin{array}{r}7 \\
69 \\
13 \\
20 \\
4 \\
4 \\
104 \\
20\end{array}$ & $\begin{array}{l}186 \\
299 \\
206 \\
235 \\
224 \\
246 \\
183 \\
279\end{array}$ & $\begin{array}{r}8,810 \\
9,960 \\
14,170 \\
9,990 \\
7,160 \\
8,900 \\
10,090 \\
11,560\end{array}$ \\
\hline
\end{tabular}

TABLE 24.-Total transmountain diversions, in acre-feet, from the Green River basin below the White River, water years 1914-57 [In totals, diversions prior to water year $\mathbf{1 9 5 0}$ are estimated on basis of recorded water rights and reported dates of enlargement of canals]

\begin{tabular}{|c|c|c|c|c|c|c|c|}
\hline $\begin{array}{l}1914 \\
1915 \\
1916 \\
1917 \\
1918 \\
1920 \\
1921\end{array}$ & $\begin{array}{l}3,900 \\
3,900 \\
3,900 \\
4,000 \\
4,100 \\
4,100 \\
4,100 \\
4,100 \\
4,100 \\
4,100 \\
4,200\end{array}$ & $\begin{array}{l}1925 \\
1926 \\
1927 \\
1928 \\
1929 \\
1930 \\
1931 \\
1932 \\
1933 \\
1934 \\
1935\end{array}$ & $\begin{array}{l}4,100 \\
4,200 \\
4,200 \\
4,200 \\
4,200 \\
4,300 \\
4,800 \\
5,200 \\
5,300 \\
5,400 \\
5,400\end{array}$ & $\begin{array}{l}1936 \\
1937 \\
1938 \\
1939 \\
1940 \\
1941 \\
1942\end{array}$ & $\begin{array}{r}5,400 \\
5,400 \\
5,400 \\
8,100 \\
9,800 \\
11,450 \\
10,510 \\
9,580 \\
10,390 \\
10,900 \\
10,240\end{array}$ & $\begin{array}{l}1947 \\
1948 \\
1949 \\
1950 \\
1951 \\
1952 \\
1953 \\
1954 \\
1955 \\
1956\end{array}$ & $\begin{array}{r}10,880 \\
9,360 \\
10,970 \\
8,810 \\
9,960 \\
14,170 \\
9,990 \\
7,160 \\
8,900 \\
10,090 \\
11,560\end{array}$ \\
\hline
\end{tabular}


TABLE 25.-Summary data on utilization of surface water in the Green division for developments existing in 1957

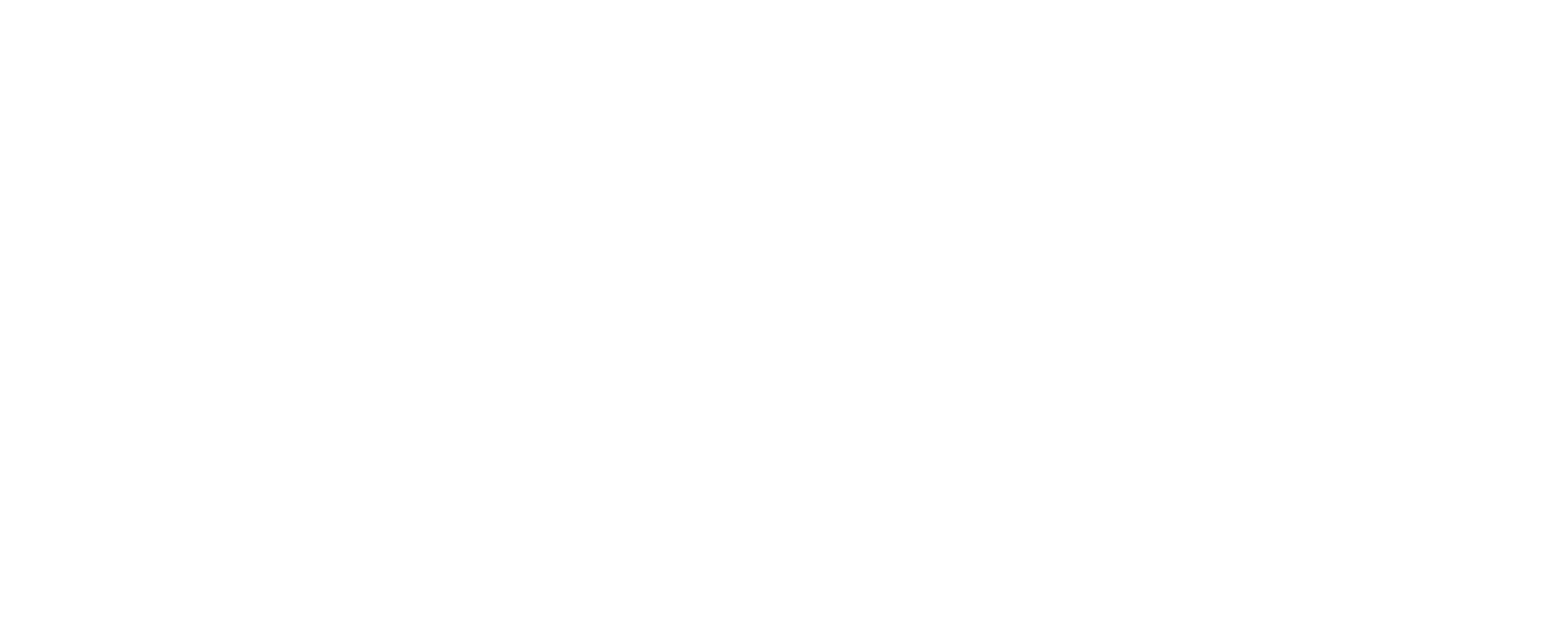

1 Amount diverted annually is unknown, but reported to be small.

2 Does not include amounts diverted annually by the three small diversions in the two upper subbasins.

TABLE 26.-Water budget, Green division

$$
\begin{array}{r}
\text { Average annual } \\
(\text { acre-ft) } \\
4,660,100 \\
112,200 \\
728,900 \\
6,700 \\
134,138,000 \\
\hline 39,645,900
\end{array}
$$

Transmountain diversions

Irrigation consumptive use

Domestic and industrial consumptive use

\begin{tabular}{|c|c|c|c|c|}
\hline Locations of stations on the Green River & $\begin{array}{l}\text { Drainage } \\
\text { area (sq mi) }\end{array}$ & $\begin{array}{l}\text { Streamflow } \\
\text { (acre-ft per } \\
\text { sq mi) }\end{array}$ & $\begin{array}{l}\text { Weighted- } \\
\text { average con- } \\
\text { centration } \\
\text { (ppm) }\end{array}$ & $\begin{array}{l}\text { Dissolved- } \\
\text { solids yield } \\
\text { (tons per } \\
\text { sq mi) }\end{array}$ \\
\hline $\begin{array}{l}\text { At Warren bridge near Daniel, Wyo } \\
\text { Near Fontenelle, Wyo } \\
\text { At Green River, Wyo } \\
\text { Near Linwood, Utah, } \\
\text { Near Greendale, Utah } \\
\text { At Jensen, Utah, } \\
\text { Near Ouray, Utah } \\
\text { At Green River, Utah. }\end{array}$ & $\begin{array}{r}468 \\
3,970 \\
7,670 \\
14,300 \\
15,100 \\
26,100 \\
35,500 \\
40,600\end{array}$ & $\begin{array}{l}836 \\
294 \\
170 \\
109 \\
109 \\
128 \\
127 \\
112\end{array}$ & $\begin{array}{l}151 \\
185 \\
284 \\
366 \\
378 \\
316 \\
392 \\
427\end{array}$ & $\begin{array}{r}172 \\
74 \\
66 \\
54 \\
56 \\
55 \\
68 \\
65\end{array}$ \\
\hline
\end{tabular}

Evapotranspiration loss.

Total

1 Includes 234,000 acre-ft estimated evaporation from water surfaces.

$\mathrm{T}_{\mathrm{ABLE}}$ 27.-Average annual streamflow and dissolved-solids data at stations on the Green

$$
\text { River }
$$

[Based on water years 1914-57 adjusted to 1957 conditions] 
TABLE 28.-Summary of average annual water, dissolved-solids, and suspended-sediment discharge from the subbasins in the Green division [Based on water years 1914-57 adjusted to 1957 conditions]

\begin{tabular}{|c|c|c|c|c|c|}
\hline \multirow[b]{2}{*}{ Data } & \multicolumn{4}{|c|}{ Subbasin } & \multirow[b]{2}{*}{ Green division } \\
\hline & $\begin{array}{c}\text { Green River Basin } \\
\text { above the Yampa } \\
\text { River }\end{array}$ & Yampa River basin & $\begin{array}{c}\text { Green River basin } \\
\text { between the Yampa } \\
\text { and White Rivers } \\
\text { including the White } \\
\text { River basin }\end{array}$ & $\begin{array}{c}\text { Green River basin } \\
\text { below the White } \\
\text { River }\end{array}$ & \\
\hline $\begin{array}{l}\text { Drainage area } \\
\text { Water discharge } \\
\text { Dissolved-solids discharge: } \\
\text { Total. } \\
\text { Probable from natural sources... } \\
\text { Do } \\
\text { Probable from activities of man } \\
\text { Do. } \\
\text { Suspended-sediment discharge }\end{array}$ & $\begin{array}{c}17,000 \\
1,645,000 \\
967,100 \\
646,600 \\
38 \\
320,500 \\
1.2 \\
3,677,200\end{array}$ & $\begin{array}{c}8,000 \\
1,602,600 \\
405,800 \\
343,400 \\
43 \\
62,400 \\
0.8 \\
1,807,400\end{array}$ & $\begin{array}{r}10,800 \\
1,260,400 \\
1,034,100 \\
471,800 \\
44 \\
562,300 \\
2.3 \\
7,339,400\end{array}$ & $\begin{array}{r}8,900 \\
152,100 \\
521,100 \\
288,400 \\
32 \\
232,700 \\
3.9 \\
15,051,400\end{array}$ & $\begin{array}{r}44,700 \\
4,660,100 \\
\\
2,928,100 \\
1,750,200 \\
39 \\
1,177,200 \\
2.0 \\
27,875,400\end{array}$ \\
\hline
\end{tabular}

1 Does not include runoff from $1,900 \mathrm{sq} \mathrm{mi}$ in the subbasin between Green River near Greendale gaging station and the Yampa River.

2 Does not include runoff from $800 \mathrm{sq} \mathrm{mi}$ in the subbasin between Yampa River near Maybell, Colo. and Little Snake River near Lily, Colo., gaging stations and

8 Includes runoff from the two areas described in footnotes 1 and 2. Does not include runoff from 2,400 sq mi between Green River at Green River, the Green River.

Utah, and San Rafael River near Green River, Utah, gaging stations 


\section{Surface-Water Resources}

\section{of the San Juan Division}

By W. V. IORNS, C. H. HEMBREE, and G. L. OAKLAND

WATER RESOURCES OF THE UPPER COLORADO RIVER BASIN-TECHNICAL REPORT

GEOLOGICAL SURVEY PROFESSIONAL PAPER 441-E

Analysis and appraisal of the water resources of the San Juan division of the Upper Colorado River Basin, with special emphasis on surface water and its quality

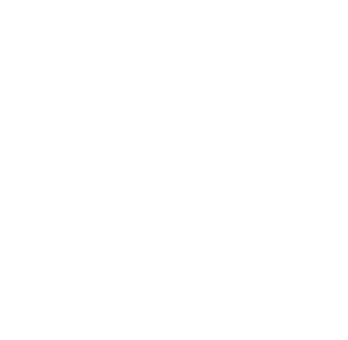




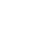




\section{CONTENTS}

Abstract.-.

Introduction

Location and subbasins.

Hydrologic environment.

Physiography and stream net

Soils.

Climate

Effect of topography and altitude.......

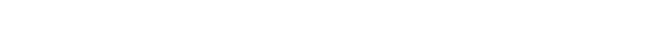

Temperature and evaporation.

Vegetation .........

San Juan River basin

Present utilization of surface water

Storage reservoirs

Transmountain diversions.

Irrigation ... . .

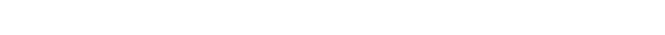

Streamflow

Variability of seasonal runoff

Flow-duration curves.........

Variability of annual runoff

Chemical quality of water.

Dissolved-solids discharge and concentration...

Variations in chemical quality . .

Relation to streamflow . . .

Relation to geology

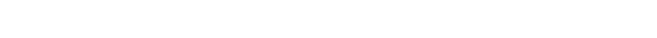

Effect of transmountain diversions. ........

Effect of the activities of man

Fluvial sediment._...
Purpose and scope
Page

299

299

299

299

299

299

302

302

302

302

304

304

305

305

305

305

305

305

305

305

306

308

311

311

311

312

312

317

318

318

319
San Juan River basin-Continued

Suitability of water for various uses. . . . . . . . . 319

Domestic ........ 319

Agricultural_...

Industrial and recreational ................ 321

Colorado River Basin below the Green and San Juan

Rivers and above "Lee Ferry," Ariz . . . . . . . . . . . 321

Present utilization of surface water............. 321

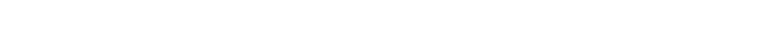

Transmountain diversions.................. 321

Irrigation............ 321

Domestic and industrial. . . . .

Streamflow............... 321

Variability of seasonal runoff .............. 321

Flow-duration curves........ 322

Variability of annual runoff .......... 323

Chemical quality of water. . . . . . . . . . . . . . 324

Dissolved-solids discharge and concentration . . $\quad 324$

Variations in chemical quality ............. 325

Relation to streamflow . . . . . . . . . . . . 325

Relation to geology $\ldots \ldots$

Relation to ground water. . . . 329

Effect of transmountain diversions

Effect of the activities of man ............ 331

Fluvial sediment. . . . . . . . . . . . 331

Suitability of water for various uses............. 332

Domestic....... 332

Agricultural

Industrial and recreational . . . . . . . . . . . 332

Summary _.. 332

References. 335

Index $\ldots$

\section{ILLUSTRATIONS}

[Plates are in separate volume]

Plate 8. Map of San Juan division showing average annual precipitation and evaporation, key streamflow-gaging stations, and coefficients of variation of annual runoff.

9. Map of native vegetation zones and irrigated lands in the San Juan division.

FIGDRE 125. Relief map of the San Juan division of the Upper Colorado River basin

126. Normal precipitation and temperature and frost-free seasons at representative stations in the San Juan division

127. Photograph of the blackbrush type of native vegetation, 7 miles north of Bluff, Utah

128. Photograph of grasslands with mixed shrubs near the headwaters of the Chaco River

129. Photograph of the sparse vegetation and barren character of large areas in the western part of the San Juan division, Bullfrog Creek valley at Eggnog, Utah

130. Seasonal pattern of runoff of streams in the San Juan River basin, 1954 water year

131. Flow-duration curves of streams in the San Juan River basin

132. Relation between the variability index of streamflow and percentage of average annual discharge estimated to be contributed by ground water for selected stations in the San Juan division

133. Variability of annual discharges of streams in the San Juan River basin, water years 1914-57... 
FigURE 134. Approximate dissolved-solids discharge and streamflow expressed as percentages of the dissolved-solids discharge and streamflow of San Juan River near Bluff, Utah . .

135. Dissolved-solids concentration of San Juan River near Bluff, Utah, for the 1951 and 1957 water years

136. Relation of the variability of dissolved-solids concentration to the variability of water discharge in the San Juan division.

137. Dissolved-solids concentration and discharge, and water discharge at four daily stations in the San Juan River basin

138. Relation of the chemical composition and concentration of dissolved solids to water discharge in the San Juan River basin.

139. Approximate weighted-average concentration of dissolved solids in streams in the San Juan River basin

140. Analyses of water from selected streams in the San Juan River basin and from alluvium nearby

141. Seasonal pattern of runoff of streams in the Colorado River Basin below the Green and San Juan Rivers and above "Lee Ferry," Ariz., 1954 water year.

142. Flow-duration curves for streams in the Colorado River Basin below the Green and San Juan Rivers and above "Lee Ferry," Ariz

143. Variability of annual discharges of Colorado River at Lees Ferry, Ariz., water years 1914-57 adjusted to the 1914 base

144. Approximate dissolved-solids discharge and streamflow expressed as percentages of the combined dissolvedsolids discharge and combined streamflow of Colorado and Paria Rivers at Lees Ferry, Ariz

145. Dissolved-solids concentration and water discharge at four daily stations in the Colorado River Basin below the Green and San Juan Rivers and above "Lee Ferry," Ariz

146. Relation of the chemical composition and concentration of dissolved solids to water discharge in the Colorado River Basin below the Green and San Juan Rivers and above "Lee Ferry," Ariz .

147. Approximate weighted-average concentration of dissolved solids in streams in the Colorado River Basin below the Green and San Juan Rivers and above "Lee Ferry," Ariz

\section{TABLES}

$\mathrm{T}_{\mathrm{ABLE}}$ 1. Average monthly precipitation at 13 index-precipitation stations in the San Juan division, water years 1914-57.-

2. Annual precipitation at 13 index-precipitation stations in the San Juan division and weighted-average precipitation in the subbasins and in the division, water years 1914-57.

3. Reservoirs in the subbasins in the San Juan division

4. Transmountain diversions from the San Juan River basin, water years 1923-57

5. Irrigated acreage in the subbasins in the San Juan division

6. Flow-duration table for stations in the subbasins in the San Juan division

7. Methods and accuracy of adjusting flow-duration data for stations in the subbasins in the San Juan division to base period and 1957 conditions

8. Variability index of streamflow and percentage of average annual discharge estimated to be contributed by ground water for selected streams in the San Juan River basin, Colorado

9. Average discharge, standard deviation, and coefficient of variation for selected streams in the subbasins in the San Juan division.

10. Water and dissolved-solids discharge in the subbasins in the San Juan division

11. Duration table of dissolved-solids concentration for selected stations in the subbasins in the San Juan division .-

12. Duration table of dissolved-solids discharge for selected stations in the subbasins in the San Juan division ...-.-

13. Variability of annual weighted average concentration of dissolved solids as related to the variability of annual water discharge for daily chemical-quality stations in the San Juan River basin .

14. Relation between water discharge and chemical quality of water at selected stations in the San Juan division..-

15. Water and dissolved solids contributed by ground water to selected streams in the San Juan River basin, Colorado.

16. Water and dissolved-solids budget, La Plata River basin

17. Average annual dissolved-solids discharge and probable amounts of dissolved solids from natural sources and from the activities of man in the subbasins in the San Juan division.

18. Summary of the suspended-sediment discharge at daily stations in the subbasins in the San Juan division

19. Estimated suspended-sediment discharge at selected stations in the subbasins in the San Juan division ........

20. Suitability of surface water for irrigation in the subbasins in the San Juan division .

21. Annual discharge of Tropic and East Fork canal near Tropic, Utah

22. Adjustments added to historical streamflow record of Colorado River at Lees Ferry, Ariz., to adjust to 1914 base

23. Summary data and utilization of surface water in the San Juan division, 1957

24. Water budget, San Juan division

25. Summary of average annual water, dissolved-solids, and suspended-sediment contributions in the San Juan division. 


\title{
WATER RESOURCES OF THE UPPER COLORADO RIVER BASIN-TECHNICAL REPORT
}

\section{SURFACE-WATER RESOURCES OF THE SAN JUAN DIVISION}

\author{
By W. V. Iorns, C. H. Hembree, and G. L. Oakland
}

\begin{abstract}
This chapter presents the results of an appraisal of the surface-water resources of the San Juan division, which includes the 38,300 square miles of drainage area of the Colorado River and its tributaries below the Green River and above "Lee Ferry," Ariz., a point 1 mile downstream from the mouth of the Paria River. Water uses existing in 1957 are reported, and interpretations are made of stream behavior, chemical quality of water, and sediment yield on the basis of the average that would have occurred if the 1957 level of upstream development had existed throughout water years 1914-57. The appraisal will be useful in planning additional development of surface-water supplies and in evaluating changes in streamflow, chemical quality of water, and sediment yield that may result from water-development projects constructed after 1957.

Annual precipitation in the division averaged $25,880,600$ acre-feet in the water years 1914-57. Had the developments in 1957 existed throughout the 44-year period, the average annual consumption of water would have been about 301,100 acre-feet for irrigation and about 7,100 acre-feet for domestic and industrial uses. Annually, about 2,800 acre-feet would have been diverted out of the division, about 102,600 acre-feet would have been imported into the division, and about $2,539,000$ acrefeet from the division would have been contributed to the Colorado River. Evapotranspiration probably accounted for the remaining $23,133,200$ acre-feet of water, on the assumption that there was no ground-water outflow from the division. Annually, transmountain diversions export about 300 tons of dissolved solids and import about 17,700 tons. The annual contribution of dissolved solids to the stream system in the division is computed to average about $1,543,600$ tons for the water years 1914-57 adjusted to 1957 conditions. Of this amount, about 351,800 tons is attributed to the activities of man, principally irrigation.
\end{abstract}

Suspended sediment contributed to the Colorado River in the division is estimated to average about $55,585,000$ tons annually.

In the headwaters of the division most of the surface water in the streams is suitable for domestic and industrial use. The concentrations of dissolved solids in most streams increase downstream, and some exceed the standards for domestic use. The waters in the lower reaches of some of the tributary streams are not suitable for agricultural use during periods of low flow.

\section{INTRODUCTION}

\section{PURPOSE AND SCOPE}

This chapter of the report presents in detail the appraisal of the surface-water resources of the San Juan division. In the appraisal the following items were considered: The present utilization of the surface- water supplies, the flow characteristics of the streams and the effects of environmental factors on streamflow, the chemical-quality characteristics of the streams and the influence of environmental factors on the quality of water, and the sediment yield of the streams. The appraisal and the data presented will be useful in planning additional water-development projects and in managing water resources of the area.

The basic data, hydrologic techniques, and criteria used in the appraisal of the surface-water resources are discussed and explained in chapter B, which also contains a glossary of technical terms used.

\section{LOCATION AND SUBBASINS}

The San Juan division of the Upper Colorado River Basin has a drainage area of 38,300 square miles. It is those parts of Colorado, Utah, New Mexico, and Arizona drained by the Colorado River and its tributaries below the Green River and above "Lee Ferry"-an unmapped arbitrary point defined by the Colorado River Compact as "a point 1 mile downstream from the mouth of the Paria River." In this report this division is divided into two subbasins (chap. A, fig. 2).

The San Juan River basin is the drainage area of the San Juan River (24,900 sq mi). The gaging station on San Juan River near Bluff, Utah, records the outflow from 23,000 square miles of the basin.

The Colorado River Basin below the Green and San Juan Rivers and above "Lee Ferry" (13,400 sq mi) is the area drained by the Colorado River between the Green River and "Lee Ferry," Ariz., excluding the San Juan River basin. The gaging stations on Colorado and Paria Rivers at Lees Ferry, Ariz., record the outflow from the Upper Colorado River Basin. Lees Ferry is a small community above the mouth of the Paria River.

\section{HYDROLOGIC ENVIRONMENT}

\section{PHYSIOGRAPHY AND STREAM NET}

The San Juan division extends from the junction of the Green and Colorado Rivers to 1 mile below the mouth of the Paria River (fig. 125). Included in the division are the drainage basins of the Dirty Devil, Escalante, San Juan, and Paria Rivers. Principal high- 


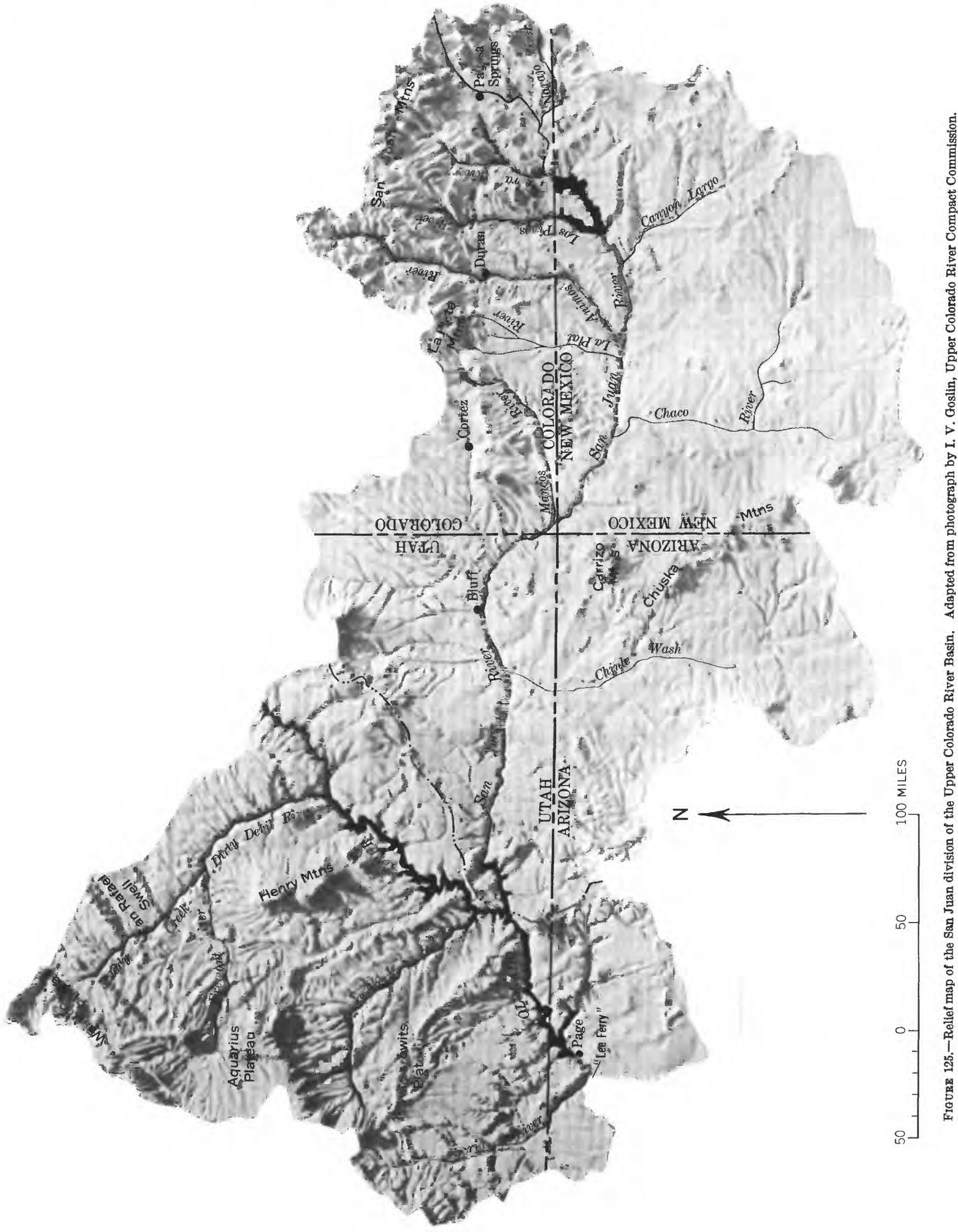


lands on the boundaries of the division are the San Juan and La Plata Mountains and the Aquarius and Wasatch Plateaus. Within the division are the Henry, Chuska, and Carrizo Mountains. The San Juan division is a region of great contrasts-parched deserts and lush mountain meadows; high mountains, deep canyons, and broad alluvial valleys; and dry washes and rushing mountain torrents.

The San Juan Mountains, from which most of the surface-water supply of the division comes, are composed chiefly of volcanic rocks of Tertiary age. In these mountains are also older rocks of Precambrian age and sedimentary rocks of the Paleozoic, Mesozoic, and Cenozoic Eras.

In other parts of the division the rocks are chiefly of sedimentary origin and range in age from late Paleozic to Recent. South of the San Juan Mountains in New Mexico, the San Juan River basin is underlain mostly by sedimentary rocks of Cretaceous and Tertiary ages. Westward from New Mexico the basin is underlain by rocks of Permian, Triassic, and Jurassic ages. The remainder of the division to the west is also underlain by sedimentary rocks of similar ages. In addition, there are sedimentary rocks of Cretaceous age and igneous rocks of Tertiary age.

The outcrop areas of rock formations in the division have been classified into eight groups in each of which the hydrologic properties are generally similar. (See chap. A, table 1 and pl. 2.)

Hunt $(1956$, p. 2$)$, in describing the Canyon Lands section of the San Juan division, which encompasses most of the division west of the Mancos River and north of the San Juan River, where the surface is generally 5,000 to 7,000 feet above sea level, said:

This area has been epeirogenically upwarped, and on top of the upwarp are several huge folds. Throughout this area the drainage is deeply incised in canyons in the pre-Tertiary rocks. Geomorphic features of the area are the elevated plateaus on the upfolds, hogbacks on their flanks, lower plateaus between the upfolds, laccolithic mountains rising above the plateau surfaces, and an intricate set of deep canyons. Among the unusual geomorphic features are the natural bridges and the related alcove arches that provide huge shelters along the canyon walls.

South of the San Juan Mountains, in the eastern part of the division and south of the San Juan River west of the Mancos River, is the Navajo section of the Colorado River Plateau (Hunt, 1956, p. 2). The greater part of the San Juan basin is in this section, which according to Hunt is

about as high as the Canyon Lands but much less dissected-it is an area of mesas and broad open valleys. The formations are similar to those in the Canyon Lands section, but they have been less folded. Locally, the drainage is deeply incised into the rocks, but examples are few as compared with the Canyon Lands section.

The stream valleys and canyons of the Colorado River, the San Juan River, and their tributaries give evidence of the effect of the rocks and structural features on the stream patterns. Hunt (1956, p. 67-71) believed that superposition or anteposition of the drainage patterns, or a combination of the two, occurred at least twice in the histories of the streams.

The courses of the Dirty Devil and one of its principal tributaries, the Fremont River, were evidently shifted northward by the doming of the Henry Mountains resulting from igneous intrusion.

The Escalante and Paria Rivers cut across uplifts in their courses and were probably at least partly superposed from younger rocks that once covered the upwarps.

The courses of the San Juan and Colorado Rivers in this division are anomalous in that both streams cross upwarps in their paths. Hunt $(1956$, p. 71$)$, in his discussion of the seeming lack of any regard by some of the streams for uplifts in their paths, said:

The relationship, or lack of relationship, of the Colorado River to the epeirogenic or regional structure of the plateau as a whole is anomalous and seems to be that of an antecedent or anteposed stream. The plateau tilts northeastward, and the Colorado and Green Rivers enter it at the Uinta Basin, which structurally is the lowest part of the plateau. From here, the rivers flow southwestward onto the epeirogenic platform in southeastern Utah and northeastern Arizona. At Grand Canyon, the Colorado River flows across one of the structurally highest parts of the rim of the plateau. This relationship is not that of a superposed stream, unless it is postulated that virtually the entire Colorado River Plateau, and all the ranges crossing the lower Colorado River, are exhumed. It seems more likely that the river's course is partly the result of antecedence and partly the result of anteposition dating from an early stage in the epeirogenic upwarp of the plateau.

The San Juan River, by far the largest tributary to the Colorado River in the division, rises on the south slopes of the San Juan Mountains and flows westward to its junction with the Colorado River. Major tributaries of the San Juan River are the Navajo, Piedra, Los Pinos, and Animas Rivers which also rise in the San Juan Mountains, and the La Plata and Mancos Rivers which rise in the La Plata Mountains. These headwater streams are all perennial and produce the major part of the water supply in the division.

South of the San Juan River, the region is dominated by desert topography characterized by buttes and mesas and broad dry washes which contain water only when 
the infrequent thunderstorms are of sufficient magnitude to cause surface runoff. These stormflows are heavily laden with sediment. Major streams draining this area are Canyon Largo, the Chaco River, and Chinle Wash.

Below Chinle Wash, the San Juan River flows through a deep canyon, and the small tributaries that enter the river also flow through deep canyons before reaching the main stream. The channels of the small tributaries are dry much of the time but become silt-laden torrents after intense thunderstorms, which occur infrequently.

The Colorado River below the mouth of the Green River is entrenched in a deep canyon, and the smaller tributaries entering the river have the same characteristics as those of the lower San Juan River. The larger tributaries-the Dirty Devil, Escalante, and Paria Rivers-also flow through deep canyons before reaching the main river. Though the headwaters of these tributaries are in high plateaus where melting snow produces most of their water supply, the lower reaches of the stream channels are dry at times. Infrequent but intense thundershowers cause flash floods laden with sediment.

\section{soILs}

Except for small areas of alluvium along the streams and valley alluvium in the Little Navajo and Navajo River basins and in an area between the Animas and Los Pinos Rivers southeast of Durango, Colo., the unconsolidated mantle in the San Juan division is principally residuum developed by weathering of the underlying rocks. Because of the arid climate of much of the subbasin, the residuum is relatively thin and soils are poorly developed. These soils and the underlying residuum retain many of the geochemical characteristics of the parent rocks. Generally, where the underlying rock is shale, a relatively impermeable residuum has developed that is high in soluble minerals. Where the parent rock is sandstone the residuum is permeable and low in soluble minerals.

The valley alluvium (pl. 2) in the Little Navajo and Navajo River basins and in the area between the Animas and Los Pinos Rivers in Colorado is generally permeable and low in soluble minerals. The river alluvium along the streams draining the south slopes of the San Juan and La Plata Mountains is also generally permeable and low in soluble minerals. However, in the lower reaches of some of these streams and along the San Juan River below Rosa, N. Mex., where the underlying rocks are the Mancos Shale and rocks of Tertiary age, the river alluvium contains relatively large amounts of soluble minerals.

River alluvium along the streams draining the mountainous areas north of the Colorado River in the western part of the division is closely related to the under- lying rocks. For the most part these rocks, and the alluvium derived from them, contain an abundance of soluble minerals.

\section{CLIMATE}

GFFECT OF TOPOGRAPHY AND ALTITUDE

The climate of the San Juan division ranges from extremes of high precipitation and low temperatures in the San Juan Mountains to scant precipitation and high summer temperatures at the lower altitudes. The major part of the basin is less than 6,000 feet in altitude and receives less than 8 inches of precipitation annually.

Airmasses from the Gulf of Mexico and, at times, from the Pacific Ocean predominate over the subbasin. The uplands forming the southern boundary are lower than those along most of the northern boundary and allow these airmasses to move from the south across the basin. In the eastern part of the basin, where the moisture-laden airmasses are lifted along the San Juan Mountains, precipitation is copious, especially at the higher altitudes. Thunderstorms over the large area of relatively low altitude in the arid part of the subbasin, where temperatures are high during the summer, cause infrequent downpours of high intensity.

Comparison of figure 125 with plate 8 demonstrates the effect of topography on the distribution of annual precipitation.

\section{PRECIPITATION}

Snow at the higher altitudes is the principal source of water supply for the division. The average annual precipitation generally ranges from 60 inches in some parts of the San Juan Mountains to 6 inches in the desert areas (pl. 8). Monthly distributions of precipitation at representative stations are shown in figure 126. In contrast to most of the rest of the Upper Colorado River Basin, the monthly precipitation during the summer is greater than that during other seasons.

The distribution of average annual precipitation over the division is shown in plate 8. This map-which is adjusted for topography, exposure to airmass movements, and climatic factors-is based on precipitation data observed during calendar years 1921-50. The average annual precipitation for this period as planimetered from the map is 12.72 inches. The following tabulation shows the areal distribution of precipitation over the 38,300 square miles of drainage area :

\begin{tabular}{|c|c|c|c|}
\hline Precipitaton range (inches) & $\underset{(s q m i)}{A r e a}$ & Precipitation range (inches) & $\underset{(s q m i)}{\text { Area }}$ \\
\hline $60-70$ & 31 & 16-20. & 3,229 \\
\hline $50-60$ & 213 & $12-16$ & 7,108 \\
\hline $40-50$ & 627 & $10-12$ & 6,71 \\
\hline $30-40$ & 903 & $8-10$ & 8,02 \\
\hline $25-30$ & 745 & $6-8 \ldots$ & 8,017 \\
\hline $20-25$ & 1,132 & $4-6$ & 1,54 \\
\hline
\end{tabular}




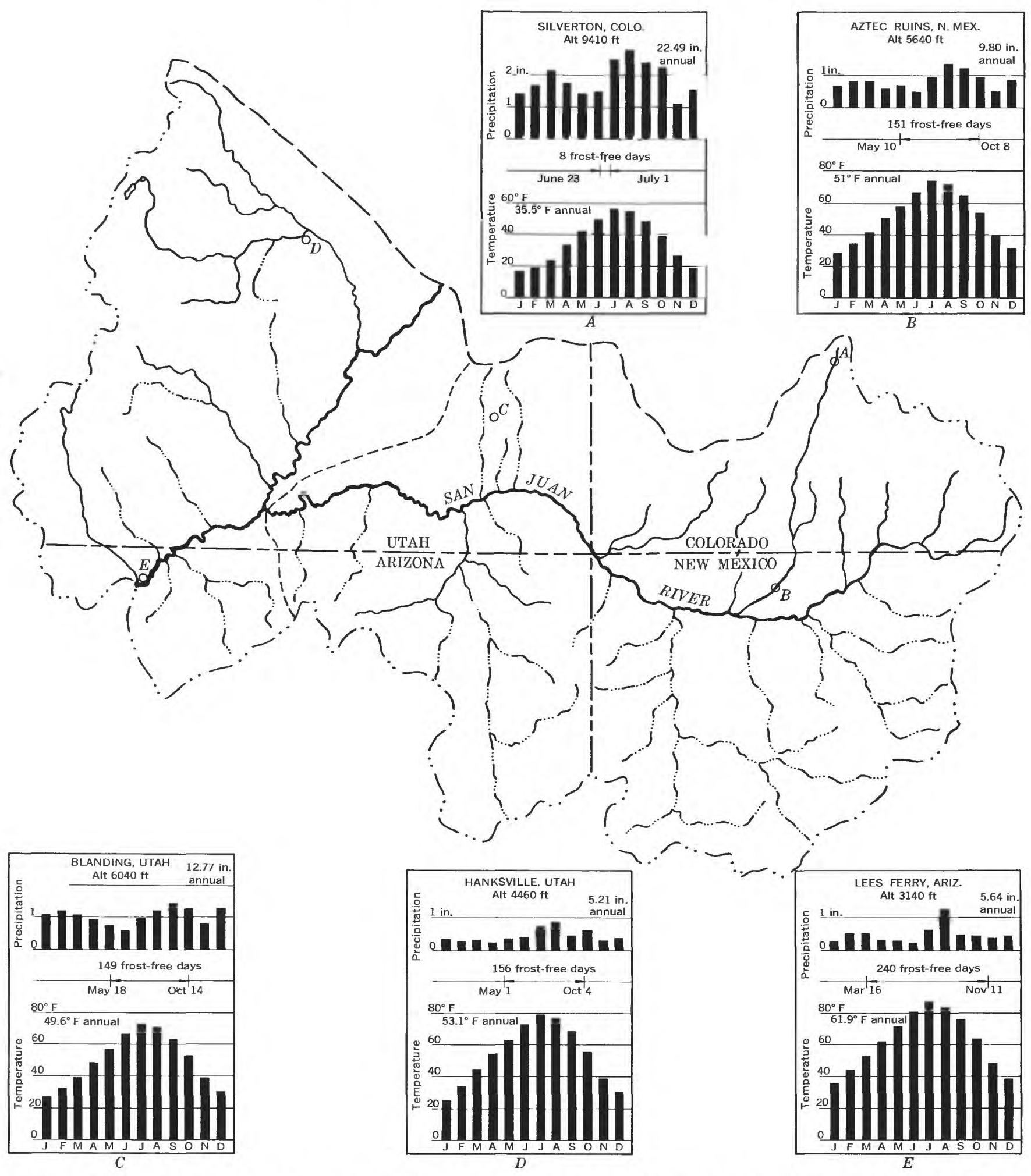

FIGURE 126.-Normal precipitation and temperature and frost-free seasons at representative stations in the San Juan division. Data from U.S. Weather Bureau normals (average for calendar years 1921-50). 
For computing precipitation data applicable to the base period adopted for this study and for other periods, 13 index stations in or adjacent to the division were selected (tables 1 and 2, pl. 8). As explained in chapter B' (pp. 44-45), precipitation records at the index stations were used to compute the average annual precipitation over the division, which for the 44-year base period was 12.67 inches, for a total of $25,880,600$ acre-feet.

The greatest precipitation was 20.78 inches in 1941 and the least was 6.91 inches in 1956. These were about 64 percent above and 46 percent below the 44-year annual average, respectively. As indicated by the annual quantities, the precipitation over the division was generally above average from 1914 to 1929 , below average from 1930 to 1940 , above average from 1942 to 1949, and considerably below average from 1950 to 1956.

Table 2 is subdivided to include index stations applicable to the San Juan River basin and to the remainder of the division. Index stations for the San Juan River basin are applicable to the drainage area above the gaging station on San Juan River near Bluff, Utah. The average annual precipitation for the drainage area above this gaging station (23,000 sq mi) adjusted to water years $1914-57$ is 13.75 inches, or $16,866,700$ acre-feet.

\section{TEMPERATURE AND EVAPORATION}

The average monthly temperatures and length of frost-free season at five locations in the division are shown in figure 126. Comparison of the annual precipitation, temperature, and frost-free season at Lees Ferry, Ariz., with those at Silverton, Colo., shows the wide range of climate.

Isopleths of average annual evaporation, from a map by Kohler and others $(1959, \mathrm{pl} .2)$, are shown in plate 8 . The isopleths are generalized and do not take into account large variations in topography and exposure which may considerably influence evaporation at specific locations.

The average annual evaporation from water surfaces in the San Juan division, estimated by Meyers (1962, p. $71-100)$, is given in the following tabulation:

Principal reservoirs and regulated lakes Annual
eaporation
(acre-ft)

Other lakes over 500 acres _._.

Principal streams and canals _... 68, 000

Small ponds and reservoirs

Small streams....

Total

125,000

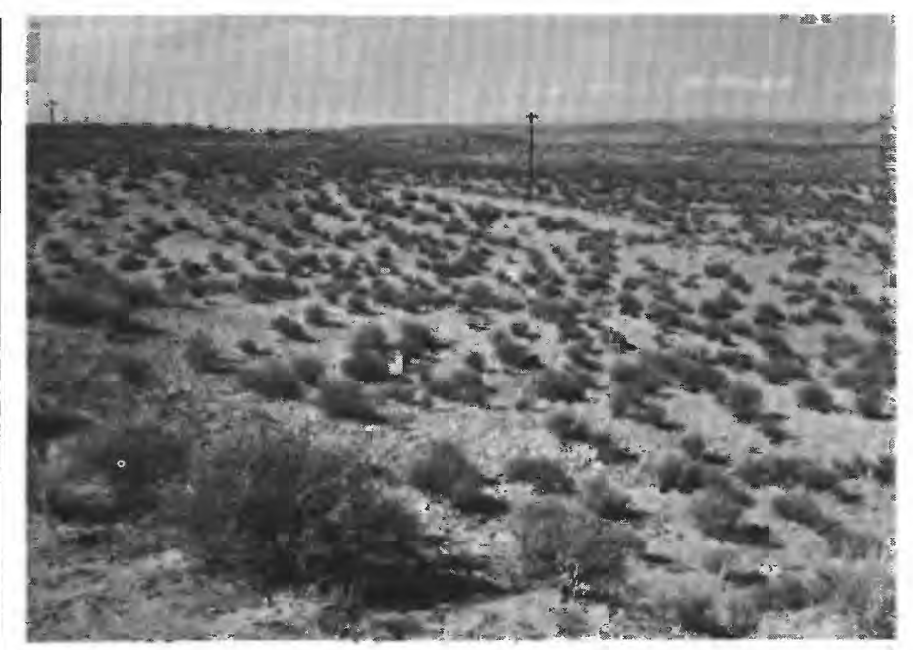

FIGURE 127.-The blackbrush type of native vegetation, 7 miles north of Bluff, Utah. Photograph by F. A. Branson.

\section{VEGETATION}

The native species of vegetation in the San Juan division are about the same as those that existed before settlement. In mountainous areas where the climatic environment is favorable, the vegetative growth is lush. The net hydrologic effect of native vegetative cover in these areas has probably changed little in the last hundred years. In the semiarid and arid parts of the division the vegetation is sparse, and there are large areas of barren rock.

Much of the vegetative cover in the arid areas is in a precarious state of existence even at its best, and overgrazing may have resulted in some changes in the hydrologic effect of native vegetation in local areas. However, runoff data from the arid parts of the division are not sufficient to identify any resulting hydrologic change in water years 1914-57.

The most important plant communities in the area are the alpine meadow, subalpine forest, montane forest, mountain brush, pinyon-juniper, shadscale, black-

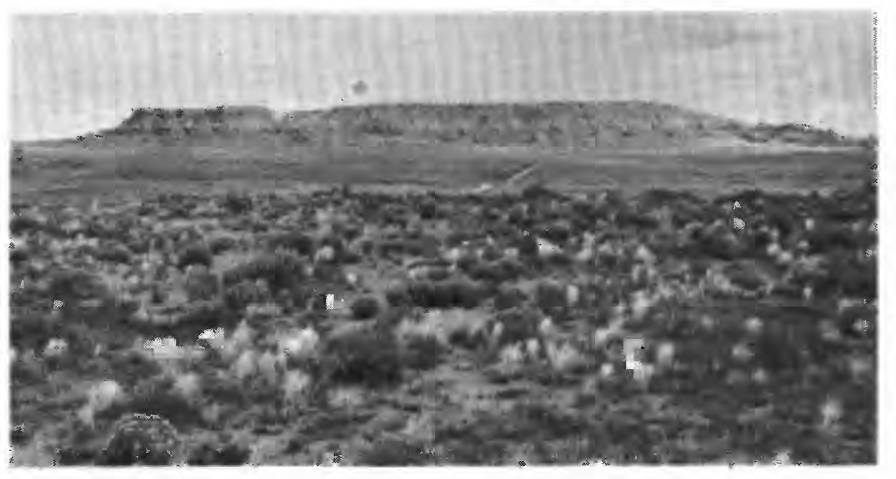

Figure 128.-Grasslands with mixed shrubs near the headwaters of the Chaco River. Photograph by D. A. Phoenix. 


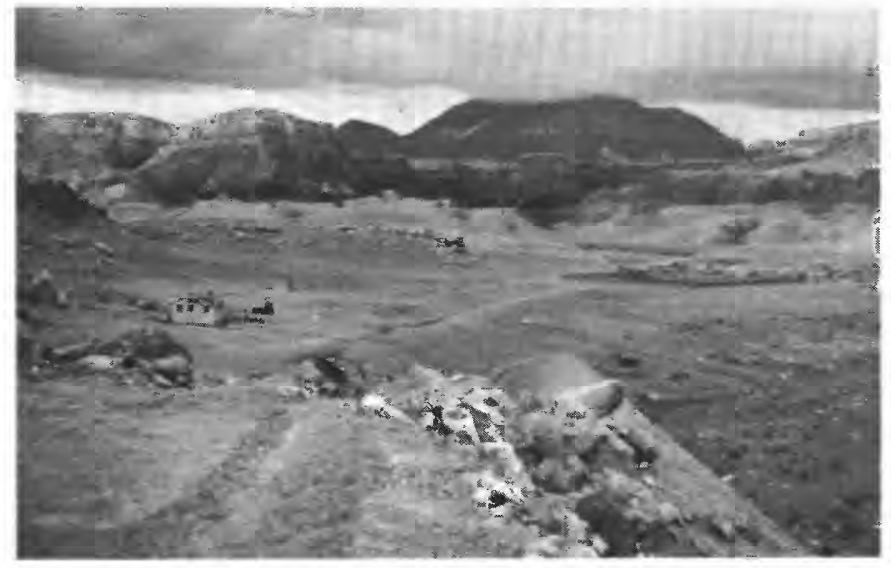

FigURE 129.-The sparse vegetation and barren character of large areas in the western part of the San Juan division is illustrated by this view of the Bullirog Creek valley at Eggnog, Utah, with Mount Hilliers in the background. Photograph by D. A. Phoenix.

brush, greasewood, grassland, and big sagebrush communities. The general zones of occurence of these communities are shown in plate 9 , and the plant species in the communities are described in chapter $\mathrm{C}$, pages $80-81$. Vegetation that is typical of some of the zones is shown in figures 127-129.

\section{SAN JUAN RIVER BASIN}

\section{PRESENT UTILIZATION OF SURFACE WATER STORAGE RESERVOIRS}

Twelve reservoirs that have usable storage capacities greater than 1,000 acre-feet have been constructed (1957) in the San Juan River basin (table 3, and pl. 8). Of these, 11 are for irrigation and 1 is for the generation of hydroelectric power. All receive their water supply from the drainage basin in which they are located except the Summit and Narraguinnep Reservoirs, for which the water supply is diverted from the Dolores River and Lost Canyon Creek in the Grand division.

In addition to the reservoirs listed in table 3, many small lakes, reservoirs, and stock ponds are scattered throughout the basin.

\section{TRANSMOUNTAIN DIVERSIONS}

Five small ditches divert water from headwaters of the San Juan River to the Rio Grande basin (table 4). The Treasure Pass ditch began diverting water in 1923, the Fuchs and Raber-Lohr ditches in 1937, the Squaw Pass ditch in 1938, and the Piedra Pass ditch in 1939. The average annual diversion by these ditches for water years 1948-57 was 2,754 acre-feet. For the purpose of the report, this average is assumed to be representative of the water supply for water years 1914-57 and of developments existing in 1957.

Water is imported into the McElmo Creek drainage basin from the Dolores River basin for the irrigation of about 37,000 acres. No records are available on the amount of water imported, but it has been estimated to average about 100,000 acre-feet annually (U.S. Dept. of the Interior, 1947, p. 128). These diversions were in operation before 1914 .

\section{IRRIGATION}

Table 5 gives the approximate irrigated acreage in various drainage basins and reaches of the stream system in the San Juan River basin. Location of the irrigated lands is shown in plate 9. Generally, the streams draining the San Juan and La Plata Mountains furnish an adequate water supply for the irrigated lands dependent upon them. Supplies are deficient for much of the irrigated lands south of the San Juan River and lands along Montezuma and Recapture Creeks.

The Upper Colorado River Basin Compact Commission (1948) estimated that the $1914-45$ average annual consumptive use of water in the subbasin due to irrigation was 256,617 acre-feet. The Commission estimated that 189,900 acres was irrigated and that 24,962 acres received water incidental to irrigation practices.

\section{DOMESTIC AND INDUSTRIAL USES}

The San Juan River basin has a drainage area of about 24,900 square miles and had a population of about 100,000 in 1960. The two largest communities and their populations are Farmington, N. Mex., 23,786, and Durango, Colo., 10,530. Farming, stockraising, petroleum production, and tourist trade are the principal occupations.

The major industrial use of water in the basin is for the production of hydroelectirc power at the following sites:

Location of powerplant $\quad \begin{gathered}\text { Installed } \\ \text { capacity } \\ (k w)\end{gathered}$

San Juan River at Pagosa Springs, Colo_._.......... 150

Animas River near Tacoma, Colo_._.

Animas River at Aztec, N. Mex............... 80

Animas River at Farmington, N. Mex......... 200

4,930

Small amounts of water are used by uranium mills at Durango, Colo., Shiprock, N. Mex., and Mexican Hat, Utah, in their milling processes and by other small industrial plants. The estimated consumptive use of water for domestic and industrial purposes is about 6,700 acre-feet annually.

\section{STREAMFLOW}

VARIABIIITY OF SEASONAL RUNOFF

In the San Juan River basin precipitation during the summer and fall produces a substantial part of the annual runoff. In marked contrast, summer and fall precipitation are of little consequence in producing runoff in the Grand and Green divisions and the other sub- 


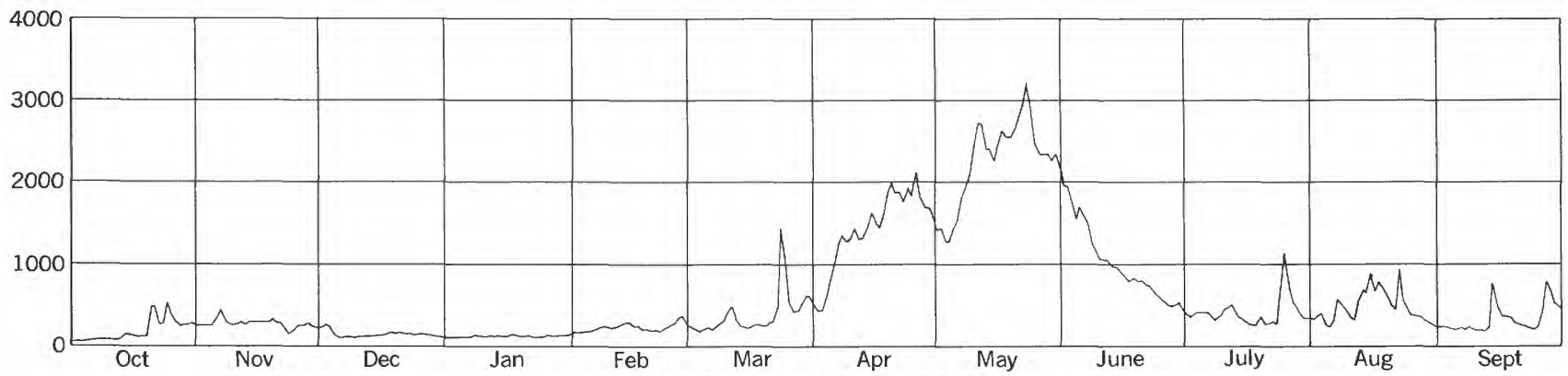

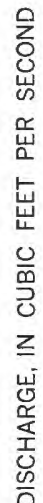

A. San Juan River near Rosa, N. Mex.
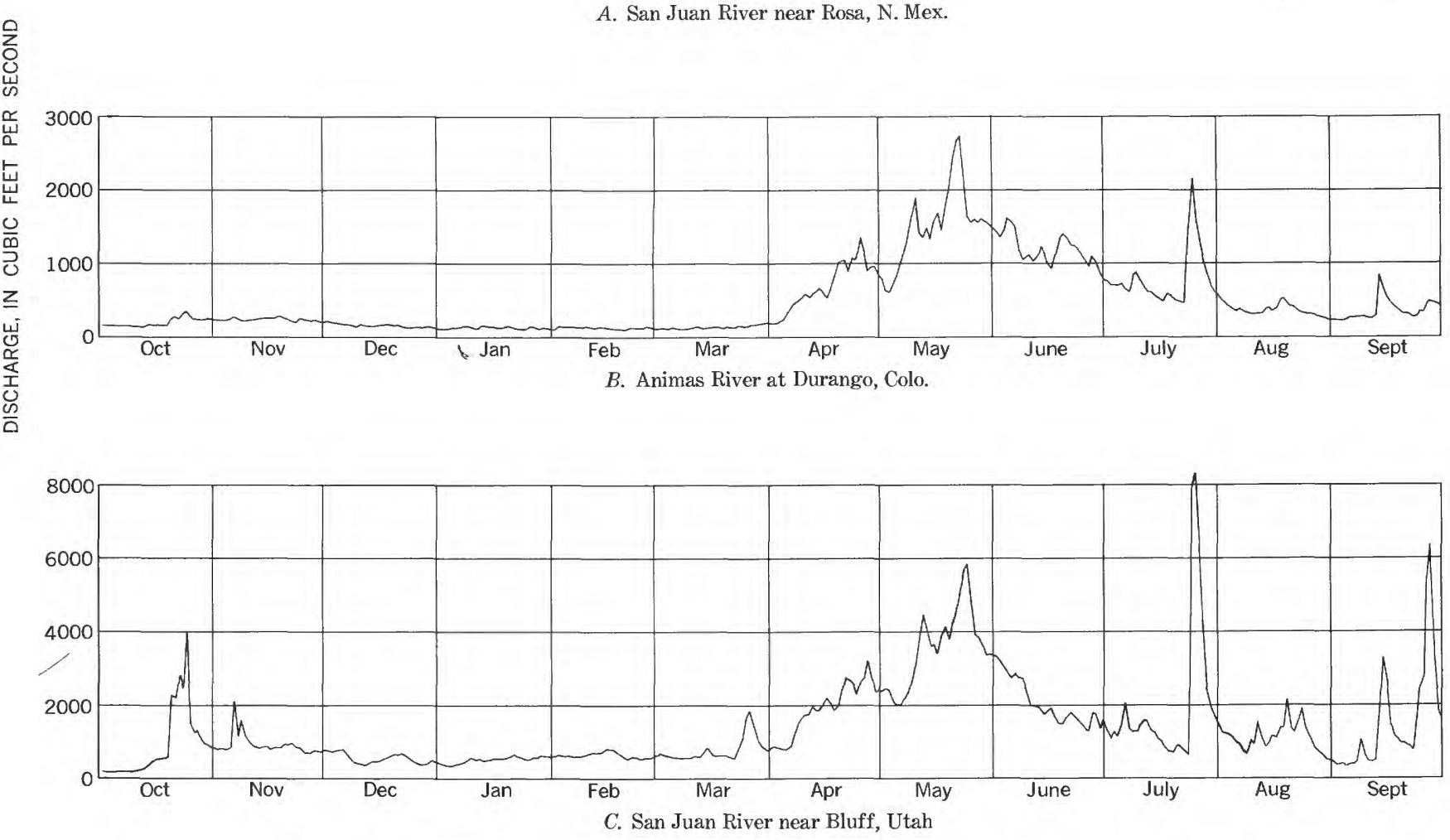

Figure 130.-Seasonal pattern of runoff of streams in the San Juan River basin, 1954 water year.

basin of this division. The hydrographs for three gaging stations (fig. 130) illustrate the relative effect of the summer and fall storms on the annual pattern of runoff. Although most of the runoff occurs in April, May, and June from the melting of winter snow in the mountains, the effect of summer and fall storms is very pronounced. These storms are usually of high intensity and, although some cover only small areas, others are of large areal extent. Their occurrence over the large area of sedimentary rocks at the lower altitudes produces much of the sediment carried by the subbasin's streams.

\section{FLOW-DURATION CURVES}

Historical flow-duration curves were developed for streams at 22 sites in the subbasin. The usefulness of these curves in hydrologic studies, their characteristics, and the methods used to adjust them for short periods of record to the 44-year base period are explained in chapter B (pp. 46-48). By use of these methods, flowduration curves for all the streams except McElmo Creek near Colorado-Utah State line were adjusted to the 44-year base period and for developments existing in 1957. Only the curves for stations downstream from the Vallecitos Reservoir required adjustment to be representative of 1957 conditions of upstream development. The data for historical and adjusted flow-duration curves are given in table 6 .

In table 7, the methods used in adjusting the historical flow-duration curves to the 44-year base period and for developments existing in 1957 are outlined. The authors' rating of accuracy of the resultant long-term curves is also given.

Flow-duration curves of streams at four sites are shown in figure 131. The curves for San Juan River at Rosa, N. Mex., and Animas River at Durango, Colo., are generally representative of streams draining the 

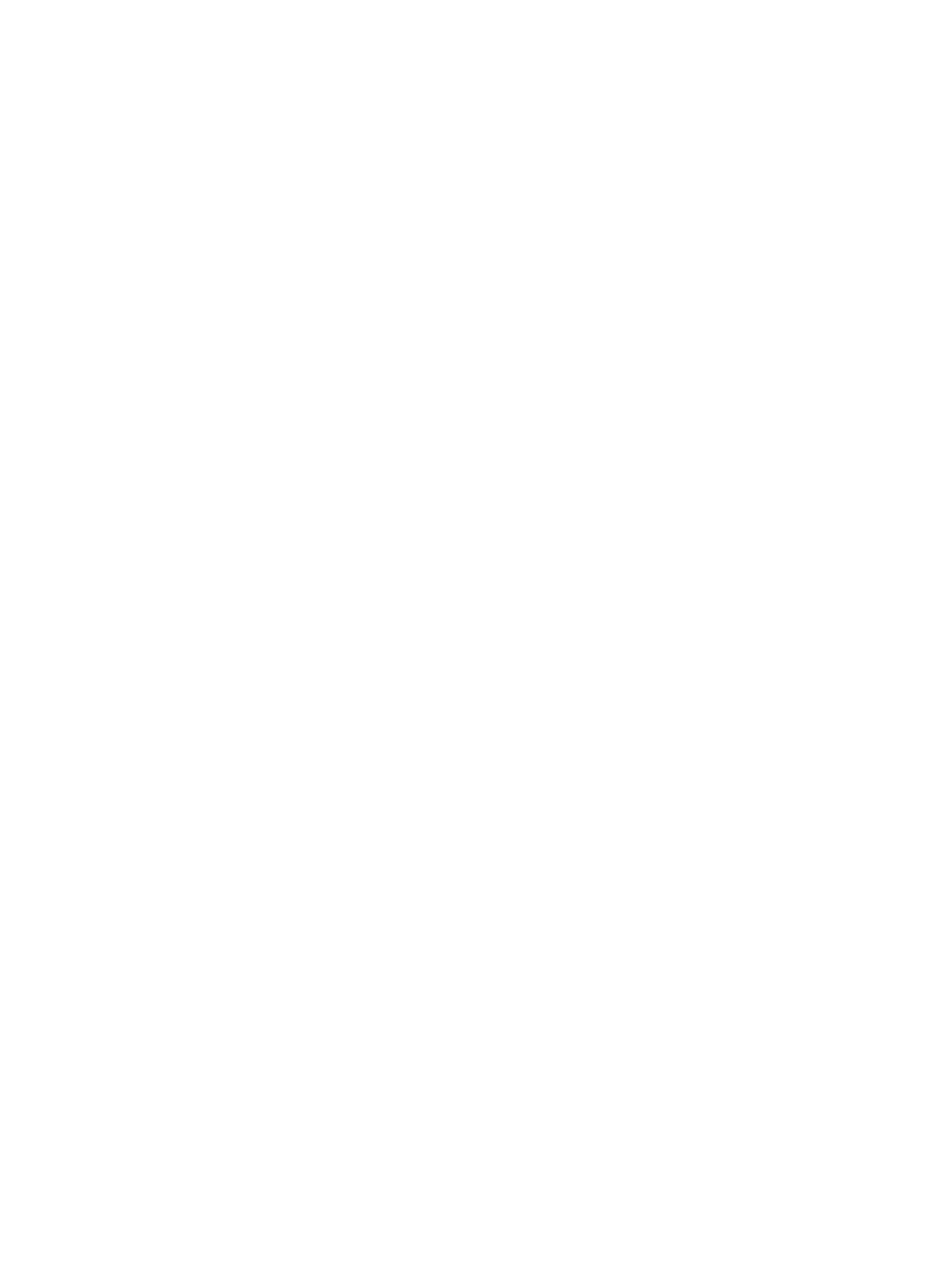

Figure 131.-Flow-duration curves of streams in the San Juan River basin, water years 1914-57 adjusted to 1957 conditions. 


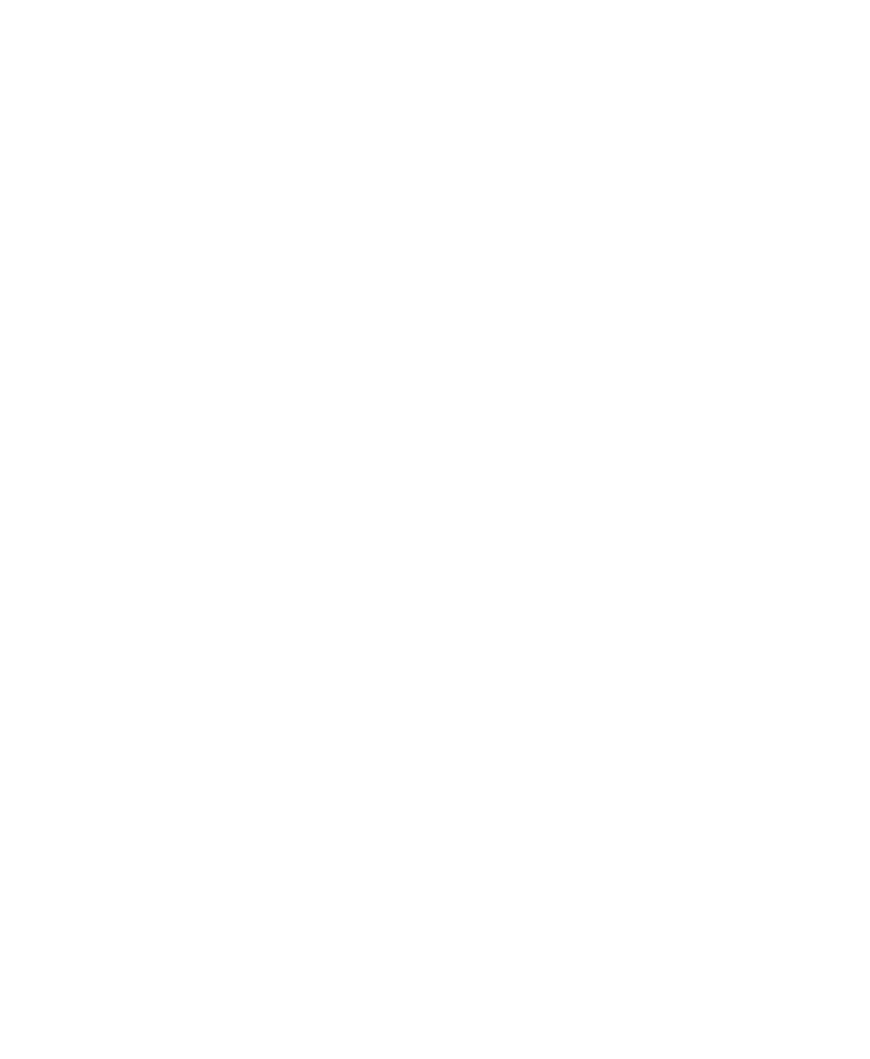

FIGURE 132.-Relation between the variability index of streamflow and percentage of average annual discharge estimated to be contributed by ground water for selected stations in the San Juan division, water years 1914-57 adjusted to 1957 conditions.

north side of the basin upstream from the La Plata River. The curve for Mancos River at Towaoc, Colo., is representative of streams whose drainage areas are mostly arid but have some mountains in the headwaters.

No streamflow data are available on the streams draining the southern part of the basin. However, on the basis of studies of storm runoff for Mancos River at Towaoc, Colo., and probable relation of average annual discharges, an approximate flow-duration curve for the Chaco River was developed (fig. $131 C$ ). This curve was prepared only to illustrate the most likely shape of the flow-duration curves for streams draining the southern and western parts of the subbasin. These streams are usually dry and flow only as a result of heavy storms.

The variability indices (Lane and Lei, 1950) and percentages of ground-water contribution to stream systems (see chap. B, pp. 48-53) were computed for selected streams in the subbasin (table 8). In general, there is an inverse relation between the two parameters (fig. 132). The average curve is based on selected streams in the Upper Colorado River Basin.

The headwaters of the San Juan, Piedra, and Animas Rivers are underlain mostly by Tertiary volcanics that have been highly altered, are clay rich, and are relatively impermeable. However, extensive outcrops of flow breccia and tuff in the headwater areas of the Animas River are probably responsible for the slightly lower variability index for Animas River at Howardsville, Colo., than for San Juan River near Pagosa Springs, Colo., and Piedra River near Piedra, Colo. The headwaters of the La Plata River are underlain by intrusive igneous rocks of Tertiary age and rocks of Permian and Pennsylvanian ages, and Hermosa Creek is underlain almost entirely by rocks of Permian and Pennsylvanian ages. These rocks are fairly impermeable.

Extensive areas of valley alluvium underlie part of the drainage area above the gaging station on Navajo River at Edith, Colo. Ground-water storage in the alluvium is probably the cause of the lower variability index for this stream and greater percentage of groundwater contribution. Valley alluvium, irrigation, and regulation by the Electra Reservoir probably cause the relatively low variability index for Animas River at Durango, Colo.

\section{VARIABHITY OF ANNUAL RUNOFF}

The annual water discharges adjusted for upstream transmountain diversions and reservoir regulation (Vallecitos Reservoir only) at three gaging stations in the San Juan River basin are shown in figure 133. The water discharge of San Juan River at Rosa, N. Mex., for water years 1914-20, is the sum of records of stations on Piedra and San Juan Rivers at and near Arboles, Colo. The record for San Juan River near Bluff, Utah, is estimated for water years 1914 and 1918-27.

The coefficients of variation of annual discharges at eight gaging stations in the basin are given in table 9 . The coefficients for all stations have a relatively small range except those for the Animas and Mancos Rivers. Ground-water storage in the Animas River basin may be extensive enough to provide carryover from wet to dry years. The record for Mancos River near Towaoc, Colo., reflects storm runoff, which is much more variable than snowmelt runoff. The higher coefficients for San Juan River at Farmington, N. Mex., and near Bluff, Utah, are probably the result of storm runoff from large areas in the lower part of the subbasin.

On the assumption that the average annual discharge and coefficients of variation of the stations listed in table 9 are representative of the 44-year base period, the data may be used for estimating probable future streamflow for periods of various length and confidence limits as explained in chapter B (pp. 57-58). The waterdischarge data for Navajo River at Edith, Colo., may be used as an example. The computed average discharge 


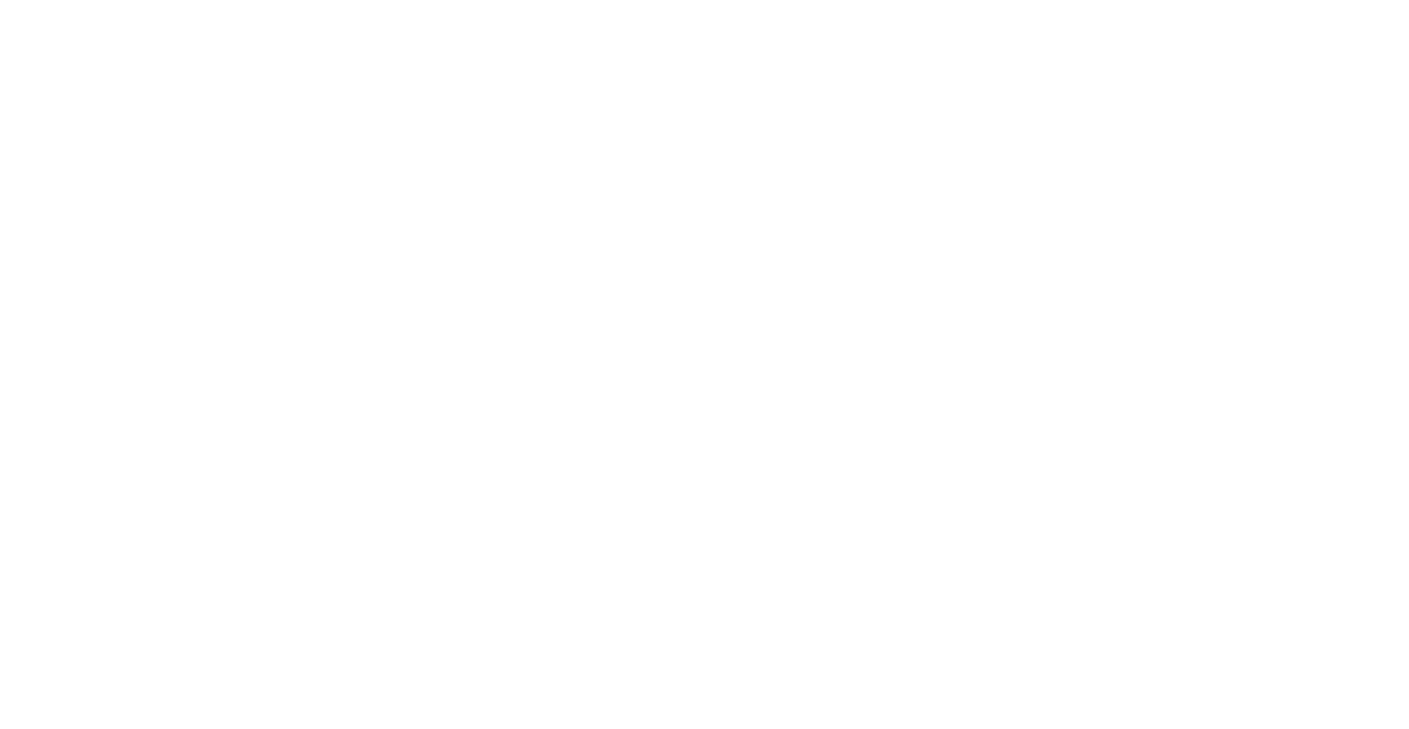

A. San Juan River at Rosa, N. Mex.

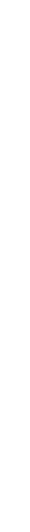

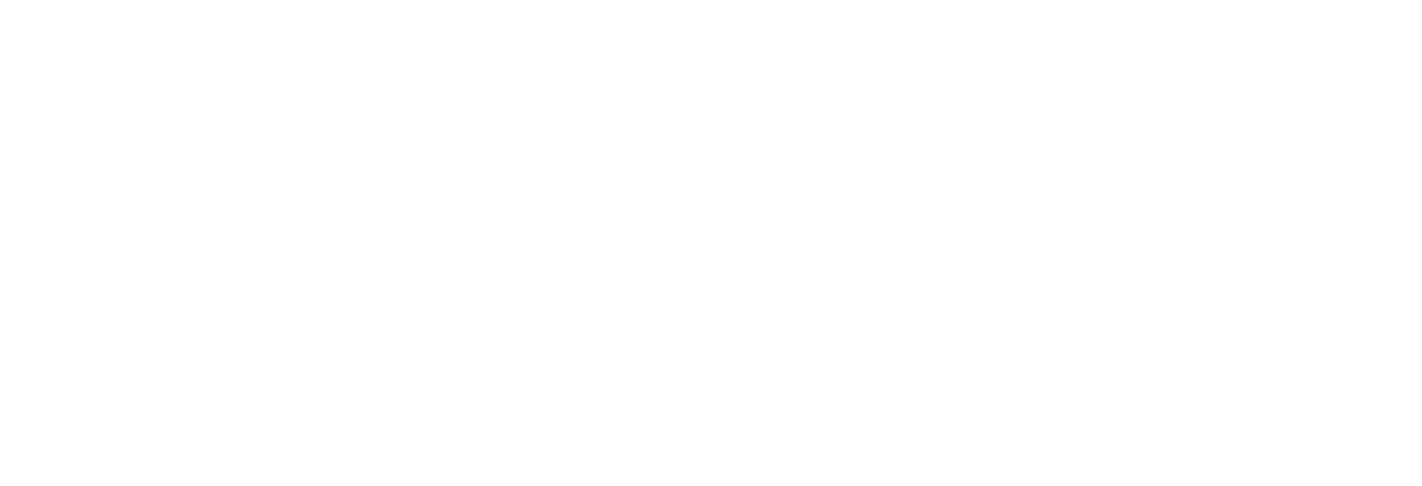

B. Animas River at Durango, Colo.

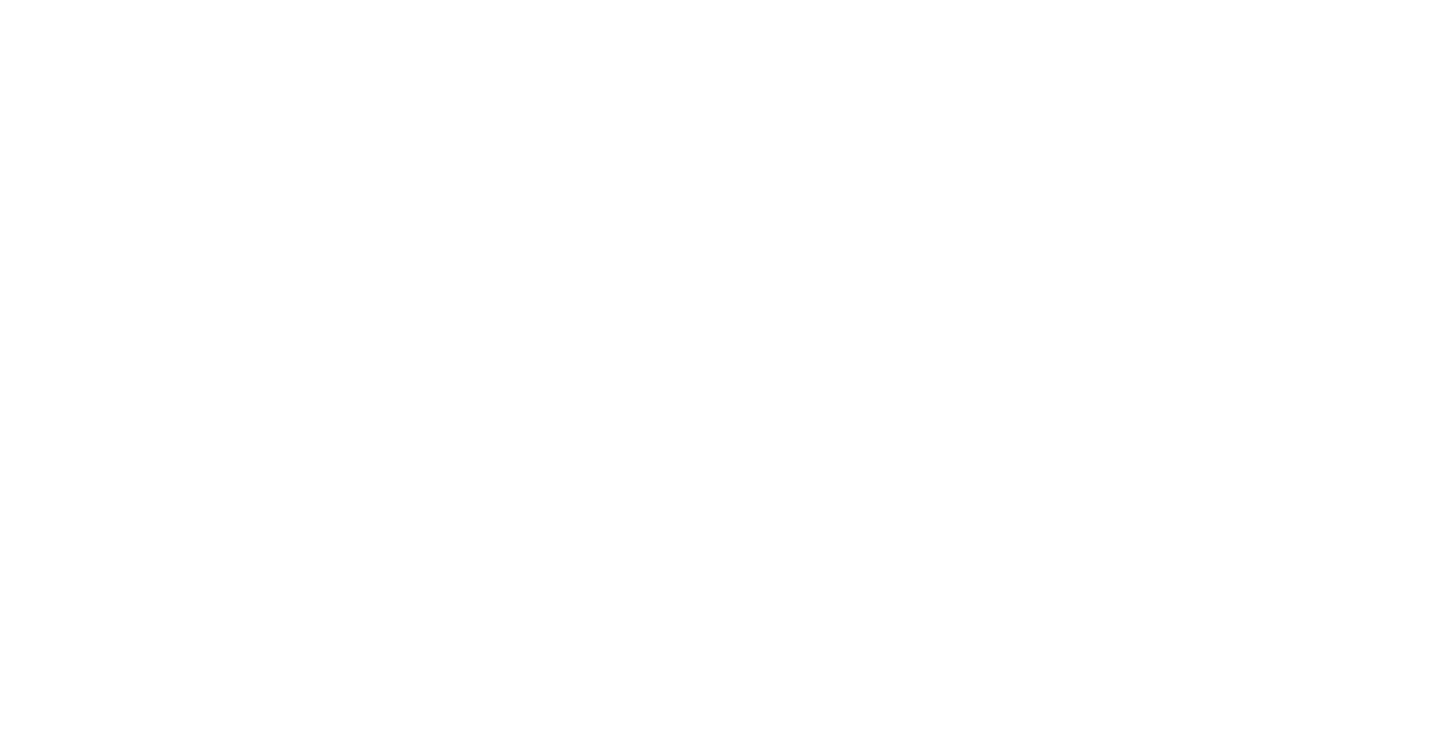

FigURE 133.-Variability of annual discharges of streams in the San Juan River basin, water years 1914-57. 


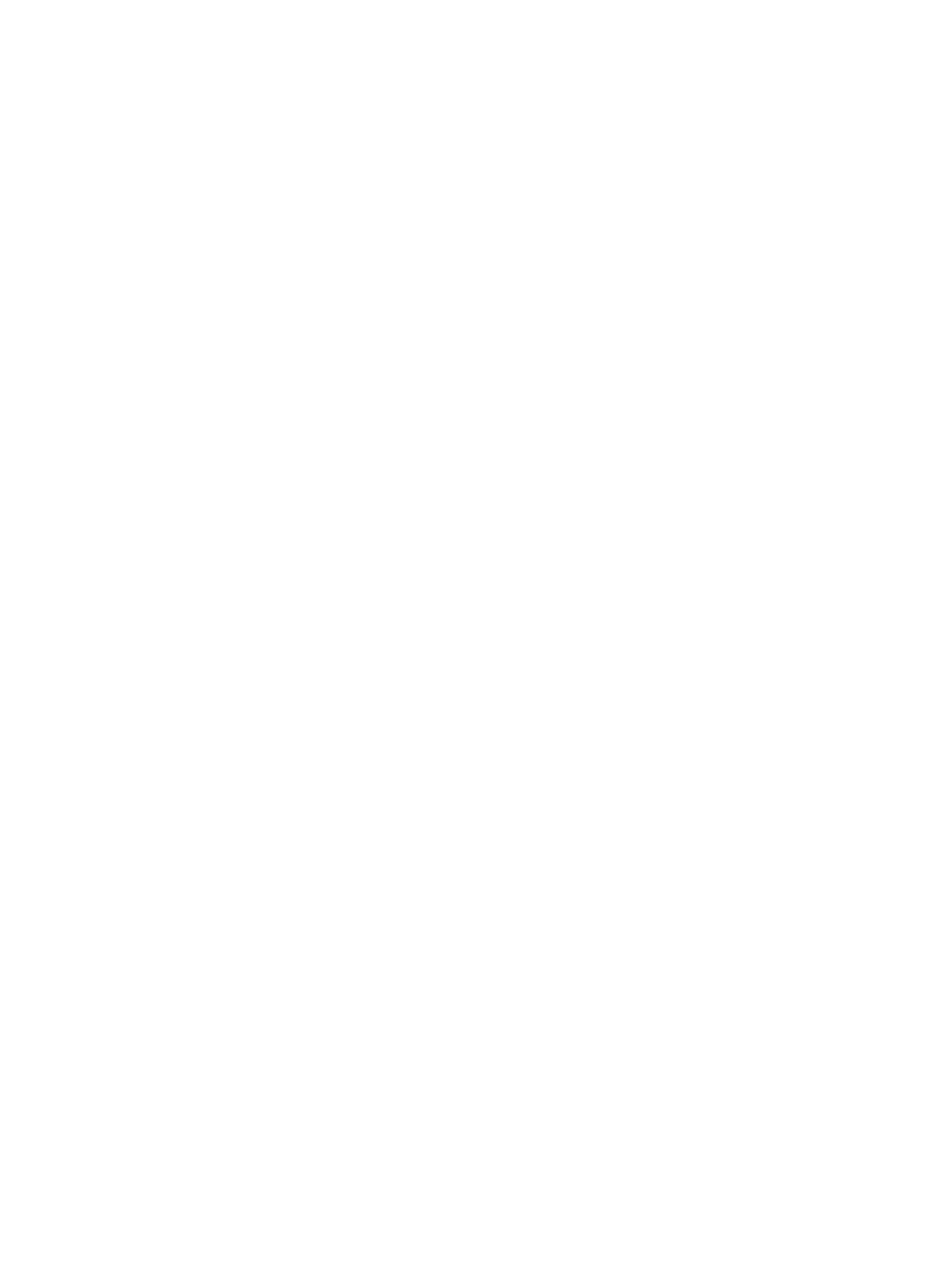


at Edith for the water years 1914-57 is 165 cfs (cubic feet per second) and the coefficient of variation is 0.39 . The probable deviations of average discharge for various periods in the future from the computed 44-year average for a 50-percent chance are given in the following tabulation:

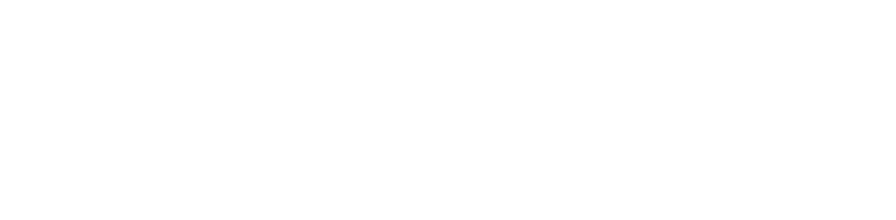

CHEMICAL QUALITY OF WATER

\section{DISSOLVED-SOLIDS DISCHARGE AND CONCENTRATION}

Daily chemical-quality data have been obtained at six stations in the San Juan River basin. Monthly and annual weighted-average chemical analyses of water at these stations are given in the basic data report (Iorns and others, 1964, tables 211-216). The records for San Juan River near Archuleta, N. Mex., and San Juan River near Blanco, N. Mex., are equivalent. In addition to the daily data, chemical analyses of streams at other sites in the subbasin have been obtained. The dissolved-solids discharges for the daily stations and for some of the other sites have been computed (table 10). The quantities given in table 10 are averages that would have occurred if the developments in 1957 had existed throughout water years 1914-57.

Duration tables of dissolved-solids concentration and discharge for the stations listed in table 10 are given in tables 11 and 12. In computing these tables the analyses of water samples, water discharge at the time of sampling, curves showing relation of dissolvedsolids concentration to water discharge, and flow-duration curves of water discharge were used. The methods used to compute the data are described in chapter B (pp. 58-59).

The concentrations of dissolved solids in the headwater streams listed in table 10 are less than $100 \mathrm{ppm}$ except for Hermosa Creek near Hermosa, Colo., where the water has a weighted-average concentration of 219 $\mathrm{ppm}$. The concentration of dissolved solids in many of the tributaries that drain the south slopes of the San Juan Mountains increases greatly in the lower reaches.

Computed dissolved-solids discharges for seven sites on the San Juan River show that the average dissolvedsolids discharge increases from 28 tons per day near Pagosa Springs, Colo., to 2,730 tons per day near Bluff, Utah (table 10). In the same reach the dissolved solids carried by the river per unit of drainage area decreased from 118 to 43 tons per square mile. The decrease in dissolved-solids yield downstream is the result of a decrease in runoff per square mile and an increase in the size of the drainage basin.
The average annual discharges of dissolved solids and water in. San Juan River near Bluff, Utah, was used as a base to compute the contribution (in percent) of dissolved solids and water from other parts of the basin (fig. 134). The data in figure 134 indicate that most of the water comes from the San Juan Mountains and most of the dissolved solids comes from areas downstream from the mountains. Almost 90 percent of the water comes from less than 20 percent of the total area of the San Juan River basin.

\section{VARIATIONS IN CHEMICAL QUAHTTY}

The seasonal variation in dissolved-solids concentration of San Juan River near Bluff, Utah, is large (fig. 135). Other streams whose major source of water supply is snowmelt have a similar pattern, but the variation is much less near their headwaters.

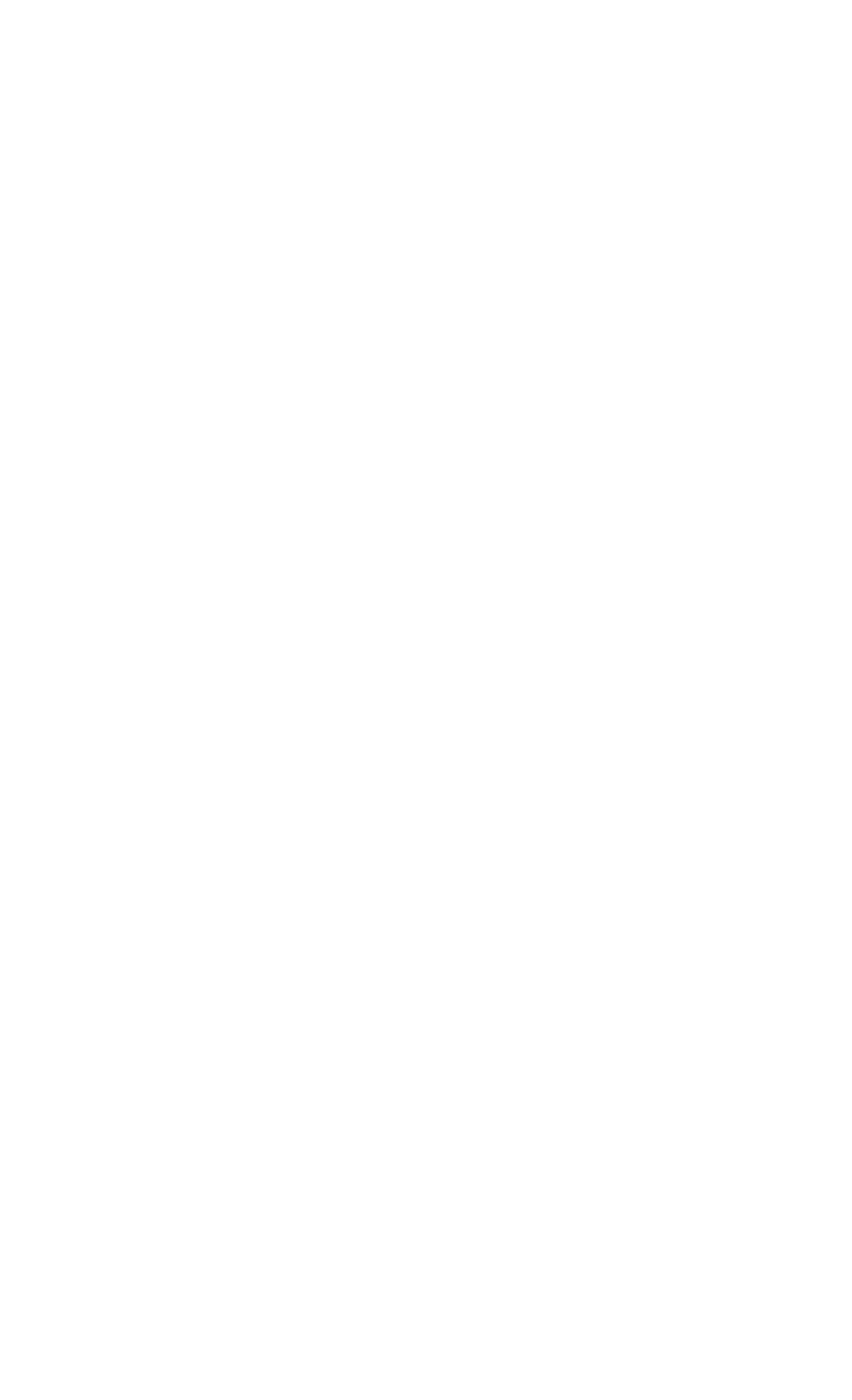

Figure 135.-Dissolved-solids concentration of San Juan River near Bluff, Utah, for the 1951 and 1957 water years. 


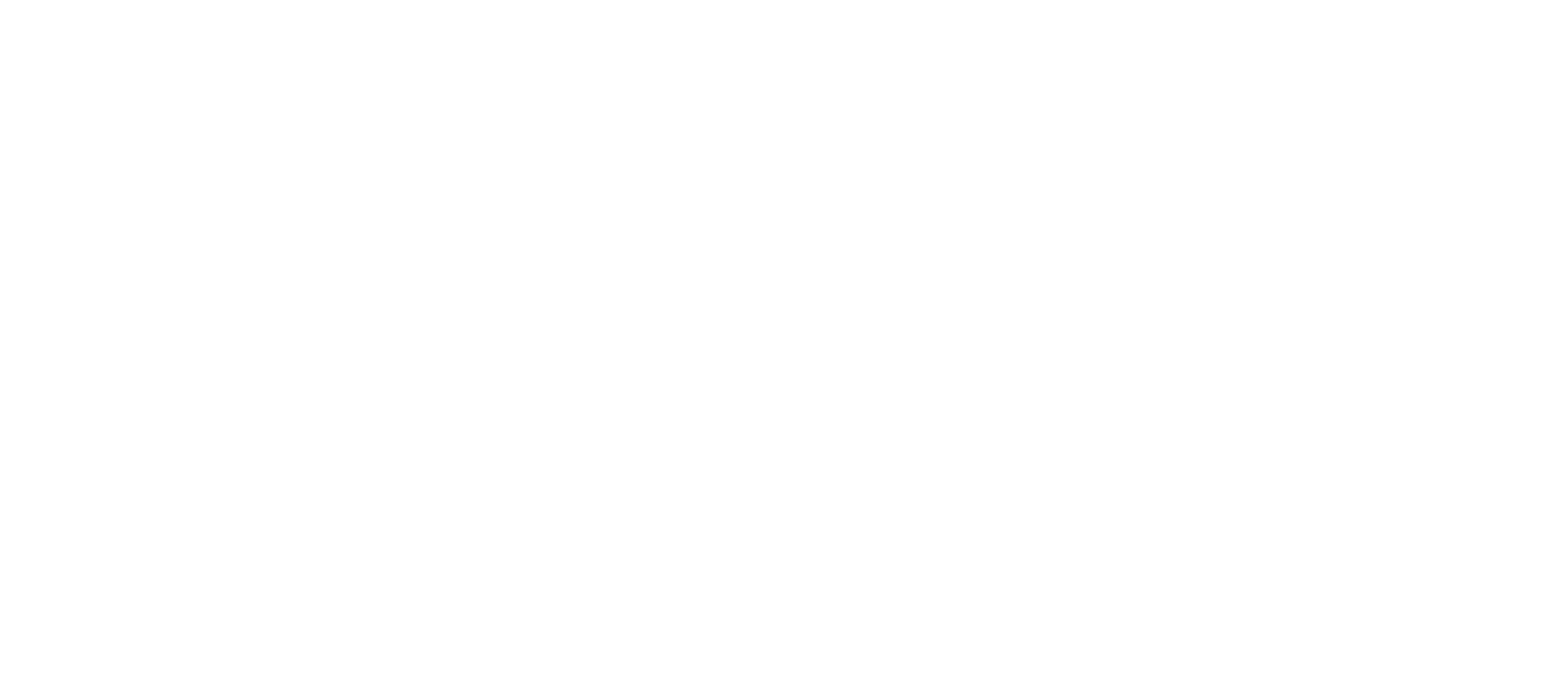

Figure 136.-Relation of the variability of dissolved-solids concentration to the variability of water discharge in the San Juan division. $A$, Animas River at Farmington, N. Mex.; B, San Juan River near Blanco, N. Mex.; $C$, San Juan River near Bluff, Utah; $D$, Colorado River at Lees Ferry, Ariz.

The coefficients of variation of annual weightedaverage concentrations of dissolved solids and annual historical water discharges were computed for three streams in the San Juan River basin (table 13). (See chap. B, p. 60.) The relations of the coefficients for the three streams and for Colorado River at Lees Ferry, Ariz., are shown in figure 136. The correlation between the coefficients is not as reliable as was found for the other two divisions. However, the equation of a straight line (least-squares method) averaging the four points in figure 136 is:

$$
V_{d}=0.22 V_{w}+0.07
$$

where $V_{d}$ is the coefficient of variation of weightedaverage annual concentration of dissolved solids, and $V_{w}$ is the coefficient of variation of annual stream discharges.

The poor correlation may be due to large additions of dissolved solids by runoff in the arid parts of the basin from infrequent thunderstorms, which contribute only a relatively small amount of water. Also, some of the records may be too short for a reliable statistical analysis.

\section{RELATION TO STREAMFLOW}

The patterns of relation between streamflow and dissolved solids at four stations in the San Juan River basin are shown in figure 137. These stations are all at downstream locations, and similar data are not available for headwater streams. However, from meager data obtained in the headwater areas the concentration of dissolved solids in most of the headwater streams probably varies little between low and high discharges.
The relation between the chemical composition of water and streamflow at the four stations is given in table 14 and illustrated in figure 138 for low, median, and high discharges. The waters of the streams, especially at downstream sites, have a different chemical composition during high flows than during low flows. The water of the San Juan River and its principal tributaries changes from the calcium bicarbonate type during high flows to the calcium sulfate type during median and low flows.

\section{RELATION TO GEOLOGY}

The headwaters of the principal tributaries of the San Juan River above Farmington, N. Mex., are in the San Juan Mountains. Near the Continental Divide and the divide between the San Juan and Gunnison River basins, the rocks are mostly volcanic rocks of Tertiary age. In the Animas and Los Pinos River basins, large areas are underlain by igneous and metamorphic rocks of Precambrian age. In the upper reaches of the Piedra and Navajo River basins and in the San Juan River basin above Pagosa Springs, Colo., large areas are underlain by sedimentary rocks of Cretaceous and older ages. The midreaches of the Animas and Los Pinos Rivers also are underlain by similar rocks. The lower reaches of all these tributaries except the Navajo River are underlain mostly by rocks of Tertiary and Quaternary ages.

The waters of the Los Pinos, Piedra, Navajo, and East and West Forks San Juan River in their upper reaches are of the calcium bicarbonate type, and the weighted-average concentration of dissolved solids is 

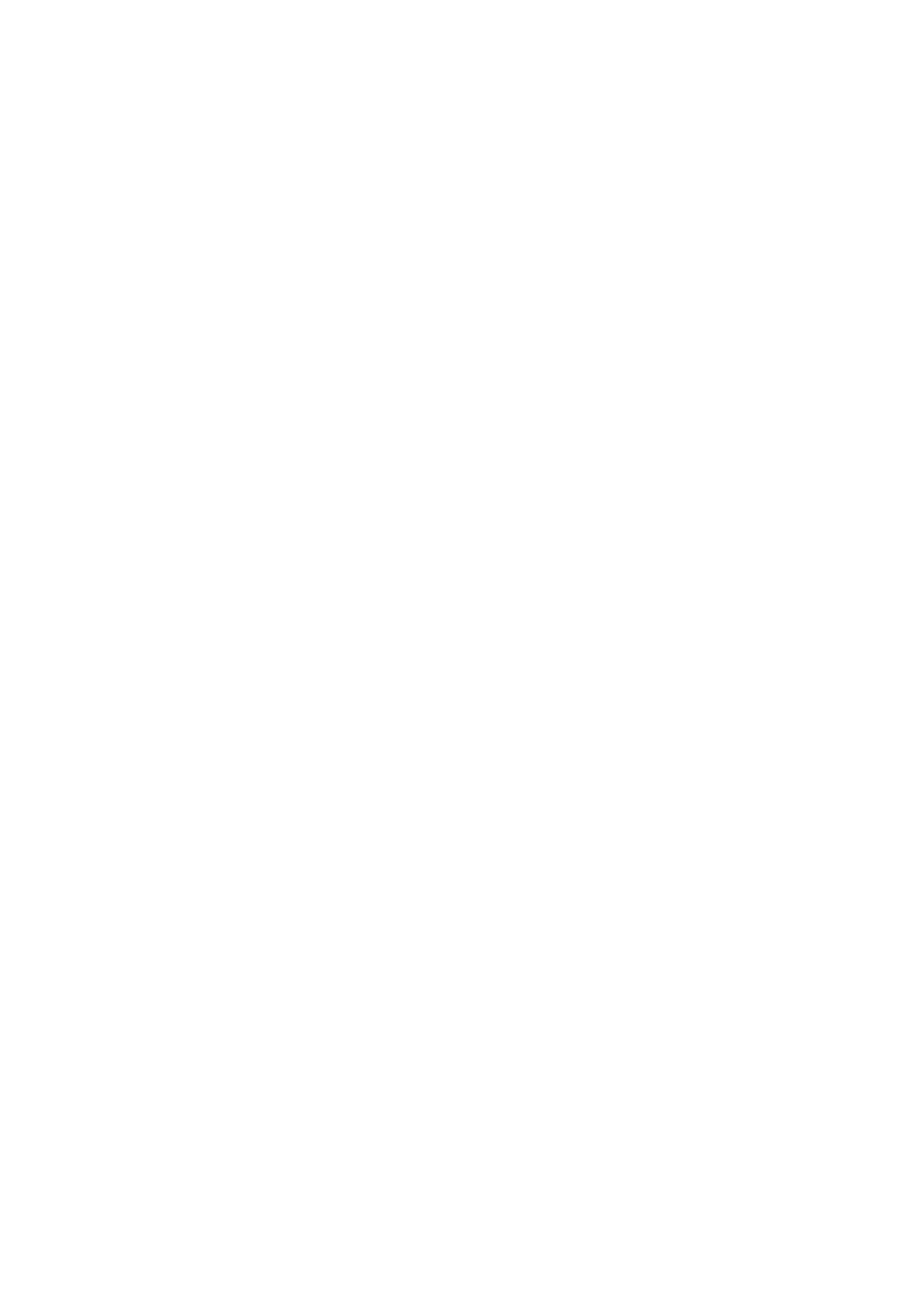

FIGURE 137.-Dissolved-solids concentration and discharge, and water discharge at four daily stations in the San Juan River basin. 


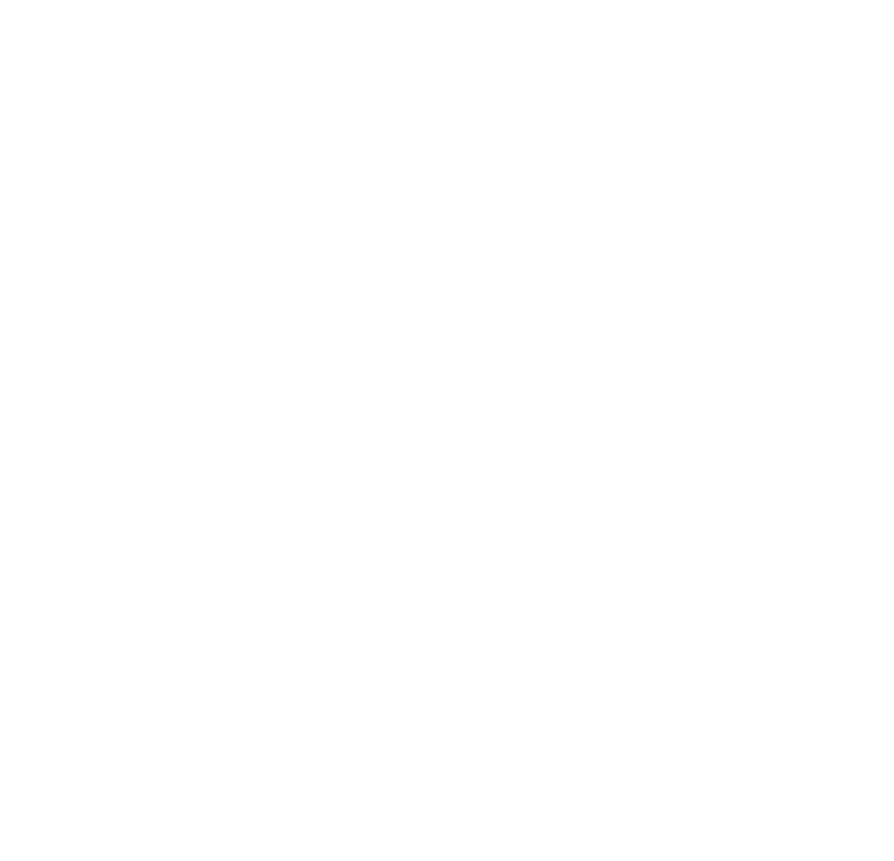

A. San Juan River near Blanco, N. Mex.

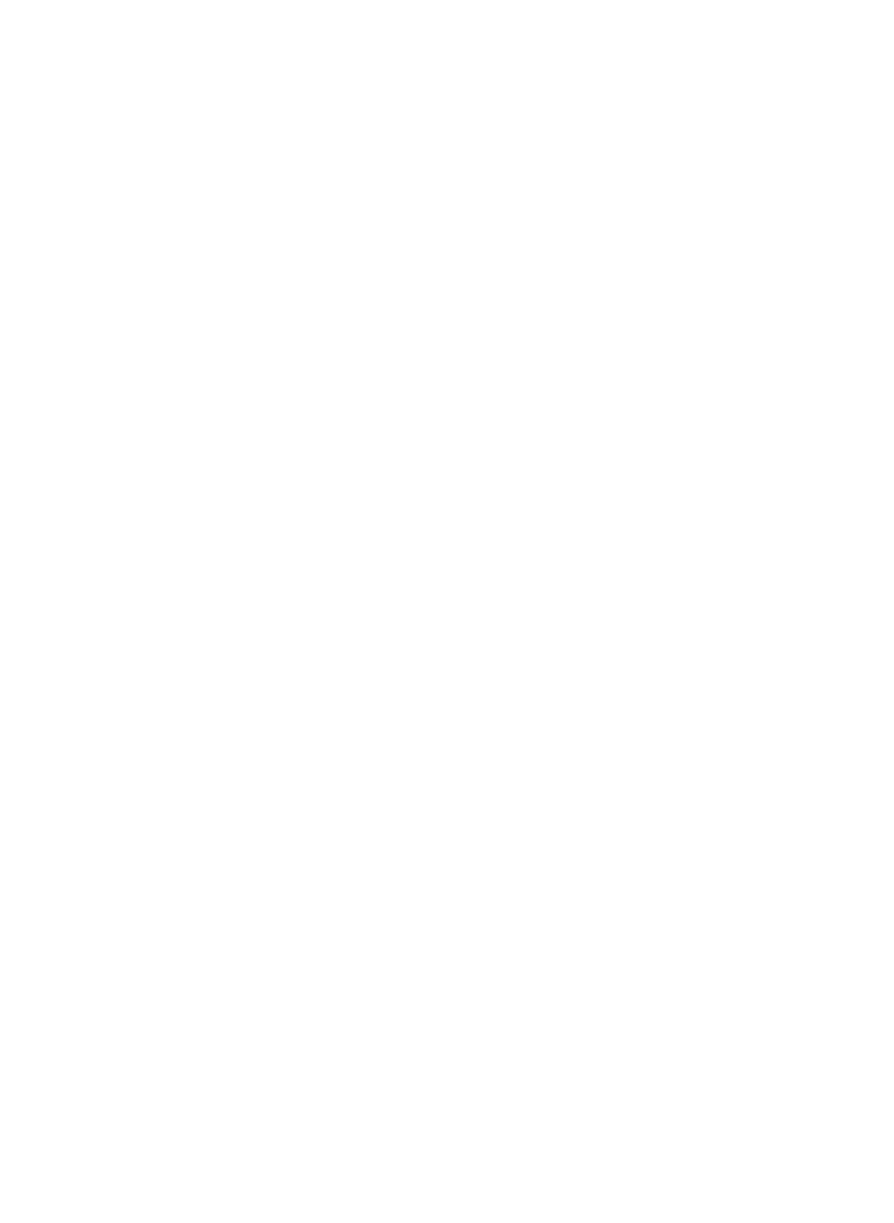

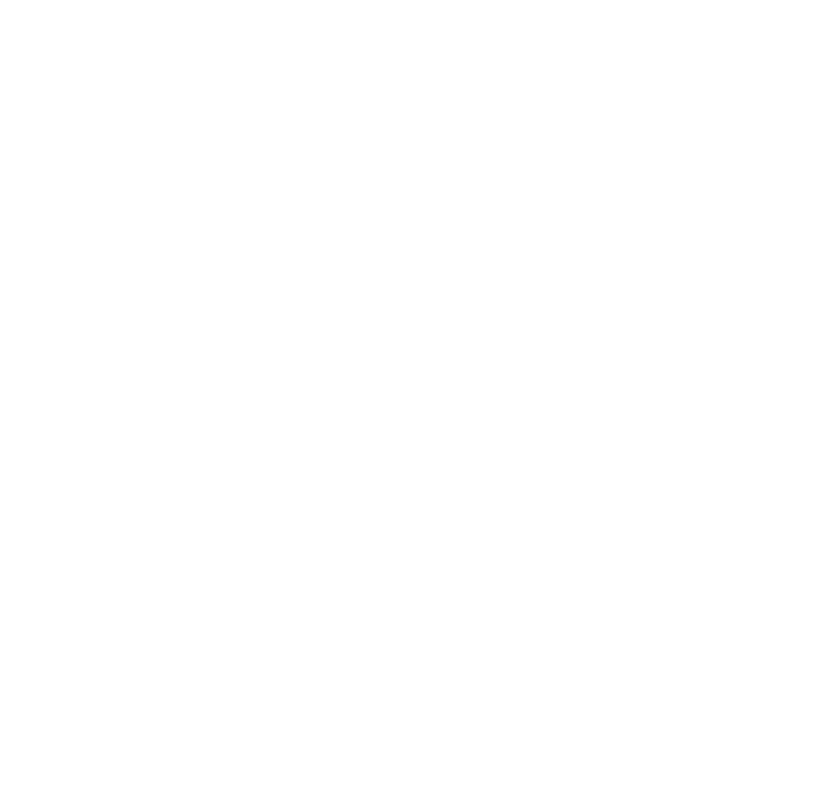

EXPLANATION

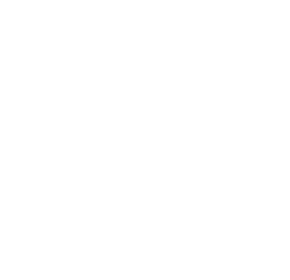

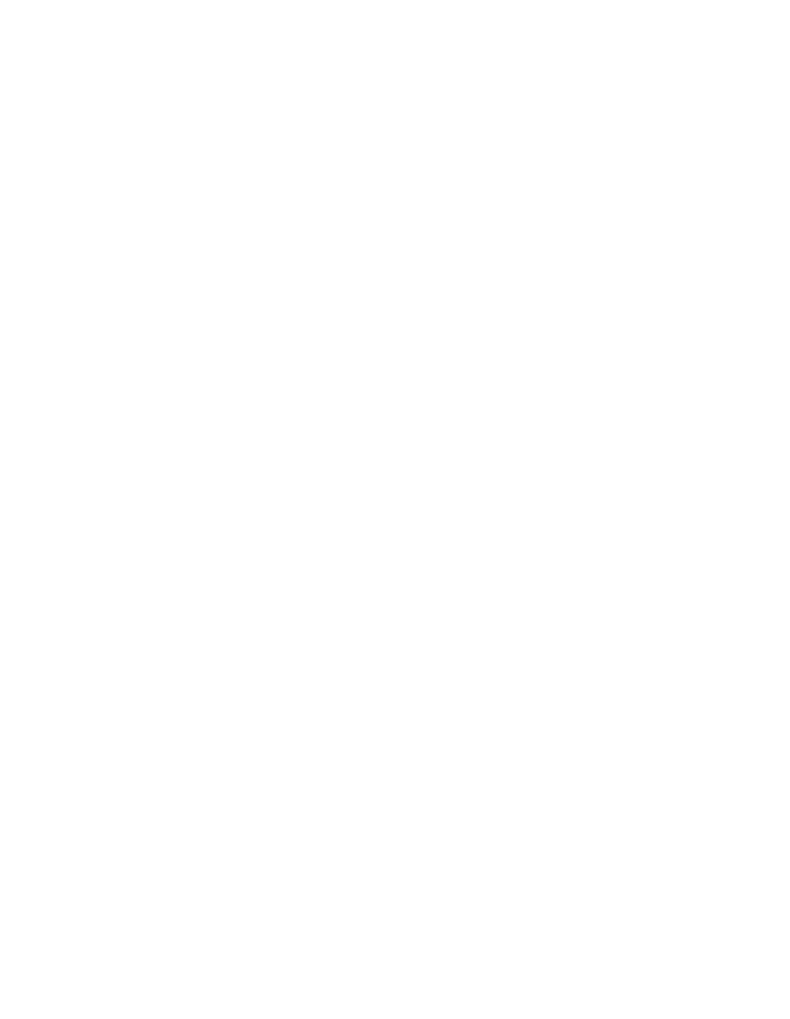

FIgure 138.-Relation of the chemical composition and concentration of dissolved solids to water discharge in the San Juan River basin. The concentration of specific ions, in equivalents per million (epm), is shown for the 10th, 50th, and 90th percentiles of the flow-duration curve for each location. The flow-duration curves are for water years $1914-57$ adjusted to 1957 conditions. 
low. In their middle and lower reaches, especially downstream from irrigated fields, the streams contain progressively more magnesium, sodium, and sulfate ions.

The waters of the Animas River differ from those of the other streams that drain the San Juan Mountains in that, even in the headwaters of the Animas River, calcium sulfate waters predominate, except during high flows in the spring. Most of the headwaters of the Animas River are underlain by the Silverton Volcanic Group, and calcium sulfate water from an area underlain by volcanic rocks is unusual. One possible explanation for the anomaly is that some of the formations in the Silverton Volcanic Group contain beds of limestone and calcareous shale, presumably somewhat gypsiferous. Larsen and Cross $(1956$, p. 79) said:

A variable amount of fine-grained tuffs is usually found at the tops of the Burns quartz latite, especially in the region around the head of the Animas and farther eastward, and they locally reach a thickness of several hundred feet. Commonly these tuffs are similar to those of the lower horizon, but in places the upper 50 feet or more is made up of calcareous shales and thin beds of limestone. Plant remains and gastropod shells are present in the uppermost parts of these beds.

The tributaries of the San Juan River from the south between the Animas and Navajo Rivers are underlain by sedimentary rocks of Tertiary age. Only one sample of surface water from this large area has been collected. The analysis of this sample, from the drainage basin of Canyon Largo, suggests that water coming from this area would be of the sodium sulfate type and also would contain a large percentage of calcium and bicarbonate.

The next large tributary of the San Juan River from the south, west of Canyon Largo, is the Chaco River, whose drainage basin is underlain chiefly by sedimentary rocks of Cretaceous age. Analyses of samples collected in the headwaters of the Chaco River indicate that its waters would be of the sodium sulfate type, similar to waters in the Canyon Largo basin.

The La Plata River, which flows into the San Juan River a short distance below the mouth of the Animas River, rises in the La Plata Mountains, which are composed of igneous intrusives and sedimentary rocks of Late Permian and Pennsylvanian ages. In the La Plata Mountains the water of the La Plata River is of the calcium bicarbonate type at all flows. Between Hesperus, Colo., and the mouth of the La Plata River, large areas underlain by the Mesaverde Group of Cretaceous age are irrigated (pl. 9), and the return flow from irrigated fields is partly responsible for the high dissolved-solids concentration of the river water during and after the irrigation season. At these times the water is either of the sodium or of the calcium sulfate type.
The Mancos River drainage basin is underlain chiefly by sedimentary rocks of the Mesaverde Group, Mancos Shale, and other rocks of Cretaceous age. During high flows in the spring the water of the Mancos River is of the calcium bicarbonate type, during low flows in August through October the water is influenced by irrigation return flows and contains large percentages of magnesium and sulfate. Near Towaoc, Colo., which is downstream from about 10,000 acres of irrigated land, the water is of the calcium sulfate type at most stages of flow.

The drainage basin of McElmo Creek is underlain principally by rocks of Cretaceous age. Soils developed on these rocks are irrigated extensively in the Montezuma irrigation district, which imports water from the Dolores River basin. The water imported and applied to the land is low in dissolved solids-the weightedaverage concentration being about $125 \mathrm{ppm}$ (parts per million) - and is of the calcium bicarbonate type. At the station near Cortez, Colo., the flow is mainly return water from irrigated lands of Montezuma irrigation district (U.S. Geol. Survey, 1954, p. 516). At most flows, the water at the station has high concentrations of dissolved solids and is of the magnesium sulfate type but has large percentages of calcium and sodium. The weighted-average concentration of dissolved solids at this station for the water years 1914-57 adjusted to 1957 conditions is about $2,200 \mathrm{ppm}$. At the lowest flows the concentration may exceed $5,000 \mathrm{ppm}$ (table 11).

Montezuma Creek and its tributaries that head in the Abajo Mountains near Monticello, Utah, usually contain less than $200 \mathrm{ppm}$ of dissolved solids, and the waters are of the calcium bicarbonate type. No chemical analyses of the water of Montezuma Creek at its mouth are available. However, the rocks that underlie most of the drainage basin are similar to those in the drainage basins immediately to the west and are mostly of Cretaceous age. The water from the streams to the west, where they enter the San Juan River, contains 1,000 to $3,000 \mathrm{ppm}$ of dissolved solids and is of the calcium sulfate type. The concentration of magnesium and sodium ions in these streams is also high.

The water of San Juan River near Bluff, Utah, is of the calcium sulfate type at all flows except during high flows in the spring, when the water is of the calcium bicarbonate type. The weighted-average analyses of the water for any year at this station indicates that the water is of the calcium sulfate type.

A map of the San Juan River basin, showing zones within which the weighted-average concentration of dissolved solids in waters of the streams is between indicated limits, is shown in figure 139. The zones indicate that the weighted-average concentrations of dissolved solids in the waters of the streams that supply 


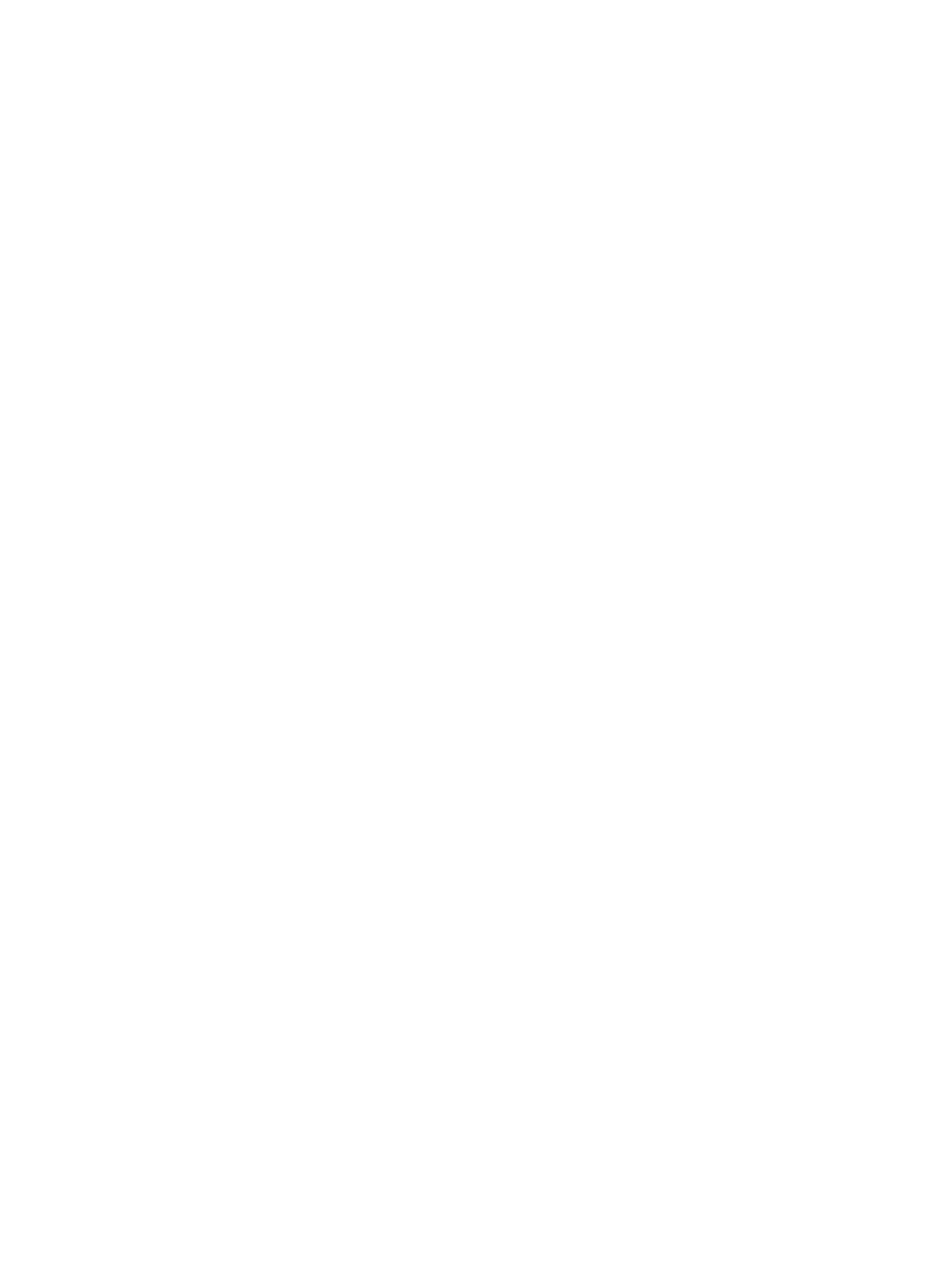


most of the water in the San Juan River basin do not exceed 300 ppm.

The diagrams in plate 2 show the geochemical character and ionic concentration of surface waters at 44 sites in the subbasin. The diagrams are representative of the chemical character of the streams during low flow, when the effect of geology on chemical quality is more evident than during high flow. The significance of the size and shape of the diagrams is given in the explanation in plate 2 .

\section{RELATION TO GROUND WATER}

Natural recharge to ground-water reservoirs occurs in the mountainous areas of the basin, where precipitation is abundant. The water discharged from these reservoirs, which maintains the perennial streams during periods of low flow, has a higher concentration of dissolved solids than the water that runs off directly to the streams. Comparison of the weighted-average concentration of dissolved solids in the ground-water contribution to selected headwater streams with weighted-average concentration of the stream water (table 15) indicates the relative effect of ground water in the headwater areas on the chemical quality of water in the streams. (See chap. B, pp. 59-60 for an explanation of the method used in determining the amount of dissolved solids added to the streams by ground water.)

In most of the subbasin the precipitation is low, and very little ground water reaches the streams except from the alluvium along the perennial streams. There, water enters the alluvium chiefly during the high flows in the spring. During low flows, part of this water is returned to the stream. As the water circulates through the alluvium, it picks up additional dissolved solids which increase the concentration in the stream to which it returns. Figure 140 compares the quality

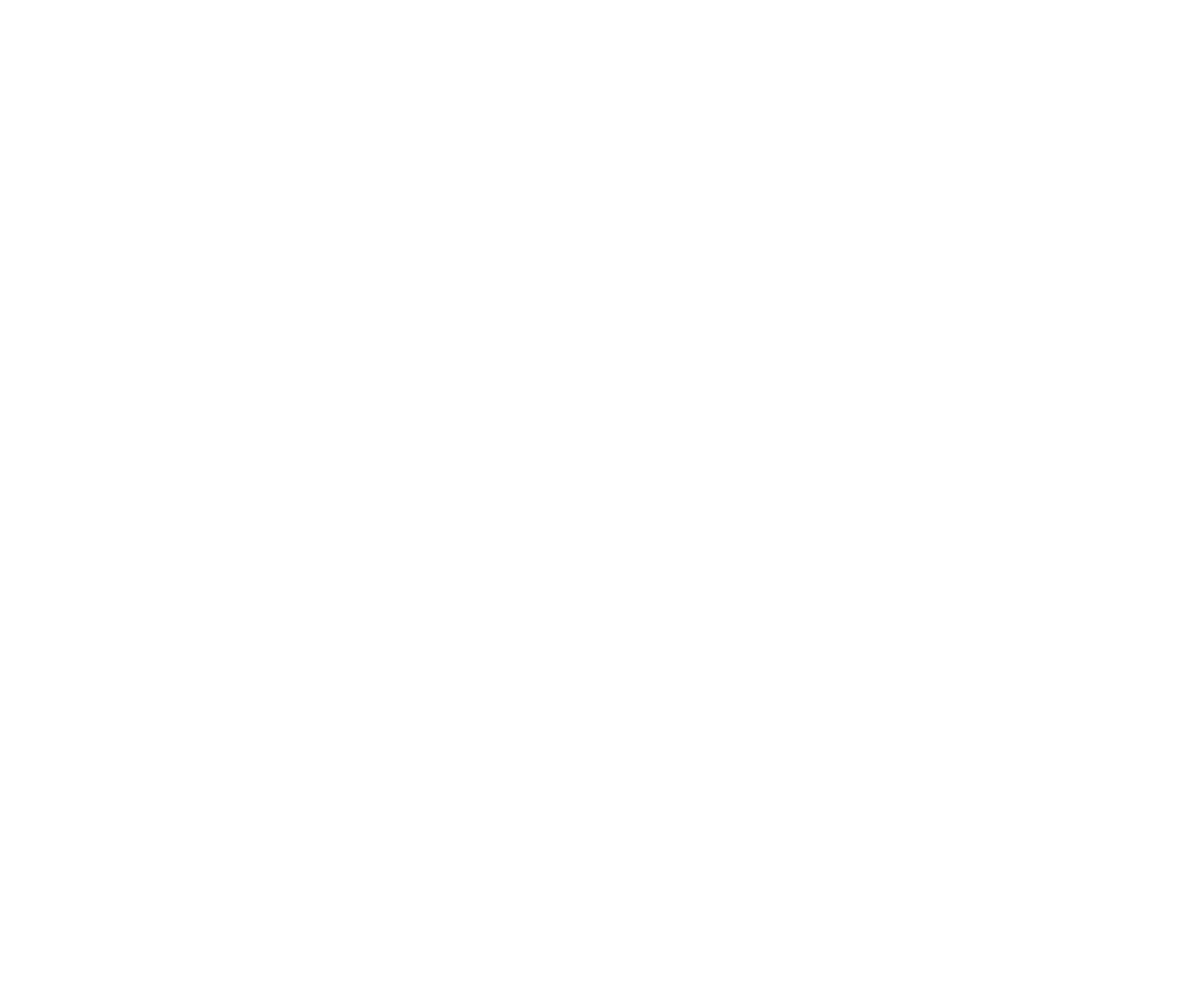

FIGURE 140.-Analyses of water from selected streams in the San Juan River basin and from alluvium nearby. 
of the ground water along selected streams with water in the streams nearby during low flows.

In irrigated areas much of the applied water may return to the stream as ground-water inflow. This inflow is usually of poorer quality than the streams and thus adversely affects their quality.

The water from some of the thermal springs in this subbasin has high concentrations of dissolved solids - which adversely affect the quality of water in the streams into which it flows. For example, the water entering the San Juan River from the springs at Pagosa Springs, Colo., contains about 3,600 ppm of dissolved solids and is of the sodium sulfate type. The flow is about $2 \mathrm{cfs}$, and the dissolved-solids discharge to the river thus is about 7,100 tons annually. Five thermal springs, having a total discharge of about 1 cfs and a dissolved-solids concentration of about 4,000 ppm, are known to be in the Animas River basin. The dissolved-solids discharge is about 4,000 tons annually. Other thermal springs, most of which have flows of less than 10 gallons per minute, but whose water is of unknown concentration, are in the basin (Stearns and others, 1937).

\section{EFFECT OF TRANSMOUNTAIN DIVERSIONS}

For the water years 1948-57, an average of about 2,750 acre-feet of water per year was diverted from the San Juan River basin to the Rio Grande basin. (See p. 305.) Most of this water was diverted from the headwaters of the Los Pinos River (2,500 acre-ft). These diversions from the San Juan River basin adversely affect the quality of the water downstream in that basin, but the amount diverted is so small that this effect on the quality is negligible. It is estimated that the 2,750 acre-feet of water diverted annually carries only about 260 tons of dissolved solids.

About 100,000 acre-feet of water is imported annually into the San Juan River basin from the Dolores River basin. The weighted-average concentration of dissolved solids of this water is about $125 \mathrm{ppm}$. The importation adds about 17,000 tons per year of dissolved solids to the McElmo Creek basin. The theoretical effect of this importation would be a decrease in the weighted-average concentration of San Juan River near Bluff, Utah. However, because this water is used for irrigation in the McElmo Creek basin, where the water picks up additional dissolved solids in the irrigated areas, the net effect is to increase the dissolvedsolids concentration and discharge of San Juan River near Bluff. Although the importation of 17,000 tons per year of dissolved solids into this subbasin is a result of an activity of man, it is considered in this report to result from a natural source.

If no water were exported from or imported into the San Juan River basin, the theoretical average annual discharge of the river near Bluff, Utah, would be about 97,200 acre-feet $(100,000$ minus 2,800 acre-ft) less, and the average annual discharge of dissolved solids would be about 16,700 tons (17,000 minus 300 tons) less than the average for the water years 1914-57 adjusted to 1957 conditions. If no water had been imported the weighted-average concentration of dissolved solids of the river near Bluff would theoretically be $373 \mathrm{ppm}$, an increase of $12 \mathrm{ppm}$ from that during 1957 conditions. In this determination it was assumed that the irrigated lands supplied by water diverted from the Dolores River obtained their supply from sources within the San Juan River basin.

\section{EFFECT OF THE ACTIVITIES OF MAN}

In chapter B (pp. 61-66) the effect of the activities of man (domestic, industrial, and irrigation uses) on the dissolved-solids discharge of streams is discussed, and the methods for computing the amount of dissolved solids added to the stream as a result of these uses are described. In chapters C and D (Grand and Green divisions) the amounts of dissolved solids contributed to streams as a result of the activities of man were computed for many areas. In the San Juan River basin, the La Plata River basin is the only area for which sufficient data are available to make similar computations.

In the area between gaging stations on La Plata River at Hasperus, Colo., and at Colorado-New Mexico State line, about 16,500 acres is irrigated on alluvium underlain mostly by the Mesaverde Formation. The consumptive use of water by irrigation in the area is estimated to be about 18,200 acre-feet annually (1.1 acre-ft per acre). An approximate water and dissolvedsolids budget for the area is given in table 16 .

Data for water and dissolved solids given in table 16 for the stations at Hesperus and at the State line are from table 10 and are rounded to three significant figures. The unmeasured inflow (11,100 acre-ft) is the amount required to balance the inflow-outflow budget. The weighted-average concentration of dissolved solids in the unmeasured inflow is based on Devil Creek near Piedra, Colo., and Stolsteimer Creek near Dyke, Colo. (Iorns and others, 1964, table 225). Drainage areas above these stations are underlain by similar rocks (Mesaverde Group of Cretaceous age), are about the same altitude, and have about the same precipitation as the drainage area of the unmeasured inflow. On the assumption that the dissolved-solids increase is 
mostly caused by irrigation, the irrigated lands yield about 0.4 tons per year per acre.

Between the gaging stations on La Plata River at Colorado-New Mexico State line and near Farmington, N. Mex., about 9,500 acres is irrigated on alluvium partly underlain by the Mesaverde Formation and partly by rocks of Tertiary age. An approximate water and dissolved-solids budget for the area is given in table 16.

The amount of water consumed by irrigation in the area is based on an annual consumptive use of 1.1 acrefeet per acre. The unmeasured inflow in the intervening area between the two gaging stations is the amount required to balance the inflow-outflow budget. The concentration of dissolved solids in the unmeasured inflow is based mostly on Cox Canyon Creek at Cedar Hill, N. Mex., during low flow (Iorns and others, 1964, table 225). The increase in dissolved solids from other sources in the reach is equivalent to 1.4 tons per year per acre of irrigated land.

In other areas of the San Juan basin for which sufficient data were not available to make similar determinations, calculations indicate that the amount of dissolved solids added to the streams as a result of irrigation ranges from about 0.4 ton to 2.6 tons per acre. Lands underlain by valley alluvium similar to that of irrigated areas in the Los Pinos River basin had the lower rate, and lands underlain by Mancos Shale similar to the irrigated lands along the Mancos River had the higher rate.

In table 17 the estimated amounts of dissolved solids from natural sources and as a result of the activities of man are summarized for three main-stem gaging stations and for the San Juan River basin.

If there had been no activities of man in the subbasin, the weighted-average concentration of dissolved solids of the San Juan River at the gaging station near Bluff, Utah, would have been about $228 \mathrm{ppm}$ as compared with a weighted-average of $361 \mathrm{ppm}$ for water years 1914-57 adjusted to 1957 conditions. In this determination 6,700 acre-feet of water annually was estimated to be used consumptively by domestic and industrial uses and 256,600 acre-feet annually by irrigation.

The increase in dissolved solids due to irrigation in the subbasin is estimated to be about 278,100 tons per year. This estimate is based on 100 tons per year per 1,000 people as the contribution of dissolved solids resulting from domestic and industrial uses of water and on the assumption that the remainder of the dissolved solids attributed to the activities of man was contributed as a result of irrigation.

\section{FLUVIAL SEDIMENT}

Daily suspended-sediment records have been obtained at the station on San Juan River near Bluff, Utah, since August 1928. Daily records have also been obtained at six other stations in the basin for shorter periods ranging from 6 months to almost 7 years. Records of suspended-sediment discharge at the seven stations are given in table 18. Suspended-sediment discharges have also been measured on a miscellaneous basis at several other sampling sites.

Estimated suspended-sediment discharges at five of the daily stations and at four other sites in the San Juan River basin for the water years $1914-57$ adjusted to 1957 conditions are given in table 19. A large part of the sediment discharged by the river near Bluff probably comes from Canyon Largo, the Chaco River, and Chinle Wash.

During the period of record for the sediment station near Bluff, there have been several changes in the relation of the suspended-sediment discharge to water discharge. During the drought of the 1930 's, the annual suspended-sediment concentration near Bluff was greater than during the wetter years of the 1940's.

\section{SUITAFILITY OF WATER FOR VARIOUS USES}

\section{DOMESTIC USE}

The classification of the surface water in the San Juan River basin is based on water-quality criteria for major uses. (See chap. B, pp. 66-73.)

The chemical analyses of water from the San Juan River and the tributaries above Arboles, Colo., show that the water, except that from Pagosa Springs at Pagosa Springs, Colo., is suitable for domestic use by the standards accepted for this report. The water of Pagosa Springs has a sulfate concentration of about $1,500 \mathrm{ppm}$ and contains about $3,600 \mathrm{ppm}$ of dissolved solids. The spring water is very hard $(700 \mathrm{ppm}$ as $\left.\mathrm{CaCO}_{3}\right)$ and contains between 50 and $70 \mathrm{ppm}$ of silica. Stream water in this area is low in dissolved solids and is soft. However, the concentration of silica is usually about $20 \mathrm{ppm}$, which is a reflection of the effect of the volcanic rocks in the headwaters of the streams.

The water of the Piedra River, which enters the San Juan River at Arboles, Colo., has a higher concentration of dissolved solids, except in the headwaters, than the San Juan and its tributaries above Piedra. However, none of the constituents in the water of the Piedra and its tributaries exceed the maximum limits accepted for domestic use. In the upper reaches of the Piedra River, the water is dilute and soft but contains 20 to $25 \mathrm{ppm}$ of silica. In the lower part of the Piedra River basin the waters of the Piedra River 
and some of its tributaries, such as Devil Creek and Stolsteimer Creek, contain about $250 \mathrm{ppm}$ of sulfate, but apparently the sulfate seldom exceeds $250 \mathrm{ppm}$. In the lower reaches the waters of the Piedra and its tributaries are moderately hard.

The surface waters of the Los Pinos River basin are suitable for domestic use. Above Bayfield, Colo., they are dilute (dissolved-solids concentration usually less than $100 \mathrm{ppm}$ ) and soft. At La Boca, Colo., the dissolved-solids concentration of the river water usually does not exceed $200 \mathrm{ppm}$, and the water is moderately hard. Spring Creek at La Boca, Colo., is below land that is partly irrigated by water diverted from the Los Pinos River, and its water may contain more than $500 \mathrm{ppm}$ of dissolved solids during low flows. The water may have a hardness of as much as $200 \mathrm{ppm}$ during low flows and would require softening for use by laundries and some other industries.

The water of San Juan River at Bloomfield, N. Mex., which is upstream from the mouth of the Animas River and downstream from Canyon Largo, always contains less than $500 \mathrm{ppm}$ of dissolved solids. However, the water is hard and would require softening for many uses.

The Animas River rises in the high peaks of the San Juan Mountains in a region underlain by volcanic rocks that produce water of the calcium sulfate type. Above Cedar Hill, N. Mex., the waters of the Animas River and its tributaries contain less than $500 \mathrm{ppm}$ of dissolved solids, and the concentration of constituents considered to be important for domestic use never exceeds the maximum limits accepted for this report. The surface waters in the Animas River basin above Cedar Hill range from soft to hard and the concentration of silica is less than $10 \mathrm{ppm}$, except in some of the tributaries close to the divide. For example, a sample of water from Cement Creek near Silverton, Colo., which is near the divide, contained $34 \mathrm{ppm}$ of silica.

At the mouth of Animas River at Farmington, $N$. Mex., the water may contain as much as $700 \mathrm{ppm}$ of dissolved solids, of which about $300 \mathrm{ppm}$ is sulfate. The maximum sulfate concentration permitted by the standards accepted for this report is $250 \mathrm{ppm}$. In most years these high sulfate concentrations occur in the fall and winter. The hardness of the water at Farmington generally ranges from $100 \mathrm{ppm}$ during the high flows in the spring to $400 \mathrm{ppm}$ in the fall. This range indicates that softening of the river water would be desirable for most purposes.

In its headwaters the water of the La Plata River has concentrations of dissolved solids similar to those of the Animas River in its headwaters and is suitable for all domestic uses. At the mouth of the river, how- ever, the water never meets the requirements for domestic use. Here, the water may contain less than 700 ppm of dissolved solids; but during part of the year the concentration of magnesium exceeds $125 \mathrm{ppm}$, and the concentration of sulfate is never less than 300 ppm. The concentration of chloride is sometimes as high as $400 \mathrm{ppm}$. The water is very hard, even during the high flows in the spring.

The concentration of sulfate in San Juan River at Shiprock, N. Mex., and near Bluff, Utah, and at points between these two stations, exceeds $250 \mathrm{ppm}$ for about half the year. During this period the water is not suitable for domestic use under the standards accepted for this report.

The concentration of nitrate in the surface waters of the San Juan basin is usually less than $6 \mathrm{ppm}$ and, therefore, does not constitute a hazard for domestic use. Fluoride seldom exceeds $0.5 \mathrm{ppm}$. In the lower reaches of most streams, the water is very hard and would require softening for most purposes.

\section{AGRICULTURAL USE}

The principal use of water in the San Juan River basin is for irrigation. Table 20 classifies the waters of many of the streams in this subbasin of the San Juan division according to their suitability for irrigation. The classification of the water for the different sites is for high, medium, and low flows. The chemical analyses on which the classification is based are given in the basic data report (Iorns and others, 1964). Most of the terms used in the table are self-explanatory or are explained in chapter B (pp. 69-73), except the classification of water discharge as low, medium, or high. High flows are those greater than the discharge exceeded 20 percent of the time, low flows are those less than the discharge exceeded 80 percent of the time, and medium flows are those exceeded 80 percent of the time and less than the discharge exceeded 20 percent of the time. The range of discharge for low, medium, and high flows for most of the sampling sites was determined from table 6 .

The values for residual sodium carbonate given in table 20 indicate that the water of all the perennial streams contains much less than 1.25 epm (equivalents per million) of residual sodium carbonate. The highest residual sodium carbonate for any of the perennial streams, most of which enter the San Juan River from the north, was $0.41 \mathrm{epm}$ for Florida River at Bondad, Colo., and this occurred during low flow.

Chemical analyses of surface- and ground-water samples from the area south of the San Juan River show that many of the waters from intermittent streams may contain more than $1.25 \mathrm{epm}$ of residual sodium bicar- 
bonate. For example, water from two streams contained 1.35 and 1.49 epm (table 20).

The surface waters of the San Juan River basin, as classified for irrigation, range from $\mathrm{C} 1-\mathrm{S} 1$ to $\mathrm{C} 4-\mathrm{S} 3$. However, most sources of irrigation water in the basin are C2-S1 or better; hence, only a moderate amount of leaching is required, and there is little danger of development of harmful levels of sodium.

Percent sodium is low except in some spring waters and in some of the intermittent streams south of the San Juan River. The amount of required leaching is usually small except for the waters of a few streamssuch as McElmo Creek near Cortez, Colo.-whose flow is principally return flow from irrigated lands.

Boron is apparently not a hazard in any of the surface waters of the basin.

\section{INDUSTRIAL AND RECREATIONAL USES}

The water of the principal headwater streams can be used by most industries without treatment. The water increases progressively in concentration of dissolved solids downstream, and in the lower reaches it could not be used by many industries without treatment.

Most of the streams and lakes in the San Juan Mountains are ideal for all types of recreational pursuits and are used extensively for this purpose. This use will continue to expand.

\section{COLORADO RIVER BASIN BELOW THE GREEN AND SAN JUAN RIVERS AND ABOVE "LEE FERRY," ARIZ.}

\section{PRESENT UTILIZATION OF SURFACE WATER} STORAGE RESERVOIRS

Six irrigation reservoirs that have usable storage capacities greater than 1,000 acre-feet have been constructed (1957) in the Colorado River Basin below the Green and San Juan Rivers and above "Lee Ferry" (table 3, and pl. 8). Many small lakes, reservoirs, and stock ponds also are scattered throughout the subbasin.

\section{TRANSMOUNTAIN DIVERSIONS}

There are no transmountain diversions of water from this subbasin. The Topic and East Fork canal imports water from the East Fork of Sevier River (Great Basin) for irrigation in the upper Paria River basin. Available records of annual imports by this canal are given in table 21 . The average annual discharge for water years $1950-57$ was 2,600 acre-feet.

\section{IRRIGATTON}

About 33,300 acres is irrigated in the subbasin (table $5)$. All the land is along the upper reaches of the three principal tributary streams (pl. 9).

The Upper Colorado River Basin Compact Commission (1948) estimated that the 1914-45 annual consumptive use of water in the subbasin due to irrigation was 44,518 acre-feet, of which 4,000 acre-feet was imported water. The Commission estimated that 32,620 acres was irrigated and 4,775 acres received water incidental to irrigation.

\section{DOMESTIC AND INDUSTRIAL USES}

The 1960 population of the subbasin was about 6,000 . The five largest communities and their populations are Page, Ariz., 2,960; Escalante, Utah, 702; Bicknell, Utah, 366; Loa, Utah, 359; and Emery, Utah, 326. The population of Page, Ariz., is engaged mostly in the construction of Glen Canyon Dam and related activities. Other principal activities are farming and ranching.

A hydroelectric powerplant on the Fremont River at Torrey, Utah, has an installed capacity of 140 kilowatts and is the major industrial user of water in the subbasin.

Escalante, Utah, obtains its water supply from springs. No data are available on sources of water supply for the other communities. However, for the purpose of the report it is estimated that the domestic consumptive use of water is about 60 gallons per day per capita, or about 400 acre-feet annually.

\section{STREAMFLOW}

VARIABITIY OF SEASONAL RUNOFF

Most of the Colorado River Basin below the Green and San Juan Rivers and above "Lee Ferry" is desert. Little or no snow accumulates during the winter except in the mountains that form the northwest boundary of the subbasin. The streams, except those draining the mountains, are intermittent and carry water only after infrequent thunderstorms, most of which are brief and cover only small areas. However, some of the storms are intense and cause flash floods. During the irrigation season most of the water from the headwaters of the perennial streams is diverted for irrigation or consumed by evapotranspiration in the long, meandering sand-filled channels. All tributaries have cut deep canyons in their lower reaches, where some tributaries intercept the water table and receive flow from seeps and springs.

The hydrograph for Muddy Creek near Emery, Utah (fig. 141), which is a tributary of the Dirty Devil River, is typical of headwater streams that rise in the mountainous area in the north western part of the subbasin. The hydrograph for Dirty Devil River near Hite, Utah, shows the pattern of runoff of the river at its mouth. During the nonirrigation season, water usually flows in the river all the way from the mountains, where its principal tributaries rise, to its junction with the Colorado River. However, during the 


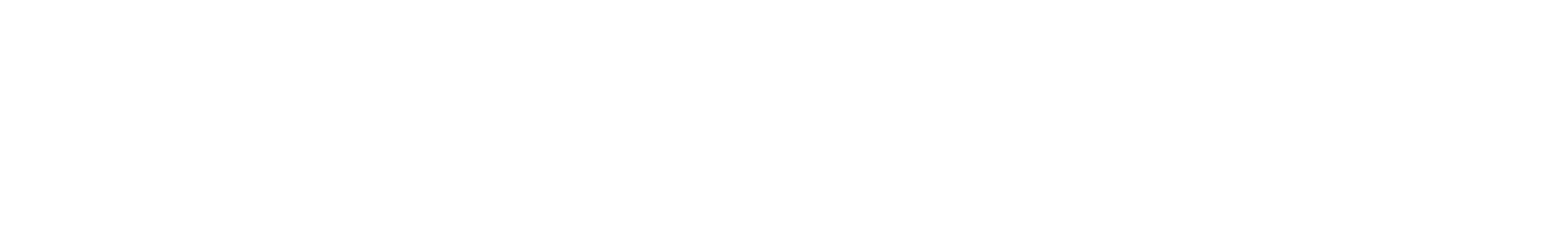

A. Muddy Creek near Emery, Utah

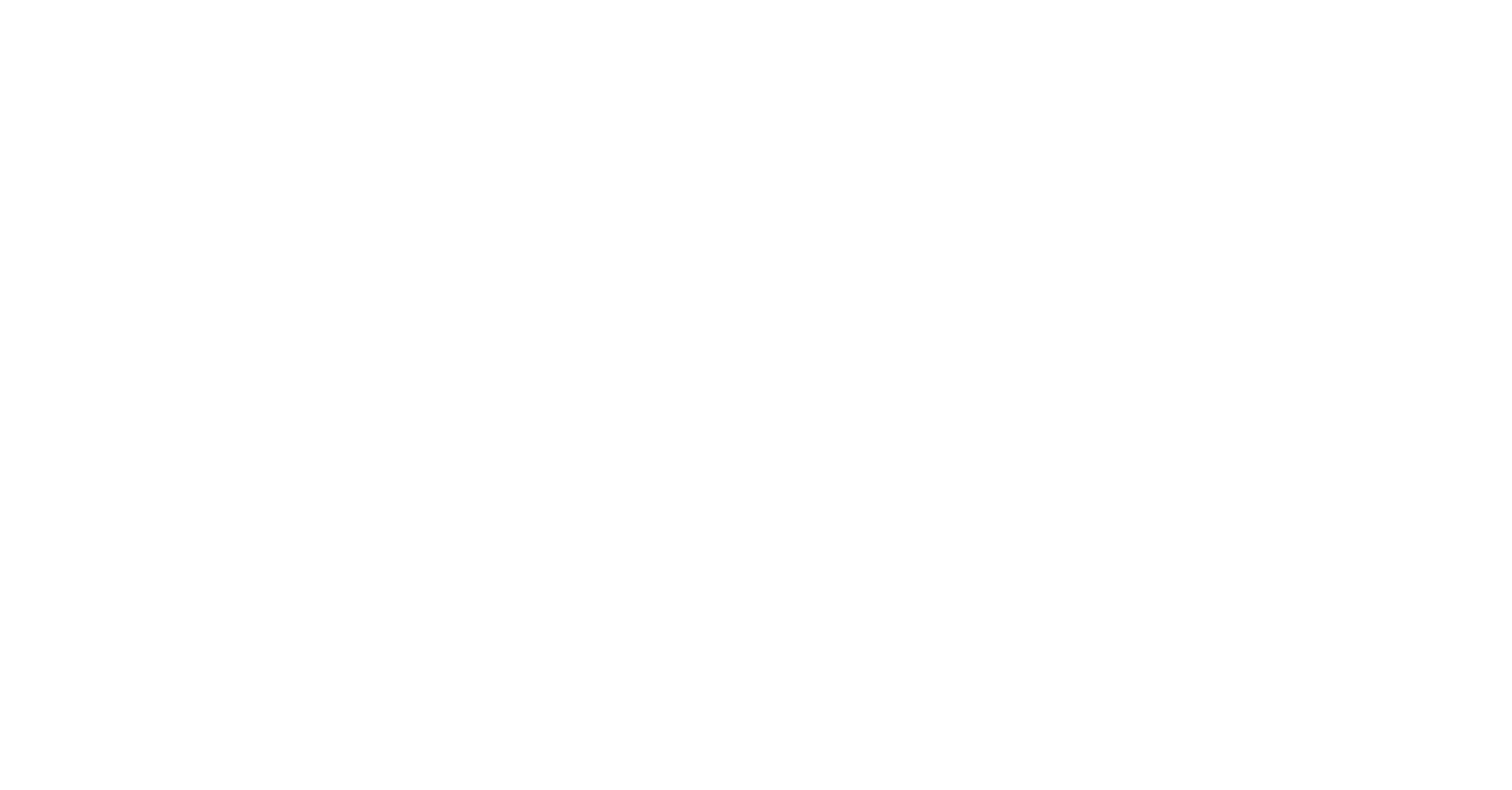

Figure 141.-Seasonal pattern of runoff of streams in the Colorado River Basin below the Green and San Juan Rivers and above "Lee Ferry," Ariz., 1954 water year.

irrigation season, most of the water supply is diverted for irrigation of lands along the headwater streams, and the channels downstream are dry except at times of storms. Many of these storms occur in the drainage basin below the irrigated lands, as may be observed by comparing the time of occurrence of increases in discharges at the gaging stations on Muddy Creek and the Dirty Devil River.

The pattern of flow of Colorado River at Lees Ferry, Ariz., is also shown in figure 141.

\section{FLOW-DURATION CURVES}

Historical flow-duration curves were developed for streams at eight sites in the subbasin. By use of the methods described in chapter $\mathrm{B}$, the flow-duration curves for four of the sites were adjusted to the 44year base period. The curves for four sites could not be extended to the 44-year base period because of the shortness of record and poor correlation with other stations having longer records. The curves for Colorado River at Hite, Utah, and Lees Ferry, Ariz., were adjusted to 1957 conditions of upstream development. Because no substantial change occurred in upstream developments on the tributary streams during the base period, no adjustments for upstream developments were made for these streams. Data on the historical and adjusted curves are given in table 6. Table 7 outlines the methods used in adjusting the historical flow-duration curves and the upstream developments in which changes occurred. The table also gives the authors' accuracy rating of the adjusted long-term curves.

The characteristic behavior of the principal tributary streams in the subbasin is shown in figure 142 by the flow-duration curve for Paria River at Lees Ferry, Ariz. The upper part of the curve (between about the 0.01 and 15 percentiles) is principally the result of storm runoff. The humped part of the curve (between about the 15 and 80 percentiles) is principally winter and snowmelt runoff. The part between about the 80 and 99.99 percentiles is mostly ground water discharged to the river in its lower reach.

The long-term adjusted flow-duration curve for Colorado River at Lees Ferry, Ariz., is also shown in figure 142. 

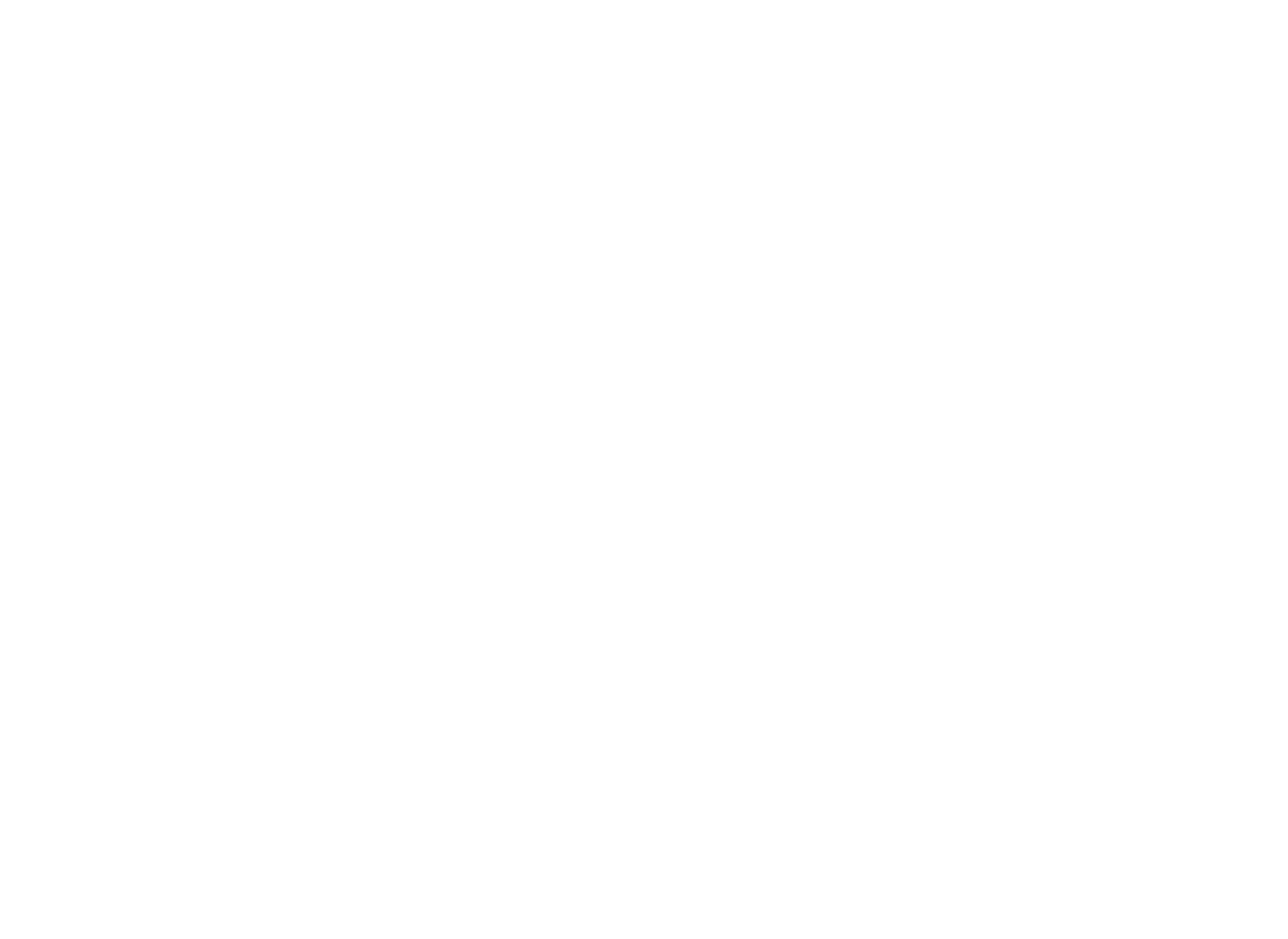

Figure 142.-Flow-duration curves for streams in the Colorado River Basin below the Green and San Juan Rivers and above "Lee Ferry," Ariz., water years 1914-57 adjusted to 1957 conditions.

Variability indices and percentage of ground-water contribution for tributary streams were not computed for this subbasin because of the effect of summer storms on the pattern of runoff.

\section{VARIABILITY OF ANNUAL RUNOFF}

Figure 143 illustrates the variability of annual discharge of Colorado River at Lees Ferry, Ariz. Quantities shown are the historical discharge adjusted for increases in transmountain diversions and increases in storage in the principal reservoirs in the Upper Colorado River Basin, exclusive of the Strawberry Reservoir. On the assumption that irrigation consumptive use has been constant throughout the period, these data are considered to be the most reliable basis for studying the variability of annual discharges. The historical record for this station has been estimated for water years 1914-21 (U.S. Geol. Survey, 1954, p. $521)$. Table 22 gives the computed adjustments, due to transmountain diversions and change in storage in reservoirs, that were added to the historical record of Colorado River at Lees Ferry, Ariz., to adjust the data to the 1914 base.

The coefficients of variation of annual water discharges at five selected stations in the subbasin are given in table 9. To illustrate the effect of the activities of man, results of probability studies are given for three types of records for Colorado River at Lees Ferry. In this report depletions caused by irrigation have been assumed to be constant, and adjustments have been made only for increase in transmountain diversions and change in storage in reservoirs. As indicated by the values for the three given conditions, the adopted method would increase the slope of the frequency curve about $31 / 2$ percent over that for natural conditions; if the historical record had been used, the slope would have been increased 10 percent.

As shown by the data in table 9, the reconstructed record of the annual discharges representing virgin flow for water years 1914-57 for Colorado River at 


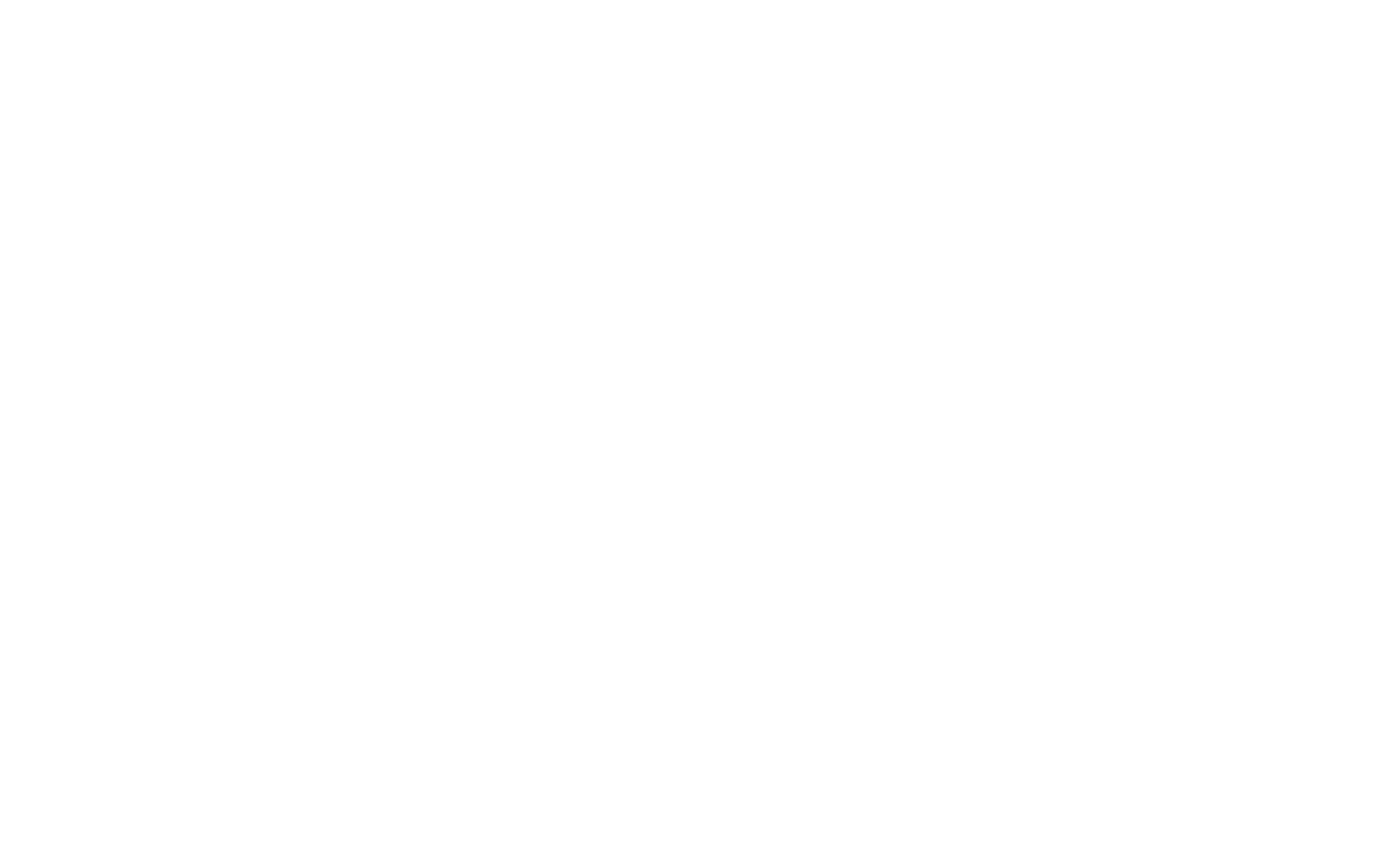

Lees Ferry, Ariz., averages about 15.03 million acrefeet annually. The standard deviation of the annual discharges during this period is about 4.41 million acre-feet, and the coefficient of variation is 0.29 . The following tabulation gives the probable deviation from the computed 44-year average annual discharge of 15.03 million acre-feet for a 50-percent chance for periods of various lengths in the future. (See chap. B, pp. 57-58.)

\begin{tabular}{|c|c|c|c|}
\hline Period of years & $\begin{array}{c}\text { Probable } \\
\text { deviation, } \\
\text { in } \\
\text { millions } \\
\text { of } \\
\text { acre-ft }\end{array}$ & Period of years & $\begin{array}{c}\text { Probable } \\
\text { deviation, } \\
\text { in } \\
\text { millions } \\
\text { of } \\
\text { acre-ft }\end{array}$ \\
\hline sor & 2.95 & 10 & _- 1.63 \\
\hline & 2. 56 & $20 \ldots$ & - 1.32 \\
\hline & 2. 12 & 44 & _. 1.15 \\
\hline
\end{tabular}

Because records for the tributary stations are short, the coefficients of variation given in table 9 may not be representative of a long-term period. The results for the headwater streams, Muddy Creek near Emery, Utah, and Escalante River near Escalante, Utah, as compared with the coefficients for similar headwater streams in other parts of the Upper Colorado River Basin appear to be reasonable, but those for Dirty Devil River near Hite, Utah, and Paria River at Lees Ferry, Ariz., are probably too low. Generally, the streams subject to runoff from infrequent thunder- storms have higher coefficients of variation than streams whose major source of water is snowmelt.

\section{CHFMICAL QUAITY OF WATER}

DISSOLVED-SOLIDS DISCHARGE AND CONCENTRATION

Daily chemical-quality data have been obtained at five stations in the Colorado River Basin below the Green and San Juan Rivers and above "Lee Ferry." At the end of the 1957 water year, the length of record at these stations ranged from 1 to 9 months for Dirty Devil River near Hanksville, Utah, and was as much as 15 years for Colorado River at Lees Ferry, Ariz. Monthly and annual weighted-average chemical analyses for streamflow at these stations are given in the basic data report (Iorns and others, 1964, tables 207-210, 217).

In addition to the daily data at the five stations, chemical analyses of streams at other sites in the subbasin have been obtained. The dissolved-solids discharge for the daily stations and for some of the other sites have been computed (table 10). The quantities given in table 10 are averages that would have occurred if the developments in 1957 had existed throughout water years 1914-57.

Duration tables of dissolved-solids concentration and discharge for the stations listed in table 10 are given in tables 11 and 12. The methods used to compute the 
data are described in chapter B (pp. 58-59).

Of all the tributaries to the Colorado River in this subbasin, exclusive of the San Juan River, the Dirty Devil River contributes by far the most dissolved solids. Its average water discharge (102 cfs) is but very little greater than the average water discharge of the Escalante River, yet its dissolved-solids discharge is almost eight times as great (table 10).

The combined average annual dissolved-solids discharges and combined water discharges of Colorado and Paria Rivers at Lees Ferry, Ariz., were used as a base to compute the contribution (in percent) of dissolved solids and water from other areas of this subbasin (fig. 144). The data show that the contribution of dissolved solids from this subbasin is relatively small-less than 6 percent of the dissolved solids from the entire Upper Colorado River Basin.

\section{VARIATIONS IN CHFMICAL QUALTTY}

The dissolved-solids concentration in the streams in this subbasin, as is common in the rest of the Upper Colorado River Basin, is lowest during periods of high flow and highest during periods of low flow (fig. 145), except for the Paria River in which dissolved-solids concentration is highest at high flows. (See p. 329.)

The coefficient of variation of weighted-average concentration of dissolved solids is 0.14 and the coefficient of variation of water discharge is 0.32 for Colorado River at Lees Ferry, Ariz., for water years $1929-30,1943-45$, and 1948-57. The relation of the coefficients and their relation to the coefficients for other streams in the San Juan division are discussed on page 312 .

\section{RELATION TO STREAMFLOW}

The dissolved-solids concentration of the streams, except for the Paria River, decreases as the water discharge increases. In the headwaters the range in concentration between high and low flow is not as great as it is in the lower reaches of the principal tributaries and in the Colorado River (table 11).

In the drier parts of the subbasin and downstream from irrigated land, the ratio of maximum to minimum concentration may be large. That for the Colorado River is greater than that for most of the tributaries. For example, the ratio at Hite, Utah, is 6.1 $(1,100$ to $180 \mathrm{ppm})$. In contrast, the ratio for Dirty Devil River near Hite, Utah, is 2.3 (3,400 to 1,500 ppm).

The relations between the chemical composition of water and streamflow for five streams where daily chemical-quality records have been obtained are given in table 14. The relations for low, median, and high discharges at four sites are illustrated in figure 146 .

Not only do the waters of most of the streams in this subbasin have higher concentrations of dissolved solids during low flows than during high flows, but some also have different chemical compositions at the extremes of flow. The water of Dirty Devil River near Hite, Utah, is of the calcium sulfate type at all flows and the water of Escalante River at mouth, near Escalante, Utah, is of the calcium bicarbonate type for all except the lower flows. The water of Colorado River at Hite, Utah, and at Lees Ferry, Ariz., is of the calcium bicarbonate type during high flows and of the sodium or calcium sulfate type at median and low flows (fig. 146).

\section{RELATION TO GEOLOGY}

The three principal tributaries of the Colorado River in this subbasin rise in the high plateaus west of the main stem. Within a narrow band next to the divide, the waters of the tributaries of the Dirty Devil and Escalante Rivers usually contain less than $300 \mathrm{ppm}$ of dissolved solids. These headwater areas are underlain mostly by rocks of Tertiary age.

In the Dirty Devil River basin downstream from the areas where the dissolved-solids concentration is relatively low, the streams cross areas underlain by rocks of Cretaceous age and older. These areas receive small amounts of precipitation, which fall mostly during thunderstorms. The rocks contain large amounts of soluble minerals, some of which are picked up by the runoff that results from the infrequent summer storms. In the headwaters of the Dirty Devil River, the water is of the calcium bicarbonate type. Downstream, the quality of the water is affected by return flow from irrigation and by runoff from areas underlain by the rocks that contain readily soluble minerals; consequently, the concentrations of dissolved solids and of magnesium, sodium, and sulfate ions increase downstream.

The Escalante River below the irrigated areas near Escalante, which are underlain mostly by rocks of Cretaceous age, contains more dissolved solids than it contains above the irrigated lands, where the water is of the calcium bicarbonate type but where, during low flows, the sulfate content (in equivalents per million) is almost as great as the bicarbonate content. Near the mouth of the river, the dissolved-solids concentration is less than at Escalante because of runoff from the drainage basin of Boulder Creek and the lower reaches of the Escalante River, which are under. lain mostly by sandstones of the San Rafael and Glen Canyon Groups. 


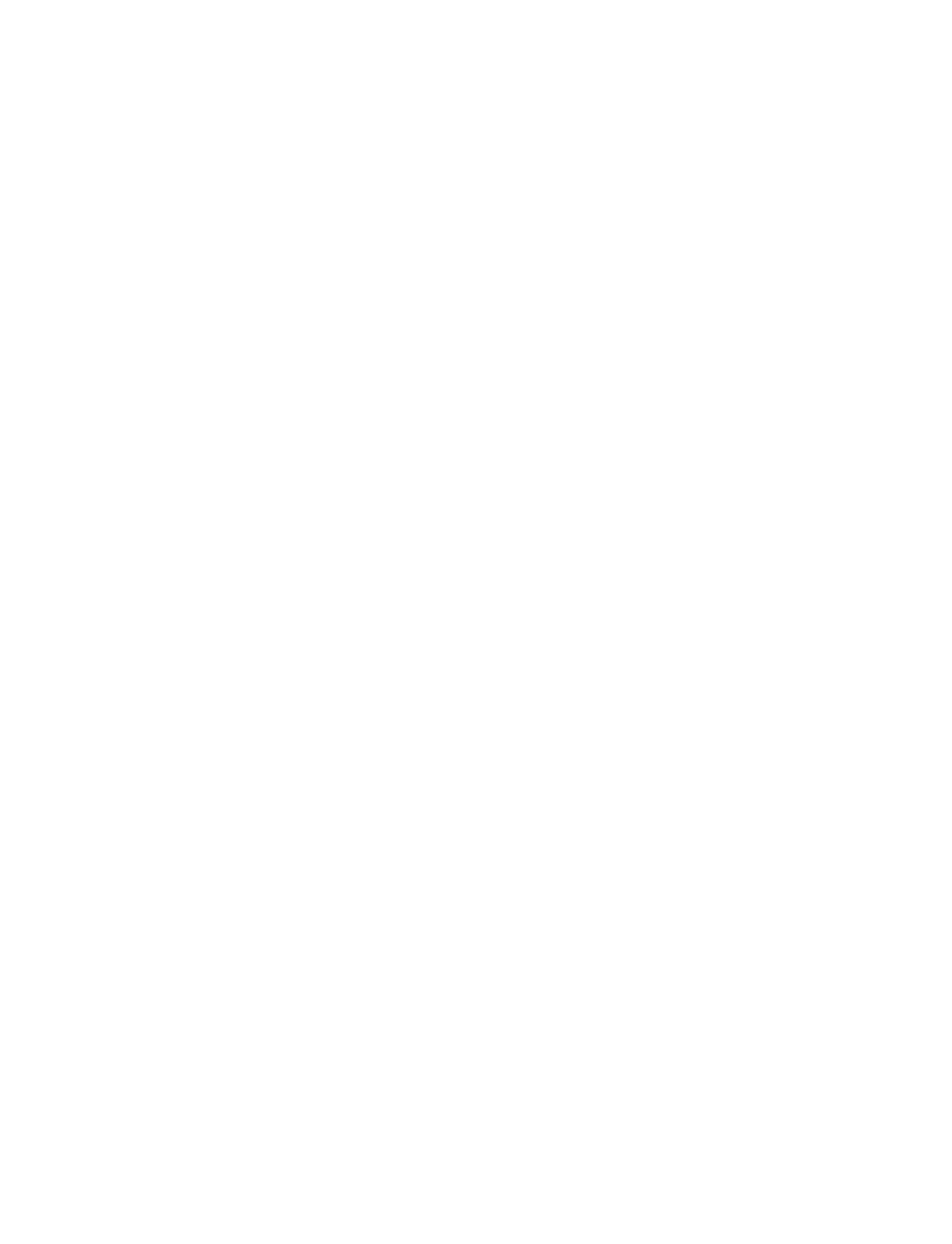

Figure 144.-Approximate dissolved-solids discharge and streamfiow expressed as percentages of the combined dissolved-solids discharge and combined streamflow of Colorado and Paria Rivers at Lees Ferry, Ariz. 


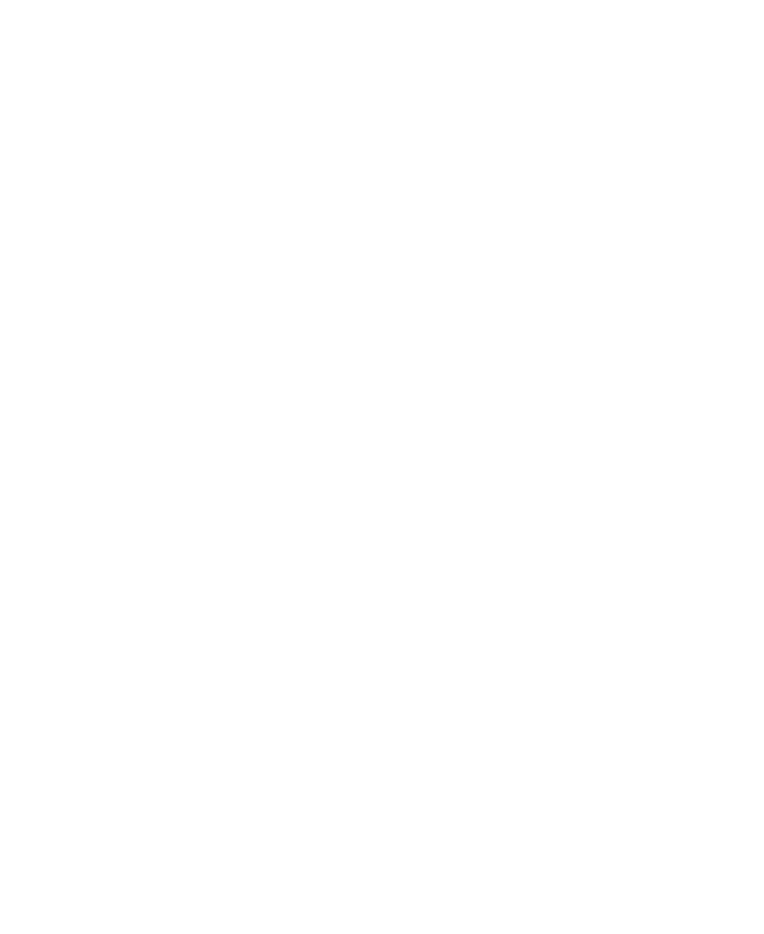

A. Dirty Devil River near Hite, Utah

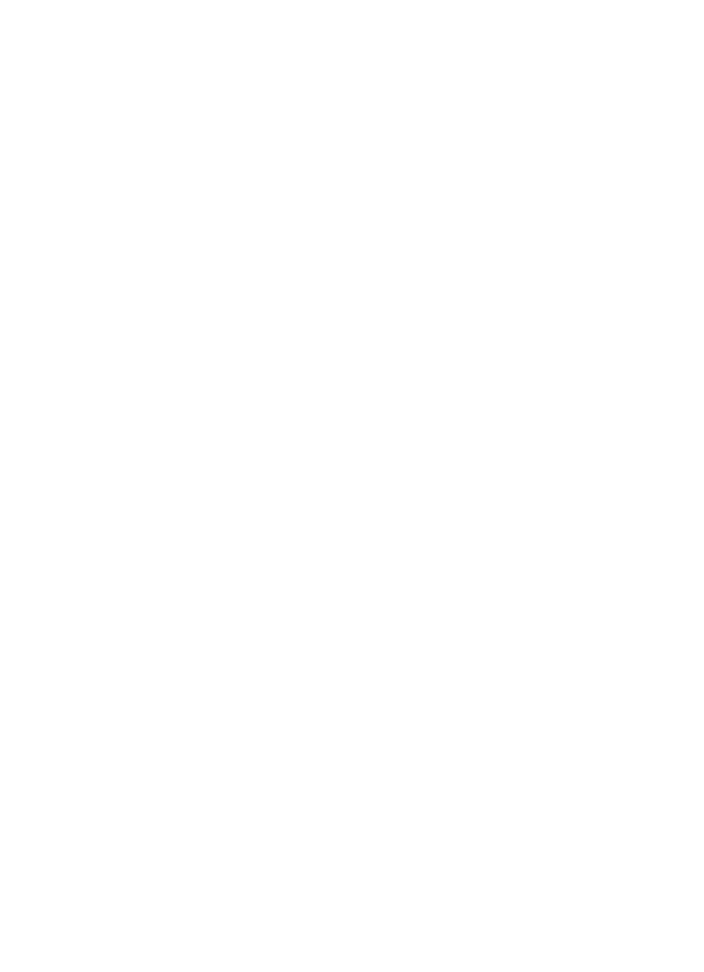

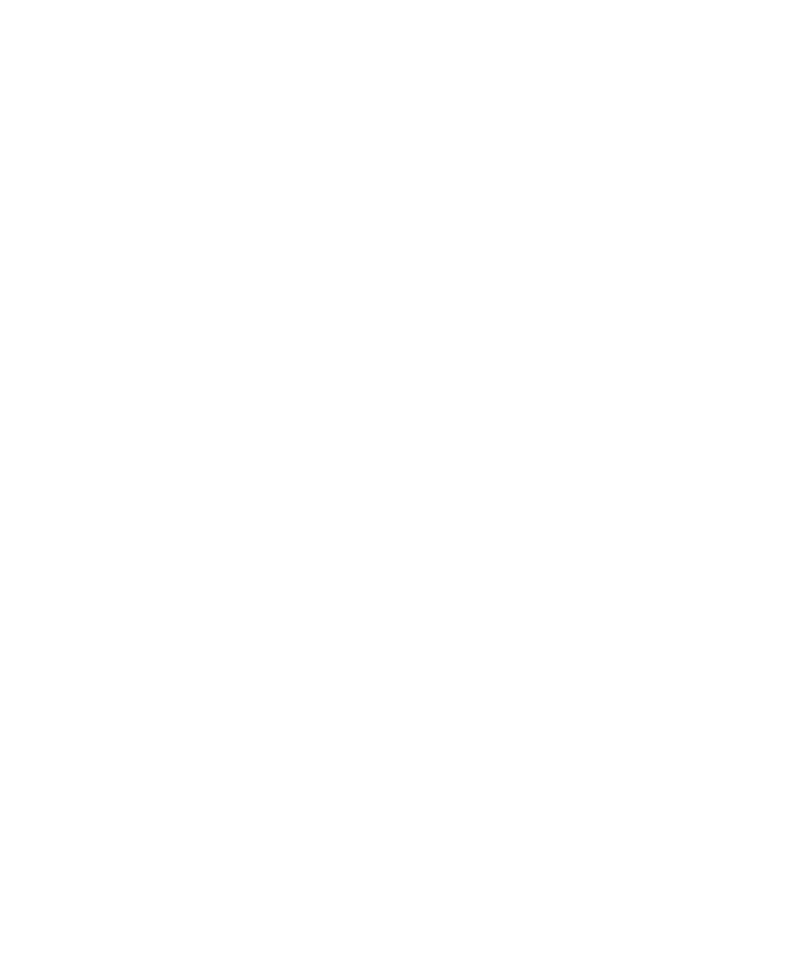

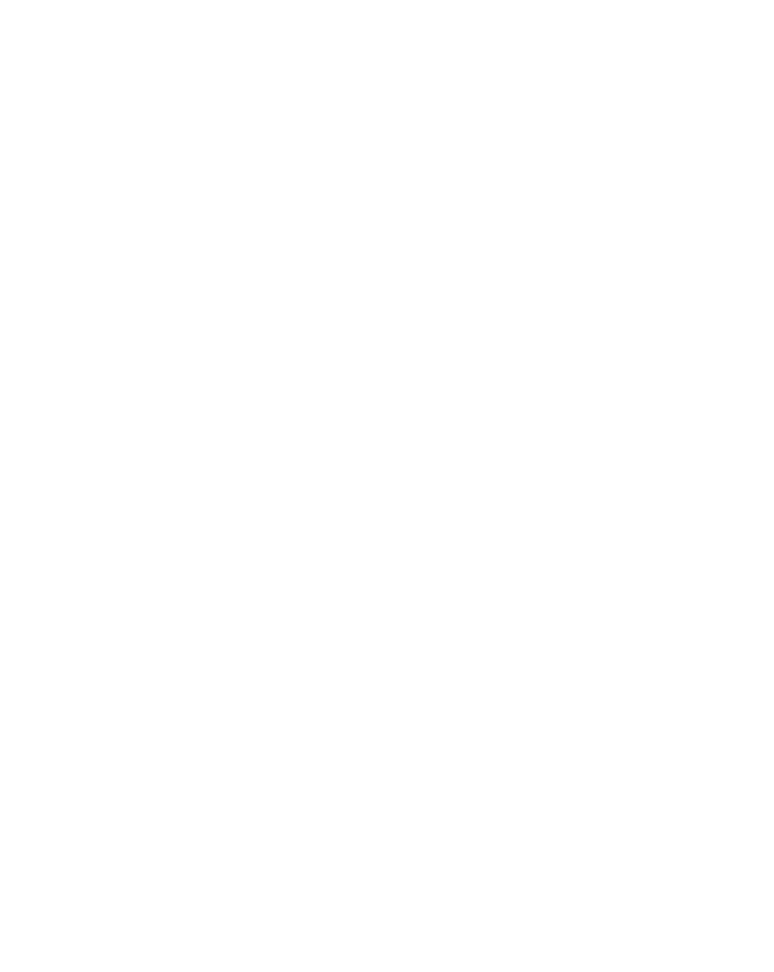

FigURE 145.-Dissolved-solids concentration and water discharge at four daily stations in the Colorado River Basin below the Green and San Juan Rivers and above "Lee Ferry," Ariz. 

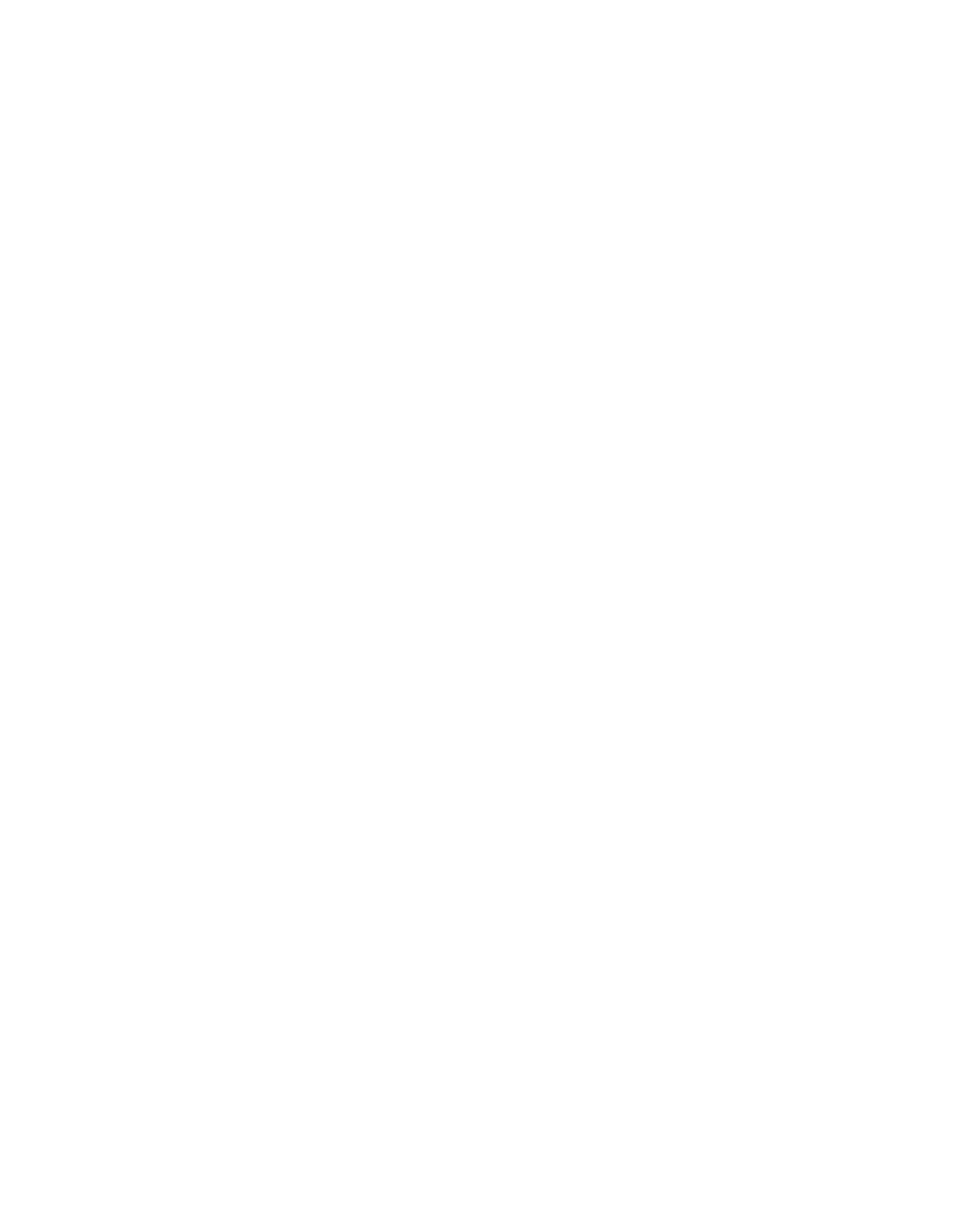

Figure 146.-Relation of the chemical composition and concentration of dissolved solids to water discharge in the Colorado River Basin below the Green and San Juan Rivers and above "Lee Ferry," Ariz. The concentration of specific ions, in equivalents per million (epm), is shown for the 10th, 50th, and 90th percentiles of the flow-duration curve for each location. The flow-duration curves are for water years 1914-57 adjusted to 1957 conditions. 
The water of the Paria River is of the sodium calcium magnesium sulfate type at most flows; near Cannonville, Utah, it is often of the sodium magnesium calcium sulfate type. The concentrations of dissolved solids in Paria River at Lees Ferry, Ariz., are highest when the water discharge is highest (table 14). This is an exception to the general coincidence of low concentration with highest flows for most of the streams in the Upper Colorado River Basin. The probable reason for this exception is that the water of the Paria during low flows comes from springs and seeps in the lower canyon reach of the stream. This water, which issues from rocks of the Glen Canyon and San Rafael Groups, is dilute compared with surface runoff, which originates mostly in the badlands near Bryce Canyon, a region underlain by rocks that contain large amounts of soluble minerals.

Figure 147 is a map of the Colorado River Basin below the Green and San Juan Rivers and above "Lee Ferry," Ariz., showing zones within which the approximate weighted-average concentration of dissolved solids of the streams is between indicated limits. Comparison of the zones with distribution of the rocks (pl. 1) and of the irrigated areas (pl. 9) indicates the general effect of the rock types and irrigation on the dissolved-solids concentration of the surface water.

The diagrams in plate 2 show the geochemical character and ionic concentrations of surface waters at 51 sites in the subbasin. The diagrams are representative of the chemical character of the streams during low flow, when the effect of geology on chemical quality is more evident than during high flows. The significance of the size and shape of the diagrams is given in the explanation in plate 2.

\section{RELATION TO GROUND WATER}

In most of this subbasin, the precipitation is low and very little ground water reaches the streams except in the lower canyon reaches and in some of the alluviated reaches that are under irrigation or that are flooded during storm runoff. In most of the canyon reaches the streams have cut to or below the water table, and the streams are sustained by ground-water inflow. Water levels in deep wells on both sides of the Colorado River near Page, Ariz., and the locations of springs along the river and in the side canyons indicate that the gradient of the water table toward the river is appreciable.

Between the gaging stations on Colorado River at Hite, Utah, and Lees Ferry, Ariz., about 2,450,000 acre-feet of water and about 1,275,000 topns of dissolved solids are added to the Colorado River annually (table 10). About 2,089,720 acre-feet of this water and about
$1,022,300$ tons of dissolved solids come from the Escalante River basin and from the area above San Juan River near Bluff, Utah. This leaves about 360,300 acrefeet of water and 252,700 tons of dissolved solids that must come from the remaining 6,290 square miles of drainage area. The channel loss by evaporation has been estimated to average 103,000 acre-feet per year from the reaches of the Colorado and San Juan Rivers in the 6,290 square miles of drainage area (Upper Colorado River Basin Compact Comm., 1948, p. 46-48). This loss, added to the residual of 360,300 acre-feet of water, indicates a total water contribution of 463 ,300 acre-feet.

On the basis of records of streams similar to those draining the area, the surface-water inflow is estimated to average 25,000 acre-feet annually (4 acre- $\mathrm{ft}$ per sq mi), leaving about 438,000 acre-feet which evidently comes from ground water. This ground water would have a weighted-average concentration of slightly more than $400 \mathrm{ppm}$, if one assumes that most of the dissolved solids contributed in the area $(252,700$ tons) were added by the ground water. That the $400-\mathrm{ppm}$ concentration is reasonably correct is indicated by an average of 425 ppm for 24 springs and seeps along the river between Hite and "Lee Ferry."

In the subbasin there are about 277 miles of river channel along the San Juan and Colorado Rivers and an unknown length of channel in the numerous side canyons. If the side canyons were ignored and if it were assumed that all ground-water inflow occurred along the 277 miles of river channel, the inflow would be about $2.2 \mathrm{cfs}$ for each mile of river channel. This is a relatively low rate of ground-water discharge if one considers the great depth to which the canyons are intrenched in permeable rocks. It is equivalent, however, to a ground-water recharge of about 70 acre-feet per year per square mile of drainage area.

Only one thermal spring, in Warm Springs Canyon, is known in this subbasin (Stearns and others, 1937). Its flow and dissolved-solids content are unknown, but the flow is probably small.

\section{EFFECT OF TRANSMOUNTAIN DIVERSIONS}

No water is diverted from this subbasin into areas outside the Colorado River Basin. However, the Tropic and East Fork canal has diverted water since about 1887 from the East Fork of Sevier River (Great Basin) to a tributary of the Paria River. This importation averaged about 2,600 acre-feet annually in water years 1950-57. The water, which has a weightedaverage concentration of about $200 \mathrm{ppm}$ of dissolved solids, adds about 700 tons per year to the Paria River. Above "Lee Ferry," Ariz., an average of about 468,700 acre-feet of water and about 37,500 tons of dissolved 


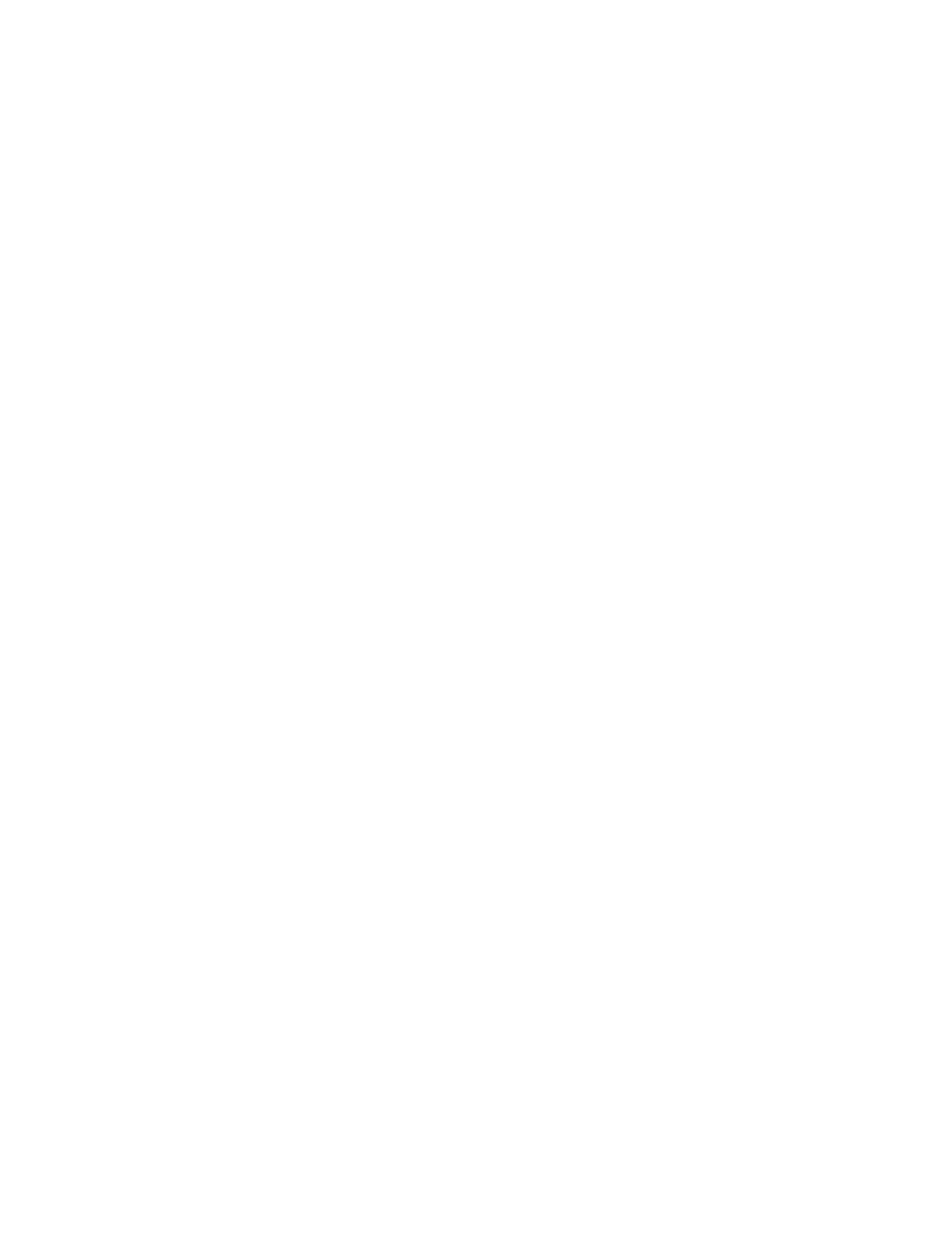

FIGURE 147.-Approximate weighted-average concentration of dissolved solids in streams in the Colorado River Basin below the Green and San Juan Rivers and above "Lee Ferry," Ariz. 
solids are exported from the Colorado River Basin. The weighted-average concentration of the Colorado River at "Lee Ferry" is about 501 ppm for the 1957 level of development (computed from sum of weightedaverage concentration and water discharge of Colorado River and Paria River at Lees Ferry, Ariz., table 10). If there were no transmountain diversions, the water and dissolved-solids discharges of the Colorado River at "Lee Ferry" would be about 13,201,400 acre-feet and $8,713,800$ tons, respectively. The weighted-average concentration of the river at "Lee Ferry" for these conditions would be $485 \mathrm{ppm}$, or about $16 \mathrm{ppm}$ less than that for the present level of upstream development. This is equivalent to about $3.4 \mathrm{ppm}$ for each 100,000 acre-feet of water diverted.

\section{FFFECT OF THE ACTIVITIES OF MAN}

The activities of man in the Colorado River Basin below the Green and San Juan Rivers and above "Lee Ferry" affect the quality of surface waters in much the same way that man's activities affect the quality of surface waters in other areas of the Upper Colorado River Basin. They result in the addition of an estimated average of about 63,700 tons of dissolved solids to the streams in the subbasin annually. Of this amount 61,600 tons is estimated to be contributed from the part of the subbasin above the Paria River and about 2,100 tons from the Paria River basin, of which 700 tons is imported by the Tropic and East Fork canal. This estimate is based principally on indicated rates of dissolved-solids yield from irrigated lands in other parts of the Upper Colorado River Basin that are underlain by similar rocks. Chemical analyses of water at miscellaneous sites in the subbasin also are taken into account in the estimates. Table 17 summarizes data on dissolved solids contributed by natural sources and as a result of the activities of man.

The estimated amounts attributed to the activities of man are the increase over and above that which would naturally come from inflow in each subunit. Of the 63,000 tons of dissolved material estimated to be added to the streams as a result of the activities of man in this subbasin, exclusive of that in imported water, an estimated 600 tons is caused by domestic and industrial uses and 62,400 tons by irrigation. These estimates are based on the assumption that 100 tons per year per 1,000 people is added by domestic and industrial uses. The remainder is attributed to irrigation.

If there were no activities of man in the Upper Colorado River Basin, exclusive of transmountain diversions, the weighted-average concentration of dissolved solids of the water that would flow out of the basin would be about $263 \mathrm{ppm}$. This determination is based on average annual water and dissolved-solids discharges of $12,733,000$ acre-feet and $8,676,300$ tons, respectively, for the 1957 level of development and on an average annual consumptive use of 1,791,700 acrefeet of water by irrigation, domestic, and industrial uses, which result in the addition of an average of $3,479,600$ tons of dissolved solids to the streams annually. The increase in dissolved-solids concentration of $238 \mathrm{ppm}$ (501 ppm minus $263 \mathrm{ppm}$ ) because of domestic, industrial, and agricultural uses of water is equivalent to $13.3 \mathrm{ppm}$ for each 100,000 acre-feet of water consumed, which is about four times as great as the increase caused by the diversion of 100,000 acre-feet of water out of the basin.

\section{FLUVIAL SFDIMENT}

Suspended-sediment data have been obtained daily at five stations in the Colorado River Basin below the Green and San Juan Rivers and above "Lee Ferry" (table 18) and at irregular intervals at other sites. These data are given in the basic data report (Iorns and others, 1964).

Estimated suspended-sediment discharges for the water years $1914-57$ adjusted to 1957 conditions for the five stations where daily data have been obtained are given in table 19.

An average of 20,495,000 tons of suspended sediment is estimated to be discharged annually by the Colorado River above the Green River (chap. C, table 34) and $27,875,000$ tons annually by the Green River (chap. $\mathrm{D}$, table 28) into this subbasin. The annual suspendedsediment discharge of San Juan River near Bluff, Utah, is $37,100,000$ tons (table 19), and that computed for Colorado and Paria Rivers at Lees Ferry, Ariz., is $103,955,000$ tons, leaving a balance of $18,485,000$ tons contributed to the Colorado River annually from this subbasin and from the San Juan basin below the station near Bluff, Utah. Of this amount about 9,412,000 tons annually is contributed by the Dirty Devil, Escalante, and Paria Rivers and 9,073,000 tons, or 1,440 tons per square mile per year, from other tributaries in this subbasin and in the lower part of the San Juan River basin. At a rate of 1,440 tons per square mile per year, 2,739,800 tons comes from the San Juan River basin below the Bluff station. This area of very low runoff is subject to infrequent but intense thunderstorms that carry large quantities of suspended sediment into the river. The estimated suspendedsediment contribution from the subbasin is $15,745,200$ tons per year.

During the period of record for the sediment station on Colorado River at Lees Ferry, Ariz., several changes in the relation of suspended-sediment discharge to water discharge have taken place. During the drought 
of the 1930's, the concentration at the Lees Ferry station was greater than that during the wetter years of the early 1940's. As indicated by the similarity of changes at other stations in the Upper Colorado River Basin, the effects of the factors that caused the changes appear to have been similar in all parts of the basin (See chap. D, p. 242.)

\section{SUITABIITTY OF WATER FOR VARIOUS USES}

\section{DOMESTIC USE}

The classifications of the surface waters in the Colorado River Basin below the Green and San Juan Rivers and above "Lee Ferry," Ariz., are based on waterquality criteria for major uses. (See chap. B, pp. 66-73.)

Chemical analyses of waters from the headwater tributaries of the Dirty Devil and Escalante Rivers show that the water is suitable for domestic use. In the Dirty Devil River and in the lower reaches of its tributaries, the water usually contains more sulfate and total dissolved solids than is desirable. (See basic data report, Iorns and others, 1964.) The waters range from moderately hard in the upper part of the Dirty Devil River drainage basin to very hard in the middle and lower parts of the basin. Softening of the water would be necessary for most uses.

The dissolved-solids constituents in the water of the Escalante River below Boulder Creek are less than the maximum limits permitted by the standards accepted for this report. Below the irrigated areas near Escalante, the concentration of sulfate during part of the time exceeds the maximum of $250 \mathrm{ppm}$ permitted by the standards for domestic use. The waters of the Escalante River and tributaries are hard to very hard.

The waters of the Paria River, except in the extreme headwaters, usually contain more than $500 \mathrm{ppm}$ of sulfate, and the concentration of dissolved solids is often greater than $1,000 \mathrm{ppm}$. The water is very hard.

The waters of many of the small tributaries in the Glen Canyon reach of the Colorado River are comparatively dilute and are suitable for domestic use, except that they are hard to very hard.

The monthly summaries of chemical analyses for Colorado River at Hite, Utah, and Lees Ferry, Ariz., show that the concentrations of sulfate exceed 250 ppm during about three-quarters of each water year. During the spring runoff-usually in A pril, May, June, and July - the water is suitable for domestic use. After the Glen Canyon Reservoir is completed, the water in the reservoir would probably be suitable for domestic use because of the mixing of the dilute water from the spring runoff with the more concentrated water from runoff during the rest of the year.

Concentration of nitrate in the surface waters of this subbasin does not usually exceed about $5 \mathrm{ppm}$.
Concentrations of boron and fluoride are usually less than $0.5 \mathrm{ppm}$.

\section{AGRICULTURAL USE}

The principal use of water in this subbasin, as in all parts of the Upper Colorado River Basin, is for irrigation. In table 20 the waters of many of the streams are classified as to their suitability for irrigation. The classification is for high, medium, and low flows or for flows for which chemical analyses are available. The chemical analyses on which the classification is based are given in the basic data report (Iorns and others, 1964). Most of the terms used in the table are self-explanatory or are explained on page 320 or in chapter B (pp. 69-73).

The values for residual sodium carbonate in table 20 indicate that all the waters contain very much less than $1.25 \mathrm{epm}$ of residual sodium carbonate and, therefore, are suitable for irrigation insofar as this property is concerned.

As indicated in table 20 , most of the stream waters presently used for irrigation are in the $\mathrm{C} 2-\mathrm{S} 1$ category or better. To control salinity only moderate leaching is required, and there is little danger of the development of harmful levels of exchangeable sodium. Most waters in the poorer categories are in downstream reaches or canyon areas and are not used for irrigation.

Required leaching for the waters in this subbasin is low except in a few local areas. The concentrations of boron do not appear to be a hazard.

\section{INDUSTRIAL AND RECREATIONAL USES}

The concentration of dissolved solids in the waters of the principal tributaries of the Colorado River is high, except a few tributaries in the extreme headwaters where the waters could not be used by most industries without treatment.

The streams and lakes in the high plateau areas in the headwaters of the Dirty Devil and Escalante Rivers furnish recreation for many people. Boat trips down the canyons of the Colorado and San Juan Rivers climax the vacations of the large number of people who visit this scenic area every year, and fishing on Lake Powell and below Glen Canyon Dam will furnish recreation for thousands of people.

\section{SUMMARY}

The San Juan division is a region of great contraststowering mountains, desert plateaus, and deep canyons. All the area is above an altitude of 3,120 feet, but the major part of the land surface ranges from 5,000 to 7,000 feet in altitude.

The exposed rocks range in age from late Precambrian to Recent. The San Juan Mountains are composed chiefly of volcanic rocks of Tertiary age, but 
the lower parts of the San Juan basin in Colorado and New Mexico are underlain mostly by sedimentary rocks of Cretaceous and Tertiary ages. Parts of the area at intermediate altitudes are underlain mostly by sedimentary rocks of Permian, Triassic, and Jurassic ages. Except for river alluvium along the streams and valley alluvium in the Navajo River basin and in an area between the Animas and Los Pinos Rivers, unconsolidated deposits that mantle the consolidated rocks are chiefly material weathered from the underlying rocks but not transported far.

The climate ranges from extremes of high precipitation and low temperatures in the mountains to scant precipitation and high temperatures in the lower altitudes. The average annual precipitation generally ranges from 6 inches at the lower altitudes to 60 inches in parts of the San Juan Mountains. Ninety percent of the basin receives an annual average precipitation of less than 20 inches, and 46 percent receives less than 10 inches.

Snow that accumulates in the mountains provides most of the water supply of the perennial streams, and runoff varies with the seasons. As the snow melts in the late spring and early summer, the flow in the perennial streams rises to a peak and then subsides as the supply of snow is exhausted. Usually by late July the flow of these streams has subsided to nearly a minimum (base flow). This base flow generally prevails until the following spring. Infrequent localized thunderstorms occur along the front of the mountains and at the lower altitudes of the division. These storms at times produce flash floods in the usually dry washes that drain the intermediate and lower altitudes.

Flow-duration curves, which show the percentages of time during which specified water discharges were equaled or exceeded, were developed and adjusted to be representative of the streamflows that would have occurred if the developments in 1957 had existed throughout water years 1914-57. From these curves the 44-year average discharges of the streams adjusted to 1957 conditions of upstream development were computed.

The effect of environmental factors on the flow of the streams was analyzed by comparing the slopes and shapes of the flow-duration curves of different streams and by comparing the variability of annual discharges of these streams. The variability indices (slopes of flow-duration curves) for headwater streams that rise in the San Juan and La Plata Mountains ranges from 0.46 to 0.64 . The shape of the flow-duration curves for these streams in their headwaters indicates that about 16 to 28 percent of the average annual discharge was contributed to the stream systems by ground water. The relative permeability of the underlying rocks and extent of permeable alluvial deposits appear to be the major causes of differences in variability indices and ground-water contributions to the headwater streams in the San Juan River basin.

The coefficients of variation (ratio of standard deviation to average discharge) of the streams in the San Juan River basin for which statistical analyses of annual flows were made ranged from 0.32 to 0.64 . The Animas River, which had the lowest coefficient, apparently has ground-water reservoirs extensive enough to provide carryover from wet to dry years. The Mancos River, which had the highest coefficient, receives a major part of its annual discharge from summer storms.

The coefficient of variation of historical annual water discharges of Colorado River at Lees Ferry, Ariz., for water years $1914-57$ is computed to be 0.32 , and the coefficient of variation for the same period of years of annual discharges representing virgin flow is 0.29 . In the analytical procedure used to adjust streamflow to 1957 conditions, the assumption was made that the depletions caused by irrigation were constant and that the historical annual discharges needed to be adjusted only for increase in transmountain diversions and change in storage in reservoirs. The computed coefficient of variation for water years 1914-57, adjusted to 1957 conditions, is 0.30 , which is only about 3 percent greater than that for virgin-flow conditions.

The major use of water is for irrigation. Table 23 summarizes data on storage reservoirs and water utilization in the San Juan division for developments existing in 1957.

Table 24 shows an approximate water budget for the division. The total average annual water supply from precipitation is $25,880,600$ acre-feet, which is equivalent to an average of 12.67 inches. All the precipitation not accounted for in outflow, transmountain diversions, and consumptive use due to the activities of man is considered to be evapotranspiration loss from land and water surfaces and from native vegetation. This loss is computed to be 89.4 percent of the precipitation, or 11.32 inches of water.

In the San Juan division, records of chemical quality of streams have been obtained daily at 11 stations and at irregular intervals at many other sites. These records were used in conjunction with the flow-duration tables to develop duration tables of dissolved-solids concentration and other chemical-quality data for the water years 1914-57 adjusted to 1957 conditions and for other periods. The weighted-average concentration of dissolved solids at these sites ranges from 42 to $2,180 \mathrm{ppm}$, and the average annual yield of dissolved solids ranges from 13 to 494 tons per square mile of drainage area. 
The difference in the chemical quality of the streams is the result of hydrologic and other environmental factors prevailing in the drainage basins. The major environmental factors that determine the chemical quality of each stream are apparently precipitation, type of rocks and soils, and the activities of man.

The perennial streams in the division are of the snowmelt type, in which dissolved-solids concentration is lowest during the months of maximum water discharge and highest during periods of low flow, when the streams are maintained largely by ground water. One of the streams, however, Paria River at Lees Ferry, Ariz., has highest concentrations at times of high discharge and lowest concentrations at times of low discharge. Ground-water inflow in the lower reaches of the Paria River has a lower concentration of dissolved solids than runoff from the headwaters area, which is underlain by the Mancos Shale.

A statistical analysis of the variations in the annual weighted-average concentration of dissolved solids and water discharges of streams was made for four stations in the division. Plotting of the data showed poor correlation between the coefficients of variation of weighted-average concentration of dissolved solids and water discharge. The poor correlation is possibly due to the shortness of the available records.

Except in the mountains, the precipitation is so low that there is little opportunity for ground-water recharge, even where the exposed rocks are relatively permeable. Consequently, even though the main streams in much of the basin flow in deep canyons cut to or below the water table, the amount of ground water that enters these streams in the canyon reaches is relatively small as compared with the flow of water in the main streams. Analyses of water of springs and seeps in the canyon reaches along the Colorado River indicate that the average concentration of dissolved solids in the ground water is probably about $400 \mathrm{ppm}$. Because the weighted-average concentration of dissolved solids of Colorado River at Lees Ferry, Ariz., is $499 \mathrm{ppm}$, the ground-water inflow in the canyon reaches apparently improves the quality of water in the river slightly.

Ground-water contributions to headwater streams draining the San Juan and La Plata Mountains are computed to provide about 16 to 20 percent of the average annual water discharge of the streams. The weighted-average concentration of dissolved solids in the ground-water contribution to these streams is greater than that in the streams. Exchange of water between the streams and the alluvium bordering and underlying the streams in their downstream reaches and return flow from irrigation add dissolved solids to the stream system. The effect of these actions on the dissolved-solids concentration of the streams is greatest during the periods of low flow.

Thermal springs in the division add about 11,000 tons of dissolved solids and about 2,200 acre-feet of water to the streams. The principal thermal springs are along the San Juan River at Pagosa Springs, Colo., and on the upper Animas River.

Water diverted out of the San Juan division carries with it the dissolved minerals in the diverted water. The effect of the diversion on the master stream at downstream points is to deplete the flow and to decrease the dissolved-solids load. The effect of the exportation of water has been to decrease the average annual water contribution in the division by about 2,800 acre-feet and the average annual dissolved-solids discharge by about 300 tons. On the other hand, the importation of water into the division increases the water supply and increases the dissolved-solids discharge of the streams. The water imported from the Dolores and East Fork of Sevier Rivers increases the water supply by about 102,600 acre-feet and the dissolved-solids discharge by about 17,700 tons annually. Part of the water imported is consumptively used in irrigation, but the imported dissolved solids have to be kept flushed out of the soils in the irrigated areas to maintain a salt balance.

In the basin the principal uses of water by man that affect the chemical quality of water in the streams are those for domestic, industrial, and irrigation purposes. Of the total dissolved solids estimated to be added to the stream system in the division as a result of the activities of man, about 97 percent is estimated to be caused by irrigation. Table 25 summarizes data on water and dissolved solids contributed to the stream system from the two subbasins in the San Juan division.

About 468,700 acre-feet of water containing about 37,500 tons of dissolved solids is diverted out of the Upper Colorado River Basin annually. If this water were not diverted, the weighted-average concentration of the Colorado River at "Lee Ferry" would be about $19 \mathrm{ppm}$ less than the weighted-average concentration for conditions of upstream development existing in 1957 (501 ppm). The change of $19 \mathrm{ppm}$ is equivalent to about $3.4 \mathrm{ppm}$ for each 100,000 acre-feet of water diverted.

Domestic, industrial, and irrigation uses of water in the entire Upper Colorado River Basin result in the consumption of about 1,791,700 acre-feet of water and in the addition of about $3,379,600$ tons of dissolved solids to the Colorado River annually. These uses, ex- 
clusive of transmountain diversions, have caused an increase in the weighted-average concentration of dissolved solids of the Colorado River at "Lee Ferry" of about $241 \mathrm{ppm}$, which is equivalent to about $13 \mathrm{ppm}$ for each 100,000 acre-feet of water consumed, or about four times the increase caused by the diversion of an equivalent amount of water from the basin.

The average annual suspended-sediment contribution to the stream system in the San Juan division is estimated to be $55,585,000$ tons (table 22). Of this amount about 72 percent comes from the San Juan River basin, about 9 percent from the Dirty Devil River basin, about 3 percent from the Escalante River basin, about 5 percent from the Paria River basin, and about 11 percent from the remainder of the division.

Determinations of suspended-sediment discharge in the division were made at four sites on the San Juan River, two sites on the Colorado River, and eight sites on tributary streams. San Juan River near Blanco, N. Mex., had the highest rate of yield (2,607 tons per sq mi per yr) and Los Pinos River near Bayfield, Colo., the lowest ( 6 tons per sq mi per yr). Of the subareas in the division for which suspended-sediment data can be computed, the 1,228 square miles of drainage area below the gaging stations on San Juan River at Rosa, N. Mex., Los Pinos River near Bayfield, Colo., and Spring Creek at La Boca, Colo., and above the gaging station on San Juan River near Blanco, N. Mex., has the highest rate of yield (3,946 tons per sq mi per $\mathrm{yr}$ ). The next highest is from the drainage area between the junction of the Colorado and Green Rivers and above the gaging station at Hite, Utah, exclusive of the Dirty Devil River basin. The rate of yield from this drainage area $(1,040 \mathrm{sq} \mathrm{mi})$ is about 2,560 tons per square mile per year.

An annual average of about $48,370,000$ tons of suspended sediment is contributed to the Colorado River from the Grand and Green divisions. With the contribution from the San Juan division, about 103,955,000 tons of suspended sediment is discharged annually from the Upper Colorado River Basin.

Chemical-quality data indicate that the water in many streams in the division, especially in their headwaters, is suitable for domestic use. The concentrations of dissolved solids in the lower reaches of some streams, however, exceed the maximum limits acceptable for domestic use.

The waters in the lower reaches of some tributary streams in the division are not suitable for agricultural use during periods of low flow.

\section{REFERENCES}

Andrews, D. A., and Hunt, C. B., 1948, Geologic map of eastern and southern Utah: U.S. Geol. Survey Oil and Gas Inv. Prelim. Map 70, 1 sheet, reprinted 1956.

Burbank, W. S., Lovering, T. S., Goddard, E. N., and Eckel, E. B., 1935, Geologic map of Colorado: U.S. Geol. Survey map, 2 sheets, reprinted 1959.

Cannon, Helen L., 1960, Development of botanical methods of prospecting for uranium on the Colorado Plateau: U.S. Geol. Survey Bull. 1085-A, 56 p.

Colby, B. R., Hembree, C. H., and Rainwater, F. H., 1956, Sedimentation and chemical quality of surface waters in the Wind River Basin, Wyoming: U.S. Geol. Survey Water-Supply Paper 1373, 336 p.

Dane, C. H., and Bachman, G. O., 1957, Preliminary geologic map of the northwestern part of New Mexico: U.S. Geol. Survey Misc. Geol. Inv. Map I-224, 1 sheet.

Eaton, F. M., 1954, Formulas for estimating the drainage and gypsum requirements of irrigation waters: Texas Agr. Expt. Sta. Misc. Rept. 111, 18 p.

Hunt, C. G., 1956, Cenozoic geology of the Colorado Plateau: U.S. Geol. Survey Prof. Paper 279, 99 p.

Iorns, W. V., Hembree, C. H., Phoenix, D. A., and Oakland, G. L., 1964, Water Resources of the Upper Colorado River Basin, Basic Data Report: U.S. Geol. Survey Prof. Paper 442, $1036 \mathrm{p}$.

Kohler, M. E., Nordenson, T. J., and Baker, D. R., 1959, Evaporation maps of the United States: U.S. Weather Bur. Tech. Paper 37, 13 p.

Lane, E. W., and Lei, Kai, 1950, Streamflow variability: Am. Soc. Civil Engineers Trans., v. 115, p. 1084-1134.

Larsen, E. S., Jr., and Cross, Whitman, 1956, Geology and petrology of the San Juan region, southwestern Colorado: U.S. Geol. Survey Prof. Paper 258, 303 p.

Leopold, L. B., 1959, Probability analysis applied to a watersupply problem: U.S. Geol. Survey Circ. 410, 18 p.

Love, J. D., Weitz, J. L., and Hose, R. K., 1955, Geologic map of Wyoming: U.S. Geol. Survey map, 1 sheet.

Meyers, J. S., 1962, Evaporation from the 17 Western States, with a section on evaporation rates, by T. J. Norderson: U.S. Geol. Survey Prof. Paper 272-D, p. 71-100.

Shantz, N. L., and Zon, Raphall, 1924, Natural vegetation: U.S. Dept. Agriculture Atlas Am. Agriculture, 22 p.

Stearns, Norah D., Stearns, Harold T., and Waring, Gerald A., 1937, Thermal springs in the United States: U.S. Geol. Survey Water-Supply Paper 679-B, 191 p.

Upper Colorado River Basin Compact Commission, 1948, Final report of Engineering Advisory Committee to Upper Colorado River Basin Compact Commission: 203 p.

U.S. Bureau of the Census, 1953, Colorado and Utah, Irrigated acreage by drainage basins, 1949: U.S. Bur. Census map, 2 sheets.

U.S. Department of the Interior, 1947, The Colorado River: U.S. 80th Cong., 1st sess., H. Doc. 419, 295 p.

U.S. Geological Survey, 1954, Compilation of records of surface waters of the United States through September 1950, pt. 9, Colorado River Basin: U.S. Geol. Survey Water-Supply Paper 1313, 749 p.

U.S. Salinity Laboratory Staff, 1954, Diagnosis and improvement of saline and alkali soil: U.S. Dept. Agriculture, Handb. $60,160 \mathrm{p}$. 



\section{TABLES 1-25}

$769-332$ O-65-24 
TABLE 1.-Average monthly precipitation, in inches, at 13 index-precipitation stations in the San Juan division, water years $1914-57$

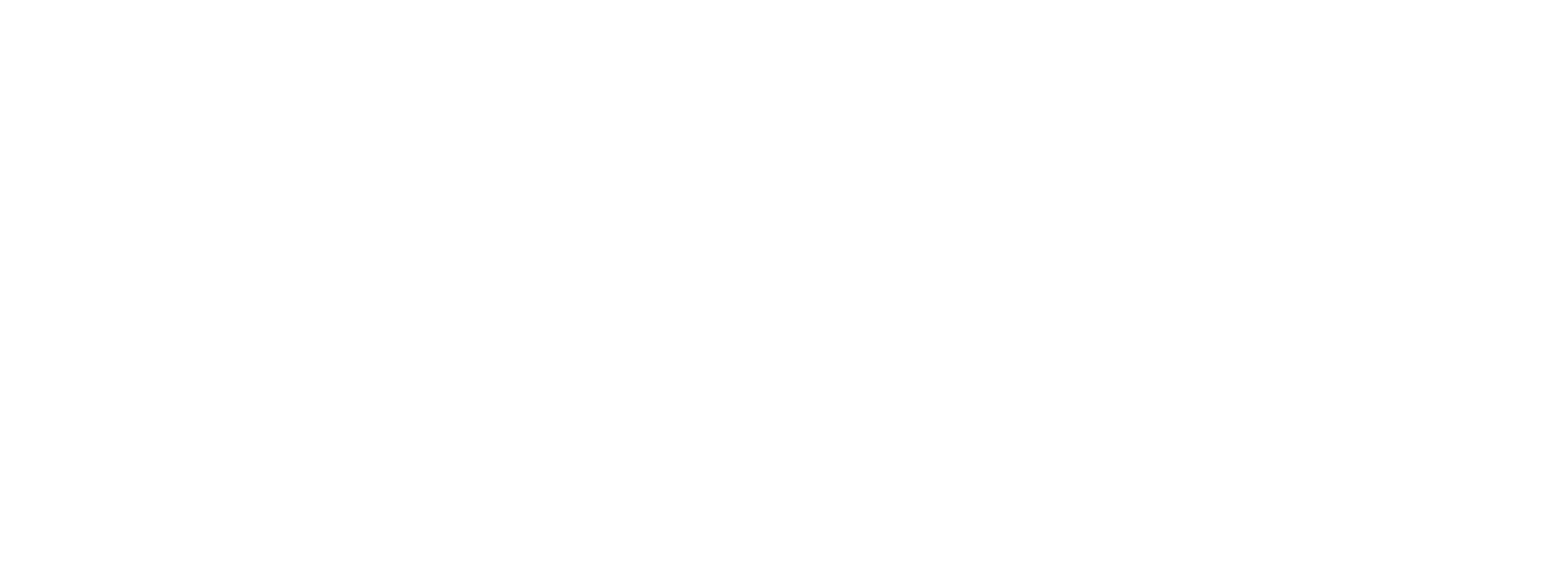

TABLE 2.-Annual precipitation, in inches, at 13 index-precipitation stations in the San Juan division and weighted-average precipitation in the subbasins and in the division, water years 1914-57

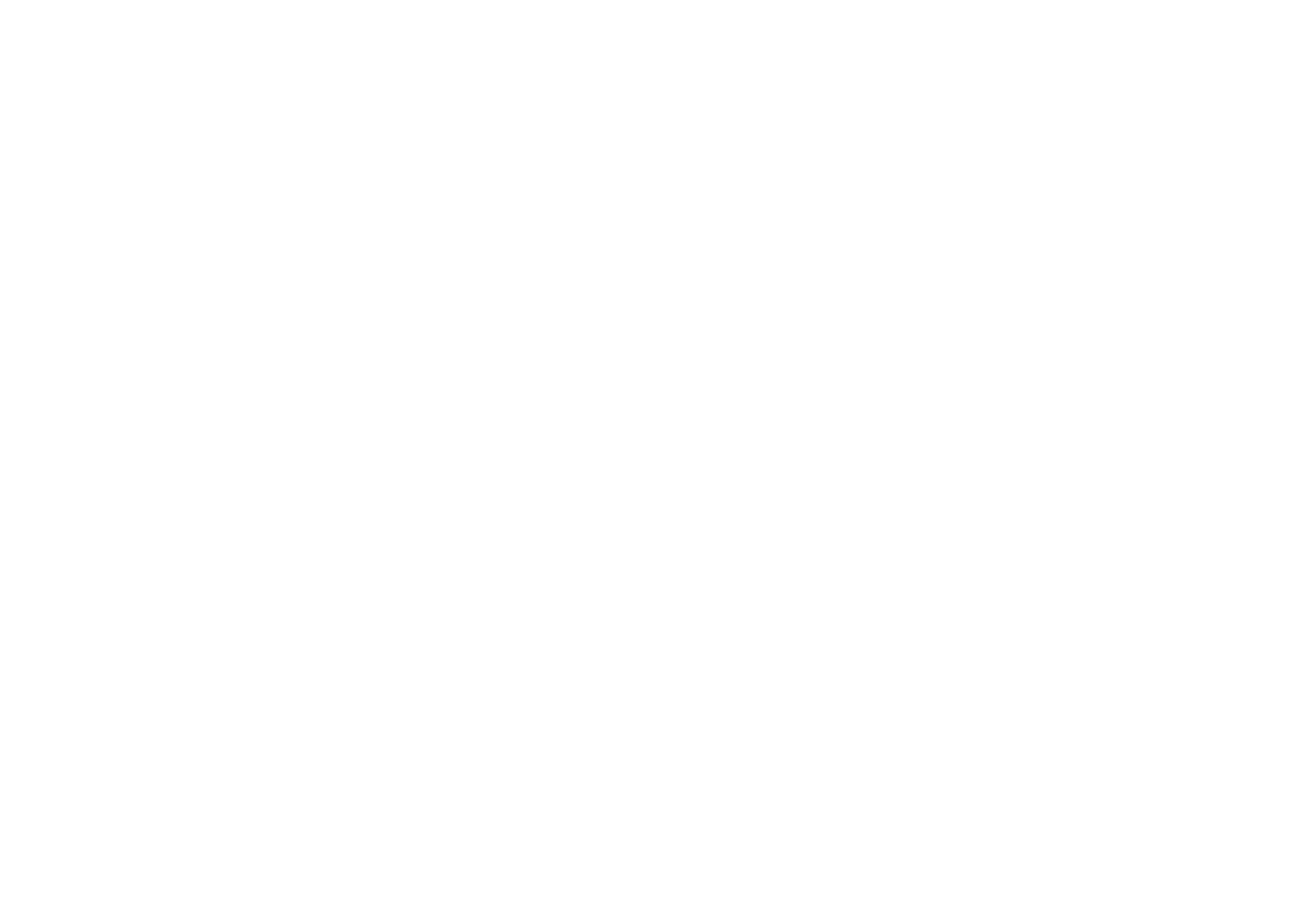


TABLE 3.-Reservoirs in the subbasins in the San Juan division

[Source of data: U.S. Dept. of the Interior (1947) and files of the State Engineer of Utab]

\begin{tabular}{|c|c|c|c|c|c|}
\hline Reservoir & Location & $\begin{array}{l}\text { Usable } \\
\text { capacity } \\
\text { (acre-ft) }\end{array}$ & Reservoir & Location & $\begin{array}{l}\text { Usable } \\
\text { capacity } \\
\text { (acre-ft) }\end{array}$ \\
\hline \multicolumn{6}{|c|}{ San Juan River basin } \\
\hline $\begin{array}{l}\text { Vallecitos. } \\
\text { Electra Lake... } \\
\text { Juans Lake } \\
\text { Captain Tom } \\
\text { Jackson Gulch. } \\
\text { Bauer Lake. } \\
\text { Summit. }\end{array}$ & $\begin{array}{l}\text { Lake Pinos River } \\
\text { Cascade Creek (Animas River) } \\
\text { Kimenola Wash (Chaco River) } \\
\text { Toadlena Wash (Chaco River) } \\
\text { West Mancos River } \\
\text { Chicken Creek (Mancos River) } \\
\text { Lost Canyon Creek (Dolores River) }\end{array}$ & $\begin{array}{r}126,300 \\
21,000 \\
5,000 \\
1,730 \\
9,800 \\
1,070 \\
4,800\end{array}$ & $\begin{array}{l}\text { Narraguinnep } \\
\text { Wheatfield. } \\
\text { Many Farms } \\
\text { Lower Rock Point. } \\
\text { Marsh Pass. } \\
\quad \text { Total }\end{array}$ & $\begin{array}{l}\text { Dolores River } \\
\text { Wheatfield Creek (Chinle Wash) } \\
\text { Chinle Wash. } \\
\text { Laguna Creek (Chinle Wash) }\end{array}$ & $\begin{array}{r}9,300 \\
1,000 \\
25,000 \\
1,000 \\
1,160 \\
207,160\end{array}$ \\
\hline \multicolumn{6}{|c|}{ Colorado River Basin below the Green and San Juan Rivers and above "Lee Ferry," Ariz. } \\
\hline $\begin{array}{l}\text { Fish Lake } \\
\text { Johnson Valley } \\
\text { Forsythe } \\
\text { Mill Meadows.-..- }\end{array}$ & \begin{tabular}{|c|} 
Fremont River (Dirty Devil River) \\
do
\end{tabular} & $\begin{array}{l}4,000 \\
4,000 \\
3,400 \\
5,200\end{array}$ & 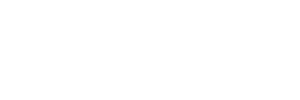 & $\begin{array}{l}\text { Oak Creek (Dirty Devil River) } \\
\text { Escalante River. }\end{array}$ & $\begin{array}{r}3,150 \\
1,250 \\
21,000\end{array}$ \\
\hline
\end{tabular}

TABLE 4.-Transmountain diversions, in acre-feet, from the San Juan River basin, water years 1923-57

\begin{tabular}{|c|c|c|c|c|c|c|c|c|c|c|c|c|c|}
\hline \multirow{2}{*}{ Water year } & \multirow{2}{*}{\begin{tabular}{|c|}
$\begin{array}{c}\text { San Juan } \\
\text { River }\end{array}$ \\
$\begin{array}{c}\text { Treasure } \\
\text { Pass ditch }\end{array}$
\end{tabular}} & \multicolumn{2}{|c|}{ Piedra River } & \multicolumn{2}{|c|}{ Los Pinos River } & \multirow{2}{*}{ Total } & \multirow{2}{*}{ Water year } & \multirow{2}{*}{$\frac{\begin{array}{c}\text { San Juan } \\
\text { River }\end{array}}{\begin{array}{c}\text { Treasure } \\
\text { Pass ditch }\end{array}}$} & \multicolumn{2}{|c|}{ Piedra River } & \multicolumn{2}{|c|}{ Los Pinos River } & \multirow{2}{*}{ Total } \\
\hline & & $\begin{array}{c}\text { Piedra } \\
\text { Pass } \\
\text { ditch }\end{array}$ & $\begin{array}{l}\text { Squaw } \\
\text { Pass } \\
\text { ditch }\end{array}$ & $\begin{array}{l}\text { Fuchs } \\
\text { ditch }\end{array}$ & $\begin{array}{l}\text { Raber } \\
\text { Lohr } \\
\text { ditch }\end{array}$ & & & & $\begin{array}{l}\text { Piedra } \\
\text { Pass } \\
\text { ditch }\end{array}$ & $\begin{array}{l}\text { Squaw } \\
\text { Pass } \\
\text { ditch }\end{array}$ & $\begin{array}{l}\text { Fuchs } \\
\text { ditch }\end{array}$ & $\begin{array}{l}\text { Raber } \\
\text { Lohr } \\
\text { ditch }\end{array}$ & \\
\hline $\begin{array}{l}1923 \\
1924 \\
1925 \\
1926 \\
1928 \\
1929 \\
1930 \\
1931 \\
1932 \\
1933 \\
1934 \\
1935\end{array}$ & $\begin{array}{rl}1 & 100 \\
1 & 130 \\
1 & 130 \\
1 & 130 \\
1 & 130 \\
1 & 130 \\
218 \\
154 \\
154 \\
188 \\
33 \\
128 \\
119 \\
192 \\
361 \\
82 \\
265 \\
199\end{array}$ & $\begin{array}{r}0 \\
0 \\
0 \\
0 \\
0 \\
0 \\
0 \\
0 \\
0 \\
0 \\
0 \\
0 \\
0 \\
0 \\
0 \\
0 \\
0 \\
148\end{array}$ & $\begin{array}{r}0 \\
0 \\
0 \\
0 \\
0 \\
0 \\
0 \\
0 \\
0 \\
0 \\
0 \\
0 \\
0 \\
0 \\
0 \\
76 \\
183 \\
230\end{array}$ & $\begin{array}{c}0 \\
0 \\
0 \\
0 \\
0 \\
0 \\
0 \\
0 \\
0 \\
0 \\
0 \\
0 \\
0 \\
0 \\
247 \\
57 \\
360 \\
256\end{array}$ & $\begin{array}{r}0 \\
0 \\
0 \\
0 \\
0 \\
0 \\
0 \\
0 \\
0 \\
0 \\
0 \\
0 \\
0 \\
0 \\
301 \\
255 \\
663 \\
412\end{array}$ & $\begin{array}{r}100 \\
130 \\
130 \\
130 \\
130 \\
130 \\
218 \\
154 \\
154 \\
188 \\
33 \\
128 \\
119 \\
192 \\
909 \\
470 \\
1,471 \\
1,245\end{array}$ & $\begin{array}{l}1941- \\
1942- \\
1943 \\
1944 \\
1945 \\
1946 \\
1947 \\
1948 \\
1949 \\
1950 \\
1951 \\
1952 \\
1953 \\
1954 \\
1955 \\
1956 \\
1957\end{array}$ & $\begin{array}{r}115 \\
31 \\
201 \\
38 \\
259 \\
78 \\
186 \\
29 \\
0 \\
69 \\
160 \\
198 \\
96 \\
60 \\
90 \\
128 \\
0\end{array}$ & $\begin{array}{r}150 \\
128 \\
182 \\
0 \\
46 \\
62 \\
0 \\
0 \\
0 \\
0 \\
67 \\
0 \\
42 \\
0 \\
0 \\
84 \\
0\end{array}$ & $\begin{array}{r}226 \\
107 \\
190 \\
153 \\
183 \\
243 \\
88 \\
145 \\
0 \\
208 \\
159 \\
240 \\
192 \\
211 \\
71 \\
177 \\
0\end{array}$ & $\begin{array}{r}480 \\
234 \\
960 \\
219 \\
526 \\
473 \\
532 \\
319 \\
90 \\
361 \\
175 \\
536 \\
381 \\
1,110 \\
696 \\
941 \\
1,260\end{array}$ & $\begin{array}{r}1,570 \\
870 \\
2,090 \\
543 \\
1,620 \\
1,480 \\
1,300 \\
1,590 \\
422 \\
976 \\
735 \\
1,730 \\
1,340 \\
3,650 \\
3,490 \\
2,630 \\
2,680\end{array}$ & $\begin{array}{l}2,541 \\
1,370 \\
2,623 \\
953 \\
2,634 \\
2,336 \\
2,106 \\
2,083 \\
512 \\
1,614 \\
1,296 \\
2,704 \\
2,051 \\
5,031 \\
4,347 \\
3,960 \\
3,940\end{array}$ \\
\hline
\end{tabular}

1 Estimated. 
$\mathrm{T}_{\mathrm{ABLE}}$ 5.-Irrigated acreage in the subbasins in the San Juan division

[Source of data: U.S. Bur. of the Census (1953), and Upper Colorado River Basin Compact Comm. (1948)]

Location

San Juan River basin

Source..............

Intervening area...

Total area, San Juan at Pagosa Springs, Colo.-

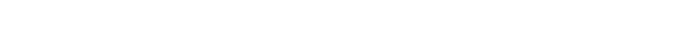

Navajo River basin tributary area. Intervening area........

Piedra River basin tributary area...... Intervening area......

Total area, San Juan River near Rosa, N. Mex

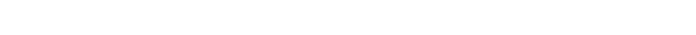

Los Pinos River basin tributary area

Totál area, San Juan River at Blanco, N. Mex

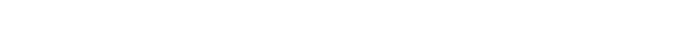
Animas River near Durango, Colo., tributary area...Intervening area.....

Animas River basin tributary area.

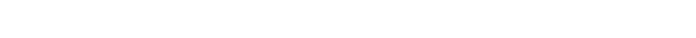

La Plata River at Colorado-New Mexico State line

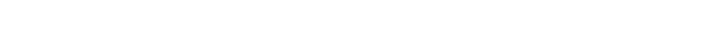
Intervening area.....

La Plata River basin tributary area. Intervening area

$\begin{array}{r}\multicolumn{1}{|c|}{\begin{array}{r}\text { Irrigated } \\ \text { acreage }\end{array}} \\ 0 \\ 5,500 \\ \hline 5,500 \\ 4,500 \\ 2,800 \\ 500 \\ 5,000 \\ 0 \\ \hline 18,300 \\ 2,500 \\ 40,200 \\ 600 \\ \hline 91,600 \\ 9,000 \\ 5,500 \\ 30,000 \\ 35,500 \\ 200 \\ 8,500 \\ \hline 5000 \\ \hline 5000 \\ \hline 5\end{array}$

Irrigated

acreage

San Juan River basin-Continued

Chaco River basin tributary area._............ 5, 800

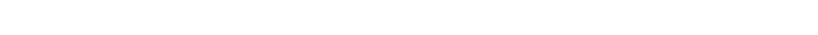

Total area, San Juan River at Shiprock, N. Mex_ 146, 900 Intervening area...... 0

Mancos River basin tributary area

Intervening area........................ 0

MeElmo Creek basin tributary area_._. _..._. . 37, 800

Intervening area.......................... 0

Montezume Creek basin tributary area . . . . . 3, 000

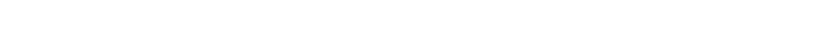

Recapture Creek basin tributary area. 2, 000

Intervening area...... 0

Chinle Creek basin tributary area._............ 3, 800

Intervening area.......

Total area, San Juan River near Bluff, Utah_-_._. 206, 400

Colorado River Basin below the Green and San Juan Rivers and above "Lee Ferry," Ariz.

Dirty Devil River tributary area _.............. 23, 300

Escalante River tributary area._........ 7, 000

Paria River tributary area..... 3, 000

Total area, Colorado River Basin below the Green and San Juan Rivers and above "Lee Ferry," Ariz......................... 33, 300 


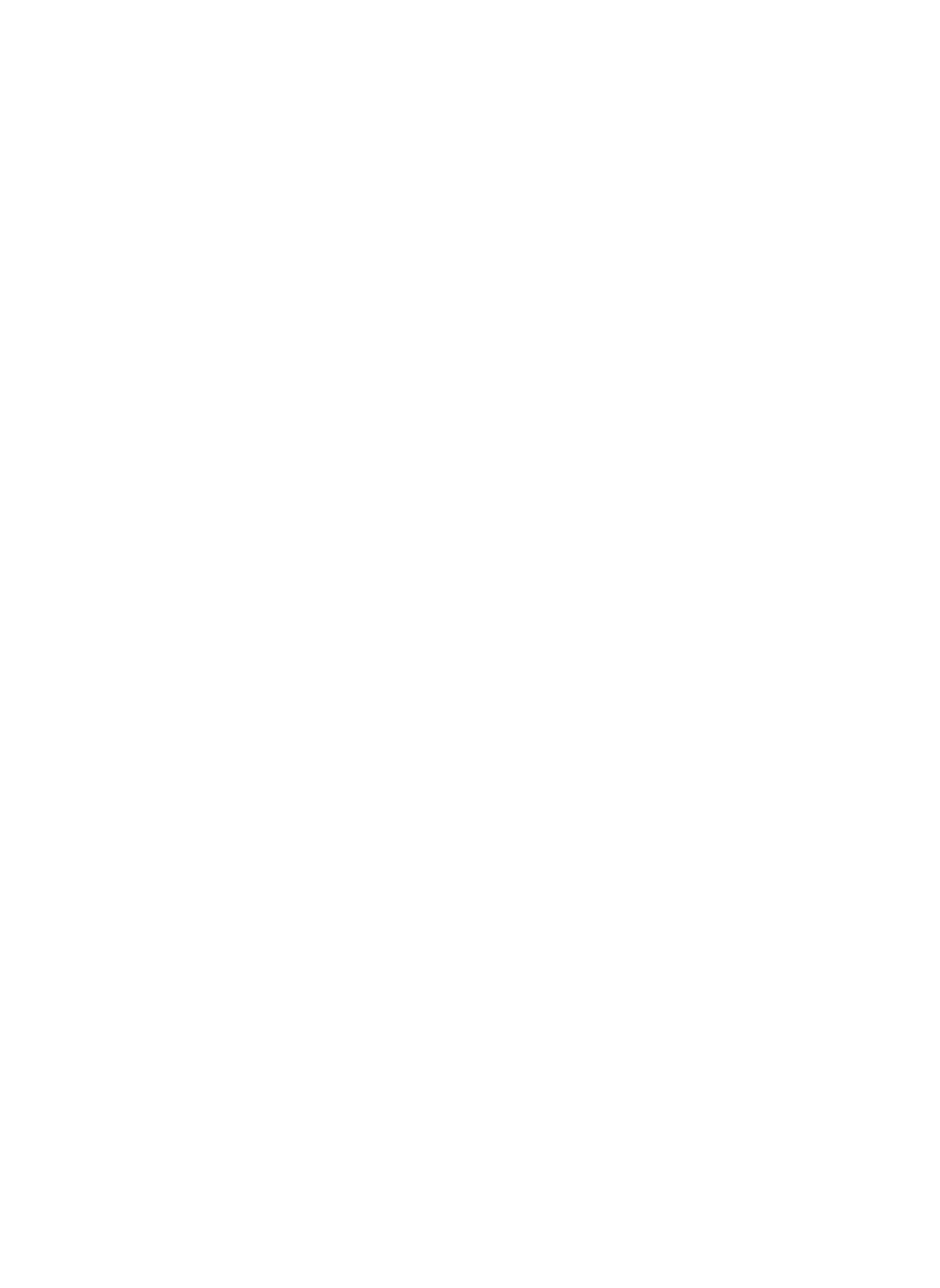




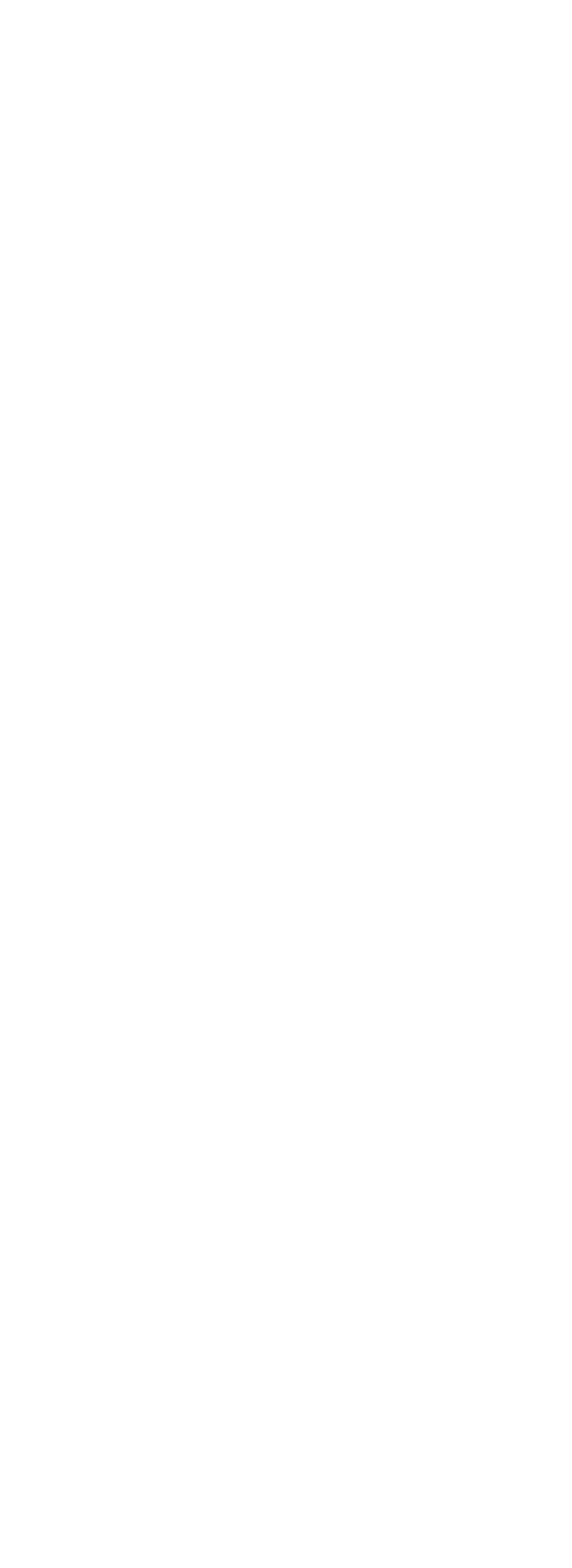


TABLE 7.-Methods and accuracy of adjusting flow-duration data for stations in the subbasins in the San Juan division to base period and $195 \%$ conditions

Index-station No.: Index station used in adjusting flow-duration curve to base period of correlation station used in estimating data for missing periods of record.

Years of record: Number of years of available historical flow-duration data during water years 1914-57.

Base period adjustment method: Method used in adjusting historical data to base period; I, index-station method, $M$, monthly means method, S, substitute method. U pstream water developments: Upstream reservoirs, irrigation, and transmountain

\begin{tabular}{l|c|c|c|c|c||c|c|c|c|c|c}
\hline $\begin{array}{c}\text { Sta- } \\
\text { tion } \\
\text { No. }\end{array}$ & $\begin{array}{c}\text { Index- } \\
\text { station } \\
\text { No. }\end{array}$ & Years of & $\begin{array}{c}\text { Base- } \\
\text { period } \\
\text { adjust- } \\
\text { ment } \\
\text { method }\end{array}$ & Upstream water developments & $\begin{array}{c}\text { Accuracy } \\
\text { rating } \\
\text { (percent) }\end{array}$ & $\begin{array}{c}\text { Sta- } \\
\text { tion } \\
\text { No. }\end{array}$ & $\begin{array}{c}\text { Index- } \\
\text { station } \\
\text { No. }\end{array}$ & $\begin{array}{c}\text { Years of } \\
\text { record }\end{array}$ & $\begin{array}{c}\text { Base- } \\
\text { period } \\
\text { adjust- } \\
\text { ment } \\
\text { method }\end{array}$ & $\begin{array}{c}\text { Upstream water developments } \\
\text { recuracy } \\
\text { rating }\end{array}$ \\
\hline
\end{tabular}

San Juan River basin

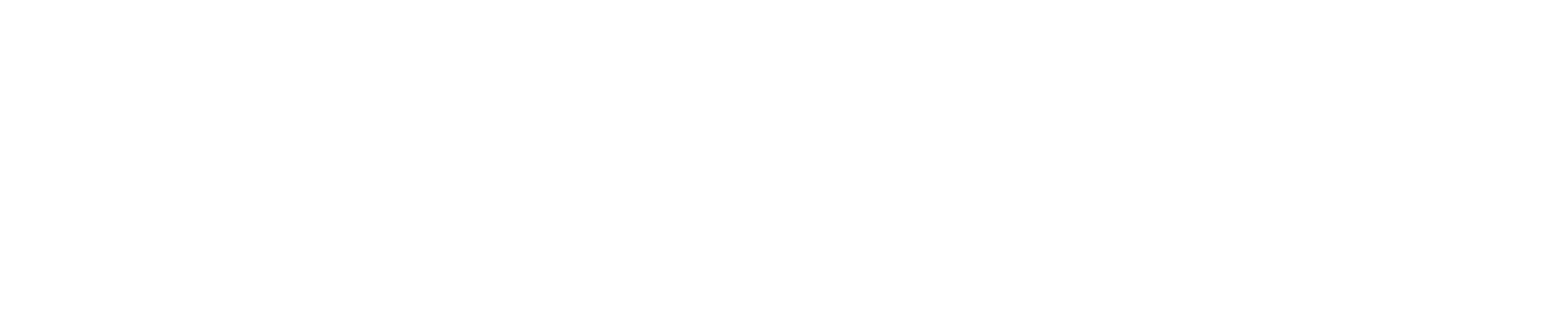

Colorado River Basin below the Green and San Juan Rivers and above "Lee Ferry," Ariz.

\begin{tabular}{|c|c|c|c|c|c|}
\hline $\begin{array}{l}3305 \\
3350\end{array}$ & $\begin{array}{r}13265 \\
{ }^{3} 1805,{ }^{8} 3150\end{array}$ & $\begin{array}{r}8 \\
10\end{array}$ & $\begin{array}{l}\text { I } \\
\text { I }\end{array}$ & $(3)-(1)$ & $\begin{array}{l}15+ \\
10\end{array}$ \\
\hline
\end{tabular}

1 Flow-duration curve and data for index station that had been adjusted to base period were used.

2 Annual estimates of discharge by Upper Colorado River Compact Commission (1948) were used.

Flow-duration curve and data for index station that had been adjusted to base 4957 conditions were used

3 Annual estimates by U.S. Geol. Survey (1954) were used. project, Willow Creek Reservoir, Williams Fork Reservoir, Jones Pass and Hoosier

diversions in which changes occurred in base period requiring adjustment in historical data to 1957 conditions.

ceuracy rating: Authors' rating of accuracy of adjusted flow-duration curve for water years 1914-57 to 1957 conditions. The accuracy rating indicates that the final developed flow-duration curve throughout its range is believed to be correct
within the percentage indicated.

\begin{tabular}{l|l|l|l}
3800 & $(6)$ & 36 & $\mathrm{M}$ \\
$\mathbf{3 8 2 0}$ & $(2)$ & $\mathbf{3 4}$ & $\mathrm{S}$
\end{tabular}

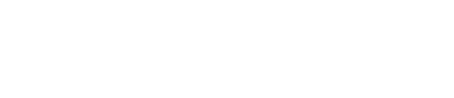

Lakes and Busk-Ivanhoe tunnels, Taylor Park Reservoir, Gunnison tunnel, and

Duchesne tunnel.

mission (1948) were used. project, Willow Creek Reservoir, Williams Fork Reservoir, Jones Pass and Hoosier Pass tunnels Green Mountain Reservoir, Columbine and Wurtz ditches, Twin Lakes and Busk-Ivanhoe tunnels, Taylor Park Reservoir, Gunnison tunnel, Duchesne tunnel, and Vallecito Reservoir.

TABLE 8.-Variability index of streamflow and percentage of average annual discharge estimated to be contributed by ground water for selected streams in the San Juan River basin, Colo.

[Data are for the water years 1914-57 adjusted to 1957 conditions]

\begin{tabular}{|c|c|c|c|c|c|c|c|}
\hline $\begin{array}{l}\text { Station } \\
\text { No. }\end{array}$ & Station name & $\begin{array}{c}\text { Variability } \\
\text { index }\end{array}$ & $\begin{array}{c}\text { Ground } \\
\text { water } \\
\text { (percent) }\end{array}$ & $\begin{array}{l}\text { Station } \\
\text { No. }\end{array}$ & Station name & $\begin{array}{c}\text { Variability } \\
\text { index }\end{array}$ & $\begin{array}{c}\text { Ground } \\
\text { water } \\
\text { percent }\end{array}$ \\
\hline $\begin{array}{l}3400 \\
3425 \\
3495 \\
\mathbf{3 5 0 5} \\
\mathbf{3 6 5 5}\end{array}$ & $\begin{array}{l}\text { San Juan River near Pagosa Springs. } \\
\text { San Juan River at Pagosa Springs } \\
\text { Piedra River near Piedra...... } \\
\text { San Juan River at Rosa. } \\
\text { La Plata River at Hesperus. }\end{array}$ & $\begin{array}{r}0.64 \\
.62 \\
.61 \\
.61 \\
.60\end{array}$ & $\begin{array}{l}16 \\
17 \\
17 \\
19 \\
17\end{array}$ & $\begin{array}{l}3575 \\
\mathbf{3 6 1 0} \\
\mathbf{3 4 6 0} \\
\mathbf{3 6 1 5}\end{array}$ & $\begin{array}{l}\text { Animas River at Howardsville } \\
\text { Hermosa Creek near Hermosa } \\
\text { Navajo River at Edith... } \\
\text { Animas River at Durango }\end{array}$ & $\begin{array}{l}.58 \\
.58 \\
.50 \\
.46\end{array}$ & $\begin{array}{l}20 \\
19 \\
25 \\
28\end{array}$ \\
\hline
\end{tabular}


TABLE 9.-Average discharge, standard deviation, and coefficient of variation for selected streams in the subbasins in the San Juan division

\begin{tabular}{|c|c|c|c|c|c|}
\hline Station No. & Station name & Period of record & $\begin{array}{l}\text { A verage dis- } \\
\text { charge (cfs) }\end{array}$ & $\begin{array}{l}\text { Standard } \\
\text { deviation } \\
\quad \text { (cfs) }\end{array}$ & $\begin{array}{l}\text { Coefficient } \\
\text { of variation }\end{array}$ \\
\hline
\end{tabular}

\begin{tabular}{|c|c|c|c|c|c|}
\hline \multicolumn{6}{|c|}{ San Juan River basin } \\
\hline 3425 & San Juan River at Pagosa Springs, Colo & 1914 & 376 & 159 & 0.42 \\
\hline 3460 & Navajo River at Edith, Colo. & $\begin{array}{l}1936-57 \\
1914-57\end{array}$ & 165 & 64. 7 & .39 \\
\hline 3505 & San Juan River at Rosa, N. Mex... & $1914-57$ & 1,208 & 523 & .43 \\
\hline 3615 & Animas River at Durango, Colo & $1914-57$ & 859 & 278 & .32 \\
\hline 3650 & San Juan River at Farmington, N. Mex & $1914-57$ & 2,633 & 1,160 & .44 \\
\hline 3655 & La Plata River at Hesperus, Colo & $1918-57$ & 46.2 & 18.4 & .40 \\
\hline 3710 & Mancos River near Towaoc, Colo & $\begin{array}{l}1921-43 \\
1952-57\end{array}$ & 58.8 & 37.8 & .64 \\
\hline 3795 & San Juan River near Bluff, Utah. & $1914-57$ & 2,842 & 1,275 & 45 \\
\hline
\end{tabular}

Colorado River Basin below the Green and San Juan Rivers and above "Lee Ferry," Ariz.

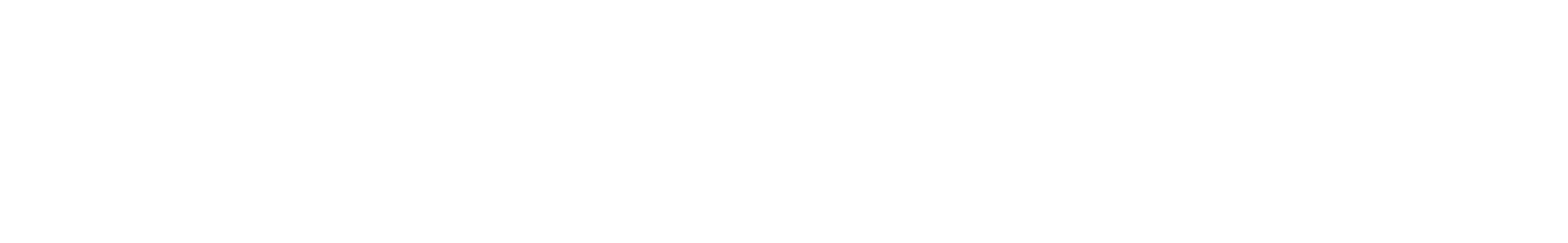

1 Historical record.

record plus transmountain diversions and adjustment for change in

3 Reconstructed record of annual discharge values representing virgin flow (Leostorage reservoirs.

pold, 1959) and later data furnished by I. V. Goslin (oral commun., 1960). 
TABLE 10.-Water and dissolved-solids discharge in the subbasins in the San Juan division

[Water and dissolved-solids discharge for the water years 1914-57 adjusted to 1957 conditions except as indicated]

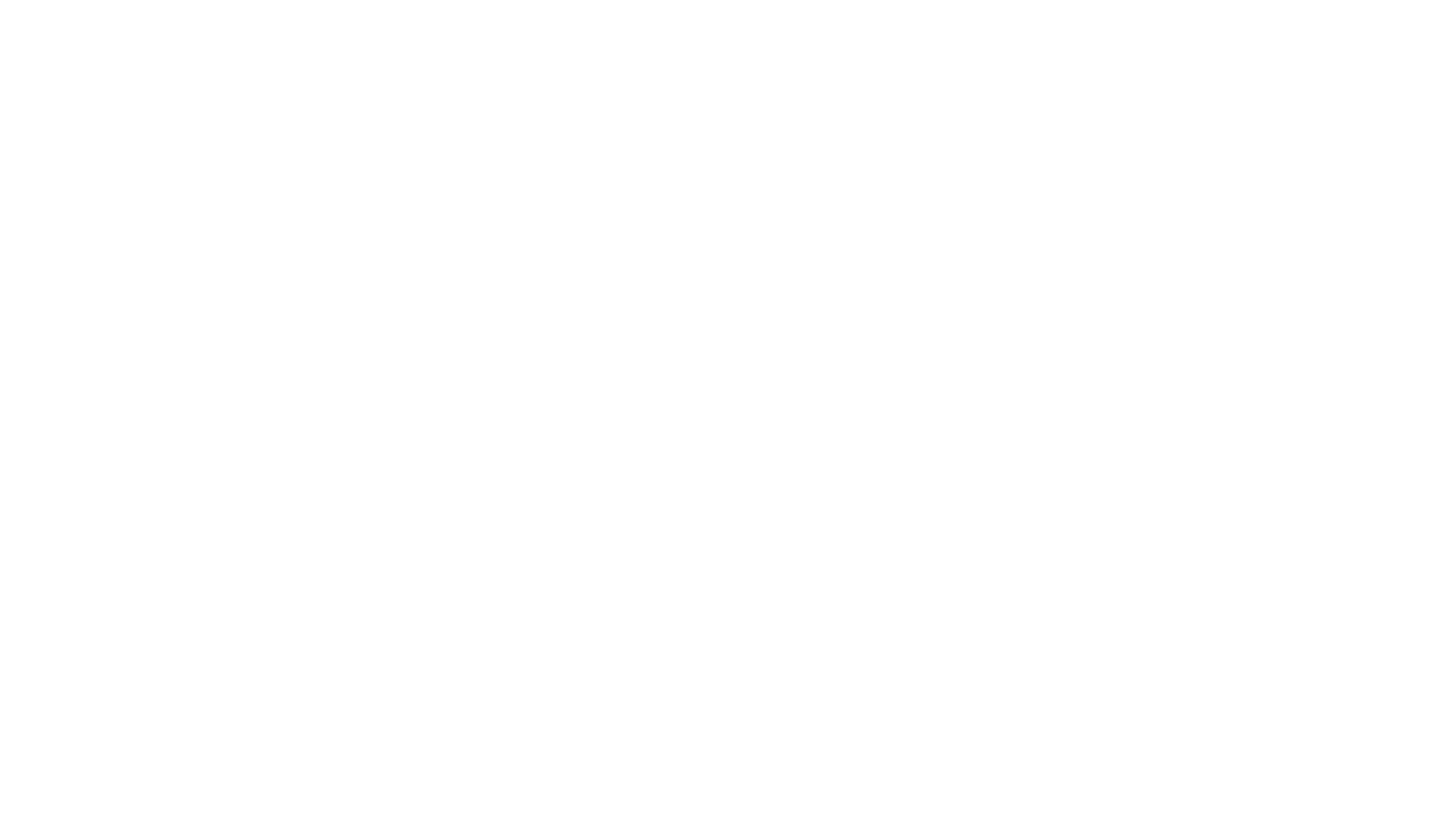

Colorado River Basin below the Green and San Juan Rivers and above "Lee Ferry," Ariz.

\begin{tabular}{|c|c|c|}
\hline 3300 & Fremont River near Bicknell, Utah ${ }^{1}$ & 776 \\
\hline 3305 & Muddy Creek near Emery, Utah. & \\
\hline 3335 & Dirty Devil River near Hite, Utah ${ }^{2}$ & 4,360 \\
\hline 3350 & Colorado River at Hite, Utah & 76,600 \\
\hline 3375 & Escalante River near Escalante, Utah ${ }^{3}$ & 315 \\
\hline 3395 & $\begin{array}{l}\text { Escalante River at mouth, near Es- } \\
\text { calante, Utah }\end{array}$ & \\
\hline $\begin{array}{l}3800 \\
3820\end{array}$ & $\begin{array}{l}\text { Colorado River at Lees Ferry, Ariz } \\
\text { Paria River at Lees Ferry, Ariz }\end{array}$ & $\begin{array}{r}107,900 \\
1,570\end{array}$ \\
\hline
\end{tabular}

1 For water years $1938-43,1947-57$.

2 For water years 1949-57.

\begin{tabular}{|c|r|r|r|r|r}
85.8 & 62,160 & 302 & 70 & 33 & 25,570 \\
36.1 & 26,150 & 213 & 21 & 86 & 7,670 \\
102 & 73,890 & 1,960 & 541 & 45 & 197,600 \\
14,167 & $10,260,000$ & 527 & 20,170 & 96 & $7,367,000$ \\
13.2 & 9,560 & 477 & 17 & 20 & 6,210 \\
& & & & & \\
85.2 & 61,720 & 300 & 69 & 13 & 25,200 \\
17,550 & $12,710,000$ & 499 & 23,660 & 80 & $8,642,000$ \\
31.9 & 23,110 & 1,090 & 94 & 22 & 34,330 \\
& & & & & \\
\hline
\end{tabular}

3 For water years $1943-55$.
1 For water years $1951-55$. 
SURFACE-WATER RESOURCES OF SAN JUAN DIVISION

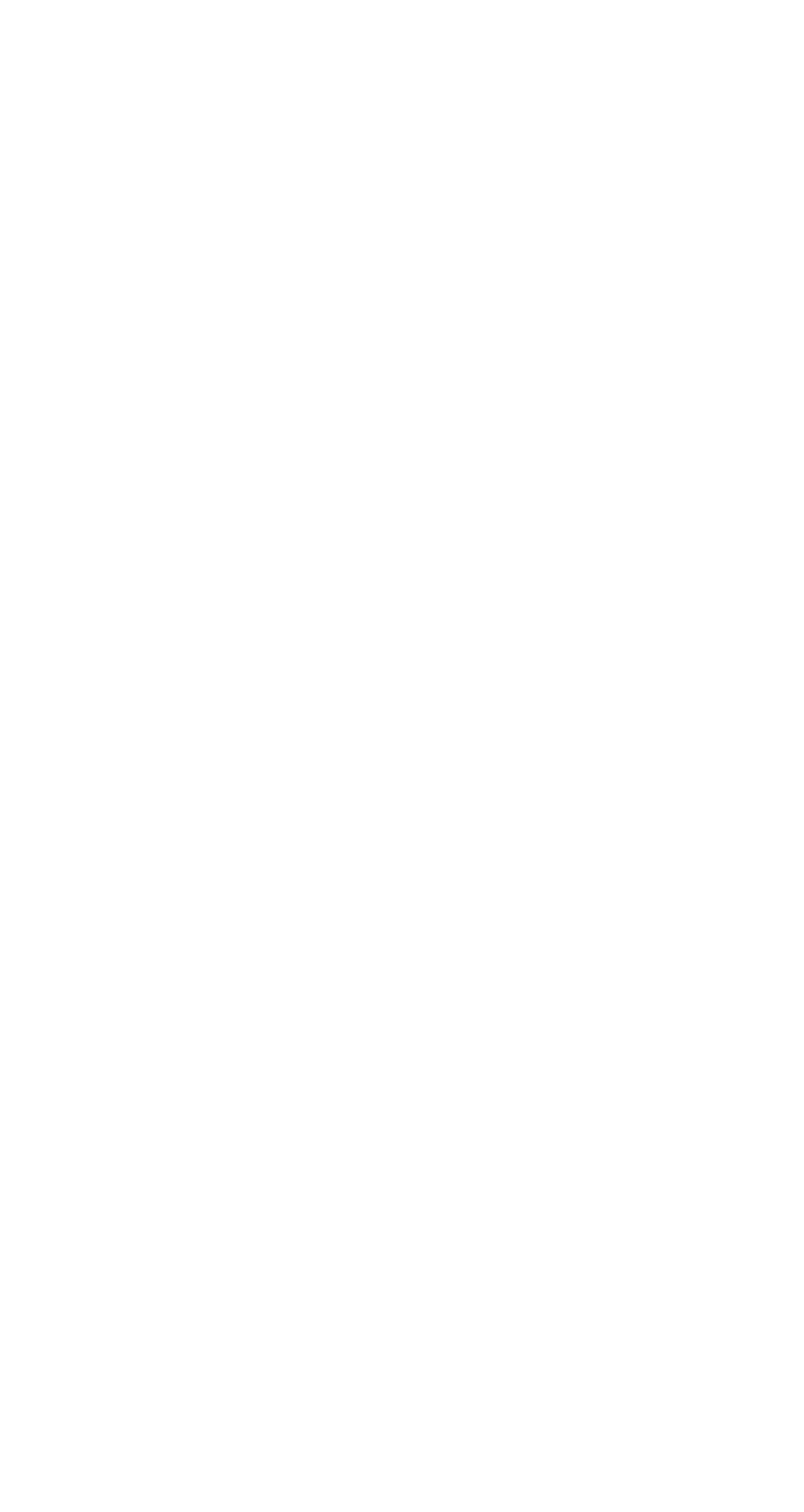




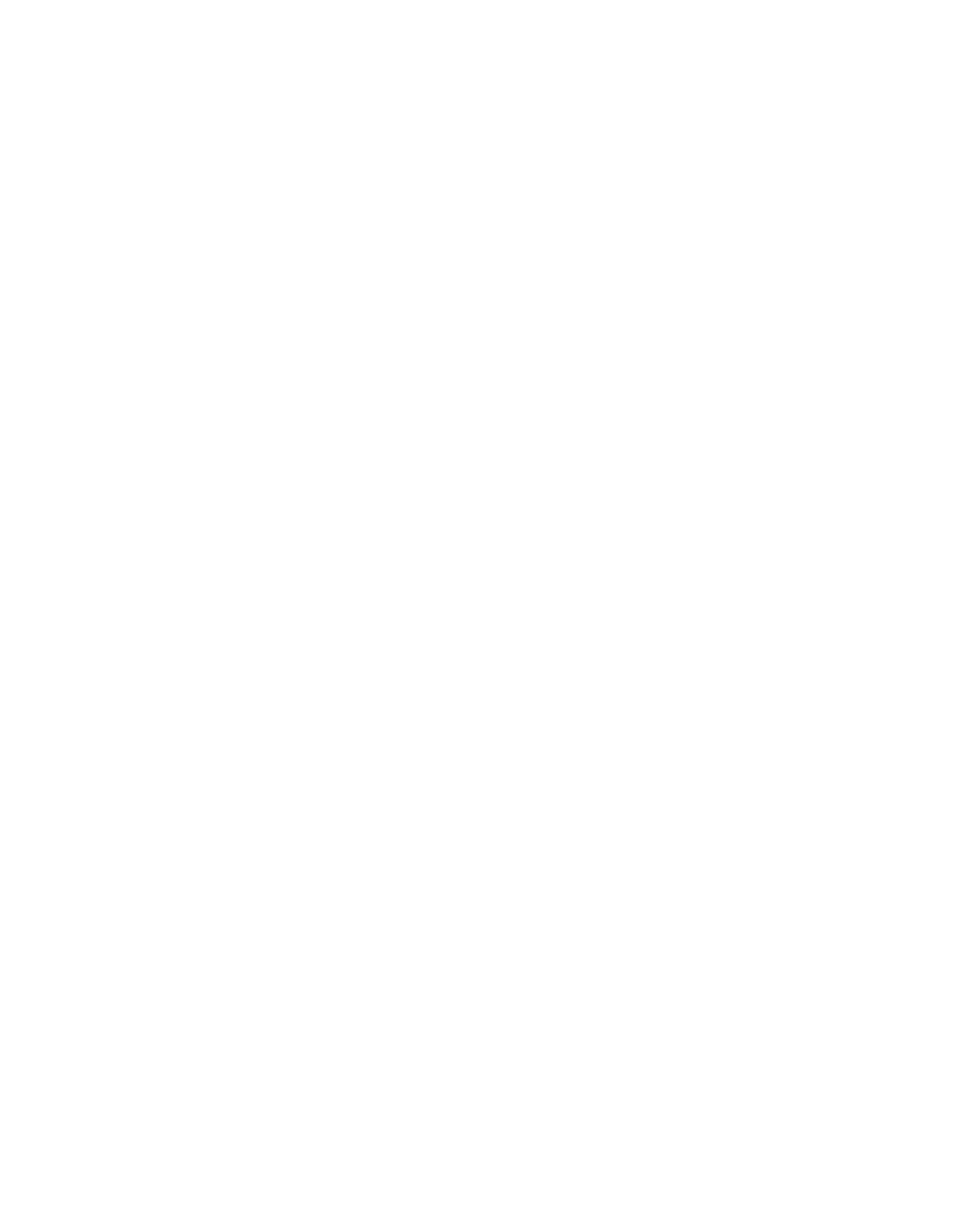


TABLE 13.-Variability of annual weighted-average concentration of dissolved solids as related to the variability of annual water discharge for daily stations in the San Juan River basin

\begin{tabular}{|c|c|c|c|c|}
\hline \multirow[b]{2}{*}{$\begin{array}{l}\text { Station } \\
\text { No. }\end{array}$} & \multirow{2}{*}{ Station name } & \multirow{2}{*}{ Water years } & \multicolumn{2}{|c|}{ Coefficient of variation } \\
\hline & & & $\begin{array}{c}\text { Water } \\
\text { discharge }\end{array}$ & $\begin{array}{l}\text { Weighted- } \\
\text { average } \\
\text { concentra- } \\
\text { tion }\end{array}$ \\
\hline $\begin{array}{l}3645 \\
3565 \\
3795\end{array}$ & $\begin{array}{l}\text { Animas River at Farmington, N. Mex } \\
\text { San Juan River near Blanco, N. Mex.- } \\
\text { San Juan River near Bluff, Utah...- }\end{array}$ & $\begin{array}{l}1941-57 \\
1946-54 \\
1930-57\end{array}$ & $\begin{array}{r}0.45 \\
.59 \\
.51\end{array}$ & $\begin{array}{r}0.20 \\
.16 \\
.19\end{array}$ \\
\hline
\end{tabular}

TABLE 14.-Relation between water discharge and chemical quality of water at selected stations in the San Juan division [Chemical-quality data and weighted averages are in parts per million and equivalents per million (italicized) except where indicated; data are for the water years 1914-57

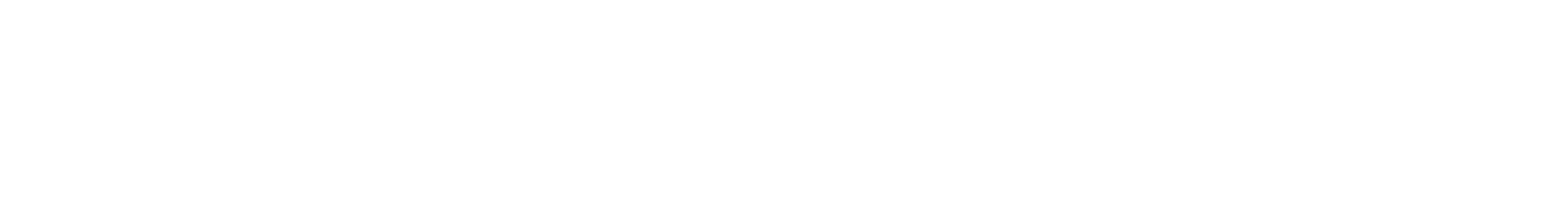

San Juan River near Blanco, N. Mex.

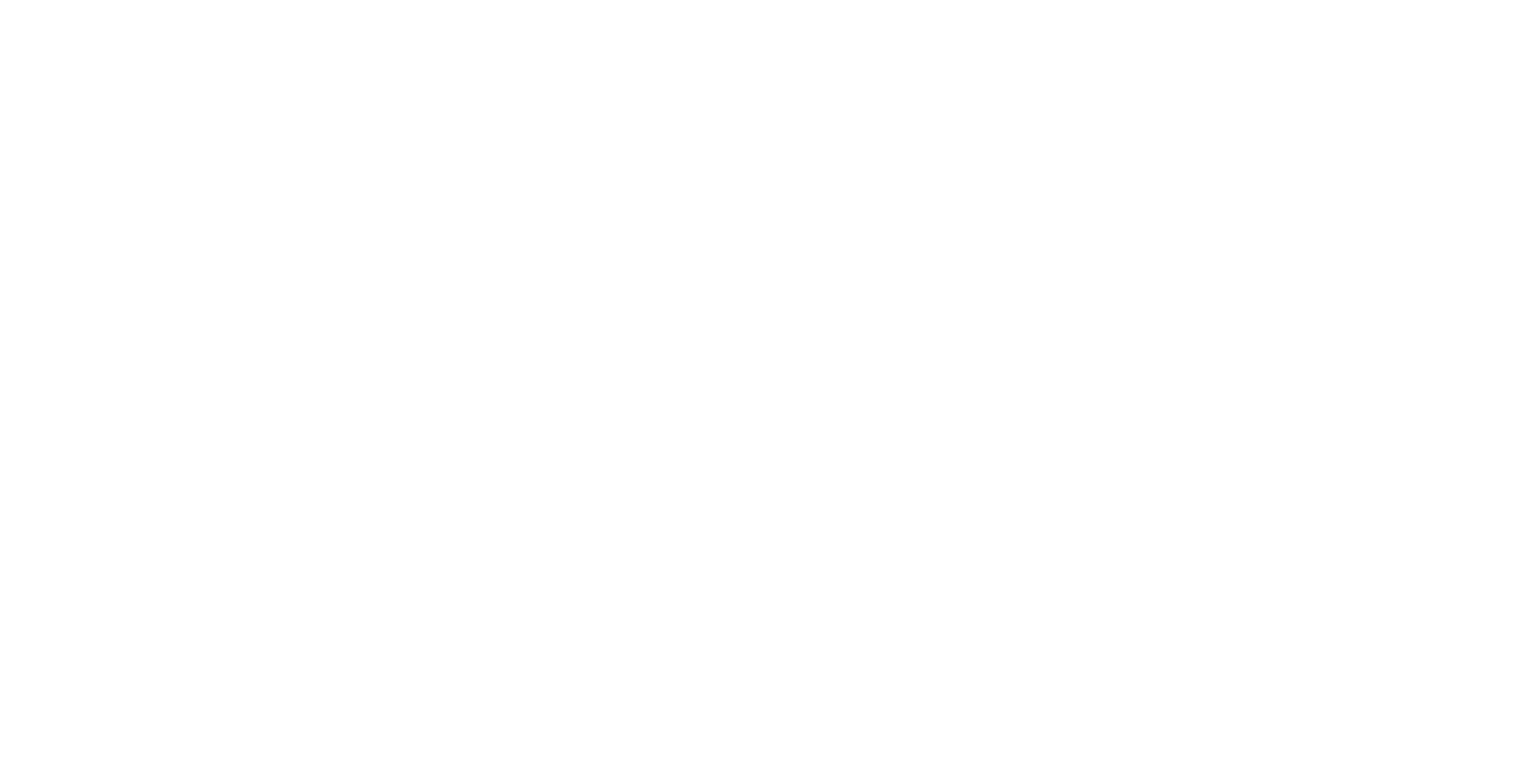

See footnotes at end of table. 
TABLE 14.-Relation between water discharge and chemical quality of water at selected stations in the San Juan division-Con.

\begin{tabular}{|c|c|c|c|c|c|c|c|c|c|c|c|c|c|c|c|c|}
\hline \multirow[b]{2}{*}{$\begin{array}{c}\text { Discharge } \\
\text { (cfs) }\end{array}$} & \multirow[b]{2}{*}{$\begin{array}{c}\text { Calcium } \\
\text { (Ca) }\end{array}$} & \multirow{2}{*}{$\underset{\substack{\text { Mag- } \\
\text { nesium } \\
(\mathrm{Mg})}}{ }$} & \multirow[b]{2}{*}{$\begin{array}{l}\text { Sodium } \\
(\mathbf{N a})\end{array}$} & \multirow{2}{*}{$\begin{array}{l}\text { Potas- } \\
\text { sium } \\
(\mathrm{K})\end{array}$} & \multirow{2}{*}{$\begin{array}{c}\text { Bicar- } \\
\text { bonate } \\
\left(\mathrm{HCO}_{3}\right)\end{array}$} & \multirow[b]{2}{*}{$\begin{array}{l}\text { Sulfate } \\
\left(\mathrm{SO}_{4}\right)\end{array}$} & \multirow[b]{2}{*}{$\underset{\text { (Cl) }}{\text { Chloride }}$} & \multirow[b]{2}{*}{$\underset{(B)}{\text { Boron }}$} & \multicolumn{3}{|c|}{$\begin{array}{c}\text { Dissolved solids } \\
\text { (residue at } 180^{\circ} \mathrm{C} \text { ) }\end{array}$} & \multicolumn{2}{|c|}{$\begin{array}{c}\text { Hardness } \\
\text { as } \mathrm{CaCO}_{3}\end{array}$} & \multirow{2}{*}{$\begin{array}{c}\text { Per- } \\
\text { cent } \\
\text { sodium }\end{array}$} & \multirow{2}{*}{\begin{tabular}{|} 
Specific \\
conduct- \\
ance \\
(micro- \\
mhos \\
per cm \\
at $25^{\circ} \mathrm{C}$ )
\end{tabular}} & \multirow[b]{2}{*}{$\begin{array}{c}\text { Sodium } \\
\text { adsorp- } \\
\text { tion- } \\
\text { ratio }\end{array}$} \\
\hline & & & & & & & & & $\begin{array}{c}\text { Parts } \\
\text { per } \\
\text { million }\end{array}$ & $\begin{array}{c}\text { Tons } \\
\text { per } \\
\text { acre-ft }\end{array}$ & $\begin{array}{l}\text { Tons } \\
\text { per } \\
\text { day }\end{array}$ & $\begin{array}{c}\text { Calcium, } \\
\text { nag- } \\
\text { nesium }\end{array}$ & $\begin{array}{c}\text { Non- } \\
\text { carbon } \\
\text { ate }\end{array}$ & & & \\
\hline
\end{tabular}

Animas River at Farmington, N. Mex.

\begin{tabular}{|c|c|c|c|c|c|c|c|c|c|c|c|c|c|c|c|c|}
\hline 11,000 . & & 3.1 & 5.4 & 1.1 & 82 & 35 & 2.9 & & 137 & 0.19 & 4,070 & 92 & 26 & 11 & 225 & 0.2 \\
\hline 9,950 . & 32 & $\begin{array}{l}.25 \\
3.2\end{array}$ & $\begin{array}{c}.23 \\
5.4\end{array}$ & 1. 03 & $82^{1.34}$ & $36^{.79}$ & $\begin{array}{l}.08 \\
2.9\end{array}$ & & 137 & .19 & 3,680 & 93 & 26 & 11 & 225 & .2 \\
\hline 9,200 . & 33 & 3.26 & 5. .23 & 1. 1 & $8^{1.34}$ & $37^{.10}$ & $\begin{array}{l}.08 \\
2.9\end{array}$ & & 137 & .19 & 3,400 & 96 & 28 & 11 & 225 & .2 \\
\hline 7,700 & 34.00 & 3. 30 & 5.64 & 1. 2 & 84.36 & 38 & 3.08 & & 138 & .19 & 2,870 & 98 & 30 & 11 & 230 & .2 \\
\hline 5,740 & 34.70 & $\begin{array}{l}.27 \\
3.6 \\
80\end{array}$ & $\begin{array}{c}.24 \\
6.3 \\
07\end{array}$ & 1. 2 & $\begin{array}{l}1.98 \\
86\end{array}$ & $41_{85}^{.79}$ & $\begin{array}{l}.08 \\
3.1 \\
09\end{array}$ & & 138 & .19 & 2,140 & 100 & 30 & 12 & 230 & .3 \\
\hline 4,450 & 35 & 3.8 & 6. 9 & 1.4 & $88^{1.41}$ & $44^{\circ}$ & 3. 4 & & 140 & .19 & 1,680 & 103 & 31 & 12 & 230 & .3 \\
\hline 3,350 & $\begin{array}{l}36 \\
1.80\end{array}$ & $\begin{array}{l}4.21 \\
.35\end{array}$ & $\begin{array}{l}7.8 \\
.34\end{array}$ & $\begin{array}{c}1.54 \\
.04\end{array}$ & $90_{1.48}^{1.44}$ & $48^{.02}$ & $\begin{array}{l}3.10 \\
.11\end{array}$ & & 146 & .20 & 1,320 & 108 & 34 & 13 & 240 & .3 \\
\hline 2,350 & $\begin{array}{l}1.00 \\
40 \\
2.00\end{array}$ & 4.9 & $\begin{array}{l}.04 \\
9.4\end{array}$ & I. 8 & $96^{1.40}$ & 57.00 & $\begin{array}{l}.11 \\
4.8\end{array}$ & & 168 & .23 & 1,070 & 120 & 42 & 14 & 275 & .4 \\
\hline 1,430 & $\begin{array}{l}48 \\
2.40\end{array}$ & 6.7 & $13^{.41}$ & 2.3 & 110 & 78 & $\begin{array}{l}6.7 \\
19\end{array}$ & $-\cdots$ & 213 & .29 & 822 & 148 & 58 & 16 & 340 & .5 \\
\hline 770 & $\begin{array}{l}67.40 \\
3.34\end{array}$ & $10^{\circ} .82$ & 23 & $\begin{array}{l}3.2 \\
.08\end{array}$ & $\begin{array}{r}143 \\
2.35\end{array}$ & $\begin{array}{r}125 \\
2.60\end{array}$ & 11.81 & & 293 & .40 & 609 & 208 & 90 & 19 & 460 & .7 \\
\hline 505 & 80.04 & $13^{.02}$ & 33 & $\begin{array}{l}3.90 \\
.10\end{array}$ & 163 & $\begin{array}{c}2.00 \\
166 \\
8.45\end{array}$ & $15^{.01}$ & $\because$ & 370 & .50 & 505 & 253 & 120 & 22 & 580 & .9 \\
\hline $375^{2}$ & $\begin{array}{l}90 \\
4.49\end{array}$ & 15 & $\begin{array}{r}42.44 \\
1.83\end{array}$ & $\begin{array}{c}4.5 \\
.12\end{array}$ & $\begin{array}{r}177 \\
2.90\end{array}$ & $\begin{array}{l}200 \\
4.16\end{array}$ & $19^{.42}$ & $-\cdots$ & 430 & .58 & 435 & 286 & 141 & 24 & 670 & 1.1 \\
\hline 308. & $\begin{array}{r}97.40 \\
4.84\end{array}$ & 16 & $\begin{array}{r}49 \\
2.13\end{array}$ & $\begin{array}{c}4.9 \\
.13\end{array}$ & $\begin{array}{r}186 \\
3.05\end{array}$ & $\begin{array}{r}222 \\
4.62\end{array}$ & 22.62 & & 475 & .65 & 395 & 308 & 156 & 25 & 740 & 1.2 \\
\hline 265 & $\begin{array}{r}102 \\
5.09\end{array}$ & 17.40 & 53 & 5.1 & 191 & 240 & $25^{\circ}$ & & 511 & .69 & 366 & 324 & 168 & 26 & 770 & 1.3 \\
\hline 232 & $\begin{array}{c}106 \\
5.29\end{array}$ & $\begin{array}{c}18 \\
1.48\end{array}$ & $\begin{array}{r}57.41 \\
2.48\end{array}$ & $\begin{array}{c}5.3 \\
.14\end{array}$ & 197 & $\begin{array}{r}254.88 \\
5.28\end{array}$ & $27_{.76}^{.0}$ & $\cdots$ & 560 & .76 & 351 & 338 & 177 & 26 & 840 & 1.3 \\
\hline $192^{3}$ & 111 & $\begin{array}{c}19 \\
1.56\end{array}$ & $\begin{array}{c}62 \\
2.70\end{array}$ & $\begin{array}{c}5.6 \\
.14\end{array}$ & $\begin{array}{l}202 \\
3.31\end{array}$ & $\begin{array}{r}274.20 \\
5.70\end{array}$ & $\begin{array}{r}30.0 \\
.85\end{array}$ & - & 608 & .83 & 315 & 355 & 190 & 27 & 910 & 1.4 \\
\hline 83. & $\begin{array}{r}124 \\
6.19\end{array}$ & 22 & $\begin{array}{r}79 \\
3.44\end{array}$ & $\begin{array}{c}6.4 \\
.16\end{array}$ & $\begin{array}{l}220 \\
3.61\end{array}$ & $\begin{array}{r}330 \\
6.86\end{array}$ & $\begin{aligned} 41 \\
1.16\end{aligned}$ & $\cdots$ & 698 & .95 & 156 & 400 & 220 & 30 & 1,000 & 1.7 \\
\hline 25. & 130 & 24.97 & 94.09 & $\begin{array}{l}\text { 7. } 0 \\
18\end{array}$ & 230 & 360 & 51 & $\ldots$ & 751 & 1.02 & 51 & 423 & 234 & 32 & 1,070 & 2.0 \\
\hline 8.3 & $\begin{array}{r}133.48 \\
6.64 \\
\end{array}$ & $\begin{array}{r}24 \\
1.97 \\
\end{array}$ & $\begin{array}{r}102.08 \\
4.44 \\
\end{array}$ & $\begin{array}{c}7.10 \\
.18 \\
\end{array}$ & $\begin{array}{r}235 \\
3.85 \\
\end{array}$ & $\begin{array}{r}370.49 \\
7.70 \\
\end{array}$ & $\begin{array}{r}1.44 \\
1.58 \\
\end{array}$ & 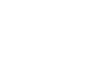 & 800 & 1.09 & 18 & 430 & 238 & 34 & 1,140 & $\begin{array}{r}2.1 \\
\cdots\end{array}$ \\
\hline $971 \ldots$ & $\begin{array}{l}52 \\
2.59\end{array}$ & $\begin{array}{l}7.2 \\
.59\end{array}$ & ${ }^{17} .74$ & $\begin{array}{c}2.4 \\
.06\end{array}$ & $\stackrel{115}{1.89}$ & $\stackrel{91}{1.89}$ & $\begin{array}{l}8.3 \\
.23\end{array}$ & & 233 & .32 & 611 & 159 & 64 & 19 & 369 & .6 \\
\hline
\end{tabular}

San Juan River at Shiprock, N. Mex.

\begin{tabular}{|c|c|c|c|c|c|c|c|c|c|c|c|c|c|c|c|c|}
\hline 30,100 & 29 & 4.9 & 12 & 1.0 & 98 & 35 & 2.2 & 0.02 & 135 & 0.18 & 10,970 & 92 & 12 & 22 & 210 & 0.5 \\
\hline 27,100 & 29.40 & $\begin{array}{l}40 \\
4.9\end{array}$ & $12^{.0 \%}$ & 1. 0 & 98 & $35^{.73}$ & 2.30 & .02 & 136 & .18 & 9,950 & 92 & 12 & 22 & 210 & .5 \\
\hline 24,800 & $29^{1.40}$ & $\begin{array}{c}40 \\
4.9 \\
\end{array}$ & $12^{.0 z}$ & 1. 0 & 98 & $35^{.73}$ & 2.3 & .02 & 136 & .18 & 9,110 & 92 & 12 & 22 & 210 & .5 \\
\hline 20,000 & 30 & 4.90 & $13^{.0 z}$ & $\begin{array}{l}.03 \\
1.1\end{array}$ & 99 & $37^{.7}$ & $\begin{array}{l}.00 \\
2.5\end{array}$ & .02 & 138 & 19 & 7,450 & 95 & 14 & 23 & 220 & .6 \\
\hline 15,000 & 30 & $\begin{array}{l}5.0^{40} \\
11\end{array}$ & $14^{.57}$ & $\begin{array}{l}.03 \\
1.2\end{array}$ & 100 & $39^{.77}$ & 2.7 & .02 & 144 & .20 & 5,830 & 96 & 14 & 24 & 225 & .6 \\
\hline 12,000 & 31 & 5. 0 & $16^{\circ}$ & 1. 3 & 102 & $43^{\circ}$ & 3. 0 & .02 & 153 & 21 & 4,960 & 98 & 14 & 26 & 240 & .7 \\
\hline 9,300 & 32 & 5. 3 & $18^{\circ}$ & 1. 5 & $10^{\circ}$ & $48^{.89}$ & 3. 5 & .02 & 165 & .22 & 4,140 & 102 & 18 & 27 & 260 & .8 \\
\hline $6,600{ }^{1}$. & 34.00 & 5.44 & $22^{.78}$ & $\begin{array}{l}.04 \\
1.9\end{array}$ & $\begin{array}{l}1.69 \\
105\end{array}$ & 65 & 4. 3 & .03 & 190 & .26 & 3,390 & 109 & 23 & 30 & 300 & .9 \\
\hline 4,150 & 38 & 7. 3 & 31 & 2.5 & 111 & $90^{1.00}$ & 5.9 & .03 & 235 & .32 & 2,630 & 125 & 34 & 35 & 370 & 1.2 \\
\hline 2,450 & 48 & 9. 6 & $43^{1.87}$ & $\begin{array}{l}3.00 \\
.08\end{array}$ & 130 & 130 & 9,0 & .04 & 305 & 41 & 2,020 & 160 & 53 & 36 & 470 & $1 . \overline{5}$ \\
\hline $1,450 \ldots$ & 66 & 13 & 57 & 3.3 & 150 & 190 & $14^{\circ}$ & .05 & 410 & .56 & 1,610 & 218 & 95 & 36 & 620 & 1.7 \\
\hline $1,020^{2}$ & 77 & 17 & 67.40 & 3.3 & 160 & 240 & $19^{.38}$ & .06 & 505 & .69 & 1,390 & 262 & 131 & 35 & 750 & 1.8 \\
\hline 800 & $\begin{array}{c}86.04 \\
4.29\end{array}$ & $\begin{array}{c}20 \\
1.64\end{array}$ & $\begin{array}{c}73 \\
3.18\end{array}$ & 3.3 & $163^{2.07}$ & $282^{4.89}$ & $22^{.04}$ & .06 & 565 & .77 & 1,220 & 296 & 163 & 35 & 820 & 1.8 \\
\hline $640 \ldots$ & 92 & 21 & 77 & 3.4 & 165 & 304 & $25^{\circ}$ & .06 & 620 & .84 & 1,070 & 316 & 180 & 34 & 900 & 1.9 \\
\hline 560 & 100 & 22 & 79 & 3. 4 & 167 & 328 & $27^{.70}$ & .06 & 650 & $.88^{-1}$ & 983 & 340 & 203 & 33 & $940^{-}$ & 1.9 \\
\hline $440^{3}$ & $\begin{array}{r}104 \\
5.19\end{array}$ & 22.81 & $81_{3.58}^{.44}$ & $\begin{array}{l}3.4 \\
.09\end{array}$ & 168 & $\begin{array}{c}340 \\
70 \gamma\end{array}$ & $30_{85}$ & .06 & 690 & .94 & 820 & 350 & 212 & 33 & 1,000 & 1.9 \\
\hline 168 & $\begin{array}{r}107 \\
5.34\end{array}$ & $\begin{array}{c}23 \\
1.89\end{array}$ & $\begin{array}{l}84 \\
3.65\end{array}$ & $\begin{array}{l}3.4 \\
.09\end{array}$ & $\begin{array}{c}175 \\
2.87\end{array}$ & $\begin{array}{c}340 \\
7.07\end{array}$ & 33.98 & .07 & 720 & .98 & 327 & 362 & 218 & 33 & 1,030 & 1.9 \\
\hline 15 & 109 & $\begin{array}{r}24 \\
1.97\end{array}$ & $\begin{array}{l}86 \\
3.74\end{array}$ & $\begin{array}{l}3.5 \\
.09\end{array}$ & 185 & 345 & 34.96 & .07 & 730 & .99 & 30 & 370 & 219 & 33 & 1,050 & 1.9 \\
\hline 6.0 & $\begin{array}{r}110 \\
5.49 \\
\end{array}$ & $\begin{array}{r}24 \\
1.97 \\
\end{array}$ & $\begin{array}{r}86 \\
3.74 \\
\end{array}$ & $\begin{array}{c}3.5 \\
.09\end{array}$ & $\begin{array}{r}187 \\
3.07\end{array}$ & $\begin{array}{r}345 \\
7.18\end{array}$ & $\begin{array}{r}34.90 \\
\quad .96\end{array}$ & .07 & 735 & 1.00 & 12 & 373 & 220 & 33 & $\mathbf{1}, 050$ & 1.9 \\
\hline 2,679 & $\begin{array}{l}44 \\
\text { 2. } 20\end{array}$ & $\begin{array}{c}8.3 \\
.68\end{array}$ & ${ }_{1.85}^{31}$ & $\begin{array}{l}2.1 \\
.05\end{array}$ & $\begin{array}{r}117 \\
\quad 1.92\end{array}$ & $\begin{array}{l}102 \\
\quad 2.12\end{array}$ & $\begin{array}{l}7.5 \\
.21\end{array}$ & .03 & 256 & .35 & 1,850 & 144 & 48 & 32 & $\begin{array}{c}392 \\
-\end{array}$ & 1. 1 \\
\hline
\end{tabular}

See footnotes at end of table. 
TABLE 14.-Relation between water discharge and chemical quality of water at seleoted stations in the San Juan division-Con.

\begin{tabular}{|c|c|c|c|c|c|c|c|c|c|c|c|c|c|c|c|c|}
\hline \multirow[b]{2}{*}{$\begin{array}{c}\text { Discharge } \\
\text { (cfs) }\end{array}$} & \multirow[b]{2}{*}{$\underset{\text { (Ca) }}{\text { Calcium }}$} & \multirow{2}{*}{$\begin{array}{c}\text { Mag- } \\
\text { nesium } \\
\text { (Mg) }\end{array}$} & \multirow[b]{2}{*}{$\underset{(\mathrm{Na})}{\text { Sodium }}$} & \multirow{2}{*}{$\begin{array}{l}\text { Potas- } \\
\text { summ } \\
(\mathbf{K})\end{array}$} & \multirow{2}{*}{$\begin{array}{c}\text { Bicar- } \\
\text { bonate } \\
\left(\mathrm{HCO}_{3}\right)\end{array}$} & \multirow[b]{2}{*}{$\begin{array}{l}\text { Sulfate } \\
\left(\mathrm{SO}_{4}\right)\end{array}$} & \multirow[b]{2}{*}{$\underset{(\mathrm{Cl})}{\text { Chloride }}$} & \multirow[b]{2}{*}{$\underset{\text { (B) }}{\text { Boron }}$} & \multicolumn{3}{|c|}{$\begin{array}{l}\text { Dissolved solids } \\
\text { (residue at } 180^{\circ} \mathrm{C} \text { ) }\end{array}$} & \multicolumn{2}{|c|}{$\begin{array}{l}\text { Hardness } \\
\text { as } \mathrm{CaCO}_{3}\end{array}$} & \multirow{2}{*}{$\begin{array}{c}\text { Per- } \\
\text { cent } \\
\text { sodium }\end{array}$} & \multirow{2}{*}{$\begin{array}{l}\text { Specific } \\
\text { conduct- } \\
\text { ance } \\
\text { (micro- } \\
\text { mhos } \\
\text { per com } \\
\text { at } 25^{\circ} \mathrm{C} \text { ) }\end{array}$} & \multirow{2}{*}{$\begin{array}{c}\text { Sodium- - } \\
\text { adsorp- } \\
\text { tion- } \\
\text { ratio }\end{array}$} \\
\hline & & & & & & & & & $\begin{array}{c}\text { Parts } \\
\text { per } \\
\text { million }\end{array}$ & $\begin{array}{c}\text { Tons } \\
\text { per } \\
\text { acre-ft }\end{array}$ & $\begin{array}{l}\text { Tons } \\
\text { per } \\
\text { day }\end{array}$ & $\begin{array}{c}\text { Calcium, } \\
\text { mag. } \\
\text { nesium }\end{array}$ & $\begin{array}{l}\text { Non- } \\
\text { carbon } \\
\text { ate }\end{array}$ & & & \\
\hline
\end{tabular}

\begin{tabular}{|c|c|c|c|c|c|c|c|c|c|c|c|c|c|c|c|c|}
\hline \multicolumn{17}{|c|}{ San Juan River near Bluff, Utah } \\
\hline 32,000 & & 8.4 & & 1.9 & 118 & 60 & 3.7 & 0.05 & 183 & 0.25 & 15,810 & 132 & 35 & 18 & 285 & 0.5 \\
\hline $27,000 \ldots$ & 39 & $\begin{array}{l}.69 \\
8.6\end{array}$ & $14^{.61}$ & 2.05 & 118 & 60 & 3. .70 & .05 & 190 & .26 & 13,850 & 133 & 36 & 18 & 295 & .5 \\
\hline $24,000 \ldots$ & 39.95 & $\begin{array}{l}.71 \\
8.6\end{array}$ & $14^{.61}$ & 2.05 & 118 & 60 & 3.7 & .05 & 194 & .26 & $12,570^{-}$ & 133 & 36 & 18 & 305 & .5 \\
\hline $19,100 \ldots$ & $\begin{array}{l}1.90 \\
40\end{array}$ & $\begin{array}{l}.71 \\
8.9\end{array}$ & $14{ }^{.01}$ & 2.1 & 118.94 & 64.25 & 3. .8 & .05 & 203 & .28 & 10,470 & 136 & 40 & 18 & 315 & .5 \\
\hline 14,400 & 41.00 & $\begin{array}{l}.78 \\
9.2 \\
76\end{array}$ & $15{ }_{65}^{.01}$ & 2.2 & 119 & 68 & 4. 0 & .05 & 217 & .30 & 8,440 & 140 & 43 & 18 & 340 & .5 \\
\hline $11,400 \ldots$ & $\begin{array}{r}2.00 \\
43\end{array}$ & $\begin{array}{l}.70 \\
9.4\end{array}$ & $16{ }^{.00}$ & 2.4 & 120 & 74.41 & 4.2 & .05 & 230 & .31 & 7,080 & 146 & 48 & 19 & 355 & .6 \\
\hline $4,400_{\ldots}$ & $\begin{array}{l}52 \\
2.59 \\
2.59\end{array}$ & $12{ }^{.08}$ & $22{ }_{96}^{.0}$ & 2.8 & 130 & 112 & $\begin{array}{l}6.10 \\
19\end{array}$ & .06 & 308 & 42 & 3,660 & 179 & 72 & 21 & 470 & .7 \\
\hline $2,690 \ldots$ & 64 & $14^{.00}$ & $33^{\circ 00}$ & 3. 1 & 145 & 157 & $\begin{array}{l}.10 \\
9.3 \\
0\end{array}$ & .06 & 385 & .52 & 2,800 & 217 & 98 & 25 & 590 & 1.0 \\
\hline $1,810 \ldots$ & & $\begin{array}{l}17.1 b \\
17\end{array}$ & $\begin{array}{l}1.44 \\
48\end{array}$ & 3.4 & $\begin{array}{c}2.38 \\
160\end{array}$ & $210^{3.2}$ & $133^{.26}$ & .06 & 500 & .68 & 2,440 & 260 & 128 & 28 & 750 & 1.3 \\
\hline $1,240^{2}$ & $\begin{array}{r}3.79 \\
91\end{array}$ & 23 & $\begin{array}{l}2.09 \\
70\end{array}$ & 3. 7 & $\begin{array}{r}2.62 \\
174\end{array}$ & $\begin{array}{l}4.37 \\
305\end{array}$ & $17^{.36}$ & .07 & 660 & .90 & 2,210 & 322 & 179 & 32 & 950 & 1.7 \\
\hline 930 & 105.04 & 29 & $\begin{array}{l}5.04 \\
85\end{array}$ & 3. 9 & $\begin{array}{r}2.85 \\
182\end{array}$ & $\begin{array}{c}6.34 \\
375 \\
7.8\end{array}$ & $22^{.40}$ & .08 & 780 & 1.06 & 1,960 & 381 & 232 & 32 & 1,100 & 1.9 \\
\hline 240. & $\begin{array}{c}125 \\
125 \\
6.24\end{array}$ & $\begin{array}{c}3.21 \\
40 \\
3.29\end{array}$ & $\begin{array}{r}122.83 \\
5.31\end{array}$ & $\begin{array}{l}5.12 \\
5.13\end{array}$ & $\begin{array}{c}3.25 \\
201 \\
3.30\end{array}$ & $\begin{array}{l}500 \\
10.40\end{array}$ & $\begin{array}{l}39.98 \\
1.10\end{array}$ & .12 & 1,050 & 1.43 & 680 & 476 & 312 & 35 & 1,450 & 2.4 \\
\hline 76 & 128 & $\begin{array}{r}42 \\
3.45\end{array}$ & $\begin{array}{r}130 \\
5,66\end{array}$ & 6. 4 & 201 & 540 & 46 & .12 & 1,080 & 1.47 & 222 & 492 & 327 & 36 & 1,480 & 2.6 \\
\hline 20 & $\begin{array}{r}130 \\
6.49 \\
\end{array}$ & $\begin{array}{r}43.40 \\
3.53 \\
\end{array}$ & $\begin{array}{r}135 \\
5.87 \\
\end{array}$ & $\begin{array}{l}8.2 \\
.21 \\
\end{array}$ & $\begin{array}{c}202 \\
3.91 \\
3.91\end{array}$ & $\begin{array}{c}550 \\
11.44\end{array}$ & $\begin{array}{r}49 \\
1.38 \\
\end{array}$ & .12 & 1,100 & 1.50 & 59 & 501 & 336 & 36 & $\mathbf{1}, 500$ & 2.6 \\
\hline 2,800 & $\begin{array}{l}58 \\
2.89\end{array}$ & ${ }_{1.15}^{14}$ & ${ }_{1.95}^{31}$ & $\begin{array}{l}2.8 \\
.07\end{array}$ & $\begin{array}{c}136 \\
2.23\end{array}$ & $\begin{array}{l}143 \\
\quad 2.97\end{array}$ & $\begin{array}{c}8.6 \\
.24\end{array}$ & .06 & 361 & .49 & 2,730 & 202 & 90 & 25 & 539 & .9 \\
\hline
\end{tabular}

Dirty Devil River near Hite, Utah

\begin{tabular}{|c|c|c|c|c|c|c|c|c|c|c|c|c|c|c|c|c|}
\hline 9,400 . & 200 & 34 & 89 & 7.3 & 126 & 580 & 94 & 0.15 & 1,500 & 2.04 & 38,070 & 638 & 535 & 23 & 1,950 & 1.5 \\
\hline 5,000 . & 206 & 35 & 90 & 7.3 & 135 & $\begin{array}{l}12.00 \\
590\end{array}$ & 94.00 & .15 & 1,500 & 2.04 & 20,250 & 658 & 548 & $\mathbf{2 3}$ & 1,950 & 1.5 \\
\hline 2,700 & 208 & $\begin{array}{l}2.88 \\
36\end{array}$ & 91 & $\begin{array}{l}.19 \\
7.4\end{array}$ & 142 & $\begin{array}{l}12.27 \\
610 \\
10.69\end{array}$ & 95 & .16 & 1,500 & 2.04 & 10,940 & 667 & 550 & 23 & 1,950 & 1.5 \\
\hline 1,100 & 220 & 38 & 97 & 7.4 & 155 & 650 & 96 & .17 & 1,530 & 2.08 & 4,540 & 705 & 578 & 23 & 1,970 & 1.6 \\
\hline 480 . & 239 & 40 & 108 & $\begin{array}{l}.19 \\
7.4\end{array}$ & 165 & 710 & 98 & .17 & 1,620 & 2.20 & 2,100 & 761 & 626 & 23 & 2,100 & 1.7 \\
\hline 310. & 250 & 42 & 113 & 7.6 & 170 & 740 & 100 & .18 & 1,700 & 2.31 & 1,420 & 796 & 657 & 23 & 200 & 1.7 \\
\hline 220 & 263.40 & 45 & 120 & 7.8 & 176 & 805.00 & 102 & .19 & 1,780 & 2.42 & 1,060 & 841 & 696 & $\mathbf{2 3}$ & 2,280 & 1.8 \\
\hline $166^{1}$ & $\begin{array}{r}274 \\
13.67\end{array}$ & 37. 86 & $\begin{array}{c}125 \\
5.44\end{array}$ & $\begin{array}{l}8.0 \\
.20\end{array}$ & $\begin{array}{c}180 \\
2.95\end{array}$ & $\begin{array}{c}835 \\
17.97\end{array}$ & $\begin{array}{c}105 \\
2.96\end{array}$ & .21 & 1,880 & 2.56 & 843 & 876 & 729 & $\mathbf{2 3}$ & 2,400 & 1.8 \\
\hline 130. & 287 & 50 & $\begin{array}{r}136 \\
5.92\end{array}$ & $\begin{array}{l}8.3 \\
21\end{array}$ & 184 & $\begin{array}{l}880 \\
18.30\end{array}$ & 112 & .22 & 1,990 & 2.71 & 699 & 922 & 770 & 24 & 500 & 1.9 \\
\hline 107 & 299 & 53 & $\begin{array}{r}147 \\
6.39\end{array}$ & $\begin{array}{l}8.6 \\
.22\end{array}$ & $\begin{array}{r}187 \\
3.07\end{array}$ & $\begin{array}{c}930 \\
19.34\end{array}$ & 117.30 & .23 & 090 & 2.84 & 604 & 964 & 810 & 25 & 2,560 & 2.1 \\
\hline 89. & 310 & $\begin{array}{l}56 \\
4.60\end{array}$ & $\begin{array}{c}160 \\
6.96\end{array}$ & 9.0 & $\begin{array}{c}190 \\
3.12\end{array}$ & $\begin{array}{l}990 \\
20.59\end{array}$ & 123 & .25 & 2,200 & 2.99 & 529 & 1,000 & 848 & 26 & 2,750 & 2.2 \\
\hline 712 & 325 & 60 & $\begin{array}{c}180 \\
7.8 .8\end{array}$ & $\begin{array}{l}9.6 \\
9.5\end{array}$ & 193 & 1,070 & 133 & .27 & 2,380 & 3.24 & 456 & 1,060 & 899 & 27 & 2,940 & 2.4 \\
\hline 52. & 348 & 68 & $\begin{array}{c}206 \\
8.96\end{array}$ & $11^{. N o}$ & 200 & 1,200 & 148 & .31 & 2,600 & 3. 54 & 365 & 1,150 & $\mathbf{9 8 4}$ & 28 & 3,200 & 2.6 \\
\hline 34. & $\begin{array}{c}380 \\
18.96\end{array}$ & 81 & 244.61 & $13^{\circ}$ & 207.39 & 1,330 & 180 & .36 & 2,860 & 3.89 & 263 & $1,280^{-}$ & 1,110 & 29 & $3, \mathbf{4 5 0}$ & 3.0 \\
\hline 16. & $\begin{array}{r}440 \\
21.96\end{array}$ & $\begin{array}{r}102 \\
8.38\end{array}$ & $\begin{array}{c}316 \\
13.75\end{array}$ & $18^{.00}$ & 220 & 1,640 & $\begin{array}{r}245 \\
6.91\end{array}$ & & 3,100 & 4.22 & 134 & $1,520^{-}$ & 1,340 & 31 & 3,700 & 3.5 \\
\hline 1.7 & $\begin{array}{c}540 \\
26.95\end{array}$ & $\begin{array}{l}140 \\
11.51\end{array}$ & $\begin{array}{l}400 \\
17.40\end{array}$ & 22.56 & $\begin{array}{r}265 \\
4.35\end{array}$ & $\begin{array}{r}1,740 \\
36.19\end{array}$ & $\begin{array}{c}580 \\
16.36\end{array}$ & .85 & 3,400 & 4.62 & 16 & 1,920 & $1,710^{\circ}$ & 31 & 4,000 & 4.0 \\
\hline & & & & & & & & & & & & & & & & \\
\hline & & $1-20-0-1$ & & & . & ...... & $\cdots$ & & & $\cdots-1$ - & 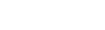 & & & & & $\cdots$ \\
\hline 102. & $\begin{array}{l}279 \\
18.92\end{array}$ & $\begin{array}{l}50 \\
4.11\end{array}$ & $\begin{array}{r}139 \\
6.05\end{array}$ & $\begin{array}{l}8.6 \\
.22\end{array}$ & $\begin{array}{r}177 \\
2.90\end{array}$ & $\begin{array}{l}874 \\
18.18\end{array}$ & $\stackrel{116}{3.27}$ & .22 & 1,960 & 2.67 & 541 & 902 & 756 & 25 & 2,470 & 2.0 \\
\hline
\end{tabular}

See footnotes at end of table. 
TABLE 14.-Relation between water discharge and chemical quality of water at selected stations in the San Juan division-Con.

\begin{tabular}{|c|c|c|c|c|c|c|c|c|c|c|c|c|c|c|c|c|}
\hline \multirow{2}{*}{$\begin{array}{c}\text { Discharge } \\
\text { (cfs) }\end{array}$} & \multirow{2}{*}{$\underset{(\mathrm{Ca})}{\text { Calclum }}$} & \multirow{2}{*}{$\underset{(\mathrm{Mg})}{\substack{\text { Mag- } \\
\text { nesium }}}$} & \multirow{2}{*}{$\begin{array}{l}\text { Sodium } \\
(\mathrm{Na})\end{array}$} & \multirow{2}{*}{$\begin{array}{l}\text { Potas- } \\
\text { sium } \\
(\mathbf{K})\end{array}$} & \multirow{2}{*}{$\begin{array}{c}\text { Bicar- } \\
\text { bonate } \\
\left(\mathrm{HCO}_{3}\right)\end{array}$} & \multirow[b]{2}{*}{$\begin{array}{l}\text { Sulfate } \\
\left(\mathrm{SO}_{4}\right)\end{array}$} & \multirow{2}{*}{$\begin{array}{l}\text { Chloride } \\
\text { (Cl) }\end{array}$} & \multirow{2}{*}{$\begin{array}{l}\text { Boron } \\
\text { (B) }\end{array}$} & \multicolumn{3}{|c|}{$\begin{array}{l}\text { Dissolved solids } \\
\text { (residue at } 180^{\circ} \mathrm{C} \text { ) }\end{array}$} & \multicolumn{2}{|c|}{$\begin{array}{l}\text { Hardness } \\
\text { as } \mathrm{CaCO}_{3}\end{array}$} & \multirow{2}{*}{$\begin{array}{c}\text { Per- } \\
\text { cent } \\
\text { sodium }\end{array}$} & \multirow{2}{*}{$\begin{array}{c}\text { Specific } \\
\text { conduct- } \\
\text { ance } \\
\text { (micro- } \\
\text { mhos } \\
\text { per cm } \\
\text { at } 25^{\circ} \mathrm{C} \text { ) }\end{array}$} & \multirow{2}{*}{$\begin{array}{l}\text { Sodium- } \\
\text { adsorp- } \\
\text { tion- } \\
\text { ratio }\end{array}$} \\
\hline & & & & & & & & & $\begin{array}{c}\text { Parts } \\
\text { per } \\
\text { million }\end{array}$ & $\begin{array}{c}\text { Tons } \\
\text { per } \\
\text { acre-ft }\end{array}$ & $\begin{array}{l}\text { Tons } \\
\text { per } \\
\text { day }\end{array}$ & $\begin{array}{c}\text { Calcium, } \\
\text { mag- } \\
\text { nesium }\end{array}$ & $\begin{array}{c}\text { Non- } \\
\text { carbon } \\
\text { ate }\end{array}$ & & & \\
\hline
\end{tabular}

Colorado River at Hite, Utah

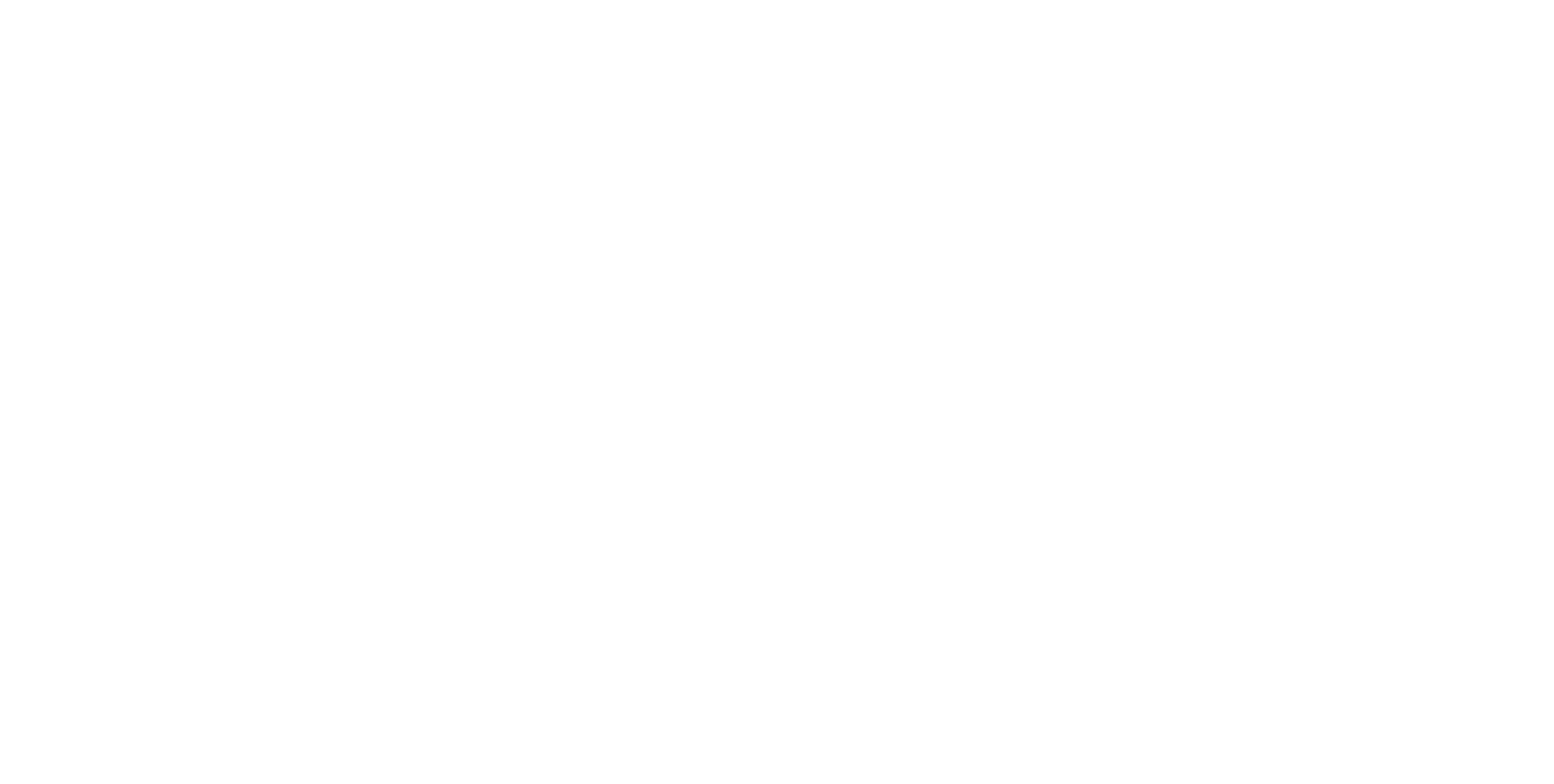

Escalante River at mouth, near Escalante, Utah

\begin{tabular}{|c|c|c|c|c|c|c|c|c|c|c|c|c|c|c|c|c|}
\hline 6,100 . & 39 & 11 & & 2.2 & 144 & & 12 & & 190 & 0.26 & 3,130 & 142 & 21 & 18 & 295 & 0.5 \\
\hline 3,750 & $\begin{array}{l}1.90 \\
40\end{array}$ & $11^{.90}$ & $15^{.60}$ & 2.2 & 145 & $43_{89}^{.89}$ & $12^{.34}$ & -- & 190 & .26 & 1,920 & 145 & 26 & 18 & 295 &.$\overline{5}$ \\
\hline 2,350 & $\begin{array}{c}41 \\
2.00 \\
2.05\end{array}$ & $11^{.90}$ & $15^{.00}$ & $\begin{array}{c}.06 \\
2.3 \\
06\end{array}$ & $\begin{array}{c}2.38 \\
148\end{array}$ & & $13^{.34}$ & & 190 & .26 & 1,210 & 148 & 26 & 18 & 295 & .5 \\
\hline 870 & 42 & 12 & 16 & 2.5 & 155 & $44^{\circ}$ & $14^{.07}$ & --1 & 198 & .27 & 465 & 154 & 28 & 18 & 310 &.$\overline{6}$ \\
\hline 315. & 45 & 15 & $18{ }^{.70}$ & $\begin{array}{l}.00 \\
2.9\end{array}$ & $\begin{array}{c}2.04 \\
165\end{array}$ & $52^{.98}$ & $18^{.39}$ & -- & 220 & 30 & 187 & 174 & 38 & 18 & 340 & 6 \\
\hline 205. & $\begin{array}{l}47 \\
2.35\end{array}$ & 16 & 19.83 & $\begin{array}{l}4.21 \\
.11\end{array}$ & $\begin{array}{c}169 \\
2.7 \gamma\end{array}$ & $\begin{array}{l}60 \\
1.250\end{array}$ & $19^{.01}$ & & 241 & .33 & 133 & 184 & 45 & 18 & 380 & .6 \\
\hline 150. & 50 & 17 & 21 & 4.4 & 171 & 70 & $21^{.04}$ & & 269 & .37 & 109 & 195 & 55 & 18 & 430 & .7 \\
\hline $120^{1}$ & 51 & 18 & $22^{.96}$ & $\begin{array}{l}4.6 \\
.12\end{array}$ & $\begin{array}{r}172.00 \\
8.82\end{array}$ & $\begin{array}{c}76 \\
1.58\end{array}$ & $23^{.09}$ & & 290 & .39 & 94 & 201 & 60 & 19 & 460 & .7 \\
\hline 99. & $\mathbf{5 2}$ & 19 & $24^{\circ}$ & 4. 7 & 173 & 83 & 24 & & 312 & .42 & 83 & 208 & 66 & 20 & 500 & .7 \\
\hline 85. & 53 & 19 & 25 & $\begin{array}{l}4.9 \\
.13\end{array}$ & 175 & $90^{1.73}$ & $26^{\circ}$ & & 328 & .45 & 75 & 210 & 66 & 20 & 520 & .8 \\
\hline 73. & 54 & 20 & 26 & 5. 0 & 176 & 96 & 28 & & 342 & .47 & 67 & 216 & 72 & 20 & 550 & .8 \\
\hline $62^{2}$ & 56 & 21 & 28 & 5.1 & 178 & 103 & 29 & & 359 & .49 & 60 & 226 & 80 & 21 & 580 & .8 \\
\hline 53. & 58 & 22 & 29 & $\begin{array}{l}5.3 \\
.14\end{array}$ & $\begin{array}{c}2.92 \\
179 \\
9.94\end{array}$ & $\begin{array}{c}110^{2.14} \\
2.29\end{array}$ & $31^{\circ}$ & & 372 & .51 & 53 & 235 & 88 & 21 & 600 & .8 \\
\hline 43. & 59 & 23.89 & 31 & & 180 & 118 & 33 & & 387 & .53 & 45 & 242 & 94 & 21 & 620 & .9 \\
\hline 34. & 60 & 24 & 34 & 5. $7^{14}$ & $\begin{array}{r}7.90 \\
182\end{array}$ & $\begin{array}{r}2.4^{0} \\
129\end{array}$ & $35^{.93}$ & & 400 & .54 & 37 & 248 & 99 & 22 & 640 & .9 \\
\hline $24^{3}$ & 61 & $\begin{array}{l}26 \\
2.14\end{array}$ & $\begin{array}{l}38 \\
1.65\end{array}$ & $\begin{array}{l}6.00 \\
.15\end{array}$ & $\begin{array}{c}186 \\
3.05\end{array}$ & $\begin{array}{r}140 \\
\text { 2. } 91\end{array}$ & $38_{1.07}^{.98}$ & & 410 & .56 & 27 & 259 & 106 & 24 & 650 & i. 0 \\
\hline 16. & 62.09 & 28 & 40 & 6. 4 & 190 & 152 & 39 & & 410 & .66 & 18 & 270 & 114 & 24 & 650 & 1. 1 \\
\hline 12. & 63 & $\begin{array}{c}29 \\
2.38\end{array}$ & $\begin{array}{r}41 \\
1.78\end{array}$ & $\begin{array}{l}6.7 \\
.17\end{array}$ & 191 & 157 & 40 & & 410 & .56 & 13 & 276 & 120 & 24 & 650 & 1.1 \\
\hline 9.2 & $\begin{array}{c}64 \\
3.19 \\
\end{array}$ & $\begin{array}{c}31 \\
2.55 \\
\end{array}$ & $\begin{array}{r}42 \\
1.83 \\
\end{array}$ & $\begin{array}{c}7.0 \\
.18\end{array}$ & $\begin{array}{c}193 \\
3.17\end{array}$ & $\begin{array}{c}160 \\
3.39\end{array}$ & 41.16 & & 410 & .56 & 10 & 287 & 128 & 24 & 650 & 1.1 \\
\hline $85.2 \ldots$ & $\begin{array}{l}51 \\
2.54\end{array}$ & $\stackrel{18}{1.48}$ & ${ }_{1.04}^{24}$ & $\begin{array}{l}4.4 \\
.11\end{array}$ & $\begin{array}{l}171 \\
\quad 2.80\end{array}$ & ${ }_{1.71}^{82}$ & ${ }^{24} .68$ & & 300 & .41 & 69 & 201 & 61 & 20 & 478 & .7 \\
\hline
\end{tabular}

See footnotes at end of table. 
TABLE 14.-Relation between water discharge and chemical quality of water at selected stations in the San Juan division-Con.

\begin{tabular}{|c|c|c|c|c|c|c|c|c|c|c|c|c|c|c|c|c|}
\hline \multirow[b]{2}{*}{$\underset{\text { (cfs) }}{\text { Discharge }}$} & \multirow[b]{2}{*}{$\underset{(\mathrm{Ca})}{\text { Calcium }}$} & \multirow{2}{*}{$\underset{\text { (Mgsium }}{\text { Mag- }}$} & \multirow[b]{2}{*}{$\begin{array}{l}\text { Sodium } \\
(\mathrm{Na})\end{array}$} & \multirow{2}{*}{$\begin{array}{l}\text { Potas- } \\
\text { sium } \\
\text { (K) }\end{array}$} & \multirow{2}{*}{$\begin{array}{c}\text { Bicar- } \\
\text { bonate } \\
\left(\mathrm{HCO}_{3}\right)\end{array}$} & \multirow[b]{2}{*}{$\begin{array}{l}\text { Sulfate } \\
\left(\mathrm{SO}_{4}\right)\end{array}$} & \multirow[b]{2}{*}{$\underset{\text { (Cl) }}{\text { Chloride }}$} & \multirow[b]{2}{*}{$\begin{array}{c}\text { Boron } \\
\text { (B) }\end{array}$} & \multicolumn{3}{|c|}{$\begin{array}{l}\text { Dissolved solids } \\
\text { (residue at } 180^{\circ} \mathbf{C} \text { ) }\end{array}$} & \multicolumn{2}{|c|}{$\begin{array}{l}\text { Hardness } \\
\text { as } \mathrm{CaCO}_{3}\end{array}$} & \multirow{2}{*}{$\begin{array}{c}\text { Per- } \\
\text { cent } \\
\text { sodium }\end{array}$} & \multirow{2}{*}{$\begin{array}{c}\text { Specific } \\
\text { conduct- } \\
\text { ance } \\
\text { (micro- } \\
\text { mhos } \\
\text { per cm } \\
\text { at } 25^{\circ} \mathrm{C} \text { ) }\end{array}$} & \multirow{2}{*}{$\begin{array}{l}\text { Sodium } \\
\text { adsorp- } \\
\text { tion- } \\
\text { ratio }\end{array}$} \\
\hline & & & & & & & & & $\begin{array}{c}\text { Parts } \\
\text { per } \\
\text { million }\end{array}$ & $\begin{array}{c}\text { Tons } \\
\text { per } \\
\text { acre-ft }\end{array}$ & $\begin{array}{l}\text { Tons } \\
\text { per } \\
\text { day }\end{array}$ & $\begin{array}{c}\text { Calcium, } \\
\text { magg- } \\
\text { nesium }\end{array}$ & $\begin{array}{l}\text { Non- } \\
\text { carbon } \\
\text { ate }\end{array}$ & & & \\
\hline
\end{tabular}

Colorado River at Lees Ferry, Ariz.

\begin{tabular}{|c|c|c|c|c|c|c|c|c|c|c|c|c|c|c|c|c|}
\hline 178,200 & ${ }^{46}$ & ${ }_{13}^{13}$ or & ${ }^{22}$ & 3.5 & 149 & 80 & 10 & 0.09 & 250 & 0.34 & 120,300 & 168 & 46 & 22 & 405 & 0.7 \\
\hline 137,300 & 46 & 13 & $22^{\circ 00}$ & 3.5 & 149 & $80^{1.00}$ & $11^{\circ}$ & .09 & 253 & .34 & 93,790 & 168 & 46 & 22 & 410 & .7 \\
\hline 122,200 & $\begin{array}{l}2.30 \\
46\end{array}$ & 13 & 22.96 & $\begin{array}{l}.09 \\
3.5\end{array}$ & 149.44 & $\begin{array}{l}1.66 \\
81\end{array}$ & $11^{.31}$ & .09 & 256 & .35 & 84,460 & 171 & 49 & 22 & 415 & .7 \\
\hline 101,500 . & 47 & 13 & 23 & 3. 5 & $149^{44}$ & 82 & $12^{.01}$ & .09 & 262 & .36 & 71,800 & 171 & 49 & 22 & 425 & .8 \\
\hline 82,090 & 48 & 1.07 & 24.04 & $\begin{array}{c}3.5 \\
.09\end{array}$ & 150 & 83 & 13 & .09 & 270 & .37 & 59,840 & 174 & 50 & 23 & $440^{-1}$ & .8 \\
\hline 69,120 & $\begin{array}{c}49 \\
2.45\end{array}$ & 13 & $\begin{array}{c}26 \\
1.18\end{array}$ & $\begin{array}{c}3.5 \\
.09\end{array}$ & $\begin{array}{r}152 \\
2.49\end{array}$ & 87 & 14 & .09 & 280 & .38 & 52,250 & 176 & 52 & 24 & 460 & .9 \\
\hline 55,060 & $\begin{array}{l}50 \\
2.50\end{array}$ & 14.15 & 29 & $\begin{array}{c}3.5 \\
.09\end{array}$ & $\begin{array}{c}154 \\
2.53\end{array}$ & 95 & $16^{.00}$ & .09 & 295 & .40 & 43,860 & 182 & 56 & 25 & 480 & .9 \\
\hline 41,660 & $\begin{array}{l}53 \\
2.64\end{array}$ & $\begin{array}{l}15 \\
1.28\end{array}$ & $\begin{array}{l}35 \\
1.52\end{array}$ & $\begin{array}{c}3.5 \\
.09\end{array}$ & $\begin{array}{l}158 \\
2.59\end{array}$ & $\begin{array}{l}115 \\
\text { 2. } 39\end{array}$ & 20.56 & .09 & 322 & .44 & 36,220 & 194 & 64 & 28 & 520 & $1 . \overline{1}$ \\
\hline 25,690 & $\begin{array}{r}62 \\
3.09\end{array}$ & $\begin{array}{c}19 \\
1.56\end{array}$ & 51 & $\begin{array}{l}3.7 \\
.09\end{array}$ & $\begin{array}{r}170 \\
2.79\end{array}$ & $\begin{array}{c}160 \\
3.38\end{array}$ & 31.87 & .09 & 420 & .57 & 29,130 & 232 & 93 & 32 & 660 & 1.5 \\
\hline 16,120 & $\begin{array}{c}76 \\
3.79\end{array}$ & $\stackrel{25}{2.06}$ & $\begin{array}{c}74 \\
\text { S.22 }\end{array}$ & $\begin{array}{l}4.0 \\
.10\end{array}$ & $\begin{array}{c}184 \\
3.02\end{array}$ & 235 & $48^{\circ}$ & .11 & 580 & .79 & 25,240 & 292 & 142 & 35 & 890 & 1.9 \\
\hline 11,280 & 90 & ${ }_{21}^{31}$ & 100 & $\begin{array}{c}4.8 \\
.12\end{array}$ & 199 & 310 & 66 & .14 & 730 & .99 & 22,230 & 352 & 189 & 38 & 1,120 & 2.3 \\
\hline $8,680^{2}$ & $\begin{array}{c}103 \\
5.14\end{array}$ & $\begin{array}{l}37 \\
8.04\end{array}$ & $\begin{array}{c}122 \\
5.31\end{array}$ & $\begin{array}{c}5.3 \\
.14\end{array}$ & $\begin{array}{l}208 \\
\text { S. } 41\end{array}$ & $\begin{array}{l}372 \\
7.74\end{array}$ & $\begin{array}{l}83 \\
2.34\end{array}$ & .16 & 860 & 1.17 & 20,150 & 409 & 238 & 39 & 1,300 & 2.6 \\
\hline 7,430 . & $\begin{array}{r}112 \\
5.59\end{array}$ & $\begin{array}{c}40 \\
3.29\end{array}$ & $\begin{array}{r}135 \\
5.87\end{array}$ & $\begin{array}{c}5.8 \\
.15\end{array}$ & $\begin{array}{r}213 \\
3.49\end{array}$ & $\begin{array}{c}410 \\
8.58\end{array}$ & $\begin{array}{c}95 \\
2.68\end{array}$ & .18 & 935 & 1.27 & 18,760 & 444 & 270 & 39 & 1,400 & 2.8 \\
\hline 6,490 . & $\begin{array}{l}118 \\
5.89\end{array}$ & $\begin{array}{l}44 \\
\text { 3. } 62\end{array}$ & $\begin{array}{r}145 \\
6.31\end{array}$ & $\begin{array}{c}6.2 \\
.16\end{array}$ & $\begin{array}{r}218 \\
3.58\end{array}$ & $\begin{array}{l}445 \\
\quad 9.26\end{array}$ & $\begin{array}{l}105 \\
2.96\end{array}$ & .19 & 990 & 1.35 & 17,350 & 476 & 296 & 39 & 1,470 & 2.9 \\
\hline $5,650 \ldots$ & $\begin{array}{l}125 \\
6.24\end{array}$ & $\begin{array}{l}48 \\
\text { S. } 95\end{array}$ & $\begin{array}{l}150 \\
6.52\end{array}$ & $\begin{array}{c}6.6 \\
.17\end{array}$ & $\begin{array}{l}221 \\
\text { 8. } 62\end{array}$ & $\begin{array}{l}480 \\
\quad 9.98\end{array}$ & ${ }_{3.24}^{115}$ & .20 & 1,040 & 1.41 & 15,870 & 510 & 328 & 39 & 1,550 & 2.9 \\
\hline 4,580 & $\begin{array}{c}133 \\
6.64\end{array}$ & $\begin{array}{c}53 \\
4.36\end{array}$ & $\begin{array}{r}157 \\
6.88\end{array}$ & $\begin{array}{c}7.2 \\
.18\end{array}$ & $\begin{array}{l}226 \\
\text { S. } \gamma_{1}\end{array}$ & $\begin{array}{l}510 \\
10.61\end{array}$ & $\begin{array}{r}130 \\
8.67\end{array}$ & .21 & 1,120 & 1.52 & 13,850 & $550^{\circ}$ & 364 & 38 & 1,620 & 2.9 \\
\hline 3,260 & $\begin{array}{r}142 \\
\quad 7.09\end{array}$ & $\begin{array}{l}60 \\
4.98\end{array}$ & $\begin{array}{r}165 \\
7.18\end{array}$ & $\begin{array}{l}7.8 \\
.80\end{array}$ & $\begin{array}{l}230 \\
\text { S. } 77\end{array}$ & $\begin{array}{l}550 \\
11.44\end{array}$ & $\begin{array}{r}145 \\
4.09\end{array}$ & .23 & 1,170 & 1.59 & 10,300 & 601 & 412 & 37 & 1,700 & $2 . \overline{9}$ \\
\hline $2,160 \ldots$ & $\begin{array}{l}146 \\
\quad 7.29\end{array}$ & $\begin{array}{l}66 \\
5.43\end{array}$ & $\begin{array}{c}173 \\
7.58\end{array}$ & $\begin{array}{c}8.3 \\
.21\end{array}$ & $\begin{array}{l}230 \\
\text { s. } 77\end{array}$ & $\begin{array}{l}590 \\
12.27\end{array}$ & ${ }_{4.26}^{151}$ & & 1,200 & 1.63 & 7,000 & 636 & 448 & 37 & 1,720 & 3.0 \\
\hline 1,490 & $\begin{array}{r}147 \\
\quad 7.94 \\
\end{array}$ & $\begin{array}{c}68 \\
5.59\end{array}$ & $\begin{array}{c}175 \\
7.61\end{array}$ & $\begin{array}{c}8.6 \\
.22\end{array}$ & $\begin{array}{r}230 \\
3.77\end{array}$ & $\begin{array}{l}600 \\
12.48\end{array}$ & $\begin{array}{r}156 \\
4.40\end{array}$ & .23 & 1,210 & 1.65 & 4,870 & 646 & 458 & 37 & 1,720 & 3.0 \\
\hline 17,550 & $\begin{array}{l}70 \\
\text { \$. } 49\end{array}$ & $\stackrel{23}{1.89}$ & $\stackrel{62}{2.70}$ & $\begin{array}{c}4.2 \\
.11\end{array}$ & $\begin{array}{l}174 \\
\quad 2.85\end{array}$ & $\begin{array}{l}198 \\
4.12\end{array}$ & $\stackrel{41}{1.16}$ & .11 & 499 & .68 & 23,660 & 269 & 126 & 33 & 772 & 1.6 \\
\hline
\end{tabular}

Paria River at Lees Ferry, Ariz.

\begin{tabular}{|c|c|c|c|c|c|c|c|c|c|c|c|c|c|c|c|}
\hline 7,500 & ${ }_{6.54}^{131}$ & $\stackrel{59}{4.85}$ & ${ }_{7.40}^{170}$ & 219 & ${ }_{14.85}^{690}$ & ${ }^{24} .68$ & & 1,200 & 1.63 & 24,300 & 570 & 390 & 39 & 1,600 & 3.1 \\
\hline 3,400 & $\begin{array}{r}131 \\
6.54\end{array}$ & 59 & $170^{40}$ & 219 & 685 & $24_{68}^{.00}$ & & 1,190 & 1,62 & 10,920 & 570 & 390 & 39 & 1,600 & 3.1 \\
\hline 1,800 & $\begin{array}{l}130 \\
6.49\end{array}$ & 59 & $\begin{array}{l}165 \\
7.18\end{array}$ & $\begin{array}{c}217 \\
\$ .56\end{array}$ & 675 & $24^{\circ} .68$ & & 1,170 & 1.59 & 5,690 & 567 & 389 & 39 & 1,600 & 3.0 \\
\hline 570. & $\begin{array}{r}129 \\
6.44\end{array}$ & $\begin{array}{r}59 \\
4.85\end{array}$ & $\begin{array}{c}155 \\
6.74\end{array}$ & $\begin{array}{c}216 \\
3.54\end{array}$ & $\begin{array}{c}660^{4} \\
13.78\end{array}$ & $24^{.08}$ & & 1,150 & 1.56 & 1,770 & 564 & 388 & 37 & 1,550 & 2.8 \\
\hline 190. & $\begin{array}{r}128 \\
6.39\end{array}$ & 59 & $\begin{array}{r}145 \\
6.31\end{array}$ & $\begin{array}{r}214.04 \\
3.51\end{array}$ & $\begin{array}{c}650 \\
18.52\end{array}$ & 23.00 & $\cdots$ & 1,140 & 1. 55 & 585 & 562 & 386 & 36 & 1,550 & 2.7 \\
\hline 97. & $\begin{array}{r}126 \\
6.29\end{array}$ & $\begin{array}{l}59 \\
4.85\end{array}$ & $\begin{array}{r}135 \\
5.87\end{array}$ & $\begin{array}{c}210 \\
3.44\end{array}$ & $\begin{array}{c}630 \\
13.10\end{array}$ & & & 1,130 & 1. 54 & 296 & 557 & 385 & 35 & 1,530 & 2.5 \\
\hline 6c. & $\begin{array}{c}124 \\
6,19\end{array}$ & 59 & $\begin{array}{c}130 \\
5.66\end{array}$ & $\begin{array}{r}206 \\
3.38\end{array}$ & $\begin{array}{c}615 \\
12.79\end{array}$ & 23.65 & & 1,110 & 1.51 & 180 & 552 & 383 & 34 & 1,500 & 2.4 \\
\hline 381. & & $\begin{array}{c}58 \\
4.77\end{array}$ & $\begin{array}{c}125 \\
5.44\end{array}$ & $\begin{array}{c}198 \\
3.25\end{array}$ & $\begin{array}{c}600 \\
12.48\end{array}$ & 23.65 & $\cdots$ & 1,100 & 1.50 & 113 & 543 & 380 & $\mathbf{3 3}$ & $1,5 c 0$ & 2.3 \\
\hline 27 & $\begin{array}{c}120 \\
5.99\end{array}$ & $\begin{array}{c}58 \\
4.77\end{array}$ & $\begin{array}{r}120 \\
6.22\end{array}$ & $\begin{array}{r}195 \\
3.20\end{array}$ & $\begin{array}{c}590 \\
12.27\end{array}$ & ${ }^{23} .65$ & $\ldots$ & 1,080 & 1.47 & 79 & 538 & 378 & $\mathbf{3 3}$ & 1,490 & 2.3 \\
\hline 22. & $\begin{array}{c}118 \\
5.89\end{array}$ & 5877 & $\begin{array}{r}117 \\
6.09\end{array}$ & 191 & $\begin{array}{c}580 \\
18.06\end{array}$ & ${ }^{23} .65$ & & 1,060 & 1.44 & 63 & 533 & 376 & 32 & 1,450 & 2.2 \\
\hline 18. & $\begin{array}{r}116 \\
5.79\end{array}$ & $\begin{array}{c}58 \\
4.77\end{array}$ & 114.96 & $\begin{array}{r}189 \\
3.10\end{array}$ & $\begin{array}{c}570 \\
11.86\end{array}$ & & & 1,030 & 1.40 & 50 & 528 & 373 & 32 & 1,410 & 2.2 \\
\hline $14^{2}$ & $\begin{array}{r}112 \\
5.59\end{array}$ & $\begin{array}{r}57 \\
4.69\end{array}$ & 109 & $\begin{array}{l}181 \\
\text { Q. } .97\end{array}$ & $\begin{array}{l}550 \\
11.44\end{array}$ & 22.62 & & 1,000 & $1 . \mathbf{3 6}$ & 38 & 514 & 366 & 32 & 1,390 & 2.1 \\
\hline 11. & $\begin{array}{c}107 \\
5.34\end{array}$ & 56 & $\begin{array}{r}105 \\
4.57\end{array}$ & $\begin{array}{r}175.87 \\
2.87\end{array}$ & $\begin{array}{c}530.44 \\
11.02\end{array}$ & $22^{.0 z}$ & & 940 & 1.28 & 28 & 497 & 354 & 31 & 1,310 & 2.0 \\
\hline 6.8. & $\begin{array}{l}90 \\
4.49\end{array}$ & $\begin{array}{l}43 \\
3.58\end{array}$ & $\begin{array}{c}76 \\
\text { S. } 51\end{array}$ & $\begin{array}{c}162 \\
2.66\end{array}$ & $\begin{array}{c}395 \\
8.22\end{array}$ & & & 770 & 1.05 & 14 & 401 & 268 & 29 & 1,110 & 1.7 \\
\hline 4.9. & $\begin{array}{c}72 \\
S .69\end{array}$ & $\begin{array}{l}32 \\
2.68\end{array}$ & $\begin{array}{l}53 \\
2.31\end{array}$ & 154 & $\begin{array}{c}265 \\
5.51\end{array}$ & $15^{.04}$ & & 570 & .78 & 7.5 & 311 & 184 & 27 & 860 & $1 . \overline{3}$ \\
\hline $3.8^{\circ}$ & $\begin{array}{l}56 \\
2.79\end{array}$ & $\begin{array}{l}26 \\
2.14\end{array}$ & $\begin{array}{l}39.01 \\
1.70\end{array}$ & $\begin{array}{r}147 \\
2.41\end{array}$ & $\begin{array}{c}183.81 \\
\$ .81\end{array}$ & $13{ }^{.45}$ & $\cdots$ & 430 & .58 & 4.4 & 246 & 126 & 26 & 680 & 1.1 \\
\hline 2.9 & $\begin{array}{l}48 \\
2.40\end{array}$ & $\begin{array}{l}23 \\
1.89\end{array}$ & $\begin{array}{l}34 \\
1.48\end{array}$ & $\begin{array}{r}140 \\
2.30\end{array}$ & $\stackrel{148}{\$ .08}$ & 12.84 & & 330 & .45 & 2.6 & 214 & 100 & 26 & 540 & 1.0 \\
\hline 2.3 . & $\begin{array}{c}46 \\
2.30\end{array}$ & 22 & 30 & $\begin{array}{c}135 \\
2.21\end{array}$ & $\begin{array}{l}140 \\
2.91\end{array}$ & 11.31 & & 300 & .41 & 1.9 & 206 & 95 & 24 & 500 & .9 \\
\hline 1.9. & $\begin{array}{c}45 \\
2.25 \\
\end{array}$ & $\begin{array}{r}22 \\
1.81 \\
\end{array}$ & $\begin{array}{r}30 \\
1.30 \\
\end{array}$ & $\begin{array}{r}133 \\
2.18 \\
\end{array}$ & $\begin{array}{r}140 \\
2.91 \\
\end{array}$ & 11.81 & & 295 & .40 & 1.5 & 203 & 94 & 24 & 495 & $\begin{array}{r}.9 \\
- \\
\end{array}$ \\
\hline 31.9 & 121 & $\begin{array}{c}57 \\
4.69\end{array}$ & $\begin{array}{c}134 \\
6.83\end{array}$ & $\stackrel{203}{3.39}$ & $\begin{array}{l}608 \\
12.65\end{array}$ & ${ }^{23} .65$ & & 1,090 & 1.48 & 94 & 536 & 370 & 36 & 1,480 & 2.5 \\
\hline
\end{tabular}


TABLE 15.-Water and dissolved solids contributed by ground water to selected streams in the San Juan River basin, Colo. [Data are for the water years 1914-57 adjusted to 1957 conditions; weighted-average concentration of dissolved solids from table 10]

\begin{tabular}{|c|c|c|c|c|c|}
\hline \multirow{3}{*}{$\begin{array}{c}\text { Station } \\
\text { No. }\end{array}$} & \multirow{3}{*}{ Station name } & \multirow{3}{*}{$\begin{array}{c}\text { Weighted- } \\
\text { average } \\
\text { concentration } \\
\text { of dissolved } \\
\text { solids } \\
\text { (ppm) }\end{array}$} & \multicolumn{3}{|c|}{ Ground water } \\
\hline & & & \multirow[b]{2}{*}{$\begin{array}{l}\text { Discharge } \\
\text { (acre-ft } \\
\text { per yr) }\end{array}$} & \multicolumn{2}{|c|}{ Dissolved solids } \\
\hline & & & & Tons per yr & $\begin{array}{l}\text { Weighted- } \\
\text { average } \\
\text { concentration } \\
\text { (ppm) }\end{array}$ \\
\hline $\begin{array}{l}3400 \\
3425 \\
3460 \\
3495 \\
3505 \\
3575 \\
3610 \\
3615 \\
3655\end{array}$ & $\begin{array}{l}\text { San Juan River near Pagosa Springs } \\
\text { San Juan River at Pagosa Springs } \\
\text { Navajo River at Edith. } \\
\text { Piedra River near Piedra. } \\
\text { San Juan River at Rosa } \\
\text { Animas River at Howardsville. } \\
\text { Hermosa Creek near Hermosa } \\
\text { Animas River at Durango. } \\
\text { La Plata River at Hesperus. }\end{array}$ & $\begin{array}{r}77 \\
73 \\
113 \\
126 \\
117 \\
111 \\
219 \\
183 \\
84\end{array}$ & $\begin{array}{r}15,400 \\
48,800 \\
29,400 \\
48,000 \\
166,600 \\
17,200 \\
20,400 \\
171,000 \\
6,100\end{array}$ & $\begin{array}{r}2,090 \\
9,130 \\
7,300 \\
16,600 \\
50,000 \\
4,050 \\
11,400 \\
69,800 \\
950\end{array}$ & $\begin{array}{l}100 \\
138 \\
183 \\
254 \\
221 \\
173 \\
411 \\
300 \\
115\end{array}$ \\
\hline
\end{tabular}

TABLE 16.-Water and dissolved-solids budget [Data are for the water years 1914-57 adjusted to 1957 conditions]

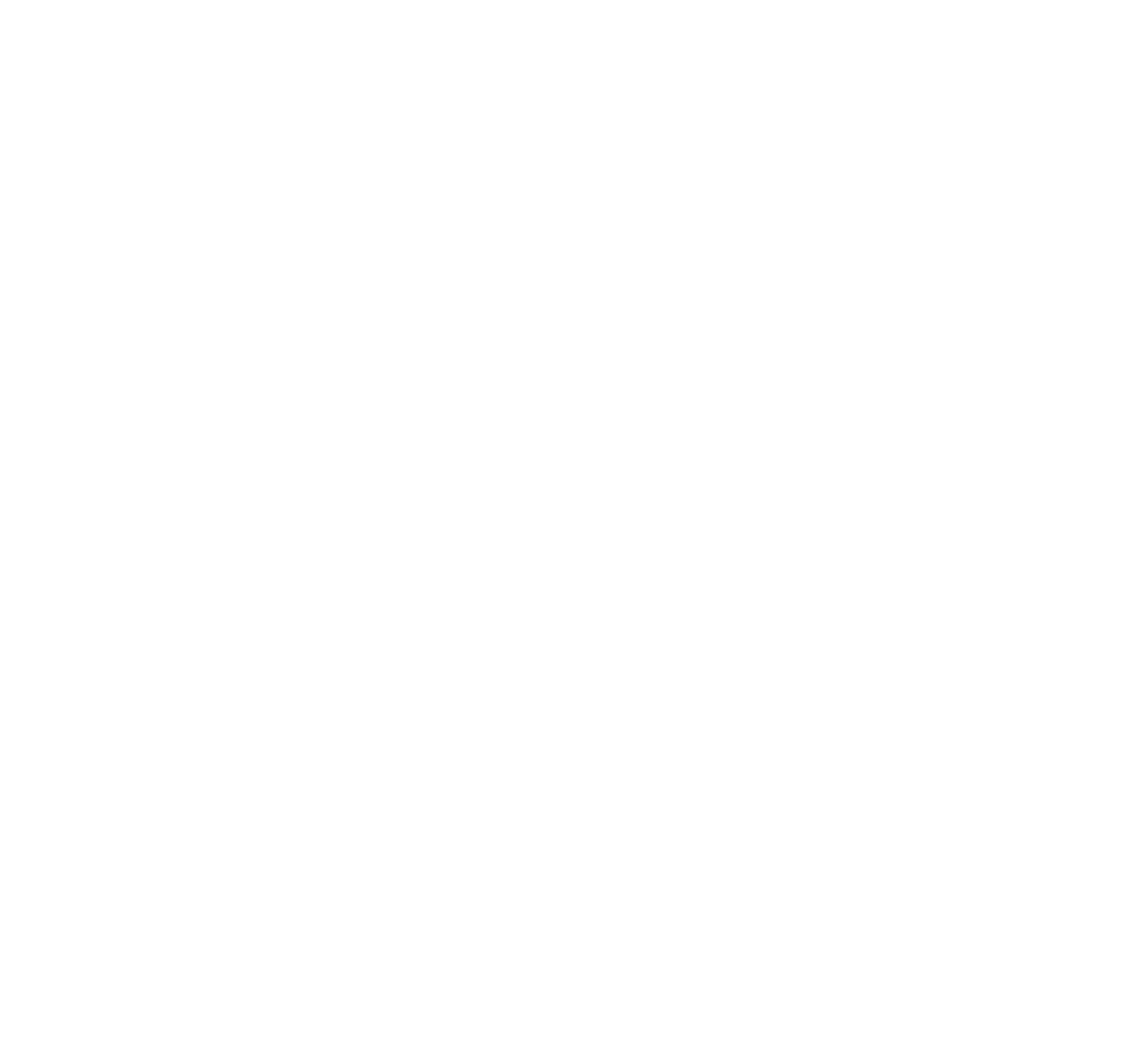


TABLE 17.-Average annual dissolved-solids discharge and probable amounts of dissolved solids from natural sources and from the activities of man in the subbasins in the San Juan division

[Data are for the water years 1914-57 adjusted to 1957 conditions]

\begin{tabular}{|c|c|c|c|c|c|c|c|}
\hline \multirow{3}{*}{ Gaging station or subbasin } & \multirow{3}{*}{$\begin{array}{c}\text { Drainage } \\
\text { area } \\
\text { (sq mi) }\end{array}$} & \multirow{3}{*}{$\begin{array}{c}\text { Acres } \\
\text { irrigated }\end{array}$} & \multicolumn{5}{|c|}{ Dissolved-solids discharge } \\
\hline & & & \multirow{2}{*}{ Total (tons) } & \multicolumn{2}{|c|}{ Natural } & \multicolumn{2}{|c|}{ Man-caused } \\
\hline & & & & Tons & $\begin{array}{l}\text { Tons per } \\
\text { sq mi }\end{array}$ & Tons & $\begin{array}{l}\text { Tons per } \\
\text { acre irrigated }\end{array}$ \\
\hline \multicolumn{8}{|c|}{ San Juan River basin } \\
\hline $\begin{array}{l}\text { San Juan River near Arboles, Colo. } \\
\text { San Juan River near Blanco, N. Mex } \\
\text { San Juan River near Bluff, Utah. } \\
\text { San Juan River basin }\end{array}$ & $\begin{array}{r}1,340 \\
3,560 \\
23,000 \\
24,900\end{array}$ & $\begin{array}{r}13,300 \\
61,600 \\
206,400 \\
206,400\end{array}$ & $\begin{array}{r}77,000 \\
187,000 \\
997,000 \\
1,073,000\end{array}$ & $\begin{array}{r}64,100 \\
147,000 \\
708,900 \\
784,900\end{array}$ & $\begin{array}{l}40 \\
41 \\
31 \\
32\end{array}$ & $\begin{array}{r}12,900 \\
40,000 \\
288,100 \\
288,100\end{array}$ & $\begin{array}{l}\text { 1. } 0 \\
.6 \\
\text { 1. } 4 \\
\text { 1. } 4\end{array}$ \\
\hline \multicolumn{8}{|c|}{ Colorado River Basin below the Green and San Juan Rivers and above "Lee Ferry," Ariz. } \\
\hline $\begin{array}{l}\text { Dirty Devil River near Hite, Utah. } \\
\text { Escalante River at mouth, near Es- } \\
\text { calante, Utah, } \\
\text { Paria River at Lees Ferry, Ariz } \\
\text { Colorado River at Lees Ferry, Ariz } \\
\text { Colorado River Basin below the Green } \\
\text { and San Juan Rivers and above "Lee } \\
\text { Ferry," Ariz. }\end{array}$ & $\begin{array}{r}4,360 \\
2,010 \\
1,570 \\
107,900\end{array}$ & $\begin{array}{r}23,300 \\
7,000 \\
3,000 \\
1,410,000\end{array}$ & $\begin{array}{r}197,600 \\
25,200 \\
34,300 \\
8,642,000\end{array}$ & $\begin{array}{r}144,100 \\
17,100 \\
32,200 \\
5,164,500\end{array}$ & $\begin{array}{l}33 \\
\\
8.5 \\
21 \\
48\end{array}$ & $\begin{array}{r}53,500 \\
8,100 \\
12,100 \\
3,477,500\end{array}$ & $\begin{array}{r}2.3 \\
1.2 \\
\text { 2. } 5\end{array}$ \\
\hline
\end{tabular}

1 Includes 700 tons imported in the Tropic and East Fork canal.

TABLE 18.-Summary of the suspended-sediment discharge at daily stations in the subbasins in the San Juan division

\begin{tabular}{|c|c|c|c|c|c|c|c|c|}
\hline \multirow{3}{*}{ Water year } & \multicolumn{2}{|c|}{ Water discharge } & \multicolumn{6}{|c|}{ Suspended sediment } \\
\hline & \multirow[b]{2}{*}{ Cfs-days } & \multirow[b]{2}{*}{ Acre-ft } & \multirow[b]{2}{*}{ Load 1 (tons) } & \multicolumn{3}{|c|}{ Daily load (tons) } & \multicolumn{2}{|c|}{ Concentration (ppm) } \\
\hline & & & & A verage & Maximum & Minimum & $\begin{array}{l}\text { Weighted } \\
\text { mean }\end{array}$ & $\underset{\text { daily }}{\text { Maximum }}$ \\
\hline
\end{tabular}

SAN JUAN RIVER BASIN

3505. San Juan River at Rosa, N. Mex.

\begin{tabular}{|c|c|c|c|c|c|c|c|c|}
\hline $\begin{array}{l}\text { Mar. } 25 \text { to Sept. 30, } \\
1949 \\
1950\end{array}$ & $\begin{array}{l}495,411 \\
240,637\end{array}$ & $\begin{array}{l}982,600 \\
477,300\end{array}$ & $\begin{array}{r}1,412,000 \\
475,800\end{array}$ & $\begin{array}{l}7,430 \\
1,300\end{array}$ & $\begin{array}{l}77,400 \\
33,800\end{array}$ & $\begin{array}{l}0 \\
3\end{array}$ & $\begin{array}{r}1,060 \\
732\end{array}$ & $\begin{array}{l}12,800 \\
14,700\end{array}$ \\
\hline $\begin{array}{l}\text { Dec. 1, 1954, to Sept. } \\
30,1955 \\
1956\end{array}$ & $\begin{array}{l}251,173 \\
281,295 \\
756,673\end{array}$ & $\begin{array}{r}498,200 \\
558,000 \\
1,501,000\end{array}$ & $\begin{array}{l}1,641,000 \\
1,276,000 \\
5,352,000\end{array}$ & $\begin{array}{r}5,400 \\
3,490 \\
14,660\end{array}$ & $\begin{array}{r}152,000 \\
367,600 \\
522,000\end{array}$ & $\begin{array}{r}210 \\
10 \\
9\end{array}$ & $\begin{array}{l}2,420 \\
1,680 \\
2,620\end{array}$ & $\begin{array}{l}32,800 \\
34,200 \\
18,000\end{array}$ \\
\hline \multicolumn{9}{|c|}{ 3565. San Juan River near Blanco, N. Mex. } \\
\hline $\begin{array}{l}\text { Mar. } 15 \text { to Sept. } 30, \\
1949 \\
19501\end{array}$ & $\begin{array}{l}641,117 \\
269,758 \\
167,079 \\
751,291 \\
257,083 \\
259,268\end{array}$ & $\begin{array}{r}1,271,740 \\
535,100 \\
331,400 \\
1,490,000 \\
509,900 \\
514,200\end{array}$ & $\begin{array}{r}3,505,000 \\
397,800 \\
455,300 \\
3,530,000 \\
589,000 \\
2,034,000\end{array}$ & $\begin{array}{r}17,520 \\
1,090 \\
1,250 \\
9,640 \\
1,610 \\
5,570\end{array}$ & $\begin{array}{r}141,000 \\
24,100 \\
52,900 \\
342,000 \\
348,400 \\
3418,000\end{array}$ & $\begin{array}{r}0 \\
10 \\
1 \\
2 \\
4 \\
5\end{array}$ & $\begin{array}{r}2,020 \\
546 \\
1,010 \\
1,740 \\
849 \\
2,910\end{array}$ & $\begin{array}{r}17,800 \\
8,950 \\
11,300 \\
20,000 \\
13,700 \\
51,300\end{array}$ \\
\hline
\end{tabular}

See footnotes at end of table. 
TABLE 18.-Summary of the suspended-sediment discharge at daily stations in the subbasins in the San Juan division-Con.

\begin{tabular}{|c|c|c|c|c|c|c|c|c|}
\hline \multirow{2}{*}{ Water year } & \multicolumn{2}{|c|}{ Water discharge } & \multicolumn{6}{|c|}{ Suspended sediment } \\
\hline & Cfs-days & Acre-ft & Load ${ }^{1}$ (tons) & Average & Maximum & Minimum & $\begin{array}{l}\text { Weighted } \\
\text { mean }\end{array}$ & $\underset{\text { daily }}{\text { Maximum }}$ \\
\hline
\end{tabular}

COLORADO RIVER BASIN BELOW THE GREEN AND SAN JUAN RIVERS AND ABOVE "LEE FERRY," ARIZ.

3335. Dirty Devil River near Hite, Utah

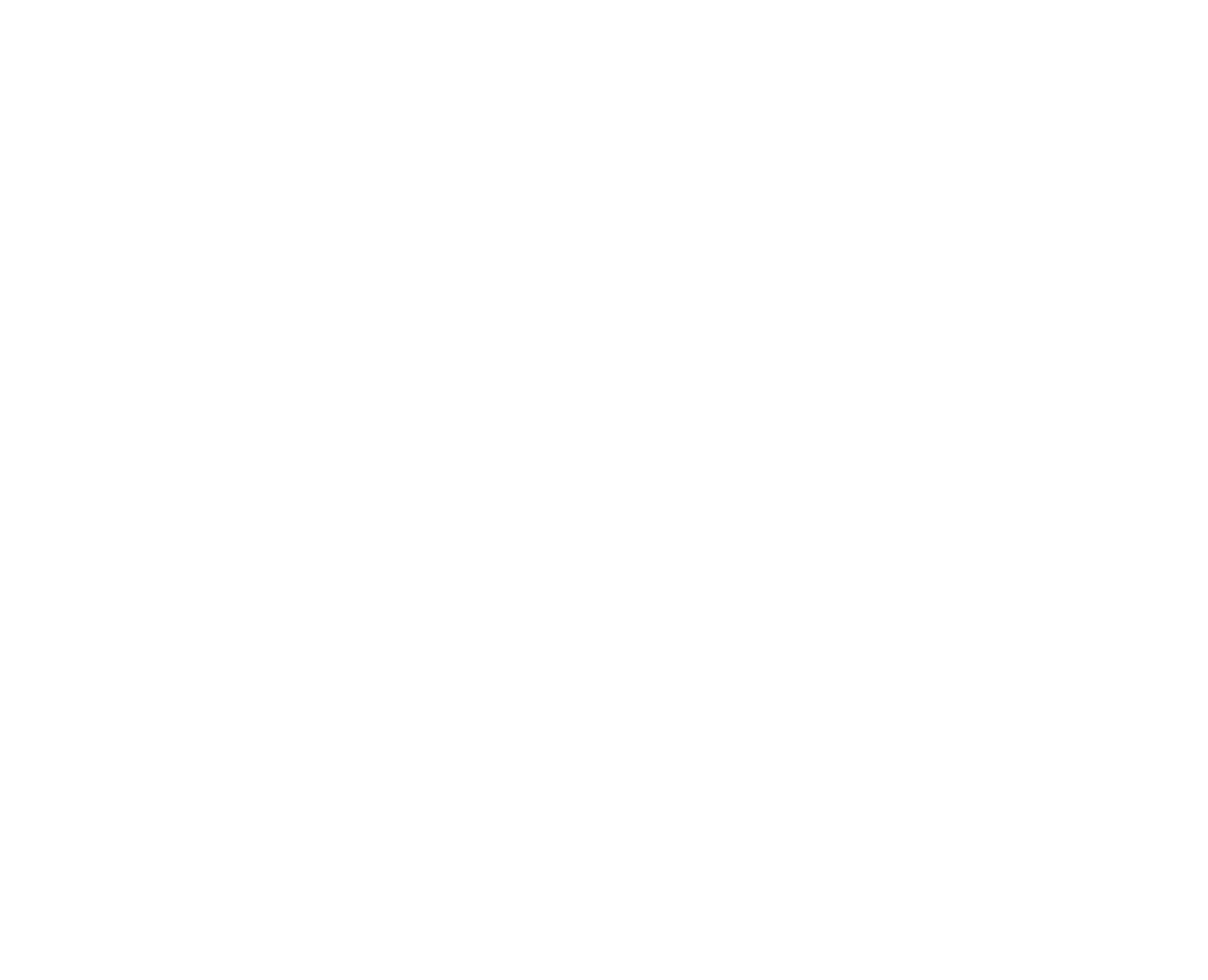

\begin{tabular}{|c|c|c|c|c|c|c|c|c|}
\hline \multicolumn{9}{|c|}{ 3820. Paria River at Lees Ferry, Ariz. } \\
\hline $\begin{array}{l}1948 \\
1949 \\
1950 \\
1951 \\
1952 \\
1953 \\
1954 \\
1955 \\
1956\end{array}$ & $\begin{array}{l}9,634.6 \\
9,873.9 \\
6,803.2 \\
7,014.0 \\
9,507.2 \\
9,017.8 \\
7,907.0 \\
8,903.0 \\
5,006.0 \\
8,362.8\end{array}$ & $\begin{array}{r}19,110 \\
19,590 \\
13,490 \\
13,910 \\
18,860 \\
17,880 \\
15,690 \\
17,670 \\
9,940 \\
9,940\end{array}$ & $\begin{array}{l}2,643,000 \\
2,592,000 \\
1,437,000 \\
1,522,000 \\
1,975,000 \\
4,553,000 \\
2,300,000 \\
4,315,000 \\
1,041,000 \\
3,198,000\end{array}$ & $\begin{array}{r}4,180 \\
5,920 \\
3,940 \\
4,170 \\
5,400 \\
12,470 \\
6,300 \\
11,820 \\
2,840 \\
8,760\end{array}$ & $\begin{array}{r}3 \\
34403,000 \\
3713,000 \\
3910,000 \\
1,260,000 \\
3999,000 \\
31,100,000 \\
3 \quad 307,000 \\
3 \quad 697,000\end{array}$ & $\begin{array}{l}0^{0} \\
<.05 \\
.2 \\
<.05 \\
<.05 \\
<.05 \\
<.05 \\
<.05\end{array}$ & $\begin{array}{r}94,270 \\
90,520 \\
75,440 \\
77,500 \\
74,190 \\
168,300 \\
100,300 \\
161,600 \\
74,270 \\
131,900\end{array}$ & $\begin{array}{l}332,000 \\
284,000 \\
209,000 \\
411,000 \\
283,000 \\
272,000 \\
355,000 \\
317,000 \\
309,000\end{array}$ \\
\hline
\end{tabular}

1 Includes estimated loads for missing days.
2 Estimated.
3 Computed by subdividing day.
4 Computed from water-sediment discharge curve. 
$\mathrm{T}_{\mathrm{ABLE}}$ 19.-Estimated suspended-sediment discharge at selected stations in the subbasins in the San Juan division [Data are for the water years 1914-57 adjusted to 1957 conditions]

\begin{tabular}{|c|c|c|c|c|c|}
\hline \multirow{2}{*}{$\begin{array}{l}\text { Station } \\
\text { No. }\end{array}$} & \multirow{2}{*}{ Station name } & \multirow{2}{*}{$\begin{array}{l}\text { Average water } \\
\text { discharge (cfs) }\end{array}$} & \multicolumn{3}{|c|}{ Suspended sediment } \\
\hline & & & $\begin{array}{l}\text { Weighted- } \\
\text { average } \\
\text { concentration } \\
\text { (ppm) }\end{array}$ & Tons per yr & $\begin{array}{l}\text { Tons per sq } \\
\text { mi per yr }\end{array}$ \\
\hline \multicolumn{6}{|c|}{ San Juan River basin } \\
\hline
\end{tabular}

Colorado River Basin below the Green and San Juan Rivers and above "Lee Ferry," Ariz.

\begin{tabular}{|c|c|c|c|c|c|}
\hline $\begin{array}{l}3335 \\
3350 \\
3395 \\
3800 \\
3820\end{array}$ & $\begin{array}{l}\text { Dirty Devil River near Hite, Utah } \\
\text { Colorado River at Hite, Utah, } \\
\text { Escalante River at mouth, near Escalante, Utah } \\
\text { Colorado River at Lees Ferry, Ariz } \\
\text { Paria River at Lees Ferry, Ariz }\end{array}$ & $\begin{array}{c}102 \\
14,167 \\
85.2 \\
17,550 \\
31.9\end{array}$ & $\begin{array}{r}50,200 \\
4,000 \\
20,900 \\
5,800 \\
84,400\end{array}$ & $\begin{array}{r}5,000,000 \\
55,960,000 \\
1,757,000 \\
101,300,000 \\
2,655,000\end{array}$ & $\begin{array}{r}1,147 \\
731 \\
874 \\
939 \\
1,691\end{array}$ \\
\hline
\end{tabular}


TABLE 20.-Suitability of surface water for irrigation in the subbasins in the San Juan division

[Calcium $a$, to adjust water to 70 percent sodium; calcium $b$, to offset bicarbonate precipitation; and calcium $c$, to supply calcium plus magnesium taken by plants in excess of sodium]

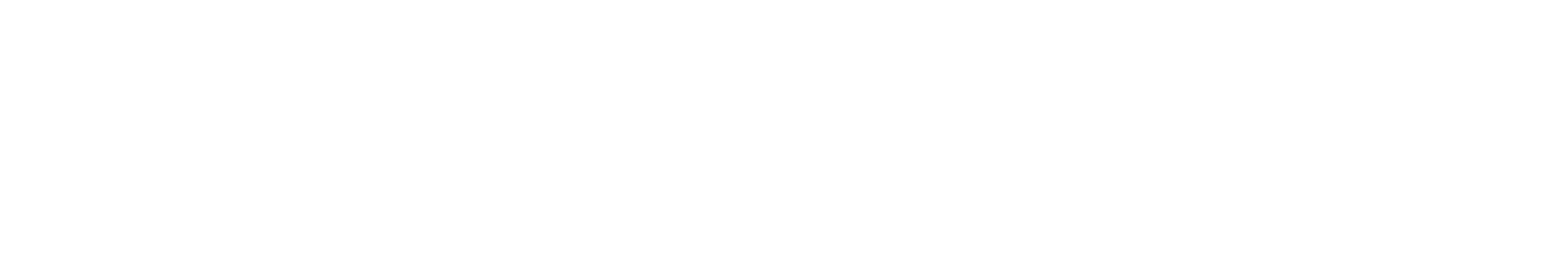

San Juan River basin

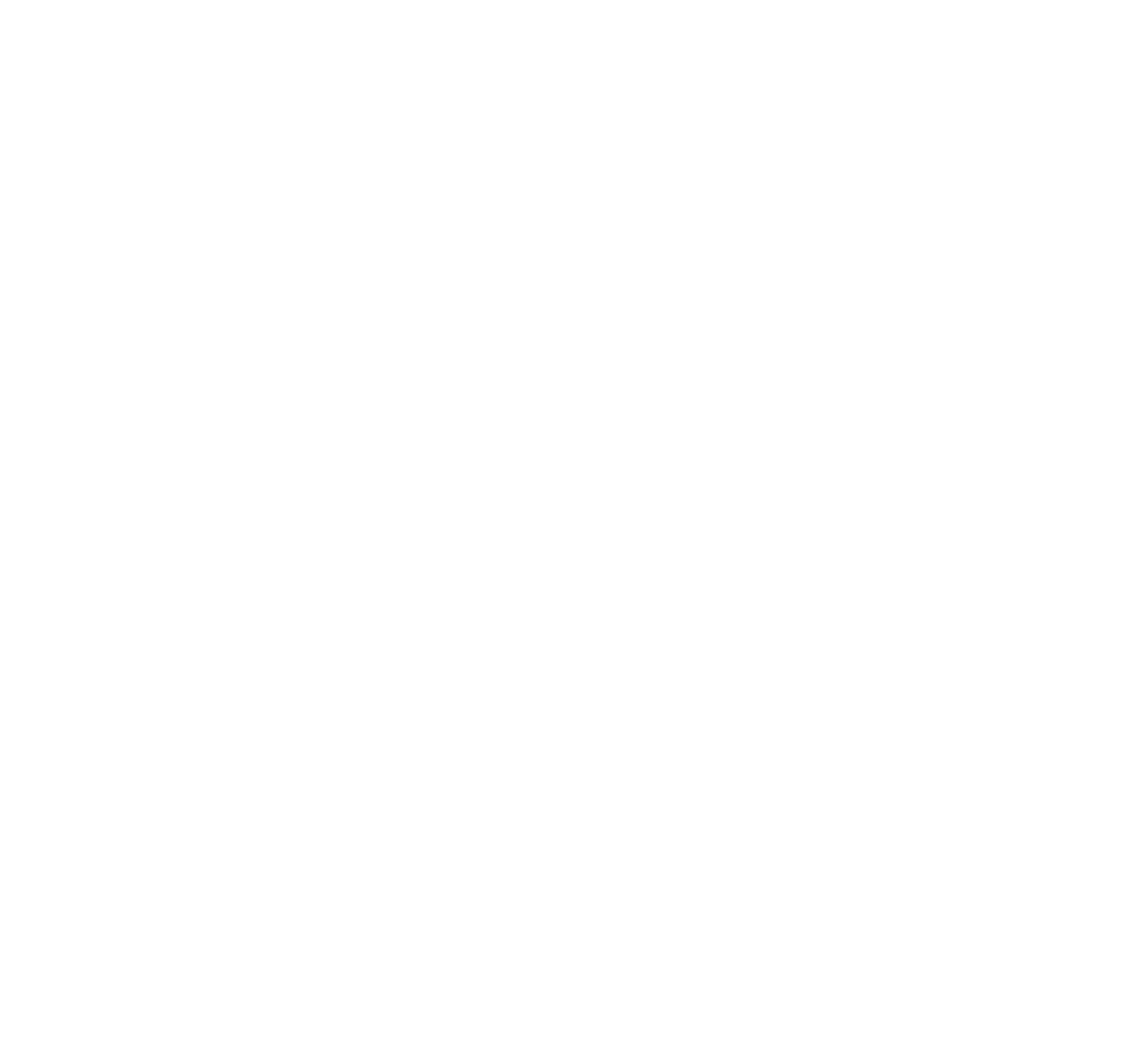

See footnotes at end of table. 
TABLE 20.-Suitability of surface water for irrigation in the subbasins in the San Juan division-Continued

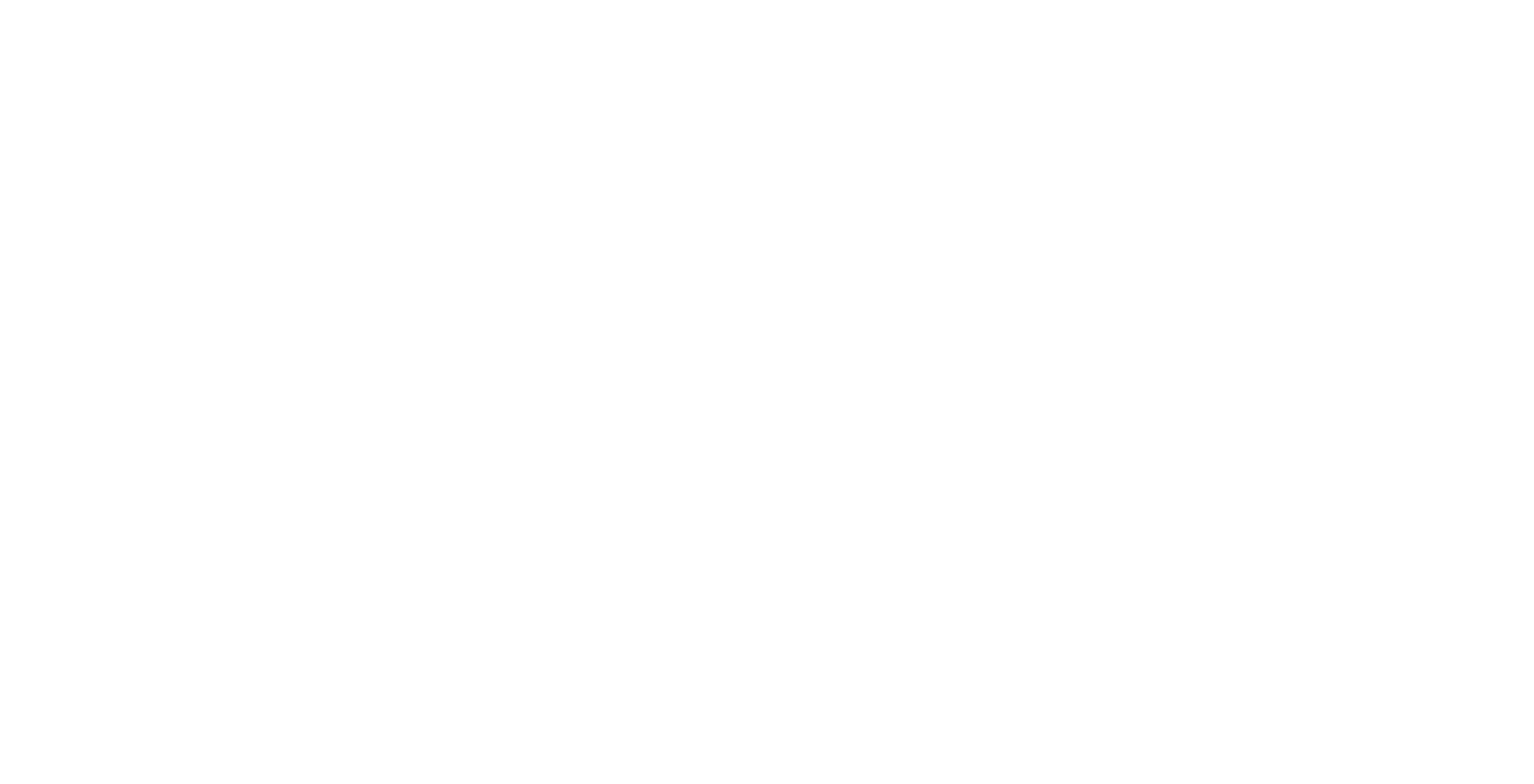

Colorado River Basin below Green and San Juan Rivers and above "Lee Ferry," Ariz.

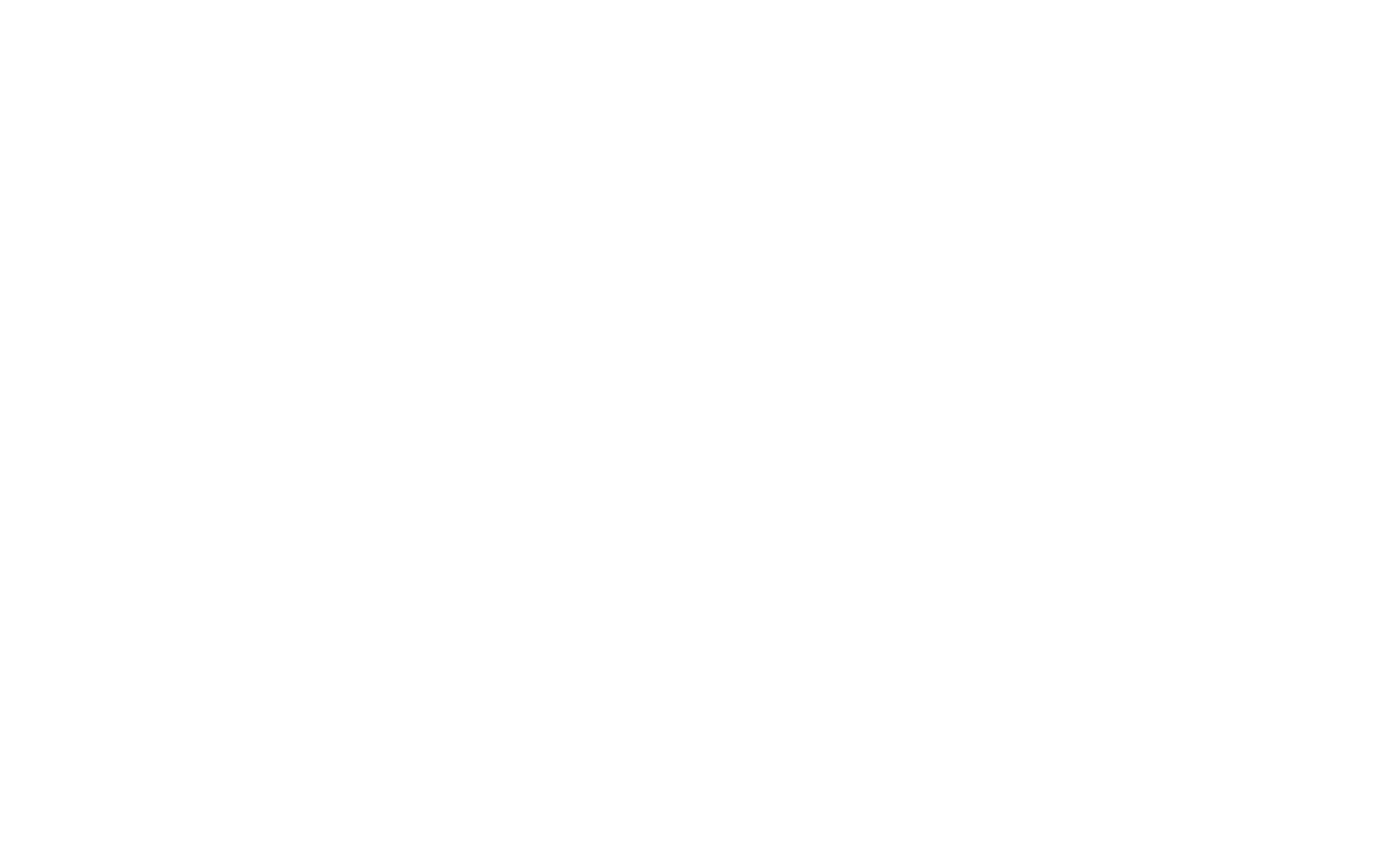

See footnotes at end of table. 
TABLE 20.-Suitability of surface uater for irrigation in the subbasins in the San Juan division-Continued

\begin{tabular}{|c|c|c|c|c|c|c|c|c|c|c|c|c|c|c|}
\hline \multirow{4}{*}{$\begin{array}{l}\text { Station } \\
\text { No. }\end{array}$} & \multirow{4}{*}{ Source } & \multirow{4}{*}{ Date } & \multicolumn{2}{|c|}{ Water discharge } & \multirow{4}{*}{$\begin{array}{l}\text { Specific } \\
\text { conduct- } \\
\text { ance } \\
\text { (micro- } \\
\text { mhos } \\
\text { per cm } \\
\text { at } 25^{\circ} \mathrm{C} \text { ) }\end{array}$} & \multirow{4}{*}{$\begin{array}{c}\text { Per- } \\
\text { cent } \\
\text { so- } \\
\text { dium }\end{array}$} & \multirow{4}{*}{$\begin{array}{l}\text { Sodium- } \\
\text { adsorp- } \\
\text { tion- } \\
\text { ratio }\end{array}$} & \multirow{4}{*}{$\begin{array}{c}\text { Residual } \\
\text { sodium } \\
\text { car- } \\
\text { bonate }\end{array}$} & \multicolumn{6}{|c|}{ Classification } \\
\hline & & & \multirow{3}{*}{$\begin{array}{l}\text { Cublc feet } \\
\text { per second }\end{array}$} & \multirow{3}{*}{$\begin{array}{l}\text { Classifi- } \\
\text { cation }\end{array}$} & & & & & & & Afte & Eaton & $(1954)^{1}$ & \\
\hline & & & & & & & & & $\begin{array}{l}\text { After U.S. } \\
\text { Salinity } \\
\text { Laboratory } \\
\text { Staff, 1954 }\end{array}$ & $\begin{array}{l}\text { Cal- } \\
\text { cium } a\end{array}$ & $\begin{array}{l}\text { Cal- } \\
\text { cium } b\end{array}$ & $\begin{array}{l}\text { Cal- } \\
\text { cium } c\end{array}$ & \multirow{2}{*}{$\begin{array}{l}\text { Re- } \\
\text { quired } \\
\text { leach- } \\
\text { img } \\
\text { (per- } \\
\text { cent) }\end{array}$} & \multirow{2}{*}{$\begin{array}{c}\text { Re- } \\
\text { quired } \\
\text { gypsum } \\
\text { (lb per } \\
\text { acre-ft) }\end{array}$} \\
\hline & & & & & & & & & & \multicolumn{3}{|c|}{$\begin{array}{l}\text { Milliequivalents per } \\
\text { liter }\end{array}$} & & \\
\hline
\end{tabular}

Colorado River Basin below Green and San Juan Rivers and above "Lee Ferry," Ariz.-Continued

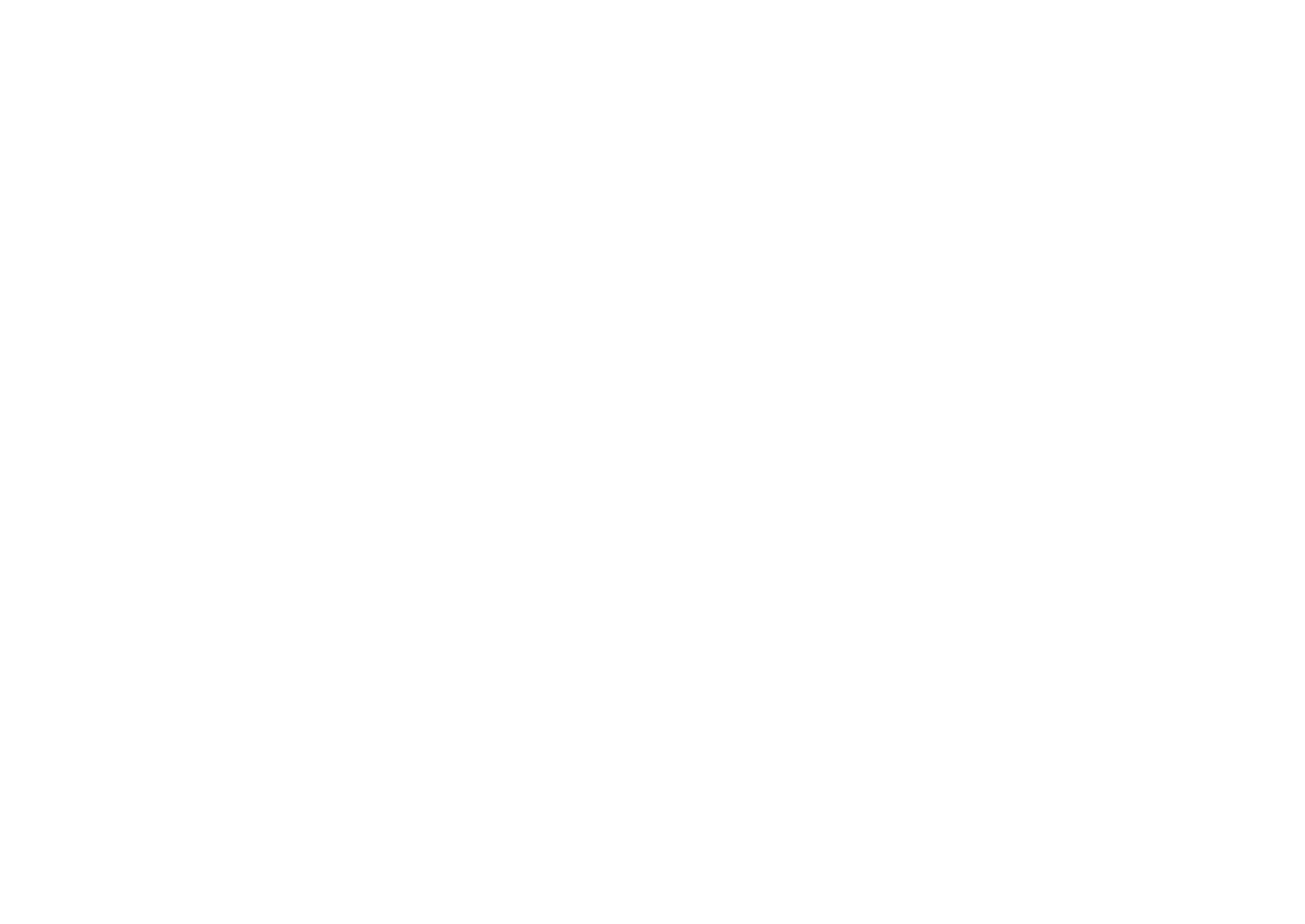

1 For good yield.

2 From gage height or measurement at time of sampling.

Estimated. 
TABLE 21.-Annual discharge of Tropic and East Fork canal near Tropic, Utah

\begin{tabular}{|c|c|c|c|}
\hline $\begin{array}{l}\text { Water } \\
\text { year }\end{array}$ & $\underset{\text { (acre-ft) }}{\text { Discharge }}$ & $\begin{array}{c}\text { Water } \\
\text { year }\end{array}$ & $\underset{\text { (acre-fi) }}{\text { Discharge }}$ \\
\hline 1950. & $-3,910$ & 1954 & $-2,180$ \\
\hline 1951. & $-2,400$ & 1955 & $-2,050$ \\
\hline 1952. & $-4,980$ & 1956 & 934 \\
\hline 1953. & $-1,880$ & 1957 & $-2,490$ \\
\hline
\end{tabular}

TABLE 22.-Adjustments, in thousands of acre-feet, added to historical streamflow record of Colorado River at Lees Ferry, Ariz., to adjust to 1914 base

\begin{tabular}{|c|c|c|}
\hline $\begin{array}{l}\text { Water } \\
\text { year }\end{array}$ & & $\begin{array}{c}\text { Water } \\
\text { year }\end{array}$ \\
\hline $1914 \ldots$ & 11 & 1925 \\
\hline 1915. & 15 & 1926 \\
\hline 1916 & 18 & $\ldots$ \\
\hline 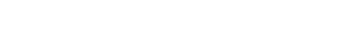 & 11 & 1928 \\
\hline 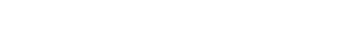 & 18 & $1929 \ldots$ \\
\hline $1919_{--}$ & 13 & 1930 \\
\hline 1920. & 17 & $1931 \ldots$ \\
\hline 1921 & 12 & $1932 \ldots \ldots$ \\
\hline 1922 & 15 & 1933 \\
\hline $1923 \ldots$ & 16 & 1934 \\
\hline $1924 \ldots$ & 11 & $1935 \ldots$ \\
\hline
\end{tabular}

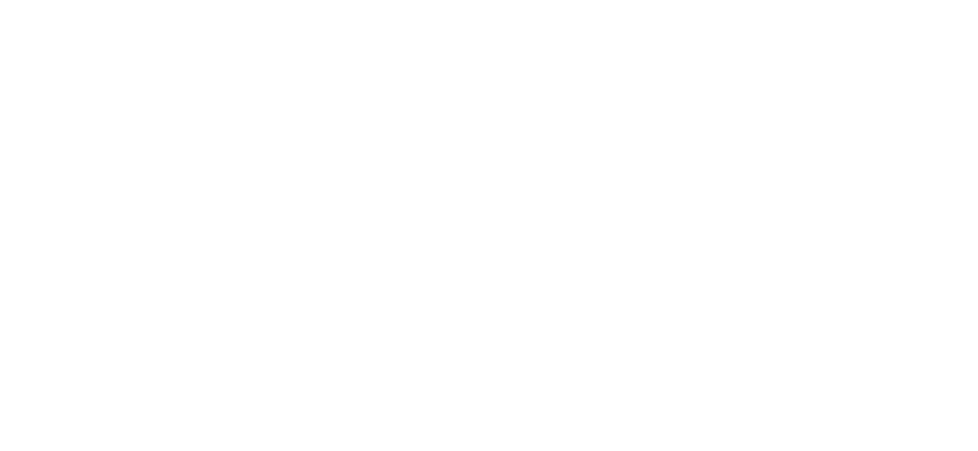


TABLE 23.-Summary data and utilization of surface water in the San Juan division, 1957

\begin{tabular}{|c|c|c|c|}
\hline \multirow[b]{2}{*}{ Water use } & \multicolumn{2}{|c|}{ Subbasin } & \multirow[b]{2}{*}{ San Juan division } \\
\hline & $\begin{array}{c}\text { San Juan } \\
\text { River basin }\end{array}$ & $\begin{array}{c}\text { Colorado River } \\
\text { Basin below } \\
\text { the Green and } \\
\text { San Juan Rivers } \\
\text { and aboove "“Lee } \\
\text { Ferry," Ariz. }\end{array}$ & \\
\hline $\begin{array}{l}\text { Storage reservoirs having usable capa- } \\
\text { cities greater than 1,000 acre-ft: } \\
\text { Number. } \\
\text { Total usable capacity } \\
\text { Transmountain diversions: } \\
\text { Number } \\
\text { Exported (average annual) } \\
\text { Imported (average annual) acre-ft_- } \\
\text { Irrigation: } \\
\text { Irrigated. } \\
\text { Estimated consumptive use (aver- } \\
\text { age annual) } \\
\text { Domestic and industrial use: } \\
\text { Population (1960) } \\
\text { Estimated consumptive use (aver- } \\
\text { age annual) } \\
\text { Hydroelectric powerplants: } \\
\text { Number_- } \\
\text { Installed capacity }\end{array}$ & $\begin{array}{r}12 \\
207,160 \\
16 \\
2,800 \\
2100,000 \\
206,400 \\
256,600 \\
100,000 \\
6,700 \\
4 \\
4,930\end{array}$ & $\begin{array}{r}6 \\
21,000 \\
1 \\
0 \\
32,600 \\
33,300 \\
44,500 \\
6,000 \\
400 \\
1 \\
140\end{array}$ & $\begin{array}{r}18 \\
228,160 \\
7 \\
2,800 \\
102,600 \\
239,700 \\
301,100 \\
106,000 \\
7,100 \\
5 \\
5,070\end{array}$ \\
\hline
\end{tabular}

TABLE 24.-Water budget, San Juan division

Outflow from division less inflow from the Colorado River above Green River and Green River.

Transmountain exportation

Transmountain importation

Irrigation consumptive use......

Domestic and industrial consumptive use

Average annual $($ acre-ft $)$

Evapotranspiration loss $123,133,200$

Total_

$25,880,600$

1 Includes 125,000 acre-ft estimated evaporation from water surfaces. 
TABLE 25.-Summary of average annual water, dissolved-solids, and suspended-sediment contributions in the San Juan division

[Data are for the water years 1914-57 adjusted to 1957 conditions]

\begin{tabular}{|c|c|c|c|}
\hline \multirow[b]{2}{*}{ Data } & \multicolumn{2}{|c|}{ Subbasin } & \multirow[b]{2}{*}{ San Juan division } \\
\hline & $\underset{\text { River basin }}{\text { San Juan }}$ & $\begin{array}{l}\text { Colorado River } \\
\text { Basin below } \\
\text { the Green and } \\
\text { San Juan Rivers } \\
\text { and above "Lee } \\
\text { Ferry," Ariz. }\end{array}$ & \\
\hline 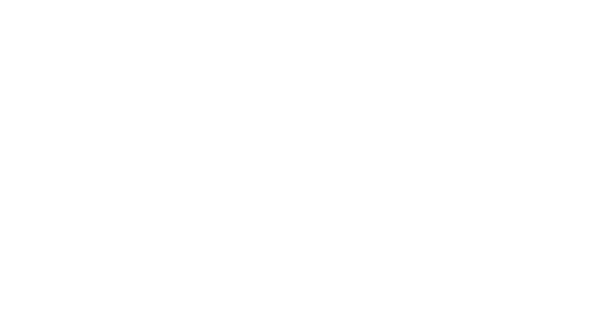 & $\begin{array}{r}24,900 \\
12,028,000 \\
1,073,000 \\
3784,900 \\
32 \\
288,100 \\
1.4 \\
30,839,800\end{array}$ & $\begin{array}{r}13,400 \\
511,000 \\
470,600 \\
406,900 \\
30 \\
463,700 \\
1.9 \\
15,745,200\end{array}$ & $\begin{array}{r}38,300 \\
2,539,000 \\
1,543,600 \\
1,191,800 \\
31 \\
351,800 \\
1.5 \\
55,585,000\end{array}$ \\
\hline
\end{tabular}

1 From San Juan River basin above gaging station near Bluff, Utah.

Includes contribution from San Juan River basin

Includes 17,000 tons of dissolved solids in water imported from Dolores River.

below gaging station near Bluff, Utah.

in Tropic and East Fork canal. 


\section{N D E X}

[Italic page numbers indicate major references]

Page

Abstract................ 1, 41, 75, 181, 299 Acknowledgments water $104,120,136,200,218,227,241,318,381$ effect on dissolved-solids discharge Agricultural use of water............. 37, 69,107 $122,189,205,215,280,243,246,320,382$ See also Irrigation.

Airmasses...

(1) 119

Alluvium....... 8, 29, 99, 102, 111, 121, 134, 141, 302, 317 defined.

Almont, Colo., East River at

Alpine meadows.......... 80,304

Altitude.................. $76,78,82,184,187,216,802$

Alva B. Adams Tunnel........................ 95, 104

Anhydrite.

Animas River..... 315, 320

at Durango, Colo

at Farmington, N. Mex _..._._._. $320,350,356$

Anticline...................................... 130

Aquifers..

Arboles, Colo., San Juan River and tributaries above....................... 319 San Juan River at............................. 319 Archuleta, N. Mex., San Juan River near.. 311,355 Ashley Creek, at Sign of Maine, Utah........ 228 near Jensen, Utah........................... 228 Ashley Creek basin, Utah..................... 283

Aspen, Colo., Castle Creek near............. 105

Roaring Fork near....................... 105

Avalanche Springs, Colo., dissolved-solids concentration.............

B

Backbrush.

Badger Wash

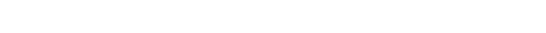

Basalt............. 5

Base flow .............................. 48, 204

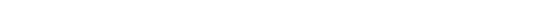

Bayfleld, Colo., Los Pinos River near....... 34, 335

Los Pinos River basin above. ........... 320

Bedrock, Colo., Dolores River at............. 130 well in alluvium at........................ 134

Bentonite............ 5

Bibliography ....................... 40, 73, 142, 246, 335

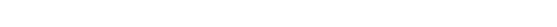

Bicknell, Utah.

Bidahochi Formation....................... 8

Big sagebrush

Big Sandy, Wyo., East Fork near. ......... 188, 200

Big Sandy Creek, below Eden, Wyo......... 201 near Eden, Wyo....................... 201 near Farson, Wyo

Big Sandy Creek basin, Wyoming ........... 281

Blackbrush ..................................... 81, 305

Blackhawk Formation . . . ................ 231,239

Blacks Fork.............. 40 near Green River, Wyo................... 202, 271 near Lyman, Wyo........................ 202 near Marston, Wyo.................... 270 near Millburne, Wyo.................... 191,202

Blacks Fork basin. .............. 202 above Muddy Creek, Wyo............... 282

\section{Page}

Blanco, N. Mex., San Juan River near....... $\quad 24$ $34,311,335,349,355$

Blanding, Utah, precipitation station..... Bloomfield, N. Mex., San Juan River at_... 320, 356 Blue babies, result of nitrate................. 69 Bluff, Utah, San River near $27,37,43,299,304,308,311,318,319$, $320,329,331,351,356$.

Boiler-feed water.

Boiler-fed water- - Colo. Florida River a

at._-1......... 320

Book Cliffs.

Boron -........................... 29, 71, 213, 227, 230, 332

Boulder Creek, Escalante River below . . ..... 332

New Fork River near............... 191, 200, 201

Breccia................ 5, 109

Bridger Formation.................... 5, 201, 202, 214

Browns Park Formation ....

Browns Wash near Green River, Utah...- 126

Brush Creek basin. . . . .

Bryce Canyon.

$\begin{array}{ll}\text { White River at................................ } 229 & 228\end{array}$

White River drainage basin below White River.

Buzzard Creek.

Burro Canyon Formation.

\section{C}

Calcium.

Cameo, Colo. Colorado River near 69 $103,104,106,123,163,232$

Plateau Creek near................... 64, 92,104

water quality near....................... 107

Canal capacities............................... $\quad 230$

Canyon Largo_..... 315, 320

Carbonate........................................ 69

Castle Creek near Aspen, Colo............. 105

Castle Dale, Utah, San Rafael River near. 236, 241

Castlegate, Utah, Willow Creek at.......... 239

Cebolla Creek, springs near................ 119

Cedar Hill, N. Mex., Cox Canyon Creek at.. 319

Cedaredge, Colo................................ 109

Cement Creek, near Silverton, Colo .........- 320 springs on ............................... 118

Chaco River.............. 315

flow-duration curve for..................... $\quad 308$

Channel loss................ $\quad 329$

Chemical properties of water - ...........-..- $\quad 67$

Chemical-quality data, computing

Chemical quality of water................ 19,48 $91,111,126,191,205,221,231,311,324$

effect of activities of man. ............. relation to ground water............. 29 relation to streamfiow .................. 29 variations in ............................. 20 , $92,118,126,198,206,221,235,311,325$

See also Activities of man; Dissolved solids: Geology; Ground water; Transmountain diversions.

Chinle Formation

Chloride_......................... 69, 71, 242, 243

Chuska Formation.

Chuska Sandstone

Cimarron Creek, spring at mouth of....... 119
Page

Cisco, Utah, Colorado River near............ 23, $26,37,43,64,123,124,126,127,129$, $136,138,141,153,165,179$.

Dolores River near... 37, 64, 126,130, 136, 165, 179 Clark, Colo., Elk River at............ 208, 212, 214 Climate................ 8, $44,78,140,184,244,302,333$ Climax, Colo..................... 83 Coal Coal Creek.................. 229 Coefficient of variation, equation. . ..........- 94 streams.................................. 89 annual streamflow See also discussion under Chemical quality of water, variation; Runoff, variation.

Cold Sulphur Spring, Colo._................ 119 Colona, Colo

Uncompahgre River at.............. 24, 109, 111 Colorado-Big Thompson project.......... 81, 92, 95 Colorado-New Mexico State line, La Plata River at._....................... 318, 319

Colorado River............................... 302 above the Gunnison River............. 76,81 alluvium east of Kremmling, Colo......... 102 at Glenwood Springs, Colo.......... 89, 103, 153 at Grand Junction, Colo .................. 42 at Hite, Utah. ......... 322, 325, 329, 332, 352, 357 at Hot Sulphur Springs, Colo........... 92, $95,104,141,162$ at "Kremmling, Colo at Lees Ferry, Ariz. _ 19, 27, 34, 37, 53, 91, 299,322, $323,324,325,331,332,333,334,353,357$

below Granby and Willow Creek Reservoirs and above Hot Sulphur Springs................................ 167 between the Gunnison and Green Rivers. 76, $122,146,147,150,151,152,154,155,156$, $158,160,161,165,166,170,175$.

above confluence with Green River....... 331 diversions above Hot Sulphur Springs, Colo near Cameo, Colo _ _ 92, 103, 104, 106, 123, 163, 232 near Cisco, Utah. ....... 23, 26, 37, 43, 64, 123,124, $126,127,129,136,138,141,153,165,179$ near Dotsero, Colo. .................... 103 near Glenwood Springs, Colo........ 103, 141, 163 near Kremmling, Colo..................... 106 near Page, Ariz................ 329 tributaries.-

Colorado River Basin............... 34 above the Gunnison River - 146,147, 148, 151, 152, $154,155,157,159,161,162,166,170,171$ below the Green and San Juan Rivers and above "Lee Ferry," Ariz ... 299, $\$ 21,329$, $341,343,344,345,346,347,348,355,358$, 360.

below the Gunnison River, Utah......... 161 Colorado-Utah State line, McElmo Creek near- 306 Consumptive use of water........... 83, 91, 104,106, $109,123,138,187,201,228,318,319,334$

See also Agricultural use; Domestic use; Industrial use.

Continental Divide Continental Divide ditch...................... 187, 200 Continental rocks............................ 5,184 


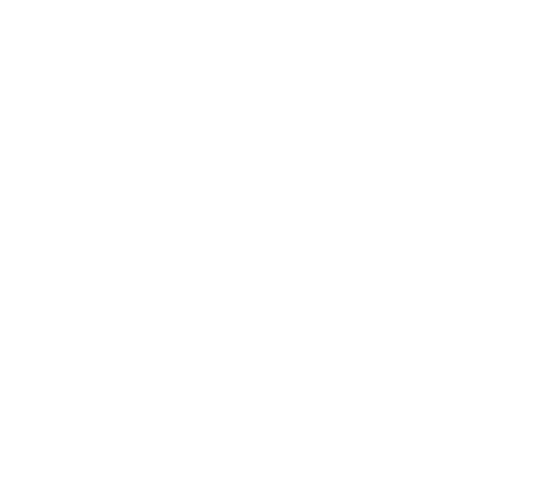

D

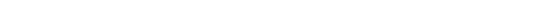

Dakota Sandstone.................... 6, 35, 78, 114, $121,123,124,129,130,137,138,204,212$

Data, computing chemical quality ......... 58 computing sediment..................... 66 kinds.

See also Suspended-sediment discharge.

standard deviation formula

De Beque, Colo., Roan Creek at. ............

Roubideau Creek near.

Uncompahgre River at.................. 117,120

Devil Creek, chemical quality of water near Piedra, Colo

Diatomite

Diatremes.

Dikes

Direct runoff.

Dirty Devil River

near Hanksville, Utah.................... 324 near Hite, Utah . . . . . . suitability of water....................... 332

Dirty Devil River basin

Disappointment Creek, quality of water.-.-. 130

Dissolved solids............................ 58 $61,91,92,95,108,111,116,126,191$, $205,221,223,231,311,324$.

budget. . ..............

discharge and concentration 19

from irrigated lands, yield rates............ 33, 66

objectional amounts of ................. 40

variability of 60

Diversions of water. See Transmountain diversion.

Divide Creek at mouth, near Silt, Colo.......- 107 Dixon, Wyo., Little Snake River near...... 214

Dolores River, at Bedrock, Colo.............. 130 at Dolores, Colo............. 123,124, 126,129, 138 at Gateway, Colo dissolved-solids concentration............ 127, 134 headwaters above Dolores, Colo......... 129 near Cisco, Utah ...... 37, 64, 126, 130, 136, 165, 179 suitability of water ....................... 139 water quality below Rico, Colo.......... 129

Dolores River basin . . .................... 122, 137

Domestic use of water...................... 14, $33,36,68,88,106,109,121,128,139$, $141,188,203,204,215,216,229,231$, $242,246,305,319,321,332$.

Dotsero, Colo., Colorado River near.......... 103 irrigated lands near._._.................. 82 suitability of water near.................. 92

Dragerton, Utah................................

Drainage area . .

Drainage pattern

Dry Fork near mouth, near Dry Fork, Utah_..- 228
Page

Duchesne, Utah Duchesne River at .............. 24, 218, 274 Strawberry River at............... 37, 227, 230, 274

Duchesne River............................. 40, 227 above the mouth of the Uinta River (at Ouray School canal headgate),

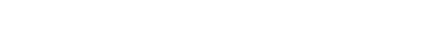
at Duchesne, Utah............... 218, 228, 274 at Myton, Utah 275 near Randlett, Utah........................... 276 near Tabiona, Utah..................... 228

Duchesne River basin above Duchesne, Utah.................... 284

Duchesne River tunnel. . . .................... 32

Durango, Colo 10

Animas River at

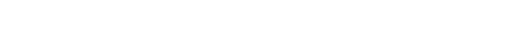

Duration curve, defined......... V (chap. B)

Duration tables, dissolved solids.............. $\quad 58$,

$92,99,127,191,206,232$

dissolved-solids concentrations and discharges 20,324

Dyke, Colo., Stolsteimer Creek near......... 318

Eagle River at Gypsum, Colo. drainage basin below Gypsum, Colo....... 91

Eagle Valley Evaporite

East Fork, above New Fork, Wyo., spring on

near Big Sandy, Wyo................... 188, 200

East Fork of Sevier River.................... $\quad 329$

East Hoosier ditch.

East Rifle Creek . . . . . .

East River, at Almont, Colo . . . . dissolved-solids concentration

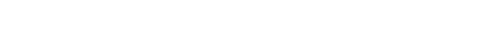

Eaton, F. M., formulas by .......... 72

Eden, Wyo., Big Sandy Creek below......... 201 Big Sandy Creek near........ 201 Little Sandy Creek above.................. 201

Edith, Colo., Navajo River at................ 308

Effect on quality of water, transmountain

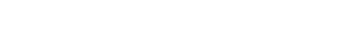

Electra Reservoir, Colo Elk Creek ranger station, Wyoming, Hams Fork near.......... 189, 202

lk River, at Clark, Colo............. 208, 212, 214 at Trull, Colo

Elk River basin, Colorado................ 283

Elkhead Creek near Elkhead, Colo............ 214

Elkhorn, W yo., Little Sandy Creek near.... 201

Emery, Utah........ 321 Muddy Creek near.

Entrada Sandstone........................ 135

Equivalents per million, defined...... V (chap. B)

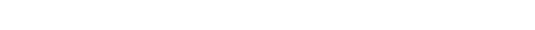

Escalante, Utah. Escalante River near............. 324, 325, 352, 357

Escalante River, below Boulder Creek........ 332 near Escalante, Utah. ......... 324, 325, 352, 357

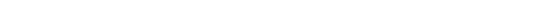

Evaporation ............... 67, 78,91, 185, 304,329 defined............................... $\mathrm{V}$ (chap. B)

Evaporite

Evapotranspiration ................... 1, 19, 29, 63, 321

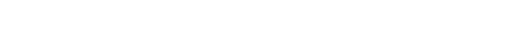

Fairview ditch. Farmington, N. Mex Animas River at. ............... 320, 350, 356 La Plata River near................... 319 Farson, Wyo., Big Sandy Creek near........... 201 Pacific Creek near....................... 201 Faulting
Page

Flagstaff Limestone . . . . . . . . . . . . . 231, 239, 240 Floods, flash Florida River at Bondad, Colo .............. $\quad 320$ Fluoride.......... 68, 69, 213, 215, 242, 243, 320, 332 Flow-duration curve........... 14, $45,84,95,109,123$, $140,188,204,217,231,244,306,322,333$ deflned.............. V (chap. B) Fluvial sediment........................ 34 , $106,121,198,203,215,229,242,319,931$

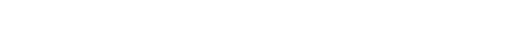

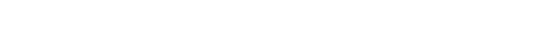
Fontenelle, Wyo., Fontenelle Creek at...... 201 Green River near. 202

Fontenelle Creek. at Fontenelle, W yo $\ldots$ near Hershler Ranch, Wyo............... 201

Fontenelle Creek basin, Wyoming ............ 281 Forest Camp, Colo., thermal spring at........ 214 Fort Union Formation.................... 214

Fraser, Colo., irrigated lands near.......... 82 St. Louis Creek near.

Fraser River, at Granby, Colo............. 63,104 near Winter Park, Colo. .............. 63, 89

Fremont Pass ditch

Fremont River at Torrey, Utah.

Frontier, W yo., Hams Fork near............ 191, 202

Fruita, Colo................................ 123

Fruitgrowers Reservoir, Colo_...... 108

Fryingpan Creek, at Norrie, Colo............ $\quad 105$ drainage basin............................ 84 spring on

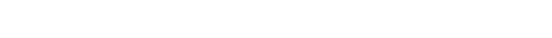

G

Gaging station, defined............... V (chap. B) Gallons per minute, defined......... V (chap. B) Gas deposits.................................. 188, 204

Gateway, Colo., Dolores River at. . ....... 164

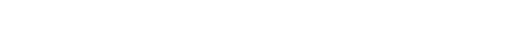
Geochemistry of water. See discussion under Geology, relation to chemical quality of water.

Geologic formations, list

Geologic history

relation to chemical quality of water $114,127,193,207,221,238,312,325$

relation to streamflow

Glacial deposits

Glen Canyon Dam, Ariz ................. 321, 332

Glen Canyon Group........... 5,7, 127, 130, 325, 329

Glenwood Springs, Colo irrigated lands near........................ 82 suitability of water near Colorado River at ............... 89, 103, 141, 153 Colorado River near............... 103, 141, 163 Roaring Fork at._._..... 34, 55, 60, 61, 103, 105 Glossary . . . . IV (chap. B) Gordon Creek near Price, Utah............... 239

Gore Pass Ranch, Colo_.................. 102 Gould Reservoir, Colo........ 108 Granby, Colo., Fraser River at_........... 63, 104 Granby Dam, Colo Grand division Grand Junction, Colo _ . Colorado River at . . Gunnison River at............... 42

Gunnison River near.............. 109, 111, 164 Grand Lake, Colo., Alva B. Adams Tunnel... 104 Grand Valley ............................... 122 Granite . . . . . Grasslands . . . . . . 81,305 Greasewood . . . Green division. . . . . . . . Green Mountain Reservoir, Colo............. 82, 106 
Page

Green River, Utah

Browns Wash near -126

Green River at.............. 26, 37, 42, 43,278, 287

Salaratus Wash at.......................... 126

San Rafael River near..................... 231, $232,241,242,243,279,287$

Green River, Wyo.... 188 Blacks Fork near- 202,271 Green River at_........ 188, 191, 202, 203, 270, 286 Green River, above Warren Bridge, Wyo., spring near......................... 200 at Green River, Utah ..................... 26, $37,42,43,231,233,235,242,243,278,287$ at Green River, Wyo... 188, 191, 202, 203, 270, 286 at Jensen, Utah. at Ouray, Utah............................ 22 at Warren Bridge, Wyo.................. 191 location -...-..-..-.-.-. near Fontenelle, Wyo .................... 202 near Greendale, Utah.................... 202, 272 near Jensen, Utah. ..................... 203, 229, 286 near Ouray, Utah. ......................... 59 $221,227,229,232,233,238,243,277,286$

suspended sediment......................... 242 tributaries

Green River basin ............................ 34 above the Yampa River................... 181, $185,252,253,254,258,259,260,261,264$ $266,269,270,280,281,285,286,288,289$

below the White River................... 182 $290,252,253,259,260,263,265,268,269$ $277,280,285,286,288,294,295$.

between the Yampa and White Rivers... 182, $252,253,256,259,260,262,265,267,269$ $273,280,283,285,286,288,292,295$.

Green River Formation ........ 5, 35, 184, 201, 230, 239 Greendale, Utah, Green River near.......... 202, 272 Ground water, dissolved solids contributed to streams.

relation to chemical quality of water.....-. 29 $99,116,182,195,211,223,240,317,329$

relation to geology

relation to streamflow...................... 48 reservoirs..

$29,99,102,199,218$

See also Recharge.

Grover, Nathan C., quoted.....................

Gunnison, Colo............................. 109, 116

Gunnison River, above Gunnison tunnel,

Colorado

at Grand Junction, Colo................... 42 below the Gunnison tunnel................ 109, 113 near Delta, Colo.................. 117 near Grand Junction, Colo ................ 64, 109 $110,111,113,114,117,121,123,164$

near Whitewater, Colo water quality below Smith Fork ........... 122 Gunnison River basin, Colorado.............. 76, 108, $146,147,149,151,152,154,155,156,158$ $160,161,164,166,170,173$

above Tomichi Creek

Gunnison tunnel, Colorado................... 109

Gunnison River above

Gunnison tunnel diversion..................... 113

Gypsum........................-...-... 5, 73, 107, 203

required for good crop yields........ 39

Gypsum, Colo., Eagle River at................ 92, 162

Gypsum Creek near............ 19, 49, 51, 53, 86

Gypsum Creek, chemical quality of water.... 130

near Gypsum, Colo............. 19, 49, 51, 53,86

Gypsum Creek drainage basin ................. 86, 91

Gypsum Valley anticline....................... 130

Hams Fork, irrigated lands above Kemmerer,

Wyo. . . . ................ 202 near Elk Creek ranger station, Wyoming. 189, 202 near Frontier, Wyo.
Hams Fork basin, Wyoming.-

282

Hanksville, Utah, Dirty Devil River near.... 324

Hardness of water........ 69, 108, 203, 215, 242, 319, 320 defined ...... V (chap. B)

Harvey Gap Reservoir ..................... 82

Hatch Wash near La Sal, Utah.............. 126

Hayden, Colo.................................... 204

Headwater streams. .......... 20, 24, 31, 32, 36, 39, 109 $122,141,184,193,204,207,221,324$

Yampa River. . . .

Heiner, Utah...... 239

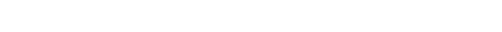

Helper, Utah.......... 231

Henry Mountains

Henrys Fork at Linwood, Utah. ........ 193, 203, 27

Hermosa Creek near Hermosa, Colo........... 311

Hermosa Formation........................ 130,135

Hershler Ranch, Wyo., Fontenelle Creek near. 201

Hesperus, Colo., La Plata River at. . . . . . . - 318

High-salinity water........................... 71

High-sodium water.....................- 72

High flows, defined.............. V (chap. B), 107

Histogram, defined............... V (chap. B), 89

Hite, Utah. . . . . . . 335 Colorado River at. ...... 322, 325, 329, 332, 352, 357 Dirty Devil River near.......... 321, 324, 351, 357 North wash near. .

White Canyon near. 126

Hobble Creek ditch

Hogbacks . . . . . . . . . .

Homestake Creek, near Red Cliff, Colo....... 19 ,

drainage basin

Hoosier Pass tunnel...

Hot Sulphur Springs, Colo., Colorado River

$$
\text { at }
$$

Hotchkiss, Colo., springs near................ 119

Hunt, C. G., quoted .... 301

Huntington Creek, near Huntington, Utah... 231

Hydroelectric power.......... 82, 83, 123, 188, 305, 321

Hydrogen-ion concentration, defined. - V (chap. B)

Hydrograph ....... 14, 46, 49, 109, 123, 217, 231, 306, 321 defined.

$V$ (chap. B)

Hydrologic cycle......................... 1,14,45

Hydrologic environment................... 76,182,299

Hydrologic map......................... 44

Hydrologic unit 1, unconsolidated continental deposits

2 , continental rocks.........................

3 , marine and continental rocks

4 , predominantly continental rocks........

5 , continental and marine rocks............

6 , predominantly marine rocks..............

7, igneous rocks.................................

8, igneous and metamorphic rocks........

Igneous rocks..... 4, 7, 24, 99, 109,110, 184, 245, 308, 312 Index-precipitation stations................ 44, 78 Index station, defined . ................. V (chap. B)

Index-station method, adjusting flow-duration curves to base period. . .............

Indian Creek, water quality, above Duchesne, Utah

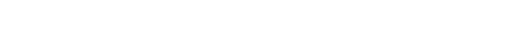
Industrial use of water $69,83,107,122,128,189,141,188,203$ $204,215,216,230,231,243,246,305$ 321, 382.

Industry . also Activities of man.

$10,62,123$

Industry. See also Activities of man.

Intermittent stream, defined.........- V (chap. B) Introduction. . ...................... 1, 41,75, 181, 299 Investigations, previous ...................... 12

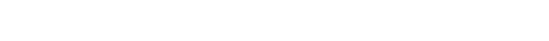
Iron

Irrigated lands map. .........................
Page

Irrigation -. $32,37,42,55,63,66,71,82,105,107$, $108,122,141,187,204,216,281,246$, 305, 321.

defined................................ (chap. B)

See also Activities of man; Agricultural use of water; Dissolved solids from irrigated lands; water use.

Ivanhoe Reservoir, Colo............................

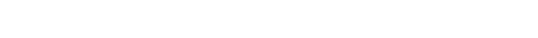
Jensen, Utah, Ashley Creek near............. 228 Green River at............................ 273 Green River near.................. 203, 229, 286

$\mathbf{K}$

Kemmerer, Wyo .......... 188 Knobel, E. W., and others, quoted Kremmling, Colo., Colorado River at ........ 106

Colorado River near...................... 106

\section{$\mathbf{L}$}

La Boca, Colo., Spring Creek at............. 34, 320 Labyrinth Canyon. Laccoliths.

Lake City, Colo.

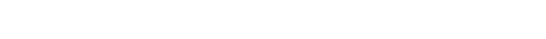

Lake Fork, drainage basin ................... $\quad 110$ springs on .............................. 119 Lake Granby Reservoir, Colo. . . . Lakes. . . ........... 182 Lance Formation............................ 214 La Plata River, at Colorado-New Mexico

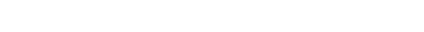
at Hesperus, Colo near Farmington, N. Mex............ 319 water quality in headwaters.............. $\quad 320$

La Plata River basin in Colorado........... $\quad 354$

Lake Powell, Ariz . . Larsen, E. S., Jr., and Cross, Whitman,
quoted.

La Sal, Utah, Hatch Wash near........... 126

Lava_........ 5

required for good crop yields.............. 37 see also Required leaching.

Leaching percent, defined. .......... V (chap. B)

"Lee Ferry," Ariz Colorado River at . ............... 20, 32, 33, 91, 335

Lees Ferry, Ariz.......... 2, 304 Colorado River at...- 19, 27, 34, 37, 53, 91, 299, 322 , $323,324,325,331,332,333,334,353,357$

Paria River at $34,299,322,324,325,329,331,334$, $353,357$.

Lily, Colo., Little Snake River at bridge on State Highway 318, near . . . . 203, 215, 273

Limestone

Linwood, Utah, Henrys Fork at........ 193, 203, 271

Little Dolores River, near the Colorado-Utah State line....... 65 suitability of water....................... 139

Little Sandy Creek above Eden, Wyo........ 201 near Elkhorn, Wyo........... 201

Little Snake River, at bridge on State Highway 318 , near Lily, Colo ..... 203, 215, 273 dissolved-solids concentration............... 209 near Dixon, Wyo...................... 214 near Slater, Colo . . .

Little Snake River basin . . ................... 204 above Dixon, Colo.............. 283 Livestock watering Location of area . . ..................... 2, 75, 181, 299 Loa, Utah.................................... 321 Los Pinos River, diversions from near Bayfield, Colo................... 335 
Page

Low flows, defined.................. V (chap. B), 107

Low-salinity water

Low-sodium water

Lower Gunnison River basin

Lyman, Wyo., Blacks Fork near.

$\mathbf{M}$

McElmo Creek, near Colorado-Utah State line.. near Cortez, Colo.......................... 321 drainage basin ...................................... 315

Magnesium .............................. 69, 243

Mancos River at Towaoc, Colo.............-. 308

Mancos Shale ........................... $6,35,78,110,121,124,136,184,214,228$, $229,241,302,334$.

Seealso Geology, relation to chemical quality of water: Ground water, relation to chemical quality of water.

Marine rocks.

Marl.

Marston, Wyo., Blacks Fork near -.........-.

Mass diagram of dissolved-solids contribution

Maybell, Colo., Yampa River at bridge on county road near........ 203, 215, 272, 286

Yampa River near................ 206

Maybell and Steamboat Springs, Colo., Yampa River between............... 209

Medium flows, defined............ V (chap. B), 107

Medium-salinity water

Medium-sodium water........................... $\quad 72$

Meeker, Colo

White River near-

Mesa, Colo., springs near......................... 103

Mesaverde Formation.......... 6, 35, 110,114, 318, 319

Mesaverde Group................ 5, 211, 239, 315, 318

Metamorphic rocks................... 4, 24, 99, 193, 312

Mexican Hat, Utah, uranium mill at........ 305

Mill Creek near Moab, Utah.................. 45

Millburne, Wyo., Blacks Fork near........ 191, 202

Minnie Maud Creek at Nutter Ranch, Utah. 239, 243

Moab, Utah................................. 123

Courthouse Wash near................... 126

Mill Creek near............................. 45

precipitation station........................ 45

Moenkopi Formation......................... 5

Montane Forests ..................... 80,304

Montezuma Creek, chemical quality of....... 315

Montezuma irrigation district.................. 315

Monthly means method, adjusting flowduration curves to base period... 46

Montrose, Colo............................... 109

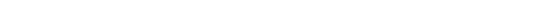
$121,123,124,129,130,135,204,212,239$

Mount Barris, Colo _........................ 204

Mount Richtofen

Mountain brush

Mountain Home, Utah, Rock Creek near .... 228

Mountainview, Wyo..................... 188

Cottonwood Creek below Sage Creek,

near-
Muddy Creek near Emery, Utah.................. 321, 324

Mudstone-............... 5

Murray, Utah, industry ..................... 62

Myton, Utah, Duchesne River at ........... $\quad 275$

$\mathrm{N}$

Narraguinnep Reservoir, Colo._._.............. 305

Native vegetation map....................... 44

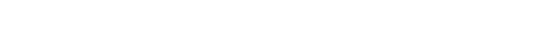
San Miguel River at_...................... 137

Navajo River at Edith, Colo .................. 308

New Fork River near Boulder, Wyo... 191, 200, 201

New Fork River basin, Wyoming ........... 281

Nitrate_... 29, 37, 69, 107, 118, 139, 203, 215, 227, 242, 243

Norrie, Colo., Fryingpan Creek at............. 105
North Horn Formation................ 231, 238

North Inlet............................... 84

North Wash near Hite, Utah $\ldots \ldots \ldots \ldots \ldots \ldots . . . .126$

Nutter Ranch, Utah, Minnie Maud Creek at . .

\section{o}

Oak Creek, Colo........ Yampa River near................... 213

Oil ............................ 188, 204, 228, 229

Oil shale

Orangeville, Utah, Cottonwood Creek near... 236

Organization of the report................ 10

Ouray, Utah, Green River at_................. 227

Green River near........................ 221, $229,1232,233,238,243,277,286$

Willow Creek near .............. 29, 232, 242, 277

Ouray School canal headgate, Utah _......... 275

\section{$P$}

Pacific Creek near Farson, Wyo.............. 201

Page, Ariz...- 321 Colorado River near. 329

Pagosa Springs, Colo., dissolved solids near... 311 springs near. ............................ 318, 334 water quality near. San Juan River basin above.............. $\quad 312$

Paonia, Colo .......... 109

Paradox Member of the Hermosa Formation

Paradox Valley, alluvium in

water quality in ........................ 134

Paria River at Lees Ferry, Ariz .......... 19, 34, 299 $322,324,325,329,331,334,353,357$

Paria River basin, suspended sediment....... 335

Park Springs, water quality of............. 120

Particle-size analyses .......................... 43,44

Parts per million (ppm), defined... VI (chap. B)

Pass Creek valley, spring in................ 102

Pearmont, Colo., Troublesome Creek near.... 105

Per capita use of water. . . ................ 83, 204, 216

Percent sodium

defined............. VI (chap. B)

Percolation...................................

Perennial stream, defined........... VI (chap. B)

pH.

Phosphoria Formation. ..................... 200

Physical properties of water.

Physiography .................... 8, 76, 182, 243, 299

Physiological effects of dissolved solids........ 69

Piceance Creek, near White River, Colo...... 230

Piedra, Colo., Devil Creek near.

Piedra Pass ditch............................ 305

Piedra River basin

Pinedale, Wyo._..... 188

Pinyon-juniper ...... 81,304

Placerville, Colo., San Miguel River at..... 124,137

San Miguel River near.................. 132, 137

Plateau Creek, suitability of water........... 107

Plateau Creek basin......................... 83

Platesu Creek near Cameo, Colo......... 64, 92,104

Population _... 10, 65, 83, 109, 123, 188, 204, 231, 305, 321

Pot Creek basin, reservoir in. .......... 216

Potassium ..................................... 69

Powderhorn, Colo., springs near............. 119

Powell, J. W., quoted...................... 182

Precambrian complex.................... 7

Precipitation. ...................... 10,

$19,41,64,65,66,78,91,105,111,126,184$ $202,208,214,228,231,241,242,244,30 \%$, 333.

computation of average annual........... 45

data, computing and adjusting. .......... 44

defined.

Preclpitation-runoff relation $\ldots . . . \ldots \ldots . . . .91,111,126$
Page

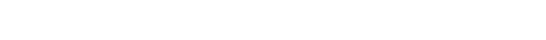

Gordon Creek near...................... 239

Price River above Scofield Reservoir, Utah. ........ 231, 239 at Wellington, Utah.................... 42 at Woodside, Utah . ............. 232, 243, 278 dissolved solids ............................. 40 headwaters above Helper, Utah.......... 243 near Heiner, Utah....................... 231 tributaries below Price, Utah.............. 243

Price River Formation.......... 239 Probable deviation, defined. ........ VI (chap. B)

Purpose and scope of report .... ....... 2, 75, 181, 299

\section{$\mathbf{R}$}

Raber-Lohr ditch 305

Rainfall, defined. . ................. VI (chap. B)

Ranch Creek near Taberriash, Colo....... 63

Randlett, Utah, Duchesne River near.......- 276

Rangely, Colo

Recharge .............................. 99, 199, 317

Record-completion method, adjusting flowduration curves to base period...- 46

Recreational use of water ............ 39 $108,122,209,215,230,321,382$

Red Cliff, Colo., Homestake Creek near..... 19 , $49,52,53,86$

Redstone, Colo., Crystal River near......... 105 Required leaching....... 72, 107, 139, 203, 243, 321, 332 Reservoirs .................... 13, 185, 216, 305, 308, $\$ 21$ See also Storage reservoirs.

Residual sodium carbonate.................. 37 $72,107,122,230,243,320,332$ defined (chap. B) Residuum...... 8, 127, 132, 140, 184, 199, 214, 241, 302 defined..................... 77 Return flow, defined............ VI (chap. B) Rico Formation. .................... 123, 124, 129, 132 Rifie, Colo. . . . . . ............................. 83 Rifle Creek, streamflow . . . . . Roan Cliffs Roan Creek at De Beque, Colo.............. 107 Roaring Fork, at Glenwood Springs, Colo.... 34, $55,60,61,103,105$ dissolved solids. ................ 107 near Aspen, Colo ........ 105 Roaring Fork basin

Rock Creek, near Mountain Home, Utah.... 228 near Uranium, Colo................... 137 Rock Creek basin. Rock Springs, Wyo

Rocky Mountains....................... 5,76

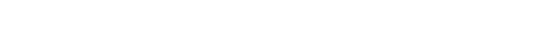

Root zone._....................................... 72

Rosa, N. Mex., San Juan River at.......... 34, 355 San Juan River below ................ 302, 335 Roubideau Creek near Delta, Colo........... 210 Roubideau Creek basin ........................ 108

Runoff. ..... 45, 55, 65, 91, 92, 111, 140, 202, 206, 214, 228 defined............... VI (chap. B) variability ......... 89,109,110,128,124,188,191, 204, 206,

$204,206,218,281,244,305,308,321,323$

See also Direct runoff.

Runoff-precipitation relation. ............. $\quad 91$

S

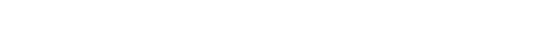

St. Louis Creek near Fraser, Colo.

Salaratus Wash at Green River, Utah........ 126

Saline minerals.............................. 5

Salinity water, classification for irrigation...-- 71

Salt

See also Saline minerals; High, low, and medium sodium water.

Salt balance................................ 32

Salt Creek, water quality................. 130

Salt Wash Sandstone Member of the Morrison Formation. 
Saltbush. Page

San Juan division. .................... 8, 19,299

San Juan Mountains . . .................... 24, 301

San Juan River, at Arboles, Colo.............. 319

at Bloomfield, N. Mex............... 320,356

at Rosa, N. Mex.... 34, 35

at Shiprock, N. Mex.......... $320,350,356$

below Rosa, N. Mex.................. 302, 335

near Archuleta, N. Mex

near Blanco, N. Mex..... 24, 34, 311, 335, 349,355

near Bluff, Utah............ 23, 27, 37, 43, 299, 304, $308,311,318,319,320,329,331,351,356$

tributaries

San Juan River basin $299,305,335,339,340,341,342,344$ $345,346,347,348,355,358,359$.

above Pagosa Springs, Colo........... $\quad 312$

San Miguel Mountains.................... 129

San Miguel River, at Naturita, Colo.......-. 137

at Placerville, Colo.................... 124, 137 near Placerville, Colo................. 132, 137

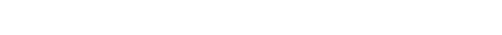

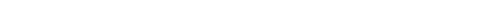

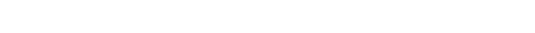
between Placerville and Naturita, Colo... 168 San Rafael basin, Utah.................... 284 San Rafael Group. San Rafael River, dissolved solids.......... 40 near Castle Dale, Utah................ 236, 241 near Green River, Utah. .............. 231 $232,241,242,243,279,287$

Sandstone-.................................. 5,6 Savery Creek, at upper station, near Savery, Wyo . .

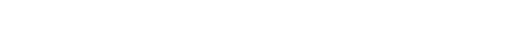
Scofield Reservoir, Utah, Price River above .- 231,

Scope of report. See Purpose and scope of report.

Searcy, J. K., quoted...........-......-.-. 48 Seasonal runoff, variability.......... 84, 217 Sediment, defined........ VI (chap. B) discharge, defined. ................ VI (chap. B) station, defined............ VI (chap. B) transport...................... 67, 106 yleld, defined....... VI (chap. B)

Sedimentary rocks... 8, 24, 29, 105, 141, 184, 193, 301, 333 See also Alluvium; residuum.

Sewage disposal . . . . . Shadscale........................................... 81, 304

Shadow Mountain Reservoir, Colo_.......... 81

Shiprock, N. Mex., San Juan River at.- 320, 350, 356 uranium mill at. . . .

Sign of Maine, Utah, Ashley Creek at ........ $\quad 228$ Silica

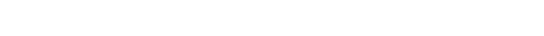
Silt, Colo., Divide Creek at mouth, near..... 107 Siltstone......................................... 5

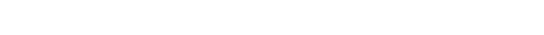
Cement Creek near........... 320 Silverton Volcanic Group.................... 315 Slater, Colo., Little Snake River near...... 212, 214 Slater Fork near Slater, Wyo.............. 214 Slope, measure of....... 48 Smith Fork basin............. 110 Snowmelt. . ........... 45, 46, 95, 109, 204, 333 Sodium Sodium-adsorption-ratio............... 71, 107, 139 defined........................... VI (chap. B) Sodium carbonate. ................ 230 Sodium chloride........ 30, 103, 132 Sodium hazards

Sodium water, classification for irrigation..... 72 Soil. ... . . . . . See also Residuum.

Soil survey

South Fork White River, near Buford, Colo.. 228 Spanish Fork, Utah.
Specific conductance

Page VI (chap. B) Spring Creek at La Boca, Colo............. 34, 320

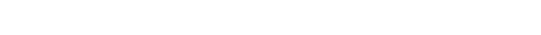
$119,129,136,230,245,318,329,334$ thermal . . . . ................ 29, 102, 103, 135, 136 , $141,200,213,214,227,245,318,329,334$

Squaw Pass ditch. . ................... 305 Standard deviation................ 89,111, 124, 324 defined. . . . . . . . . . . . . . . . . formula.

Star Point Sandstone................. 231, 239, 240 Statistical analysis, streamflow............... 68 annual suspended-sediment discharge..... 138

Steamboat Springs, Colo _................ 37, 215 alluvium at.......... 215 irrigated land above........... 204 Yampa River at........................ 23, 24, 213 Yampa River drainage basin above......- 205 Steele Hot Spring............................ 200 Stillwater Reservoir No. 1.......... 204 Stolsteimer Creek, near Dyke, Colo........... $\quad 318$ water quality.......... 320

Storage reservoirs .................... 13, 81, 108,12\%, $140,185,204,216,230,305,321$

Straight-line equation. See discussion under Chemical quality of water, variations in.

Strawberry Reservoir................... 47, 216, 217

Strawberry River at Duchesne, Utah...... 37

Strawberry River ditch................... 216

Strawberry River tunnel.................. 32, 216, 217

Stream gaging

Stream net. ......................... 2,76, 182, 299

Streamflow..$109,128,188,204,216,281,305,321$

defined............... VI (chap. B) effect of ground water on from ground-water storage, computation of. $\quad 49$ relation to chemical quality of water..... 28,95 , $114,127,195,207,221,286,312,325$

statistical analysis of annual flows. ........ 58 variation in.

See also Coefficient of variation; Variability index.

data, computing and adjusting. Structural features............................... 8 Subalpine forests.............. 80, 217, 304 Substitute method, adjusting fiow-duration curves to base period.

Sulfate_................. $37,68,71,230,243,320,332$ Summary........................... 12,199, 248, 382

Summer-cypress.

Summit Reservoir .......... 305

Sunnyside, Utah.

Surface tension of liquid surfaces .............. 67

Surface water, base for appraising resources .. $\quad 41$ use-_..... 81, 108, 122 See also particular stream and Streamfiow.

Suspended sediment defined.............. VI (chap. B) discharge.......... $34,106,121,138$, $142,208,215,229,242,246,319,331,335$

$\mathrm{T}$

Tabeguache Creek near Uravan, Colo........ 137 Tabernash, Colo., Ranch Creek near........ 63 Tabiona, Utah, Duchesne River near........ 228 Talus slopes...................................... 111 Taylor Park Reservoir, Colo . ...... 108, 109, 113, 114 Taylor River, above Taylor Park Reservoir.- 114 headwater area. ......................... 111

Teeth, mottling of

Temperature........................ 8, 78, 185, 244 See also Water temperature.

Terrace deposits.
Page

Thermal springs . ....... 29, 102, 103, 135, 136, $141,200,213,214,227,245,318,329,334$ Tomichi Creek, alluvium at Gunnison, Colo.. 116 dissolved solids............................. 121 headwaters of .................................. 109

Tons per day, defined............-. VII (chap. B) Tons per square mile per year, defined. VII (chap. B) Topography................. 76, 78, 184, 243, 301, 302

Torrey, Utah, Fremont River at. ............ 321 Towaoc, Colo., Mancos River at..._._._._. 308 Transmountain diversions..................... 13, $31,55,61,82,99,104,108,120,122,186$, $187,200,204,216,227,230,241,305$, $318,321,323,329$.

Treasure Pass ditch.............. 305

Trona Tropic and East Fork canal............ 321, 329, 331 Troublesome Creek, dissolved solids .......... 102 near Troublesome, Colo. ............... 105 near Pearmont, Colo . Troublesome Creek basin, Colorado .......... 167 Trull, Colo., Elk River at.................. 214 Tuff.................................. 109 Turbidity, defined.

Uinta Formation.............. 5, 6, 184, 228, 230, 239 Uinta Mountains Uncompahgre Plateau........................ 5 Uncompahgre River, above Dallas Creek..... 114 at Colona, Colo at Delta, Colo ......................... 117, 120 drainage basin above Colona, Colo. .... 109, 111 near Ironton, Colo ...................... 120 near mouth of Cow Creek, Colo ......... 117 suitability of water Uncompahgre River basin, Colo.........- 108

Uncompahgre uplift ........................ 132

U.S. Salinity Laboratory, analyses of samples of irrigation water.............. 132 cited

U.S. Public Health Service, standards for drinking water .................... 68 Upper Colorado River Basin Compact Commission............................. 65

Uranium, Colo., Rock Creek near..._._._.. 137 Uranium mills.............. 305 Uravan, Colo ............................... 123

Tabeguache near........................ 137 Use, defined ........... VII (chap. B) Utah State Agricultural College. ........... 43

Vallecitos Reservoir . . . Variability index _ $188,204,217,231,244,308,323,333$ defined............... VII (chap. B) of streamflow ................... 53 Vegetation............. 80, 111, 185, 804 Vernal, Utah............................ 62, 216 Very high salinity water.................... 71

Very high sodium water...................... 72

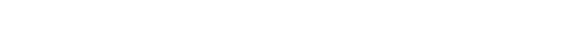
116, 132, 204, 207, 211, 221, 312, 319, 332

W

Warm Springs Warm Springs Canyon, spring in Warren Bridge, Wyo., Green River at........ 191 Wasatch Formation ............. 5, 34, 84, 110, 230, 239 Waste disposal. See Sewage disposal.

Water, budget........................... 19, 63, 105, $120,140,202,214,228,241,244,318,333$ chemical properties..................... 67

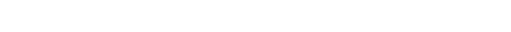




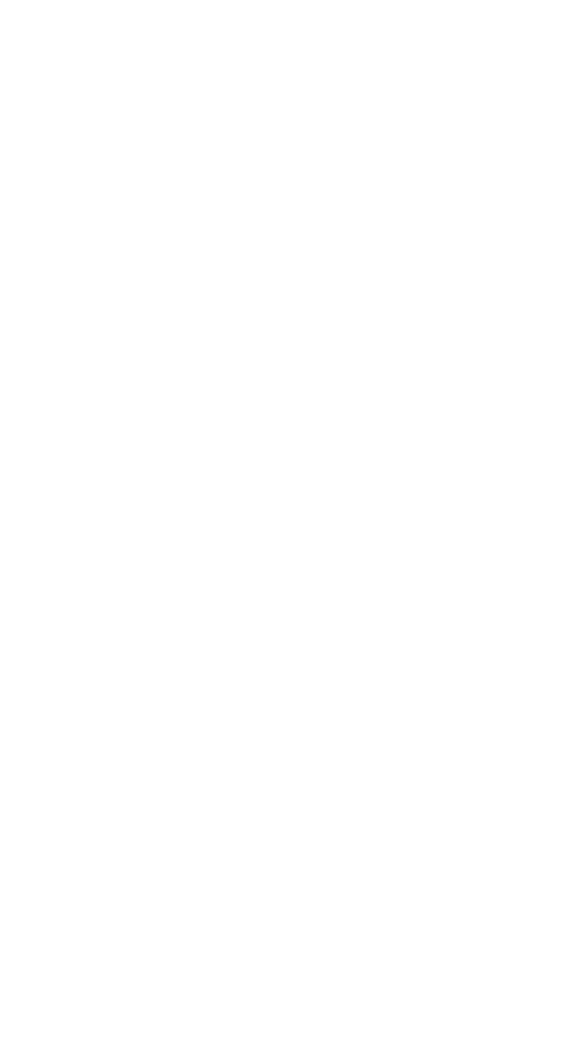

Water use-Continued Page See also Agricultural use; Consumptive use; Domestic use; Industrial use; Irrigation; Recreational use; Water budget.

Water year, defined. . ....... VII (chap. B) Water yield, defined .......... VII (chap. B) Watson, Utah, White River at ............. 229 White River near.................. 221, 227, 276

Waunita Hot Springs.................... 119

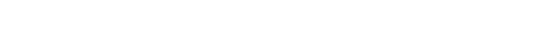

Weighted-average concentration of dissolved solids .... 92, 99, 120,121, 132, 136, 141, $193,202,207,209,213,221,223,227$, $229,232,239,245,317,318,319,329,333$

defined. ..................... VII (chap. B) equation............................ 58,60,61 Wellington, Utah, dissolved solids near....... 239 Price River at ........................... 42

Wells.......... 214

West Creek at Gateway, Colo . . . . . . . 65,135

West Hoosier ditch.........................

West Paradox Creek, diversion from......... 134

White Canyon near Hite, Utah............ 126

White River, Colo., Piceance Creek near ....- 230

White River, at Buford, Colo _........... $\quad 229$ at Watson, Utah . .

Green River basin below. . ............. 182, 230 near Meeker, Colo.................... 228 near Watson, Utah............... 221, 227, 276

White River basin... 182, 252, 253, 256, 259, 260, 262, $265,267,269,273,280,283,285,286$, 288, 292, 295.

below White River at Buford, Colo....... 228 between Buford and Meeker, Colo........ 284 White River Plateau.
Page

Wilcox diagram

Willlams Fork above Williams Fork Reservoir, Colo_............ 63

Williams Fork Reservoir, Colo ............ 81, 106

Williams River drainage basin...... 84

Willow Creek above Willow Creek Reservoir.......... 63 at Castlegate, Utah.. .................... 239 near Cora, Wyo......................... 201 near Ouray, Utah. ............ 29, 232, 242, 277

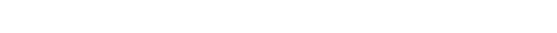

Willow Creek Reservoir................. 81, 104, 106

Wind River Range...................... 5, 182, 192

Wingate Sandstone.............................. 135

Winter Park, Colo., Fraser River near . . . . _ 63, 89

Woodside, Utah, Price River at _...... 232, 243, 278 water quality near..................... 239, 243

Yampa River ...... 204 at bridge on county road, near Maybell, Colo at Steamboat Springs, Colo........... 23, 24, 213 between Steamboat Springs and Maybell, Colo 209 Green River basin above . . near Maybell, Colo................... 206 near Oak Creek, Colo ............... 213

Yampa River basin ... 182, $204,253,255,258,259,260$, $262,264,267,269,272,280,282,285$, 286, 288, 291.

above Steamboat Springs, Colo.

between Morrison Creek and Steamboat Springs, Colo.................... 282

between the Yampa and White Rivers including the White River basin.... 216 



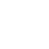

